Louisiana State University

LSU Digital Commons

1965

\title{
A Distributional Survey of the Birds of Honduras.
}

Burt Leavelle Monroe Jr

Louisiana State University and Agricultural \& Mechanical College

Follow this and additional works at: https://digitalcommons.Isu.edu/gradschool_disstheses

\section{Recommended Citation}

Monroe, Burt Leavelle Jr, "A Distributional Survey of the Birds of Honduras." (1965). LSU Historical Dissertations and Theses. 1046.

https://digitalcommons.Isu.edu/gradschool_disstheses/1046

This Dissertation is brought to you for free and open access by the Graduate School at LSU Digital Commons. It has been accepted for inclusion in LSU Historical Dissertations and Theses by an authorized administrator of LSU Digital Commons. For more information, please contact gradetd@lsu.edu. 
This dissertation has been $65-11,398$ microfilmed exactly as received

MONROE, Jr., Burt Leavelle, 1930-

A DISTRIBUTIONAL SURVEY OF THE

BIRDS OF HONDURAS.

Louisiana State University, Ph.D., 1965

Zoology

University Microfilms، Inc., Ann Arbor, Michigan 


\section{A DISTRIBUTIONAL SURVEY OF THE BIRDS OF HONDURAS}

\section{A Dissertation}

Subittted to the Graduate Faculty of the Loulsiana State University and Agricultural and Mechantcal College in partial fulfiliment of the requirements for the degree of Doctor of Philosophy

In

The Department of Zoology and Physiology

$$
\begin{gathered}
\text { by } \\
\text { Burt Leavelie Monroe, Jr. } \\
\text { B.S., Untvers ity of Loulsville, } 1953 \\
\text { May, } 1965
\end{gathered}
$$




\section{ACKNOWLEDGMENTS}

A distributional survey of the scope of the present work could not be satisfactorily completed without the cooperation and assistance of a great number of people. To the many friends who helped me during this project, I am greatly indebted.

First and foremost among those who have assisted me are the personnel of the United Fruit Company. Captain B. Ross, of New Orleans, graclously provided our main field party with transportation to and from Honduras, including the shipment of a vehicle and all supplies as well as passage for three people. In addition, the personnel at the Tegucigalpa office of the company, especially the managers, C. M. Shaw and his successor, Fred P. Sheehy, alded us in obtaining vehicle and gun importation permits and acted as intermediaries in other business conducted with the Honduran government. While we were traveling in Honduras, the United Fruit Company also placed at our disposal their facilities wherever available. At the San Alejo station, Richard Washburm provided accomodations and transportation and showed us excellent areas for ornithological study. The late Paul Allen accompanied us on our trip through the company station at Lancetilla. 
Financial support for the Louisiana State University Museum of zoology expeditions to Honduras was obtained from several sources. Throughout the research phase of this study, I utilized a National Science Foundation Cooperative Graduate Pellowship. Assistantships were made available through the Louisiana State University Museum of Zoology to support my field assistants while in Honduras. Personal contributions to the project by Clarence J. Schoo, of Springfield, Massachusetts, and by Dulaney Logan, of Loulsville, Kentucky, were Indispensible in support of the field operations, and I extend my sincerest thanks to these gentlemen for their generosity.

The research phase of the study in the United States, consisting of visits to varlous museums for examination of Honduran specimens therein and a three-month study of comparative material at the American Museum of Natural History in New York, was supported by the contributions of Mr. Schoo and by a grant from the Frank M. Chapman Memorial Fund of the American Museum of Natural History.

During the field studies in Honduras, I was given assistance in many different ways by a great number of people, to whom I wish to extend my deepest gratitude. William W. Plowden, Jr., was of continuing help throughout our stay in Honduras. He graciously placed at our disposal the facilities at his coffee plantation at Finca Fé, where we made our headquarters. In addition, he provided us with 
transportation on numerous occasions and greatly facilitated our trips throughout the country by means of contacts with his many acqualntances there. Frank Matthews, of San Pedro Sula, spent much time arranging and coordinating our first expedition from the Honduran end; in addition, he offered the use of his home while we were in San Pedro Sula. Excellent facilities were also made avallable to us at Puerto Salamax by Milson Magee and at Choluteca and San Francisco by Carlos Rodríguez Williams. J. B. Alegria, of Choluteca, gaciously permitted us to use facilities at his coffee plantation, Finca El Rubi. Miguel and Francisco Talavera, of San Lorenzo, organized boat trips to Tigre Island and to the Los Farallones and extended us every consideration. While at La Ceiba and Coyoles, my wife and I were provided accomodations by the Standard Frutt Company through the courtesy of G. T. Feyling: Ezra knight, of Montecristo, provided us with transportation in the region around La Ceiba.

The two trips to the lowland pine savanna of the Mosquitia could not have been made without the assistance of the Pure 011 Company of Honduras. They provided me with atr transportation on one trip and the entire fleld party with excellent accomodations at their Puerto Lempira camp on both occasions. I wish to thank especially the managers of the Pure Oil Company, Robert M. Benson and his successor, E. Paul Ramirez. William Lady, pilot for the Pure $0 i 1$ 
Company and a naturalist as well, permitted us to utilize his facilities on Lietle Hog Island, in the Cayos Cochinos. The ornithological records published herein for the first time are the result of a cooperative effort. In addition to the material secured by expeditions from the Louisiana State University Museum of Zoology, a number of Ornithologists have placed their records at my disposal. Mark Trafton, Jr., has made avallable to me his records from many years of intensive 8 tudy. While he was director of the research division of the United Fruit Company at La Lima, he made extensive notes, obtained many photographs, and collected a number of rarities for identification purposes. He has very graciously permitted publication of much of his original data in the current study. Marforie H. Carr and Arthur C. Twomey, both of whom collected birds In Hor uras, have made their collections avallable to me, and many of their records are published now for the first time. Thomas R. Howell, who collected at Arenal on several occasions, has supplied me with much original unpublished data concerning his work at that locality. Kenneth S. Hamilton, of the United Fruit Company, has been actively banding birds at La Lima since 1962; he has given me his data up to the present time. Vida Roth, of San Pedro Sula, accompanied our party in the fleld on several occasions; in addition, her husband, Marvin Roth, provided 
us with air transportation to the Cayos Cochinos and to Coyoles .

Richard R, and Jean W. Graber made two ornithological trips to remote areas of the Olancho rain forest specifical1y for the purpose of obtaining data for my current study. In addition, they accompanted me on my second trip to Honduras. I wish to extend to them my special thanks for their work, cooperation, and companionship during this study.

During my first and longest field expedition to Honduras, I was accompanied by my wife, Rose S. Monroe, and by J. Alan Feduccia, of the Loulsiana State University Museum of Zoology. Feduccia's ability as a field collector and preparator of bird specimens increased the efficiency of the expedition to a great degree. The assistance and encouragement given to me by my wife, including her work as a field collector and preparator, was absolutely indispensible and I cannot adequately express my apprectation for all she has done for me in connection with this study.

In the research phase of the work dealing with comparison of honduran material and associated problems, I am indebted to a number of Individuals and to their associated institutions for cooperation during my study. I wish to extend my personal thanks to the following: Alden $\mathrm{H}$. Miller and Ned K.. Johnson, Museum of Vertebrate Zoology, University of Callformia, Berkeley; Thomas R. Howell, vi 
University of California at Los Angeles; J. William Hardy, Moore laboratory of Zoology, Occidental College; Robert M. Mengel, Museum of Zoology, University of Kansas; Aus tin L. Rand and Emmet R. Blake, Chicago Natural History Museum; Emerson Kensies, University of Cincinnati; Kenneth $C$. Parkes, Carnegle Museum; James Bond, Academy of Natural Sciences at Philadelphia; Dean Amadon, Eugene Eisermann, and Wesley E. Lanyon, American Museum of Natural History; Peter L. Ames, Peabody Museum, Yale University; Raymond A. Paynter, Jr., Museum of Comparative Zoology, Harvard University; Philip S. Humphrey and Richard L. Zusi, United Statec National Museum; J. C. Dickinson, Jr., and Oliver L. Austin, Jr., Florida State Museum, Gainesville; Archie F. Carr, Jr., and Hugh Popenoe, University of Florida; and Allan R. Phillips, Mexico City. For comments concerning avifaunal problems (mainly taxonomic), I wish to extend my appreciation to those ornithologists who are currently working on or have recently completed distributional surveys In other parts of Middle America: Laurence $C$. Binford (Oaxaca), Stephen M. Russell (British Honduras), Hugh C. Land (Guatemala), Thomas R. Howell (Nicaragua), Paul Slud (Costa Rica), and Alexander Wetmore (Panama). I also wish to thank George H. Lowery, Jr., who has been my advisor during the entire project, and Robert J. Newman, who has critically read the manuscript, for their encouragenent and for their time given in connection with my work. 
PAGE

TITLE PAGE $\ldots \ldots \ldots \ldots \ldots \ldots \ldots \ldots \ldots \ldots \ldots \ldots \ldots \ldots \ldots \ldots \ldots \ldots \ldots \ldots$

ACKNOWLEDGMENTS $\ldots \ldots \ldots \ldots \ldots \ldots \ldots \ldots \ldots \ldots \ldots \ldots \ldots \ldots \ldots \ldots$

TABLE OF CONTENTS $\ldots \ldots \ldots \ldots \ldots \ldots \ldots \ldots \ldots \ldots \ldots \ldots \ldots \ldots \ldots \ldots \ldots$

LIST OF TABLES $\ldots \ldots \ldots \ldots \ldots \ldots \ldots \ldots \ldots \ldots \ldots \ldots \ldots \ldots \ldots \ldots \ldots \ldots$

LIST OF FIGURES $\ldots \ldots \ldots \ldots \ldots \ldots \ldots \ldots \ldots \ldots \ldots \ldots \ldots \ldots \ldots \ldots \ldots \ldots$

ABSTRACT $\ldots \ldots \ldots \ldots \ldots \ldots \ldots \ldots \ldots \ldots \ldots \ldots \ldots \ldots \ldots \ldots \ldots \ldots \ldots$

INTRODUCTION $\ldots \ldots \ldots \ldots \ldots \ldots \ldots \ldots \ldots \ldots \ldots \ldots \ldots \ldots \ldots \ldots \ldots \ldots$

GENERAL PHYSICGRAPHY ......................... 12

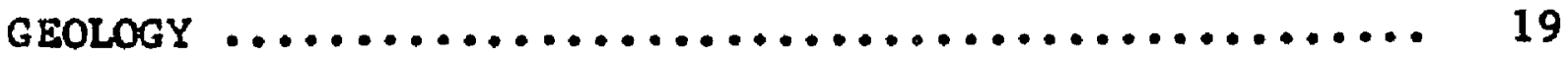

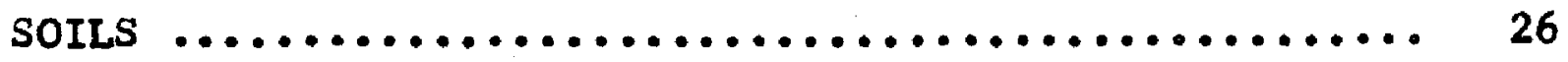

CLIMATE ...................................... 29

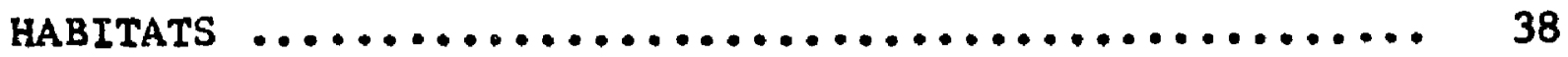

Troptcal lowland rain forest................. 43

Tropical deciduous (monsoon) forest ........... 46

cloud (montane rain) forest .................. 48

Arld (mixed) scrub and thorn forest ............... 51

Highland pine (ocotal) and pine-oak associations

(encinal-robledal) $\ldots \ldots \ldots \ldots \ldots \ldots \ldots \ldots \ldots \ldots \ldots \ldots \ldots \ldots \ldots$

Lowland pine savanna ....................... 54

Marsh and swamp .......................... 56

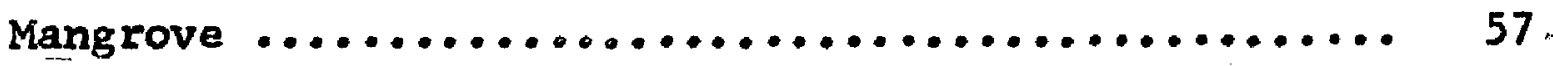

HISTORY OF HONDURAN ORNITHOLOGY .................. 59 
PAGE

PLAN OF THE SPECIES ACCOUNTS ................... 89

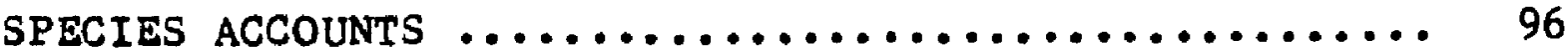

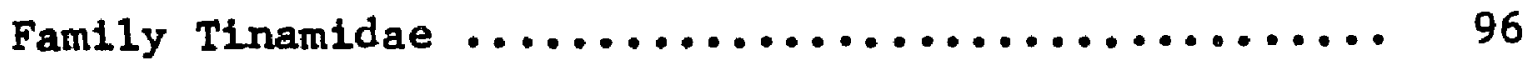

Family Podtcipedidae ....................... 102

Family Phaethontidae ........................ 104

Family Pelecanidae ......................... 104

Family sulidae ........................... 106

Family Phalacrocoracidae .................... 109

Family Anhingidae .......................... 110

Fantly Fregatidae ......................... 111

Family Ardeidae ............................ 113

Family Cochlearildae ..................... 128

Family Ciconiidae .......................... 129

Family Threskiornithidae ................... 131

Family Phoenicopteridae ..................... 133

Family Anatidae .......................... 135

Family Cathartidae ......................... 148

Family Accipitridae ....................... 153

Family Pandionidae ......................... 195

Family Falconidae .......................... 197

Family Cracidae ........................... 209

Family phasianidae ....................... 215

Family Aramidae ......................... 229

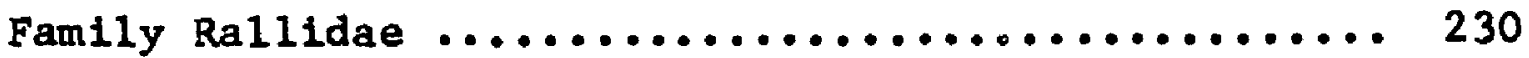

Family Heliornithidae ....................... 240

Family Eurypygidae ......................... 241 
Family Jacanidae ............................ 242

Family Haematopodidae ....................... 243

Family Charadrildae ........................... 244

Family scolopacidae ........................ 249

Family Recurvirostridae .................... 267

Fanily Phalaropodidae ....................... 268

Family Burhinidae ........................ 270

Family Laridat ............................ 271

Family Rynchopidae ........................ 280

Family Columbidae ......................... 281

Family Psittacidae ........................ 304

Family Cuculidae ........................ 326

Family Tytonidae ........................ 338

Family strigidae ......................... 340

Family Nyctibildae ....................... 352

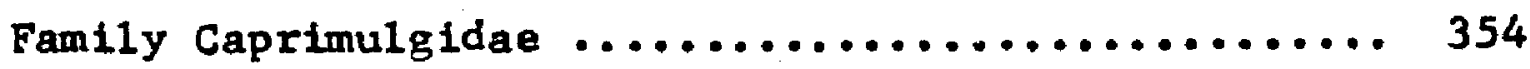

Family Apodidae ......................... 365

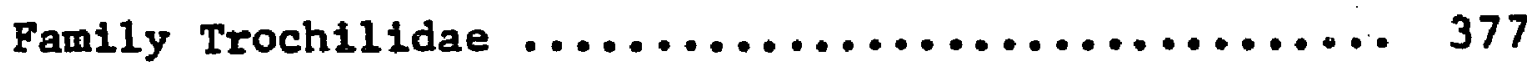

Fanily Trogonidae ........................ 423

Family Alcedinidae ........................ 433

Family Momotidae .......................... 439

Family Galbulidae ........................... 446

Family Bucconidae ......................... 447

Family Ramphastidae ........................ 450

Family Plcidae ........................... 456

Family Dendrocolaptidae ..................... 483 
PAGE

Family Furnariidae ........................... 499

Family Formicarildae ..................... 510

Family Pipridae ........................... 528

Family Cotingidae ......................... 534

Family Tyrannidae ......................... 549

Family Hirundintdae ....................... 611

Family Corvidae ........................... 622

Family Certhildae ....................... 633

Family Cinclidae ......................... 635

Family Troglodytidae ...................... 635

Family Mimidae ............................... 657

Family Turdidae .......................... 663

Fanily sylvildae ........................... 684

Family Motacillidae ........................ 688

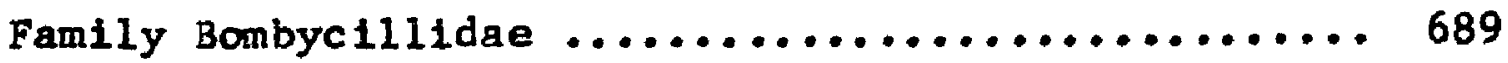

Family Cyclarhidae ......................... 690

Family vireolanildae ........................ 692

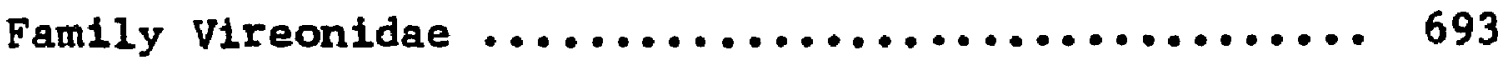

Family Coerebidae .......................... 706

Family Parulidae .......................... 711

Family Icteridae ............................ 764

Family Thraupidae ......................... 787

Family Fringillidae ....................... 815

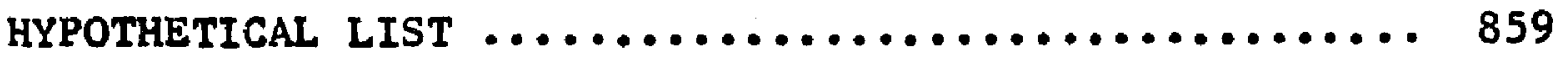

MIGRATION IN HONDURAS ......................... 869 
ANALYSIS OF THE AVIFAUNA .................... 881

SUMMARY AND CONCLUSIONS ......................... . . . 924

GAZETEER OF LOCALITIES ........................ 930

LITERATURE CITED ............................. 974

BIOGRAPHY ............................... 1014 


\section{LIST OF TABLES}

TABLE

PAGE

I. Average Monthly Rainfal1 in Inches in the C1imatological Zones of Honduras ....... 34

II. Mean Monthly Atmospheric Relative Hunidities

in Per Cent for Stations in Honduras .... 35

III. Mean Monthly Atmospheric Temperatures in

Degrees Fahrenheit for stations in

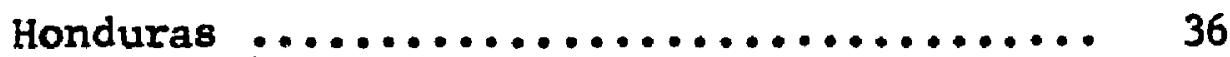

IV. Day by Day Itinerary of Major LSUMZ Honduran Expedition, 2 August 1962 to 13 May

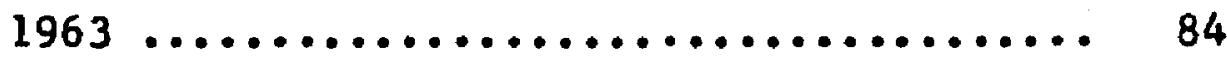

V. Key to Numbered Localities Appearing in

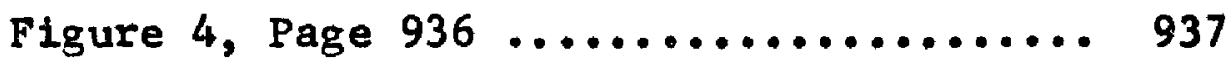




\section{LIST OF FIGURES}

FIGURE

PAGE

1. Alluvial and Terrace Plains of Honduras ..... 22

2. C1Imatological Zones of Honduras ........... 31

3. Distribution of the Major Habitats in

Honduras $\ldots \ldots \ldots \ldots \ldots \ldots \ldots \ldots \ldots \ldots \ldots . \ldots . \ldots . \ldots 4$

4. Map Showing Honduran Departments and Selected

Collecting Localities ................ 936

5. Map of Physiographic Features of Honduras ... 940 


\section{ABSTRACT}

The purpose of this distributional survey is to analyse the composition of the avifauna of Honduras, with specific emphasis on the distribution of birds within the country, geographically and ecologically as well as seasonally, and on geographic variation within each species. Honduras was selected as the country of study since at the time of the inception of this work in 1958, this repub11c was the only one in Central America for which no distributional survey had been published or was in progress.

Since the appearance of Eisemmann's The Specles of Middle American Birds in 1955, which presented ranges of all species that occur in Mexico and Central America and which 1 lsted 585 species from Honduras, 958 pecles have been added to this total and 10 of the 585 removed, the lacter 10 being based on errors or on doubtful records. Thus 670 species are treated in the present work as comprising the known avifauna of the country.

General physiography, geology, soil, climate, and habitats in Honduras are discussed in relation to bird distribution. The occurrence of species of birds in the republic is analysed by habltat. A history of omithological research in Honduras is presented, as well as a 
gazeteer of all localities mentioned in the ornithological 1iterature or on specimen labels. The Literature Cited chapter is basically a bibllography of Honduran ornithology. Migrational movements of Honduran species are discussed. Of the 670 species occurring in the country, 178 are known to be migratory. Six spectes and two subspectes of other species are summer residents only in Honduras, wintering to the south of the republic. The remaining migrants are transient through the country or are visitants, including at least one that migrates north from South America during the Southern Hemisphere winter.

There is a separate account for each of the 670 species. More than 17,000 Honduran specimens, including more than 2,000 obtzined by expeditions originating from the Louisiana State University Museum of Zoology, were examined during this study and are 118 ted in the species accounts. A sumary of all pertinent published data is presented. In the text of each species account, information is given concerning the Honduran status of the species, relative abundance, seasonal occurrence, habitat preference, altitudinal range, geographic distribution within the republic, additional specimen and breeding data of importance, taxonomic problems, and geographic and subspecific variation. 
INTRODUCTION

In 1958, when I undertook the present study of the distribution of the birds of Honduras, this country was the only one of the Central American republics for which there was no comprehensive ornithological work either in print or in preparation. Distributional surveys have been published for Guatemala (Griscom, 1932b), El Salvador (Dickey and van Rossem, 1938; Rand and Traylor, 1954), British Honduras (Russe11, 1964), and Costa Rica (Carriker, 1910; Slud, 1964). Work is in progress on similar ornithological surveys of Nicaragua (by Thomas R. Howell) and of Panama (by Alexander Wetmore), and another study of Guatemala (by Hugh C. Land) is also being prepared. Prior to the present Honduran study, only a single publication has appeared that dealt exclusively with the entire Honduran avifauna as such, an annotated 1 ist by Stone (1932) that treated 420 forms representing 410 species.

The country has certainly been one of the most neglected of the Central American republics from a zoological aspect, despite the fact that it is zoogeographically one of the most important. Honduras supports a known avifauna of 670 species, exceeding that of any of the adjacent countries. Its geographic position with relation to the origin 
of Central American bird life and to the current distribution of the avifauna of this region is one of considerable significance. Parts of the Honduran interior have been above the surface of the sea since Paleozoic times and at periods during the Cenozolc have been isolated from either North or South America or from both; this region today forms a more or less continuous highland area from Chiapas, Mexico, to northern Nicaragua. Such a geographic history no doubt influenced the development and evolution of bird forms in this region.

At the present time, Honduras is ornithologically important in several ways. The vast expanse of lowland rain forest in southern Central America becomes constricted and broken up in northern and eastern Honduras, thus forming the first partial barrier to continuous distribution of rain forest inhabitants north of Panama. Honduras and northern Nicaragua form the southern boundary of the extent of pine in this hemisphere, both in the interior highland pine regions and in the lowland pine savanna of the Mosquitia. The Honduras Depression, the lowest point along the Continental Divide between Chiapas and Nicaragua, forms a corridor for passage of arid Pacific lowland forms to the arid interior valleys on the Caribbean drainage. Both Caribbean and Pacific slopes of Honduras are major avenues of flight for passage of North American migrants to and from their wintering grounds to the south. The islands off the north 
coast of Honduras are noteworthy for the strong Caribbean and Yucatán elements of the avifauna, despite their relative isolation from these regions and their close proximity to the Honduran mainland. It seems apparent, therefore, that a study of bird distribution in Honduras is essential to an understanding of the ornithogeography of Central America. The present work, along with other studies in progress in Nicaragua and Panama, is designed to complete the surveys of bird distribution in Central America.

The most recently published check-1ist that specifically listed species of birds recorded from Honduras was that of Eisemmann (1955a). He recorded 575 species from Honduras that I regard as being based on reliable records and another 10 (Eudocimus ruber, Hoploxypterus cayanus, Thalasseus elegans, I. Sandvicensis, Otus cooperi, Amazilia microrhyncha, Empidonax difficilis, Vireo altiloquus, Basileuterus rufifrons, and Tanagre minuta) that I consider to be the result of errors or at least to be of doubtful occurrence in the country. In addition, he inadvertently omitted Mimocichla plumbea, a species recorded from the Swan Is lands. In the subsequent 1 ists in this chapter, any references to Honduran records published since Eisemann's list are indicated in parentheses following the spectes involved.

In the course of examination of the extensive Honduran collections of C. F. Underwood, I found specimens of 20 
species that were not Iisted for Honduras by Eisenmann; of these only the record of Spodiornis rusticus has been published. A number of these species have been taken or reported subsequently by other ornithologists, but the specimens in the Underwood collections constitute the first Honduran records for the following:

Haxpagus bidentatus

Accipiter striatus

Harpyhaliaetus solitarius

Falco detroleucus

Porzana carolina

Ereunetes maur1

Qtus choliba

Lophostrix cristata

Glaucidlum gnoma

Campylopterus curvipennis

Amazilia yucatanensis

Procnias tricarunculata

Tyrannus vociferans

Legatus leucophaius

Mylarchus cinerascens

Smaragdolanius pulchellus

Vireo bellii

Coereba Elaveola

Sporophila minuta

Spodiornis rusticus (Moore and Medina, 1957) 
In Eisenmann's 1ist, Honduras was not included in the range of the following two species recorded by Archie F. and Marjorie H. Carr:

\section{Ara ambigua}

Cypseloides rutilus (Carr and Dickinson, 1951)

Between 1947 and 1951, Arthur C. Twomey and his associate, Roland W. Hawkins, made several trips to Honduras. The following 10 species were obtained by them in Honduras and these records are published heretn for the first time, except where an earlier publication is indicated:

Agamia agami

Buteo brachyurus (Rand, 1960)

Leptotila jamaicensis

Amazona xantholora

Caprimulgus maculicaudus

Cypseloides cryptus (Eis enmann and Lehmann, 1962)

Hylophylax naevioides

Cistothorus platensis

Uropsila leucogastra

Amaurospiza concolor

From 1949 to the present time, the personnel at the Research Division of the United Fruit Company at La Lima have made ornithological records. Mark Trafton, Jr., took extensive notes and photographed or examined in the hand specimens of most of the rarities reported; all species in the following 1ist are based on his records except for 
Phoenicopterus ruber, Oporornis agilis, and Chondestes

grammacus. Several individuals of $\underline{\underline{P}}$. ruber were seen aíter a storm by a number of people who were not ornithologists; V. C. Dunlap reported $\underline{0}$. agilis; and Kenneth S. Hamilton obtained the specimen of $\mathrm{G}$. grammacus. Fourteen of the 24 species. in the following list are based entirely upon sight records and are marked with an asterisk (*); circumstances surrounding these sight records may be obtained by referring to the individual species accounts. These 24 species are:

Jabiru mycteria*

Plegadis chihi*

Phoentcopterus ruber*

Chen caerulescens

Anas cyanoptera

Aythya valisineria

Oxyura jamaicens is

Buteo swainsoni*

Harpla harpyia

Laterallus jamaicensis*

Micropalama himantopus

Recurvirostra americana

Steganopus tricolor

Lobipes lobatus

Hydroprogne caspia*

Sterna forsteri*

Sterna albifrons* 
Rynchops nigra*

Streptoprocne [semicollaris ?]* (see species account)

Threnetes ruckeri*

Dendroica auduboni*

Oporomis agilis*

Cardellina rubrifrons*

Chondestes grammacus

Thomas R. Howell and his assistant, J. G. Montrello, collected at Arenal in the olancho rain forest in January 1953 and January 1955; Montrello also worked at Arenal in January 1954 and collected along the Río Segovia in July 1954. This region was at that time considered to be in Nicaragua but has subsequently, by decision of the World Court, been located within the boundaries of Honduras. The following 13 species recorded by them are additions to the Honduran avifauna, those based on sight records being indicated by an asterisk (*):

Ortalis garrula

Laterallus melanophatus

Microchera albocoronata*

Monasa morphoeus

Deconychura longicauda (Howe11, 1956)

Cymbilatmus Iineatus

Dysithamnus striaticeps

Gra11aria fulviventris* 
Corapipo leucorrhoa

Mylozetetes granadens is

Cacicus uropygialis

Tanagra Lutelcapil1a*

Lanio leucothorax

Charles $\mathrm{H}$. Blake made a short visit to the Swan Is lands in November 1958 and added four species to the Honduran avifauna, all on the basis of sight records except for a specimen of passerculus sandwichensis, which has subsequently been lost. These four additions, a11 published by Bond (1959), are as follows:

Bubulcus ibis

Oxyura dominica

Anthus spinoletta

Passerculus sandwichensis

As a result of the ornithological explorations in Honduras by the Louisiana State University Museum of Zoology, 20 species were added to the Honduran 1ist. These records were made by Richard R. Graber, Jean W. Graber, J. Alan Feduccia, Rose S. Monroe, and me. In the following 1ist, those species based entirely on sight records are indicated by an asterisk (*):

Sula nebouxi1

Cathartes burrovianus

Elanus leucurus

Ictinia misisippiensis 
Accipiter cooperti*

Buteogallus subtilis

Haematopus palliatus

Charadrius alexandrinus

Heteroscelus incanus

Larus pipixcan

Gelochelidon nilotica

Nyctibius grandis*

Phaenostictus mcleannani

Piprites griseiceps

Notiochelidon pileata

Turdus rufitorques

Vireo gilvus

Vermivora pinus

Sicalis luteola

Almophila petenica

In addition to the above, we collected and preserved 13 additional species for which there were only previous sight records or photographs known from the country. These 13 species are as follows:

Bui ulcus is

Aythya affinis

Oxyura dominica

Totanus melanoleucus

Limnodromus griseus

Micropalama himantopus 
Steganopus tricolor

Lobipes lobatus

Sterna albifrons

Threnetes ruckeri

Dendroica auduboni

Cardelina rubrifrons

Dolichonyx oryzivorus

Chordeiles gundlachil has been raised to the rank of a full species since the appearance of Eisenmann's check-1ist and is a Honduran addition on the basis of an old specimen from the Swan Islands. I have also added Anas platyrhynchos on the basis of reports from a number of hunters although there are no records by ornithologists. These last two species bring the total to 670 for the current known avifauna of Honduras.

I should like to point out at this time that when one is working an area of this size, a distributional survey is never really complete. Despite the amount of work that has been conducted in Honduras, it is still the least known of the Central American republics. More than half the country is inaccessible except by boat or on foot and explorations of these areas have been 1imited. Collections have been made in the vast Olancho rain forest only on its periphery and in all probability at least 20 additional species that range well north into Nicaragua will eventually be found there. The high mountain ranges of the Cordillexa Nombre 
de Dios and the Sierra de Agalta, both relatively isolated ranges, have not been studied at the higher elevations; the Montaña La Esperanza, in a critical region of northeastern Honduras, has not been visited by an ornithologist. Additional study is needed in the pine savanna of the Mosquitia, in the mountains of extreme western Honduras (especially in winter), on the islands in the Bay of Fonseca, and in the Pacific lowlands in spring. I estimate that the Honduran avifauna comprises at least 710 species; the additions most probably will consist of species yet to be discovered in the Olancho and of North American migrants that are known to range south to Guatemala and El Salvador in winter. 
GENERAL PHYSIOGRAPHY

The republic of Honduras, with an area of 43,277 square miles, is the second largest of the Central American countries, being exceeded in size only by Nicaragua; Honduras is thus roughly equivalent in area to the state of Tennessee. There is a coastal region on both Caribbean and Pacific sides of Honduras, with a long north coast running generally west-east for at least $400 \mathrm{miles}$ and a restricted stretch of only about 75 miles along the Bay of Fonseca on the Pacific side (south coast). The country is bounded elsewhere by the republics of Guatemala (on the northwest), El Salvador (on the southwest), and Nicaragua (on the southeast), the boundary with the latter country stretching at least 350 miles from coast to cosst. This boundary on the Caribbean drainage, now determined to be the Rio Segovia (RIo Coco), was in dispute for many years and has only recently been settled by a decision of the World Court (Gavito, 1962: 10-12).

The Pacific coast of Honduras is restricted entirely to the shores of the Bay of Fonseca. The mouth of the bay is only 19 miles across from Punta Mala, El Salvador, to Punta Cosegülna, Nicaragua. There are also several large 1slands (belonging to El Salvador) lying in the bay just northeast 
of Punta Mala that further occlude the mouth of the bay. Honduras possesses two large islands, actually the remains of extinct volcanoes, which are situated well within the bay Itself; these two islands, Tigre and Zacate Grande, are four and seven miles in diameter and 2,500 and 2,250 feet in maximum elevation, respectively. In addition, Honduras claims a small group of rocky islets, known as the Los Farallones, located in the mouth of the bay five miles northwest of the Nicaraguan shore near Punta Cosegüina. In the Caribbean Sea off the north coast of central Honduras is sttuated the Bay Islands group consisting of three main islands and a number of lesser ones. The group is oriented more or less in a southwest-northeast direction and appears to represent, geologica11y, a continuation of the Sierra de Omoa of northwestern Honduras. The westernmost island, Utila, is the smallest of the three major is lands, measuring seven miles long by three miles wide and rising to a maximum elevation of only 290 feet; Utila is also the closest to the Honduran mainland, being located 20 miles north-northwest of La Ceiba. The center island of the group, Roatin, is the largest of the Bay Islands; it stretches some 30 miles in length but 18 only four miles in greatest width. The westermmost point of Roatain is 18 miles northeast of Utila and 29 miles from the nearest point on the mainland to the south; the center of Roatain is located almost due north of Balfate. Maximum elevation on 
Roatán is about 800 feet. At the extreme eastern tip of the 18 land is a shallow channel less than a mile wide separating Roatán from Santa Elena Island (two miles in diameter), and the latter in turn is within one mile of Barbareta, a small island about four by two miles in size, located just east of Santa Elena. The eastermost of the group, Guanaja Island, is also the most rugged, rising to a maximum elevation of 1,200 feet. It is approximately nine by four miles in size and is located 27 miles northnortheast of Puerto Castilla and 15 miles due east of Barbareta.

Only nine miles north of the mainland and $15 \mathrm{miles}$ northwest of Balfate are found the Cayos Cochinos, a small group of islands and cays. The two largest islands of the group, Big and Little Hog Lelands, are the only ones that are forested; they measure two miles and one mile in diameter, respectively, both rtsing to a maximum elevation of about 200 feet.

The Cayos Zapot11108 and the Swan Islands have at times been claimed by Honduras and have been mentioned in the ornithological 1iterature, particularly the Swan Islands group. The latter group, consisting of two main 1slands, the largest of which is only two miles long, is situated in the Caribbean Sea about 125 miles due north of the Laguna Caratasca and about 200 miles southwest of Grand Cayman, in the West Ind1es. The Cayos Zapotillos are the 
southernmost group of small cays located in the line of is lets of the coast of British Honduras and about $30 \mathrm{miles}$ northwest of Puerto Cortés.

The mainland of Honduras is primarily mountainous with narrow regions of coastal plains along both coasts. In a few places along the north coast, such as in the La Ceiba and Trujillo regions, the coastal plain is constricted to a few miles in width by the mountain ranges just inland. The coastal plains penetrate inland on the Caribbean slope up the valleys of the Ulía, Chamelecón, and Aguán rivers. In the eastern fourth of the country, the Patuca and Segovia rivers have built up a broad alluvial plain, the expanse of which exceeds all other lowland regions of Honduras conbined. This lowland region, generally referred to as the Mosquitia, passes gradually into the higher elevations to the southwest in the eastern parts of 01ancho. On the Pacific coast, the coastal plain extends inland along the Goascorán, Pespire, and Choluteca rivers, reaching its maximum extent into the interior in the valley of the latter. The interior mountainous or serranfa region is a mass of mountain ranges broken up by scattered arid valleys. The mountains fall into three general categorles: the Northern Cordillera, consisting of the Sierra de Omoa, the Montafia del Tiburon, the Cordillera Nombre de D10s, and the Montafia La Esperanza; the Central or Southern Cordillera, which is made up of most of the remainder of the interior 
mountain ranges; and the Pactfic Colinas, a chain of volcanoes extending down the Pacific slope of northern Central America, in Honduras being represented only by the extinct volcanoes (Tigre and Zacate Grande islands) rising from the Bay of Fonseca.

In general, the mountains of Honduras do not approach the maximum elevations reached in Guatemala but do exceed those of northern Nicaragua by a considerable margin. While Guatemalan peaks may top 11,000 feet, in Honduras the maximum elevation attained in the Sierra de Celaque of the Department of Lempira is 9,400 feet. The 1solated mountain Cerro Santa Bárbara, located on the western side of "Lake Yojoa, reaches 9,300 feet elevation. Heights of 8,000 feet are exceeded in parts of the Cordillera de Merendón along the El Salvador border, in the Sierra de Agalta of Olancho, and by a few peaks in the Cordillera Nombre de Dios Just inland from La Ceiba. Elevations in excess of 6,000 feet, which is about the average maximum in parts of northern Nicaragua, are common throughout most mountain ranges in Honduras.

As previous Iy mentioned, the mountains of Honduras are greatly broken up by numerous valleys and canyons. In several places the Continental Divide is bridged by regions of relatively low elevation. The Honduras Depression, which connects the Comayagua Valley with the valley of the Río Goascorán, reaches a maximum elevation of only 2,850 
feet and is thus the lowest point along the Continental Divide anywhere between the Isthmus of Tehuantepec in southern Mexico and central Nicaragua. Two other points along the divide do not exceed 3,500 feet elevation; one joins a tributary of the Rio Lempa in the Department of La Paz with the Otoro Valley and the other connects a tributary of the Rio Choluteca in the Department of E1 Paraiso with the upper reaches of the Rlo Guayambre.

Except for coastal lagoons, there is but a single lake of any significant size in the country. Lake Yojoa, a kidney-shaped body of water $18 \mathrm{miles}$ by five miles in $81 z e$, is located in west-central Honduras at an elevation of 2,050 feet. The lake 1s drained naturally at the southern end by the Río Jaitique, which eventually empties into the Río Ulua; the latter river, after a circuitous course, finaliy terminates on the north coast about 100 miles due north of the lake. The lake 18 also drained artificlally from the north end into the Rio Blanco through a recently built hydroelectric plant.

There are six major river systems draining the Caribbean slope of Honduras. The Chamelecón and U1 tia-HumuyaSulaco drainages, both systems with nearly confluent mouths in the Sula Valley, form the major drainage in the western third of Honduras north of the Continental Divide. The Aguán and Sico rivers are relatively short in length and drain the Aguán and Agalta valleys, respectively. The 
Patuca drainage, a complex river system formed in large part by the Guayambre, Guayape, and Jalán rivers in the upper reaches, covers a much greater area of the country than any other system; it drains most of Olancho and eastern E1 Paraiso as well as the central portion of the Nosquitia. The Rio Segovia forms the boundary between Honduras and Nicaragua but drains, for the most part, the mountainous areas of northern Nicaragua.

On the Pacific slope the largest river is the Rfo Choluteca, originating in the Tegucigalpa region. Just west of the preceding are the relatively short Pesplre and Goascorán rivers. The Río Lempa, a large river originating in eastern Guatemala and winding through much of E1 Salvador to empty into the Pacific Ocean on the coast of the latter, possesses a number of short tributaries that drain the narrow Pacific slope in the departments of Ocotepeque, Lempira, Intibucá, and La Paz. 


\section{GEOLOGY}

For the basic information utilized in the following discussion of the geology of Honduras, I have relled heavily upon Schuchert (1935), Bengston (1926), Sapper (1905), and Redfield (1923).

The interior highlands of Honduras are relatively ancient, being part of the Antillean Geanticline, a series of folds running west-east from southwestern Mexico through northern Central America out into the eastern Greater Antilles. There is some argument as to whether this geanticline is pre-Carbontferous or pre-Cambrian but, in any event, it certainly originated sometime prior to the Mesozolc. From an ornithological standpoint, we are not at all concerned with pre-Mesozoic events or, for practical purposes, with pre-Cenozolic ones; the most important consideration here is that part of Honduras dates back to the Paleozolc and has been above the sea since before the origin of birds.

The Sierra de Omoa, in northwestern Honduras, possesses a core of $\mathrm{Paleozo} i c$ crystalline metamorphic rocks, which reappear in the three main islands of the Bay Islands group. This situation, along with the general west-east itne of folding, seems to indicate that these islands are a 
continuation of the Sierra de Omoa. Farther to the northeast, In a general Iine with the Bay. Islands, the Swan Is lands may also represent this continuation, a supposition supported by the trend of submerged fault lines. The Swan Islands possess the topographic characteristics of a horst (a raised region separated from surrounding depressed areas by faults).

Just to the south of the Sierra de Omoa, the Cordillera de Merendón is composed primarily of Lower Cretaceous sedimentary rocks, with ancient crystallines forming but a small part. Most of the remaining ranges in the Northern Cordi1lera and in parts of the Southern Cordillera are overlain with late Mesozolc or very early Cenozoic rocks; Cretaceous or Eocene limestone is characteristic of these regions. South of the Mesozolc ranges, late igneous rocks of Pliocene (or possibly earlier) origin form the principal part of the Southern Cordillera from southern Guatemala to northern Nicaragua. In northern 0lancho, the mountains are composed primarily of granite of Paleozolc origin.

The coastal plains on both Caribbean and Pacific coasts are generally covered with horizontal marine Pleistocene sediments. These recent alluvial areas are most extensive In the Mosquitia (see Figure 1). Pliocene fresh-water deposits have been reported from the Department of Gracias [=Lempira] by Olson and McGrew (1941), and Eocene and PIIocene sediments have been recorded from the valley of the Rio 
Figure 1. Alluvial and terrace plains of Honduras. (After Bengston, 1926). 


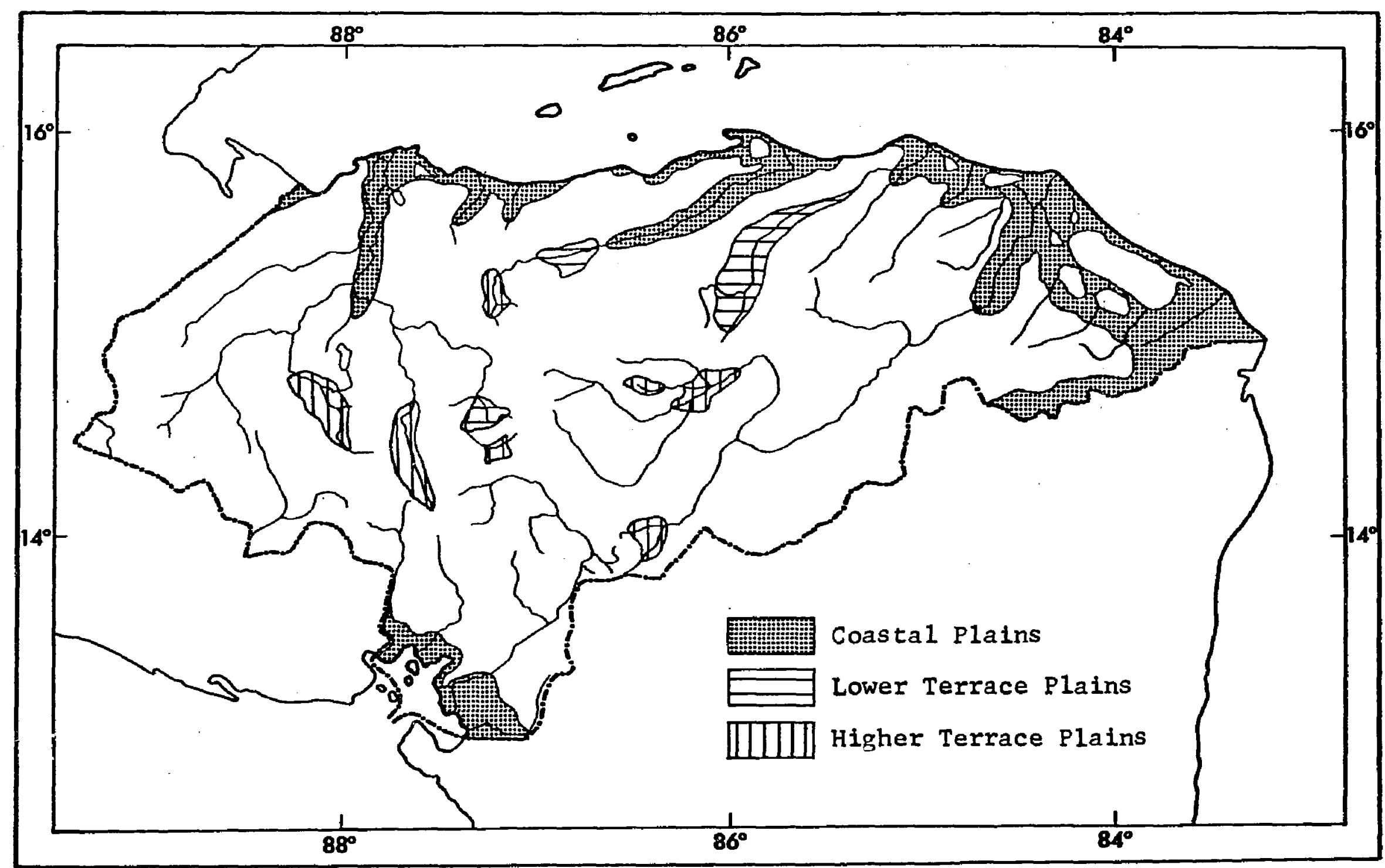


Segovia. Lower Miocene strata are known from northwestern Honduras but not elsewhere in the country.

The mountainous interior of Honduras is disrupted by the presence of the Honduras Depression, a low transverse structural graben valley, produced in middle Tertiary by north-south faulting. This valley connects the Comayagua Valley with the valley of the Rio Goascorán and, as previously mentioned, forms the lowest point along the Continental Divide in northern Central America.

According to Bengston (1926), there are two chief terrace plains in the Honduran interior, the lower ranging from 300 to 1,000 feet in elevation, the higher from 2,000 to 2,400 feet (see Figure 1). These terraces may be noted along stream borders in the serrania region and are actually the remnants of terraces formed either when land levels were lower than at present or before erosion had incised into the uplands sufficiently to drain the high structural valleys of that time. Most prominent of the higher terrace plains are the Otoro, Comayagua, Olancho, and Jamastrán valleys, and the plains around Talanga and around the town of Yoro. The lower terrace plains are present in the Aguán and Agalta valleys and in the region of the upper reaches of the Rfo Sulaco.

Bengston (1926) also recognized two old peneplains in the uplands, the lower lying between 2,500 and 3,000 feet, the upper between 3,300 and 4,500 feet. The lower 
peneplain is most evident in the region between Tegucigalpa and Sabana Grande and in the area around Yuscarán, but in most areas it hes been so severely dissected and the present relief is so great that the region appears mountainous. The upper peneplain may be recognized as that from which the mountains to the north and northeast of Tegucigalpa and those of the Sierra de Opalaca arise.

According to Schuchert (1935), the ancient Honduran interior has at times been separated from North or South America (or from both) by water barriers across Tehuantepec or somewhere between southern Nicaragua and northern Colombia. His diagrams of the distribution of land and sea during various periods indicate the following patterns: 1) extensively above the sea during most of the Mesozoic until late Cretaceous, the old Antillean Geanticline area connected Honduras and the West Indies (Ant1llea) but was isolated from both North and South America, while in Upper Cretaceous, Middle America was broadly connected with both North and South America as well as with Antillea; 2) a Nicaraguan water barrier was formed in the 0ligocene with a secondary Panamanian water barrler appearing in Upper 0ligocene as well as a separation of Antillea from Middie America at about this time; 3) in Miocene and Lower Pliocene, the Tehuantepec water barrier was present but connections with Antillea and South America were re-established; and 4) from Upper Pliocene to the present, continental connections have 
been much as they are today, although the variation in the sea level during glacial pertods has changed the continental outlines considerably.

We can now summarize the geological events that are of importance with regard to bird origins in northern Middle America and to the study of present bird distribution in this region. Factors of primary 81 ignificance are as follows: 1) the ancient Paleozoic mountalnous interior has been above the sea since before the origin of birds; 2) from Cretaceous to, at least P1iocene times, water barriers, as well as concoraitant connections between Honduras and Antillea, were present, these barrlers being either north or south of Honduras or on both sldes, in the latter case formIng a Middle American island; 3) there was extensive vulcanism during both Eocene and Pliocene; 4) general uplifting terminated in Miocene or P1locene, with minor uplifts occurring later to produce terrace systems; 5) faulting during early and middle Tertiary produced graben . valleys; and 6) sea levels (along with climatological changes) fluctuated considerably during the Pleistocene periods of glaciation. 
SOILS

Although there has been very little detalled work done on the solls of Honduras, data are sufficient to glve a general picture of sotl conditions throughout the greater part of the country. Both Carr (1950: 573-575) and Wise (1958: 10-17) presented summarles of Honduran soils, from which much of the following account is taken.

Most of the Honduran sol1s have been formed from types of bedrock that yield poor soil-bullding materials. Weathering of underlying strata over long periods of time has produced both residual and alluvial soils in the mountains while secondary deposition of soils transported by rivers has left old alluvial soils on the upland plains and interior valleys and has formed either old or recent alluvial soils in the lowlands and along the rivers. In areas where man has discupted the natural vegetation, erosion has been greatly accelerated; nowhere is this more evident than in parts of Honduras.

In regions of high rainfall along the north coast, residual soils are mainly deep in extent and red (occasionally black) in color, in contrast to the recent alluvial 80ils, which are usually brown or grayish. In more arid reglons, most of the alluvial soils in the valleys are gray 
to black when wet and grayish to white when dry. Sandy loams and silty clays are common in valleys and plains, where some heavier soils might be expected.

In the Interior highlands, where soils have developed under arid or semihumid conditions, two distinct types are found. On granite and limestone occurs a moderately fertile brown clay loam that may support a deciduous forest or a broad-leaved oak association, while on the acidic rocks of volcanic origin are found dark gray to black solls that will support only grasslands or pine. On the Pacific slope acidic tuffs and other, older metamorphosed volcanics have given rise to shallow black clay solls that are relatively infertile, supporting at best a growth of pine.

Under more humid conditions in the mountains may be found slightly more fertile brown to reddish brown loams containing considerable organic matter. According to Wise (1958), however, alluvial solls in these regions tend also to be relatively infertile.

The alluvial soils of the Interior valleys are usually sandy or silty loams, blackish gray to graylsh white in color, and very friable when molst but hard when dry. There is considerable variation in these soils; when the clay content is low, there is generally some sort of xeric vegetation or deciduous forest present thereon, while a hard clay pan usually supports only some sort of savanna growth. Most of these valley solls are very poor in nitrogen and 
humus content and are mostly acidic, although the $\mathrm{pH}$ ranges from 6.0 to 8.0 .

Soils of the Pacific coastal plains are, for the most part, shallow, sandy, and infertile. They tend to become extremely wet and marshy during the rainy season but dry out and crack deeply during the dry season. The vegetation is generally of a xeric or savanna type, with characteristic stands of 1icaro (Crescentia alata) frequently present. The recent alluvial soils along the river banks on the Caribbean drainage and in the flood plains built by the rivers are generally both good and friable loams, with a fairly 1ight texture and deep profile; humus content is very high in areas of forest but may be low elsewhere, with a correspondingly low nitrogen content. The $\mathrm{pH}$ varles considerably from place to place, being mostly alkaline (ranging from 5.5 to 7.8 ) in the Sula Valley but slightly acidic $(6.2$ to 6.9$)$ in the Tela region.

The relatively older alluvial soils of the Mosquitia in eastern Honduras are very different from those elsewhere in areas of high rainfall. These solls have become extremely Impoverished and are now 1ight yellowish, very acidic, and greatly leached. At the present time, these solls support a short-grass savanna with scattered pine. 


\section{CLIMATE}

The climate of Honduras is, of course, basically tropical, with freezing temperatures and frosts occurring only on rare occasions in the higher mountains in the western part of the country. Under the Köppen system of climate classification, only two major divisions of climate may be recognized in Honduras. Tropical ralny climates (designated by "A" in the Köppen system) of several types occur; in this category the average monthly temperature always exceeds $64.4^{\circ} \mathrm{F} .\left(18^{\circ} \mathrm{C}.\right)$, there is no winter season, and the annual rainfall is heavy and always exceeds potential evaporation. Of the dry climates (designated by "B"), in which potential evaporation during the year exceeds precipitation and there is no water surplus (hence no permanent 8 treans originatixig therein), only the tropical steppe or semiarid climate ("BS") is recognizable in Honduras, although there are a number of variations within this type.

Three subdivisions of the tropical rainy climates may be seen in Honduras. Tropical rain forest climate ("Af") has adequate precipitation in all months (more than 3.94 inches) and lacks the dry season; this type of climate occurs only in scattered areas of zones 1 and 2 (see Figure 
Figure 2. Climatological zones of Honduras. (Adapted from Wise, 1958.) 


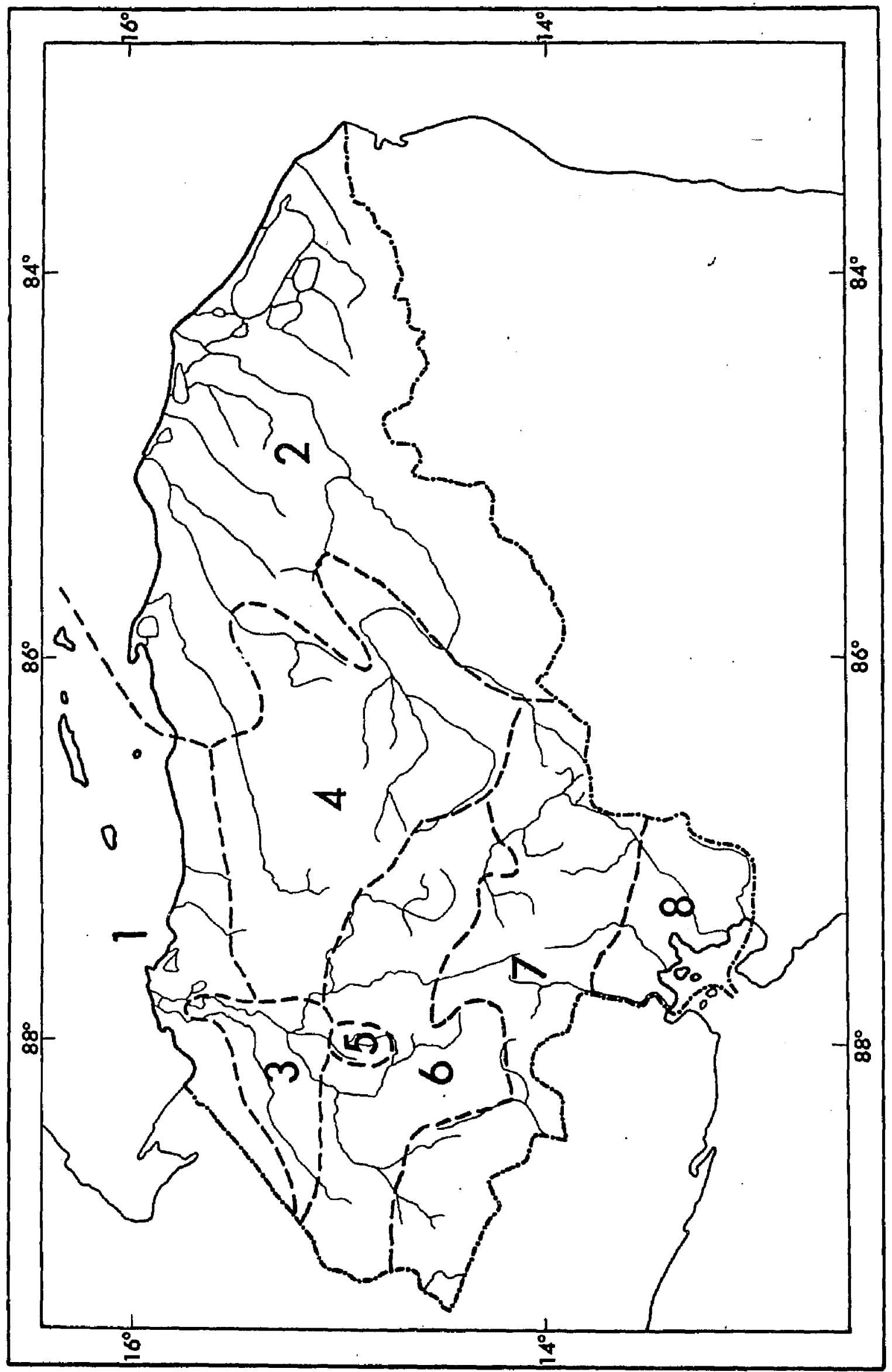


2). Tropical savanna climate ("Aw") has a mild dry season during the winter months but there are no very dry months (with precipitation less than 2.36 inches). The third subdivision, tropical monsoon climate ("Am"), has adequate rainfall but a definite monsoonal cycle with a short but marked dry season.

The basic variations in climate in Honduras are produced by the wind patterns. The country is located in the transitional area between the two major air masses that affect weather in the northern tropics. As the doldrums shift seasonally north and south, Honduras is subjected alternately to dry, tropical air (November through Apri1) and molst, equatorial atr (May through October). Although the prevailing winds remain generally northeasterly throughout the year (on the Caribbean slope, at least), this change in moisture content of the air produces the wet (inviermo) and dry (verano) seasons that occur throughout most of the country. Only portions of the Caribbean coastal region and certain areas of cloud and montane rain forests on the windward slopes of the interior mountains remain more or less unaffected by the Honduran dxy season.

The northeast trades are generally strong enough to continue to the Pacific slope but becone virtually devold of molsture by losing most or all of it in transit through the mountainous interior. However, from May to October, and especially in September and October, a deflected southeast 
tradewind, blowing from a generally southwesterly direction, brings considerable precipitation to the south coast. Thus the Pacific coastal regions are subjected to the greatest extremes in conditions during the wet-dry cycle that may be found in Honduras (see Table I).

In the winter months from November to February, a few cold fronts (northers) manage to penetrate as far as the north coast of Honduras, generally producing several days of overcast skies and moderately heavy rainfall but not lowering temperatures to any great extent. The north coast is also subjected to hurricanes between June and October, but these storms are infrequent in Honduras, primarily because of the low latitude and the west-east orientation of the north coast; hurricanes are much more 11kely to strike the north-south coast of British Honduras.

Rainfall and humidity data for Honduras, presented in Tables I and II, respectively, were obtained from Wise (1958). The climatological zones of Honduras, as depicted in Figure 2, were also based on Wise. It may be seen by comparison of Table $I$ and Figure 2 that zones 1 and 2 are basically of the tropical rain forest climate (locally) and of tropical savanna climate, although the months of March and April sometimes fall slightly below the minimum requirement of the 1atter. Zones 3, 4, and 5 exh1bit typ1cally a tropical monsoon climate; it is interesting to note that zone 5 (the Lake Yojoa region) has the highest rainfall 


\begin{tabular}{|c|c|c|c|c|c|c|c|c|}
\hline ZONE: & 1 & 2 & 3 & 4 & 5 & 6 & 7 & 8 \\
\hline Number of stations.......... & 8 & 4 & 13 & 9 & 6 & 16 & 23 & 6 \\
\hline Annual rainfall............ & 105.1 & 104.8 & 60.5 & 52.4 & 111.4 & 57.3 & 42.8 & 65.1 \\
\hline January.................. & 9.8 & 9.5 & 3.4 & 2.0 & 3.5 & 1.0 & 0.4 & 0.1 \\
\hline February ................. & 5.6 & 4.6 & 2.0 & 1.2 & 2.4 & 0.7 & 0.4 & 0.2 \\
\hline March................................. & 3.8 & 2.9 & 1.5 & 0.7 & 1.8 & 0.7 & 0.4 & 0.4 \\
\hline Apri1_................. & 3.6 & 3.3 & 1.4 & 1.1 & 1.9 & 1.4 & 1.2 & 1.2 \\
\hline May.................................. & 4.1 & 5.4 & 4.0 & 4.9 & 8.6 & 5.4 & 5.8 & 10.0 \\
\hline June.................... & 5.6 & 7.3 & 6.7 & 7.8 & 15.9 & 11.1 & 8.3 & 11.3 \\
\hline July............. & 7.9 & 9.0 & 6.9 & 7.6 & 16.4 & 8.1 & 5.4 & 5.8 \\
\hline August........................ & 8.8 & 6.7 & 6.0 & 5.6 & 19.5 & 7.2 & 4.4 & 7.1 \\
\hline 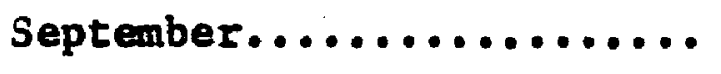 & 8.0 & 7.3 & 7.8 & 6.6 & 18.4 & 11.1 & 8.7 & 16.9 \\
\hline 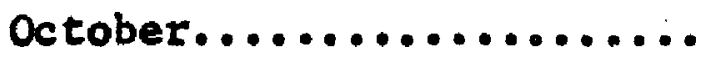 & 15.3 & 16.0 & 7.8 & 7.5 & 11.2 & 6.7 & 5.8 & 10.7 \\
\hline November.......................... & 17.5 & 19.3 & 7.4 & 4.1 & 5.9 & 2.1 & 1.3 & 1.2 \\
\hline December & 14.8 & 13.5 & 5.6 & 3.3 & 5.9 & 1.2 & 0.7 & 0.2 \\
\hline
\end{tabular}

TABLE I. Average monthly rainfall in inches in the climatological zones of Honduras (see Figure 2). (After Wise, 1958.) 


\begin{tabular}{lllllllllllllll}
\hline Amapala............ & 4 & 66 & 56 & 55 & 54 & 59 & 69 & 73 & 70 & 69 & 79 & 80 & 68 & 61 \\
Catacama........... & 4 & 74 & 74 & 68 & 64 & 61 & 67 & 76 & 81 & 80 & 78 & 81 & 77 & 78 \\
La Ceiba........... 6 & 74 & 76 & 73 & 71 & 70 & 72 & 73 & 72 & 71 & 73 & 77 & 77 & 78 \\
Comayagua.......... 4 & 71 & 72 & 65 & 57 & 60 & 70 & 73 & 75 & 72 & 75 & 77 & 77 & 77 \\
Guanaja............ 5 & 78 & 78 & 79 & 77 & 75 & 77 & 79 & 80 & 77 & 76 & 82 & 80 & 81 \\
San Pedro Sula...... 5 & 75 & 77 & 75 & 69 & 67 & 68 & 75 & 77 & 76 & 76 & 84 & 81 & 81 \\
Santa Rosa de Copán.. 5 & 78 & 81 & 75 & 69 & 64 & 71 & 78 & 79 & 78 & 81 & 86 & 85 & 85 \\
Tegucigalpa.........12 & 72 & 73 & 67 & 61 & 60 & 67 & 77 & 76 & 74 & 79 & 80 & 78 & 76 \\
Tela............... 8 & 83 & 84 & 83 & 81 & 81 & 81 & 81 & 82 & 82 & 82 & 84 & 86 & 87
\end{tabular}

TABLE II. Mean monthly atmospheric relative humidities in per cent for stations in Honduras. First column: number of years data recorded from each station. Second column: mean annual relative humidity at each station. Tegucigalpa readings were taken at the Toncontin alxport. (After Wise, 1958.) 
Amapala........... 883.482 .784 .485 .987 .584 .981 .282 .984 .081 .680 .881 .982 .6 Catacamas.........6 $675.871 .172 .975 .678 .579 .678 .376 .076 .7 \quad 78.076 .7 \quad 74.272 .2$ La Celba..........31 78.6 74.3 74.778 .678 .780 .680 .981 .181 .782 .379 .076 .674 .8 Comayagua......... $8 \quad 73.8 \quad 67.1 \quad 70.0 \quad 74.0 \quad 77.3 \quad 77.6 \quad 76.2 \quad 75.7 \quad 77.0 \quad 74.0 \quad 74.6 \quad 70.5 \quad 71.8$ La Esperanza........ $6 \quad 63.8 \quad 57.860 .163 .3 \quad 65.6 \quad 65.3 \quad 66.164 .765 .464 .765 .6 \quad 62.2 \quad 57.6$ Guanaja.......... $881.1 \quad 77.2 \quad 78.280 .181 .882 .783 .282 .183 .484 .081 .580 .2 \quad 77.7$ Nueva Ocotepeque.... $8 \quad 8 \quad 75.972 .2 \quad 73.477 .1 \quad 79.0 \quad 77.8 \quad 76.7 \quad 75.977 .2 \quad 75.7 \quad 74.8 \quad 74.2 \quad 71.7$

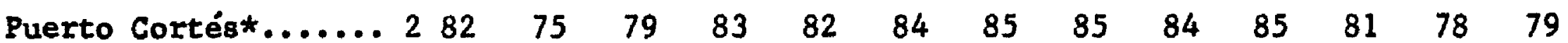
San Pedro Sula......27 $78.873 .5 \quad 75.278 .781 .2 \quad 82.2 \quad 82.3 \quad 80.5 \quad 81.181 .678 .6 \quad 76.8 \quad 74.2$ Santa Rosa de Copán.. $867.962 .764 .568 .171 .471 .371 .269 .7 \quad 70.270 .067 .865 .362 .9$ Teguc 1galpa........20 71.3 $66.5 \quad 68.671 .273 .874 .8 \quad 73.473 .073 .273 .271 .5 \quad 69.167 .7$ Tela.............20 78.273 .974 .677 .279 .280 .381 .280 .480 .681 .379 .076 .274 .4 Yoro*............ $4 \begin{array}{lllllllllllll}77 & 72 & 73 & 79 & 82 & 82 & 81 & 77 & 79 & 79 & 75 & 74 & 75\end{array}$ Zambrano*

$\begin{array}{lllllllllll}63 & 66 & 68 & 68 & 70 & 68 & 68 & 68 & 67 & 65 & 64\end{array}$

TABLE III. Mean monthly atmospheric temperatures in degrees Fahrenheit for stations in Honduras. First column: number of years data recorded from each station. Second column: mean annual temperature at each station. Information for stations marked with an asterisk $(*)$ taken from Wise (1958); other data from Wernstedt (1961). 
in the country despite a marked dry season. Zones 6, 7, and 8 exhibit a dry climate, although the monsoonal effect is most prominent in zone 8 , which probably should be classified as a tropical monsoon climate despite the long dry season.

Temperatures in Honduras range from those that are decidedly tropical along the coasts to those that are moderately temperate in the intertor highlands. At a single locality, however, there is generally little annual fluctuation in monthly mean temperatures (see Table III). The lowest monthly mean temperature that has been recorded is $57.6^{\circ} \mathrm{F}$. For the month of December at La Esperanza; the highest is $87.5^{\circ} \mathrm{F}$. for Apr1l at Amapala. Data for Table III were taken from Wise (1958) and Wernstedt (1961). 
HABITATS

The choice of a system for the allocation of animal species into the array of ecological situations that exist in any geographical region is a decided problem for the 200geographer. Many such systems, some based entirely on climatological data, others on actual plant-antmal assoctattons, are avatlable for use. In certain instances one method of characterization of reglons is superior to another, while in a different area this same system is not as satisfactory. For example, Slud (1964) has employed the 1ife-zone (formation) in his study of the avifauna of Costa Rica. This classification, developed by Holdridge (1947), is based entirely on climatological data (primarily temperature and rainfall) and does not take into consideration any edaphic factors or other conditions that may result in entirely different plant-animal associations within the same life-zone (formation). The great advantage of this system is that it may be applied to any region in the world and thus widely separated areas may be compared; furthermore, regions may be placed in a life-zone (formation) through knowledge only of the temperature and rainfall, without the necessity of actually studying the region itself. In Costa Rica this system is satisfactory from an avifaunal 
standpoint since, although each life-zone (formation) may consist of several edaphic associations, there are fairly well-defined regions corresponding to life-zones (formations) that have characteristic avifaunas. Unfortunately, the system is not nearly so desirable for characterization of regions in Honduras. This situation is due in large part to the peculiar lowland pine savanna of the Mosquitia, a disclimax of some sort in a region of high temperature and high rainfall that should produce and support a "tropical moist forest," $1 . \underline{e} \cdot$, a rain forest in the broad sense. A Holdridge map of Honduras shows this region in the tropical moist forest life-zone (formation), as dictated by the climate, despite the known presence of this pine savanna habitat that would normally be representative of more arid regions. Furthermore, the Holdridge system does not take into consideration the seasonal distribution of rainfall, which has a profound effect on the vegetation. Thus I have found this system very difficult to utilize for classification of Honduran birds into satisfactory zonal categories. Both Griscom (1932b) and Dickey and van Rossem (1938), in their respective treatises on the bird iffe of Guatemala and El Salvador, employed a modification of Merriam's life zone concept in their studies. Since the life zones are also based primarily on climatological data, the same disadvantage exists here as in the case of the Holdridge system. 
I have decided that the most satisfactory procedure in the present work is to use a system of major habitat class 1fication for treatment of bird distribution in Honduras. This decision was prompted by the existence of an excellent outline for a classification of animal habitats in Honduras (Carr, 1950), which I have followed for the most part, with certain minor modifications. I must confess that my usage of habitats, especially my distinctions between them, is based largely on the avifauna; that is to say, if there are two different plant associations that are regarded as distinct habitats by Carr but which display no differences in avifauna, I have usually considered them under the same general habitat heading. In the discussion of the specific habitats considered in the present work, I have attempted to equate them as closely as possible to the life zones (as used by Griscom and by Dickey and van Rossem) and to the life-zones (formations) of Holdridge.

Current distribution of the major Honduran habitats is depicted on the habitat map (Figure 3). Information employed in construction of this map was drawn from various sources. The distribution of habitats in the eastern third of Honduras was based primarily on the work of Helbig (1959) and on personal aerial observations. Habitats in the remainder of the country were allocated on the basis of the work of Sapper (1902), of personal visits, of a study of recent aerial photographs, and of reference to a map 
Figure 3. Distribution of the major habitats in Honduras.

\section{Legend}

Tropical lowland rain forest

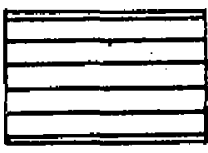

Tropical deciduous (monsoon) forest

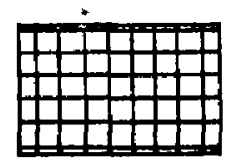

Cloud (montane rain) forest

$+++$

Arid (mixed) scrub and thorn forest

Highland pine (ocotal) and pine-oak assoctations (encinal-robledal)

TTT T T T Towland pine savanna

TTTTS

Marsh and swamp

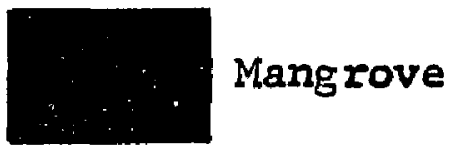




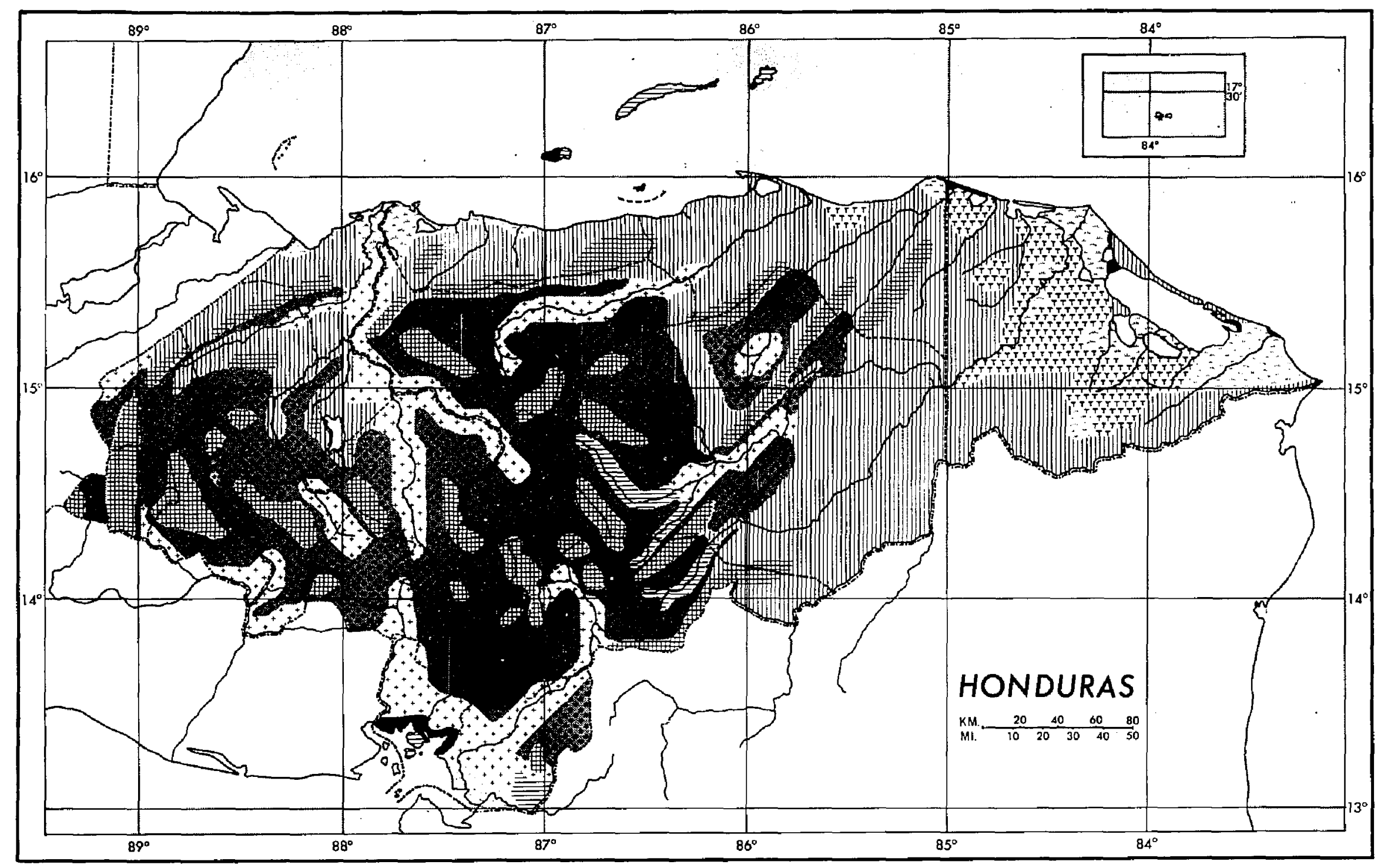


constructed by Hugh Popenoe of the University of Florida. Tropical lowland rain forest

I follow Carr in retention of the use of the term "rain forest" for the present habitat instead of restricting it to an extremely wet forest, as advocated by Holdridge. Rain forest, as here construed, is generally comparable to the Humid Lower Tropical Zone and to the Tropical moist forest 1ife-zone (formation) and in Honduras is confined to the Caribbean drainage. It is found in regtons having at least 80 inches of rainfall annually (with minimal seasonality in the precipitation cycle). The vegetation consists primarily of broadleaf evergreen trees with at most only a sattering of deciduous species. Carr (1950: 585-586) divides this habitat into several categories on the basis of successional stages, but I am here considering "rain forest" to be a single major habitat. While there is some variation in the avifauna within Carr's categories, the same basic bird species inhabit all or most of them. Where a bird is restricted or typical of a certain subdivision of rain forest habitat, the species account so indicates. The true primeval forest, generally considered to be a "virgin mesophytic climax," is termed selva by Carr. Dominant trees often exceed 200 feet in height and consist of a bewlldering array of species, very few of which exist in pure stands. In general, the upper canopy is continuous, 
trees are heavily buttressed, and the understory is relatively open. In areas that have been rendered semiopen, either by storms or by man, a successional stage in which the undergrowth is dense and the canopy incomplete occurs; this situation is referred to as "jungle."

A man-made situation brought about by clearing of rain forest lands had best be mentioned here also. An area that has been completely cleared of rain forest but has subsequently been permitted to return to forest passes initially through an association termed guamil. Guamil is a virtually impenetrable tangle of dense brush, saplings, and vines; brush-inhabiting and forest edge species of birds occur frequently in this situation. I should like to point out that guamiles also are found at higher elevations where cloud forests have been similarly cleared; the avifauna there is, of course, dertved from brush inhabitants and forest edge species typical of the particular elevation. In regions where the rainfall may not be sufficient to produce a rain forest but where the water table is relatively high, such as along rivers, a forest that is for all practical purposes a rain forest may appear; "gallery forest" of this type generally has the same avifauna as that of the rain forest although usually somewhat depauperate. Carr refers to this forest along the rivers as a "vega forest" and the term is so used in the present work. As Carr has pointed out, the vega forests are important as 
mesic highways since in many areas, fingers of the forest strips extend well into arid regions and, in some cases, even connect with cloud forest. Frequently the vega forests extend upstream along large rivers, originating in rain forest regions but gradually passing into a typical deciduous forest type farther inland. In such cases, rain forest inhabitants may be able to occupy deciduous forest during rainy seasons, retreating downstream into rain forest during dry seasons. Indeed, if one enters such a declduous forest in the rainy season, the general appearance of the flora and much of the fauna appears typical of humid rain forest. Typical rain forest, as defined in the present work, ranges altitudinally to an elevation of about 2,500 feet. At this point, in reglons where broadleaf evergreen forest is more or less continuous upwards to much higher elevations, one begins to notice a transition into cloud forest. Typical elements of the rain forest avifauna may thus range to elevations in excess of 5,000 feet, broadly overlapping with residents of the cloud forest. This phenomenon will be considered in more detail when the cloud forest habitat is discussed.

In most areas of the tropics throughout the world, the rain forest regions are being rapidly reduced by man. In certain parts of Honduras, rain forest has been dectmated, notably in the Quimistán Valley, in the lower Sula Valley, and in the region of the north coast from the Sula Valley 
east to Truj1110. Most of the vast expanse of the Olancho rain forest is virtually untouched and uninhabited by man except along the larger rivers and along the extreme western edge. I wish to point out also that the region indicated in rain forest in western Olancho between the Guayape and Aguán rivers is very poorly known and may not actually be in rain forest at the present time. Reglons along the upper reaches of the Guayape, Jalán, and Guayambre rivers, shown to be in "deciduous forest" on the map (Figure 3), are actually regions of extensive vega forests that are partially evergreen and partially deciduous but possess primarily a deciduous forest avifauna. Vega forests of the rain forest type exist along the lower reaches of the Chamelecón, Ulua, Aguán, and Guayape rivers, too narrow to be shown on the map.

Tropical deciduous (monsoon) forest

The "monsoon forest" of Carr, often termed "tropical deciduous forest," "dry forest," or "wet-seas on forest" is widespread through the lowlands of Honduras, replacing rain forest in reglons where seasonality of rainfall is such that a mesic rain forest cannot exist. On the Pacific slope it is the only broadleaf lowland forest to be found. There is one magnificent forest of this type in the region around 51 Corpus, in the Department of Choluteca, which is the only extensive area of this habitat known from the Pacific slope 
of Honduras, although it does exist in narrow strips along most of the larger streams. Monsoon forest is also present along the lower reaches of the Goascorán, "Pespire, and Choluteca rivers. On the Caribbean slope it is generally of such scattered distribution that mapping is not possible, except in regions of extensive vega forests, as mentioned in the discussion of rain forest. Typical monsoon forest may be found in narrow strips along all the large rivers of the Caribbean drainage that pass through arid country, such as the upper reaches of the Ulua in the Otoro Valley and along the Humuya, Sulaco, Aguán, and Sico rivers farther to the east. In the Lake Yojoa region, patches of gallery-type deciduous forest may be found adjacent to patches of typical rain forest and, as is the case with vega forest, may contain rain forest elements of the avifauna in the rainy season.

Deciduous forest, because of its scattered distribution, cannot be readily related to any zonal system. In general, it corresponds best to the Arid Lower Tropical zone and to the Tropical dry forest 11fe-zone (formation) although it shares these zones with other different and more xerlc habitats.

I have included also in this category the scrubby, partly deciduous forests found in the Bay Islands and Cayos Cochinos in the Cartbbean Sea and the "sea-breeze scrub forest" found on the islands of Zacate Grande and Tigre in 
the Bay of Fonseca, which consists mostly of rather stunted and primarily deciduous trees.

Typical monsoon forest, such as that in the region of El Corpus, is a most interesting habitat to observe with relation to seasonal changes. In the rainy season it has the general appearance of a typical rain forest; the avifauna, however, is very depauperate by comparison, consistIng mainly of species that occur also under more arid conditions, as would be expected. In the dry seas on, the forest complexion changes completely, with a loss of most of the leaves of the canopy and a concomitant drying out of the understory and the humus.

\section{Cloud (montane rain) forest}

Once again I follow Carr in the usage of the broad term "cloud forest" for the major habitat of the interior highlands that is characterized by the presence of tall, evergreen trees extensively covered with epiphytic growth and by a retention of moisture below the canopy due to low evaporation rates and/or locally high rainfall. This habitat is generally comparable to the Subtropical Zone of Griscom, to the Humid Upper Tropical Zone of Dickey and van Rossem, and to the Lower Montane wet forest and Lower Montane moist forest life-zones (formations) of Holdridge.

Cloud forest may be produced by two very different climatic phenomena that, nevertheless, result in the same 
general habitat and the same avifauna. "True cloud forest" is found generally on the intertor mountain slopes where the rise of the mountains intercepts the prevailing winds (which have dropped much of their moisture as precipitation on the seaward mountain slopes), causing the daily formation of clouds. Although such regions have relatively little annual rainfa11, the presence of clouds reduces the evaporation rate to such an extent that constant dripping moisture is present and the end result is a lush vapor forest. In Honduras these typical cloud forests are invariably 180lated from lowland rain forest by a band of pine or other arid association of varying width; altitudinal range of these forests in the country is from 4,500 to 7,500 feet. Because of the lower rainfall, these regions appear on a Holdridge map as Lower Montane molst forest life-zone (formation).

On the windward slopes of the northern mountains of Honduras, the cloud forest habitat is produced by a large amount of direct orographic rainfall in addition to the normal presence of clouds. The resulting forest, which may be termed "montane rain forest," if a distinction from true cloud forest is desired, has the same appearance as true cloud forest and supports the same avifauna. Since this rainfall is more or less continuous at all levels on these mountain slopes, the broadleaf evergreen forest is likewise continuous from lowland rain forest up into cloud forest, as 
mentioned earlier. As a result, there is a broad transitional zone from rain to cloud forest; I use the term "low montane rain forest" to indicate this transitional region. In this low montane rain forest, a definite mixing of rain and cloud forest avifaunas produces one of the richest regions for bird study in the country. This mixing ranges from about 2,500 to almost 5,000 feet elevation but occurs most characteristically from 3,000 to 4,500 feet. Most of the low montane rain forest is part of the Subtropical wet forest life-zone (formation) of Holdridge, although the higher elevations correspond to his Lower Montane wet forest 1ife-zone (formation). On the accompanying map (Figure 3), the low montane rain forest would be found in a narrow strip along the junction of rain and cloud forest, wherever these two habitats are adjacent.

Carr distingulshed several types of cloud forest. "Hardwood cloud forest" is the basic climax type as described above. Along the margins of this assoctation, where it borders on highland pine, there is usually a band of pinabetes (Ptnus pseudostrobus), which in turn gives way to a "high ocotal association" of Pinus oocarpa; both these associations possess a luxurlant undergrowth and an extensive epiphytic flora. Birds inhabiting these ecotonal associations are basically the same as those of cloud forest edge with the addition of a few species that inhabit the highland pine or pine-oak associations. 
On the top of Cerro Santa Bárbara, as described by Allen (1955), there is a restricted association consisting of Guatemalan cypress (Cupressus Benthami) and Guatemalan fir (Abies guatemalensis) in addition to several species of Pinus and a few hardwoods, a combination unknown anywhere else in Honduras. Because of its isolation, one might expect an interesting avifauna, related to that of the Guatemalan highlands, but the zone is very restricted in extent on that mountain. We found none of the Guatemalan species there in 1964.

\section{Arid (mixed) scrub and thorn forest}

These two associations considered as a whole generally correspond to the Arid Lower Tropical Zone or to the Tropical dry forest and Subtropical dry forest iffe-zones (formations). There are several local varlations but in general both habitats occur in areas of low rainfall and high temperatures, mixed scrub being slightly more mesic than thorn forest (rainfall ranging from 40 to 60 inches annually, usually with marked seasonality). Both associations are characterized by scrubby growth, usually thorny, and with trees (if any) generally of a short stature. The presence of carbon (Mimosa tenulflora) is indicative of the thorn forest habitat. I have included in this category also the specialized "jfcaro tree savanna" of Carr, an open association of jicaro (Crescentia alata) 
with a short grass understory, which is characteristic of portions of the Pacific coastal lowlands. The avifauna of all associations included under this heading is basically the same and, for that reason, will be treated as a unit. On the habitat map (Figure 3), the Olancho Valley is represented by the arid scrub habitat, but the ecological situation there is not exactly the same, although the avifauna is primarily that of arid scrub. Rainfall here 18 usually greater, and much of the area was formerly a tallgrass savanna with scattered deciduous trees. Most of the savanna has been replaced or encroached upon recently by scrubby growth; therefore, its treatment under the arid scrub habitat-seems best for the present.

$$
\text { Highland pine (ocotal) and }
$$

pine-oak associations (encinal-robleda1)

Extensive areas of the interior highlands of Honduras are covered by 8 tands of ocote pine (pinus oocarpa), with a few P. cartbaea in regions around Lake Yojoa, in Olancho, and in parts of El Paraiso; this highland pine habitat is referred to by Carr as ocotal. It is perhaps the most widespread of the Honduran habitats and is relatively uniform in its appearance except for variations in the understory vegetation. The latter may range from completely open, consisting of nothing but short grasses, to a rather dense growth of low shrubs, brackens, and tall grasses. 
This habitat, along with pine-oak associations that appear under certain edaphic conditions, constitutes most of the Temperate Zone of Griscom, the Arid Upper Tropical Zone of Dickey and van Rossem, and the Subtropical moist forest 11fe-zone (formation) of Holdridge. Altitudinally, highland pine ranges from 2,000 to at least 6,000 feet, with fingers extending downward locally to about 1,500 feet in parts of the Quimistán and Agalta valleys.

The presence of pine in any highland region seems to be correlated with low rainfall, sloping terrain, and acidic soil. Frequentjy, where the slopes tend to flatten out into shallow valleys, the water table is relatively high and more favorable alluvial soils are present; as a result, oaks (quercus sp.) may appear, usually in association with a few pines, occastonally in pure stands. The oaks may be one of several, broad-leaved, dectduous species or, less frequent1y, a small-leaved, deciduous species (usually $Q$. eleoides). Locally the broad-leaved oaks are called roble, the small-leaved ones encino. For this reason, Carr has termed this association "falda encinal-robledal," but I prefer to use the nore frequently employed general term "pine-oak association."

Areas of pine-oak are generally restricted in extent in Honduras, occurring in scattered stands through the highland pine where situations are favorable. Beacuse of this distribution, pine-oak is not separated from highland pine on 
the habitat map (Figure 3).

Where conditions are extremely severe in the Honduran Interlor, large areas of treeless and often vegetationless ground may be found; Carr referred to this country as "steppe." Since this region is virtually devoid of bird life and since the steppe reglons are scattered through the highland pine, they are not distinguished from the latter on the habitat map.

\section{Lowland pine savanna}

The presence of an extens ive lowland pine savanna in a region of high rainfall and high temperature, conditions that generally result in the presence of rain forest, is most surprising. In addition, the avifauna, while consisting in large part of species that inhabit the interior highland pine, exhibits a number of endemic forms. Because of the climatic conditions, the region must be considered as part of the Humid Lower Tropical Zone or the Tropical moist forest life-zone (formation). In view of all the above factors, the lowland pine savanna is here considered as a habitat distinct from highland pine.

The pines present in this region are exclusively plnus cartbaea. Other species of trees present in the area are hardwoods confined to the narrow strips of vega forest along the larger streams running through the savanna. In Honduras the pine savanna is restricted to the Mosquitia of 
extreme eastern portions of the country and to very narrow strips of habitat on the ridges of Roatán and Guanaja islands, in the Bay Islands (too narrow to be shown on the habitat map). Both the highland pine and lowland pine regions are continued into northern Nicaragua where pine reaches its southern limit of distribution in the Western Henisphere, but nowhere are the two pine habitats contiguous. The lowland pine savanna habitat appears again in the "pine ridges" of British Honduras but does not exist anywhere in between; the mainland areas of this savanna in British Honduras and in the Mosquitia are separated by a distance in excess of $300 \mathrm{miles}$. Despite this isolation, the avifaunas of the two areas are bastcally the same, a phenomenon that will be discussed in greater detail later.

There has been much speculation and study concerning the origin of this pine savanna and its occurrence in a region of such great humidity (Parsons, 1955; Radley, 1960). There can be little doubt that the pine savanna is gradually being supplanted by rain forest, where fire does not prevent it. The present extent of the Mosquitia savanna, at least on the Nicaraguan side, is today controlled primarily through burning by man. The theory has been advanced that the savanna can be maintained through natural burning (by lightning fires) and that the pine savanna is really a fire disclimax. Hugh Popenoe suggested to me that the large herblvores that were known to be 
present in Central America until recent times may have been responsible in part for the maintenance of the savanna, much as they help control the extent of the veldt in Africa today. Still others suggest that the savanna is merely the result of extensive and repeated cutting and cultivation of the land by man to the point where the soll is so leached that only grasses and pines are able to exist.

Regardless of what produced the savanna in this humid region, we are concerned now only with the avifaunal element present, its probable origin, and its current relationships, which will be discussed later. Suffice it to say now that the avifauna indicates a recent reduction in extent of the savanna, a resultant recent isolation of the Mosquitia from the British Honduran region, and a relatively long isolation of both lowland areas from the interior highland pine.

\section{Marsh and swamp}

I have treated these two rather different habitats under a single heading for mapping purposes, since both are relatively restricted in extent and distribution and very often grade into one another. Marsh refers to any situation dominated by grasses, sedges, and low herbs on solis that remain wet throughout the year (or are only rarely dry). Swamp, in the sense used here, refers to any similarly wet area that is dominated by some sort of woody 
growth, excluding the special tidal mangrove swamp habitat, which is treated separately.

Marshes are most extensive in Honduras in the delta of the Uluia and Chamelecón rivers, in parts of the Mosquitia, and around the Bay of Fonseca. More restricted areas of marsh (too small to be mapped) may be found scattered along the north coast and along the northern and eastern shores of Lake Yojoa. Most of the marshes mentioned here are freshwater, with some brackish areas near the mouth of the Rio Uluia and around the Bay of Fonseca. The habitat, as well as the avifauna associated with it, is similar to that found in parts of southern Florida.

Swamps vary widely in character in Honduras from dense regtons of thorny huiscoyol palm (Bactris sp.), often found in relatively pure stands, to swamp forests with characteristics approaching those of rain forest. From an avifaunal standpoint, swamps are most important as habitats for utilization by colonies of herons, anhingas, cormorants, and the 11ke.

Mangrove

Regions of mangrove, consisting primarily of red mangrove (Bhizophora mangle), are scattered throughout the littoral areas in the Bay Islands and along both coasts of Honduras. The habitat supports a distinct avifauna and, for that reason, is treated separately from other types of 
swamp. On the habitat map (Figure 3), numerous, very narrow strips of mangrove along the north coast and around the is lands of Roatain and Guanaja could not be shown. 


\section{HISTORY OF HONDURAN ORNITHOLOGY}

In the early part of the Nineteenth Century, Honduras occupied an area covering part of southern Yucatán, part of the Petén (Guatemala), all of British Honduras, and the northern half of what is Honduras today. It is very difficult, therefore, to trace the travels of ornithologists during this period unless specific localities were mentioned. Many records from "Honduras" prior to 1850 can never be definitely located, even to country. On the basis of existing data and knowledge, I have pinpointed the work of early collectors as closely as possible. Cuvier (1820: 1-4) described Meleagris ocellata [= Agriocharis ocellata $]$ from "Honduras," but the type specimen really came from British Honduras. Likewise, Gould's descriptions of Ortyx guttata [= Odontophorus guttatus] (1838: 79-80) from the "Bay of Honduras," later amended to "Honduras" (1846: text opposite plate XXXVIII), and of Ortyx nigroguläis [= Colinus nigrggularis] (1843: 181-182) from "Mexico," later amended to "Honduras and Yucatán" (1846: text opposite plate IV), were also based on specimens taken in British Honduras. Delattre obtained a specimen of Melanoptila glabrirostris from "Honduras" about this same period of time, but I can find no evidence that he 
collected anywhere in the Omoa region, the only locality in Honduras from which the species is known.

The earliest ornithological reference that definitely pertained to Honduras, of which I am aware, was in the description of Plpra Cande1 [= Manacus candei] by Emile Parzudak1 (1841: 306). The type specimen was taken at Trujillo by M. F. de Maussion Candé, the captain of a salling vessel.

In the British and Derby museums are specimens that David Dyson obtained in "Honduras." Dyson journeyed to Central America primarily for the purpose of securing a living Agriocharis ocellata for the aviary of Lord Derby. Although I have been unable to trace Dyson's movements either geographically or chronologically, most of his work was conducted prior to 1846 in British Honduras. He did, however, collect in northern Honduras to a limited extent, since a few of his specimens are listed from San Pedro [Sula]. :

The first ornithologist to collect extensively in Honduras was Thomas Joseph Leyland. During 1855 and 1856 he worked in north-central Honduras, collecting along the lower Chamelecón and "Aloor" [= Ulúa] rivers, in the general vicinity of Omoa, Choloma, and San Pedro Sula. He was also credited with one trip into the interior to Comayagua (Stone, 1932: 292), but it is likely that he never made such a journey. Moore (1859: 50-65), who reported on Leyland's 
ornithological collections, mentioned mostly localities in the coastal regions near Omoa, with one exception. In Moore's description of Qrtyx leylandi $[=$ Colinus cristatus leyland1], he stated that the type specimen came from "Flores, on the road from Omoa to Comayagua." The use of the phrase "between Omoa and Comayagua," a distance of some 150 miles with several large towns on the way, is very puzzling, although Moore employed it in discussing several other observations by Leyland. I have also been unable to trace any "Flores" in the region covered by Leyland (there is one, however, in the Comayagua Valley south of Comayagua, not "between Omoa and Comayagua"). There is a good possibility that "Comayagua" is a lapsus for "Choloma"; if such is the case, it would place "Flores" within the region known to be covered by Leyland. Forbes and Robinson (1899b: 63) were of the opinion that many of Leyland's localities on specimen labels were in error. Leyland's material is presently deposited in the Derby Museum in Liverpool, Eng land.

In late December 1857, George Cavendish Taylor and Amory Edwards, along with a group of engineers, arrived at La Unión, E1 Salvador, to begin a trip that was to take them across Honduras along the route of the proposed "Honduras Interoceanic Railway." They crossed the Bay of Fonseca to Tigre Island on 26 December, where they remained until 9 January 1858; on 1 January, Taylor visited Bird Island and 
later (1859: 150-152) published an account of the frigatebird colony there. From 9 January through 14 January, they journeyed from La Brea through Nacaome, Langue, Aramecina, Caridad, San Juan, and Lamani to Comayagua, where they remained until 1 February. From the latter date through 8 February, they traveled to Lake Yojoa, passing through Opoteca, Siguatepeque, and Taulabé. They stayed at Lake Yojoa unt11 10 February, departing on that date; they passed through Potrerillos and San Pedro Sula, arriving at Omoa on the north coast on 14 February. Taylor sailed for Belize, British Honduras, on that date but Amory Edwards remained in Honduras, collecting for some additional period of time. Sclater (1858b: 356-360) 1isted the birds recorded by Taylor, and Taylor himself (1860: 10-24, 110-122, 222-228, 311-317) published his travels with extensive accounts of the birds recorded. The specimens taken by Taylor and Edwards are deposited, for the most part, in the Salvin and Godman Collection at the American Museum of Natural History; a few additional skins obtained by Amory Edwards are currently in the United States National Museum.

In the fall of 1869 and the early part of 1870 , George M. Whitely visited Honduras in company with contractors working on the Caribbean coastal segment of the Interoceanic Railway; thus he collected in the same general area as did Leyland. Whitely's collection of some 520 bird specimens, representing 135 species, was 11 sted by Sclater and Salvin 
(1870b: 836-839). The latter do not mention spectfic 10calities, but many of these may be found by consulting the ornithological volumes of the "Blologia Centrali-Americana" (Salvin and Godman, 1879-1904). Whitely's specimens were collected at Puerto Cabello [= Puerto Cortés], Medina, Julián [= Tulián], and San Pedro [Sula]. They are currently deposited in the British Museum, in the American Museum of Natural History (Rothschild Collection), and in the Academy of Natural Sciences at Philadelphia (Tristam Collection).

George F. Gaumer was the first ornithologist to visit the Bay Islands, off the north coast of Honduras. During 1886 and 1887 Gaumer visited Roatán and Bonacca [= Guanaja] 1s lands, collecting specimens representing 42 migrant species and 30 resident ones. Although his trip there is generally listed as "1887-1888" (Stone, 1932: 293), his specimen labels are dated "1886," "1887," or "September, 1887" (1atter for Bonacca Island specimens). His material, except for a few specimens that have been exchanged with various museums, is in the Salvin Collection in the British Museum. Salvin (1888: 241-265; 1889: 359-379; 1890: 84-95) published a series of papers on Gaumer's collection. In the early part of 1887 , Colonel N. S. Goss collected briefly at Puerto Cortés and Choloma, Honduras, after several years of collecting elsewhere in Central America. D. E. Lantz (1899: 218-224) listed the specimens taken by 
Goss after the latter's material had passed to the Kansas Academy of Science. Although some of Goss' specimens have disappeared and a few more were given to the Washburn University Museum of Natural History in Topeka, Kansas, the bulk of his material is currently housed in the Memorial Building of the Kansas State Historical Society in Topeka (Janes, 1964: 12).

Charles $H$. Towns end made an extensive trip to Honduras in 1887. From 1 February through 16 April he worked in the Swan Islands, the first ornithologist to visit this island group. From 12 June through 18 August he sailed up the Rio Segovia, the boundary between Honduras and Nicaragua. According to Stone (1932: 292-293), Townsend "did not ascend the river more than 150 miles and did most of his work in the low country adjacent to it, not penetrating far into the pine lands above." This distance upstream placed Townsend along the border of the Department of Olancho; exact 10calities of specimens taken are not known as all his material is labelled "Segovia River." The pineland specimens that he secured are representative of the species and races found exclusively in the lowland pine savanna of the Mosquitia; Townsend was the only orntthologist to collect in the Honduran Mosquitia prior to my trip in 1962. After the journey up the Río Segovia, Townsend visited Roatán Island on 8 September 1887; it is interesting to note that Gaumer was in the Bay Islands during this same month, but 
there is no indication that either was aware of the other's presence. From 19 September to 1 October, Townsend visited Trujillo, collecting in the vicinity of that town. Most of Townsend's 415 skins, 10 alcoholic specimens, two skeletons, and five sets of eggs are deposited in the United States National Museum. Notes on his Honduran collections were published by Robert Ridgway (1888c: 572-597).

From early 1889 through early 1893, Erich Wittkügel collected birds in northern Honduras. In March and April 1889, he made a journey inland to Volcán de Puca, in the northern part of the Department of Lempira. From September 1889 into 1893, he spent his entire time in the vicinity of the Sula Valley, collecting at San Pedro Sula, Chamelecón, La Cumbre, Río Permejo [= Bermejo], La Pita, Guaruma, Santa Ana, Rio Blanco, Rio de Las Pledras, La Bomba, Los [= Dos] Caminos, Chasnigua, La Puerta, and Nisperal [= Nispero]. The bulk of his specimens passed to the Brunswick Museum and to the Berlepsch Collection, the latter birds going eventually to the Frankfurt Museum. There are, however, more than 250 skins in the United States National Museum, the American Museum of Natural History (Rothschild Collection), and the Carnegle Museum (Anthony Collection). Ridgway (1892: 467-471) reported on the specimens in the National Museum, 197 skins taken in 1890 and 1891. Many of Wittkügel's birds in the European museums were examined by Hellmayr in connection with the "Birds of the Americas" 
series and may be found listed therein.

In 1891 or 1892 , exact date not known, Gorgonio Lopez collected a few birds at Copán, in extreme western Honduras. These birds, of which I have traced only 11 skins, are presently in the Museum of Comparative Zoology, having come there from the Peabody Museum of Ethnology. These specimens are of importance since the type of Eumomota superciliosa dickeyi is one of this series.

Joseph Carleton Ingersoll collected at San Pedro Sula from 2 July to 5 August 1897. His collection, about which nothing has been published, consists of 88 skins and one alcoholic specimen deposited in the United States National Mus eum.

Around the turn of the century, W. B. Richards on collected extensively in Central America. In April 1898 he made a short journey from Jalapa, Nicaragua, to Tegucigalpa, Honduras, returning to Nicaragua the same month. From 6 through 20 April he was collecting in Honduras at Danlí, Yuscarán, E1 Paralso, and Tegucigalpa. All but a few of his 70 Honduran skins are in the British Museum. During November and December 1908, he secured more than a hundred specimens from the "Río Coco" [= Río Segovia], but evidence (Thomas R. Howell, personal communication) indicates that all this collecting was conducted on the upper reaches of that river in territory that lies wholly within Nicaragua. There is a collection of 76 skins in the Museum of 
Comparative Zoology, formerly in the Bangs Collection, that was made by an engineer on a boundary survey between Honduras and Nicaragua. The specimens were purchased in 1901 (date collected not known) from Frank B. Webster and are all labeled "boundary line between Honduras and Nicaragua 180 miles from Pacific coast." A careful examination of this collection has shown that almost all birds therein are representative of the arid scrub habitat of the Pacific coast, a habitat that does not extend inland along the Honduras-Nicaragua boundary more than $20 \mathrm{miles.} \mathrm{A} \mathrm{distance}$ of 180 miles would place the locality in the middle of the Caribbean rain forest of olancho; only two species of birds taken are characteristic of this latter habitat. It seems evident that most of the specimens were secured in the Pacific lowlands of the Department of Choluteca, within 20 miles of the coast.

During early 1901, Howard S. Reed obtained 83 bird skins that are now deposited in the United States National Museum. All his material was secured between 16 February and 12 March at Chamelecón, except for a few specimens taken on 27 and 28 February at Corfridia [= Cofradla], some 10 miles west of Chamelecón.

W. W. Brown collected extensively during early 1902 in the La Ceiba region of northern Honduras. From 1 through 25 January he worked around La Ceiba. From 7 through 27 February he collected at an elevation of 1,000 feet at 
Yaruca, some 15 miles inland from La Ceiba. Because of many dificulties he was forced to abandon his proposed trip into the coastal mountain range just to the west of Yaruca. Notes pertaining to his Honduran collection have been published by Bangs (1903: 141-159). Almost all of the 644 skins taken by Brown are now in the Museum of Comparative Zoology and the United States National Museum.

In 1908 Percy $R$. Lowe visited the Swan Islands, where he remained from 19 January through 10 February. He recorded 25 species there, all but seven based on specimens, and listed an additional eight based on reports of the local residents (Lowe, 1909: 304-347). He added two more to this list in a later account of his trip (Lowe, 1911).

Following Lowe, George Nelson was next to work in the Swan Islands, collecting there in 1912 from 25 February to 22 March and from 10 to $14 \mathrm{July}$, and in 1913 from 8 to 19 April. His 75 specimens, most of which are now in the Museum of Comparative Zoology, have been mentioned by Paynter (1956: 103-110).

In early $1923 \mathrm{Kar} 1 \mathrm{P}$. Schmidt and L. L. Walters were engaged in a collecting expedition, mostly for herpetological material, in the San Pedro Sula region. Between 12 and 30 March they obtained 16 bird skins from the mountains to the east of the town. Their specimens are in the Chicago Natural History Museum.

The Swan Islands were again visited by an ornithologist 
in 1926 and 1927. Between 25 September 1926 and 10 April 1927, Neal wilson remained in the islands, collecting a series of 18 specimens representing as many species. Data on his skins, which are deposited in the Museum of Comparative Zoology, have been published by Paynter (1956: 103-110).

During the early part of 1928 , James L. Peters and Edward Bangs collected birds in the north-central coastal region of Honduras. From 14 through 28 January they were located at Lancetilla, just inland from Tela. On the latter date they journeyed by rail to Progreso, returning to Lancetilla on 1 February, where they remained until 9 March; during this time they made one short trip on 27 and 28 February to Martinez Creek and Laguna Toloa, approximately 20 miles west of Tela. On 9 March they worked at kilometer 52 on the Tela Railroad, a locality near Urraco, where the digging of the Toloa Canal was in progress. They spent three days there, returning to Lancetilla on 12 March. The remainder of their time in Honduras, until their departure from Tela on 2 April, was spent at Lancetilla. Detalls of the expedition and a report of the birds collected and observed were published by Peters (1929b: 397-478).

On 19 and 20 April 1929, A. K. Fisher visited the Swan Islands, working on both Big Swan and Little Swan islands while there. He recorded 21 species (Fisher and Wetmore, 1931: $1-66)$. 
Alexander F. Skutch is well known for his exhaustive work on Iife history studies of Central American birds. Although most of his work was conducted in Costa Rica and Guatemala, he remained at Lancetilla, Honduras, through one breeding season (April to November 1930). Numerous references to birds studied there have appeared in his publications.

During the late summer of 1930, John T. Emlen, Jr., and C. Brooke Worth, under the leadership of James A. G. Rehn, collected extensively in the mountains near Tegucigalpa and, to a lesser degree, in the Caribbean lowlands around Tela. From 7 July through 15 August they worked in the San Juancito region, mostly in cloud forest areas, with side trips to the low country around Cantarranas on $20 \mathrm{July}$ and from 2 to 10 August. From 23 August to 9 September they collected mostly at Lancetilla, with a trip to Laguna Toloa on 30 August. Their collection of 569 skins is deposited in the Acadeny of Natural Sciences at Philadelphia. Stone (1932: 291-342) published a paper based on this collection in which he summarized the known Honduran ornithological work to that time. This annotated 1 ist consisted of 420 species and subspecies but was incomplete even then, a number of published records having been omitted. Nevertheless, prior to the present study, this list has been the only published work that attempted to treat the entire Honduran avifauna as such. 
By far, the most extensive ornithological collecting in Honduras has been done by C. F. Underwood, who worked more or less continuously in the country from early september 1931 through mid-February 1938. During this period of time he amassed a great number of specimens, both birds and mamnals. Since he was primarily a professional collector, his specimens passed to many different museums and are scattered today throughout most of the major museuns of the world. I have been able to trace and examine more than 9,300 skins and am aware of additional material in the Paris Museum (mostly hummingbirds) and a very few more in private collections. There was a substantial block of specimens that Underwood himself deposited in the natural history museum in Tegucigalpa, Honduras; however, the structure in which these were housed was destroyed a few years ago and the collections have disappeared or were themselves destroyed. His existing collections have never been worked as a unit, although a number of his specimens in various museums has been examined in connection with other taxonomic and distributional studies. Goodwin (1942: 107-195), in dealing with Underwood's mammal specimens, listed many of the latter's collecting localities; however, no one has attempted to trace Underwood's movements during his years in Honduras. Since more than half the known skins from Honduras are those of Underwood, and since a good many of his localities have been assigned by various authors to 
incorrect locations in Honduras, I feel that an 1tinerary of Underwood's travels is essential to the present distributional work. Exact locations of his collecting stations, as far as I am able to determine them, appear in the Gazeteer chapter of the present work.

From 7 September 1931 through 9 September 1932, Underwood collected in the general vicinity of Tegucigalpa, working for the most part in the mountains within 25 miles to the north and northeast of the town. It is not known precisely where Underwood himself was located on any given date as it is apparent from the specimen data that he was assisted by local collectors and skinners. His daily output often exceeded 50 specimens from several different, but usually nearby, localities. Apparently his helpers would go out collecting daily to several locations, Underwood remaining at some central area. During the period of about a year mentioned above, most of his specimens were taken at Monte Redondo, Cantoral, La Flor Archaga, Montaña Vásquez, Rancho Quemado, and Comayagüela. On 2 January 1932 there are eight skins taken at Lake Yojoa, probably brought to him by someone returning from the lake, as Underwood was collecting primarily at Montaña Vásquez at this time. During this one-year period he secured in excess of 2,000 bird skins.

In the fall of 1932, from 11 september to 6 october, Underwood made his one and only trip to the Pacifle 
lowlands, collecting at San Lorenzo. He obtained more than 275 skins during this month of work.

In the interim between his San Lorenzo trip and his initial journey to the Caribbean lowlands in mid-January 1933, Underwood obtained only a very few specimens, all from the general Teguclgalpa region. From 20 January to 28 February 1933, he collected at Las Peñitas, on the outskirts of San Pedro Sula; he moved to Cofradía on 2 March and completed this trip at Catacombas, in the foothills of the mountains northwest of Cofradia, from 20 March through 23 April. During this three month period he obtained more than 1,850 bird skins, in addition to numerous marmal skins, a remarkable total for that length of time.

Except for rather extensive collecting at E1 Derrumbo from 9 July through 9 August (171 skins) and three days at Cerro Santa Maria from 28 to 30 December (20 skins), the remainder of 1933 was spent in the Tegucigalpa area with only an occasional specimen being taken.

From 1 January to 4 June 1934, he worked continuous 1y at Cantoral and La Flor Archaga, obtaining 394 specimens. From 5 June through $12 \mathrm{July}$, he collected in the Gualmaca region, mostly in the mountains of the Montaña de Guaimaca before 15 June and at San Marcos de Guaimaca after that date; I have examined 177 specimens that were secured on this trip.

From mid-July 1934 to early March 1935, collecting was 
again confined to the general Tegucigalpa region, with no extensive work being done. From 4 March through 1 July 1935, he traveled extensively through the departments of Santa Bárbara and Copán, his only trip to this reglon of Honduras. In the Department of Santa Bárbara, he worked at Ceguaca from 4 to 12 March, in the vicinity of San José de Santa Bárbara (including Cerro Nieve and El Higuito) from 1 April to $6 \mathrm{May}$, and in the vicinity of the town of Santa Bárbara from 24 April to 1 June. On 26 and 27 April he obtained specimens from the lower slopes of Cerro Santa Bárbara on the western side of the mountain. From 3 June to $1 \mathrm{July}$, he collected in the Department of Copán, working mostly at La Libertad and Merendón Copán; on 24 and 25 May he collected at La Leona. During this four month period he secured more than 625 bird skins.

Apparently there was no extensive collecting conducted by Underwood from early July 1935 to mid-January 1936, since only a few scattered skins from the Tegucigalpa region are recorded. From 21 January to 13 April 1936, he took about 250 skins from Cantoral, with a few other specimens being secured in the general Archaga district.

From 10 May through 31 July 1936, Underwood made his only trip to the Department of Ocotepeque. His movements have been difficult to trace here because of his use of locality names of local origin (not ones usually found on maps); furthermore, specimens taken on any one day may have 
come from as many as $\mathrm{six}$ different collecting stations, indicating again that he had several local collectors bringing material to him daily. From 10 May to $16 \mathrm{July}$, most of his specimens are labeled from locations in the Nueva Ocotepeque-Plan del Rancho region, including the mountains along the El Salvador border to the southwest of Nueva Ocotepeque. His localities during this perlod were Monte E1 Conejo, Monte E1 Portillo, Monte El Candado, Montaña E1 Chorro, Montaña Los Cedros, Monte El Sillón, Montaña La Cruz, and Plan del Rancho. After mid-July he moved to the eastern part of the department, working around Belén Gualcho (including the localities of Monte Verde and Las Ventanas). It is interesting to note that he added an extra day to the month of June, a number of his specimens being labeled "31 June"; I do not know when he discovered his error, and it is likely that most of his July 1936 dates are one day off. On his Ocotepeque trip he obtained 830 bird skins, most of which are currently deposited in the Moore Laboratory of Zoology at Occidental College.

The fall and early winter of 1936 was spent in work in the general Tegucigalpa region, except for a trip to Lake Yojoa from 26 september to 16 october. He obtained about 30 specimens at E1 Jaral during this latter period.

From 5 December 1936 through 4 February 1937, he traveled through the departments of Intibucá and La Paz, collecting at the following localities: E1 Horno, La Florida, 
Intibucá, Llano Grando, Muín, Muye, El Pedernal, and E1 Guayabal; he obtained about 120 specimens during this time. He also recorded about 35 specimens from Muye during late February, while he was also obtaining specimens from the Sabana Grande region, some 40 miles distant. Underwood was probably having some or all of these birds brought to him, but it is not known just where he was located at the time. Since 108 of his specimens from 17 February to 2 Apri1 1937 were taken at Sabana Grande and Piedra de Jesus, it seems likely that he was in this region for that period of time. From 3 through 13 April he recorded more than 55 specimens from Soluteca, a locality in La Paz.

Underwood's material from mid-April until late June 1937 once again came mostly from the Tegucigalpa region. From 24 June until 2 August, he obtained more than 170 specimens at El Caliche, a locality in northern Francisco Morazán. He followed this trip with travels into the Department of olancho, his only work in that section of Honduras. From 17 August to 30 October 1937, he secured more than 425 specimens in the Olancho Valley at Catacamas and E1 Boquerón.

After returning to the Tegucigalpa region for a while in the early winter of 1937-1938, Underwood embarked upon his last collecting trip in Honduras. From 29 December 1937 through 11 February 1938, he worked on the Montaña de Puca in the Department of Lempira; a few of his specimens 
during this period are from Lepaera, in the foothills of this mountain. I have examined 287 skins from this collection.

The most recent Honduran specimen of Underwood's was taken at Tegucigalpa on 12 February 1938, assuming the date to be correct. He obtained five skins on 11 February on Montaña de Puca, so possibly the year is incorrect on the Tegucigalpa specimen. In any case, it is apparent that Underwood did not collect in Honduras after this period unless specimens obtained later were deposited in the Tegucigalpa collection and subsequently lost or destroyed.

I should like to point out that Underwood was of ten careless in the recording of data on specimen labels. I have found obvious errors relating to sex and date, so that information obtained directly from his specimen labels should be used with caution.

Honduran specimens taken by Underwood are presently located, for the most part, in the following museums: Museum of Comparative Zoology (3,226 skins), American Mus eum of Natural History $(2,933$ skins), Moore Laboratory of Zoology (1,911 skins, 36 skeletons), Chicago Natural History Museum (331 skins), Academy of Natural Sciences at Philadelphia (286 skins), British Museum of Natural History (253 skins), United States National Museum (88 skins), and the Carnegie Mus eum ( 44 skins).

Raymond Stadelman was a naturalist who resided in the 
Department of Yoro during the 1930's. He collected birds extensively in the mountains to the west of the towns of Yoro and Yorito. It was he who was responsible for von Hagen (1946) traveling to the Montaña de Pijol of Yoro to obtain living Quetzals (Pharomachnus mocinno). From 8 December 1932 to 2 Apri1 1933, and from 8 March 1934 to 16 March 1935, Stadelman collected extensively at Subirana and Portillo Grande, with a few specimens taken at Yorito. There is a gap in his collecting as the next known specimens were obtained four years 1ater. From 6 June 1939 to 26 February 1940, he secured skins mostly from Subirana, with a few from Agua Colorado, Santa Marta, and Pueblo Viejo. There are 444 specimens taken by $S$ tadelman that are deposited in the Museum of Comparative Zoology and the Chicago Natural History Museum. His specimen records have not been previously published.

From 18 March to 1 May 1933, Herbert G. Deignan (1936: 186-193) collected in the vicinity of La Celba. He obtained about 85 specimens, now deposited in the United States National Museum. In his published report, Deignan also mentioned a few specimens taken by $W$. D. Strong, who ascended the Rio Patuca as far as Huanquibila.

During the early spring of 1936, James Bond visited the Bay Islands, off the north coast of Honduras. From 27 February to 4 March he was on Bonacca [= Guanaja] Island and from 7 to 13 March he worked on Utila Is land. His 
collection of about $50 \mathrm{specimens}$ is deposited in the Academy of Natural Sciences at Philadelphia. He published (1936: 353-364) the results of his trip and discussed at length the restdent birds of the Bay Islands, including the descriptions of six new subspecies from the islands.

Jean Delacour (1938: 541-557) visited the Swan Islands on 20 October 1937 and recorded about a dozen species, several new to the islands. He did not, however, secure any specimens.

In January 1940 Rudyerd Boulton visited the 1slands off the north coast of Honduras. On 5 January he collected 15 specimens in the Swan Islands and from 7 through 10 January secured another 32 on Roatán Is land, in the Bay Islands. While in the Bay Islands he trained a local resident, Cardie Parsons, who collected an additional 26 specimens on Utila Is land between 25 January and sometime in March 1940. A11 these specimens are in the Chicago Natural History Museum. From September 1945 through August 1949, Marjorte H. Carr resided in Honduras at the Escuela Agrícola Panamericana at El Zamorano, where her husband, Archie F. Carr, Jr., was teaching. She collected birds throughout this period of time, mostly from the general vicinity of the Yeguare River Valley near E1 Zamorano. Many of her specimens were taken at localities within short distances of El Zamorano, with a number of trips to San Juancito, Güinope, Moroceli, and Yuscarán. From 5 to $26 \mathrm{July} 1947$ she collected in the 
general vicinity of Danlí, and she made at least two trips to the Jamastrán Valley east of Dan1i from 11 to 17 August 1947 and on 19 and 20 February 1949. On 5 February 1949 she obtained a number of specimens along the road from Tegucigalpa to San Lorenzo. She made at least four trips to Lake Yojoa, collecting there from 21 to 26 June 1948, on 8 September 1948, on 24 and 25 February 1949, and Erom 26 July to 14 August 1949; the February and June trips also involved visits to the gallery forests at Amapa, north of the lake. On 1 April 1949 she secured several specimens from Lancetilla, near the north coast. From May to July 1948, she was accompanied on her collecting trips by J. C. Dickinson, Jr. Most of the Carr and Dickinson specimens (761) are deposited in the collections of the University of Florida and the Museum of Comparative Zoology. Records by Mrs. Carr that are additions to the Honduran avifauna have been included in the ranges published by Eisenmann (1955a). Arthur $C$. Twomey made four extensive collecting trips to Honduras, one each in the years 1947, 1948, 1950, and 1951. On all except the 1947 expedition, he was accompanied by an assistant, Roland W. Hawkins .

On the 1947 trip Twomey visited La Celba (26 March-1 Apri1), Roatán Is land (3-9 April), Barbareta Is land (10-11 Apr11), and Guanaja Is land (12-15 April). In 1948 Twomey and Hawkins worked on Guanaja Island (22-26 March), at Trujillo (30 March-9 Apri1), on Barbareta Island (12 April), 
on Utila Island (18-24 March), at La Ceiba (24 April-7 June), at Los Planes (9-11 June), at Coyoles (16 June), and at San Esteban (21 June-2 July). Two years later in 1950, they returned to Honduras, collecting at Coyoles and Los Planes (13 June-18 July), La Celba (24 July-10 August), and Lake Yojoa (13-17 August), with a trip to S1guatepeque on 15 August. Their last trip in 1951 was the most extensive. They remained in Honduras from 12 June through 28 August. Their collecting stations were from Lake Yofoa to Tegucigalpa, with side trips to San Juancito and to Sabana Grande; other collecting localities included Siguatepeque, Comayagua, E1 Hatillo, Cuesta Grande, and Río Hondo. The four expeditions yielded 2,995 bird skins, al1 deposited in the Carnegie Museum.

From 1949 through 1961, Mark Trafton, Jr., of the Research Division of the United Fruit Company at La Lima, studied the avifauna of Honduras, primarily in the La Lima and Tela regions. He made extensive notes on the birdlife, secured many photographs, and collected a few birds for identification purposes, although he did not preserve any specimens. He has been responsible for the greatest volume of data on many species, especially migrant waterfowl and shorebirds. His records and notes are published herein for the first time.

Thomas R. Howell and J. G. Montrello collected in the rain forests of Olancho and along the Río Segovia during the 
1950's. They worked at Arenal, fust north of the river in the Department of E1 Paraíso, from 20 to 28 January 1953 and from 17 to 28 January 1955. Montrello collected there alone in 1954 from 15 January to 16 February and from 29 May to 4 June. In July 1954 Montrello descended the Río Segovia, obtaining a few specimens at Kiyras on 6 July and at Crasa on $17 \mathrm{July.} \mathrm{Howell} \mathrm{and} \mathrm{Montrello} \mathrm{secured} 249$ skins in Honduran territory, all of these now deposited in the collections at the University of California at Los Angeles.

From 3 through 27 November 1958, Charles H. Blake observed and banded birds on Big Swan Island. Records that were additions to the avifauna of the Swan Islands were published by Bond (1959: 8-9).

Field parties of the Louis iana State University Museum of Zoology began ornithological research in the country in 1962. In January of that year, Richard R. and Jean W. Graber spent three weeks in the Department of Olancho collecting for this museum. They worked for the most part in the foothills along the southeastern base of the Sierra de Agalta between San José de Río Tinto and Dulce Nombre de Culmí. On this trip they obtained specimens from a region about five miles south of San Esteban (from 12 to 23 January) and along the Río Pataste 12 miles south of Dulce Nombre de Culmi (from 27 to 29 January). The Grabers returned to the same general area in March and early April 1963, collecting along the Río Guampi 10 miles east of 
Dulce Nombre de Culmi (from 11 to 23 March) and at the base of Cerro El Triumpho 20 miles southeast of San Esteban (from 27 March to 2 April).

From 2 August 1962 to 13 May 1963, I conducted field studies in Honduras, visiting a11 departments and collecting in all major habitats at some time during this period. On this trip I was accompanied by my wife, Rose Sawyer Monroe, who assisted in the preparation of specimens and in the general field work. From 1 September 1962 to 15 January 1963, J. Alan Feduccia also was part of our field party. During this period of time, our base of operations was Finca Fé, a coffee plantation owned by William W. Plowden, Jr.; the finca is situated near the northwestern shore of Lake Yojoa at the eastern base of Cerro Santa Bárbara. Observations and collections were made here and in the general vicinity of Lake Yojoa and Cerro Santa Bárbara during every month of the period. Trips to various parts of Honduras originated from Finca Fé; our itinerary of travel outside the Lake Yojoa region is presented in Table IV.

From $15 \mathrm{July}$ to 21 August 1963, J. Alan Feduccia worked alone, collecting for the most part in the regions around Lake Yojoa and between Lake Yojoa and San Pedro Sula. He Made one trip to La Esperanza and Güise (16-17 July) and one to San Alejo (on 9 August).

In the spring of 1964, Richard R. Graber, Jean W. 
TABLE IV. Day by day itinerary of major LSUMZ Honduran expedition, 2 August 1962 to 13 May 1963. On days omitted from the itinerary, work was conducted only in the Lake Yojoa-Cerro Santa Bárbara area. Transportation between localities by jeep unless otherwise indicated.

2 August--Puerto Cortés to San Pedro Sula.

3 August--San Pedro Sula to La Lima.

4 August--San Pedro Sula to Finca Fé.

10 August--Lake Yojoa to San Pedro Sula.

11 August--San Pedro Sula-La Lima to Lake Yojoa.

15 August--Lake Yojoa to San Pedro Sula-La Lima.

16 Augus t--San Pedro Sula to Tela.

17-18 August--Tela.

19 August--Lancetilla.

20 August--Tela to Lake Yojoa.

22 August--Lake Yojoa to Tegucigalpa.

23 Augus t--Tegucigalpa.

24 August--Tegucigalpa to Lake Yojoa.

29 August--Lake Yojoa to San Pedro Sula.

30 August--Puerto Cortés to Lake Yojoa.

7 September--Lake Yojoa to San Pedro Sula.

9 September--Lake Yojoa to Puerto Cortés.

13 September-Lake Yojoa to San Pedro Sula.

18 September--Lake Yojoa to Amapa.

19 September--Lake Yojoa to Omoa.

21 September-Lake Yojoa to La Lima.

24 September--Lake Yojoa to Tegucigalpa.

25 September--Tegucigalpa.

26 September--Tegucigalpa to San Lorenzo.

27 September--San Lorenzo to Choluteca and Cedeño:

28 September--San Lorenzo to Namas igüe.

29 September--San Lorenzo to E1 Corpus.

30 September--San Lorenzo to Choluteca.

1 October--Goas corán to Choluteca.

2 October--San Lorenzo to Choluteca.

3 October--Choluteca to E1 Corpus.

4 October--Choluteca to Cedeño.

5 October--Choluteca to San Lorenzo; San Lorenzo to Is la Pájaro (by boat).

6 October--Choluteca to San Francisco.

7 October--San Francisco to E1 Corpus.

8 October--San Francisco to E1 Triunfo.

9 October--San-Francisco to Cedeño.

10 October-San Francisco to San Lorenzo; San Lorenzo to Los Farallones (by boat).

11 October--San Francisco.

12 October--San Francisco to Cedeño.

13 October--San Francisco to Choluteca.

14 October--San Francisco. 
TABLE IV--Continued

15 October--San Francisco to Tegucigalpa.

16 Dctober--Tegucigalpa.

17 October--Tegucigalpa to Lake Yojoa.

19 October-Lake Yojoa to San Pedro Sula.

23 October--Lake Yojoa to Omoa.

24 October--La Lima to Finca Fé.

29 October--Lake Yojoa to La Esperanza.

30 October--La Esperanza to Sabanetas.

31 October--La Esperanza to Jesús de otoro.

2 November--Lake Yojoa to Valle Bonito.

3 November-Lake Yojoa to San Pedro Sula.

6 November--Lake Yojoa to San Pedro Sula.

9 November--Lake Yojoa to La Lima.

12-13 November--Lake Yojoa to San Pedro Sula.

15 November--Lake Yojoa to Tegucigalpa.

16-17 November--Tegucigalpa.

18 November--Tegucigalpa to San Lorenzo.

19 November-Tegucigalpa to Lake Yojoa.

21 November--Lake Yojoa to San Pedro Sula.

26-27 November--Lake Yojoa to San Pedro Sula.

29 November--Lake Yojoa to Amapa.

3 December-Lake Yojoa to San Pedro Sula.

4-5 December--San Pedro Sula to Copán.

6 December--San Pedro Sula to Lake Yojoa.

10 December--Lake Yojoa to San Pedro Sula.

13 December--Lake Yojoa to San Pedro Sula.

21 December-10 January--[no field work].

11 January--Lake Yojoa to San Pedro Sula.

14-15 January--Lake Yojoa to La Lima.

18 January--Lake Yo joa to San Pedro Sula.

21 January--Lake Yojoa to San Pedro Sula.

22 January--Lake Yojoa to La Esperanza.

23 January--La Esperanza to Güise.

24 January--La Esperanza to Lake Yojoa.

25-26 January--Lake Yojoa to San Pedro Sula.

29 January--Lake Yojoa to Tegucigalpa.

30 January--Tegucigalpa.

31 January--Tegucigalpa to San Lorenzo.

1 February-Goascorán to Tegucigalpa.

2 February--Tegucigalpa to San Lorenzo.

3-4 February--Tegucigalpa.

5 February--Tegucigalpa to Puerto Lempira (by air).

6 February--Puerto Lempira.

7 February--Puerto Lempira to Tegucigalpa (by air).

8 February--Teguc 1galpa.

9 February--Tegucigalpa to San Lorenzo.

10 February--San Lorenzo to El Corpus. 
TABLE IV--Continued

11 February--San Lorenzo to Cedeño.

12 February--San Lorenzo to San Francisco.

13 February--San Lorenzo.

14 February--San Lorenzo to Tegucigalpa.

15 February--Tegucigalpa to E1 Zamorano.

16 February--Tegucigalpa to Lake Yojoa.

18 February--Lake Yojoa to San Pedro Sula.

21 February--Lake Yojoa to San Pedro Sula.

25 February--Lake Yojoa to San Pedro Sula.

26 February--Lake Yojoa to Santa Rosa de Copán.

27 February--Santa Rosa de Copán to Nueva Ocotepeque.

28 February--Santa Rosa de Copán to Gracias, to Lake Yojoa.

4-5 March--Lake Yojoa to San Pedro Sula.

6 March--San Pedro Sula to Progreso.

7-9 March--San Pedro Sula.

10-11 March--San Pedro Sula to Cuyamel.

12-13 March--San Pedro Sula to Lake Yojoa.

14 March--San Pedro Sula to Tela.

15-18 March--Tela and San Alejo.

19 March--San Alejo to San Pedro Sula.

20-21 March--San Pedro Sula.

22 March--San Pedro Sula to La Celba (by air).

23-24 March--La Ceiba and Montecristo.

25 March--La Ceiba to Tocoa and Trujillo (by air).

26 March--La Celba to San Pedro Sula (by atr); San

Pedro Sula to Lake Yojoa.

28 March--Lake Yojoa to San Pedro Sula.

29 March--San Pedro Sula to Tela.

30 March-3 Apri1--Tela and San Alejo.

4 April--San Alejo to San Pedro Sula.

5 April--San Pedro Sula.

6 April--San Pedro Sula to Little Hog Island (by air).

7 April--Little Hog Is land.

8 April--Little and Big Hog islands.

9 April--Little Hog Island.

10 April--Little Hog Island to San Pedro Sula (by air).

11-12 Apri1--San Pedro Sula.

13 April--San Pedro Sula to Lake Yojoa.

16 April--Lake Yojoa to San Pedro Sula.

17 April--San Pedro Sula to Cofradia.

18 April--San Pedro Sula to San Alejo.

19 April--San Pedro Sula to Lake Yojoa.

22 April--Lake Yojoa to San Pedro Sula.

23 April--San Pedro Sula to Coyoles (by air).

24 April--San Pedro Sula to Lake Yojoa.

28 April--Finca Fé to Amapa.

29 April--Lake Yojoa to San Pedro Sula. 


\section{TABLE IV--Continued}

30 April-1 May--San Pedro Sula and La Lima.

2 May--San Pedro Sula to Utila Island (by air). 3-9 May--Utila Is land.

10 May--Utila Island to La Ceiba (by boat); La Celba to San Pedro Sula (by air).

11-12 May--San Pedro Sula and La Lima.

13 May--San Pedro Sula to Puerto Cortés. 
Graber, and I returned to Honduras specifically for the purpose of climbing Cerro Santa Bárbara and studying the relict conifer community at the summit. We remained in Honduras from 30 March to 18 April, ascending the mountain on 3 April. After finding that the summit supported a very restricted conifer habitat lacking any unusual birds, we descended the mountain on 4 April and returned to San Pedro Sula on 5 April, visiting San Alejo also on this latter date. We flew to Tegucigalpa on 7 April and to Puerto Lempira on 8 April. From this date until 14 April we remained at Puerto Lempira, working for the most part in the pine savanna; on 13 April we crossed the Laguna Caratasca by boat and visited the large rookery near Cauquira. On 15 April we returned by air to San Pedro Sula, flying along the north coast the entire way. We departed Honduras on 18 April.

Kenneth S. Hamilton, of the Research Division of the United Fruit Company at La Lima, has been studying, banding, and collecting birds in Honduras since early 1962. Most of his work has been in the Lake Yojoa-San Pedro Sula-Tela region, with a few visits to Utila Island. Many of his specimens are deposited in the Louisiana State University Mus eum of zoology. 
PLAN OF THE SPECIES ACCOUNTS

The sequence of families, genera, and species follows Eisenmann (1955a), except where taxonomic changes subsequent to his work have necessitated a rearrangement. As has been the current trend in distributional studies, I have treated the avifauna under species headings and have relegated a discussion of subspecific variation to subordinate position, instead of treating each subspecific entity under a separate heading.

Each species account is headed by the scientific name and author of that name, followed by the vernacular name. The latter has been subject to confusing variability in recent years and, for that reason, I follow Eisermann or the American Ornithologists' Union (1957) in the application of vernacular names, except where taxonomic studies have forced a change. Although I have very definite ideas concerning the philosophy and usage of vernaculars, a distributional work on a restricted geographical region is not the place to discuss this problem. To avoid confusion, I have adopted the standard names from these two references.

Spectes that have been recorded from Honduras solely on the basis of sight records (lacking specimen or photographic substantiation) have the scientific name enclosed in square 
brackets. Species of doubtful occurrence in the republic are treated separately in the Hypothetical List following the Species Accounts.

Taxonomic nomenclature in general follows Peters' "Birds of the World" series (Peters, 1931a, 1934-1951; Mayr and Greenway, 1960-1962; Mayr and Paynter, 1964), the "Birds of the Americas" series (Cory, 1918-1919; Cory and Hellmayr, 1924; Hellmayr, 1925-1938; Hellmayr and Conover, 1942-1949), and the American Ornithologists' Unton "Checklist of North American birds" (1957). Where there has been disagreement among these various works or where there have been subsequent taxonomic studies that have indicated changes were desirable, I have discussed my reasons for following a particular usage. I will no doubt be termed a "splitter" at the generic and specific levels and a "lumper" at the subspecific level, but in a distributional survey it is necessary to treat all forms in some fashion, and I feel very strongly concerning recent trends in ornithological taxonomy. The describing of subspecies has sometimes gotten out of hand, and we are faced with the existence of numerous races based on nongeographic variation; in many cases where geographic variation does exist, it is of such a slight degree that the assignment of most individual specimens to a subspecies is not feasible. I feel that the primary purpose of the subspecific name is to categorize the individual, not merely to indicate that geographic variation 
is present. In my opinion, at least some slight geographic variation is to be expected in almost any two populations of any animal that might be compared. Thus in the present study I have reduced a good many subspecies to synonymy because I feel that they are of little practical use, $1 . \underline{e}$. , because the great majority of individuals cannot be satisfactorily assigned to race.

At the species level, on the other hand, I feel that there has been too much combining of allopatric forms on the basis of similarities of specimens, without regard for possible isolating mechanisms that might operate should these populations come in contact. There also seems to be a tendency now to lump into a single species two morphologically distinct populations that meet in a very narrow zone of secondary contact and form hybrid swarms. I wonder if we are not defeating the purpose of taxonomy by lumping such populations, for nearly everyone concedes that with the binomial system it is not feasible by means of the genus and species to indicate all the various stages in the speciation process that exist today. In the present study I have considered a few taxa to be distinct at the species level that are not so treated by other current authors; In all cases I have expressed my reasons for such action in the discussion in the individual species accounts.

Since the genera are even more subjective in limits than are the species under current concepts, the situation 
here has become even worse. The broadening of the generic limits seems to me to be detrimental to nomenclature because of the resultant confusion in the literature through the creation of many homonyms and the resultant resurrection of old names or creation of new ones. Furthermore, I feel that it is a greater evil to combine in one genus two or more species that might not be closely related than to have two more closely related forms in separate genera; in other words, I prefer to maintain generic 1 imits at their present level, lumping only when the accumulated evidence overwhelmingly indicates a change.

Following the scientific and vernacular names in the species accounts is a section entitled SPECIMENS. Listed here are all specimens from Honduras of which I am aware, with the exception of those in European museums that I have not visited (among the European museums, I have seen only those specimens in the British Museum). Data obtained on specimens not listed in this section are presented in the discussion.

The specimens are listed in groups by subspecies. Following the subspecific name (or following the word SPECIMENS, if the species is monotypic), the total number of specimens listed is given in parentheses. Localities for these specimens are then presented, followed by the date or set of dates pertaining to this locality; omission of the date indicates that this information was not given on the 
labels of the specimens in question. The number of spec1mens, 11 sted by age (if subadult) and sex and by the museums in which they are located, is given in parentheses Immediately following each locality and set of dates. Dates are restricted to days and months of the year; if the year is deemed important, further information is presented in the discussion. The sequence of localities in this section is the same as that given in the numerical sequence in Table $V$. The sequence of dates at any one locality is chronological and the sequence of museums alphabetical; thus the sequence of dates does not necessarily correspond to that of individual specimens listed for each museum. Names of museums are abbreviated as follows: Acadeny of Natural Sciences at Philadelphia (ANSP); American Museum of Natural History (AMNH); British Museum, Natural History (BMNH); Carnegie Museum (CM); Chicago Natural History Museum (CNHM); Cleveland Museum of Natural History (CLM); Cornell University (CU); Kansas Academy of Science, Topeka (KAS); Los Angeles County Museum (LACM); Louisiana State University Museum of Zoology (LSUMZ); Moore Laboratory of Zoology, Occidental College (ML); Museum of Comparative Zoology, Harvard University (MCZ); Museum of Vertebrate Zoology, Berkeley (MVZ); United States National Museum (USNM); University of California, Los Angeles (UCLA); University of Cincinnati (UC); University of Costa Rica, San José (UCR); University of Miami (UM); University of Michigan Museum of Zoology (UMMZ); and Peabody Museum, Yale Univers 1ty (YPM). 
Following the SPECIMENS section is a list of PUBLISHED RECORDS, if any. Included herein are all primary published Honduran records of which I am aware. I have omitted only those references that simply repeated an earlier record without including any additional information or those that merely mentioned Honduras in the range of the species, unless the republic was specifically stated in the range and there were no previously published reports on which the range inclusion was based. Records in this section are listed chronologically by locality, followed by the literature reference in parentheses. If two or more authors reported the species from the same locality (or set of localities), all such references are given in succession within the same set of parentheses.

In the text of the species accounts, I have discussed the Honduran status, additional specimen and breeding data of importance, taxonomic problems, and geographic and subspecific variation, generally in that sequence. Relative abundance, seasonal occurrence, habitat preferences, altitudinal range, and geographic distribution within Honduras, as well as extreme recorded dates of occurrence of migratory species, are presented. Any other data deemed of interest are also given in text.

Primary citations of scientific names are given only if Honduras is involved in the type locality or if the citation does not appear in the "Birds of the Americas" series (see 
page 90) or the "Birds of North and Middle America" series (Ridgway, 1901-1904, 1907-1911, 1914, 1916-1919; Ridgway and Friedmann, 1941-1950). All other citations may be found in the references 1 isted above and, in the interest of conserving space, are not repeated in the present study. The primary citations that are included appear in text enclosed in square brackets; they consist of origtnal name (if different from the present usage), author, year of publication (see Bibliography for complete reference), page, and type locality, in that sequence. 
SPECIES ACCOUNTS

Family TINAMIDAE

Tinamus major (Gmelin)

SPECTMENS.--T. m. robustus (15): San Alejo, 2-3 April ( $\delta$, $\%$ LSLMZ); Lancetilla, 24 Jan. ( 7, MCZ); La Ceiba, 4 Aug. ( 8, CM); Yaruca, 22 Feb. ( $\$, M C Z)$; Catacombas, 1 April ( $\phi, q, M C 2)$; La Leona, 25 June ( $\$$, CNHM); Merendón Copán, 16 June ( $q$, CNHM); Ceguaca, 5-8 March ( ${ }^{\circ}, q$, CNHM); Lake Yojoa, 15 June ( $q, C M)$; "Honduras" ( $q, ?$, juv., AMNH).

RUBLISHED RECORDS.--Omoa (Moore, 1859: 63). Yaruca (Bangs, 1903: 142). Lancetilla (Peters, 1929b: 401-402). Ceguaca, la Leona, Merendón Copán (Hellmayr and Conover, 1942: 12). Copán [= Merendón Copán], Santa Bárbara [= Ceguaca $]$ (Blake, 1958; 504).

The Great Tinamou is a bird of rain forest, occurring primarily in undisturbed areas on the Caribbean slope below 4,000 feet. It does not inhabit second growth, where Crypturellus sout is common, but is found alongside the other forest tinamou, $\mathcal{C}$. boucardi. Tinamus major and $\mathcal{C}$. boucardi, where present together, seem to exist in about equal numbers. Joseph Leyland (Sclater and Salvin, 1868a: 87-88) reported $I$. major as comon throughout the Omoa district while Peters (1929b: 401-402) 118ted it as "not at all numerous" in the Lancetilla region. C. H. Townsend collected a set of three eggs (U.S.N.M., Honduras, 1887, no further data), presumably from Trujillo or the Ria segovia. 
Most Honduran specimens agree with examples of $\underline{\underline{T}}$. $\underline{m}$. robustus Sclater and Salvin from Mexico, and I consider all to be closest to that race. Griscom (1929a: 151) regarded the Honduran birds as intergrades between $\underline{T}$. $\underline{m}$. robustus and I. m. fuscipennis Salvadort, and Blake (1958: 504) mentioned the appearance of fuscipenis characters in some Honduran specimens. Honduran material, however, appears to me to be nearer robustus since all specimens are definitely less brown above and paler below than Nicaraguan examples of fuscipennis. Intergradation of robustus and I. m. percautus Van Tyne occurs in central British Honduras and does not involve Honduran populations.

Grypturellus soul (Hermann)

Little Tinamou

SPECIMENS. - -C. . - meserythrus (50): Lanceti11a, 14 Jan. ( $9, \mathrm{MC2}$ ); La Ceiba, 5-27 Apri1, 5-7 Aug, (o, 2\%, CNHM; o, \&, CM); Yaruca, 26-27 Feb. (o, \%, MCZ); Catacombas, 28 March-5 April ( $\sigma^{\circ}$, MLZ; 29, MCZ); Cofradí, 9-14 March (20, MLZ; 20, ${ }^{\circ}, ?$, MCZ); Las Peñltas, 7-15 Feb. ( 8 , MLZ; \&, MCZ); Río Guampú, $10 \mathrm{mi}$. NE Dulce Nombre de Culmi, $16^{\circ}$ March (o, LSUMZ); La Libertad, 15 June (Juv. o, CNHM); Merendón Copán, 18 June ( $\$$ CNHM); Cerro Higuito, Santa Bárbara, 25 Apri1 ( $\%$, AMNH); San José de Santa Bárbara, 2930 April ( ${ }^{\prime \prime}$, AMNH; downy yg. $\sigma^{\circ}$, CNHM); Santa Bárbara, 24 May-1 June ( $d$, ANSP; $2 q$, AMNH; ${ }^{\prime},{ }^{q}$, CLM); Ceguaca, 4-12 March $\left(30^{\circ}, 3 \%\right.$, CNHM); Finca Fé, 1 March, 10 sep., 23 Nov. ( $\sigma^{\circ}$, \&, ?, LSUMZ); Lake Yojoa, 16 Aug. ( $\$$, CM); San Marcos de Guaimaca, 4 July ( $d^{\circ}$, ? CNHM); EI Boquerón, 10 Sep.-15 Oct. (20", AMNH; \&, ANSP); Catacamas, 26 Aug.-20 Oct. ( $\sigma^{\circ}$, \%, Imm. $\delta$, imm. $\%$, CNKM).

PUBLISHFD RECORDS,--Yaruca (Bangs, 1903: 142). Lancetilla (Peters, 1929b: 402). La Ceiba (Deignan, 1936: 187). La Celba, Merendón Copán, La Libertad, San José de Santa Bárbara, Ceguaca, San Marcos de Guaimaca, Catacamas (Hellmayr and Conover, 1942: 32). 
In contrast to Iinamus major, the Little Tinamou is a resident of second growth and the more open edges of rain forest. Ranging to an elevation of at least 4,500 feet, it Is the commonest member of the family on the Caribbean slope of Honduras.

Honduran examples are referable to $\mathrm{C}$. $\mathrm{s}$ - meserythrus (Sclater) and show no approach to G. E. modestue (Cabanis), although there is a great amount of variability within each subspecies.

Crypturellus boucard1 (Sclater)

Slaty-breasted Tinamou

SPECTMENS.--C. b. costarlcensig > boucard1 (7): Catacombas, 27 March-8 Aprtil (25, 2\%, MCZ); Las Peñitas, 2 Feb. (?, MCŹ); La Cumbre (?, BMNH); Chamelecón (?, BMNH); C. b. costaricensis (37): San Alejo, 16 March ( $0^{\circ}$, LSLMZ); Lancetilla, 22 March ( $9, \mathrm{MCZ}$ ); La Ceiba, 4-7 Aug - (20, CM); San Esteban, 21 June ( $\left.\sigma^{\circ}, C M\right)$; E1 Boquerón, 9 Sep.-21 Oct. (40, 5\%, imm. $0^{\circ}, 2$ downy yg., AMNH; $20^{\circ},{ }^{\circ}$, imm. of, CNHM; 20, 29, juv. $0^{\circ}, M C Z$ ); Catacamas, 21 Aug.-19 Oct. (40, 4\%, imm. 8 , ?, CNIM); Arenal, 23 Jan. (?, UCLA) C. boucardi $\times$ C. cinnamomeus (2): E1 Boquerón, 17 oct. (F, AMNH); Catacamas, 27 Aug. (9, CNHM).

PUBLTSHED RECORDS.--San Pedro region (Sclater and Salvin, 1870b: 838). Lancetilla (Peters, 1929b: 402). La Cumbre, Chamelecón, Catacamas (Hellmayr and Conover, 1942:

73-74): San Pedro Sula (Todd, 1942a: 18).

This species is an inhabitant of lowland rain forest of the Caribbean slope below an elevation of 2,000 feet, occurring with Tinamus major. It is perhaps even more retiring than the latter, preferring denser growth and flying very 1ittle. In fact no Honduran specles of Crypturellus is 1ikely to fly even to escape, while Tinamus mafor frequently 
resorts to flight when disturbed.

Hybridization between $\underline{C}$. boucardi and $\underline{C}$. cinnamomeus occurs occasionally, as evidenced by the two specimens cited above, both collected in 1937 by C. F. Underwood. They are morphologically intermediate between the two species, resembling cinnamomeus in general aspect but being much darker above and below, especially on the breast, and having the light bars on the wing coverts more tawny, as in boucardi. Apparently the 1solating mechanisms (perhaps call notes in this case) are not completely effective in areas of contact, such as the Catacamas region where rain forest borders on arid scrub or cultivated lands. In most of the range of the two species, however, the difference in habitat preference prevents thetr contact.

The race $\underline{c}$. b. costaricensis (Dwight and Griscom) may be distinguished by the darker (less rufescent) back; in addition, the breast is often darker and the flanks are less distinctly barred in females, in comparison with $\underline{c}$. $\underline{b}$. boucardi (Sclater). Honduran specimens from east of the Sula Valley do not differ from a series of Costa Rican individuals; west of the Sula Valley the populations are somewhat intermediate between boucardi and costaricensis in having slightly more rufescent (less dark) backs, but they are closer to costaricensis. While comparing favorably with eastern Guatenalan material, these intermediates are definitely darker than a long series of British Honduran 
specimens. I cannot agree with Hellmayr and Conover (1942:

73) that eastern Honduran birds are boucardi; I believe treating them as intermediates closer to costaricensis better expresses the situation.

\section{Crypturellus cinnamomeus (Lesson)}

\section{Rufescent TInamou}

SPECTMENS.- - C. c. vicinior (50): Coyoles, 19 June (2o, CM); El Caliche, 5 May, 9 July (downy Yg., AMNH; $q$, CNMM); Cerro Cantora 1, 29 May ( $0^{\circ}$, CMMM); Monte Redondo, 29 May, 25 Sep., 18 Nov. ( 9, CM; of CNHM; $\&$, CLM); La Flor Archaga, 10 Jan., 9 Apri1, 1 May-17 July ( $70^{\circ}, 9$, Juv; $\delta^{\circ}$, AMNH; 4o, 28, CNHM; 20, MCZ); E1 Hat1l10, 20 Apri1-13 May (20, AMNH;

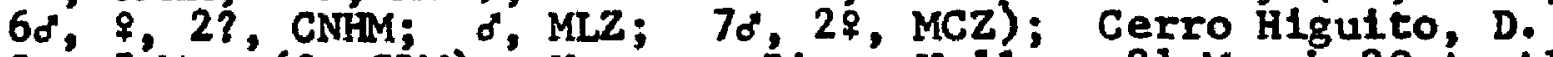
C.; 5 May ( 9, CLM); Yeguare River Valley, 21 March-20 April (2o, $\$$, UF). c.. c. cinnamomeus (1): Sabana Grande, 18 March ( $f$, CNHM). Undetermined (1): "Honduras" (?, BMNH).

PUBT.TSHED RECORDS.--Aramecina (Taylor, 1860: 312). "Honduras (Gray, 1867: 100). El Hatillo, La Flor Archaga, Monte Redondo, Cerro Cantoral [as vicinior] (Conover, 1933: 115-116). Sabana Grande [as cinnamomeus] (Hellmayr and Conover, 1942: 70). Monte Redondo las vicinior] (Todd, 1942a: 20).

The Rufescent Tinamou is the arid representative of the family in Honduras. It occurs in the Pactfic lowlands, in the drier parts of the interior highlands below 6,000 feet, and in the arid intertor valleys on the Cartbbean slope. It comes in contact with $C$. boucardi in the vicinity of Catacamas (and probably elsewhere) where rain forests border the drier portions of the Olancho Valley. As mentioned under $\mathcal{C}$. boucard1, the Rufescent Tinamou hybridizes with that spectes at Catacamas and E1 Boquerón.

In the vicinity of San Lorenzo, on the Pacific coast, 
C. cinnamomeus was fairly common, the whistles being heard throughout the day in the arid scrub of the region. Farther to the east, along the edges of monsoon forest near El Corpus, the species was also noted dally.

The single specimen in the British Museum, taken by David Dyson but without further data, is a flat skin and not identifiable to race. Hybrids between $\underline{C}$. boucardi and $\underline{\mathrm{C}}$. cinnamomeus are discussed under the former.

The race $C$. . . vicinior Conover [1933: 115; La Flor Archaga, Honduras] appears to be valid, although the males are difficult to distinguish. Both sexes average a trifle larger than $\mathrm{C}$. $\subseteq$. cinnamomeus (Lesson) and the females are much paler, less reddish, both above and below. c. c.. vicinior is the interior highland and (probably) the interior valley race, occurring from Chiapas to Honduras; the nominate race is confined to the Pacific lowlands below 3,000 feet, the single female fron Sabana Grande being typical of this race. The type of $\underline{c}$. $\underline{c}$. cinnamomeus was taken at La Unión, El Salvador, only a few miles from the Honduras border in the region of Goascorán. The two Coyoles males are tentatively assigned to vicinior on the basis of size (wing, 161.0 and 173.5, the former worn), but positive allocation of the interior valley birds must await collection of female specimens. 
Family PODICIPEDIDAE

Podiceps dominicus (Linnaeus)

Least Grebe

SPECTMENS.--p. d. brachypterus (14): Micos Lagoon, 5 mf. W Tela, 16 March $^{-1} \sigma^{\prime}$, LSUMZ); Los Planes, 15 July (26, , CM); Cofradla, 28 Feb. (?, USNM); Cerro Cantoral, 8 Apr11 (o, MCZ); Archaga, 30 oct. (o, AMNH); El Hatillo, 218 May (2o, $q, \mathrm{MCZ}$ ); Teguctgalpa, 22 Feb. ( 9, AMNH);

Yeguare River Valley, $8 \mathrm{Feb} .(d$, UF); [Dept. of] E1

Paralso, 22 Jan. ( 9 , UF).

PUBLISHED RECORD.--Tigre Is land (Taylor, 1860: 317).

The Least Grebe is widespread throughout Honduras in

suitable habitat and is generally more common than Podi-

lymbus podiceps, except at Lake Yojoa. P. dominicus pre-

fers weedy ponds, streams, and lake shore margins, rarely

venturing into open water.

Honduran specimens are all referable to the race $\underline{p}$.

d. brachypterus Chapman.

Podilymbus podiceps (Linnaeus)

Pied-billed Grebe

SPECIMENS:--P. P. podiceps (27): $3 \mathrm{mt}$. E La Lima, 3 Oct. ( $\sigma^{\prime}$ LSUMZ); El Jaral, $90 \mathrm{ct}$. ( $\sigma^{\prime}$, MCZ); Lake Yojoa, at Agua Azul, 11 Sep. ( , LSUMZ); Lake Yojoa, 25 Feb., 17-26 June, 8-13 Aug ., 8 Sep. (2o, imm., Juv. \&, CM; of, \$, MCZ; $60^{\circ}, 39,4$ imm. of, imm. $q$, juv. $\sigma^{\circ}, 2$ downy yg., UF; ; Archaga, 30 oct. ( $\delta$, AMNH).

PUBLISHED RECORP.--[Big] Swan Island (Bond, 1959: 8).

There is a breeding population of this grebe on Lake Yojoa, and Individuals may be seen throughout the year on almost any part of the lake. The downy young listed above 
were collected by Marjorie H. Carr in June; juvenal birds were taken as late as September. During the flooding of banana lands in the 1950's, Pled-billed Grebes nested on the temporary flood-fallow lakes in the San Pedro Sula area; on 4 October 1953 at Copén, Mark Trafton, Jr., observed eight nests floating on trash in the water, one of these nests with five eggs.

Charles H. Blake (Bond, 1959: 8) saw the species on Big Swan Island on 14 November 1958. This record is the only one for the Swan Islands.

Geographic variation is poorly understood in this spectes. The West Indian P. P. antillarum Bangs differs from ․ P. podiceps (Linnaeus) chiefly in its shorter wing; in respect to this measurement the Central American birds are very puzzling. The wings of seven sumer adult males from Honduras measured 124.5-139.0 (131.3) while four summer females measured 117.5-122.5 (119.9); these figures indicate a size within the range of variation of nominate podiceps. According to Hellmayr and Conover (1948a: 37), some presumed breeding birds from Mexico and Central America agree with antillarum, others with podiceps. The most conservative procedure, I belleve, would be to suppress antillarum and recognize only nominate podiceps north of South America. In any event, I cannot detect any differences between breeding Honduran birds "and North American podiceps. 
Family PHAETHONTIDAE

\section{[Phaethon aethereus Linnaeus]}

Red-billed Tropicbird

The erroneous record of this spectes from "Tigre is land" listed by Stone (1932: 296) is based on a specimen collected by a "Captain Dow" at Acajutla, E1 Salvador, and reported by Salvin and Godman (1901: 138). References to occurrence in Honduras have been based on this specimen.

While visiting Los Farallones, the rocky islets at the mouth of the Bay of Fonseca, I was informed by local fishermen from San Lorenzo who regularly visit these islands that an occasional individual of this species may be seen resting there among the boobies. Their descriptions were very accurate and could pertain only to the Red-billed Tropicbird.

\section{Family PELECANIDAE \\ Pelecanus occidentalis Linnaeus}

Brown Pelican

SPECIMENS.--Undetemined (4): Little Hog Island, 9 April (?, LSUMZ); La Celba, 26 July (imm. 6, CM); $4 \mathrm{mi}$. SW San Lorenzo, 5 oct. (Imm. \%, LSUMZ); "Honduras" (Imm., BMNH).

PUBLISHEP RECORDS.--Bird Is land, Bay of Fonseca (Taylor, 1859: 151-152). "Honduras" (Sharpe and Ogilvie-Grant, 1898: 478). Tela (Peters, 1929b: 414). Utila Island (Bond, 1936: 354).

Brown Pelicans are common along both coasts of Honduras throughout the year. Taylor (1859: 151-152) reported 
them to be breeding on an island in the Bay of Fonseca, but not on Bird Island; he was not more specific as to the is land involved and, as far as I am aware, there is no breeding colony at present anywhere on the bay. The birds are common, however, and may be noted roosting with Fregata magnificens in the trees on BIrd Island and among the boobies (Sula leucogaster and $\underline{S}$. nebouxii) on Los Farallones, at the mouth of the bay. On the Caribbean coast they are also common everywhere, but once again there is no known breeding colony within Honduran waters at the present time.

On 10 October 1964, Kenneth S. Hamilton observed one at Lake Yojoa, the only recorded occurrence of the species in the interior.

The four Honduran specimens, unfortunately, do not shed much light on the subspecific status of Honduran birds. Three of the four individuals are immatures, including the lone Pacific coast specimen. The wing of the latter (a female) measures 501.5, thus falling within the range of variation of either P. Q. carolinensis Gmelin or P. Q. cal1fornicus Ridgway, both of which are recorded from the Pacific coast of Middle America. The adult of undetermined sex from Little Hog Island, in the Caribbean Sea, measures 481.0, placing it within the variation of $\underline{P} \cdot \underline{Q}$. occidentalis Linnaeus and below that of either sex of carolinensis, according to the figures given by Wetmore (1945b: 579-580); 
but in coloration this specimen matches carolinensis and is not nearly 80 dark below as typical occidentalis. None of the Honduran specimens, therefore, may be allocated with certainty to race.

\section{Family SULIDAE}

Sula nebouxil Milne-Edwards

Blue-footed Booby LSUMZ $\stackrel{\text { SP }}{\text {. }}$

SPECIMENS.--(2): Los Farallones, 10 oct. ( $\%$, \&,

There is a fine colony of Sula leucogaster and $\underline{S}$. nebouxit on Los Farallones, small rocky islets at the mouth of the Bay of Fonseca, on the Pacific Ocean. On 10 October 1962, J. Alan Feduccia, my wife, and I visited these islands in company with two residents of San Lorenzo. The number of birds present was estimated in excess of 75 individuals of S. nebouxil and 200 of S. Leucogaster. There was no indication of breeding at this season, of course, but judging by the information from the local people, nesting does occur during the early spring months. These specimens are the first record of this species anywhere between Mexico and Costa Rica.

\section{Sula sula (Linnaeus)}

\section{Red-footed Booby}

\footnotetext{
SPECTMENS.--S. S. Bula (5): Swan Is lands, 6-31 March ( $\sigma, 8$, Juv. USNM); Little Swan Is land, 5 Jan: ( $\sigma^{\circ}$, CNEM); "Honduras" (?, BMNH).
} 
PUBLISHED RECORDS.--Swan Islands (Ridgway, 1888c: 578; Lowe, 1909: 333). "Honduras" (Sharpe and Ogilvie-Grant, 1898: 434). Little Swan Island (Fisher and Wetmore, 1931: 3; Hellmayr and Conover, 1948a: 131).

The Red-footed Booby is a common nesting species on Little Swan Island, although it is less abundant than the other breeding booby, S. 1eucogaster. C. H. Townsend collected juvenal birds in early March 1887 and also obtained six eggs, now deposited in the United States National Museum and listed as "Sula bassana." The first published report of breeding was that of Lowe (1909: 333), who stated that many were nesting on the eastern island (1.e.e., Little Swan) during his visit in January and February 1908. A. K. Fisher (Fisher and Wetmore, 1931: 3) noted young at different stages of growth on 19 and 20 April 1929.

A11 Honduran specimens are assigned to the nominate race, S. s. sula (Linnaeus). Many early reports in the 1iterature were 1 isted under the name "Sula piscator."

\section{Sula leucogaster (Boddaert)}

Brown Booby

SPECIMENS.--S. 1. 1eucogaster (10): Swan Is lands, 4 Feb., 6 March ( $q, 2 ?$, juv. $q$, juv., USMM); Little Swan Is land, 5 Jan. ( $\sigma^{\prime}, q$, imm. $\sigma^{\circ}$, imm. $q$, CMIM); Booby Cay, Cayos Cochinos, 8 April (imm., LSUMZ). S. 1. etesieca (2): Los Farallones, 10 0ct. ( $\%$, imm. \%, LSUMZ).

PUBLISHED RECORDS.--Bird Island, Bay of Fonseca (Taylor, 1859: 15I) Swan Is lands (Ridgway, 1888c: 578; Lowe, 1909: 333). Little Swan Island (Fisher and Wetmore, 1931: 3).

Both Sula leucogaster and S. sula are common breeding birds on Little Swan Island. C. H. Townsend (Ridgway, 
1888c: 578) obtained juvenal birds in February and March 1887, and Lowe (1909: 333) described them as nesting "in quantities" there. The Brown Booby is the commonest member of the family in Honduran waters. In the Cayos Cochinos, just off the north coast, during early April 1963, about 50 boobies would appear at dusk each day to roost on Booby Cay, a tiny sandy is let covered with palms. Breeding on the Caribbean side of Honduras, however, is known only on Little Swan Island.

In the Bay of Fonseca, on the Pacific Ocean, there is a sizable colony on Los Farallones, at the mouth of the bay; more than 200 individuals were seen there in October 1962, as mentioned under the discussion of S. nebouxil. Taylor (1859: 151) saw a single individual on Bird Island on 1 January 1858; it had its nest on a low tree, among the breeding frigatebirds, Fregata magnificens.

The species has been known under several names, some of which lead to confusion. "Sula fusca" is used by Taylor (1859: 151; 1860: 316), while Lowe (1909: 333; 1911: 40) treated it as "Sula sula," a name that is currently applied to the Red-footed Booby; the latter was long known as "Sula plecator."

Caribbean specimens of $\underline{S}$. Leucogaster are referable to the nominate race, S. 1. 1eucogaster (Boddaert). $\underline{S}$. 1 . etestaca Thayer and Bangs is the race to be expected on the Pacific coast; Hellmayr and Conover (1948a: 135-136) 
allocated the Bird Is land record to that form, although no specimen was available from the Bay of Fonseca at that time. The two birds obtained by $\mathrm{J}$. Alan Feduccia and me on 10 October 1962, although neither is a male (the sex that is easily distinguished), are representative of etesiaca and not of either of the two Mexican races, $\underline{S}$. 1 . brewsteri Goss, or $\underline{S}$. 1 . nesiotes Heller and Snodgrass. Adult females of etestaca, in series, are darker brown above and virtually uniform, with no contrast between head and back; our adult female compares favorably with a series of this race. The Bay of Fonseca colony appears to be the northern outpost of etesiaca.

\section{Family PHALACROCORAC IDAE}

\section{Phalacrocorax olivaceus (Humboldt)}

Olivaceous Cormorant

SPECIMENS:--P. O. mextcanus (10): Laguna Toloa, 28 Feb., 30 Aug. ( 8,9, ANSP; imn. $\$$, MCZ); Chamelecón, 20 March (?, USNM); Amapa, 18 Feb. ( $q$ ?, LSUMZ); Lake Yojoa, 13 Aug. ( $\left.\sigma^{*}, C M\right)$; Alto Cantoral, 9 March ( $\sigma^{\prime}$, MLZ); Cantarranas, 3 Aug. ( $\sigma$, ANSP); Yeguare River Valley, 6 June (imm., UF); Río Choluteca, near Danlf, 16 Dec. ( $\delta$, UF).

PUBLISHED RECORDS---Lake Yojoa (Taylor, 1860: 315). Toloa Lagoon (Peters, 1929b: 413-414). Laguna Toloa, Cantarranas (Stone, 1932: 297).

This cormorant, the only member of the family recorded from the country, is widespread throughout Honduras, occurring on both coasts and to elevations of at least 6,500 feet in the interior. It is most abundant in the Caribbean 
lowlands and may be found in almost any type of aquatic situation including bays, lakes, lagoons, rivers, swamps, and even small streams. The species is resident in Honduras, breeding in scattered colonies throughout the lowlands, especially in wooded swamp situations. Young in nests were noted on 13 April 1964 in the rookery on the Laguna Caratasca near Cauquira. Birds recorded from higher elevations in the interior are probably wanderers during the nonbreeding season.

Honduran specimens are not distinguishable from a long series of Mexican birds and are assigned to the race $\underline{P}$. $Q$. mextcanus (Brandt).

\section{Family ANHING IDAE}

\section{Anhinga anhinga (Linnaeus)}

\section{Anhinga}

SPECTMENS.--A. a. leucogaster (6): Toloa Lagoon, 30 Aug. (7, ANSP); M̀icós Lagoon, 5 mi. W Tela, 16 March (d, LSUMZ); La Celba, 29 April ( $\sigma^{\circ}, \mathrm{CM}$ ); Cantarranas, 3 Aug. (20, ANSP); Yeguare River Valley, 2 Dec. $\left(\sigma^{\circ}\right.$, UF $)$.

PUBLISHED RBCORDS.--Lake Yojoa (Taylor, 1860: 316). Cantarranas, Laguna Toloa (Stone, 1932: 297).

The Anhinga is a resident species throughout the lowlands of Honduras up to an elevation of 3,000 feet. It is not nearly so common as the Olivaceous Cormorant, Phalacrocorax olivaceus, and is even more attached to wooded, swampy areas, although individuals may be noted along wooded streams and around the larger lakes and lagoons. 
Mark Trafton, Jr., reported a mixed colony of Anhingas and Boat-billed Herons (Cochlearius cochlearius) in a flooded coastal area between San Alejo and the Laguna Micos. Nests of the Anhinga, some 20 in number, were placed in palm trees three to elght feet above the water. On 13 April 1964, I noted a few occupied nests in mangroves in the Laguna Caratasca rookery, which consists primarily of Wood Storks (Mycteria americana) and Roseate Spoonbills (Afaia afa (a).

Honduran birds are referable to the North American subspecies, A. a. 1eucogaster (Vielllot).

Family FREGATIDAE

Fregata magnificens Mathews Magnificent Frigatebird SPECTMENS :-E. m- rothschildi (13): Swan Is lands, 4 Jan. (20, 29, CNHM); La Celba, $26^{\circ} \mathrm{July}\left(20^{\circ}, \mathrm{CM}\right)$; Is la Pájaro, Bay of Fonseca, 5 Oct. (1mm., LsuMz). 319). PUBLISHED RECORDS.--Bay of Fonseca (Taylor, 1858: 31 152; 1860: 316). Swan Is lands (Ridgway, 1888c: 578; Lowe, 1909: 333-334). Tela (Peters, 1929b: 414). Little Swan Is land (Fisher and Wetmore, 1931: 3; Hellmayr and Conover, 1948a: 164). Bonacca [= Guanaja] Island (Bond, 1936: 355).

Throughout the year, Magnificent Frigatebirds are daily sights along both coasts of Honduras. A few are normally present anywhere along the north coast, and large numbers may be seen around the Islands in the Cartbbean Sea and the 
Bay of Fonseca on the Paciflc coast. There is a breeding colony on Little Swan Island, first reported by Lowe (1909: 333-334), who found then breeding in January and February 1908; he observed that the nests were placed in the tops of tal1 trees some 30 feet above the ground. The colony was visited again by Fisher and Wetmore (1931: 3), who recorded breeding on 19 and 20 April 1929. In addition, there are four eggs in the United States National Museum that were collected by C. H. Townsend in the Swan Islands on 31 March 1887.

George Cavendish Taylor found an extensive breeding colony ("thousands of birds") on Bird Island, in the Bay of Fonseca, on 1 January 1858. The eggs that he collected were first described by his brother, E. Cavendish Taylor (1858: 318-319). On 5 October 1962, J. Alan Feduccla, my wife, and I visited Bird Island and found it to be under extensive cultivation (which began in 1958, according to local residents), with only a few trees remaining on the western side of the island. There were some 50 frigatebirds and a number of pelicans present, but there was no evidence that any frigatebirds are still breeding there.

On 9 December 1962, we observed a frigatebird at an elevation of 4,000 feet soaring around Cerro Santa Bárbara, a locality some 100 miles inland. Strong northerly winds may have been responsible for the bird being at this opot. The location indicates that it is possible for this species 
to cross from coast to coast even in a mountainous country such as Honduras.

Honduran specimens are all referable to $\mathrm{F}$. $\mathrm{m}$. rothschildi Mathews. The species has often been listed as "Fregata aquila," but all Honduran records pertain to $\mathrm{E}$. magnificens.

Family ARDEIDAE

Ardea herodias Linnaeus

Great Blue Heron

SPECIMEN.--Undetermined (1): Micos Lagoon, $5 \mathrm{mi}$. W Tela, 16 March ( $\sigma$, LSUMZ).

PUBLISHED RECORDS.--Swan Is lands (Fisher and Wetmore, 1931: 3). Lancetilia (Stone, 1932: 297).

The Great Blue Heron is an uncommon winter visitant to Honduras. The published records listed above are sight records of single individuals at the narrow $\mathrm{rlft}$ between $\mathrm{Big}$ and Little Swan 1slands, 19 or 20 April 1929 (by A. K. Fisher) and at Lancet111a, 28 August 1930 (by John T. Enlen, Jr.).

I observed single Individuals at Lake Yojoa on 11 September 1962 and 14 April 1963; a few dally during October, January, and February along the Bay of Fonseca; three on 5 February 1963 and one on 13 Apri1 1964 at Puerto Lenpira, in the Mosquitia; and three (of which the specimen collected was one) on the Laguna Micos, about five miles west of Tela, on 16 March 1963. 
I feel that more study is required before combining this species with the old World A. cinerea Linnaeus, as advocated by Parkes (1955: 287-288).

The single specimen cannot be allocated with certainty. It is much darker above than any $A$. $\underline{h}$. herodias Linnaeus of the eastern United States, the race most 11kely to occur in Honduras, and comes closest to matching $\underline{A}$. h. Eannini Chapman. That the specimen actually represents this sedentary race of the northwestern coast of North America seems extremely unlikely; the bird may well be an extreme variant of herodias, but I belleve it is best to await further material before positive identification of Honduran birds is made.

\section{Butorides virescens (Linnaeus)}

\section{Green Heron}

SPECIMENS. - -B. $v$. virescens (8): Swan Is lands, 6 March-19 April, 25 sèp. ( $8,9, ?$, USMM; ?, MCZ); Lancetilla, 2 Sep. ( $\delta$ ?, ANSP); La Ceiba, 14 Jan., 15-16 March (28, CM; o, MCZ). B. $\mathbf{y}$. maculatus (12): Utila Is land, 19 Apri1 ( $\left.{ }^{\circ}, \mathrm{CM}\right)$; French Harbor, 6 April (o, $\mathrm{CM}$ ); Roatán Is land, 10 Jan. ( 8, CNHM); Lancetilla, 29 Aug. ( $\%$, ANSP); Urraco, 11 March ( $\$, M C Z$ ); Subirana, 13 Feb. ( $\%$, MCZ); Coyoles, 21-29 June ( $\left.\sigma^{\prime}, q, C M\right)$; Agua Azul, 25 oct. (1mm. , LSLMZ); Lake Yojor, 12 June ( $\sigma, C M)$; Yeguare River Valley, 5 May ( 8, UF); Crasa, 17 July ( $\sigma^{\circ}$, UCLA). Undetermined (5): Roatán Island (2? BMNH); French Harbor, 5 April ( ${ }^{\circ}$, CM); Guanaja Is land, 22 March ( $\delta, C M)$; La Ceiba, 16 May $(q, C M)$.

PUBLISHED RECORDS.--Omoa (Moore, 1859: 63). Swan Is lands (RIdgway, 1888c: 577-578; Fisher and Wetmore, 1931: 4; Paymter, 1956: 104). Roatán Island (Salvin, 1889: 376; Sharpe and Ogilvie-Grant, 1898: 190). Yaruca [= La Celba] (Bange, 1903: 141). Palomas-Toloa Canal [= Urraco] (Peters, 1929b: 411-412). Lancet11la, Laguna 
Toloa, Tela (Stone, 1932: 297). Utila Island, Bonacca [= Guanaja $]$ Is land (Bond, 1936: 355).

This heron is a fairly common resident throughout the lowlands of both coasts in suitable situations such as marshes, swamps, lake margins, and shallow streams, ranging to an elevation of about 3,000 feet. In winter, when its numbers are supplemented considerably by an influx of migrants from the north, the species becomes common. It was once thought to be resident in the Swan Islands; the insular bird was described as a new species, Butorides Saturatus Ridgway [1888c: 577; Swan Island]. Fisher and Wetmore (1931: 4) have shown that in the Swan Islands the Green Heron is a migrant only and that $\underline{B}$. saturatus is based on dark examples of the nominate race. In the Bay Islands, however, the species is probably resident.

Bangs (1903: 141) recorded a specimen from Yaruca, but the only bird in the Museum of Comparative Zoology from the collection on which he reported is the adult male I have listed from La Ceiba, taken on 14 January 1902.

The resident race in Central America is B. y. maculatus (Boddaert), which differs from the wintering $\underline{B} \cdot \underline{v}$. virescens (Linnaeus) only in smaller size. On the basis of measurements of breeding birds of known origin, I have considered the following extremes of wing measurements to be representative of the two races: maculatue $\left(0^{\circ},<169.5\right.$; $q$, <173.0); yirescens $\left(\sigma^{\circ},>167.0 ; \%,>172.0\right)$. Specimens listed are allocated to race only when they do not fall 
within the region of overlap. Wing measurements of three specimens listed as "undetermined" (the two in the British Museum were not examined) are 167.0 (o', Roatán Island), 168.5 ( $d$, Guanaja Is land), and 172.0 ( $\%$, La Ceiba). The western race, B. $\underline{y}$. anthongl (Mearns), is known to winter as far outh as El Salvador and probably occurs in the vicinity of the Bay of Fonseca, although there are no records at present.

\section{Florida caerulea (Linnaeus)}

\section{Little Blue Heron}

SPECIMENS.--(4): $1 \mathrm{mi}$. W El Jaral, $15 \mathrm{Sep}$. ( $\sigma$, ISUMZ); Cantarranas, 5 Oct. (o", ANSP); Honduras-Nicaragua boundary [near Pacific coast] (?, MCZ); "Honduras" (juv., BMNH).

$$
\text { PUBLISHED RECORPS.--Omoa (Moore, 1859: 63). Bay of }
$$
Fonseca (Taylor, 1860: 313). "Honduras" (Sharpe and Ogilvie-Grant, 1898: 104). Swan Islands (Lowe, 1909: 339). Martinez Creek, Toloa, Tela River, Lancetilla (Peters, 1929b: 410-411). Cantarranas, Tela, Puerto Castilla (Stone, 1932: 297). Utila Is land, Bonacca [= Guanaja] Is land (Bond, 1936: 355). Bonas Village (Cooke, 1938a: 83). Bonacca [= Guanaja] Is land, S1co (Coffey, 1943: 38). Bonacca [= Guanaja] Is land, "17 mi. from Iriona" [= Sico] (Coffey, 1948: 2).

of all the herons found in Honduras, this spectes is the most widespread and common. It is more abundant in the lowlands of both coasts but has been recorded in the interior to an elevation of at least 3,000 feet. Swampy and marshy areas are most suitable, but even roadside ditches and the like may have a few Little Blue Herons in evidence. Taylor (1860: 313), who reported the species as Demiegretta peal11, observed trees full of them on the Bay of Fonseca. 
The species occurs commonly in the Bay Is lands, probably breeding there as well as in a number of colontes on the adjacent mainland, and has been recorded as a migrant in the Swan Islands (sight record, Lowe, 1909: 339).

The records 1isted by Coffey (1943: 38; 1948: 2) are band recoveries and are worthy of spectal note. One bird banded on 23 May 1937 at Glen Allan, Mississippi, was recovered on Guanaja Island on 10 September 1937; the other, banded in the same place on 6 June 1937, was recovered at Sico, about nine miles southeast of Iriona, on 8 October 1937.

Two additional banding recoveries are also of interest. An individual was banded by $E$. Milby Burton at Heron Island, Charleston County, South Carolina, on 12 June 1933 and was subsequently shot at Bonas Village, near Cedros, on 16 January 1934 (Cooke, 1938a: 83). Another, banded as a nestling by Warren M. Pulich at Dallas, Texas, on 23 May 1963, was shot by a hunter at Omoa on 15 September 1963.

I cannot distinguish the supposed Central American race, E. c. caerulescens (Latham), and I regard the species as monotypic.

Casmerodius albus (Iinnaeus)

Common Egret CM).

SPECTMEN.--C. a. egretta (1): Lake Yojoa, 13 July (?, 313). PUBLISHED RECORDS --T1gre Is land (Taylor, 1860: 312-
Mart1nez Creek, Toloa, Palomas-Toloa Cana 1 (Peters, 
1929b: 410). Puerto Cast11la (Stone, 1932: 297; Cooke, 1938a: 81; Coffey, 1948: 2). [Big] Swan Is land (Bond, 1936: 8).

The Common Egret is a fairly common resident in Honduras, being confined primarily to the lowlands below 2,500 feet. It is not nearly so comon as any of the other white herons and egrets. The resident population is supplemented by the addition of wintering individuals from the north, as evidenced by the reports of Cooke (1938a: 81) and Coffey (1948: 2) of a bird banded by the latter at Holly Bluff, Mississippi, on 1 June 1935 and recovered at Puerto Castilla on 3 January 1936.

Charles H. Blake (Bond, 1959: 8) recorded the species on Big Swan Island on 21 November 1958, the only report for the Swan Is Lands.

On 13 April 1964 I noted several breeding pairs of this species in the rookery on the Laguna Caratasca. Young were almost ready to leave the nest on this date.

I agree completely with Parkes (1955: 288) concerning the retention of Casmerodius as distinct from Egretta. Honduran birds represent the American race, C. a. egretta (Gmelin).

\section{Egretta thula (Molina)}

Snowy Egret

Oct. $(\%$, LSUMZ).

SPECTMEN.--E. t. thula (1): $4 \mathrm{ml}$. SW San Lorenzo, 5 PUBLISHED RECORDS.--Choloma RIver (Moore, 1859: 64). Toloa Canal (Peters, 1929b: 411). Puerto Castilla (Stone, 1932: 297). [Btg] Swan Is land (Bond, 1959: 8). 
In Honduras the Snowy Egret is uncommon to fairly common throughout the year, occurring exclusively in the lowlands of both coasts below 2,500 feet. It is not as abundant as Florida caerulea, but it outnumbers Casmerodius albus. There is probably an influx of northern birds during the winter, as evidenced by a report of Charles $H$. Blake (Bond, 1959: 8), who observed the species on Big Swan Is land on 4 November 1958.

I agree with Parkes (1955: 288) that there is no bas is for placing this species in the monotypic genus Leucophoyx. The single Honduran specimen is referable to the nominate race, E. $\underline{t}$. thula (Molina).

\section{Bubulcus ibis (Linnaeus)}

\section{Cattle Egret}

SPECTMENS.--B. i. ibis (3): Utila Island, 22 Feb. ( LSUMZ) ; $2 \mathrm{mi}$. N Pito Solo, 29 Oct. (o", $\%$, LSUMZ).

PUBLISHED RECORD.--[Big] Swan Is land (Bond, 1959: 8). One of the most remarkable range extensions of a bird in modern times is that of the Cattle Egret. As might be expected, this species has now invaded Honduras and is one of the conspicuous features of the avifauna of the Caribbean lowlands. The first record for the country is that of Robert R. Brooks (as reported to me by Mark Trafton, Jr.), who in January 1958 found two flocks, each of about two dozen Individuals, feeding among cattle about four miles northwest of Comayagua, in the Comayagua Valley. Trafton 
observed them subsequently at San Alejo (in November 1959), near Puerto Cortés (in December 1959), and near Quimistán (in February 1960).

In the summer and fall of 1962 , the species was not in evidence until 29 October, on which date the first two Honduran specimens were secured by J. Alan Feduccta, my wife, and me from a flock of 40 just north of Pito Solo, near Lake Yojoa. Within two weeks the egrets became abundant in the Sula Valley, flocks of more than 100 being noted. Groups were recorded as far inland as the otoro Valley (near the town of Jesús de Otoro) and the Quimistán Valley (at Quimistán); along the north coast Cattle Egrets were common as far east as La Celba. In 1962-1963 a small flock of about 35 wintered on Utila Island, in the Bay Islands; Kenneth S. Hamilton secured the third specimen on 22 February 1963 from that flock. In 1963 the first Gattle Egrets appeared at Lake Yojoa on 2 October (William W. Plowden, Jr., personal communication). During early April 1964, Richard R. Graber, Jean W. Graber, and I observed small groups daily around Puerto Lempira, in the Mosquitia of eastern Honduras. On 8 September 1964 Hamilton noted 18 Cattle Egrets on Utila Is land, the earliest fall record for Honduras.

Charles H. Blake (Bond, 1959: 8) saw the species on Big Swan Is land from 3 through 27 November 1958, the only occurrence recorded from the Swan Islands group. 
As yet there is no evidence of breeding in Honduras. The species possibly does nest locally, but there are no. records for it between 17 May and 8 September.

Western Hemisphere birds represent the nominate race, B. 1. ibis (Linnaeus).

\section{Hydranassa tricolor (Müller)}

Louis iana Heron $(\sigma$, USNM)

SPECIMEN.--H. t. ruficol11s (1): Chamelecón, 17 Feb.

PUBLISHED RECORDS.--Martinez Creek, Toloa (Peters, 1929b: 411). Utila Is land; Bonacca [= Guanaja] Is land (Bond, 1936: 355).

The Louisiana Heron is an uncommon to fairly common resident in Honduras, occurring on both coasts below 2,000 feet. In the Caribbean lowlands the species is uncommon, us ually recorded singly, rarely in small groups. Bond (1936: 355) reported it as "not uncomono" on Utila and Guanaja 1slands, in the Bay Islands, but I failed to note it on Utila during the first week of May 1963. On the Pacific coast the species is common along the Bay of Fonseca; flocks of 25 or more may be seen datly feeding on the tidal mud flats or flying to roost in the mangroves with Little Blue Herons (Florida caerulea) and several spectes of egrets. The Louisiana Heron is another spectes that Increases in abundance in winter because of an influx of northern birds. 
There is no direct evidence of breeding in Honduras, but this heron is present throughout the year and certainly must nest in rookeries somewhere in the Caribbean lowlands. The single specimen is referable to the North American race, 브. 드. ruficollis (Gosse).

\section{Agamia agami (Gmelin)}

Chestnut-bellied Heron

SPECTMEN.--(1): La Ceiba, 28 July ( $\%$, CM).

This species is extremely rare in Middle America north of Panama. It is found primarily along streams in lowland rain forest, being much more retiring than other herons.

The only record for Honduras is the specimen listed above, collected at La Ceiba on $28 \mathrm{July} 1950$ by Arthur C. Twomey and Roland $W$. Hawkins. It has not been previously recorded from Honduras.

\section{Nycticorax nycticorax (Linnaeus)}

Black-crowned Night Heron

PUBLISHED RECORDS---Omoa (Moore, 1859: 63). Bay of Fonseca (Taylor, 1860: 313). Toloa Canal (Peters, 1929b: 411).

In the lowlands of both coasts of Honduras, the Blackcrowned Night Heron is locally common; it is unrecorded above an elevation of 500 feet. Joseph Leyland (Moore, 1859: 63) reported it as common around Onoa. Peters (1929b: 411) stated that two or three were flushed along the Toloa Canal on 28 February 1928. I observed a number of 
Individuals of this species mixed with a colony of Boatbilled Herons (Cochleartus cochlearius) along a stream at San Alejo. Although the date of this observation (14 March 1963) is before the breeding seas on, Richard Washburn, of San Alejo, told me that both species had nested together at this spot for at least three years.

On the Pacific coast the only record is that of Taylor (1860: 313), who reported that Amory Edwards shot one on the Bay of Fonseca; the specimen was not preserved.

Although no specimens are extant, Honduran birds undoubtedly represent the North American race, N. ㅁ. hoactli (Gmelin), which occurs from Canada to Argentina.

\section{Nyctanassa violacea (Linnaeus)}

Yellow-crowned Night Heron

SPECIMENS - - N. y. violacea (2): Swan Is lands, 14 April (o, MCZ); $4 \mathrm{ml}$. SW San Lorenzo, 5 Oct. (o, LSUMZ).

PUBL.TSHED RECORDS.--MHonduras" (Moore, 1859: 63). Roatán Island (Salvin, 1889: 376). Puerto Castilla (Stone, 1932: 298). Utila Is land, Bonacca [= Guanaja] Is land (Bond, 1936: 355). Swan Islands (Paynter, 1956: 104).

This species is fairly common and more widespread than the Black-crowned Night Heron, Nycticorax nycticorax. It occurs in the lowlands of both coasts below 2,500 feet and in the Bay Is lands. It is resident, at least on the mainland, but is known from the Swan Islands by the single specimen taken on 14 April 1913.

Moore (1859: 63) mentioned a specimen of this species 
taken in Honduras by David Dyson; Salvin (1861b: 357) and many subsequent authors attributed this specimen to Joseph Leyland, who collected at Omoa, but Leyland recorded only Nycticorax nycticorax at that locality.

The specimen from the Swan Islands, as expected, is referable to the nominate race, N. $\underline{v}$. ytolacea (Linnaeus). Surprisingly enough, the specimen taken near San Lorenzo on the Bay of Fonseca is also of this race (exposed culmen, 70.0), not $\mathbf{N} \cdot \mathbf{v}$. bancrofti Huey, a subspecies known to breed south to El Salvador and to winter to Nicaragua on the Pacific coast. The latter race probably occurs on the Bay of Fonseca, but no specimens have as yet been taken. Caribbean slope birds are probably all referable to the nominate race. I have not examined the Dyson specimen in the Derby Museum and therefore am not allocating it subspecifically.

Iigrisoma lineatum (Boddaert)

Banded Tiger Heron $(?$, USNM).

SPECIMON.--T. 1. 11neatum (1): Segovia River, 13 Aug. 597).

PUBLISHED RECORD.--Segovia River (Ridgway, 1888c: 595-

The oniy record of this species for Honduras is the one cited above. The specimen was taken by $\mathrm{C}$. H. Townsend on 13 August 1887 and was described as new species, I. excellens Ridgway [1888c: 595; Segovia River, Honduras]. Todd and Carriker (1922: 137) have shown that the 
description was based on one of the three distinct plumage phases exhibited by this spectes.

Southeastern Honduras is the northern 1imit of the range of the species, except for one record from Chiapas, probably representing a vagrant individual.

Central American records all pertain to the nominate race, I. 1. 1ineatim (Boddaert).

Heterocnus mexicanus (Swains on)

Bare-throated Tiger Heron

SPEC IMENS.--H. ․‥ mextcanus (20): Laguna Toloa, 30 Aug. ( $?$ ?, ANSP); San Alejo, 8 Aug. ( ${ }^{\prime}$, LSUMZ); Lancetilla, 20 Feb. ( $\$, M C Z$; La Celba, 16-29 May ( $\delta, 3 \%, C M)$; Truj1110, 9 April (o, CM); Río de Las Piedras, 16 Jan. ( 9 CM); Chamelecón, 20 Feb., 2 March (2\%, USNM); Amapa, 20 July (imn. $\$ ?$ ?, LSUMZ); Coyoles, 28-30'June (2\%, CM); Lake Yojoa, 5 Aug. (Imm., UF); Cantarranas, 8 Aug. ( 8 , ANSP); Yeguare RIver Valley, 24 Feb., 29 oct. (20, UF); Puerto Salamar, 2 Oct. ( $\sigma^{\circ}$, LstuZ); Tigre Island, 1 Jan. ( $\sigma^{\prime}$, AMNH).

\section{PUBLISHED RACORDS.--Tigre Island (Sclater, 1858b:} 359) Onoa, Ulua River (Moore, 1859: 63). Bird Is land, Bay of Fonseca (Taylor, 1859: 151). Bird Island, Lamaní (Taylor, 1860: 313). Lancetilla, Palomas-Toloa Canal (Peters, 1929b: 412). Cantarranas, Laguns Toloa, Tela (Stone, 1932: 298).

This tiger heron is fairly common and widespread throughout the lowlands of both coasts of Honduras and in the interior, where it ranges to an elevation of 3,000 feet along streams and rivers. It prefers wooded areas and does not normally flock, although many may be seen in the same general area. Its guttural croak may be heard at night as well as in the day.

Heterocnus mexicanus has appeared in the literature 
under several different names, including Tigrisoma cabanis 1 and $\underline{I}$. brasiliense. The name cabanisi was used until van Rossem (1942b: 572) demonstrated that mexicanus had priority. The genus Heterocnus is sometimes combined with Tigrisoma; since structural differences are present and since Iigrisona (sensu stricto) consists of a natural group of two closely related species, I can see no point in lumping the two genera.

Individuals of this species throughout the range, except in extreme northwestern Mexico, are referable to the nominate race, H. m. mexicanus (Swainson).

\section{Ixobrychus exilis (Gmelin)}

Least Bittern

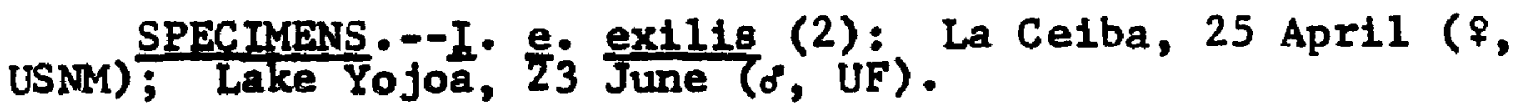
PUBLISHED RECORD.--La Ceiba (Deignan, 1936: 187).

The Least Bittern is an uncommon to rare resident with local distribution throughout much of its Middle American range. In Honduras there is one certain breeding colony at Lake Yojoa, and the species presumably bred on the floodfallow lakes at Copén during the early 1950's. In addition to the specimen taken by Marjorie H. Carr on 23 June 1948, there are several sight records at Lake Yojoa. Mark Trafton, Jr., has records of Least Bitterns from the lake for the months of January, May, June, July, August, and December, and for the La Lima area in January, June, and August. 
Paul Slud noted the spectes at Lake Yojoa on 23 June 1948, and V. C. Dunlap saw it there on 4 June 1952, 11 January 1953, and 8 December 1958. The La Ceiba specimen, taken on 25 Apr11 1933, may have been a migrant from North America. The two specimens from Honduras are referable to the eastern race, I. e. exilis (Gmelin); the wing measurements of the birds are 110.9 ( 9 , La Ceiba) and 118.5 ( 8 , Lake Yojoa). The western race, I. e. hesperis Dickey and van Rossem, winters south to South America and may occur in western Honduras during migration, although there are no known specimens.

Botaurus lentiginosus (Rackett)

American Bittern

SPECIMEN.--(1): Tegucigalpa, Nov. ( $\%, M C Z)$. PUBLISHED RECORD.--Swan Is lands (Lowe, 1909: 339).

Although the specimen and other record 1 isted above are the only reports of this species from Honduras, it is probably a regular winter visitant to the country. It is easily overlooked in its marsh habitat but is known to be a regular wintering bird as far south as Panama. The single specimen was taken in November 1936 by C. F. Underwood. The record from the Swan Islands is based on a sight identification by Lowe (1909: 339) in January or February 1908. During 1962-1964 I falled to find the species in Honduras. 
I cannot distinguish the western race, $\underline{B}$. 1. peeti Brodkorb, and therefore consider the species to be monotypic.

\section{Family COCHLEARIIDAE}

Cochlearlus cochlearius (Linnaeus)

Boat-billed Heron

SPECTMENS.-C. c. zeledont (11): San Alejo, 14 March (o, LSUMz); La Céiba, $18 \mathrm{May}$ ( $\%$ CM); Cofradla, 28 Feb. ( ${ }^{\circ}, \AA$, USNM); Coyoles, 17 June $\left(0^{\circ}, 5 \%, C M\right)$; Lake Yojoa, 2 Jan. $(q, \mathrm{MCZ})$.

The Boat-billed Heron is a widespread tropical heron occurring in locally distributed colonies along wooded streams, lakes, and swamps, and in mangroves. It has been found in Honduras primarily on the Caribbean slope up to an elevation of 2,100 feet.

Mark Trafton, Jr., reported a breeding colony at Lake Yojoa during the $1940^{\prime} \mathrm{s}$ and $1950^{\prime} \mathrm{s}$, but I failed to record the species there during 1962-1964. Trafton also found the species breeding in the $1950^{\prime s}$ at two other localities, one between San Alejo and the Laguna Micos and the other along the Río Chamelecón downriver from La Lima. The San Alejo colony was pointed out to me by Richard Washburn, of San Alejo, on 13 March 1963. This colony consisted of mixed Boat-billed Herons and Black-crowned Night Herons (Nycticorax nycticorax).

Taylor (1860: 313) observed "a bird with a broad bill, 
possibly Cancroma cochlearia" along the banks of the Río Nacaome [= Río Pespire], on the Pacific slope. This record very likely does pertain to the Boat-billed Heron. Birds north of Costa Rica are referable to $\mathrm{C}$. $c$. zeledoni (Ridgway).

$$
\text { Family CICONIIDAE }
$$

\section{Mycteria amaricana Linnaeus}

$$
\text { Wood Stork }
$$

SPECTMEN.--(3): Urraco, 11 March (o", MCZ); La Ceiba, 22 May (o, CM); 1 mi. S Cauquira, 13 April (juv., LSUMZ).

$$
\text { PUBLISHED RECORDS.--Lamaní (Taylor, 1860: 313). }
$$
Toloa, Palomas-Toloa Canal (Peters, 1929b: 410). Puerto Castilla, Cantarranas (Stone, 1932: 298).

In the lowlands of both coasts, the Wood Stork, or Wood Ibis, is a common spectes, occurring in a wide variety of wet situations ranging from open flooded fields to wooded swamps. The spectes usually is seen in flocks, often exceeding 50 individuals each. Under suitable meteorological conditions, the Wood Stork frequently soars at great heights, sometimes being seen with groups of hawks or vultures.

Taylor's (1860: 313) record for Honduras is often overlooked in the 1iterature. Under his discussion on the White Ibis (Eudocimus albus), he stated that he "found a specimen of Tantalus loculator [= Mycteria americana $]$ lying dead near the village of Lamanf." C. Brooke Worth (Stone, 
1932: 298) saw three at Cantarranas, an interior location at an elevation of about 3,000 feet, the greatest elevation from which I have a Honduran report of the species. The rookery on the Laguna Caratasca near Cauquira contained about 600 breeding pairs on 13 April 1964. On this date young varied in age from half-grown nestings to juvenals just out of the nest.

\section{Jabiru mycteria (Iichtenstein)}

\section{Jabiru}

The Jabiru is a rare bird in most of Central America and Honduras is no exception. In Honduras it is known only from the Caribbean lowlands. The species does not flock as does the Wood Stork (Mycteria americana) and observations are usually of single individuals or pairs. Mark Trafton, Jr., informed me that he had seen as many as eight in one day from the air and that he had yearly records from 1950 through 1961 for the species at Puerto Arturo, near Tela. V. C. Dunlap recorded it as Los Planes in the Aguán Valley on 23 January 1950 and at Puerto Arturo on 23 January 1953. All these observations were made in the months of December and January.

William Lady, of Tegucigalpa, told me that he had seen single Jabirus on several occasions while he was flying over the Mosquitia in eastern Honduras. On 31 January 1962, Robert Benson, of the Pure Oil Company in Tegucigalpa, 
photographed a Jabiru 20 miles southeast of Puerto Lempira, in the Mosquitia. The photograph is now in my possession and is unquestionably that of a Jabiru; it constitutes the only record for Honduras other than sight records.

Along the highway 17 miles north of San Pedro Sula on 30 Auguet 1962, J. Alan Feduccia and I saw a Jabiru in flight and perched in top of a tall tree.

The seasonal occurrence of this species in Honduras indicates that it probably does not breed in the country but is instead a visitant during the nonbreeding season, probably from populations in Panama or northern South America.

\section{Family THRESKIORNITHIDAE}

\section{Eudocimus albus (Linnaeus)}

\section{White Ibis}

SPECIMENS.--(3): Utila Island, 28 April (?, CM); San Lorenzo, 25 Sep. ( $\$, M C Z$ ); Puerto Salamar, 9 Feb. (Imm. of, LSUMZ).

PUBLISHED RECORDS.--Nacaome River (Taylor, 1860: 313). Puerto Castilla (Stone, 1932: 298). Utila Island (Bond, 1936: 355).

This ibis is fairly common in the lowlands of both consts, occurring below 2,500 feet; In addition, there 18 a colony on Ut1la Island, in the Bay Islands. The stscies is most common near the coast, where groups may be seen feeding on tidal flats or roosting in mangroves. Flocking is the usual behavior and $s$ ingle individuals are rarely noted. The birds on Utila Island roost and nest in the mangroves at 
the western end of the island; the flock may be seen in the early morning flying to feeding grounds elsewhere on the 1sland and in the evening returning to the mangroves.

Whether migrants from the north winter in Honduras is not known. It seems 1ikely that such is the case although probably not in such great numbers as the herons, since seasonal fluctuations in the ibis population are not as pronounced.

\section{[Plegadis chihi (Vieillot)]}

\section{White-faced Ibis}

The inclusion of this species in the Honduran list is based upon an observation by Mark Trafton, Jr., during the winter of 1953-1954. A single adult appeared on the floodfallow lakes at Copén on 29 November 1953. Trafton informed me that although the bird should have been in winter plumage, there was a definite white feathered area on the sides of the face. This Individual was observed dally at close range for more than a week, after which time a few others appeared and remained into February 1954 in ascociation with the thousands of other water birds present there. Until the matter of reported sympatric breeding of this spectes and the Glossy Ibis, P. falcinellus (Linnaeus), in Florida, Louisiana, and Texas is completely proved or disproved, it seems best to matntain the two forms as separate species. 


\section{Alaja ajaja (Linnaeus)}

Roseate Spoonbill

SPECTMENS.--(4): Ut1la Is land, 19 Apr11 ( $(, C M)$; LOS Planes, I6 July ( $\delta, C M)$; Lake Yojoa, 3 Aug. ( $d, U F) ; 1 \mathrm{mi}$. S Cauquira, 13 April (juv. \&, LSUMZ).

PUBLISHED RECORDS.--Tela, Toloa, Ulia River, Martinez Creek (Peters, 1929b: 410). Puerto Castilla (Stone, 1932: 298).

The Roseate Spoonbill is fairly common in the lowlands of both coasts and on Utila Island, in the Bay Ieland; it has not been recorded above 2,500 feet. The specles is not as common as either Eudocimus albus or Mycteria americana, with which it commonly associates. On the Bay of Fonseca, numbers may be seen daily feeding on the tidal mud flats with ibises and herons. Occasionally, flocks of more than 50 individuals may be noted.

The Laguna Caratasca rookery near Cauquira contained approximately 300 breeding pairs of this species on 13 April 1964. Many young had left the nest on this date, but several individuals were only a few days old.

Family PHOENICOPTERIDAE

[Phoentcopterus ruber Linnaeus]

American Flamingo

In the sumer of 1936, Peter Keenagh (1938: 267) and a friend set out on an exploring trip to eastern Honduras. In their account of reaching the western end of the Laguna Caratasca from the Laguna Guarunta is the following passage: 
"In a few places we saw flamingoes, squatting strangely on tall conical nests." If the report is accurate, it could apply only to this species. Although Keenagh was not a naturalist, other natural history observations reported by him seem satisfactory.

In view of the above record, I asked William Lady of Tegucigalpa, a pilot, explorer, and naturalist in his own right, if he knew of this colony. He informed me that he had conducted flights many times over the Laguna Caratasca and that there are no flamingos there now. It is 1ikely that we shall never know the status of Keenagh's observation.

During the middle $1950^{\prime} \mathrm{s}$, after a Caribbean hurricane, a group of eight flamingos was sighted flying over the town of Tela. The observation was made by perbonnel of the United Fruit Company at Tela, but unfortunately none was an ornithologist, although the persons involved were familiar with the Roseate Spoonbill (Ajala afala), the only other pink or red heronlike bird. In addition, three birds were reported from the Tela golf course several days subsequent to the initial report. No further deta11s on these observations are available. 
Family ANATIDAE

\section{Chen crerulescens (Linnaeus) \\ Snow Goose}

A specimen of the white phase of this species was shot by N. C. Thornton, of the United Fruit Company, on 23 November 1957 on the flood-fallow lakes at Campin, near La Lima. The bird, an immature male that had been banded, was taken from a group of three individuals that had been present for more than a week in the same area. The remaining two birds were seen there until 2 December. Mark Trafton, Jr., who was first to observe these birds in Honduras, made the identification and obtained a photograph of the Individual that was shot; the photograph, along with the band return report, is now on file with the Fish and Wildife Service in Laurel, Maryland.

I tentatively follow Cooch (1961: 72-89) in regarding the Blue Goose, Chen caerulescens, and the Snow Goose, $C$. hyperborea (Pallas), as color phases of a single species.

The Honduran record is the first one of the Snow Goose south of central Mexico.

\section{Dendrocygna btcolor (Vieillot)}

Fulvous Tree Duck

SPECIMEN.--(1): Lake Yojoa, 17 June (f, CM).

PUBLISHED RECORD.--"Honduras" (Eisemann, 1955a: 17). The Fulvous Tree Duck 18 resident in Honduras, breeding 
In the Lake Yojoa area. The size of the breeding population there is not known, but the species is certainly less common than Dendrocygng autumnalis. The greatest number that I recorded during a period of eight months, when we visited the lake on the average of once a week, was a flock of about 30 Individuals on 27 April 1963.

The species was first reported from the lake by Marjorie H. Carr, upon whose observations Eisenmann (1955a: 17) recorded it from the country. The single specimen was collected by Arthur C. Twomey and Roland W. Hawkins on 17 June 1951.

Mark Trafton, Jr., informed me that Fulvous Tree Ducks were regular on the flood-fallow lakes in the La Lima area from 1952 through 1954. He recorded them in every month except May and June. They were most common on the Copén lakes in September 1954.

The single specimen matches North American material, but I cannot detect any constant differences in color or in b111 size between North American and South American birds. I therefore regard the northern race, $\mathbf{D}$. $\underline{b}$. helva Wetmore and Peters, to be a synonym of bicolor, thus restoring the species to monotypic status.

\section{Dendrocygne autumnalis (Linnaeus)}

Black-bellied Tree Duck

SPECTMENS.--D. a. antumnalis (8): Lake Yojoa, at Agua Azul, 25 Oct. (imm., Lsuxz); Lake Yojoa, 18-26 June, 26 July, 16 Aug. (3o, \&, CM; \&, MCZ; of, \&, UF). 
PUBTISHED RECORDS.--Lake Yojoa (Sc1ater, 1858b: 360; Taylor, 1860: 315).

Although previous published records pertain only to the population found on Lake Yojoa, this species is widespread In Honduras and is probably the most common breeding anseriform bird. It is a fairly common resident in the lowlands of both coasts, occurring below 2,500 feet. During 19621964 I recorded them regularly on Lake Yojoa (every visit) and on the Bay of Fonseca (in October, January, and February). I occasionally noted small groups in marshy fields and roadside ponds near San Pedro Sula and Potrerillos and in February 1963 observed others on marshy ponds in the pine savanna of the Mosquitia. In Middle America the species is hunted widely and frequently domesticated.

The taxonomic picture is somewhat confused in this species. Friedmann (1947: 189-195) claimed that Linnaeus' name should be applied to the South American subspecies, long known as D. a. discolor Sclater and Salvin, and he therefore renamed the northern form D. a. Eulgens. Friedmann went a step further and also named D. a. lucida as new, assigning this name to the Mexican and Central American populations (restricting fulgens to the southeastern United States and Tamaulipas) on the basis of blacker and glossier abdomens in Iucida. Hellmayr and Conover (1948a: 314-316) disagreed, glving arguments for retention of autumnalis for northern birds and also claimed that the darkness depends on 
age. Their arguments for retention of autumnal is for northern populations are very strong and I agree with their conclusion. Furthermore, it seems that they were right in the suppression of lucida, since a series of spectmens from throughout the range south to Panama contains birds with black abdomens and birds with brown abdomens; older individuals apparently acquire the darker color and gloss iness with age.

\section{Cairina moschata (Linnaeus)}

\section{Muscovy Duck}

SPECIMENS.--(3): Lake Yojoa, 15-23 June ( $\sigma^{\prime}, \mathrm{CM} ;$;, UF); Yeguare River Valley, 9 Feb. ( $\delta$, UF).

PUBLISHED RECORDS.--Chamelecón River, Aloor [= Ulúa] River (Moore, 1859: 65). Lake Yojoa (Taylor, 1860: 315). Tela, Martinez Creek, Toloa Canal (Peters, 1929b: 412).

Cairing moschats is one of the two widespread resident ducks of Honduras, the other being Dendrocyena autumnalis. The Muscovy Duck is found in the lowlands of both coasts and in the interior along 8 treams to at least 3,000 feet above sea level. It is the favorite food duck in Honduras and great numbers are ktlled annually. Flocks of 50 or more indifiduals are occasionally reported. Since there is much wandering after the breeding season, numbers in any one locality may fluctuate both seasonally and annually. For several years in the recent past, large numbers appeared in winter in the marshes along the Bay of Fonseca, but during 
the winter of 1962-1963, only a small fraction of the normal number was present.

\section{Anas crecca Linnaeus}

Common Teal

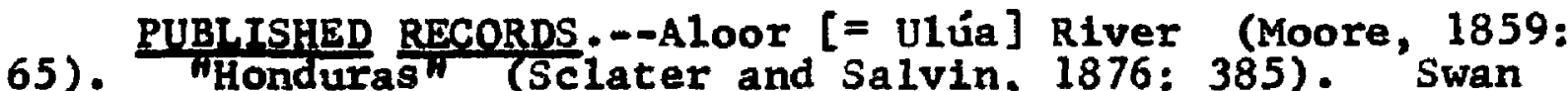
Islands (Lowe, 1909: 339).

This teal is an uncoumon winter visitant to Honduras. Joseph Leyland (Moore, 1859: 65) first reported it from the country on the basis of observations along the Aloor [= Ulua] River in 1855-1856. Sclater and Salvin (1876: 385) stated that Leyland had actually taken examples of it in Honduras and, in addition, attributed it to Honduras through the report of David Dyson; however, it is possible that Dyson's record is actually founded on that of Leyland. The Swan Islands report of Lowe (1909: 339) was based ent1rely on observations by the local residents.

Mark Trafton, Jr., observed the species occasionally on the flood-fallow lakes of Copen during the years from 1951 through 1953. The earliest date of arrival that he recorded was 25 September; he noted it in every month thereafter through February. On several occasions he examined birds taken by hunters. V. C. Dunlap reported it from La Itma on 24 November 1952.

I did not observe it during the winter of 1962-1963, but this particular season was exceptionally poor for 
waterfow1 in Honduras.

I agree with Parkes (1958b: 121) that the Green-winged Teal (A. carolinens1s) is conspeciftc with A. crecca.

Although no specimens are extant, Honduran records of this species undoubtedly pertain to the American race, A. C. carolinensis Gmelin.

\section{Angs acuta Linnaeus}

Common Pintail

PUBLISHEP RECORDS.--Swan Is lands (Lowe, 1911: 51-52). Lower Ulua Valley (Peters, 1929b: 413). Laguna de Garrobas (Lincoln, 1936: 143).

The Common Pintall is a regular winter visitant to Honduras, varying in numbers depending upon the year and season. According to Mark Trafton, Jr., who observed the species in the Copén area from 1951 through 1955, it was uncommon in the early winter but became very common in some years during February and March. His earliest arrival date was 18 October; he has recorded it every month from October through March. On 18 January 1955 he noted several small flocks in the Martinez creek area.

Lowe's (1911: 51-52) report froin the Swan Is lands was based entirely upon information of the local residents. Peters (1929b: 413) noted pintails among huge flocks of Anas discors and Spatula clypeata in 1928, in the lower Ulia Valley. I did not observe the species during the winter of $1962-1963$. 
Lincoln (1936: 143) reported that a pintail banded at Ellinwood, Kansas, on 11 April 1934 by F. W. Rob1 was shot at the Laguna de Garrobas on 29 January 1935. In addition, there have been at least elght other banding recoveries in Honduras. A11 the latter were made between November and March at Lake Yojoa or in the Sula Valley. These individuals had been banded in California (5), Montana, Manitoba, and South Dakota.

\section{[Anas platyrhynchos Linnaeus]}

\section{Common Mallard}

The only reports of the Common Mallard for Honduras are those of local hunters who observed this species in at least two regions of Honduras. Some years produce several records by hunters in the Bay of Fonseca area, and a few individuals have been reported from the Sula valley. The species is known to occur in winter as far south as Panama, 80 its occasional appearance in Honduras is not surprising.

\section{Anas cyanoptera Vieillot}

\section{Cinnamon Teal}

The Cinnamon Teal is a rare migrant or spring visitant to Honduras. Mark Trafton, Jr., observed an adult male on the Copén flood-fallow lakes in March 1953. He also received reports of others having been killed by hunters in the same general area. In March 1954 one was shot by a 
hunter on the Laguna Micos near Tela and Identified by Trafton.

A male Cinnamon Teal, banded on 27 September 1957 in the Imperial Valley of California, was recovered in the Sula Valley on 25 March 1958.

The species has not been previously recorded from Honduras.

\section{Anas discors Linnaeus}

\section{Blue-winged Teal}

SPECIMENS.--(2): Utila Is land, 19 April ( $d, C M) ; 1$ mi. S Potrerillos, $19 \mathrm{Feb}$. (wing only, LSUMZ).

PUBLISHED RECORDS.--Omoa (Moore, 1859: 64-65). Tigre Is land, Lake Yojoa (Taylor, 1860, 315). Swan Islands (Lowe, 1909: 339; Delacour, 1938: 544). Toloa (Peters, 1929b: 413). "Honduras" [" Puerto Cortés and Corocito] (Lincoln, 1933: 31). Utila Island (Bond, 1936: 354). Puerto Cortés, Corocito (Lincoln, 1936: 143).

By far, this teal is the most abundant duck wintering in Honduras. It occurs in tremendous flocks and 18 very. widespread in the lowlands of both coasts and in the interior; it ranges up to an elevation of at least 3,000 feet. Uncountable numbers were present during the early 1950's on the flood-fallow lakes in the San Pedro Sula region, according to Mark Trafton, Jr. Extreme dates of arrival and departure for Honduras are 15 September and 27 April; one banding recovery from Honduras during the last 10 days of May 1957 was reported.

Moore (1859: 64-65) recorded Blue-winged Teal "in flocks of two or three hundreds" in winter about omoa; he 
also reported that they bred in the 8 ame area, but there is no evidence of nesting anywhere in Honduras. Taylor (1860: 315) gave an interesting account of one individual on Tigre Island, wounded from a small flock, being caught on the wing by a large hawk (species unknown). Lowe's (1909: 399) report from the Swan Islands was based entirely on sightings by local restdents; however, Delacour's (1938: 544) observation of the species in the Swan Islands substantiated its occurrence there.

The specimen of a wing from near Potrerillos was taken from a blrd collected by a local hunter in 1963; the male from Ut1la Island was obtained by Arthur C. Twomey and Roland W. Hawkins in 1948.

Lincoln (1933: 31; 1936: 143) reported that two ind1viduals banded at Ellinwood, Kansas, on 13 and 24 April 1930 were respectively recovered in February 1931 at Puerto Cortés and on 7 November 1931 at Corocito. There have been at least 17 additional banding recoverles of this species from Honduras. These latter individuals were banded in Alberta (6), Saskatchewan (2), Manitoba, North Dakota, South Dakota (3), Minnesota, Illinols (2), and Missouri. In Honduras, recoveries were reported from the south coast, the Sula Valley, and the Mosquitia. 


\section{Spatula clypeata (Linnaeus)}

Northern Shoveler

PUBLISHED RECORDS:--Swan Is lands (Lowe, 1911: 51-52). Toloa Canal (Peters, 1929b: 413).

The shoveler is a fairly common winter visitant to Honduras, at least on the Caribbean slope below 2,500 feet. Lowe's (1911: 51-52) record from the Swan Islands was based entirely on reports of local residents. Peters (1929b: 413) reported several individuals with flocks of Blue-winged Teal (Anas discors) on 10 and 11 March 1928 along the Toloa Canal; on 11 March one was shot for identification purposes but was not preserved.

Mark Trafton, Jr., informed me that the species was common in the La Lima region on the flood-fallow lakes from 1952 through 1961. The earliest fall record was reported from Copén on 18 September 1954, and the latest spring departure was recorded by V. C. Dunlap on 15 May 1953. A single individual was noted on Lake Yojoa on 12 January 1955. I failed to find the species on Lake Yojoa during the winter of 1962-1963.

Two males banded in Saskatchewan on $31 \mathrm{July} 1956$ and 13 July 1955 were recovered in the Sula Valley on 19 November 1956 and in the spring of 1957, respectively.

Mareca americana (Gmelin)

American Wigeon

[Big] SWan Is land (Bond, 1959: 8). 
In Honduras, the American Wigeon is a fairly common winter visitant, at least on the Caribbean slope; it has not been reported above 2,500 feet. During the early 1950's, the years of the flood-fallow lakes in the Sula Valley, numbers were observed regularly from November through March by Mark Trafton, Jr., and V. C. Dunlap. During this period the species was recorded at Copén, at La Lima, and on the Laguna Micos near Tela. In the winter of 1962-1963, a flock of about 50 individuals remained on Lake Yojoa from 12 December through 27 April. I obtained several photographs of them there on 29 January.

Lowe's (1909: 339) report from the Swan Islands was based on statements of local residents, but Charles $\mathrm{H}$. Blake (Bond, 1959: 8) saw the species on Big Swan Island from 4 through 15 November 1958.

Aythya valisineria (Wilson)

Canvas back

PUBLISHED RECORD.--Swan Is lands (Lowe, 1909: 339). The Canvasback is a rare winter visitant to Honduras. Mark Trafton, Jr., examined an individual shot by a hunter on a flood-fallow lake at Copén, sometime in November 1953. V. C. Dunlap reported the species from the lakes at Tibombo, near La Lima, on 30 March 1960. Local residents on the Paciftc coast told me that the Canvasback used to appear occasionally on the Bay of Fonseca, sometimes in large flocks, but had not been seen in recent years. 
Lowe (1909: 339) based his Swan Island record on reports of the islanders, one of whom claimed to have shot 40 birds in a single week.

The species has not been previously recorded on the mainland of Central America south of Guatemala.

\section{Aythya collaris (Donovan)}

Ring-necked Duck

PUBLISHED RECORD.--"Honduras" (Eisenmann, 1955a: 19).

Although this species has been observed only at Lake Yojoa, as far as I am aware, it is probably a regular but uncommon winter visitant to the Caribbean lowlands of Honduras. The inclusion of Honduras in the range of the spectes by Eisenmann (1955a: 19) was based on sight records at Lake Yojoa by Marjorie H. Carr. From 12 January through 24 February 1963, a flock of about 40 individuals remained at the lake. I secured photographs of a male on 22 January. These records are the only ones for the country.

\section{Aythya affinis (Eyton)}

Lesser Scaup (8, LSLEL ). PUBLISHED RECORP.--[Big] Swan Island (Bond, 1959: 8). This wintering species is common in Honduras, being exceeded in numbers (among the anseriform birds) only by the Blue-winged Teal (Angs discors). Flocks of several thousand have been recorded on the larger lakes and lagoons. 
Mark Trafton, Jr., and V. C. Dunlap observed the species annually from 1950 through 1961; their extreme dates of arrival and departure were 18 September and 2 June, and their records included observations from Copén, Laguna Micos, Progreso, Guaruma, and Lake Yojoa. Paul Slud observed the species on Laguna Micos in June 1952, and Charles H. Blake (Bond, 1959: 8) noted it on Big Swan Is land on 14 November 1958.

On 16 March 1963 I encountered a flock estimated in excess of 8,000 individuals on the Laguna Micos; the single specimen was secured from this flock.

Despite the abundance of this species in Honduras, there are no previous records of its occurrence on the mainland.

\section{Oxyura dominica (Linnaeus)}

Masked Duck

SPECIMEN.--(1): Lake Yojoa, at Agua Azul, 22 Feb. (imm. o, LSUMZ).

PUBLISHED RFCORD.--[Big] Swan Island (Bond, 1959: 9).

The status of this duck in Honduras is uncertain. It is rarely recorded anywhere in Middle America north of Panama. The species was first noted in Honduras by Mark Trafton, Jr., who observed four on the Copén flood-fallow lakes on 18 September 1954; he also observed it there occastonally from January through March 1955. On 2 January 1954 Trafton collected an immature male at Copén. Its 
measurements were: wing, 157; ta11, 80; tarsus, 31; and exposed culmen, 33. The specimen was not preserved.

Charles H. Blake (Bond, 1959: 9) observed the species on Big Swan Is land from 4 through 14 November 1958.

On 22 February 1963 Rose Monroe and I observed a group of three birds, one adult male and two females or immatures, on Lake Yofoa at Agua Azul. The specimen listed was taken at this time. On 1 April 1964, Richard R. Graber, Jean W. Graber, and I saw a flock of nine, including two adult males, also at Agua Azul.

\section{Oxyura jamaicensis (Gmelin) \\ Ruddy Duck}

The Ruddy Duck is a rare fall and winter visitant to Honduras. V. C. Dunlap's observation of one at Toloa on 20 November 1938 is the first Honduran record. Mark Trafton, Jr., noted several individuals, including adult males, at the Copén flood-fallow lakes on 19 September 1954. He also examined several that had been taken by hunters, always in the month of September.

\section{Family CATHARTIDAE}

Sarcoramphus papa (Linnaeus)

King Vulture

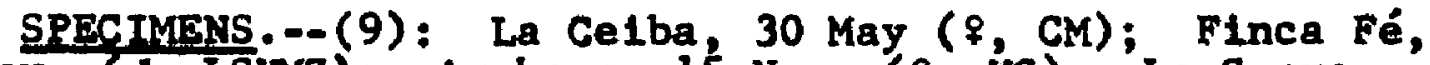
27 Nov. ( ${ }^{\circ,}$ LSUMZ); Archaga, 15 Nov. ( $($, UC); La Cueva Archaga, 6 oct. ( $\left.\sigma^{\circ}, \mathrm{MCZ}\right)$; La Flor Archaga, 5 Nov. (d, UC); 
Catacamas, 1 Sep., 8 Oct., 16 Nov. ( $8, \mathrm{MCZ} ; 20^{\circ}$ UC); "Honduras" ( 9, UC $)$.

52) PUBR,ISHED RECORDS.--Onoa, San Pedro (Moore, 1859: $51-$ (Stone, 1932: 2993.

Ranging from sea level to about 5,000 feet, the King

Vulture is fairly common and widespread in Honduras. It is more frequently seen at lower elevations on the Caribbean slope than in the interior or in the Pacific lowlands. Both the Black Vulture (Coragyps atratus) and the Turkey Vulture (Cathartes aura) are much more abundant. The King Vulture does not flock as do these two species; the maximum number that has been reported in one group in Honduras is four. Although I observed the specles frequently during most of a year in Honduras, I never saw more than three at once. It does occur, however, in flocks of the other two vultures .

An interesting observation, one that indicates the possibility of a partial migration in this specles, was made by Mark Trafton, Jr., on 3 October 1953. Between Amapa and Potrerillos he observed a few King Vultures intermixed with a huge flight of Swainson's Hawks (Buteo swainsoni) and moving with them. Of course, it is not known how far these vultures continued to fly with the hawks.

Joseph Leyland (Moore, 1859: 51-52) reported that specimens were taken at Omoa and In the mountains of San Pedro and stated that they were not common at Omoa. Thomas 
Barbour (Peters, 1929b: 414) noted four together over Lancetilla on 18 March 1928; single birds were seen on other occas ions .

Stone (1932: 299) 1isted the San Pedro record as being mentioned by Sclater and Salvin, but this record pertains to Leyland's material and was not published by Sclater and Salvin.

Coragyps atratus (Bechstein)

Black Vulture

SPECTMENS.--(17): $1 \mathrm{mi}$. S Potrerillos, 6 Dec. ( $\sigma^{\circ}$, LSUMZ); La FTor Archaga, 15 Dec. ( $\delta$, UC); San Juancito, 15 July (\$, ANSP); Tegucigalpa, 20-26 oct., 12 Nov., 23 Jan. $\left(80^{\circ}, 6 \%\right.$, UC $)$.

PUBLISHED RECORDS.--Onoa (Moore, 1859: 51). "Honduras (Taylor, 1860: 222-223). Tela, Ulúa Vailey. (Peters, 1929b: 415). San Juancito (Stone, 1932: 299).

The Black Vulture, or "zopilote," is certainly the most abundant falconiform bird in Honduras. It occurs everywhere on the mainland below 7,500 feet and is especially common around habitation; it is not found in the Bay Islands. Flocks numbering in the hundreds may be noted daily around the larger villages. It is apparently sedentary, although movements have not been critically studied; there is a possibility that some migration or at least local movement occurs in this species.

Temperate populations in North America and in South America average larger than tropical ones in between 
(Brodkorb, 1944a: 115-121), but the variation is clinal with much overlap. It seems best to suppress the South American C. a. foetens (Lichtenstein) and to treat the species as monotypic.

Cathartes burrovianus Cassin Yellow-headed Vulture Feb. $\frac{\text { SPECTMENS }}{(2 \%, \text { LSUMZ }) .}$ PUBLISHED RECORD;--Puerto "Lampira" [= Lempira] (Wetmore, 1964: 12-13).

The Yellow-headed Vulture was an enigma until recently. North of Panama it was long confused with the Turkey Vulture (Cathartes aura) despite the differences in morphology and ecology. The Louisiana State University Museum of Zoology now has specimens from Tabasco, Oaxaca, British Honduras, and Honduras, indicating that it is widespread and locally common in parts of Middle America. The basic habitat of the species is marsh, especially marsh in long grass savanna areas. The specles outnumbers the Turkey Vulture in this habitat, apparently everywhere the habitat is found on the Caribbean slope of Middle America from Veracruz to Panama. In Honduras the bird 18 very common seasonally in the grass savanna of the Mosquitia, in extrene eastern portions of the country. During the days of 5 through 7 February 1963, I noted more than 50 of these 
vultures in contrast to only two $\underline{\mathrm{C}}$. aura. The two females taken at this time had enlarged ovaries.

On 16 March 1963 I saw two Yellow-headed Vultures over the Laguna Micos, about $10 \mathrm{miles}$ west of Tela, and two more over the Tela alrport on 18 March. During a week in the Mosquitia in April 1964, I observed only two individuals; the contrast between the observations at this time and those in February 1963 suggests that the species may not breed in Eonduras.

The Honduran specimens have been examined by Wetmore (1964: 11-13) and assigned to the smaller, northern race c. b. burrovianus Cassin.

\section{Cathartes aura (Linnaeus)}

\section{Turkey Vulture}

SPECIMENS - -C. a. meridiona11s (6): El Horno, 7 Dec. (8, UC); La Fior Archaga, 13 Nov. ( 6, \&, UC); Cantarranas, 6 Aug; ( 7, ANSP); Tegucigalpa, 1 Jan, 24 0ct. ( 8, CNHM; $\therefore$ UC). C. a. aurra (9): Finca Fé, 27 Nov. (Imm. o", LSUMZ); Intibuca, 6 Dec. ( $\left.\sigma^{\circ}, U C\right)$; E1 Horno, 1-4 Feb. 6-10 Dec. (3o, \&, UC); La Flor Archaga, 1 April, 23 Nov., 12 Dec. (30, UC).

PUBLISHED RECORDS.--Omoa (Moore, 1859: 51). "Honduras (Taylor, 1860: 222). Roatán Island, Bonacca [= Guanaja] Is land (Salvin, 1889: 375-376). Tela (Peters, 1929b: 415). Cantarranas (Stone, 1932: 299). Utila Island, Roatán Is land, Bonacca [ = Guanaja] Island (Bond, 1936: 355). Tegucigalpa (Hellmayr and Conover, 1949: 8).

In Honduras this species is more widespread but less comon than the Black Vulture (Coragyps atratus). The Turkey Vulture occurs throughout Honduras, including the Bay Is lands, in virtually every habitat from sea level to above 
9,000 feet. In addition to the resident birds, there is an influx of migrants in fall and winter. Occasionally the migratory flocks are spectacular. During mid-October 1963 I witnessed notable flights of several hundred individuals each, proceeding southeastward along the Pacific coast. Migrating individuals were sometimes mixed with flocks of Broad-winged Hawks (Buteo platypterus) or Swainson's Hawks (ㅌ. swatnsoni).

Subspecific determinations of Honduran specimens were made by Alexander Wetmore. C. a. meridionalis Swann (wing >487) is the migratory race from western North America; $C$. a. aura (Linnaeus) (wing <495) is the resident subspecies. For the use of merldionalis in lieu of $\underline{C}$. a. teter Friedmann, see Wetmore (1964: 3-5).

Family ACCIPITRIDAE

\title{
Elanus leucurus (Vieillot)
}

White-tailed Kite

\begin{abstract}
SPECTMENS.--E. 1. maiusculus (2): $6 \mathrm{mt}$. W Puerto Cortes, 19 Sep. (9, LsuMZ); La Lima, 27 oct. ( 7 , LsuMZ).

Despite the absence of previous records, the White-
\end{abstract} tailed Kite is a falrly common winter visitant and possible resident in the lowlands of both coasts; it has not been recorded above a ground elevation of 500 feet. During the winter of 1962-1963, I observed the species on a number of occasions. J. Alan Feduccia and I collected the first 
8 pecimen for Honduras on 19 September 1962 near Puerto Cortés. Other individuals were noted during the winter near Choloma, San Pedro Sula, La Lima, Tela, and La Ceiba, In the Caribbean lowlands. A single individual was seen at Choloma on 17 May 1963, the day I departed from Honduras; this late date indicates the possibility of the species breeding locally in Honduras. On 10 April 1964 I noted one at Puerto Lempira in the Mosquitia, apparently an individual in migration.

From October 1962 to February 1963, I saw this kite at least 10 times in the Pacific lowlands. Observations were made in the vicinity of San Lorenzo, Choluteca, and Namasigüe.

The second Honduran specimen was collected at La Lima on 27 October 1962 by Kenneth S. Hamilton. He informed me that he had seen the species previously in the La Lima area on 22 February 1962. On 21 July 1964 he noted one at La Lima, further indicating the likelthood of local nesting. I do not follow Parkes (1958a: 139-140) in combining E. leucurus with the old World $\underline{E}$. caeruleus (Desfontaines), although this taxonomic treatment may eventually prove to be sound. In view of the two sibling species of Elanus in Australia (E. notatus Gould and E. scriptus Gould) and lack of knowledge concerning isolating mechanisms in these two spectes, it seems best to retain all forms as full species pending study of the entire group. 
The Honduran specimens are referable to the northern race, E. 1. majusculus Bangs and Penard.

\section{Elanoides forficatus (Linnaeus)}

Swallow-tailed Kite

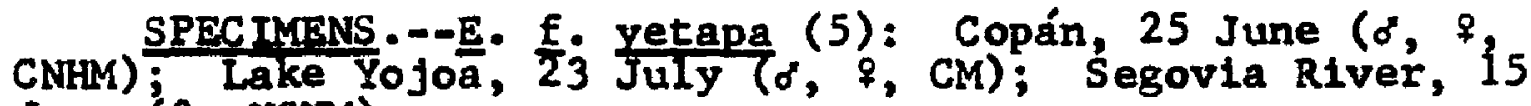
June (?, USNM).

PUARLISHED RECORDS.--Segovia River (Ridgway, 1888c: 592). Copán (Hellmayr and Conover, 1949: 22).

This kite is a faixly common migrant and summer resident confined to the Caribbean lowlands below 3,500 feet. In the spring of 1963 it was first noted on 14 April; shortly thereafter, the species became rather common, with groups of 10 to 15 individuals often being noted. In 1964 individuals were first noted on 1 April. Presumably many of the birds in these migrating flocks are from northern breeding populations as the species is much more common at this time than during the nesting season in June and July. However, all Honduran specimens represent the breeding subspecies.

In fall the Swallow-tailed kite is a very early migrant. The latest departure date of the species in Honduras is based on an observation by J. Alan Feduccia of 30 migrating individuals near El Jaral on 19 August 1963.

The five Honduran specimens are representative of the greenish Middle American race, E. f. yetapa (Vleillot). 
The North American subspecies, E. E. forficatus (Linnaeus), very likely occurs in migration.

\section{Leptodon cayanensis (Latham)}

Gray-headed Kite

SPECIMENS.--(11): La Ceiba, 27 April ( $6, C M)$; Santa Ana, 25 0ct. ( $0^{\circ}$, USMM); San Pedro Mountains ( $\sigma^{\circ}$, AMNH); Lake Yojoa, 25 June ( 9 UF); El Caliche, 18 July ( $\sigma^{\circ}$, MCZ); Catacamas, 3-13 Sep. (20, $9, \mathrm{MCZ}$; o, UC); $1 \mathrm{mi}$. NW Namas1güe, 8 óct. ( $q$, LSUMZ); MHondurash (juv., BMNH).

PUBLISHED RECORDS.--San Pedro Mountains (Moore, 1859: 52; Sclater and Salvin, 1859: 219). San Pedro region (Sclater and Salvin, 1870b: 838). "Honduras" (Sharpe, 1874: 334).

The Gray-headed Kite is an uncommon resident of the lowlands of Honduras, occurring to an elevation of about 5,000 feet. It is more common, however, than the other two resident tropical lowland kites, Harpagus bldentatus and Chondrohterax uncinatus. It may be found on both coasts and is not restricted to rain forest areas as are the other two mentioned above.

During his stay in Honduras in 1855 and 1856, Joseph Leyland (Moore, 1859: 52) collected only the single individual from the San Pedro Mountains. Sclater and Salvin (1859: 219) mentioned that there is a spectmen, supposedly from Honduras, in the Norwich Museum; the source of this individual is not known.

The species has often appeared in the 11terature as odontriorchis palliatus (Teminck). The name Leptodon is older and hence valid, as it is not preoccupled by an 
earlier molluscan genus Leptodea, sometimes misspelled "Leptodon." Furthermore, Latham's name Falco cayanens is is not preoccupied by Gmelin's earlier name, Falco cayennensis, which pertains to the osprey (Pandion haliaetus).

\title{
Chondrohierax uncinatus (Temminck) Hook-błlled Kite
} MCZ).

SPECTMEN.--C. u. uncinatus (1): Catacamas, 5 Sep. (q,

There are but two records from Honduras for this species. The only specimen is the female taken by $C . F$. Underwood in 1937 at Catacamas. On 19 January 1963 I saw a single individual flying over a forested area at Finca Fé, near Lake Yojoa; this location is at an elevation of 2,300 feet. Although the species is reported elsewhere in its range as occurring in marshland as well as in rain forest, both Honduran records were obtained in forested reglons. The single specimen is referable to the nominate race, ‥ 쏘. uncinatus (Teminck).

\section{Hacpagus bidentatus (Latham)}

Double-toothed Kite

\author{
MCZ). \\ SPECTMEN.--H. b. Easclatus (1): Cantoral, 3 Dec. (q,
}

The Double-toothed Kite is a rare species in Middle America north of Panama. It is known from Honduras only by the specimen taken by C. F. Underwood in 1937. Since the species is primarily restricted to lowland rain forest, its 
occurrence at Cantoral is surprising. Most of Underwood's specimens labelled "Cantora1" were taken at an elevation of about 5,000 feet in pine or oak forests. But a number of specimens from this locality are typical of lowland rain forest or monsoon forest. Presumably these specimens, including the one of this kite, were taken tn the patches of vega forest at an elevation of 4,000 feet along the river, a tributary of the Río Choluteca.

The single specimen is representative of the Middle

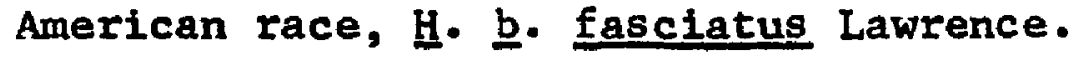

\section{Ictinia misisippiensis (Wilson)}

Mississippi Kite

SPECIMENS.--(3): Finca Fé, 26 April (o", LSUMZ); $6 \mathrm{mi}$. NE Choluteca, 3-12 Oct. (2 imm. $₹$, LSUMZ).

Despite the previous absence of records of migrating Mississippi Kites from Central America south of Guatemala, the species is apparently a regular and fairly common transient in Honduras. On 26 September $1962 \mathrm{~J}$. Alan Feduccia and I noted a flock of eight adults migrating eastward along the coast of the Bay of Fonseca. From that day through 15 October the species was seen daily in the Pacific lowlands from San Lorenzo east to Choluteca, San Francisco, and E1 Corpus. On 3 October, in the arid Choluteca Valley, we saw more than 100 individuals, the greatest number recorded in a single day. The species did not associate with other migrating falconiform birds, of which there were huge 
flocks in the area, but remained in discrete groups, usually at much lower flight levels than the migrating Buteos. Almost half the total number recorded in the fall were immature birds. Although I searched for them, I did not see any Plumbeous Kites (Ictinia plumbea) during this migration. The Mississippi kite did not winter in this area as they were absent during February when I revisited the Choluteca region.

From 25 through 29 April 1963, individuals of the species were noted daily migrating in a generally northwestward direction over Finca Fé, near Lake Yojoa, on the Caribbean slope. More than 30 individuals made up the largest flock noted, recorded on 26 April, from which the adult specimen was secured. The Plumbeous Kites had been present locally for at least $s i x$ weeks at this time. As was the case in the fall, the two species were not in mixed flocks. All spring birds observed were in adult plumage.

\section{Ictinia plumbea (Gmelin)}

Plumbeous Kite

SPECTMENS.--(12): Roatán Island (?, BMNH); La Ceiba, 5-6 June $\left(\delta^{\prime}, 7, C M\right)$; Los Planes, 11 June $\left(\delta^{\circ}, C M\right)$; Coyoles, 16-20 June $\left(\sigma^{\circ}, ?, C M\right)$; Lake Yojoa, 12 June, 16 July ( $20^{\circ}$, CM); El Caliche, 13 July, 2 Aug. ( $9, \mathrm{MCZ}$; $\%$, UC); EI Paráso, 20 April (o, BMNH); "Honduras" (?, BMNH).

PUBLTSHED RECORDS.--"Honduras" (Sclater and Salvin, 1859: 220) Roatán Is land (Salvin, 1890: 84). Bonacca [= Guanaja] Island (Bond, 1936: 355).

The Plumbeous Kite is a fairly common migrant and 
summer resident in Honduras. It is known primarily from the lowlands on the Caribbean slope, but migrant individuals have been reported from the Pacific slope and the interior up to 4,000 feet, and from the Bay Islands. Sclater and Salvin (1859: 220) 118ted a specimen in the Norwich Museum taken in Honduras, presumably by Joseph Leyland, although it was not mentioned by Moore (1859), who reported on Leyland's specimens. Miller and Griscom (1921b: 5-7) examined a pair from Honduras but gave no further data.

Mark Trafton, Jr., recorded the species annually from 1951 through 1957. The localities represented were La Lima, Los Dragos, Lancetilla, Lake Yojoa, and Amapa, and the period of these observations was from February through July. From 8 through 10 March 1952 he observed courtship and mating of the species at Los Dragos; in addition to aerial acrobatics, mating in a pine tree at dusk and twig carrying were noted. Immature birds were seen at Lake Yojoa on 23 June 1952. On 14 June 1953 Trafton collected an adult male (not in breeding condition) at Lake Yofoa, but the specimen was not preserved.

During the fall of 1962 I did not observe the species, although I noted many examples of Ictinia misisippiensis. In the spring of 1963 the first individual was seen on 28 February in the upper part of the Quimistain Valley near Quimistán. Shortly thereafter the species became fairly common and was observed daily. It is apparent that the 
Plumbeous Kite migrates south in the fall some two months prior to the passage of the Mississippi Kite and returns about $s 1 x$ weeks earlier in the spring.

The records of the species from Roatain and Guanaja islands in the Bay Islands probably refer to migrant individuals as breeding has not been reported there.

The supposed race I. $\mathrm{D}$. yagans Miller and Griscom, based on size, is not deemed valid; birds from South America that were presumed breeding are not significantly smaller than Middle American ones.

Rostrhamus sociabilis (Vieillot)

Everglade Kite

SPECIMENS:--R. s. plumbeus (12): Laguna Toloa, 28 Feb., 30 Aug. (2\%, AÑSP; imm. ' MCZ); Lake Yojoa, at Agua Azul, 17 Aug., 11 Sep;' 14 Dec. '(28, \&, 3 imm. o', 9 's kel.; LSUMZ); Lake Yojoa, 2 'Jan., 18 June ( $\$, C M$; iman. $₹$, MCZ).

PUBLISHED RECORDS.--Toloa Lagoon (Peters, 1929b: 418). Laguna Toloa, Lake Yojoa (Stone, 1932: 299).

Although in Honduras the Everglade Kite has been recorded on1y from the marshes around Laguna Toloa and Lake Yojoa, it is common throughout the year at both localities. Stone (1932: 299) mentioned that it had been recorded from Tigre Island by Sclater (1858b), presumably on the basis of a record by G. C. Taylor, but this report is in error. The species was not observed by Taylor anywhere in Honduras, although his fallure to find it at Lake Yojoa to surprising. This kite probably occurs locally in Honduras elsewhere on the Caribbean slope. 
The Honduran specimens are indistinguishable from Florida specimens of R. s. plumbeus Ridgway in size, the only character by which the latter differs from examples of the nominate race, R. ‥ soctabilis (Vielllot). Wing measurewents of soclabilis $(\delta,<341 ; q,<350)$ are taken from Ridgway and Friedmann (1950: 133). The Honduran birds (11 skins) measure as follows: $\delta, 353.0-383.0$ (371.2); $q$, 345.0-372.0 (360.0). These individuals are much too longwinged for the nominate race and must be referred to plumbeus, restricting the range of the nominate race to South America and southern Central America north to Nicaragua. The wing measurements approach the larger Mexican race, B. s. maior Nelson and Goldman, but the culmen measurements of the Honduran birds $(<29.0)$ fall below the range of varlability of maior $(>30.0)$.

\section{Accipiter bicolor (Vieillot)}

Bicolored Hawk

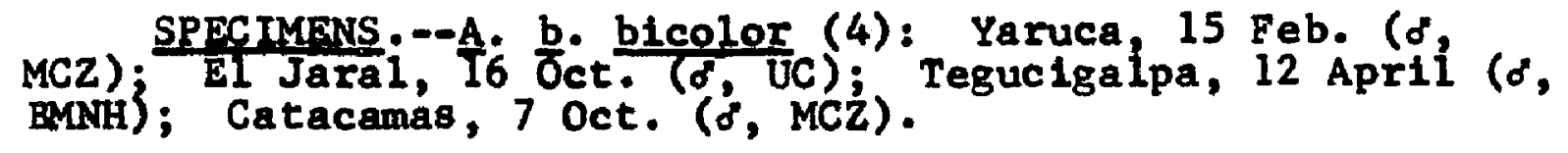

PUBT, ISHFD RECORDS,--San Pedro region (Sclater and Salvin, 1870b: 838). Tegucigalpa (Salvin and Godman, 1899: 47-48; Hellmayr and Conover, 1949: 55). Yaruca (Bangs, 1903: 141).

This hawk is uncommon in Honduras, occurring chiefly in rain forest on the Caribbean slope. It has been recorded, however, in the interior at Tegucigalpa at an elevation of 3,000 feet. It probably occurs also on the Pacific slope 
in monsoon forest but has never been recorded there. G. M. Whitely (Sclater and Salvin, 1870b; 838) collected a Bicolored Hawk in the San Pedro region, but I did not find the specimen in the British Museum. The Tegucigalpa individual was secured by W. B. Richardson in 1898 . The Yaruca specimen was taken in 1902 by $W$. W. Brown. C. F. Underwood collected specimens at EL Jaral in 1936 and at Catacamas in 1937. Mark Trafton, Jr., and Paul Slud observed two individuals at Lake Yojoa in July 1952. I failed to find the species in Honduras during 1962-1964. The specimens from Honduras are representative of the nominate race, … b. bicolor (Vieillot).

\section{[Accipiter cooperii (Bonaparte)]}

Cooper's Hawk

The Cooper's Hawk is a North American species wintering south to southern Mexico and Guatemala, occasionally to Costa Rica. On 13 November 1962, J. Alan Feduccia, my wife, and I saw a large Accipiter, presumably this species (identification was not positive), near Potrerillos. My wife and I observed a second bird, definitely this species, on the Paclfic slope at San Lorenzo on 11 February 1963; in addition, we noted another individual, almost certainly not the same bird, the following day about 10 miles west of Choluteca.

These sight records constitute the first report of the species from Honduras. 
Accipiter striatus Vieillot

Sharp-shinned Hawk

SPECTMENS.--A. S. yelox (6): Alto Cantoral, 12 Jan., 1 March (?, MLZ; $q$, MCZ); Monte Redondo, 30 Nov. ( $\left.{ }^{\circ}, \mathrm{MCZ}\right)$; Comayagüela, 10 Nov. (d, MCZ); Yeguare River Valley, 27 Feb., 24 Nov. ( 9, ? , UF).

Although previously unrecorded from Honduras, the Sharp-shinned Hawk is an uncommon winter visitant, occurring widely but locally throughout the country to an elevation of at least 5,500 feet. C. F. Underwood collected the Comayagüela and Monte Redondo specimens in 1931 and the Alto Cantoral birds in 1934. Marjorie H. Carr took the Yeguare River Valley specimens in November 1948 and February 1949. Mark Trafton, Jr., observed single individuals of this species at Copén, near La Lima, on several occasions during April 1953. V. C. Dunlap 8 aw one there on 26 December 1954.

Single birds were noted by J. Alan Feduccla, my wife, and me near Choluteca on 8, 9, and 12 October 1962. We saw two Individuals in pine woods near Marcala on 30 october 1962. I observed the species on three additional occastions in 1963: two individuals in the otoro Valley, near Jesuis de Otoro, on 24 January; one at San Francisco (Dept. of Choluteca) on 12 February; and one other four miles west of Lepaera (Dept. of Lempira) on 28 February.

The Honduran specimens are Indistinguishable from eastern North American examples of $A$. S. velox (W11son). 


\section{Accipiter chionogaster Kaup}

White-breas ted Hawk

SPECTMENS.--(32): Truj1110, 19 Sep. (?, USNM); Coyoles, 15-19 June (o, $\$$, CM); San Esteban, 21 June ( $0^{\circ}$, CM); Montaña El Chorro, 1 July (?, MLZ); Plan del Rancho, $8 \mathrm{July}$ ( $q, \mathrm{MLZ}$ ); Mt. Puca, $16 \mathrm{Jan}$. ( $q, \mathrm{MCZ}$ ); $10 \mathrm{mi}$. NW Siguatepeque, 29 Jan. ( $d$, LSUMZ); MuÍn, 20 Dec. ( $\$$, UC); E1 Caliche, 20 July ( $\left.\sigma^{\circ}, M C Z\right)$; Cantoral, 5 March, 18 Nov., 7 Dec. (o", MLZ; 8 , $\$$, MCZ); Cerro Cantoral, 5 Sep. ( $\$$ MCZ); Alto Cantoral, 7 Jan. ( $9, \mathrm{MCZ}$ ); La Laguna Cantoral, 17 July, 7 Nov. (29, MCZ); La Flor Archaga, 15 March, 18 Aug., 8 Dec. ( $\sigma^{\circ}, \mathrm{MCZ}^{\circ} \sigma^{\circ}, ?$, UC); Ilamapa, 28 Aug. ( $\sigma^{\prime}, \mathrm{MCZ}$ ); Cantarranas, 9 Aug ( $\left(\sigma^{\circ}\right.$ ANSP); Cerro El Tigre, 1 July ( $\sigma^{\circ}$ UC); E1 Derrumbo, 17-22 July (d, ₹, MCZ); Tegucigalpa, 25 Nov. (?, MCZ); Las Flores Tegucigalpa, 18 Dec. ( 9 , CNHM); Yeguare River Valley, 7 April, 26 July (20, \&, UF); near Sabana Grande, 14 Aug. ( $\sigma^{\circ}$, CM); "central Honduras," 17 May (o, MLZ).

PUBIISHED RECORDS.--Trufillo (Ridgway, 1888c: 583). Cantarranas (stone, 1932: 299). San Pedro, Las Flores Tegucigalpa (Hellmayr and Conover, 1949: 74-75). Cerro Cantoral, La Laguna Cantora1, El Derrumbo (Storer, 1952: 285-287)?

This hawk is an uncommon to fairly common resident throughout the interior highlands of Honduras, occurring chiefly in pine woods but occasionally wandering into cloud forest, montane rain forest, or semi-open areas. Altitudinally, it is found primarily above 2,000 feet, rarely as low as sea level.

In addition to the specimens listed above, there is one in the Brunswick Museum that was taken by Erich Wittkügel at San Pedro on 14 June 1890 (Hellmayr and Conover, 1949: 7475).

I encountered the species only three times during 19621964. On 9 December 1962 I saw a single individual on the east slope of Cerro Santa Bárbara at an elevation of 3,700 
feet; the bird was perched high on a dead snag in an area of montane rain forest. I collected a single specimen in pines on 29 January 1963 about 10 miles northwest of Siguatepeque at an elevation of 3,100 feet. Vida Roth, my wife, and I saw a third individual on 17 April 1963 in pines just northwest of Cofradia at an elevation of 3,500 feet.

The taxonomic status of A. chionogaster Kaup is still In doubt. It was lumped by Hellmayr and Conover (1949: 7477) with the South American A. erythronemius Kaup on the basis of the close morphological approach between adult chlonogaster and the extreme, light phase of erythronemius. In view of the polymorphic nature of exythronemius and the lack of detailed knowledge of ethological factors and possible isolating mechanisms, I believe it is best to retain them as distinct species.

Storer (1952: 288) went a step further and united the Sharp-shinned Hawk (A. striatus) and the other two groups, erythronemius and chlonogaster, into a single species. The basis for this move was the apparent bridge between $\underline{A}$. striatus and $A$. chionogaster through the superficially

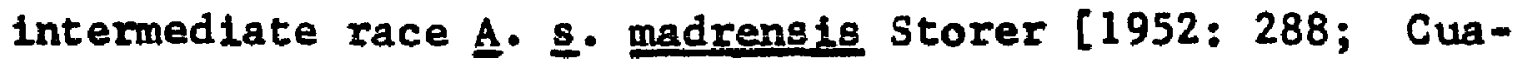
ponga, Guerrero, Mexico]. I do not agree with Storer that the pale rufous underparts of madrensis indicate gene flow between this race and chlonogaster. A. striatus exhibits a north-south cline from very dark rufous barring to a pale, rather uniform, buff condition, which may not have anything 
to do with an approach to the white-breasted chionogaster. Furthermore, Storer (1952: 286) mentioned differences in the immatures of the two species. In view of the morphological differences (including that of the Immature plumages) and the rather narrow isolation of the two species (by the Isthmus of Tehuantepec), I feel that the situation is best represented by retaining striatus and chionogaster, as well as erythronemius, as distinct species, pending further ethological studies.

\section{Buteo albicaudatus Vieillot}

White-tailed Hawk

SPECIMENS - - - B. a. hypospodtus (4): Subirana, 20 Dec. ( $\%$, MCZ); RIo "Guanaca" $l=$ Jalán, 10 June ( 8 , CNHM); Yeguare River Valley, 31 July ( $\%$, UF); Puerto Lempira, 5 Feb. ( $\sigma^{*}$, LSUMZ).

PUBLISHED RECORD.--Rfo Guanaca [= Jalán] (Hellmayr and Conover, 1949: 154).

Occurring in savanna situations throughout Honduras up to an elevation of at least 4,000 feet, the White-tailed Hawk is a decidedly uncomnon resident with a local distribution. Apparently the only ecological requirement of the species is the open savanna situation since this hawk is found in the lowland pine savanna of the Mosquitia, in the scrub and steppe country of the arid interior valleys, and In the savannas and pastureland of more humid situations in the Olancho Valley.

The specimen listed by Hellmayr and Conover (1949: 154), taken by C. F. Underwood in 1934, was reported from 
the "Rlo Guanaca, Colón." The label of this spectmen reads "Río Guaymaca" and in June 1934 Underwood was indeed collecting in the vicinity of Guaimaca. The specimen was apparently obtained along the Rio Jalán, then called the Rio Guaimaca, which runs through the town of Guaimaca.

Raymond Stadelman obtained a specimen at Subirana in 1932. Marjorie H. Carr collected one in the Yeguare River Valley in 1946.

In addition to the specimen collected at Puerto Lempira, in the Mosquitia, on 5 February 1963, I recorded the species a number of other times during 1962-1964. One immature, possibly a migrant individual, was seen on 4 October 1962 near Cedeño, on the Pacific coast; single adults were recorded in the Comayagua Valley on 15 and 19 November 1962 and near San Pedro Sula on 10 December 1962 and 4 March 1963; and a pair was seen in the otoro Valley near Mazaguara on 24 January 1963.

Honduran specimens are representative of the northern race, B. a. hypospodtus Gurney.

Buteo jamaicensis (Gmelin)

Red-talled Hawk

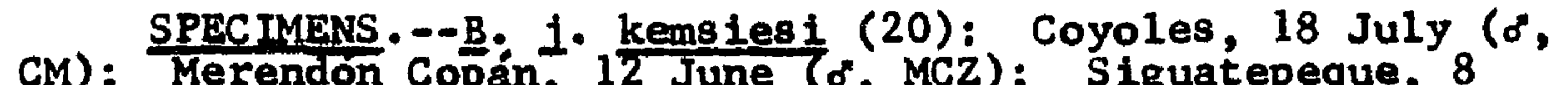
July ( $8, C M)$; Muln, 6 Jan. ( $0^{\circ}$, UC); Cantoral, 12 March ( $\sigma^{\prime}$, CNHM); La Laguma Archaga, 28 June ( $\sigma^{\prime,}$ UC); La Flor Archaga, 3 Apri1, 15 Aug.; 10 Nov. (imm. o, MCZ; 2\%, UC); E1 Hattilo, 16 Aug. ( $q, \mathrm{CM}$ ); Tegucigalpa, 10-15 Apri1, 28 June, 17 Sep. -3 Dec. ( $\$$, CNHM; $\$, 2$ imm. $d$, MCZ; $d, 2$ 
imm. o, MCZ; d, 2 imm., UC); near Tegucigalpa, 13 Aug. ( $\sigma^{\circ}$, CM); Yeguare River Valiey, 6 Aug. ( 8 ?, UF); Sabana Grande; 6 Dec. $(\%, M C Z)$.

PUBLISHED RECORDS.--Swan Islands (Lowe, 1911: 52). Cerro Cantoral (Hellmayr and Conover, 1949: 104). Tegucigalpa, Muín, La Laguna Archaga, La Flor Archaga (oberholser, 1959: 159).

The Red-tailed Hawk is an uncommon resident in Honduras, ranging from sea level to 8,000 feet. It is primarily a bird of the pine forests above 2,500 feet, exclusively so during the breeding season. There is an influx of transients during migration, individuals being seen in migrating flocks of other Buteog. Except in summer, the Red-tailed Hawk occurs commonly in the lowlands of both coasts. Migrating individuals are often in the dark phase, a plumage not known in the resident population; presumably these dark birds are representative of the western North American race, B. 1. calurus Cassin, although no Honduran specimens of this subspecies are known at present. I noted single individuals in the dark phase at Finca Fé on 30 November and 9 December 1962, at San Lorenzo on 2 February 1963, and at San Pedro Sula on 10 March 1963.

Lowe's (1911: 52) report from the Swan Islands was based on observations of a local resident who said that the Red-tailed Hawk was "a constant visitor."

A11 Honduran specimens are referable to the resident race, B. 1. kemsies] Oberholser [1959: 159; Tegucigalpa, Honduras]. This newly described subspecies is valid 
(Storer, 1962: 77-78), being distinguished from B. 1 .

costaricensis Ridgway by the over-all paler coloration, with less rufous on the thighs and fewer streaks below. The male taken at Cantoral and the female collected at Siguatepeque are not typical of kemsles 1 , for they possess a greater amount of rufous on the thighs, but they compare well in all other respects to this race. Migrant individuals, as mentioned earlier, are presumed to be representative of the western North American race, B. 1 . calurus Cassin.

\section{Buteo albonotatus Kaup}

Zone-tailed hawk

SPECIMENS.--B. a. albonotatus (3): Tegucigalpa, 30 Nov.--3 Jan. (Imn. d, CNHM; \%, MCZ; ??, UC).

Although previous ly unrecorded from Honduras, this hawk is probably a rare resident in the interior highlands. It occurs widely in Middle America and is known to breed as far south as Nicaragua, but all Honduran records are from the winter months. The three specimens were taken by $C$. F. Underwood and all have been previously misidentified. A female from Tegucigalpa, taken on 3 January 1938, had been catalogued as "Buteo Jamaicensis" for years; it is current$1 y$ in the Museum of Comparative Zoology and has been examined by a number of workers, myself included. Another specimen, in the Brandt Collection at the University of Cincinnat, has a label reading "Buteo albicaudatus"; it 
was taken on 30 November 1937. I recently measured this specimen and found the wing to be 224.0 and the tail 391.0 . It is too long-winged and short-tailed for albicaudatus and is apparently a missexed male albonatatus. The third specimen, collected on 15 December 1937, has also been identified as "ㅁ․ jamaicensis"; the middle toe and bare portion of the tarsus both measure 45.0 , which is typical of B. albonotatus.

I personally saw the species only once in Honduras. On 22 January 1963 at an elevation of 3,800 feet, I observed a pair soaring high over the pine forests of the Cordillera de Montecillos about eight miles northeast of Jesús de Otoro.

The Honduran specimens are typical of the northern race, B. a. albonotatus Kaup.

\section{[Buteo swainsont Bonaparte]}

Swainson's Hawk

The Swainson's Hawk breeds in western North America and winters in South America, passing through Central America during migration in huge flocks. Apparently the entire body of migrating birds, or at least a large percentage of them, passes through a given area in a short period of time, a matter of a few days or even hours on some occasions. The movement of these birds on migration is very characterIstic, the huge flocks spiraling upward on thermal updrafts in wheeling clouds of birds, then using the altitude 
advantage to attain distance in the direction of migratory movenent. Rarely do the birds flap during this migration and rarely do they descend to low flight levels. Other migrating falconiform birds scmetimes use this flight method, but it is most characteristic of this species.

Passages of Swainson's Hawks through Honduras have been noted during only two migrational perlods, both in fall. On 3 October 1953 Mark Trafton, Jr., witnessed one at 9:30 a.m. between Amapa and Potrerillos, on the Caribbean slope. The birds appeared from the northwest, proceeding southeastward, in the typical migratory fashion described above. During the hour of observation, thousands of birds passed by. A few King Vultures (Sarcoramphus papa) were mixed with the hawks.

During October 1962, J. Alan Feduccta, my wife, and I witnessed remarkable hawk migrations in the San LorenzoCholuteca region of the Pacific slope. Many thousands of Broad-winged Hawks (Buteo platypterus) were seen, with the peak around 6 october. The first Swainson's Hawks, a flock of some 50 individuals, were noted at San Francisco (elevation 3,500 feet) on 11 october. The numbers recorded daily increased to a maximum of an estimated 700 birds on 13 October in the Choluteca region. We apparentiy missed the big passage, however, on 14 October as we saw only two individuals near Choluteca, but the local residents at San Francisco sald that "the sky was black" with migrating hawks 
during the morning of that day. I presume the birds were Swainson's Hawks as the peak of Broad-wings had occurred the week before. On 15 october, our last day in that area, we saw about 50 Swainson's Hawks. A11 flocks of this species contained a few Broad-winged Hawks and a few Turkey Vultures (Cathartes aura) mixed with them. I took a number of telephoto pictures of the migrating flocks but the birds are not identiflable in the pictures. Attempts to collect the birds as they passed low over a ridge near San Francisco were unsuccessful. Direction of migration on the Pacific slope was west to east, with the flocks crossing the Continental Divide to the Caribbean slope in the vicinity of San Francisco.

Buteo platypterus (Vieillot)

Broad-winged Hawk

SPECTMENS.--B. p- platypterus (5): La Ceiba, 10 April ( $d$, USNM); La Laguna Archaga, 7 Nov. ( $\%$, UC); Arenal, 18 Jan., 16 Feb. (2o, UCLA); $7 \mathrm{mi}$. NE Choluteca, 8 oct. ( $d$, LSUMZ).

PUBLISHED RECORD.--La Celba (Deignan, 1936: 187).

In Honduras the Broad-winged Hawk is an irregularly recorded migrant and a rare winter visitant. During the fall migration, huge flocks pass through Honduras, at least on the Pacific slope. In the spring the species is more sporadic in occurrence, usually being recorded singly or in small groups. Occasional individuals winter throughout the country, occurring primarily below 3,500 feet. 
During the fall of 1962 , this species was the most abundant migrating hawk on the Pacific slope. Some 40 individuals were seen on 3 october, the first date of observation for the season, and more were noted daily in ever increasing numbers until the maximum flight, estimated to be in excess of 6,000 individuals, was recorded on 6 october. The birds were passing generally west to east, more or less parallel to the coast, and were funneling into the Choluteca Valley just east of the town of Choluteca. The birds grouped into large spirals at the end of the valley, which is shut in on three sides by mountains of 3,500 feet elevation. Upon reaching sufficient height by riding thermal updrafts, the hawks would top the ridges and pass over to the Caribbean drainage in the vicinity of San Francisco and on eastward into Nicaragua. The flocks were often mixed with Turkey Vultures (Cathartes aura) and Swainson's Hawks (Buteo swainsoni).

In the spring of 1963 , I noted the species only twice, on 1 May an individual at La Lima and on 3 May another on Utila Is land, in the Bay Islands.

The Underwood specimen, taken in 1937 at La Laguna Archaga, was probably a wintering individual; the two taken by J. G. Montrello at Arenal in January and February 1954, in the olancho rain forest, almost certainly were wintering birds . 
There are a number of specimens in the Brandt Collection at the University of Cincinnati that are labeled "Buteo platypterus" but are actually misidentifications of imature B. nitidus.

The Honduran specimens of Broad-winged Hawks are referable to the North American race, B. D. platypterus

(Vieillot).

Buteo magnirostris (Gmelin)

Roadside Hawk

SPECIMENS.--B. m. Sinushonduri (13): Oak Ridge, 9 Apri1 (7, CM); Roatä Is land, 7 Jan. (5?, BMNH; \&, CNHM); Barbareta Is land, 12 Apri1 ( $f, C M)$; Bonacca [= Guanaja] Island, 27 Feb. (d, ${ }^{8}$ ANSP; 3?, BMNH). B. m; direptor (78): Toloa Lagoon, 28 Feb. ( 7, MCZ); Tela, 21 Feb. (f, MCZ); Lancetilla, 5 Feb. -4 March ( $\left.\sigma^{\prime} 2 \%, M C Z\right)$; La Ceiba, 25 Apr11-30 May (5d, 3, CM); Truj1110, 30 March-9 Apr11 (38, CM; ?, USNM); San Pedro (2?, AMNH; ?, BMNH); Río Blanco, Cortés, 19 Dec. ( $\%$, USNM); Urraco, 9 March ( 8 , MCZ); Chamelecón, 16 Feb. (?, USNM); Subirana, 25 Jan. -6 Feb. ( $\left.\delta^{\circ}, 2 \%, M C Z\right)$; Coyoles, 20 June $\left(\alpha^{\circ}, C M\right)$; San José de Santa Bărbara, 9 Apri1 ( 7, CNHM); E1 Jara1 4 Oct. ( $\%$ UC); Finca Fé, 8 Sep. ( $q$, LSUMZ); Lake Yojoa, 27 July ( $q, C M)$; Las Flores, Lempira, $30 \mathrm{Dec}$ ( ( $8 \mathrm{kel}$., MLZ); Int 1bucá, 12 Dec. ( $\sigma^{\prime}$, UC) ; El Caliche, 24 June-15 July $\left(40^{\circ}, 2\right.$ ?, ?, 2 imm. of, imm. \&, imm., UC); La Laguna Cantoral, 15 July ( ${ }^{\prime \prime}$, UC); La Flor Árchaga, 16 April-2 June (20, $₹$, UC); La Cueva Archaga, 6 March (inm. \$, UC); Montaña Vásquez, 14 June (1m. o, UC); Monte Redondo, 15 Jan., 23 March, 2 Nov. -7 Dec. ( $q$, CNHM; o", q, ?, MCZ; o, imin. ₹, UC); Cantarranas, 10 Aug. ( $\sigma^{\circ}$ ANSP); E1 Hatillo, 3 July ( $\left.\sigma^{\circ}, C M\right)$; Tegucigalpa, 19 Feb., 26 May-2 July, $11-14$ oct., 9 Nov. (?, MCZ; 3o, $\%, 3$ imm. of, UC); Comayagüela, 1 Jan. ( 8, MCZ); San Juan Tegucigalpa, 2 Jan. ( $\%$, MCZ); Las Flores Tegucigalpa, 14 Sep. ( ${ }^{\prime}$, CNHM); Yeguare River Valley, 29 Jan., 2 Dec. (20, UF); Catacamas, 30 Aug ., 1 Oct. ( $\sigma^{\circ} q$, UC); Segovia River, 19 July ( 9 , USNM); near Cabo Gracias a Dlos, 4 April (?, CU); Honduras-Nicaragua boundary [near Pacific coast ] (2?, MCZ); $7 \mathrm{mi}$. NE Choluteca, 7 0ct. ( 8 , LSLMZ). 
PUBLISHED RECORDS.--Omoa (Moore, 1859: 52). "Honduras (Taylor, 1860: 225). San Pedro region (Sclater and Salvin, 1870b: 837). Trujillo, Segovia River (Ridgway, 1888c: 583,593). Roatán Is land, Bonacca [= Guanaja] Island (Salvin, 1889: 374-375; Bond, 1936: 355-356;

Hellmayr and Conover, 1949: 122). Tela (Peters, 1929b: 417). Urraco, Toloa Lagoon, Tela, Lancetilla, Honduras Nicaragua boundary [near Pacific coast] (Peters and Griscom, 1929: 46-47). Cantarranas, Tela, Puerto Castilla (Stone, 1932: 299). Tegucigalpa, San Juan Tegucigalpa, Monte Redondo, "Comayagua" [= Comayagüela] (Brodkorb, 1940b: 4). San José de Santa Bárbara, Monte Redondo, Las Flores Tegucigalpa (Hellmayr and Conover, 1949: 124-125).

The Roadside Hawk is the most common and widespread of the resident hawks in Honduras. It occurs in almost any open or semi-open situation from sea level to 7,000 feet, ranging occasionally even into rain forest. It is most abundant in the lowlands of the Caribbean slope. In the Bay Is lands it is found on Roatán and Guanaja is lands.

The specimen examined by Brodkorb (1940b: 4) and 1isted by him as from "Comayagua" is an individual collected by C. F. Underwood at Comayagüela.

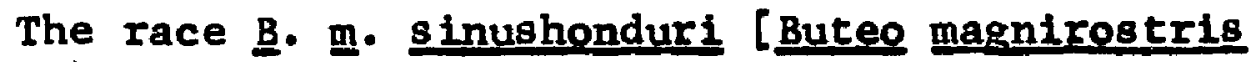
sinus-hondurt Bond, 1936: 355; Bonacca Island, Spanish Honduras ] is based on the darker coloration of these birds as compared with malnland forms and is valid; it occurs on Roatán and Guanaja is lands, In the Bay Islands, but is absent from Ut1la Island. Peters and Griscom (1929: 46-47) described two new races from Central America, B. $\underline{\text { m. direptor }}$ for the northern birds (southern Mexico to British Honduras and E1 Salvador) and B. $\underline{\text {. arguta }}$ [= argutus] for the southern Caribbean slope birds (Honduras to Panama). The 
race argutus is supposedly paler above, with contrasting crown and back, and smaller in size. The character of paleness above, especially of the gray crown, is highly variable and probably dependent upon age, as individuals of both types appear throughout the range of the two races. The southern birds, on the average, are slightly paler, but there is a wide area through El Salvador, Honduras, and Nicaragua where the birds are decidedly intermedtate. In regard to size, the northern birds average very slightly larger, but this variation is a gradual, average, northsouth cline and no line of demarcation can be drawn. In al1, I can see no reason for maintaining two races in this area of Central America and, as first reviser, I select $\underline{B}$. m. direptor as the name to be applied to the populations currently recognized under the names direptor and argutus.

Buteo brachyurus Vieillot

Short-tailed Hawk

SPECIMENS.--B. b. Eyliginosus (5): La Celba, 7 May (imm. S, CM); La Lima, 13 Apri1 (\%, LSUMZ); San Marcos de Guaimaca, 15 Aug. ( $d^{\prime}$, MCZ); La Flor Archaga, 27 May ( $\$$, MCZ); Puerto Lempira, 14 April. ( $\$$, LSUMZ). 1960: $\frac{\text { PUBLISHED RECORD.--"Honduras" [ }}{452}$ "La Ceiba] (Rand,

The Short-tailed Hawk is an uncommon resident of open or semi-open situations in the lowlands of both coasts and in the interior, ranging up to at least 4,500 feet. Between 11 September 1962 and 22 April 1963, I noted the species 15 times in the Carlbbean lowlands, a single 
Individual in each case; these observations were made at Lake Yojoa, Villa Nueva, San Pedro Sula, La Lima, and Laguna Micos. On 12 October 1962 I saw a single bird near Cedeño, on the Pacific coast, and on 14 April 1964 I collected a female at Puerto Lempira, in the Mosquitia. Only 1ightphase birds have been recorded from Honduras.

The immature male specimen, taken in 1948 at La Ceiba by Arthur $C$. Twomey and Roland W. Hawkins, was the one examined by Rand (1960: 452). C. F. Underwood collected individuals at La Flor Archaga in 1932 and at San Marcos de Guaimaca in 1934. The La Lima specimen was obtained by Kenneth S. Hamilton in 1963.

An interesting observation was made by Mark Trafton, Jr., on 17 February 1956. He noted several of these hawks at San Alejo, apparently migrating. Very little is known concerning movements of this species in Middle America; it seems 1ikely that it does migrate to a greater extent than is presently evident.

I follow Rand (1960: 448-459) in recognizing B. b. fuligingsus Sclater for the populations north of South America. It may be distinguished from the nominate race, B. b. brachnurus Vieillot, by the browner general coloration and, according to Rand, by the higher wing/tail index. 


\section{Buteo nitidus (Latham)}

Gray Hawk

SPECTMENS.--B. n. plaglatus (81): Roatán Island (12?, BMNH) ; French Har̆bor, 3 April ( $0^{\prime}$, CM); Tela, 13 March ( $0^{\circ}$, MCZ); Lancetilla, 20 Jan., 29 March (2\%, MCZ); La Celba,

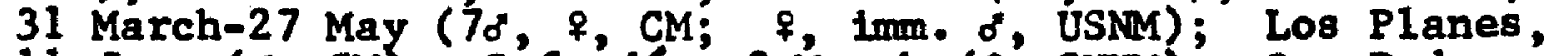
11 June ( $\delta, C M)$; Cofradla, 9 March ( $\%$, CNHM); San Pedro Sula, 24 Dec. (o", USNM); La Lima, 25 Nov., 10 Dec. (2?, UM); Urraco, 9 March ( 8 , MCZ); Progreso, $31 \mathrm{Jan}$. ( $\$$, MCZ); LA Cumbre, 29 Dec. ( $q$, USMM); Coyoles, 14-30 June (o", 29 , CM); La Leona, 25 June ( $q$, UC); Santa Bárbara, 24 May ( $\$$ CNHM); Lake Yojoa, 2 Jan. ( ${ }^{\circ}$, MCZ); El Callche, 25 June-20 July, 2-6 Nov. (78, $39,2 ?, 4$ imm. 8 , imm. \&, UC; $20^{\circ}, ?$, MCZ); Alto Guaimaca, 10-13 July ( $\sigma^{\circ}, q$, MLZ); Cantora 1, 30 Oct. ( $\left(\right.$, UC ); La Cueva Archaga, 2 Aug;, 2 oct. (2 imm. " $\sigma^{*}$, UC); La Flor Archaga, 17 Dec. ( $f, M C Z) ;$ Cantarranas, 20 July ( $\sigma$, ANSP); Tegucigalpa, 29 March, 18 Sep., 15 Dec. (o", MLZ; ?, MCZ; imm. of, UC); Comayagüela, $28 \mathrm{Sep.} \mathrm{(} 9, \mathrm{MCZ}$ ); Capa Rosa 4 July, 3 Aug. $\left(\sigma^{*},{ }^{8}, \text { UF }\right)_{2}$; Yeguare River Valley, 20 Jan., 15 May, 9 Dec. ( $\sigma$, $q$, , UF); Rio de La Orilla, 29 May-2 June ( $\$$, juv. of, UF); Catacamas, 1 Sep., 17 Oct. ( 8 , imm. $\&$, UC); $7 \mathrm{mi}$. W Choluteca, $28 \mathrm{Sep}$ ( $\$$, LStaM ).

PUBLISHED RFCORDS.-Comayagua, TIgre Island (Taylor, 1860: 225). San Pedro reglon (Sclater and Salvin, 1870b: 838). Roatán Island (Salvin, 1889: 374). Lancetilla, Tela, Progreso, $52 \mathrm{~km}$. W Tela [n Urraco] (Peters, 1929b: 416). Cantarranas (Stone, 1932: 300). La Celba (Deignan, 1936: 187-188). Cofrad fa, Santa Bárbara (Hellmayr and Conover, 1949: 160). Urraco, Lake Yojoa, San Pedro, La Cumbre (Ridgway and Friedmann, 1950: 365).

In Honduras the Gray Hawk is second in abundance only to Buteo magntrostris. It occurs in slightly more arid situations than the latter and is most abundant on the Pacific slope and in the arid interior. The spectes has been recorded up to 6,000 feet but is rare above 3,500 feet. On the humid Caribbean slope it is uncommon and has not been recorded east of La Celba or Los Planes.

The spectes also occurs on Roatain Island, in the Bay Is lands. Bond's (1936: 356) doubtful sight records from 
Guanaja and Utila islands, however, are probably erroneous. I did not observe it in May 1963 on Utila and Arthur C. Twomey failed to find it on Guanaja.

The supposed race ‥ … micrus [Asturina plaglata micrus Miller and Griscom, 1921b: 4; 4 miles northeast of Chinandega, Nicaragua] was described from a specimen taken not far from the Honduran border. The race was separated from B. n. plagiatus (Schlegel) by the smaller size and by the single instead of double tall band. The character of the tail band is too variable to be of use in defining this race (Hellmayr and Conover, 1949: 159); I have examined a serles from the Sula Valley in north-central Honduras that ranged from one well-defined white band (and traces of a second) to two we11-defined bands with a third indicated by spots. Individuals from any part of the range may exhibit one or two tail bands. While it is true that there is a size variation from north to south (decreasing southward), the difference is by no means as well marked as indicated in the original description. A wide band of populations from Guatemala to northern Nicaragua (including the type locality of micrus) would have to be regarded as intermediate in size. I can see no advantage in recognizing this gradual cline nomenclatorially and therefore refer all Honduran spectmens to B. n. plagiatus. 
Leucopternis albicollis (Latham)

White Hawk

SPECIMENS.--L. a. costaricens is (19): Lancetilla, 21 Jan.-22 Feb: (40, $q$, MCZ); La Celba, 5 May (,$C M)$; Los Planes, 11 June $\left(\sigma^{\circ}, \mathrm{CM}\right)$; Subirana, 20 March (?, MCZ); Plan del Rancho, 9 July ( $q$ MLZ); El Mochito, 26 June ( $q$, UF); Lake Yojoa, 16 June-14 Aug. (40, CM); San Marcos de Gua1maca, 28 June ( $\sigma^{\circ}, \mathrm{MLZ}$ ); Alto Cantoral, $11 \mathrm{Feb}$ ( 8, MLZ); Arenal, 26 Jan. ( $\delta$, UCLA); Segovia River, 13 June ( $d$, USNM); "Honduras" (?, BMH).

PUBLISHED RECORPS.--Segovia River (RIdgway, 1888c: 592). Honduras" (Salvin and Godman, 1900: 82-83). Lancetilla (Peters, 1929b: 417-418; Stone, 1932: 300).

This magnificent species is fairly conmon in the lowland forests of the Caribbean slope of Honduras, occurring in the interior along forested streams to an elevation of 6,000 feet, but it is rare above 3,000 feet. It is most frequently encountered in lowland rain forests. On 23 April 1963 I counted more than 35 individuals flying over the rain forests of the Montafia de E1 Tiburon; this observation was made from an aircraft and thus the White Hawks stood out in bold relief against the green background of the forest.

All Honduran birds are referable to the race $L \cdot a$. costaricensis Sclater, which is easily distinguished by the dark markings on the secondaries and inner primaries. The northern race, $L_{-}$모 ghiesbreght1 (Du Bus), possesses entirely white secondarles, No Honduran specimen shows any approach to ghiesbreghti. 
Leucopternis semiplumbea Lawrence

Semiplumbeous Hawk

SPECTMEN---(1): Segovia River, 28 June (?, USNM). 592).

RUBLISHED RECORD.--Segovla River (Ridgway, 1888c:

On 28 June 1887 along the Rfo Segovia, C. H. Townsend (Ridgway, 1888c: 592) obtalned the single specimen and only record of Leucopternis semiplumbea for Honduras. This rain forest species reaches its northern limit of distribution along the Honduras-Nicaragua boundary, probably extending into Honduras in the rain forests of olancho.

\section{Busarellus nigricolils (Latham)}

Black-collared Hawk

SPECMYaNS. -B. n. niericol118 (3): San Alejo, 8 Aug . (\%, LSUMZ); La Ceiba, 14 April (d, USN ); Coyoles, 17 June $(?, \mathrm{CM})$.

PUBLISHED RECORD.--La Celba (Deignan, 1936: 188).

The Black-collared Hawk is uncommon to rare in northern Central America, occurring usually around or near marshes on the Caribbean slope. Deignan (1936: 188) collected one of a pair frequenting a marsh at La Celba on 14 April 1933. Arthur C. Twomey and Roland W. Hawkins secured one at Coyoles in 1950, presumably from the marshes along the Rio Aguán. J. Alan Feduccla obtained the other specimen in 1963 on the o1l-palm plantation of the United Fruit Company at San Alejo. 
Mark Trafton, Jr., informed me that the species bred formerly at Lake Yojoa. He observed it annually there from 1943 through 1953 and recorded nesting in February and March for the years 1948 through 1951. After 1953 he recorded the species only once or twice, and I falled to find it there during 1962-1964. Trafton a180 observed it along the Río Chamelecón in 1953 (in a swamp near Puerto Cortés) and in January 1955 (below La Lima).

The Honduran birds are representative of the nominate race, B. n. nigricollis (Latham).

\section{Buteogallus anthracinus (Deppe)}

Common Black Hawk

SPECIMENS.--B. a. anthracinus (28): Tela, 7 March (imm. 7, MCZ); La Ceiba, 4 April-27 May (40, CM; $\$$, imm. \$, USMM); San Pedro Sula, 29 Jan. (Juv. o, USNM); Choloma (o, KAS); La Mica, 24 oct. ( $\%$, UC); Finca Fé, 22 July, 21 Nov. (2\%, LSUMZ); Lake Yojoa, 28 July (imm. $\%, C M$ ); Muin, 21 Jan. ( $\delta$, UC); Soluteca, 9 April ( $q$ UC); Siguatepeque, 8 July ( $\$, C M) ;$ Cantoral, 17 April, 12 May (o, $\$$, AMin); Monte Redondo, 19 Dec. ( $f$, CNHM); La Flor Archaga, 22 Apri1, 22 Nov. (3d, UC); Cantarranas, 5 Aug. (juv. o, ANSP); Tegucigalpa, 2 Jan.-21 Feb. (28, CNIM; of, UC); Yeguare RIver Valley, 12 May ( $\%$, UF); 2 mi. S Cauquira, 13 April (f, LSUMZ). B. B. ut lengis (13): Utila Island, 15 Feb., 24 March-4 May ( 9 , ANSP; 58, 2\%, CM; \%, CNM; o", imm., LSUMZ); Guanaja Ísland, 24 March, 15 April (20, CM).

PUBLISHED RECORDS - -OMnoa (Moore, 1859: 52). San Pedro region (Sclater and Salvin, 1870b: 838). Choloma (Lantz, 1899: 219). Tela, Lancetilla Valley (Peters, 1929b: 417). Cantarranas (Stone, 1932: 300). Ut11a Island [as anthracinus] (Bond, 1936: 356). La Celba (Deignan, 1936: 188). Tegucigalpa, Monte Redondo, Utila Is land (Hellmayr and Conover, 1949: 192), Ut1la Island and Guanaja Island las ut1lensis]" (Twomey, 1956: 387-388). Utila Isiand [as B. Bubtilis utilensis] (Monroe, 1963a: $1-5)$. 
The Comon Black Hawk is a fairly common resident throughout Honduras in semi-open situations or in open forest, recorded from sea level to 6,000 feet. It occurs also in the Bay Islands on Utila and Guanaja Islands, being very common on the former but decidedly uncommon to rare on Guanaja; It has not been recorded from Roatán Is land. On the mainland it is frequent in either humid situations on the Caribbean slope or more arid conditions in the interior and in the Pacific lowlands. In comparison with Buteogallus urubitinga, the Common Black Hawk is the more common specles in all regions of the country.

In an earlier paper (Monroe, 1963a: 1-5) I considered the Bay Islands population of black hawks to be related to Buteogallus subtilis, a mangrove inhabitant that I now restrict to the Pacific slope of Central and northern South America. In treating the Utila birds, my reasons for considering this population to be a race of $\underline{B}$. subtilis included similarity in smaller size, in gray rather than rufous mottling on the secondaries, and in the fact that both are basically mangrove inhabitants; I did, however, mention that the situation was rather puzzling (1963a: 4).

Further evidence obtained in the spring of 1964 has caused me to reverse this opinion. On 13 Apri1 1964 I collected a female black hawk at an occupied nest in a mangrove swamp along the Laguna Caratasca near Cauquira; this Individual in all respects is a typical $\underline{B}$. $\underline{\text { a }}$ anthracinus. 
It seems evident now that anthracinus may utilize the mangrove habitat if the latter is unoccupied by $\underline{B}$. subtilis. Thus the similarities between the Utila population and that of B. subtilis shizophorae may be the result of convergence. Kenneth C. Parkes has also called my attention to the fact that a few of the Utila birds show a trace of rufous mottling on the secondaries and that in tone of black in the plumage, the Ut1la birds are slightly more brownish than anthractnus on the adjacent mainland and much more so than Honduran individuals of subtilis, which have a grayer cast. Two Individuals from Guanaja Island are just like Utila uttlensis except that both also display slight rufous tinges in the mottling on the secondaries. In addition, Paynter (1955: 64) reported Butegga1lus anthracinus from mangroves in Yucatán and from islands off the coast of Quintana Roo, Mexico.

The foregoing considerations lead me to believe that the Utila population was derived from anthractnus and is convergent towards subtilis, possibly through the influence of imilar ecological conditions of the mangrove habitats. I should like to point out, however, that this problem concerning the status of utilensis in no way affects the situation that exists between B. anthracinus and B. subtilis along the Pacific coast of Middle America. The evidence as stated (Monroe, 1963a: 3-4) st111 indicates that these two taxa are full species. Only the relationship and position 
of utilens is is changed.

For a discussion of the differences between $B$. anthracinus and $\underline{B}$. subtil18, see the account under the latter. The Bay Is lands subspectes, B. a - utilensis Twoney [1956: 387; Is la Ut11a, Bay Is lands, Republic of Honduras] differs from the mainland race, B. a. anthracinus (Deppe), in smaller average size (wing: $d, 346.0-383.0$, mean 364.0; $\$, 365.0-381.5$, mean 370.2) and in the mottling on the inner webs of the secondaries being whitish or only tinged with rufous rather than decidedly rufous. The insular birds also average slightly more brownish in general coloration.

\section{Buteogallus subtilis (Thayer and Bangs)} Mangrove Black Hawk

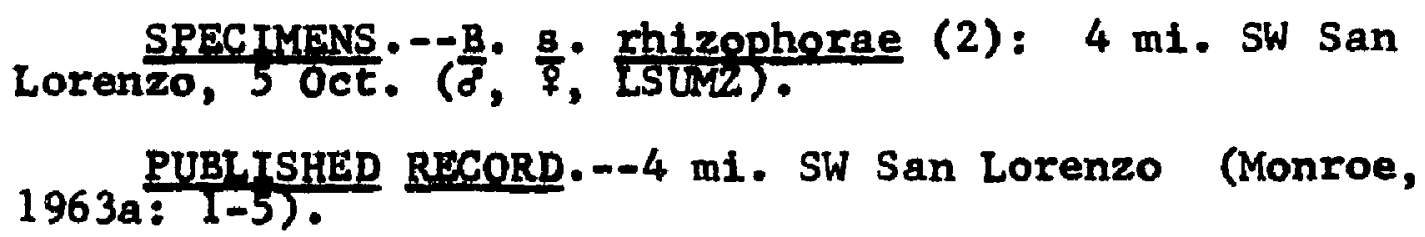

Confined in Honduras to the immediate vicinity of mangrove swamps on the Pacific coast bordering the Bay of Fonseca, the Mangrove Black Hawk is abundant in its restricted habitat. In the vicinity of San Lorenzo, as many as 25 may be seen perched in trees along a few miles of mangrove swamp. Breeding is apparently confined to mangroves, but individuals may forage dally some distance away frow this habitat. On 9 October 1962 I saw one individual on the beach at Cedeño, at least three mlles from the 
nearest mangroves; it was feeding on crabs, the primary food of the species.

The specific status of subtilis has been discussed in an earlier paper (Monroe, 1963a: 1-5). I based my conclusions on several factors: 1) B. anthracinus and B. subtilis are in daily contact, since anthracinus has been recorded at San Lorenzo, Honduras, on the edge of the mangroves and subt1118 forages away from this habitat, as mentioned earlier; 2) despite a great variation in size within each species, the wing measurements of each (excluding utilensig) do not show apparent overlap that should occur if the two do interbreed; and 3) anthracinus exhibits little or no geographic variation throughout a wide range adjacent to subt111s while the latter exhibits a great deal, with three rather well-marked races between E1 Salvador and Colombla. The taxonomic situation, with reference to status at the species level, is parallel to that of the African drongos, Dicrurus adsimt11s and D. Ludwigit, mentioned by Mayr (1963: 23).

In the serles of specimens that I measured, the following measurements pertain to wing: anthracinus, exclusive of uttlens 18 (118 specimens, 86 adults), $\sigma>365.0$, \% $>371.5$; subti11s ( 31 specimens, 24 adults), o <358.0, f $<369.0$. These figures agree well with Dickey and van Rossem (1938: 125) and with Wetmore (personal comminication); they disagree with Aldrich and Bole (1937: 44-49) 
and with the general works of Hellmayr and Conover (1949: 191) and Ridgway and Friedmann (1950: 400-406). If one may judge from Aldrich and Bole, these discrepancies are apparently due to the fact that Pacific slope birds from Central America (and especially those from Guanacaste Province in northwestern Costa Rica) are arbitrarily assigned to subtilis when they probably include examples of both species. Pacific slope birds of Honduras are representative of the race B. S. Fhizophorae Monroe [1963a: 1; 4 miles southwest of San Lorenzo, Department of Valle, Honduras], which differs from more southern races of subtilis in the gray Instead of rufous mottling on the inner webs of the secondaries; in this character it also differs from the larger B. a. anthracinus, the latter also having rufous mottling on the secondaries. From B. a. utilensis, the race rhizophorae differs mainly in average smaller size and grayer body coloration. Another member of the genus, B. gund1achit (Cabanis) of Cuba, enters the taxonomic problem. The latter species appears to be related to the subtilis group and, if it is considered to be conspecific with subtilis, the species will be known under the name gundlachil, which has priority. For the present, I am retaining $B$. gundlachil as a separate spectes (1963a: 4). 
Buteogallus urubitinga (Gmelin)

Great Black Hawk

SPECTMENS.--B. CM); Sublrana, 29 Dec. ( $(7, \mathrm{MCZ})$; La Laguna Archaga, 15 May, 11 July (\$, imm. \%, UC); Tegucigalpa, 24 Sep. (o, UC); Catacamas, 6 Aug.-28 Sep. (d, 39,?, UC); Segovia River, 27 July (?, USNM); $10 \mathrm{mi}$. NE Choluteca, 12 Oct. ( $0^{\circ}$, LSIMZ). 592).

PUBLISHED RECORD.--Segovia RIver (RIdgway, 1888c:

The distribution of this black hawk in Honduras is basically the same as that of Buteogallus anthracinus, although it is absent from the Bay Islands. The Great Black Hawk occurs in open and semi-open situations throughout the country below 5,500 feet. It is decidedly uncommon and is easily overlooked because of its similarity to $\underline{B}$. anthractnus. I obtained only four personal records of the species in Honduras: single birds in the Pacific lowlands near Choluteca on 12 October 1962 (specimen taken) and on 11 February 1963; one adult near Lake Yojoa on 22 November 1962; and another adult at Progreso on 6 March 1963. J. Alan Feduccia recorded one at San Alejo on 9 August 1963.

I tentatively follow Amadon and Eckelberry (1955: 66) and Paynter (1957a: 250) in considering Hypomorphnus to be generically Inseparable from Buteogallus.

Honduran specimens are referable to the northern race, B. ㅆ‥ Iidgway1 (Gurney). 


\section{Haxpyhaliaetus solitarius (Tschudi)}

\section{Solitary Eagle}

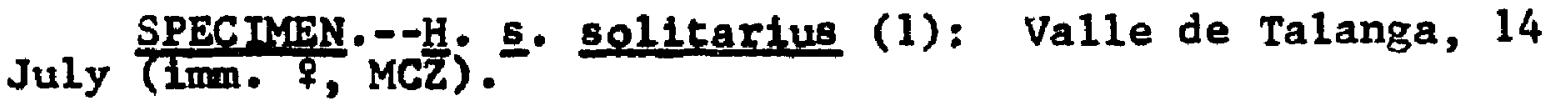

North of Panama the Solitary Eagle 18 very rare and has not been previously reported from Honduras. The single specimen, taken by C. F. Underwood in 1937, is the only Honduran record.

I agree with Hellmayr and Conover (1949: 199-200) that there are no constant structural differences between Urubitornis and Harpyhaliaetus but disagree that H- coronatus (Vielllot) and $\underline{H}$. solitarlus are conspecific. The well-marked and constant color differences (evident even in juvenal individuals) and slight structural differences warrant recognition of the two at the species level pending life history studies.

The Honduran specimen is representative of the nominate race, $\underline{\text { H. }}$. Solitarius (Tschudi).

Morphnus guianensis (Daudin)

Crested Eagle

SPECTMENS.--(2): La Ceiba, 18 Jan. (1mm. d'?, MCZ); San Pedro Sula, 15 Jan. (d, BMNH).

PUBL,ISHEP RECORDS.--La Ceiba (Bangs, 1903: 142). San Pedro Sula (Hellmayr and Conover, 1949: 203).

Morphnus gulanensis is another of the rare falconiform birds in Central America. There are very few records north of Panama. The only Honduran records are the specimens 
listed above, one collected by Erich Wittkügel at San Pedro Sula in 1890 and the other taken by W. W. Brown at La Ceiba in 1902 .

These records are the northernmost ones for the species .

Harpia harpyla (Linnaeus)

Harpy Eagle

The Harpy Eagle is very rare north of Panama and has not been previous ly reported from Honduras. The species is an inhabitant of lowland rain forest.

In November 1956 a wounded adult male was brought to Mark Trafton, Jr., at Lancet1lla; the bird had been shot in the Montaña de El Tiburón on the edge of the Leán Valley. This individual had a wingspread of $81 x$ feet, seven and onehalf inches and weighed 15 pounds. Trafton made color photographs of the bird, substantiating the record.

On 5 February 1963 William Lady, of Tegucigalpa, and I flew near one of these eagles as it soared over the rain forest of 0lancho; the bird, an adult, was seen fust south of the Rfo Patuca about $20 \mathrm{miles}$ north of Arenal.

\section{Splzagtur melanoleucus (Vielllot)}

Black-and-white Hawk Eagle

SPECTMENS.--(3): Los Planes, 11 June (o", CM); Chamelecón (7, BiNH); Catacamas, 4 óct. ( 9, MCZ). 1949: 208$)$.

PUBLISHED RECORD.--Chamelecón (Hellmayr and Conover, 
The Black-and-white Hawk Eagle is a bird of lowland rain forest and is rare to uncommon in Middle America north of Panama. The three specimens listed are the only Honduran records. The one from Catacamas was obtained by $C$. F. Underwood in 1937 and the one from Los Planes by Arthur $C$. Twoney and Roland $W$. Hawkins in 1948. I have not examined the Chamelecơn specimen, presumably taken by Erich Wittkügel in 1890 and now deposited in the British Museum.

\section{Spizaetus ornatus (Daudin)}

Ornate Hawk Eagle

SPECIMENS. - - . o. vicarius (8): San Pedro (?, CNHM); between San Pedro and Potrerillos (?, AMNH); Subirana, 6 March ( 9, MCZ); Cerro PuCa, 25 Jan. ( 8 , UC); Catacamas, 12 Sep. ( $\left.\sigma^{\circ}, \mathrm{MCZ}\right)$; Arenal, 21-22 Jan. (2 $\sigma^{\circ}, 1 \mathrm{~mm}$. $\$ ?$, UCLA). PUBLISHED RECORDS.--Between San Pedro and Potrerillos (Sclater, 1858b: 357; Taylor, 1860: 223); "Puerto Caballos near Omoa" [= near Puerto Cortés] (Moore, 1859: 52). "San Pedro, Colón" [= San Pedro Sula] (Hellmayr and Conover, 1949: 213).

In Honduras this hawk eagle is uncommon and is restricted to the Caribbean slope below 5,500 feet. In addition to the specimens 1 isted above, Joseph Leyland obtained two at Puerto Cortés; presumably these individuals are in the British Museum but I have not examined them.

I saw the spectes in Honduras on only one occasion. Vida Roth, my wife, and I observed a pair perched in a tree about 10 miles northwest of Cofradia (elevation 5,000 feet); the country in the vicinity was pine with cut-over cloud forest patches on the ridges. 
The Honduran specimens are referable to the Middle American race, S. o. vicarius Friedmann.

Splzaetus tyrannus (Wied)

Black Hawk Eagle

SPECIMENS.--(3): Subirana, 29 Jan. ( 9, MCZ); Lake Yojoa, 15 July ( $\%$, CM); Comayagüela, 13 DeC. ( $\sigma$, UC).

PUBLISHED RECORD.--San Pedro region (Sclater and Salvin, 1870b: 838 ).

The Black Hawk Eagle occurs sympatrically with

Spizaetus ornatus and the two forms were long considered to be color phases of the same species. $\underline{s}$. tyrannus is a rare bird in Middle America and occurs in forested regions in Honduras, especially in lowland rain forest, ranging into the interior to at least 3,000 feet.

Records of "S. tyrannus" from Potrerillos (Sclater, 1858b: 357; Salvin and Godman, 1901: 93; Stone, 1932: 300) refer to a specimen of $\underline{S}$. ornatus. Salvin and Godman (1901: 93) also 1isted a specimen in the British Museum, in addition to the San Pedro record, but I do not know on what individual this record is based; Sharpe (1874) did not list any specimens from Honduras in the British Museum.

Raymond Stadelman collected the Subirana individual in 1933. The Conayagüela bird was taken by $C$. F. Underwood in 1936. Arthur C. Twomey and Roland W. Hawkins obtained one at Lake Yojoa in 1951.

I noted the species twice in Honduras. I recorded a single individual near Progreso on 6 March 1963 and two 
birds over San Pedro Sula on 5 April 1963.

\section{Circus cyaneus (Linnaeus) \\ White-rumped Harrier}

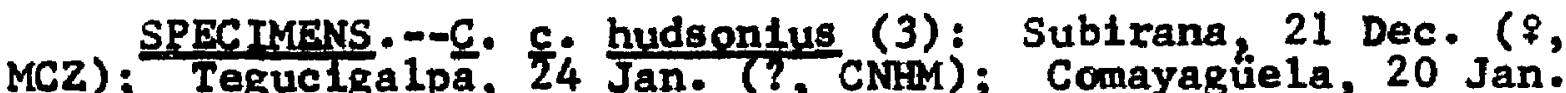
$(\$, \mathrm{MCZ})$.

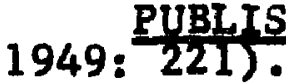

The White-rumped Harrier, more commonly called "Marsh Hawk" in the United States, is a rare to uncommon winter visitant in Honduras. The specimens were collected by Raymond Stadelman at Subirana in 1932 and by C. F. Underwood at Tegucigalpa in 1935 and at Comayagüela in 1932. Kenneth S. Hamilton noted one bird at La Lima on 28 February 1962. I observed a single individual about five miles south of Zambrano $(3,100$ feet elevation) on 16 February 1963. In the Mosquitia near Puerto Lempira I saw single birds on 10 and 13 April 1964. The species seems to be widespread in its occurrence in Honduras, preferring grassy areas of either the arid interior or the Mosquitia.

Honduran specimens are referable to the American race, c. c. hudsonius (Linnaeus).

\section{Geranospiza caerulescens (Vieillot) \\ Crane Hawk}

SPECTMENS.--G. c. niera (12): San Pedro (?, BMNH); Coyoles, 15-30 June (20, CM) EI Caliche, 21-29 June (o, \&, UC); La Laguna Archaga, 28-29 June (Imm. of Imm. ${ }^{8}$ UC)? 
Sep. ( 7, UF); Catacamas, 3 Sep. ( 9, MCZ); "Olancho," 6

Sep. ( $d$, MCZ); Puerto Salamar, 11 Feb. ( $\delta$, LSUMZ). PUBLISHEP RECORD.--San Pedro region (Sclater and Salvin, I870b: 838).

Occurring generally in the vicinity of water, the Crane Hawk 18 an uncommon resident in Honduras. It is most frequent in lowland swamp forests and mangroves but may be encountered in most any type of forested or semi-open country from sea level to 5,000 feet.

In addition to the specimen taken at Puerto Salamar in 1963, I saw a single individual at Onoa on 11 March 1963 and a group of six birds at Coyoles on 23 April 1963.

As Howel1 (1957: 77) pointed out, there is but one species in the genus Geranosplza. The dark northern birds (nigra) and the pale South American populations (caerulescens) differ only in general color and this feature is bridged by the Panamanian race, $G$. $\subseteq$. balzarens is Sclater.

Honduran birds are representative of the dark northern subspecies, G. $s$. nigra (Du Bus).

\section{Family PANDIONIDAE}

\section{Pandion hallaetus (Linnaeus) \\ Osprey}

SPECTMENS.--P. h. Carolinensis (4): Roatán Island (?, EMNH); La CeIba, 29 ApIII (o, CM); MHonduras" (2?, BMNH):

PUBLTSAED RECORPS.--"honduras" (Gray, 1848a: 22). Roatán Irland (Salvin, 1889: 374). Swan Is lands (Lowe, 1909: 339). Tela (Peters, 1929b: 419-420). Bonacea [= Guanajaj Island (Bond, 1936: 356). 
The osprey is a fairly comnon winter visitant to Honduras, found primarily in the lowlands of both coasts near large bodies of water. It occurs inland regularly at Lake Yojoa (elevation about 2,100 feet) and irregularly at other localities during migration. On 4 December 1962 I saw one at Copán and on 17 April 1963 noted another soaring over a pine and cloud forest area north of Cofradia (elevation 4,000 feet). Between 26 September and 12 October 1962 , Ospreys were seen daily along the Bay of Fonseca, but I did not observe any in the same area in February 1963. I noted a late migrant on Utila Island on 3 May 1963. Daily foragIng behavior of an individual at Puerto Lempira from 9 to 15 April 1964 suggested breeding. A successful catch of fish by this individual invariably resulted in its carrying the prey many miles, possibly to a nest, although the latter was not found.

The report from Amapala (Salvin and Godman, 1899: 39; Stone, 1932: 300) was supposed1y based on a record of 0sbert Salvin, but I found no mention of it in any of Salvin's other publications; Salvin (1889: 374) 1isted only the Roatán Island record of G. F. Gaumer. The reports from the Swan Is lands, Tela, and Guanaja Island are all based on sight records.

A11 Honduran specimens and reliable sight records are referable to the northern race, $\underline{P}$. h. carolinensls (Gmelin). 
The race carolinensis is distinguishable, even in the field, from the white-headed race of the West Indies and British Honduras, $\underline{\text {. }}$ h. rldgwayi Maymard.

\section{Family FALCONIDAE}

\section{Herpetotheres cachinnans (Linnaeus)}

\section{Laughing Falcon}

SPECIMENS.--H. c. cachinnans (28): La Ceiba, $16 \mathrm{May}$,

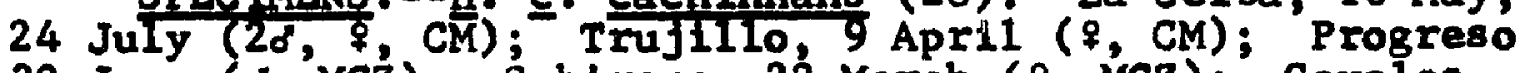
30 Jan. ( $d$, MCZ); Subirana, 22 March ( $q$ MCZ); Coyoles 18 June $(o, C M) ;$ La Sapote, 24 June ( $\$$, UF); Agua Azul, 25 Oct. (f; LSUMZ); E1 Guayabal, 16 Dec. (\&, UC); E1 Caliche, 1 Aug. ( $₹$, UC); Zambrano, 9 Feb. ( $d$, UC); Monte Redondo, 27 March ( $0^{\circ}$, CNHM); Cantarranas 4 Aug. ( 9 , ANSP); Teguc1galpa, 8 Jan., 8 March, 15 Aug.-12 Oct. ( 9, CMHM; of, $\$$ MCZ; $\left.\delta^{\prime}, ?, U C\right)$; vicintty of Tegucigalpa, 7 May ( $\left.\sigma^{\prime}, U C\right)$; Escuela Agrícola Panamericana, 29 June-22 Aug. (28, AMNH; ₹, UF); Yeguare River Valley, 1 Feb. ( $d$, UF); Catacamas, 2 Sep., 3 oct. ( $d, f$, UC); $2 \mathrm{mi}$. NW Namas igüe, 8 Oct. ( $\sigma^{\circ}$, LSUMZ); "Honduras" (?, BMNH).

PUBITSHED RECORDS.--Omoa (Moore, 1859: 52). San Pedro region (Sc1ater and Salvin, 1870b: 838). "Honduras" (Sharpe, 1874: 278). Progreso (Peters, 1929b: 418). Cantarranas (Stone, 1932: 300). Escuela Agrícola Panamericana, Subirana (Brodkorb, 1948: 409). Tegucigalpa, Monte Redondo (Hellmayr and Conover, 1949: 241).

Occurring in a wide varlety of open and semi-open situations from sea level to at least 6,000 feet, the Laughing Falcon is an uncommon to fatriy common resident in Honduras. It is most common in the lowlands of both coasts in open situations with scattered trees or scrubby growth. This species is extremely variable and, in most cases, the varlation cannot be correlated geographical1y. The general tendency is for northern birds to be paler, less 
buffy below and for individuals of the Central American populations occurring at higher elevations to be larger, but in these characteristics there is a great deal of variation within populations. Brodkorb (1948: 408-409) recognized the race $\underline{H}$. $c$. excubitor van Rossem as a large, pale, highland form occurring south to Honduras. The measurements of a series of highland birds from Honduras (wing, 276.5-307.5, mean 291.2) do indicate an average larger size, but very slightly so; furthermore, the specimen from the Pacific lowlands near Namasigüe measures 312.5 and is thus larger than any other from Honduras. The Pacific lowland birds are supposed to represent the small, nominate race, $\underline{H} \cdot \underline{c}$. cachinnans (Linnaeus).

The Caribbean lowland birds are usually included in the race $\underline{H}$. C. chapmant Bangs and Penard, supposedly differing from nominate cachinnans only in paler coloration. After examination of a large series from all parts of Middle America, I feel that this characteristic is based on an average difference, with a greater percentage of paler birds to the northward.

I agree with Russell (1964: 52) that the situation is best represented by considering all Middle American populations north of Panama to be a single subspecies, H. C. cachinnans (Linnaeus), and I therefore assign all Honduran material to this race. 


\section{Micrastur semitorquatus (Vieillot)}

Collared Forest Falcon

SPECIMANS.--M. s. naso (6): La Celba, 23 March-1 April ( $\sigma, \mathrm{CM}^{\circ} \delta$, USIM); San Pedro Sula, 21 Jan. ( $q$, USNM); Cerro Santa Bárbara, east 8 lope, 7 Nov. ( 9 , LSLMz); Catacamas, 30 Sep. ( $\delta$, MCZ); "Olancho," 14 Sep. (, MCZ).

PUBLISHEP RECORDS.--"Honduras" (Taylor, 1860: 225226). La Celba (Delgnan, 1936: 188). San Pedro Sula (RIdgway and Friedmann, 1950: 570).

This forest falcon is uncommon in Honduras, occurring in forested and semi-open areas up to an elevation of 4,500 feet. It has been recorded only on the Caribbean slope but probably will be found in the monsoon forests of the Pacific slope as well.

I encountered the species in Honduras on four occasions during 1962-1964. On 24 September 1962 I noted a single bird near Agua Azul, on the edge of Lake Yojoa, and I observed single birds on the east slope of Cerro Santa Bárbara, at elevations from 3,500 to 4,000 feet, on 7 and 11 November and 1 December 1962.

Honduran specimens are all referable to the Middle American race, M. s. naso (Lesson).

\section{Micrastur ruficollis (Vieillot)}

Barred Forest Falcon

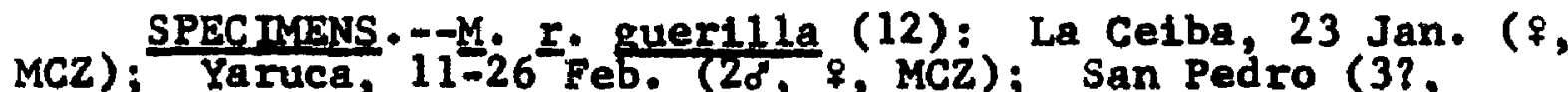
BMNH); Cerro Santa Bárbara, east slope, 7 Nov. ( 8 skel. LSLaz; 2 mi. N Pito Solo, 27 Oct. ( 9 , Lsumz); Cantoral, 6 April (o MCZ); Alto Cantoral, 7 Jan. ( $\$$ MCZ); RIo Guampú, $10 \mathrm{mi}$. B Dulce Nombre de Culmi, 17 March (d, LSUMz). 
PUBLISHED RECORDS.--San Pedro regton (Sclater and Sa1vin, 1870b: 838). San Pedro (Ridgway, 1875: 487-488; Helimayr and Conover, 1949: 251). La Ceiba, Yaruca (Bangs, 1903: 141). Cantoral, Alto Cantoral (Ridgway and Friedmann, 1950: 575).

In Honduras the Barred Forest Falcon is another uncomon forest species, inhabiting primarily rain forest below 6,000 feet. The specles is much more strictly confined to the forest than is $M$. semitorquatus. It is easily attracted by "squeaking"; on several occasions I have squeaked individuals to within a few feet of me.

Ridgway and Friedmann (1950: 575) recorded the species from near Manatee Lagoon, Honduras," but this locality is actually in British Honduras.

Honduran populations are representative of the northern race, M. I. guertila Cassin.

\section{Daptrius americanus (Boddaert) \\ Red-throated Caracara}

\footnotetext{
SPECTMENS.--D. a. guatemaleng18 (18): Subirana, 29 Dec. (f, MCZ); Coyoles, $15-16$ June (2。, $\%$, C4); San Esteban, 2 July (o', $\$, C M)$; El Caliche, 18 June-19 July (3o", 3\%, 2?, UC; $\delta$, ?, MCZ); Catacamas, 3 Sep. (d, UC); Arenal, 18 Jan. (o, UCLA).
} San Pedro region (Sclater and Salvin, 1870b: 838).

This species is an uncommon resident of rain forests throughout the Caribbean slope of Honduras, occurring below 3,500 feet. Taylor (1860: 223-225) gave an interesting account of a group of five or $81 x$ individuals, from which he shot four, at Taulabé; he mistook the birds for curassows 
(Crax), to which they have a remarkable resemblance, and as a result he named this species of Daptrius the "Curassow Hawk." Taylor also mentioned that Amory Edwards saw additional birds in Honduras but gave no further data concerning this observation.

Honduran specimens are referable to the larger Middle American race, Q. a. guatemalens is (Swann).

\section{Polyborus plancus (J. F. Miller)}

Crested Caracara

SPFC TMENS:--P. D. audubonit (10): Subirana, 12 Jan. ( ${ }^{\circ}, \mathrm{MCZ}$; San Esteban, 2 July ( $\sigma^{\circ}, \mathrm{CM}$ ); Finca Fé, 30 Nov. ( $q$, LSUMZ); E1 Caliche, 29 June ( $\$$, UC); Zambrano, 2 Nov., 21 Dec. ( $\sigma^{\circ},{ }^{\circ}$, CNHM); San Juancito, 27 July ( $\sigma^{\circ}$, ANSP); Tegucigalpa, $20 \mathrm{Feb}$. ( $\%, ?$, UC); $10 \mathrm{~km}$. N Sabana Grande, 14 Aug. (d, CM).

PUBLISHED RECORDS, -- "Honduras" (Taylor, 1860: 223). San Pedro region (Sclater and Salvin, 1870b: 838). San Juancito, Cantarranas (Stone, 1932: 301). Zambrano (Hellmayr and Conover, 1949: 287).

This species of caracara is common to uncommon in open arid or semi-arid situations throughout Honduras, occurring to an elevation of at least 6,500 feet. It is most abundant in the lowlands of the Pacific coast, where it is a conspicuous feature of the arid scrub habitat. It is a carrion feeder and generally gets 1ts share after the vultures have finished. On the Caribbean slope it occurs primarily in the arid portions of the interior valleys, where it is considerably less comon than in the Pacific lowlands. 
Amadon (1954: 203-204) has shown that Polyborus vielllot refers to this group of caracaras and that it antedates Caracara Merrem. For the treatment of Polyborus cherlway (Jacquin) as conspecific with $\underline{\text {. }}$ Plancus, see Amadon (1964: 15).

Honduran specimens are referable to the northern race, R. R. audubonit Cassin.

Falco peregrinus Tunstall Peregrine Falcon USNM)

SPECIMEN.--E. 2. anatum (1): Swan Islands, 17 Feb. (?,

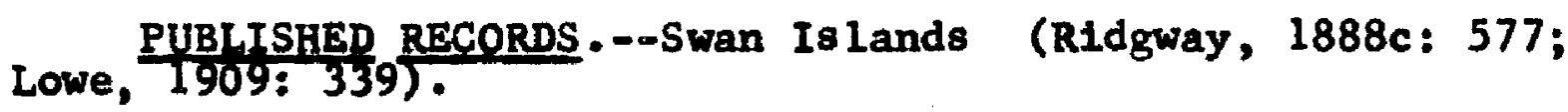

Although previously recorded in Honduras only in the Swan Islands, the Peregrine Faicon 18 an uncommon migrant and rare winter visitant in the lowlands of both coasts as well as in the Caribbean 1slands.

The only specimen from Honduras was taken by $\mathrm{C}$. H. Townsend In the Swan Is lands in 1887 (Ridgway, 1888c: 577). The species was again seen there in January and February 1908 by Lowe (1909: 339).

I saw Falco peregrinus a number of times in Honduras during migration: 12 October 1962, two near Choluteca, on the Pacific 8lope; 23 October 1962, a single Individual at Baja Mar, Just east of Puerto Cortés; and in the spring of 1963, Bingle individuals on Little Hog Island, in the Cayos Cochinos, on 7 and 9 April, and on Utila Is land, in the Bay 
Is lands, on 7 and 10 May. Both birds on Utila Island were headed in a general northerly direction out over the Caribbean Sea.

The single Honduran specimen is representative of the widespread North American race, F. p. anatum Bonaparte.

Falco deiroleucus Teminck

$$
\text { Orange-breasted Falcon }
$$

SPECIMEN.--(1): EI Hatillo, 8 Dec. ( 7, MCZ).

The Orange-breasted Falcon is certainly one of the rarest of Central American birds of prey. North of Panama it is known from a very few specimens, although $T$. R. Howell (personal communication) informed me that he has found it several times in parts of the Nicaraguan Mosquitia. A search for it on the Honduran side of the Rfo Segovia will probably reveal it to be of regular occurrence there.

At the present time the spectes is known from Honduras only by the single specimen taken by C. F. Underwood at E1 Hatillo in 1937.

\section{Falco albigularis Daudin}

Bat Falcon

SPECTMENS.--F. a. albigularis (27): Utila Island, 24 April ( $\sigma^{\prime}$, CK); Roatăn Island 7 Jan. (?, BMNH; $\delta, ?$, CNHM); Lancetilla, 6 March, 26 Aug - ( $\$$, ANSP; $\$, M C Z$ ); La Celba, 24 March ( $q$, USNM); Los Planes, 14 July ( $\$, C M$ ); Trujtilo, 19 Sep. ( $q$, USMM); San Pedro (2?, BMNH); Río Blanco, Cortés, 28 Jan. (o', USMM); Santa Ana, 5 Jan. ( $($, USNM); Coyoles, 28 June-11 July (d, $q, C M)$; San Esteban, 21 June (o, CM); Lake Yojoa, 9 Aug: ( $q$, UF); Alto Gua1maca, 9 June ( $\sigma^{\circ}$, MLZ); La Flor Archaga, 8 Dec. ( $\left.\$, M C Z\right)$; 
Ilamapa, 20 Aug. ( $\&, \mathrm{MCZ}$ ); Madre Vieja, 31 Aug. (?, UF); Yeguare River Valley, 20 oct. ( $\delta$, UF); Catacamas, $20 \mathrm{Sep} .-2$ Oct. ( $\delta, 7, M C Z)$; Segovia River, 20 June (?, USMM); Honduras-Nicaragua boundary " 180 miles from Pacific coast" $(?, \mathrm{MCZ})$; "Honduras" ( $\%$, AMNH).

PUBLISHED RECORDS.--"Honduras" (Taylor, 1860: 226). San Pedro regton (Sclater and Salvin, 1870b: 838). Trujillo, Segovia River (R1dgway, 1888c: 583, 592). Roatán Island (Salvin, 1889: 375). Lancetilla (Peters, 1929b: 418-419; Stone, 1932: 301) Roatán Is land, Bonacca [: Guanaja] Island (Bond, 1936: 356). La Celba (Deignan, 1936: 188). Roatán Island, San Pedro (Hellmayr and Conover, 1949: 304-306). Río Blanco, Santa Ana (Ridgway and Friedmann, 1950: 676).

In the lowlands of both coasts of Honduras, the Bat Falcon is an uncommon to fairly common resident, occurring in the interior to an altitude of at least 5,500 feet. It is primarily a species of the forest edge or open country in the humid lowlands on the Caribbean slope. When perching, it almost invarlably chooses the highest dead snag in the vicinity. Apparently it migrates or wanders to a small degree, at least. The records from Utila Is land are based on visitants, as the species does not breed there; Roatán Island records may also pertain to nonresident birds, though breeding is a possibility on that 18land. Bond's (1936: 356) report of the species from Guanaja Island is based entirely on accounts of the natives and there is too great a possibtlity of confuston with migrant falcons (Falco peregrinus and E. columbarius) to accept this report without further substantiation.

Salvin and Godman (1901: 116-117) attributed Roatán Is land reports of this species to Townsend, but the only 
records from the is lands at that time were those of $G$. F. Gaumer (Salvin, 1889: 375).

I agree with Peters (1929b: 419) that both Falco albigularis and E. rufigularis, described by Daudin on the same page, are equally applicable to the Bat Falcon. I follow Ridgway and Friedmann (1950: 674) in accepting the name albigularis, generally in use by authors who consider both names as applicable to this species, although I am not certain who qualifies as the first reviser with relation to this taxonomic problem. The name albigularis has line priority, and it is likely that all early authors used albigularis when faced with a choice.

Honduran specimens are referable to the nominate race, E. a. albigularis Daudin, as the race $F$. a. petoensis Chubb [1919a: 22; Peto, Yucatan] seems to be based either on an age characteristic (paler, less blackish above, especially on the pileum) or, at best, on average differences. Birds of both color types appear throughout the range of the species.

Falco columbarius Linnaeus

Merlin

SPEC MENS. - - F. C. columbarius (4): Swan Islands, 14 April (?, USNM); Utila Island, 28 April (?, CM); Roatán Is land (?, BMNH); San Lorenzo, 6 Oct. ( $\delta$, MCZ).

Lowe PUBLISHED RECORDS--Swan Islands (RIdgway, 1888c: 577; Is land (Saivin, 1889: 375). 
The Merlin, or Pigeon Hawk, is an uncommon migrant and rare winter visitant in the lowlands of both coasts of Honduras and in the islands in the Caribbean Sea. It has been recorded in the interior on the Caribbean drainage to an elevation of 4,500 feet.

In the Swan Islands the species has been recorded three tImes: by C. H. Townsend (Ridgway, 1888c: 577), who collected a specimen in 1887; by Lowe (1909: 334), who shot one in January or February 1908; and by A. K. Fisher (F1sher and Wetmore, 1931: 5), who observed one on 19 or 20 April 1929. G.F. Gaumer (Salvin, 1889: 375) collected it on Roatán Island; it is this record upon which Bond (1936: 354) based its inclusion in his 11 st of the birds of the Bay Islands. Arthur C. Twomey and Roland W. Hawkins obtained one on Utila Island on 28 April 1948. The other Honduran specimen was taken by C. F. Underwood at San Lorenzo, on the Pacific coast, in 1932 .

Mark Trafton, Jr., noted the species on many occasions; these observations were made at La Lima, Lancetilla, Los Drag08, Siguatepeque, and Lake Yojoa. At the higher elevations he recorded groups of as many as 30 individuals migrating in August and September, generally resting in mixed pine-oak groves at night. During the months from November through March, he also observed wintering birds in the lowlands. 
The Honduran specimens are all typical of the eastern North American race, E. c. columbarius Linnaeus.

\section{Falco sparvertus Linnaeus}

\section{American Kestrel}

SPECIMENS. --F. 8. Sparvertus (21): Lancet111a, 14 Jan. (o", MCZ); San Pedro Sula, 5 Nov. ( ${ }^{\circ}$, USNM); La Lima, 1 Nov. ( $\%$, LSUMZ); Subirana, 30 Jan., 14 DeC. ( ${ }^{\circ}, 9$, MCZ); 5 mi. S Jesús de Otoro, 31 Oct. ( $\%$, LSUMZ); Zambrano, 14 Nov. ( $\&$ UC); Cerro Cantoral, $15 \mathrm{Feb}$. ( $\left.\sigma^{\prime}, \mathrm{MCZ}\right)$; Monte Redondo, 22 Nov. -3 Dec. (2\%, MCZ); Tegucigalpa, 10 Jan., 22 Feb., 11 Sep., 28 oct. (2\%, MCZ; 2\%, UC); Comayagüiela, 23 Jan., 31 Oct.-12 Nov. ( $39, ?, \mathrm{MCZ}$ ); Piedra de Jesus, 18 Feb. ( $f$, UC); $6 \mathrm{mi}$. NE Choluteca, 8 Oct. ( 9 , LSUMZ); Honduras Nicaragua boundary [near Pacific coast] (o, MCZ). F. $s$. tropical1s (25): Subirana, 31 Jan. (d", MCZ; of, USNM); Coyoles, 18 July (o, CM); San Esteban, 21 June $\left(70^{\circ}{ }^{\circ}, \mathrm{CM}\right)$; $5 \mathrm{mi}$. SW Lucerna, $27 \mathrm{Feb}$. ( $\sigma^{\circ}$, LSUMZ); Lake Yojoa, 31 July ( $9, C M)$; Siguatepeque, 11 July ( $\circ, C M)$; El Caliche, 1 July ( ${ }^{\circ}, \&$, UC) ; La Flor Archaga, $14 \mathrm{July}$ ( $d^{\prime}, \mathrm{MCZ}$ ); Rancho Quemado, 16 Aug. (o, MCZ); E1 Hat 1110, 11 Aug; (?, CM); Tegucigalpa, 15 Aug. ( $\$$, MCZ); Las Mesas, 8-12 June ( $\$$, MCZ; ;, UF); $1 \mathrm{mi}$. E Las Mesas, 8 June ( $\$, q, M C Z) ; 3 \mathrm{mi}$. W Ojo de Agua, 8 June ( $\sigma^{\circ}, M_{C Z}$ ). E. s. subsp. nov. (1): Puerto Lempira, 10 April ( $\delta$, LSUMz). Undetermiñed (8): Cofradía, 5 Feb. (o, MLZ); Las Peñitas, 1 Feb. (?, MLZ); San Pedro ( $\%$ BMNH); Alto Cantora 1, 15 Feb. (o, CNHM); Escuela Agrfcola Panamericana, 6 March, 20 oct. ( $2 \%$, UF); Yeguare River Valley, 22 Jan., 6 March $\left(\delta^{\circ},+\right.$, UF).

PUBLTSHED RECORDS.--Tigre Is land (Sclater, 1858b: 357; Taylor, 1860: 226). Omoa (Moore, 1859: 52). San Pedro region (Sclater and Salvin, 1870b: 838). Lancetilla (Peters, 1929b: 419). San Juancito (Stone, 1932: 301). Swan Is lands (Delacour, 1938: 544). Cerro Cantora1 [= Alto Cantoral] (Helimayr and Conover, 1949: 324). Flor Archaga, Subirana, and Rancho Quemado [as troplcal18] (Ridgway and Friedmann, 1950: 743).

The American Kestrel, or Sparrow Hawk, is a fairly common to common species throughout Honduras, occurring during the breeding season in highland pine and in the lowland pine savanna of the Mosquitia. Numbers of Individuals increase during migration and winter with an influx of birds 
from North America. Migrant kestrels may be found in any open habitat on the mainland or in the Caribbean islands. Breeding is frequent in pine woods, espectally above 2,500 feet elevation.

The record from the Swan Islands (Delacour, 1938: 544) was based on an individual seen there on 20 october 1937. G. C. Taylor (Sclater, 1858b: 357) collected a specimen on Tigre Island in early 1858, presumably now deposited in the British Museum, but I was unable to locate this specimen in 1961 .

The eastern North American race, E. s. Sparverius Linnaeus, is a common migrant and winter visitant in Honduras. The resident highland birds are referable to the race E. S. tropicalis (Griscom), which differs from the nominate race in average smaller size (wing: tropicalis, 6 , <175.5, mean $171.5,9,<190.0$, mean 182.0; sparverius, $\delta,>174.0$, mean 183.0, $\$,>178.0$, mean 195.6), darker coloration above, usually unstreaked chest of males, greater amount of black markings (usually spots) on the flanks and abdomen, and usually reduced hazel crown patch (espectally in males). Griscom (1930b: 1-2) has shown that $\underline{F}$. $\underline{s}$. guatemalensis [Cerchneis sparverla guatemalensis Swann, 1920b: 156; Huehuetenango, Guatemala] is a strict synonym of the nominate race, being based on a wintering individual. T. R. Howell (personal communication) informed me that the breeding population of the lowland pine savanna of the 
Nicaraguan Mosquitia is a distinct and undescribed race. It is smaller than tropicalis (wing: o, 160.3-178.8, mean 167.3; $7,167.9-176.6$, mean 172.7), almost always lacks the hazel crown patch, is paler above in the males, and has less sexual dimorphism, the females being somewhat masculoid in appearance because of increased slate on the wing coverts and reduced dark barring on the back. I observed the species in the Honduran Mosquitia near Puerto Lempira in early February 1963 and collected a male there on 10 April 1964; the specimen was typical of the undescribed form.

\section{Family CRACIDAE}

\section{Crax nubra Linnaeus}

Great Curassow

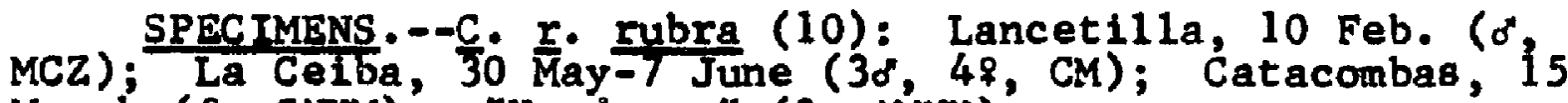
March ( $q$, CNEM); "Honduras" (?, AMNH).

PUBLISHED RECORDS.--Choloma (Moore, 1859: 61). Tigre Island, "between the Pacific coast and Comayagua," near lake Yojoa (Taylor, 1860: 311). San Pedro region (Sclater and Salvin, 1870b: 838). Lancet111a (Peters, 1929b: 403). Catacombas (Hellmayr and Conover; 1942: 132).

The Great Curassow occurs in lowland forests of Honduras below 4,000 feet. It is found in heavy rain forest, in dry monsoon forest, or occasionally in heavy second growth. Hunting pressures have reduced populations in many parts of Honduras. Crax rubra at present is generally uncommon and is usually outnumbered by Penelope purpurascens whenever the two species occur together. 
Honduran birds are representative of the nominate race, C. ‥ rubra Linnaeus.

\section{Penelope purpurascens Wagler}

Crested Guan

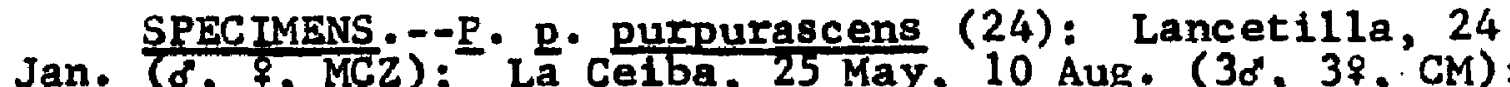
Río Blanco, Cortés, 22 June (imm. d, UF); Cerro Santa Bárbara, east slope, 7 Dec. ( $\$, 1 \mathrm{~mm}$. \&", LSUMZ); Lake Yojoa, 14 Aug. (2\%, CM); San Marcos de Guaimaca, 28 June ( $d$, CNHM); Cantoral, 8 Feb., 30 March-5 Apri1, 18 July (o", \&, CNHM; o", \%, CLM; $\delta, 28, \mathrm{MCZ})$; A1 to Cantoral, 10 Feb. $(\sigma, \mathrm{CNHM})$; Rancho Quemado, 29 June ( 9, UF); "Honduras" (?, AMNH).

\section{PUBLISHED RECORDS.-- "Honduras" (Moore, 1859: 61;} Sclater and Salvin, 1870a: 522). Lancetilla Valley, Tela (Peters, 1929b: 403). San Marcos de Guaimaca, Alto Cantoral, Cantoral (Hellmayr and Conover, 1942: 135).

This species is an uncommon resident of forested areas on both slopes and in the interior to an elevation of at least 6,000 feet. It is slightly more widespread and more common than Crax rubra but, along with that species, is becoming rare due to hunting pressures. It is usually encountered in heavy rain forest or, to a lesser degree, in monsoon forest.

Honduran specimens are all typical of the northern

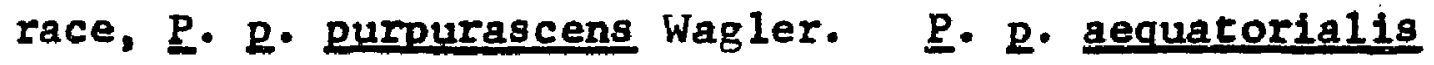
Salvadori and Festa occurs north to Nicaragua, where it intergrades with purpurascens. Honduran specimens match those from Mexico in brown (not chestnut) rump, in grayishbrown (not rufous) abdomen, and in larger size, showing no approach to aequatortalis. 
Ortalls vetula (Wagler)

Plain Chachalaca

SPEC IMFNS.--0. y. deschauensee1 (14): Utila Island, 9

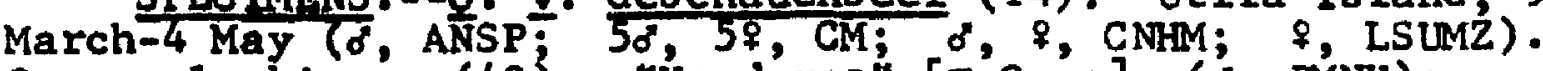
O. v. plumbiceps (40): "Honduras" [= Omoa] ( $\delta$, BMNH); Lancetilla, 30 March ( ${ }^{\circ}$, MCZ); La Ceiba, 10 April, 16 May-1

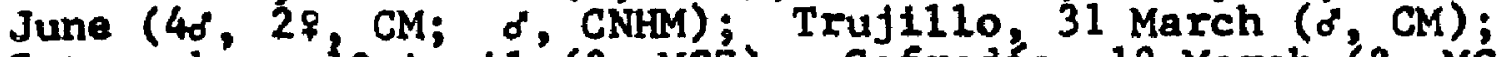
Catacombas, 10 Apri1 (?, MCZ); Cofradía, 12 March (?, MCZ); Choloma (?, KAS); Progreso, 1 Feb. ( $9, \mathrm{MCZ}$ ); Chamelecón, 8 March ( $\%$, USNM); Amapa, 24 June, 16 Dec. ( 9 skel., LSUMZ; $\checkmark$, UF); San Jooé de Santa Bárbara, 6 April ( $\sigma^{\circ}, \%$, UMMZ); Ei Jaral, 8 oct. ( $\%$, CNHM); Finca Fé, 17 Sep. ( $\%$ LSUMZ); Lake Yojoa, 12 June ( $\sigma^{*}, \mathrm{CM}$ ); Muín, 6 Jan. ( $\$$, UCR); Cantoral, 22 March ( $\delta$, CNHM); Cerro Cantoral, 15 oct. ( $\$$, CNHM); Monte Redondo, 23 Nov.-12 Dec. ( $0, \%$, CNHM); La Flor ATchaga, 20-27 May ( $\left.0^{\circ}, ?, \mathrm{MCZ}\right)$; E1 Hatillo, 8-11 May (40, 59, MCZ); Yeguare River Valley, 11 March, 21 April (of, \&, UF).

PUBITSHED RECORDS.--Omoa (Moore, 1859: 62). Atlantic s lope of Honduras [as plumbiceps]; Pacific slope of Honduras [as leucogastra] (Taylor, 1860: 311). "Honduras" [= Omoa] (Gray, 1867: 11). San Pedro region (Sclater and Salvin, 1870b: 838). "British Honduras" [= Omoa, Honduras ] (Ogilvie-Grant, 1893: 513). Choloma (Lantz, 1899: 219). Progreso, near Lancetilla, Ulúa Valley (Peters, 1929b: 403404). Ut1la Is land [as deschauenseei] (Bond, 1936: 356357). La Ceiba (Deignan, 1936: 188). Utila Is land [as deschauenseel]; La Celba, El Jaral, Monte Redondo, La Flor [= Cerro Cantora1], Cantoral [as plumbiceps] (Helimayr and Conover, 1942: 173). Chamelecón, San Pedro (Ridgway and Friedmann, 1946: 41).

Ranging up to 6,000 feet in Honduras, the Plain Chachalaca is a fairly common species in forested regions of the lowlands of both coasts. On the Caribbean slope, it does not occur east of Trujillo. It is also found on Utila Is land, in the Bay Islands. Preferring heavy vegetation, it frequents dense second growth and guamil. In drier situations the species may be encountered in arid scrub, but the habitat generally preferred is forest or forest edge. 
The subspecies from Utila Island, ‥ $\underline{y}$. deschauensee 1 Bond [1936: 356; Utilla Island, Spantsh Honduras], is a distinct form, differing from the mainland race, $\underline{o} \cdot \underline{y}$. plumbiceps [Ortalida plumbiceps Gray, 1867: 11; "British Honduras and Guatemala" (= Omoa, Honduras)], in the more ochraceous tips to the outer rectrices, greener (less brown) coloration above, lack of sharp contrast between the gray pileum and the back color, and larger size (wing >205 as opposed to $(198)$ ). Q. y. plumbiceps occurs on the Caribbean slope of Honduras and in the highlands of the interior, but ‥ v. Leucogastra (Gould) replaces it in the Pacific lowlands. Although no Honduran specimen of leucogastra is extant, the race is easily distinguished in the field by the white abdomen; Indeed, it is often regarded as a distinct species. Taylor (1860: 311) reported this race from the Pacific slope of Honduras, and I saw two individuals at Puerto Salamar, just east of San Lorenzo, on 12 February 1963 that were definitely representative of this subspecies.

\section{Qrtal1s garrula (Humboldt)}

Ches tnut-winged Chachalaca

UCLA). SPECIMEN.--0. g. cinereiceps (1): Arenal, 20 Jan. (o',

This species replaces ortalis vetula in the Caribbean rain forests from southeastern Honduras southward. It occurs in much the same habitat as the latter, being found 
in the dense vegetation of forest edge or in heavy second growth.

The only known Honduran specimen was secured by T. R. Howell at Arenal in 1955. Slud (1964: 76) included Honduras in the range of ortalis garrula on the basis of this specimen. The species probably occurs widely throughout the olancho rain forest of southeastern Honduras as it is common not far away in Nicaragua.

The Honduran specimen is representative of the northern race, Q. g- cinereiceps (Gray). Howel1 (1957: 77) gave reasons for considering $\underline{Q}$. $g$. frantzil Huber as a synonym of cinereiceps. I am in complete agreement.

\section{Penelopina nigra (Fraser)}

Black Chachalaca

SPECIMENS.--(24): [Dept. of] Ocotepeque, 30-"31" June ( 0 , 9 , CLM); Montaña E1 Chorro, "31" June ( 2 , MLZ); E1 Sillón, 10 July ( $\delta$, MLZ); Montaña La Cruz, 25 June-7 July (30", MLZ); Monte Verde, 25 July (d, MLZ); Mt. Puca, 11-13 Jan. (d, 2q, MCZ); Cantoral, 15-20 Feb., 5-17 Apri1, 30 Aug. ( 7 , ANSP; $20^{\circ}, 28$, imm. $\delta$, downy yg. 8 , downy yg. $q$, CNHM; 20, MCZ); Alto Cantoral, 3 Feb. ( 8, CNHM); Chili Mt., 25 March ( $\$$, UF).

\section{PUBLISHED RECORDS.--"adjacent Honduras" [= near E1} Sillón] (van Rossem 1934a: 364-365). Cantoral (Hellmayr and Conover, 1942: 184). Montaña E1 Chorro (Ridgway and Friedmann, 1946: 54).

In Honduras Penelopina nigra is a fairly common resident in cloud forest, occurring above 5,500 feet. It prefers the dense undergrowth found along ravines and in areas of the forest where light penetrates. It has been reported, however, from more open situations and even from areas 
of pine.

The First Honduran report of the species was that of van Rossem (1934a: 364-365), who collected the type of $\underline{p}$. dickeyi van Rossem within one mile of the Honduran line at Los Esesmiles, E1 Salvador; he also "saw others on the Honduran side of the line," 1.e., near El Sillón in the Department of Ocotepeque.

The two races described by van Rossem (1934a: 364-365), $\underline{\text { P. }}$. dickeyi and $\underline{\text { p. }}$. . rufescens (latter from Nicaragua), were based in large part on the color of the semi-nude ocular area, which fades in preserved material. Both dickeyi and rufescens were supposed to differ from the nominate race, $\underline{P}$. n. nigra (Fraser), in having this ocular area brownish-red instead of purplish (in life) in the male sex. In addition, males of dickeyt and rufescens were supposed to be glossed with more bluish than greenish. Females of dickeyi and nigra were said to be indistinguishable, while females of rufescens differed in being paler and more rufescent-brown rather than sandy brown. My examination of a series of skins from the Department of Ocotepeque, some taken within a few miles of Los Esesmiles, El Salvador, the type locality of dickeyi, revealed no plumage differences in either sex between nominate nigra from Chlapas and "dickeyi" from Honduras. The Nicaraguan race rufescens does display some difference in the female sex only (judging from the few skins avallable), being generally somewhat 
more rufescent, but a few were darker, not paler, than either nigra or dickeyi. At this point, until the matter of the ocular skin color in life can be checked with fresh material, I feel that it is best to regard the spectes as monotypic. The race rufescens may prove to be distinct, but redefinttion will be required.

Family PHAS IANIDAE

Dendrortyx leucophrys (Gould)

Buffy-crowned Wood Partridge

SPECTMENS.--D. 1. leucophrys (59): Santa Marta, 31 Jan. ( $\delta$ CNEM); La Libertad, 25 June ( $\sigma, M C Z)$; Montaña La Cruz, 26 June (2 Juv., MLZ); San José de Santa Bárbara, 10 April ( ${ }^{\circ}$, CNHM); Cantora 1, 3 April-27 May, 12 July-22 Aug., Dec. (2\%, ANSP; of, $2 \%, ?$, AMNH; $3 \%, q, j u v . ~ \delta$, CNHM); Cerro Cantoral, $30^{\circ} \mathrm{June}-8^{\circ}$ Aug. ( $0^{\circ},{ }^{\circ}$, CNHM; $110^{\circ}, 6 \%$, MCZ); Alto Cantoral, 16 Jan.-15 Feb., April, 15 July (2\%, juv. \&, CNHM; 20, 29, MLZ; o, MCZ); Archaga 7 Aug •, 26 Nov. ( $0^{\circ}$, 2\%, AMNH); La Flor Archaga, 25 June, 15 Nov., Dec. (d", ANSP; do, juv., downy yg; CNEM); Rancho Quemado, 20 March ( $0^{*}, \mathrm{MCZ}$ ); E1 Derrumbo, $17 \mathrm{July}-9$ Aug - (o", \%, ANSP; $0^{\circ}$ AMNH; 2 juv. \&, CNHM; o", \&, UMME); "Honduras" (?, AMNH).

PUBLISHED RECORDS.--Cerro Cantoral, Cantoral, E1 Derrumbo, Alto Cantoral, La Flor Archaga (Hellmayr and Conover, 1942: 228). [Dept. of] Teguclgalpa, Alto Cantoral, Cerro Cantoral,. [San José de] Santa Bárbara, Santa Marta, Rancho Quemado, La Libertad Copán (Ridgway and Friedmann, 1946: 251).

In the highlands of Honduras, this wood partridge is a fairly common resident in dense scrub and undergrowth, occurring above 3,500 feet. It inhabits 8 uitable growth in areas of pine, oak, or cloud forest but prefers the drier situations. It is the most common of the highland quail 
but does not tend to covey as much as do many other species. The Nicaraguan race, D. 1. nicaraguae Miller and Griscom [1925b: 1; Jalapa (4000 ft.), Nicaragua], was based on generally darker coloration, smaller size, and sooty (not chestnut) auriculars. He11mayr and Conover (1942: 227) stated that the only difference of any value at all was the darker coloration. I agree that there is no significant difference in size from Chiapas to Nicaragua, the range occupled by D. 1. Leucophrys (Gould) and by nicaraguae; in addition, a long series that I examined exhibited no geographic variation in color of the auriculars, since sooty or chestnut auriculars (or intermediate shades) appear throughout the series. It is true that there is an average trend towards darker populations in a north-south direction, but the populations in most of Guatemala, all of E1 Salvador, and all of Honduras would have to be regarded as intermediate, since dark and light birds occur in all these regions. I doubt the advisability of maintaining nicaraguae and I therefore consider it as a synonym of Leucophrys. The only other race, D. 1. hypospodius Salvin, of Costa Rica, is easily recognizable.

\section{Colinus nigrogularis (Gould)}

Black-throated Bobwhite

SPECIMENS.--C. n. Segoviensis (6): Puerto Lempira, 7 Feb., 9 -10 April $\left(2 \sigma^{\circ}, \frac{1}{2}\right.$, LSUMZ); Segovia River, 19-22 July 
593).

PUBLISHED RECORD.--Segovia River (RIdgway, 1888c:

The Black-throated Bobwhite is a fairly conmon resident of the lowland pine savanna of the Mosquitia in eastern Honduras. The species is known also from Yucatán, the Petén, British Honduras, and recently (T. R. Howell, personal communication) the Nicaraguan Mosquitia. There is no definite record of its occurrence elsewhere in honduras; with respect to range, it is closely similar to a number of species of lowland pine savanna birds that inhabit the Mosquitia and the pine ridges of British Honduras but nowhere in between. Gould (1843: 181-182) described the species as 0rtyx nigrogularis, giving the type locality as "Mexico," exact locality unknown. He later (1846: text opposite plate 4) gave the habitat as "Honduras and Yucatán," stating that David Dyson had Informed him of its occurrence in the pine ridges of those areas. In what is now Honduras, Dyson collected only in the north-central part (where there are no "pine ridges"); at that time, "Honduras" Included all of British Honduras and part of Yucatán. There seems to be 11ttle doubt that Dyson's types of nigrogularis came from the pine ridges of British Honduras, not Honduras. Gray (1867: 76) 1isted three specimens in the British Museum, collected by Dyson from "Honduras," but Sclater and Salvin (1873a: 137) apparently were aware of the true situation as they restricted the range of the species to British Honduras and Yucatán. Van Tyne and Trautman (1941: 3-6) examined a 
specimen in the Liverpool Museum that, according to the label, was the bird used by Gould (1846: plate 4) for his painting. The label indicated that it was caught alive in "Honduras" in 1830 (or possibly earlier, since 1830 may have been the year it died in captivity); once again the real source was almost certainly the pine ridges of British Honduras.

The specimens obtained by C. H. Townsend in July 1887

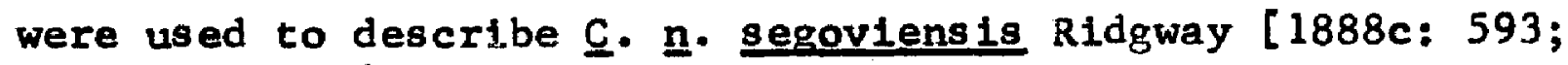
Segovia River, Honduras]. This reference furnished the first unquestioned record of the species for Honduras. Stone (1932: 302) 11sted the species from Cantarranas on the basis of call notes, but this record pertains to $C$. cristatus, which is common in that region; the call notes of the two species are identical and cannot be distinguished in the fleld. In February 1963 and April 1964 I found $\underline{C}$. nigrogularis to be fairly common around Puerto Lempira in the Mosquitia.

I have recently compared a series of $\underline{\text {. nigrogularis }}$ from the pine ridges of British Honduras with the Mosquitia specimens and find the race segoviensis to be valid on the basis of smaller size (wing: o, mean 93.5, as opposed to 99.0 in nigrogularis), darker coloration above, and deeper chestnut (1ess rufous) on the upper back and sides of the breast. The exact status of $\mathrm{C}$. $\mathrm{n}$. coffini Nelson has not been determined, but it is either a synonym of nominate 
nigrogularis of British Honduras or a weak race differing from the latter in slightly smaller size and perhaps slightly darker coloration; coffini is, however, paler than the geographically isolated segoviensis and should not be lumped with that race, despite the suggestion of Van Tyne (1935: 12) to the contrary.

\section{Colinus cristatus (Linnaeus)}

\section{Crested Bobwhite}

SPECTMENS.--C. c. leylandi (21): Catacombas, 27 March9 AprII (3ठ, BMNH); Cofradla, 4-6 March ( 9, BMNH; $\sigma$, MCZ); Villa Nueva, 7 Sep. ( $\sigma^{\circ}$, Lsumz); $3 \mathrm{mi}$. N Villa Nueva, 24 Oct. ( $\sigma^{*}$ skel., LSUMZ); Santa Bárbara, 16 March ( $\$$, ANSP); San José de Santa Bárbara, 29 April-14 May ( $\sigma^{\prime}{ }^{\circ}$ UMMZ); Agua Azul, 27 July ( $\sigma^{\circ}, \%$, UF); Lake Yojoa, 12-19 June, 16 July, 13 Aug. (78, 2f, CM). C. C. Sclateri (124): Subirana, 12 Jan. ( $\sigma^{\circ}, \mathrm{MCZ}$ ); Siguatepeque, 10-II July (36, CM); $10 \mathrm{mi}$. N Siguatepeque, $11 \mathrm{July}$ ( $\mathrm{d}^{\circ}, \mathrm{CM}$ ); El Caliche, 3-20 July (40, 8, CNHM); Cantora 1, 2 April, $19 \mathrm{July}$ ( $0^{\circ}$, AMNH; \$, MLZ); Cerro Cantoral, 30 June ( $\left.{ }^{\circ}, C M\right)$; La Flor Archaga, 16 Jan.-18 Apri1, 21 May-15 June, 18 Aug -, 13 Sep., 23 Oct.

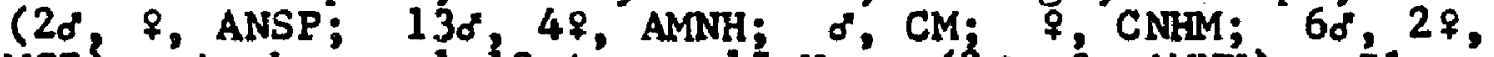
MCZ); Archaga, 1-12 Aug., 15 Nov. (20, ₹, AMNH); Ilamapa, 20 Aug. ( $\sigma^{\circ}, \mathrm{AMNH}^{2}$; Monte Redondo, 14 Sep., 2 Nov.-14 Dec. (6o, 10\%, 3 juv. \$, juv., CNHM; 8,8 , UCLA); E1 Hatillo, 3

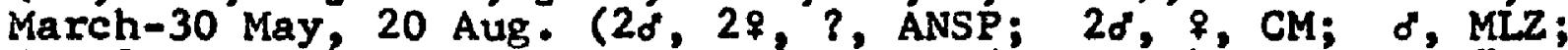
70, 109, MCZ); Tegucigalpa, 19 Sep. ( $\$$, AMNH); Comayagüe$1 a, 15$ Sep. 20 Oct., 15 Nov. (3\%, CNHM; 28, \&, UCLA); Escuela Agrícola Panamericana, 10 March ( $\$, \&$, UF); Las Mes as, 19 May-8 June (d, $\&$, MCz; 2\%, UF); 3 mi. N Las Mesas, 2 June ( 8, MCZ); Yeguare River Valley, 10 March, 22 Apri1, 2-6 June ( $\sigma^{\circ}, 3 \%$, UF); Tegucigalpa-Danif road at Yuscarán turnoff, 8 June (2\%, \$, MCZ; o, UF); E1 Paraíso, 20 Apri1 (20,3\%, BMNH); E1 Boquerón, 13 Sep. ( 9, CNHM); "Honduras" (?, AMNH), C. c. leucopogon (10): E1 Conejo, 9-10 Aug. ( $\left.\sigma^{\circ},{ }^{q}, \mathrm{MLZ}\right)$; Monte EL Conejo, 21 May ( $\sigma^{\prime}$, MLZ); Monte EI Portillo, 28 May ( $d^{\prime}$, MLZ); Plan del Rancho, 12 June-9 July (40, $2 \%$, MLZ). 'C. C. Leucopogon $x$ sclateri (6): Sabana Grande, 8 March, 1-To April (28, 2\%, CNHM); Puerto Salamar, 31 Jan. (f, LSUMZ); $5 \mathrm{mi}$. NE Choluteca, 13 oct. (9, LsuMz).

PUBLISHED RECORPS.--"Flores, on the road from Omoa to Comayagua" (Moore, 1859: 62-63). "Honduras" [as 
Eupgychortyx leucofrenatus] (E1110t, 1860: 106-107). Near Comayagua (Taylot, 1860: 312). E1 Paralso (Salvin and Godman, 1903: 295): Monte Redondo, Comayagüela (Conover, 1932: 175). Cantarranas [as C. nigrogularis segoviens is, part] (Stone 1932: 302). Goascorán RIver (Dlckey and van Rossem, 1938: 149). E1 Caliche, Catacamas [ E1 Boquerón],'Sabana Grande (Hellmayr and Conover, 1942: 251).

In the arid portions of the Pacific lowlands and interior of Honduras below 6,000 feet, the Crested Bobwhite is a common resident of open grassy or scrubby areas. It occurs also in the arid valleys on the Carlbbean slope, being found in open situations in the Comayagua, Sula, Quimistán, and olancho valleys.

Stone (1932: 302) attributed bobwhite calls heard in the vicinity of Cantarranas to the Black-throated Bobwhite (․ nigrogularis), but the latter is not known from any 10cality in Honduras other than the Mosquitia. The Crested Bobwhite, on the other hand, is common throughout most of the interior of Honduras and is the species that occurs in the Cantarranas area.

The northern Central American populations of this group of bobwhites have often been considered as constituting a separate spectes (‥ leucopogon) on the basis of the absence or reduction of the crest. Since some examples of $\mathrm{C}$. leucopogon from El Salvador have crests fully as long as many Panamanian examples of $\mathrm{G}$. cristatus, I can see no reason for spectfic separation of the leucopogon and cristatus groups on this basis. In other known respects, both ecologically and ethologically, the two groups are identical and are obvious geographical representatives of one another. 
Indeed, there is 1 ess morphological difference between Panamanian crlstatus and Honduran "leucopogon" sclateri than there is between Honduran examples of the races $\underline{C}$. $c$. $\underline{\text { ley- }}$ land1 and $\mathrm{C}$. c. Leucopogon.

E111ot (1860: 106-107) described "Eupsychortyx leucofrenatus" from Honduran on the basis of a specimen obtained by Amory Edwards. This type is now in the American Museum of Natural History. I recently examined this specimen and found it to be a faded example of the highland race, $\underline{c}$. $\underline{\text {. }}$ sclateri, of which the name leucofrenatus becomes a synonym.

I recentiy examined a large series of this species from Honduras and discovered that the interior lowland populations (of the arid Caribbean slope valleys) are racially distinct from the highland ones. The lowland birds, of both sexes, differ in the darker ground color of the under parts, almost a black, with very little or no gray overtone; thus the under parts are darker than in any other Central American race. In addition, females tend to have the black streaking on the throat reduced or absent, much as in the race leucopogon, in contrast to the heavy streaking of the throats of the highland birds.

The type specimen of G. c. leyland1 [ortyx leyland1 Moore, 1859: 62; "Flores, on the road from Omoa to Comayagua, Honduras"] was taken by Joseph Leyland, in whose honor it was named by Moore. The type locality poses somewhat of a problem. Leyland did most of his collecting in 
the Omoa area, but he is reputed to have made at least one trip into the interior. Moore's use of the phrase "between Omoa and Comayagua" is puzzling, as this distance is some 150 miles, with a number of other (and larger) towns along the way. In addition, there is no "Flores" anywhere along this route (and never has been, so far as I am able to ascertain). There is a "Las Flores" in the Comayagua Valley, however, some 20 miles beyond (south of) Comayagua, and it is possible that this is the Flores meant by Moore, although I suspect that "Comayagua" is a lapsus for "Choloma" (see page 61). In any event, the entire route from Omoa to Comayagua, and on to Las Flores, is occupled by the dark Caribbean slope race, and I therefore apply the name leylandi to these populations. I have not examined the type, which is deposited in the Derby Museum in Liverpool, England.

C. ‥ sclateri (Bonaparte) was described from western Nicaragua. I can detect no differences in the highland birds of Honduras and Nicaragua and therefore apply the name sclateri to these populations. The race $\underline{C}$. $c$. leyland (Moore), as mentioned above, is restricted to the Comayagua, Sula, and Quimistain valleys on the Caribbean slope; the spectmen from the Olancho Valley (at E1 Boquerón) is typical of sclateri. C. c. leylandi does not occur above 3,000 feet elevation. The white-throated race, $\underline{c}$. $c$. leucopogon (Lesson), is found in Honduras in the Department of 
Ocotepeque and possibly along the Río Goascorán on the E1 Salvador border, as there are sight records there (Dickey and van Rossem, 1938: 149) and the type locality of the race is La Unión, E1 Salvador, only about six miles away. All specimens, however, from the Pacific lowlands of Honduras, below an elevation of 2,500 feet, are intermediate between leucopogon and sclateri, so the exact eastward extent of the race leucopogon is not known.

\section{Odontophorus erythrops Gould}

Rufous-fronted Wood Quail

SPECIMENS.--o, e. verecundus (3): Lancetilla, 10 Feb. (29, MCZ); Trujilio, 7 April ( $\left.\sigma^{\prime}, \mathrm{CM}\right)$. ㅇ. e. melanotis

(1): Río Guampu, $10 \mathrm{mi}$. E Dulce Nombre de cūimi, 13 March ( 0 , LSUMZ). 405).

PUBLISHED RECORD.--Lancetilla (Peters, 1929b: 404-

This wood quail is an inhabitant of dense lowland rain forest on the Caribbean slope, ranging to an altitude of 1,500 feet. The species reaches its northern limit of distribution in north-central Honduras, east of the Sula Valley, and is decidedly uncommon in the republic.

The race $Q$. e. verecundus [Q. melanotis verecundus Peters, 1929b: 404; Lancetilla (1,100 feet), Honduras ] was described from the two females collected in 1928 by James $L$. Peters. It is characterized by the grayer coloration above, less pronounced black markings on the scapulars and wing coverts, and the more obsolete dark tibial bars, in comparison with the Nicaraguan and Costa Rican race, $\mathrm{Q}$. e. 
melanotis Salvin. A third specimen from the coastal rain forest was taken at Truj1llo by Arthur C. Twomey and Roland W. Hawkins in 1948; this specimen agrees well with the Lancetilla individuals in all respects. Rlchard R. Graber collected a male in the Olancho rain forest on 13 March 1963; In the darker coloration and distinct tibial bars, this specimen compares favorably with individuals of melanotis. The Aguán Valley appears to separate the populations of verecundus and melanotis in Honduras.

\section{Qdontophorus guttatus (Gould) \\ Spotted Wood Qua11}

SPECTMENS.--(41): Catacombas, 23 March-10 Apri1 (30', 39. AMNH; o, 9, MLZ; ?, MCZ); Cofradía, 14 March (\$, MLZ); Las Peñitas, 16-23 Feb. ( $d$, ${ }^{\circ}$, AMNH; 2?, MCZ); Port11lo Grande, 5-14 April (20, MCZ); Cerro El Triumpho, 20 mi. SE San Esteban, 27-31 March (20, LSUMZ); San José de Santa Bárbara, 18-27 Apri1 (20, CNHM); Alto Nieve, 4 May ( $\left.{ }^{\prime}, \mathrm{CM}\right)$; Santa Bárbara, 27 April ( $\delta$, ANSP); Falda de Santa Bárbara, 27 April ( $\left.{ }^{2} \mathrm{CM}\right)$; Cerro Santa Bárbara, east slope, 1 Dec. ( $\%$, LSUMZ); 2 mi. SE E1 Jaral, 3 March (o LSUMZ); Alto Guaimaca, 9-12 June (20, CNHM); Cantoral, 15-29 Feb.,

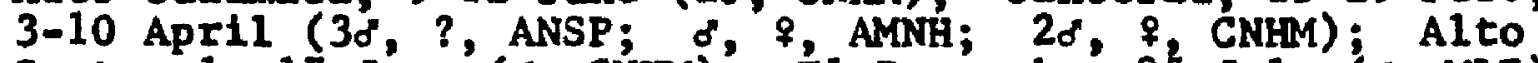
Cantoral, 17 Jan. ( ${ }^{\circ}$, CNHM); El Derrumbo, 25 July ( $\sigma^{\circ}$, MLZ); E1 Boquerón, 24-29 Sép. ( $\delta^{\circ}$, AMNH; 28, CNHM).

$$
\text { PUBLISHED RECORDS--"Honduras" (Brodkorb, 1939: 4-5). }
$$
Alto Cantoral, Cantoral, Alto Guadmaca, San José de Santa Bárbara, Catacamas [= Ei Boquerón] (Hellmayr and Conover, 1942: 280).

Occurring in Honduras up to an elevation of 6,500 feet, Odontophorus guttatus is a falrly common resident of forested areas. It is found in montane rain or cloud forest or, less frequently, in lowland rain forest; it is most common above 2,000 feet. 
Gould (1838: 79-80) described the species from a specimen presented to the Zoological Society of London by a Captain Barlow; it was taken from "the Bay of Honduras." Gould later (1846: text opposite plate 38) stated that David Dyson said it inhabited "the Cahoon palm ridges" of Honduras, and that the specimen Dyson had alive was taken in Honduras "on the borders of Yucatán." It is evident that the type came from British Honduras, not Honduras, as this entire region was called "Honduras" in Gould's day. Gray's (1867: 72) and Ogilvie-Grant's (1893: 439-441) reports of the species from "Honduras," based on Captain Barlow's specimen or on Dyson's bird, likewise pertain to British Honduras .

Dactylortyx thoracicus (Gambel)

Singing Quail

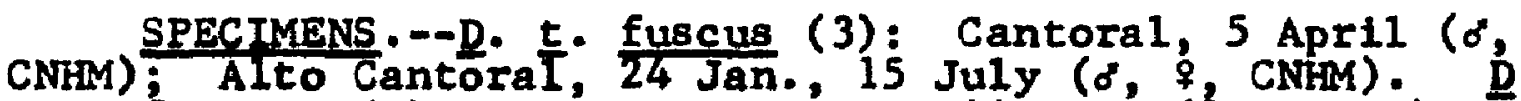
t. Iufescens (3): San Juancito, 22-29 July (28, ANSP); Rancho Quemado, 13 March ( 9 MCZ). D. E. conover1 (6): Catacamas, 13-30 Sep. (28, 28, 2 imm. o, CNHM).

PUBLISHED RECORDS:--San Juancito (Stone, 1932: 302). Alto Cantoral, Cantoral, Rancho Quemado, and San Juancito [as fuscus] (Conover, 1937: 73-74). Catacamas [as fuscus] (Helimayr and Conover, 1942: 284). Alto Cantoral and Cantoral [as fuscus]; Rancho Quemado and San Juancito [as rufescens]; Catacamas [as conoveri] (Warner and Harrel1, 1957: (41-143).

In Honduras the Stnging Quail is an uncommon resident, confined to cloud forests above an elevation of 4,500 feet. In other parts of its range, the species ts often found in 
more arid situations, especially in dry deciduous oak forests. Honduras is the southerm limit of the range of the spectes.

I tentatively follow Warner and Harrel1 (1957: 141-143) in their analysis of the races occurring in Honduras. I re-examined all the Honduran matertal and found their characteristics as they described them to be correct in all detalls for the few specimens avallable. Although no further specimens have been taken subsequent to their paper, I suspect that a long series from Honduras will show the characteristics of the three races involved to be bridged by Individual variation.

The race $\mathrm{D}$. $t$. fuscus Conover [1937: 73; Alto Cantoral, Dept. Tegucigalpa, Honduras], described from all $\mathrm{six}$ specimens now allocated to the races fuscus and rufescens, has been restricted by Warner and Harrell (1957: 141-142) to the Cantoral region. They characterized the race fuscus by the much darker coloration in both sexes (only two males and one female known) than that in any other race. The San Juancito and Rancho Quemado populations were described as $\underline{D}$. t. rufescens Warner and Harre11 [1957: 142; Rancho Quemado (San Juancito Mountains, Dept. Tegucigalpa), Honduras] on the basis of the very reddish coloration in the three known spectmens, all female. Harrell also noted the reddish coloration in the field when he observed a female in the cloud forest on San Juancito Mountain on 8 August 1954. 
The Catacamas series, from which $\underline{D} . \underline{t}$. conover 1 Warner and Harre11 [1957: 143; Catacamas, Department of Olancho, Honduras] was described, consists of four males and two females. Although two of the males are dark gray and two light gray, they all differ from the geographically adjacent fuscus in being grayer, less fuscous. The two females of conoveri are more reddish below than female fuscus. Peters (1934: 56) included Mt. Cacaguatique, El Salvador, and "adjacent parts of southern Honduras" in the range of $\underline{D}$. $\underline{t}$. taylori van Rossem, but this statement was based on a comment of van Rossem (1932a: 151-152) that the race was known from Mt. Cacaguatique and was "probably more or less widely distributed over similar areas in southern Honduras." There are no definite records of taylori for Honduras.

\section{Cyrtonyx ocellatus (Gould)}

Ocellated Quail

SPECIMENS.--(36): Port1110 Grande, 27 Oct. (downy yg., CNHM); San Esteban, 21 June ( $\left.\sigma,{ }^{\circ}, \mathrm{CM}\right)$; Santa Bárbara, 10 May ( $\$$, CNHM); Ceguaca, 10 March ( 7, CNHM); Siguatepeque, 9 July ( $8, C M)$; $10 \mathrm{mi}$. SE Siguatepeque, 20 June $\left(20^{\circ}, \mathrm{CM}\right)$; Comayagua, 22 Aug. (downy yg. $d$, downy yg. $7, C M$ ); San Marcos de Guaimaca, 22 June (juv., MLZ); Alto Guaimaca, 11 June ( $d^{\prime}$, CNKM); Montaña Vásquez, 14 June $(\delta, M C Z)$; Cantoral, 12-15 May, 20 July, 10 Sep. (20, \&, CNHM; 2 juv. d, UMMZ); Cerro Cantoral, 16 Dec. ( $(2, M C Z)$; Alto Cantoral, 18 July ( $\sigma$, CNMM); La Laguna Cantoral, 16-18 July (1mm. $\delta$, imm. $₹$, CNHM); Monte Redondo, 8 Sep. ( $\sigma^{\circ}, M C Z$ ); La Flor Archaga, 19 May, 15 June (2\%, juv. $\%$, CNFM); E1 Derrumbo, $18 \mathrm{July}$ (?, MCZ); E1 Hat1110, 19 Apri1, 8 May, 11-17 Aug. (28, imm. \&, CM; o, \&, MCZ); near Uyuca, 6 oct. ( $\delta$, UF); $6 \mathrm{mi}$. W Escuela Agrícola Panamericana, 21 May (o, MCZ); Yeguare River Valley, 8 oct. ( $d$, UF); Danll, April ( $q$, BMNH). 
PUBLISHED RECORDS.--Danlí (Salvin and Godman, 1903: 307). El Hatillo (Griscom, 1932c: 56). Alto Cantoral, La Laguna Cantoral, Alto Guaimaca, Ceguaca, Santa Bárbara, La Flor Archaga (Hellmayr and Conover, 1942: 288).

This quail is an uncommon to fairly common resident in highland pine areas of Honduras, occurring in open or semiopen situations where there is heavy undergrowth or long grass. The species has not been recorded in Honduras below an elevation of 2,500 feet.

Specimens of the Ocellated Quail collected by W. B. Richardson (Salvin and Godman, 1903: 307) at "Jalapa, Honduras" were taken at Jalapa, Nicaragua. Richards on did, however, collect the species just across the line in Honduras at Dan1f.

I agree with Hellmayr and Conover (1942: 401) that there is no significant geographical variation in the species and that the race $C$. $g$. differens Griscon [1932c: 56; Hatillo, Honduras I is not valid. There is a slight variation in size, but the largest birds are found in Guatemala, at the center of the distribution of the species, and the overlap is so great that subdivision is impractical.

\section{Rhymchortyx cinctus (Salvin)}

Tawny-faced Quail

SPECTMENS- - -R. c. pudibundus (9): San Alejo, 3 April ( ${ }^{*}, 9$, LSUMZ); Lancet1 1la 17-23 Jan., 18 July (d, 28, MCZ; o, f, UMAZ); Los Planes, 10 June (28, CM).

PUBLISHED RECORD.--Lancetilla (Peters, 1929b: 405). 
In the coastal lowland rain forests of north-central Honduras, just east of the Sula Valley, the Tawny-faced Quail reaches its northern limit of distribution. It occurs in dense rain forest below 1,500 feet elevation on the Caribbean slope and is uncomon in Honduras.

James L. Peters and Edward Bangs (Peters, 1929b: 405) collected a male and two females in January 1928 at Lancetilla at an elevation of 1,000 feet. F. H. Test secured a pair at Lancet111a in July 1933, and Arthur C. Twomey and Roland W. Hawkins obtained two males at Los Planes in 1948. Rose Monroe flushed a pair at San Alejo on 2 April 1963 and on the following day succeeded in collecting a pair from a group of three birds at the same locality.

Honduran specimens are representative of the northern race, ‥ ‥ pudibundus Peters [1929b: 405; Lancetilla ( 1,000 feet), Honduras], which differs from the nominate race, ‥ c. cinctus (Salvin), in being grayer above, more extensively white on the abdomen, and less buffy on the flanks. The race pudibundus is found south to southern Nicaragua.

Family ARAMIDAE

Aramus guarauna (Linnaeus)

Limpkin

SPECIMENS.--A. g. dolosus (9): Martinez Creek, $34 \mathrm{~km}$. W Tela, 27 Feb. ( $\left.3 d^{\circ}, \mathrm{MCZ}\right)$; La Celba, 12 April (o", CNM ); 
Truj1110, 6 April ( $9, C M)$; Lake Yojoa, 1 mi. W El Jaral, 24 Feb. ( $f$, LSUMZ); Lake Yojoa, 25 June $\left(2 d^{\circ}, 9\right.$, UF).

PUBLISHED RECORDS.--Omoa (Moore, 1859: 64). La Ceiba (Cooke, 1914: 13 ; Delgnan, 1936: 188). Martinez Creek, 34 $\mathrm{km}$. W Tela (Peters, 1929b: 409): Laguna Toloa, wes of Tela (Stone, 1932: 302).

The limpkin is fairly common locally in marshes of the Caribbean lowlands below 2,100 feet elevation. It has been recorded from the Omoa region by Jogeph Leyland (Moore, 1859: 64), from Lake Yojoa by Marjorie H. Carr, from the Tela and Laguna Toloa region by Peters (1929b: 409) and by Stone (1932: 302), and from La Ceiba by Deignan (1936: 188). Cooke (1914: 13) specifical1y mentioned "Celba, Honduras" in the range of the species, but I do not know the basis for this record. The specimen 1 isted by Hellmayr and Conover (1942: 305) 1s the one collected by Deignan.

During 1962-1964 I found the species to be fairly common at the north end of Lake Yojoa.

Honduran specimens are representative of the Central American race, A. g. dolosus Peters.

Family RALLIDAE

Amaurolimnas concolor (Gosse)

Uniform Crake (\%, LSUMZ).

SPECIMEN.--A. c. guatemalensis (1): San Alejo, 9 Aug. PUBLISHED RECORD.--Omoa (Moore, 1859: 64). 
The Uniform Crake is a rare bird in Central America north of Panama, confined to the lowlands of the Caribbean slope. It is known from Honduras on the basis of two records. Joseph Leyland, in 1855 or 1856, reported it as "not common" in the Omoa region. J. Alan Feduccia collected a female at San Alejo in 1963. Feduccia remarked that all he could see of the bird was its bright orange legs as It walked along in the heavy shadow of the forest floor.

Hellmayr and Conover (1942: 342) combined the Central American race, A. c. guatemalensis (Lawrence), with the South American $\underline{A}$. ‥ castaneus (Pucheran). I am tentative1y maintaining guatemalensis on the basis of its smaller size, although I have not examined a series of this species. The wing of the Honduran specimen measures 116.5.

\section{Aramides cajanea (Müller)}

\section{Gray-necked Wood Rail}

SPECIMENS.--A. s pactfica (31): San Alejo, 9 Aug. ( 9 LSUMZ); Los Pianes, i6 July (7, CM); NW of Bambí River, 19 Nov. (?, CNHM); Román [= Aguán] River (2?, BMNH); Río de Las Pledras, 26 Jan. ( $0^{\circ}, 2$ imm. $\left.\$, C M\right)$; Lake Ticamaya (2?, CNHM); Montagnes La Cumbre, 10 Dec. ( ${ }^{\circ}$, AMNH); Amapa, 28 April ( $\%$, LSUMZ); Subirana, 8 Feb. ( $0^{\circ}, \mathrm{MCZ}$ ); Lake Yojoa, near Pito Solo, 25 Feb. (?, UF); Lake Yojoa, 13 July-23 Aug. (2f, ?, imm. ₹, CM); El Boquerón, 11 Sep. -12 Oct. (40", \$, AMNH; 30", 39, CNHM); Segovia River, 13 Aug. ( ${ }^{\circ}$, USNM); "Honduras" (imm., AMNH)?

PUBLISHED RECORDS---Omoa (Moore, 1859: 64). San Pedro region (Sclater and Salvin, 1870b: 837). Segovia River (Ridgway, 1888c: 594; Bangs, 1907a: 186-187). Román [= Aguán]'River (Milier and Griscom, 1921b: ii). Boquerón, Lake Ticamaya, [near Río] Bambú, (Ridgway and Friedmann, 1941: 119). Lake Ticamaya, Trujillo [= near Río Bambúi, Ei Boquerón (Hellmayr and Conover, 1942: 350). 
In Honduras Aramides cafanea is a fairly common resident on the Caribbean slope. It is found in a wide variety of situations including marshes, swamps, and dense undergrowth of rain forests and guamil. It occurs up to an elevation of at least 3,000 feet.

All Honduran specimens are best referred to the race A. c. pacifica Miller and Griscom, currently restricted to Honduras and Nicaragua. It differs from the Costa Rican race, A. C. Plumbetcollis Zeledon, in the less richly colored, more grayish-olive upper parts. From the geographically adjacent race, A. c. albiventris Lawrence, a distinct subspecies occurring south to central British Honduras, pacifica differs primartly in lacking the broad white patch on the abdomen. A few scattered specimens from Honduras (Amapa, Subirana, and $E 1$ Boquerón) have a touch of white there, but the Honduran populations show no real approach to albiventris. The Pacific lowlands race, $\underline{A}$. . vanrossemi Dickey, was described by Dickey (1929: 33) from western El Salvador and may range south to the Pacific lowlands of Honduras; it closely resembles albiventris but is larger.

\section{Aramides axillaris Lawrence}

Rufous-necked Wood Rail

SPECIMENS.--(4): Guana ja (Bonacca) Is land, 1 March, 15 April $(\delta$, ANSF; $2 \%, C M)$; Puerto Salamar, 30 sep. ( $\sigma^{\circ}$, LSUMZ). 


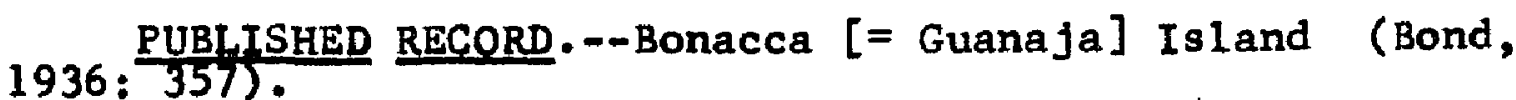

In Honduras this wood rail is an uncommon resident in mangroves, presumably occurring on both coasts. It has been recorded from Honduras only from Guanaja Island, in the Bay Islands, and from the coastal mangroves of the Bay of Fonseca at Puerto Salamar. Bond (1936: 357) collected two males on Guanaja, one of which was too badly shot to preserve; his lone prepared specimen was taken on 1 March 1936. Arthur C. Twomey obtalned two females there on 15 April 1947.

I encountered the species only once in Honduras, securing a male in the mangroves at Puerto Salamar in 1962. This specimen is the first record for the Pacific coast of Middle America between Guerrero, Mexico, and Costa Rica.

\section{Porzana carolina (Linnaeus)}

Sora

SPECIMENS -- (3): Swan Is lands, 25 March (d, USNM); Lake Yojoa, at Agua Azul, 24 Nov. ( $\$$, LSLMZ); Cómayaguela, 12 oct. ( $\%, M C Z)$.

PUBLISHED RECORD.--Swan Is lands (Ridgway, 1888c: 578).

The Sora is an uncommon winter visitant in Honduras, occurring in marshy places on the Caribbean slope, in the islands off the north coast, and in the intertor to an elevation of 3,000 feet.

C. H. Townsend (RIdgway, 1888c: 578) obtained a male in the Swan Islands in 1887. C. F. Underwood collected one at 
Conayagüela in 1931. V. C. Dunlap observed two Individusls at Copén on 6 January 1952, and Mark Trafton, Jr., 8 aw a single bird there dally for two weeks during December 1954 and January 1955.

I recorded the species only once in Honduras. J. Alan Feduccia and I collected a specimen in the deep marsh on the eastern shore of Lake Yojoa on 24 November 1962. The opecies is probably more common than the data indicate, the scarcity of records being due to its secretive hablts.

\section{[Laterallus jamaicensis (Gmelin)]}

\section{Black Ra11}

On 10 March 1953 near La Pimienta, Mark Trafton, Jr., observed a single individual of this species in the wet, marshy grassland adjacent to the Río Ulua. Trafton had several close looks at the bird and is certain of the Identification. On 12 March he obtained a glimpse of another (or the same) individual very close to the same locality.

Laterallus iamsicensis has been taken in winter in Guatemala, and Stephen M. Russell (personal communication) informed me that he has discovered a breeding colony of the species in British Honduras; thus its occurrence in Honduras 18 not unexpected.

The Black Rail has not been previously recorded from Honduras . 
Laterallus ext118 (Teminck)

Gray-breasted Crake

SPEC MYFN.--(1): Segovia River, 17 July (o', USNM). 595).

PUBLISHED RFCORD.--Segovia River (Ridgway, 1888c:

This crake is known from Honduras only by the single specimen collected by C. H. Towns end (Ridgway, 1888c: 595) along the Río Segovia in 1887. The species ranges north to British Honduras (Stephen M. Russe11, personal comunication).

The Honduran specimen has been described as a distinct race, L. e. yagans [Porzana ext118 vagans Ridgway, 1888c: 595; Segovia River, Honduras], but Hellmayr and Conover (1942: 374) and Howell (1957: 77-78) have shown that there are no differences in size or color between the Honduran bird and South American specimens.

Laterallus melanophaius (Vieillot)

White-throated Crake UCLA).

SPECIMFN.--L. ․․ clnerelcepg (1): Kiyras, 6 July (

PUBLTSHED RECORD.--MExtreme southeastern Honduras" [In range] (S1ud, 1964: 84).

The White-throated Crake reaches its northern limit of distribution along the Rio Segovia. The single known Honduran specimen was taken by J. G. Montrello at Kiyras in 1954; Slud'B (1964: 84) mention of Honduras in the range is based on this individual. The species is probably fairly 
common in southeastern Honduras as it is rather common just to the south in the Caribbean lowlands of Nicaragua.

I agree with Hellmayr and Conover (1942; 375) and Howell (1957: 78) that the Central American L. albigularia (Lawrence), which includes the race ctnereiceps, is conspecific with the South American L. melanophalus, differing from the latter only in the color of the auriculars (rufous Instead of gray).

The Honduran specimen is typical of the northern race, L. m. cinereiceps (Lawrence).

Laterallus ruber (Sclater and Salvin)

Ruddy Crake

SPECDMENS.--(16): San Alejo, 2 Apr11 (\%, LSURZ); Lancet11la, 20 Jan. -14 March, 29-30 Aug. ( ${ }^{\circ}, 7$, ANSP; 38, 29, MCZ); Coyoles, 22 June (o,, CM); Plan del Rancho, 27 May (2॰, MLZ); Santa Bárbara, 25 May-1 June (o, 9, MCZ); Lake Yojoa, near E1 Jaral, 24 Feb. (?, UF); Lake Yojoa, $17 \mathrm{July}$ ( $f, C M)$; Puerto Lempira, 14 Apri1 (o", LSUMZ).

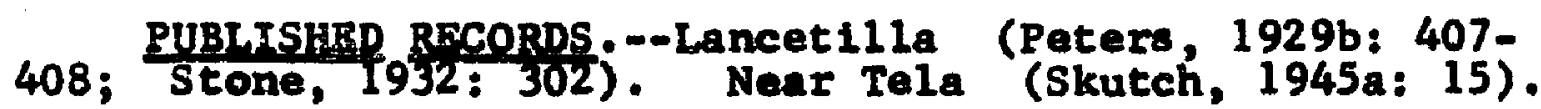

Ranging to an elevation of 3,000 feet in Honduras, the Ruddy Crake is a fairly common to common resident in the lowlands of both coasts. It occurs in a wide varlety of marshy habitats but is most common in wet, deep grass situations. During the dry seas on it may be found in grassy areas far from water. Breeding data from the Tela region have been published by Skutch (1945a: 15).

Stone (1932: 302) listed the spectes as having been recorded from Omoa on the basis of Moore (1859), but the 
latter does not mention the spectes from Honduras. Heine and Reichenow (1890: 320) 1isted a male specimen in the Heine Museum from "Belize, Honduras," but this individual was taken in British Honduras. Ridgway and Friedmann (1941: 169) mentioned the spectes as occurring at "Laguna Tolva" [= Laguna Toloa], but I can find no basis for this record.

I encountered the species a number of times during 1962-1964, it was recorded at El Sauce, at San Alejo, around Lake Yojoa, near Choloma, and between Omoa and Cuyamel. On 14 April 1964 Richard R. Graber and Jean W. Graber collected a male in a marsh at Puerto Lempira, in the Mosquitia. This locality is the southermost for the species on the Caribbean slope of Central America.

I am not able to distinguish $L$. . muberrimus (Miller and Griscom), described from the Pacific lowlands of B1 Salvador and Nicaragua. On geographical grounds, the specimens from Plan del Rancho should belong to this race, but they compare favorably with pale examples from the Caribbean slope. In addition, individuals in the plumage attributed to muberstmus (darker chestnut under parts, with the chestnut extending to the lower back and rump) and with a shorter blll appear frequently in a long series of specimens from British Honduras, along with the paler, largerbliled birds typical of the nominate race. It appears that "muberrtmug" 18 besed on characters that vary sexually, with 
Individuals of this type being mostly females. In any event, ruberrimus does not seem to be based on geographic variation. I follow Brodkorb (1943b: 34-36), Paynter (1955: 90), and Russell (1964: 58-59) in regarding the spectes as monotypic.

\section{Gallinula chloropus (Linnaeus)}

Common Gallinule

SPRCTyENS.--G; C. Cachlnnang (5): Laguna E1 Camen, 15 Feb. (f, EVII); Ei Jaral, 27 Sep, -9 oct. ( $\delta, q$, AMNH; $q$, MCZ); Lake Yojoa, at Agua Azul, 11 sep. (f, LSÚM). Swan ISLATds (Lowe, I909: 339).

(Taylor, 1860: 314).

The Common Gallinule is a locally comon resident on Lakes and lagoons of the Caribbean slope of Honduras. The colony at Lake Yojoa numbers in excess of 75 pairs. The remaining Honduran records may pertain to migrant ind1viduals, but there are probably other breeding colonies in the Caribbean lowlands. Lowe's (1909: 339) report from the Swan Is lands, based entirely on observations of the local people, undoubtedly refers to migrants as the species is not present on the islands in the breeding season.

Honduran specimens are all referable to the race $G$. $c$. cachinnang Bangs, the subspectes found in North and Middle America. The supposed Central American race, G. c. centralis Miller and Griscom, is not valid (Hellmayr and Conover, 1942: 396). Ridgway and Friedmann (1941: 190-191) assigned the record from the Swan Islands to the West Indian 
race, G. c. cerceris Bangs, but it is just as likely that migrants in the Swan Is lands are referable to cachinnans.

\section{Porphyrula martinica (Linnaeus)}

Purple Gallinule

SPECTMENS.--(7): Roatán Island (?, BMNH); La Celba, 26 April (9, USMM); Lake Yojoa, at Agua Azul, 11 Sep. ( 9 , LSUNZ); Lake Yojoa, 2 Jan., 22 June, 13 Aug. ( $\$, C M$; $\$$ MCZ; \&, UF); vicinity Tegucigalpa, 1 May (o skel., MLZ).

PUBLISHED RECORDS.--Roatán Island (Salvin, 1889: 378; Sharpe, 1894: 189). La Cetba (Deignan, 1936: 188).

In Honduras this gallinule is an uncommon resident locally in marshes and swamps of the Caribbean lowlands, occurring in the interior during migration to an elevation of 3,000 feet. The only known breeding colony in Honduras Is at Lake Yojoa, at an elevation of 2,100 feet. The species likely breeds in many localities in the Caribbean lowlands. The records from Roatain Island and from near Tegucigalpa are most 11 kely based on migrant individuals.

At Lake Yojoa the species 18 much $188 s$ comnon than Gallinule chloropus, being outnumbered about 10 to one. A few individuals, however, may be seen daily at the lake throughout the year.

\section{Fulica americana Gmelin}

\section{American Coot}

SPECIMENS.--F. ‥ Amertcang (7): Swan Islands, 25 Dec. (d, MCZ); San Pedro Sula, 2 Fob. ( $\%, M Z)$; Lake Yojoa at Agua Azul, 14 Dec. (d, LSUMZ); Lake Yojoa, 2 Jan., 18-23 June ( $d$, CM; $\delta$, MCz; $\$$, UF); Archaga, 10 Dec. ( $\delta$, AMNH). 
Yojoa (TAYLIOr, 1860: 314 ). Swan Is lands (Paynter, 1956:
104).

In addition to wintering commonly in Honduras, the American Coot is a locally uncommon resident. It is most abundant on the Caribbean slope but occurs also on the Pacific slope and in the Swan Islands. It ranges up to an elevation of at least 3,500 feet. During the winter months rafts numbering 1,000 individuals may be seen on Lake Yojoa, and countless numbers were present on the flood-fallow lakes In the San Pedro Sula-La Lima region during the early $1950^{\prime} 8$.

The species breeds on Lake Yojoa and posstbly on other lakes or lagoons on the Caribbean slope. In the Swan Islands it is purely a migrant and winter visitant, as it is in the interior of Honduras.

Honduran specimens are referable to the widespread nominate race, $E$. ‥ americans Gmelin.

\section{Family HELIORNITHIDAE}

\section{Heliornis fulica (Boddaert)}

Sungrebe

SPECTMENS.--(5): Micos Lagoon, $5 \mathrm{mi}$. W Tela, 16 March (d skol, LSUL); La Celba, 16-23 Jan., 29 April (d, CM; 28, MCZ); Nacunta River, 3 mi. S Puerto Lempira, 6 Feb. (o", LStan).

PUBLISHED RECORDS.--San Pedro region (Sclater and Sa1vin, 1870b: 838). La Celba (Bangs, 1903: 142). 
The Sungrebe, or American Finfoot, is an uncommon resident, confined in Honduras to the Caribbean lowlands. It occurs along streams and lagoons, usually where there is much overhanging vegetation along the bank. All Honduran reports of the species have come from localities below 500 feet elevation.

G. M. Whitely (Sclater and Salvin, 1870b: 838) collected the species in the San Pedro region in 1869-1870. W. W. Brown (Bang8, 1903: 142) obtained two females at La Celba in January 1902, and Arthur C. Twomey and Roland W. Hawkins took a male there in Apr11 1948. I saw the species only twice In Honduras; I collected single males along the Rio Nacunta in 1963 (from at least six seen) and on the Laguna Micos in the same year (from a pair noted).

\section{Eamily EURYPYGIDAE}

\section{Eurypyga helias (Pallas) \\ Sunbtttern} USNM).

SPECIMENS.--E. h. Mator (2): La Cetba, 23 April (d, f, PUBLISHED RECORD.--La Ceiba (Deignan, 1936: 188).

The Sunbittern is a rare species in Central America, occurring primarily along watercourses in dense lowland rain forest on the Caribbean slope.

Delgnan (1936: 188) collected a paix about five miles Inland from La Celba at an elevation of 400 feet; the birds 
were taken below a waterfall in dense forest. Mark Trafton, Jr., observed one along the wooded border of a floodfallow lake at Copén in September 1953. V. C. Dunlap recorded one at Lancetilla on 5 June 1959.

I saw the spectes only once in Honduras. Accompanied by the late Paul Allen, of the United Fruit Company, and my wife, I attempted unsuccessfully to collect a single individual that was feeding along a wooded stream at Lancetilla on 19 August 1962.

The Honduran specimens are representative of the Middle American race, E. $\underline{h}$. major Hartlaub.

Family JACANIDAE

Jacana spinosa (Linnaeus)

American Jaçana

SPECTMENS.--J. s. 8pinosa (32): Laguna Toloa, 28 Feb., 30' Aug. (25", ?, ANSP; Imm. ${ }^{\circ}$, MCZ); La Ceiba, 16-22 Jan., 25-29 April ( $q, \mathrm{CM} ; 2 \delta^{\prime}, \mathrm{MCZ} ; \sigma^{\circ}$, USNM); Trujillo, 9 April, 30 Sep. ( $\$, C M ; \delta$, USNM); Cofradla, 27 Feb. ( $\$$ USNM); Las Penitas, 16 Feb. ( 0 , BMNH); Choloma (?, KAS); Coyoles, 21-29 June ( $d, q, C M)$; Oromilaca, 8 June ( $d^{\prime}$, AMNH); E1 Jaral, 11 Oct. (26, 9, AMNH); Lake Yojoa, at Agua Azul, 11 Sep. ( $\&$, LSUMZ); Lake Yojoa, 2 Jan., 21 June-13 July, 23 Aug. ( $\delta, 39, \mathrm{CM}$; of, MCZ; of $q$ UF); Honduras-Nicaragua boundary [near Pacific coast] (4?, MCZ); "Honduras" (?, BMNH).

PUBLTSHFD RECORDS.-."Honduras" (Sclater, 1856b: 283; Sharpe, 1896: 86; Forbes and Robinson, 1899: 60). TIgre Is land (Sclater, 1858b: 360). Onoa (Moore, 1859: 64). Tigre Igland, Lake Yojoa (Taylor, 1860: 314-315) Trujillo (Ridgway, 1888c: 584). Choloma (Lantz 1899: 219). La Ceiba (Bangs, 1903; 142; Delgnan, 1936: 189). Laguna Toloa, Tela (Peters, 1929b: 409; Stone, 1932: 303). 
In sultable situations throughout the lowlands of both coasts of Honduras below 3,000 feet, this jaçana is a common resident. It occurs in a wide varlety of wet habitats including marsh, swampy flelds, lagoon and lake edges, and roadside ponds.

Early records from "Petén, Honduras" and "Belize, Honduras" refer, of course, to Guatemala and British Honduras, respectively.

In addition to the specimens 11 sted above, there are single female and juvenal skins in the Derby Museum from Honduras (Forbes and Robinson, 1899: 60).

Honduran specimens represent the Middle American race, J. s. Spinosa (Linnaeus).

Family HAEMATOPODIDAE

Haematopus palliatus Temminck American Oystercatcher *, Isuriz).

SPECTMENS.--H. R. pelliatus (2): Baja Mar, 9 Sep. ( 6 ,

Haematopus pallifatus is apparently a straggler or very rare migrant along the Caribbean cosst of Honduras. On 9 September $1962 \mathrm{~J}$. Alan Feduccla and I collected a pair on the open beach at Baja Mar, about five miles east of Puerto Cortés. They were sitting on the beach in coupany with Laughing Gulls (Larus atricilla). There are no other Honduran records. 
The lumping of all world-wide oystercatchers into a single spectes (H. ostralegus Linnaeus) may not be the best procedure in 1ight of our present knowledge of the relationships of the black and pied races, espectally in the Australian region. I feel that the most desirable course, pending a study of the complex on a world-wide basis, is to retain our pled birds as a full species, H. pallitup.

The two Honduran specimens are typical of the eastern race, H. 2. palliatus Teminck, in all characteristics; these features include a lighter back (contrasting with the head and neck), white upper tall coverts, white outer webs on the innermost secondaries, and an immaculate white breast. The Pacific coast race, H. R. frazari Brewster, may possibly occur along the Bay of Fonseca in winter.

\section{Family CHARADRIIDAE}

\section{Squatarola squatarola (Linnaeus)}

Black-bellied Plover

SPECIMTENS.--(3): Baja Mar, 19 Sep. (d, alc., LsuM); La Celba, 31 March ( 8 , USNM).

$$
\text { PUBLISHFD RECORDS.--Puerto Cortés (Stone, 1932: 303). }
$$
La Celba (Delgnan, 1936: 189).

The Black-bellied Plover, or Gray Plover, is a falrly comon migrant and winter visitant along both coasts of Honduras. It may be seen along the outer beaches from September through Apri1. During the winter of 1962-1963, I observed it dally during trips to the north coast or to the 
Bay of Fonseca, on the Pacific coast. Extreme dates of arrival and departure in Honduras are 9 September and 15 Apr11.

Stone (1932: 303) recorded this plover from Honduras on the basis of several seen on the beach at Puerto Cortés on 14 September 1930. Specimens have been taken by Deignan at La Ceiba in 1933 and by J. Alan Feduccia and me at Baja Mar In 1962.

This genus should perhaps be merged with luvialis. I an tentatively following the American Ornithologists' Union (1957: 173-174) In maintaining Squatarola on the basis of structural differences.

\section{Charadrius semipalmatus Bonaparte}

Semipalmated Plover

SPFCnYFNS:--(7): Swan Is lands, 11 Oct. (f, MCZ); Baja Mar, 9 Sep., 23 Oct. ( 8,8, alc, LSUMz); La Cétba, 11 April (ó, USNM); San Lorenzo, 30 Sep.-3 Oct. (2\%, MCZ). PUBLTSHEP RECORDS-- La Ceiba (Deignan, 1936: 189). Bay Islands (Delecour, 1938: 545). Swan Islands (Paynter, 1956: 105).

Though not frequently recorded in Honduras, this plover 18 probably a fairly common migrant and winter visitant along both coasts and in the Caribbean 1slands. It is most common on the outer beaches and on mud flats in the lowlands. Bxtreme dates of occurrence in Honduras are 9 September and 1 May.

Delacour (1938: 545) did not state the basis for his report of the species from the Bay Islands, where it 
almost certainly occurs regularly in migration. Neal Wilson (Paynter, 1956: 105) collected a specimen In the Swan Islands in 1926. The spectmen from La Ceiba was taken by Deignan (1936: 189) in 1933. C. F. Underwood collected the two San Lorenzo individuals in 1932. J. Alan Feduccla and I shot the Baja Mar birds on the outer beaches in 1962. I follow Vaurie (1964: 2-5) in retaining C. semipal-

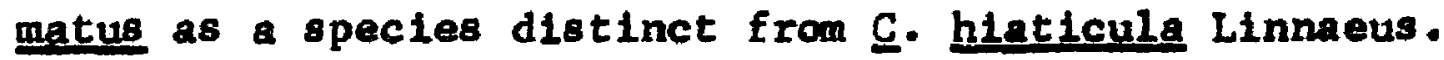

\section{Charadrius alexandrinus Linnaeus}

\section{Snowy Plover} LSUMz).

SPECIMEN.--C. a. ntyosus (1): Baja Mar, 9 sep. (7,

The Snowy Plover must be regarded as an accidental fall visitant in Honduras. The only record is the specimen Iisted above, collected by J. Alan Feduccia and me at Baja Mar in 1962. It was on the outer beach with Squatarola squatarola and Crocethla alba. The species has not been recorded previously from Honduras nor from Central America north of Panama.

The Honduran specimen matches representatives of the Texas population and will be considered as belonging to that population. I follow the American Ornithologists' Union (1957: 168) in placing the Texas birds in the western race, C. a. nivosus (Cassin). They are intermediate in coloration between the dark-backed c. ‥ tenulrostrls (Lawrence), of the southeastern United States and the West Indies, and 
the pale-backed nivosus, of the western United States. Admittedly the Texas birds could be placed with either race, depending upon one's viewpoint.

\section{Charadrius collaris Vieillot}

Collared Plover

SPECIMFNS---(12): Baja Mar, 9 Sep., 23 oct. (d, 29, a1c., LSLitz); $1 \mathrm{mt}$. W Tela, 18 Aus. (d, LSUMz); La Ceiba, 31 March ( 8 , USNM); Chamelecón, 3 Jan. ( 8 , USMM); Coyoles, 17 June-9 July $\left(2 \delta^{\circ}, \&, C M\right)$; San Lorenzo, 3-6 Oct. ( $\delta^{\circ}, q$, MCZ).

PUBLTSHEP RECORPS.--Chamelecón (Ridgway, 1919: 141). La Celba (DeIgnan, 1936: 189).

The Collared plover is a falrly common resident of both coasts of Honduras and occurs infrequently in the interior along watercourses and lakes up to an altitude of 2,500 feet. It is most common on the outer beaches and lowland mud flats, where it outnumbers all other plovers.

On 18 August 1962 I observed downy young, accompanied by a number of adults, on the beach at Tela. This observation is the first definite evidence of breeding of the 8 pectes in Honduras.

\section{Charadrtus yociferus Linnaeus}

\section{Killdeer}

SPFC MYENS.--C. y. yociferus (6): Ut11a Island, 25 Jan.

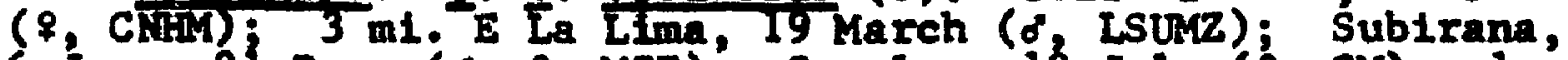
6 Jan., 21 Dec. (d, $q, M C Z$ ); Coyoles, 18 July (q, CM); 1 m1. W El Jaral, 24 Nov. ( $q$, LsLuz).

RUBLISHED RECORDS.--Omoa (Moore, 1859; 63). Tigre Island, Comayagua Plain (Taylor, 1860: 313). San Pedro reglon (Sclater and Salvin, 1870 b: 838). Tela, Lancetilla 
(Peters, 1929b: 408). Utila Island (Hellmayr and Conover, 1948b: 69). [Big] Swan Island (Bond, 1959: 9).

In Honduras the Killdeer is a fairly common to common species in winter, occurring to an elevation of at least 4,000 feet. It frequents open situations from mud flats and outer beaches to short grass savannas or 1 lanos of the arid steppe interior. Extreme dates of arrival and departure for Honduras are 8 September and 26 April; the specimen collected by Arthur $C$. Twomey and Roland $W$. Hawkins at Coyoles on $18 \mathrm{July} 1950$ was either an early southbound migrant or a sumering, nonbreeding individual.

The only record from the Swan Islands is based upon a sighting there by Charles H. Blake in November 1958 (Bond, 1959: 9).

Honduran specimens are referable to the North American race, $\mathcal{C}$. $Y$. vociferus Linnaeus. The specimen I collected near La Lima on 19 March 1963 was "partially albinistic"; 1t is pure white except for extensive black in the wings and tail and the color of the soft parts, which 18 normal.

\section{Charadrius wilsonia ord}

\section{Wilson's Plover} LSUMZ).

SPECIMEN--C. w. wilsonta (1): Baja Mar, 9 Sep. (\%,

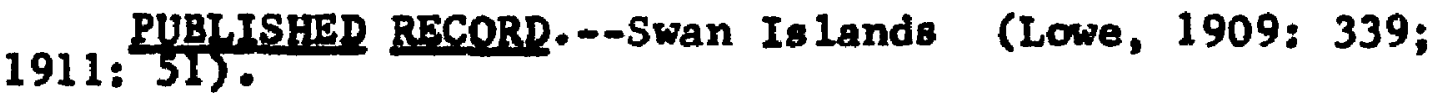

Along the north coast of Honduras and in the Caribbean islands, the Wilson's Plover is apparently rare but probably 
regular in migration and in winter. There are only two known records of the species for Honduras: Lowe (1911: 51) reported a flock in the Swan Islands present during his entire stay in January and February 1908, and J. Alan Fedducla and I collected one of two individusis seen on the beach at Baja Mar on 9 September 1962.

I refer the Honduran specimen to the North American race, C. ‥ wilsonia Ord. After examination of a series of specimens from Sonora and from Louisiana, I cannot see any differences at all between $\underline{G}$. w. wilsonis and $\mathcal{G}$. w. beldingi (Ridgway), and I therefore relegate the latter to synonymy.

Family SCOLOPACIDAE

\title{
Bartromter longtcauda (Bechstein)
}

Upland Sandpiper

\begin{abstract}
SPECTMENS $--(9)$ : Roatán Island (8?, BMNH); Yeguare River Valley, 7 sep. ( $0^{\circ}$, UF). Sharpe, 1896: 5 (13).

PUBLISHED RECORD---Roatán Island (Salvin, 1889: 379;
\end{abstract}

The Upland Sandplper, or Upland Plover, is an uncommon1y recorded migrant in Honduras. It appears to be rather irregular, occurring sometimes in large numbers, other times being unseen during the field work of an entire migrational period. It must have been very common in the fall of 1887 , when G. F. Gaumer secured the eight specimens on Roatán Island, in the Bay Is lands (Sharpe, 1896: 513). The only other record of its occurrence in Honduras is the specimen 
taken by Marjorle H. Carr at 2,600 feet in the Yeguare RIver Valley in 1946. I falled to find it in the spring and fall migrations of 1962-1963 or in the spring of 1964 .

\section{Numentus phgeopus (Linnaeus) \\ Wh1mbrel}

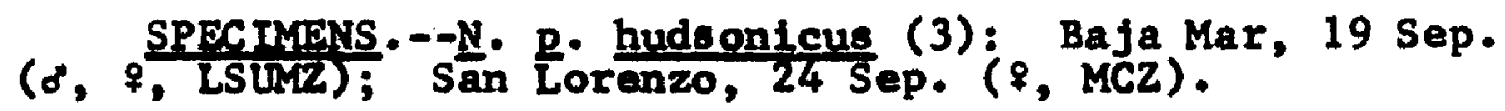
PUBLISHED RECORD.--Fonseca Bay (Taylor, 1860: 313). The Whimbrel, or Hudsonian Curlew, as the American race is often called, is a migrant and winter visitant along the coasts of Honduras, uncommon on the Caribbean cosst and common along the Bay of Fonseca on the Pacific side. Individuals of this species occur in Honduras from early September to May and have never been recorded away from the coastal reglons.

Taylor (1860: 313) stated that he "found them abundant on the shores of Fonseca Bay, where they used to sit on the branches of the mangrove trees overhanging the water." In the fall and winter of 1962 I observed numbers of this species on the Bay of Fonseca, many of them perched as described by Taylor. Willets (Cacoptrophorus semipalmatus) also occur with the Whimbrels and frequently perch on mangroves in this manner.

Honduran specimens are referable to the American race, N. R. hudsontcus Latham. 


\section{[Numentus americanus Bechstein]}

$$
\text { Long-billed Curlew }
$$

PUBLISHED RRCORD.--San Lorenzo (Stone, 1932; 304).

A flock of 15 Long-billed Curlews was noted by John $T$. Emlen, Jr., and C. Brooke Worth at San Lorenzo on 5 July 1930 (Stone, 1932: 304). The species is known to winter regularly south to Guatemala and its occurrence in Honduras is not unexpected, although the date in July is rather surprising .

This observation is the only record for Honduras and is the southermost for the species.

\section{Limosa fedoa (Linnaeus)}

Marbled Godwit

SPECTMEN.--(1): La Ceiba, 30 March (d, USNM).

PUBLTSHED RECORD.--La Ceiba (Deignan, 1936: 189).

Though known from Honduras by the single record listed above, the Marbled Godwit is probably a rare but regular migrant and winter visitant. Deignan (1936: 189) collected a male at La Ceiba in 1933. The species winters regularly as far south as Guatenala and British Honduras, and occasionally to South America and Panama.

The published record from the "cosst of Honduras" (Sclater and Salvin, 1873b: 456) is based on a report of Joseph Leyland (Moore, 1859: 64) from Belize, Brit1sh Honduras. 
Totanus melanoleucus (Gmelin)

Greater Yellowlegs (9, LSULC ).

Surprisingly, this species has not been previously recorded from Honduras. It is an uncoumon, though regular, migrant and winter visitant in the lowlands of both coasts of Honduras and in the Bay Islands.

During the years from 1951 through 1954, Mark Trafton, Jr., recorded the species regularly from October through January on the flood-fallow lakes in the San Pedro Sula region. He observed occasional flocks of 15 to 20 ind1viduals.

On the mud flats at Cedeño, near the Bay of Fonseca, I saw a single Individual on 4, 9, and 12 October 1962, probably the same bird in each case. On 6 March, 4 Aprtl, and 16 Aprt1 1963, I noted a single bird on the mud flats of the Río Ulía at Progreso, again probably the same individual in each observation. On Utila Is land I saw a group of three Greater Yellowlegs and one Lesser Yellowlegs (Totanus Elayipeg) at the village of Ut1la on 3 May 1963; on 10 May a group of two Greater and one Lesser Yellowlegs was noted at the same spot. In 1964 I collected a female at Lake Yojoa near El Jaral.

The genus Totanue should perhaps be merged with Iringa, but for the present I follow the American Ornithologists ' Union (1957: 190-191) in maintaining Totamus as distinct. 
Totanus Elavipes (Gmelin)

Lesser Yellowlegs

SPECIMFNS.--(6): Swan Islands, 19 Feb., 13-27 March (29, MCZ; of USNM); Utila Island "Spring" ( 8, CNHM); 4 mi. N RIo Lindo, 29 Nov. (8, LSUMZ); 1 m1. W El Jaral, 21 Aug. (c, Lsurz).

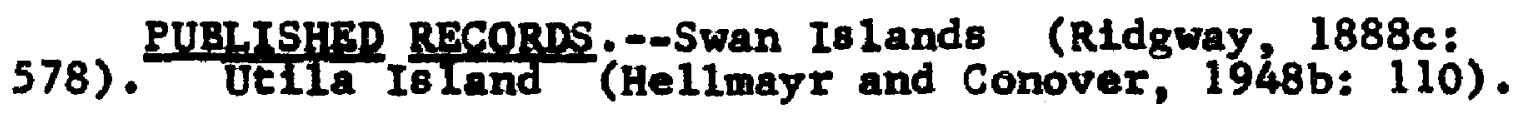

The Lesser Yellowlegs is a fairly common migrant and

winter visitant in Honduras, occurring on both coasts and on ponds and lakes in the interior to an levation of at least 3,000 feet. It is considerably more common than the Greater Yellowlegs (I. melanoleucus). Extreme dates of arrival and departure for Honduras are 11 August and 10 May.

\section{Intnge solitaria wilson}

\section{Solitary Sandpiper}

SPFCTMENS.--T. R. Solltaria (9): Roatán Island (?,

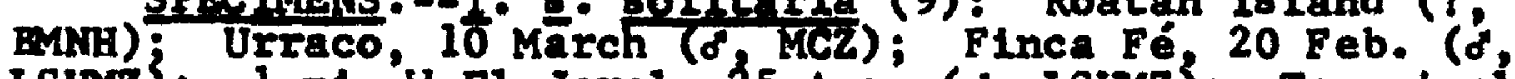
LSURZ; $1 \mathrm{ml}$. W E1 Jaral, 25 Aug: ( ${ }^{\prime}$, LSUMZ); Tegucigalpa, 4 Feb.; 30 March ( $\%, ?$, AMNH); Ei Boquerón, 2 oct. ( $\delta$, AMNH); San Lorenzo, 26 Sep. ( $9, \mathrm{MCZ}$ ); $6 \mathrm{mi}$. NE Choluteca, 12 Oct. (?, LSUMZ).

PUBL,TSHED RECORDS.--San Pedro region (Sclater and SAlvin, 1870b: 838) . Roatán Is land (Salvin, 1889: 379; Sharpe, 1896: 448). Toloa Canal (Peters, 1929b: 408).

In Honduras Iringa solitaria is a falrly coumon to common migrant and an uncommon winter visitant, occurring on both coasts and in the interior to an elevation of 4,000 feet. It prefers fresh water and comonily frequents sma11, temporary, roadside ponds as well as marshy flelds and muddy margins of larger lakes and rivers. Extreme dates of 
arrival and departure in Honduras are 11 August and 29 Apri1.

All Honduran specimens examined are referable to the eastern race, I. 8. golitarta Wilson; in the characteristics of darker upper parts, lack of mottling on the outer primaries, and smaller size, they are typical of this race. The wings of male specimens $(<129.5)$ fall well within the range of 123-132.5 given by Hellmayr and Conover (1948b: 120) for this race. The western subspecies, I. R. cinnamonea (Brewster), is also a comnon migrant in Central America but has not yet been taken in Honduras.

\section{Actitis maculariag (Linnaeus)}

Spotted Sandpiper

SPEC MYNS.--(21): Roatán Ioland (2?, BMNH); Guanaja Island, 26 March ( 9, CM); Puerto Cortes, 30 Sep. (? skel., LSLMZ); 1 mi. W Tela, 18 Aug. ( $\sigma$, LSUMZ); La Ceiba, 12 Jan., 26 July (f, CM; f, MCZ); Truj111o, 21 Sep. (?, USNM); Cofradla, 2-9 March (29, MLZ); Chamelecón, 3 Jan. ( $q$, USNM); Choluteca River, Cantarranas, 5 Aug. ( $\delta$, $\&$, ANSP); Tegucigalpa, 5-15 Feb. ( $\left.\alpha^{\circ}, 2, A M N H\right)$; vicinity of Tegucigalpa, 30 March ( 9 skel., ML); Comayagüela, 20 Oct.3 Nov. ( $\delta$, \&, MCZ); Yeguare River Valley, 19 March, 28 Aug ., 1 Dec. $\left(2 \sigma^{\circ}, \stackrel{9}{9}\right.$ UF).

PUBLTSHED RECORPS.--Truj1110 (Ridgway, 1888c: 594). Roatán Island (Salvin, 1889: 379; Sharpe, 1896: 468). La Ceiba (Bangs, 1903: 142). Swan Is lands (Lowe, 1911: 51; Delacour, 1938: 544-545). Tela, Palomas-Toloa Cana1 (Peters, 1929b: 408). Choluteca River near Cantarranas (stone, 1932: 304). Chamelecón (Burleigh, 1960: 212).

This species is one of the most common and widespread of the migrant and wintering sandpipers in Honduras. It is fairly common to common in the lowlands of both coasts and in the Caribbean islands, and is uncommon in the interior, 
rnaging up to at least 4,000 feet. It is found in a wide variety of wet situations from open beach and lake shores to temporary, muddy ponds and banks of wooded streams. A few nonbreeding individuals remain in Honduras throughout the 8 umer, but the bulk of the birds is present only from August to May.

The western North American breeding populations have been described as A. m. Iava Burleigh [1960a: 210; Lewis ton, Nez Perce County, Idaho] on the basis of grayer upper parts and $198 s$ heavily spotted under parts. I cannot see any differences in a long serles of breeding North American birds, except possibly a very slight grayer trend to the westward, and cannot see how winter birds could possibly be identified on any basis. In all, I think it is best to maintain the species as monotypic. Burleigh (1960: 212) examined the specimen from Chamelecón, taken by Erich Wittkügel in 1891, and allocated it to the race rava.

\section{Catoptrophorus semipalmatus (Gmelin)}

$$
\text { willet }
$$

SPECTMFNS.-C. B. semtpalmatus (1): Baja Mar, 9 Sep. (o, LSULY). C. B. InomatuB (4): La Ceiba, 16 April (o", $\%$ USNM); San Lorenzo, 26 Sep, -3 oct. (2\%, MCZ). undetermined (1): San Pedro (d, BMNA).

\section{La Celba (DaIgnan, 1936: 189). \\ (Sharpe, 1896: 407). \\ The willet is a falrly comon to comon migrant and} winter visitant along both coasts of Honduras. It general1y occurs on the outer beaches or along mud flats not far 
from the beach. It is not known from the interior of Honduras. Along the Bay of Fonseca it frequently perches Just above the water in low-hanging mangroves. Extreme dates of arrival and departure for Honduras are 17 August and 16 Apri1.

Only a single specimen, which I obtained in 1962 at Baja Mar on the Caribbean coast, is representative of the smaller, eastern race; . s. semipalmatus (Gmelin) [wing measurement <195.5, exposed cuimen <59.0]; the Honduran specimen is typical of this race (wing, 186.0; culmen, 55.5). I have ass Igned all other Honduran specimens examined to the larger, western race, C. S. inornatus (Brewster) [wing measurement $>193.0$, exposed culmen $>56.0$ ]; Honduran individuals fall well within this range of variation (wing, 194.0-208.0; culmen, 57.0-58.5). I have not examined the San Pedro specimen in the British Museun, which was 11sted by RIdgway (1919: 319 ) under the race semipalmatus and by Stone (1932: 304) under the race inormatus. Both races occur on both coasts of Central America in winter. The use of the name $\mathcal{C}$. s. speculiferus (Cuvier) in lieu of Inornatus, as recomended by PhIll1ps (1962b: 334335), is not permissible, since the former is a nomen eblitum and therefore not avatlable.

Heterogcelus Incanus (Gmelin)

Wandering Tattler SPECIMEN.--(1): LO8 Farallones, 10 Oct. (q, LSUMZ). 
On 10 October 1962 I collected a male Wandering Tattler from four individuala seen in the Los Farallones, a group of rocky 18lets situated in the mouth of the Bay of Fonseca. It is likely that this tattler is regular in migration and in winter on these islands.

This record is the first report of the species between Mexico and Costa Rica.

\section{Arenaria interpres (Linnaeus) \\ Ruddy Turnstone}

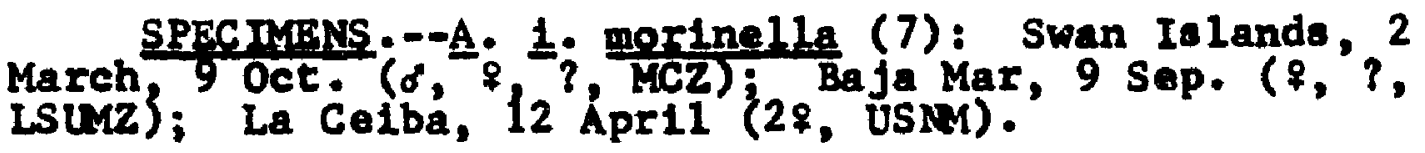

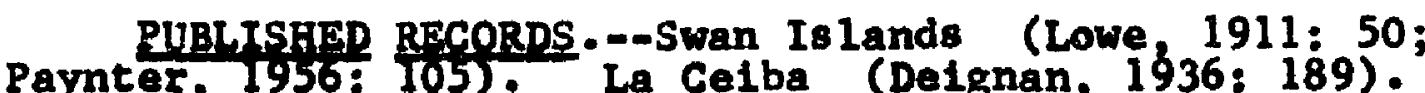

The Ruddy Turnstone is a fairly common migrant and winter visitant in Honduras, occurring along both cossts and In the 18 lands in the Caribbean Sea. It 18 seldom found away from the outer beach, where it forages commonly with the Sanderling (Crocethia alba). Extreme dates of arrival and departure in Honduras are 8 August and 12 April.

The distribution of the races of this species is poorly understood. The nominate race, A. 1. Interpres (Linnaeus), 1s currently recognized as breeding in the old World and in Alaska and may occur in winter on the Pacific coast of Honduras. In winter plumage the North American race, $A .1$. morinel1a (Linnaeus), is very difficult to distinguish, 
differing primarily in average smaller size (wing averaging $<150$ as opposed to $>150$ for interpres). Since all known Honduran specimens are from the Caribbean coast, and the range of variation in the wings is 141.5-152.5, I have allocated these specimens to morinella. The breeding plumages are distinct, with interpres being much blacker, 1 ess rufous, above.

\section{Limnodromus griseus (Gmelin)}

Short-billed Dowitcher

SPECTMENS.--L. g. caurinus/hendersoni (6): $2.5 \mathrm{mi}$. NE Cedeño, 27 Sep., I2 Oet. (2\%, $4 \%$, LSUKL).

This species is an uncommon migrant and winter visitant in Honduras, becoming fairly conmon in certain years. It occurs both in fresh and salt water marshes and on mud flats in the lowlands of both coasts.

During the winters of 1952-1954, from September through January, large flocks of dowitchers appeared on the floodfallow lakes at Copén, in company with thousands of other assorted shore birds. On 18 October 1953, Mark Trafton, Jr., collected a female that was not preserved; he did, however, photograph this Individual and take measurements (wing, 142; tail, 56; tarsus, 35; exposed culmen, 63). From 27 September through 12 October 1962, a flock of about 25 individuals of this species was present on the mud flats near Cedefio, on the Pacific coast. J. Alan Feduccia and I secured specimens from this flock, three each on 27 
September and 12 october. I did not encounter the species elsewhere in Honduras.

The specific status of L. Bcolopaceus (Say), the Longbilled Dowitcher, has been established by Rowan (1932: 2122) and by Pitelka (1950: 1-108). The Short-billed Dowitcher has recently been divided into three races on the bas is of color differences in the breeding plumage and an east-west clinal variation in size. The largest race, L. g. caurimus Pitelka [1950: 34, 43; Yakutat, southeastem Alaska] is the northwestern subspecies that winters in South America and migrates through Central America; it is to be expected on the Pacific coast of Honduras in migration. The central North American race, L. g. hendersont Rowan [1932: 22; Dev11's Lake, Alberta] also migrates through Central Amertca and is to be expected in Honduras on either coast. The eastern race, L. g. griequs (Gmelin) migrates chiefly through the West Indies and is probably rare or absent in Central America.

Two of the Honduran specimens, a pair takon on 12 october, seem to be typical (In measurements) of hendersont. These two individuals measure ( $\delta$ given first): wing, 141.0, 142.0; tarsus, 36.2, 36.8; exposed culmen, 55.5, 55.9. Another Honduran specimen ( $q, 27$ September) measures as followe: wing, 143.0; tarsus, 38.8; exposed culmen, 64.8. It is either hendersont or caurfinue. The other three individuals (d, 12 October; 28, 27 September) measure, 
respectively: wing, $145.0,141.0,147.5$; tarsus, 38.0 , 38.1, 38.9; exposed culmen, 62.9, 63.8, 62.5. These three birds are probably capurinus. None of the opecimens is as small as nominate griseus but, on the other hand, the range of variation in the other two races precludes definite allocation of any of the winter plumage specimens.

\section{Capella gallinago (Linnaeus)}

Common Snipe

SPECIMENS.--C. g. delicata (4): Río Permejo $\left[=R I_{0}\right.$ Berme Jo, 5 Nov. $\left(\sigma^{\circ}, q\right.$, USNM); $4 \mathrm{mi}$. N Río Lindo, 29 Nov. (\%, LSUMZ); La Flor Archaga, 16 Jan. ( 9, AMNH).

PUBLISHED RECORDS.--Omoa (Moore, 1859: 64). Near Comayagua (Taylor, 1860: 314). [Big] Swan Island (Bond, 1959: 9).

In Honduras the Common Snipe is an uncommon winter visitant, found in open, marshy situations from sea level to at least 5,000 feet; it also occurs in the Swan Islands, as Charles H. Blake (Bond, 1959: 9) observed the specles on Big Swan Island in November 1958. The specles prefers fresh water and is most common in wet flelds of long grass. Extreme dates of arrival and departure for Honduras are 9 November and 11 April.

Honduran specimens are referable to the American race, C. g. dellcata (Ord).

\section{Calidris canutue (Linnaeus)}

Red Knot

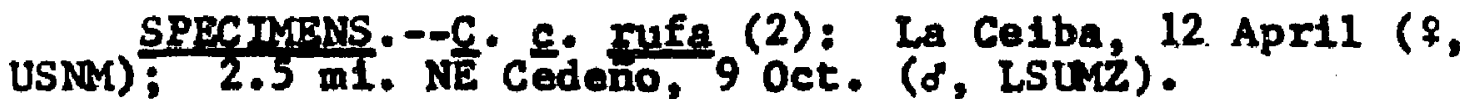




\section{BUBLISHED RECORD,--La Cetba (Deignan, 1936: 189).}

The Red Knot is a rare migrant in Central America, occurring on both coasts. It is known from Honduras by two records. Delgnan (1936: 189) collected a female at La Ceiba in 1933. In $1962 \mathrm{~J}$. Alan Feduccia and I secured one of two birds in a mixed flock of small sandpipers on the mud flats near Cedeño, on the Pactfic coast.

Honduran specimens of the Red Knot are referable to the North American race, $\underline{C}$. c. rufa (W118on).

Crocethla alba (Pallas)

Sanderling

SPECTMENS.--(3): Ba ja Mar, 9-19 Sep. ( ${ }^{*}, 8$, LSLMZ); La Celba, 1 April ( 9 , USNM).

PUBLISHED RECORD.--La Ceiba (Deignan, 1936: 189).

In Honduras the Sanderling is a fairly common to common migrant and winter visitant, found on the outer beaches of both coasts and in the Cartbbean is lands. It rarely strays away from the sandy beaches. Extreme dates of occurrence In Honduras are 17 August and 1 May.

Deignan (1936: 189) secured the first specimen for Honduras at La Ceiba in 1933. In $1962 \mathrm{~J}$. Alan Feduccia and I collected a male on 9 September and a female on 19 September at Baja Mar, just east of Puerto Cortés. These three speclmens are the only ones from Honduras.

I follow the American Ornithologists I Union (1957: 
192-208) in maintaining Crocethia, Ereunetes, and Erolia as genera distinct from Calldris.

\section{Erainetes pusillus (Linnaeus)}

Semipalmated Sandpiper

SPECIMENS.-- (7): Swan Is lands, 16 April ( 9 , USNM); Baja Mar, 9 Sep., 23 Oct. ( ${ }^{*}, 2 \%$, LSUMZ); Puerto Lempira, 8 Apri1 (28, LSUMZ); $2.5 \mathrm{ml}$. NE Cedeño, 9 Oct. (d, LSUMZ). PUBLISHED RECORDS.--Swan Islands (RIdgway, 1888c: 578; Lowe, 1911: 51 ).

This sandpiper is an uncomnon to fairly common migrant and winter visitant in Honduras, frequenting the outer beaches and mud flats of the Caribbean slope and the islands off the north coast. It occurs, at least casually, on the Pacific coast, where it is greatly outnumbered by the Western Sandpiper (E. mauri) around the Bay of Fonseca. Extreme dates of arrival and departure in Honduras are 9 September and 16 April.

C. H. Townsend (Ridgway, 1888c: 578) collected a single individual in the Swan Islands in 1887. The specles was observed there also by Lowe $(1911: 51)$. I noted Semipalmated Sandpipers several times in September and October 1962 on the Caribbean coast at Baja Mar and In April 1964 on the Laguna Caratasca. In every case they were feeding with E. mauri, which usually outnumbered them about two to one. On the Pacific coast I observed two individuals on 9 October 1962 and two more on 11 February 1963; in each case these 
birds were in large flocks of Western Sandpipers, the latter being present in the hundreds.

The species has not been reported previously from the mainland of Honduras.

\section{Ereunetes mauri Cabanis}

\section{Western Sandpiper}

SPECTMENS. - (10): Utila Island, 18 Aprt1 ( $9, \mathrm{CM}$ ); Baja Mar, 9-19 Sep. (20, o skel., alc., LSUMZ); Puerto Lempira, 8 April ( $q$, LSUMZ); San Lorenzo, 30 Sep. ( $q$, MCZ); 2.5 m1. NE Cedeño, 9 Oct. (2\%, skel., isUMZ).

Despite the absence of previous Honduran records, the Western Sandpiper is a common migrant and winter visitant along the Pacific cosst and an uncommon migrant and winter visitant along the Caribbean coast and in the 18 lands in the Caribbean Sea. It occurs on mud flats as well as open beach, often in great numbers, exceeding all other spectes of shorebirds in abundance on these occasions. Extrene dates of arrival and departure for Honduras are 9 September and 18 April.

C. F. Underwood collected the first specimen for Honduras at San Lorenzo in 1932. Arthur C. Twoney and Roland W. HawkIns obtained one on Utila Island in 1948. The remainder of the Honduran material was taken by J. Alan Feduccia and me in the fall of 1962 and the spring of 1964 . 
Erolia minut111a (Vieillot)

Least Sandpiper

SPECIMFAS.--(12): Utila Is land, "Spring" ( 9, CNHM); Baja Mar, $9-19$ Sep. (o", imm. of, o skel., 4 alc., LSUMz); La Ceiba, 21 Jan. (ơ MCZ); Chamelecón, 3 Jan. ( 8 , USMM); 4 mi. N Río Lindo, 29 Nov. (f skel., LSUMz); Puerto Lempira, 8 April ( $\%$, LSURZ).

PUBLISHED RECORDS.-La Ceiba (Bangs, 1903: 142). Bonacca [= Guanaja] Isiand (Bond, 1936: 354).

The Least Sandpiper is a fair̨ly comon migrant and winter visitant in Honduras, occurring in the lowlands of both coasts below 2,500 feet. It 18 most common on fresh water mud flats, ponds, or wet grassy fields, being only rarely found on the outer beaches. On mud flats or ponds in the interior, it generally outnumbers all other small sandpipers. Extreme dates of arrival and departure in Honduras are 16 August and 27 April.

Bond's (1936: 354) report from Guanaja Is land in the Bay Islands is based on his sight record.

\section{Erolla fuscicollis (Vielliot)}

White-rumped Sandpiper

SPECTMEN.--(1): La Ceiba, 18 Apri1 (o', USNM). PUBLISHED RFCORD.--La Celba (Deignan, 1936: 189).

The White-rumped Sandpiper is a rare migrant in Central America. It is known from Honduras by the single record listed above, a specimen taken by Deignan (1936: 189) at La Ceibe on 18 April 1933 and another seen at the same place on 24 April. It 1s probably a regular spring and fall migrant 
on the Caribbean slope of Honduras.

\section{Erolis melanotos (Vieillot)}

Pectoral Sandpiper

SPECTMENS - - (12): Swan Is lands, 24 March ( ${ }^{\circ}$, USNM); Roatán IBland (2?, BMNH); La Celba, 11 Apri1 (o, $f$, USNM); Lake Yojos, at E1 Jara1, 20-27 April (2\%, LSUMZ); Yeguare River Valley, 5 May (?, UF); San Lorenzo, 11 Sep.-6 Oct. (20, 29, MCZ).

\section{PUBLTSHED RECORDS.--Swan Is lands (Ridgway, 1888c:} 578). Roatán Island (Salvin, 1889: 379; Sharpe, 1896: 473). La Celba (Deignan, 1936: 189).

Occurring primarily on fresh-water ponds and in marshy fields below 3,500 feet, the Pectoral Sandpiper is an uncommon to fairly common migrant in Honduras; it also migrates through the Caribbean islands. It has never been recorded from the open beach and is most common in wet pastures or on muddy-temporary ponds. Extreme dates of arrival and departure for Honduras are 11 September and 9 October for fall and 24 March and 5 May for spring.

\section{Micropalama himantopus (Bonaparte)}

Stilt Sandpiper

SPECIMENS.-(4): Baja Mar, 23 Oct. (9, LSUMZ); Lake Yojoa, at EI Jaral, 27 Apri1 (o", LSUMZ); $2: 5 \mathrm{ml}$. NB Cedefio, 9 oct: (d, \&, LSUMZ).

Although previously unrecorded from Honduras, the Stilt Sandpiper is an uncommon migrant, occurring primarily on mud flats, at roadside ponds, or in marshy fields. Occasional1y it may be found on the outer beaches. 
During the winters of 1951-1953, the species was observed by Mark Trafton, Jr., on the Copén flood-fallow lakes from October through January. He remarked that stilt Sandpipers were relatively numerous in association with many other species of shorebirds. His earliest arrival date was 4 october.

On 9 October $1962 \mathrm{~J}$. Alan Feduccia and I took the first specimens for Honduras from eight individuals seen on the mud flats near Cedeffo. Two weeks later I collected a single female at Baja Mar; it was associated with Ereunetes pusillus and E. mauri that were feeding on the open beach, at a temporary puddle of water. I also obtained a lone male in breeding plumage at Lake Yojoa in 1963; this ind1vidual was feeding along the edge of a muddy drainage ditch.

\section{Tryngites subruficollis (Vieillot)}

Buff-breasted Sandpiper

SPECIMFNS.--(2): Roatán Island (2?, RMH).

PUBLTSHED RECORD.--Roatán Island (Salvin, 1889: 379; Sharpe, 1896: 524 ).

The Buff-breasted Sandpiper is a rare migrant in Central America. It 18 known from Honduras only from Roatán Island and from the Cartbbean lowlands. It commonly frequents dry, open pastures during migration but also may be encountered feeding with other shorebirds on mud flats or in wet fields. 
G. F. Gaumer (Salvin, 1889; 379) collected two individuals on Roatán Island in 1887. In September 1953 Mark Trafton, Jr., observed a few individuals at the flood-fallow lakes at Copén and obtained a specimen (not preserved) for identification. Kenneth S. Hamilton and Richard L. Zusi saw one at Tela on 22 October 1964.

Nothing further 18 known concerning this species in Honduras. It is probably a regular migrant, especially in the fall.

\section{Family RECURVIROSTRIDAE}

\section{Himantopus mexicanus (Müller)}

Black-necked stilt

SPEC MMENS.--(3): Roatán Island (?, BMNH); $2.5 \mathrm{mi}$. NE Cedeño, 27 Sep. -4 Oct. ( $8, \&$, Lsum).

PUBLISHED RECORD,--Roatán Island (Salvin, 1889: 379; Sharpe, 1896: 322).

In Honduras the Black-necked Stilt is an uncommon to fairly common migrant and winter visitant in the lowlands of both coasts and in the Bay Islands. It occurs primarily on fresh water mud flats, ponds, and marshy fields. Extrene dates of arrival and departure for Honduras are 29 August and 6 March.

During the years 1952-1954 from August through December, Mark Trafton, Jr., observed this species on the floodfallow lakes at Copén singly and in small groups of up to 10 individuals each. He considered it relatively rare in view 
of the thousands of other shorebirds present.

Between 27 September and 12 October 1962, there were more than 100 Individuals present on the mud flats near Cedeño, on the Pacific coast. On the Caribbean slope I noted two individuals on a sand bar in the Rio Ulua at Progreso on 6 March 1963.

Recurvirostra americana Gmelin

American Avocet

This species is a rare winter visitant to Honduras. From 14 November 1953 through January 1954, Mark Trafton, Jr., observed the species on the flood-fallow lakes at Copén. As many as eight individuals were noted at a single observation. He secured a photograph of one on 2 January 1954 and was also able to collect a nonbreeding female (not preserved) for positive identification. The measurements of this specimen were: wing, 227; tall, 77; tarsus, 79; exposed culmen, 80.5 .

This report is the first from Honduras and the southernmost for the species.

Family PHALAROPODIDAE

Steganopus tricolor vieillot

Wilson's Phalarope

SPECIYFN.--(1): $2.5 \mathrm{ml}$. NE Cedeño, 4 Oct. ( 8 , LSUMZ). 
This phalarope is a rare, though probably regular, migrant through the lowlands of Honduras. On 9 May 1951 v. C. Dunlap observed four individuals on the flood-fallow lakes at Guaruma, near La Lima. Mark Trafton, Jr., noted the species on the Copén flood-fallow lakes from 4 October 1953 into November of that year.

J. Alan Feduccia and I observed it on several occasions on the mud flats near Cedeño in the fall of 1962. On 4 October a total of 16 individuals was recorded, including the single specimen collected. On 9 October more than 25 birds were present and at least 15 were still there on 12 October.

The species has not been previously recorded in Honduras.

\section{Lobipes lobatus (Linnaeus)}

Northern Phalarope Is land, 10 Oct. ( $0^{\circ}, q$, LSUMZ).

Mark Trafton, Jr., observed and collected alive an individual of this species on the golf course at La Lima on 28 October 1956, following two days of heavy wind and rain. A color photograph of the specimen was taken to substantiate the record.

J. Alan Feduccia and I collected a pair that had alighted on the surface of the water well out in the Bay of Fonseca; these birds were taken on 10 October 1962 and were 
the only ones seen.

The species has not been recorded previously from Honduras. It very likely occurs occasionally along the coasts of Honduras not only during migration but also in winter.

\section{Family BURHINIDAE}

Burhinus bistriatus (Wagler)

Double-striped Thickknee

SPECTMENS.--B. b. vigilans (8): $3 \mathrm{ml}$. E Manacal, 14 Aug. (skel, IsUMZ); Coyoles, 18 July ( $\left.{ }^{\prime}, C M\right)$; Tallenga [= Talanga]; 8 Nov. ( $\$$, ANSP); Monte Redondo, 1 Apr11, 15 Dec; ( $\delta$ skel., MLZ; o, 29, MCZ); Tegucigalpa, 19 June (o', MCZ).

PUBLISHED RECORDS.--Between La Brea and Nacaome, Comayagua Plain (Taylor, 1860: 314).

Burhlnug bistriatus, known locally as "alcaraván," is uncomon to fairly comon in Honduras, occurring throughout the arid regions below an elevation of 5,000 feet. It is most common on the short-grass savannas or steppes of the arid interior valleys and the arid Pacific lowlands. In addition to being good eating, the species is also widely employed as a pet or watchdog by the local residents. It is primarily nocturnal but may also be noted occastonally during the day. It is less common now than it was at the time of Taylor (1860: 314), who described shooting six while he was riding his mule through the Comayagua Valley.

The secies has been recorded from the Aguain, Sula, Quimistán, Otoro, and Comayagua valleys and undoubtedly occurs also in the Olancho Valley. On the Pacific coast I 
noted several that were being kept as pets and, according to information obtained from the residents, the species is fairly common in the regton of Choluteca and San Lorenzo. Honduran specimens are typlcal of the Central American race, B. b. yigilans van Rossem.

\section{Family LARIDAE}

\section{Larus argentatus Pontoppidan}

Herring Gull March $(\$$, LSUMAZ)

a. smithsontanus (1): Puerto Cortés, 10 PUBLISHED RECORDS:--Tela (Gross, 1940: 140). "Honduras "Smith, 1959: 100).

The Herring Gull is an unconmon, but regular, winter visitant to the north coast of Honduras and to the offshore 18lands. Local residents on Utila Island, at Puerto Cortés, and at Tela were familiar with this larger species, of which a few appear every winter.

Gross (1940: 140) reported that an individual banded at Kent Island, New Brunswick, on 10 July 1937 was subsequently recovered at Tela on 24 December 1937. Smith (1959: 100) mentioned that an individual banded in Michigan was recovered in Honduras on 2 February 1935, but he failed to give the specific Honduran localtty.

I saw only one Herring Gull in Honduras. At Puerto Cortés on 10 March 1963, I collected a first-year bird that was associated with the many Laughing Gulls (L. atricilla) 
that were present.

The Honduran spectmen is representative of the eastern North American race, $I$. a. Smithsonianus Coues.

Larus atricilla Linnaeus

Laughing Gull

PUBLISHED RECORD.--Puerto Castilla (Stone, 1932: 304). This gull is a common species along the north coast of Honduras and in the Caribbean islands throughout the year. There 18, however, no known breeding colony within Honduran territory. It is by far the commonest gull along the north coast at any season.

At the present time there is no specimen for Honduras. The record of Stone (1932: 304$)$ is based on a few birds observed at Puerto Castilla on 29 June 1930 by John T. Emlen, Jr., and C. Brooke Worth. On 5 November 1963 Mr. and Mrs. E. S. Rose, of Ut1la Island, recovered a banded Laughing Gul1 there; It had been banded on 30 June 1963 at Robins Marsh in Chincoteague Bay, south of Ocean City, Maryland.

I observed a flock of 13 individuals at Lake Yojoa, 100 m1les Inland, on 16 March 1963. The occurrence of the spectes away from the seacoast is surprising.

\section{Larus plplxcan Wagler}

\section{Franklin's Gull} 10 oct. (F, LSUM Bay of Fonseca, $5 \mathrm{mi}$. SE Tigre Island, 
The Franklin's Gull is an uncommon migrant and winter visitant along the Pacific coast of Honduras. On 9 October $1962 \mathrm{~J}$. Alan Feduccia and I observed 21 individuals of this species migrating southeastward in small groups along the beach at Cedeño, on the Bay of Fonseca. Single birds were also seen on 10 and 12 october, the specimen being taken on the former date.

The species was still present on the Bay of Fonseca on 11 February 1963. On that date elght birds were noted. These records are the first reports of the species from Honduras.

\section{Chlidonias niger (Linnaeus)}

Black Tern

(o, ., UF); Is la Zacate Grande, 5 oct. (imm., LSUMZ). $1896: \frac{\text { PUBLTSH. }}{201}$

PUBLTSHED RECORD.--"Honduras" (Saunders and Salvin,

Though sometimes encountered in large numbers, the Black Tern is an uncommonly recorded migrant in Honduras, occurring along both coasts and in the interior at Lake Yojoa. The species was 118 ted from "Honduras" in the range given by Saunders and Salvin (1896: 20), but I do not know on what basis. Two specimens taken by Marjorie H. Carr at Lake Yojoa in 1949 are the first definite record of which I am aware.

On 9 September 1962 I observed a large flock of more than 200 Individuals on the bay at Puerto Cortés. On 19 
The Frankiln's Gull is an uncommon migrant and winter visitant along the Pacific coast of Honduras. On 9 October $1962 \mathrm{~J}$. Alan Feduccta and I observed 21 individuals of this species migrating southeastward in small groups along the beach at Cedeño, on the Bay of Fonseca. Single birds were also seen on 10 and 12 October, the specimen being taken on the former date.

The species was still present on the Bay of Fonseca on 11 February 1963. On that date elght birds were noted. These records are the first reports of the species from Honduras.

\section{Chlidonias niger (Linnaeus)}

\section{Black Tern}

SPECIMENS.--C. n. Surinamens is (3): Lake Yojoa, 2 Aug. ( $\sigma, 8$, UF); Is la Zacate Grande, 5 oct. (imm., LSUMZ). $1896: \frac{\text { PUBLI }}{20)}$.

$$
\text { PUBLISHED RECORD.--"Honduras" (Saunders and Salvin, }
$$

Though sometimes encountered in large numbers, the Black Tern is an uncommonly recorded migrant in Honduras, occurring along both coasts and in the interior at Lake Yojoa. The species was 11 sted from "Honduras" in the range given by Saunders and Salvin (1896: 20), but I do not know on what basis. Two specimens taken by Marjorie H. Carr at Lake Yojoa in 1949 are the first definite record of which I am aware.

On 9 September 1962 I observed a large flock of more than 200 individuals on the bay at Puerto Cortés. On 19 
September about 40 birds appeared on Lake Yojoa. Between 27 September and 12 October, the species was common on the Bay of Fonseca, with more than 100 individuals being recorded in a single flock near Zacate Grande Island on 5 October. On 13 Apr1l 1964 I saw one on the Laguna Caratasca at Puerto Lempira. On 22 october 1964 Kenneth S. Hamilton and Richard L. Zus1 noted one at Tela. Honduran specimens are referable to the American race, C. ‥ Gurinamensis (Gmelin).

\section{Gelochelidon ntlotice (Gmelin)}

Gull-billed Tern (6) LSULE).

Previously unrecorded from Honduras, the Gull-billed Tern is an uncommon migrant (and probably also winter visitant) along both coasts. It is undoubtedly more common than records indicate.

On 9 and 19 September $1962 \mathrm{~J}$. Alan Feduccia and I observed single birds flying westward along the outer beach at Baja Mar, on the Caribbean coast just east of Puerto Cortés, possibly the same individual in both cases. From $27 \mathrm{sep}-$ tember through 9 October 1962, we noted another single bird on a mud flat near Cedeño, on the Paclfic coast; attempts to collect this bird were finally successful on 9 October. In addition to the above, we saw a group of $81 x$ individuals moving southeastward over the Bay of Fonseca at Cedeño on 4 
October. On 11 April 1964 I noted one flying over the savanna near Puerto Lempira, less than one mile from the Laguna Caratasca. On 22 October 1964 Kenneth S. Hamilton and Richard L. Zusi saw one at Tela.

The single male spectmen 18 representative of the smaller, eastern race, G. ‥ aranea (Wilson), being conBiderably smaller than measurements for males of the Salton Sea race, G. $n$. yanrossemi Bancroft, given by Hellmayr and Conover (1948: 297) [wing, >303; tail, >107; exposed culmen, $>40$; depth of bill at the angle of gonys, >10.5]. The Honduran specimen measures as follows: wing, 184.5; tail, 93.3; exposed culmen, 33.7; bill depth at the angle of gonys, 9.9. Both races migrate through Central America and winter south to South America.

\section{[Hydroprogne caspla (Pallas)] \\ Caspian Tern}

In June 1952 Paul Slud observed this spectes on the Laguna Micos near Tela. Mark Trafton, Jr., Identifled a few Individuals there among the terns in September 1955. Trafton noted several more in the same month at the mouth of the Rio Ulua. These records are the southernmost for the species in the Western Hemisphere. It is very likely a rare migrant or visitant to the north coast of Honduras every year.

The species has not been previously recorded from Honduras. 
Sterna hirundo Linnaeus

Common Tern

PUBLISHED RECORDS.--Iriona (Lincoln, 1936: 146). "Honduras" (Austin, 1953: 46, 52).

The Common Tern is apparently a rare migrant along the north coast of Honduras. It is certainly more common than is indicated by the records given below.

Lincoln (1936: 146) mentioned that a Common Tern banded on Lone Tree Island, Sebawaing, Michigan, on 13 July 1932 by F. E. Ludwig was found dead at Iriona on 19 November 1932 . Austin's (1953: 46, 52) report of a banding recovery from Honduras did not give further data and may have pertained to the same record.

On 19 October $1962 \mathrm{~J}$. Alan Feduccia and I observed three Individuals of this species with a large flock of Black Terns (Chlidonias niger) feeding over the open bay at Puerto Cortés.

\section{[Sterna forsteri Nuttall]}

\section{Forster's Tern}

On 25 September 1953 Mark Trafton, Jr., observed several individuals of this species feeding over the floodfallow lakes at Copen. Identification of the winterplumaged adults was definite. The birds were seen repeatedly into November.

This report is the first record for the species south of Guatemala. 


\section{Sterna fuscata Linnaeus}

\section{Sooty Tern}

MCZ).

SPECIMEN.--S. E. Euscata (1): Swan Island, 4 Oct. ( ${ }^{\prime \prime}$,

PUBLISHED RECORDS.--Roatán Is land (Oates, 1901: 191). Puerto Castilla (Stone, 1932: 304). Swan Islands (Paynter, 1956: 105).

This tern is a pelagic spectes that occurs in the Caribbean Sea off Honduras (casually on the mainland) and perhaps has bred on Roatán Island, in the Bay Islands. Oates (1901: 191) recorded a set of eggs, now in the British Museum, collected by G. F. Gaumer presumably on Roatán in 1886 or 1887. The reliability of this record has not been checked; subsequent ornithologists visiting the island have not recorded the species there. On the Swan Islands, as Paynter (1956: 105) pointed out, the Sooty Tern is not a breeding species; the only record for the 1slands is the specimen collected by Neal wilson in 1926.

Along the north coast of Honduras in the bay at Puerto Castilla, several Sooty Terns were observed by John T. Emlen, Jr., and C. Brooke Worth on 29 June 1930 (Stone, 1932: 304). On 29 August 1954 Mark Trafton, Jr., noted three individuals on the flood-fallow lakes at Copen, some 30 miles inland. $\quad$. C. Dunlap observed a pair on Utila Is land on 5 December 1959.

The Swan Island specimen is referable to the Atlantic race, S. f. fuscata Linnaeus . 


\title{
Sterna albifrons Pallas
}

Least Tern

\begin{abstract}
SPEC IMFN.--Undetermined (1): $2 \mathrm{mi}$. NW Cedeño, 9 Oct. (imm, \%, LSUMZ).
\end{abstract}

The Least Tern is an uncommonly recorded migrant in Honduras, occurring along both coasts. Although not previously reported from Honduras, it is undoubtedly more common than the few records indicate.

Mark Trafton, Jr., observed two Least Terns on the flood-fallow lakes at Copén on 19 September 1954. He also noted the species in October 1965 on the Laguna Micos near Tela.

J. Alan Feduccia and I collected a single immature female on the beach near Cedeño, along the Bay of Fonseca, in 1962. This bird was alone and was migrating southeastward along the beach.

Caribbean slope individuals are probably referable to the eastern race, S. a . antillarum (Lesson); I am unable to recognize $\underline{\text { s. }}$ a. athalassos Burleigh and Lowery and consider it to be a synonym of antillarum. The single Honduran specimen is an immature and not identifiable with certainty; it does, however, have the three outermost primaries dusky, a characteristic most frequent in the three west Mexican races, S. a. strebleri Brodkorb, S. a. mexicana van Rossem and Hachisuka, and S. a. browni Mearns, and is probably referable to one of these three races. The wing 
measurement (171.5) places it within the range of variation of either browni or staebleri, but further determination is not possible.

Thalasseus maximus (Boddaert)

Royal Tern

SPEC MENS.--T. m. maximus (3): Baja Mar, 9 Sep. ( 8 , LSUMZ); La Ceiba, 26 July (,$+ C M)$; "Honduras" (?, BMNH). PUBLISHED RECORDS.--"Honduras" (Saunders and Salvin, 1896: 80). Bay Islands (Bond, 1936: 357).

This tern is a fairly common visitant at all seasons to both coasts of Honduras. It is more common on the Caribbean coast and in the offshore islands, and there is indication that it breeds in the Cayos Cochinos. On the Caribbean coast it is the commonest species of tern throughout most seasons, being exceeded in numbers only by the irregular fall flocks of the Black Tern (Chlidonias niger).

According to the local residents, a colony of birds fitting the description of this spectes breeds on Fowl Key, a tiny sandy islet only 50 yards in length, located about 200 yards west of Little Hog Island, in the Cayos Cochinos. When I visited these islands in early April 1963, I found no Indication of nesting although the species was in evidence; the breeding birds are supposed to return and nest in late May and June.

Arthur C. Twomey and Roland W. Hawkins collected a Royal Tern at La Ceiba in 1950. J. Alan Feduccia and I secured another at Baja Mar in 1962. The British Museum 
specimen from "Honduras" is without further data.

Honduran birds represent the American race, $\underline{T}$. $\underline{\text {. }}$ maximus (Boddaert).

\section{Anous stolidus (Linnaeus)}

Brown Noddy

vin, 1870b: 838$)$.

The Brown Noddy is an oceanic species that breeds on islands off the coast of British Honduras and ranges occasionally into the Caribbean waters of Honduras. G. M. Whitely (Sclater and Salvin, 1870b: 838) collected the species in Honduras, presumably on the coast at Puerto Cortés, in 1869-1870. The specimen was deposited in the British Museum, but I have not examined it. There are no other records for Honduras although this tern probably occurs regularly in open waters of the Caribbean Sea. The Caribbean race is A. s. stolidus (Linnaeus) and presumably the Honduran specimen represents this race. The Pacific coast race, A. S. ridgwayi Anthony, has been taken off Guatemala and Costa Rica and may occur around the Bay of Fonseca on occasions.

Family RYNCHOPIDAE

\section{[Rynchops nigra Linnaeus]}

Black Skimmer

North American breeding populations of the Black 
Skimmer winter south to Guatemala, E1 Salvador, and Nicaragua. Although previously unrecorded from Honduras, there are two records for the republic.

In June 1952 Paul Slud observed the species on the Laguna Micos near Tela. In September 1955 Mark Trafton, Jr., saw several adults and an immature at Puerto Sal, northwest of Tela. The species is probably a regular, but rare, visitant to Honduras.

\section{Family COLUMBIDAE}

\section{Columba leucocephala Linnaeus}

White-crowned Pigeon

SPECIMENS.--(32): Swan Islands, 3-29 Feb., 22 March, 17 Apri1 (38, 3\%, MCZ; 38, 2\%, USMM); Utila Island, 25 Jan. ( $\$, C N H M)$; French Harbor, 4 April ( $\left.\sigma^{*}, C M\right)$; Roatán Island, Sep. (13?, BMNH); Barbareta Island, 12 April ( ${ }^{\circ}$, 28, CM); Guanaja Is land, 15 April ( $\left.\sigma^{\circ}, C M\right)$; Little Hog Island, 9 April ( $\sigma^{\circ}$, LSUMZ); Big Hog Island, 8 April ( $\sigma^{\circ}$, LSUMZ).

PUBLISHED RECORDS.--Swan Is lands (RIdgway, 1888c: 577; Lowe, 1909: 332-333; Fisher and Wetmore, 1931: 5-6; Delacour, 1938: 544-545; Paynter, 1956: 105; 107). Roatán Island (Salvin, 1889: 377; Salvadori, 1893: 280; Hellmayr and Conover, 1942: 432). Roatán Is land, Bonacca [= Guanaja]'Island, Utila Is land (Bond, 1936: 357).

This pigeon is a common Antillean spectes that is widespread throughout the islands of the western Caribbean Sea. It is a fairly common to common resident on all the larger, forested 1slands off the north coast of Honduras, Including the Swan Islands, Bay Islands, and Cayos Cochinos. Its numbers have been somewhat reduced in recent years by 
extensive hunting pressures. The species wanders considerably and flocks have often been reported at sea, but the species has never been found on the mainland of Honduras. Joseph Leyland (Moore, 1859: 61) observed flocks flying "between the islets between Omoa and Belize," British Honduras; these islets are all British Honduran except the southernmost, the Cayos Zapotillos, and Leyland was not more specific as to which islets were involved. Bond (1936: 357) collected a male on Guanaja Is land that was not preserved.

In early April 1963 I found the spectes to be fairly common on both Big Hog and Little Hog islands in the Cayos Cochinos. Groups of individuals were noted flying between these two islands, which are separated by about two miles of water.

\section{Columba Elavirostris Wagler}

\section{Red-billed Pigeon}

SPECIMENS - - C. . f. flavirostris (27): Coyoles, 16 June (27, CM); Plan dê1 Rancho, 8 July ( 6 , MLZ); Montaña Vás quez, 9 Dec. (o", AMNH); Monte Redondo, 25 Sep., 14 Dec. (28, 1mm. of, CNMM); Archaga, $10 \mathrm{July,} \mathrm{13-15} \mathrm{Sep.,} \mathrm{5-17} \mathrm{Nov.}$ $\left(50^{\circ}, \%\right.$, AMNH); La F lor Archaga, 1 May, 23 June ( $\$$, AMNH; $\delta^{\circ}$ CNHM); Cantarranas, 8 Aug. (20, ANSP); San Juancito, 27 July (?, ANSP); E1 Hat 1110, 22 April ( 8, MCZ); Comaya güela, 21 oct. ( 9, CNHM); Yeguare River Valley, 17 Feb., 26 June (2。, UF); Eí Boquerón, 6 Sep. ( $\sigma^{\circ}$, AMNH); Piedra de Jesús, 17 Feb., 16 March ( $0^{\circ},{ }^{\circ}$, AMNH); $6 \mathrm{mi}$. NE Choluteca, 12 Oct. ( $\delta$, skel.; LSUMZ).

PUBLISHED RECORDS.--TIgre Island (Taylor, 1860: 226227). Cantarranas, San Juancito (Stone, 1932: 305). Monte Redondo, Comayagüela, La Flor Archaga (Hellmayr and Conover, 1942: 453). 
The Red-billed Pigeon is a bird of the arid open or semi-open country of the Pacific slope and the interior of Honduras up to an elevation of 6,000 feet. It is common in the Pacific lowlands, fairly common in the arid interior highlands, and uncommon in the arid interior valleys (Aguán, Comayagua, and Olancho) on the Caribbean slope. In parts of the interior valleys mentioned above, this species occurs sympatrically with $\underline{C}$. cayennensis, an inhabitant of the Caribbean lowlands.

I assign Honduran birds to the nominate race, $\underline{C}$. flavirostris Wagler. I am unable to recognize the race from Nicaragua and Costa Rica, C. E. minima Carriker, based on its smaller size, as there is too much overlap in measurements in the gradual north-south cline.

\section{Columba cayennens is Bonnaterre}

Pale-vented Pigeon

SPECTMENS.-C. c. pallidicrissa (19): Lancetilla, 20 Jan. $\left(\sigma^{\circ}, \mathrm{MCZ}\right) ;$ Là Cétba, 3-6 June $\left(\sigma^{\circ}, q, \mathrm{CM}\right)$; Cofradla, 4-5 March (? BMNH; 20", MLZ); San Pedro Sula (?, AMNH; ?, BMNH; $\delta, C M$ ); Las Peñitas, 26 Jan. ( ${ }^{\prime}$ BMNH); Progreso, 30 Jan. ( 9, MCZ); $4 \mathrm{mi}$. N Río Lindo, 29 Nov. ( $0^{*}$, LSUMZ); San José de Santa Bárbara, 4 March (o", CNHM); El Jaral, 25 Sep. ( $\sigma^{\circ}$, AMNH); Lake Yojoa, at Agua Azul, 11 Sep. ( $\sigma^{\circ}$, LSUMZ); Lake Yojoa, 19 June ( $\left.\sigma^{\circ}, C M\right)$; Catacamas, 15 oct. ( $d$, CNHM); E1 Boquerón, 6 Sep., 15 oct. ( $d$, \&, AMNH).

PUBLTSHED RECORDS.--San Pedro region (Sclater and Salvin, 1870b: 838). San Pedro (Salvadori, 1893: 289). Lancetilla, Progreso (Peters, 1929b: 406). San José de Santa Bárbara, Catacamas (Heilmayr and Conover, 1942: 455).

Columba cayennensis is a fairly common to common resident of open situations in the humid Caribbean lowlands of 
Honduras. It is found below 2,500 feet and often occurs in large flocks of 100 or more individuals. In portions of the arid interior valleys, especially in the edges of the monsoon forests along the rivers, it occurs sympatrically with the Red-billed Pigeon (C. flavirostris).

According to local residents, the heron rookery on the Laguna Caratasca near Cauquira is occupied annually in September by a breeding colony of hundreds of Pale-vented Pigeons .

Honduran specimens are referable to the Middle American race, $\underline{C}$. c. pallidicrissa Chubb.

\title{
Columba Easciata Say \\ Band-tailed Pigeon
}

\begin{abstract}
SPECIMENS. - -C. F. fasclata (29): El Chorro, 17 June (7, MLZ); Montaña EI chorro, I9-"31" June (2d, 2q, MLZ); Montaña El Sillón, 2 July ( $\left.\sigma^{\prime}, M L Z\right)$; E1 Conejo, 19 June ( $q$, MLZ); Montaña La Cruz, 22 June-7 July ( $30^{\circ}, 9$, MLZ); $4 \mathrm{mi}$. SE La Esperanza, 24 Jan. (o", LSUMZ); Cantoral, 9 March, 3-

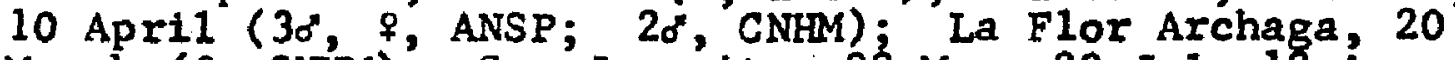
March ( $\$, C N H M)$; San Juancito, 22 May, 22 July-12 Aug. (20", 27, ANSP; of, CM; $9, \mathrm{MCZ}$ ); E1 Derrumbo, 13-16 July (2?, MCZ); Mt. UYuca slopes, 7 April (?, UF); near Uyuca, 7 April (o", UF).
\end{abstract}

PUBLISHED RECORDS.--San Juancito (Stone, 1932: 305). Cantoral, La Flor Archaga (Hellmayr and Conover, 1942: 444).

The Band-tailed Pigeon occurs primarily in deciduous oak groves and in pine-oak associations, ranging frequently into pine and occasionally into cloud forest. It is the most commonly encountered large pigeon in the interior highlands of Honduras. 
I cannot see any constant geographic differences in Mexican and Guatemalan specimens as compared with those of El Salvador and Honduras, to whtch the name $\underline{C}$. $E$. letonai Dickey and van Rossem has been applied. The race letonai was based on paler coloration and a more pointed wing, with the tenth primary longer than the seventh. Dark and light birds appear throughout the series (the darkest example I have seen came from El Salvador near the type locality of letona1), and the pointed wing is not a constant character, since a number of Honduran specimens have the seventh primary longer than the tenth. When compared with Nicaraguan examples of the smaller race, $\underline{c}$. $\underline{f}$. parva Griscon (wing, $<195.0$ ), Honduran birds all measure longer in the wing (>196.5). Brodbork (1943a: 20) recorded a range of wing measurement for Honduran and Salvadorean specimens of 191 to 207, which indicates that perhaps even parva is not worthy of taxonomic recognition. A complete revision of the species is needed to determine the status of the various subspecies.

\section{Columba speciosa Gmelin}

Scaled Pigeon

SPECIMEN.--(1): La Ceiba, 15 Jan. (d, MCZ).

PUBLISHED RECORD.--La Ceiba (Bangs, 1903: 142).

The Scaled Pigeon is a spectes of the humid lowland rain forests and is rare in Central America north of Costa 
Rica. In Honduras it is known from the single record listed above, a male taken by W. W. Brown (Bangs, 1903: 142) in 1902. It is probably widespread, although rare, in the lowland rain forests of olancho and of the north coast.

\section{Columba nigrirostris Sclater}

\section{Short-billed Pigeon}

SPECIMENS.--(9): San Alejo, 30 March ( 8 , LSUMZ); Los Planes, 13 July ( $\$, C M)$; Román $\left[=\right.$ Aguán] River ( ${ }^{\circ}$, USNM); Cofradía, 11 Feb. ( $\sigma^{\circ}$, MLZ); Las Peñitas, 15 Feb. ( $\sigma^{\circ}$, MLZ; ?, MCZ); Arenal, 21 Jan. ( ${ }^{*}$, UCLA); Segovia River, 2 Aug. $(\sigma, q$, USNM).

594). $\frac{\text { PUBLISHED }}{\text { Román [ }} \stackrel{\text { RECORDS }}{=}$ Aguán] River (Ridgway, $1916: 329-330$ ).

Columba nigrirogtris is an uncommon resident of the humid lowland rain forests of the Caribbean slope in Honduras, ranging up into low montane rain forest to an altitude of 4,500 feet. It is very difficult to observe, staying in the high canopy of the rain forest, where it remains unnoticed unless the distinctive call notes reveal its presence. On Cerro Santa Bárbara the species occurs in montane rain forest where the latter is continuous with lowland rain forest.

\section{Zenaidura macroura (Iinnaeus)}

Mourning Dove

SPECTMENS.--Z. m. margine1la (16): Monte Redondo, 23

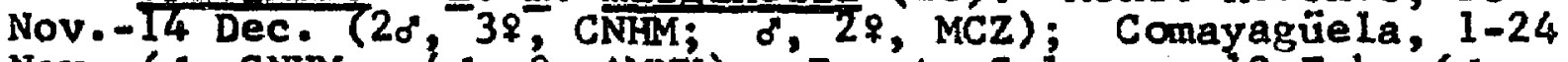
Nov. ( $\sigma^{\circ}$, CNHM; 4 $4 \sigma^{\circ}, q^{\circ}$, AMNH); 'Puerto Salamar, 10 Feb.' ( $\sigma^{\circ}$, LSUMZ). 
PUBLISHED RECORDS.--"Honduras" (Taylor, 1860: 227). Monte Redondo, Comayagüela (Hellmayr and Conover, 1942: 479). Valladolid (Cooke, 1950a: 16).

Although it is known to breed south to Panama, the Mourning Dove is a fairly common to common winter visitant to the arid portions of the Pacific lowlands and interior valleys of Honduras, being unknown from the republic during the sumer season. Extreme dates of arrival and departure for Honduras are 1 November and 27 February.

Taylor (1860: 227) stated that in Honduras Mourning Doves seemed to prefer the woods and open plains of the arid Pacific lowlands. In the winter of 1962-1963 I observed the species frequently in the Comayagua and Otoro valleys in the interior and in the arid lowlands around San Lorenzo and Choluteca. On 2 November 1962 I saw a single bird in the lower end of the Comayagua Valley near the junction of the Humuya and Sulaco rivers, and I had reports from local residents that the species occurs in the Sula Valley around La Lima and San Pedro Sula. On 27 February 1963 I saw a flock of about a dozen individuals flying over a bleak llano in arid steppe country in the Department of Ocotepeque near Lucerna.

Cooke (1950a: 16) reported that a bird banded by J. A. Neff at Alvin, California, on 1 July 1940 was recovered at Valladolid, in the Department of Lempira, in April 1942.

All Honduran specimens are referable to the paler, western North American race, $\underline{Z}$. m. margine11a (Woodhouse). 
The eastern subspecies, $\underline{Z}$. … carolinensis (Linnaeus), has been taken occasionally in Central America, but none of the Honduran specimens is dark enough for this race. The smaller, Panamanian population has been described as $\underline{z}$. $\underline{m}$. turturilla Wetmore [1956: 123; El Espino, Provincia de Panamá, Panamá]; Wetmore listed the measurements of the new race as wing, o 135.2-139.9, $q 124.7-129.7$ (as compared with that of margine11a, $\sigma$ 142.0-156.5, $\$ 132.5-152.0)$. Aldrich and Duvall (1958: 110) gave the wing measurements of male turturilla as 135.0-142.0. In any event, all Honduran specimens fall within the following limits: $d$, 142.0-148.1; \$, 133.5-144.5. The series includes one specimen, a female from Monte Redondo, that is marked "turturilla" on the label, but its wing measures 138.5 , well within the range of variation of marginella. Thus there is nothing to indicate the supposed northward movement of turturilla after the breeding season, at least as far as present Honduran material indicates. Furthemore, the probability is that the small specimens from Guatemala and Nicaragua recorded as turturilla are small examples of marginella.

\section{Zenaida asiatica (Linnaeus)}

White-winged Dove

SPECIMENS.--Z. a. asiatica (12): Monte Redondo, 2 Nov. -9 Dec. (3o, 2q, CNHM; 3\%, \&, MCZ); Comayagüela 31 oct. ( $\%, \mathrm{MCZ}$ ); Choluteca River, Dept. of Choluteca, 13 Feb. ( $\sigma$, UF); $5 \mathrm{mi}$. W Nacaome, 1 Oct. ( $\$$, ISUMz). Z. a. as lattca $x$ australis (20): Catacombas, 5 March ( ${ }^{\circ},{ }^{\circ}$ BNH); Chamelecón, 4 March ( $\$$, AMNH); Subirana, 20 Feb., 8 Dec. (30, MCZ); Coyoles, 16 June $\left(20^{\circ}, \circ, \mathrm{CM}\right) ;$ Siguatepeque, 11 
July (o", CM); E1 Caliche, 21 July (?, AMNH); Monte Redondo, 13 Sep. (imm. of, CNHM); Archaga, 18 Oct. ( 8 , AMNH); La Flor Archaga, 22-27 May ( $\left.{ }^{*},{ }^{7}, \mathrm{MCZ}\right)$; Río Hondo, 18 Aug. $\left(20^{\circ},{ }^{\circ}, C M\right)$; E1 Hatillo, 5 Aug. ( $\left.\$, C M\right)$; Yeguare River Valley, 15 June ( $q$, juv. of, UF). Undetenmined (2): San Pedro (Juv., BMNH); "Honduras" (?, BMNH).

PUBLTSHED RECORDS.--Omoa (Moore, 1859:61). Near Pacific coast, Comayagua (Taylor, 1860: 227). San Pedro region (Sclater and Salvin, 1870b: 838). San Pedro (Salvadori, 1893: 395). Monte Redondo (Hellmayr and Conover, 1942: 501). [Big] Swan Island (Bond, 1959: 9).

In addition to being a conmon to abundant migrant and winter visitant in the arid Pacific coast region and the arid interior below 5,500 feet, the White-winged Dove is also an uncommon breeding bird in the interior and in the drier portions of the Caribbean lowlands. It has also been recorded in winter in the Swan Islands.

Joseph Leyland (Moore, 1859: 61) reported it as "not common" in the Omoa region, and George M. Whitely collected it at San Pedro (Salvadori, 1893: 395); both localities are in the Caribbean lowlands. A pair of these doves have been breeding for a number of years (through 1964) on the United Fruit Company grounds at La Lima. Scattered individuals may be observed in the vicinity of San Pedro Sula at any season, and occasional small flocks may be noted during the winter months.

On the Pacific coast the species sometimes occurs in incredible numbers. These migrant individuals come from as far away as Texas, as shown by numerous banding recoveries between Guatemala and Costa Rica. During the winter of 1962-1963 I observed several flocks each in excess of 100 
Individuals in the San Lorenzo region.

In the interior the species is both resident and migratory, breeding in the valleys (Comayagua, Otoro, Aguán, Sula, Olancho, and Yeguare) and at scattered localities in the highlands (Siguatepeque, Monte Redondo). In winter, the numbers of birds in the interior are not as great as in the Pacific lowlands, but the population increase in the species at that season is noticeable.

The record from the Swan Islands (Bond, 1959: 9) is based on a sight record of Charles H. Blake, who recorded one individual on Big Swan Island on 19 November 1958. Migrant individuals, on the basis of specimens examined, are all representative of the eastern race, $\underline{z}$. a. aslatica (Linnaeus). The larger and paler western race, $Z$. a. mearnsi (Ridgway), has not been definitely recorded south of Mexico. The breeding Honduran birds average slightly darker and slightly smaller than asiatica and approach the small southern race, Z. a. austral1s (Peters), of Costa Rica and Panama, rather than the larger subspecies, Z. a. alticola Saunders [1951: 83; near Patzún, Department of Chimaltenango, Guatemala, altitude about 6,900 feet]. There seems to be a gradual cline in the breeding birds toward a small, dark southern extreme, with the Honduran birds generally intermediate. On the other hand, a few of the presumed breeding Honduran individuals (taken between May and August) are indistinguishable from asiatica. A 
complete and careful study of the variation in this species must be done in order to determine the correct taxonomy.

\section{Scardafella Inca (Lesson)}

Inca Dove

MLZ); Chamelecón, 2-26 Dec. (28, 9 , USNM); Subirana, ( $13-14$ Dec. (3\%, MCZ); Coyoles, 16-20 June (40, $2 \%, C M)$; Plan del Rancho, 30 June ( $\sigma^{\circ}$, MLZ); E1 Horno, 25 Dec. ( ${ }^{\circ}$, AMNH); El Caliche, $1 \mathrm{July}(\delta$, AMNH $)$; Cerro Cantora 1, 21 Sep. ( $q$, MCZ); Monte Redondo, 24 Nov. -10 Dec. (o, i, inm. d, CNHM; ₹, MCZ); Cantarranas, 9 Aug. ( 8 , ANSP); Rancho Quemado, 19 May (d, MCZ); Conayagüela, 9 oct. ( $q$, imm. of, imm. \&, CNIM); Yeguare River Valley, 6 July $(\sigma, q$, UF); San Lorenzo, 26-27 Sep. (30, MC2); Puerto Salamar, $13 \mathrm{Feb}$. ( $\%$, LSUMZ); Honduras-Nicaragua boundary [near Pacific coast] (?, MCZ); "Honduras" (?, AMNH).

PUBLISHED RECORDS.--San Pedro (Moore, 1859: 61). "Honduras" (Taylor, 1860: 227-228). Chamelecón (Ridgway, 1892: 471). Boundary Iine between Honduras and N1caragua "180 miles from Pacific coast" [" near Pacific coast] (Bangs, 1905a: 152). Cantarranas (Stone, 1932: 305-306). Comayagüela, "near Archaga" [= Monte Redondo] (Hellmayr and Conover, 1942: 510).

The Inca Dove is a common species in the arid Pacific lowlands and an uncommon to fairly common species in the arld interior highlands and in the drier portions of the valleys of the Caribbean slope. It occurs in almost any arid or semi-arid situation in the country below 6,500 feet, but its center of abundance is in the arid scrub of the Pacific coast. On the Caribbean slope it is confined to drier parts of the valleys and is found most frequently in the vicinity of human habitation. In the Sula and Quimistán valleys it is uncommon, but in the Aguán, Otoro, and Comayagua valleys it is fatrly common. 
Johnston (1961: 377) merged the genera Scardafella and Columbigallina in columbina. In view of the distinct morphological differences and the fact that each of these genera form discrete groups of closely related species, I can see no advantage in combining the genera.

This species is sometimes considered a race of the South American S. Squamata (Lesson), as it may well prove to be. But until ethological and other comparisons can be made, I feel that it is best to maintain the two taxa as separate species on the basis of sharp morphological distinctions.

The southern population of $\underline{S}$. inca in Central America has been described as $\underline{S}$. 1 . dialeucos Bangs [1905a: 152; "boundary line between Honduras and Nicaragua, 180 miles from Pacific coast"]. I agree with Hellmayr and Conover (1942: 510) that the southern race is not valid; a long series of Honduran birds is indistinguishable from a Mexican series. As mentioned earlier (see page 67), the type locality of dialeucos is in error. The type came from the Pacific lowlands along the Honduran-Nicaraguan boundary within 20 miles of the coast, not 180 miles.

\section{Columbigallina passerina (Linnaeus)}

\section{Common Ground Dove}

SPECIMENS.--C. D. neglecta (32): Utila Island, 22 Feb. (o, LSUMZ) B Barbareta Island, 10 April ( $\sigma^{*}, C M$ ); Guanaja Island, 2-26 March ( $\%$ ANSP; $\left.20^{\circ}, 29, C M\right)$; Los Planes, 16 June $\left(\sigma^{\circ}, q, C M\right)$; Trujillo, 30 March-7 April $\left(2 \sigma^{\circ}, q, C M\right)$; 
mouth of Román [= Aguán] River (9?, AMNH); Coyoles, 14 June-11 July (20, $5 \circ$, CM); Lake Yojoa, 26 July ( $\$, C M)$; Puerto Lempira, 8-13 April ( $d, 2 \%$, LSUMZ). c. p. neglecta

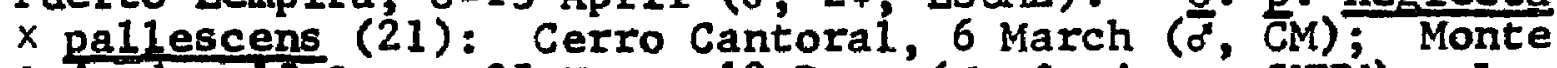
Redondo, 15 sep., 25 Nov., 12 Dec.' ( $\sigma, q$, juv., CNHM); Ia Flor Archaga, 3 June ( $\sigma^{\circ}, \mathrm{MCZ}$ ); Cantarranas, 2-4 Aug. ( $\sigma^{\prime}$, 2\%, ANSP); San Juancito, 27 July ( $\$$, ANSP); El Hatillo, 6 Juily ( $\left.{ }^{\circ}, 9, C M\right)$; Tegucigalpa, 18-20 June (2\%, CNHM); vicinity Tegucigalpa, 12 March ( 9 sel., MLZ); Comayagïela, 9 oct.-18 Nov. (40, CNHM); Escuela Agrícola Panamericana, $27 \mathrm{Feb}$. (?, UF); Yeguare River Valley, 18 May, 27 Oct. ('), MCZ; o, UF). C. $R$. pallescens (7): San Lorenzo, 25-29 Sep. ( $\sigma^{\prime}, q, ?, \mathrm{MCZ}$ ); $8 \mathrm{mi}$. W Choluteca, 11 Feb. ( $\$$ skel., LSUMZ); 7 mi. NE Choluteca, 7 oct. ( $\delta$, LSUMZ); San Francisco, Choluteca, 11 oct. ( $\sigma^{*}$ LSUMZ); Honduras-Nicaragua boundary [near Pacific coast] (?, MCZ).

PUBT.ISHED RECORDS.--Mouth of Román [= Aguán] River, Honduras-Nicaragua boundary "180 miles from Pacific coast" [= near Pacific coast] (Todd, 1913: 596). San Juancito, Cantarranas (Stone, 1932: 306). Bonacca [= Guanaja] Is land (Bond, 1936: 357-358). "Near Archaga" [= Monte Redondo], Comayagüela, Tegucigalpa (Hellmayr and Conover, 1942: 517).

Ranging in Honduras up to an elevation of 6,000 feet, the Common Ground Dove is widespread in the lowlands of both coasts and in the interior. It prefers more arid habitat than does $\underline{C}$. talpacoti. Consequently, $\underline{C}$. passerina is commonest in the arid Pacific lowlands, where it is the most abundant small dove. It is the predominant small dove also In the arid interior valleys (Otoro, Comayagua, and Aguán), where it outnumbers the Ruddy Ground Dove about five to one. Under more humid conditions, such as those that occur in the Sula Valley and along the north coast, the Common Ground Dove is decidedly uncommon and is usually outnumbered by $\underline{c}$. talpacoti by about ten to one; in the Mosquitia, however, the latter species has not been recorded, although $\mathrm{C}$. passerina is fairly common. In the Bay Islands the Common 
Ground Dove is the only small dove and, contrary to the statement of Bond (1936: 357-358), occurs on all the main islands of the group. It is absent, however, from the Cayos Cochinos.

The use of the genus Columbigallina in preference to Columbina is discussed under Scardafella inca.

Geographic variation in this species in Central America is rather puzzling. The western race, C. $\mathrm{g}$ - pallescens (Baird), is found throughout Mexico and south to British Honduras on the Caribbean coast and to El Salvador and Honduras on the Pacific slope. It ts much paler below and less vinaceous above than the Caribbean slope race $\underline{G}$. $\mathrm{L}$. neglecta (Carriker), which occurs from Honduras to Costa Rica. In Honduras all the lowland Pacific coast birds are pale, matching well a series from Mexico, and are here considered to be pallescens. This allocation represents a southward extension of the known range of this subspecies. Specimens from the humid parts of the Cartbbean slope and from the Bay Islands are all typical of the darker race neglecta. Interior birds are varyingly intermediate, sometimes with individuals of each type occurring at the same locality. Until a critical study of series of breeding material can be made, I am considering all interior populations as intermediate between pallescens and neglecta. 


\section{Columbigallina talpacoti (Temminck) \\ Ruddy Ground Dove}

SPECIMENS.--C. t. rufipennis (62): Lancetilla, 8 Feb., 24-26 Aug. (25, ANsp; $9, \mathrm{MCZ})$; La Ceiba, 17 Jan., 2 Apri129 May $\left(30^{\circ}, 28, \mathrm{CM}\right.$; $\$$, MCZ; $\$$, USNM); Truj1110, 23-26 Sep. (2\%, USNM); Cofradia, 3-4 March (o, 9, MLZ); San Pedro Sula, 5 April, 20-29 July, 25 Aug. (29, AMNH; of, CM; 20", ₹. USNM); Las Peñitas, 1 Feb. (o, BMNH; $\&$, MLZ); Urraco, 12 March ( $\sigma^{\circ}, \mathrm{MCZ}$ ); $1 \mathrm{mi}$. N Pimienta Nueva, 7 Sep. ( $\sigma^{\circ}, \sigma^{\prime \prime}$ ske1., ISUMZ); Coyoles, 9-12 July (20, CM); Finca Fé, 22 July ( $\sigma^{\circ}$, LSUMZ); Lake Ýojoa, 25 June ( $\sigma^{\circ}$, MCZ); El Caliche, 1-19 July (2d, 2\%, AMNH; 2\%, CNHM); Cantarranas, 3-5 Aug. (30, 2q, ANSP); E1 Hati11o, 6 July ( $9, C M)$; Tegucigalpa, 17-18 June, 11 Oct. (20, \&, AMNH); Comayaguela, 7-15 July, 5-10 Nov. (2o, imm. $\delta$, CNHM; $\delta, \$, M C Z)$; Yeguare River Valley, 27 Jan., 22-28 June ( $0^{\circ}, 29$ UF); El Boquerón, 3-18 oct. (20, AMNH); San Lorenzo, 23-30 Sep. $\left(20^{\circ}, 59, \mathrm{MCZ}\right)$; "Honduras" (?, AMNH).

PUBLISHED RECORDS.--Comayagua (Sclater, 1858b: 359; Taylor, 1860: 227). San Pedro (Moore, 1859: 61). San Pedro region (Sclater and Salvin, 1870b: 838). Trujillo (RIdgway, 1888c: 584). La Celba (Bangs, 1903: 142; Deignan, 1936: 189). San Pedro Sula (Todd, 1913: 602-603). Tela, Ulúa Valley, Lancetilla, Urraco (Peters, 1929b: 406). Cantarranas, Lancetilla (Stone, 1932: 306). Comayaguiela, E1 Caliche "La Paz" [= E1 Caliche] (Hellmayr and Conover, 1942: 543).

The Ruddy Ground Dove is a common resident in the open areas of the humid Caribbean lowlands, occurring also in the arid interior valleys, in the arid interior highlands below 3,500 feet, and in the arid Pacific lowlands. In the more arid regions, it is in general decidedly uncommon (though perhaps fairly common locally) and is usually outnumbered by C. passerina (see account for the latter). C. talpacoti does not occur in the Bay Islands nor in the Mosquitia. Honduran specimens are referable to the Central American race, $\underline{c}$. $t$. rufipennis (Bonaparte). 


\section{Claravis pretiosa (Ferrari-Perez)}

Blue Ground Dove

SPECIMENS.--(34): La Pita, Cortés, 4 Jan. (20, USMM); San Alejo, 31 March (o" skel., LSUMZ); Lancetilla, 20 Jan.-9 Feb., 25-28 Aug (20, ANSP; 36, 29, MCZ); La Ceiba, 17-22

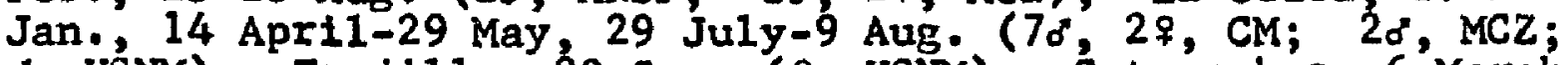
o, USNM); Trujillo, 20 Sep. (\%, USNM); Catacombas, 6 March (o, MLZ); San Pedro Sula, 5 April (o, CM); Las Peñitas, 6 Feb. ( $\sigma^{\circ}$, BMNH); Amapa, 26 Jan., 24 June ( $\sigma^{\prime \prime}$ ske1, LSUMZ; o, UF); Finca Fé, 22 July, 14 Sep. (20, \%, LSUMZ); Catacamas, 6-26 0ct. ( 0 , $\$$, CNHM); "Honduras" (?, AMNH).

PUBLISHED RECORPS.--Omoa (Moore, 1859: 61). Trujillo (Ridgway, 1888c: 584). La Ceiba (Bangs, 1903: 142; Deignan, 1936: 189). La Ptta (Ridgway, 1916: 432-433). Lancetilla (Peters, 1929b: 406; Stone, 1932: 306). Catacamas (Hellmayr and Conover, 1942: 557).

Ranging up to 3,000 feet, this ground dove is a fairly common resident of rain forest areas on the Caribbean slope of Honduras. It occurs commonly within the dense forest Itself but also frequently forages in more open situations, especially in areas of heavy scrub, second growth, or cultivation. In regions of cut-over rain forest it is a conmon species along the roadsides and forest edges.

Hellmayr and Conover (1942: 557) do not recognize the South American race, C. p. 1lvida Bangs, retaining the species as monotypic. If this race is accepted as valid, the Honduran birds would represent the northern, nominate race, c. p. pretiosa (Ferrari-Perez).

\section{Claravis mondetoura (Bonaparte)}

Maroon-chested Ground Dove SPECIMENS.--C. m. salvini (4): Monte Verde, 23-25 July 
( $\left.0^{\circ}, \$, M L Z\right)$; Volcán de Puca, 2 April ( $0^{\circ}$, BMNH); La Florida, 11 Dec. (o", MCZ).

\section{PUBLISHED RECORD.--Volcán de Puca (Hellmayr and Conover, 1942: 559).}

This species is exceedingly rare in northern Central America, being known from a few specimens from vera Cruz, Chiapas, Guatemala, and Honduras, It is restricted to cloud forest above 4,500 feet.

Erich Wittkügel collected a male on Volcán de Puca in 1889. In $1936 \mathrm{C}$. F. Underwood obtained a pair at Monte Verde, in the Department of Ocotepeque, and collected another male at La Florida, in the Department of La Paz. These specimens constitute the only known records for Honduras.

Honduran specimens are representative of the race $\underline{C}$. $\underline{m}$. salvini Griscom, which occurs from Chlapas to Honduras. It differs from all races from Costa Rica south in the greater amount of white in the abdominal region of the males. I have not examined examples of the Vera Cruz race, $C$. $m$. ochoterena van Rossem, and cannot comment on its validity.

\section{Leptot1la verreauxi Bonaparte}

White-tipped Dove

SPECIMENS.-- - $y \cdot$ b. bang8 1 (54): Cofradla, 13-14 March (2d, MLZ; "MCZ); Las Penitas, 3-4 Feb. (o", \%, MLZ); Chamelecón, 23 Nov. ( $\$$, AMNH); Portillo Grande, 11 May ( MCZ); Coyoles, 18 June-11 July $(\delta, 38 \mathrm{CM})$; Sánta Bárbará, 29 May (\%, AMNH); 1 mi. SW E1 Jaral, 27 April ( $\%$ LSUMZ); Lake Yojoa, 19 June $\left(\sigma^{\prime}, \mathrm{CM}\right.$ ); Montana Elchorro, 22 June ( ${ }^{\prime \prime}$, MLZ); Plan del Rancho, 2-30 June ( $q, ?$, MLZ); Monte Redondo, 30 Jan., 14 Sep. -20 Oct., 22 Nov. -15 Dec. (30, 39 , CNHM; 98, 5\%, MCZ); La Cueva Archaga, 5 April ( $\$$, AMNH); 
La Flor Archaga, 23 Nov.-15 Dec. (2\%, AMNH; \%, MCZ); Archaga, 27 Sep. ( $q$, AMNH); Cantarranas, 10 Aug. (? ANSP); El Derrumbo, 21-24 July ( $\%$, AMNH; $\$$, ML2); Comayaguela, 19 Oct. (imm. o, CNHM); Yeguare Rtver Valley, 2 Feb., 26 May (\$?, MCZ; o", UF); Río Cobri, 23 Jan. ( 9 , UF); Eí Boquerón, 27 sep. (20, AMNH); $10 \mathrm{~km}$. N Sabana Grande, 14 Aug. (o", CM); "Honduras," 4-15 March (20", CNHM). L. $\underline{y} \cdot$ bangsi $>$ nutting (2): Puerto Salamar, 1 oct. ( 8 , LSUMZ) 7 mi. NW Choluteca, 7 oct. ( $\$$, LSUMZ). Undetermined (1): San Francisco, Choluteca, 11 Oct. ( $q$ skel., LSUMZ).

The White-tipped Dove, often called the White-fronted Dove, is a resident of the arid lowlands and interior of Honduras below 6,000 feet. It is a fairly common species in wooded areas or in semi-open areas adjacent to wooded situations. The other two mainland species of the genus (L. Cassinii and L. plumbeiceps) are species of the humid lowland forests of the Caribbean slope and are more or less ecologically isolated from $\mathrm{L}$. yerreauxi. On the Caribbean slope the White-tipped Dove is found in the drier parts of the Quimistán, Sula, Comayagua, Aguán, and Olancho valleys.

The race $\underline{L} \cdot \underline{\mathbf{y}}$. bangsi Dickey and van Rossem, recorded from the Pacific slope from Guatemala to northern Nicaragua, is another of those subspecies that can be distinguished only in series. It averages lighter on the forehead and paler, less ochraceous, on the under parts than $\underline{L}$. $\underline{v}$. Eulviyentris (Lawrence), a race found in eastern Guatemala and British Honduras. The Honduran material, including that from the Caribbean slope, is typical of bangsi, except for the two specimens from the Pacific lowlands. Both of these birds have an increased amount of rufous on the inner edges 
of the primaries and in this respect show a slight approach to L. $\mathrm{v}$. nuttingi Ridgway, of the Pacific lowlands of Nicaragua.

\section{Leptotila Jamaicens is (Linnaeus)}

Caribbean Dove

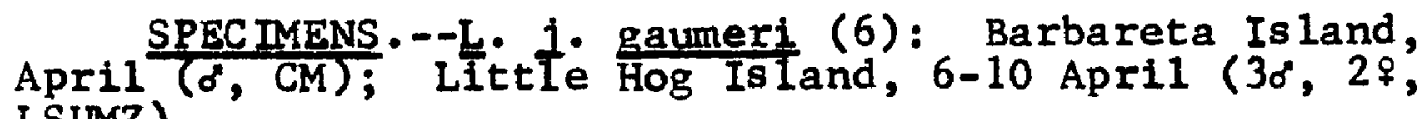
LSUMZ).

The distribution of the Caribbean Dove in Honduras is very peculiar, the species being confined to two small islands off the north coast. It is a fairly common resident on Barbareta Island, in the Bay Islands, and on Little Hog Island, in the Cayos Cochinos. Despite the fact that all the larger islands in the Caribbean Sea have been worked by a number of ornithologists, the species has never been recorded elsewhere in Honduras. In Apri1 1963 I found this dove resident on Little Hog Island, which is not more than one mile in diameter. My observations and those of the residents indicate that about 25 pairs of the species are present there. On Big Hog Island, a slightly larger island just two miles distant, the species is absent and has always been absent, at least within the memory of the present residents .

Bond (1936: 357-358) mentioned that a "larger, reddish" dove (in comparison with Columbigallina passerina) was said to exist on Barbareta Island, but he did not realize that it 
was L. jamaicensis. Delacour (1938: 546) also alluded to a white-breasted dove that was common on Barbareta, but once again the species was not known. It remained for Arthur $C$. Twomey and Roland $W$. Hawkins to collect the first specimen on Barbareta in 1948.

The single male from Barbareta Island and the three males from Little Hog Island are similar to the Cozumel

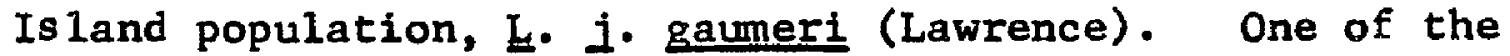
two females from Little Hog Is land is very dark on the breast, with virtually none of the purplish cast present in the males. A second female is rather intermediate, with a dark breast generally intermixed with the purplish overtones, the latter distributed asymmetrically; this condition may be the result of molt. One of the males exhibits a few scattered dark feathers (lacking the purplish overtones) in the throat region. I cannot see any grounds for distinguishing the Honduran populations of this species racially on the basis of the existing specimens.

Leptotila plumbeiceps (Sclater and Salvin)

Gray-headed Dove

SPECIMENS.--L. P- plumbetceps (21): Tela, 13 March ( MCZ); La Ceiba, 9-15 Jan. 28 April ( 6 CM; of, 28, MCZ); Cofradia, 11 March (?, MCZ); Coyoles, 18 June ( $(, \mathrm{CM})$; Santa Bárbara, 13 May-1 June (2\%, MCZ); Ceguaca, 10 March CNHM); 2 mi. SE E1 Jaral, 3 March ( $\sigma^{\circ}$, LSUMZ) $2 \%$, AMNH; $2 \sigma^{\circ}$ CNHM); 2 mi. SE El Jaral, 3 March ( $\sigma^{\circ}$, LSUMZ); Finca Fé, 2 toral, 5 sep. ( $\$$, AMNH); E1 Boquerón, 11 Sep. ( ${ }^{\circ}$, AMNH).

PUBLISHED RECORDS.--San Pedro region (Sclater and Salvin, 1870b: 838). La Celba (Bangs, 1903: 142). Tela 
(Peters, 1929b: 406-407). Lancetilla [= Tela] (Stone, 1932: 306). Ceguaca, E1 Jaral (Hellmayr and Conover, 1942: 587$)$.

The Gray-headed Dove is an uncommon resident of the lowland rain forests on the Caribbean slope of Honduras, ranging into the interior forests along the larger rivers to an elevation of 5,000 feet. It is decidedly rare above 2,500 feet. It is found alongside the other, more common forest species, L. cassinil. The Gray-headed Dove is not confined entirely to the forest; it is sometimes encountered in guamil and in open areas adjacent to forest. Honduran specimens are representative of the Middle American race, L. p. plumbeiceps (Sclater and Salvin).

\section{Leptot11a cassinit (Lawrence)}

$$
\text { Gray-chested Dove }
$$

SPECIMENS.--L. c. cerviniventris (49): San Alejo, 1-2

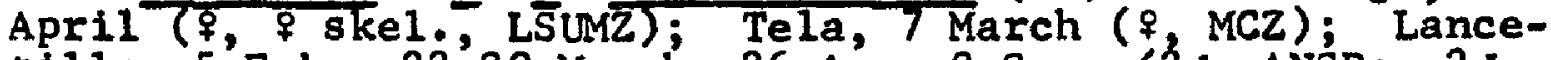
tilla, 5 Feb., 22-29 March, 26 Aug. $-8 \mathrm{Sep} \cdot\left(20^{\circ}\right.$, ANSP; $20^{\circ}$, 2\%, MCZ); La Ceiba, 8 April, 3-27 May, 8 Aug. $\left(20^{\circ}, 9, \mathrm{CM}\right.$; $\$$, CNHM); Yaruca, 13-26 Feb. (28, 2\%, MCZ); Los Planes, 13-14 Juily (20, CM); Trujillo, 6 April, 27 Sep. ( 8,9 , CM; ". USNM); Catacombas, 22 March-8 April ( ${ }^{\circ}, 49$ AMNH; ${ }^{\circ}$,

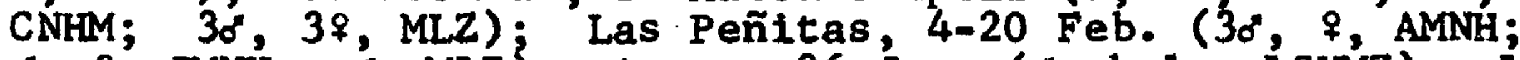
", f, BMNH; d, MLZ); Amapa, 26 Jan. (o" skel., LSUMZ); La Libertad, 10-27 June (2\%, AMNH); Cerro Nieve, 28 March, 20 April ( $\sigma^{\prime}$, AMNH; $\sigma, q$, CNHM); Cerro Santa Bárbara, east slope, 28 Nov. ( $\sigma^{\circ}$, LSUMZ); Lake Yojoa, 13 July ( $\left.\sigma^{\prime}, C M\right)$.

584) PUBLISHED RECORDS--Truji11o (Ridgway, 1888c: 583584). Yaruca (Bangs, 1903: 142). East of Lancetilia, near Tela, Lancetilla (Peters, 1929b: 407). Lancetilla (Stone, 1932: 306). La Ceiba (Deignan, 1936: 189). La Cetba, Catacombas, Cerro Nieve (Hellmayr and Conover, 1942: 567).

This dove is another inhabitant of rain forest in the lowlands of the Caribbean slope of Honduras, ranging up into 
low montane rain forest to an elevation of 4,500 feet. It is fairly common in and around heavily forested areas, being slightly more common than L. plumbeiceps.

Honduran specimens are referable to the Middle American race, $L$. c. cerviniventris (Sclater and Salvin). The birds from Honduras southward were described as Engyptila vinaceiventris Ridgway [1888c: 583; Truxillo, Honduras], but these populations are not separable from cerviniventris (Hellmayr and Conover, 1942: 566-567).

\section{Geotrygon montana (Linnaeus)}

Ruddy Quail Dove

SPECIMENS. - -G. m. montana (20): San Alejo, 6 Aug. ( $\sigma^{\prime}$, LSUMZ); Lancetilla, 29 March ( $\$$, MCZ); La Celba, 7-8 Aug. (20, $0^{\circ} \mathrm{CM}$ ); Catacómbas, 1 April ( 9 , AMNH); Cofradía, 1014 March ( $\sigma^{\circ}$ BMNH; 39 , MLZ); Amapa, 18 Sep. ( $0^{\circ}$, LSUMZ); La Leona, 25 June ( 9, AMNH); Mt. Puca, 7 Jan. ( 9 , AMNH); San José de Santa Bárbara, 8 April ( $\sigma^{\circ}$ AMNH); Cerro Santa Bárbara, east slope, 7 Dec. ( $\delta$, LSUMZ); 2 mi. SE El Jaral, 2 March ( $q$ ? skel., LSUMZ); Lake Yojoa, 16 June ( $q$, juv. $q$, CM); Monte Redondo, 3 Dec. ( $\sigma^{\prime}$, CNHM); E1 Boquerón, 29 sep. ( $\delta$, AMNH).

PUBLISHED RECORDS.--Lancet111a (Peters, 1929b: 407). Monte Redondo (Helimayr and Conover, 1942: 606).

Geotrygon montana is an uncommon resident of lowland rain forests of the Caribbean slope of Honduras, occurring also in montane rain forest and lower portions of cloud forest up to 5,500 feet elevation. This species is terrestrial and is confined almost exclusively to densely forested areas.

Honduran specimens are referable to the widespread nominate race, G. m. montana (Linnaeus). 


\section{Geotrygon albifacies sclater}

White-faced Quail Dove

SPECIMENS.--G. a. Silvestris (68): Catacombas, 25

March-5 April (20, $\%$, MCZ); mountain camp near San Pedro Sula (?, CNHM); Las Peñitas, 10-28 Feb. ( $\sigma^{\circ}, \mathrm{CM} ; 20^{\circ}, i$, CNHM; 98, 4\%,? MCZ); Portillo Grande, 21 May ( $9, \mathrm{MCZ}$ ); Merendón Copán, 15 June ( ${ }^{\circ}$, MCZ); La Libertad, 15 June-1 July ( $\%$, AMNH; $\delta, 2 \%$, CNHM); Montaña Los Cedros, 2 June ( $\sigma^{\circ}$, MLZ); EI Chorro, 14 June ( ${ }^{\circ}$, MLZ); Montafia La Cruz, 3 June ( $\%$, MLZ); Monte Verde, 20 July ( 9, MLZ); Monte E1 Portillo, 28 May ( $\sigma^{\circ}$, MLZ); Volcán de Puca (?, BMNH); Mt.

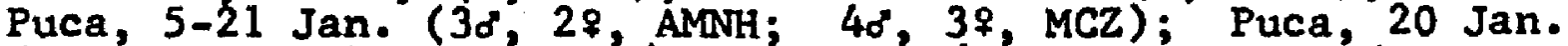
( 6 skel., MLZ); San José de Santa Bárbara, 8 April ( ${ }^{\prime \prime}$, CNHM); Cerro Santa Bárbara, east slope, 27 Jan. (2\%, $q$ ske1., LSUMZ); Cerro Santa Bárbara, southeast slope, 2 Apri1 ( $\sigma$, LSUMZ); Muín, 3 Jan. ( $\sigma^{*}$, MCZ); Alto Cantoral, 17 Jan. -9 Feb. (20, $₹$, CNHM); Cantoral, 12 Feb., 7 April ( $\sigma^{\circ}$, ANSP; $\delta$ CNHM); Archaga, 11 Aug. ( $\sigma$, AMNH); San Juancito, $22 \mathrm{May}, 29 \mathrm{July}-13$ Aug. (20, 7, ANSP; q, UF); El Derrumbo, 16 July, 3 Aug. ( $\left.\delta^{\circ}, \mathrm{MLZ} ; \delta^{\circ}, \mathrm{MCZ}\right)$; Tegucigalpa, 13 June ( $\sigma^{\circ}$, CNHM); Mt. Monserrat, 5 March ( 8 , UF); Dan11, 7 April ( $\$$, BMNH).

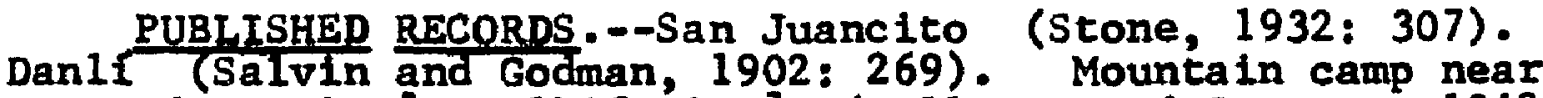
San Pedro Sula [as albifacies] (Hellmayr and Conover, 1942: 612). Las Peñitas, "Choluteca" [= Las Peñitas], Alto Cantoral, Cantoral, Tegucigalpa, San José de Santa Bárbara, and La Libertad Copán [as silvestris] (Hellmayr and Conover, 1942: 614).

Confined in Honduras to elevations above 4,000 feet, the White-faced Quail Dove is a fairly common resident of cloud forest and of montane rain forest. It is another terrestris 1 species restricted to dense forest. It is more common than $G$. montana and occurs sympatrically with the latter in low montane rain forest; I have collected both spectes together on Cerro Santa Bárbara at an elevation of 4,000 feet.

I agree with Blake (1958: 511) that albifacies should not be lumped with the South American G. linearis (Prévost). 
In view of distinct morphological differences and lack of comparative ethological studies, the conservative procedure is to maintain the two as distinct species. I also follow most recent authors in not recognizing the genus oreopeleia but regarding the Central American quail doves as members of the genus Geotrygon.

Honduran specimens of $G$. albifacies are typical of $G$. a. silvestris (Dickey and van Rossem), a race occurring from Chiapas to Nicaragua. The Guatemalan populations have often been separated as G. a. anthonyi (Griscom), on the basis of more reddish coloration below, but I cannot detect any constant differences in a long series of birds from Mexico to Honduras. The Mexican race, G. a. albifactes Sclater, occurring west of the Isthmus of Tehuantepec, is distinct, being much paler on the breast and slightly paler above. I do not agree with Hellmayr and Conover (1942: 612) that birds from near San Pedro Sula are referable to nominate albifacies; the Honduran specimens match silvestris in all details.

Family PSITTACIDAE

[Ara ambigua (Bechstein)]

Great Green Macaw

This macaw is a lowland rain forest species that is known to occur in Central America on the Ceribbean slope 
north to Nicaragua. In the Department of Olancho 8 ome species of large green macaw does exist, almost certainly Ara ambigua. The natives are familiar with the species, which is considerably rarer than $A$. macao. The presence of green macaws in Honduras was mentioned even in the 19th Century when William V. Wells (1857: 398) wrote that "toward the coast the beautiful green species is said to exist, much more elegant than his rainbow cousin." One might be tempted to disregard the above from a scientific standpoint were it not for an observation by Archie F. Carr, Jr., in the early 1950's. He saw green macaws in olancho along the road from Juticalpa to Catacamas, about 12 to 14 miles northeast of Juticalpa (Carr, personal communication).

There is always the possibility that the green macaw in Honduras represents the Military Macaw, Ara militaris (Linnaeus), a South American species with an isolated population in central Mexico. However, both geographically and ecologically, the Honduran birds are most 11kely A. ambigua. Unt1l a specimen is secured, the Identification will have to remain tentative.

\section{Ara macao (Linnaeus)}

Scarlet Macaw

SPECTMENS - - (10): Urraco, 10 March (o", MCZ); Chamelecón, 22 March ( 0 , USMM); Subirana, 20 Dec. (o, MCZ); Coyoles, 28 June, 18 July ( $\delta, \%, C M)$; Río Choluteca at Danlf bridge, 23 Jan. ( $\sigma^{\circ}$, UF); Segovia River, 22-30 July ( $\delta, ?$, USNM); $7 \mathrm{ml}$. NE Choluteca, 7-9 Oct. ( ${ }^{\prime}$, \& skel., LSUMZ). 
PUBLISHED RECORDS.--Omoa (Moore, 1859: 59). Near Comayagua, Tigre Island (Taylor, 1860: 119-120). Segovia River (Ridgway, 1888c: 592). "Honduras" (Forbes and Robinson, 1897: 10). Chamelecón (Ridgway, 1916: 129). $52 \mathrm{~km}$. W Tela [= Urraco], Lancetilla (Peters, 1929b: 420421). Cantarranas, Lancetilla (Stone, 1932: 308).

Although the Scarlet Macaw is generally regarded as a resident of the humid Caribbean lowlands in Middle America, the species is very widespread in Honduras, occurring in the arid lowlands of the Pacific slope and in the interior below 3,500 feet, as well as in the Caribbean lowland rain forest. This macaw is uncommon in most of Honduras though fairly common locally in portions of the arid Pacific lowlands. It is found not only in the vicinity of forests but also in the scrubby growth of the Pacific coast. It frequently forages in open, usua11y cultivated, country. Its popularity as a pet has no doubt reduced its numbers in some localities. At the present time the species is dectdediy uncommon on the Caribbean slope of Honduras, occurring in moderate numbers only in certain roosting areas.

Forbes and Robinson (1897: 10) mentioned that there were two female and two unsexed specimens from "Honduras" in the Derby Museum. These individuals are probably the ones obtained by Joseph Leyland in the Omoa regton.

\section{Aratinga holochlora (Sclater) \\ Green Parakeet}

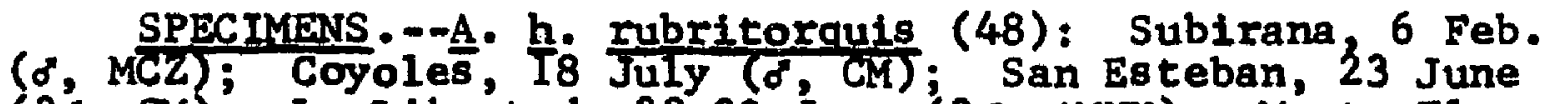

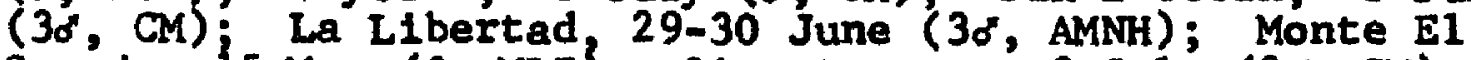
Conejo, 15 May (f, MLZ); Siguatepeque, 9 July (28, CM); 
San Marcos de Guaimaca, 29 June-4 July ( $0^{\circ}$, CM; 20, 29 , MLZ); 4 mi. SE Zambrano, 24 Aug. ( $\$$, LSUMZ); Cantorai, 23 July ( $\left.{ }^{\circ}, C M\right)$; Cerro Cantoral, 4 May, 21-23 July, 26 Nov. ( ${ }^{\circ}$, ANSP; 20, 3\%, MCZ; $\%$, USNM); Alto Cantora1, 10-16 Feb. ( $\$$, MLZ; 20, $\$, M C Z)$; Monte Redondo, 21 Sep. ( $\sigma^{\circ}$, MCZ); La Flor Archaga, 18 April-15 June (2o, AMNH; $\sigma^{\circ}{ }^{\circ}$, MCZ); El Derrumbo, 24 July-9 Aug. (30, MCZ); E1 Hatillo,

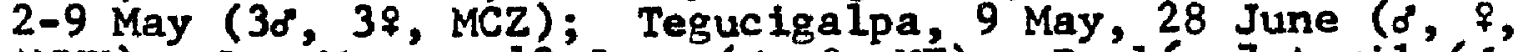
AMNH); Las Mesas, 12 June ( $d^{\prime}, q$, UF); Danl 1,7 April ( $\sigma^{\prime}$, BMNH):

PUBLISHED RECORD.--"Honduras" (Peters, 1937: 186).

Despite the virtual lack of published records of this species from Honduras, the Green Parakeet is fairly common to common in the interior highlands above 3,000 feet, descending occasionally to about 1,000 feet elevation in the nonbreeding season. It is the most abundant parakeet in the highlands, often occurring in flocks exceeding 100 individuals. Although it seems to prefer pine, it can be encountered in almost any kind of wooded situation; I have even found it in typical cloud forest associations.

The inclusion of Honduras in the range of the species by Peters (1937: 186) was no doubt based on the large series of Underwood specimens in the Museum of Comparative Zoology. After examination of a series of specimens from Mexico, Guatemala, and Honduras, I agree with the current treatment of the Red-throated Parakeet, A. h. nubritorguis (Sclater), as a subspectes of $\mathrm{A}$. holochlora of Mextco. The amount and extent of orange feathering on the throat is highly variable, both on an age basis and an individual basis, with a general tendency towards an increased amount of orange in the southern part of the range. Many individuals possess 
only a few feathers of this color on the throat, these feathers often being arranged asymmetrically. I have even seen apparently adult individuals from Honduras that lacked the orange altogether. In the matters of habits and ecology, both zubritorquis and holochlora are similar in the areas of southern Mexico and Guatemala where the two races approach one another geographically. On the other hand, the evidence seems to indicate the specific distinctness of A. Strenua; relationships between $A$. holochlora and $A$. strenua are discussed under the latter.

\section{Aratinga strenua (Ridgway)}

Pacific Parakeet

SPECIMEN.--(1): San Lorenzo, 25 Sep. ( $q, M C Z)$.

This species is known from Honduras only by the single female collected by C. F. Underwood at San Lorenzo in 1932. The species is primarily a bird of the arid lowlands of the Pacific slope from Oaxaca to Nicaragua but ranges to 4,500 feet in E1 Salvador and to 7,000 feet in Guatemala. In Honduras it is probabiy an uncommon resident of the lowlands of the Pacific coast. During my two trips to this region in 1962-1963, however, I failed to find the species.

This parakeet has sometimes been considered conspecific with A. holochlora, primarily on the basis of the entirely green coloration. As demonstrated by Bangs and Peters (1928: 388) and Griscom (1932b: 174-175), A. strenua is specifically distinct from holochlora, having a much heavier 
bill and stouter feet, as well as occurring sympatrically in certain localities. Furthermore, there seems to be no intergradation in size with regard to certain bill measurements .

The single specimen from Honduras is typical of this species, measuring as follows: wing, 173.5; culmen from cere, 26.9; maximum width of lower mandible, 18.6 .

The species has not been reported previously from Honduras.

\section{Aratinga astec (Souancé)}

\section{O1ive-throated Parakeet}

SPECIMENS.--A. a. astec (47): Lancet111a, 20 Feb., 28 Aug.-4 Sep. (20, $\frac{1}{9}$ ?, ANSP; $\left(0^{\circ}, \$, C M\right)$; Trujillo, 30-31 March, 26-27 Sep. (20, CM; 20, \$, USNM); Catacombas, 3 April ( $\$$, MLZ); Cof radla, 5-14 March (20, 9, MLZ); San Pedro (?, AMNH; ?, BMNH); Santa Ana, 19-20 Nov. (20, USNM); Las Peñitas, 7-9 Feb. ( 9, MLZ; ?, MCZ); Coyoles, $13-18$ June (30, 2\%, CM); San Esteban, 30 June ( $\$, C M)$; San José de Santa Bárbara, 22-24 Apri1 (20, AMNH); Finca Fé, $2-4$ Sep., 21 oct., 25 Nov. $\left(2 \sigma^{\prime}, ?\right.$, alc., LSLMZ); 4 mi. SW El Jaral, 2 sep. ( 9 skel., ISUMZ); El Caliche, 10-16 July ( 8,29, AMNH); Arena1, 24 Jan., 29 May ( ${ }^{*}, \&$, UCLA); Segovia River, 9 Aug. ( $\%$, USNM); Puerto Lempira, 10 April ( $\delta$, LSUMZ); "Honduras" (2?, ANSP; 2?, AMNH; ?, BMNH).

PUBLISHED RECORDS.--"Honduras ?" (Gray, 1859: 38; Griscom, 1928: 2). Near Comayagua (Taylor, 1860: 120 ). San Pedro region (Sclater and Salvin, 1870b: 837). San Pedro (Salvin, 1871: 93). Trujillo, Segovia River (Ridgway, 1888c: 583, 592). San Pedro, "Honduras" (Sa1vadori, 1891: 193). Santa Ana (Ridgway, 1916: 172). Near Lancetilla (Peters, 1929b: 421). Lancetilla (Stone, 1932: 308). La Ceiba, Trujillo, San Esteban, Coyoles (Twomey, 1950: 197-198).

In Honduras the 01ive-throated Parakeet is a fairly common to common inhabitant of the Caribbean lowlands, 
occurring primarily in and around areas of rain forest. During the day, however, flocks of this species may range widely throughout adjacent open or cultivated country, both humid and arid. It has not been recorded above 3,500 feet elevation in Honduras. In the Comayagua Valley A. astec and A. canicularis occur sympatrically, the former generally inhabiting the vega forest along the river and the latter being encountered in the more arld portions of the valley. Salvin and Godman (1897: 575) listed the species as having been recorded from Omoa by Joseph Leyland, but the latter did not observe it there (Moore, 1859: 59).

Most current authors recognize two subspecies in this species, A. a. vicinalis (Bangs and Penard) from northern Mexico and A. a. astec (Souancé) from central Mexico to Panama. The northern subspecies vicinalis is an excellent race, being slightly larger, brighter green above, and much greener (less brownish or olive) below; it ranges south to Vera Cruz. The Panamanian population was named $\mathrm{A}$. extima [Eupsittula astec extima Griscom, 1928: 2; Almirante, Boca del Toro, western Panama] on the bas $1 s$ of paler coloration than in astec and darker, duller coloration in comparison with vicinalis. The Honduran population was described as A. a. mellont Twomey [1950: 297; La Celba, Honduras] on the basis of duller coloration and more grayish under parts, when compared with astec. I have recently examined a large series of birds from southern Mexico and 
Central America and can find no significant variation in coloration from Tabasco to Panama, except possibly a paler tendency towards the south. The Tabascan and British Honduran specimens average the darkest below of the entire series. These differences are very slight and do not warrant subspecific separation. There is much variation in the intensity of green coloration due to wear (or to fading), freshly molted birds being considerably brighter. I therefore recognize only A. a. astec south of vera Cruz.

\section{Aratinga canicularis (Linnaeus)}

Orange-fronted Parakeet

SPECIMENS --A. c. canicularis (24): Monte EI Conejo, 15 May (f, MLZ); Monte Redondo, 20 Nov. -3 Dec. ( $38^{\circ}$, MCZ); Capa Rosa, 31 May ( $\%$, UF); Yeguare River Valley, 31 May ( 9 , UF); Choluteca River Valley, Dept. of El Paraíso, 23 Jan. ( $\sigma$, UF); Pledra de Jesús, 7-19 March ( $\sigma^{\prime}, 9$, AMNH); San

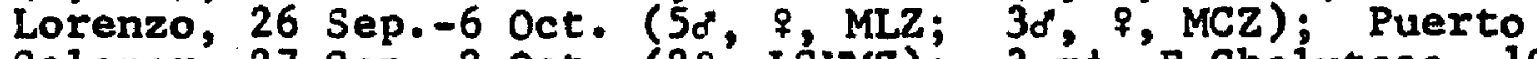
Salamar, 27 Sep. -2 Oct. ( 29 , LSLMZ); 3 mi. E Choluteca, 10 Feb. ( $\sigma^{\circ}$, LSUMZ); $6 \mathrm{mi}$. NE Choluteca, 6 oct. (\$ skel., LSUMZ); Honduras-Nicaragua boundary [near Pacific coast] $(?, \mathrm{MCZ})$.

PUBLISHED RECORDS --Pacific slope of Honduras [as Conurus petzi ? (Taylor $1860: 120-121$ ). San Lorenzo, Monte E1 Conejo (Moore, 1937: 102).

This species is the most common parakeet of the arid lowlands of the Pacific slope. It occurs also in the arid interior highlands to 5,000 feet and in the Comayagua Valley on the Caribbean drainage, but it is most common below 2,000 feet.

During the fall and winter of 1962-1963, I observed the species frequently throughout the Pacific lowlands. Flocks 
were noted in almost any type of forested or semi-open situation. They were abundant in the scrubby thorn forests in the vicinity of San Lorenzo and Choluteca. On 17 October 1962 I saw a small flock in the Comayagua Valley near Comayagua, but the species apparently does not occur elsewhere in the Caribbean lowlands or interior valleys on the Caribbean drainage.

Honduran specimens represent the nominate race, A. $\subseteq$. canicularis (Linnaeus).

Bolborhynchus 1ineola (Cassin)

Barred Parakeet

SPECIMENS.--B. 1. 1ineola (27): Finca Fé 22 Feb.-3 March (25, $9,2 \sigma^{\circ} \mathrm{keI} .$, LSUMZ); E1 Guayabal, 10-30 Jan. (40", 4\%,?, AMNH; 7", 3\%, 2?, MCZ); Alto Cantora1, 15 Feb. ( $9, \mathrm{MCZ})$.

PUBLISHED RECORD.--"Honduras" (Eisemann, 1955a: 39).

Locally distributed In Middle America, the Barred

Parakeet is basically a montane species, breeding in Honduras mostly above 5,000 feet but descending to as low as 2,000 feet in the nonbreeding season. Where it does occur, it is very common, flocks in excess of 100 individuals being Erequently observed. The species prefers cloud forest or montane rain forest, but in winter it often inhabits lowland rain forest between 2,000 and 3,000 feet elevation. C. F. Underwood secured the first Honduran spectmen at Alto Cantoral in 1934. At El Guayabal, in the Department of La Paz, the species must have been abundant during 
January 1937, when Underwood obtained the 21 specimens 1isted above. From 17 February to 4 March 1963, large flocks of this parakeet appeared in the rain forest of Finca Fé, at an elevation of 2,300 feet. The species was entirely absent at this location during the six months preceding this period and the two months following. On 17 April 1963 I noted a pair of Barred Parakeets at 5,000 feet in the mountains northwest of Cofradia, and I observed pairs subsequently at 4,000 feet on Cerro Santa Bárbara on 21 and 26 Apri1 1963.

Eisenmann (1955a: 39) listed the species from Honduras on the basis of the part of Underwood's series from E1 Guayabal that is currently deposited in the American Museum of Natural History.

Honduran specimens are referable to the Middle American race, B. 1. 1ineola (Cassin).

\section{Brotogeris tugularis (Müller)}

\section{Orange-chinned Parakeet}

SPECTMENS.--B. i. jugularis (9): Tegucigalpa, 31 Aug.

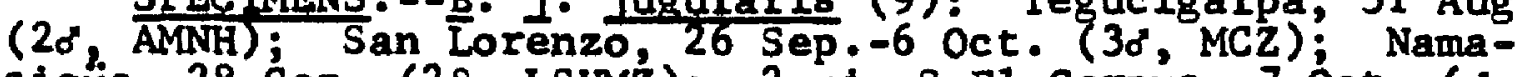
sigưe, 28 Sep. (2\%, LSUMZ); $2 \mathrm{mi}$. S El Corpus, 7 oct. ( $\sigma^{\circ}$, LSUMZ); "Honduras" (?, AMNH).

\section{(Taylor, 1860: 21 ). \\ PUBLISHED RECORD.--Tigre Is land [as Psittovius tovi]}

Brotogeris lugularis is an inhabitant of the arid Pacific lowlands and arid interior of Honduras up to 3,000 feet elevation. It is found in the same situations as is Aratinga canicularis but is silghtly less comon than the 
latter. The two species, however, tend not to $\mathrm{mix}$ in flocking.

Honduran specimens are representative of the widespread nominate race, B. 1 . fugularis (Müller). I agree with Howell (1957: 78-79) that the populations north of Costa Rica, to which the name B. 1 . chrysopogon (Lesson) has been applied, are not separable from jugularis.

Pionopsitta haematotis (Sclater and Salvin) Brown-hooded Parrot

SPEC IMENS. - -P. h. haematotis (15): San Alejo, 15 March ( 0 , LSUMZ); Lancetilia, 29 March ( $9, M C Z$ ); Yaruca, 16-27 Feb. (20, ₹, MCZ); San Pedro (2?, BMiNH); Las Peñitas 12 Feb. ( $\sigma$, BMNH); Chasnigua, 15 Jan. ( $\left.\sigma^{\circ}, C M\right)$; Arenal, 18 Jan. ( $\sigma^{\prime}$, UCLA); Segovia River, 28 June (28, $\&$, USNM); "Honduras" (2?, AMNH).

PUBLISHED RECORDS.--San Ped ro region (Sclater and Salvin, 1870b: 837). San Pedro (Salvin, 1871: 96; Salvadori, 1891: 344) Segovia River (Ridgway, 1888c: 592). Yaruca (Bangs, 1903: 143). West of Lancetilla (Peters, 1929b: 422).

In Honduras the Brown-hooded Parrot is a resident of lowland rain forest, occurring up to an elevation of 4,000 feet in low montane rain forest. It is uncommon to fairly common in the republic.

During the period from 10 November to 9 December 1962, I observed small flocks of less than 15 individuals each of this species on four separate trips to the east slope of Cerro Santa Bárbara. The area in which these birds were observed is one of low montane rain forest at 3,000 to 4,000 feet elevation. The only other occasions on which I have 
noted this spectes were during March and April 1963 at San Alejo, where these parrots were fairly common in the dense rain forest near sea level.

Honduran spectmens are typical of the Middle American race, $P$. h. haematotis (Sclater and Salvin).

\section{Pionus senilis (Spix)}

\section{White-crowned Parrot}

SPECIMENS.--(36): La Ceiba, 1-19 Jan., 29 March-12 May

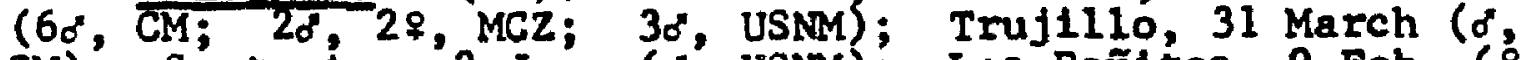
CM); Santa Ána, 2 Jan. ( $\sigma^{\circ}$, USNM); Las Peñitas, 9 Feb. ( $\$$, MCZ); Subirana, 9 Feb. ( $\sigma^{\circ}, \mathrm{MCZ}$ ); La Libertad, 11 June ( $\sigma^{\circ}$, AMNH); San José de Santa Bárbara, 17 April-6 May (5d, $q$, AMNH); $2 \mathrm{mi}$. SE El Jaral, 22 Feb. (o", LSUMZ); Lake Yojoa, 14 Aug. ( $\left.0^{\circ}, 2 \%, \mathrm{CM}\right)$; Siguatepeque, $11 \mathrm{July}(?, \mathrm{CM})$; Cantoral, 2 April ( $\delta, M L Z$ ); Monte Redondo, 21 Feb. ( $\sigma$ MCZ); Arenal, 24-28 Jan: (20", UCLA); Segovia River, 13-16 June (2d", USNM); "Honduras" (juv., BMNH).

PUBLISHED RECORDS.--San Pedro region (Sclater and Sa1vin, 1870b: 837). Segovia River (RIdgway, 1888c: 592). "Honduras" (Salvadort, 1891: 332). San Pedro (Salvin and Godman 1897: 75). La Ceiba (Bangs 1903: 143; Deignan, 1936: 190). Santa Ana (RIdgway, 1916: 216).

Occurring in Honduras primarily below 3,500 feet elevation, the White-crowned Parrot is a fairly common resident of lowland rain forests on the Caribbean slope. There are, however, records in the interior of Honduras to 5,500 feet, the secles apparently following the vega forests along the rivers to this elevation. This parrot occupies the same general habitat as does pionops 1tta haematotis and 1s decidediy commoner than the latter.

The southern Central American populations of this species have been described as P. B. decoloratus Griscom 
[1929b: 6; Pozo Azul de Pirris, southwestern Costa Rica], a race based on a more purplish (less blue) throat and chest, a darker green abdomen, and more extensively blue primaries, as comparad with the Mexican race, ‥ S. senilis (Spix). Griscom regarded birds from southern Quintana Roo, Britioh Honduras, and Honduras as intermediate but nearer desoloratus. I have examined the British Honduran and Honduran sertes and compared them with similar series from Mexico and Costa Rica. As pointed out by Brodbork (1943b: 41), there is a great deal of nongeographic variation in this species. The only geographic variation that I have been able to detect consists of a slight north-south trend toward smaller size and a very silghtly darker green abdomen in southern populations. I therefore follow Brodkorb (1943b: 40-41) and Russell (1964: 75) in considering decoloratue to be unrecognizable and the spectes to be monotypic.

\section{Amazona xantholora (Gray)}

Yellow-lored Parrot

SPECIMEN.--(1): Fronch Harbor, $4 \operatorname{Apr} 11$ ( $7, C M)$.

This spectes is found in Honduras only on Roatán Island, in the Bay Islands, where it is decidedly uncommon. It is apparently confined to the pine ridges there and is outnumbered by the much more abundant $A$. autumnalis and $\underline{A}$. ochrocephala. 
In the original description of A. xantholora Chrysotis xantholora Gray, 1859: 83; "Honduras"], which in reality was only a replacement name for the earlier Psittacus albifrons Kuhl (preoccupied), Gray only mentioned a single specimen, a skin in the British Museum taken in "Honduras" by David Dyson. As I have previously shown (see page 60), Dyson collected mostly in British Honduras, a country where xantholora is known to occur. Furthermore, the British Museun specimen is not actually the type, which is in the Temminck Collection in the Leyden Museum and is unlabelled as to locality (Peters, 1937: 217).

Ridgway (1916: 261) thought that a pair listed by Lantz (1899: 220) as Chrysotis albifrons and taken at Choloma by N. S. Goss were xantholora, but these individuals are, indeed, A. albifrons (Peters, 1937: 217).

The specimen taken by Arthur $C$. Twomey at French Harbor, Roatain Island, in 1947 is the only definite record for Honduras. This specimen is considerably smaller than a series of females from British Honduras, Yucatán, and Cozumel Island. Its wing measures 144.0 (slightly worn) as compared with 157.5-162.5 in other xantholora females. The Roatán population probably represents an undescribed race but until further material is obtained, best treatment is to retain the spectes as monotypic, since the size difference may prove to be an individual, not; geographic, variation. 


\section{Amazona albifrons (Sparrman)}

White-fronted Parrot

SPECTMENS.--A. a. nana (47): Cofradía, 7 March (20, MLZ); San Pedro ( ${ }^{\circ}$, AMNH); Choloma ( $\left.{ }^{\circ},{ }^{\circ}, \mathrm{KAS}\right)$; Urraco, 11 March ( $\left.{ }^{\circ},{ }^{\circ}, \mathrm{MCZ}\right)$; Chamelecón, 18 Nov. ( 9 , USNM); Chas nigua, $20 \mathrm{Jan} .\left(2 \sigma^{\circ}, \mathrm{CM}\right)$; Coyoles, 16 June-11 July $\left(20^{\circ}, 28\right.$, CM); Las Flores, Lempira, 26 Nov. (o skel., MLZ); Finca Fé, 13 Aug. ( $q$ ske1., LSUMZ); Montaña Vásquez, 5 Feb. ( MCZ); Monte Redondo, 24 March, 23 Sep., 22-30 Nov. (5d", 4q, MCZ); Archaga, 7 Nov. ( ${ }^{\circ}$, AMNH); La Cueva Archaga, 24 Sep. ( 8 skel., MLZ); La Fior Árchaga, 15 Nov. (2\%, AMNH); Cantarranas, 20 July (d, ANSP); E1 Hatillo, 28 April-8 May (40, 2\%, MCZ); Tegucigalpa, 18 Dec. (?, AMNH); Santa Clara, 8 June ( $\%$, UF); Rio Choluteca at Danlí bridge, 23 Jan. ( $\delta, 2 q$ UF); El Paraiso, 20 April ( $\sigma^{\circ}$, BMNH); Piedra de Jesús, 19 March ( $d$, AMNH); $8 \mathrm{mi}$. NE Choluteca, 8 oct. ( $\sigma$, LSUMZ); Honduras-Nicaragua boundary [near Pacific coast ] (?, MCZ); "Honduras" ( $\delta$, CNHM).

359). $\frac{\text { PUBLTSHED }}{\text { Between Lake Yojoa and San Pedro (Taylor, 1860: }}$ 121). San Pedro (Salvin, 1871: 97). Choloma (Lantz, 1899: 220). Chasnigua (Ridgway, 1916: 258). Palomas Toloa Canal [= Urraco] (Peters, 1929b: 422). Cantarranas (Stone, 1932: 309).

This species inhabits the arid Pacific lowlands, the arid interior below 6,000 feet, and the arid or sometimes more humid open areas of the interior valleys and Caribbean lowlands. It has been recorded from the Sula, Quimistán, Aguán, and Comayagua valleys, where on occasion it even enters more open portions of rain forest. Wherever it occurs in Honduras, it is the most frequently observed small parrot.

Honduran birds are referable to the southern race, $\underline{A}$. a. nana Miller, characterized by its much smaller size. Specimens from Honduras (wing, $\sigma<169.5, q<156.0$ ) are typical of this smaller subspecies. 


\section{Amazona autumnalis (Linnaeus)}

\section{Red-lored Parrot}

SPECTMENS.--A. a. autumnalis (62): French Harbor, 7 Apri1 $\left(3 \sigma^{\prime}, 27, \mathrm{CM}\right)$; Roatán Island, 7-9 Jan. (2?, BMNH; $\sigma^{\circ}$, q, CNFM); Tela, 21 Feb. ( ${ }^{\prime}, q$; MCZ); La Ceiba, 9-13 Jan., $10-16$ May $\left(20^{\circ}, q, \mathrm{CM} ; 30^{\circ}, \mathrm{MCZ}\right)$; Cofradia, 12 March ( $\$$, BMNH); Trujillo, 31 March-8 April, $26 \mathrm{Sep}$ (d, \&, CM; ?, USNM); San Pedro Sula, 15 July, 21 Nov. (2?, BMNH; $\delta$, CM; $\checkmark$, USNM); Chamelecón, 17 Feb.-8 March (50, 2\%, USMM); Subirana, 1 Feb. ( $\sigma^{*}, \mathrm{MCZ}$ ); Coyoles, 22 June ( $q, \mathrm{CM}$ ); San José de Santa Bárbara, 28 April-6 May (20, $₹$, AMNH; $20^{\circ}$, ₹, MCZ); E1 Jaral, 26 Sep. -15 oct. ( $\sigma^{\circ}, 2 \%$, AMNH); Finca Fé, 16 Sep., 11 Nov. (2o", LSUMz); Lake Yojoa, 23 June-25 Aug. $\left(60^{\circ}, 47^{\circ} \mathrm{CM} ;\right.$ F, UF); E1 Caliche, 30 June-6 July ( $20^{\circ}$, AMNH); San Marcos de Guaimaca, 19 June ( $\sigma^{\circ}$, AMNH$^{2}$; Alto Gualmaca, 10-14 June (20, MLZ); Segovia River, 18 June (?, USNM).

PUBLISHED RECORDS.--Omoa (Moore, 1859: 59). San Pedro region (Sclater and Salvin, 1870b: 837). San Pedro (Salvin, 1871: 98). Trujillo, Segovia River (Ridgway, 1888c: 583, 592). Roatán Is land (Salvin, 1889: 373). San Pedro, Roatán Is land (Salvadori, 1891: 304). La Ceiba (Bangs, 1903: 143). Chamelecón, San Pedro Sula (Ridgway, 1916: 235-236). $5 \mathrm{~km}$. W Tela (Peters, 1929b: 421). Lancetilla $[=5 \mathrm{~km}$. W Tela] (Stone, 1932: 309). Utila Is land, Barburat [= Barbareta Is land] (Bond, 1936: 358).

Occurring in and around lowland rain forest, the Redlored Parrot is the most common of the Amazona parrots in the humid Caribbean lowlands, ranging in the interior to an elevation of 3,500 feet. Flocks may be encountered also in more open, less humid, parts of the Caribbean slope valleys. In the Bay Islands, Bond (1936: 358) reported the species as common on Roatán and Barbareta, common in the mangroves of Utila, and absent from Guanaja. The species is very common on Roatán, but I failed to notice it or any other parrot on Utila during early May 1963. On the mainland I found the species to be most numerous in the 
Caribbean lowlands and to be the predominant parrot there. one very large roost, exceeding 200 individuals, was located in the vicinity of Agua Azul, on Lake Yojoa.

Howel1 (1957: 79) reported that specimens taken in the rain forest of Nicaragua about 100 miles south of the Honduran border were intermediate between the northern, nominate race, ㅅ․ a. autumnalis (Linnaeus), and ㅅ․ … salvini (Salvadori). The latter differs from the nominate race in having green, not yellow, cheeks. The single Honduran specimen from the Rfo Segovia, on the Nicaraguan boundary, is typical of autumnalis in having yellow cheeks, showing no signs of intergradation with salvini. I have therefore assigned all Honduran populations of the species to autumnalis.

\section{Amazona ochrocephala (Gmelin)}

\section{Yellow-headed Parrot}

SPECIMENS. - A. O. auropall lata (4): San Lorenzo, 30 Sep. (\%, MCZ); $7 \mathrm{ml}$. NE Choluteca, 9-12 0ct. (o", \& ske1; , LSIMZ); Honduras-Nicaragua boundary [near Pacific coast] (?, MCZ). A. o. subsp. nov. (15): Roatán Is land (4?, BMNH); Barbareta Is land II-12 April (20, $\left.{ }^{\circ}, C M\right) ;$ Guanaja (Bonacca) Is land, Feb., 24 March (?, ANSP; ${ }^{*}$, CM); Laguna Toloa, 30 Aug. ( $d$, ANSP); $3 \mathrm{mi}$. E La Lima, 20 Nov. ( $q$, LSUMZ); Chesnigua, 17 Jan. ( $\sigma, C M)$; Urraco, 10 March ( 9 , MCZ); Segovia River, 3 July ( $\sigma^{\prime,}$ USM ); "Honduras" (?, CM).

PUBLISHED RECORPS.--Tigre Island [as auripalliata] (Tay1or, 1860: 121-122). Yojoa [as Chrysot1s xanthops] (Taylor, 1860: 121-122, 317). Segovia River [as auripalliate] (Ridgway, 1888c: 592). Roatán Is land tas auripalliata] (Salvin, 1889: 373; Salvador1, 1891: 292; Salvin and Godman, 1897: 587). Chasnigua [as auropalliata] (Ridgway, 1916: 232). Palomas-Toloa Canal [= Urraco] [as auropalliata] (Peters, 1929b: 421). Laguna "Tela" 
[= Toloa], Tela Cana1 [= Toloa Cana1] [as auropalliata] (stone, 1932: 308) Bonacca [ Guanaja] Island las auropal11ata] (Bond, 1936: 358).

Populations of this species (or species complex) occur in Honduras in the Pacific lowlands, in the Sula Valley as far Inland as Lake Yojoa, in the Bay Islands (Roatán, Barbareta, and Guanaja islands), and in the Mosquitia. It is a fairly common to common species in all these reglons except the Sula Valley, where it is rare to uncommon and local in occurrence. In the Bay Islands and the Mosquitia, it is an inhabitant of the pine areas, while in the Pacific lowlands it is a resident of the arid scrub habitat. In the Sula Valley it is usually found in the open, scrubby areas of the drier portions of the valley.

Middle American populations of this spectes are currently being revised by Thomas $R$. Howell and myself. The taxonomic situation is greatly confused by the Honduran populations. There are three general groups of races within the species: a yellow-headed group in Mexico and British Honduras; a yellow-naped group confined to the Pactific slope of Middle America from Oaxaca to Costa Rica, except that Caribbean slope populations are found in Honduras and northeastern Nicaragua; and a yellow-crowned group resident from Panama south through much of South America. A form with the general appearance of the yellowcrowned populations occurs alongside the yellow-naped birds in the Sula Valley in Honduras, but these individuals may 
prove to be variants of the yellow-naped color type.

Prior to 1858 no A. ochrocephala at all had been recorded from Honduras. Taylor (1860: 121-122) reported the yellow-naped color type as common on Tigre Is land, in the Bay of Fonseca, and also recorded the species from Lake Yojoa. I quote from Taylor's paper:

- $\cdot$ nor did I see any large Parrots after I left the [Pacific] coast until I arrived at Yojoa, where there is a Parrot much resembling this [auropalliata] in plumage, but rather smaller, with the yellow on the fore part of the head instead of behind. They were flying in great numbers towards their roosting-places

In the appendix to his work, Taylor (1860: 317) referred to these latter birds as "Chrysotis xanthops," a synonym of the yellow-crowned A. O. ochrocephala (Gmelin). There can be 1ittle doubt that he observed a flock of the yellow-crowned color type that occurs in the Sula Valley.

The species was not reported from the Sula Valley again until Erich Wittkügel obtained a specimen in 1892 at Chasnigua, a locality on the outskirts of La Lima. Ridgway (1916: 233) reported this specimen as auropalliata and it is Indeed an Individual of the yellow-naped color type. Another specimen of the yellow-naped type was taken by Edward Bangs (Peters, 1929b: 421) in 1928 along the Toloa Canal at Urraco, about 12 miles northeast of La Lima. There have been no other reports of the yellow-naped type from the valley. 
John T. Emlen, Jr., and C. Brooke Worth collected a male of the yellow-crowned color type at Laguna Toloa, about five miles north of Urraco, in 1930 (Stone, 1932: 308); they also noted several others there, although the color type was not specifically mentioned. Kenneth S. Hamilton obtalned a female of this color type in 1962 about three miles east of La Lima. He informed me (personal communication) that the flock from which this individual was secured consisted of about 50 individuals and that the few he observed closely were all of the yellow-crowned type. It may be noted that all four Sula valley specimens, two of each color type, were taken within 20 miles of one another.

C. H. Townsend (Ridgway, 1888c: 592) collected the first specimen from the Mosquitia in eastern Honduras, a young bird that Ridgway tentatively referred to auropalliata. The apectes was not recorded from the Honduran Mosquitia again until I found it to be fairly common in the vicinity of Puerto Lempira in April 1964, although Howell (personal communication) has obtained a fine series from the Nicaraguan Mosquitia. All birds observed or collected in the Mosquitia have been of the yellow-naped type.

Thte color type 18 also common on Roatán, Barbareta, and Guanaja islands, in the Bay Islands. G. F. Gaumer (Salvin, 1889: 373) collected four specimens on Roatán in 1886 or 1887 . Bond (1936: 358) reported it as falrly common on Guanaja, securing a specimen in February 1936. 
Arthur C. Twomey and Roland W. Hawkins obtained a pair on Barbareta on 11 April 1947, a male on Barbareta on 12 Apri1 1948, and a male on Guanaja in 1948. There have been no reports of the yellow-crowned color type from either the Bay Is lands or the Mosquitia.

Salvin and Godman (1897: 587) theorized that perhaps the presence of yellow-naped Individuals on the Caribbean coast of Honduras and in the Bay Islands, while this type is confined elsewhere to the Pacific lowlands, might have been the result of birds escaped from domestication. This idea 1s supported by the presence in the Sula Valley of many caged psittacine birds of forms that occur in a wild state only in the Pacific lowlands. However, recent studies by Howell and me have shown that the Cartbbean birds all differ In a number of respects from true auropalliata on the Pacific slope. The Caribbean populations possess red at the bend of the wing in addition to red at the base of the wing near the shoulder (red trace at bend of wing in only three of 65 specimens examined), have a paler bill, and have smaller and much less massive feet and toes. The yellowcrowned Individuals from the Sula Valley are tentatively regarded as variants of this form described above, pending acquisition of additional material. Perhaps two eibling species exist in the Sula Valley, but this possibility must await further study. 
Specimens from the Pacific coast of Honduras are typical of the yellow-naped subspecies, A. ․ auropalliata (Lesson). Caribbean slope populations differ in the features given in the preceding paragraph and represent an unnamed subspecies, which will be described in a joint paper by Howell and myself, now in preparation.

\section{Amazona farinosa (Boddaert)}

Mealy Parrot

SPECIMENS. --A. f. guatemalae (3): "Honduras" [= Omoa] (?, BMNH); "Honduras" [ Santa Bárbara, east slope, 22 Nov. ( $\delta$, LSLMZ).

PUBLISHED RECORPS.-- "Honduras" (Salvin and Sclater, 1860: 44; Sclater, 1862: 353; Salvadori, 1891: 280). San Pedro region (Sclater and Salvin, 1870b: 837). San Pedro (Salvin, 1871: 98-99). Omoa (Salvin and Godman, 1897: 584).

This parrot is an uncommon resident of tropical lowland rain forest on the Caribbean slope of Honduras, occurring up into low montane rain forest to 4,000 feet.

I encountered this parrot only in the low montane rain forest on Cerro Santa Bárbara. On 26 October 1962 I noted a flock of about 10 individuals high in the forest canopy at an elevation of 3,700 feet. On six subsequent occasions between 2 November and 9 December 1962, flocks of 15 or fewer birds were seen at this same locality. This spectes did not mix with any other parrot during my observations. The northern subspecies, A. E. guatemalae CChrysotis guatemalae "Hartlaub MS." Sclater, In Salvin and Sclater, 1860: 44; "Guatemala and Honduras" (= Omoa, Honduras)], 
differs from the southern Central American race, A. $\underline{f}$. virenticeps (Salvadori), primarily in possessing a bluish rather than greenish crown. In the original description of guatemalae, Sclater mentioned that he had seen two specimens but did not designate a type; he indicated later (1862: 353) that the type was a specimen taken in Honduras by Joseph Leyland and deposited in the British Museum. Salvin and Godman (1897: 584-585) stated that the Leyland specimen was taken at Omoa, where Leyland did most of his collecting. There can be little doubt that this specimen is, indeed, the type and that it came from Omoa.

The type of guatemalae and the specimen taken at San Pedro by George M. Whitely are blue-crowned guatemalae. The single specimen that I secured on Cerro Santa Bárbara in 1962 is not entirely typical of guatemalae. It shows some approach to virenticeps in having the crown not quite so blue as guatemalae from British Honduras and Mexico. Populations in the rain forests of eastem Honduras probably are representative of virenticeps; at the present time, however, there are no specimens from the eastern half of Honduras.

Family CUCULIDAE

Coccyzus erythropthalmus (Wilson)

Black-billed Cuckoo

SPECIMRNS.--(5): Cantora1, 1 April ( 9, AMNH); Monte 
Redondo, 6 Sep. ( $\delta, M C Z$ ); El Boquerón, 23 Sep., 16 Oct. ( $\delta$, \%, AMNH); $4 \mathrm{mi}$. NE Choluteca, 3 Oct. (d, LSUMZ).

Although there are no published reports of the species for Honduras, the Black-billed Cuckoo is a fairly common migrant, occurring in most parts of the republic in a wide variety of habitats and at elevations varying from sea level to 6,000 feet. It seems to be most common, however, in the lowlands. Extreme dates of occurrence in Honduras for fall are 6 September and 4 November and for spring are 1 April and 4 May.

C. F. Underwood secured four specimens in Honduras, a male at Monte Redondo in 1932, a female at Cantoral in 1934, and a pair at $\mathrm{E} 1$ Boquerón in 1937. In the fall migration of 1962 I noted single Individuals at Taulabé on 24 September and at Finca Fé on 2 and 4 November; four individuals were seen on 3 October near Choluteca and single birds were recorded at San Francisco $(3,500$ feet elevation) on 7 October and at Cedeño on 13 october. In the spring of 1963 I saw one at 5,000 feet on Cerro Santa Bárbara on 25 April, one at San Pedro Sula on 1 May, and one on Utila Is land on 4 May.

\section{Coccyzus americanus (Linnaeus)}

\section{Yellow-billed Cuckoo}

SPECTMENS.--C. E. americanus (14): Swan Is lands, 14 April ( ${ }^{\circ}$, USNM); Roatán Is land (?, BMNH); La Ceiba,' 1 Apri1, 1-10 May (20, 28, CM); LOB Planes, 11 June ( $\$, C M)$; Coyoles, 13-19 June ( ${ }^{\circ} 22^{\circ} \mathrm{CM}$ ); Finca Fế, 27 April (ó, LSUMZ); Tegucigalpa, 20 Nov. ( $\$$, MCZ); Yeguare River Valley, 13 Nov. ( $q$, UF); $4 \mathrm{ml}$. NE Choluteca, 13 Oct. ( 9 , 
LSUME). C. a. occtdentalis (1): $6 \mathrm{mi}$. NE Choluteca, 12 Oct. ( 9, ISUMZ).

PUBLISHED RECORDS--Tigre Is land (Taylor, 1860: 118). Swan Islands (RIdgway, 1888c: 577). Roatán Island (Salvin, 1889: 372 ).

The Yellow-billed Cuckoo is a common migrant in Honduras, found in the lowlands of both coasts and to an elevation of 3,500 feet in the interior. It is also regular In the Swan Islands and in the Bay Islands off the north coast. Extreme dates of arrival and departure for fall are 11 September and 20 November and for spring are 1 April and 19 June.

The eastern race, $C$. a. americanus (Linnaeus), migrates along both coasts and is the subspecies that occurs most frequently in Honduras. The larger, western race, $\underline{C}$. $\mathrm{a}$. eccidentalis Ridgway, is an uncommon migrant along the Pacific coast of Central America and is known from Honduras only by the single female (wing, 153.5) that I collected near Choluteca in 1962. I have assigned all other spec1mens to the nominate race on the basis of size; these Honduran birds (wing, o 133.2-150.5, ๆ 134.5-148.5) all fall within the expected range of variation of americamus.

\section{Coccyzus minor (Gmelin)}

Mangrove Cuckoo

SPECTMENS.--C. m. nes lotes (5): Swan Islands, $18 \mathrm{Feb} .-$

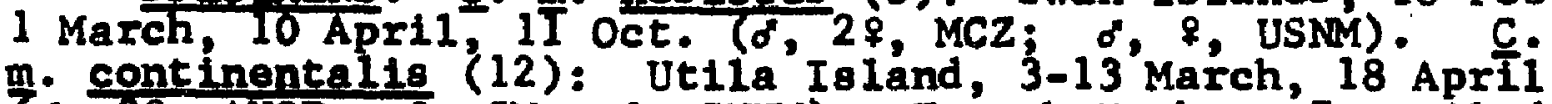
Tdi 37, ANSP; 9 , CM; 9, CNHM); French Harbor, 7 April ( 9 , CM); Roatán Is land ( 3 ? , BMNH); Puerto Cabello [ = Puerto Cortés] (?, BMNH); La Ceiba, 29 March (d, USNM). 
PUBLISHED RECORDS.--"Honduras" (Sclater, 1870: 166167). San Pedro region (Sclater and Salvin, 1870b: 837). Swan Islands (RIdgway, 1888c: 577; Paynter, 1956: 105, 107). Roatán Island (Salvin, 1889: 372). Roatán Island, Puerto Cabello [= Puerto Cortés] (Sclater and Shelley, 1891: 305). Utila Is land (Bond, 1936: 358). La Ceiba (Deignan, 1936: 190).

This cuckoo has been reported as a fairly common migrant in the Swan Islands and as a fairly common resident in the Bay Islands and along the north coast of Honduras. There seems to be little doubt that the bird does not nest in the Swan Islands but is only a migrant from Jamaica or the Cayman Islands. Moreover, all the dated records along the north coast of Honduras and in the Bay Islands are for March and April. Bond (1936: 358) recorded it as fairly common on Utila, but I failed to find the spectes there during the first two weeks of May 1963. It has been recorded from Roatán in April but has not been found on Guanaja. Since it is resident along the Caribbean coast of Central America, it is presumed to be also in Honduras, although there is no direct evidence that it is anything but a migrant.

On the Pacific coast of Central America, the race c. m. palloris Ridgway occurs, being confined primarily to the coastal mangroves. Although there are no specimens of this race from Honduras, a single individual that I saw on 2 October 1962 in the mangroves at Puerto Salamar, Just east of San Lorenzo, was undoubtedly representative of palloris. 
Specimens from the Swan Islands are all referable to the race $\underline{c}$. $\underline{m}$. nesiotes (Cabanis and Heine), the breeding subspectes of Jamaica and the Cayman Islands. The Cayman Island bird was described as G. m. caymanenstg Cory, but this population is not distinguishable from nesiotes. A11 other Honduran secimens are referable to the race $C$. m. continentalis van Rossem [1934c: 389; Volcan de Santa Ana, altitude 4500 feet, Dept. Sonsonate, E1 Salvador], which differs from palloris by its darker color and smaller size.

\section{Playa cayana (Linnaeus)}

Squirrel Cuckoo

SPECTMENS.--P. c. thermoph1la (61): Jultán [= Tulián] (?, ANSP); Lancetilia, 18 Jan. -9 Feb. 3 March, 24-31 Aug. (20, ANSP; 38, 38, MCZ); La Ceiba, 5-21 Jan., 29 April-1 June $\left(5 \delta^{\circ}, 7, \mathrm{CM} ; \delta^{\circ}, 3 \%, \mathrm{MCZ}\right.$; $\delta, \%$, USNM); Yaruca, 11-16 Feb. ( $\sigma^{\circ}, 9, \mathrm{MCZ}$; 9 , USNM); Los Planes, 11 June $\left(40^{\circ}, 2^{2}\right.$, CM); Trufillo, 6 April, 26 Sep. ( $\sigma, C M$; ?, USNM); Catacombas, 8 April ( $\%$, AMNH); Cofrad ${ }^{\prime} a, 2-15$ March ( $\$$, BMNH; 8, MLZ); San Pedro Sula, 12-30 July, 29 Dec. (?, BMinh; 28, \$. USM ; Chamelecón, 20-23 Feb. (o", 28 USNM); Subirana, 30 Jan. ( $\%, M C Z)$; Coyoles, 13-29 June $(2 \delta, 28, C M) ;$ San Esteban, 1 July (o, $f, C M)$; Finca Fé, 20-21 Ján., 12 Aug., 3 Sep., 25 Nov. -15 Dec. (d, $39, d$ skel., 39 skel., LSUYZ); $2 \mathrm{ml}$. I Pito Solo, 13 oct. (o' ske1. LSúr); Arenal, 26 Jan. ( $\delta$, UCLA); Segovia River, 14-18 June (2 $\delta$, USNA). c. theriophlia $\times$ atirtoni (16): E1 Conejo 15 May (o, MLZ); Monte Redondo, 30 Kov.-12 Dec. ( $\delta^{2} 28, \mathrm{MCZ}$ ) San Juanc1to, 15 July ( 9 , ANSP); Cantarranas, 2-5 Aug - (3o, $\%$, ANSP); Eecuela Agricola Panamericana, 3 Sep. (d, UF); Yeguare River Valley, 27 Jan., 2-26 June, 13 Nov. (48, UF); Monserrat, 28 May (q MCZ); Rio de La orilla, 29 May (o, MCZ). B. f- Btirtoni (2); $7 \mathrm{mt}$. NE Choluteca, 13 oct. (?, LSUMZ); 2 mT. NW Cedeno, 11 Feb. (of, LSUMz). Undetermined (1): vicinity Tegucigalpa, 8 May ( 8 skel., MLZ).

\footnotetext{
PUBLISHED RECORDS,--Comayagua (Sclater, 1858b: 359). Omoa (Moore, 1859: 60). "Honduras " (Taylor, 1860: 118; Forbes and Robinson, 1898a: 43). San Pedro region (Sclater and Salvin, 1870b: 837). Truj1110, Segovia River (RIdgway, 1888c: 582, 591). San Pedro (Sclater and
} 
Shelley, 1891: 376). La Celba, Yaruca (Bangs, 1903: 143). San Pedro Sula (Stone, 19n8; 499). Lancetilla, Tela (Peters, 1929b: 435). Cantarranas, San Juanc1to, Lancetilla (Stone, 1932: 307).

Ranging up to an elevation of about 5,000 feet, the Squirrel Cuckoo is a common species through most of the lowlands of Honduras. Below its altitudinal limit, it is found in almost any type of open forest, second growth, or semi-open area with the exception of pine. On the Pactfic slope it occurs in arid scrub as well as in open areas of monsoon forest. In the interior it is most common in the broadleaf vega forests along the rivers.

The Caribbean lowland race, P. c. thermophila Sclater, is the resident subspectes in most of the Caribbean drainage below 3,000 feet elevation. Pacific cosst lowland birds are decidedly paler below than thermophila and represent the race $P$. C. stirtoni van Rossem [1930a: 209; Mt. Cacaguatique, Dept. San Miguel, sl Salvador]; typical specimens of this race have been taken only below an elevation of 1,000 feet. Interior birds in Honduras are varyingly intermediate between thermophila and stirtoni, with individuals from a single locallty ranging from one extreme to the other.

\section{Crotophaga an1 Linnaeus}

Smooth-billed Ant

SPEC MENS --(21): Big Swan Island, 5 Jan. ( $\%$, CNEM); Swan Islands, 1 March (26, MCZ); Utila Is land, 28 Feb., 4 May ( ${ }^{\circ}, 7$, CNHM; 9 , LstMZ); French Harbor, 4-6 Aprt1 (3d, 
39, CM); Roatán Island (6?, BMNH); Guanaja Island, 22-24 $\operatorname{March}(\delta, 2 \%, C M)$.

PUBLISHED RECORDS.--Roatán Is land (Salvin, 1889: 372; Sclater and Shelley, 1891: 431). Swan Islands (Lowe, 1909: 335; Delacour, 1938: 544; Paynter, 1956: 105). Bonacca [= Guanaja] Is land, Utila Island (Bond, 1936: 358).

The Smooth-billed Ani is an Antillean species that has colonized the islands in the Caribbean Sea off the north coast of Honduras. It is resident in the Swan Islands and on all the main 1slands (Utila, Roatán, and Guanaja) of the Bay Islands group; it does not occur, however, in the Cayos Cochinos. The species is uncommon on Utila and on Guanaja but is decidedly common in the Swan Islands and on Roatán. The species has never been recorded from the mainland of Honduras. The report of Taylor (1860: 118) is sometimes referred to $\underline{C}$. ani (Ridgway, 1916: 102) but definitely pertains to $\mathcal{~}$. sulctrostris (Bond, 1936: 358).

\section{Crotophaga sulcirostrts Swainson}

\section{Groove-billed Ani}

SPECTMENS - -C. S. Sulcirostris (34): Lancetilla, 26 Jan., 23 Aug. ( 9, ANSP; 9, MCZ); La Ceiba, 4 Jan., 19 Apri1-29 May (29, CM; 7, MCZ; o, ₹, USMM); Yaruca, 9-16 Feb. ( $0^{\circ}, 2 q$, MCZ; $0^{\prime \prime}$ USNM); Trujilio, 23 Sep. (2q,?, USNM); Las Peñitas, 2 Feb. ( $q$, BMNH); La LIma, 18 oct. ( $\sigma^{\circ}$ skel., LSUMZ); Amapa, 8 Dec. (d skel., ISUMZ); Subirana, 10 Dec. ( $\left.\sigma^{\circ}, \mathrm{MCZ}\right)$; Coyoles, 17 June $\left(\sigma^{\circ}, C M\right)$; Finca Fé, 24 Nov. ( ${ }^{\prime},{ }^{\circ}$, LSUMZ); Cantarranas, $19 \mathrm{July}-5$ Aug. ( $0^{\circ}, 3 \%$, ANSP); vicinity Tegucigalpa, 28 April ( ${ }^{*}$ skel., MLZ); Comayagüiela, 2-23 Jan. (", \$, MCZ); Escuela Agrícola Panamericana, 6 Nov. ( $\sigma^{\prime}$, UF); Yeguare River Valley, 14-27 Jan. 10 March, 25 May (2\%, 2\%, UF); Segovia River, 12 Aug. (\%, USNM).

PUBLTSHED RECORDS --Comayagua (Sclater, 1858b: 359). Omoa (Moore, 1859: 59). "Honduras" (Taylor, 1860: 118; Forbes and Robinson, 1898a: 46). San Pedro region 
(Sclater and Salvin, 1870b: 837). Trufillo, Segovia River (RIdgway, 1888c: 582 , 591). La Celba, Yaruca (Bangs, 1903: 143). Lancetilla, Tela (Peters, 1929b: 435). Cantarranas Lancetilia (Stone, 1932: 307). La Cetba (Deignan, 1936: 190). Near Tela (skutch, 1945a: 16). Lancetilia (Skutch, 1954a: 9).

This species is one of the most conspicuous features of the avifauna of the lowlands of both coasts of Honduras. It is common to abundant in almost every open or semi-open situation below 3,000 feet, and it occurs in sparse numbers to an elevation of 5,500 feet in the interior.

In addition to the specimens Iisted above, there are others (not examined) from "Honduras" in the Derby Museum (Forbes and Robinson, 1898a: 46).

Honduran birds are representative of the nominate race, C. S. Sulcirostris Swainson.

\section{Tapera naevia (Iinnaeus)}

Striped Cuckoo

SPECIMENS - - - T. n. excellens (17): Los Planes, 11 June, $7 \mathrm{July}\left(2 \delta^{\prime}, \mathrm{CM}\right)$; Cof́radla, $4 \mathrm{March}$ ( $\left.6, \mathrm{MCZ}\right)$; San Pedro Sula, 2 July ( $\sigma^{\circ}$, USNM); La Lima, $20 \mathrm{Feb}$. ( $\%$ LSUMZ); Chamelecón, 8 March ( $\sigma^{\circ}$ USNM); Santa Bárbara, 11-15 May ( $\sigma^{\circ}$ \%, AMNH); Finca Fé, 20 Jan., 1 Dec. $\left(\sigma^{\circ}, \delta^{\prime}\right.$ skel., LSUMZ); Lake Yojoa, 18-20 July (20, CM); E1 Caliche, 10 July ( $\sigma^{\circ}$, AMNH); E1 Boquerón, 26 Aug. ( $\sigma^{\circ}$ MCZ); San Lorenzo, 1 Oct. ( $\sigma^{\prime}$, MCZ); $3 \mathrm{ml}$. NW Namasigüe, 8 óct. ( $\%$, LSUMZ); "Honduras" (d, AMNH).

PUBLISHED RECORDS:--San Pedro (Moore, 1859: 60). San Pedro Sula (Ridgway, 1916: 69).

The Striped Cuckoo is an uncommon to falrly common resident of the lowlands of both coasts, occurring in second growth and in semi-open, brushy areas below 2,500 feet. It is less frequent in the arid Pacific lowlands than in the 
Caribbean lowlands. The call-note (or song) is a plaintive double-noted whistle, the second note higher in pitch than the first; the species is more often heard than seen, being rather secretive in habits.

Honduran birds are all referable to the widespread Middle American race, $\underline{\text {. }}$. excellens (Sclater). Pacific coast populations have been distinguished as $I$. $\underline{n}$. major Brodkorb [1940a: 543; Tonalá, Chiapas] on the basis of their larger size, but I cannot detect any differences in size from Caribbean slope individuals; in fact, my specimen from near Namasigüe is the smallest of the Honduran series. If major proves to be valid, the range probably would not extend south of El Salvador.

\section{Morococcyx erythropygus (Less on)}

Lesser Ground Cuckoo

SPEC MENS. - -M. e. erythropygus (24): Manacal, 3 Feb. (ske1. LSUMZ); Santa Ana, 31 Oct. ( $\sigma$, USNM); 18 mi. SE Potrerillos, 2 Nov. ( $\sigma^{*}$, LSLMZ); Coyoles, 20 June-1 July (46, CM); La Libertad, 13 June ( $\$$, MCZ); Monte El Conejo, 20 May ( $\$$, MLZ); Santa Bárbara, 9-30 May ( $\$$, AMNH; d, MCZ); LImones, Monte Redondo, 8 Sep. (28, MCZ); Monte Redondo, 21 Sep. ( $8, \mathrm{MCZ}$ ); La Flor Archaga, 27 May ( ${ }^{\circ}$, MCZ); B1 Hati11o, 2 May, 14 Aug. ( $\$, C M$; o, MCZ); Escuela Agrícola Panamertcana, 7 April ( $\delta, U F)$; Yeguare River valley, 29 Jan., 12 June $(\delta, 9, U F)$; Yuscarén, 17 April ( $\sigma^{\circ}$, BNNH); San Lorenzo, 26 Sep. $-6^{\circ}$ Oct. ( $20^{\circ}, \mathrm{MCZ}$ ); Honduras Hicaragua boundary [near Pacific const] ( $?$, MCZ).

Santa AURA (RIdgway, 1916: 72).

In Honduras the Lesser Ground Cuckoo is a resident that is fatrly common in the arid Pacific lowlands and, in a lesser degree of abundance, in the arid interior below 5,000 
feet. It is most common in the artd scrub near sea level in the Pacific lowlands. On the Caribbean slope it is confined to the arid portions of the Quimistán, Sula, Comayagua, and Aguán valleys. It is another of the secretive ground cuckoos that is often heard but rarely seen; its song consists of a descending series of whisting notes that diminish in intensity and frequency until they seem to fade away.

Honduran specimens are representative of the nominate race, $M$. e. exythropygus (Lesson), although the Caribbean slope birds average slightly darker and more rufescent on the under parts than those from the Pacific drainage. This variation does not seem to be constant and many individuals cannot be distinguished. The large Motagua Valley race, $\underline{M}$. e. macrourus Griscom [1930b: 2; Progreso, Guatemala], does not occur in Honduras; specimens from all parts of Honduras measure consistently smaller in tail length $(<130.5)$ than does macrourus $(>138)$.

\section{Dromococcyx phastanellus (Spix)}

Pheasant Cuckoo

SPECIMENS. - - D. p. nuflgularis (9): Las Peñitas, 22 Feb. $(\sigma, q, M C Z)$; Chasntgua, $21-28$ Jan. ( $d, q$, USMM);

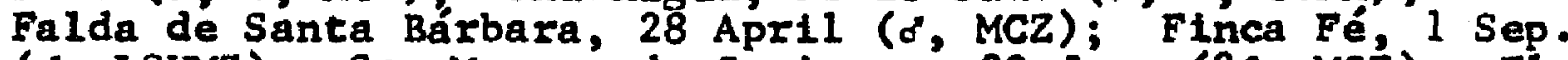
( $\sigma$, LSUMZ); San Marcos de Guaimaca, 30 June (2\%, MCZ); EI Boquerón, 23 Sep. (o, MCZ).

PUBLISHED RECORD.--Chasnigua (Ridgway, 1916: 89).

Preferring more wooded situations than its relatives, Tapera naevia and Morococcyx erythropygus, the Pheasant 
Cuckoo is dectdedly uncomon in Honduras. The species may be found in the lowlands of both coasts below 3,000 feet. I have recorded it in the more open portions of deciduous forest around Lake Yojoa and in the monsoon forest on the Pacific slope in the Department of Choluteca. The most frequently heard call-note in Honduras is very similar in pattern and quality to one call of Formicarius analis. It is a three-noted whistle, the first two notes given rapidiy with the second note higher pitched and slurred up the scale, the last whistle being finished (after a slight pause) on the same pitch as the first.

Honduran populations are referable to the Middle American race, D. p. rufigularis Lawrence.

\section{Geococcyx velox (Wagner)}

Lesser Roadrunner

SPECIMENS.--G. v. long 18 ienum (43): Cofradfa, 7 March ( $\sigma$, BMNL); Subirana, 10 March (J, MCZ); Portillo Grande, 31 Jan., 14 March ( $\sigma^{\circ}$, CNM ; $\$$, MCZ); Coyoles, 28 June-11 July $\left(\sigma^{\circ}, q, C M\right)$; San Esteban, 21 June $\left(\sigma^{\circ}, C M\right)$; Montafia E1 Chorro, 24 June (o', MLZ); Monte E1 Conejo, 27 May (o', MLZ); Plan del Rancho, 9 July (2\%, MIZ); Pito Solo, 16 Sep. (? ske1., LSUMZ); Monte Redondo, 22 Sep., 22 Nov.-2 Dec. (o", AMONH; $30^{\circ}, M^{\circ} Z$ ); Rfo Hondo, 18 Aug. ( $\left.{ }^{\circ}, 29, C M\right)$; San Juancito, 17 July-8 Aug. ( $30^{\circ}, \%$, ANSP; $\left.\%, C M\right)$; E1 Hatillo, 1 July (o, MLZ); E1 Tigre, 1-9 July (o, \&, MLZ); Cerro Tigre, 1 July ( $f$, MLZ); Tegucigalpa, 18 July, 3 Sep, $11-23$ Oct. ( $\sigma$, AMNH; $\delta, 29$, MLZ); Comayagüela, 16 Jan., 19 Sep.1 Oct. 1 Nov. (40, ?, MCZ); $9 \mathrm{mt}$. S Tegucigalpa, $26 \mathrm{sep}$. ( $d$, ISUMZ); Yeguare River Valley, 18 Nov. ( $q$, UF\}; road to San Antonto, 10 June ( $\%$, MCZ); Las Mesas, $13 \mathrm{Feb}$. ( $q$, UF); Choluteca Valley, Dept. of E1 Paraiso, 23 Jan. ( 8 , UF); "Honduras" (?, AMNH).

PUBLTSHED RECORDS.--San Juancito (Stone, 1932: 308). Comayabuela [I Comayagüela], Monte Redondo (Moore, 1934: 464-467). 
The Lesser Roadrunner is an uncommon to fairly conmon species of the arid interior of Honduras, occurring in open and seat-open situations, especially where there is at least scattered, scrubby undergrowth. It ranges mostly from 3,000 to 6,500 feet but descends to about 1,000 feet in the arid portions of the intertor valleys on the Caribbean drainage.

As has been pointed out by Stone (1932: 308), the Inclusion of Honduras in the range of this species by Ridgway (1916: 82) was not based on any record now extant. Stresemann (1954: 90) has shown that viaticus of Deppe (1830) apparently has priority over velox of Wagner (1836). In view of the fact that viattcus has not been used in recent works, it may be regarded as a nomen oblitum under the current International Code of Zoological Nomenclature. Perhaps the best procedure is to continue to use the wellknown yelox and to petition the International Commission for retention of velox as a nomen concervandum.

I refer all Honduran specimens to the race $G$. $\underline{v}$. longisignum Moore [1934a: 464; Comayabuela (= Comayagüela), Honduras], characterized by the more extensive white tips to the outer rectrices and the generally darker back coupled with more prominent white streakings than is the case in $G$. y. affinis Hartlaub. With regard to white tips on the rectrices, Honduran specimens considerably exceed the range of variation given for longisionum in the original 
description. On the average, Honduran populations fit well In longigignum (e.g, length of white tip on outer rectrix averages 42.5 in males and 36.8 in females). The Honduran series compares favorably with Nicaraguan specimens and shows no approach to affinis, even in the individuals from the Department of Ocotepeque, nearest geographically to affinis.

Family TYTONIDAE

Tyto alba (Scopoli)

Barn Ow 1

SPECIMENS.--T. a. pratincola (5) French Harbor, 7 April $(\delta, 7, \mathrm{CM})$; Bonacca $[=$ Guanaja] Is land, $29 \mathrm{Feb}$. ( $\%$. ANSP); Los Planes, 15 July $\left(\sigma^{\circ}, \mathrm{CM}\right) ;$ La Lima, 8 Jan. ( $\sigma^{\circ}$ skel. LSUMZ). I. a. guatemalae (16): Lake Yojoa, 25 June ( $9, \mathrm{MCZ})$; Siguatepeque, $10-12 \mathrm{Ju} l y$ ( $\left.{ }^{\circ},{ }^{2}, \mathrm{CM}\right)$; E1 Caliche, 30 June $(\delta$, UC): San Marcos de Guaimaca, 20 June (?, CNHM); Cantoral, 3 Nov. ( $\$, M C Z)$; La Cueva Archaga, 3 Aug. ( 8 , MCZ); La Flor Archaga, 30 May ( $\delta, U C)$; Tegucigalpa, 5 Jan., 22 Dec. ( $\sigma^{\circ}{ }^{\circ}$, CNHM) ; Escuela Agrícola Panamericana, 19 March, 4 May-22 June, 14 Oct., 30 Dec. (28, 49, UF). 1936: $\frac{\text { PUBLISHED }}{358-3595}$

The Barn Owl is an uncommon to fairly common resident in the Caribbean lowlands, in the interior highlands below 5,000 feet, and in the Bay Is lands (on Roatán and Guanaja 1slands). It is probably more abundant than records indicate.

Honduras was mentioned in the range of this species by Ridgway (1914: 611), but I do not know of any Honduran record prior to 1930 . 
The first report of the species in Honduras, as well as the first breeding record for the country, was made by Bond (1936: 358-359), who collected an adult female at a nest on Guanaja Island in 1936. The nest, placed 25 feet above the ground in a decayed pine stub, contained one newly-hatched young and two eggs.

The assignment of the Honduran specimens to either the North American race, I. a. pratincola (Bonaparte), or to the Central American race, $\underline{T}$. a. guatemalae (Ridgway), must be regarded as tentative. The primary difference between the two subspecies is the predominance of the tawny phase in guatemalae. This phase is rare in pratincola. The is land populations of Honduras are apparently correctly assigned by Bond (1936: 358) and subsequent authors to pratincola as all are white phase birds and indistinguishable from North American specimens. The lowland Caribbean birds of the mainland are also tentatively assigned to pratincola. The male taken by Arthur $C$. Twomey and Roland $W$. Hawkins at Los Planes in 1950 is a white phase individual matching pratincola; the La Lima specimen was picked up dead on the road and was skeletonized, but the color pattern was that of pratincola. The other specimens, except for several from the interior highlands, are in the tawny phase; the few white phase birds, however, are generally spotted more heavily, when compared with pratincola, and usually have a trace of rufous on the thighs. There may be some migration 
In this species in Central America, but until this fact can be established, I am regarding all populations as resident and those of the interior highlands as quatemalae.

\section{Family STRIGIDAE}

\section{Otus trichopsis (Wagler)}

Spotted Screech Owl

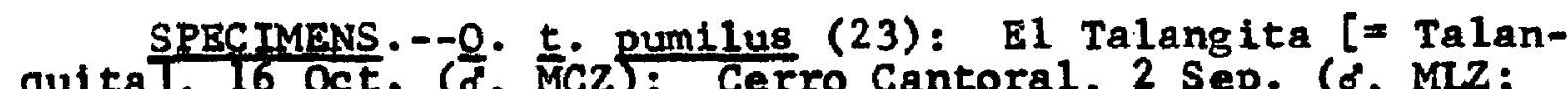
quitaJ, 16 Oct. ( $\left.\delta^{\circ}, \overline{M C Z}\right)$; Cerro Cantoral, 2 sep. (o, MLZ; $\{, M C Z$; Monte Redondo 2 Dec. ( $\$$, MCZ); La Flor Archaga, 2 May-1 July, 15 Aug., 11-16 Dec. '40, 39, MLZ; 29, MCZ; 28, UC); Ilamapa, 18-20 Aug. ( $\delta, \&, M C Z) ; ~ E 1$ Derrumbo, 10 May, 20 July (2o, MCZ); Tegucigalpa, 11 June, 6 oct. ( $\$$, MLZ; \&, MCZ); vicinity Teguctgalpa, 11 June ( $\delta$, MLZ); Yeguare River Valley, 8 June ( $\delta$, UF).

PUBLISHED RECORDS.--E1 Derrumbo, Cerro Cantoral, Ilamapa, La P1or Archaga, Monte Redondo, near Tegucigalpa, E1 Talangita [= Talanquita] (Moore and Peters, 1939: 47-48).

Confined in Honduras to elevations above 2,000 feet, this screech owl is an uncommon to fairly common resident of pine forests.

Records of $\underline{0}$. trichopsis from Tigre Is land (Sclater, 1858b: 357; Taylor, 1860: 226) probably pertain to $\underline{0}$. cooperi (see Hypothetical List).

Honduran birds are typical of the small race $Q . t$. pumilus Moore and Peters [1939: 47; Cerro Cantoral, Honduras]. The range of variation in wing length of the entire Honduran series is as follows: d, 130.0-140.0; $q$, 124.3-145.5. These measurements indicate a significantly smaller bird than the adjacent race in $E 1$ Salvador and 
Guatemala, Q. E. mesamericanus van Rossem [1932b: 184; Los Esesmiles, Chalatenango, El Salvador]. It should be pointed out, however, that this latter race probably occurs in the Department of Ocotepeque, since the type locality is only about one mile from the Honduran border.

\section{Otus guatemalae (Sharpe) \\ Vermiculated Screech Owl}

SPECIMENS.--0. g. guatemalae (8): Catacombas, 3 April (o", MCZ); San Pedro Sula, 8 Apri1, 4 oct. ( ${ }^{\circ}, f$, CM); Subirana, 13 March ( $q$, MCZ); $5 \mathrm{mi}$. S San Esteban, $21-22$ Jan. ( $\delta, q$, LSUMZ); Mt. PuCa, 29 Jan. ( $\$$, MCZ); Santa Bárbara, May (?, UC).

PUBLISHED RECORPS.--San Pedro Sula (Ridgway, 1914: 718). Subirana and Cerro Puca [as guatemalae]; Catacombas [as intergrade guatemalae $\times$ dacrysistactus] (Moore and Peters, 1939: 50, 53).

This species is the cloud forest representative of the genus, found most frequent1y above 3,500 feet, but ranging down to 2,000 feet in low montane rain forest where the latter is continuous with cloud forest. In Honduras the species is uncommon.

The allocation of Taylor's (1860: 226) record of an Qtus on Tigre Is land to this species by Ridgway (1914: 718) was not based on examination of a specimen. It is very likely that Taylor's report pertained to $Q$. cooperi (see Hypothetical List).

Although Moore and Peters (1939: 53) regarded the Catacombas specimen as an intergrade between the nominate race, Q. g. guatemalae (Sharpe), and the Nicaraguan subspecies, 
Q. g. dacryststactus Moore and Peters [1939: 53; Jalapa, northern Nicaragua], I tentatively include all Honduran material under typical guatemglae. All Honduran birds are rather heavily vermiculated below and all exhibit barring on both webs of the primaries, although in some cases this barring is not as heavy as in typical guatemalae. This species is very much in need of a complete revision.

Qtus choliba (Vieillot)

Tropical Screech owl 15 Aug. $(\bar{s}$, MLZ $)$.

SPEC IMEN.--0. c. luctisonus (1): San Juan Tegucigalpa, 130). PUBLISHED RECORD.--"Honduras" [In range] (Slud, 1964:

The above specimen, taken by C. F. Underwood in 1937, 1s the only known record of the species north of Costa Rica. I have examined this specimen and it 1s, indeed, 0 . choliba; furthermore, I cannot detect any differences between it and representatives of $Q$. c. Luctisonus Bangs and Penard from Costa Rica. Slud's (1964: 130) Inclusion of Honduras in the range of the species is based on this individual. Question may arise as to the authenticity of the record. Since Underwood collected for many years in Costa Rica, the possibility of mislabeling cannot be overlooked. However, on the date written on the label, Underwood is known to have been collecting in the Teguclgalpa area of Honduras. The specimen, now in the Moore Laboratory of 20ology at Occidental College, came with a large block of 
Underwood skins, all taken in Honduras (no Costa Rican material in this accession). On the basis of this evidence, I can see no reason for not accepting the record. As mentioned above, the single Honduran specimen is representative of $\underline{Q}$. c. 1uctisonus Bangs and Penard.

Lophostrix cristata (Daudin)

Crested ow1

SPECIMENS.--L. c. stricklandi (5): Cerro Puca, 26 Jan. ( $\sigma$, UC); San Jose de Santa Bárbara, 11 April ( $\sigma^{\circ}, \%$, CNHM); La Flor Archaga, 16 Dec. (?, UC); Catacamas, 11 oct. ( 6 , $\mathrm{MCZ}$ ).

The Crested owl is a humid forest inhabitant that is rare north of Costa Rica and previously unreported from Honduras. It has been found from sea level in lowland rain forest to 6,600 feet in cloud forest; a dense broadleaf forest seems to be its major habitat requirement.

Al1 five Honduran specimens were collected by C. F. Underwood. He secured the first pair at San José de Santa Bárbara in 1935. The La Flor Archaga specimen was obtained In 1936, one was taken at Catacamas in 1937, and the other Individual was collected on Cerro Puca in 1938. There are no other records for the republic.

Honduran specimens are representative of the widespread northern race, $L . c$. stricklandi Sclater and Salvin.

Bubo virginianus (Gmelin)

Great Horned Ow1

SPFCIMENS.--B. Y. mesembrinue (15): E1 Caliche, 10 
July (d, MCZ); Monte Redondo, 15 Nov. ( $\%$, MCZ); La Cueva Archaga, 10 Oct. ( $\%, M C Z)$; San Juancito, 4 Aug. $(\delta, C M)$; E1 Hatillo, 11 Aug.' ( $F, C M)$; Tegucigalpa, 24 Jan., 23 .Feb., 12 April, 14 Sep. 30 oct., 20 Dec. (d, BNH; $q, ?$, CNHM; \&, 8, MCZ; 28, UC); E1 Zamorano, 24 March (d, UF); Es cuela Agrícola Panamericana, 2 Aug. (ot, UF); Yeguare River Valley, 27 oct. ( $\%$, UF).

547). PUBLTSHED RaCORPS.--Tegucigalpa (Griscom, 1935b: $546-$ Cueva Archaga, Monte Redondo (Webster and Orr, 1958: 142).

In Honduras the Great Horned owl is restricted to forests in the interior above an elevation of 3,000 feet. It 18 uncommon to fatrly common, occurring either in pine or In broadleaf forests.

I follow Wobster and orr (1958: 141-142) in recognizing B. ․ mesembrtnus (Oberholser) as distinct from ‥ ‥ mayens 1s Nelson on the basis of darker coloration and silghtly larger size. The race mesembrinus ranges from southern Mexico to Panama and includes populations formerly separated as B. $y$. melancerus (Oberholser). Webster and Orx were the first revisers in uniting melancerus and mesembrinus and selected the lattar name on the basis of 1ts line priority.

\section{Pulsatrlx persplcillata (Latham)}

Spectacled owl

SPECIMENS.--P. P. Baturata (11): Lancetilla, 18 Jan.

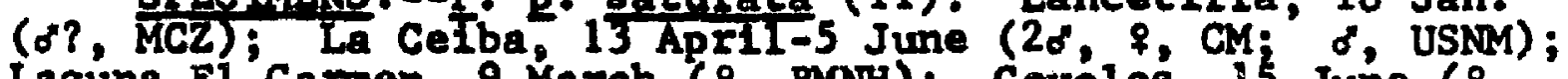
Laguna EI Carmen, 9 March ( $q$, BMNH); Coyoles, 15 June ( $q$, CM); Lake Yojoa, 27 Aug. ( $f, C M$ ); Rfo "Guape" [= Guayape], 5 Sep. $(\delta, f, M C Z)$; Catacamas, 8 Oct. ( $\delta$, UC).

PUBLISHFP RRCORPS,--Lancetilla (Peters, 1929b: 420). La Celba (Deignan, 1936: 190). 
Ranging up to an elevation of 2,500 feet, the spectacled Ow1 is an uncommon to fairly common resident of lowland rain forests on the Caribbean slope of Honduras. Honduran specimens are referable to the northern race, P. p. saturata Ridgway.

\section{Glaucidium gnoma Wagler \\ Northern Pygmy Ow1}

SPECTMENS.--G. g. cobanense (4): Mt. Puca, 29 Jan. (o, MCZ); Cerro Santa Bärbara, east slope, 25 April ( $\left.{ }^{\circ}, L S L M z\right)$; Cantora1, 17 July, 15 Aug. ( ${ }^{\circ}$, MLZ; of, MCZ).

Although previously unreported from Honduras, the Northern Pygmy Owl is an uncommon resident, occurring in highland pine and in cloud forest. C. F. Underwood obtained the two Cantoral Individuals on $17 \mathrm{July} 1934$ and 15 August 1937 and the Mt. Puca male in 1938. I collected the Cerro Santa Bárbara male in 1963; it was drinking from a spring at an elevation of 6,600 feet. Two of the Underwood skins had been previously ldentified as G. minutissimum griseiceps.

The taxonomy of this genus is still not settled. In Honduras, at least, there are three members of the genus that behave as species. Glaucldium brasiliamum is certainIy a good spectes and has always been treated as such. Of the other two, G. gnoma is the highland representative and G. minutissimum 18 the humid lowland rain forest spectes. In addition to the ecological differences, there are constant morphological differences that show no sign of 
intergradation, contrary to the opinion of Griscom (1932b: 172). In fact, I can find no indication of any intergradation between gnoma and minutisgimum anywhere in the range of either spectes, although the peculiar G. m. Banchez1 Lowery and Newman [1949: 1; Llano de Garzas, near Cerro Coneja, San Luis Potosi, México; elevation 6,800 feet] bridges the morphological differences in tall length and tail pattern.

Morphologically, G. gnoma differs from G. minutissimum (excluding sanchez1) in the longer tails (gnoma, os $>53$, $q>58$; minutissimum, $\delta<53, q<55)$, a greater number of more closely-spaced tall bars or rows of spots (usually 6, varying from 5 to 8 , not counting terminal spots, as opposed to 3 or 4 , very rarely 5 , for minut $18 \mathrm{simum}$ ), and the presence of back spotting in gnoma, the latter becoming reduced or concealed in the southern population (cobanense). This reduction of back spotting was the evidence that led Griscon to assume that intergradation was occurring. However, the tendency of back spot reduction towards the south seems to be nothing more than a clinal variation within gnoma, while the lack of back spotting is constant in all populations of minutissimum from Mexico to South America. The August adult male from Cantoral is unique in the series of Glaucidium that I have examined. It is basically in the hepatic phase, as described by Griscon (1931: 43), but the entire crown and nape region is gray, contrasting 
sharply with the rest of the plumage, which is typical of the hepatic phase. The two other Underwood skins are in the intermediate phase, differing from Mexican specimens of nominate gnoma in the generally darker upper parts and reduced back spotting. The Cerro Santa Bárbara individual is a typical gray phase bird, differing from Mexican gnoma in the same manner as do the intermediate phase birds; this specimen is the first one of cobanense that is in this phase. In all specimens of cobanense, there is at least some back spotting, either evident or concealed. Tails of the four Honduran specimens measure 53.9-57.6 (55.3).

The southern populations of this species, therefore, may be distinguished as the race G. $\mathrm{g}$. cobanense Sharpe on the basis of the presence of numerous individuals in the hepatic phase, the general darker dorsal coloration of the gray and intermediate phases, and the reduction of back spotting in any plumage; the race is confined to the highlands of Guatemala and Honduras.

\section{Glaucidium minutis8imum (Wied)}

Least Pygmy Ow1

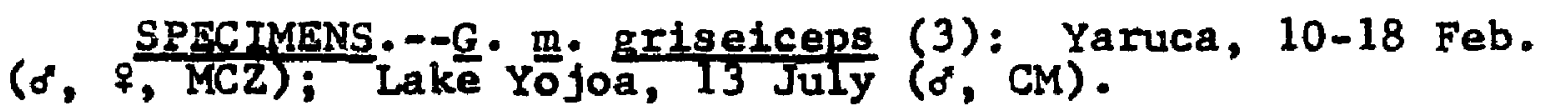
PUBLISHED RECORD.--Yaruca (Bangs, 1903: 144).

The Least Pygmy Owl is the humid lowlands representative of the genus in Honduras. It is apparently rare, being known from Honduras only through the three specimens 
listed above. W. W. Brown (Bangs, 1903: 144) secured the Yaruca pair in 1902, and Arthur $C$. Twomey and Roland $W$. Hawkins collected the male from Lake Yojoa (elevation about 2,100 feet) in 1951. The latter specimen had been misidentified on the label as $G$. brasilianum. Moore (1947: 144) mentioned that he had examined three specimens in the Museum of Comparative Zoology "In the gray phase with four tail bars" and two others "in the intermediate phase with three tall bars." The latter two individuals are the pair of G. minutissimum from Yaruca. In 1963 I found four other Honduran specimens marked "G. minutissimun" in the Museum of Comparative Zoology, which must have included the three examined by Moore. Two of these (o", Mt. Puca; o", Cantoral) are G. gnoma and the other two ( $\delta$, near Ojo de Agua; o, Alto Guaimaca) G. brasilianum.

The specific differences between $G$. minutissimum and $\underline{G}$. gnoma have been discussed under the latter. I should like to point out also that Honduran material, as well as all specimens examined by me, supports the contention of Buchanan (1964: 103-112) that G. minut 1s8 imum 18 monomorphic (with relation to color phases) while G. gnoms is polymorphic.

Honduran birds are typical of the race $G$. $\underline{\text { m. griseiceps }}$ Sharpe, which ranges from eastern Guatemala and British Honduras to Honduras, in both color and size, showing no 
approach to G. m. ramum Griscom [1931: 41; Permé, Caribbean slope of eastern Panama].

\title{
Glaucidium brasilianum (Gmelin) \\ Ferruglnous Pygmy Owl
}

\begin{abstract}
SPECTMENS.--G. b. ridgwayi (65): La Ceiba, 13-15 May (A, 7, CM); Truji110, 30 March-8 April (2\%,CM); Cof radia, 12 March ( 8 , AMNH); San Pedro Sula, April (?, CM); Las
\end{abstract} Peñitas, 26 Jan. -6 Feb. ( 9 , AMNH; o, BMNH; of, ? MLZ); Coyoles, 11 July ( $\left.{ }^{\circ}, \mathrm{CM}\right)$; San Esteban, 23 June $\left(40^{\circ}, 2 \%\right.$, CM); Merendón Copán, 15 June ( $q$, UC) ; Santa Rosa de Copán, 8 June ( $q$, UC); Monte EI Conejo, 14-21 May (o, 2q, MLZ); E1 Caliche, 5-16 July (2o, MCZ); Alto Guaimaca, 9-12 June ( ${ }^{\circ}$, AMMH; $*$, MCZ); Cantoral, 6 April ( $\%$, UC); Monte Redondo, 2 DeC. ( $\sigma^{\circ}$, MCZ); La Cueva Archaga, 6 Nov. ( $\left.q, U C\right)$; La Flor Archaga, 24 Jan. -20 March, 29 May-14 July (o", AMNH; o, \&, CNHM; 20, MCZ; \&, UC); Ilamapa, 25 Aug. (o, AMNH); E1 Hatillo, 11 March-9 May (o, $?, \mathrm{MCZ}$; o, UC); Teguc1galpa, 17 Feb., 14 April-27 July ( 9 BMNH; ${ }^{\circ}$ CNHM; 8,39, MCZ; 30, $;$, ?', UC); Comayagǘla, 29 March, 27 Oct. ( $0^{\circ}, \%$, MCZ); Yeguare River valley, 22 Jan. ( $\%, U F) ; 1$ mi. Wójo de Agua, 19 May ( ${ }^{*}$, MCZ); Choluteca River, Dept. of EI Paralso, 19 May ( 8 , UF); Catacamas, 8-22 Aug., 7 Oct. (2o", ?, MCZ); La Cueva, Sabana Grande, 15 Aug. ( $\sigma^{\circ}, \mathrm{MCZ}$ ); Piedra de Jesus, 31 March (o, CNHM); Segovia River, 15-20 July (29, USNM); Puerto Lempira, 11-14 Apri1 (o', 7, LSUMZ); "Honduras" ( juv,, BMNH).

PUBLISHED RECORDS--Near Comayagua (Taylor, 1860: 226). "Honduras" (Sharpe, 1875: 207; Phelps and Phelps, Jr., 1951: 67). Segovia River (RIdgway, 1888c: 593). "Honduras" [as G. minutissimum griselceps, part] (Moore, 1947: 144).

In Honduras ranging from sea level to 6,500 feet, the Ferruginous Pygmy owl is a falrly common to comaon resident in a variety of habitats. It 18 most common in the arid lowlands of the Pacific slope and interior valleys, occurring also in the arid interior highlands and in semi-open situations in the humid Caribbean lowlands. The species exhibits at least three color phases (Dickey and van Rossem, 
1938: $230-232$ ).

Honduran specimens are referable to the widespread Middle American race, G. b. ridgwayi Sharpe.

\section{Speotyto cunicularia (Molina)}

Burrowing Owl (o, $M \mathrm{CZ})$.

SPECIMEN.--S. c. hypugaea (1): Monte Redondo, 5 Dec. PUBLISHED RECORD.-."Honduras" (Peters, 1940: 150-151).

The status of this species in Honduras is not known. The single specimen taken by C. F. Underwood in 1931 could be either a resident or a wintering individual. The inclusion of Honduras in the range of the spectes by Peters (1940: 150-151) and subsequent authors is based on the Underwood specimen. There are no other records for Honduras .

The Honduran skin is typical of the western North American race, $\underline{S}$. $s$. hypugaeg (Bonaparte).

\section{Ciccaba virgata (Cassin)}

\section{Mottled ow1}

SPEC TMENS:- - . $\underline{v}$. central 1s (15): Balfate, 9 Nov. ( $\sigma^{\prime}$, CNHM); Cofradia, 12 March (f, BMNH); Urraco, 9 March ( $q$, MCZ); Monte E1 Port1110, 28 May ( $q$, MLZ); San José de Santá Bárbara, 24 Apri1-4 May ( ${ }^{\circ}, \%$ CNHM); Finca Fé, 17 Jan., 5 Nov. ( 8 , $\&$, ISUMz); La Flor Archaga, 15 March, 11 April, 13 Dec. (o"' $q$, CNHM; $\%$, MCZ); UYuCa, 2 Aug. (?, UF); Catacamas, 5 Sep., 7 Oct: (20, MCZ); Sabana Grande, 11 March ( $\sigma$, CNHM).

PUBLISHEP RECORDS.--"Honduras" (RIdgway, 1914: 764). Palomas -Toloa Canal, $52 \mathrm{~km}$. W Tela [s Urraco]' (Peters, 1929b: 420). 
Clacaba yirgata is common and widespread in Honduras. It 1o primarily a species of the humid Caribbean lowlands, but it may be found regularly at higher elevations in montane rain forest or cloud forest up to 5,000 feet. Its preference is for an open forest or second growth rather than dense selva. I found it to be most abundant on coffee fincas .

Honduran spectmens are typical of the widespread Middle American race, $\underline{C}$. $\underline{\text {. }}$ centralis Griscom [1929a: 159; Chivela, Oaxaca].

Ciccaba nigrolineata Sclater Black-and-white owl SPECTMEN.--(1): Santa Ana, 22 Jan. (\%, USMM). PUBLISHED RECORD.--Santa Ana (Ridgway, 1914: 762). North of Panama this spectes is decidedly rare. In Honduras it is known from a single female taken by Erich Wittkügel at Santa Ana in 1891. The species occurs in tropical lowlands, primarily in rain forest situations.

Blake (1958; 514) would lump this species with $G$. huhula (Daudin) of South America. Until intergradation 18 shown to take place, I am maintainting $\underline{C}$. nigrolineata as distinct.

The supposed South American race, G. n. spilonota (Sharpe), is not valid (Peters, 1940: 154), and the spectes is therefore monotypic. 
Strix fulvescens (Sclater and Salvin)

Fulvous Owl

SPECIMENS.--(20): Montaña La Cruz, 25 June-7 July (q, imm. T, MLZ); Las ventanas, $27 \mathrm{July}$ ( $\sigma^{\prime \prime}$, MLZ); San José dé Santa Bárbara, 4-25 March (30", UC); Cantoral, 19 Feb., 7 April, 3 Aug. ( $\left.20^{\circ}, \$, M C 2\right)$; La Cueva Archaga, 11 Sep. (o", UC); La Flor Archaga, l Oct., 22 Nov. (2?, UC); San Juancito, 3 July, 13 Aug. ( 9 , ANSP; $\delta, C M)$; Tegucigalpa, 17 Aug. ( $q$, UC); Catacamas, 11 Sép.-12 Oct. (3o, $2 \%$, UC).

PUBLISHED RECORD.--San Juancito (Stone, 1932: 309).

The Fulvous owl is a fairly common resident of cloud

forest and pine-oak associations, occurring above 4,000

feet. Honduras is the southern limit of its range, as far as is known.

The differences in call-notes, as well as in certain morphological features, indicate that $\underline{S}$. varla and $\underline{S}$. fulvescens are specifically distinct. I feel it is best to maintain them as separate species unless intergradation can be shown in areas of geographic approach in Mexico.

Family NYCTIBIIDAE

[Nyctibius grandis (Gmelin)]

Great Potoo

On 17 March 1963, in rain forest along the Rio Guampí 10 miles east of Dulce Nombre de Culmi, Richard R. Graber observed a "giant potoo" on the top of a very tall dead stub. He first noticed the bird at dusk, perched upright in typical potoo fashion. On the following day the bird was seen several times on the same perch, and the pale buffy 
coloration and rather distinct spotting on the under parts was visible. The observation could pertain only to this species.

Until very recently Nyctibius grandis was known only from Panama and South America. Land and Wolf (1961: 94) obtained a specimen in Guatemala, and when a second Guatemalan specimen came to light, this population was named $\mathrm{N}$. g. guatemalensis Land and Schultz [1963; 195; 7 km. southwest of Panzos, Department of Alta Vera Paz, Guatemala]. The Honduran birds will probably prove to be referable to this new race, distinguished primarily by its larger size, but definite allocation of the Honduran population must await the collection of specimens.

\section{Nyctibius griseus (Gme1in)}

\section{Common Potoo}

SPECIMENS.--N. g. mexicanus (13): Roatán Island, 9 Jan. (क, CNHM); Los Planes, 14 July ( $\left.{ }^{\circ}, C M\right)$; Coyoles, 7 July ( $\left.{ }^{\circ}, \$, C M\right)$; E1 Caliche, 11 July (juv., MCZ); La Flor Archaga, 16 Oct., 13 Dec. ( ${ }^{\circ}$, ANSP; ?, MCZ); Tegucigalpa, 9 Oct.-9 Nov. (20, 28 , AMNH); Sinapa, 16 Nov. ( 9, MCZ); E1 Zamorano, 7 March (o", UF).

PUBLISHED RECORDS.--Roatán Is land (Salvin, 1889: 368). Roatán Island; Utila Island? (Bond, 1936: 359).

Ranging from sea level to at least 5,000 feet in Honduras, the Common Potoo is a fairly common resident in open or semi-open situations, usually in the vicinity of wooded

it regions. It occurs in elther arid or humid areas.

The species also inhabits Roatain Island, in the Bay Is lands. Bond (1936: 359) stated that it was absent from 
Guanaja Is land but that it "is said to be found on Utila." However, there is no definite evidence that it occurs on Utila; I failed to find it there in May 1963.

I tentatively assign the Honduran populations to $N \cdot g$. mexicanus Nelson, a race that ranges south to Honduras. The Honduxan series as a whole is definitely paler than Nicaraguan and Costa Rican examples of $N$. $g$. costaricensis Ridgway, but there is, however, much variation individually in coloration. In size the Honduran serles is somewhat intermediate (wing, 288.0-306.0, mean 298.3). Additional comparative study on this species is needed.

\section{Family CAPRIMULGIDAE}

\section{Chordeiles acutipennis (Hermann)}

\section{Lesser Nighthawk}

SPECIMENS.--C. a. texens is (2): Monte Redondo, 24 Nov. ( ${ }^{\circ}, \mathrm{MCZ}$; Yeguare RIver Valley, $17 \mathrm{Feb}$ ( $\delta$, UF). C. a. itttoralis (3): Coyoles, 14-21 June ( $\left.{ }^{\circ} ; \%, C M\right)$; Sañ Esteban 25 June ( $\$, C M)$. C. a. micromerts (7): Utila Island, 18-19 Apri1 (2\%, CM); LIttIe Hog Island, 10 April (\%, LSUMZ): Trujillo, 30 Sep. ( $q$, USNM); Puerto Salamar, 9-13 Feb. (2\%, LSUMZ);" "Honduras" (\%, AMMH). Undetermined (8): Roatán Island ( $\sigma^{\circ}$, , BMNH); Big Hog Island, 8 April $\left(\sigma^{\circ}\right.$, LSUMZ); Cerro Cantoral, 1 Dec. ( $\delta$, MCZ); La Laguna Archaga, 20 Jan. ( 9, MLZ); El Hat11lo, 1 May ( ${ }^{\circ}$, MCZ); Escuela Agrícola Panamericana, 13 Nov. ( $\delta$, UF); 5 mi. NE Choluteca, 15 oct. ( 9 skel., LSUMZ).

PUBLTSHED RECORDS.--Trij1110 (R1dgway, 1888c: 581). Roatán Island (Salvin, 1889: 368; Hartert, 1892: 617). Io la Utila [as micromer1s]; Coyoles and San Esteban [as 11ttora11s] (Eisenmann, 1963: 165).

The Lesser Nighthawk is a common migrant and winter visitant in Honduras, occurring in the lowlands of both 
coasts and in the interior highlands to 4,000 feet. It prefers more arid situations and is most abundant along the Pacific coast and in the arid interior valleys. It is also a regular migrant in the Bay Islands and the Cayos Cochinos. There is no direct evidence that the species breeds in Honduras, although several specimens have been secured in June (E1senmann, 1963: 165).

Determination of migrant individuals of this species is extremely difficult and only about 50 per cent of the specimens may be allocated with any reasonable certainty. The two male specimens from Monte Redondo and the Yeguare River Valley are both pale and large (wings, 184.0 and 187.5) and are referable to the northern breeding population, $\underline{C}$. a. texensis Lawrence. The June birds from Coyoles and San Esteban, probably breeding individuals, are small and dark, being closest to the Chiapan race, $\underline{c}$. a. Littoralis Brodkorb [1940a: 543; Arriaga, Chiapas, altitude 56 meters]. Most of the remainder of the specimens are pale and small (wings, 169.5-176.0) and are referable to the Yucatán race, $\underline{\text {. }}$ a. micromeris Oberholser; included are two birds from Utila Is land identified as micromeris by Eisenmann (1963: 165) and two females from Puerto Salamar, in the Pacific lowlands, which match breeding Yucatán specimens very closely. The individual from Big Hog Is land is a dark male that matches Littoral18 fairly well but is large (wing, 183.1). The interior Honduran specimens fron Cerro Cantoral, La 
Laguna Archaga, El Hatillo, and Escuela Agrícola Panamericana are all intermediate elther in darkness or in size and cannot be assigned definitely to a subspecies. I have not determined subspecifically the Roatán birds in the British Museum nor the skeleton from near Choluteca.

\section{Chordeiles minor (Linnaeus)}

Common Nighthawk

SPECTMENS. --C. m. chapmani (1): Lake Yojoa, 28 Aug. ( $7, C M)$. C. m. neotroptcalis (4): Lake Yojoa, 25 July (o", \$, CM); Siguatepeque, 8 July (20, CM).

PUBLTSHED RECORD.--Lake Yojoa, Siguatepeque (Eisenmann, 1963: 165).

This species is a regular, though uncommonly reported, migrant through Central America, sometimes appearing in great migrating flocks, which often consist of several different subspecies from more northerly breeding areas. In addition, it apparently breeds locally in the Honduran interior and probably also in the Mosquitia.

The five specimens 11 sted above were collected in 1951 by Arthur C. Twomey and Roland W. Hawkins at Lake Yojoa (elevation about 2,100 feet) and at Siguatepeque (elevation 3,400 feet). The July specimens are apparently breeding individuals, representing the only breeding seas on records between British Honduras and Panama. During the months of June and July, from 1952 through 1955, Mark Trafton, Jr., observed this species at Siguatepeque, Los Dragos, and Lake Yojoa. He regarded it as uncommon and apparently 
migrating, but was puzzled by the late dates. He observed one rather large flock at Siguatepeque on 12 July 1952.

On several occasions during the fall migration of 1962 , I saw sma1l groups of nighthawks, presumably this species, high over Tegucigalpa but was unable to collect any Individuals for positive identification; in addition, migrating birds are usually silent, preventing identification by call. In early April 1964 the species was common around Puerto Lempira, in the Mosquitia, calling frequently. It very likely breeds there as much suitable habitat is avallable. The race from Chiapas, Mexico, C. m. neotropicalis Selander and Alvarez del Toro [1955: 144; Rancho Meyapac, 1050 meters, 4 miles north of Ocozocoautla, Chiapas, México] represents the southernmost named nesting population in Mexico and the closest geographically to Honduras, except for the recently discovered British Honduran population (Russel1, 1964: 81-82). The breeding population in Panama, described as C. ㄸ. panamensis Eisermann [1962b: 4; Cerro Campana, Panamá Province, Panamá, at about 2500 feet], is distinguished from neotropicalis by generally more rufescent or tawny coloration and by a reduced white wing patch (max. width of patch on 10th primary: $\sigma<12$, $q<9$, not reaching shaft in $₹$, narrowly reaching it in $d^{\prime \prime}$ ). In neotropicalis the wing patch is larger (max. width on loth primary: o" $>14, \&>10$, broadly reaching shaft in both sexes). Elsenmann (1963: 165) compared Honduran specimens with panamensis 
and considered the four July specimens to be neotropicalis with some slight trend towards panamensis. I have examined this series also, comparing the birds with a series of fresh neotropicalie and agree that they are definitely closer to neotropicalis. The white wing patch of these specimens is typical of that race (max. width on 10th primary: $\delta>14.6$, \& $>10.7$, reaching the shaft in all four), and they compare favorably in color with neotropicalis, though several are slightly more rufescent. The Honduran specimen taken on 28 August 1951 at Lake Yojoa is not distinguishable from specimens of $\mathrm{C}$. $m$. chapmani Coues in elther color or size (wing, 187.2); I agree with E1senmann (1963: 165) that it is apparently a migrant individual of this race.

\section{Chordeiles gundlachil Lawrence}

Antillean Nighthawik

SPECIMEN.--(1): Swan Is land, 19 April (d, USNM). $1931: \frac{\text { PUBLT }}{\text { (O) }}$

PUBL.ISHED RECORD.--Swan Islands (F1sher and Wetmore,

This nighthawk is known from Honduras only by a single specimen collected by A. K. Fisher in the Swan Islands in 1929 (Fisher and wetmore, 1931: 10).

The sympatric breeding of this spectes and $\mathrm{C}$. minor in southern Florida, as well as the distinctive differences in call-notes, indicates the specific status of the two forms (Eis enmann, 1962b: 9-10). 
The Honduran specimen was discussed at length by Fisher and Wetmore (1931: 10), who regarded it as an example of the Bahaman race, C. g. yicinus Riley; the label, however, has been marked "gundlachil," the race to which Paynter (1956: 105) assigned the specimen. I am unable to recognize the race vicinus on any grounds and therefore regard the species as monotypic.

\section{Nyctidromus albicollis (Gmelin)}

\section{Pauraque}

SPECIMENS.--N. a. albicollis (83): San Alejo, 29 March 4 Aug; ( 8, skel, LSUMZ); Tela, 4-6 Feb., 4 March (50, 5\%, MCZ); Lancetilla, 27 Aug. (o', ANSP); La Ceiba, 13

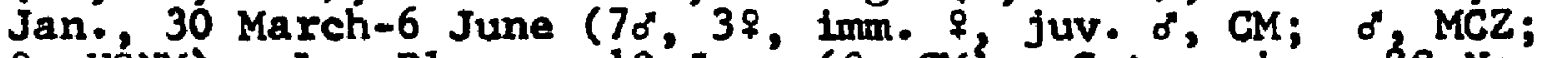
₹, USNM); Los Planes, 10 June ( $\$$, CM); Catacombas, 28 Nov. (₹. MLZ); Cofradía, 27 Feb. ( $d$, USNM); Las Peñttas, 29 Jan., 15 Feb. ( $\delta^{\prime}$, BMNH; $d$, MLZ); Chamelecón, 20 March ( USMM); Amapa, 18 sep. (o", ISUMZ); Portillo Grande, 14

March ( 9, MCZ); Coyoles, 14-17 June (28, CM); San Esteban, 1 July (1mm. o", CM); Finca Fé, 22 Oct., 13 Dec. ( $\sigma^{\circ}, \sigma^{\circ}$ skel., LSUMZ); Lake Yojoa, 21 June-26 July (4o, CM; $\sigma^{\circ},{ }^{\circ}$, UF); 'El Pedernal, 7 Jan., 1 Dec. ( $\$$, $\%$, AMNH); E1 Guayabal, 16-26 Dec. (20, 8, AMNH); Llano Grande, 22 Jan., 6 Dec. (20, AMNH); EI Horno, 25 Dec. ( $\sigma^{\circ}$, AMNH); La Florida, 14 Dec. ( $d$, AMNH); Comayagua, 22 Aug. ( $d$, CM ; Cerro Cantoral, 29 March (o., MCZ); Monte Redondo, 22 Nov., 10 Dec. ( $\left.{ }^{\prime}, \$, M C Z\right) ;$ La Laguna Cantoral, 20 Jan. ( $q$, MLZ); La Flor Archaga, 5-10 May, 14 Nov. ( $\%$ AMNH; $\delta^{\circ}, 29, \mathrm{MCZ}$ ); Cantarranas, 6-7 Aug. (3\%, 2\%, ANSP); El Derrimbo, 18 July ( MLZ); Ei Hatillo, 12 March, 2 May (o", 2\%, MCZ); Madre Vieja, $16 \mathrm{Feb}$. (?, UF); Yeguare River Valley, 23 Dec. (o", UF); Segovia River, $17 \mathrm{July}-2$ Aug ( $(\delta, \%, ?$, USNM); $10 \mathrm{~km}$. N Sábana Grande, 15 Aug. ( $\left.\sigma^{\prime}, \mathrm{CM}\right)$; San Lorenzo, 25-26 Sep. ( $\%, \$, M L Z) ; 5 \mathrm{mi}$. NE Choluteca, 13 oct. ( 9 , LSUMZ); "Honduras" ( 0 , AMNH).

PUBLISHED RECORDS.--Tigre Is land (Sclater, 1858b: 357). Tigre Island, Comayagua (Taylor, 1860: 114). San Pedro region (Sclater and Salvin, 1870b: 837). Segovia River (Ridgway, 1888c: 592). San Pedro (Salvin and Godman, 1894: 394). La Celba (Bang, 1903: 144; De1gnan, 1936: 190). Tela (Peters, 1929b: 426; Griscom, 1929b: 
8-9). Cantarranas, Lancetilla (Stone, 1932: 309-310). Lancetilia (Skutch, 1954a: 9).

The Pauraque is the commonest goatsucker in most of Honduras, occurring in and around forested and semi-open regions up to 6,000 feet. Its abundance seems to be greatest in open rain forest or semi-open areas in more humid regions on the Caribbean slope.

David Dyson's specimen in the British Museum, taken at "Belize, Honduras" and reported by Gray (1848b: 11), pertains, of course, to British Honduras. I was unable to locate in the British Museum the two specimens obtained by Taylor on Tigre Island (Sclater, 1858b: 357) or any material collected by G. M. Whitely (Sclater and Salvin, 1870b: 837).

Vartation in this species has always posed taxonomic problems. In addition to several rather distinct color phases, there is a considerable amount of individual variation apparently brought about as a phenotypic response to the humidity of the environment. The northern Central American populations have been described as N. … intercedens Griscom [1929b: 8; Tela, Honduras]; Griscom distinguished this race on the bas is of size varlation but Wetmore (1944: 46) redefined intercedens by color differences. In a large series of Central American specimens from Guatemala to Panama, I have been unable to detect any significant distinguishing characteristics of either color or size, and until further work is done on the group, I am considering intercedens to be a synonym of $\mathrm{N} \cdot \mathrm{a} \cdot \mathrm{a}$ albicol1is 
(Gmelin). The race from Yucatán and British Honduras, N. a. yucatanensis Nelson, appears to be valid on the basis of paler color and larger size; Honduran specimens show no approach to this subspecies.

\section{Caprimulgus carolinensis Gmelin}

\section{Chuck-wills -widow}

SPECTMENS---(6): Falda de Santa Bárbara, 28 April (\%, AMNH); El Jara 1, 15 oct. (o, AMNH); Cantoral, 2 April ( AMNH); Comayagüela, 18 Nov. ( $q, M C Z)$; Pledra de Jesús, 18 Nov. ( $\sigma$, AMNH); San Francisco, Choluteca, 12 oct. ( $\sigma^{\circ}$, LSUMZ).

Although previous ly unreported from Honduras, the Chuck-wills-widow is an uncommon migrant and winter visitant in the lowlands of both coasts and in the interior, ranging up to 5,000 feet. It occurs in a wide variety of forested and semi-open situations.

The only definite records of the species for Honduras are the specimens listed above. C. F. Underwood collected all of them except the male from San Francisco, which was obtained by J. Alan Feduccia in 1962. The Underwood specimens were taken at Comayagüela in 1931, at Cantoral in 1934, near Santa Bárbara in 1935, at El Jaral in 1936, and at Piedra de Jesús In 1937.

\section{Caprimulgus ridgwayt (Nelson)}

Buff-collared Nightjar

SPECIMENS.--C. r. troglodytes (7): Siguatepeque, 22 Aug. ( 7 CM); El Hatil 10, 23 May ( $d$, MCZ); La Flor Archaga, 10 Oct. ( $d$, AMNH); $10 \mathrm{~km}$. N Sabana Grande, 14-15 Aug. (20, CM); Pledra de Jesús, 22-25 Feb. (2d, MCZ). 
PUBLISHED RECORD.--"Honduras" (Sutton, 1951: 262). This goatsucker is a rare species that inhabits the arid interior of Honduras. At present, it is known only from elevations of 3,000 to 5,500 feet, but it probably ranges lower into the arid interior valleys.

C. F. Underwood secured the first known Honduran specimen at EI Hat1110 in 1932. In 1936 he collected a second individual at La Flor Archaga, and in 1937 he obtained two additional males at Piedra de Jesús. Arthur C. Twomey and Roland $\mathrm{w}$. Hawkins secured the other three individuals in 1951, two males near Sabana Grande and a female at Siguatepeque. Nothing further is known concerning the species in Honduras. Sutton's (1951: 262) report of examination of three specimens from Honduras referred to the three Underwood skins in the Museum of Comparative Zoology.

Honduran individuals (wings, 147.9-151.0) are representative of the small Guatemalan race, $\mathcal{L}$. $\underline{\text {. troglodytes }}$

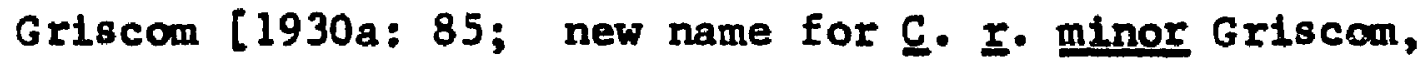
1929b: 10; Progreso, Guatemala (preoccupled)]. Honduras is the southern limit of the known range of the species.

\section{Caprimulgus yociferus Wils on}

Whip-poor-will

SPECIMENS.--C. v. vociferus (5): Catacombas, 5 April (₹, MCZ); $2 \mathrm{mi}$. SE Santa Rosa de Copán, 26 Feb. (', LSUMZ); 5 mi. SW'E1 Jaral, 1 March (o', q, LSUMz); Cerro Cantoral, 21 Feb. (q, MCZ). C. $\mathrm{v}$. vermicilatus $(26):$ Portillo Grande, 14 March ( $0^{\circ}, \mathrm{MCZ}$ ); Gu18e, 16 July ( $0^{\circ}, 2 \%$, LSUMZ); Muín, 31 Dec.-3 Jan. (2q, MCZ); Soluteca, 8 Ápril ( $\sigma^{\circ}$, ANSP); El Pedernal, 12 Jan. ( $\delta^{\circ}$, MCZ); La Cruz Grande, 29 
March ( ${ }^{\circ}$, ANSP); Cantoral, 21 Feb., 25 March ( ${ }^{*}, q$, MCZ); Cerro Cantoral, 8 April, 4 May (20, MCZ); A1to Cantoral, 5 Jan. ( ${ }^{\circ}, \mathrm{MCZ}$ ); La Flor Archaga, 25 May (d, MCZ); San Juanc1to Mountains, 22 May (7, juv., UF); Rancho Quemado, 15-17 March ( 8,7, MCZ); E1 Derrumbo, 3-9 Aug. (7, MCZ); El Hatillo, 19 April-8 May, 2-10 Aug. (20, 7, CM; 20, MCZ); Tegucigalpa (?, MCZ). Undetermined (8): Cerro Grande, 4 March (f, AMNH); La Cruz Grande, 20 March (o, $q$, AMNH); Cantoral, 18 Feb. ( $\delta$, AMNH); La Flor Archaga, 26 March, 5 Oct., Nov. (2o, \%, AMNH); EI PIcacho, 17 oct. (o, AMNH). 1940 PUBLISHED RECORDS.-- "Honduras" [as vociferus] (Peters, 200).

The Whip-poor-will is an uncommon resident and fairly common whter visitant in Honduras. The breeding populations are confined to the highlands of Honduras mostly above 4,500 feet but have been recorded as low as 2,000 feet in winter. The eastern North American breeding population winters in much of Honduras, occurring in the Caribbean lowlands as well as the interior highlands. The species is most common in and around cloud forest and in pine-oak associations.

The inclusion of Honduras in the ranges 1 isted by Peters (1940: 199-200) was based on spectmens collected by C. F. Underwood and deposited in the Museum of Comparative Zoology. Positive breeding in Honduras was established by J. C. Dickinson, Jr., who collected a female and a juvenal (the latter being fed by the former) in the San Juancito Mountains on 22 May 1948.

The breeding populations of eastern Guatemala, El Salvador, and Honduras have been described as $\mathcal{G}$. $\underline{\text {. }}$ vermiculatus [Antrostomus vocifenus vermiculatus Dickey and van 
Rossem, 1928b: 130; Los Esesmiles, Dept. Chalatenango, E1 Salvador]; this subspecies differs from $\underline{C}$. $\underline{y}$. chiapensis (Nelson) in being generally more rufous or rusty, with more conspicuous vermiculations on the breast. Although the Tegucigalpa specimen has been identified (on the label) as chlapensis by George M. Sutton, it matches vermiculatus in al1 respects. The migrant North American race, G. $\underline{y}$. vociferus Wilson, is much grayer than either Middle American subspecies. I have not examined the series of specimens listed as "undetermined."

\section{Caprimulgus maculicaudus (Lawrence)}

Spot-tailed Nightjar $\mathrm{CM})$.

SPECIMENS.--(2): Lake Yojoa, 19 June, 14 July (2\%,

The status of this species in Honduras 18 not known, but I suspect that it will prove to be a migrant or visitant only. The only Honduran records are the two specimens collected by Arthur C. Twomey and Roland W. Hawkins at Lake Yojoa in 1951. The wings of these two specimens measure 126.1 and 125.0 .

The dates indicate either a breading population (since the Mexican birds are sumer nesters) or nonbreeding migrants or vagrants from the South American region. I searched extensively for the species at Lake Yojoa during 1962-1963 but failed to find it, although I an familiar with its distinctive call. Furthermore, there is very little of 
the normal savanna habitat in the Lake Yojoa region. Although there is excellent habitat in the Mosquitia of eastern Honduras, brief searches in February 1963 and Apri1 1964 also failed to reveal it there.

The above specimens are the first records for Central America.

\section{Family APODIDAE}

\section{Streptoprocne zonaris (Shaw)}

White-collared Swift

SPECIMENS.--S. z. mexicana $x$ albicincta (28): Lancetilla, 26 Jan.: 2 Sep. (7) ANSF; ?, MCZ); La Ceiba, 30 April ( $f, C M)$;' La Lima, 3 Oct. (skèl. LSUMZ); San Esteban, 29 June ( $\left.80^{\circ}, 79, \mathrm{CM}\right)$; Finca Fé, 25 Oct. -8 Nov. ( $0^{\circ}$, imm. ₹, LSUMZ); Lake Yojoa, 28 Aug. ( $\left.2{ }^{\circ}, 9, \mathrm{CM}\right)$; $5 \mathrm{mi}$. E Siguatepeque, 17 oct. ( $\sigma^{\circ}$, LSUMz); El Hatilio, 20 Aug. ( $\sigma^{\circ}$, $C M) ; 10 \mathrm{~km}$. N Sabana Grande, 14 Aug. $(f, C M) ; 16 \mathrm{mi}$. W'San Marcos de Colón, 15 oct. (o", Ls umz).

PUBLISHED RECORDS--Tela River near Lancetilla, Lancet11la VaIley (Peters 1929b: 426-427). Lancetilla, Cantarranas (Stone, 1932: 310).

Ranging up to 4,500 feet in Honduras, the Whitecollared Swift is a common resident in the lowlands of both coasts and in the interior. It is most abundant in the humid Caribbean lowlands but also occurs in arid country on the Pacific slope and in the interior.

I consider the Honduran populations of this species to be intermediate between the northern race, $\underline{s} \cdot \underline{z}$. mexicana Ridgway, and the Central American race, $\underline{s} \cdot \underline{z}$ albicincta (Cabanis). The latter differs from the former in the 
blacker coloration (of adults) and the smaller size. in size Honduran bixds are much closer to mexicana, their wings measuring as follows: $6,193.0-215.0(204.8)$; $\$, 196.5-$ $212.0(205.7)$. The adults are definitely darker than a series from British Honduras and Mexico and in this respect are closer to albicincta. The subspecies described as $\underline{S}$. z. bouchelli1 Huber [1923: 302; Eden (Lat. $14^{\circ} 00^{\prime} \mathrm{N}$, Long. $84^{\circ} 26^{\prime} W$ ) Nicaragua] has been shown to be based on variation in age (Peters, 1929b: 426-427).

[Streptoprocne semicollaris (De Saussure) ?] White-naped Swift

The occurrence of this Mexican species in Honduras must be regarded as doubtful pending the acquisition of spectmens. Were it not for the fact that the observations of this species in Honduras are based on numerous sightings by several observers, one would be tempted to disregard them altogether.

Mark Trafton, Jr., first reported this species in Honduras. He told me that he 8 aw great numbers of 8 wifts, presumably this species, on 14 July 1952 north of Quimistán. He was accompanied by V. C. Dunlap and Paul slud on this occasion, and all were able to observe the white nape patch and the absence of a complete white collar. I now quote directly from Trafton's notes: "The flock, spread out, diving with folded wings, or gliding and flying in long sweeps, later spiralled high into the $8 \mathrm{ky}$. This large 
swift tends to soar more than the white-collared swift [S. zonaris] and the smaller ones [Cheetura sp.], which flutter." Paul slud recently told me (personal communication) that he is convinced these birds were not $S$. zonaris (occastonal individuals of this species do lack complete collars) and almost certainly were s. semicollaris or some unknown species resembling it.

Trafton observed other large flocks at Lancetilla on 21 and 22 October 1952 and on 20 August 1955; he noted another flock at Los Dragos on 30 November 1952. During the years between 1952 and 1960, he recorded the species at Lanceti1la (in January, February, June, July, August, and October), at Los Dragos (in June, July, August, October, November, and December), and at Lake Yojoa (in June). v. C. Dunlap also observed it at Chamelecón (6 August 1950), at Los Dragos (7 June 1953), and at Lancetilla (3 January 1954). Paul Slud saw additional birds at Lancetilla in June 1952.

During my stay in Honduras in 1962-1964, I watched flocks of large swifts in hopes of seeing S. semicollaris, but I recorded only s. zonaris. I have little doubt, however, that a large, white-naped swift (not S. zonarig) does exist in Honduras. The observations by reliable observers are too overwhelming to ignore. However, the definite identity of this swift will remain a mystery until a specimen can be secured. 


\section{Chaetura pelagica (Iinnaeus)}

\section{Chimney Swift}

SPECIMENS.--(11): Montecristo, 24 March ( $q$, ISUMZ); La Celba, 29 March, 26 Apri1, 7 May (40, 5\%, CM); Finca Fé, 1 Nov. (o, LSLMZ).

Despite the absence of previous records from Honduras, the Chimney Swift is an uncommon fall migrant and a common spring migrant in the Cartbbean lowlands and the is lands off the north coast.

Arthur $C$. Twomey and Roland $W$. Hawkins collected a series during spring migration at La Ceiba. They obtained a female on 29 March 1947, three of each sex on 26 April 1948, and a pair on 7 May 1948. These were the first specimens to be taken in Honduras.

A flock of more than 50 individuals of this species appeared over the rain forest at Finca Fé (elevation 2,300 feet) on 1 November 1962 and remained until 6 November. They could easily be distinguished from the abundant $\underline{c}$. yauxi by their habit of remaining together as a compact flock, each movement of the group being made in unison by all birds; C. vauxi was normally seen in loose aggregations, each individual flying its own foraging pattern with very little regard for other members in the vicinity. A specimen of $\underline{C}$. pelagica was taken on 1 November to establish identification.

In the spring of 1963 I observed the species on several occastons. A flock of about 10 was recorded at San Alejo 
on 19 March, and a mixed flock of $\underline{C}$. pelagica and $\underline{C}$. vauxi was noted at Montecristo on 24 March (specimen of pelagica taken). On Little Hog Is land, in the Cayos Cochinos, I saw six Chimney Swifts on 9 April and 10 on 10 April. On Utila Island, in the Bay Islands, flocks of 10 and 15 individuals were seen on 3 and 4 May, respectively, and additional flocks of 8 ix on 9 May and 18 on 10 May were recorded. In all the Utila observations, the flocks were passing over the island headed in a generally northerly direction out over the Caribbean Sea.

A remarkable flight of this species was observed at La Lima on 14 October 1964 by Kenneth S. Hamilton, who estimated that at least 5,000 individuals were present. An interesting and possibly correlated circumstance is that the last Chimney Swifts of the fall were recorded in the Baton Rouge, Louisiana area on 13 October 1964, a cold front passage that day apparently being responsible for the departure of these swifts.

Chaetura vauxi (Townsend)

\section{Vaux's Swift}

SPECIMENS. - - C. $\mathrm{v}$. vauxi $(1): 3 \mathrm{mi}$. S Comayagua, 17 Oct. (J, LSUMZ). C. richmond1 (39): San Alejo, 9 Aug. (o", LSUMZ); Lancetilla, $16-22 \mathrm{Jan}$, 1 Sep. ( $0^{\circ}$, ANSP; 30, 3\%, ?, MCZ); Montecristo, 23 March ( 9 , LSUMZ); La Celba, 18 May, 6 June (39, CM); Coyoles, 18 July ( $7, C M) ;$ San Esteban, 28 June ( $\left.\sigma^{\circ}, 2 q, C M\right)$; 3 mi. E Santa Rita, 4 Dec. ( , LSUMZ); Finca Fé, 10 Aug. -16 Sep., 21 Oct. -5 Nov. (40", $2 \%, 2$ imm. of, of skel., 2 alc., Lsumz; Lake Yojoa, 12-18 June $\left(40^{\circ}, 2 \%, ?, C M\right)$; Güise, 17 July ( $\sigma^{\circ}$, LSUMZ); Cantarranas, 4 Aug. ( 8 , ANSP); "Honduras" (?, BMNH). 
PUBLISHED RECOEDS.--"Honduras" (Hartert, 1892: 481). Lancetilla (Peters, 1929b: 427). Cantarranas, Lancetilla (Stone, 1932: 310). Cerro Uyuca (Dickinson, 1951: 201202).

This swift is a common species in Honduras, occurring in the humid Caribbean lowlands and in the interior up to altitudes of at least 6,500 feet. The only breeding record for Honduras consists of a nest found in a hollow tree in cloud forest on Cerro Uyuca (elevation 6,200 feet) on $3 \mathrm{July}$ 1948 by J. C. Dickinson, Jr. (1951: 201-202). J. Alan Feduccia and I recorded large flocks at Güise at 5,600 feet on several occasions.

A11 Honduran specimens except one are typical of the Central American race, $\underline{C}$. $\underline{v}$. richmondi Ridgway; the single specimen that I secured near Comayagua in 1962 is repre-

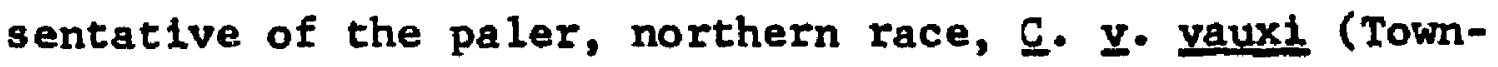
send), and extends the known wintering range of this form south of Guatemala. I am not convinced that richmond1 should be merged with the widely allopatric vauxi, but because of similarities in behavior and call-notes, as well as In general morphology, I am maintaining the two in a single species. Phillips (1962a: 336-338) considered the earlier name $C . \underline{y}$. similis Salvin and Godman to pertain to the race Ifchmond1; the name similis, however, is a nomen oblitum and cannot be used to supplant richmondi. 
Cypseloides rutilus (Vieillot)

Ches tnut-collared Swift

SPEC MMENS.--C. r. brunneitorques (16): Coyoles, 17 July $\left(2 \delta^{\circ}, C M\right) ;$ San Esteban, 28 June ( $\left.\delta^{\circ},, C M\right)$; E1 Hatillo, 2-17 Aug. (38, 3\%, CM); Escuela Agrícola Panamertcana, 17-30 June (20, ₹, MCZ); 1 mi. N Escuela Agrícola Panamericana, 17 June ( $9, \mathrm{MCZ}$ ); 2 mi. S Escuela Agrícola Panamericana, $15 \mathrm{June}$ ( $9, \mathrm{MCZ}) ;$ Yeguare River Valley, 24 Jan. ( $\%$, UF).

PUBLISHED RECORDS.--Between Santa Rosa [de Copán] and Gracias (Griscom, 1932b: 195). Yeguare River Valley (Carr and Dickinson, 1951: 272).

The Chestnut-collared Swift is an uncommon to falrly common species in the interlor highlands, occurring primarily above 3,500 feet but ranging daily down into adjacent valleys to an elevation of 1,500 feet. Although Phillips (1962a: 333-335) regarded all Middle American populations as summer residents only, the Honduran records indicate that at least some of the Honduran birds are resident or, possibly, that the summering individuals are replaced by wintering groups from the north.

A. W. Anthony (Gr18com, 1932b: 195) reported seeing a flock of this species between Santa Rosa de Copain and Gracias in July. Arthur C. Twoney and Roland W. Hawkins obtained the species at San Esteban in 1948, at Coyoles in 1950, and at El Hat1llo in 1951. All other specimens were taken by Marjorie H. Carr and J. C. Dickinson, Jr., in 1948. During 1962-1963 I noted flocks of more than 25 individuals in the Comayagua Valley on 24 August 1962, 7 September 1962, and 29 January 1963. A group of about a dozen 
was seen over Tegucigalpa on 18 November 1962.

Honduran specimens belong to the widespread Central and South American race, $\underline{\text {. }}$ I. brunneitorques (Lafresnaye). Ph111ips (1962a: 334-335) considered the type of brunneitorques to be a wintering individual of the paler, northwestern Mexican race, $\underline{\text {. }}$ r. griseifrons (Nelson), stating that this type was once a mounted bird. Since the amount of fading can never be determined in such a specimen, retention of the current nomenclature seems preferable to the use of brunneitorques for griseifrong and the resurrection of $\underline{\text {. }}$ I. nubicola [Chaetura nubicola Brodkorb, 1938: 1; Mount Ovando, Chlapas, altitude, 2000 meters] for the Central and South American populations.

\section{Cypseloides cryptus Zimmer}

White-chinned Swift

SPECTMEN.--(1): San Esteban, 28 June (o, CM). 1962: 9).

PUBLISHED RECORD.--San Esteban (EIsemann and Lehmann,

Cypselotdes cyyptus Zimmer [1945: 588; Inca Mine, Río Tavara, Peri], a recently discovered South American species, is now known to occur in Central America as far north as Brit1sh Honduras (Russel1, 1964: 84-85) but apparently only during the nonbreeding season (northern sumer). In Honduras it is known only from the single male taken by Arthur C. Twomey and Roland W. Hawkins at San Esteban in 1948 
(Eisenmann and Lehmann, 1962: 9). North of Costa Rica it has been recorded only from the Caribbean lowlands.

\section{Cypseloides niger (Gmelin)}

\section{Black Swift}

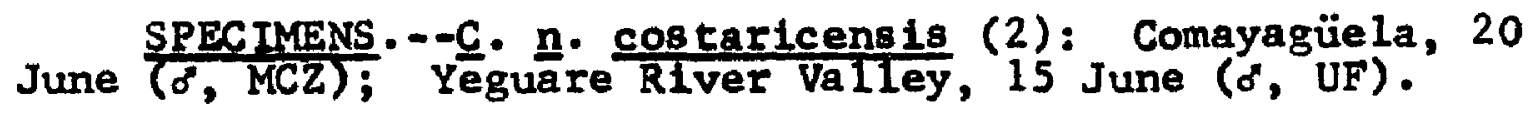
PUBLISHED RECORDS.--"Honduras" (Peters, 1940: 243). Yeguare River valley (Carr and Dtckinson, 1951: 272).

The Black Swift is rare in Honduras, being recorded only in the Tegucigalpa region (about 3,000 feet elevation). A male was collected by C. F. Underwood at Comayagüela in 1932, and another male was taken by Marjorie H. Carr in the Yeguare River Valley in 1948. No other definite records exist. The species is presumed to be resident, but there is no definite breeding evidence from Honduras. Ridgway (1911: 708) attributed the species to Honduras on the basis of a supposed report by Salvin and Godman (1894: 379), but the latter do not mention any Honduran records. Peters (1940: 243) Included Honduras in the range of $\underline{C}$. $\underline{n}$. costaricensis on the basis of the underwood specimen.

The two Honduran specimens are typical of the Costa Rican race, $\underline{C}$. n. costaricensis Ridgway. They compare favorably with Costa Rican examples in color, and the wings measure 159.0 (Comayagüela male) and 156.5, too small for the northern subspecies, $\underline{C} . \underline{n}$. borealis (Kennerly). 


\section{Aeronautes saxatalis (Woodhouse)}

White-throated Swift

Jan. (\%, LSUMZ).

SPECIMEN.--A. S. nigrior (1): $9 \mathrm{mi}$. W Zambrano, 29 PUBLISHED RECORD.--"Honduras" (Eisemmann, 1955a: 45).

This swift is an uncommon resident in the interior mountains of Honduras, occasionally descending to 2,000 feet. Honduras is the southern limit of its range.

The Inclusion of Honduras in the range of the species by Eisenmann (1955a: 45) is presumably based on sight records of Marjorle H. Carr. In June 1952 Paul Slud observed this swift at Lake Yojoa, and in June 1954 Mark Trafton, Jr., noted it on Cerro Santa Bárbara.

On 24 September $1962 \mathrm{~J}$. Alan Feduccia and I saw a flock of 15 White-throated Swifts circling a cliff along a pine ridge near Zambrano, at about 4,000 feet elevation. I secured the first Honduran specimen on 29 January 1963 from a group of eight in the same general area.

The single Honduran specimen agrees with $\underline{A}$. $\underline{\text { s. nigrior }}$ Dickey and van Rossem [1928a: 193; Los Esesmiles, Department of Chalatenango, El Salvador] in the darker dorsum, in reduced white below, and in the obsolete superciliary streak; in addition, it measures smaller (wing, 140.3) than

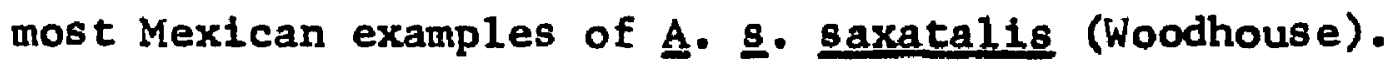




\section{Panyptila sanctihieronymi Salvin}

Great Swallow-tailed Sw1ft

SPECIMENS.--(10): E1 Hatillo, 10 Aug. ( $(9, C M) ; 1 \mathrm{mi}$. N Escuela Agricola Panamericana, 16-30 June ( $q$, juv. $\delta$, UMMZ); Yeguare River Valley, 17 June $\left(\sigma^{\prime}, 9\right.$, UF); Department of [Francisco] Morazán, 4 July (?, juv. o'?, MCZ); Mt. Chile, 22 June (juv. $\&, 2$ Juv., AMNH).

PUBLTSHED RECORDS.--Escuela Agrícola Panamericana, Cerro del Chile (Carr and Dickinson, 1951: 271-273).

Although the records are few, this species is nevertheless a common resident in the interior mountains of Honduras. It occurs primarily above 3,000 feet but occasionally descends to 1,500 feet in the interior valleys.

The discovery of Panyptila sanctihieronymi in Honduras, including the collection of three young from a nest on Cerro del Chile at 4,800 feet elevation, was made by Carr and Dickinson (1951: 271-273). All specimens listed above, with the exception of the one from El Hatillo, were taken by Carr and Dickinson; the Juvenals from Cerro del Chile were collected in 1949, while the remainder of their specimens were obtained in 1948. Arthur C. Twomey and Roland W. Hawkins collected the female from El Hatillo in 1951.

Although I failed to obtain a specimen, I saw the species on numerous occasions from 24 September 1962 to 4 February 1963. I recorded it near Santa Rosa de Copán, on Cerro Santa Bárbara, at Lake Yojoa, in the vicinity of La Esperanza and Güise, near Siguatepeque, near Zambrano, near Tegucigalpa (on two occasions over the capital city itself), and near San Francisco, Choluteca. 


\section{Panyptila cayennensis (Gmelin)}

Lesser Swallow-talled Swift

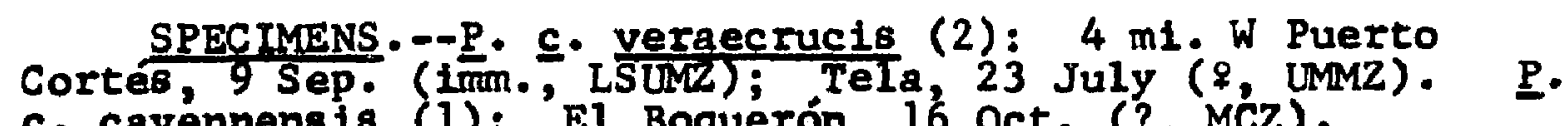
c. cayennens is (1): E1 Boquerón, 16 oct. (?, MCZ). 1947: (143).

PUBIISHED RECORD.--Catacamas $[=$ E1 Boquerón] (Moore,

The smaller species of Panyptila in Honduras is an inhabitant of lowland rain forest areas on the Caribbean slope below 1,000 feet. It is uncommon to rare anywhere north of Costa Rica.

The first Honduran specimen was taken by $C$. F. Underwood at E1 Boquerón in 1937 (Moore, 1947: 143). Paul slud collected a female at Tela in 1952. On 9 september 1962 I secured one specimen from three seen about four miles west of Puerto Cortés and observed three more at Puerto Cortés on 13 May 1963. During March and April 1964 I saw several daily at dusk over San Pedro Sula, feeding with Chaetura vauxt.

In view of the fact that only three specimens are known and two of these are of doubtful sex, their allocation to subspecies must be regarded as tentative. The specimen from E1 Boquerón is smaller than the other two (wing, 119.9) and I assign it to the small nominate race, $\underline{P}$. $c$. cayennensis (Gmelin); it was also placed in this race by Moore (1947: 143), who was the describer of the larger, northern subspectes, $\underline{P}$. c. veraecrucis Moore [1947: 143; Presido (= Presidio), Veracruz, Mexico; about $500 \mathrm{ft}$. altitude]. 
The latter race was based on a single specimen, the wing measurement of which was given as 126.8. An individual from Britigh Honduas and the two others from northern Honduras are larger than a series of cayennensis; the wing of the Tela bird measures 123.0, that of the Puerto Cortés individual 122.3. Although a large sertes from Honduras may show the entire Honduran population to be intermedlate, the specimens are tentatively assigned to race on the basis of size.

Family TROCHILIDAE

Threnetes ruckeri (Bourcier)

Band-tailed Barbthroat

SPECIMENS.--T. E. ventosus (8): San Alejo, 29 March-2

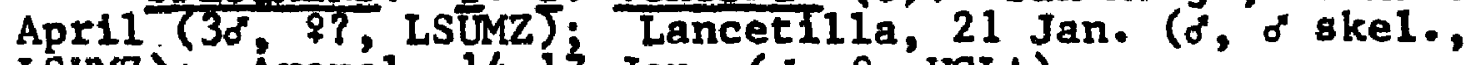
LSUMZ); Árenal, 14-13 Jan. ( $\delta^{\circ}, \%$, UCLA). 143).

PUBLISHED RECORD.--"Honduras" [in range] (Slud, 1964:

In Honduras this hummingbird is fairly common but local in the rain forests of the Caribbean slope, ranging up to 1,500 feet.

Mark Trafton, Jr., made the first observation of the species in Honduras at Lancetilla. From 1952 through 1961 he recorded it annually; his sightings are all from the months of February through September. In June 1952 Paul Slud saw it in the same area. V. C. Dunlap noted the spectes at Lancetilla on 21 February 1953, 3 February 1954, 
and 17 May 1955. Trafton recorded it as common in the underbrush on the slopes of $s$ teep, rocky ravines in heavily wooded rain forest areas. In May 1953 at Lancetilla, he found a nest that was situated about six feet above the ground. On 8 July 1953 he collected a nonbreeding female (not preserved) and photographed this individual. The measurements of this specimen were taken as follows: wing, 55; tail, 35. Kenneth S. Hamilton obtained two additional males at Lancetilla in January 1964.

J. G. Montrello collected a pair at Arenal, in the olancho rain forest, on 17 January 1954 ( $\left.0^{\circ}\right)$ and 14 January 1955 (\%).

At San Alejo, just west of Tela, I found the species to be fairly common along a stream in heavy selva during March and April 1963, at which time I secured four specimens (two males on 31 March, one male on 2 Apri1, and the other ind1vidual on 29 March). Three were obtained in a mist net strung across the stream. The wings of the three males measure $55.6,58.4$, and 59.8 ; the wing of the specimen of uncertain sex measures 55.9 .

The Arenal specimens are Indietinguishable from representatives of the race I. $\underline{\underline{r}}$. ventosus Bangs and Penard. The San Alejo and Lancetilla individuals are very olightly darker rufous on the throat than typical yentosus but not to a degree worthy of naming a new subspecies. The Honduran specimens have been examined also by Hugh $C$. Land and 
compared with material that he had secured in Guatemala; he agreed (personal communication) that the northern populations are not sufficiently different to warrant recognition as a separate subspecies.

\section{Phaethornis superciliosus (Linnaeus)}

\section{Long-tailed Hermit}

SPECIMENS $--\underline{P}$. s. longirostris (36): San Alejo, 31 March-1 April ( $d, q ?, d$ skel., $q$ skel., LSUMZ); Lancetilla, 20 Jan. -1 April ( ${ }^{\circ}, ?$ ?, ANSP; $30^{*}, 47, \mathrm{MCZ}$; $\sigma^{*}$, UF); LOMbardía (?, USNM); La Celba, 11 Jan., 28 July ( $\$$ CM; ó, MCZ); Catacombas, 24 March ( $0^{\prime \prime}$ BMNH; $\delta^{\prime \prime} \%$, MLZ); Cofradla, 10 March ( 9 , MLZ); Santa Ana, 18-25 Nov. (30, USNM); Progreso, 31 Jan. (o, MCZ); Cerro Nieve, 13 April (o, MLZ); San José de Santa Bárbara, 8-29 April ( $\sigma^{\circ},{ }^{\circ}$, MLZ); Finca Fé, 14-17 Sep. (o", ?, LSUMZ); 2 mi. SE El Jaral, 24 Feb. ( $8 ?$, LSLMZ); Lake Yojoa, 13 July-16 Aug. (20, $9, C M)$; Arena1, 20 Jan. (20, UCLÁ).

PUBLISHED RECORDS.--Santa Ana (Salvin and Godman, 1892: 318). La Ceiba (Bangs, 1903: 144). Lancetilia, Progreso, Tela region (Peters, 1929b: 427-428). Lancetilla (Stone, 1932: 310; Skutch, 1964: 6). Catacombas (Howe11, 1957: 82-83).

The Long-tatled Hermit is a cormon resident of lowland rain forests of Honduras, occurring below 4,500 feet elevation. It is most frequent in the lower story of dense rain forest but also occurs regularly in second growth and at low levels in more open rain forest.

Although Zimer (1950a: 18-29) recognized only a single species within the guperciliosus-malaris complex, such a taxonomic treatment is infeasible because of sympatry of the two forms in Cayenne. Zimmer though that a ring species might be involved, but a careful examination of South American birds indicated to me that P.malaris (Nordmann) is 
monotypic and restricted to Cayenne while $\underline{\text { P. Superciliosus }}$ 1s polytypic and widespread over Central and South America. I cannot see any differences in Central American populations with respect to darkness of plumage. It is true that the more southern populations are usually barred below, but this character crops up occasionally in Guatemalan birds and is highly variable in Honduran and Nicaraguan specimens; individuals from Costa Rica are seldom distinguishable from British Honduran material. In view of the fact that the 111-defined characteristic of barring on the under parts is the only distinguishing feature, I feel that it is best to regard $\underline{P} \cdot$ s. cephalus (Bourcter and Mulsant) as a synonym of P. s. Longirostris (Delattre). If cephalus is recognized, the entire Honduran population must be regarded as intermediate.

Phaethornis longuemareus (Lesson)

Little Hermit

SPECIMENS.--P. 1 - saturatus (29): Tela, 7-13 March (20, MCZ); Lancetilia, 23 Aug. (20,? ANSP); Catacombas, 23 March ( 8 , MLZ); Las Penitas, 4-17 Feb. (20, MLZ); Lepaera, 29-30 Dec.' (20, ₹, AMMN; $\left.0^{\circ}, \mathrm{MCZ}\right)$; San José de Santa Bárbara, 5 April-6 May (o", 2q, AMNH; 30, 2q, 2?, MLZ); Finca Fé, 7 Aug., 17 Sep., 21-30 Nov. (o", ?, of skel., \& skel., LSUMZ); Lake Yojoa, 16 June ( $q, C M)$; Segovia River, 24 June ( $\%$, USNM); "Honduras" (?, AMNH).

591) RUBLISHED RECORDS---Segovia River (Ridgway, 1888c: 591). Tela (Peters, 1929b: 428-429). Lancetilla (Stone, 1932: 310).

Occupying much the same area as $\underline{P}$. superciliosus, the Little Hermit ranges to a higher elevation, being found in 
the lower reaches of montane rain forest and cloud forest up to 5,500 feet elevation. The species is, however, primarily a lowland rain forest inhabitant with a preference for dense understory or guamil. It is common in Honduras and occurs in about the same numbers as does $\underline{P}$. superciliosus, though perhaps slightly more abundant locally.

Honduran birds are all typical of the race $\underline{P}$. 1 . saturatus Ridgway (type locality: EI Hogar, Costa Rica). I do not agree with Peters (1929b: 428-429) that the Tela specimens are somewhat intermediate between saturatus and the Mexican race, $\underline{P}$. 1. adolpht Gould, since all Honduran specimens examined are to me Indistinguishable from a Costa Rican series.

\section{Phaeochroa cuvierii (DeLattre and Bourcier)}

Scaly-breasted Hummingbird

SPECTMENS.--p. c. roberti (22): Lancetil1a, 17 Aug. ( 8 , LSUMZ); San Pedro Sula 31 Jan. ( $\sigma^{*}$, USMM); Santa Ana, 16 oct. ( $q$, USNM); Amapa, 18 Jan. ( 6 , LSUMZ); Río Pataste, $12 \mathrm{ml}$. S Dulce Nombre de Culmi, 29 Jan. ( 8 , LSUMz); San José de Santa Bárbara, 20 April-4 May (20, MLZ); Finca Fé, 26 Aug., 15 Sep., 7 Nov., 8 Dec. ( ${ }^{\circ}, 2 \%$, o skel., LSUMZ); Lake Yojoa, $19^{\circ}$ June, 16-23 July, $17^{\prime}$ Aug. (40, CM); Cata-

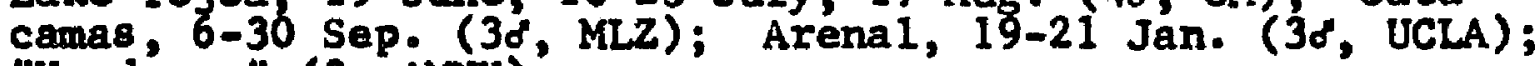
"Honduras" (?, AMNH)!

way, I891: 471 ).

This species is another humingbird characteristic of the lowland rain forests of the Caribbean slope of Honduras. It is found below 3,000 feet elevation and generally prefers second growth, forest edge, or more open areas of rain 
forest. Although it 1.8 primarily a bird of the understory and lower levels in second growth, I have collected individual males perched on dead 1 Imbs more than 75 feet above the ground. In Honduras the species is uncommon to fairly common; it apparently reaches the northern limit of its range in Guatemala and British Honduras.

Honduran specimens are representative of the northern race, $\underline{\text { P. }}$. robert1 (Salvin).

\section{Camprlopterus curvipennis (Deppe)}

Wedge-tailed Sabrewing

SPECTMENS.--C. c. pampa (5): E1 Boquerón, 17 Sep., 12 Oct. $\left(28^{\circ}\right.$, MCZ); Catacamas, 28 Sep. $\left(\sigma^{\circ}, f\right.$, MLZ); $5.5 \mathrm{mi}$. S San Esteban, 20 Jan. ( $q$, LŚMZ).

The occurrence of a population of this species in the rain forests of Olancho in enstern Honduras is certainly surprising. This locality is the southermost for the species and is separated from the nearest other known locality, in British Honduras, by approximately 300 miles. Apparentiy the species does not occur in the intervening area.

C. F. Underwood collected the E1 Boquerón and Catacamas individuals in 1937. Richard R. Graber secured the other female near San Esteban in 1962. Nothing else is known of the spectes in Honduras.

I am not altogether convinced that $\mathrm{C}$. c. pampa (Lesson) and c. c. curyipennis (Deppe) are conspecific. To be sure, they are closely related and allopatric and are obvious 
representatives of one another. However, in addition to the darker gray under parts and smaller bill of pampa ( 0 , 23.9-25.0 for 6 pampa, 26.1-29.5 for 9 curvipennis; $?$, 23.0-24.6 for 4 parpa, 26.0-27.6 for 9 curvipennis), there is one other important morphological difference, one that has not been previously brought out. The lower mandible of pampa (all ages of both sexes) is entirely black, while that of curvipennis is pale, especially towards the base. Furthermore, I have never seen a male of pampa with the swollen shaft of the outer primary angulated to the extent that is normal in curvipennis. This latter difference may be due to the small series Involved and may not, in reality, be characteristic of pampa. Nevertheless, it seems evident that a careful field study is needed to determine if possible isolating mechanisms are present in these two forms. The specific status of a closely related Mexican

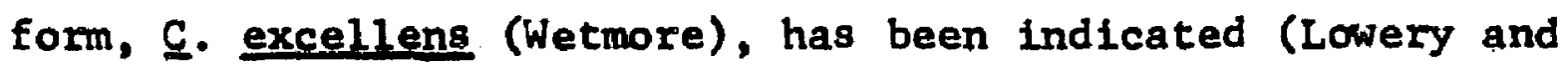
Dalquest, 1951: 583-586), so the possible speciftc status of pampa should be considered.

The Honduran specimens are tentatively assigned to $\underline{C}$. c. pampa (Lesson). The five specimens all appear to be females or young males (despite the indication on the label of the Catacamas male that it had testes "1/2 enlarged"), judging from the presence of white tail tips and lack of any swelling or angulation in the shafts of the outer primaries. In the matters of $812 e$, bill color, and darkness below, 
these birds match a series from British Honduras in all details. Although there is some difference in the amount of white in the tail tips, it seems best to regard the Honduran. population as pampa pending acquisition of further material.

\section{Campylopterus hemlleucurus (Deppe)}

\section{Violet Sabrewing}

SPECIMENS.--C. h. hemileucurus (47): La Celba, 8 Aug. $\left(\sigma^{\circ}, \mathrm{CM}\right)$; Catacombas, 21 March-7 April (30, CM; 20, ${ }^{7}$, MLZ); Santa Ana, 16 Nov. ( $0^{\circ}, \%$, USNM); Las Peñitas, 30

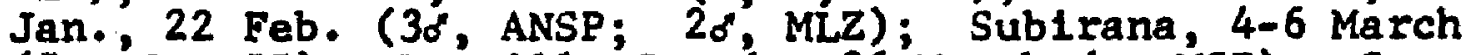
(58, \&, MCZ); Portil10 Grande, 26 March ( 8 , MCZ); Cerro E1 Triumpho, $20 \mathrm{mi}$. SE San Esteban, 27 March ( $\$$, LSUMZ); Merendón Copán, 15-17 June ( $d^{\circ}, q^{2}$ CNHM); La Libertad, 3-18 June (2 $\delta^{\circ}$ AMNH); Monte Verde, 23 July $\left(\sigma^{*}, M L Z\right)$; Cerro Nieve, 10-22 April ( $\sigma, 9$, AMNH); San Jose de Santa Bárbara, 7-8 April (2o, AMNH); Finca Fé, 1 Sep., 21 Nov.-8 Dec. (58", $\sigma$ skel., LSUMZ); Alto Guaimaca, 8 June ( $\sigma^{\circ}$, ANSP); Cerro Cantoral, 15-21 Feb., 12-13 Dec. (6 $\left.{ }^{\circ}, 29, \mathrm{MCZ}\right)$; Alto Cantoral, 3 Feb. (o", AMNH).

$1892: \frac{\text { PUBLISHED }}{324) \text { RECORPS.--Santa Ana (Salvin and Godman, }}$ Las Peñitas, Catacombas (Todd, 1942b: 289).

In Honduras the Violet Sabrewing is a fairly common resident in cloud forest, montane rain forest, and the upper reaches of lowland rain forest. The species is most abundant from 2,000 feet to 6,000 feet, but it may be found as low as sea level, at least in winter.

Honduran specimens are referable to the northern race, c. h. hemileucurus (Deppe).

\section{Florisuga mellivora (Linnaeus)}

White-necked Jacobin

SPECIMENS.--F. m. mellivora (16): San Alejo, 15 March18 April, 9 Aug. $(20,2 \%, \delta$ ske1., LSUMZ); Lancetilla, 2-8 Sep. (20, 29, ANSP); Montecristo, 24 March (o ske1., 
LSUMZ); Trujillo, 7 April ( $\%, C M)$; Catacombas, 29 March ( ${ }^{\circ}$ ANSP); Coyoles, 22 June ( $\left.\sigma^{\circ}, C M\right)$; Finca Fé, 13 Nov. ( $q$, CM); "Honduras" ( ${ }^{\prime}$; juv. $\delta$, BMNH).

PUBLISHED RECORDS.--San Pedro region (Sclater and Salvin, 1870b: 837). "Honduras" (Hartert, 1892: 330). San Pedro (Saivin and Godman, 1892: 341). Lancetilla (Stone, 1932: 312).

This humingbird is a fairly common species in the lowland rain forests of the Caribbean slope of Honduras. It has been recorded in Honduras from sea level to 2,500 feet elevation.

The occurrence of females in a masculoid plumage is definitely evidenced by one specimen from San Alejo (LSUMZ no. 29,145, $\$, 18$ March 1963). This Individual is externally a male, differing from typical male specimens only in the presence of scattered green feathers on the crown and in the more restricted area of purple gorget. I sexed this Individual carefully and found the ovary beginning to onlarge, with two ova distinctly larger than the mass of small, undeveloped ova. Other females taken in Honduras possessed the typical female plumage, lacking purple and having the throat barred with white or gray (due to pale tips on green feathers).

The Honduran populations are representative of the nominate race, $\underline{F}$. $\mathrm{m}$. mellivora (Linnaeus). 


\section{Colibri delphinae (Lesson)}

Brown violet-ear

SPECTMENS.--(4): La Ceiba, 8 Aug. ( $0^{\circ}, \mathrm{CM}$ ); Cerro E1 Triumpho, $20 \mathrm{mi}$. SE San Esteban, 27 March ( $\sigma^{\circ,}$ LSUMZ); Lake Yojoa, 26 July ( $\delta, C M)$; Catacamas, 8 oct. ( $\delta$, MLZ).

PUBI.ISHED RECORD.--San Pedro region (Sclater and Sa1vin, 1870b: 837). San Pedro (Salvin and Godman, 1892: 283 .

Inhabiting lowland rain forests on the Caribbean slope, this humningbird is decidedly uncommon to rare in honduras. It is known to range as high as 2,300 feet.

George M. Whitely collected the species at San Pedro in 1869 or 1870 (Sclater and Salvin, 1870b: 837; Salvin and Godman, 1892: 283), but I was unable to locate this specimen in the British Museum. C. F. Underwood obtained a male at Catacamas in 1937. Arthur C. Twomey and Roland W. Hawkins secured single males at La Ceiba in 1950 and at Lake Yojoa in 1951. Mark Trafton, Jr., recorded the species annually at Lancetilla between June and September during the years from 1951 through 1955; he reported that it was uncomon in the Lancetilla Valley. Paul Slud also observed it at Lancetilla in June 1952. Richard R. Graber collected a male on Cerro E1 Triumpho on 27 March 1963; he noted another individual on 1 April at the same locality. There are no other records or reports from Honduras. 
Colibri thalassinus (Swainson)

Green Violet-ear

SPECIMENS.--C. t. thalassinus (68): Merendón Copán, $15-27$ June (140, $\$$, AMNH; $\delta, \$$, CNHM; $\delta$, UCR); Montaña El Chorro, 23 June ( $\sigma^{\circ}$, MLZ); Mt. Puca, 9-10 Feb. (30, MCZ); Cerro Nieve, 10 April ( $q$, MLZ); Cerro Santa Bärbara, east slope, 27 March ( $\sigma^{\prime}$, LSUMz); Soluteca, 8 April ( $q$, MLz); Montaña Vásquez, 2 Jan., 10 March ( $\$$, AMNH; o, MCZ); Cerro Cantora 1, 4-12 March (6 $\delta^{\prime}, 2$ ?, MCZ; $\delta$, UCR); Montaña Cantoral, 24 Jan. ( $\sigma^{\circ}$, UCR); La Flor Archaga, 4 May ( $\sigma^{\circ}$, UCR); Rancho Quemado, 9-19 March, 15-16 May (2\%, AMNH; 150, 3?, MCZ); El Hatillo, 5-6 Aug. (86, $\%, C M)$; Mt. Uyuca, 22 sep. $(\sigma$, UF ) .

PUBLISHED RECORPS.--Merendón Copán (Ber1102, 1938: 9). Merendón, Montaña Vásquez, Rancho Quemado (Zimmer, 1950b: 3).

The Green Violet-ear is a common humingbird of the cloud forests of Honduras. The species occurs uncommonly In pine-oak associations a1so, and I have observed individuals feeding on flowering bushes in open situations away from forests. In Honduras this species has been recorded from 3,700 feet to at least 8,000 feet.

The Honduran populations have been described as $\underline{\underline{c}}$. $\underline{t}$. minor [Petasophora thalassina minor Berlioz, 1938: 9; Merendon, Copan, Honduras] on the basis of more slender body and less intense blue pectoral patch, in comparison with the northern, nominate race, C. t. . thalassinus (Swainson); the type of minor, which I have not examined, is in the Paris Museum. The extens lve sertes from Honduras, including a large number of topotypes, does not exhiblt any noticeable differences from Mexican specimens, and I regard minor as a synonym of thalassinus. 


\title{
Anthracothorax prevostil (Lesson)
}

\section{Green-breasted Mango}

\begin{abstract}
SPECIMENS.--A. P. grac1lirostris (75): Utila Island, 18 April (J, $9, C M)$; Roatán Island, 7 Jan. ( $0^{\circ}$, CNFM); French Harbor, 6 April (40, ${ }^{\circ}$, juv. $\left.\%, C M\right)$; Guanaja

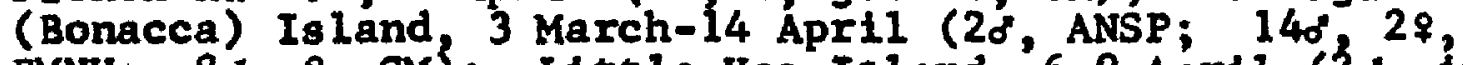
BMNH; $\left.8 \sigma^{\circ}, 8, C M\right)$; Little Hog Island, 6-9 April (20, imm. o, LSUaz); Lancetilla, 27 March ( 9, MCZ); La Ceiba, 27 March-3 May (40,2\%, CM); Cof radia; 4-10 March ( $0^{\circ}, C^{\circ}$; $40^{\circ}$, MLZ; o, $q$, MCZ); Las Penittas, 26 Jan. -2 Feb. (2。, ANSP); $6 \mathrm{mi}$. N vilila Nueva, 19 Sep. (o, Lsumz); Amapa, 26 Jan. (d, o skel., ISUMZ); Coyoles, 23 April, 12 July (d", CM; d, LSUMZ); Lake Yojoa, 26-28 July, 23 Aug. (30, CM; of, UF); Tegucigalpa, 11 Nov. (imm. of, AMNH); San Lorenzo, 28 Sep. -6 Oct. ( $\sigma^{\circ}$, ANSP; $2 \delta^{\circ}, \&$, MLZ; $30^{\circ}, \mathrm{MCZ}$ ); $5 \mathrm{mi}$. SE Namas igüe, 8 Oct. ( $\left(\right.$, LSUMZ); "Honduras" (?, ANSP); "Honduras ?" ( $\sigma^{\prime}$, EMNH).
\end{abstract}

PUBLISHED RECORDS.--San Pedro region (Sclater and Sa1vin, 1870b: 837). Bonacca [= Guanaja] Is land (Salvin, 1889: 365). "Honduras ?" (Hartert, 1892: 98-99). San Pedro (Salvin and Godman, 1892: 278). Tela River at Lancetilia [as gracilirostr18] (Peters, 1929b: 429-430). Bonacca $[=$ Guanaja] Island and Utila Island [as nigrilineatus] (Bond, 1936: 359). Bonaco [= Guanaja] Island [as gracilirostris] (Bond, 1939: 3). Cofradla (Todd, 1942b: 294).

In Honduras the Green-breasted Mango is an inhabitant of the lowlands of both coasts and the Bay Islands and Cayos Cochinos off the north coast. In the interior it ranges up to about 3,000 feet elevation, occurring primarily in the vicinity of rain forest, monsoon forest, and other areas of broadleaf trees. In the Pacific lowlands it is rather uncommon, while in the Caribbean is lands it is common and a dominant part of the avifauna. Although Bond (1936: 359) reported it as rare on Utila and unknown from Roatán, it is common on both these islands as well as on Guanaja and in the Cayos Cochinos. 
The extensive series of specimens from the Bay Islands does not exhibit any differences from mainland specimens, thus the race A. R. nigrilineatus [Anthracothorax prevost1 nlgrilineatus Bond, 1936: 359; Bonacca Island, Spanish Honduras] is invalid. Honduran birds were placed in the northern race, A. p. prevostif (Lesson), by Ridgway (1911: 463-465), but as pointed out by Peters (1929b: 429-430), Honduran populations of the species possess the shorter bill characteristic of the southern race, A. P. gracilirostris RIdgway. In the extensive Honduran series of the species, bill length of adults measured consistently smaller ( $d$, $<25.7$; $9,<25.9)$ than that of Mexican prevosti1; on this basis I refer the entire Honduran series to gracilirostris.

Klais guimeti (Bourcier)

Violet-headed Humingbird

SPECTMENS.--K. g. merrittil (6): Montecristo, 24 March (9, LSLMZ); Ta Ceiba, 29 July ( 8 , CM); Trujillo, 6 April

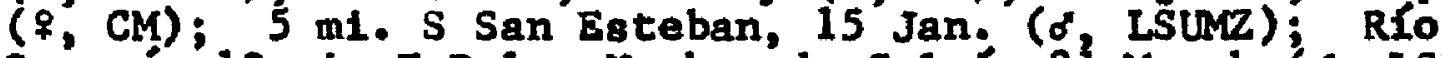
Guampú, 10 mi. E Dulce Nonbre de Culmi, 21 March (8, LSUMZ); Catacamas, 17 Oct. ( $\$$, MLZ).

PUBLISHED RECORD.--Catacamas (Moore, 1950b: 387).

Although in faunal works dealing with Central America this species is generally associated with the Subtropical Zone highlands, in Honduras it has been found only in the rain forests of the humid Caribbean lowlands west to the Sula Valley. All six Honduran specimens have been secured In lowland rain forest below 2,000 feet elevation. Furthermore, Skutch (1958a: 5-19) described the bird as common 
and breeding in a rain forest area of Costa Rica at 2,500 feet. Howell (1957: 83-84) also obtained it in rain forest in Nicaragua.

C. F. Underwood secured the first specimen for Honduras at Catacamas in 1937 (Moore, 1950b: 387). Arthur C. Twomey and Roland $W$. Hawkins collected a female at Trujillo in 1948 and a male at La Ceiba in 1950; the female was originally identified on the label as Chlorostilbon canivetif. Richard R. Graber obtained single males near San Esteban in 1962 and along the Rio Guampí in 1963. I encountered the species only once, in 1963, when I collected a female in rain forest at Montecristo.

This species is one of the many rain forest inhabitants that reach their northern 1 imit of distribution east of the Sula Valley, the northermost record being from the La Ceiba region.

The genus Klais seems to be rather poorly differentiated from Abeillia and might well be lumped with that genus; both genera are presently monotypic.

Honduran specimens are representative of the recently resurrected race, K. g. merrittif (Lawrence). Although Moore (1950b: 387) thought that the Honduran birds might represent a new race, they are not distinguishable from other Central American individuals. For a discussion of the race merrittil, see Zimmer (1950b: 11) and Howell (1957: 83-84). 


\section{Abeillia abeillel (Lesson and DeLattre)}

Enerald-chinned Huming bird

SPECTMENS.--A. a. abelilet (35): Las Peñitas, 2-24 Feb. (\%, ANSP; o, MCZ); Subitana, 6 March (2。, MCZ); La LIbertad, 16 June ( $\delta^{\prime}, M C Z$ ); Lepaera, 30 Dec.-1 Jan. ( $\sigma^{\prime}, \mathrm{CU}$; o, MCZ); Mt. Puca, 4-16 Jan. (68, ${ }^{\circ}$; AMNH; 50, 2?, MCZ); Cerro Nieve, 10 April (2\%, MIZ); San José de Santa Bárbara, 7-8 Aprt1 (3o, MLZ); Santa Bárbara, 20 May ( $\$$, MCZ); Cerro Santa Bárbara, east slope, 27 Jan. -27 March (2d, \$, \$?, LSUMZ): Lake Yojoa, 21 July, 25-27 Aug. (4o, CM). A. a.abet1lei $x$ aureg (22): Cantoral, $24 \mathrm{Jan} .-10$ March, 16 Nov. (3ठ, ANNH; o, $\%$, CNHM; of, MCZ); Cerro Cantoral, 7 March, 12 Dec. ( 0, MCZ; $\&$ UMZZ); Alto Cantoral, 6 Jan;-17 Feb. ( 9 , ANSP; $\left.120^{\circ}, \mathrm{MCZ}\right)$; Catacamas, 21 Oct. ( $\sigma^{\prime}, \mathrm{MLZ}$ ).

PUBLISHED RECORDS.-- "Notthern Honduras" [as abeillei]; "southern Honduras [as aurea] (Peters, 1945: 30).

This fairly common to common resident of cloud forests In Honduras seems to be rather local in 1ts distribution within any given forest area and is usually rather abundant where found. In Honduras the species ranges down to about 3,500 feet elevation.

The Nicaraguan population (southermost of the species) has been described as A. a. aurea Miller and Griscom [1925a: 2; San Rafael del Norte (above 4000 feet), Nicaragua] on the basis of Its smaller size and the more bronze or golden (1ess green) color of the upper parts, in comparison with the nominate race, A. a. abelllel (Lesson and DeLattre). Populations from northern and western Honduras are typical of abeillei in both color and size; southeast of the Comayagua valley, however, the birds do average more bronze (1ess green) in coloration but still retain the large size 
of abetllet (wings of males from this region measure 45.348.7). I regard these populations as intermediate between abeillel and aurea.

\section{Paphosia helenae (DeLattre)}

\section{Black-crested Coquette}

SPECTMENS.--(29): La Celba, 7 Aug. $\left({ }^{\circ}, C M\right)$; San Pedro Sula, 23 Nov. (Juv. $\delta$, USNM); Rlo Guampu, $10 \mathrm{mi}$ : E Dulce Nombre de Culmi, 18 March ( $\%$, LSUMZ); San José de Santa Bárbara, 5 April (o, AMNH); Finca Fé, 13 Sep. 5 Nov.-11

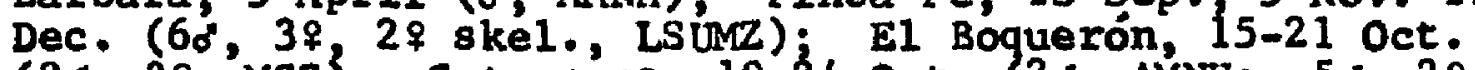
(20; 39, MCZ); Catacamas, 18-24 0ct. (20, AMNH; 58, 29 , MLZ).

\section{2: 364$)$.}

PUBLTSHED RECORD.--San Pedro Sula (Salvin and Godman,

Occurring in Honduras in and around rain forest below 2,500 feet elevation, this hummingbird is an uncommon resident of the humid Caribbean lowlands. I found it to be retiring and seldom recorded it, except when the poinsettias flowered in November and December; during this period considerable numbers of the species appeared on Finca Fé, feeding at these flowers.

\section{Chlorostilbon canivetil (Lesson)}

Fork-tailed Emerald

SPEC IMENS.-C. c. canivetil (28): Utila Is land, 18-19 Apri1 (20, $\%, \mathrm{CM} ;{ }^{\circ}$, CNFM); Roatán Is land, 8 Jan. (30, BMNH; $\delta$, CNHM); French Harbor, 6 Apri1 ( $\left.\sigma^{\circ}, C M\right)$; Oak Ridge, 8 April (o, CM); Barbareta Island, 10 April ( $9, C M)$; Guanaja (Bonacca) Island, 12 March-14 April (o', ANSP; 7o,

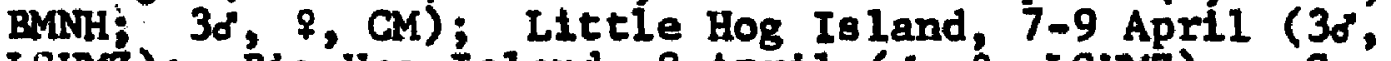
LSUMZ); Big Hog Island, 8 April ( $\sigma^{\circ}, 9$, LSUMZ); C. c. osberti (127): Catacombas, 31 March-6 April (2q, ANsP; \&, ML2); Cofradia, 1-10 March (2o, 12\%, ANSP; 9o, $\%$, MLZ); San Pedro Sula, 16 July ( 9 , USN); Coyoles, 23 April, $16-22$ June (2。, CM; $\$$ ? skel., LŚlaz); Mt. Puca, 31 Jan. ( $\$$ 
AMNH); Monte El Conejo, 20 May (?, MLZ); San José de Santa Bárbara, 5-29 April (13\%, 4\%, AMNH); Santa Bárbara, 11 May (o, AMNH); Finca Fé, 1 March (ó skel., LSuMz); Agua Azul, $26^{\circ} \mathrm{July}$ ( $\left.{ }^{\circ}, \mathrm{UF}\right) ; \mathrm{El}$ Caliche, 21 June-26 July ( $30^{\circ}$ ?, AMNH); Montafia Vásquez, 5 Jan. ( $\sigma^{*}, M C Z$ ); Cantoral, 10-27 Feb. (3o, AMNH); Cerro Cantoral, 22 Jan.; 11 April (3o, 2\%, MCZ); Alto Cantora $1,9 \mathrm{Feb}$. ( $\delta$, AMNH); Monte Redondo, 30 Jan., 7 Sep., 3 Dec. ( $\delta$, AMNH; $2 \%, M C Z)$; La Flor Archaga, 3-30 Jan.: 18-19 Sep., 10-12 Nov. (6o, \%, AMNH); Rio Hondo, 18 Aug. (2o, CM); E1 Hat111o, 28Apri1-8 May (o, \%, CNHM; 36, 3\%, MCZ); Tegucigalpa, 1 March-19 May, 10 Sép. (120, 149 , AMNH); Comayagüela, $24 \mathrm{May}$ ( $\delta, \mathrm{MCZ}$ ); Madre Vieja, 27 Sep. ( $\%, ?$, UF); Yeguare River Valley, 30 Jan. ( 0 , UF); Catacamas, 24 Aug - -29 Sep. (2o, AMNH; of $\%$, MLZ); Puerto Lempira, 5 Feb., 11-12 April (30, LSUMZ); Puerto Salamar, 11 Feb. (o", LSUMZ); San Francisco, Choluteca, 11 oct. ( $\%$, LSIMZ); "Honduras," 4 Apri1 ( $\%$, MLZ).

PUBLISHED RECORDS.--Bonacca [= Guana fa] Island, Roatán Is land (Salvin, 1889: 366; Hartert, 1892: 48). San Pedro Sula [as osberti] (Ridgway, 1911: 556). Bonacca [= Guana$j a]$ and vtila 1siands [as cantvet 1] (Bond, 1936: 359-360; 1939: 3). Bay Islands (Delacour, 1938: 545). Teguc1galpa, Las Flores [= La Flor Archaga], Catacamas, Mt. Puca, Cantoral, Archaga, $\mathrm{B} 1$ Caliche, La Flor Archaga, Cerro N1eve, Santa Bárbara, Monte Redondo, "Honduras" (Zimmer, 1950c: 10).

The Fork-tailed Emerald is perhaps the most widespread hummingbird in Honduras, occurring in the lowlands of both coasts, in the highlands below 6,000 feet, and in the islands off the north coast. In the Bay Islands and Cayos Cochinos, it is very common and one of the dominant members of the avifauna. In parts of the humid Caribbean lowlands It is fairly common, while in the more arid regions in the interior and on the Pacific slope it varies from uncomon to locally common. Virtually any type of semi-open habitat is utilized, although the species is rare or absent in areas of pine. 
As has been pointed out by Bond (1936: 359-360), the Bay Is lands populations are representative of the northern, nominate race, $\mathcal{C}$. c. canivetif (Lesson), which is found in Mexico, in the eastern Lowlands of Guatemala, in British Honduras, and on the Bay Islands (including the Cayos Cochinos, where I found it to be common). This race is distinguished from the race on the mainland of northern Central America, $\mathcal{C}$. $\subseteq$. osberti Gould, by the longer, much more deeply forked talls of males and by the broad gray tipping on the rectrices. I might add also that birds of the Bay Islands populations have longer bills ( $\delta, 32.5-35.2$; $9,27.9-29.6)$ when compared with the mainland birds ( $\sigma^{\circ}$, 24.6-31.8; $9,24.6-25.5)$. None of the Honduran specimens approaches the Nicaraguan race, L. c. Salvint Cabanis and Heine.

Thalurania furcata (Gmelin)

Common Woodnymph

SPECIMENS. - T. f. townsendi (48): San Alejo, 19 March2 April, 5 Aug. ( $50^{*}, 2{ }^{\circ}$ \& 8 kel., LSUM); Lancetilla, 15 Jan. -2 Feb. 19 March, 2 Sep. (?'AMNH; 20", 49, MCZ); LombardLa ( $\sigma^{\circ}$, USNM); Montecristo, 24 March ( $\sigma^{\circ}$, LSUMZ); La Celba, 2 May, 28 July-7 Aug. (4o, ${ }^{\circ}, \mathrm{CM}$ ); Yaruca, $13 \mathrm{Feb}$.

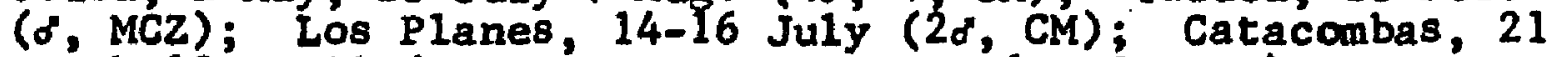

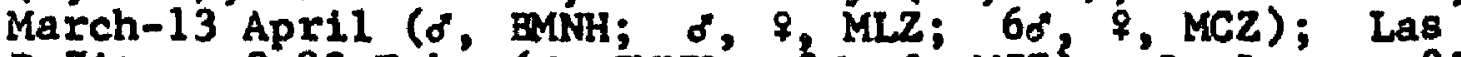
Peñitas, 9-22 Feb. ( ${ }^{\circ}$, BMNH; 30, $₹$, MCZ); La Leona, 25 June ( $0^{\circ}, \mathrm{MCZ}$ ); La Libertad, 30 June ( 7, MCZ); $5 \mathrm{ml}$. S San Esteban, 12 Jan. ( $\sigma$, LSUMZ); Rio Guampu, $10 \mathrm{~mL}$. E Dulce Nombre de Culmí, 14 March ( $q$, LSUMZ); Arenal, 22 Jan. ( $q$, UCLA); Segovia River, 18-19' June, 13 Aug. ( ${ }^{\circ}, 8,9 ?$, USMM).

PUBLISHED RPCORDS.--Segovia River (RIdgway, 1888c: 590-591) Y Yaruca (Bangs, 1903: 144). Lancetilla (Peters, 1929b: 429; Stone, 1932: 312). 
Ranging to an elevation of 3,200 feet, this humingbird is a fairly common resident in the rain forest regions of the Caribbean slope of Honduras. It occurs primarily in more open portions of forest, along the forest edges, and in second growth.

The populations from British Honduras, Guatemala, and Honduras have been described as $T$. $f$. townsendi [Thalurania townsendi Ridgway, 1888c: 590; Segovia River, Honduras] on the basis of a green abdomen; the race from Nicaragua south, I. E. venusta (Gould), exhibits a blue abdomen. Griscom (1932b: 205-206) reported intermediates between these two races "from the Honduras-Nicaragua boundary." Actually he was referring to specimens obtained by $W . B$. Richardson on the upper reaches of the Rfo Segovia in Nicaragua. Zimmer (1950c: 19) likewise regarded northern Nicaraguan birds as intermediate, but Howell (1957: 84) obtained typical venusta in the rain forest of east-central Nicaragua. I have carefully examined specimens from the Río Segovia and from Arenal, areas that are along the Honduras-Nicaragua boundary, and find no indication of any tendency towards yenusta; all Honduran specimens are typical of townsendi.

\section{Hylocharis leucot is (Vieillot)} White-eared Huming bird

SPECTMENS.--H. 1. pysmaea (112): Port 1110 Grande, 14 March-9 Apri1, 29 May (40, 2\%, 2?, MCZ); La Libertad, 11 June ( $\sigma^{\circ}$, AMNH); Monte Verde, 24 July (20, MLZ); Mt. Puca, 
10 Feb. ( $\%$, AMNH); $10 \mathrm{mi}$. NE La Esperanza, 31 Oct. ( $\sigma^{\circ}$, LSUMZ): 4 mi. SE' La Esperanza, 24 Jan. ( 9 'skel., Lsunz); 6 mi. SE La Esperanza, 30 Oct. (\&, LSUMZ); Soluteca, 3-9 Apri1 (\%, AMNH; o, MLZ); Muye; 17 Feb. (3\%, MLZ); $15 \mathrm{ml}$. NW Siguatepeque, 15 Aug. (2\%, CM); $10 \mathrm{mi}$. S Comayagua, 20 June $(\sigma, C M)$; Montaña Vásquez, 6-11 Jan. (40, \%, MCZ); Cantora 1, 23-26 Jan., 10 Sep., 16 Nov. (38, AMNH; 8 , $\%$, USNM); Cerro Cantoral, $20 \mathrm{Feb}-5$ Apri1, 23 Nov.-2 Jan. (o, 2\%, ANSP; d, 92 AMNH; $180^{\circ}, 6 \%, ?$, MCZ); Alto Cantoral, Sep.' (2o, 7, AMNH); La Flor Archaga, 16-20 Aug., 16 Nov., 5

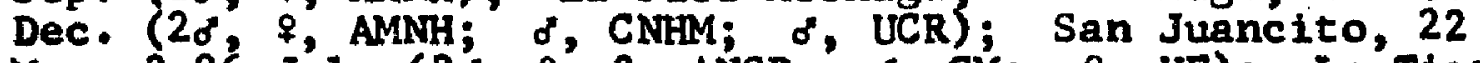
May, 3-26 July (3o, \%, ?, ANSP; o, CM; ${ }^{\circ}, \mathrm{UF}$ ); La Tigra, 22 May (?, UF); Ráncho Quemado, 14 March-5 April (3\%, ANSP; 76, MCZ); E1 Hat1110, 4 May, 6 July-12 Aug. (70, 5\%, CM; 9. MCZ); Tigre Hatilio, 2 July (\%, UCR); El Picacho, 28 Sep. ( $\delta$, AMNH); Tegucigalpa, 9 May ( $\delta$, UCR); vicintty Tegucigalpa, 8 May (o skel., MLZ); Mt: Uyuca, 27 Sep. ( $\delta$, UE); E1 Paraíso, 20 April ( $\sigma$, AMONH).

PUBLISHED RECORD.--San Juancito (Stone, 1932: 311 ).

In Honduras the White-eared Humingbird is a common species restricted to the highlands above 3,000 feet. It is primarily a species of the pine forests, being especially common In ocotal that has some shrubby undergrowth or in pine-oak associations.

Honduran populations are closely similar to the smaller, Nicaraguan race, H. 1. pygmaea (Simon and Hellmayr), both in size and in color. Although there is a greater range in 812 variation in the Honduran specimens than that given for the type series, the means in wing and culmen are typical of the smaller race. In addition, all Honduran specimens exhibit a somewhat greater amount of wite on the abdomen and a more restricted green area on the gorget than 18 typical of the nominate race, $H$. 1 . 1eucotis (Vieillot). Measurements of the Honduran serles are as 
follows: wing, o 50.6-54.3 (52.4), \& 47.5-52.3 (49.2);

exposed culmen, o $12.0-15.8(14.4)$, \& 14.7-16.7 (15.5).

Hylocharis eliclae (Bourcier and Mulsant)

Blue-throated Goldentall

SPECTMENS.--(22): San Alejo, 30 March-1 April (20, Lsumz); Lancet1lia, 23 Aug . ( $\delta$, ANSP); Catacombas, 2 April ( $\sigma^{\circ}$, BMNH); Santa Ana, 5 Aug. ( $\sigma^{\circ}$, USM); Monte E1 Portillo, 26 May (?, MLZ); San José de Santa Bárbara, 8-20 April ( 39, AMMH; 58, MLZ); Finca Fé, 28 April (2\%, LSUMZ); Lake Yojoa, 18 June, 23 July ( $\left.0^{\circ}, 9, C M\right)$; Catacamas, 17-25 Sep. (7, AMNH; 8 , MLZ); Segovia River, 13 June (ó, USMM).

PUBLISHED RECORDS.-."Honduras" (Cabanis and Heine, 1860: 42). Segovia River (Ridgway, 1888c: 591). Santa Ana (Salvin and Godman, 1892: 312). Lancetilla (Stone, 1932: 311 ).

Ranging up to 3,500 feet in Honduras, this humingbird is an uncommon to rare inhabitant of the lowland rain forests on the Caribbean slope. In EI Salvador the spectes Inhabits the arid Pacific lowlands (Dickey and van Rossem, 1938: 269-270), and it probably occurs in the monsoon forest on the Pacific coast of Honduras. The specimen secured by C. F. Underwood at Monte EI Portillo in 1936 was taken in the interior on the Pacific drainage at about 3,000 feet elevation.

In addition to the specimens listed above, there is at least one other known from Honduras. Cabanis and Heine (1860: 42) 1isted a juvenal male skin from "Honduras" that was deposited in the Heine Museum.

During 1962-1964 I encountered this species at only two localities. Along a stream in heavy selva at San Alejo, 
the specles was uncommon but falrly regular in March and Apr11 1963. On 28 Apri1 1963 Rose S. Monroe obtained two females in open forest at Finca Fé at an elevation of 2,300 feet, and I observed another individual there on 1 April 1964.

\section{Amazilia candida (Bourcier and Mulsant)}

\section{White-bellied Imerald}

SPECTMENS.--A. c. candida (80): Lancet111a, 26 Feb.-2 March, 9 Sep. $\left(?\right.$, ANSP; $\frac{\text { S, } 9}{9}$ MCZ); Montecristo, 24 March (o skel ; LSUMZ); La Ceiba, 28 July (o, CM); Trujillo, 6-8 Apri1, 19-30 Sep. (30, CM; 20, ?, USM); Catacombas, 14

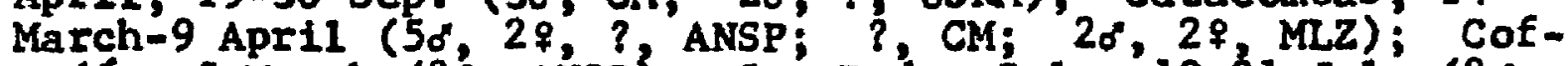
radia, 5 March ( $2 \%$, ANSP); San Pedro Sula, 19-21 July (2o, USNM); Santa Ana, 31 Oct.-12 Nov. (38, USNM); Las Peñitas, 27 Jan.-15 Feb. (48, $20^{\circ}$, ANSP; 28, CM; $20^{\circ} \%$, MLZ); Progreso, 31 Jan; ( $\left.0^{\circ}, 2 \%, M C Z\right)$; San Esteban, 22 June ( $0^{\circ}$, CM); La Libertad, 11 June (2 $\delta^{\prime}$, LSURz); Cerro Nieve, 10 April ( $\sigma^{\prime}$, MLZ); Șan José de Santa Bárbara, 8-15 April (30", \%, AMNH); Finca Fé, 13 Jan., 24 March, 13 Aug. -30 Nov. (40', $40^{\circ} 8 \mathrm{kel}$., 2 f skel., alc., LSUMZ); $4 \mathrm{mi}$. SW E1 Jaral, 22 Oct. (o') ske1., LSUMZ); Lake Yojoa, $17 \mathrm{July}-25$ Aug. ( $40^{\circ}, \%, \mathrm{CM}$ ); Cerro Cantoral, 13 Dec. ( 9 , MCZ); Catacamas, 22 Aug.-21 Oct. (40, 3\%, AMNH; $0^{\circ}$, MLZ); "Honduras" (?', USNM).

358) PUBLISHED RECORDS.--Near Potrerillos (Sclater, 1858b: 358). "Honduras" (Taylor, 1860: 116). Truj1110 (Ridgway, 1888c: 582). Santa Ana (Salvin and Godman, 1892: 2863. San Pedro Sula (Ridgway, 1911: 433). Progreso, Lancetilla (Peters, 1929b: 429): Lancetilia (Stone, 1932: 311). Las Peñitas, Catacombas (Todd, 1942b: 324).

The White-bellied Emerald is a common species of the lowland rain forests of the Caribbean slope of Honduras, occurring also in low montane rain forest and along the vega river forests to an altitude of 4,500 feet.

All Honduran specimens are typlacal of the widespread nominate race, A. c. candida (Bourcier and Mulsant). None of these individuals shows any approach to the larger race, 
A. c. pacifica LAgyrtria candida pacifica Griscom, 1929b: 10; Finca Carolina, near Tumbador (Pacific Slope), Guatemala], restricted to the Pacific slope of Guatemala.

\section{Amazilia luctae (Lawrence)}

Honduras Emerald

SPECTMENS.--(11): Cofradia, 6 March (o, MCZ); Coyoles, 13-28 June (40, CM); Santa Bárbara, 10 May (o', MCZ); E1 Boquerón, 21-25 Sep. ( $\delta^{\circ}, q, \mathrm{MCZ}$ ); Catacamas, 23 Aug. ( $($, MIZ); Las "Jabens" [= Catacamas region ?], 15 Sep. (d", LSUMZ); "Honduras" (?, AMNH).

PUBLTSHED RECORDS.-."Honduras" (Lawrence, 1867: 233; El11ot, 1878: 52). Catacamas (Moore, 1938: 534). Cofradía, Santa Bárbara, El Boquerón. (Peters, 1945: 64).

Amazilia luciae is one of the least known of Central American birds and is the only species endemic to Honduras. Only eleven specimens have been collected. The species is apparently a rain forest Inhabitant and is possibly common locally; four specimens each have been taken in the Coyoles and Catacamas regions.

The type was sent to Lawrence (1867: 233) in a collection of humingbirds that contained many A. candida but only a single specimen of this species. It was regarded by many subsequent authors as an aberrant example of some already described Amazilia or as a possibly hybrid. The eleven known specimens, representing both sexes, tndicate that A. 1uciae is either a good species or a well-markıd, isolated geographic race of a South American Amazilia.

C. F. Underwood obtained males from Cofradla in 1933 and from Santa Bárbara in 1935. At E1 Boquerón in the 
Catacamas region, he collected a female on 21 September and a male on 25 September 1937; at Catacamas he took a female on 23 August 1937. A specimen that he secured on 15 September 1937 is labeled "Las Jabens" or "Las Jabeus" and apparently came from this region also (on the basis of date), but the locality cannot be ascertained with any assurance. Arthur $C$. Twomey and Roland W. Hawkins obtained four males at Coyoles, sirigle birds on 16 June 1948 and 28 June 1950, and two individuals on 13 June 1950. Nothing further is known concerning the distribution of this species.

The Honduras Emerald looks like an A. candida that possesses a greenish-blue gorget and has a slightly longer, more decurved bill. Morphologically, it is closest to $A$. fimbriata (Gmelin), differing from that South American species in having the tail pattern of candida (bronze below, with a subterminal dark band, as opposed to the bronzy or bluish tail without a band in fimbriata). Variation in the amount of blue highlights in the gorget of luciae as exhibited by the known specimens is considerable. Two of the Coyoles males are decidedly more purplish in these reflections and exhibit some blue reflections at any angle of light, whereas most of the other specimens appear green in certain 1ight, bluish in others. There is a small amount of sexual dimorphism in luclae in that the females (and probably also young males) have a gray-tipped tail. 
Freshly molted luciae possess pale edgings to the gorget feathers, these edgings tending to become reduced with wear.

Other spectes of Amazilia belonging to this general group differ from luctae to a greater extent than does $\underline{A}$. fimbriata, mentioned previously. A. boucardi (Mulsant), a Costa Rican mangrove endemic, has a greener gorget and a shorter bill, and is more strongly dimorphic sexually, females lacking the gorget; A. lactea (Lesson) has a purple gorget and different tail pattern; and $\underline{A}$. versicolor (Vielllot) possesses a shorter bill and a conspicuous purplish tail band, as well as having a metallic bluishgreen crown in some races.

Until the life history of A. Luciae is studied, I believe that it is best retained as a full species.

\section{Amazilia cyanocephala (Lesson)}

\section{Red-billed Azurecrown}

SPECIMENS.--A. c. guatemalens 18 (168): San Alejo, 30 March ( $\sigma$, LSUMZ); Yaruca, 23 Feb. (F, MCZ); Catacombas, 22 March-4 April (50, 2\%,?, ANSP; 28, ${ }^{\circ}, \mathrm{CM} ; 40^{\circ}, 49, \mathrm{MLZ}$ ); San Pedro Sula, 22 Nov. ( $q$, USMM); Subirana, 24 Jan. ( $q$, MCZ); Portillo Grande, 20-25 Feb., 8 Apri1, 23-25 June (28, 39, CNHM; $\left.{ }^{2}, \mathrm{MCZ}\right) ;$ Coyoles, 22-29 June (38, CM); San Esteban, 22 June ( $2 \sigma, C M)$; Montaña Los Cedros, 2 June ( $\sigma^{\prime}$, ๆ, MLZ); Montaña El Chorro, 22 June ( $20^{\circ}$, MLZ); Plan del Rancho, -17 June ( $9, M L Z) ;$ Monte Verde, 25 July ( ${ }^{\circ}$, MLZ); Cerro Nieve, 13 April ( $\$$, AMNH); San José de Santa Bárbara, 7 Apri1-4 May (140, AMNH); $3 \mathrm{mi}$. N EI Mogote, 17 Jan. ( LsUMZ); Lake Yojoa, 14 June-16 Aug. (4o, 28, CM); $15 \mathrm{mi}$. NW Siguatepeque, 15 Aug. (o", CM); $5 \mathrm{mi}$. E Siguatepeque, 17 Oct. (alc., ISUMz); $4 \mathrm{mt}$. SE La Esperanza, 22 Jan. (? ske1., Lsu'Mz); Montaña Vásquez, 8-10 Jan.' (40", 3\%, ?, MCZ); Cerro Cantoral, 16 Feb.-22 Apr11, 23 Sep.-23 Dec. (d', AMNH; 250, 19\%, 3? MCZ); Alto Cantoral, 6 Jan. (d", 9 , CNGM); Archaga, $10-11$ Sep. ( $\sigma, \%$, AMNH); La Flor Archaga, 19 Sep. ( ${ }^{\circ}$, AMNH); Rancho Quemado, 14 March-5 April (o", AMNH; 6d, 
27, ?, MCZ); E1 Derrumbo, 3-9 Aug. (o, ANSP); El Hatillo, 4 May, 30 June, 2-16 Aug ( $60^{\circ}, 6 \%$, CM; $\left.\%, M C Z\right)$; Tegucigalpa, 14 April ( 0 , MLZ); Comayagüela, 14 March-14 May, 4 Oct. -27 Nov. (30, 6\%, AMNH); Escuela Agrícola Panamericana, 7 Feb. ( $\sigma$, UF); Yeguare River Valley, 5 June ( ${ }^{\circ}$, UF);

Catacamas, 14 Oct. (o, MLZ); San Francisco, Choluteca, 1114 oct. (2o, o skel., q skel., LSUMZ); $13 \mathrm{ml}$. SW San Marcos de Colón, 6 oct. (o", ISUMz). A. c. subsp. nov. (2):

Puerto Lempira, 14 April (28, LStMZ).

PUBLTSHED RECORDS.--S 1guatepeque (Taylor, 1860: 114). San Pedro Sula (Ridgway, 1891: 471). Yaruca (Bangs, 1903: 144). Catacombas (Todd, 1942b: 328).

This humingbird is a common species of the pine forests in the interior highlands of Honduras, ranging down to 2,000 feet elevation, and an uncommon to fairly common resident in the lowland pine savanna of the Mosquitia. In the nonbreeding season, individuals from highland populations wander considerably, entering cloud forest areas and sometimes descending to sea level in the lowland rain forests.

I tentatively assign al1 Honduran specimens except those from the Mosquitia to the race …‥ guatemalens is (Gould), a poorly differentiated subspecies. The character of brighter bronzy rump and upper tall-coverts, when compared with the northern race, A. c. cyanocephala (Lesson), is subject to much individual variation, but southern populations do average more bronzy than northern ones. In the Mosquitia of Honduras and Nicaragua a very distinct undescribed race of this species occurs. It is confined to the lowland pine of this region and is characterized by a glittering green (not blue) crown. Thomas $R$. Howell is presently in the process of describing it as new. The 
differences displayed by the crown color are perhaps great enough to act as an isolating mechanism in pair formation and thereby qualify the Mosquitia form as a distinct species. For the present, however, I am regarding this new bird as a race of $\mathrm{A}$. cyanocephala pending further studies.

\section{Amazilia berylilna (Deppe)}

Berylline Humingbird

SPECTMENS. - - A. b. devillel (22): Merendón Copán, 15-21

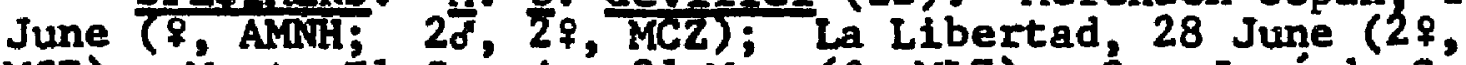
MCZ); Monte E1 Conejo, 21 May ( $q, \mathrm{MLZ}$ ); San José de Santa Bárbara, 6-29 April (\%; AMNH; 40, ?, MLZ); Santa Bárbara, 18 May (7, AMNH); Lake Yojoa, 23 June ( $9, ?$, UF); Comayagüela, 22 April-8 May (2o, 2\%, AMNH); Catacamas, 22 Aug. (\%, MLZZ).

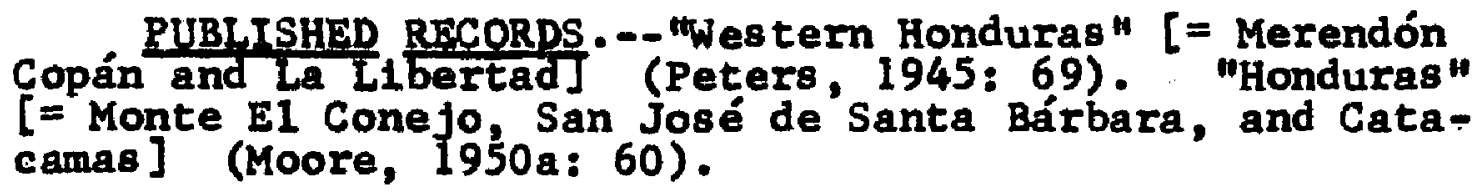

In Honduras the Berylline Hummingbird is an uncormon resident that occurs primarily in pine or pine-oak regions between 2,000 and 6,000 feet elevation, entering more humid forested areas in the nonbreeding season. Although the species is common in El Salvador and western Guatemala in the arid Pacific lowlands, it has not been found in this region in Honduras.

Dickey and van Rossem (1938: 262-265) reported extensive hybridization between $A$. beryllina and A. syanura in E1 Salvador. Although the two specles are widely symatric in Honduras, there is no Indication of hybridization in any of the known specimens. A. cyanurs, however, seems to be most 
common in the monsoon forests of the arid Pacific lowlands, where $A$. beryllina has not been found.

All Honduran individuals are typical of the well-marked southern race, A. b. devillei (Bourcier and Mulsant). Peters (1945: 69) included "western Honduras" in the range on the basis of the Merendón Copán and La Libertad skins in the Museum of Comparative Zoology. The specimen from Catacamas extends the known range of the species into eastern Honduras .

\section{Amazilia cyanura Gould}

\section{Blue-tailed Hummingbird}

SPECTMENS.--A. c. cyanura (31): San José de Santa Bárbara, 7 April ( $\delta$, AMNH; $d$, MLZ); La Flor Archaga, 13 Sep., 25 June ( $\delta$, ANSP; $\delta$ MCZ); Rancho Quemado, 2 April ( $\delta^{\prime}$, MCZ); Comáyagüela, 12 May, $20 \mathrm{sep}$. ( $\delta$, $₹$, AMNH); Jamastrán Valley, 17 Aug. ( 9 , UF); E1 Boquerón, 22 Aug.-8 Oct. ( $28^{\circ}$, 8. AMNH); Catacamas, 22 Aug -19 Sep. (20, AMNH; $50^{\circ}, 3$, MLz); San Lorenzo, 29 Sep.-1 Oct. ( $\left.\sigma^{\circ}, q, \mathrm{MCZ}\right) ; 2 \mathrm{ml}$. S E1 Corpus, $10 \mathrm{Feb}$. ( $\sigma^{\prime}, \delta^{\prime}$ ske1., LSUMZ); $5 \mathrm{ml}$. SE Namas igüe, 8 oct. (2d, ske1., LSUMZ); Honduras-N1caragua boundary [near Pacific coast] ( 3 ?, MCZ).

PUBLTSHED RECORD.--Boundary line between Nicaragua and Honduras "180 miles from Pacific coast" [= near Pacific coast ] (RIdgway, 1911: 445).

In Honduras Amazilia cyanura is primarily a resident of arid regions on the Pacific drainage below 4,000 feet, occurring also between 2,000 and 4,000 feet on the Caribbean drainage under more humid conditions. It is common in the monsoon forests in the Pacific lowlands but decidedly uncommon in deciduous forests on the Caribbean drainage and in the interior highlands. 
The relationships between $\mathbf{A}$. cyanura and $\mathbf{A}$. beryllina are discussed in the preceding account.

Honduran specimens are representative of the nominate race, A. c. cyanura Gould.

\section{Amazilia rutila (Delattre)}

\section{Cinnamon Huming bird}

SPECTMENS.--A. I. rutila (98): Cofradfa, 3-10 March (30", ANSP; ?, CM; 30, MLZ); Las Peñitas, 2 Feb. (d, ANSP; \%, MLZ); $3 \mathrm{mi}$. N Potrerillos, $19 \mathrm{Sep}$ ( $\sigma^{*}$, LSUMZ); $8 \mathrm{mi}$. S Potrerillos, 21 Feb. ( $\$$ skel., LSUMZ); Coyoles, 14 June ( $\%$, CM); Rfo Pataste, $12 \mathrm{mi}$. S Dulce Nombre de Culmi, 27 Jan.

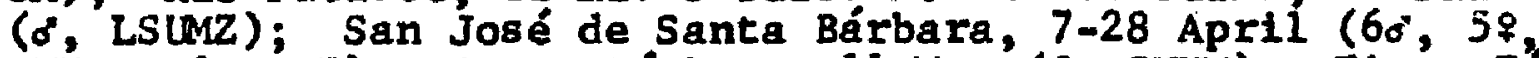
AMNH; ?, MLZ); Santa Bárbara, 11 May ( 9, CNHM); Finca Fé, 5 Nov. ( $\sigma^{*}$, LSUMZ); El Caliche, 26 June ( $\delta$, AMNH); Cerro

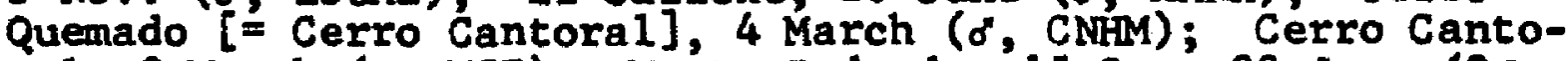
ra1, 9 March ( $\sigma^{\circ}, \mathrm{MCZ}$ ); Monte Redondo, 15 Sep.-22 Jan. (80, 39, MCZ); Archaga, 26 Sep. ( $\sigma^{\circ}$, AMNH); La Flor Archaga, 20 Aug. (?, MLZ); Cantarranas, $20 \mathrm{July}-10$ Aug. (39,?, ANSP); E1 Hatillo, 28 April-2 May (6d, MCZ); Tegucigalpa, 8 March, 8 May, 7 Sep. (2o, MLZ; o" MCZ); Comayagüela, 6 March-25 May (10\%, 69, AMNH; 20, MCZ); Madre Vie Ja, 19 May, 22 June, 31 Aug. (26, 2\%, UF); Güinope road, $2 \mathrm{mi}$. E Escuela Agrícola Panamericana, 26 May (d, UF); Catacamas, 23 Aug. -6 Oct. ( $0^{\circ}, 28$, AMNH; 20, MLZ); Puerto Lempira, 7 Feb., 9-14

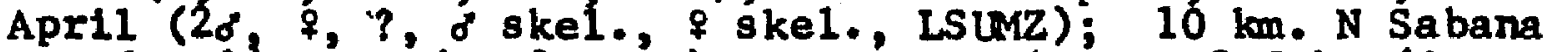
Grande, 14 Aug. ( $\sigma, 2 \%, C M)$; Puerto Salamar, 9 Feb. ( LSUMZ); $13 \mathrm{mi}$. SW' San Marcos de Colón, 3 oct. ( $\sigma^{\circ}$, LSUMZ); Honduras-Nicaragua boundary [near Pactfic coast]' (3?, MCZ).

PUBLTSHED RECORDS.--Tigre Is land (Sclater, 1858b; 358). Tigre Island near Comayagua, plain of Comayagua (Taylor, 1860: 115-116). Cantarranas (Stone, 1932: 311). Cofradia (Todd, 1942b: 329 ).

The Cinnamon Humingbird is a common species in the arid Pacific lowlands and in the more arid portions of the interior valleys in Honduras. In the interior highlands below 5,500 feet and in the silghtly more humid valleys on the Caribbean slope (Sula, Quimistán, and Aguán valleys), the spectes is uncommon to fairly common. Surprisingly, 
this hummingbird is also common in the Mosquitia; I secured several specimens at Puerto Lempira in February 1963 and in Apri1 1964.

Al1 Honduran specimens are representative of the nominate race, A. I. rutila (Delattre). Although there is some variation within Honduran populations with respect to deepness of the cinnamon coloration, none is typical of the deeply colored race, A. I. corallirostris (Bourcier and Mulsant), of the Pacific slope from Chiapas to El Salvador.

Amazilia gucatanensis (Cabot)

Buff-bellied Hummingbird $\left(\sigma^{*}, \mathrm{MLZ}\right)$.

SPECIMEN.--A. $Y \cdot$ Zucatanens is (1): Cofradía, 7 March

Although prevlously unreported from Honduras, this species is apparently a race visitant to Honduras in the nonbreeding season. C. F. Underwood obtained a male at Cofradfa, in the Quimistán Valley, in 1933. J. Alan Feduccia and I observed one feeding with an assortment of hummingbirds, including A. rutila and A. tzacat1, along a roadside hedge at La Pimienta, in the Sula Valley, on 19 September 1962. Although this area was searched repeated1y on subsequent occasions, the species was not seen again. Nothing further is known concerning its status in Honduras. It is known to be migratory in the northern part of its range and is probably only a vagrant in Honduras. The Honduran records are the southermost for the species. 
The single specimen matches examples of $A \cdot Z \cdot$ yucatanens is (Cabot) from British Honduras.

\section{Amazilia tzacatl (De la Llave) \\ Rufous-tailed Humingbird}

SPECTMENS.-A. t. tzacatl (131): Tela, 31 March ( $\sigma^{\prime}$, MCZ); Lancetilla, 18 Jan.-1 April, 23 Aug.-2 Sep. ( $\sigma^{t}, \%$, ANSP; $20^{\circ}, 3 \%$, MCZ; $\sigma^{\circ}$, UF); La Celba, 9-22 Jan., 20 March12 May, 29 July (58, CM; 49, MCZ; of, USNM); Yaruca, 19-26 Feb. (2。, MCZ); Trujillo, 8 April (20, CM); Catacombas, 26-31 March ( $q$, ANSP; $\delta, ?$, MLZ); Cofradí, 5-12 March $\left(20^{\circ}, 2{ }^{\circ}\right.$, ANSP; $30^{\circ}, 4 \%$, MLZ); Progreso, 31 Jan. (20, MCZ); Chamelecón, 3-10 March ( $60^{\circ}, 39,3$, USNM); $3 \mathrm{mi}$. N Potrerillos, 19 Sep. (o' skel., LSLMz); $4 \mathrm{mi}$. N Río Lindo, 29 Nov. (o' skel., LSUMZ); Amapa, 28 April, 18 Sep. ( 9 , alc., LSunz); Coyoles, 14 June, 12 July (20", CM); San José de Santa Bárbara, 5'Apri1-6 May (140, 7\%, AMNH); Finca Fé, 1 March, 18 July-19 Sep., 5-30 Nov.' (40,3\%,? $20^{\circ} 8 \mathrm{kel}, 39$ skel., 3 alc., LSUMZ); Lake Yojoa, 12 June-23 Aug. (10\%, 5\%, Iman, $\delta$, CM; o, UF); E1 Caliche, 26 July (\%, AMNH); Jamastrán Valley, 17 Aug. ( $\$$, UF); E1 Boquerón, 24 Aug., 19-26 Aug. (20, \&, AMNH); Catacamas, 5 Sep. -30 oct. (5\%, 5\%, AMNH; o, \&; MLZ); Segovia River, 13-16 Aug. (7, 2?, USNM); "Honduras" ( $\delta$ ", BMNH).

BUBLISHED RECORDS.--"Honduras" [as Trochilus dubusi] (Bourcier and Mulsant, 1852: 141-142). Segovia River (Ridgway, 1888c: 591). "Honduras" [as A. rleffert] (Hartert, 1892: 218). La Ce1ba, Yaruca (Bangs 1903: 144). Lancetilla, Progreso, Tela (Peters, 1929b: 429). Lancetilia (Skutch, 1931: 481-500; Stone, 1932: 311). La Cefba (Deignan, 1936: 190). Near Tela (Skutch, 1945a: 16).

This species is the most abundant of the humningbirds that are characteristic of lowland rain forest areas on the Caribbean slope of Honduras. It is commonest in open forest, along forest edge, and in second growth or semi-open areas, espectally when trees and shrubs are in flower. At Finca Fé, a locality in rain forest at 2,300 feet elevation, 1t outnumbered all other species of humningbirds. It 
ascends Into the lower edges of montane rain forest to an elevation of about 4,000 feet.

A11 Honduran specimens are referable to the widespread, Central American race, $A$. $t$. tzacat1 (De 1a Llave). Populations in northern Central America are sometimes regarded as A. t. dubusi [Trochilus dubusi Bourcier and Mulsant, 1852: 141; "Honduras"], but there is no significant geographical variation from Mexico to northern South America.

\section{Eupherusa eximia (DeLattre)}

\section{Stripe-tailed Hummingbird}

SPECIMENS.--g. e. eximia (70): Catacombas, 27 March-5 April (7, MLZ; of, $\%$ MCZ); Las Peñitas, 7-24 Feb. (6o, 5\%, MCZ); Potrillo Grande, 8 March, 21 May, 13 July (38, MCZ); 5 mi. S San Esteban, 14-18 Jan. ( June $\left(2 \sigma^{\circ}\right.$, MCZ); La Libertad, 28 June-1 July $\left(2 \sigma^{\circ}, \%\right.$, MCZ); Merendón Copán, 21 July ( $f$, UCR); Mt. Puca, 10 Jan.-10 Féb. (4ه, 38, ? MCZ); San José de Santa Bárbara, 21 April-4 May ( $0^{\circ}, 9$, MLZ); Santa Bárbara, 20-21 May (20*, MCZ); Falda de Santa Bárbara, 28 Apri1 ( 9 MLZ); Cerro Santa Bárbara, east slope, 19 Feb., 21 Apri1, 1 Dec. (2d, \&, LSLaz); Finca Fé, 11 Aug., 14 Sep. (d, alc., LSUMz); $5 \mathrm{mi}$. SW E1 Jaral, 26 Oct. (of LSUMZ); Lake Yojoa, 16 June, 21 July (20, 9, CM); Muye, 13-25 Feb. (30', MLZ; $0^{\circ}$, UCR); San Marcos de Guaimaca, 1-3 July (2d, $\$$, AlSP; 7 ML2); Cerro Santa Maria, 29 Dec. (\%, MLZ); Alto Cantoral, 18 Feb. ( $q$, MLZ); Archaga, 3 June ( $\delta$, AMNH); E1 Boquerón, 28 Sep. (o, AMNH); Catacamas, 19 Sep. -22 Oct. (90,2\%, MLZ). 1945: $(7)$.

PUBLISHED RECORD.--"Honduras" [in range] (Peters,

Despite the scarcity of previous reports, this species is a fairly common inhabitant in Honduras, occurring in cloud forest from 3,500 feet to 6,000 feet elevation. In the nonbreeding season, it descends into lowland rain forest to an elevation of 1,500 feet. 
Gray (1869: 133) 1isted the spectes from "Honduras ?" but I do not know on what he based this report. A11 other authors up to the time of Peters (1945: 77) omitted Honduras from the range; Peters based his report on the series of 8 pecimens in the Museum of Comparative Zoology.

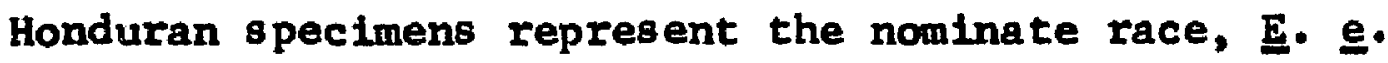
eximia (DeLattre).

\section{[Microchera alboeoronata (Lawrence)]}

\section{Snowcap}

This distinctive species is an inhabitant of lowland rain forest from Nicaragua to Panama. William Lady, of Tegucigalpa, who has made a number of prospecting expeditions to the olancho rain forest, on several occastons observed humingbirds that from his description could only have been this species. Once he found an occupied nest of the Snowcap.

Thomas R. Howell (personal communication) informed me that he saw a male of this species on the trail between Arenal and Los Paredes, in the Department of El Paraiso, on 12 January 1955. Howel1 (1957: 84) also reported the species as common in the Nicaraguan rain forest about 100 miles south of the Río Segovia. The species is probably widespread in the olancho rain forest. Nicaraguan Individuals are representative of the northern race, $\underline{M} \cdot$ a. parvirostris (Lawrence). 


\section{Lampornis amethystinus Swains on}

Amethys t-throated Humingbird

SPEC TMENS.--L. a. 8alvini $\times$ nobllis (15): Montaña E1 Chorro, 23 June-1 July (68, ML); MIZ); Montaña El Silión, 2 July (20, MLZ); Montaña La Cruz, 25-26 June (2。, MLZ); Monte Verde, 25 July ( $\sigma^{\circ}$, MLZ); Monte El Portillo, 15 July ( $\left.\sigma^{\prime}, \mathrm{ML}\right)$; Mt. Puca, 6 Feb. ( $\sigma^{\circ}$ MCZ); Santa Bárbara, 20 May ( 7, UCR). L. a. pob1l1s (39): Montaña Vás quez, 22 Nov.-11 Jan. ( $\sigma^{\prime}$, BMNH; $80^{\circ} \%, \mathrm{MCZ}$; $\%$, $?$, USNM); Cantoral, 20 Apr11-27 May, 7 Aug. (6 $\sigma^{\circ} 39,8 ?$, Miz); Cerro Cantoral, 2 Jan., 16 Feb.-2 March, 12 Aug. (6o", 28, MCZ); Alto Cantoral, 4 Féb. ( $\sigma$, MCZ); Montafia Cantorai, 22 Jan. (20, UCR); San Juanctto, 4 July ( $8, C M) ;$ Rancho Quemado, 16 Feb., 13-16 March, 19 May (40", MCZ); E1 Derrumbo, 21 July ( $\sigma, M C Z$ ).

58). $\frac{\text { PUBLISHED RECORDS.--Montafia Vásquez (Griscom, 1932c: }}{\text { Cantora1 (BerIioz, 1938: 4-6). }}$

Inhabiting cloud forests above 5,000 feet elevation, the Amethyst-throated Humingbird is an uncommon to fairly common spectes in Honduras, occurring sympatrically with $L$. viridipallens or L- sybillae, which usually outmumber it.

Berlioz (1938: 4-6) reported an adult male, an adult female, and an immature male in the Paris Museum; all were secured by C. F. Underwood at Cantoral. I have not examined these specimens, and they are not included in the 11st above.

The Honduran race, L. a. nobilis Griscon [1932c: 58; Montaña Vasquez (6500 ft.), District of Achaga (= Archaga), Honduras], is easily distinguished from the Guatemalan subspectes, L. a. palvini (RIdgway), by the smaller size and generally darker and grayer (1ess brownish) under parts. East of the Comayagua Valley, populations are typical of nobilis. West of this valley, there 18 a tendency towards 
larger size, but the gray coloration is still evident; I consider these populations to be intermediate between nobilis and salvini. The wings of male specimens west of the Comayagua Valley measure 62.3-66.5 (64.0), while those east of the valley measure $56.7-63.8(61.6)$.

\section{Lampornis viridipallens (Bourcier and Mulsant)}

\section{Green-throated Mountain-gem}

SPECTMENS.--I. v. virldipallens (88): San Pedro Sula, 29 March (2б, CNHM); Las Peñitas, 2-28 Feb. (40; BMNH; $140^{\circ}, 89, \delta^{\circ}$ ?, MCZ); Merendón Copån, 17-26 June (30, AMNH; o, CNHM; o, MLZ; 28, \&, MCZ); E1 Silión, 10 July ( $\sigma^{*}$, MĹz); Montaña La Cruz, 1 July ( ${ }^{\circ}$, MLZ); Belén Gualcho, 1718 July $\left(2 \sigma^{\circ}, \%\right.$, MLZ); Monte Verde, 22-24 July (3\%, MLZ); Mt. Puca, 7' Jan.-10 Feb. (50, 69,?, AMNH; 6o, 49, MLZ); Cerro Nieve, 10 April ( $\$$, AMNK); Sán José de Santa Bárbara, 8 Apri1 ( 9 , AMNH; $q$, MLZ); Santa Bárbara, 17-27 May ( $\%$,

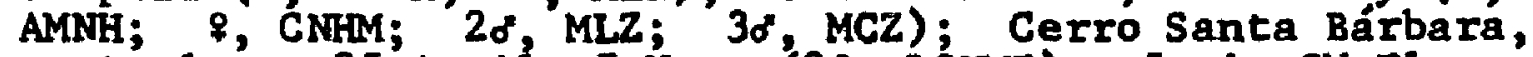
east slope, 25 April, 7 Nov. (29, LSUMZ); $5 \mathrm{mi}$. SW E1 Jaral, 4 Nov. ( ${ }^{\circ}$, LSUMZ); Lake Yojoa, 15-16 June, 18 July

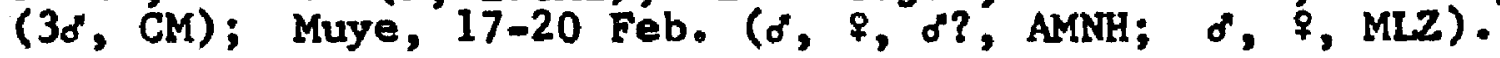

PUBLISHED RECORDS.--Merendón Copán, Santa Bárbara

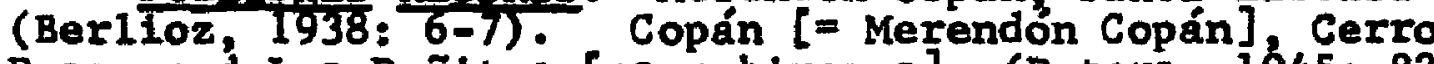
Puca, and Las Peñitas [as nubivagus] (Peters, 1945: 82). El Sillón, Montaña La Cruz, Monte Verde, Belén Gualcho, Merendón Copán, Mount Puca, Santa Bárbara, Cerro Nieve, San José de Santa Bárbara, Lake Yojoa, San Pedro Sula, Las Peñitas, Muye (Monroe, 196.3b: 7).

Lampornis viridipallens is an inhabitant of mountain forests in Honduras west of the Sula and Comayagua valleys. It is primarily a cloud forest species that occurs above 4,000 feet, but it may also be found in pine-oak associations in more arid situations. In cloud forest it is a common species, but it is decidedly uncommon under less humid conditions. 
In addition to the above listed specimens, there is a small series in the Paris Museum. Berlioz (1938: 6-7) mentioned an adult male from Merendón Copán and three immature males from Santa Bárbara.

Geographic variation within this species, as well as the relationships between $L$. viridipallens and $L$. sybillae, has been discussed at length in one of my recent papers (Monroe, 1963b: 1-10). Differences in male display patterns, as well as morphological differences regardless of sex or age, Indicate the specific distinctness of these two forms. For further discussion, see the account of $L$. sybillae.

Typical L. $\mathbf{~}$. viridipallens (Bourcier and Mulsant) ranges from central Guatemala into western Honduras; the unique type of $\mathbf{L}$. $\underline{y}$, sennectens Dickey and van Rossem [1929b: 209; Los Esesm1les, Dept. Chalatenango, 8,000 feet, El Salvador] is an example of the nominate race (Monroe, 1963b: 5-7). The race L. $y$. nubivaqus Dickey and van Rossem [1929b: 210; Volcán Santa Ana, Dept. Santa Ana, 7,000 feet, El Salvador] is valid on the basis of the reduced green areas on the sides of the breast; it is confined to a few mountain peaks in E1 Salvador.

\section{Lampornis sybillae (Salvin and Godman)}

Green-breasted Mountain-gen

$$
\text { SPECTMEN .--(143): Port1110 Grande, } 3 \text { Apri1-25 June }
$$

(58, \%, क?, CNHM; 7o, 28, क?, MCZ); Cerro E1 Triumpho, 20 mi. SE San Esteban, 23 March (f, \&, LsurZ); Montaña 
Vásquez, 19 Nov. -10 Jan. (40, 2\%, ANSP; 50, 5\%, AMNH; 270,

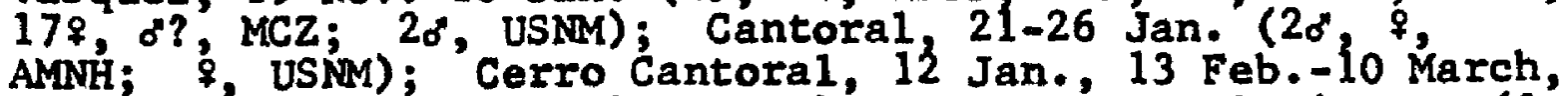
$10 \mathrm{May}\left(20 \delta^{\prime}, 12 \%, 20^{\circ}, 2\right.$ ?? MCZ); Alto Cántoral, 4 Jan. (?', CNHM); La Flor Árchaga, 24 0ct. ( $\sigma^{\circ}$, AMNH); San Juancito, 25 June-4 Aug. ( $29, \mathrm{CM} ; 20^{\circ}, 39, ?$, juv. o, ANSP); Rancho Quemado, 15 March (20, \&, MCZ); Ei Derrumbo, 3-9 Aug. (20, AMNH); E1 Hat11lo, 5 Aug. ( $\delta, C M)$; "Las Peñitas" [ TegueIgalpa ?], 18 Jan. ( 9, CNHM); Uyuca, 22 Sep. (d, $\$$, UF); Catacamas, 2 Aug. ( $\sigma^{\circ}$, MLZ).

PUBLISHED RECORPS.--San Juancito (Stone, 1932: 312). Cantoral, Montaña Vásquez (Ber110z, 1938: 6-7). Rancho Quemado, Cerro Cantoral, Montaña Vásquez, Portillo Grande (Peters, 1945: 82-83). Portillo Grande, Catacamas, Montaña Vásquez, Rancho Quemado, Cantoral, Alto Cantoral, Cerro Cantora1, E1 Derrumbo, La Flor Archaga, El Hatillo, "ilas Peñitas $"=$ probably near Teguclgalpa," San Juancito, Mount Uyuca (Monroe, 1963b: 8).

The Green-breasted Mountain-gem replaces L. viridipallens in the cloud forests of Nicaragua and of Honduras east of the Comayagua and Sula valleys. Its ecology and habitat requirements, as far as I am able to determine, are the same as those for L. viridipallens.

I have Indicated in an earlier paper (Monroe, 1963b: 1-10) that I regard $L$. sybillae as specifically distinct from L. viridipallens, despite the allopatric replacement of the two forms. The two species approach each other geographically on opposite sides of the Sula Valley (to within 35 miles) and the Comayagua Valley (to within 60 miles). Males of the two species are distinctly different morpho$\log i c a 11 y$, and I theorized that the differences would act as Isolating mechanisms were the two species sympatric. Males of viridipallens exhibit green gorgets, sharply contrasting white breasts, and no white tail flash during courtship 
display; on the other hand, males of sybillae are entirely green below, with no demarcation between the gorget and the rest of the under parts (which lack white altogether), and have a white tail flash. Females are morphologically distinct, but their differences are not as constant. Adult females of sybillae generally have the throat entirely buff, while the throat of viridipallens is white at all ages; however, immature females of sybillae are white-throated and a few adults of viridipallens show traces of buff on the throat. The presence or absence of white in the tail (if absent, it is replaced by gray) will distinguish the two species in any age or plumage of either sex.

I have mentioned (Monroe, 1963b; 3) a specimen of $\mathrm{L}$. sybillae taken by $C$. F. Underwood that was labeled "Las Peñitas / Jan. 18, 1934." This individual would seem to indicate sympatry of the two species, since Las Pefiitas has yielded a series of L. yirldipallens, but the label seems to be in error. The date Indicates that Underwood was in the Tegucigalpa region, not at Las Peñitas; in any event, the label is certainly in error in some manner and this individual should not be considered as establishing sympatry between the two species.

Lamprolatma rhami (Less on)

Garnet-throated Humaingbird

SPECIMENS.--I. r. xham1 $\times$ saturat Lor (33): Montaña E1 Chorro, 23 June-1.July $(2 \delta, 2, \overline{M L Z})$; EI Sillón, 10 July ( $\delta$, MLZ); Montafia El Sillón, "31" June-2 July (20, MLZ); 
Montaña La Cruz, 25 June-7 July (30, 4\%, $0^{\circ}$, MLZ; ${ }^{\circ}$, UCR); Monte El Candado, 30 May ( ${ }^{\circ}, \mathrm{MLZ}$ ); Monte Verde, 21-25 July (108, 3\%, MLZ); Monte El Port111o, $15 \mathrm{July}$ (d, 29, MLZ); Mt. Puca, 9 Jan. ( ${ }^{\circ}$, MCZ). L. r. saturat lor (39): El Caliche, 1 July (d, MLZ); Montaña Vásquez 16 Dec.-15 Jan. (o, BMNA; 120, MCZ); Cantoral, 15 Apri1-27 May (39, MCZ); Cerro Cantoral, $12-22$ Feb., 16 Dec. ( $80^{\circ},{ }^{2}$, MCZ; ', USNM); Montaña Cantora 125 Jan. 15 Dec. (20, UCR); San Juancito,

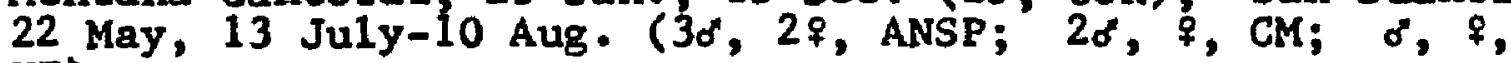
UF).

Cerro PUBLISHEP RECORDS.--San Juancito (Stone, 1932: 312 ).

Confined to cloud forest above 5,500 feet elevation, this humbingbird is fairly common locally in Honduras.

I obtained a female of this species at San Juancito (elevation 6,900 feet) on 2 February 1963, but this specimen was subsequently lost and is not 1 isted above.

The Honduran populations have been described as $\underline{L}$. $\underline{\underline{r}}$. saturatior Griscom [1932c: 58; Cerro Cantoral (6500 ft.), District of Achaga (= Archaga), Honduras] on the basis of smaller size and average color differences in the remiges and rectrices. I failed to note any color differences in the Honduran series when compared with nominate $L$. $\underline{\text {. xhami }}$ (Lesson) from Guatemala. However, there is a tendency towards smaller size in the southern part of the range of the species, which terminates in Honduras. The wings of a series of males from east of the Comayagua Valley measure 70.6-76.7 (73.0), while those of a similar series west of the valley measure $71.9-77.4(75.0)$. I have therefore considered eastern Honduran birds to be typical saturatior 
on the basis of size alone and the western Honduran populations intermediate between rhami and saturatior.

Eugenes fulgens (Swainson)

Magnificent Humingbird

SPECTMENS - -E. E: viridiceps (53): San Esteban, 22 June $(\sigma, C M)$; Merendón Copán, 21 June ( $\sigma$, AMNH; $d, C N M$ ) ; Montaña Los Cedros, 2 June ( $\sigma^{\circ}, M_{2}$ ); Montaña El Chorro, 22 24 June (36, MLZ); Montaña La Cruz, 25 June-7 July (38', MLZ); Plan del Rancho, 12-27 June (20, MLZ); Belén Gualcho, 14 July ( ${ }^{\prime}$, MLZ); Monte Verde, 22-25 July (8d, MLZ); Mt. Puca, 5 Jan.-7 Feb. (7 $7 \sigma^{\circ}, \mathrm{MCZ}$ ); Finca Fé, 13 Nov. ( $\sigma^{\circ}$, LSUMZ); El Guayabal, 27 Jan. ( $\delta$, MLZ); La Florida, 25 Dec. ( $\sigma^{\prime}$, AMMH); E1 Caliche, 13 July ( $\alpha^{\prime}$, MLZ); Montafia Vásquez, 9 Dec. ( ${ }^{\circ}$, AMMN; $20^{\circ}$, UCR); Cerro Cantoral, 20 Feb., 2 Apr11, 26 Nov.-12 Dec. (40, MCZ); Montaña Cantoral, 25 Jan, $10-20$ Sep. (39, UCR); La Laguna Cantoral, 19 July ( 9 , MLZ); Archaga, 4 Sep. (d', AMNH); La Flor Archaga, 20 Aug., 16 Nov., 13 Dec. (3d, AMNH); Rancho Quemado, 5 April (d", MCZ); E1 Derrumbo, 3-9 Aug - ( 9 , LSUMZ); E1 Hatillo, 30 June ( $q, C M$ ); Tegucigalpa, 25 Jan. ( $q$, CNFM); Uyuca, 22 Sep. ( ${ }^{\prime}$ UF); "Honduras $[=$ etther Archaga or La Libertad] (o), MLZ).

PUBLISHED RECORD.--"Honduras" (Ber11oz, 1938: 7-8).

Inhabiting cloud forest above 3,500 feet, the Magnificent Humingbird is uncomon to fairly common in Honduras. It frequently descends to 2,000 feet in the nonbreeding season. The species also occurs occasionally in pine-oak associations or in scrubby growth away from the forests when the trees and shrubs are in flower. This humingbird may also wander into rain forest in winter, as evidenced by the male I collected at Finca Fé in 1962.

Berlioz (1938: 7-8) mentioned four male and three female specimens from Honduras that are currently in the Paris 
Museum. I have not seen these skins and they are not listed above.

Honduran specimens are typical of the race E. E. viridiceps Boucard.

\section{Heliothryx barroti (Bourcler)}

\section{Puxple-crowned Fairy}

SPECIMENS.--(9): Lancetilla, 19-26 Jan. (2。, MCZ); La Ce1ba, 19 Jan., 1-13 May (d", 9, CM; d, MCZ); Yaruca, 15 Feb. (o, MCZ); Chamelecón, 26 Nov. ( $q$, USNM); "Honduras" (2ه", USNM).

PUBL,ISHED RECORPS.--Chamelecón (Salvin and Godman, 1892: 251). La Celba, Yaruca (Bangs, 1903: 144). Lancetilla (Peters, 1929b: 430).

This very distinctive humingbird in Honduras is confined to rain forest on the Caribbean slope. It is decidedly rare anywhere north of Costa Rica and is known from Honduras only by the nine spectmens 118 ted above and by two observations by Mark Trafton, Jr. (at E1 Mochito and San Alejo), both in January. The highest elevation at which it has been recorded in Honduras is 3,500 feet.

I agree with Howell (1957: 85) that this species should not be lumped with the green-crowned South American species, H. aurita (Gmelin). As Howell pointed out, the blue crown of the males of barroti may play an important role in species pair formation and might possibly act as an 180lating mechanism should the two forms occur sympatrically. Zimmer (1953a: 4-5), although considering aurita and barroti as conspecific, mentioned that no intermediates are known. 


\section{Heliomaster constantii (DeLattre)}

\section{Plain-capped Starthroat}

SPECTMENS - - - H. c. constantil > leocadiae (15): Cantarranas, 6-8 Aug. (2d, ANSP); E1 Derrumbo, 3-9 Aug. ( $q$, UCR); El Zamorano, $29^{\circ}$ Aug. ( $\sigma^{\circ}$, UF); Gülnope road, $2 \mathrm{mi}$. S Escuela Agrícola Panamerlcana, 26 May (d, UF); Yeguare River Valley, 31 Aug. ( $\sigma^{\prime, U}$ UF); Catacamas, 21 April ( ${ }^{\prime}$, MLZ); Puerto Salamar, 9-13 Feb. ( ${ }^{*}, \delta^{\prime}$ skel. , LSUMZ); $7 \mathrm{mi}$. NE Choluteca, 12 Feb. ( $\delta$, LSUMZ); San Francisco, Choluteca, 6 Oct. (d', LSUMZ); Honduras-Nicaragua boundary [near Pacific coast] (4?, MCZ).

$$
\text { PUBLISHED RECORD.--Cantarranas (Stone, 1932: 310). }
$$

The Plain-capped Starthroat occurs in the arid Pactfic lowlands of Honduras below 3,500 feet elevation. The species is uncommon to fairly common in Honduras. In the interior it is found on the Pacific dratnage only, except in the Olancho Valley, where it Inhabits the more arid regions around Catacamas.

In the more extensive lateral extensions of the gorget and in the darkness of the gray on the under parts, Honduran specimens are much closer to the southern race, $\underline{H}$. c. constanti1 (Delattre), than to the Mexican race, $\mathrm{H} \cdot \mathrm{c}$ leocadiae (Bourcter and Mulsant). When compared with examples of the nominate race from Costa Rica, the Honduran birds differ only in being a shade lighter below.

Heliomaster longlrostris (Audebert and Vieillot)

$$
\text { Long-billed Starthroat }
$$

SPECTMENS.--H. 1. pallidiceps (25): Progreso, 31 Jan. ( ${ }^{\prime}$, MCZ); San José de Santa Bárbara, 7-12 April ( $70^{\circ}, 49$, AMNH; o, MLZ; o, UCR); Finca Fé, 7 Aug.-5 Nov. ( $2 \delta^{\circ}, q^{\circ} \delta^{\circ}$ ske1., \& skel., LSUMZ); Catacamas, 21 Sep.-20 Oct. (d, 2q, AMNH; 38, MLZ). 
PUBLISHED RECORDS.--Progreso (Peters, 1929b: 430). "Honduras (Zimer, I953a: 13).

The humid lowland representative of the genus in Honduras is the Long-billed Starthroat. It occurs only in and around humid lowland rain forest on the Caribbean slope below 2,500 feet. The species is decidedly uncommon in Honduras. In the Olancho Valley it is sympatric with H. constantil, the latter tending to occur in the more arid portions of the valley.

Peters (1929b: 430) obtained a single male on an abandoned banana plantation at Progreso in 1928. C. F. Underwood secured the series from San José de Santa Bárbara in 1935 and from Catacamas in 1937. Zimmer's (1953a: 13) record is based on the series taken by Underwood.

In 1962-1964 I found the species at two localities. It was regular but uncommon in the rain forests of Finca Fé (at 2,300 feet elevation), and I noted it on two occasions in April 1963 at San Alejo, in the rain forests at sea leve1.

Al1 Honduran specimens are typical of the northern race, ㅂ. 1. pallidiceps Gould, in possessing bluish-green (not blue) crowns; In this respect they match specimens from southwestern Mexico. On the average, the Honduran serles seems to have the gorget area more restricted than does pallidiceps but not to an extent that would justify the naming of a new subspecies. 
Dortcha enicura (Vieillot)

Slender Sheartail

SPECIMENS.--(2): Montaña La Cruz, 1 July ( $q$, MLZ); Soluteca, 6 April (d", MLZ). 1939: $\stackrel{\text { PUBLTS }}{337 \% \text {. }}$

PUBLISHED RECORDS.--Montaña La Cruz, Soluteca (Moore,

Dorlcha enicura is a rare montane spectes inhabiting northern Central America from Chiapas to western Honduras. It 18 known from Honduras only by the two specimens taken by C. F. Underwood, a female at Montaña La Cruz in 1936 and a male at Soluteca in 1937. The relationships of the species within this genus and their peculiar distribution have been discussed by Griscon (1932b: 211).

\section{Tilmatura dupontil (Lesson)}

Sparkling-tailed Humingbird

SPECIMENS.--(107): Port1110 Grande; 3 Feb. ( $9, \mathrm{MCZ})$; Coyoles, 12 July (juv. o, CM); San Esteban, 22 June ( $\sigma$, CM); Plan del Rancho, 30 June ( $0^{\circ}$, MLZ); San José de Santa Bárbara, 7-30 Apri1 (8d, 49, AMNH); Finca Fé, 1 March, 27 Apri1 ( $\sigma^{\circ}, \delta^{\prime}$, LSUMZ); Lake Yojoa, 14-25 June (20, CM; $\delta$, UF); La Florida, 14-26 Dec. (o, LSUMZ; o, MCZ); E1 Caliche, 25 July, 13-20 Sep. (58, 28, AMNH); Cantora1, 29 Nov. (of, MCZ); Cerro Cantoral, 22 Jan.-10 March, 10 May (50, $10 \%, ?, \mathrm{MCZ}$; o, USNM); Alto Cantora1, 6 Jan.-29 Feb.

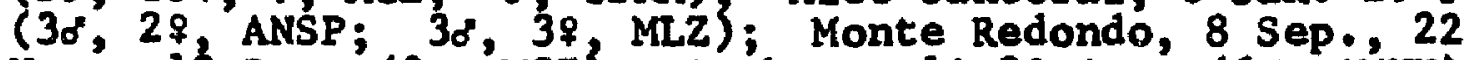
Nov., 12 Dec. (38, MCZ); Archaga, 10-20 Sep. (68, AMNH); La Cueva Archaga, 16-26 Sep. (7f, 3\%, MLZ); La Flor Archaga, 24 June-24 Oct. ( $0^{\circ}, 29$, ANSP; $\%$, AMNH; 40, 29 ,

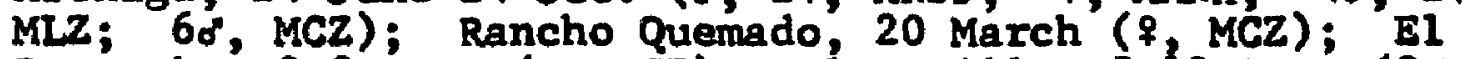
Derrumbo, 3-9 Aug. ( $\sigma^{\circ}$ MCZ); Ei Hat1110, 5-12 Aug. (30, ?, CM); Tigre Hat1lio, 1 July ( $d$, AMNH); Yeguare River Valley, 18 Nov., 9 Dec. (2 $\sigma^{\circ}$, UF); Catacamas, 18 oct. ( $\alpha^{\prime}$, MLZ); San Francisco, Choluteca, 14 0ct. ( ${ }^{\circ}, 1 \mathrm{~mm}$. o", LSUMZ); "Honduras," 5 Sep. ( $\$$, MLZ).

59). PUBLTSHED RBCORPS.-Cerro Cantoral (Griscon, 1932c: 
This hummingbird is a fairly common to common resident of areas in and around cloud forest and pine-oak associations above 3,500 feet. In the nonbreeding season it occasionally descends into rain forest to an elevation of 1,500 feet. It is a common feeder in scrubby areas away from the forest when flowering plants are in bloom.

In addition to the specimens listed above, there is a small series in the Paris Museum. Berlioz (1938: 12-13) lis ted two pairs that were taken in Honduras by C. F. Underwood and sent to that museum.

I agree with Berlioz (1938: 12-13) that the southern form, I. d. xenoura Griscon [1932c: 59; Cerro Cantoral (6500 ft.), District of Achaga (= Archaga), Honduras], is not distinguishable from the nominate race. A serles of specimens from Honduras indicates that all characters ascribed to xenoura by Griscom are bridged by individual variation. The species should be regarded as monotypic.

\section{Archilochus colubrts (IInnaeus)}

Ruby-throated Humingbird

SPECTMENS--(25): Little Hog Is land, 9 April (d, LSUMZ); Tela, 21 Feb., 28 March ( $\left.{ }^{*}, 9, M C Z\right) ;$ Lancetilla, 9 Feb. ( $\$$, MCZ); Cofradia, 5 March ( ${ }^{\circ}$, ANSP; 2o, 3\%, MLZ); Las Peñitas, 30 Jan.-2 Feb. (2d, ANSP); San José de Santa Bárbara, 7-10 April ( $8,2 \%$, AMNH); Fínca Fé, 20 Feb. (9?, LSUMZ); Cerro Cantorai, 7 Jan. (o, MCZ); Tegucigalpa, 7-13 Nov. (o, \&, MCZ); Yeguare Rtver Valley, 6-7 Nov. (2?, UF); San Lorenzo, 28-29 Sep. ( $\delta, \$, M C Z$ ); Puerto Salamar, 9 Feb. (\$ skel., LSUMZ); San Francisco, Choluteca, 14 Oct.' ( ISUMZ).

PUBLISHED RECORDS --Lancetilla, $5 \mathrm{~km}$. W Tela, near Tela (Peters, 1929b: 430-43i). 
The Ruby-throated Humingbird is a fairly common to common migrant and winter visitant in Honduras, occurring on both coasts and in the interior to an elevation of 5,000 feet. It is also found in migration in the is lands off the north coast. Extreme dates of arrival and departure for Honduras are 28 September and 18 April.

\section{Atthis ellioti Ridgway}

Wine-throated Hummingbird

SPECTMENS.--A. e. selasphoroides (88): Merendón Copán, 17-20 June (20", MCZ); Monte Verde, 24 July (o', MLZ); Mt. Puca, 5 Jan.-10 Feb. (40, AMNH; $150^{\circ}, \mathrm{MCZ}$ ); Muĺn, 14 Jan. ( $\delta$, MCZ); Montaña Vásquez, 19 Nov.-10 Jan. ( $\delta$, AMNH; d, BMNH; 30, MLZ; 30, $\$$, MCZ; $\$$, USNM); Cantoral, 15 Dec.-

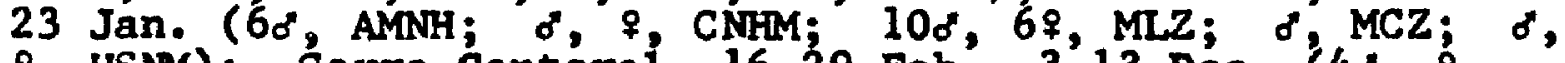
\$, USNM); Cerro Cantoral, 16-29 Feb., 3-13 Dec. (40, $\$$,

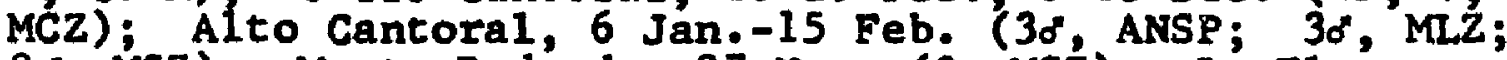
80, MCZ); Monte Redondo, 27 Nov. (?, MCZ); La Flor Archaga, 18 Aug.; 13 Sep. (28, MCZ); San Juanctto, 14 July (7, Juv. o, ANSP); Rancho Quemado, 16 March, 18 May (?, MLZ; of, MCZ); $10 \mathrm{mi}$. NE Tegucigalpa, 2 Feb. (8?, imm. o, LSUMZ).

PUBLISHED RECORDS.--San Juancito (Stone, 1932: 312). Cerro Cantoral (Griscom, 1932c: 58-59). "Honduras" (Berl1oz, 1938: 13-15). Cantoral, Montaña Vásquez, Monte Verde, "Honduras" (Moore, 1937: 99).

The Wine-throated Humingbird is a common inhabitant of areas in and around cloud forests in the interior of Honduras; it has not been recorded below 5,000 feet in the republic. It is most abundant in scrubby areas outside the forest at times when shrubs are in flower.

In addition to the specimens 1 isted above, there are several others in the Paris Museum. Berlioz (1938: 13-15) 
mentioned five males and two females from Honduras that were taken by C. F. Underwood.

I do not agree at all with Berlioz (1938: 13-15) in either of his conclusions concerning specific and subspecific limits in this genus. In addition to other morphological differences, including gorget color, $\underline{A}$. ellioti has a normal, not attenuated, outer primary. There is a distinct possibility that this feature may be sound producing in A. heloisa (Lesson and DeLattre) and might be involved as an isolating mechanism; until this matter is resolved by field study, the two forms are best retained as distinct species.

The Honduran populations have been described as $A \cdot \underline{e}$. selasphoroides [Atthis heloisa selasphoroides Griscom, 1932c: 58; Cerro Cantoral (6500 ft.), District of Achaga (= Archaga), Honduras] on the basis of buffy (not white) tail tips, more restricted white area below, and more reddish (1ess purplish) gorget. A11 of these characters seem to hold true in the large series now available from Honduras; especially noticeable is the more reddish gorget in the males.

Family TROGONIDAE

Pharomachrus mocinno de la Llave

Quetzal

SPECIMENS. --P. m. mocinno (46): Subirana, 29 Jan. (o, 
MCZ); Port111o Grande, 29 Jan.-17 Feb., 20-22 May, 12 Aug.8 Dec. (6o, 5\%, imm. \%, CNHM; 6o, 11\%, MCZ); Montaña E1 Chorro, "31" June-9 July (3\%, MLZ); Montaña La Cruz, 25-26 June ( $2 \sigma^{\circ}$, MLZ); Las Ventanas, 27 July (2。, MLZ); Mt. Puca, 10-12 Jan. (2\%, AMNH); Cerro Santa Bárbara, east slope, 7 Nov. ( $\delta$, LSuMZ); Cerro Santa Bárbara, southeast 8 lope, 2425 July (29, LSUMZ); Monserrat, 15 March ( $\delta$, UF); "Hónduras" ( ${ }^{\circ}, ?$, ANSP; $\delta$, USNM).

PUBLTSHED RECORDS.--"Mountains south and east of the plain of Comayagua" (Taylor, 1860: 118). "Honduras" (Nehrkorn, 1889: 286).

The Quetzal is a locally distributed resident of the cloud forests of Honduras above 4,500 feet. It is 8 till a fairly common species in some parts of Honduras, despite its persecution for plumes; it has not suffered in Honduras to the extent that it has in Guatemala and Chiapas.

It was apparently very common in the $1930^{\prime} \mathrm{s}$ and $1940^{\prime} \mathrm{s}$ in the Montaña de P1jol, in the Department of Yoro. Fron these cloud forests Raymond Stadelman secured the large series of Subirana and Port111o Grande specimens and von Hagen (1946) caught living young that were subsequently raised and sent to various zoological gardens.

In 1962-1964 J. Alan Feduccia and I encountered the spectes on several occasions on Cerro Santa Bárbara above 5,000 feet. It seems to be fairly common there at the present time.

Honduran specimens are referable to the nominate race, E. m. mocinno de la Llave. 
Trogon massena Gould

Slaty-tailed Trogon

SPECIMENS.--I. m. massena (39): Lancet 111 a, 24 Jan.-29 March, 24-26 Aug. ( $\sigma^{\circ}$ \%, ANSP; $\delta^{\circ}, 49,8 \mathrm{kel} .$, MCZ); Montecristo, 24 March ( $\sigma^{\prime}$, LSiMZ); La Celba, 27 May ( $\$$, CM); Los Planes, 10 June ( $\left.\sigma^{\circ}, C M\right)$; Trujillo, 7 April (o", $\left.\%, C M\right)$; Catacombas, 23 March-3 April (o", 2\%, AMNH; \&, BMNH; 20, 39, MLZ); Cofradía, 10 March ( $\sigma$, MLZ); San Pedro Sula, 26 Jan., 27 March ( $\sigma^{\prime}$, CM; $\sigma^{\prime}$, USNM); Las Peñitas, 26 Jan. ( $\sigma^{\prime}$, ML2); Chasnigua, 21 Jan. ( $\$$, USNM); La Cumbre, 3 Jan. ( $0^{\circ}$, USNM); Chamelecón, 21 Feb.-3 March ( $20^{\circ}, q$, USNM); E1 Boquerón, 9 Sep., 6 oct. (20, AMNH); Arenal, 14-23 Jan. (3\%, UCLA); Segovia River, 24 June (d", USMM); "Honduras" (2?, BMNH).

PUBLISHED RECORDS.--"Honduras" (Gray, 1848b: 40; Skutch, 1948b: 137). Omoa, San Pedro (Moore, 1859: 53). Segovia River (Ridgway, 1888c: 591). La Cumbre, Chasnigua (RIdgway, 1911: 746). Lancetilla (Peters, 1929b; 435-436; Stone, 1932: 3i3). San Pedro Sula (Todd, 1943: 5). Mouth of the Roman River [= Santa Rosa de Águán] (Zimmer, 1948b: 47).

This trogon is an uncommon to fairly common resident of lowland rain forests on the Caribbean slope of Honduras. It generally prefers the denser areas of the forest, only occasionally occurring in open forest or in second growth. It has not been recorded above 1,000 feet in Honduras. Zimmer (1948b: 47) mentioned that he examined a male of this species from the "mouth of the Roman River" [= Santa Rosa de Aguán], but I do not know where this specimen 18 located.

Honduran specimens are typical of the northern race, I. m. massena Gould. 
Trogon melanocephalus Gould

Black-headed Trogon

SPECTMENS. --I. m- melanocephalus (72): Medina ( $0^{\circ}$, BMNH) San Alejo, 15 March, 2 April (o skel, \& skel., LSUMZ); Tela, 7 March ( ${ }^{\circ}, 9$, MCZ); Lancetilia, 24 Feb.-2 March, 24-27 Aug. ( 8 , 2\%, ? ANSP; $\delta, 39$, MCZ); La Ceiba, 3-24 Jan., 25 March-30 April (40, ₹, CM; 50, 2\%, MCZ; d, USMM); Los Planes, 10 June (29, CM); Trujililo, 6-8 April, 21-30 Sep. ( $\sigma^{\circ}, 7$, CM; $\delta, 2 \%$, USMM); Cofradla, 2-11 March ( ${ }^{\circ}, 2 \%$, AMNH; 30, $20^{\circ}$, MLz); San Pedro Sula, 2 Jan. 29 March (2?, BMNH; o, CM; $?$, USNM); Las Peñitas, 1-2 Feb. ( $\sigma^{\prime}, f, M L Z$ ); Chasnigua, 21 Jan. ( $\delta$, USM); Chamelecón, 16 Feb.-2 March (3d, 2q, USNM); 2 mi. N Amapa, 24 June ( ${ }^{\circ}$, UF); Amapa, 20 July, $18 \mathrm{Sep} .\left(2 \sigma^{\circ}, \&\right.$ LSUMZ); Coyoles, 1829 June (20, CM); Puerto Lempira, 11 April ( ${ }^{\circ}$, LSUMZ); San Lorenzo, 29 Sep. -6 Oct. (30, MCZ); $8 \mathrm{mi}$. SE Namas igüe, 8

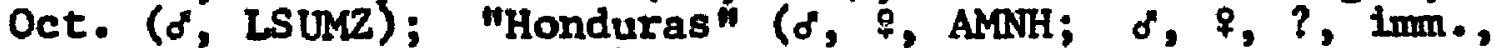
BMNH; \&, MCZ; $\%$, USNM).

PUBTLISHED RECORDS--"Honduras" (Gray, 1848b: 42). Tigre Island (Sclater, 1858b: 357). Onoa (Moore, 1859: 53). Tigre Island, near Taulabé (Taylor, 1860: 117-118). San Pedro region (Śclater and Salvin, 1870b: 837). Truj1110 (Ridgway, 1888c: 581). San Pedro, Medina (Sharpe and Ogilvie-Grant, 1892: 464). La Celba (Bangs, 1903: 144; Deignan, 1936: 190). Chasnigua, Boca de Río Román [= Santa Rosa de Aguán] (Ridgway, 1911: 758). Lancetilla, Tela (Peters, 1929b: 431-432). Lancetilla (Stone, 1932: 313). San Pedro Sula (Todd, 1943: 6).

This species is the most common trogon of semi-open situations in the lowlands of both coasts of Honduras. Although it is primarily a bird of the humid lowlands, it much prefers second growth or open woodland to dense forest, and it is fairly common in the monsoon forests and even arid scrub country of the Pacific coast. It does not occur above 2,000 feet in Honduras.

Ridgway (1911: 758) cited a specimen from Boca de Rlo Román [= Santa Rosa de Aguán]. As in the case of other 
material from this locality, I have been unable to trace the location of this specimen.

I should point out that the combination "melanocephalus" is generally treated as an adjective in ornithological nomenclature. Although Gould used the feminine combination "melanocephala" with Trogon in the original description, it is evident that he was not considering it as a noun since he later (1875: text opposite plate XXVII) used it in the masculine gender. There is consequently no reason for treating the specific name "melanocephalus" as other than masculine when used in combination with the genus Trogon.

For a number of reasons, I follow S1ud (1964: 166-167) in considering melanocephalus to be a species distinct from I. citreolus Gould of Mexico. Both forms occur In Oaxaca, although apparently not sympatrically, according to Laurence c. Binford (personal communication). There is some difference in ecology in the area of geographical approach, citreolus being found in arid regions, melanocephalus in more humid situations. Perhaps the most important factors for consideration, however, are the ventral tail patterns of the males and the colors of the head and eye ring, all of which are different in these two forms. The ventral patterns and head colors may well play an important role in species recognition in this genus and serve as 1solating mechanisms. Until field studies can be made testing this 
hypothesis, I believe the two are best retained as distinct species.

All Honduran specimens, including those from the Pacific lowlands, are typical of $T$. m. melanocephalus Gould. None exhibits any approach to the Costa Rican race, $I$. $\mathrm{m}$. illaetabilis Bangs.

Trogon mexicanus Swainson

Mountain Trogon

SPECIMENS.--T. m. mexicanus (44): Stguatepeque, 9 July ( $\sigma, \mathrm{CM})$; $4 \mathrm{mi}$. S $\overrightarrow{\mathrm{E}}$ La Esperanza, 24 Jan., 31 Oct. ( $\sigma^{\circ}, \sigma^{\prime \prime}$ skel., LSUMZ); Güise, 30 Oct. ( $\delta$, LSUMz); Muln, 21 Jan. (f, AMNH); Montaña Vásquez, 10 Jan., 19 Nov. ( $\delta$, AMNH; $\delta$, MCZ); Cantoral, 10-19 Dec. ( $\sigma, q, A M N H)$; Cerro Cantoral, 20 Feb. -2 May, 17 Nov. -16 Dec. ( $90^{\circ}, 39$ MCZ); Alto Canto-

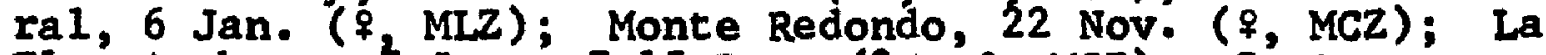
Flor Archaga, 3 June, 7-15 Dec. ( $\left.20^{\circ}, \$, M C Z\right)$; Cantarranas, 6 Aug. ( 8 , ANSP); San Juanctto, 4 July-15 Aug. (3d, 49 , ANSP; $\delta, q$, CM); E1 Hatillo, 8 May $\left(\sigma^{\circ}\right.$, MCZ); E1 Picacho, 16 Oct. ( $\sigma^{\circ}$ skel. MLZ); Cuesta Grande, 1 July ( $\left.\sigma^{\circ}, \mathrm{CM}\right)$; Mt. Uyuca, 7 April, 25 Nov. ( 8,9 , UF); Yeguare River Valley, 24 Nov. -3 Dec.' ( $d, q$, UF);" "Honduras" (Imm. $d$, AMNH).

PUBLISHED RECORDS.--San Juancito, Cantarranas (Stone, 1932: 313). Cerro Cantoral (Griscom, 1932c: 56-57).

The Mountain Trogon is an uncommon to fairly common resident of pine and pine-oak forests in the interior of Honduras above 4,000 feet, descending occas lonally to as low as 2,000 feet.

The variation exhibited by a series of this species from any one locality is considerable. The degree of deepness of the red under parts varies both with the age of the individual and with post-mortem change, the red tending to fade in preserved skins. The quality of the color of the 
upper parts (either towards green or towards bronze) is subject to a great deal of individual variation. While southern populations perhaps average more bronzy, the greenest example I have seen is a specimen from Cantoral, Honduras. The only geographic variation with respect to size seems to be a slight tendency towards smallness in the southern part of the range. In a comparison of specimens of comparable sex and age, I can find no significant variation from Mexico to Honduras and therefore consider Honduran material to represent the nominate race, $I$. $m$. mexicanus Swainson. The name applied to the Honduran populations, I. m. Iutescens Griscom [1932c: 56; Cerro Cantoral (6500 ft.), District of Achaga (= Archaga), Honduras], is placed in the synonymy of the nominate subspecies.

\section{Trogon elegans Gould}

Elegant Trogon

SPECIMENS--T. e- Lubricus (41): Coyoles, 16 June-1 July (20, CM); San Esteban, 30 June ( $\left.{ }^{\circ}, C M\right)$; Comayagua ( $q$ BMNH); near Comayagua, 23 Feb. (?, UF); Cerro Cantoral, 19 Feb. ( $\left.\sigma^{\circ}, \mathrm{MCZ}\right)$; Monte Redondo, 13 Sep.-13 Jan. (30, \&, imm. o, AMNH; 138, 49, ?, MCZ); La Flor Archaga, 12 Apri1, 9 June $\left(2 \delta^{\circ}\right.$, AMNH; $\left.\delta^{\circ}, \$, M C Z\right)$; Tegucigalpa, 12 April ( $\sigma^{\circ}$, BMNH); Conayagüela, 11 Oct. ( $8, \mathrm{MCZ})$; vicinity Tegucigalpa, 30 March ( 9 skel., MLz); Yeguare River Valley, 9 Jan., 30 March, 20 June ( 6 , 7 , imm. ${ }^{\circ,}$ UF); San Lorenzo, 6 Oct. ( $\sigma^{*}, M C Z$ ); Honduras-Nicaragua boundary [near Pacific coast] (?, MCZ).

EUBLISHED RECORDS.--Plain of Comayagua (Sclater, 1858b: 357; Taylor, 1860: 117). Comayagua (Sharpe and Og11vie-Grant, 1892: 450). Boundary between Nicaragua and Honduras "180 miles from Pacific coast" [= near Pacific coast] (Ridgway, 1911: 775). "Honduras" (Peters, 1945: 154). 
This species is the representative of the family that is characteristic of the arid portions of Honduras. It occurs primarily in the arid Pacific lowlands, in the arid interior highlands below 5,000 feet, and in the arid interior valleys on the Caribbean dralnage. It seems to be fairly common in areas of monsoon forest on the Pacific coast and in certain interior parts of the highlands but is decidedly uncommon in the Aguán, Comayagua, and Agalta valleys .

I tentatively assign all Honduran specimens to the race I. e. lubricus Peters [1945: 154; nomen novm for Trogon elegans australis Griscom, 1930c: 3; Bagaces, northwestern Costa Rica (preoccupied)]. Although Peters (1945: 154) stated that Honduran birds are intermediate between $\underline{T}$. e. elegans Gould and Lubricus, all Honduran specimens match Nicaraguan and Costa Rican examples of lubricus. I have not compared the Honduran series with an equally fresh series from the Motagua Valley in Guatemala, the type locality and known range of the nominate race.

\section{Trogon collaris Vieillot}

Collared Trogon

SPECTMENS.--T. c. puella (69): Lancetilla, 14 Feb.-22 March $\left(\delta^{\circ}, 27, \mathrm{MCZ}\right)$; Los Planes, 10 June, 14 July (2。, CM); Truj1110, 7 April ( $\circ$, CM); Catacombas, 24 March-15 April (o, 2\%, AMNH; 30, f; MZ); Las Peñitas, 3-17 Feb. (58, 2\%, AMMH; 20', 38, MLŹ); Subirana, 29 Jan.-2 Feb., 18 May (28,' q. MCZ); Porti11o Grande, 4 Jan.-15 May, 13 Sép. (5o', 58, CNHM; 3o, 39, MCZ); Pueblo Viejo, 9 oct. ( 8 , CNHM); Merendón Copán, 14-19 June $(2 \%, 2 \%$, AMNH); Montána EI Stlión, 1 July (o, MLZ); Mt. Puca, 7 Jan. ( $\left.\sigma^{\prime}, M C Z\right)$; Cerro Santa 
Bárbara, east slope, 25 April, 28 Nov. (28, q skel., LSUMZ); $4 \mathrm{mi}$. SW El Jaral, 21 Oct. ( $\%$, LSUMZ); $2 \mathrm{mi}$. SE El Jaral, 24 Feb. ( 9 gkel., LSUMZ); Finca Fé, 13 Jan., 21 July ( ${ }^{\circ}$, ?, LSUMZ); Lake Yojoa, 16 July, $15-21^{\circ} \mathrm{July}\left(30^{\circ}, 8, \mathrm{CM}\right)$; EI Pederna1, 30 Dec. ( ${ }^{\circ}$, AMNH); San Marcos de Guaimaca, 29 June $\left(\sigma^{\circ}, \mathrm{AMNH}\right)$; Alto Cantora $1,22 \mathrm{Feb}, 1$ June $\left(\sigma^{\circ}\right.$, AMNH); San Juancito, 15 Aug. ( $\%$, ANSP); Arenal, 24 Jan. ( $\sigma$, UCLA); "Honduras" ( $\delta$, USNM).

PUBLISHED RECORDS.--"Honduras" (Ridgway, 1911: 777). Lancetilla (Peters, 1929b: 431). San Juancito (Stone, 1932: 313 ).

The Collared Trogon is a species of broadleaf forest with a wide altitudinal range. It occurs from sea level to 6,000 feet in either rain forest or cloud forest, but it is most common at elevations ranging from 2,000 to 3,500 feet in areas of low montane rain forest. In lowland rain forest and in cloud forest above 4,000 feet it is an uncommon species.

Honduran populations are referable to the Middle American race, I. c. puella Gouid.

Trogon rufus Gmelin

Black-throated Trogon

SPEC MENS.--T. r. tenel1us (9): San Alejo, 16 March-18 Apri1, 5 Aug. ( $3 \sigma^{\prime} 2$, LSUMZ); Lancetilia, 8 Sep. (1ma. $\alpha$, ANSP); Arena 1, 27 Jan. ( 9 , UCLA); Segovia River, 14-18 June (2\%, USNM).

591). $\frac{\text { PUBLISHED }}{\text { Rancetilla (Stone, } 1932: 312 \text { ) }}$ (RIdgway, 1888c:

This trogon, an uncommon to fairly common resident of lowland rain forest, reaches its northern 1 imit of distribution in the coastal forests of north-central Honduras just east of the Sula Valley. It has never been recorded above 
1,200 feet in Honduras and seems to be partial to the denser areas of rain forest, being rare in second growth.

C. H. Townsend (RIdgway, 1888c: 591) collected the first Honduran specimens, two females from the Rfo Segovia In 1887. John T. Emlen, Jr., and C. Brooke Worth (Stone, 1932: 312) obtained an immature male at Lancetilla in 1930. J. G. Montrello secured a female at Arenal in 1953. In $1963 \mathrm{~J}$. Alan Feduccia and I found the species to be fairly common in the rain forest at San Alejo, where we collected pairs on 16 March and 5 August and a single male on 18 April; we saw the species there on other occasions as well. Honduran specimens are typical of the northern race, I. I. tenellus Cabanis.

\section{Irogon violaceus Gmelin}

\section{Violaceous Trogon}

SPECIMENS.--T. y. braccatus (50): Lancetilla, 24 Jan.4 March (30, ', MCZ); La Ceiba, 30 April-23 May (20, \&, CM); Yaruca, 9-26 Feb. (4ه, \%, MCZ); Truj1110, 7-8 April ( $\sigma^{\circ} \%$, CM); Catacombas, 22 March-6 April (20, AMNH; $\$$, MLz); Cofradía, 7-15 March (38, AMNH; \& MLz); San Pedro Sula, 27 March ( 7, CM); Las Peñitas, 7-13 Feb. ( $\delta$, $\%$, AMNH; 20, ₹, MLZ); Progreso; 30 Jan. (\%, MCZ); Chamelecón, 21 Feb. (o', USNM); Amapa, 27 Nov. ( 9 skel., LSUMZ); Portillo Grande, 14-15 May (2o,' $?$, MCZ); Coyoles, 18 June-1 July (2o, CM); Copán (?, MCZ); Cerro Santa Bárbara, east slope, 28 Nov.-9 Dec. ( 9,9 skel., LSUMZ); $4 \mathrm{ml}$. SW El Jaral, 11 Nov. (" skel., Lsúm); Finca Fé, 27 Aug -8 Sep., 8 Dec.

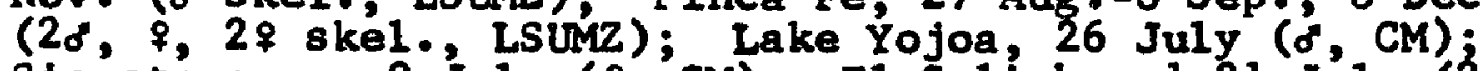
Siguatepeque, 9 July ( $f, C M)$; El Caliche, 1-21 July ( $2 \sigma^{\prime}$, 29, AMNH).

PUBL,ISHED RECORDS.--Onoa (Moore, 1859: 53). Yaruca (Bang8, 1903: 144-145). Copán (RIdgway, 1911: 788). Lancetilla, Progreso (Peters, 1929b: 432-434). San Pedro Sula (Todd, 1943: 13). Cofradla, Catacombas, Las Penitas, EI Caliche (Zimmer, 1948b: 37). 
The Violaceous Trogon is a resident of the lowland rain forests on the Caribbean slope of Honduras, extending up into low montane rain forest to an elevation of 4,500 feet. It is a fairly common species that generally prefers second growth or more open forest than that inhabited by $I$. rufus or I. massena.

A11 Honduran specimens are representative of the northern race, $\underline{T}$. $\underline{v}$. braccatus (Cabanis and heine). The use of the name braccatus in preference to sallael Bonaparte is discussed at length by Zimmer (1948b: 33-37).

\section{Family ALCEDINIDAE}

\section{Megaceryle torquata (Linnaeus)}

\section{Ringed Kingfisher}

SPECIMENS.--M. t 24 Aug, (क?, ANSP; $\overline{9}, \overline{M C Z}$ ); La Celba, 21 March (d, USNM); Trujillo, 30-31 March (20, CM); San Pedro Sula, 9 Feb. (imm。 6 ?, CM); Urraco, 9 March ( 8, MCZ); Laguna Toloa, 30 Aug. ( $\$ ?$ ? ANSP); El Jaral, 11 Oct. ( $\$$, AMNH); Lake Yojoa, 2 Jan., 25 June ( $\$, M C Z$; o, UF); La Flor Archaga, 23 May (?, AMNH); Yeguare River Valley, 19 March, 18 June, 22 Aug. (o', 29, UF); Segovia River, 14 June (o', USNM).

PUBLISHED RECORDS.--Omoa (Moore, 1859; 53). San Pedro region (Sclater and Salvin, 1870b: 837). Segovia River (RIdgway, 1888c: 591). San Pedro (Salvin and Godman, 1895: 474); Tela River at Lancet111a, Plaomas-Toloa Canal [= Urraco] (Peters, 1929b: 422-423). Lancetilla, near Laguna Toloa (Stone, 1932: 313). La Ceiba (Deignan, 1936: 190).

The Ringed Kingfisher is a falrly common to common resident along streams, around lakes, and around lagoons in the lowlands of both coasts of Honduras. It occurs also in 
the interlor, following streams to an elevation of about 3,500 feet, but it is decidedly uncommon away from the lowlands.

Specimens in the Derby Museum 1isted by Forbes and Robinson (1899a: 20) from "Honduras, Belize River" were obtained in British Honduras.

Honduran populations are typical of the widespread nominate race, $\underline{M}$. t. torquata (Linnaeus).

\section{Megaceryle alcyon (Linnaeus)}

\section{Belted Kingfisher}

SPECIMENS.--(4): Roatán Is land ( $\%, 7$, BMNH); Micos Lagoon, 10 mi. W Tela, 16 March ( 9, LSUMZ); La Ceiba, 27 May $(q, C M)$.

PUBLISHED RECORDS.--Omoa (Moore, 1859: 53). "Honduras" (Taylor, 1860: 116). Roatán Island (Salvin, 1889: 371; Sharpe and Ogilvie-Grant, 1892: 128), Swan Is lands (Lowe, 1909: 339; Fisher and Wetmore, 1931: 12). Tela region (Peters, 1929b: 423).

This species is an uncommon to fairly common winter visitant to both coasts of Honduras and to the 1slands off the north cosst. It has not been recorded above an elevation of 500 feet in the republic. Extreme dates of arrival and departure for Honduras are 9 September and 27 May.

The La Ceiba specimen was taken by Arthur C. Twomey and Roland W. Hawkins in 1948. I collected the Micos Lagoon individual in 1963. During 1962-1964 I saw the species on numerous occasions a long the north coast from Omoa to La Ceiba and elsewhere in the Caribbean lowlands at Choloma and near Progreso. Between 10 and 13 February 1963, I noted a 
single female daily at Puerto Salamar, on the Bay of Fonseca.

I agree with Phillips (1962b: 336-338) that there is too much overlap in size to permit recognition of the western race, $M$. a․ caurina (Grinnel1). I therefore regard the species as monotypic.

\section{Chloroceryle amazona (Latham)}

Amazon Kingfisher

SPECIMENS.--C. a . mexicana (26): San Alejo, 9 Aug. (?, LSUMZ); Lancetilla, 26 Jan., 19-24 Aug. ( $d, q$ ? ?, ANSP; $q$ gke1. LSUMz; $q$ MCZ); La Celba, 2 Jan., 3-18 May ( $0^{\circ}, q$, $C M$; \&, MCZ); Rlo Permejo [= Bermejo], 30 March ( $q, C M)$; Chamelecón, 17 Feb. (8, USMM); Amapa, 15 Jan. (d", LSUMZ); Coyoles, 17 July ( $\$, C M)$; La Libertad, 11 June ( $d$, AMMH); Lake Yojoa, 21 June ( $\sigma^{*}$, MCZ); La Laguna, 14 July ( $\$$, AMNH); Cantarranas, $19 \mathrm{July}-3^{\prime}$ Aug - (2d, $\%$, ANSP); Comayagüela, 8 Jan., 10 Oct. ( 8 AMNH; of, MCZ); Yeguare River Valley, 30 Jan.' ( $\$$ UF); Rio Choluteca, Dept. EI Paraĺso, 11 Aug; ( $\delta$ UF); RIo de La Orilla, 2 June (o, MCZ); Río Vallecilio, 26 July ( $\delta$, UF); "Honduras" ( $\$$, BMNH).

Yojoa (SClater and Saivin, 1859: 1313. "1859: "53). Lake (Sharpe and Ogilvie-Grant, 1892: 130). La Ceiba (Bangs, 1903: 143). Tela River, Lancetilla (Peters, 1929b: 423 ). Cantarranas, Lancet11la (Stone, 1932: 314). Near Tela (Skutch, 1945a: 15). Tela River (Skutch, 1957: 219).

Chloroceryle amazona is a fairly common resident in the Caribbean lowlands of honduras, occurring in lesser numbers in the Pacific lowlands and along rivers in the interior up to 4,000 feet. Nesting in the Caribbean lowlands around Tela has been reported by Skutch (1945a: 15; 1957: 217229).

In addition to the specimens already 11 sted, there are several in the Derby Museum labeled "Honduras" (Forbes and 
Robinson, 1899a: 20), but I have not seen these skins.

I refer all Honduran specimens to the Middle American race, C. A. mexicana Brodkorb [1940a: 543; Barra de Cahuacán, Chlapas, sea level].

\section{Chloroceryle americana (Gmelin) \\ Green King fisher}

SPECIMENS. --C. a. septentrionalis (46): San Alejo, 2 Apri1 ( $\%$, LSUMZ); Lancetilla, 12 Feb., 25-30 Aug. (2\%, $?$ ?, ANSP; 9, MCZ); La Ceiba, 27 March ( ${ }^{\circ}$, CM); Yaruca, 11 Feb. ( ${ }^{\circ}$, MCZ); Trujillo, 31 March-9 April, 26 Sep. $\left(0^{*}, 3 \%\right.$, CM; o, USNM); Cofradía, 2-15 March ( $\$$, BMNH; $\&$, MIZ); San Pedro ( $\%$, BMNH); Laguna Toloa, 30 Aug . (?, ANSP); Amapa, 18 Jan., 18 Sep. ( ${ }^{\prime}$, ?, LSUMZ); Subirana, 19 Dec. ( $\delta$, MCZ); Coyoles, 14-29 June ( $\sigma^{\circ}, 9, C M$ ); San Esteban, 25 June ( $d, C M)$; near Lake Yojoa, 5 Aug. (imm., UF); Monte Redondo, 4 Dec. ( $8, q, \mathrm{MCZ}$ ); Cantarranas, 3-6 Aug. (3\%, ANSP); E1 Hatillo, 2 May ( $\delta$, AMNH); Tegucigalpa, 12 Feb. ( $q$, MCZ); Comayagüela, 22 Feb., $27^{\prime}$ June, $17 \mathrm{July}, 11 \mathrm{Sep}$., 21 Oct. (30, AMNH; $q$, MLZ; $\sigma^{\circ}$, MCZ); Capa Rosa, 31 May-8 June $(6, f, M C Z)$; Yeguare River Valley, 14 Feb., 13-29 Dec. (o', 2\%, ?, UF); Segovia River, 19 June, 10 Aug • (2o', $\%$, USNM); "Honduras" ( $\delta$, $\$$, BMNH).

PUBT TSHED RECORDS.--Lake Yojoa (Sclater, 1858b: 358; Taylor, 1860: 117). San Pedro region (Sclater and Salvin, 1870b: 837). Truj1110, Segovia River (Ridgway, 1888c: 582, 591). San Pedro (Sharpe and Ogllvie-Grant, 1892: 135). Yaruca (Bangs, 1903: 144). Lancet111a, Tela River (Peters, 1929b: 423). Cantarranas, Lancet11la, Laguna Toloa (stone, 1932: 314).

The Green Kingfisher is a fairly common to common species of the humid Caribbean lowlands of Honduras, occurring also in the interior below 5,500 feet and on the Pacific coast. It is much less common away from the humid lowlands.

Forbes and Robinson (1899a: 21) reported a series of specimens in the Derby Museun taken at Belize, "Honduras," 
but this record pertains, of course, to British Honduras. Populations in Central America from British Honduras and Guatemala southward are generally regarded as being representative of the race $\mathrm{C}$. A. 18thntca (Goldman) or as intermediates between 1sthmica and the northern subspecies, c. a․ septentrionalis (Sharpe). Examination of a series of specimens from all parts of Middle America Indicates that all characters ascribed to elther race may be bridged by individuals in any given population. The confusion that has arisen 18 to be noted in the comments of various authors as to the allocation of specimens from a particular Middle American region. Both Austin (1929a: 374) and Griscon (1932b: 181) regarded most of northern Central America as an area of intergradation, but the latter assigned Guatemalan specimens to isthmica. Dickey and van Rossem (1938: 290292) thought that birds from E1 Salvador were septentrionalis and expressed surprise at Griscom's allocation of Guatemalan birds to isthmica. Examination of many specimens from Central America reveals that no character, not even Bize, is constant in populations of septentrional1s or isthmica. Unless there is an extensive post-breeding movement of this spectes, which would result in the mixing of the two forms, one must conclude that 1sthmica is not recognizable. Unt1l migration in this species can be demonstrated to account for the variability in population samples, I am 
considering all Middle American populations south of northwestern Mexico as the race septentrionalis.

\section{Chloroceryle aenea (Pallas)}

Pygmy Kingfisher

SPECIMENS.--C. a. sttctoptera (13): Guanaja (Bonacca) Is land, 4-22 March ( ANSP); Tela River, Lancetilla, 1 April (\%, UF); La Ceiba, 25 March ( $q$, USNM); Los P1anes, 10 June ( $\sigma$, CM); Río Permejo [= Bermejo], 3 Aug. ( 9, CM); 5 mi. E La Lima, 21 Feb. (?, LSUMZ); Urraco, 10 March ( 9, MCZ); E1 Jaral, 8 Oct. ( $\sigma^{\circ}$, AMNH); San Lorenzo, 30 Sep. ( $\sigma^{\prime}, ?$ ?, MCZ); "Honduras," 2 Dec. (o", USNM).

RUBLISHED RECORDS.--San Pedro region (Sclater and Sa1vin, 18706: 837) "Fonduras" (Ridgway, 1891: 471; Forbes and Robins on, 1899a: 21). San Pedro (Salvin and Godman, 1895: 479). Palomas-Toloa Canal [= Urraco] (Peters, $1929 \mathrm{~b}: 424)$. Bonacca [= Guana Ja] Is land, Ut $11 \mathrm{a}$ Is land ? (Bond, 1936: 360). La Celba (Deignan, 1936: 190).

This small kingfisher is a resident of the lowland rain forests of the Caribbean slope of Honduras, ranging as high as 2,500 feet along woodland streams. It has been recorded at Lake Yojoa and occurs in the mangroves along the Pacific coast. There is a population on Guanaja Island (Bond, 1936: 360), but I doubt Bond's reference to the occurrence of the species on Utila Island, which he based on reports of the natives, for I saw no sign of it there during May 1963. The species is decidedly uncomion in Honduras.

The reference of Forbes and Robinson (1899a: 21) to specimens in the Derby Museum taken In "Honduras" is based on Individuals secured by David Dyson and probably refers to British Honduran material. 
The Honduran spectmens are all referable to the northern race, C. a. stictoptera (RIdgway).

\section{Family MOMOTIDAE}

\section{Hylomanes momotula Lichtenstein}

\section{Tody Motmot}

SPECIMENS.-H. 뜨. momotula (25): Lancetilla, 10-22 Feb. ( $8, \%$, MCZ); Trujillo, TApril (o, CM); Catacombas 23 March-5 Apri1 (20, 29, AMNH; o, \&, MIZ); Cofradia, 15 March ( $\$$, AMNH); San Pedro Sula, Feb. ( $\alpha$, CM); Santa Ana, 9 Oct. ( 2 \%, USN); La L1bertad, 10-16 June ( $\%$, AMNH; \&, MCZ); Cerro Nieve, 21 April ( 9 , AMNH); San José de Santa Bárbara, 7 April (ơ, AMNH); Finca Fé, 30 Nov, -8 Dec. (2\%, ?. ISUM(Z); Lake Yojoa, 16 June, 21 July, 28 Aug; (30, CM); San Marcos de Gualmaca, 22 June-2 July (2q, AMNH).

\section{PIBTISHED RFCORDS.--Omoa (Moore, 1859: 54). Santa} Ana (RIdgway, 1891: 471). San Pedro Sula (Ridgway, 1914: 486). East of Lancetilia (Peters, 1929b: 425-426).

The Tody Motmot 18 an uncommon Inhabitant of the lowland rain forests of Honduras, ranging into the interior in suitable habitat to an elevation of 3,500 feet. It appears to be most frequent at elevations of 1,000 to 2,500 feet, being decidedly rare in the forests near sea level. I saw the species only three times in Honduras, single specimens being secured at Finca Fé on 30 November, 2 December, and 8 December 1962.

Honduran specimens are typical of the nominate race, H. ㄸ. momotula Lichtens tein. 


\section{Aspatha gularis (Lafresnaye)}

Blue-throated Motmot

SPECTMENS:--(11): Montaña Los Cedros, 4 June (of, ML, 2 ); Montań EI SIIIón, "31" June ( $\delta$, MLZ); Monte Verde, 20-24 July ( ${ }^{\circ}, ?$, MLZ); Mt. Puca, 18 Jan.-7 Feb. (38, ?, ?, MCZ); MuÍn, 21 Jan. (?, MCZ); Alto Cantoral, 7 Feb. ( $8, M C Z)$. 1945: 221).

PUBLTSHED RECORD.--"Honduras" [in range] (Peters,

Confined to cloud forest at high elevations, the Bluethroated Motmot is a rare species throughout its range, which extends from southern Chiapas to Honduras. It has been recorded in Honduras only from elevations above 6,000 feet.

A11 Honduran specimens were taken by C. F. Underwood. He obtained the first at Alto Cantoral in 1934. In 1936 he took the small series from the Department of Ocotepeque (Montaña Los Cedros, Montaña E1 Sillón, and Monte Verde). He secured one individual at Muin in 1937 and collected the Mt. Puca series in 1938.

The inclusion of Honduras in the range as given by Peters (1945: 221) was based on the series in the Museum of Comparative Zoology.

\section{Electron platyrhynchum (Leadbeater)}

Broad-billed Motmot MCZ).

SPECIMEN. --E. D. minor (1): Lancetilla, 17 Jan. (d, PUBLISHED RECORD.--Lancetilla (Peters, 1929b: 424). 
This species is the rarest of the motmots in Honduras. It is known only from the population inhabiting the rain forest in the vicinity of Lancetilla and from near San Esteban, although the range is probably more or less continuous throughout the forests of eastern Honduras. The records from Lancetilla are the northernmost for the species.

Peters (1929b: 424) obtained the only Honduran specimen at Lancetilla in 1928. He collected the bird at an elevation of 800 feet in dense rain forest and saw no others. Marik Trafton, Jr., observed the species at Lancetilia on four occasions between 1953 and 1955, all in the months of May and June. These observations were made in heavy forest along a rocky ravine. Trafton described the call of the birds as a soft "wook," which he likened to the call of the Spectacled Ow1 (Bulsatrix perspicillata). Richard R. Graber observed a pair in dense rain forest five miles south of San Esteban on 23 January 1962.

Although Peters (1929b: 424) mentioned s1ight differences in the Lancetilla Individual when compared with examples of the race that ranges from Nicaragua to Colombia, E. P. minor (Hartert), I can see none between the Honduran bird and a series of minor from Costa Rica and Panama. The wing measurement of the Lancetilla specimen is 113.3. 


\section{Electron carlnatum (DuBus)}

Keel-billed Motmot

MCZ); SPECMENS.--(14): Lancetilla, 20-25 March (20, \&, Santa Bárbara, east 8 lope, 27 March, 7 Nov. (20, LSUMZ); Lake Yojoa, 19 June (?, BMNH; $9, C M) ; 19 \mathrm{~km}$. E Jalapa, Nicaragua $[=1 \mathrm{~km} . \mathrm{E}$ Los Paredes, Honduras], $28 \mathrm{Jan}$. (?, UCLA); Arenal, 20-22 Jan. ( $\delta, 9$, UCLA); Segovia River, 2327 June (28, USNM).

PUBLISHED RECORDS.--Near Lake Yojoa (Sclater, 1858b: 357-358). Between Taulabé and Lake Yojoa (Taylor, 1860: 117). Lake Yojoa (Sclater, 1862: 263). Segovia RIVer (Ridgway, 1888c: 591). San Pedro Montaña, Santa Ana (Ridgway, 1914: 475). Lancetilla (Peters, 1929b: 424).

The Keel-billed Motmot is an uncommon species in Honduras, inhabiting primarily lowland rain forests on the Caribbean slope. It occurs also in low montane rain forest up to an elevation of at least 5,000 feet. The only individuals that I have encountered in Honduras were in the transition zone between rain forest and cloud forest on Cerro Santa Bárbara between 4,000 and 5,000 feet; the 1nd1vidual collected on 7 November 1962 was taken within 50 feet of a Quetzal (Pharomachrus mocinno), a typical cloud forest spectes.

Bangs (1903: 143) 11sted an adult male taken at La Ceiba by $W$. $W$. Brown, but this specimen 18 not in the Museum of Comparative Zoology, where Brown's Honduran collection is located, nor is the specimen entered in the catalogue of his collection.

Griscom (1932b: 185) has shown that the supposed southern race, E. c. viridis Ridgway, was based on the green 
color phase, which occurs throughout the range of the species. Electron carinatum is therefore monotypic.

\title{
Eumomota superciliosa (Sandbach)
}

Turquoise-browed Motmot

\begin{abstract}
SPECTMENS.--E. 8. euroaustris (43): San Alejo, 6 Aug. ( $\sigma$, LSUMZ); Lancet1Ila, 9 Feb.-IApril, 29 Aug. (d, ANSP; 20, ${ }^{\circ}, \mathrm{MCZ}$; o, UF); La Celba, 24 Jan., 27 March-7 June

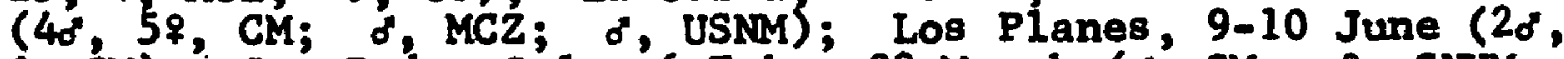
\%, CM); San Pedro Sula, 6 Feb., 22 March (o, CM; 2, CNHM; 3?, BMNH); La Lima, Sep., 20 Nov. (skel., LSUMZ; ? IM); Agua Colorado, 9 Aug. (28, CNHM); Coyoles, 14 June-12 July

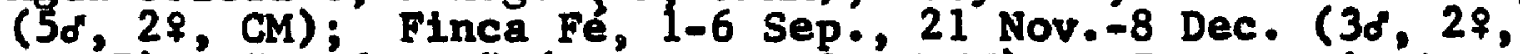
LSUMZ); "Honduras" ( 8, ANSP; ?, AMNH). E. 8. aplaster (45): Copán (4?, MCZ; ?, USNM; ? UCLA); Monte Redondo, 2 Dec. (\%, MCZ); La Flor Archaga, 18 April (o, ?, AMNA); Cantarranas, 5-10 Aug. (20, $2 \%$ \%?, ANSP); Tigre Hat1110, 4 July (f, AMNH); Comayagüela, 22 Feb., 21 April, 4-21 July, 12 Oct.-8 Nov. (2o, 9 , AMNH; 60, $2 \%, \mathrm{MCZ})$; Escuela AgrIcola Panamericana, 31 May, 21 oct. ( $\sigma^{\prime}, q$ UF); Yeguare River Valley, 15 April, 18 May, 19 Nov. (28, \&, UP); San Lorenzo, 6 Oct. (d', MCZ); $3 \mathrm{mi}$. B Choluteca, 10 Feb. (d", LSLMZ); Finca E1 Rub1, 29 oct. ( $d, \%$, LSuzz); San Franc1sco, Choluteca, 11 Oct. ( $\sigma^{*}$ LSUMZ); Honduras-N1caragua boundary [near Pacific coast] (9?, MCZ). Undetermined (2): "Honduras" (2?, LACM).

PUBLISHED RECORDS.-Onoa, Choloma (Moore, 1859: 54). Near Comaysgua (Taylor, 1860: 117). "Honduras" (Sclater, 1862: 263). San Pedro region (Sciater and Salvin, 1870b: 837). San Pedro (Sharpe and Ogilvie-Grant, 1892: 318). La Celba (Bangs, 1903: 143). Copán, Santa Ana, San Pedro Sula, and San Pedro Montaña [as blpartita] (Ridgway, 1914: 480): Lancetilla [as bipartita] (Peters, 1929b: 425). Copán [as dfckey1]; "western Honduras" [as aplastur]; Lancetilla and La Celba [as enroaustris] (Griscom, 1929c: 54-56). Cantarranas [as aplastur]; Lancetilla [as euroaustrie] (Stone, 1932: 314). La Ceiba (Deignan, 1936: 190). Near Tela [as bipartita] (Skutch, 1945a: 15). Lancet1lla Valley near Tela [as euroaustris] (skutch, 1947: 201-202).

In Honduras the Turquoise-browed Motmot is the arid habitat representative of the genus. It is fairly common to common in most open or semi-open situations in the lowlands of both coasts and in the intertor valleys, ranging up 
to 3,500 feet. In the Caribbean lowlands it has adapted to more humid conditions and occurs even in the open areas of the very humid Lancetilla Valley, but it is most abundant in the more arid portions of the Quimistán, Sula, Comayagua, and Aguán valleys.

Ridgway's (1914: 480) Inclusion of the Río Segovia in the list of Honduran localities is probably an error, since C. H. Townsend (Ridgway, 1888c: 591) did not record the species there.

Examination of the large series of specimens from Honduras Indicates that Peters (1945: 223-224) was entirely correct in his treatment of the races. The Caribbean lowlands of Honduras as far Inland as Lake Yojoa and the Department of Yoro (but not including the area around Copán) are occupled by the race E. S. euroaustris Griscom [1929c: 54; Lancetilla, Honduras]. This race differs from the interior highland and Pacific coast subspecies, E. s. aplaster (Lesson), In being darker green, in having the brow stripe a much deeper (1ess silvery) blue, and in having the blue on the wings and tail more purplish. The remainder of the Honduran specimens, including the Copán birds, which were described as E. 8. dickey1 Griscon [1929c: 55; Copan, Honduras], are typical of the race apilister. The Copán population shows no approach to the geographically adjacent Motagua Valley race, E. B. yanrossemi Griscom [1929c: 55; Sacapulas, Rio Negro valley, Gutemala], a form that is much 
brighter green. Pacific lowland individuals show no indication of intergradation with the paler southern subspecies, E. S. australis Bangs. The race E. E. bipartita Ridgway is now restricted to southern Mexico and northwestern Guatemala.

\section{Momotus momota (Linnaeus)}

\section{Blue-crowned Motmot}

SPECIMENS.- - - m. lessonil (81): San Alejo, 5 Aug. ( LSUMZ); Lancet11la, 15 Jan. -6 Feb. ( $3 \sigma^{\circ}, \mathrm{MCZ}$ ); La Celba, 1 21 Jan., 25 March-7 June, 5 Aug. (6o, 3\%, CM; o, f, MCZ; 28, ₹, USN); Yaruca, 12-23 Feb. ( ${ }^{\circ}$, ${ }^{\circ}, \mathrm{MCZ}$; 28, USNM); Los Planes, 10 June ( $\left.\sigma^{\circ}, C M\right)$; Balfate, 29 Nov. ( $\sigma^{\circ}$, CNHM); Trufillo, 30 March-7 April, 19-20 Sep: (30", \&, CM; of, f, ?, USNM); "coast of Hondurash (2?, USMM); Cofradla, 15 March (? BMHE); San Pedro Sula, 20-26 March (?, BMNH; \&, CM); Chamelecón, 3 Jan. ( $\$$, USMM); Amapa, 26 June ( $\delta^{\circ}$, UF); Santa Marta, 18 June, 8 Aug. ( $\delta$, ?, CNHM); Subirana, 6-25 March (28, $q$, MCZ); Port1llo Grande, 8 Jan., 5 Feb. (?, CNHM; $\%$, MCZ); Coyoles, 15 June ( ${ }^{\circ}, 7$, CM); Copán ( USNM); Mt. Puca, 30 Jan. (o, MCZ); Cerro Santa Bárbara, east slope, 1-9 Dec. (20, ISLMZ); $5 \mathrm{mi}$. SW E1 Jaral, 26 Oct. ( 8 skel., LSUMz); Finca Fé, 3 March, 31 July-16 Sep., 8 Dec. (58, \%, ?, 8kel., alc., LSUMZ); Lake Yojoa, 27 Aug. (o, CM); 2 mi. W Taulabé, 15 Dec. (f skel., LSUMZ); Monte Redondo, 6-15 Dec. (20", MCZ); Cantarranas, 10 Aug - ( ANSP); E1 Hat11lo, 12 May (", MCZ); Comayagũela, 15 July (20", BMNH); E1 Zamorano, 23 March ( $\sigma^{\circ}$ UF); Yeguare RIVer Valiey, I4 June ( $\sigma^{\circ}$, UF); Arenal, 14-21 Jan. (38, \&, UCLA); Segovia River, 18 Aug. (?, USNM); $13 \mathrm{mi}$. SW San Marcos de Colón, 3 Oct. ( $d$, LSUMZ); Honduras-Nicaragua boundary [near Pacific coast] (?, MCZ); "Honduras" (?, AMNH; ?, CNIM).

PUBLISHED RECORDS.--Onoa (Moore, 1859: 54). "Honduras (Taylor, 1860: 117; Forbes and Robinson, 1899a: 18; Chapman 1923: 34). San Pedro region (Sclater and Salvin, 1870b: 837). Truj1110, Segovia River (Ridgway, 1888c: 582, 591). San Pedro (Sharpe and Ogilvie-Grant, 1892: 325). La Ceiba, Yaruca (Bangs, 1903: 143). Copán, Chamelecón (Ridgway, 1914: 458). Lancet11la (Peters, 1929b: 425). Cantarranas, Lancetilla (Stone, 1932: 314-315). La Ceiba (Deignan, 1936: 190). 
Momotus momota is the most common forest motmot in Honduras. It is primarily an inhabitant of lowland rain forest on the Caribbean slope, but it occurs also in broadleaf forest in other parts of Honduras to an elevation of almost 6,000 feet. I have encountered it along the vega river forests in the interior, in low montane rain forest on Cerro Santa Bárbara to an elevation of 5,000 feet, in lowland monsoon forest on the Pacific coast, and even in isolated cloud forest on the Pacific drainage at an elevation of 4,000 feet. It is found in the semi-open and in second growth as well as in dense selva.

In addition to the specimens 1 isted above, there are a few others reported from Honduras. Forbes and Robinson (1899a: 18) mentioned several in the Derby Museum that were taken in "Honduras."

Honduran populations are typical of the widespread Centra1 American race, M. m. 1essonil Lesson.

\section{Family GALBULIDAE}

\section{Galbula muficauda Cuvier}

Rufous-talled Jacamar

SPECTMFNS.--G. F. melanogente (53): Julián [= Tulián] (4?, ANSP); San Älejo, 4 Aug ( 9 , LSUR); La Ceiba, 9 Jan., 1 May ( $\alpha, f, C M$; $\alpha$, MCZ); Yaruca, 7 Fob. ( $d$, MCZ); Los Planes, 9-11 June, 13 July (40, CM); Cofradia, 7-10 March ( $\delta$, $\$$, AMNH; of, BMAH); San Pedro ( $?$ BMNH); Rlo Blanco, Cortés, Is oct. ( $\delta$, USNM); Amapa, 29 Nov. ( LSUMZ); Coyoles, 14-22 June (38, $\%, ?$, GM); Finca Fe, 9 Aug.-8 Dec. (5d, \%, d skel., 2 alc. Lsuyz); Jamastrán Valley, 20 Feb. (f, UF); Ei Boquerón, 21 Aug.-13 Sep. (6", 
5\%, AMNH; Arenal, 22-25 Jan. (?, ?, UCLA); Segovia River, 10 Aug. ( $8, ?$, USNM); "Honduras $(\delta, 2 ?$, ANSP; ?, LACM).

PUBLISHED RECORDS,--0moa (Sclater, 1858b: 357; Forbes and Robinson, 1899a: 89). "Road from Omoa to Comayagua" (Moore, 1859: 53). Near Omoa (Sclater and Salvin, 1859: 131). Wear the Atlantic coast" (Taylor, 1860: 116). San Pedro region (Sclater and Salvin, 1870́b: 837). Segovia River (Ridgway, 1888c: 591). San Pedro (Sclater and Shelley, 1891: 167): Choloma (Lantz, 1899: 220). La Celba, Yaruca (Bangs, 1903: 145). Julián [= Tulián], R1o Blanco (Ridgway, 1914: 367).

In Honduras the Rufous-tailed Jacamar is a fairly common spectes, confined to the humld lowland rain forests on the Caribbean slope. It occurs in both dense forest and second growth. In Honduras it has been recorded to an elevation of 2,500 feet.

In addition to the specimens 11 sted above, there are others in the Derby Museum that were collected at Omoa, presumably by Joseph Leyland (Forbes and Robinson, 1899a: 89).

Honduran specimens are referable to the Middle American race, G. ‥ melangoenia Sclater.

\section{Family BUCCONIDAE}

Notharchus macrornymchos (Gmelin)

White-necked Puffbird

SPECTMENS.--N. m. hyperrhynchus (12): Santa Ana, 20-29 Oct. (8, 28, USNM); Coyoles, 28 June-11 July (28, 29, CM); E1 Caliche, 9-16 July (o, $\$$ AMNH); E1 Boquerón, 26 Aug. ( ${ }^{\prime}, \uparrow$, AMNH); MHonduras in ( $\}$, BMNH). 
PUBLISHED RECORDS.--"Honduras" (Sclater, 1855b: 193194; Sclater and Sheliey, 1891: 182; Salvin and Godman, 1896: 511-512; van Rossem, 1934d: 4; Sassi, 1939: 161). Santa Ana (Ridgway, 1914:'377-378).

This puffbird is an uncommon resident, occurring in the humid Cartbbean lowlands of Honduras below 2,500 feet. It is generally a forest edge species and has the habit of perching very high in the tallest trees available. The species, in addition, almost certainly occurs in the swampy forests along the Pacific coast, since it has been recorded in both E1 Salvador and western Nicaragua.

Sassi (1939: 161) mentioned a specimen from Honduras that was located in the Berlin Museum. I have not examined this individual, which most 1ikely is a specimen taken by Erich Wittkügel in the Sula Valley.

Honduran specimens from the Caribbean slope are referred by most authors to $\underline{N}$. m. hyperrhynchus (Sclater), a subspecies occurring from Mexico to Peru. Birds from Venezuela north are sometimes separated as the race $\mathbb{N}$. 프. dyson1 [Bucce dysont Sclater, 1855b: 193; "Honduras" (= restricted to northwestern Honduras by van Rossem, 1934b: 4)]. I have not examined a series of South American specimens. Like most current authors, I am following Sassi (1939; 161) and Peters (1948: 10) in their ractal treatment, suppressing dysoni. The Pacific coast lowland race of El Salvador and Nicaragua (and probably also Honduras) has been described as ‥ m. sryptoleucus INotharchus hyperrhymchus cryptoleucus 
van Rossem, 1934d: 3; Barra de Santiago, Dept. of Ahuachapan, El Salvador] on the basis of barred upper tail-coverts and generally paler, more slaty plumage; this race has not yet been recorded from Honduras.

Malacoptila panamensis Lafresnaye

White-whiskered Puffbird

SPECIMENS.--M. R. Inornata (20): La Celba, 2 Aug. (d), CM) : San Pedro Sula, 10 Feb. ( $\left.{ }^{\prime}, \%, C M\right)$; Coyoles, 18 June ( $9, C M) ; 5$ mi. S San Esteban, 17 Jan. ( $\$$ LSUMZ); Río Guampú, $10 \mathrm{mi}$. E Dulce Nombre de Culmi, 18 March (ó, LSUMZ); Cerro Higuito, Santa Bárbara, 24-25 April (26, MCZ); San José de Santa Bárbara, 5 May ( $\delta, M C Z$ ); $E 1$ Boquerón, 21 Aug.-10 Oct. (5o', 5\%, AMMH); Arena 1, $20 \mathrm{Jan.} \mathrm{( \delta ',} \mathrm{UCLA).}$ 391). $\frac{\text { PUBLISHED }}{\text { Lancetilla (Stone, 1932: 315; Skutch, 1948a: 90). }}$ The White-whiskered Puffbird is an uncomon inhabitant of lowland rain forests of Honduras, occurring up to an elevation of 3,000 feet. It seems to be more restricted to the interior of the forest than does Notharchus macrorhynchos, although it is known to enter second growth on occasion.

Honduran specimens are representative of the northern race, M. D. Inornata (DuBus). There does not seem to be any approach in Honduran material to the race M. p. fuliginosa Richmond, which ranges north to southern Nicaragua.

Monasa morphoeus (Hahn and Küster)

White-fronted Nunbird

SPEC TMENS.--M. m. grandior (4): Arena 1, 13-23 Jan. (28, 2\%, UCLA). 
PUBLTSHED RECORD - "Extreme southeastern Honduras" [in range] (Slud, 1964: 180).

Monasa morphoeus reaches its northern limit of distribution in the lowland rain forests of olancho. T. R. Howell and J. G. Montrello reported it as fairly common in forest edges and second growth in the vicinity of Arenal, where they secured a female on 21 January 1953, two males on 23 January 1953, and another female on 13 January 1955. The species is probably widespread in the olancho rain fores ts but apparently does not occur as far north as Catacamas or Dulce Nombre de Culmí.

Slud (1964: 180) included Honduras in the range of the species on the basis of the above specimens.

Honduran material is typical of the northern race, $M$. m. grandior Sclater and Salvin.

Family RAMPHASTIDAE

Aulacorhynchus prasimus (Gould)

Emerald Toucanet

SPECTMENS. - -A. $\mathrm{p}_{5}$ ylrescens (99): La Ceiba, 21 Jan. ( $\delta$, MCL); Cofradia, 5 March ( $\sigma$, MCZ); San Pedro Sula, 2230 March (40, $2 \%$, CNHM); Santa Ana, 24 Jan., 8-19 Nov. (20, \%, USNM); Las Peñitas, 6-25 Feb. ( $\$$, ANSP; 2\%, ANaNH; 6o, 28, MCZ); Chasnigua, 2 Jan. ( $\$$ USNe); Subirana, 29 Jan. (f, MCZ); Port11lo Grande, 3-13 Feb., 3 April, 5-20 May, 1 Sep., 15-16 Oct. ( $8,2 \%, ?$, juv. $\delta$, juv. $\%$, Juv, $+?$, CNHM; $100^{\circ}, 4 \%$, MCZ); Merendón Copản, 13 June ( $\%$, MCZ); E1 Chorro, 22 June (Juv. o, MLZ); Montafia E1 Chorro, 1 July ( $\delta$, ML ); Monte Verde, 23 July ( $\delta, \%$, MLZ); Mt. Puca, 7 Jan.-10 Feb. ( 9 , AMMH; 6 6", 2 \%, MCZ); Cerro Santa Bárbara, east slope, 28 Nov. -1 Dec. ( $\left({ }^{\circ}, 298 \mathrm{kel}\right.$., LSUMZ); $5 \mathrm{mi}$. SW E1 Jara 1, 4 Nov. ( $q$, ISUMZ); Lake Yojoa, 25 Aug. ( ${ }^{\circ}$, CM); Siguatepeque, 9 July ( $\left.\sigma^{\circ}, \mathrm{OM}\right)$; $5 \mathrm{mi}$. N Sabanetas, 30 Oct. 
(o', Imm. $\sigma^{\prime}$, LSUMZ); Muín, 7 Jan. ( ${ }^{\circ}$ AMNH); Montaña Vás quez, 12 Jan. ( 8 , AMNH); Cantora 1, $10 \mathrm{Feb}$., 10-30 March, 24 May (20, AMNH; $\left.\delta^{\circ}, q, C M\right)$; Cerro Cantoral, 6 Aug. ( $\left.q, M C Z\right)$; Alto Cantora 1, 7 Jan. -25 Feb. (26, 2\%, AMNH; 40, 39, MLZ; 28, MCZ); San Juancito, 3 July-12 Aug. ( 39 , ANSP; 8 CM); El Derrumbo, 3-9 Aug . (20, ${ }^{7}$, MCZ); Monserrat Mt., 31 March (o", UF); Segovia River, 23-27 June (2o", USNM); "Honduras" (?, ANSP; o, AMNH).

PUBLISHED RECORDS.--Near Yojoa (Taylor, 1860: 119). San Pedro region (Sclater and Salvin, 1870b: 837). Chas nigua (Ridgway, 1891: 471; 1912: 88). San Pedro (Salvin and Godman, 1896: 560). Puerto Cortés (Lantz, 1899: 220). San Juancito (Stone, 1932: 315-316).

The Emerald Toucanet is a common resident of the cloud forests of Honduras above 3,500 feet, occurring in pine-oak associations on occasion and in lowland ratn forest during the nonbreeding season. This species is one of the dominant birds in the cloud forest. It is essentially a species of the tree canopy.

The Honduran and Nicaraguan populations have been distinguished as the race $\underline{A}$. P. virescens Ridgway [1912: 88; Chasniguas (= Chasnigua), Honduras], based on smaller size, deeper chestnut under tail-coverts, and more yellowish-green (less deep green) under parts, in comparison with the Mexican race, A. R. prasinus (Gould). Two races have been described from El Salvador, A. R. Stenorhabdus Dickey and van Rossem [1930a: 52; Cerro Los Naranjos, Volcan Santa Ana, Dept. Sonsonate, El Salvador] and A. p. volcanius Dickey and van Rossem [1930a: 53; Volcan San Miguel, Dept. San Miguel, El Salvador]. The race yolcanius, based mainly on paler coloration, is isolated on Volcán San Miguel in eastern $\mathrm{El}$ Salvador and is of no concern to the present 
study. The name stenorhabdus has recently been applied to populations from Chiapas to central El Salvador; it was based malnly on a narrower black maxillary tomial stripe, when compared with prasinus. I have examined a large serles from northern Mexico to Nicaragua and can find no constant geographical differences in the populations now ascribed to prasinus, stenorhabdus, and virescens, except for smaller average size and narrower tomial stripes in the southern part of the range; in series, there is also a very slight tendency towards more yellowish-green on the chest. The race stenorhabdus is nothing more than a broad band of intermediate individuals and is probably not worth recognizing nomenclatorially. All Honduran specimens may be referred to virescens, the race stenorhabdus becoming a synonym of yirescens. Wing measurements of the Honduran sertes are as follows: o, 117.0-135.1 (128.2); $\$, 116.1$ $125.9(121.2)$. The maximum width of the tomial stripe varies as follows: o, $3.4-6.1(4.8)$; $9,4.0-5.7$ (4.8).

\section{Pteroglos8us torquatus (Gmelin)}

\section{Collared Araçar1}

SPECTYYXXS.--P. t. torquatus (57): Lancet11la, 14 Jan.20 Feb., 24-26 Aug. (3d, ANSF; 30, 49, MCZ); La Celba, 721 Jan.' 28 March-5 June, 2 Aug. ( $6 \delta^{\circ}, 2 \%$, CM; 4d, \&, MCZ; 9. USNM ; Yaruca, 21-23 Feb: (₹, MCZ; Ó, USMM); Truj11io, 7 April (o, CM); Catacombas, 28 March-1 April (q, BMNH; $q$; ML2); Manacal April (o'skel LSUL); San Pedro Sula (?, BMaNH; ?, CNMM); Santa Ana, 19 Hov. ( $\$$, USNM); Las Peñitas, 25 Jan. ( 9, MIZ); Chamelecón, 4 Jan. 17-23 Feb. ( $\circ, 2 \%$, USNM); Amapa, 24 June ( $\sigma$, UF); Portillo Grande, 5 Feb. ( 8 , CNHM); Copán ( $q$, USM); Peña Blanca, 25 June ( $q$, 
UF); Finca Fé, 6 Aug., 23 Nov, -11 Dec. (20, \%, \& skel., LSUMZ); Lake Yojoa, 16 Aug. ( $\left.{ }^{\circ},{ }^{\circ}, \mathrm{CM}\right)$; Cacao, $15 \mathrm{Dec}$. (28 skel. LSUMZ); Arenal, 22-26 Jan. ( $7, ?$, UCLA); Segovia River, 12 June (??, USNM); Honduras-Nicaragua boundary [near Pacific coast] (2?, MCZ); "Honduras ANSP; o", AMNH).

PUBLISHED RECORDS --Near Omoa (Sclater, 1858b: 359; Taylor, 1860: 119). "Honduras" (Moore, 1859: 59; Forbes and Robinson, 1898a: 98). San Pedro region (Sclater and Salvin, 1870b: 837). Segovia River (Ridgway, 1888c: 591). San Pedro (Sclater and Shelley, 1891: 142). La Cetba, Yaruca (Bangs, 1903: 145). Chamelecón, mouth of Rfo Román [= Santa Rosa de Aguán], Copán (Ridgway, 1914: 343). Lancetilla, Tela region (Peters, 1929b: 436). Lancetilla (Stone, 1932: 315). La Ceiba (Deignan, 1936: 191).

The Collared Araçari is a fairly common to common species in the lowland rain forests of the Caribbean slope of Honduras and an uncommon resident in the Pacific coast lowlands, primarily in and around monsoon forests. It may be found in dense forest, open forest, semi-open regions, and second growth; it is generally a bird of the high canopy. In Honduras the species has not been recorded above 4,000 feet.

Forbes and Robinson (1898a: 98) mentioned specimens in the Derby Museum that were taken in "Honduras." Ridgway (1914: 343) examined at least one specimen from the mouth of the Río Romain [= Santa Rosa de Aguán], but I do not know the location of this individual.

Honduran material is representative of the widespread nominate race, $\underline{P}$. t. torquatus (Gmelin). It shows no approach to the smaller Yucatán and British Honduran race, P. t. erythrozonus Ridgway. Wings of Honduran specimens 
measure as follows: o, 134.1-148.0 (142.6); $\$, 137.5-149.9$ (146.2).

\section{Selenidera spectabilis Cass in}

Yellow-eared Toucanet

$$
\text { SPECIMENS.--(8): Lancetilla, } 24 \text { Jan., } 20 \text { March (40", }
$$
29, MCZ); $5 \mathrm{mi}$. S San Esteban, 18 Jan. ( $\delta$, LSUMZ); Arena 1, 22 Jan. ( 0 , UCLA).

PUBLISHED RECORD.--Lancetilla (Peters, 1929b: 436).

This toucanet is a lowland rain forest species that reaches its northern limit of distribution along the coast of north-central Honduras east of the Sula Valley. It has been uncommonly recorded in Honduras. The spectes has not been reported above 1,500 feet elevation in the republic. Peters (1929b: 436) collected three males and two females in open rain forest at Lancetilla on 24 January 1928; on 20 March 1928 Edward Bangs obtained another male at the same spot. In June 1952 Paul Slud observed the species also at Lancetilla.

T. R. Howell collected a male at Arenal in 1955. Richard R. Graber secured one of a pair seen in heavy selva near San Esteban on 18 January 1962.

As Peters (1929b: 436) pointed out, there are no differences in the Honduran specimens when compared with birds from Costa Rica and Panama. 


\section{Ramphastos sulfuratus Lesson}

\section{Keel-billed Toucan}

SPECDENS.--R. S. brevicarinatus (49): Lancetilla, 15 Jan. -2 Feb., 26 Aug. (d, ANSP; 35, MCZ); La Ceiba, 4-21 Jan., 28 March-9 Aug. ( $70^{\circ}, 69^{\circ}, \mathrm{CM}^{\circ}$ 20, \&, MCZ; $0^{\circ}$, USMM); Trujillo, 31 March-6 April (o', $\$$, CM); San Pedro (2?, Juv., BMNH); Las Peñitas, 7-11 Feb. (2\%, BMNH); Progreso, 1 Feb. (d, $q^{\text {MCZ }) ; ~ C h a m e l e c o ́ n, ~} 12$ Marcch ( $\$$, USNM); Subirana, 31 Jan. -23 Feb. ( $30^{\circ}, \mathrm{MCZ}$ ); San José de Santa Bárbara, 30 Ápri1 (o', AMNH); Santa Bárbara, 24 May ( $\%$, AMNH); Finca Fé, 2-16 Sep., 30 Nov. ( $\sigma^{\prime}, ?, \sigma$ skel., \& skel., LSLMZ); near El Mochito, 26 June ( ${ }^{\circ}$, UF); Agua Azul, 24 Feb., 7 Aug. (d', \&, UF); Lake Yojoa, 2 Feb., 15 July ( 9 , CM; skel., MIZ); Mocorina [= Mocorín], $7 \mathrm{Feb} .\left(\sigma^{\circ}, \mathrm{CU}\right)$; MHonduras" (?, ANSP; o, AMNH; ?, BMNH).

PUBLISHED RECORDS.--"Honduras" (Moore, 1859: 59; Forbes and Robinson, 1898a: 97). San Pedro region (Sclater and Salvin, 1870b: 837). San Pedro (Sclater and Shelley, 1891: 126). La Ceiba (Bangs, 1903: 145). Lancetilla, Progreso, Tela region (Peters, 1929b: 435-436). Lancetilla (Stone, 1932: 315).

The Keel-billed Toucan is a common resident of the humid Caribbean lowlands of Honduras, ranging up to 4,500 feet. The species is most frequently encountered in open rain forest and second growth woodland.

R1dgway (1914: 335) reported a record from the "mouth of Río Tuma," Honduras, but I do not know on what he based this report nor am I able to locate any "Rio Tuma" in Honduras.

All Honduran specimens are typical of the race $B \cdot s$. brevtcarinatug Gould, characterized by shorter bill, smaller size, deeper yellow throat, and posterior red border to the yellow throat. In all these features, the Honduran populations agree with those of southern Central American regions and differ from nominate R. S. sulfuratus Lesson from 
British Honduras and Mexico. Contrary to the opinion of Peters (1929b: 435-436), the northern Honduran populations do not show any approach to the nominate race but are typical of brevicarinatus in every way.

\section{Ramphastos swainsonil Gould}

\section{Ches tnut-mandibled Toucan}

SPECTMENS.--(6): Arena1, 25-27 Jan. (d,, ${ }^{\circ}$, UCLA); Patuca River, at mouth of Yapuras [= Yapahuás] River, 25 Feb. ( $\sigma^{\circ}$, USNM); Segovia River, 17 June (20, $\$$, USNM). 591). PUBLISHED RECORDS.--Segovia River (Ridgway, 1888c: rivers (Deignan, 1936: 190).

This large toucan reaches its northern limit of distribution in the rain forests of olancho. Its habitat preference and general habits are similar to those of $\underline{R}$.

sulfuratus, but it is decidedly uncommon in Honduras. The only Honduran records are the spectmens listed above. C. H. Townsend collected the three Río Segovia birds in 1887; W. D. Strong obtained a specimen on the Río Patuca in 1933; and T. R. Howell and J. G. Montrello collected a male on 25 January and a female on 27 January 1953 at Arenal.

\section{Family PICIDAE}

\section{Picimnus olivaceus Lafresnaye}

\section{Olivaceous Pleulet}

SPECTMENS.--P. o. dimotus (38): $2 \mathrm{mi}$. E Omoa, 23 oct.

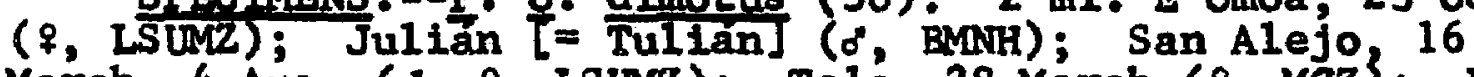
March, 4 Aug. ( 0,9, LSUMZ); Tela, 28 March ( 8, MCZ); Lancetilia, 27 March (o', MCZ); La Ceíba, 21-24 Jan., 24 
April-13 May (40, CM; $0^{\circ}, 9, \mathrm{MCZ}$ ); Los Planes, 9-10 June (20, $\$, C M)$; San Pedro Sula, 30 July ( $0^{\circ}$, BMNH; ${ }^{\circ}$, USNM); Coyoles, 14-29 June (20, 28, GM); Finca Fé, 14 Jan., 7 Aug - -8 Dec. ( $60^{\circ}, 3 \%, 30^{\circ}$ skel., o alc., LSUMZ); Lake Yojoa, $28 \mathrm{July}\left(0^{\circ}, 9, \mathrm{CM}\right)$; E1 Boquerón, 25 Sep. (20', MCZ).

PUBLTSHED RECORDS.--San Pedro region (Sclater and Salvin, 1870b: 837-839). Julián [= Tulián], San Pedro (Hargitt, 1890: 548-549). La Celba (Bangs, 1903: 146-147). San Pedro Sula (Ridgway, 1914: 307). Lancetilla, Tela (Peters, 1929b: 438-439).

The Olivaceous Piculet is a fairly common to common resident in the humid Caribbean lowlands of Honduras, ranging as high as 2,500 feet. It occurs in rain forest but is most common in second growth or in the more open areas of rain forest. I found the species to be common in the open forests at Finca Fé, near Lake Yojoa. During the late fall of 1962, I discovered two nests there, one an occupted cavity that was located in a fence post only four feet of $f$ the ground. A second nest was dug in a dead 1 imb about 20 feet above the ground but was apparently abandoned soon after completion.

The species is known to range north to Guatemala (Land and Wolf, 1961: 94). Birds from Nicaragua north are all referable to the race $\underline{P}$. o. dimotus [Picummus dimotus Bangs, 1903: 146; Ceiba, Honduras ].

\section{Colaptes auratus (Linnaeus)}

Common Flicker

SPECTMENS.--C. A. mextcanoides (71): Subirana, 30 Jan., 11-21 Dec. (20, ?, MCZ); Portillo Grande, 30 May (o', MCZ); San Esteban, 30 June ( $8, C M$ ); Los Cedros, 15 June (?, MLZ); Montaña EI Chorro, 5-19 June (2d, 7 , MLZ); Montañ̉a La Cruz, 25 June (o, $\$$, MLZ); Plan del Rancho, 2-9 
July (o, 28, ?, MLZ); $15 \mathrm{mi}$. NW Siguatepeque, 15 Aug . (d", CM); Siguatepeque, 9-31 July ( $\left.\sigma^{\circ}, \stackrel{?}{?} ?, \mathrm{CM}\right)$; $8 \mathrm{ml}$. W Zambrano, 17 Oct. (f?, ISUMZ); Montaña Văsquez, $10 \mathrm{Jan.,} 7$ Dec. (o", 7, MCZ); Cantoral, 29 May-24 July, 7 Dec. ( 8 , 29, AMNH; $\sigma^{\circ}$, MLZ); Cerro Cantoral, 29 Feb., 8 April-29 May, 26 July, 6 Nov. -12 Dec. ( $q$, ANSP; $\circ$, CM; $;$, MLZ; o, 3\%, ?, MCZ); Monte Redondo, 6 Dec. (o', AMNH); La Flor Archaga, 10-12 Jan., 24 May-9 June ( 9 , ANSP; o, \$, AMNH; 2\%, MCZ); San Juancito, 18 July-15 Aug. ( $\%, 3 ?$, ANSP); San Juancito Mts., 29 June ( 8, UF); Rancho Quemado, 4 March-20 May (40", 48, MCZ); E1 Hat1110, 22 Apri1-8 May, 29-30 June, 5 Aug.

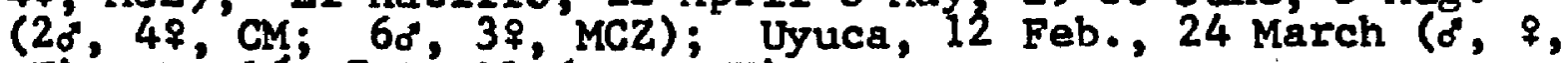
UF); Danl1, 7 April (o', BMNH).

PUBLISHED RECORD.--San Juancito (Stone, 1932: 316).

This woodpecker is a fairly common resident in pine or pine-oak associations in the interior of Honduras, occurring primarily above 2,500 feet but occasionally ranging to lower elevations .

Lester L. Short, Jr. (unpublished MS. and personal communication) has established the conspecificity of all the flickers north of South America, thus the specific name $C$. auratus in lieu of $\mathrm{C}$. cafer (Gmelin).

I cannot detect any constant geographic variation in the flickers from Chlapas to Nicaragua and therefore consider C. a. pinicolus [Colaptes mexicanoldes pinicolus Dickey and van Rossen, 1928b: 131; Los Esesmiles, Dept. Chalatenango, El Salvador] to be a synonym of c. a. mexicanoides Lafresnaye.

\section{Plculus rubiginosus (Swainson)}

Golden-olive Woodpecker

SPECIMENS ---P. . . yucatanens is (78): Catacombas, 1-8 April ( 8, ANSP; $2 \%, M L)$; Cofradia, 12 March ( $9, M L Z)$;

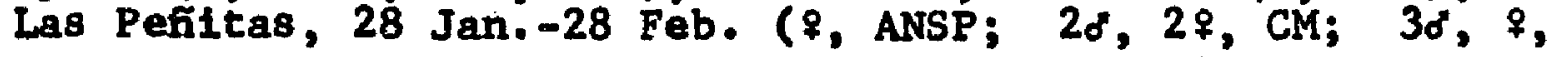


MLZ; o, \$, MCZ); Subirana, 29 Jan. ( $\%$, MCZ); Portillo Grande, 11 March, 14 May ( $0^{\circ}$, , MCZ); San Es teban, 30 June (30, 3\%, CM); 6 mi. S Cucuyagua, $27 \mathrm{Feb}$. (d, LSUMZ); Montaña E1 Chorro, 22-24 June (?, Juv. ?, ML2); Monte E1 Conejo, 22 May ( 9, MLZ); Plan del Rancho, 1-30 June (?,?, MLZ); Belén Gualcho, 21 July ( $\%, M Z) ;$ San José de Santa Bárbara, 30 April-1 May ( $\$$, ANSP; $d$, AMNH); Cerro Santa Bárbara, east 8 lope, 19 Feb., 28 Nov. -7 Dec. ( $d, 2 \%$, LSUMZ); Finca Fé, 12 Sep., 30 Nov.-19 Jan. (30, 3\%, Lsumz); Lake Yojoa, 14 June-16 Aug. (30, \&, CM); $16 \mathrm{ml}$. NW Valle Bonito, 2 Nov. (\%, LSUMZ); $15 \mathrm{mi}$. NW Siguatepeque, 15 Aug. (\$, CM); S1guatepeque, 31 July (o', CM); Cerro Cantoral, 15 Feb.-29 March, 4-12 May, 9-13 Dec. (45, 3\%, MCZ); Monte Redondo, 22 March, 14 May, 2 Nov., 2 Dec. '(20", ANSP; $\delta$, AMNH; ₹, MCZ); La Flor Archaga, 25 May, 3 Dec. (?, ANSP; 7, MCZ); Rancho Quemado, 5 April (d, MCZ); E1 Hatillo, 29 April-12 May, 16 Aug. ( $0^{\circ}, \mathrm{CM} ; 2 \sigma^{\circ}, 2 \%, \mathrm{MCZ}$; Comayagüela, 3 June, 11 Oct. (20", MCŹ); E1 Paralso, 20 April (o, BMNH); Puerto Lempira, 7 Feb. 10-14 Apr11 (40, ${ }^{\circ}$, LSUMZ); San Francisco, Choluteca, 12 Feb. (o", LSUMZ); $16 \mathrm{mi}$. ŚW San Marcos de Colón, 13 Oct. ( $\sigma$, LSUMZ).

PUBLISHED RECORD.--"Honduras" (Moore, 1859: 60).

Despite the scarcity of published records, the Goldenolive Woodpecker is a fairly common resident in Honduras, occurring in virtually every type of situation in which there are trees, with the exception of heavy lowland rain forest. In Honduras it ranges from sea level to at least 7,500 feet and inhabits open parts of lowland rain forest, monsoon forest, second growth, cloud forest, lowland pine savanna, highland pine, pine-oak assoctations, and arid scrub habitats, being least common in the arid situations. Although it is not as plentiful as Centurus aurifrons, it is found in most of the habitat of the latter in addition to cloud forest, a situation in which $\mathrm{C}$. aurifrons is absent.

This species is one of the most varlable of woodpeckers. In Honduras its variation is not well correlated 
with distribution. Differences in color are primarily Individual in nature, although birds from more humid regions (especially cloud forest areas) tend to have darker gray cheeks and more reddish ground color on the breast in both sexes; these differences, however, are not completely constant since white-cheeked individuals may be taken in cloud forest on occasion. All Honduran birds do average smaller than birds from the Pacific slope of Guatemala and Chiapas, which are distinguished as the race $\underline{P}$. $\underline{\text { - maximus }}$ Griscom [1929b: 11; Chanquejelve (5000 ft.), Huehuetenango, Guatemala]. The race from the Pacific lowlands of Guatemala, described as $\underline{\text { P. }}$ r. differens Griscom [1929b: 11; Finca Carolina, ten miles south of Tumbador, District of San Marcos, alt. $3000 \mathrm{ft}$. , on the Pacific slope of Guatemala], is not valid as all differences of color represent individual variation, these characteristics appearing in the Honduran series. The two specimens taken on 7 February 1963 and the three additional males obtained in Apri1 1964 at Puerto Lempira, in the lowland pine savanna of eastern Honduras, are separable from all other Honduran specimens on the basis of average smaller size (wing: $\delta, 121.4,122.5$, $123.4,124.1$; $9,117.1)$; until further material is available, however, I am considering all Honduran populations as

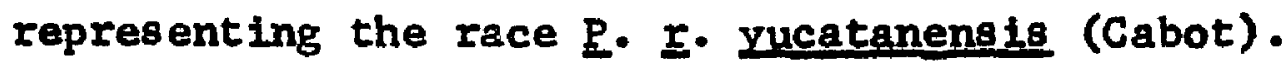




\section{Plculus simplex (Salvin)}

Rufous-winged Woodpecker

SPEC MEENS.--P. s. allophyeus (2): San Alejo, 2 April (o, LSUMZ); Yaruca, 11 Feb. (f', MCZ). P. s. simplex (1): Arena1, 20 Jan. ( $\%$, UCLA).

\section{3: $\frac{\text { PBLISHED }}{145-146)}$ \\ PUBLTSHED RECORD.--Yaruca [as Allophyeus] (Bangs,}

This woodpecker is a rare species inhabiting lowland rain forest on the Caribbean slope of Honduras. It occurs from sea level to at least 1,200 feet and reaches its northern known Iimit of distribution just east of the Sula Valley.

The first Honduran specimen, a male taken on 11 February 1902 by $W$. W. Brown at Yaruca (1,000 feet elevation), was the only individual recorded by him in Honduras. T. R. Howel1 obtained a female at Arenal (1,200 feet elevation) on 20 January 1955. I collected a single male at San Alejo (sea level) in 1963; this individual was in the top of a huge celba tree in relatively dense rain forest. It was first noted by Rose $S$. Monroe and was the only example of the species that we observed in Honduras, despite several subsequent searches in the San Alejo area. Nothing further is known concerning the spectes in Honduras.

The Yaruca specimen was described as a new subspecies, p. E. allophyeus [Chloronerpes simplex allophyeus Bangs, 1903: 145; Yaruca, Honduras, 1,000 feet altitude], on the basis of smaller size, smaller bill, yellowish on the throat, yellower coloration below, larger spots on the 
breast, and narrower black bars on the belly; measurements of this specimen are wing, 111.7 , and exposed culmen, 17.9. The male from San Alejo agrees in all detalls with the type of allophyeus, both in color and in size (wing, 111.0; exposed culmen, 18.1). On the other hand, the single female from Arenal compares favorably with the nominate race, $\underline{P} \cdot \underline{s}$. simplex (Salvin), from Costa Rica and Panama; its measurements are wing, 114.3, exposed culmen, 19.3. Although allophyeus is known from only two males, the race appears to be valid on the basis of these two individuals. Its range is probably confined to the narrow band of rain forest along the north coast of Honduras west to the Sula valley. The nominate race occurs at least as far north as Arenal and is probably widespread through the rain forests of 0lancho.

\section{Celeus castaneus (Wagler)}

Ches tnut-colored Woodpecker

SPECTMENS.--(50): Julián [= Tulián] (imm. o, BMNH); San Alejo, 3 April ( 9 skel. LSUMZ); Lancetilla, 18 Jan. -9 Feb. (39, MCZ); La Ceiba, 16 Apri1-1 May, 6 June (2 ${ }^{\circ}$, CM; 9. USMM); Trujillo, 7 April (ó, CM); Catacombas, 22 March6 Apr11 ( ${ }^{\circ}$, ANSP; 40, $q$ MIZ); Cofradia, 4-14 March ( $0^{\circ}$, \%, ML2); San Pedro Sula, 24 Dec. ( ${ }^{\circ}$, BMNH; q, USMM); Santa Ana, 22 Dec. ( $0^{\circ}$, USNM); Las Peñitas, 2-8 Féb. (30, 2\%, MLZ); San Pedro Montaña, 15 Feb. ( ${ }^{\circ}$ CM); Chamelecón, 2 Dec.-2 Jan. ( $\sigma^{\circ}, 29$, USN); Amapa, 19 Apri1, 24 June ( $\sigma^{\circ}$ skel. ISUMZ; 'o, UF); Coyoles, 28 June ( $7, ?, \mathrm{CM})$; San José de Santa Bárbara, 28-30 April (o, 28, AMNH); $6 \mathrm{ml}$. SW E1 Jaral, 22 Oct. ( $\delta$, 'LSUMz); Finca Fé, 12-13 Jan. 8 Dec. (20, ${ }^{\circ}$, LSUMZ); Lake Yojoa, 19 June, 13 July (2\%, CM); Ei Boquerón, 2 Sep. ( $\sigma^{\circ}$, AMNH); Arena1, 17-21 Jan. ( $\delta^{\prime}, 2 \%$, UCLA); 2 mi. S Cauquira, 13 April (\%, LSUMZ); "Honduras" (d, \%, imm, o", BMNH). 


\begin{abstract}
PUBLISHED RECORDS.--Potrerillos (Sclater, 1858b: 359). Omoa (Moore, 1859: 60). "Atlantic slope of Honduras" (Sclater and Salvin, 1859: 137). Near Potrerl1los (Tay1or, 1860: 119). "Honduras" (Sclater, 1862: 336; Gray, 1868: 88-89). San Pedro region (Sclater and Salvin, 1870b: 837). Jultán [= Tulián], San Pedro (Hargitt, 1890: 434). Choloma (Lantz, 1899: 220). Chamelecón, Santa Ana, San Pedro Sula, San Pedro Montaña (Ridgway, 1914: 142). Lancetilla (Peters, 1929b: 437-438). La Ceiba (Deignan, 1936: 191).
\end{abstract}

Celeus castaneus is a fairly common resident of the lowland rain forests on the Caribbean slope of Honduras. It has been recorded up to an elevation of 3,500 feet and occurs in dense selva as well as in open forest or second growth.

\title{
Dryocopus Iineatus (Linnaeus)
}

\section{Lineated Woodpecker}

SPECIMENS. - -D. 1. Similis (46): Lancetilla, 5 Feb. ( $\sigma^{\circ}$, MCZ); La Ceiba, 22 Jan., 1 April-22 May, 3 Aug. (40, 29 , CM; o, MCZ; $\%$, USNM); Yaruca, 23-26 Feb. (f, क?, MCZ); Los Planes, 13 July ( $q, C M)$; Balfate, 28 Oct. ( $\$$, CNFM); Trujillo, 9 April, 23 Sep. ( ${ }^{\circ}, \mathrm{CM}$; 9 , USNM); Catacombas, 28 March ( ${ }^{\prime}$, MLZ); Las Peñitas, 29 Jan. ( 9 ML); Subirana, 11 Jan. ( $\sigma^{\circ}, \mathrm{MCZ}$ ); Portillo Grande, 25 Dec. ( $\sigma^{\circ}$, CNEM); Coyoles, 1 July $(d, q, C M)$; San Esteban, 1 July ( $\$, C M)$; Finca Fé, 23 Nov. ( $d$, LSUMZ); Cerro Cantoral, 23 July (?, MCZ); Monte Redondo, 24 Nov. -15 Dec. $\left(2 \delta^{\circ}, \$, M C Z\right)$; La Flor Archaga, 27 May, 24 Nov. ( $\delta^{\circ}$, AMNH; 20, MCZ); Cantarranas, 6 Aug. ( $q$, ANSP); San Juancito, 27 July ( $\%$, ANSP); E1 Hatillo, 30 April (o", MCZ); Yeguare River Valley, 9 Jan.-17 Feb, 7 Nov. ( $30^{\circ}$, $\uparrow$, UF); $1 \mathrm{ml}$. E Las Mesas, 8 June ( $d^{\prime}$, MCZ); Rio Choluteca, Dept. Francisco Morazán, 11 Aug. (??, UF); trail to Rlo Cobr1, 22 Jan. ( 8, UF); Arenal, 17-26 Jan. ( $\delta, 29$, UCLA); Honduras-Nicaragua boundary [near Pacific coast ] (2 $\left.\sigma^{\circ}, \mathrm{MCZ}\right)$; "Honduras" ( $\left.{ }^{\circ}, \mathrm{AMNH}\right)$.

PUBLTSHED RECORDS.--TIgre Island (Sclater, 1858b: 359; Taylor, 1860: 119). Omoa (Moore, 1859: 60). San Pedro region (Sclater and Salvin, 1870b: 837). Trujillo (RIdgway, 1888c: 582). San Pedro (SaIvin and Godman, 1895: 451). "Honduras" (Forbes and Robinson, 1898a: 115). La Celba, Yaruca (Bangs, 1903: 146). Lancet111a (Peters, $1929 \mathrm{~b}: 438$ ). Honduras-Nicaragua boundary "180 miles from 
Pacific coast" [= near Pacific coast] (Peters, 1920b: 319320). San Juancito, Cantarranas (Stone, 1932: 317). Ia Celba (Deignan, 1936: 191).

In Honduras the Lineated Woodpecker is an uncomon to fairly common species, occurring in a wide variety of forested situations from sea level to 5,500 feet. Although the species Inhabits pine-oak associations in the interior highlands, it is most frequently found in the semi-open forested regions of the humid Cartbbean lowlands. In addition, it is found uncommonly in and around monsoon forests in the Pacific lowlands. The species is slightly more abundant than Phloeoceastes guatemalensis and prefers more open situations than the latter.

Forbes and Robinson (1898a: 215) mentioned specimens from Honduras in the collections of the Derby Museum, presumably taken at Onoa by Joseph Leyland. I have not examined these individuals and they are not listed above.

Honduran specimens are referable to the widespread race, D. 1. s1milis (Lesson).

Melanerpes formicivorus (Swains on) Acorn Woodpecker

SPECIMENS:--M. E. albeolus (6): Segovia River, 19-25 July (40, USNM); Puerto Lempirs, 12 Apri1 ( $0^{\circ},{ }^{\circ}$, LSUMZ). M. E. 1ineatus > albeolus (6): San Bsteban, 25 June (20, 47, CM): M. f. IIneatus (48): Choloma ( ${ }^{\circ}$, KAS); Subirana, 27 Dec.-9 $\mathrm{Feb}$. (2\%, 39, MCZ); Port1llo Grande, 15 May, 25 Aug. ( $0^{\circ},{ }^{8}$, MCZ); Coyoles, 28 June ( 9, CM); Monte Verde, 20-26 July $\left(2 \delta^{\circ}, q, ?\right.$, ML $) ; 4 \mathrm{mi}$. SW EI Jaral, 12 Sep. ( $\alpha$, LSUMZ); 5 mi. SW El Jaral, 28 Oct. ( $q$, ISUMZ); Lake Yojoa, 16 June ( $\left.\sigma^{\circ}, C M\right)$; Siguatepeque, 8 July ( $\left.\delta^{*}, C M\right)$; Güise, 16 July (o", LSUMZ); Las Palmas, 31 Oct. (o", IŚMZ);

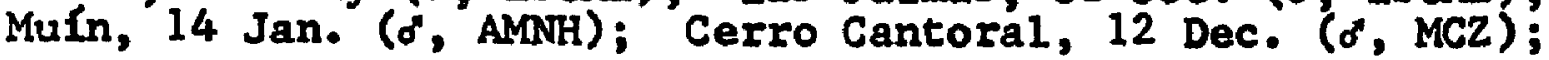


Monte Redondo, 8 Nov. -15 Dec. ( $\sigma^{\prime}, f$, AMNH; 6o, 49, MCZ); San Juancito, 27 July-12 Aug. ( $3 \%$, ANSP); Rancho Quemado, 5 Apri1 ( $\left.\sigma^{\circ}, M C Z\right)$; E1 Hatillo, 20 Aug. ( $\left.{ }^{*}, C M\right)$; Comayagüela, 4 Aug. ( $d$, AMNH); $2 \mathrm{mi}$. NE "Morazán" [= E1 Zamorano], 10 June ( $\delta$, MCZ); Escuela Agrícola Panamericana, 15 Jan. (q, UF); Yeguare River Valley, $15 \mathrm{Jan} ., 18$ Nov. (20, 29 , UF); Cues ta Grande, 1 July ( $\sigma$, CM); "Honduras" ( $\sigma$, $\&$, BMNH). PUBLISHED RECORDS.--Choloma (Moore, 1859: 60; Lantz, 1899: 220). "Honduras" (Sclater, 1862; 341). Segovia River (RIdgway, 1888c: 591). "Near Ocotepeque" (Dickey and van Rossem, 1938: 316 ).

The Acorn Woodpecker is a common resident of the pineoak assoclations in the interior highlands of Honduras. The species is most common from 2,500 to about 6,500 feet elevation but occurs below 1,000 feet in the Quimistán and Agalta valleys and at sea level in the pine savanna of the Mosquitia. It ranges into cloud forest, especially where cutting or burning has produced semi-open situations.

Dickey and van Rossem (1938: 316) 11sted a specimen in the museum at San Salvador, El Salvador, that was supposedly taken In Honduras "near Ocotepeque." I have not examined this Individual nor can I confirm its source.

The subspecific situation in this species in Honduras is parallel to that of several other pine-inhabiting species that occur both in the highlands and in the lowland pine savanna of the Mosquitia. As is the case with Dendroica graclae, Aimophlla zufescens, and several others, the Mosquitia population is the same as (or very similar to) the race inhabiting the pine ridges of British Honduras and different from the interior highland populations. The Mosquitia birds compare favorably with the British Honduran 
race, M. $\underline{\text { f. albeolus }}$ Todd, in reduced streaking on the Elanks, in the paler yellow throat, and in the more restricted yellow area on the throat. Honduran highland populations are typical of the more heavily streaked race, M. E. 1ineatus [Balanosphyra formicivora lineata Dickey and van Rossem, 1927a: 1; Mt. Cacaguatique, Department San Miguel, E1 Salvador], which has the yellow of the throat more extensive and deeper in color. Specimens from San Esteban are somewhat intermediate but are nearest lineatus. In this regard too, parallels exist: the only evidences of intergradation between the lowland pine and highland pine races of Plranga flava and Atmophila rufescens are also from the San Esteban region.

\section{Centurus aurifrons (Wagler)}

Golden-fronted Woodpecker

SPECIMENS:-C. a. insulanus (17): Utila Island, 15

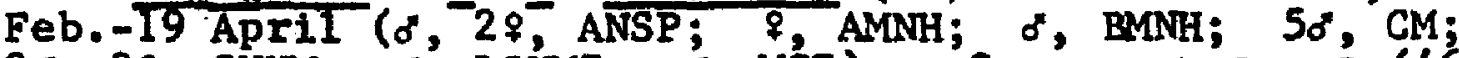
$20^{\circ}, 3 \%$, CNHM; $0^{\circ}$, LSUMZ; $\delta^{\circ}$, MCZ). C. a. canescens (46): French Harbor, 3-5 April (58, 3\%, CM); Roatán I81and, 7 Jan., 8 Sep. ( $0^{\circ}$, ANSP; 100, 14\%, BMNH; 40, 29,2 ?, CNHM; 29, USNM); Barbareta Is land, 10-12 April (20, $8, C M)$. C. a. pauper (72): Lancet111a, 14 Jan.-2 March, 29 Aug.-1 Sep; ( $\sigma^{\circ}, 2 \%$, ANSP; 20, 4\%, MCZ); Tela, 8-13 March (2\%, MCZ); La Célba, 1-22 Jan., 27 March-3 May (40, 58, CM; 50, 59; MCZ; of, USNM); Los Planes, 9-11 June (d, 47, CM); Balfate, 7 Nov. ( $\sigma^{\circ}$, CNHM); Trujillo, 30 March-9 April, 2030 Sep. (48, 28, CM; 20, 2q, USNM); Cofradí, 2 March (?, MLZ); San Pedro Sula, 8-30 July ( ${ }^{\circ},{ }^{\circ}$, BMNH; 20, 29 , USNM); Las Peñitas, 27 Jan. -9 Feb.' ( $d^{\prime}, q$, MLZ); Choloma ( $\sigma^{\circ}, K A S$ ); La Lima, 1 Nov. (o skel., ISUMZ); PImtenta Nueva, 7 Sep. ( 9 , LSUMZ); Coyoles, 23 April, 18-29 June (29, CM; of, LSUMZ); San Esteban, 26 June ( $\left.{ }^{\circ}, C M\right)$; Finca Fé, 5 Sep. -1 Dec. (3o, ${ }^{\circ}, 20^{\circ} 8 \mathrm{kel}$., skel., LSUMZ); Lake Yojoa, 21 June (o, UF); Jaitique, 15 Dec: (d skei., IS UMZ). C. a. santacruzi (51): Subirana, 27 Jan., 25 March ( $20^{\circ}$, MCZ); El Conejo, 15 May $(f, M L Z) ;$ Monte E1 Conejo, 21 May 
(o, ₹, MLZ); Mt. Puca, 9 Jan. ( 7, MCZ); $13 \mathrm{mi}$. NW Gracias, 28 Feb. (\%, LSUMZ); 5 mi. 5 Comayagua, 19 Nov. (3\%, IS LMZ); Cantoral, 23-24 July (o, $₹, C M)$; Cerro Cantora 1, 20 Feb., 28 July ( $\delta$, ANSP; $\left.\sigma^{\circ}, \mathrm{MCZ}\right)$; Monte Redondo, 22 Nov, -30 Jan. ( $\sigma^{\prime,}$ AMNH; $5 \sigma^{\prime}$ 2\%, MCZ); La Flor Archaga, 22 May ( $\left.\$, M C Z\right)$; Cantarranas, 20 July-10 Aug. (3o, $q, ?$, ANSP); E1 Hat1llo, 18 Apri1-12 May, 12 Aug. ( ${ }^{\circ}, \mathrm{CM} ;$ 4, MCZ); Tegucigalpa, 26 oct. (skel., MLZ); vicinity Tegucigalpa, 4 June (o skel., MLZ); Comayagüela, $4 \mathrm{May}, 10$ oct. -13 Nov. (o, $2 \%$, AMNH; 40, 4\%, MCZ); Capa Rosa, 24 April (o, UF); Escuela Agrí-

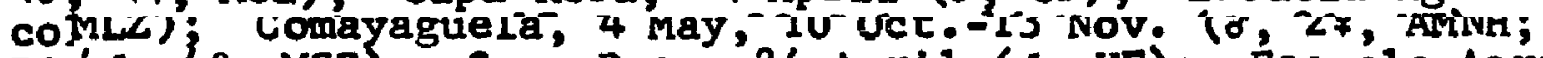
Pifo, 4\%, MCZ); Capa Rosa, 24 April ( $\sigma^{\circ}$ UF); Éscuéla Agrícola Panamericana. $17 \mathrm{Jan} . .30 \mathrm{Julv} .16$ Nov. (6. 29. UF); PUBLTSHED RECORDS --Comayagua (Sc1ater, 1858b: 359). Omoa (Moore, 1859: 60; Forbes and Robinson, 1898b: 105). "Honduras" (Taylor, 1860: 119). San Pedro region (Sclater and Salvin, 1870b: 837). Trujt11o [as pauper] Roatán Island [as dubius ?] (Ridgway, 1888c: $579,582-583$ ). Roatán IB 1and [as canescens] (Salvin, 1889: 370-371; Hargitt, 1890; 174; Cory, 1919: 420-421). San Pedro [as santacruzi] (Hargitt, 1890: 181). Choloma [as pauper] (Lantz, 1899: 220). La Ceiba [as pauper] (Bangs, 1903: 146; Delgnan, 1936: 191). Lancetilla and Tela [ás pauper] (Peters, 1929b: 437). Cantarranas and Lancet111a [as pauper]" (Stone, 1932: 316). Ut11a Island [as insulanus]; Roatan Is land and Barburat [ = Barbareta] Is land [as canescens] (Bond, 1936: 361). Roatán Is1and, Barbarat [= Barbareta Island], and Héléne [= Santa Elena Island] [as canescens] (Délacour, 1938: 545-546).

This species is one of the most widespread and common woodpeckers in Honduras. It is found in most any type of semi-open situation in the Caribbean lowlands, In the Bay Islands (except on Guanaja Island), and in the interior highlands up to 6,500 feet. In the arid Pacific lowlands, it ranges down to about 1,000 feet, occasional1y lower along the river valleys, where it hybridizes with $\mathrm{C}$. hoffmannil along a very narrow front. $\quad$. gurifrong prefers silghtly arid situations and is absent from dense forest. It is decidediy uncommon in pine areas in the interior and does not occur in the pine savanna of the Mosquitia in eastern 
Honduras. It is most abundant in the dry interior valleys and in semi-open situations in the Caribbean lowlands. The spectes is replaced in heavy selva by $\mathrm{G}$. pucherani.

Gray (1868: 202) 11sted under "Centurus albifrons" a pair of specimens in the British Museum taken in "Honduras" by David Dyson. Hargitt (1890: 174) listed them again under "Melanerpes dublus" and they are, Indeed, representative of the race $\underline{\underline{C}}$. . . dubius (Cabot), a subspecies that apparently does not range south into Honduras. These birds were undoubtedly secured by Dyson in British Honduras, not Honduras, as Dyson did not distinguish between the two regions. Several spectmens in the Derby Museum labeled "Honduras," which are also dubius (Forbes and Robinson, 1898b: 105), were 11kewise probably obtained in British Honduras.

Ridgway (1914: 89) attributed the species to Julián [= Tulián], a locality in the vicinity of Puerto Cortés, on the basis of Sclater and Salvin (1870b: 837), but the latter were not specific as to locality and I have been unable to locate any specimen in the British Museum taken at Tulián.

The relationships of $G$. aurifrons and $G$. hoffmannil are discussed under the latter species.

Each of the three main islands forming the Bay Islands group (Utila, Roatán, and Guanaja) has its own distinct woodpecker of the genus Centurus. On Guanaja Is land is found a race of $\underline{C}$. pygmaeus, a spectes known elsewhere only 
from Cozumel Island and the Yucatán Peninsula. Roatán Island, including the associated small islands of Santa Elena and Barbareta, is the home of a distinct form of the dublus group of $c$. aurifrons, a group known from Mexico south to Petén, Guatemala, and British Honduras. On Utila Island is a race of the santacruzi group of $\mathrm{C}$. aurifrons, which is the group found on the adjacent mainland of Honduras. Th1s distribution is evidence that the Bay Islands have been invaded by Centurus woodpeckers on three different occasions, twice from the northwest across the Caribbean Sea, each invasion resulting in colonization of one of the larger islands.

I do not agree with Selander and Giller (1963: 267)

that the Caribbean lowland race, $\underline{C}$. a. pauper [Centurus Santacruzi pauper Ridgway, 1888c: 582; Truxillo, Honduras], cannot be distinguished from the highland subspecies, $\underline{\text {. }}$ a. santacruzi Bonaparte. The two are separable on the basis of size alone. Wing lengths of 74 spectmens of pauper from Honduras were as follows: $\delta, 111.9-131.0 ; \%, 108.3-128.0$. Wings of 51 specimens of santacnuzi from the Honduran highlands measured: $\delta, 130.9-148.5 ; \%, 127.2-140.1$. In addition to size, for which there is very little overlap, the upper parts are generally more broadly barred with white In santacrua1. However, other characters used in separation of the two races in the original description (rump barring, darkness of under parts, barring on rectrices) do 
not hold true. The race pauper is found in the Caribbean lowlands of Honduras below an elevation of 2,500 feet, including in the Quimistán, Sula, and Aguán valleys. C. a. santacruzi occurs in the highlands generally above 3,000 feet, but it descends to 1,900 feet in the Comayagua and olancho valleys and almost to sea level along the rivers in the Pacific lowlands. There is a possibility that the Comayagua valley population represents an undescribed race since the three known specimens, all females, are the darkest of the entire Honduran serles. On the Pacific slope santacruzi hybridizes with . . hoffmannil at about 200 feet elevation, according to Selander (personal communication). The race on Roatán Island, $\underline{C}$. $\underline{a}$ - canescens [Centurus canescens Salvin, 1889: 370; Ruatan I., Bay of Honduras], differs from all other Honduran races in being much paler gray on the head and under parts (especially on the forehead and in the superciliary region), in having the abdomen and the nasal tufts red (not yellowish or orange), and in having the white bars on the upper parts and wings broader. In these characteristics canescens closely resembles dubius. The Utila subspecies, $\underline{\text {. }}$ a. insulanus [Centurus santa-cruzi Insulanus Bond, 1936: 360; Utilla Island, Spanish Honduras], is close to c. a. pauper of the adjacent mainland, differing in the larger size (wing: $\sigma, 128.7-138.1$; \&, 127.0-128.1) and in the average greater amount of whitish on the forehead and in the superciliary region. From $\underline{C}$. a. 
santacruzi, the larger highland race, insulanus differs in the more whitish head region and in narrower white bars above. A single specimen of insulanus, taken on Utila on 19 Apri1 1948 by Arthur C. Twomey and Roland W. Hawkins, has the abdomen and nasal tufts extensively red, but this ind1vidual does not show any approach to canescens in the characters of paleness below or in broader white stripes above; I regard this specimen as a variant of insulanus.

Centurus hoffmannil Cabanis

Hof fmann's Woodpecker

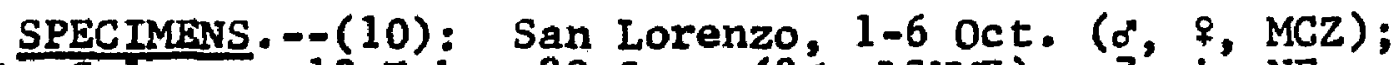
Puerto Salamar, 13 Feb., 28 Sep. (20, LSUMZ); 7 mt. NE Choluteca, 12 Feb. ( $\%$, LSUMZ); $8 \mathrm{ml}$. SE Namasigüe, 8 0ct. ( 8 , LSUMZ); Honduras-NLcaragua boundary [near Pacific coast $]\left(d^{*}, 29, ?, \mathrm{MCZ}\right)$.

PUBLISHED RECORD.---Extreme southern Pacific Honduras" [in range] (S1ud, 1964: 190).

This spectes of the genus Centurus occurs in the Pacific lowlands of Honduras up to a maximum elevation of about 500 feet. A common and conspicuous bird of the arid scrub country, it is the dominant woodpecker of the Pacific lowlands.

The specimens from the Honduras-Nicaragua boundary are without further data; they were obtained prior to 1901 . C. F. Underwood collected a female and a male at San Lorenzo on 1 and 6 October 1932, respectively. I obtained the remaining individuals in the fall and winter of 1962-1963. 
Although this form is often regarded as a race of $\mathrm{C}$. aurifrons, Selander and Giller (1963: 240-241) gave evidence for its status as a species. These authors did not know of any Honduran material, however, at the time of their paper and gave the range of the species as north to Nicaragua. Although there is a close geographical approach of $\underline{C}$. aurifrons and $\underline{G}$. hoffmannit, the former species descending to about 200 feet elevation along river valleys, there is no evidence of any intergradation in any of the specimens that I have examined. I have been informed, however, that Selander (personal communication) recently obtained several hybrid individuals in Honduras along the Rfo Pespire between Nacaome and Pespire; at Nacaome pure $\underline{C}$. hoffmannil exists while at Pespire only $C$. aurifrons is known, the hybridization apparently taking place in a narrow zone along a few miles of the river. Selander is still of the opinion that hoffmannil may be regarded as a distinct species, with a limited area of partial hybridization with aurifrons. I entirely agree. Until the exact nature of this intergradation can be determined, I feel it is best to retain hoffmannil as a full species, especially since it may prove to be more closely related to $c$. rubricapillus Cabanis of Costa Rica and Panama than to $C$. aurifrons.

Centurus pygmaeus Ridgway

Red-vented Woodpecker SPECIMENS.--C. R. tysoni (33): Guanaja (Bonacca) 
Island, 27 Feb. -15 April, Sep. (5d, 4q, ANSP; d, \&, AMNH;

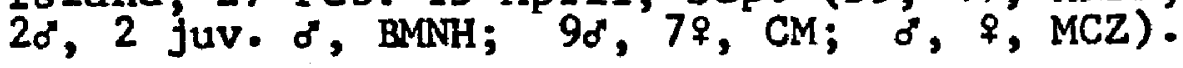

PUBLISHED RECORDS.--Bonacca [:= Guanaja] Is land (Sa1vin, 1889: 369; HargItt 1890; 174; Salvin and Godman, 1895: 417-418; Bond, 1936: 361).

In Honduras this spectes of Centurus is restricted to Guanaja Is land, in the Bay Islands. It occurs throughout the island, except in the zone of pine, and is very common; it is the only species of woodpecker on the island. The occurrence of the species on Guanaja and the peculiar distribution of the Centurus woodpeckers in the Bay Islands have been discussed under $\underline{C}$. aurifrons.

It seems very unwise to lump this species with $\mathrm{C}$. rubricapillus Cabanis of Costa Rica, Panama, and northern South America. About the only characteristic that they have in common, not shared by most other Centurus, is their relatively small size. The distribution does not indicate any relationship between these two and, furthermore, $\underline{\mathrm{C}}$. rubricapillus appears to be allied to $\mathrm{C}$. hoffmannil, the latter a close ally and possibly a race of $\underline{C}$. aurlfrons. C. pygmgeus and $\underline{C}$. aurifrons are unquestionably distinct species as both are sympatric on the Yucatán Peninsula and on Cozumel Island.

The birds from Guanaja have been described as $\underline{\mathrm{C}}$. $\mathrm{L}$. tysoni [Centurus rubriventris tysoni Bond, 1936: 361; Bonacca Island, Spanish Honduras], differing from C. R. pygmaeus Ridgway of Cozumel Island in slightly larger size, more extensively white middle rectrices, and clearer yellow 
(not orange-yellow) forehead. The race is valid and is undoubtedly very closely allied to the nominate race, probably being derived from it.

\section{Centurus pucherant (Malherbe)}

Black-cheeked Woodpecker

SPEC IMENS. - -C. p. perileucus (24): San Alejo, 16 March-3 ApriI, 5-7 Aug. (38, 27, LSUMZ); Lancetilia, 3-9 Sep. ( $0^{\circ},{ }^{\circ}$, ANSP); Yaruca, 9-19 Feb. (30, 49, MCZ); Los Planes, 9-11 June (30, 2q, CM); Trujillo, 27 Sep. (2 9 ?, USNM); Lake Yojoa, 23 June ( $\sigma^{\circ}$, UF); "Honduras" ( $\sigma^{\circ}$, ANSP; 9. BMNH). C. p. pucherant (8): Arenal, 21-27 Jan., 1 June (4\%, UCLA); Segovia River, 15 June-19 July (30", $\$$, USNM).

PUBLISHED RECORDS.--Near Omoa (Moore, 1859; 60). "Honduras ?" (Gray, 1868: 101). San Pedro region (Sclater and Salvin, 1870b: 837). Trujillo, Segovia River (Ridgway, 1888c: 583, 591). "Honduras" (Hargttt, 1890: 165). San Pedro (Salvin and Godman, 1895: 415). Omoa (Forbes and Robinson, 1898a: 105). Yaruca (Bangs, 1903: 146). Lancetilla (Stone, 1932: 317).

The Black-cheeked Woodpecker is the representative of the genus that inhabits lowland rain forest on the Caribbean slope of Honduras. It is fairly common in Honduras, occurring primarily in denser forest than that in which $\underline{C}$. aurifrons is found; it ranges into semi-open areas and second growth but is decidedly uncommon in these situations. In Honduras it has been taken as high as 2,500 feet elevation.

Forbes and Robinson (1898a: 105) mentioned specimens from Omoa in the Derby Museum, presumably those taken by Jos eph Leyland.

As pointed out by Austin (1929: 119), the best character for distinguishing the northern race, C. p. perileucus (Todd), from the southern race, c. p. pucherani (Malherbe), 
is the size of the white spots on the upper wing coverts. In perileucus these spots are larger and never obsolete, while in pucherani they are reduced in size or absent. There is a sharp break between the races in Honduras, perileucus occurring in the forests of the north coast as far east as Trujillo and pucherani ranging north into the rain forests of olancho. Specimens from Arenal and the Rio Segovia in the Olancho match Costa Rican birds very we11; al1 other Honduran specimens are typical of perileucus. On the basis of the known specimens, there is no evidence of an intermediate population, but in all probability one is present in northern 0lancho. I should point out also that the other characters ascribed to perlleucus (back more broadly barred and white transverse bars on secondaries broader) are true on the average but are subject to considerable variation. I was not able to detect any distinet break in size variation, although there is a general clinal trend towards smaller size in the southern part of the range of the species.

\section{Sphyrapicus vartus (Linnaeus)}

Yellow-bellied Sapsucker

SPEC MMENS. --S. ‥ varius (11): Swan Islands, 7 March (f, MCZ); La Celba, 5-24 Jan. (2\%, MCZ); Port1lio Grande, 12 Feb. ( $q$, MCZ) ; E1 Guayabai, 12 Jan. ( 8, AMNH) MuIn, 13 "June" [= Jan. ?] (ó, AMNH); $1 \mathrm{mi}$. NW Zambrano, 19 Nov.' ( $q$, LSUMZ); Cantoral, 22 Jan. ( 9 , AMNH); Cerro Cantoral, 6 Dec. (q, MCZ); Mt. Uyuca, 24 Feb., 4 April (q,?, UF). 
119UBLISHED RECORDS.--Near Siguatepeque (Taylor, 1860: 119). "Honduras" (Forbes and Robinson, 1898a: 105). La Celba (Bangs, 1903: 146). Near Tela (Peters, 1929b: 437). Bonacca [= Guanaja] Is land (Bond, 1936: 354). Swan Is lands (Paynter, 1956: 105).

In Honduras the Yellow-bellied Sapsucker is a fairly common winter visitant. It is found from sea level to at least 6,000 feet but seems to be most common In regions of highland pine. It has been recorded in migration in the Swan Islands, Bay Islands, and Cayos Cochinos. Extreme dates of arrival and departure for Honduras are 30 October and 6 April. One Individual taken by C. F. Underwood at Muín is labeled "13 June 1937," but this date is almost certainly a lapsus for "13 Jan. 1937," since Underwood is known to have collected at Muín only in December 1936 and January 1937.

Forbes and Robinson (1898a: 105) 1isted specimens from "Honduras" in the Derby Museum, but I have not examined them. The report from Tela by Peters (1929b: 437) was not based on observation of the bird but rather on the finding of the characteristic rows of puncture marks on trees.

In March 1953 at Los Dragos, Mark Trafton, Jr., collected an adult of the western race, $\underline{S} \cdot \underline{y}$. nuchalis Baird, for Identification purposes, but the specimen was not preserved. Trafton also observed two more individuals of this race at Los Dragos in January 1952.

A11 Honduran specimens that I examined represent the eastern North American race, $\underline{S}$. $\underline{y}$. varius (Linnaeus). 


\section{Veniliornis funigatus (d'orbigny)}

Smoky-brown Woodpecker

SPECIMENS. - - $\underline{V}$. E. Sanguinolentus (20): Lancetilla, 14

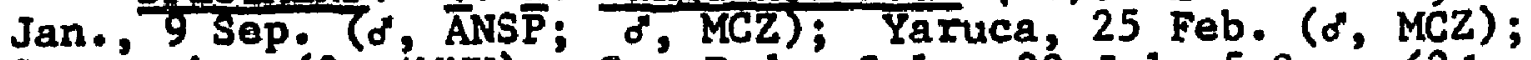
Catacombas (?, AMNH); San Pedro Sula, 30 July-5 Sep. (20, \$, USNM); Santa Ana, 17 Jan. ( $\$$, USNM); Cerro Santa Bárbara, east slope, 7 Dec. ( 8 , LSLMZ); Finca Fé, 3 Sep. ( ISUMŹ); E1 Jaral, 5 Sep. (d, MCZ); 4 mi. SW E1 Jara1, 21 Oct. ( $\$$, LSUMZ); 5 mi. SW El Jaral, 26 Oct. ( 9 , LSUMZ); Yojoa, 27-28 July ( $\left.\sigma^{\circ}, \$, C M\right)$; Arena 1, $21-28 \mathrm{Jan} .\left(2 \sigma^{\circ}, \&\right.$, UCLA)?

PUBL,ISHED RECORDS.--Omoa (Moore, 1859: 60-61; Sundeval1, 1866: 35; Salvin and Godman, 1895: 439). Yaruca (Bangs 1903: 146). Santa Ana, San Pedro Sula (R1dgway, 1914: 190). Lancetilla (Peters, 1929b: 437; Stone, 1932: 316). Catacombas (Zimmer, 1942a: 8).

This small woodpecker is an uncommon inhabitant of lowland rain forests on the Caribbean slope of Honduras, ranging up to 4,000 feet. It perhaps occurs also in the monsoon forest on the Pacific slope, since it is found in El Salvador, but there are no records at present from this part of Honduras. The specles ranges up into low montane rain forest in areas where this habitat is continuous with lowland rain forest. It primarily inhabits open forest but may also be encountered on occasion in second growth. Honduran specimens are typical of the widespread Middle American race, $\underline{\underline{ }}$. $\underline{\text {. }}$ sanguinolentus [Chloronerpes sanguinolentus Sclater, in Moore, 1859: 60; Omoa, Honduras]. The type is located in the Derby Museum. 


\section{Dendrocopos villosus (Linnaeus)}

Halry Woodpecker

SPECIMENS.--D. v. sanctorum (48): Port1110 Grande, 112 Sep. (o, CNHM; of, MCZ); Merendón Copán, 19 June ( MCZ); Belén Gualcho, $18 \mathrm{July}$ ( $\sigma^{\circ}, \mathrm{MLZ}$ ); Monte Verde, 20-21 July ( ${ }^{\circ}, f$, MLZ); Cerro Puca (Mt. Puca), 22-31 Jan. ( ske1., MLZ; $\delta, M C Z)$; Cerro Santa Bárbara, east slope, 20 April, 28 Nov; (2\%, LSUMZ); $16 \mathrm{mi}$. NW Valie Bonito, 2 Nov. (o", ISUMZ); $10 \mathrm{mi}$. N Siguatepeque, $11 \mathrm{July} \mathrm{(} 9, \mathrm{CM}$ ); Siguatepeque, 31 July ( $q, C M)$; MuIn, 30 Dec.-22 Jan. ( $\%$, AMNH; o, MCZ); Soluteca, 6 April (\%, AMNH); La Honda, 22 Jan. ( $F$, MCZ); Dept. of Comayagua, 27 June (of, UF); $3 \mathrm{mi} . \mathrm{W}$ Zambrano, 17 Oct. ( $\%$, LSUMZ); Cantora 1, 26 Jan. (o', AMNH); Cerro Cantoral, 4-29 March, 9 Dec. ( ${ }^{\circ}$, ANSP; 28, $\$$ MCZ); Alto Cantoral, 5 Jan. ( $\%$, MLZ); La Flor Archaga, 24-25 May (2?, MCZ); San Juanc1to, 27 Aug. ( $f$, ANSP); Rancho Quemado, 5-9 April, 25 May (o", AMNH; $0^{\circ}$ \%, MCZ); E1 Derrumbo, 14 July (d, AMNH); El Hat111o, 22 Apri1-4 May, 1-20 Aug. ( 8 , ANSP; $20^{\circ}, 29^{\circ}$ CM; 40, MCZ); Cerro Tigre, I July ( ${ }^{\circ}$, AMNH); Tegucigalpa, 11 April ( $\delta$, BMNH); Cuesta Grande, 1 July ( $\sigma^{\circ}$, juv. d? CM); Mt. Uyuca, 4 June (o'?, MCZ); Yeguare River Valley, 24 Nov. ( $q$, UF).

\section{PUBLISHED RECORDS.--Near "Tanlav1" [= Taulabé]} (Sclater, 1858b: 359). Near Siguatepeque (Taylor, 1860: 119). "Honduras-El Salvador boundary at Los Esesmiles" [= just south of E1 Sillón] (Dickey and van Rossem, 1929d: 219-220). San Juancito (Stone, 1932: 316-317).

In Honduras the Hairy Woodpecker is a fatrly comon resident, inhabiting the interior highlands above 2,000 feet. The species occurs in both cloud forest and pine; it is most common above an elevation of 4,500 feet.

Geographic varlation in this species in northern Central America is poorly understood. At the present time, there are three races recognized from Chlapas to Nicaragua. D. y. sanctorum (Nelson) is found in Chiapas and Guatemala; D. Y. parvulus [Dryobateg v11losus parvulus Dickey and van Rossem, 1929d: 219; Los Esesmiles, Dept. Chalatenango, E1 Salvador] is recognized for populations in El Salvador and 


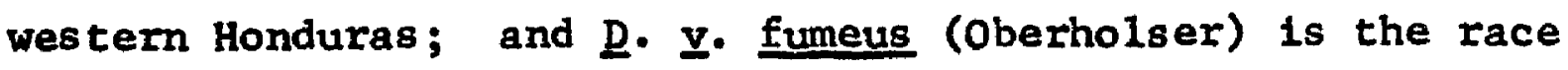
In southern Honduras and northern Nicaragua. The basic criteria for recognition of these three forms are size and degree of darkness on the under parts. The race parvulus is supposed to be the smallest and sanctorum to be the darkest. Examination of a series of specimens from E1 Salvador, Honduras, and Nicaragua showed that there is no significant size difference at all in these populations and that parvulus is the same as fumeus. The Guatemalan birds average slightly larger and almost all specimens are of the dark type, but the size overlap is large, as the variation in this respect represents a gradual north-south cline. Dark Individuals appear throughout the Central American range (the darkest and lightest birds examined in the entire Honduran series both came from Cerro Santa Bárbara), and populations inhabiting cloud forest generally average darker than those found in pine, possibly as a result of the humidity of the environment. Wings of Honduran specimens measured as follows: o, 97.5-107.2 (103.1); $9,95.3-106.2$ (101.5). Birds from the Department of Ocotepeque, within a few miles of the type locality of parvulus, averaged about one millimeter larger in wing length than the remainder of the Honduran specimens. In view of the variation described above, I feel that all northern Centra1 American populations of the spectes are best regarded as a single subspectes, $\underline{D}$. v. sanctorum. 


\section{Dendrocopos scalaris (Wagler)}

Ladder-backed Woodpecker

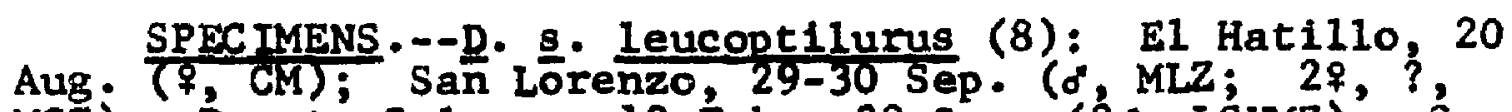
MCZ); Puerto Salamar, 13 Feb., 28 Sep. (2o, LSUMZ); Śan Francisco, Choluteca, 12 Feb. ( $\%$, LSUMZ). $1948:-\frac{214}{2}$.

PUBLISHED RECORD.--Paciftc coast of Honduras (Peters,

The distribution of this woodpecker in Honduras is one of the strangest found among Honduran birds. In Central America the species is known only from the lowland pine savanna of northeastern Nicaragua (T. R. Howel1, personal communication) and from widely scattered localities in Honduras and British Honduras. In Honduras it is fairly common in the arid scrub of the Pacific coast; it also is found locally at elevations from 2,500 to 5,000 feet as an uncommon to rare inhabitant of highland pine, pine-oak associations, and even stands of pure deciduous oak. It undoubtedly also occurs in the Honduran Mosquitia, but it has not yet actually been recorded there. I have also seen the species in the mangroves along the Bay of Fonseca on the Pacific coast.

At San Lorenzo in 1932, C. F. Underwood obtained the first Honduran specimens; these were the basis for the inclusion of Honduras in the range of the spectes by Peters (1948: 214). At E1 Hat1110 in 1951, Arthur C. Twomey and Roland $W$. Hawkins collected a female, presumably in highland pine at an elevation of about 3,500 feet. J. Alan Feduccia 
and I secured two males in arid scrub at Puerto Salamar (at sea leve1) on 28 September 1962 and 13 February 1963, and I obtained a female in an oak forest at San Francisco $(3,500$ feet) on 12 February 1963. The species was fairly common in the arid scrub of the San Lorenzo region, and on several occasions I noted it there in the coastal mangroves. Mark Trafton, Jr., recorded it from highland pine at Los Dragos in Jamuary 1952 and in July 1953 and 1954. In company with Paul Slud, Trafton saw the species at Siguatepeque in June 1952. V. C. Dunlap observed it at Los Dragos on 15 January 1955. It seems to be rather widespread in highland pine but is decidedly local and uncommon there.

Honduran specimens agree in all details, except for a slightly darker breast, with the British Honduran race, ‥ 8. leucoptilurus (oberholser). In a species as variable as this one, such constancy of characters is surprising. I am informed by T. R. Howell (personal communication) that the Mosquitia population of Nicaragua is 1ikewise nearly Identical with leucoptilurus, but this situation is to be expected as most Mosquitia species are of the same race, or very nearly the same, as the British Honduran populations. Wing measurements of the Honduran series are as follows: $\delta$, $82.2-91.0(86.5) ; 9,85.5-89.8(87.1)$. I tentatively assign all Honduran populations to leucoptilurus. 


\title{
Phloeoceastes guatemalens is (Hartlaub)
}

\section{Pale-billed Woodpecker}

\begin{abstract}
SPECTMENS.--P. g. guatemalens is (45): Lancetilla, 19 Jan. -6 Feb., $25-26$ Aug. ( ${ }^{\circ} \%$, ANSP; 30, MCZ); Yaruca, 14 Feb. (d', MCZ); Trujilio, 4-8 April, 23 Sep. (o', ${ }^{\circ}, \mathrm{CM} ;$

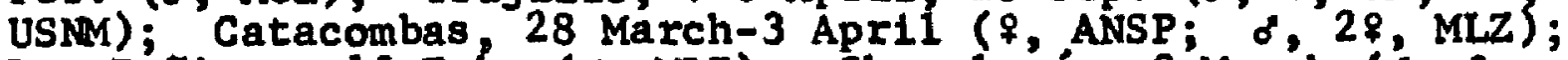
Las Peñitas, $15 \mathrm{Feb}$. ( 8 , MLZ); Chamelecón, 9 March ( 8 , ${ }^{\circ}$, USNM); Amapa, 29 Nov. (o skel., LSUMZ); Subirana, 28 Dec. (o", MCZ); Portillo Grande, 21 May ( ${ }^{\circ}$, MCZ); Coyoles, 18 June ( $q, C M)$; Monte Verde, 22-24 July (28, MLZ); Mt. Puca, 3 Feb. ( $q, ?$ ? AMNH); Finca Fé, 9 Aug - -30 Nov. (2d, ?, o skel., LSuMz); Lake Yojoa, 13 Aug. ( 8, CM); Cerro Cantoral, 28 July ( $d, M C Z)$; San Juancito, 25 July ( $d, 29$, ANSP); Comayagüiela, 13 Dec. ( $\delta$, AMNH); Valle Encantado, 3 Dec. ( $q$, UF); E1 Boquerón, 1 oct. ( $q$, AMNH); Arenal, 26 Jan. ( $d$, UCLA); Segovia River, 19 June $\left(\sigma^{\circ}, 7, ?\right.$, USNM); HondurasNicaragua boundary [near Pacific coast]' (?, MCŹ); "Honduras" ( 0 , $?, ?$, AMNH; $\%$, BMNH).

PUBLISHED RECORDS.$=$ "Near Omoa" [= near San Pedro] (Sclater 1858b: 359) - "Honduras" (Sclater and Salvin, 1859: 135; Gray, 1868: 57; Hargitt, 1890: 475). Near San Pedro (Taylor, 1860: 119). Truj11lo, Segovia Rlver (RIdgway, 1888c: 582, 591). Omoa (Forbes and Robinson, 1898a: 114). Choloma (Lantz, 1899: 220). Yaruca (Bang8, 1903: 146). Lancet1lia (Peters, 1929b: 438; Stone, 1932 : 317 ).
\end{abstract}

This woodpecker is an uncommon to fairly common inhabitant of forested areas of Honduras, occurring up to 5,000 feet. It is primarily a species of lowland rain forest, but it has been taken at higher elevations in cloud forest and even in pine-oak associations. In the lowlands it is usually found in denser forest than is Dryocopus 1ineatus, but it does range occasionally into the semi-open areas and second growth.

Forbes and Robinson (1898a: 114) mentioned specimens in the Derby Museum taken at Omoa, but I do not know the origin of these Individuals. Most of the Derby Museum material 
from Omoa was collected by Joseph Leyland, but Moore (1859) falled to report this species in Leyland's collections. Sclater (1858b: 359) 1isted the species from "near Omoa" on the basis of specimens obtained by G. C. Taylor, but Taylor himself (1860: 119) stated that this woodpecker was secured only near San Pedro. Salvin and Godman (1895: 447) indicated also that the record pertained to "Omoa" and that the specimen was in the British Museum. I was unable to locate it in that museum in 1961. Lantz (1899: 220) said that specimens from Choloma, taken by N. S. Goss, were in the Kansas Academy of Science collections, but I have not seen these birds.

Honduran specimens are representative of the Central American race, P. g. guatemalens is (Hartlaub).

Family DENDROCOLAPTIDAE

Dendrocincla fullginosa (Vieillot)

Plain-brown Woodcreeper (?, USMM).

SPECIMEN.--D. f. ridgwayl (1): Segovia River, 16 June 590). PUBLISHED RECORD.--Segovia River (Ridgway, 1888c:

In Honduras Dendrocincla fuliglnosa 18 known from the single specimen taken by Charles $\mathrm{H}$. Townsend along the Río Segovia in 1887. The species reaches its northern limit of distribution in the rain forests of 0lancho. In the northern part of its range, it is decidedly rare. 
The single Honduran specimen is an example of the northern race, ‥ E. ridgwayi Oberholser.

\section{Dendrocincla anabatina Sclater}

Tawny-winged Woodcreeper

SPECTMENS.--D. a. anabatina (19): San Alejo, 7 Aug. ( 7 , LSUMZ); Lancetilia 6 Feb., 19 March ( 8 , $9, \mathrm{MCZ}$ ); La Ceiba, 5 April ( $\sigma$, USNM); San Pedro (?, BMNH); Santa Ana, 20-22 Nov. ( ${ }^{\circ}, \mathrm{CM}^{\prime}$; , USNM); La Puerta, 12-24 Nov. ( 9 , CM; $\sigma$, USNM); Amapa, 18 Sep. (o'skel., LSUMZZ); $5 \mathrm{mi}$. S San Esteban, 14 Jan. ( $\sigma^{\circ}$, IS UMZ); Finca Fé, 11-12 Aug., 5 Nov. (\%, imm., \& skel., LSUMZ); $5 \mathrm{mi}$. SW El Jaral, 29 óct. ( $\%$, LSUMZ); ' 2 mi. SE' El Jaral, 22 Feb. ( $q$ LSUMZ); Lake Yojoa, 28 July ( $q, C M) ; 2 \mathrm{mi}$. N Pito Solo, 24 Nov. (o', LSUMZ); Segovia River, 13 June ( $\%$, USNM).

PUBLISHED RECORDS - - Omoa (Moore, 1859: 54). San Pedro region (Sclater and Salvin, 1870b: 837). Segovia River (Ridgway, 1888c: 590). San Pedro (Sclater, 1890: 163). Santa Ana, La Puerta (Ridgway, 1911: 289). Near Lancetilla (Peters, 1929b: 443). La Celba (Deignan, 1936: 191).

The Tawny-winged Woodcreeper is an uncommon to fairly common resident of lowland rain forests on the Caribbean slope of Honduras. It extends up to at least 4,000 feet into low montane rain forest in the Lake Yojoa region. Honduran specimens are referable to the nominate race, D. a. anabatina [Dendrocincla anabatina Sclater, in Moore, 1859: 54; Omoa, Honduras ].

Dendrocincla homochroa (Sclater)

Ruddy Woodcreeper

SPECIMENS.--D; h: homochroa (18): La Ceiba, 7 Aug. ( CM); Catacombas, 7-23 Apri1 (\%, ANSP; o, MCZ); Las

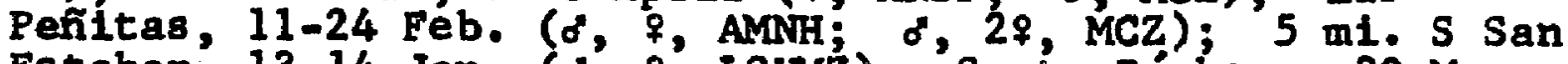
Esteban, 13-14 Jan. ( $\sigma^{\circ}, 8$, ISUkz); Santa Bárbara, 30 May ( ${ }^{\prime}$, MCZ); Cerro Santa Bárbara, east slope, 22 Nov. ( ${ }^{\circ}$, LSUMZ); Cerro Santa Bárbara, southeast slope, 24 July ( $d$, 
LSUMZ); Finca Fé, 8 Dec. (o", LSUMZ); $5 \mathrm{mi}$. SW El Jaral, 4 Nov. ( $\sigma^{\prime}, 9$, LSUMZ); $\mathrm{E} 1$ Boquerón, $2-13 \mathrm{sep} \cdot\left(\delta^{\prime}, d^{\prime}\right.$ ?, AMNH). 1951: PUBLISHED RECORD.--"Honduras" [in range] (Peters,

In Honduras this woodcreeper occupies virtually the same area as the preceding species, D. anabatina. The Ruddy Woodcreeper is an uncommon spectes in the republic, almost everywhere slightly less common than $D$. anabatina. D. homochroa seems to be most frequent in dense rain forest at medium elevations $(1,000$ to 4,000 feet), but it does occur in open forest and second growth as well. Both species frequently $\mathrm{mix}$ in the $s$ ame forest flocks.

Peters (1951: 17) included Honduras in the range of the species on the basis of skins in the Museum of Comparative Zoology that were taken by C. F. Underwood.

The status of the race from Nicaragua and western Costa Rica, D. h. acedesta Oberholser, is somewhat doubtful. Most Costa Rican and Panamanian populations, currently regarded as the race D. h. ruficeps (Sclater and Salvin), are distinct from homochroa on the basis of more olivaceous coloration and average larger size, but the populations from Honduras to Costa Rica are apparently intermediate between ruficeps and homochroa. I tentatively include all Honduran specimens in D. h. homochroa (Sclater) on the basis of coloration, as they match Mexican specimens very well in this respect. In size the Honduran populations average larger in the males and smaller in the females (wing: of, 
102.5-109.4, mean 105.4; $9,95.5-98.1$, mean 96.8) when conn= pared with Mexican homochroa; however, the series consists of relatively few specimens and the exact status will have to await collection of additional material. The best course at the present time is to recognize only homochrog and ruficeps in northern Middle America and to define the two races on the basis of coloration alone; the size variation appears to be a general north-south cline with no sharp break.

Deconychura longicauda (PelzeIn)

Long-tailed Woodcreeper o?, UCLA).

PUBLISHED RECORD.--Arenal (Howe11, 1956: 517-528).

The Long-tailed Woodcreeper is another of the lowland rain forest species that reach their northern 1 imit of distribution in the rain forests of olancho. The two specimens 11sted above, collected in 1953, are the only ones known from Honduras. They were originally reported by Howel1 (1956: 517-528) as from Nicaragua, but the recent boundary settlement between Honduras and Nicaragua has placed Arenal in Honduras. The two specimens were secured in rain forest at 1,200 feet elevation.

These two specimens are representative of the northern race, D. 1. typica Cherrie. 


\section{Sittasomus griseicapillus (Vieillot)}

Olivaceous Woodcreeper

SPECIMENS.--S. g. sylvioides (59): Lancetilla, 22 March ( $\delta$, MCZ); Los Planes, $10 \mathrm{~J}$ une (d, CM); Catacombas, 25 March-20 Apri1 (20, 5\%, ?, ANSP; \&, AMNH; of, ?, MLZ); Cofradia, 8-15 March (40, ANSP; o, MLZ); Santa Ana, 20 Nov. ( $\sigma^{\circ}$, USNM); Las Peñitas, 15-24 Feb. ( $0^{\circ},{ }^{\circ}$, ANSP; $0^{\circ}$, AMNH; \&, MLZ); San Esteban, 1 July (2o, CM); Merendón Copán, 12-13 July ( $\%, ?$, AMNH); San Josể de Santa Bárbara, 6 Apri1 (7, AMNH); Cerro Santa Bárbara, east 8 lope, 28 Nov.-1 Dec: (20, + , LSUMZ); Finca Fé, 1-8 Sep. ( $\sigma^{\circ}$, imm. ?, 1mm. skel., LSUMZ); $4 \mathrm{mi}$. SW El Jaral, 26 Oct. (o", LSUMZ); $5 \mathrm{ml}$. SW El Jaral, 28 oct. (o' ske1., LSUMZ); Agua Azul, 7 Aug. ( ${ }^{\circ}$, UF); Lake Yojoa, 14 June-16 Aug. (78, 48, CM); San Marcos de Gualmaca, 23 June-5 July (30, 4\%, 2?, ANSP; o, MLZ); Arenal, 27 Jan. (o", UCLA).

PUBLISHED RECORDS.--Santa Ana (Ridgway, 1911: 281). East of Lancetilla (Peters, 1929b: 443-444).

Inhabiting lowland rain forests on the Caribbean slope, the Olivaceous Woodcreeper is a fairly common resident in Honduras. It ranges up to about 4,000 feet in the low montane rain forest around Lake Yojoa. The species occurs in dense forest as well as open forest and guamil.

Honduran specimens are representative of the widespread race S. g. sylvioldes Lafresnaye.

\section{Glyphorynchus spirurus (Vleillot)}

Wedge-billed Woodcreeper

SPECIMENS.--G. 8. pectora 1is (19): San Alejo, 30 March, 7 Aug. (2o, LSUMi); Lancetilla, 18 Jan, -22 March, 3 Sep. ( $0^{\circ}$, ANSP; $30^{\circ}, 3 \%$, MCZ); La Celba, 8 Aug. ( 9, CM); Los Planes, 10 June $(2 \%, C M)$; Las Pefitas, 14 Feb. ( $\sigma$, BMNH); Cerro Puca, 22 Jan. (q skel., MLZ); $5 \mathrm{ml}$. SW El Jaral, 4 Nov. ( $($, LSUMz); 2 mi. N Pito Solo, 25 oct. (imm. o, ISUMZ); Arena1, 23 Jan. (o, UCLA); Segovia River, 13-23 June $\left(2 \delta^{\circ}\right.$, USNM). 
PUBLISHED RECORDS.--Segovia River (RIdgway, 1888c: 590). Lancetilla (Peters, 1929b: 442-443; Stone, 1932: 318 ).

This woodcreeper is an uncommon resident of lowland rain forests on the Caribbean slope of Honduras, ranging up to 4,500 feet. It occurs in both dense forest and second growth but is decidedly rare in more open situations. In Nicaragua and Costa Rica this species becomes rather common and is one of the dominant waodcreepers of the rain forest. Honduran specimens are all typical of the northern race, G. S. pectoralis Sclater and Salvin. The race G. sublestus Peters, from Costa Rica south, is poorly differentiated but, in any case, the Honduran series matches Mexican and British Honduran material in all respects.

Xiphocolaptes promeropirhymchus (Lesson)

Strong-billed Woodcreeper

SPECIMENS. - X. p p enigrans (45): Catacombas, 24 March (7, MCZ); Cotradia, 16 March (o, MCZ); Port 1110 Grande, 25 Aug. ( $f, M C Z)$; San Esteban, 30 June ( $\left.\sigma^{\circ}, 2 \%, C M\right)$; La Libertad, 10 June (d, AMNH); Monte Verde, 23 July (o, 2?, MLZ); Mt. Puca, 6 Feb: (\%, MCZ); Cerro Nieve, 22 April (\%, AMNH); Cerro Santa Bárbara, east slope, 1 Dec.' ( $\$$, LSLuz); Cerro Santa Bárbara, southeast s lope, 25 July ( $\%$, LSUMZ); Valle Bonito, 14 Dec. (?, LSUNZ); $15 \mathrm{ml}$. NW Siguatepeque, 15 Aug . $\left(\sigma^{\prime}, ?, \mathrm{CM}\right)$; Siguatepeque, 9-31 July (20, 29, CM); Soluteca, 4-5 April ( 0,8 , AMNH); La Cruz Grande, 8 March (o", AMNH); Montaña Vásquez, 22 Nov. ( $\delta$, USNM); Cantora1, 2 Feb., 1 March, 12 May (20,, AMNH; $0^{\circ}$, MLZ); Cerro Cantoral, 29 Féb., 29 June-28 July, 12 Dec. ( $\$$ CM; ${ }^{2}$ MLZ; 20, 29 , MCZ); La Flor Archaga, 24-30 May, 14 July, 12 Aug., 15 Dec. ( ${ }^{\circ}$, ANSP; $2 \sigma^{\circ}, 2 \%$, MCZ); Rancho Quemado, 16 May ( ${ }^{\circ}$, MLZ);

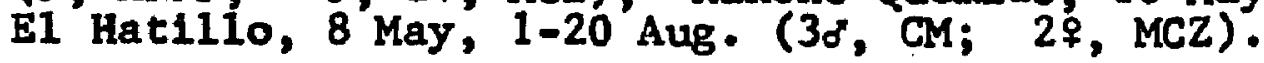
$1951: 27)$. PUBLISHED RECORD.--"Honduras" [in range] (Peters, 
The Strong-billed Woodcreeper is an uncommon to fairly common resident of pine, pine-oak associations, and cloud forest in the interior highlands of Honduras. It ts normally found above 4,000 feet but in the nonbreeding seas on descends to as low as 2,000 feet and occasionally enters areas of open rain forest.

The inclusion of Honduras in the range of the species by Peters (1951: 27) was based on the series of specimens in the Mus eum of Comparative Zoology.

Honduran specimens are referable to the race $X$. emigrans Sclater and Salvin.

\section{Dendrocolaptes certhia (Boddaert)}

\section{Barred Woodcreeper}

SPECIMENS.--D. c. sanct thomae (44): La Ceiba, 7 June (7, CM) ; Yaruca, 18 Feb. (F, MCZ); Catacombas, 24 March-8 Apri1 (2o, 2\%, BMNH; $\delta^{\circ}$, MLZ); Cofradla, 11 March (o, MLZ); Santa Ana, 20 Nov. (20,' USMM); Las Peñitas, 7-24 Feb. ( $\sigma^{\prime}$, ANSP; $20^{\circ}, q$, BMNH; $\sigma^{\prime}, q$ MLZ); Urraco, 12 March ( $\sigma^{\circ}$, MCZ); Portillo Grande, 4 Jan., 12 Feb., 8 April ( $\delta$, CNHM; $8, q$, MCZ); Coyoles, 28 June ( $\left.\sigma^{\circ}, C M\right)$; Santa Bárbara, 23 May -1 ' June (2d, 2\%, AMNH); Cerro Santa Bárbara, east 8 lope, 7-22 Nov. (7, skel, , LSLMZ); Finca Fé, 9-31 Aug., 20 Oct.-2 Dec. ( $\sigma^{\circ}, 4 \%$, ISUMZ); $10 \mathrm{mi}$. N Siguatepeque, 11 July $\left(\sigma^{\circ}, \mathrm{CM}\right)$; E1 Caliche, 16-24 July (2\%, \%, AMNH); Montaña Vásquez, 13 June (o, AMNH); Cerro Cantora1, 21 Feb. ( $\sigma$, MCZ); Arenal, 22-23 Jan. ( $d, \$$, UCLA); Segovia River, 13 Aug. ( $\$$, USNM); "Honduras" ( 3 ?, BMNH).

PUBLISHED RECORDS.--"Honduras" (Sclater, 1858a: 96; 1862: 163; 1890: 175). Omoa (Moore, 1859: 54). Segovia River (Ridgway, 1888c: 589). Yaruca (Bangs, 1903: 151). Santa Ana (R1dgway, 1911: 230-231). Near Urraco (Peters, 1929b: 444-445).

Dendrocolaptes certhia is a fairly common resident of tropical lowland rain forest on the Caribbean slope of 
Honduras. It has been recorded on the Paciflc drainage only in the Archaga district near Tegucigalpa. It is normally found from sea level to 4,000 feet, but it occasionally ranges, at least in the nonbreeding season, to about 6,000 feet, entering pine-oak associations or cloud forest. The species is most frequent at medtum elevations from 1,500 to 3,500 feet elevation.

Honduran specimens are all referable to the northern race, D. c. sanctithomae [Dendrocops Sancti-Thomae Lafresnaye, 1852: 466; "in Sanct1-Thomae insula" (= Santo Tomás, Guatemala)]. The exact location of the type locality has been in doubt for many years. Sclater and Salvin (1859: 118) actually hit upon the solution when they attributed the type to the Belgian colony of Santo Tomás, on the Bay of Honduras. Since that time many authors have given the type locality as "Santo Tomás, Honduras" rather than in Guatemala, the correct location. Santo Tomás is a town on the Bay of Amatique, an inlet off the Bay of Honduras, very near the large seaport of Puerto Barrios; there is no Santo Tomás anywhere in Honduras that could possibly be the type locality. Salvin and Godman (1891: 192) again correctly assumed that the town of Santo Tomás (not the 1sland of St. Thomas, as indicated in the original description) was the source of the type, but they stated that it was in Honduras "near Onoa"; this statement was probably based on the report of a specimen from Omoa taken by Joseph Leyland 
(Moore, 1859: 54). Peters (1929b: 444-445), although admitting that any "Santo Tomás" in Honduras was an unlikely type locality, nevertheless adopted "Santo Tomás, Honduras" as the correct location, and this type locality has persisted to the present time. Todd $(1950: 237)$ was the only recent author to recognize that Santo Tomás, Guatemala, was the correct type locality, but his statement has generally been overlooked. There can be little doubt that this locality should read "Santo Tomás, Guatemala."

\title{
Dendrocolaptes picumnus Lichtenstein
}

\section{Black-banded Woodcreeper}

\begin{abstract}
272). PUBLISHED RECORD.--Volcán de Puca (Hellmayr, 1925:
SPECIMENS. --D. P. puncticol11s (34): Cofradía, 7 March ( 9 , MLZ); Portillo Grande, $8 \mathrm{Feb}^{\circ}, 17$ May $\left(2 \sigma^{\circ}, \mathrm{MCZ}\right)$; Monte Verde, 19 July (?, MLZ); Mt. Puca, 4 Feb. ( 9, MCZ); Cerro Santa Bárbara, southeast slope, 3 April ( 8 , LSUMZ); Soluteca, 4-10 April (20, \%, AMNH); Montaña Vásquez, 10 Jan., 14 June, 16 Dec. ( $\sigma^{\circ}$, AMNH; 20', MCZ); Cantoral, 27 Jan. 4 May, 14 July (30, AMNH); Cerro Cantora1, 14-15 Feb., 2-25

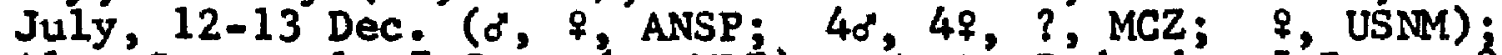
Alto Cantora 1, 7 Jan. ( $\left.\sigma^{\prime}, \mathrm{ML}\right)$; Monte Redondo, 5 Dec, 22 Nov. ( $\left.d^{\prime}, \$, M C Z\right)$; La Cueva Archaga, 5 April ( $\$$ AMNH); E1 Hatillo, 8 May (d", MCZ); Uyuca, 4 April (d, UF); Yeguare River Valley, 24 Nov. ( 9, UF).
\end{abstract}

Inhabiting cloud forest and pine-oak associations in the Interior highlands, the Black-banded Woodcreeper is an uncommon to fairly common resident in Honduras. It normally occurs above 4,000 feet but ranges down to at least 2,500 feet in the nonbreeding season.

Hellmayr (1925: 272) mentioned examination of a single male of this species in the Berlepsch Collection, obtained 
by Erich Wittkügel on 25 February 1889 on Volcán de Puca. Honduran specimens represent the northern race, D. $\mathrm{D}$. puncticolilis Sclater and Salvin.

\section{Xiphorhynchus guttatus (Lichtens tein)}

Buff-throated Woodcreeper

SPECIMENS -.- -X. g. confinis (14): Medina (?, BMNH); San Alejo, 19 March-2 April, 6-9 Aug. (20, 28, LSUMZ); Lancetilla, 6 Feb., 23-29 March, 3-9 Sep. (3o" ANSP; 20, $\&$, MCZ); La Celba, 24 Jan. (o', MCZ); Las Peñitas, 15-17 Feb. (20, BMNH). X. g. confinis $\times$ costaricensis (1): Río Guampí, $10 \mathrm{mi}$. E Dulce Nombre de Culm1, 16 March ( 9 , LSUMZ). X. g. costartcensis (8): Arenal, 13-28. Jan. (50, $20^{\circ}$, UCLA); Segovia River, 19 June ( 8 , USNM).

PUBLISHED RECORDS.--San Pedro region (Sclater and Sa1vin, 1870b: 837). Segovia River (Ridgway, 1888c: 589). Medina (Sclater, 1890: 134). La Ceiba [as confinis] (Bangs, 1903: 150-151). Lancetilla [as confinis] (Peters, 1929b: 444; Stone, 1932: 318).

This species of Xiphorhynchus is a resident of lowland rain forest on the Caribbean slope of Honduras, occurring alongside its sibling, x. flavigaster. It is decidedly uncommon in Honduras north of the Olancho rain forest but is fairly common locally along the Honduras-Nicaragua boundary. It has not been recorded above 1,500 feet in Honduras. Although primarily a rain forest species, it is most plentiful in open forest and may sometimes be encountered in second growth.

Populations along the north coast of Honduras and in eastern Guatemala, the northern limit of the range of the species, have been described as $X . \mathrm{g}$. confinis [Dendrornis nana confinis Bangs, 1903: 150; Celba, Honduras, sea 
level]. This race differs from the one ranging from southeastern Honduras to Panama, X. g. costaricensis (Ridgway), in having the throat more whitish (less buffy) and the shaft stripes on the breast less distinct, extending more extensively over the abdomen. The specimen from the Río Guampu is intermediate, indicating that intergradation occurs in the northern part of the Olancho rain forest.

\section{Xiphorhynchus flavigaster Swainson}

\section{Ivory-billed Woodcreeper}

SPECIMENS.--X. f. eburneirostris (90): San Alejo, 15 March, 7 Aug ( ${ }^{*}, q$, LSUMZ); M1cos Lagoon, 5 mi. W Tela, 16 March ( ${ }^{\prime}, \mathrm{LSUMZ}$ ) Lancetilia, 2-4 Sep. ( $\sigma^{\circ}, 9$, ANSP); La Ceiba, 23 March-13 May, 27 July-2 Aug. (40, $2 \%$, CM; 20, $\$$, USNM); Los Planes, 9-10 June (2o, $\$, C M) ;$ Trujilio, 31 March-9 April, 22-23 Sep. (20, $2 \circ^{\circ}$, CM; 20, USNM); Catacombas, 22 March-5 April ( $2 \delta^{\circ}, q^{\circ}$ ANSP; $\delta$, MLZ); Cofradla, 415 March (30, 3\%, ANSP; o", AMNH; $\%$, MLZ); San Pedro (2? , BMNH); Santa Ana, 29 oct. (\%, USNM); Las Peñitas, 25 Jan.17 Feb. (20, ${ }^{\circ}$, ANSP; $\delta^{\circ}, 28$, MIZ); Choloma (?, KÁs); Portillo Grande, 3 Feb.' ( $\$$, MCZ); Coyoles, 13-17 June (20, 2\%, $C M)$; San Esteban, 30 June $\left(\sigma^{\circ}, C M\right)$; San José de Santa Bárbara, 1 May ( 9 , AMNH); Santa Bárbara, 24 April ( $\sigma^{\circ}$, AMNH); Finca Fé, 8 Aug - -11 Dec. (70, $1 \mathrm{~mm} .00^{\circ} 39$ skel., alc.; LSUMZ); $2 \mathrm{mi}$. SE E1 Jaral, 2 March ( $\$$ skel., LSUMZ); Lake Yojoa, 16 July-16 Aug. ( $\left.3 \sigma^{\circ}, 29, \mathrm{CM}\right) ; 2 \mathrm{mi}$. N Pito Solo, 24 Nov. (o, LSUMZ); 3 mi. N E1 Mogote, 17 Jan. (o, LSUMZ); E1 Caliche, 21-25 July (2\%, AMNH); Cantoral, 2 March (?, AMNH); Cerro Cantoral, 29 March-1 Apri1 (8, \&, MCZ); Monte Redondo, 23 Nov. ( $\sigma^{\prime \prime}, \mathrm{MCZ}$ ); La Flor Archaga, 30 March, 18 May, 23 June $\left(2 \%, 2 ?\right.$, AMNH); E1 Hatillo, 7 May ( $0^{\circ}$, AMNH); Rlo Choluteca, Dept. E1 Paraiso, 11 Aug. ( $q$, UF); Jamastrán Valley, 20 Feb. ( $0^{*}$, UF); E1 Boquerón, 19 Sep.-17 Oct. (30", AMNH); Dept. Choluteca, 6 Feb. ( 9 , UF).

PUBLISHED RECORDS.--San Pedro region (Sclater and Sa1vin, 1870b: 837). Truj1110 (RIdgway, 1888c: 580) Choloma (Lantz, 1899: 221). Santa Ana (Ridgway, 1911: 246). Lancetilla (Stone, 1932: 317). La Celba (Deignan, 1936: 191). Lago de Yojoa, La Ceiba, Trujillo, Los Planes, San Esteban, Santa Ana (Wetmore and Parkes, 1962: 59). 
In Honduras the Ivory-billed Woodcreeper is a common species, occupying a wide variety of habitats. It is most abundant in open rain forest or second growth at medium elevations (1,500 to 4,000 feet) but occurs a1so in humid lowland rain forest, deciduous forest, pine-oak associations, and a variety of arid lowland habitats on the Pacific coast, especially monsoon forest. During the nonbreeding season it may even range into cloud forest or highland pine. In open rain forest it is exceeded in abundance among the woodcreepers only by Lepidocolaptes souleyetii.

Honduran specimens are typical of the widespread Middle American race, $\underline{x}$. $\underline{\text { f }}$ eburneirostris (Des Murs).

\section{Xiphorhynchus erythropygius (Sclater)}

Spotted Woodcreeper

SPECIMENS.--X. e - parvus (64): Yaruca, $22 \mathrm{Feb}$ ( 9 , MCZ); Catacombas, 30 March-8 April (20, ANSP; $0^{\circ}$;, MLZ; 28, MCZ); Las Peñitas, 3-27 Feb. (5\%, 2?, ANSP; 40, CM; o", ${ }^{\circ}$, CNHM; 20, ${ }^{\circ}$, MLZ; 50"39, MCZ); Subirana, 30 March ( $d$, MCZ); Portillo Grande, 12 Feb., 15 April, 28 Dec. (o", CNFM; $28, \mathrm{MCZ}$ ); San Esteban, 30 June ( $q, \mathrm{CM}) ; 5 \mathrm{mi}$. S San Esteban, $18 \mathrm{Jan}$. ( $\%$, LSUMZ); Cerro El Triumpho, $20 \mathrm{ml}$. SE San Esteban, 2 April ( $\sigma^{\prime \prime}$, LSUMZ); Monte Verde, 20 July ( $q$, MLZ); Mt. Puca, 30 Jan. -8 Feb. $\left(30^{\circ}, 9\right.$, MCZ); Cerro Santa Bárbara, east slope, 19 Feb., 7 Nov. $-9^{\circ}$ Dec. ( $40^{\circ}, 39,9$ skel., LSUMZ); $4 \mathrm{mi}$. SW EI Jaral, 26 oct. ( $($, LSUMŹ); 5 mi. SW E1 Jaral, 28 oct. (o", LSUMZ); 2 mi. SE E1 Jara1, 20 April ( $\delta$, LSUMZ); Lake Yojoa, 18 July, 25 Aug. (2\%, CM); Muye, 21 Feb. ( 8 , AMNH); San Marcos de Gua imaca, 4 July (?, ANSP ; Montaña Vásquez, 22 Nov. ( 9 , USNM); Cantoral, 6 Feb. ( 7, AMNH); Archaga, 5 Aug - ( $\%$, AMNH); La Cueva Archaga, 4 April ( $\$$, AMNH); E1 Derrumbo, is July-9 Aug. (?, AMNH; o , USNM).

PUBLISHED RECORDS.--Yaruca (Bangs, 1903: 151). Las Peñtas (Griscom, 1937b: 196-197). 
Inhabiting primarily the humid forested regions on the Caribbean slope in Honduras, the Spotted Woodcreeper is a common species in the medium elevations $(2,000$ to 5,000 feet) of rain forest. It ranges uncommonly into cloud forest or montane rain forest to 6,000 feet and into lowland rain forest down to at least 1,000 feet. Although Griscom (1932b: 243) reported this species as rare and little-known in Guatemala, it is common in parts of Honduras. In the Low montane rain forest on Cerro Santa Bárbara from 3,500 to 5,000 feet, it is the dominant woodcreeper.

The Honduran populations have been described as the race X. e. parvus Griscom [1937b: 196; Las Peñitas, southcentral Honduras]. This race is valid on the basis of its more rufescent coloration above, more olive coloration below, slightly buffier throat, and average smaller size, when compared with the Mexican race, $\underline{x}$. e. erythropygius (Sclater), but the character of amount and extent of back spotting is too variable to be of any value for racial determination. Wings of Honduran specimens measure as follows: $0,105.1-122.4(116.7) ; \&, 105.0-117.8$ (110.6).

\section{Lepidocolaptes souleyet1i (Des Murs)}

Streak-headed Woodcreeper

SPECIMENS:--L. S- compressus (97): Puerto Cabello [= Puerto Cortés] (?, BMNH); Julián [= Tulián] (?, ANSP); Medina (?, ANSP); San Alejo, 3 April, 7 Aug. (2q, LSUMZ); Tela, 13 March ( $f$, MCZ); Lancetilla, 27 March ( $\%$, MCZ); La

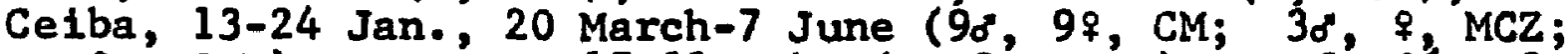
o, 9 , USNM); Yaruca, 17-22 Feb. ( 8,28, MCZ); Cofradla, 210 March (?, BMNH; o, 2\%, MLZ); Santa Ana, 14 Nov. ( 
USNM); Las Peñitas, 17 Feb. (?, MLZ); Coyoles, 13-22 June $\left(20^{\circ}, 3 q, \mathrm{CM}\right)$; San Esteban, 30 June (2\%, CM); Finca Fé, 20 July-5 Sep., 2 Nov.-19 Jan. (40, 6q, imm. d, imm., o skel., q skel., imm. o skel., alc., ISUMZ); Lake Yojoa, 12 June-13 Aug. ( $30^{\circ}, 3 \%, \mathrm{CM} ;$;, MCZ; $q$, UF); E1 Caliche, 25-31 July (2\%, AMNH); La Flor Archaga, 26 Sep. ( $\%$, ANSP); E1 Hatillo, 8 May ( 9 , ANSP); Las Lomas, $19^{\circ}$ Feb. ( $0^{*}$, UF); Arena 1, 20-24 Jan., 4 June ( $d^{*}, 29$, UCLA); Segovia River, 8 Aug. ( 8 , USNM); San Lorenzo, 23-30 Sep. (58, 38, ?, AMNH; o, ₹, BMNH; of, \&, MLZ; o, USNM); Puerto Salamar, 9 Feb. (q, ISUMZ); Finca EI Rubi, $29 \mathrm{Sep.} \mathrm{( \% ,} \mathrm{LSUMZ);} \mathrm{"Honduras"}$ (?, BMNH).

PUBL.ISHED RECORDS.--Omoa (Moore, 1859: 54). San Pedro region (Sclatex and Salvin, 1870b: 837). Segovia River (R1dgway, 1888c: 590). Puerto Cabello [= Puerto Cortés] (Sclater, 1890: 153-154). La Celba, Yaruca (Bangs, 1903: 151). Santa Ana (Ridgway, 1911: 267). Tela, Lancetilla (Peters, 1929b: 444). La Ceiba (Deignan, 1936: 191). San Lorenzo (Brodkorb, 1938: 3).

This woodcreeper is a common species in open forest, semi-open situations, and second growth on both slopes of Honduras, ranging up to at least 4,500 feet. It is less common at sea level and seems to have its center of abundance in open rain forest at medium elevations $(1,500$ to 2,500 feet). Its distribution is parallel to that of Xiphorhynchus flavigaster, which it generally outnumbers. In areas of low montane rain forest $\underline{L}$. souleyetil and its sibling, L. affinis, sonetimes occur in mixed flocks, especially in the nonbreeding season.

I have examined the two specimens from San Juancito in the Academy of Natural Sciences at Philadelphia that were reported as L. souleyetil (Stone, 1932: 318) and found them to be examples of $L$. affints.

The great amount of variation in this species has led to the description of no less than five races in northern 
Central America. The effects of age, wear, and individual variation have been mentioned by Griscom (1932b: 244). The larger the series that is available, the more puzzling the situation seems. There can be little doubt that the characters used to distinguish L. S. decoloris Austin [1929: 380; El Cayo, British Honduras], L. S- matudae Brodkorb [1938: 3; Finca Esperanza, 150 meters, Chiapas], and $\underline{L} . \underline{\text {. }}$ correctus van Rossem [1941: 171; Puerto del Triunfo, Dept. Usulatan, El Salvador] represent nongeographic varlation; Peters (1951: 48) recognized this fact and synonymized all three races under $\underline{L}$. $\underline{s}$. compressus (Cabanis) and $\underline{L} \cdot \underline{s}$. insignis (Nelson). The race insignis has been recognized as distinct from compressus on the basis of broader buffy streaks above and below and more extensively buff throat. The buffiness of the throat is highly variable and, in addition, seems to be correlated with age, immatures generally averaging more buffy. The width of buffy stripes is not geographically correlated either, being variable to both extremes in both Chiapan and Costa Rican populations, as well as most populations in between. The only geographic variation that I can detect in a very large series of Middle American birds is a gradual north-south cline towards smaller size. In view of the foregoing considerations, I can recognize only one race from southern Mexico to Panama. L. S. compressus is the oldest available name for this subspecies. 


\section{Lepidocolaptes affinis (Lafresnaye)}

Spot-crowned Woodcreeper

SPECTMENS.--L. a. affinis (53): Las Peñitas, 20 Feb. ( $*$, MCZ); Porttilo Grande, 8 Feb. ( $\$, M C Z)$; Montaña El Chorro, 23 June-1 July ( $\delta$ ?, MLZ); Monte Verde, 22 July (8, MLZ); Monte E1 Portillo, 28 May (o', MLZ); Mt. Puca, 30 Jan.-5 Feb. (o", 2q, MCZ); Cerro Santa Bárbara, east slope, 27 March, 9 Dec. (2\%, LSUMZ); Finca Fé, 22 Oct., 6 Dec. ( $\delta$, \$, LSUMZ); E1 Jara1, 1 Oct. (8, AMNH); $4 \mathrm{mi}$. SE La Esperanza, 24 Jan. ( $\$$ skel., ISUMZ); Güise, 30 oct. ( $\$$, LSUMZ); Montaña Vásquez, 10 Jan. ( $\$$, MCZ); Cantora1, 22-24 Feb., 22-29 May, 15 Dec. (26", $2 \%, \mathrm{AMNH}^{\circ} ;$, CNHM); Cerro Cantora1, 3-29 March, 1 July, 26 Nov.-17 Dec. ( 8 , ANSP; ${ }^{\circ}$, CNHM; $30^{\prime}, 49, \mathrm{MCZ}$ ); Álto Cantoral, $7 \mathrm{Jan} .(8, \mathrm{MLZ})$; La Flor Archaga, 10 Jan., 25 May-18 July ( $6,2 \%$, ANSP; $\delta, ~ ?, ~ A M N H ;$ 30", ${ }^{\circ}, \mathrm{MCZ}$ ); San Juancito, 2 Feb., 27 July-12 Aug. (2?, ANSP; ₹, LSUMZ); San Juancito Mts., 10 Aug. ( $d^{\prime}$, UF); Rancho Quemado, 20 March-2 April (20, MCZ); El Hatilio, 8 May ( $9, \mathrm{MCZ}$ ); Tigre Hatillo, 9 July ( 9 , AMNH); Mt. Uyuca, 3 July, 20 Nov. ( $\$, M C Z$; $\delta$, UF); Monserrat, 28 May ( $d^{\prime \prime}$, MCZ); Dept. El Paralso, 10 March (q, UF).

PUBLISHED RECORD.--San Juancito las L. souleyetei insignis] (Stone, 1932: 318).

Despite the scarcity of published records, the Spotcrowned Woodcreeper is a fairly common resident in Honduras, breeding in cloud forest above 3,500 feet. In the nonbreeding season a few individuals descend into the upper reaches of lowland rain forest to about 1,500 feet elevation, often occurring in the same flock as the lowland representative of the genus, ㄴ. souleyeti1.

The specimens from San Juancito were misidentified by Stone (1932: 318) as L. souleyetil (see page 496).

Honduran specimens are referable to the nominate race, ㄴ. a. affinis (Lafresnaye). 
Family FURNARIIDAE

Syna1laxis brachyura Lafresnaye

Slaty Spinetail

SPECTMENS.--S. b. nigrofumosa (9): Montecristo, 24 March (?, $9 ?$, LSUMZ); LOs Planes, 10 June $\left(30^{\circ}, \%, \mathrm{CM}\right)$; Arena 1, 20 Jan. (d", UCLA); Segovia River, 4 July (o", $\$$, USNM). 590).

PUBLISHED RZCORD.--Segovia River (Ridgway, 1888c:

The Slaty Spinetail is an uncommon to fairly common resident in the humid Caribbean lowlands of Honduras east of the Sula valley. The species occurs in heavy brush, dense undergrowth, or brushy second growth below 1,500 feet elevation. It reaches its northern limit of distribution in the lowlands of the north coast of Honduras.

C. H. Townsend secured the first Honduran specimens, a pair near the Rlo Segovia in 1887 (Ridgway, 1888c: 590). Arthur C. Twomey and Roland W. Hawkins obtained four specimens at Los Planes in 1948. T. R. Howell collected a single male at Arenal in 1953.

Mark Trafton, Jr., observed the species at Lancetilla from 1952 through 1960, recording it in January, May, June, and November. Paul Slud noted it there in June 1952. In June 1953 Trafton found a nest in a thick clump of bamboo along the creek at Lancetilla. He described the call-note of this species as a two-noted "chee-ah," distinctly different from the four-noted call of $\underline{s}$. erythrothorax. This latter species occurs also in the Lancetilla region, the 
only area anywhere in which the two species are sympatric. In March 1963 I found the species to be fairly common. locally along fence rows in the vicinity of Montecristo, just west of La Ceiba. I did not encounter the species elsewhere in Honduras.

Honduran specimens are typical of the northern race, s. b. nigrofumosa Lawrence.

\section{Synallaxis erythrothorax Sclater}

$$
\text { Rufous-breasted Spinetail }
$$

SPECIMENS.--S. e. erythrothorax (37): San Alejo, 5-9 Aug. (क ? LSUMZ); Lancetilla, 15 Jan.-2 Feb., 27-30 March, 23-25 Aug. ( ${ }^{\circ}, 39$, ANSP; 60, 2\%, MCZ); Catacombas, 25 March (o, MLZ); San Pedro Sula, 10 July-28 Aug., 30 Oct. -25 Nov. ( $\sigma^{\prime}$, AMNH; 46", 3\%, USNM); Amapa, 26 Jan., 24 June, 29 Nov. ( $\sigma^{\prime}, \&$, LSUMZ; $\delta$, UF); Finca Fé, 27 Aug.-17 Sep., 29 Nov. -13 Jan. (20, 8 , imm. $\$$, skel., LSLMZ); Lake Yojoa, 18 June ( ${ }^{\circ}, \mathrm{CM}$ ); "Honduras" (30", AMMH; $\&$, BMNH; alc., USNM).

$$
\text { PUBLISHED RECORDS.-- "Honduras" (Sclater, 1855a: 75-76; }
$$
1862: 153). San Pedro region (Sclater and Salvin, 1870b: 837). San Pedro (Salvin and Godman, 1891: 150). San Pedro Sula (Ridgway, 1911: 190). Lancetilla, Tela region (Peters, 1929b: 441): Lancetilla (Stone, 1932: 318; Skutch, 1954a: 9). Near Tela (Skutch, 1945a: 18). Lake Yojoa (Russe11, 1964: 105).

In the Caribbean lowlands of northwestern Honduras the Rufous-breasted spinetail is a common resident. It occurs as far east as the $\mathrm{Tela}$ region and as far south as Lake Yojoa, ranging altitudinally to at least 2,500 feet. It occupies much the same habitat as the preceding species, $\mathrm{S}$. brachyura, and replaces it in northwestern Honduras; the two species, however, do occur sympatrically at Lancetilla. Although $\underline{S}$. erythrothorax is secretive, it is very 
susceptible to squeaking and can be readily attracted to within a short distance of the observer. The distinctive four-noted cal1, best represented as "zhee-zhee-zhee-zhoo," the first three buzzy notes each increasing in pitch, the last note low and slurred, can be heard in most brushy areas within the range of the spectes.

The type locality of the species has not been entirely clarified. The species was first described as Synallaxis erythrothorax Sclater [1855a: 75; "in America Centra11, Coban et Honduras" (= Honduras)]. As van Rossem (1934c: 413-414) has pointed out, the type is the specimen in the British Museum labeled "1853 / Honduras / Parzudak1" and not the one from Coban, Guatemala, which is in the Derby Museum. Whether or not the specimen actually came from Honduras, rather than British Honduras, is not known, but at the moment the matter is of no consequence. I can see no reason for not accepting the locality "Honduras" at its face value, since the species does occur there and Parzudaki did obtain other specimens from Honduras, such as the type of Manacus candei.

Al1 Honduran specimens are typical of the blackthroated nominate race, $\underline{S}$. e. erythrothorax Sclater. Miller, Friedmann, Griscom, and Moore (1957: 52) listed the race s. e. pacifica Griscom [1930b: 3; San Felipe, Retalhuleu, Pacific slope of Guatemala] as occurring to "western Honduras." As far as is known, the species is absent on 
the Pacific slope of Honduras and reaches its southern limit on that coast in EI Salvador. None of the existing Honduran specimens shows any approach to the gray-throated pacifica.

\section{Anabacerthia variegaticeps (Sclater)}

Scaly-throated Follage-gleaner

SPECIMENS.--A. v. varlegaticeps (56): Catacombas, 22 March-2 April ( $\sigma^{\prime}, M L \bar{z}$; $\sigma^{\prime}, \mathrm{MCZ}$ ); San Pedro Sula, 30 March ( 9 , CNHM); Las Peñitas, 8-22 Feb. ( 9 , ANSP; $20^{\circ}, 39$, AMNH; $0^{\prime 2}$ MLZ; 20, MCZ); Portillo Grande, 6-15 April (o, \$, MCZ); Cerro EI Triumpho, $20 \mathrm{mi}$. SE San Esteban, 30 March ( $q$, LSUMZ); E1 Chorro, 27 June ( 8 , MLZ); Montaña E1 Chorro, 23 June ( $\$$, MLZ); Montaña La Cruz, 25 June ( ${ }^{\circ}$, MLZ); Belén Gualcho; 18 July ( $q$ ?, MLZ); Las Ventanas; 29 July ( $q$, MLZ); Monte EI Portillo, 28 May ( ${ }^{\circ}$, MLZ); Mt. Puca, 8 Jan. $-8 \mathrm{Feb}$. ( $40^{\circ}, 3 \%$ ?, MCZ); Cerro Nieve, 10-13 Apri1 (50", 4\%, AMNH); San José de Santa Bárbara, 8 April (?, MCZ); Falda de Santa Bárbara, 28 April ( $\$$, AMNH); Cerro Santa Bárbara, east slope, 19 Feb., 28 Nov. -9 Dec. $\left(20^{\circ}, 38\right.$, LSUMZ); Cerro Santa Bárbara, southeast s lope, 25 July (2\% LSUMZ); Finca Fé, 8 Sep. (?, LSUMZ); $5 \mathrm{mi}$. ŚW El Jaral, 26 Oct. -4 Nov. (2o, skel., ISUMz); Lake Yojoa, 20 July, 25 Aug. (2\%, CM); E1 Derrumbo, 14 July, 3 Aug. ( 9 , AMNH; $\&$, MCZ). 198).

$$
\text { PUBLISHED RECORD.--San Pedro Sula (Hellmayr, 1925: }
$$

In Honduras this species is a fairly common to very common inhabitant locally in montane rain forest; it occurs also in true cloud forest but is decidedly uncommon in this habitat. The species normally ranges from 3,500 to at least 7,000 feet, but in the nonbreeding season some individuals descend into lowland rain forest to about 1,500 feet. Despite the statement of Griscom (1932b: 239) that this species is uncomon in Central America, it is locally one of the most common Subtropical Zone species in Honduras. 
On Cerro Santa Bárbara, in the zone of transition from low montane rain forest to cloud forest $(4,000$ to 5,000 feet), it was outnumbered only by the abundant tanager Chlorospingus ophthalmicus.

After examination of South American material, notably specimens from Colombia, I agree with the treatment of de Schauensee (1964: 211-212), who considered A. variegaticeps to be a species distinct from A. striaticollis Lafresnaye.

Honduran specimens are referable to the Central American race, A. v. variegaticeps (Sclater).

\section{Automolus rubiginosus (Sclater) \\ Ruddy Follage-gleaner}

SPEGIMENS.--A. I. rubiginosus (18): La Libertad, 10-22 June $(2 \delta, q, \mathrm{MCZ})$; Montaha El Sil1on, 3 June-2 July ( 3 ?, MLZ); Mt. Puca, 7 Jan. -6 Feb. (40' MCZ); Santa Bárbara; 17-27 May ( $\left.\sigma^{\prime},{ }^{\circ}, \mathrm{MCZ}\right)$; Cantoral, 15-27 Feb. ( 8,29, MCZ); Alto Cantoral, 16 Jan.-2 Feb.; 4 April (20, $\%$, MCZ). 215).

PUBLISHED RECORD.--Volcán de Puca (Hellmayr, 1925:

Occurring in Honduras from 4,500 to 6,500 feet elevation, the Ruddy Foliage-gleaner is an uncommon resident in cloud forest. All the specimens 1isted above were collected by C. F. Underwood between 1934 and 1938. Hellmayr (1925: 215) examined a specimen in the Brunswick Museum taken on Voicán de Puca on 8 April 1889 by Erich Wittkügel. I failed to find the species in Honduras in 1962-1964. 
I agree with Miller, Friedmann, Griscom, and Moore (1957: 53) that the races A. ‥ veraepacis Salvin and Godman and A. ‥ umbrinus Salvin and Godman, the latter usually including Honduran populations, are not distinguishable from

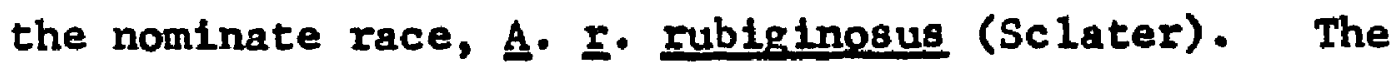
characters upon which veraepacis and umbrinus are based, primarily degree of deepness of the rufous coloration, vary on an Individual basis and through the foxing of specimens. I can see no constant geographic variation from Chlapas to Honduras when specimens of comparable sex and post-mortem age are compared.

\section{Automolus ochrolaemus (Tschudi)}

\section{Buff-throated Follage-gleaner}

SPECTMENS. --A. o. hypophaeus (93): San Alejo, 3 April, 7 Aug. (o, 9, ?, LSUMZ); Lancetilia, 14 Jan., 17-23 March, 26 Aug - -9 Sep. ( $q$ ? , ANSP; o, $q, ?$ MCZ); La Celba, 28 July-9 Aug - (30, $\left.2{ }^{\circ}, \mathrm{CM}\right)$; Yaruca, 23-26 Feb. ( $0^{\circ}, 29, \mathrm{MCZ}$ ); Los Planes, 16 July ( $q$ CM); Catacombas, 23 March-7 April

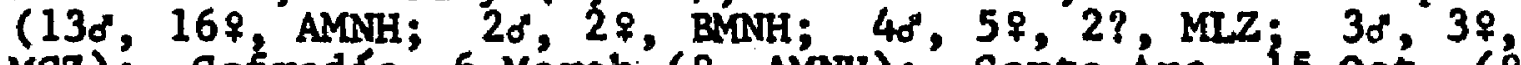
MCZ); Cofradia, 6 March' (?, AMNH); Santa Ana, 15 Oct. ( USNM); Subirana, 29 Jan. (?, MCZ); $5 \mathrm{mi}$. S San Esteban, 16 Jan. ( $\delta$ LSUMZ); La Libertad, 27-28 June ( ${ }^{\prime}, q^{\circ}$, AMNH; o, \$, CMYM); Merendón Copán, 16 June ( $\sigma^{\circ}$, AMNH); San José dé Santa Bárbara, 12-30 April (38, AMNH); Santa Bárbara, 25 May ( 8, AMNH); Finca Fé, 3 Sep., 5 Nov. (20, LSUMZ); Lake Yojoa, 28 July (o, CM); 2 mi. N Pito Solo, 24 Nov. ( $\sigma^{\circ}$, LSUMZ ; Yuscarán, 20 April ( 9 , BMNH); Arena 1, 17-24 Jan. (3d, 2\%, UCLA); "Honduras" (2?, AMNH; ?, BMNH).

BUBLISHED RECORDS.--"Honduras" (Sclater, 1890: 92). Sante Aña (RIdgway, 1891: 471). Yaruca (Bangs, 1903: 150). Lancetilia and Yaruca las amusos] (Peters 1929b: 441-442). Lancet111a [as amusos] (Stone, 1932: 318). Catacombas [as cervinigularts]; Lancetilla, Yaruca, and Subirana [as amusos] (Peters, 1951: 138). 
The Buff-throated Follage-gleaner is a fairly common to common resident of the lowland rain forests of Honduras, ranging into low montane rain forest to an elevation of about 3,500 feet. It occurs both in dense forest and in second growth, usually in the undergrowth or in the lower story of the forest. The species is apparently very common locally in Honduras, as evidenced by the 50 specimens secured at Catacombas by C. F. Underwood in a two-week period. In rather open rain forest on Finca Fé, at an elevation of 2,300 feet, I found it to be rather uncommon, but in the selva at San Alejo (at sea level) it was common.

The subspecific status of the Honduran populations has been thoroughly confused until very recently. The populations along the north coast of Honduras were separated as A. o. amusos Peters [1929b: 138; Lancetilla, Honduras (500 feet elevation)]; this race was differentiated from $A$. hypophaeus Ridgway only by its paler coloration. From the adjacent race to the north, A. 2. cervinigularis (Sclater), amusos was said to differ in paler, less contrasting pileum as well as paler coloration. Peters (1951: 138) assigned a wierd distribution to these races, with amusos occurring in eastern British Honduras, eastern Guatemala, and northern Honduras west to Subirana and Yaruca; this range actually crossed that of cervintgularis, which was supposed to range from western British Honduras, central Guatemala, and Catacombas, Honduras, to Nicaragua. Catacombas is situated in 
the more or less continuous band of coastal rain forest, on the part that extends inland into the Quimistán Valley. Howell (1957: 89-90) discussed the variation and range of these three races at length and came up with a sensible arrangement. He extended the range of hypophaeus north to Include Catacombas, Honduras, restricting cervinigularis to more northerly areas. I agree with this conclusion since the race cervinigularis as thus restricted may be distinguished on the basis of its much darker pileum and brighter, more orange-buff under parts; its range would include all of southern Mexico and most of Guatemala. British Honduran birds are intermediate, with the brighter under parts of cervinigularis but with a paler pileum, as in hypophreus. I disagree with Howell only in his opinion that amusos is recognizable. The paleness on which this race 18 based does not hold true geographically, as both dark and light individuals appear in all Honduran populations. I can find no characteristic by which the coastal birds may be distinguished from examples of hypophaeus. On the basis of the large series of Honduran specimens, I believe that only one race may be defined within the republic, namely, hypophaeus. The name amusos will become a synonym of the latter and cervinigularis will be restricted to Mexico and part of Guatemala. 


\section{Xenops minutus (Sparrman)}

Plain Xenops

SPECIMENS. - -X. m. mextcanus (40): San Alejo, 19-31

March, 5-9 Aug. ( $3 d, 2 \%, 9$ gkel., LSUMZ); Lancetilla, 17-28 Aug. ( ${ }^{\circ}$, ANSP; Imm. $\delta^{\circ}$, LSUMZ); La Celba, 3 May-8 Aug. (5 \%, CM); Catacombas, 28 March-6 April (o, 8, AMNH; o, MLZ); San Pedro Montaña, 2 April ( $\sigma^{\circ}$, CM); Rlo Blanco, Cortés, 28 Nov. ( $\sigma^{\circ}, \%$, USMM); Santa Ana, 4-22 Dec. ( $\sigma^{\circ}, \%$, USNM); Las Peñitas, 6-19 Feb. ( 6 , 9 , AMNH; 7, MLZ); Coyoles, 13 June ( $\left.\sigma^{\prime,} G M\right) ;$ San Esteban, 1 July $\left(d^{\prime}, C M\right)$; Cerro Higuito, Santa Bárbara, 25 April (o, AMNH); Finca Fé, 17 Aug.-6 Dec. (20", 3\%, imm. of, 2 \& skel., imm, skel., LSUMz); $2 \mathrm{mi}$. SE E1 Jaral, 20 April (f, LSUMZ); Lake Yojoa, 17 July ( ${ }^{\prime},{ }^{\&}, \mathrm{CM}$ ). x. m. mexicanus > ridgwayi (13): El Boquerón, 2 Sep -23 Oct. (7f, 3\%, AMNH); Arena1, 19-22 Jan. ( ${ }^{\circ}, q$, UCLA); Segovia River, 10 Aug. (d, USNM).

PUBLISHED RECORDS.--Segovia River (Ridgway, 1888c: 590) San Pedro Montanas, Santa Ana, Rlo Blanco (RIdgway, 1911: 174). Lancetilla (Stone, 1932: 318). "Honduras" (Howe11, 1957: 90).

This species is an uncommon to fairly common resident of lowland rain forests of Honduras, ranging up to 4,000 feet elevation. It occurs in both dense forest and second growth. The tendency of Xenops to hang upside down while feeding is reminiscent of behavior of chickadees and titmice (Parus sp.).

Birds from Honduras northward are generally regarded as the race $\underline{x}$. m. mexicanus Sclater, while those from the Rio Segovla southward are treated as $\mathrm{x}$. $\mathrm{m}$. rldgway 1 Hartert and Goodson. As Austin (1929: 379-380) has pointed out, the amount of rufescent coloration above is clinal. Austin regarded birds from Honduras, British Honduras, and Guatemala as intergrades. Foxing can increase the amount of rufous coloration visible and further complicate the problem. 
When specimens of a given post-mortem age are compared, most of the populations from Mexico to northern Honduras seem to be relatively uniform in being more rufescent above than those from Nicaragua south. The area of intergradation does not appear to be as wide as envisioned by Austin, involving only the 0lancho rain forest of eastern Honduras and adjoining parts of northern Nicaragua (Howe11, 1957; 90). All the Honduran birds from Olancho are nearer mexicanus but do show some tendency towards rldgwayi in more olivaceous coloration.

\section{Sclerurus mexicanus Sclater}

Tawny-throated Leafscraper

SPECTMENS. --S. m. mexicanus (19): Catacombas, 25 March (o", MCZ); Las Peñitas, 17-22 Feb. (o', AMNH; o, MCZ); 5 mi. S San Esteban, 15 Jan. (o", LSUMz); Cerro Ei Triumpho, $20 \mathrm{mi}$. SE San Esteban, 29 March ( ${ }^{\circ}$, LSUMZ); La Leona, 25 June ( $\sigma, M C Z)$; Merendón Copán, 12 June (7, MCZ); E1 Chorro, 27 July, ( ${ }^{*}$ MLZ); Montaña El Chorro, "31" June (o", MLZ); El Sillón, 10 July ( $\%$, MLZ); Monte Verde, 25 July ( ${ }^{\circ}$, MLZ); Mt. Puca, 4 Jan., 4 Feb. (2\%, MCZ); Volcán de Puca, 8 April (ó, USNM); Cerro Santa Bárbara, east slope, 7 Dec. ( 8 , LSUMZ); Muye, 22 Feb. ( $₹$, AMNH); San Juancito, 25 June-4 Aug. $\left(20^{\circ}, 9, \mathrm{CM}\right)$. 471).

PUBLISHED RECORD.--Volcán de Puca (RIdgway, 1891:

Occupyling cloud forests from 3,500 to at least 7,500 feet, the Tawny-throated Leafscraper is a rare to uncommon resident in Honduras. I encountered it only once in Honduras, in 1962 when I collected a female on Cerro Santa Bárbara; the bird flushed from the ground in deep shadow and perched on a low limb. 
Honduran specimens represent the nominate race, $\underline{s}$. $\underline{m}$. mexicanus Sclater. Hellmayr (1925: 248) has shown that $\underline{\text { S. }}$ m. certus Chubb, described from Guatemala, is a synonym of mexicanus. Honduran individuals show no appraach to the Costa Rican race, s.. m. pullus Bangs.

\section{Sclerurus guatemalensis (Hartlaub)}

Scaly-throated Leafscraper

SPECTMENS.--S. g. guatemalens is (17): San Alejo, 3 Apr11 ( $\sigma$, LSUMZ); La Celba, 4 Aug. ( $\$$ CM); Catacombas, 27 March-6 April ( $\sigma^{\prime}, ?$, AMNH; 2o, BMNH; $\delta, ~ q 2$, MCZ); Santa Ana, 6-20 Nov. ( $20^{\circ}, q$, USNM); La Puerta, 12 Nov. ( $\sigma^{\circ}$, USNM); Choloma ( 9, KAS); 5 mi. S San Esteban, 16 Jan. ( 8 , isUMZ); Río Pataste, $12 \mathrm{mt}$. S Dulce Nombre de Culmí, 27 Jan. ( $f^{\prime}$, ISUMZ); Arena1, 22 Jan. ( $\%$, UCLA).

1891: PUBLISHED RECORDS--Santa Ana, La Puerta (Ridgway,

In Honduras this leafscraper is a rare to uncommon resident of lowland rain forests on the Caribbean slope. It occurs from sea level up to 2,500 feet, occasionally to 4,000 feet in low montane rain forest.

The only individual of this species that I noted in Honduras was the male collected at San Alejo in 1963. The bird flushed from a hole in a dirt bank along a wooded path. The hole, approximately two feet in length and excavated horizontally, contained a nest and two eggs. The hole entrance was only 15 inches above the foot of the bank.

Honduran specimens are referable to the Middle American race, S. g. guatemalens is (Hartlaub). 
Family FORMICARI IDAE

Cymbilaimus lineatus (Leach)

Fasclated Antshrike (o, $\frac{\text { SPECIMENS }}{\text { UCLA). }}--\underline{C} \cdot 1$ fasciatus (2): Arena1, 16-24 Jan. PUBLISHED RECORD - -"Extreme southeas tern Honduras" [in range] (stud, 1964: 210).

Cymbilaimus 1ineatus reaches its northern 1 imit of distribution in the rain forests of olancho. It is known in Honduras only from the vicinity of Arenal, at an elevation of 1,200 feet, but it probably occurs elsewhere in Olancho. J. G. Montrello secured the two specimens, a male on 24 January and a female on 16 January 1955. T. R. Howell (personal communication) informed me that the species is uncommon around Arenal. This antshrike inhabits heavy and usually low growth along the forest edge or in semi-open situations.

Slud's (1964: 210) Inclusion of Honduras in the range of the species was based on the above specimens.

The Honduran specimens are typical of the northern race, C. 1. fasciatus (Ridgway).

\section{Taraba mator (Vieillot)}

Great Antshrike

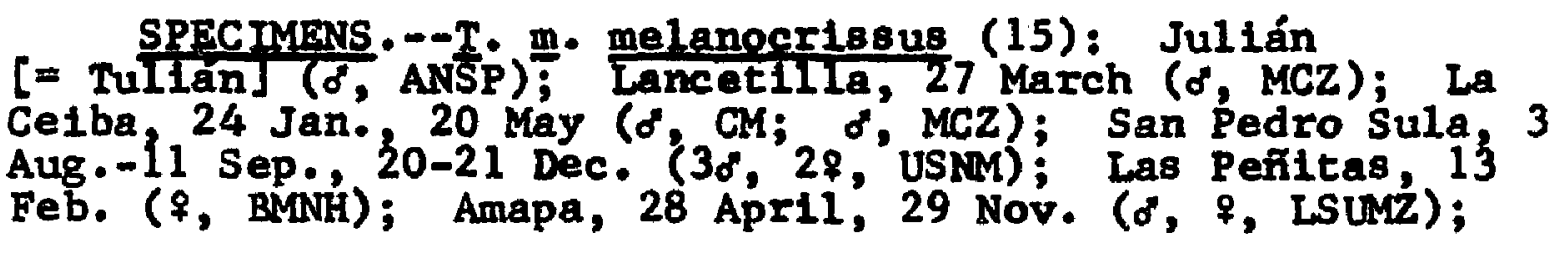


Lake Yojoa, 16 Aug. (o", CM); "Honduras" (o", ANSP; 8 , USNM).

PUBLISHED RECORPS.--Omoa (Moore, 1859: 57). San Pedro region (Sclater and Salvin, 1870b: 837). San Pedro Sula (RIdgway, 1891: 471). San Pedro (Salvin and Godman, 1892: 197). La Ceiba (Bangs, 1903: 150). Julián [= Tulián] (Ridgway, 19i1; 30$\}$. Tela River near Lancetilla (Peters, 1929b: 439).

Ranging up to an elevation of 2,500 feet, this antshrike is an uncommon inhabitant in lowland rain forest on the Caribbean slope of Honduras. As is the case with most antshrikes, it occurs primarily in heavy undergrowth in forest edge, semi-open situations, or guamil, usually near the ground.

Honduran specimens are representative of the widespread Middle American race, I. m. melanocrissus (Sclater).

\section{Thamnophilus doliatus (Linnaeus)}

Barred Antshrike

SPECIMENS:-T. d. Intermedius (97): San Ale jo, 30 March, 7 Aug (20, LSUMZ); Tela, 7-13 March (o, \%, MCZ); Lancetilla, 26 Feb., 1 Apri1, 29 Aug. ( $d$, ANSP; d, MCZ;

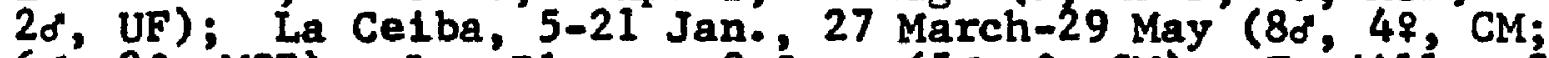

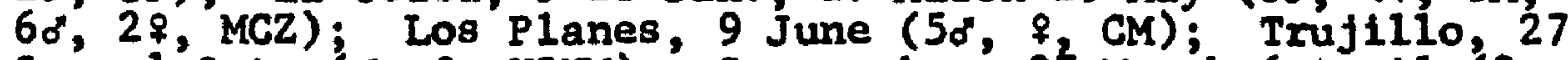
Sep.-1 oct. ( $\sigma^{\circ},{ }^{\circ}$, USNM); Catacombas, 23 March-6 April (30,

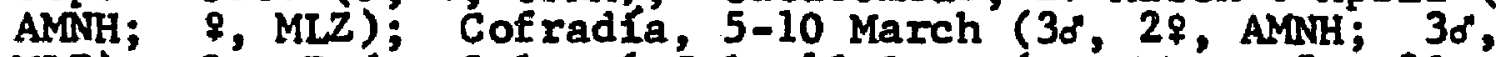
MLZ); San Pedro Sula, 6 July-10 Sep. ( $0^{\circ}$, BMNH; $50^{\circ}, 3 \%$, USNM); Santa Ana, 21 Oct. ( $\%$, USNM); $3 \mathrm{mi}$. NE Progreso, 10 Aug. (o skel., LSUMz); $3 \mathrm{mi}$. N Río Lindo, $7 \mathrm{sep}$. ( $q$, LSUMZ); Amapa, 18 Feb. ( $\delta$, LsUMZ); Coyoles, 23 April, 14 June-1 July ( $30^{\circ}, 2 \%, C M ;{ }^{\circ}$, LSUMZ); San Esteban, 30 June ( $\$, C M)$; La Libertad, 18 June ( $\$$ AMNH); Santa Bárbara, 11-14 May (39, AMNH); Finca Fé, 23 July, 12 Sep. -9 Dec. ( $3 d^{\circ}, 28, q$ alc., LSUMZ); $1 \mathrm{ml}$.'W E1 Jaral, 15 Sep. ( skel., LSUMZ); $2 \mathrm{ml}$. SE E1 Jaral, 24 Feb. ( 0 , LSUMZ); Lake Yojoa, 12 June-23 Aug. $\left(2 \sigma^{\circ}, 29, \mathrm{CM}\right)$; 2 mi. N Pito Solo, 25 Oct. ( $\sigma^{\circ}$, LSUMZ); E1 Caltche, 7-11 July (20, 2\%, AMaNH); A1 to Guaimaca, 10-11 June ( $\delta$, AMNH; $\delta$, MLZ); Jamastrán Va11ey, $20 \mathrm{Feb} ., 17$ Aug • (20, \%, UF); E1 Boquerón, $15 \mathrm{Sep}$. ( , AMNH); "Honduras," 27 Nov. ( $d$, AMNH; o, BMMH). I. d. 
intermedius $\times$ pacificus (13): Plan del Rancho, 26 May ( 9 , MiL); Soluteca, 6 April ( $\%$ AMNH); Cantoral, 30 June ( $\sigma^{\circ}$, AMNH); Cerro Cantoral, 4-12 March, 26 July (", AMNH; 28, MCZ); La Flor Archaga, 20 March, 30 May-10 June $\left(20^{\circ}\right.$ AMNH; o, MCZ); El Hatillo, 2-8 May (20, $\$$ MCZ); Comayaguela, 11 oct. (d, MCZ). T. d. pacificus (13): Yeguare River Valley, 8 Feb., 26 March, 1-24 May (20, MCZ; $20^{\circ},{ }^{\circ}$, UF); Pledra de Jesús, 17 March, 17 Nov. ( $2 d^{\circ}$, \&, AMNH); $2 \mathrm{ml}$. NW Cedeño, 12 oct. ( $\left(8\right.$, LSUMZ); $6 \mathrm{ml}$. NE Namasigüe, $29 \mathrm{Sep}$. ( ${ }^{4}$, LSUMZ); $2 \mathrm{ml}$. S El Corpus, 10 Feb., 7 oct. (d", q, LSUMZ); Honduras-Nicaragua boundary [near Pacific coast] $\left({ }^{\circ}, \mathrm{MCZ}\right)$.

PUBLTSHED RECORDS.-OMnoa (Moore, 1859: 57). "Honduras (Sclater, 1862: 175). San Pedro region (Sclater and Salvin, 1870b: 837). Trujillo (Ridgway, 1888c: 581). San Pedro (Sclater, 1890: 208). La Celba (Bangs, 1903: 150). San Pedro Sula, Santa Ana (Ridgway, 1911: 42). Lancetilla, Tela (Peters, 1929b: 439). Lancetilla (Stone, 1932: 319). San Pedro Sula (Brodkorb, 1938: 4). The Barred Antshrike is a common resident in the lowlands of both coasts of Honduras and locally in the interior, occurring up to 4,000 feet elevation. The spectes Inhabits low brushy areas or dense undergrowth in open or semi-open situations; it is most abundant in heavy growth along forest edge or in guamil.

The populations on opposite coasts of Honduras are distinct. The dark race, I. d. Intermedius Thamnophilus intermedius Ridgway, 1888c: 581; Truxillo, Honduras ], is resident in the humid Caribbean lowlands, and the lighter race, I. d. pacificus Ridgway, inhabits the Pacific lowlands. Males of the two subspecies are more distinct than females; males of intermedlus are much more heavily barred with black below, with the black bars wider than the white, while males of pacificus are usually paler, being mostly white below with narrower black bars, these sometimes almost 
obsolete on the abdomen. Females of pacificus are usually paler, both on the back and below, than those of intermedius. The race intermediug occurs entirely on the Caribbean drainage, populations above 1,500 feet generally showIng $s$ ome trend towards pacificus. The latter race occupies the Facific lowlands, extending up the Río Choluteca to the Yeguare River Valley. Interior populations in the Tegucigalpa area are intermediate between the two subspectes but on the average are closer to intermedius. I tentatively consider the females from Plan del Rancho and Soluteca, interior localities west of the Comayagua Valley, as intermediates pending collection of males from this region.

\section{Thamnophilus punctatus (Shaw) \\ Slaty Antshrike}

SPECIMENS. -T. p. atrinucha (14): Puerto Cabello [= Puerto Cortés ] (ó, BMiNH); Medina ( $q$, BMNH); San Alejo, 15-18 March (20, LSUMZ); La Celba, 16 Jan., 1 May, 1 June ( ${ }^{*}$, \%, CM; \&?, MCZ); Catacombas, 10 AprI1 (d, BMNH); Río Blanco, Cortés, 11 Nov. (o", USNM); Chamelecón, 20 Nov. -4 Dec. ( $\sigma_{1} \&$, USNM); Coyoles, 22 June (2\&, CM); Segovia River, 13 Áug. ( $\$$; USNM).

PUBLISHED RECORDS.-- "Honduras" (Sclater and Salvin, 1873a:70). Segovia River (RIdgway, 1888c: 590). Puerto Cabelio [= Puerto Cortés] Medina (Sclater, 1890: 198). La Celba (Bangs, 1903: 150). Chamelecón, Río Blanco (Ridgway, 1911: 51).

In Honduras this antshrike is an uncommon resident of the humid lowlands of the Caribbean slope, occurring up to 1,500 feet. Its habits are much like those of $I$. doliatus, but it is more closely restricted to forest undergrowth or forest edge than the latter. 
Honduran specimens are referable to the Middle American race, I. p. atrinucha Salvin and Godman.

\section{Thamnistes anabatinus Sclater and Salvin}

Russet Antshrike

SPECTMENS.- $-T$. a. anabatinus $>$ Saturatus (3): Lancet111a, $10 \mathrm{Feb} ., 29$ March (f, $\$$ MCZ); Catacombas, 5 April (o, MCZ). I. a. saturatus (4): Arenal, 17-27 Jan. (3o, \&, UCLA).

PUBLISHED RECORDS.--San Pedro region (Sclater and Salvin, 1870b: 837). Lancetilla (Peters, 1929b: 440).

The Russet Antshrike is an uncommon inhabitant of the lowland rain forests of Olancho in eastern Honduras and a rare resident in the coastal forests of northern Honduras. The species is found in dense forest, second growth, and semi-open situations; it has not been recorded in Honduras above an elevation of 1,200 feet.

G. M. Whitely (Sclater and Salvin, 1870b: 837) collected the species in the San Pedro region, but I was unable to locate any specimens in the British Museum. Peters (1929b: 440) obtained the two specimens from Lancet111a, a female on 10 February and a male on 29 March 1928; he observed no others. C. F. Underwood secured a male at Catacombas in 1933. T. R. Howell and J. G. Montrello collected single males on 25 and 27 January 1953 and on 17 January 1955, and a female on 22 January 1955, all from Arenal. I did not encounter the species in Honduras in 1962-1964. The specimens from Lancetilia are very close to the nominate race, I. a. anabatinus Sclater and Salvin, which is 
paler (more ochraceous, less olivaceous) above, while the bird from Catacombas is almost exactly intermediate between anabatinus and I. a. Saturatus Ridgway; I consider the north coast populations as intermediate, nearer anabatinus. The birds from the Olancho rain forest at Arenal match saturatus from Nicaragua and Costa Rica in all respects, and I assign them to that race.

\section{Dysithamnus mentalis (Teminck)}

\section{Plain Antvireo}

SPECIMENS.--D. m. Beptentrtonalis (38): Catacombas, 25

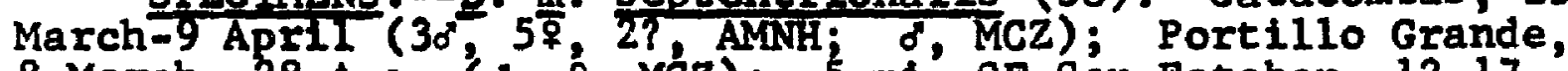
8 March, 28 Aug. ( $\sigma^{\prime}, \uparrow, M C Z$ ); $5 \mathrm{mi}$. SE San Esteban, 12-17 Jan. ( $q$, $8 ?$, LSinz); La Libertad, 10 June ( $\sigma^{\circ}$, AMNH); Merendón Copán, 14-22 June ( 8 , \&, AMNH); Cerro Higuito, Santa Bárbara, 25-26 Apri1 (45, AMNH); San José de Santa Bárbara, 16 April-6 May ( ${ }^{\circ}, 8$, AMNH); Santa Bárbara, 21-30 May (20, ₹. AMNH); Cerro Santa Bárbara, east slope, 19 Feb., 28 Nov. (20, of skel., LSUMZ); $4 \mathrm{mi}$. SW El Jaral, 26 oct. ( $0^{\circ,} \&$, ISUMZ); $5 \mathrm{mi}$. SW E1 Jaral, 28 Oct. ( ${ }^{\circ}$ skel., LSUMZ); $2 \mathrm{mi}$; SE E1 Jaral, 24 Feb.-2 March (20, ₹, LSLMZ); Lake Yojoa, 21 July $\left(0^{\circ}, 9, C M\right)$. Russell, 1964: 107).

$$
\text { PUBLISHED RECORDS.--"Honduras" (Peters, 1951: 182; }
$$

In Honduras the Plain Antvireo is an unconmon to locally fairly comon inhabitant of rain forests on the Caribbean slope. It is most common at medium elevations $(1,500$ to 4,000 feet), occurring in low montane rain forest and in the lower reaches of cloud forest where the latter is continuous with lowland forest. The species has been recorded up to 5,000 feet in Honduras. In the rain fores ts around Lake Yofoa and on Cerro Santa Bárbara, it is one of the nucleus species of most forest flocks. Within the forest it 
usually is found at medium heights above the ground, always below the high canopy.

Honduran specimens are referable to the Middle American race, $\mathrm{g}$. m. Septentrionalis Ridgway.

\section{Dysithamnus striaticeps Lawrence}

Streak-crowned Antvireo

SPECTMENS.--(3): Arena 1, $18 \mathrm{Jan} .\left(2 d^{\prime}, 7 ?\right.$, UCLA).

PUBL.TSHED RECORD.--"Extreme southeastern Honduras" [in range] (Slud, 1964: 214).

The rain forests of olancho are the northern limit of distribution of this species. Its habits are much the same as those of D. mental1s.

The species is known from Honduras only by the specimens taken in 1955 at Arenal (1,200 feet elevation) by $T$. R. Howell; Slud's (1964: 214) mention of Honduras was based on these specimens. Howell (personal communication) informed me that the species was not uncommon in the Arenal region; he did not, however, record $D$. mentalis there.

\section{Myrmotherula fulviventris Lawrence}

Ful vous-bellied Antwren
SPECTMENS.-M. f. costaricensis (2): Arenal, 24 Jan. ( , UCLA); Segovia River, 13 June (f, USNM). 590).
PUBLISHED RECORD.--Segovia RIver (RIdgway, 1888c:

As is the case with the preceding species, the Fulvousbellied Antwren reaches its northern limit of distribution in the Olancho of eastern honduras. Th1s antwren is a bird 
of lower levels in rain forest and generally occurs in dense a reas or in heavy second growth.

C. H. Townsend secured a female along the Río Segovia in 1887; another supposed female fulyiventris collected by Townsend on 19 June (Ridgway, 1888c: 590) proved later to be an example of M. axillaris (RIdgway, 1911: 69). J. G. Montrello obtained a female at Arenal (elevation 1,200 feet) in 1953. These are the only known Honduran records.

Both Honduran females compare well with examples of $\underline{M}$. f. costaricensis Todd from Costa Rica.

\section{Myrmotherula axtilaris (Vieillot)}

White-flanked Antwren (\%, USNM).

SPFCIMEN.--M. a. albigula (1): Segovia River, 19 June PUBLISHED RECORD.--Segovia River [as M. fulviventris, part] (Ridgway, 1888c: 590 ). Segovia River Tas $\underline{M}$. axillaris] (Ridgway, 1911: 69).

The status of this antwren in Honduras is the same as that of $M$. fulviventris. The species occurs in the same situations as $\underline{M}$. fulviventris and also reaches its northern Iimit of distribution in the olancho rain forests.

only a single spectmen of this species has been taken in Honduras. It was obtained by $C$. H. Townsend along the Río Segovia in 1887. It was originally (Ridgway, 1888c: 590) reported as a specimen of $\underline{M}$. Eulviventris, but Ridgway later (1911: 69) corrected this error. The specimen 1s, indeed, an example of $\underline{\mu}$. axt11aris. 
The single Honduran female is not different from examples of the northern race, $M$. a. albigula Lawrence.

\section{Myrmotherula schisticolor (Lawrence)}

\section{Slaty Antwren}

SPECTMENS.--M. s. 8chisticolor (24): Lancetilla, 22 Feb. (o, MCZ) Cataçombas, 6 ApriI, 7 Aug. (?, AMNH; of, MCZ); Las Peñitas, $10 \mathrm{Feb}$ ( $q$, AMNH); $5 \mathrm{ml}$. S San Esteban, 15-16 Jan. (20, LSƯZ); Rio Guampí, $10 \mathrm{mt}$. E Dulce Nombre de Culmí, 23 Márch ( $\sigma^{\circ}$, LSLMZ); La Leona, 24-25 June (20, AMNH); La Libertad, 1 July ( $\sigma, 8$, AMNH); Merendón Copán, 12-22 June (3d, 2\%, AMNH); Cerro Nieve, 10 Apri1-4 May (3o", AMNH); Cerro Santa Bárbara, east slope, 19 Feb., 21 April ( $20^{\circ}$, LSUMZ); $5 \mathrm{ml}$. SW El Jara 1, 4 Nov. ( ${ }^{\circ}$, LSUMZ); Cantoral, 4 June ( $\%$, AMNH); Arena1, 19 Jan. ( 8 , UCLA). PUBLISHED RECORD.--Lancetilla (Peters, 1929b: 440).

The Slaty Antwren is an uncommon resident of lowland and low montane rain forests in Honduras. Occurring at low levels within heavy forest or dense second growth, it is most common in forests at medium elevations between 1,500 and 4,000 feet. There are several records of it from elevations of about 5,000 feet. On Cerro Santa Bárbara, in the transition zone from low montane rain forest to cloud forest at 4,000 to 5,000 feet, was the only location in Honduras where I encountered the species. Although decidedly uncommon there, it was recorded on almost every trip to that 1ocality.

Honduran specimens are referable to the widespread nominate race, $\underline{M}$. E. Schisticolor (Lawrence). 


\section{Microrhopias guixensis (Cornalia)}

Dot-winged Antwren

SPECIMENS.--M. g. boucardi > virgata (18): San Alejo, 15-19 March, 7 Aug. (48, 2\%, d skel., LSUM( ); Montecristo, 24 March (\%, LSUMZ); La Ceiba, 24 July-5 Aug. (20, CM); Los Planes, 10 June, 14-16 July (40", 39, CM); Río Blanco, Cortés, 11 Nov. (o", USMM). M. g. virgata (6): Río Guampú, $10 \mathrm{mi}$. E Dulce Nombre de Culmi, I7 March (o, LSUMZ); Arenal, 20-27 Jan. (28, 3\%, UCLA).

PUBLISHED RECORDS.--Omoa (Moore, 1859: 55; Sclater and salvin, 1859: 119). San Pedro regton (Sclater and Salvin, 1870b: 837). San Pedro (Salvin and Godman, 1892: $216-213$ ).

Microrhopias quixensis is a locally fairly common resident in lowland rain forests on the Caribbean slope of Honduras. It occurs in open forest and in second growth, usually at medium levels of the vegetation. In Honduras it has not been recorded above 1,200 feet elevation.

Honduran specimens from localities along the north coast are closer to the northern race, M. g. boucard 1 (Sclater), but they do show some tendency towards the southern race, $M$. g. yirgata (Lawrence), in the greater extent of black on the under parts of the males and the darker rufous under parts of the females. The series from Los Planes exhibits a great deal of variability but averages closer to boucardi. Specimens from the Olancho rain forest are generally typical of virgata, but there is one female from Arenal that is paler than most yirgata. There can be 1ittle doubt that the transition from one race to the other takes place In Honduras, since most spectmens exhibit at least some sign of intermediacy. 


\section{Cercomacra tyrannina (Sclater)}

Dusky Antbird

SPECIMENS.--C. $t$. crepera (87): Omoa ( 7 , BMNH); San Alejo, 16-19 March ( $\sigma^{\circ}, \frac{9}{9, \text { ISUMZ) }}$; Lancetilla, 23 Aug. ( $\sigma^{\prime}$, ANSP); La Celba, 3-5 Aug. (20, $\$, C M)$; Los Planes, 10 June ( $\circ^{\circ}$, CM) ; Catacombas, 3-28 March (20, AMNH; 20, MLZ); Cofradia, 4-15 March (40, 5\%, AMNK; 2\%, MLZ); San Pedro Sula, 23-31 July, 31 Oet. -2 Nov. (40", 28 USNM); Río Blanco, Cortés, 11 Nov. ( $d$, USNM); Las Pen̂ltas, 3-15 Feb. (3d", 39, AMNH); La Bomba, lo Sep. (q, USNM); $5 \mathrm{mi}$. E Progreso, 6 March (f, LSUMZ); Amapa, 19 Apr11, 24 June, 18 Sep., 29 Nov. ( $\delta, \%, q$ alc., LSUMz; \&, UF); Río Guampí, 10 mi. E Dulce Nombre de Culmf, 16 March (d, $\%$, ISUMZ); San José de Santa Bárbara, 29 April-6 May ( $50^{\circ}, \%$, AMNH); Santa Bárbara, 11-24 May (40, 59, AMNH); Finca Fé, 7 Aug.-17 Sep., 23 Nov.16 Jan. (40, $2 \%, 3 \sigma^{\circ}$ skel., $\$$ skel., $20^{\circ}$ alc., $\$$ alc., LSUMZ); Lake Yojoa, 17 July $\left(3 \sigma^{\circ}, q, C M\right)$; 2 mi. N Pito Solo, 24 Nov. (\% skel., is UMZ); San Marcos de Gualmaca, 23 June-1 July (40, AMNH; $\$, M L Z$ ); El Boquerón, 26 Aug.-24 Sep. (20, $q$, AMNH); Arenal, 26 Jan. ( $\sigma^{\circ}, \delta^{\prime}$, UCLA).

PUBLISHED RECORDS.--Omoa (Sclater, 1862: 184). San Pedro reglon (Sclater and Salvin, 1870b: 837). San Pedro (Salvin and Godman, 1892: 214), San Pedro Sula, Río Blanco, La Bomba (Ridgway, 1911: 96). Lancetilia (Stone, 1932: 319).

The Dusky Antbird is a common resident of lowland rain forests on the Caribbean slope of Honduras, occurring up to 3,500 feet. The species inhabits low undergrowth in forest, in the semt-open, or in second growth, being especially coumon in guamil. The ratting call of this species is one of the sound most frequently heard in the rain forest.

Honduran specimens are typical of the Middle American race, $\underline{C}$. $t$. crepera Bangs. 


\title{
Gympocichla nudiceps (Cassin)
}

Bare-crowned Antbird

\begin{abstract}
SPECIMENS,--G. n. chiroleuca (3): Santa Ana, 20 Nov. (\%, Imm. $\delta$, USNM); Amapa, 18 Jan. ( 8 , LSUMZ).

Ana $\frac{\text { PUBLISHED }}{\text { (RIdgWay, }}$ 1891: 469-470). (Moore, 1859: 55). Santa
\end{abstract}

Gymnocichla nudiceps is a rare species that occurs in dense lowland rain forest on the Caribbean slope of Honduras. It is one of the few rain forest birds that reach northwestern Honduras but fail to extend north into Mexico. It is found on or near the ground in dense forest or second growth and has not been recorded in Honduras above 500 feet elevation.

Joseph Leyland (Moore, 1859: 55) saw only two or three Bare-crowned Antbirds at Omoa; he remarked that they made sounds similar to the breaking of small twigs. Erich Wittkügel collected a female and an immature male at Santa Ana In 1890 (Ridgway, 1891: 469-470). Mark Trafton, Jr., observed the species at La Lima In May 1952 and at Lancetilla in May, June, and July of 1952 and 1953. On 24 June 1953 at Lancetilla, he observed two individuals along a creek; one bird gave a call that was described as a "Bingle, loud, cheep." In June 1952 Paul Slud also noted the epectes at Lancetilla. I encountered only one individual, the single male taken at Amapa in 1963; the bird had emerged from thick brush to drink in a small creek. 
Honduran birds represent the northern race, $\underline{G}$. $\underline{n}$. chiroleuca [Gymnocichla chiroleuca Sclater and Salvin, 1869c: 417; "In Costa Rica et in rep. Honduratensi" (m Tucurriqui, Costa Rica, and Omoa, Honduras)]. Presumably the cotype from Omoa is presently in the Derby Museum; I have not examined this specimen.

Fomicarius anal1s (d'Orbigny and Lafresnaye)

\section{Black-faced Antthrush}

SPECIMENS.-F. a. Intermedius (48): Lancetilla, 6 Feb. (9, MCZ); Catacombas ; 25 March-5 Aprt1 (29, BMNH; \&, CNHM; 40", 39, MCZ); Cofradia, 13 March ( 9 , BMNH); Las Peñitas, 1-8 Feb. (2 $\delta^{\prime \prime}$ ?, BMNH); Portillo Grande, 3-5 April (o, f, MCZ); La Libertad, 10-27 June (20, 2\%, MCZ); Merendón Copán, 12-19 June (30, AMNH; \&, MCZ); Mt. Puca, 3-10 Feb. (d, \&, MCZ); E1 Higuito, 24-26 April (d, 8, MCZ); Cerro

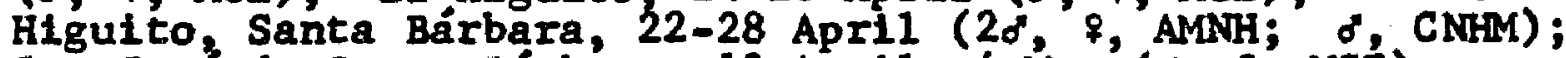
San Josế de Santa Bárbara, 12 Apri1, 4 May (d, \&, MCZ); Santa Bárbara, 26-27 May (20, AMNH); Cerro Santa Bárbara, east 8 lope, 27 Jan. ( 9 , LSUMz); Finca Fé, 20 Jan., 7 Aug.20 Sep. (2\%, $\%$, $q$ skel, alc., LSLMZ); Lake Yojoa, 17 June (o, CM); El Derrumbo, 17 July, 3 Aug. ( $0^{\prime}, 8$, BMNH); E1 Boquerón, 24 Sep. -3 oct. (2o, AMNH). F. a. umbrosus (1): Río Guampú, $10 \mathrm{mt}$. E Dulce Nombre de CuIm 1,12 March (d, LSUMZ).

PUBLISHFD RECORDS.--East of Lancet11la (Peters, 1929b: 440). Catacombas, Cerro Higuito [Santa Bárbara] (Blake, 1950: 406).

In Honduras the Black-faced Antthrush is a fairly common to common resident of rain forests and occurs also in cloud forests to an elevation of at least 6,000 feet. It is a secretive species, primarily terrestrial, and is much more often heard than seen. Its center of abundance seems to be in rain forests at medium elevations from 1,500 to 4,000 feet. The species may be found in either dense 
forest or second growth, but it is most common where there is a good tree canopy with much shade. Honduran populations north of the Olancho rain forest represent the race $\underline{F}$. a. Intermedius Ridgway. The single specimen from the Rfo Guampi, in the northern part of Olancho, 18 typical in every way of the southern Central American race, E. a. umbrosus Ridgway; 1t lacks the chestnut foreneck entirely, is much darker on the breast, has the under tall-coverts darker brown, and is much more vinaceous (1ess chestnut) on the auriculars. Oddly, no other Honduran specimens, not even the two from El Boquerón, only about 40 miles southwest of the Rio Guampu, show any approach to umbrosus. Just where the zone of intergradation occurs is not known, as there are no other 0lancho specimens, but probably most of the olancho rain forest is occupled by umbrosus, with the zone of intergradation 10cated in the Catacamas or San Esteban regions.

\section{Gymnoplthys leucaspis (Sclater)}

\section{Bicolored Antbird}

SPFCTMENS. --G. 1. ollvascens (7): La Celba, 8 April (8, USNM); Los PIanes, 16 July (f, $\&$ CM); Santa Ana, 20 Nov. (2o, USNM); Choloma ( $q$, KAS); $5 \mathrm{mi}$.' S San Esteban, 12 Jan. ( 8, LSLAZ).

PUBLISHED RECORDS---Santa Ana (Ridgway, 1891: 469). Choloma (Lantz, 1899: 221). La Celba (Deignan, 1936: 191).

The Blcolored Antbird, a rare to uncommon resident of lowland rain forests on the Caribbean slope of Honduras, 
reaches its northern 1 imit of distribution near San Pedro Sula. It is an inhabitant of heavy forest and usualiy is found on or near the forest floor; most observations have been made at amy ant concentrations. In Honduras it has not been recorded above 1,500 feet.

N. S. Goss (Lantz, 1899: 221) secured the first Honduran specimen, a female taken at Choloma in 1887. Erich Wittkïgel (Ridgway, 1891: 469) collected two males at Santa Ana in 1890. Arthur C. Twomey and Roland W. Hawkins obtained a pair at Los Planes in 1950. Mark Trafton, Jr., recorded a number of observations of single individuals of this spectes at Lancetilla in 1952, 1953, 1955, and 1956, all In the months of June and October. In June 1952 Paul Slud also saw it at Lancetilla.

At a rain forest camp in the Olancho south of San Esteban, Richard $R$. Graber caught several individuals in mist nets. On 12 January 1962 he obtained the specimen listed above. He further netted single birds on 14 and $16 \mathrm{Janu}-$ ary, four on 15 January, and two on 22 January. In 1963 along the Rfo Guampu about 10 miles east of Dulce Nombre de Culmí, he observed a pair in rain forest on 20 March and another pair on 22 March, the latter following army ants. Honduran specimens are referable to the northern race, G. 1. oliyascens [Pithys bicolor oliyascens Ridgway, 1891: 469; Santa Ana, Honduras]. 


\section{Hylophylax naevioides (Lafresnaye)}

\section{Spotted Antbird}

SPECIMENS. - -h. n. capnit is (4): Los Planes, 16 July (o, CM) ; Rio Guampu, $10 \mathrm{mI}$. E Dulce Nombre de Cúlmí, 16-20 March (2\%, LSUMZ); Árenal, 24 Jan. ( $\sigma^{\circ}$, UCLA). 221). PUBLISHED RECORD.--"Honduras" [in range] (S1ud, 1964:

Thts spectes is another of the rare Central American antbirds that reach their northern 1imit of distribution in eastern Honduras. It is found on or near the ground in dense forest. In Honduras it has not been recorded above 1,200 feet.

Arthur C. Twomey and Roland W. Hawkins obtained the first Honduran specimen at Los Planes in 1950. J. G. Montrello collected a male at Arenal in 1955. Richard R. Graber netted two females, one each on 16 and 20 March 1963, along the Río Guampú east of Dulce Nombre de Culmf. Nothing further is known concerning the occurrence of this spectes in Honduras.

Honduran specimens are typical of the northern race, H. n. Capnitis (Bangs).

\section{Phgengstictus meleannani (Lawrence)}

Ocellated Antthrush
15 Jañ. (क, LSUMZ).
(1): $5 \mathrm{ml}$. S San Es teban,
PUPITSHEP RFCORD.--"Southeas tern Honduras" [in range] (S1ud, 1964: 222). 
The occurrence of the Ocellated Antthrush in the Olancho rain forest near San Esteban came as a distinct surprise, as it is a rare bird even as far north as Nicaragua. It is another rain forest species reaching its northern 1 imit of record in the olancho forests. Its habitat preference is the same as that of Hylophylax naevioldes and Gymnopithys Leucaspis.

Richard R. Graber caught two individuals in mist nets set in heavy rain forest about five miles south of San Esteban on 15 January 1962; the single specimen saved proved to be a male. On 18 January he netted a third individual at the same locality. These are the only reports of the species for Honduras and the ones on which Slud (1964: 222) based his inclusion of Honduras in the range. It is probably widespread throughout the olancho rain forest.

The single specimen from Honduras matches examples of B. m. saturatus (Rtchmond) from Nicaragua.

\section{Grallaria guatimalensis Prévost and Des Murs}

Scaled Antpitta

SPECTYSNS.--G. 8. guattmalensis (45): Catacombas, 8 April (f, MCZ); Santa Ana, 24 Oct. (Juv, on, USNM); Las Peñitas, 6-24 Feb. ( $\sigma^{\circ}$, AMà; $\delta^{\circ}, 2 \%$, MCZ); Subirana, 1 Feb. (ó, MCZ); Cerro El Trilumpho, $20 \mathrm{ml}$. SE San EBteban, 28 March ( $\delta$, LSUMz); La Leona, 25 June ( $\delta$, AMaNH); La Libertad, 27 June ( 8, CNFM); Merendón Copan, 24-26 June ( $q$, CNFM; ?, MCZ); Montaha EI Chorro, 24 June ( 8, MLZ); Monte E1 Sillón, 2 July (o, MLz); Montaha La Cruz, 26 June ( ${ }^{\circ}$, MLZ); Mt. Puca, 17 Jan.-7 Feb. (40, MCZ); Santa Bárbara,

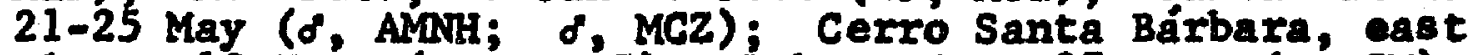
slope, 10 Nov. (d, LSURz); Lake YoJoa, 27 Aug. ( $\left.\sigma^{\circ}, C M\right)$; Cantoral, 6-29 Feb., 2 Apri1-18 May (58, 27, AMNH; 40, ML2; 28, 9, MCZ); Alto Cantoral, 16 Jan. ( $\sigma^{\circ}$, MCZ); San 
Juanc1to, 3-10 Aug. ( $q$, CM; $q$, UF); E1 Derrumbo, 16 July-9 Aug. ( $\sigma^{\circ}, \%$, MLZ; 2\%, $\left.\$, M C Z\right)$.

PUBLISHED RECORD.--Santa Ana (Ridgway, 1891: 470).

The Scaled Antpitta is an uncommon to falrly common

resident in cloud forests of Honduras, ranging from 3,500 to at least 6,500 feet elevation. It occurs, at least in the nonbreeding season, down into lowland rain forest to an elevation of about 1,500 feet. Bastcally a terrestrial

species, it is found in heavy forest or in dense undergrowth in areas of second growth. It is very secretive and much more often heard than seen.

Honduran populations are typical of the nominate race, G. g. guatimalengis Prévost and Des Murs.

\section{[Grallaria fulviventris Sclater] \\ Fulvous-bellied Antpitta}

T. R. Howell (1957: 93) recorded this species as a common bird in eastern Nicaragua about 100 miles south of the Honduran boundary; Its distinctive song was frequently heard at that locality. Howell (personal communication) further informed me that at Arenal in January 1955 he heard the song repeatedly and observed one individual. The spectes is probably widespread in the rain forests of Olancho.

Specimens from Nicaragua are typical of the distinctive northern subspecies, G. f. diyes Salvin, sometimes regarded 
as a full species. Honduran birds will probably prove to represent this race.

\section{Family PIPRIDAE}

\section{Piprites griseiceps Salvin}

Gray-headed Manakin

Culmi, SPFCIMENS.--(2): Río Guampú, $10 \mathrm{mi}$. E Dulce Nombre de

The Gray-headed Manakin is a rare rain forest species that occurs from Guatemala to Costa Rica. North of Nicaragua it is known from a single specimen from eastern Guatemala (Land and Wolf, 1961: 95) and the two examples from Honduras, a pair that Richard R. Graber secured in mist nets along the Rio Guampí in 1963. He also caught a third individual in a net at the same locality on 22 March 1963. Nothing further is known concerning this bird in Honduras.

\section{Pipra mentalis Sclater}

\section{Red-capped Manakin}

SPECTMENS.--P. m. mentalis (119): San Alejo, 30 March3 Apr 11, 5 Aug. ( 39 , 8 Bkel., Lsumz); Lancetilla, 14 Jan.-

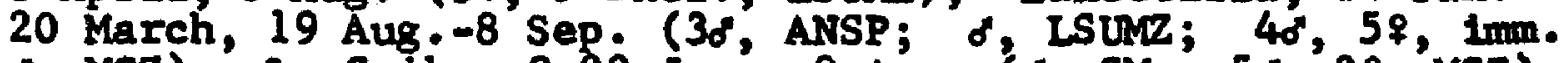
$\circ$ MCZ); La Ceiba, 9-22 Jan., 8 Aug. ( ${ }^{\circ}, \mathrm{CM}^{\circ}$ 5 $50^{\circ} 39, \mathrm{MCZ}$ ); Truj1110, 7 Apri1 ( 9, CM); Catacombas, 25 March-7 April

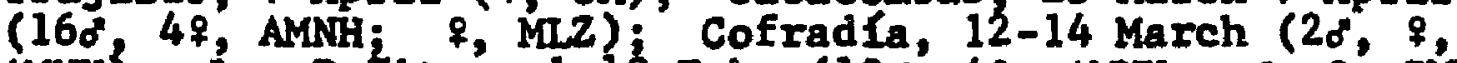
AMNH); Las Peñitas, 1-19 Feb. (130, 49, AMNH; $0^{\circ}, 9$, BMNH; 5\%, \&, MLZ); Chamelecón, I March ('?, AMNH); San Es teban, 1 July (o, CM); Cerro Santa Bárbara, east slope, 27 March (20, LStuź); 2 mi. SE E1 Jaral, 24 Feb. ( 9, LSUMz); Lake Yojoa, 16 June-27 Aug. (6d, 59, Imm. $\delta^{\prime}$, CM; $\%$, UF); San Marcos de Gualmaca, 30 June-5 July (40, \&, AMNH; $0^{\circ}$, MLZ); Cantoral, 12 Feb.-2 Apri1 (48, \%, ?, AMNH); E1 Boquerón, 11 
Oct. ( $0^{\circ}$, AMNH); Arenal, 13-24 Jan. (20, 29, UCLA); Segovia

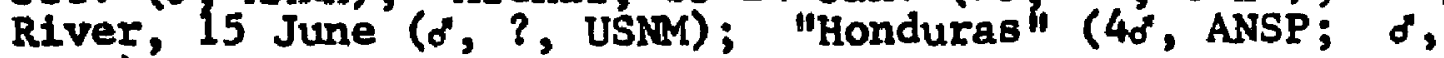
BMDH)?

PUBLISHED RECORDS.--San Pedro region (Sclater and Salvin, 1870b: 837). Segovia River (Ridgway, 1888c: 589). "Honduras" (Sclater, 1888: 296). La Cetba (Bangs, 1903: 149). Chamelecón (Ridgway, 1907: 747). Lancetilla (Peters, 1929b: 452; Stone, 1932: 325).

In Honduras the Red-capped Manakin is a common species inhabiting the lowland rain forests on the Caribbean slope below 4,000 feet elevation. It also extends into the interior in the vega forests along rivers and occurs altitudinally to at least 5,000 feet, being falrly common in areas of low montane rain forest at about 3,500 feet. The species is found both in dense forest and in second growth. In some areas it is exceedingly abundant while in others it is outnumbered by Manacus candel.

Honduran specimens are referable to the nominate race, P. m. mentalis Sclater.

\section{Chiroxiphia linearis (Bonaparte)}

Long-tailed Manakin

SPECIMPYS --(5): 2 mi. s E1 Corpus, 10 Feb., 7 Oct. (d, 2\%, Imm. $\delta$, \& si a1., LSUMZ).

Although previously unrecorded from Honduras, the Longtailed Manakin is a locally comon resident in the monsoon forest on the Pacific slope of Honduras. At the present time, it is known in Honduras only from the extensive monsoon forest near E1 Corpus, at an elevation of 1,000 feet. on 7 October $1962 \mathrm{~J}$. Alan Feduccia and I visited this forest 
and found the Long-tailed Manakin to be one of the dominant species of birds in the understory there; on that day we obtained all the specimens listed above except one female. The latter bird was collected on 10 February 1963 when Rose S. Monroe and I revisited this spot; the species was also common on that date. In El Salvador it occurs widely throughout the Pacific slope in all types of broadleaf forest and even in the lower reaches of cloud forest. In spite of the lack of further records, the species is probably widespread on the Pacific slope of Honduras.

This species may eventually prove to be conspecific with the South American $C$. pareola (Iinnaeus), as suggested by Sassi (1939: 176-177).

The southern populations in Nicaragua and Costa Rica have been distinguished as $\underline{C}$. 1 . fastuosa (Lesson) on the basis of a shorter and narrower bill and longer central rectrices of males. The four Honduran specimens do not differ in bill length or width from examples from Oaxaca and Costa Rica, except that bill length averages slightly less in the Honduran birds. An interesting point is that there is no difference at all between Oaxacan and Costa Rican individuals in this respect; I cannot see how bill size can be of use in determining subspecies of this manakin. The single adult male from Honduras does not have a full length set of central rectrices and cannot be compared with respect to tail length. This character vartes geographically, but 
in addition to requiring adult males in breeding dress for comparison, there is considerable overlap in measurements between Oaxacan and Costa Rican populations. I feel it is best to regard the species as monotypic.

\section{Corapipo altera Hellmayr}

White-ruffed Manakin

SPECIMENS. - -C. a. altera (3): $5 \mathrm{mi}$. S San Esteban, 13 Jan. ( $\sigma^{\circ}$, LSUMZ); Arena1, 14-27 Jan. (20, UCLA). (S1ud, 1964: 237 ).

PUBL,ISHED RECORD.--"Southeastern Honduras" [in range]

Corapipo altera 18 another species that reaches its northern limit of distribution in the rain forests of 0lancho. It is a rare species in Honduras, inhabiting the lower levels of dense rain forest. T. R. Howell secured the first Honduran specimens at Arenal on 14 and 27 January 1955. Richard R. Graber was successful in obtaining this manakin in mist nets near San Esteban, on the edge of the 0lancho rain forest. On 13 January 1962 he collected the specimen 1 isted above; on the following day another individual was netted and two more were caught on 16 January. These records are the only reports of the White-ruffed Manakin from Honduras and are the basis for Slud's (1964: 237) inclusion of Honduras in the range of the species.

For treatment of this species as distinct from G. leucorrhos (Sclater), see Blake (1958: 535-536).

The Honduran specimens are not different from examples of $\underline{\text {. }}$ a. altera Hellmayr from Nicaragua and Costa Rica. 


\section{Manacus candei (Parzudaki)}

White-collared Manakin

SPFCIMENS. --(78): San Alejo, 5-6 Aug. (20, 9, LSUMZ); Lancetilla, 21 Jan.-1 April, 19 Aug.-8 Sep. ( $39^{2}$ ?, ANSP; \%, LSUMZ; 30, 48, MCZ; $q$, UF); Montecristo, 24 March ( \& skel., LSUMz); La Célba, 1-22 Jan., 1 May-6 June (50, 5 , CM; 68, 39, MCZ); Los Planes, 14 July (40, CM); Trujillo,

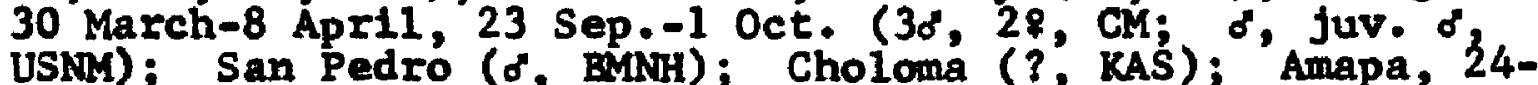

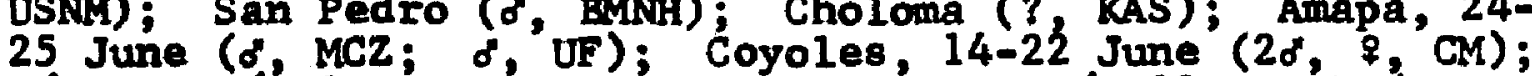
RIo Guampú, $10 \mathrm{mi}$. E Dulce Nombre de Culmi, 12 March ( $\delta^{\circ}$ LSURZ); Rio Pataste, $12 \mathrm{ml}$. S Dulce Nombre de Culmí, 27 Jan. (\%, Lsuaz); Cerro Higuito, Santa Bárbara, 22-27 April (20, \$, AMNH); El Jaral, 5-11 Oct. (20, 29, AMMH); $2 \mathrm{mt}$. SE El Jara 1, 22-24 Feb. ( $\sigma, 2 \%, \delta$ ske1.' LSUMZ); Agua Azul, 7 Aug. ( $q$, juv. of, UF); Lake Yojoa, 26-28 July (29, CM); Arenal, 20 Jan. ( $q$, UCLA); Nacunta RAver, $3 \mathrm{mi}$. S Puerto Lempira, 6 Feb. ( 6 , LSUMZ); "Honduras" (o", ANSP; 20", AMNH; o, BMNH).

PUBLISHED RECORDS--Truj1110 (Parzudak1, 1841: 306; Ridgway $1888 \mathrm{c:}$ 580). "Honduras" (Cabanis and Heine, 1859: 93). San Pedro region (Sclater and Salvin, 1870b: 837). San Pedro (Sclater, 1888: 314). Choloma (Lantz, 1899: 221). La Celba (Bangs, 1903: 149). Lancetilla (Peters, 1929b: 452-453; Stone, 1932: 325).

In the lowland rain forests of the Caribbean slope of Honduras, this manakin is a common and locally even abundant species, ranging to an elevation of about 2,500 feet. A displaying group of males of this species makes the forest sound like a fireworks display. The sharp "crack" produced by the wings during courtship is a remarkable sound, especially so when numerous males are engaged in this behavior at the same time in a confined area of forest. At San Alejo there were display arenas, small patches of forest floor about two feet in diameter, completely cleared of debris and litter, scattered through regions of relatively heavy undergrowth. Males were observed in March and Apri1 
displaying on these cleared areas, as well as occasionally on perches above the ground. At San Alejo $\underline{M}$. candel far outnumbered Pipre mentalis, while in the rain forests of Olancho the reverse was true.

Cabanis and Heine (1859: 97) 1isted a male specimen in the Heine Museum that was taken In Honduras, but I have not examined this spectmen.

Manacus cande1 [Pipra Cande1 Parzudaki, 1841: 306; Truxil1o, Honduras] does not exhibit any significant geographic vartation and should be regarded as monotypic.

\section{Schiffornts turdinus (Wied)}

Thrushlike Manakin

SPECIMENS.--S. t. veraepacts (20): San Alejo, 30 March, 7 Aug ( $\delta, 7, q$ skel., LSLMZ); Lancetilla, 14 March, 26 Aug.-5 Sep. ( $\sigma^{\circ},{ }^{2}$, ANSP; $\delta$, MCZ); La Celba, 8-9 Aug. (20*, CM); Yaruca, 24 Feb. ( $\$$, MCZ); San Pedro Sula, 4 Nov. (o", USNM); Santa Ana, 24 Oet. (Juv. $\$$ USMY); Choloma ( $\sigma^{\circ}$, KAS); Chamelecón, 6 Jan. ( 9 , USNM); $5 \mathrm{ml}$. S San Esteban, 13 Jan. ( $\$$ LSUMZ); E1 Jarai, 1 oct. ( $\%$, AMNH); $2 \mathrm{m1}$. SE E1 Jaral, 24 Feb.-2 March (20, LSUMz); Lake Yojoa, 13 July25 Aug. (30", CM).

PUBLISHED RECORDS.--San Pedro ragion (Sclater and Sa1vin, 1870b: 837). San Pedro (Salvin and Godman, 1890: 116). Choloma (Lantz, 1899: 221). Yaruca (Bangs, 1903: 149). San Pedro Sula, Chamelecón, and Santa Ana [as veraepacis]; Yaruca [as dumicola] (Ridgway, 1907: 759-760). San Pedro Sula (Hellmayr, 1929: 86). East of Lancetilla (Peters, 1929b: 453). Lancetilla (Stone, 1932: 325).

In the humid lowland rain forests of the Caribbean slope of Honduras is found this rather aberrant suboscine, currently considered to be manakin. It occurs at low levels in dense forest and sometimes second growth, below 3,000 feet. In Honduras it is decidedly uncommon. 
The proper allocation of this genus must await extensive studies of internal anatomy, as well as ethological comparisons. That this plain-colored species, lacking any sexual dimorphism, is really a member of the Pipridae seems unlikely.

Honduran specimens are referable to the widespread Middle American race, $\underline{S}$. $t$ - veraepacti (Sclater and Salvin). The supposed race $\underline{S}$. $t$. dumicola (Bangs) is not valid (Hellmayr, 1929: 85).

Family COTINGIDAE

Cotinga amabilis Gould

Lovely Cotinga

SPEC TMENS.--(59): La Ceiba, 3-24 Jan. ( 7 , UMRZ; 18 ,

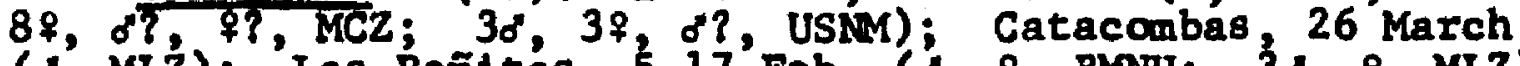
(d, MLZ); Las Peñitas, 5-17 Feb. (o, \%, BMNH; 3d, \&, MLZ); Chasnigua, 18-20 Jan. (30, USNM); Nisperal [x Nispero], 20 Dec. ( $\$, C M)$; Los [ $=$ Dos] Caminos, 29 Jan. (o, USIM); Port1110 Grande, 29 Jan.-5 Feb. ( $d, 8$, CNTM); Copán (?, MCZ); $4 \mathrm{mi}$. SW E1 Jaral, 21 Oct. ( $q$, ĹSuMz); $5 \mathrm{mi}$. SW E1 Jaral, 28 oct. ( $0^{\circ}$, LSumz); Cantora1, 11 March (o, AMNH); Arenal, 13-27 Jan.' (48, 9, UCLA).

PUBLISHED RECORDS.--La Cetba (Bangs, 1903: 149). Chasnigua, LOB $[=$ DO8] Caminos (RIdgway, 1907: 783). San Pedro, Los $[=$ Dos ] Caminos (Hellmayr, 1929: 106). Lancetilla (Peters, 1929b: 456).

The male of the Lovely Cotinga must be regarded as one of the most beautiful of Central Amertcan birds. The spectes is an uncommon to locally common resident of lowland rain forests of Honduras, extending into the interior in low montane rain forest and along the vega forests to an 
elevation of at least 4,000 feet. The spectes is usually found high in the tree canopy in forest edge or in semi-open situations, especially when food trees are in fruit.

The experience of $\mathrm{W}$. W. Brown (Bangs, 1903: 149) was remarkable. He collected 51 birds within three weeks from the same tree at La Ceiba, and could have taken more. Under normal conditions Lovely Cotingas are encountered singly or in pairs.

Peters (1929b: 456) based his record from Lancetilla on some blue contour feathers that were picked up there; he did not observe the species.

\section{Carpodectes nitidus Salvin}

\section{Snowy Cotinga}

Arenal, SPFCIMENS.--(8): La Celba, 8 Jan. (40, $9 ?, \mathrm{MCZ})$;

PUBLISHED RECORD.--La Ceiba (Bangs, 1903: 150).

The Snowy Cotinga is a rare resident of humid lowland

rain forests on the Caribbean slope of Honduras, reaching its northern limit of distribution in the rain forests of the north coast. It has been recorded at only two localities within Honduras, namely, La Ceiba (sea level) and Arenal $(1,200$ feet $)$.

W. W. Brown (Bangs, 1903: 150) obtained five specimens at La Celba, all on 8 January 1902 and all from the same dead tree; on other occasions he saw additional males in this particular tree and one Individual elsewhere in the 
general vicinity. At Arenal, J. G. Montrello collected a female on 17 January 1954 and single males on 13 and 16 January 1955. There are no other records for Honduras. Although Hellmayr (1929: 111-112) recognized only a single polytypic species in the genus Carpodectes, the sharply different morphological patterns of males of the three named forms seem to indicate their specific status. C. nitidus is therefore monotypic.

\section{Attila spadiceus (Gmelin)}

\section{Bright-rumped Attila}

SPECTMENS. --A. S. flammulatus (33): San Alejo, 29 March 6 Aug. (d, 8, LSUMZ); Lancet1lia, 6 Feb; 19 Aug; 6 Sep. (? ANSP; \% LSUMZ; \%, MCZ); La Celba, 12 Jan., 28 March, 10-15 May (38, 29, CM; $\delta$, MCZ); Cofradla, 2 March ( $\sigma^{\prime}$, MLZ); San Pedro Sula, 3 Dec. ( $\delta$, USNM); Santa Ana, 4 Dec. ( $\{$, USNM); Las Peñitas, 3-15 Feb. (26, MLZ); Chamelecón, 22 Jan. 10-22 Nov. (30", USNM); Cerro Higuito, Santa Bárbara, 24-26 April (०, \$, ẢMNH); San José de Santa Bárbara, 8 April, 1 May (o', \%, AMMH); Finca Fé, 29 March, 28 Aug.-7 Sep. 7 Dec. -16 Jan. (2\%, $?$ ?, 27 , o skel., skel., alc., LSUMZ); Lake YoJos, 14 June (d, CM); Alto Cantoral, 15 oct. (o', AMNH). A. 8. citreopygus (4): $5 \mathrm{mi}$. S San Esteban, 16 Jan. ( 9 , ISUMZ); I Boquerón, 26 Aug.-21 Oct. (28, \%, AMNH).

PUBLTSHED RECORDS.--San Pedro region (Sclater and Sa1vin, 1870b: 837). La Celba (Bangs, 1903: 149). Santa Ana, San Pedro Sula, Chamelecón (Ridgway, 1907: 808). San Pedro Sula (Hellmayr, 1929: 139). East of Lancetilla (Peters, 1929b: 455-456). Lancetilla (Stone, 1932: 324 ).

In Honduras the Bright-rumped Attila is a fatrly common and widespread species in the lowlands of the Caribbean slope (and probably also the Pacific slope). It occurs in open rain forest, semi-open situations, and second growth, usually high in trees. It is falrly common on the Pacific 
slope of E1 Salvador and undoubtedly will be found along the Pacific coast of Honduras though not yet recorded there. The species ranges from sea level to at least 4,500 feet. The variation exhibited by this species is considerable. In addition to several color phases (Stresemann, 1925: 274-277), there is much other nongeographic variation. Examination of a large series of Central American birds from Guatemala to Panama indicates that the only significant geographic variation throughout this regton is a clinal tendency from large to small size (north to south) and a rather abrupt change in central Honduras from an ochraceous rump and a brown pileum (northern populations) to a yellow rump and a more olivaceous pileum (southern birds). The best taxonomic treatment seems to be to recognize only two subspecies between Chiapas and Panama, A. s. Elammulatus Lafresnaye [Mexico to north-central Honduras and El Salvador] and $A$. S. citreopygus (Bonaparte) [southeas tern Honduras to central Panama]. The race A. S. Salvadorensis Dickey and van Rossem [1929c: 219; Lake Olomega, Dept. San Miguel, El Salvador] was based on slightly paler individuals (compared with flammulatus), but I can see no differences in this population. I have not studied examples from Cozumel Island and the Yucatán Peninsula and cannot comment on the races described from that region. 
Laniocera rufescens (Sclater)

Speckled Mourner

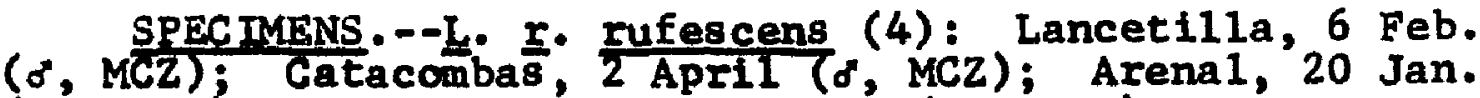
( $\sigma^{\circ}$, UCLA); Segovia River, 18 June ( $\delta$, USNM).

589) PUBLTSHED RECORDS.--Segovia River (Ridgway, 1888c: 589). East of Lancetilla (Peters, 1929b: 453).

North of Panama the Speckled Mourner is an exceedingly rare resident, inhabiting lowland rain forests. In Honduras it is known from only four males taken in the Caribbean lowlands below 1,200 feet elevation.

C. H. Townsend (Ridgway, 1888c: 589) obtained one Individual along the Rio Segovia in 1887. Peters (1929b: 453) secured another at Lancetilla in 1928. C. F. Underwood, during his elght years in Honduras, collected only a single specimen (at Catacombas in 1933). J. G. Montrello obtained a specimen at Arenal in 1955.

The four Honduran individuals are typical of the

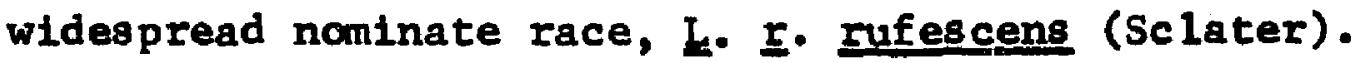

\section{Rhytipterna holerythra (Sclater and Salvin)}

\section{Rufous Mourner}

SPECTMENS.--R. h. holerythra (13): Lancet111a, 14 Jan., 26 Aug. ( $\%$ ANSP; $q, \mathrm{MCZ}$ ); Yaruca, $12-18 \mathrm{Feb}$. ( 8 , \&, MCZ); Los Planes, 9 June (30, CM); Río Blanco, at Amapa, 24 Feb. ( $\%$, UF); 'Rlo Guampú, $10 \mathrm{mi}$. E Dulce Nombre de Culmf, 23 March (o, LSUMZ); $2 \mathrm{mi}$. SE E1 Jaral, 2 March (o", LSUMZ); Arena1, $21-28$ Jan. (30, UCLA).

PUBLISHED RECORDS.-Yaruca (Bangs, 1903: 149). Chamelecón (Hellmayr, 1929; 155). Tela River at Lancetilla (Peters, 1929b: 455). Lancetilla (Stone, 1932: 324). 
The Rufous Mourner is a rare to uncommon inhabitant of lowland rain forests on the Caribbean slope of Honduras, occurring below 2,500 feet elevation. The three generally rufous species in the genera Laniocera, Rhytipterna, and Lipaugus, which are probably not closely related, are a11 scarce north of Costa Rica, but $\underline{R}$. holerythra is the one recorded most frequently in Honduras.

Hellmayr (1929: 155) Iisted a specimen from Chamelecón, presumably taken by Erich Wittkügel and deposited in the collections of the Brunswick Museum, but I have not examined this individual.

Honduran skins are referable to the widespread nominate race, ‥ h. holerythra (Sclater and Salvin).

\section{Lipaugus unirufus Sclater Rufous Piha}

SPECIMENS. --L. u. unirufus (5): Lancetilla, 6-10 Feb., 29 March (40, MCZ); Catacombas, 3 April (o", BMNH). L. u. castaneotinctus (4): Arenal, 13-24 Jan. (20, 29 , UCLA). 455).

PUBLISHED RECORD.--Lancetilla Valley (Peters, 1929b:

This species is a rare to uncommon inhabitant of humid lowland rain forests on the Cartbbean slope of Honduras, ranging up to an elevation of 1,500 feet.

Peters (1929b: 455) reported it as uncomnon in the Lancetilla Valley in 1928; he obtained four males, one on 6 February, two on 10 February, and one on 29 March. C. F. Underwood collected a single male at Catacombas in 1933. 
T. R. Howell and J. G. Montrello obtained four specimens at Arena1, a female on 24 January 1953, single males on 13 and 20 January 1955, and a female on 24 January 1955. There are no other Honduran records.

In the study of geographic variation in this species, I noted a substantial amount of individual variation. As pointed out by Peters (1929b: 455), some foxing of specimens occurs and wear has a great effect on plumage coloration. With respect to coloration, the small series available from Central America exhibits a slightly paler trend towards the middle of the range of the species in Costa Rica and Panama. Size varles geographically, with a rather marked change in central Honduras from larger northern birds to smaller southern ones. A series of specimens from Mexico, British Honduras, and northern Honduras were measured as follows: wing, $\sigma>133.4, \&>132.2$ (one specimen from Veracruz, 127.5). The wings of the four spectmens from Olancho fall within the range of variation of the smaller southern populations $(\sigma, 128.9,132.8 ; \&, 126.5,128.1)$. I therefore consider the northern race, L. u. unirufus sclater, to range south to the northern coastal areas of Honduras and the southern race, $L$. u. castaneotinctus (Hartert), to extend north to the rain forests of 0lancho, in southeastern Honduras . 


\section{Pachyramphus cinnamomeus Lawrence}

Cinnamon Becard

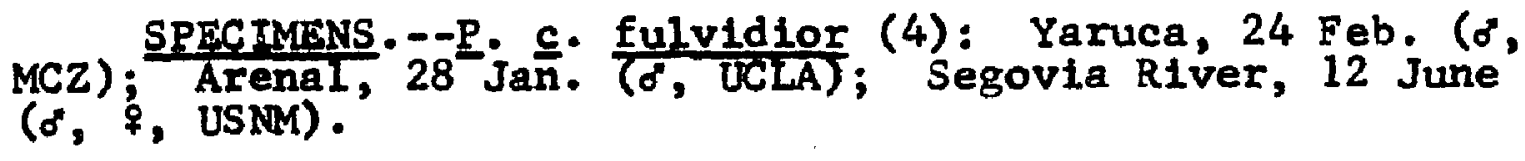
589). $\frac{\text { PUBLTSHED }}{\text { Yaruca }} \frac{\text { RECORDS }}{\text { (Bangs }},-$ Segovia River (RIdgway, 1888c: Among the becards the present species is the rarest in Honduras. It is not common anywhere north of Costa Rica and must be considered as rare in Honduras on the basis of known records. It inhabits the humid Caribbean lowlands below 1,500 feet and prefers semi-open situations, second growth, and more open areas of rain forest.

C. H. Townsend (Ridgway, 1888c: 589) secured a pair of Cinnamon Becards in 1887 along the Rio Segovia. W. W. Brown (Bangs, 1903: 149) obtained an adult male at Yaruca in 1902. T. R. Howell collected a male at Arenal in 1953. I did not encounter the species in Honduras during 1962-1964. Phelps and Phelps, Jr. (1955: 54), mentloned the examination of five specimens in the Museun of Comparative Zoology that were supposedly taken in "Honduras"; this series included the type of $P$. c. "vividior" [" fulvidior]. These specimens were obtained in British Honduras, not Honduras.

Honduran specimens are typical of the northern race, $\underline{P}$. c. fulvidior Griscon [1932a: 357; Toledo district, British Honduras ]. 


\section{Pachyramphus polychopterus (Vieillot)}

White-winged Becard

SPECIMENS.--P. $p$. cinereiventris (26): $2 \mathrm{mi}$ E Omoa, 23 Oct. (ó, LSUMZ); San Alejo, I April ( $0^{\circ}$, LSUMZ); Tela, 28 March (o", MCZ); Lancetilla, 13 Feb., 28 Aug. -5 Sep. (20, ANSP; $\sigma^{\circ}$ MCZ); La Ceiba, 3-29 May (20, 49, CM); LOB Planes, 9-11 June ( $\left.0^{\circ}, 29, \mathrm{CM}\right)$; Cof radía, 6 March (o, MCZ); Santa Ana, 25 Dec. ( $\$$, USNM); Coyoles, 23 Apri1, 28 June (6", CM; \&?, LSUMZ); La Leona, 25 June ( $0^{\circ}$, MCZ); Finca Fé, 14 Aug., 7 Sep., 2 Dec. (d, of', alc., LSUMz); Ei Jaral, 4 Oct. (d', MCZ); Lake Yojoa, 27 July ( 6, CM); Jamastrán Valley, 17 Aug. ( 9, UF).

PUBLISHED RECORDS.--Omoa (Moore, 1859: 56); Santa Ana (Ridgway, 1907: 832; Bangs and Penard, 1921a: 392). Lancetilla, Téla (Peters, 1929b: 454). Lancetilia (Stone, 1932: 324).

At the northern end of the range of the White-winged Becard, in Guatemala and Honduras, it is an uncommon to fatrly common resident of lowland rain forests, occurring only on the Caribbean slope below 3,500 feet. It is found mostly in areas of open forest, in semi-open situations, or in second growth.

Joseph Leyland (Moore, 1859: 56) reported this spectes from Omoa as "P. polychropterus," but Salvin and Godman (1890: 127-128) and Ridgway (1907: 835) thought that the record pertained to $\underline{p}$. mafor. The latter species does not occur at sea level in Honduras, as far as $18 \mathrm{known}$, and in addition, Moore stated that the bird taken by Leyland was "much smaller than the Brazilian bird $[=\underline{P}$. p. polychopterus (Vieillot)]." This size indication could apply only to the White-winged Becard, not to the much larger $\underline{p}$. major. I 
have not seen the specimen from Omoa, which is presumably in the Derby Museum.

Honduran specimens are referable to the widespread northern race, P. p. cinereiventris sclater. For a discussion of the suppression of P. R. Similis Cherrie for the northern populations, see Peters (1929b: 454).

\section{Pachyramphus major (Cabanis)}

\section{Gray-collared Becard}

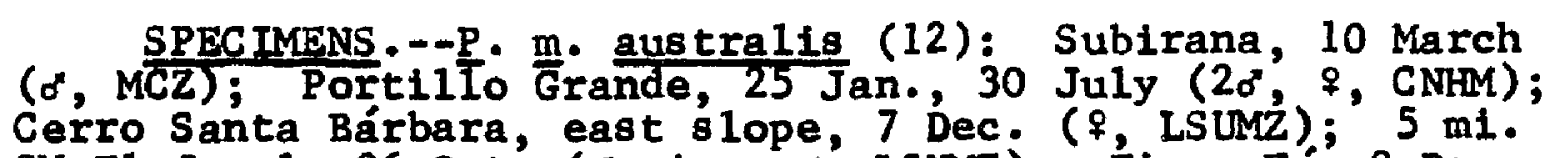
SW E1 Jaral, 26 Oct. ( $\sigma^{\circ}$, imm. $\sigma^{\circ}$, LSUMZ); Finca Fé, 8 Dec. ( $q$, LSUMZ); Lake Yojoa, 25 Aug. ( $\%, C M)$; El Caliche, 5 July (o, $\$, M C Z)$; Cantoral, 25 Feb. ( $\$, M C Z)$. 191).

PUBLISHED RECORD.--Volcán de Puca (Hellmayr, 1929:

The Gray-collared Becard is an uncommon resident in Honduras, breeding in cloud forests and pine-oak associations from 3,500 to at least 5,500 feet. In the nonbreedIng season, some individuals descend into the upper reaches of lowland rain forest to an elevation of 2,000 feet. The species prefers areas of open broadleaf forest.

Hellmayr (1929: 191) examined a specimen taken on Volcán de Puca by Erich Wittkügel on 7 March 1889 and presumably deposited in the Brunswick Museum. I have not seen this bird and it is not 11 sted above.

Honduran specimens are referable to the race $\underline{\underline{P}}$. $\mathrm{m}$. australis Miller and Griscom, which differs from $\underline{P}$. $\underline{\text { m. major }}$ 
(Cabanis) of Mexico by the slightly smaller size and, in the females, the darker rufescent back and more yellowish under parts .

\section{Platypsarts aglaiae (Lafresnaye)}

\section{Rose-throated Becard}

SPECIMENS.--P. a. hypophaeus (79): Julián [= Tulián] (f, ANSP); San AIejo, 3 Apri1 (7, LSUMZ); Lancetilla, 24 Feb. ( $\%, M C Z)$; La Ceiba, 12-23 Jan., 24 March-6 June (10d', 2\%, CM; 20", 39, MCZ; o', 29 , USNM); Catacombas, 1-4 Apri1 (?', AMNH; $;$, MCZ); San Pedro Sula, 2-28 Jan., 4 Oct., 2930 Nov. ( $\sigma^{\circ}, 29,2$ imm. $\sigma$, USNM); Santa Ana, 6 Nov. (imm. $\sigma^{\prime}$, USNM); 3 mi. E La Lima, 18 Nov. ( 9 ske1., LSUMZ); Amapa, 18 Sep. (1mm. o, LSUMZ); Coyoles, 23 Apri1 ( $\sigma^{\circ} q^{\circ}$, IS UMZ); San Es teban, $30^{\prime}$ June ( $\left.\sigma^{\prime},{ }^{\circ}, \mathrm{CM}\right)$; Rfo Guampú, $10 \mathrm{mi}$. E Dulce Nombre de Culmi, 20 March ( $q$, LŚMZ); $3 \mathrm{mi}$. E Copán, 5 Dec. (o', LSUMZ); Finca Fé, 27 Oct. (Imm., LSUMZ); $4 \mathrm{ml}$. SW E1 Jara1, 12 Sep. ( $\sigma^{\circ}$, LSUMZ); 5 mi. SW El Jaral, 26 Oct. ( $\sigma^{\circ}$, LSUMZ); E1 Caliche, 5-29 July ( ${ }^{\circ},{ }^{\circ}$, ANSP; 6 $0^{\circ}, 12 \%, 2$, AMNH; 20, MCZ); Cantarranas, 8-10 Aug. (20, ANSP); E1 Boquerón, 31 Aug. -12 Oct. (58, \%, AMNH); Arena 1, 22-28 Jan. (3o", 2\%, UCIA). P. a. sumichrasti $\times$ latirostris (2):

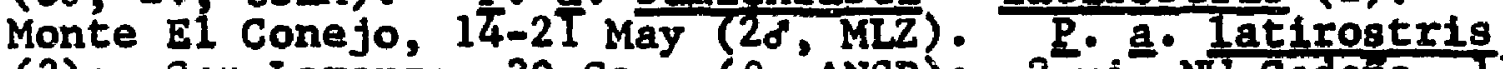
(3): San Lorenzo, 30 Sep. ( 9 , ANSP); 2 mi: NW Cedeńo, I1 Feb. ( $q$, LSUMZ); $15 \mathrm{mi}$. NE Cédefio, 4 Jan. ( $d$, LSUMZ).

PUBLISHED RECORDS.--San Pedro region (Sclater and Salvin, 1870b: 837). San Pedro (Salvin and Godman, 1890: 122). La Celba (Bangs, 1903: 149; Deignan, 1936: 19i). San Pedro Sula, Santa Ana (Ridgway, 1891: 463-469). Lancetilla (Peters, 1929b: 454). Cantarranas along the Rio Choluteca (Stone, 1932: 324). "Honduras" [ = La Celba and San Es teban, as hypophaeus; San Lorenzo, as Latirostris] (Webster, 1963: 396-398).

This species is the most widespread becard in Honduras, occurring in a variety of habitats in the lowlands of both coasts below 3,500 feet. Its preference is for semi-open situations with broadleaf trees in elther humid or arid climates. On the Pacific slope it is falrly common in the arid scrub and monsoon forests, ascending the river valleys 
into the interior. In Guatemala it ranges altitudinally to at least 8,500 feet, but the upper limits of its distribution in Honduras seem to be considerably lower.

Despite the recent revision of the Rose-throated Becard by Webster (1963: 383-399), geographic variation in northern Central America is poorly understood. There are two reasonably wel1-defined races on opposite slopes of Honduras, the very dark ‥ a. hypophaeus RIdgway [1891: 467; San Pedro Sula, Honduras] on the Caribbean and the pale $\underline{P}$. a. latirostris (Bonaparte) on the Pacific. The former race is dark in the male, with little or no contrast between pileum and back and with the under parts darker than in other races; the females of hypophaeus are usually deeper tawny above and below than in other races. Males generally lack the rose throat or, if it is present, it is usually greatly reduced and of a deep purplish-red shade, the color as in the race $\underline{\underline{p}}$. . Sumichrasti Nelson. The Pacific coast race is very pale, with a sharp contrast between pileum and back in the male and paler coloration in both sexes. Males of latirostris may possess or lack the rose throat (present more often in northern populations of this race) but, if the rose throat is present, it 18 broad and of a pale rose shade with none of the purplish-red cast present in sumichrast1 or hypophaeus. The populations in the Motagua Valley in Guatemala and at Copán in Honduras are very puzzling; they are dark as in hypophaeus but the males usually have a trace 
of a rose red throat (color as in latirostris). Webster (1963: 396-397) regarded these birds as intermediate between hypophaeus and latirostris, but I cannot see how this conclusion can be tenable from a geographic standpoint. The race sumichrast1 occupies most of the intervening area in Guatemala, intergrading with latirostris in El Salvador and western Honduras (Department of Ocotepeque). Specimens from E1 Caliche, in central Honduras, show some silght approach also to sumichrast1 in that virtually all males have some red on the throat; they also average very 81 ightly paler than hypophaeus. Seemingly, therefore, sumichrast1 extends down the Central American highlands at medium elevations, intergrading with hypophaeus on one slope and with latirostris on the other. That intergradation between hypophaeus and 1atirostris could occur in the Motagua Valley, with sumichrasti intervening, is not possible. I think that the Motagua birds may be a locally derived population of hypophaeus, having nothing to do with latirostris; perhaps study of a serles from there would demonstrate that it is an undescribed race. At the present time, however, I prefer to treat them as part of the race hypophaeus.

\section{Tityra semifasciata (Spix)}

Masked Tityra

SPECTMENS.-T. - S. personata $(87):$ Medina $(d$, ANSP); Tela, 7-26 March (28, 2q, MCZ); Lancet11la, 21 Jan., 3
March (2d, MCZ); La Celba, 1-25 Jan., 23-30 March, 3 May-7 
June $\left(8 d^{\circ}, \&, C M ; 40^{\circ}, q\right.$, MCZ; $\sigma^{\circ}$, USNM); Truj1110, 30 March-8 April ( $\left.{ }^{\circ}, 29, \mathrm{CM}\right)$; Cofradla, 6-7 March ( $\$$ BMNH; \&, f?, MLZ); San Pedro Sula, 12-20 March, 9 July-27 Oct.

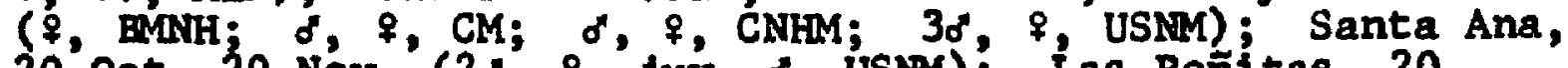
$20^{\circ}$ Oct. -20 Nov. (20, $\&$, Juv. $\delta$, USAM); Las Peñitas, 20 Jan.-11 Feb. (30, $\%$, MLz); Chamelecón, 21 Feb., 12 March ( $\sigma^{*}, 7$, USNM); $2 \mathrm{mi}$. N Amapa, 24 June ( $\sigma^{\circ,}$ UF); Coyoles, 20 June ( $7, C M)$; Plan del Rancho, 3 July ( $\left.\sigma^{\prime}, M L 2\right)$; Finca Fé, 31 Aug. -8 Sep., 27 Nov. -20 Jan. (3o, 38, 2o skel., i skel., LSUMZ); Lake Yojoa, 23 June, 17 July (o, 8, CM; o, UF); Monte Redondo, 20 sep., 18 oct. -19 Dec. ( $\left.7 \delta^{\circ}, 49^{\circ}, \mathrm{MCZ}\right)$; Archaga, 28 Nov. ( $\sigma^{*}$, AMNH); Río Hondo, 18 Aug. ( $\left.\sigma^{\circ}, C M\right)$; Cantarranas, 5 Aug. ( $\sigma^{\prime}$, ANSP); El Derrumbo, 3-9 Aug. ( $\sigma^{\circ}$, BMNH); E1 Hatillo, 8 March, 19 April (20, MCZ); Comayagüela, 4 oct. ( $\$, M C Z) ;$ Yeguare River Valley, 4 March ( ${ }^{\circ}$, UF); Choluteca River, Dept. EI Paralso, 13 Féb. ( $\alpha$, UF); Río Cobr1, 26 March ( $\sigma^{\circ}$, UF); Jamastrán Valley, $20 \mathrm{Feb}$. ( $($, UT); $10 \mathrm{~km}$. N Sabana Grande, 14 Aug. ( $\left.\sigma^{\circ}, \mathrm{CM}\right)$; Honduras Nicaragua boundary [near Pacific coast] (?, MCZ); "Honduras" (?, ANSP). I. s. costaricens 1s (4): Arenal, 20-21 Jan. ( $\sigma^{\circ}, \%$, UCLA); Segovia River, $12-19$ June (20, USNM).

PUBLISHED RECORDS.--San Pedro region (Sclater and Salvin, 1870b: 837). Segovia River (Ridgway, 1888c: 589). San Pedro (Sclater, 1888: 331). La Celba, Yaruca (Bangs, 1903: 149). Santa Ana, San Pedro Sula (Ridgway, 1907:

872). San Pedro Sula (Hellmayr, 1929: 215). Lancetilla, Tela (Peters, 1929b: 453-454). Cantarranas, Te1a (Stone, 1932: 325). La Celba (Delgnan, 1936: 191-192).

The Masked Tityra is a resident in the lowlands of both coasts of Honduras and in the Interlor below 5,000 feet elevation. The species is an inhabitant of seni-open situations, usually staying high in trees; it is found in both humid and arid lowlands, generally requiring only broadleaf trees of some sort in the habitat. It is fairly common in the monsoon forests of the Pacific slope and in the vega forests along the rivers in the interior, entering pine-oak associations and edges of cloud forest on occasion. On the Caribbean slope it 18 a common bird in most humid, semi-open situations. 
Northern Honduran populations are referable to the

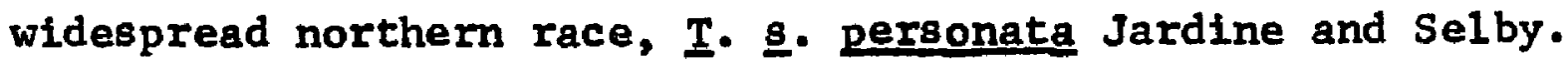
Although most Honduran populations tend somewhat to approach the southern Central American race, $\underline{T}$. $\underline{\text { s. costarlcensis }}$ Ridgway, there is a rather sharp break in characters in the Honduran Olancho. Examples from the rain forests of southeastern Honduras are both paler and smaller than personata. Howe11 (1957: 94-95) reported that specimens from northern Nicaragua were intermediate in color between the two races but closer to costaricensis in size; Olancho birds are definitely closer to costaricensis from Costa Rica in both color and size. Measurements of wings of specimens from Honduras, exclusive of those from Olancho and one aberrantly small individual from La Ceiba (wing, o, 117.9), are as follows: $\sigma, 122.9-137.0(128.3) ; \%, 118.9-128.0$ (123.3). Wings of Olancho specimens measure as follows: $\delta, 118.0-$ $124.4(120.8) ; \quad$; 122.2 .

\section{Tityra inquisitor (Lichtenstein)}

Black-crowned Tityra

SPEC IMENS. --T. 1. fraserit (19): La Ceiba, 15-23 May

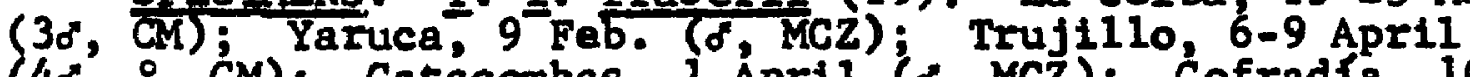
(40", ${ }^{\circ}, C M$ ); Catacombas, 1 Ápril (", MCZ); Cofradía, 10 March ( $\%$, MCZ); San Pedro Sula, 4 Aug. ( $\mathrm{imm}$. 6, USNM); Coyoles, 13 June, 1 July $\left(20^{\circ},{ }^{\circ}, C M\right)$; Finca Fé, 25 Nov, -1 Dec. (2\$, LSUMZ); EI Boquerón, 1 Oct. ( 8 , AMMH); Segovia River, 5 Aug. (d", USNM).

PUBLISHED RECORDS.--San Pedro region (Sclater and Salvin, 1870b: 837) . Segovia River (Ridgway, 1888c: 589). San Pedro (Salvin and Godman, 1890: 120). Yaruca (Bangs, 1903: 149). 
This tityra is resident on the Caribbean slope of Honduras and is much less common than $I$. semifasciata. It occuples much the same sort of habitat as the latter but is confined to humid situations below 2,500 feet elevation. It is uncommon to fairly common in Honduras.

Although this species is sometimes placed in a distinct genus, Erator, I am maintaining it in Tityra pending completion of ethological and anatomical studies.

Honduran populations are typical of the widespread Middle American race, I. 1. Eraseril (Kaup).

Procnias tricarunculata (J. and E. Verreaux) Three-wattled Bellbird

SPECIMENS.--(11): E1 Boquerón, 22 Aug.-25 oct. ( $90^{\circ}$, o? , MCZ); Arena1, 13 Jan. ( $\%$, UCLA). 233).

PUBLISHED RECORD.--"Honduras" [in range] (S1ud, 1964:

Although this species is regarded as an inhabitant of the highlands of southern Central America from Nicaragua to Panama, it occurs at medium elevations in the rain forests of Olancho, where it is a regular but uncommon resident. C. F. Underwood obtained a fine series at E1 Boquerón in 1937, collecting two males on 22 August, three males on 23 September, single males on 29 September, 4 October, 13 October, and 14 October, and a female-plumaged bird (sexed male on the label) on 25 October. T. R. Howell secured a female at Arenal in 1955. Slud's (1964: 233) inclusion of Honduras in the range is based on the above records. 
Family TYRANNIDAE

Sayornis nigricans (Swainson)

Black Phoebe

SPECIMENS. --S. n. aquatica (23): La Ceiba, 27 April,

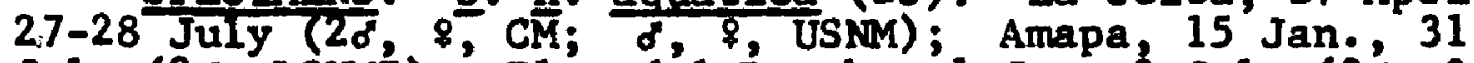
July (2 ${ }^{\circ}$, LSUMz); Plan dél Rancho, 1 June-8 July (28, ?, MIZ); Cantora 1, 24 March (o, MCZ); Archaga, 20-26 Sep. (20", AMNH); La Flor Archaga, 29 March, 15 Oct. (29, MCZ); Tegucigalpa, 26 March (2o, 2\%, MLZ); Comayagüela, 26 March (?, AMNH); Rfo Cobri, at Morocell, $24 \mathrm{March}$ (o, UF); Río Cobrí, 22 Jan. ( 9 , UF); near Yuscarán, 21 April ( $q$, UF).

PUBLISHED RECORDS.--Cantarranas (Stone, 1932: 322). La CeIba (Delgnan, 1936: 192).

Widespread but uncommon in Honduras, the Black Phoebe is resident along streams from sea level to at least 4,000 feet elevation. It occurs in both arid and humid regions but almost invariably along watercourses. During 1962-1964 I noted the species on several occasions along small streams at Río Lindo and at Amapa, and also along the Rio Jaitique near Taulabé.

The record from Cantarranas (Stone, 1932: 322) was based on a single bird observed by John T. Enlen, Jr.; no specimen was taken there.

Honduran individuals are representative of the Middle American race, $\underline{S}$. $\underline{n}$. aquatica Sclater and Salvin.

\section{Colonta colonus (Vieillot)}

Long-tailed Tyrant

SPECTMENS. - -C. c. Le leuconota (4): Arenal, $15 \mathrm{Jan}$. (d, \%, UCLA); Segovia RIver, 15 June ( 8,8 , USNM). 

589).

PUBLISHED RECORD.--Segovia River (Ridgway, 1888c:

The Long-tailed Tyrant is another of the lowland rain forest species that reach their northern limit of distribution in the Olancho of southeastern Honduras. This species is usually found in semi-open situations. In Honduras it has not been recorded above 1,200 feet.

C. H. Townsend (Ridgway, 1888c: 589) obtained the fixst two Honduran specimens, a pair along the Río Segovia In 1887. J. G. Montrello collected another pair at Arenal in 1954. There are no other Honduran records.

The Honduran specimens are referable to the widespread northern race, $\underline{c}$. c. leuconota (Lafresnaye).

\title{
Pyrocephalus rubinus (Boddaert)
}

\section{Vermilion Flycatcher}

\author{
SPECTMENS.--P. E. Subsp. nov. (6): Segovia River, 12 \\ June, 17-19 Juiy $\left(40^{\circ}, 9, ?\right.$, USNM). \\ 589). \\ PUBLISHED RECORD.--Segovia River (Ridgway, 1888c:
}

There are a number of species of birds inhabiting the lowland pine savannas of northern Central America that possess a disjunct distribution in the Honduran region. Many of these species occur in the pine ridges of central British Honduras and do not recur until the Mosquitia in eastern Honduras and northeastern Nicaragua. The Vermilion Flycatcher is a bird with such a range. It apparently is resident in Honduras only in the lowland pine savanna of the 
Mosquitia, where it is fairly common. A single male observed on the golf course at La Lima from 21 October to 4 November 1964 by Kenneth S. Hamilton was probably a vagrant from a northern population.

The only Honduran specimens are the series obtained by C. H. Townsend (Ridgway, 1888c: 589) along the Rio Segovia in 1887. He collected a pair on 12 June, three males on 17 July, and a sixth individual (of questionable sex) on 19 July, Although I falled to observe Vermilion Flycatchers in the Mosquitia in February 1963 or Apr11 1964, personnel at the Pure 011 Company camp at Puerto Lempira described males that were seen from time to time in the vicinity of the camp. T. R. Howell (personal communication) informed me that the species is locally fairly common in the Nicaraguan Mosquitia.

Honduran examples are currently assigned by most authors to the British Honduran race, $E_{\text {. }} \underline{x}$. blatteus Bangs, from which I cannot distinguish the Río Segovia specimens. However, T. R. Howell informed me that comparison of freshly acquired material shows that Mosquitia populations differ from those of British Honduras and represent an undescribed race. Howell is currently in the process of describing this new subspecies. 


\section{Muscivora forficata (Gmelin)}

\section{Scissor-tailed Flycatcher}

SPECIMENS.--(16): La LIma, 1 Nov. (o, LSUMZ); Comayagüela, 6 Nov.-10 Jan. ( $30^{\circ}, 8$, AMNH; 40, ?', MCZ); Escuela Ágrícola Panamericana, 5 March, 14 Aug. ( $\%, ?$, UF); Sabana Grande, 27 Feb. (20, AMNH); San Lorenzo, 25 Sep. ( $q$, MLZ); 13 mi. W Choluteca, 1 oct. ( $\sigma$, LSUMR).

PUBLTSHED RECORD.--"Honduras" [= Langue] (Sclater, 1859a: 439-440). Langue (Taylor, 1860: 114).

Despite the relative scarcity of published records and specimens from Honduras, the Scissor-tailed Flycatcher is a common to abundant migrant and winter visitant in the arid Pacific lowlands and arid interior valleys, occuriing below 3,500 feet. It also has been found in open situations in the humid Caribbean lowlands but is decidedly uncommon to rare there. Extreme dates of arrival and departure for Honduras are 14 August and 5 March.

During the fall and winter of 1962-1963, the species was a dominant part of the avifauna of the arid Pacific lowlands of Honduras. On 1 February 1963 I witnessed the largest migratory movement of this species that I have ever seen. From early morning until dusk, numbers of these birds were flying in off the Bay of Fonseca in the San Lorenzo region headed in a northerly direction, presumably having come from the Cosagüina Peninsula in Nicaragua. From my vantage point overlooking the bay at Puerto Salamar, flycatchers mixed with a few Western Kingbirds (Tyranmus verticalis) could be seen for miles to the east and west. An estimated 4,000 scissor-talled Flycatchers passed within 
one mile of Puerto Salamar that day. In the interior, residents recalled large movements of this species in recent years through the Comayagua and Otoro valleys.

\section{Muscivora tyrannus (Linnaeus)}

\section{Fork-tailed Flycatcher}

SPECIMENS.--M. t. monachus (21): $3 \mathrm{mi}$. S Chamelecón, 18 Jan. ( ${ }^{\circ}$, LSLMZ); Subirana, 27 Jan., 24 March (28, MCZ); Coyoles, 30 June $\left(0^{\circ}, C M\right)$; San Es teban, 22 June $\left(20^{\circ}, 49\right.$, CM); Agua Azul, 12-14 Aug. (?, AMNH; 8,29 UF); Lake Yojoa, 19 June $(\sigma, 2 \%, C M)$; Alto Guaimaca, $9-11$ June ( $2 \sigma^{\circ}$, AMNH); 1 mi. S Escuela Agrícola Panamericana, 18 June ( $\sigma^{\circ}$, MCZ); Puerto Lempira, 9 April (o' skel., LSUMZ).

PUBLISHED RECORDS.--Lake Yojoa (Sclater, 1858b: 358). Comayagua, Omoa (Moore, 1859: 55-56). Plain of Comayagua, near Langue; Agua Azul, near Lake Yojoa (Taylor, 1860: 114). Agua Azul (Zimner, 1937a: 11).

The Fork-tailed Flycatcher is an uncomon to locally fairly common resident in open situations on the Caribbean slope and in the interior, ranging up to 3,500 feet. Most common in a savanna habitat, it occurs in moderate numbers in the Sula, Quimistán, Comayagua, Aguán, Agalta, Olancho, and Yeguare River valleys, as well as in the lowland pine savanna of the Mosquitia. Although according to Zimer (1937a: 5-7) direct evidence of migration in Central American populations is lacking, at least some local movement of the species certainly takes place. It appears suddenly in areas from which it has been absent and is often irregular in known breeding areas from year to year as well as season to season. It has, however, been recorded in Honduras at all seasons. 
Honduran birds are referable to the Central American race, $\underline{M}$. $\underline{t}$. monachus (Hartlaub), a subspecies resurrected by Zimmer (1937a: 5-7).

\section{Tyrannus tyrannus (Linnaeus)}

Eastern Kingbird

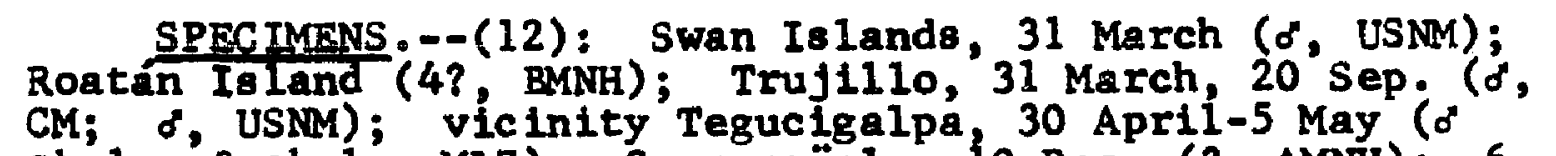
skel., q skel., MLZ); Comayagüela, 10 Dec. (?, AMNH); 6 m1. NE Choluteca, 12 oct. (?, LSUMZ); "Honduras" (?, ANSP).

PUBLISHED RECORDS.--Omoa (Moore, 1859: 55). San Pedro region (Sclater and Salvin, 1870b: 837). Trujil1o (RIdgway, 1888c: 580). Swan Islands (Ridgway, 1888c: 576) Roatán Is land (Sclater, 1888: 268; Salvin, 1889: 362-363). San Pedro (Salvin and Godman, 1889: 983).

Occurring in Honduras on both coasts and in the interior below 3,500 feet, the Eastern kingbird is a fairly common to uncommon migrant and rare winter visitant. It is most abundant along the north coast and in the islands in the Caribbean Sea. On the Pacific coast it is uncommonly observed and is greatly outnumbered by $T$. verticalis. Extreme dates of arrival and departure in Honduras are 7 September and 7 May.

On 19 Septenber 1962 I witnessed an incoming flight along the north coast about one mile inland from Puerto Cortés. At about $10 \mathrm{a} . \mathrm{m}$., several hundred Eastern Kingbirds passed over headed south; many dropped down to rest and a few scattered trees were covered with kingbirds. On the Pacific coast I observed about 40 individuals on 12 October 1962, the largest group noted in the Pacific 
lowlands. In the spring of 1963 I saw a pair on Little Hog Is land on 6 April and about 50 on Utila Island on 4 May.

Tyrannus vociferans Swainson

Cassin's kingbird (o, MCZ).

SPECTMENS.--I. y. vociferans (1): Comayagüela, 18 Nov.

The Cassin's Kingbird breeds in western North America and has been known to winter regularly as far south as Guatemala. C. F. Underwood obtaIned a male at Comayagüiela In 1931, the only Honduran record. Although I searched for this species among the hundreds of $T$. verticalis present in Honduras in winter, I did not observe the Cassin's Kingbird during 1962-1964. It is probably a regular but rare visitant to the Honduran highlands in winter.

The single specimen is referable to the widespread nominate race, $\underline{I} \cdot \underline{v}$ vociferans Swainson.

\section{Tyrannus verticalis Say}

Western Kingbird

SPECTMENS.--(19): Catacombas, 30 March (7, AMNH); Cofradia, 7 March ( $\left(\right.$, AMNH); $6 \mathrm{ml}$. S Comayagua, 19 Nov. ( ${ }^{*}$, ISLMZ); Monte Redondo, 2 April, 23 Nov. -15 Dec. $\left(\sigma_{2}^{2} \%\right.$, AMNH; J, MCZ); Comayagüela, 27 Jan., 23 July, 1-27 Nov. ( $\$$, AMNH; 30, 6\%, MCZ); Yeguare River Valley, 21-27 Jan., 16 Nov. (d, 2\%, UF).

Although there are relatively few specimens and records of Tyrannus verticalis from Honduras, the species is one of the commonest migrants in the Pacific lowlands. It is 
fairly common in migration and in winter in the interior highlands (ranging up to 3,500 feet) and in the arid interlor valleys on the Caribbean slope, though in the humid Caribbean lowlands it is a decidedly rare transient. There are recent sight records from the Swan Is lands also (Bond, 1959: 9). Extreme dates of arrival and departure for Honduras are 23 July and 2 April.

In late January and early February 1963, moderate numbers of this species passed daily over Puerto Salamar heading in a general northerly direction. Most of the migration occurred from two hours before sunset until it was almost dark. On 10 February an estimated 500 individuals were recorded, the largest number observed in one day. The inclusion of Honduras in the range given by Eisenmann (1955a: 66) was based on Underwood specimens in the American Museum of Natural History. Observations by Charles H. Blake (Bond, 1959: 9) on Big Swan Is land on 5, 11, and 26 November 1958 indicate that the species is partially a trans-Gulf migrant.

\section{Tyrannus melancholicus Vieillot}

\section{Troplcal Kingbird}

SPECTMENS--T. m. chloronotus (66): Tela, 5-8 March (d, 2\%, MCZ); Lancetilla, 16 Jan. -26 Peb., 24 Aug, -8 Sep. ( ${ }^{\circ},{ }^{\circ}$ ANSP; $3 \sigma^{\circ}, ?$, MCZ); La Celba, 2-24 Jan., 26 Aprt1-18

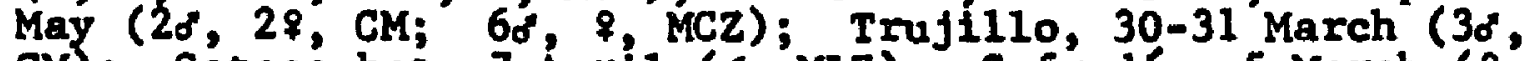
CM); Catacombas, 7 April (d, MLZ); Cofradla, 5 March ( 7 , MIZ); San Pedro Sula, 8-23 July (28, USNM); Las Peñitas, 30 Jan. (o, MLZ); Subirana, 24-26 Jan., 15-17 March, 10 Dec. (3d, 2\%, MCZ); Coyoles, 30 June-9 July ( ${ }^{\circ}, 29$, CM); San Esteban, 30 June $\left(\sigma^{\circ}, \mathrm{CM}\right) ; 1 \mathrm{ml}$. SW Lucerna, $27 \mathrm{Feb}$. ( $\sigma^{\circ}$, 
LSUMZ); Finca Fé, 20 Feb., 14 Dec. ( $q$; skel., LSUMZ); Agua Azul, 14 Aug. (d, UF); $10 \mathrm{ml}$. N Siguatepeque, 11 July ( $\delta$, CM); Cantarranas, 20 July-10 Aug. (3o, 2\%, ANSP); vićintty Tegucigalpa, 30 April (o skei., MLz); Comayagüela, 3-12 Nov. (28, MCZ); Madre Vieja, 7 Nov. ( $($, UF); Escuela Agrícola Panamericana, 31 May, $26^{\prime}$ oct. ( $\sigma^{\prime}, 9$, ? UF); Rfo de La Orilla, 2 June ( 8, MCZ); Segovia River, 12-19 June ( 6 , 7 , USNM); Puerto Lempira, 8-12 April (2\%, LSUMZ); San Lorenzo, 26 Sep. (o, \&, MLZ); Puerto Salamar, 13 Feb., 28 Sep. -2 oct. (o', $2 \%$, skel., LSUMZ); $12 \mathrm{ml}$. W Choluteca, 2 Oct. (d, LSTNZ).

PUBLISHED RECORDS.--Omoa (Moore, 1859: 55). "Honduras h (Taylor, 1860: 113; Skutch, 1954b: 24). San Pedro region (Sclater and Salvin, 1870b: 837). Segovia Rtver (RIdgway, 1888c: 589). San Pedro (Salvin and Godman, 1889: 102) La Ceiba (Bangs, 1903: 148). San Pedro Sula (R1dgway, 1907: 702). Lancetilla, Tela (Peters, 1929b: 451-452): San Juancito [= Cantarranas] (Stone, 1932: 320).

Tyrannus melancholicus is a common resident in the lowlands of both coasts of Honduras and in the interior, rangIng up to an elevation of about 4,000 feet. It occurs in most any type of open situation but is most abundant in the lowlands below 1,500 feet.

Stone (1932: 320) 1isted five specimens taken at "San Juancito" on various dates in June and July 1930, but these five specimens were obtained at Cantarranas on an entirely different set of dates (according to the labels). How Stone became confused in his account of this species is not known.

Al1 Honduran specimens are typical of the resident Middle American race, $\underline{T}$. m. chloronotus Berlepsch. None shows any approach to $I$. m. occidentalis Hartert and Goodson, a Mexican race that winters south to Guatemala. 


\section{Tyramus dominicensis (Gmelin)}

\section{Gray Kingbird}

March (d, MCEIMEN;--I. d. domintcensts (1): Swan Is lands, 20 Paynter, 1956: $\frac{\text { PUBLTSHED }}{\text { 105). }}$.--Swan Islands (Lowe, 1909: 339;

The Gray kingbird is a rare migrant to the Swan Is lands and probably also to the north coast of Honduras. Lowe (1909: 339) based his report from the Swan Islands on information given him by the local residents; he did not observe the species there. On 30 March 1927, however, Neal Wilson collected a male there (Paynter, 1956: 105). Bond (1937: 102) reported an observation of two individuals during a train trip from La Celba to Puerto Castilla on 15 March 1936, but he later (1954: 7) retracted this sight identification.

I refer the single Honduran specimen to the nominate race, I. d. dominicens is (Gmelin). I cannot see any constant geographical differences between the nominate race and two recently described forms, I. d. Eugax Brodkorb [1950: 335; Cedar Key, Levy County, Florida] and I. d. Bequax Brodkorb [1950: 337; Nueva Gerona, Is le of Pines]. Brodkorb recorded fugax from the Cayman Is lands and seguax from the Cayman Islands and from Greytown, Nicaragua. 


\section{Legatus leucophaius (VIelllot)}

\section{Piratic Flycatcher}

SPECIMENS. - -L. 1. 1eucophaius $\times$ variegatus (4): San Alejo, 3 AprII (2 , LSUMZ); San Jose de Santa Barbara, 30 April (o, \&, MCZ).

Although previously unrecorded from Honduras, the Piratic Flycatcher is a fairly common sumer resident of the rain forests on the humid Caribbean slope, occurring below 3,500 feet. C. F. Underwood secured the first Honduran specimens, a pair from San José de Santa Bárbara in 1935. Mark Trafton, Jr., and V. C. Dunlap observed the species annually at La Lima, Lake Yojoa, and Lancetilla from 1951 through 1961. Paul Slud recorded it at Lancetilla in June 1952. Trafton noted nesting at Lancetilla and La Lima during the months of May and June. In all instances the Piratic Flycatchers occupied nests built by Tolmomylas sulphurescens. In six cases Trafton actually observed the Piratic Flycatchers driving $\underline{\underline{T}}$. Sulphurescens from completed nes ts .

In the spring of 1963 I recorded three individuals at San Alejo on 3 April and one on the following day. The two specimens collected on 3 April were very fat and may have been transients, although their smaller slze indicates that they were part of the resident population. The species is definitely absent from Honduras in the winter; extreme dates of arrival and departure are 9 March and 20 August (Trafton). 
The populations from Mexico and Guatemala have been separated as L. 1. variegatus (Sclater) on the basis of larger size. The smaller nominate race, $L \cdot 1$. Leucophaius (Vielllot), ranges from Nicaragua southward. The Honduran specimens seem to be intermediate in size between the two (wing: $5,87.1-91.3$ ). An adequate series may show that the size variation is entirely clinal or possibly that the species should be monotypic. Until more material is available, however, I am considering the Honduran birds to be intermediate.

\section{Myiodynastes luteiventris Sclater}

Sulphur-bellied Flycatcher

SPEC IMENS.--(57): Medina (2?, ANSP); Lancetilla, 2831 March, 24 Aug. (?, ANSP; 20, $\$$, MCZ); La Ceiba, 26 March-6 June (100, 6\%, CM; 20, USNM); Trujillo, 7 April (₹, CM); Amapa, 28 April, 18 Sep. ( $\$$, imm., LSUMZ); Coyoles, 14-29 June ( $\left.0^{\circ}, \&, C M\right)$; San Es teban, $30^{\circ}$ June ( $\left.0^{\prime}, C M\right)$; Las Ventanas, 27 July ( 9 , MLZ); Finca Fé, 18 July-12 Aug. (2ه, \& skel., alc., LSUMZ); Lake Yojoa, is June-28 July (30, $\$$, CM; $0^{\circ}$, UF); E1 Caliche, 12-20 July ( $0^{\circ}, \%$, AMNH); Archaga, 4 Aug. ( 9 , AMNH); La Flor Archaga, 12 April, 17 June, "Dec." $\left(20^{\circ}, q\right.$, AMNH ; Cantarranas, 20 July ( $0^{\circ}$, ANSP); E1 Hati11o, 28 Apri1-2 May (28, \&, MCZ); Capa Rosa, 25 April ( $0^{\circ}, q$ UF); Choluteca River, Dept. El Paraiso, 11 Aug. ( $\sigma^{\circ}$, UF); Río de La Or11la, 2 June ( $q$, UF); Dan1f, 7 April ( $\delta$, BMNH); Segovia River, 12 June ( $\$$, USNM); "Honduras," 1 Aug. ( $\%$, UF).

PUBLISHED RECORDS.--San Pedro region (Sclater and Sa1vin, 1870b: 837). Segovia River (Ridgway, 1888c: 589). San Pedro (Salvin and Godman, 1889: 48). Lancetilla, Tela (Peters, 1929b: 448-449) Cantarranss, Lancetilla (Śtone, 1932: 320). La Ceiba (Deignan, 1936:'192).

In Honduras the Sulphur-bellied Flycatcher is a common summer resident in the lowlands of both coasts and in the intertor, ranging up to an elevation of 3,500 feet. It 
occurs in open forest and in semi-open sttuations around broadleaf forests. Extreme dates of arrival and departure In Honduras are 9 March (Trafton) and 18 September (Monroe). There is one Underwood specimen from La Flor Archaga dated "Dec., 1935," but the label may be in error; the omission of the day infers that the label was prepared a considerable time after collection of the individual.

Mark Trafton, Jr., has recorded the species as nesting regularly at La Lima, Lancetilla, Los Dragos, and Lake Yojoa in the months of April, May, and June. Two nests observed at Lancetilla were in holes in palm trees.

The species is migratory throughout its Middle American range, breeding birds leaving in late summer or fall and spending the winter in South America.

The northwestem breeding population in southern Arizona has been separated as a distinct race, $M$. 1 . gwarthi van Rossen, based on its supposedily paler yellow under parts and narrower dark streaking below. I cannot see any distinct difference between breeding Arizona populations and those of Mexico with regard to yellowness of the under parts, and the amount of streaking below is subject to much Individual variation. At any rate, migrants and wintering individuals cannot be assigned on any basis. I can see no reason for recognizing swarthi and therefore regard the species as monotypic. 


\title{
Mylodynastes maculatus (Müller)
}

Streaked Flycatcher

\begin{abstract}
SPECIMEN.--M. m. Insolens (1): San José de Santa Bár-

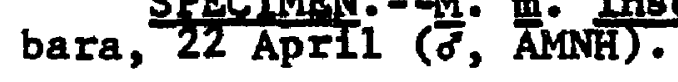

The Streaked Flycatcher is an uncoumon sumer resident found in lowland rain forests on the Caribbean slope of Honduras. Its habitat preferences are not visibly different from those of its sibling species, M. 1uteiventris. The two species occur together but $M$. maculatus is much less numerous .

C. F. Underwood collected the only known Honduran specimen at San José de Santa Bárbara in 1935. Mark Trafton, Jr., noted the species annually between April and August during the years from 1952 through 1960; he observed the bird at Lancetilla, La Lima, and Lake Yojoa. Although Trafton failed to find a nest, actions of the species indicated that it was breeding locally. He did observe an individual fighting with a Sulphur-bellied Flycatcher, presumably over a nest cavity. V. C. Dunlap also recorded the 8pecies at Lancetilla in May of 1952, 1953, and 1958.

The call-note of $M$. maculatus is different from that of M. Lutelventris. According to Trafton, the Streaked Flycatcher has a series of four or five whistled notes, all tending to rise in pitch, the first more prolonged than the others. M. Luteiventris gives a sneezy but loud doublenoted call, the last note lower in pitch than the first. 
Eisenmann (1955a: 66) did not exclude Honduras from the range of the species (although he did not mention Honduras specifically) since he was aware of the existence of the Honduran specimen.

The single specimen from Honduras is representative of the northern race, $\underline{M} \cdot \underline{m}$. insolens Ridgway.

\section{Megarymchus pitangua (Linnaeus)}

Boat-billed Flycatcher

SPECTMENS. - -M. D. mexicanus (45): Lancetilla, 9 Feb., 3 March, 21-29 Aug. (20, $\%$, ANSP; $20^{\circ}, 7$, MCZ); La Celba, 13-16 Jan., 28 April-15 May (2o, CM; 30, MCZ); Yaruca, 14 Feb. ( $d$, MCZ); San Pedro (?, BMNH); Choloma (?, KAS); Subirana, 12-13 March (20, MCZ); Coyoles, 11 July ( $\$$, CM); Plan del Rancho, 30 June-2 July ( $\left.0^{\circ}, 9, M Z Z\right)$; Finca Fé, 27 Aug .-14 Sep., 2-7 Dec. ( ${ }^{\circ}, 39,{ }^{\circ}$ skel., Lsunz); Lake Ýojoa, 23 Aug. ( $\left.0^{\circ}, C^{\circ}\right)$; El Caliche, 27 June, 16 July (20, AMNH); San Marcos de Guaimaca, 29 June ( $\sigma^{\circ}$, Miz); Monte Redondo, 23 Nov. (o', MCZ); E1 Hatillo, 8 May ( 9, MCZ); Comayagüela, 18-28 June, 1 Oct., 12 Nov. ( $\%$, AMMN; o'?, MCZ); Yeguare River Valley, 20 Jan., 12 May (2d, UF); Río Choluteca, Dept. El Pará́so, 19 May (\%, MCZ); Arenal, 16 Jan. ( 6 , UCLA); Segovia River, 8 Aug ( $f$, USNM); San Francisco, Choluteca, 11 oct. ( 9 , LSUMZ); $13 \mathrm{mi}$. SW San Marcos de Colón, 13 oct. ( $\%$, LsumZ); Honduras-Nicaragua boundary [near Pacific coast] ( 3 ?, MCZ); "Honduras" (alc., USNM).

PUBLISHED RECORDS.--Taulabé (Sclater, 1858b: 358; Taylor, 1860: 113). San Pedro region (Sclater and Salvin, 1870b: 837). Segovia River (RIdgway, 1888c: 588). San Pedro (Sclater, 1888: 191). Choloma (Lantz, 1899: 221). La Celba, Yaruca (Bangs, 1903: 148). Lancetilla (Peters, 1929b: 449; Stone, 1932: 320). Pian del Rancho, San Marcos de "Guaymas" [= Gualmaca] (Moore, 1941: 37).

In Honduras the Boat-billed Flycatcher is a fairly common resident in the lowlands of both coasts and in the interior, occurring up to an elevation of 5,000 feet. It inhabits open forest, semi-open situations, and second growth, usually staying at fairly high levels above the 
ground. Although it can be found in most any type of broadleaf tree situation, it is most plentiful in areas along rivers and streams.

Taylor (1860: 113) reported this species as common on the Caribbean slope from Taulabe to the coast, but he failed to mention the very similar and much more common Pitangus sulphuratus; his observations certainly must have included individuals of both species.

Honduran specimens are all representative of the widespread Middle American race, M. R. mexicanus (Lafresnaye). None is referable to the slightly paler race, M. . deserticola Griscom [1930b: 4; Sacapulas, 25 miles east of Nebaj, In the arid Rio Negro Va1ley, Guatemala], which is confined to the arid interior valleys in Guatemala.

\section{Myiozetetes similis (Spix)}

Social Flycatcher

SPECIMENS.--M. B. texens 18 (72): Medina (?, ANSP); Tela, 13 March ( $\%$, MCZ) Lancetilla, 16 Jan. -4 March, 19-30

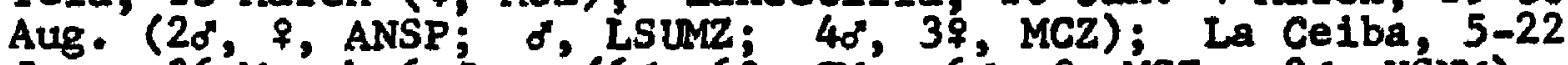

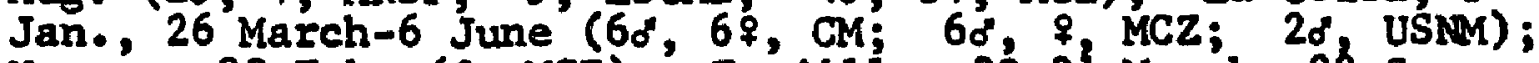
Yaruca, 23 Feb. ( $F$, MCZ); Trujilio, 30-31 March, 22 Sep. (20, \&, CM; ?, USNM); Catacombas, 29 March-5 April ( $\sigma^{\circ}, 2 \%$, MIZ); 'San Pedro (?, BMNH); Las Peñttas, 4 Feb. (d, BMNH); Chamelecón, 23 Sep.' ( $\delta$, AMNH); Amapa, 29 Nov. ( $\delta$, LSUMZ);

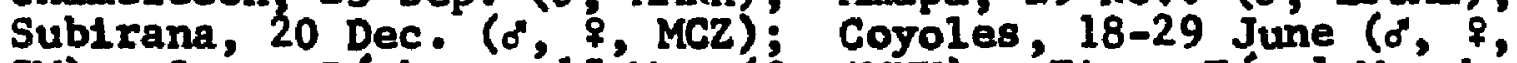
CM); Santa Bárbara, 15 May ( $\$$, AMNH); 'Finca Fé, 1 March, 29 Nov. (29, LSUMZ); Cantarranas, 3-4 Aug. (20, ANSP); E1 Hat11lo, 2 May (o, MCZ); Tegucigalpa, 4 June, 17-18 oct. (20, ${ }^{\circ}$, AMNH) ; Comayaguiela, 13 oct., 13 Nov. (20, \&, MCZ); Madre Vieja, 22 Nov. ( $d$ ? , UF); Yeguare River Valley, 4 June, 7 Sep., 29 Dec. ( $2 \delta^{\circ}, q^{2}$ UF); Segovia River, 23 June (o, USNM); Puerto Lemp1ra, 14 Apri1 (o, LSUMZ); San Lorenzo, 6 oct. ( $\%, M C Z$ ); Honduras-N1caragua boundary [near Pacific cosst] (?, MCZ); "Honduras" (?, AMNH; alc., USNM). 
PUBLISHED RECORDS. --Omoa (Moore, 1859: 56). San Pedro region (Sclater and Salvin, 1870b: 837). Trujillo, Segovia River (RIdgway, 1888c: 580, 589). San Pedro (Sclater, 1888: 163). La Celba, Yaruca (Bangs, 1903: 148). Lancetilla, Tela (Peters, 1929b: 447-448). Cantarranas, Lancetilla (Stone, 1932: 320). Chamelecón (2immer, 1937b: 22). Near Tela (Skutch, 1945a: 20; 1960: 432).

The Social Flycatcher is one of the most conspicuous species in the lowlands of both coasts of Honduras and in the interior below 3,500 feet. It is a common to abundant bird of open forest and semi-open situations and is regular around human habitation, including in the larger towns.

Skutch (1960: 432) described a nest found near Tela on 15 May 1930; it was placed beneath a railroad tie on a trestle above a small stream.

Honduran specimens are typical of the widespread Middle American race, $\underline{M}$. S. texensis (Giraud). The use of the name texensis in preference to the older $\underline{M}$. 8 . superciliosus (Bonaparte) has been discussed by Zimmer (1937b: 20-21).

\section{Myiozetetes granadens is Lawrence}

Gray-capped Flycatcher

SPECTMENS.--M. g. granadens is (3): Río Guampí, $10 \mathrm{mi}$. E Dulce Nombre de Culmi, 31 March ( $\$$, LSUMZ); Arena $1,17-19$ Jan. (20, UCLA).

PUBLISHED RECORD.--"Extreme southeastern Honduras" [ In range] (SIud, 1964: 247).

This flycatcher belongs to the large group of tropical lowland species that reach their northern limit of distribution in 0lancho in eastem Honduras. The Gray-capped Flycatcher occupies the same general habitat as M. Similis, but 
in Honduras $M$. granadensis is a much rarer bird and is restricted to humid, heavily forested regions. It is known from Honduras by the three specimens 11 sted above, two males taken by T. R. Howell at Arenal in 1955 (one each on 17 and 19 January) and a female collected by Richard R. Graber along the Río Guampi in 1963.

Sclater (1871b: 754) mentioned that he had a specimen of M. granadensis from Honduras, but I was unable to find any such specimen in the British Museum collections in 1961. This reference has been generally ignored by subsequent authors. Slud (1964: 247) included Honduras in the range of the species on the basis of the known spectmens.

Interspecific relationships, including differences in call-notes, have been discussed by Howell (1957: 95).

The three Honduran specimens are typical of the widespread nominate race, M. g. granadens is Lawrence.

\section{Pitangus sulphuratus (Linnaeus)}

Great Kiskadee

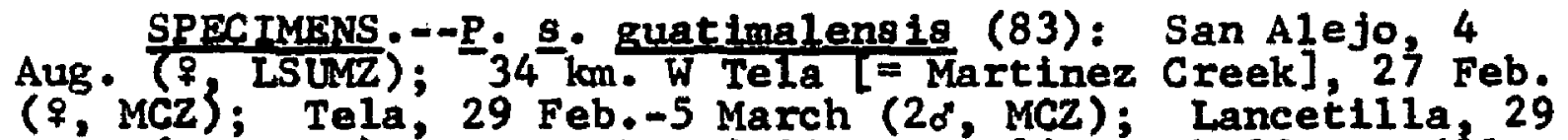
Aug. ( 5 , ANSP); La Ceiba, 2-23 Jan.; 26 Maxch-23 May (110", 2\%,?, CM; 17\%, 59, MCZ; 50, USNM); Trujillo, 31 March-9 April, 20-21 Sep. (28, CM; $q ?, ?$, USNM); Cofradla, 7 March ( $\$$, AMNH); San Pedro Sula, 30 July (?, BMNH; o, CM; $\delta$, USNM); Coyoles, 16-29 June (3\%, CM); $3 \mathrm{mi}$. E Copán, 5 Dec. (o' skel., LSuMz); Finca Fé, 30 Nov. ( $\$$ skel., LStazz); Agua Azul, 12 Aug - ( $q$, UF); Lake Yojoa, 23 Aug. ( $\$, C M)$; Cantarranas, 20 July-4 Aug. (3\%, ANSP); Teguclgalpa, 25 June ( $\sigma, 7$, AMNH); Comayaguiela, 9 oct.-2 Jan. ( $\left.30^{\circ}, 2 \%, \mathrm{MCZ}\right)$; Escuela Agrícola Panamericana, 13 March (d, UF); Capa Rosa, 8 June ( $\sigma^{\prime}, \mathrm{MCZ}$ ); Yeguare River Valley, $13 \mathrm{Feb}, 18 \mathrm{May}, 16$ Nov. (o, 28, UF); Rlo Choluteca, Dept. E1 Paralso, 23 Jan. 
( $\sigma^{\circ}$, UF); Segovia River, 2-18 June ( $0^{\circ},{ }^{\circ}$, USNM); San Lorenzo, 26-27 Sep. ( 7 , AMNH; $\delta$, $\&$, MLZ); $2 \mathrm{ml}$. SE Nama8 igüe, 8 0ct. ( 9 , LsimZ).

PUBLISHED RECORDS---Omoa (Moore, 1859: 56). San Pedro region (Sclater and Salvin, 1870b: 837). Trujillo, Segovia River (RIdgway, 1888c: 580, 589). San Pedro (Sclater, 1888: 176). La Celba, Yaruca (Bangs, 1903: 148).

In Honduras the Great Kiskadee, or Derby Flycatcher, is another common and conspicuous spectes of the lowlands of both coasts and the interior, ranging up to 3,500 feet. It Is a spectes of the semi-open, occurring commonly along forest edge, in most open situations with scattered trees or scrub, and along streams. It often enters towns and villages and is found alongside the similarly patterned Myiozetetes similis. In forest and streamside habitats it is found with Megarynchus pitangua, another species with the same general color pattern.

Honduran populations are referable to the race $\underline{\underline{P}} \cdot \underline{\mathbf{s}}$. guatimalens is (Lafresnaye). No Honduran specimen approaches the supposedly paler race, ‥ ․ pallidus Griscom [1930b: 4; Sacapulas, 25 miles east of Nebaj, in the arid Rio Negro Valley, Guatemala]; this latter race may prove to be based on individual variation when an adequate series becomes avallable.

\section{Myiarchus crinitus (Linnaeus)}

\section{Great Crested Flycatcher}

SPECIMENS.--(20): Little Hog Island, 8 April ( 9 , LSLMZ); Lancetilla, 16 Jan., 26 Feb. ( $\sigma^{\circ}, 29, \mathrm{MCZ}$ ); La Celba, 11-15 Jan., 24 Aprt1 (o, CM; 20, MCZ); Truj111o, 
19-20 Sep. ( 8,3 ?, USNM); Las Feñitas, 1-2 Feb. (o', AMNH; 29, MLZ); 3 mi. E La Lima, 9 Dec. ( $9 ?$, LSUMZ); Amapa, 18 Sep. (imm. o", LSLMZ); Coyoles, 23 April (o", LSUMZ); Finca Fé, 20 Feb. (do, LSUMŹ); Archaga, 28 sep. ( $\sigma^{\prime \prime}$, AMNH); Comayagüela, 17 Nov. (ot, MCZ).

PUBLISHED RECORDS.--Truj1110 (RIdgway, 1888c: 580). La CeIba (Bang8, 1903: 148). Lancetilla (Peters, 1929b: 450).

A migrant and winter visitant in Honduras, the Great Crested Flycatcher is fairly common in the lowlands on the Caribbean slope and uncommon in the interior, ranging up to 4,000 feet. Although the only 1sland record is a specimen from Little Hog Island in the Cayos Cochinos, the species is undoubtedly also a regular migrant in the Bay and Swan 18lands. Extreme dates of arrival and departure in Honduras are 18 September and 24 April.

Size varies clinally in eastern North America, with longer-billed and larger individuals occurring in more northern localities. There is no way, however, to divide the species satisfactorily into subspecies on the basis of size without having a broad zone of intermediates. In view of this situation, I prefer to maintain the species as monotypic. Some of the existing specimens from Honduras have been previously identified by other authors as $\underline{M}$. $c$ - boreus Bang8; none can be definitely allocated to $M$. c. crinitus (Linnaeus) no matter where a division of the range is made, and most must be regarded as intermediate in size or indeterminate. 


\section{Myiarchus cinerascens (Lawrence)}

Ash-throated Flycatcher

SPECTMFNS.--M. c. Cinerascens (13): Monte Redondo, 24 Nov. -7 Dec. $\left(98^{\circ}, ?, \overline{\mathrm{MCZ}}\right.$; Puerto Salamar, $13 \mathrm{Feb}$ ( LSUMz); $3 \mathrm{mi}$. E Choluteca, $10 \mathrm{Feb}$. ( 9 , ISUMZ); $7 \mathrm{mi}$. NE Choluteca, 12 Feb. (o", LSunz).

Despite the absence of previous Honduran records, this species of Myiarchus is an uncommon to fairly common winter visitant to the Pacific slope, occurring below 5,500 feet elevation. C. F. Underwood obtained the Monte Redondo series in 1931. I collected the three individuals from the Pacific coastal lowlands in February 1963. In this region other birds presumably of this spectes were seen during October 1962 and February 1963.

Relationships between $\underline{M}$. cinerascens and $\underline{M}$. nuttingi, as well as characteristics of the two species, have been discussed at length by Lanyon (1961: 441-449). Lanyon has verified the specific identity of all examples of cinerascens and nuttingi taken in Honduras.

All Honduran specimens fall within the range of variation of the nominate subspecies, M. c. sinerascens (Lawrence). In wing length, the males measure 101.0-103.8 (102.2), the two sexed females measure 95.5 and 94.9 , and the unsexed specimen (probably a female) measures 93.7. 
Mylarchus nuttingl Ridgway

Nutting's Flycatcher

SPECIMENS. - - . . n. mutting 1 (20): Cerro Higuito, D.C.,

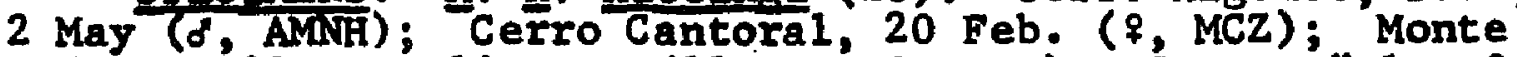
Redondo, 22 Nov. -14 Dec. (11\%, ₹, ?, MCZ); Comayagüiela, 9 oct. ( $\sigma^{\prime}$, AkNH); La Ceiba, 2 mi. NW Escuela Agricola Panamericana, 13 June ( $\$, M C 2)$; Yeguare River Va11ey, 20-27 Jan. ( $q, ?, \mathrm{UF})$; Sabane Grande, 14 Feb. ( $q$, AMNH). M. n. flavidior (4): Puerto Salamar, 13 Feb., 2 oct. (o", imm. of, LSUMZ); $8 \mathrm{mi}$. SE Namas igüe, 8 Oct. (imm., LSUMZ); Honduras-Nicaragua boundary [near Pacific coast] (?, MCZ).

PUBLISHED RECORDS.--Honduras-NIcaragua boundary "180 miles from Pacific coast" [= near Pacific coast] (Nelson, 1904: 37-38). "Choluteca Valley" [= Yeguare River Valley], "Comayagua Valley" [= vicinity of Cantoral and Monte Redondo] (Lanyon, 1961: 444).

Nutting's Flycatcher is resident in the Pacific lowlands and in the interior highlands on the Pacific slope below 5,500 feet elevation. Preferring arid conditions, the species occurs in arid scrub and in more open areas of monsoon forest and vega forest. It is fairly comnon in Honduras .

Lanyon (1961: 441-449) has discussed characteristics and interspecific relationships between $\underline{M}$. nuttingi and $\underline{M}$. cinerascens. He mentioned occurrence of nuttingt in the Choluteca and Comayagua valleys, but this allusion was probably an inference based on the existence of specimens from Cerro Cantoral, Monte Redondo, and the Yeguare River Valley area.

The interior populations of this species in Honduras are representative of the race $M \cdot \underline{n}$. nuttingl Ridgway, characterized by its smaller average size and less yellow 
under parts. Wing measurements of Honduran specimens of the nominate race are as follows: $\delta, 81.8-88.7(85.6)$; 79.7-84.8 ( 81.7$)$. In Honduras $M$. n.. nutting 1 has been taken only from 2,500 to 5,500 feet elevation. The Pacific coastal race, $\underline{M}$. ‥ Elavidior Mylarchus cinerascens flavidior van Rossem, 1936a: 116; Lake Olomega, Depto. San Miguel, El Salvador], is slightly larger and brighter yellow below; wings of the two sexed Honduran males measure 87.1 and 90.3, while the other two Honduran specimens of questlonable sex measure 83.0 and 88.0 . The race flavidior has been recorded in Honduras only below 1,000 feet.

\section{Mylarchus tyrannulus (Müller)}

\section{Brown-crested Flycatcher}

SPECIMENS.--M. t. insularum (48): Utila Is land, 7

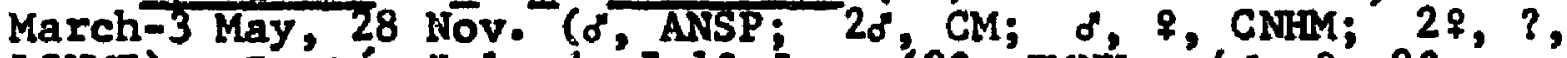
LSUMZ); Roatán Is land, 7-10 Jan. (9?, BMNH; '40', 9,2 , CNHM); French Harbor, 3-5 April (20, 59, CM); Barbareta

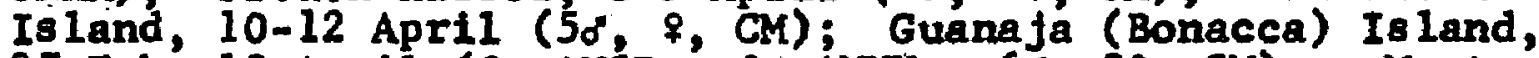

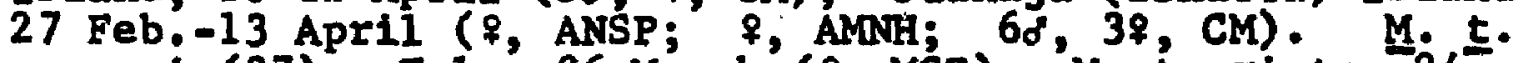
cooperi (37): Tela, 26 March ( $9, \mathrm{MCZ}$ ); Montecristo, 24 March ( ${ }^{\circ}$, LsuMz); La Ceiba, 16 Jan., 1 Apri1-29 May (7d, 68, CM; $\delta$, MCZ); Truj1110, 31 March-9 Apri1, 23 Sep. ( $\delta^{\circ}$, 9, CM; ?, USMM); Cofradfa, 7-9 March (2o, \%, MLZ); San Pédro (?, BMNH); Las Pefiltas, 21 Jan.-5 Feb. (28, \$ MLZ); Coyoles, 13 June-1 July (5o, $2 q^{\circ}$ CM); Finca Fe, 16-20 Jan. ( $28^{\circ}$, \&, LSUMZ); $22 \mathrm{mi}$. NW Valle Bonito, 2 Nov. (?, LSUMZ). M. t. cooper1 $\times$ brachyurus (22): Monte $E 1$ Cone jo, 14 May (o, MLZ); Monte Redondo, 23 Nov. -14 Dec. ( ${ }^{\circ}$, AMMH; 40, 28 , MCZ); Escuela Agrícola Panamericana, 27 Oct. ( $d$ ? , UF); Yeguare River Valley, 15 March, 11 May (o, $\%$, UF); Río Choluteca, Dept. E1 Paralso, 23 Jan. ( $q$, UF); San Lorenzo, 26 Sep. -6 Oct. ( $\sigma^{\prime}$, AMNA; $20^{\circ}, \mathrm{MLZ}$; $30^{\circ}, ?, \mathrm{MCZ}$ ); Puerto Salamar, 31 Jan. 27 Sep. (2\%, LSUMZ); $6 \mathrm{mi}$. NE Choluteca, 6 Oct. ( 6 , ISIMZ).

PUBT.TSHED RECORDS.--San Pedro region (Sclater and Sa1vin, 1870b: 837). Truj1110 (Rldgway, 1888c: 580). Roatán Island, San Pedro (Sclater, 1888: 251). Roatán Island 
(Salvin, 1889: 361-362). La Ceiba (Bangs, 1903; 148; Nelson 1904: 31-32). Roatán Island [as nélson1] (He11mayr, 1927: 163). Tela (Peters, 1929b: 450-45I). Utila Island and Bonacca [x Guanaja] Is land [as insulanum] (Bond, 1936: 361-362). Ut11a, Bonaco [= Guanaja], and Roatán is lands [as insularum] (Bond, 1939: 4). Coyoles and Trujillo [as cooperi]; Mouthern Honduras" [= Monte Redondo and San Lorenzo, as cooperf $\times$ brachyurus] (Lanyon, 1960: 348-349).

Ranging up to an elevation of about 3,500 feet, the Brown-crested Flycatcher is a fairly common to coumon resident in the lowlands of both coasts and in the interior of Honduras; It is also a common species in the Bay Islands but is absent from the Cayos Coch1nos. Northern populations of the species are known to be migratory but there is no evidence to indicate that any Honduran birds are other than residents, although there may be some local movement. The species occurs in most types of open forest in either arid or humid situations; in the interior, however, it generally is found in and around the vega forests of the river valleys.

The race $\underline{M}$. $\underline{t}$. brachyurus Ridgway was formerly considered a separate species, but Lanyon (1960: 341-350) has demonstrated intergradation of brachyurus and $M$. $t$. cooperi Baird in E1 Salvador and southern Honduras.

The Bay Islands population constitutes a distinct subspecies, M. t. Insularum Bond [1936; 361; Utilla Island, Spanish Honduras], characterized by its much darker dorsal coloration, darker than in any other Middle American race. Caribbean slope birds are typical sooperi, while populations 
from the interlor and the Pacific slope are intermediate between cooperi and brachyurus. The latter race differs in Its smaller size and the narrower fuscous stripe on the inner web of the outer rectrix (less than $1 \mathrm{~mm}$. wide at central part of feather) when compared with the larger cooper1 (fuscous stripe usually $2 \mathrm{~mm}$. or more). Wings of the populations of cooperi in Honduras measure as follows: $8,100.5-106.1$ (102.5); $7,97.0-98.2$ (97.6). Wings of spectmens from intermediate populations measure: of, 95.5$101.6(99.1) ; 9,91.1-96.0(94.0)$.

Myiarchus tuberculifer (Lafresnaye and d'Orbigny)

Olivaceous Flycatcher

SPECIMENS - - - M. t . connectens (144): Medina (?, ANSP); Tela, 28 March ( $\sigma$, MCZ) L Lancetilia, 14 Jan. -30 March, $19-$ 29 Aug - (d, ANSP; of skel., LSUNZ; 78, 78, ?, MCZ); La Ceiba, 9-24 Jan., 25 April-15 May (68, 58, CM; 98, 58, MCZ; 3。, USNM); Yaruca, 9-25 Peb. (20, 38, MCZ); Los Planes, 911 June, 13 July (4o, CM); Trujillo, 8-9 April, 19-30 Sep. ( ${ }^{\circ}, 28, \mathrm{CM} ;$ ?, ?, USNM); Catacombas, 15 March-5 April (78, 9, MLZ); Cofradía, 5-11 March ( ${ }^{\circ}, 29$, MLZ); San Pedro Sula, 17 July (?, BMaN; 9 , USNM) Las Pefiltas, 5-13 Feb. (o", BMNH; \&, MLZ); Chamelecón, $17 \mathrm{Feb}$. ( $\sigma^{\circ}$, \&, USMA); Amapa, 18 Sep. (alc., LSLaZ); Subirana, 17-20 March ( $\sigma^{*}, 2$, MCZ); Coyoles, 14-22 June (2。, 28,?, CM); E1 Chorro, 20 June ( $\delta$, MLZ); Monte El Conejo, 14 May ( ${ }^{\circ}$, ML); Plan del Rancho, 27 May-8 July (3đ, 37, MLz); Belén Gualcho, 19 July (o, ML2); Finca Fé, 1-15' Sep., 23 Kov. -19 Jan. (40, \&, 2 $1 \mathrm{~mm}$. of, 2o ske1., 2 alc., LSUMZ); Lake Yojoa, 14 June, 2628 July $\left(20^{\circ}, 39\right.$, juv. $q$, CM); $4 \mathrm{mi}$. SE La Bsperanza, 31 Oct. (imm., is uiz); E1 Caliche, 24 June, 11 July ( $d^{\prime}, \%$, AMNH); Monte Redondo, 20 Nov. -14 Dec. (20, \&, MCZ); La Flor Archaga, 25-30 May ( $8,29, \mathrm{MCZ})$; Cantarranas, 10 Aug. (8, ANSP); E1 Hatillo, 19 April-8 May, 6-12 Aug; (d, \&, CM; 26", MCZ); vicinity Tegucigalpa, 29 March (d skel., s ske1., MLz); Comayagüela, 8 March, 4 April, 4 June, 10 Oçt. (2d", ₹, AMNH; \&, MCZ); San Francisco, Francisco Morazán, 14 June ( $q$, UF); Yeguare River Valley, 8 Feb. 4-12 June ( $d$, 9, ?, UF); Puerto Lempira, 9-10 April ( $0^{\circ}$, \&, LSLaz); 10 $\mathrm{km}$. N Sabana Grande, 14 Aug. (2d, ?, CM); MHonduras" (2 
Imm., BMIH; ?, MLZ) . M. t. connectens $\times$ nigricapillus (2): Río Pataste, $12 \mathrm{mi}$. B Dulce Nombre de Culmi, 29 Jan. (\%, LSUMZ); E1 Boquerón, 3 Sep. ( ${ }^{\circ}$, AMNH). M. t. 11ttoIalis (5): San Lorenzo, $28-29$ Sep. ( $\sigma$, AMNH; $q$, MLZ); Puerto Salamar, 27 sep.-2 Oct. ( $\delta$, ??, LSLKZ); 2 mi. NW Cedeño, 11 Feb. ( $\alpha$, LStuz). M. $t$. platyrhynchus (1): 1 m1. SE Cauquira, 13 April (ó, Lsturz).

PUBL,TSHED RECORDS.--"Honduras" (Sclater, 1862: 234). Tigre Island (Taylor, 1860: 114). San Pedro region (Sclater and Salvin, 1870b: 837). Truj1110 (RIdgway, 1888c: 580). San Pedro (Sclater, 1888: 257). La Céiba, Yaruca (Bangs, 1903: 148). La Celba [as connectens] (M111er and Griscom, 1925a: 6-8). Lancetilia and Tela [as ntortcap111ug] (Peters, 1929b: 451) . Cantarranas and Lancetilla [as ntericap11lus] (Stone, 1932: 321). San Lorenzo [as Ifttoralis]; El Boquerón, Tegucigalpa, Comayagüela, Ei Hatillo, Sabana Grande, and EI Caliche [as connectens] (Zimmer, 1953b: 1-3). Lancetilla Valley (Skutch, 1960: 396-399).

This flycatcher is the most common specles of the genus Mytarchus in Honduras. It occurs in open forest, semi-open situations, and second growth throughout the lowlands of both coasts and in the interlor below 4,000 feet, ranging occasionally to 6,000 feet in pine-oak associations. Breeding in Honduras from April through June has been described by skutch (1960: 396-399).

The report of "Mylarchus lawrencif" from Roatán Is land by Salvin (1889: 362) was apparently an error. The British Museum has no specimens of $M$. tuberculifer from Roatán but does have nine $M$. tyrannulug taken by George Gaumer on that 181and. I concur with Bond (1936: 362) that these specimens were probably the basis for this report, since Salvin failed to mention $M$. tyrannulus.

Differences between described races of this species are sight but seem to be relatively constant. Most of 
Honduras, except for the Pacific coast lowlands below 500 feet, the 0lancho rain forest, and mangroves in the Mosquitia, is occupled by the race $M$. $t$. connectens Miller and Griscom. The lowlands along the Pacific coast are the habitat of the recently described $M$. t. 1ittoralis Zimmer [1953b: 1; E1 Zapota1, Guanacaste, Costa Rica], which differs from connectens in the slightly paler, more brownish pileum and the paler back; in serles the throat averages more whitish than in connectens. From Nicaragus south, on the Caribbean slope, the subspecies M. t. nigricapillus Cabanis replaces connectens, from which it differs in smaller size, darker plleum, and more olivaceous back. Populations from the rain forests of Olancho are intermediate between connectens and nigricapillus. Wing measurements of the series of connectens from Honduras are as follows: $6,75.5-89.0(81.9) ; \$, 73.6-80.5(77.5)$. Spectmens of littoralis from Honduras measure as follows: o, 81.1, 79.5; $\$, 74.6$. The Rio Pataste female measures 75.7. A single male in breeding condition, collected on 13 Apr11 1964 in a mangrove swamp near Cauquira, on the Laguna Caratasca, differs from connectens in having a paler crown, darker throat, and paler yellow abdomen; in addition, the rectrices are devold of any rufous edgings. In every respect it matches examples of M. t. platyrhymchus Ridgway from the Yucatan Peninsula and extends the known range of 
this race south of British Honduras. The wing measurement of this specimen is 81.1 .

\section{Nuttallornis borealis (Swainson)}

$$
\text { Olive-sided Flycatcher }
$$

SPECTMENS.--(8): Cerro Higuito, Santa Bárbara, 25 April ( $\delta$, AMiNH); San José de Santa Bárbara, 4 May, "6 June" (20, AMNH); Finca Fé, 4-5 Sep. ( 8 , alc., ISLMZ); Monte Redondo, 5 Sep. ( $9, \mathrm{MCZ}$ ); La Flor Archaga, 14 Sep. (?, MCZ); San Francisco, Choluteca, 11 oct. (' ske1., Lsiaz).

Although previously unrecorded from Honduras, the Olive-sided Flycatcher is an uncommon transient in Honduras, occurring primarily in the interior highlands from 2,000 feet to 5,500 feet elevation; it does migrate occasionally through the lowlands of both coasts, especially in the fall. During the spring migration the species is considarably less common everywhere in Honduras.

Extreme dates of arrival and departure for the fall migration in Honduras are 2 September and 10 November. The only spring records are the specimens obtained by C. F. Underwood in the Department of Santa Bárbara In April and May 1935. A specimen in the American Museum of Natural History labeled "San José, June 5, 1936" is apparently misdated, since Underwood was not in Santa Bárbara at that time; furthermore, Allan R. Phillips (personal communication) informed me that the conditions of the worn plumage with a few fresh feathers indicates that it is probably an August specimen. Underwood also collected the fall specimens from La Flor Archaga and Monte Redondo in 1932. I 
secured the Finca Fé and San Francisco specimens in the fall of 1962 .

In North America there is a cline in size in this species with a tendency from west to east towards smaller size. The differences, however, are slight and with the amount of overlap present, recognition of this geographic variation by named subspectes seems undesirable.

\section{Contopus virens (Linnaeus)}

\section{Eastern Wood Pewee}

SPECIMENS --(56): Swan Is lands, 26 March-19 April (20,

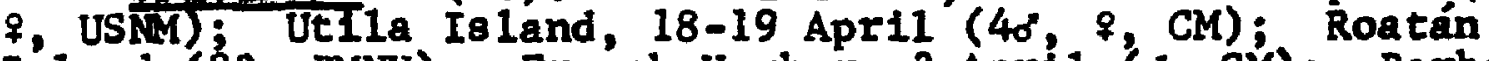
Island (8?, BMNH); Franch Harbor, 3 Apri1 (o, CM); Barbareta Island, 10 April ( $9, C M)$; Little Hog Island, 9 April (d, LSUMZ); Puerto Caballo l= Puerto Cortés] (?, ANSP); La Ceiba, 1-13 May (36, 39, CM); Trujil10, 20-23 Sep. ( 8 , ? USNM); Catacombas, 3 Apri1 ( 8, MLZ); Monte El Conejo, 15 May ( $\$$, MLZ); Finca Fé, 3 Sep. ( $\delta$, $q$, imm. LSLMZ); Archaga, 19-28 Sep. (40, AMNH); EI hatillo, 7 May (?, MCZ); E1 Plcacho, 28 Sep. (o , AMMH); Yeguare River Valley, 18-28 April, 8-27 Sep. (3\%, ?, UF); E1 Boquerón, 28 Aug.-3 Oct. ( $5 \delta^{\circ}, 5 \%, ?$ AMNH); Yuscarán, 16 April (\%, BMNH); Puerto Lempira, 12 Apri1 (d, LSUMZ).

PUBLTSHED RECORDS.--San Pedro region (Sclater and Salvin, 1870b: 837). Swan Islands [as G. vicinus] (Ridgway, 1888c: 576-577). Truj1110 (RIdgway, 1888c: 580). Roatán Island (Sclater, 1888: 239). San Pedro (Salvin and Godman, 1889: 84). Swan Islands [as G. virens] (RIdgway, 1907: 519; Fisher and Wetmore, 1931: 14).

This wood pewee is a common transient in the Caribbean lowlands and in the islands off the north coast of Honduras. It ranges in the intertor highlands up to 4,500 feet but is decidedly uncommon above 3,000 feet, being outnumbered by $\mathrm{C}$. sordidulus. There are no records for the Pacific lowlands but it may occur there also. Extreme dates of arrival and 
departure for Honduras are 24 March and 15 May For spring and 13 August and 27 September for fall.

Ridgway described two specimens taken on 14 April 1887 In the Swan Islands as a new species, c. vicinus Ridgway [1888c: 576; Swan Island, Caribbean Sea]. As he later realized (Ridgway, 1907: 519), these two birds were migrant individuals and fell within the range of variation of $\mathrm{C}$. virens from eastern North America. I re-examined these skins and they are indeed $\mathrm{C}$. virens.

\section{Contopus sordidulus Sclater}

Western Wood Pewee

SPECIMENS.--Undetermined (16): Lancetilla, 24 Aug.-9 Sep. (28, ANSP); Monte EI Conejo, 15 May (o, MLZ); Finca Fé, 12 Sep. (imm. $\delta$, LSUMZ); Monte Redondo, 22 Sep. ( $\delta$, MCZ); Ilamapa, 19 Aug. ( 8, MCZ); Cantarranas, 20 July (o", ANSP); E1 hatillo, 12 Aug. ( $\left.{ }^{\prime}, C M\right)$; Comayagüela, 19 Sep. (o, AMNH); E1 Pará́so, 20 Apri1 ( $\$$, BMNH); E1 Boquerón, 12 oct. (20, AMNH); San Lorenzo, 26 Sep. (o, MLZ; \&, MCZ); San Francisco, Choluteca, 11 Oct. (imm. \%, LSUMZ); Honduras-Nicaragua boundary [near Pacific coast] (?, MCZ). 1932: $\frac{\text { PUBLTS }}{321)}$

Occurring primarily in pine and pine-oak associations, the Western Wood Pewee is an uncommon sumer resident in the highlands of Honduras, ranging down to 3,500 feet. In migration it is fairly common in the highlands, uncommon in the Pacific lowlands, and rare in the Caribbean lowlands. Extreme dates of arrival and departure in Honduras are 20 April and 11 october. 
Geographic variation in this species is very difficult to detect. There is a definite cline in size from north to south, the smallest individuals occurring in the Middle American resident populations. In addition, there are some differences in richness of coloration above and in contrast between the pileum and back, when birds in freshly molted plumage and of corresponding post-mortem age are compared. Worn individuals and migrants are virtually impossible to allocate. There can be little doubt that the specimens from Cantarranas, Ilamapa, and E1 Hatillo are representative

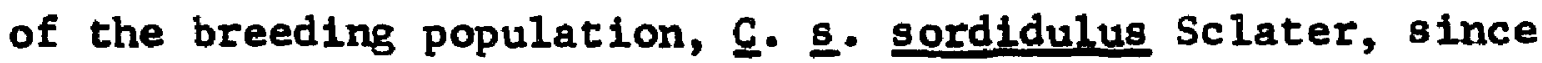
all are of small size and all were taken in July and August. The remainder of the specimens cannot be subspecifically determined with any degree of certainty, but all the northern named populations apparently migrate through Honduras to reach their wintering grounds in South America.

\section{Contopus cinereus (Spix)}

\section{Tropical Pewee}

SPECIMENS. - -C. c. brachytarsus (20): Lancetilla, 2 Sep. (?, ANSP); Subirana, 8 Dec. ( $\sigma^{\circ}$, MCZ); San Esteban, 1 July ( $\left.\delta^{\circ}, C M\right)$; Alto Guaimaca, 10 June ( $\delta^{\circ}$, ML); Limones, Monte Redondo, 8 Sep. ( $\delta$, MCZ); La Flor Archaga, 8 Sep. ( $q$, MCZ); Cantarranas, 20 July, 3 Aug. ( $\delta^{\circ}, q$ ?, ANSP); Madre Vieja, 7 Nov. ( 8 , UP); Yeguare River Valley, 10 March, 1629 May ( $\sigma^{\circ}$, UF); Jamastrán Valley, 17 Aug. (imm. UF); Arena1, 23 Jan. (o", UCLA); Segovia River, 19 July-15 Aug. (20, 9 , USNM); San Lorenzo, 27 Sep. (d, MCZ); $5 \mathrm{mi}$. SE Namas igüe, 8 oct. ( $d$, LSLMZ).

589). PUBLISHED RECORDS --Segovia River (Ridgway, 1888 
An uncommon species in Honduras, the Tropical Pewee is the resident lowland representative of the genus, occurring in the lowlands of both coasts and in the interior below 3,500 feet elevation. It is a bird of open forest or semiopen situations and follows the vega forests along the rivers in the interior. In the Pacific lowlands it occurs in arid scrub and, to a lesser degree, in mangroves.

Al1 Honduran specimens are referable to the widespread Middle American race, $\underline{C} . \subseteq$. brachytarsus (Sclater). The supposed Pacific lowlands race, G. c. rhizophora (Dwight and Griscom), based on general paler coloration and shorter b111, does not hold up. The two specimens from the Pacific coast of Honduras match Caribbean slope birds in both coloration and bill size.

\section{Contopus pertinax Cabanis and Heine}

\section{Greater Pewee}

SPECIMENS.--C. p. minor (78): Subirana, 10 Jan. -2

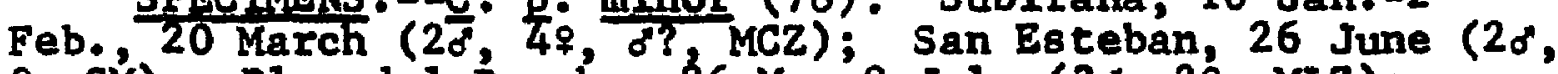
₹, CM); Plan del Rancho, 26 May-8 July (30, 2\%, MLZ); Belén Gualcho, 18-19 July ( $\%$, $\%$, MLZ); Monte Verde, 19-26 July (39, MLZ); Siguatepeque, 9 July $\left(\delta^{\circ}, 9, \mathrm{CM}\right)$; $4 \mathrm{ml}$. SE La Esperanza, 24 Jan. ( $\sigma^{\circ}$, LSUMZ); Gülse, 30 Oct. ( $\$$, LSUMZ); 2 mi. S Marcala; 30 Oct. ( , LSUMZ); Cerro Santa Marla, 30 Dec. ( $q$, MLZ); Las Deliclas, 15 Nov. ( $q$, AMNH); Cantora1, 9 Dec. ( 7, ?, AMNH) ; Cerro Cantora 1, 2 Apr11, 14 July-7 Aug ., 26 Nov. -26 Dec. (6o, $49, \mathrm{MCZ})$; Alto Cantoral, 7 Jan. ( $F$, MLZ); La Flor Archaga, 23 May, 6 Aug. (d, $q$, MCZ); Cantarranas, 8 July (\&, ANSP); San Juancito, 22 July (9, ANSP); Rancho Quemado, 2-5 Apri1, 16 Aug. (o, ANSP; $20^{\circ}, 29$, MCZ); E1 Derrumbo, 18 July ( 9, MIZ); EI Hatilio, 19 April-4 May, 30 June, 1-17 Aug. ( 8 , ANSP; 78, 28, CM; of 3\%, MCZ); Tigre Hatillo, 9 July (o, AMNH); E1 Picacho, 28 Sep., 23 oct. (28, AMNH); $10 \mathrm{ml}$. NE Tegucigalpa, 2 Feb., 18 Nov. ( $\sigma^{\prime}$, \&, LsuMz); Tegucigalpa, 12 April (2o, BMH); Yeguare River Valley, 10 Jan., 27 Sep. ( $\sigma^{\circ}, f$, UF); road to 
Güinope, 4 Aug ( $($, UF); $\operatorname{Dan11}, 7$ April (o, BMNH); San Francisco, Choluteca, 12 Feb., 11-14 0ct. ( $\sigma^{\circ}, 29$, LSUMZ). 1932: 321 ).

PUBL,ISHED RECORD.--Cantarranas (Stone, 1931: 1-2;

Contopus pertinax is a common resident in pine and pine-oak associations in the interlor highlands of Honduras, occurring above 1,500 feet elevation. As far as is known, the species is not migratory in Honduras.

Zimmer (1939: 1-2) considered $G$. pertinax as conspecific with the South American $C$. fumigatus (Lafresnaye and d'Orbigny), but in view of the distinct morphological differences and the presence of two sibling species of this group in Costa Rica (C. Lugubris Lawrence and $\mathcal{C}$. ochraceus Sclater and Salvin), I feel that the conservative approach of maintaining them as separate species is the best procedure.

Honduran specimens are all referable to the smaller southern race, $\subseteq$. . minor (Miller and Griscom), which differs from the nominate race, C. R. pertinax Cabanis and Heine, only in smaller size. Wings of Honduran specimens measure as follows: of, 98.3-105.2 (102.1); 9, 92.3-96.9 (94.8). Specimens from the Department of Ocotepeque, nearest the range of pertinax in Guatemala, average very slightly larger than the remainder of Honduran material but still are within the normal range of varlation of minor. The supposed species $\mathcal{C}$. emlent [yyiochenes emlent stone, 1931: 1; Cantarranas, Honduras, 2300 feet] 18 based on 
examples of minor and does not differ from the latter in any way.

\section{Empidonax flaviventris (Baird)}

\section{Yellow-bellied Flycatcher}

SPECTMENS.--(70): Yaruca, 11-21 Feb. (28, MCZ); Truj1110, 21 Sep. (d, USNM); Catacombas, 21 March-4 April (2o, 39 , AMNH; $\delta, 3 \%$, MLZ); Cofradía, 12-14 March ( 9 , AMNH; $q$, MI2); Las Pefittas, 3-9 Feb. (40, AMNH; 30, MLZ); Subirana, 12-17 March ( $0, q$, MCZ); Port1llo Grande, 11 Feb., 8 March ( $0,8, M C Z) ; 5$ mi. S San Esteban, 16 Jan. ( $\sigma^{\circ}$, LSUMZ); $12 \mathrm{mi}$. S Dulce Nombre de Culmí, 27 Jan. ( $\sigma$, LSUMZ); Monte E1 Conejo, 20 May ( $\$$, MLZ); Santa Bárbara, 20 May ( $q$, AMNH); 5 mi. SW El Jaral, 28 Oct. ( $\sigma^{\circ}$, LSUMZ); Finca Fé, 20 Jan., 1-2 March, 31 Aug. -25 Nov. (50, 3i, i?,?, 6 imm. o, 2 imm., 2 imm. skel., 8 alc., LSUMz); Lake Yojos, 27 Aug. ( 8 , CM); Monte Redondo, 15 Dec. ( $\left.\sigma^{\circ}, \mathrm{MCZ}\right)$; $\mathrm{B1}$ Hat1ilo, 30 Apri1-8 May (7, ?, MCZ); Rio Hondo, 18 Aug. (d, CM); Tegucigalpa, 14 March ( $\$$ AMNH); Yeguare River Valley, 7 Sep. (\%, UF); Arenal, $16-27$ Jan. (28, $\%, ?$, UCLA); San Francisco, Choluteca, 11 Oct. ( $q$, Lsunz).

PUBLISHED RECORDS.--San Pedro region (Sclater and Sa1vin, 1870b: 837). Trufillo (Ridgway, 1888c: 580). San Pedro (Saivin and Godman, 1889: 73). Yaruca (Bangs, 1903: 148). Monte El Conejo, Catacombas, Las Peñitas, Cofradia (Moore, 1940b: 351).

The Yellow-bellied Flycatcher is a common migrant and winter visitant in the Caribbean lowlands of Honduras, being perhaps the commonest migrant from North America in the rain forests of the northern part of the republic. It occurs in dense rain forest, open forest, second growth, and even semi-open situations. The species also migrates through the interior highlands but is uncommon to rare above 3,000 feet or at any elevation on the Pacific drainage. Between August and March in the open rain forest at Finca Fé, near Lake Yojoa, this specles was the most abundant bird. 
Extreme dates of arrival and departure in Honduras are 18 August and 20 May.

\section{Empidonax virescens (Vieillot)}

Acadian Flycatcher

SPECTMENS.--(8): Roatán I8land (5?, BMNH); Trujil10, 31 March $(7, C M)$; Finca Fé, 21 oct. (Imm. o, LSUMZ); 2 mi. N Pito Solo, 25 oct. (Imm. \$, LSUMZ).

PUBLISHED RECORD.--Roatán Island (Sclater, 1888: 229).

Apparently the Acadian Flycatcher is a rare to uncommon but regular migrant in Honduras, occurring along the Caribbean slope and in the Bay Islands. Because of its close 8 imilarity to the abundant E. flaviventris, collecting is necessary to establish identification.

G. F. Gaumer obtained the specimens from Roatán Island In 1886 or 1887. Arthur C. Twomey and Roland W. Hawkins secured a specimen at Trujillo in 1948. I collected two specimens in the fall of 1962, one at Finca Fé and the other near Pito Solo. These records are the only definite ones for Honduras. The report by Moore (1940b: 351-352) of a skin from Cofradia was based on a misidentified example of E. minimus (Phillips, 1960: 359).

Empidonax brewstert Oberholser

Willow Flycatcher

SPECIMENS.--(22): Lancet1lla, 25 Feb. (?, MCZ); La Ceiba, 3-5 Jan. (o, \&, MCZ); Cofradí, 5 March (2d, AMNH; 9, MLZ); Finca Fé, 7 Dec. ( $d$, ISUMZ); La Tigra [m San Juancito], 22 May ( $q$, UF); Ei Hat1110, 19 April (?, MCZ); Yeguare River Valley, 15 Jan. ( $\sigma^{\circ}$, UF); Rio Choluteca, Dept. E1 Paraiso, $13 \mathrm{Feb}$. (q, UF); San Lorenzo, 21-30 Sep.' (2?, 
AMNH; 46, $₹$, MLZ; 2\%, MCZ); Puerto Salamar, 2 oct. (imm. 9?, LSUMZ); $7 \mathrm{mi}$. NE Choluteca, 7 oct. (Imm., LSUMZ).

PUBLTSHED RECORDS--La Ceiba (Bangs, 1903: 148). Lancetilla (Peters, 1929b: 450; stone, 1932: 322). Cofradia, San Lorenzo, and Las Peñitas [as E. t. traili1]; San Lorenzo and Cofradia [as E. $t$. breweteri] TMoore, 1940b: 352-354).

The Willow Flycatcher is a fairly common migrant and rare winter visitant on both coasts of Honduras and in the interlor, ranging up to 5,500 feet elevation. It seens to be most common, however, in the arid lowlands along the Pacific coast. One individual that I noted about 10 miles northeast of Cedeño on 4 October and again on 9 October 1962 gave the characteristic "fitz-bew" call-note of this 8pecies. Extreme dates of arrival and departure in Honduras are 21 September and 22 May.

Stein (1963) has demonstrated that the populations of flycatchers previously known as "E. traillif" consist of two blological species, differing in call-notes, song, nesting behavior, habitat, and other ethological characteristics. On the basis of morphology alone, not uure than 80 per cent of the specimens can be determined as to spectes. I have applied Stein's formula (1963: 44) and found that all Honduran specimens fall within the vartation exhibited by $\underline{E}$. brewsteri; none can be assigned to the species E. traililif (Audubon), the Tralli's Flycatcher, although the latter undoubtedly occurs in Honduras in migration. I have included all honduran records under $E$. brewsteri, but several of these may possibly pertain to E. trailili. 
Stone (1932: 322) reported a specimen taken at Lancetilla on 2 September 1930 , but I was unable to locate this Individual in the collections of the Academy of Natural Sciences at Philadelphia in 1961.

The supposed races currently assigned to the species E. traillii have no meaning as they often embrace populations of both species, but Stein is presently working on the problem of geographic variation in the group. Prior to the realization that two sibling species were involved, Allan R. Phillips had Identified a female from Cofradia taken on 5 March 1933 as the race E. t․ adustus Oberholser [1932: 3; Hart Mountain, northern end of Warner Valley, 20 miles northeast of Ade1, Oregon] and a male from San Lorenzo collected on 27 September 1932 as E. ․․ extimus Phillips [1948: 512; Feldman, lower San Pedro River, Arizona]. A11 northern populations of both species presumably migrate through Central America.

Empidonax minimus (Baird and Baird)

Least Flycatcher

SPECTMENS.--(43): Tela, 21 Feb. ( $q, \mathrm{MCZ}$ ); Lancetilla, 29 March ( $9, \mathrm{MCZ})$; Cofradía, 5-11 March (o", 2\%, ?, AMNH; of 2\%, MLZ); Las Peñitas, 1-2 Feb. (2o, AMNH); Progreso, 31 Jan. ( $q$, MCZ); San José de Santa Bárbara, 12-30 Apri1 (29, AMNH); 1 mi. W E1 Jaral, 21 Aug. (1mm. o, LSUMZ); Finca Fé, 20 Jan., 30 Nov: (2\%, LSUMz); Alto Cantoral, 17 Jan. ( $\%$, AMNH); Monte Redondo, 1-14 Dec. (20, 2?, AMNH; 30, $29, ?, M C Z$ ); La Flor Archaga, 19 Jan. ( $\%$, AMNH); E1 Hatillo, 19 April (o, ${ }^{\circ}$, MCZ); Ei P1cacho, 9 April ( ${ }^{\circ}$, AMNH); Conayagüela, 4-29 March ( $d^{\prime}, f$, AMNH); Yeguare River Valley, 20-27 Jan,' 10 March, 30 April (20, \&, \&?, UF); Fledra de Jesús, 9 March ( 8, AMNH); San Lorenzo, 6 Oct. ( ${ }^{\circ}$, 
AMNH); Puerto Salamar, 9 Feb. (d, LSUMZ); San Francisco, Choluteca, 12 Feb., 11 oct. (2d", LSUMZ).

PUBILISHED RECORDS.--San Pedro region (Sclater and Sa1vin, 1870b: 837) . San Pedro (Salvin and Godman, 1889: 72): Progreso, $5 \mathrm{~km}$. W Tela, Lancet1lla (Peters, 1929b: 450). Cofradía [as E. virescens] (Moore, 1940b: 351-352). Cofradia, Las Peñitas, san Lorenzo (Moore, 1940b: 354-355).

This species of Empldonax is a common migrant and winter visitant in Honduras, occurring in semi-open situations throughout the country below 5,500 feet elevation. It is not quite so abundant as E. flaviventris and prefers more open situations, the latter species being mostly a forest inhabitant. The Least Flycatcher is very difficult to distinguish in the field from E. brewsteri; both are genera1ly found in semi-open situations, but in Honduras E. brewsteri seems to be more common in arid habitats. Collecting is necessary to establish positive identification. Moore (1940b: 351-352) misidentified a Honduran specimen of E. minimus as E. virescens (Phillips, 1960: 359).

Extreme dates of arrival and departure in Honduras are 19 August and 30 April.

\section{Empidonax hammondii (Xantus)}

\section{Hammond's Flycatcher}

SPEC IMENS.--(29): Portillo Grande, 11 Feb. (?, MCZ); Mt. PUCa, 11 Feb. (?, AMNH); La Esperanza, 23 Jan. (d", ISUMZ); 4 mi. SE La Esperanza, 22-24 Jan,' $30-31$ Oct.' (3d", \$, ISUMZ); Güise, 30 0ct. (imm. of LSUMZ); Soluteca, 9 April (o", AMNH); La Cruz Grande, 13 March ( $\delta$, AMNH); $1 \mathrm{mi}$. NW Zambrano, 19 Nov. ( ${ }^{*}$, LSUMZ); Cantora1, 14 Dec. (?, AMNH); Cerro Cantoral 28 Feb.; 9 Nov.-16 Dec. (40, 48, ?, MCZ); Alto Cantoral, 12 Jan.-14 Feb. (28, 2\%, AMMH; ;, MLZ); Monte Redondo, 6 Dec. (?, MCZ); La Flor Archaga, 11 March (o", MCZ); Rancho Quemado, 5 April (7, AMNH). 
PUBLISHED RECORDS.--Alto Cantoral, Cantoral (Moore, $1940 \mathrm{~b}: 355-356)$.

The Hammond's Flycatcher is a fairly common winter visitant to pine and pine-oak associations in the interior highlands of Honduras, ranging from 3,500 feet to at least 6,500 feet elevation. Extreme dates of arrival and departure in Honduras are 17 October and 17 April.

\section{Empidonax flavescens Lawrence}

Yellowish Flycatcher

SPEC TMENS.--E. E. dwighti (105): Las Peñitas, 30 Jan. $\left(\sigma, f\right.$, MCZ); Portil to Grande, $1-11$ Feb., 18 May $\left(\sigma^{\circ}, q\right.$, CNEM; $\delta, 8, M C Z$ ); $5 \mathrm{mt}$. S San Esteban, $15 \mathrm{Jan}$ ( (d", LSUMZ); Merendón Copán, 15 June (o, MCZ); E1 Chorro, 22 June-9 July (20, 27, MIZ); Montaña E1 Chorro, 30 June-3 July (20, 29 ,

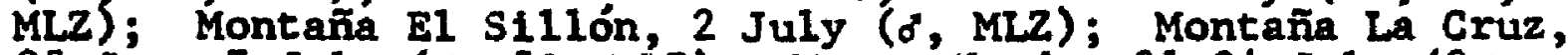
25 June-7 July ( $0^{\circ}, 5 \&$, MLz); Monte Verde, 21-24 July (2o, \&, ?, MLZ); Las Ventanas, 27 July ( $\sigma^{*}, \&, ?$, MLZ); Monte E1 Portillo, 30 May ( $\$$, MLZ); Mt. Puca, 5-8 Feb. (40, MCZ); Cerro Nieve, 10-13 April ( $\sigma^{\circ}, f$, AMNH); San José de Santa Bárbara, 7 April ( ${ }^{\circ}$, ANSP); Sante Bárbara, 17 May ( $\sigma^{\prime}$, AMNH); Cerro Santa Bárbara, east slope, 19 Feb., 22 Nov. -9 Dec. ( $20^{\circ}, 7^{9}$, LSLAZ); 5 mi. SW EI Jara 1; 28 0ct. -4 Nov. ( 9 , imm. $\delta^{\prime}$, L suMz); Muye, 18-27 Feb. (30, 2\%, AMNH); Cerro Santa Maria, 28 Dec. ( $q, \mathrm{MCZ}$ ); Cantoral, 22 Jan.-20 Feb.,

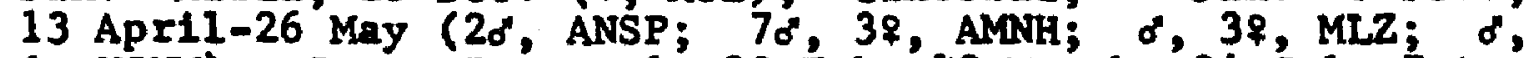
9. USNM); Cerro Cantoral, 20 Feb.-19 March, 24 July-7 Aug., 26 Nov, -9 Dec. $\left(60^{\circ} \%\right.$, MCZ; ${ }^{\circ}$, LMM ); Alto Cantoral, 16 Jan. -14 Feb. (40", 2\%, 2?, AMNH; 20, MLZ; o, $\%, \mathrm{MCZ}^{\circ}$; UMMZ); San Juancito, 11-29 July (30, $\$$, ANSP); Rancho Quemado, 15 March, 2 April ( 6 , ANSP; o", MCZ); EI Derrumbo, 16 July-9 Aug. ( $\sigma^{\circ}$, AMNH); $20^{\circ}, 29$, MCZ); El Hat11lo, 1 May ( $\sigma^{\prime}$, MCZ); Uyuca, 2 Feb., 4 June ( $9 ?$ ?, UF); Monserrat, 28 May (juv., UF); "Honduras" (?, BMNH).

\section{PUBLISHED RECORDS..."Honduras" [as E. Balvini]}

(Sclater, 1888; 231 ) San Pedro Mounta Ins [as E. diffic11is salvini] (Helimayr, 1927: 214). San Juancito [as dwiaht T) (Stone, 1932: 322). Montaña El Chorro, El Chorro, Montaña E1 Silión, Montafia La Cruz, Las Ventanas, Monte Verde, and EI Derrumbo [ 28 E. difficilis seclusus]; Montafa E1 Chorro, E1 Chorro, Las Ventanas, Monte Verde, Montaña La Cruz, Monte E1 Portilio, Alto Cantoral, Cantoral, and E1 Derrumbo [as dutght1] (Moore, 1940a: 26-29). Cerro 
Nieve, Santa Bárbara, Port1llo Grande, Las Peñitas, Rancho Quemado, Merendón Copán, Mt. Puca, Muye, Cerro Santa Maria, Cerro Cantoral, Alto Cantoral, Cantoral, and El Derrumbo [as dwight1] (2immer, 1953b: 6-7).

Occurring from 3,500 feet to at least 7,500 feet elevation, the Yellowish Flycatcher is a common resident of cloud forests in Honduras. The species occasionally enters pineoak associations.

Hellmayr (1927: 214) examined a male in the Berlepsch Collection that was obtained by Erich Wittkügel in the San Pedro Mountains in March 1892. I have not seen this individual.

Zimmer (1953b: $3-7$ ) has discussed at length the relationships of this species and E. difficilis. After examination of the type series of E. difficilis seclusus Moore [1940a: 26; Montaña E1 Chorro, Ocotopeque, north-western Honduras], I agree with 2 immer that these specimens are worn examples of $\underline{E}$. Elavescens dulghti van Rossem [1928a: 359; Los Esesmiles, Chalatenango, El Salvador, C.A.; altitude 8,000 feet] and that seclusus is invalid. 2immer has further shown that E. flavescens and E. difficilis Baird are essentially allopatric, and that the latter does not occur In Guatemala or Honduras. There is a possibility that flavescens is conspecific with difficilis, but until further fleld studies are completed on both groups, especially those concerned with vocalizations, I am maintaining the two as distinct species. Ned $K$. Johnson is currently working on these two spectes. 
Empidonax albigularis Sclater and Salvin

White-throated Flycatcher

SPECTMENS.--E. a. albigularis (24): Lancetilla, 27 March ( $\delta^{\prime}$, MCZ); Pian del Rancho 26 May, 24 June-3 July (40, $30^{\circ}, 4$ ?, MLZ); Lake Yojoa, 21 July, 25 Aug. (28, CM); El Callche, 14 July ( 8 , AMNH); Cantarranas, 3 Aug; ( $\sigma^{\prime \prime}$, ANSP); San Juancito, 3 July-3 Aug. ( $0^{\circ}, ?$, ANSP; $40^{\circ}, q$, CM); Rancho Quemado, 5 April (o, MCZ).

PUBLISHED RECORDS.--Lancetilla [as australis] (Peters, 1929b: 449-450). San Juancito and Cantarranas las australis] (stone, 1932: 322). Plan del Rancho [as albigular is ] (Moore, 1940b: 383).

This species of Empidonax is an uncommon resident in Honduran with a very local distribution. It is an inhabitant of grassy fields, espectally those with long grass and widely scattered shrubs or small trees. During the breedIng season it occurs from 2,000 feet to at least 6,000 feet, but in winter it may descend to sea level. The northern populations are possibly migratory, but definite evidence is lacking at the present time. The species does not occur in cloud forest, despite Moore's (1940b: 383) statement to the contrary.

Geographic variation of populations south of Mexico is puzzling. There is considerable individual vartation in specimens due to wear and to fading or foxing. Birds from eastern Guatemala, Honduras, and northern Nicaragua are often placed in the race E. a. australis Miller and Griscom, characterized by its darker coloration, but I cannot see any significant variation from Chiapas to Nicaragua. Since the type of the species came from Guatemala, Honduran birds must 
belong to the nominate race, E. a. albigularis Sclater and Salvin, if they are not assigned to australis. The resident populations of Honduras cannot possibly belong to the Mexican race E. a. axillaris Ridgway; to assign the Honduran birds to axillaris, as is done by Miller, Friedmann, Griscom, and Moore (1957: 94), would sp1it the range of axillaris with albigularis intervening. Until a complete study is undertaken for this species, I regard the breeding birds of Central America as representing the single race, E. a. alblgularis.

\section{Empidonax fulvifrons (Giraud)}

Buff-breasted Flycatcher

SPECIMENS.--E. E. Inexpectatus (66): Plan del Rancho, 9 July (f, MLZ); Monte Verde, 22-29 July (3?, MLZ); $10 \mathrm{mi}$. N Siguatepeque, $11 \mathrm{July}\left(2 \sigma^{\prime \prime}, \mathrm{CM}^{2}\right.$ ); Siguatepeque, 9-31 July (30, 9, CM); La Esperanza, 23 Jan. ( $\sigma^{*}$, LSUMZ); $4 \mathrm{mI}$. SE La Esperanza, 24 Jan. ( $\%$, LSUMZ); Soluteca, 3-13 Apri1 (30", \%, AMNH); $2 \mathrm{mi}$. S Marcala, 30 Oct. (o", LSUMZ); $1 \mathrm{ml}$. NW Zambrano, 19 Nov. ( $q, 8$ ?, LSUMZ); Cantoral, 3 March, 2-6 May, 18 July-5 Aug. ( ${ }^{\circ}, q$, ANSP; $2 q$, AMNH; $\delta$, MLZ); Cerro Can-

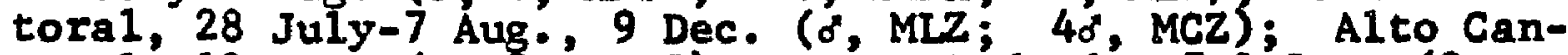

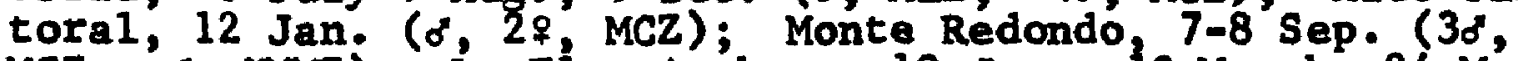
MCZ; of, LMMZ); La Flor Archaga, 19 Jan., 10 March, 24 May-

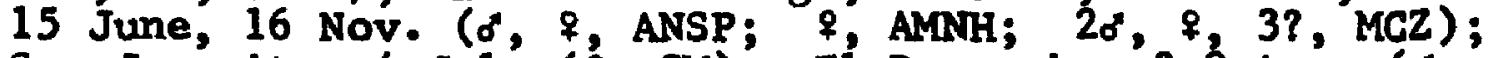
San Juancito, 4 July ( 9, CM); Ei Derrumbo, 3-9 Aug. ( $d$, MCZ); El Hatillo, 9 April-8 May, 20 Aug. ( 9, ANSP; $;$, BMNH; $\sigma^{\circ}, \mathrm{CM}$; of MLZ; 20, 28, MCZ; + , UMMZ); Cerro Higuito, D.C., 19 April ( $\%$, AMNH); Tegucigalpa, 22 Oct. ( $\$$, AMNH); Mt. Uyuca, 26 May ( 7 , UF); Cuesta Grande, 1 July (30, 28, GM); road to Gülnope, 4 Aug. (?, UF); Dan1f, 7 April ( $\%$, BMNH).

PUBLTSHED RECORDS.--Cerro Cantoral (Griscom, 1932c: 60). Monte Verde, Plan del Rancho, Cantoral, El Hatillo (Moore, 1940b: 385).

Ranging from 2,000 to 6,500 feet elevation in Honduras, the Buff-breasted Flycatcher is a fairly common resident in 
pine-oak associations in the interior highlands; it also occurs sparingly in areas of ocotal.

Honduran specimens are all typical of the small southern race, E. f. inexpectatus Griscom [1932c: 60; Cerro Cantoral (alt. $6500 \mathrm{ft.}$ ), District of Achaga (= Archaga), Honduras ]. Their wings measure as follows: $\delta, 55.7-60.2$ $(57.6) ; \uparrow, 54.3-56.7(55.5)$. None shows any close approach to the larger Guatemalan subspecies, E. f. fusciceps Nelson.

\section{Mitrephanes phaeocercus (Sclater)}

Tufted Flycatcher

SPECIMENS. - $-M$. $\mathrm{P} \cdot$ quercinus (98): Port1110 Grande, 1 Sep. (f, MCZ); Cerro E1 Triumpho, $20 \mathrm{mi}$. SE San Esteban, 31 March ( $\$$, LSUNZ); E1 Chorro, 9 July ( $q$, MLZ); Montaña La Cruz, 25 June-7 July ( $\%, ?$, MLZ); Monte Verde, 20-24 July (28, 28, 8?, MLZ); Mt. PuCa, 22-31 Jan. (o, 2q, MCZ); Lepaera, 30 Dec. ( $0^{\circ}$, AMNH); Cerro Santa Bárbara, east slope, $19 \mathrm{Feb} ., 7-9$ Dec. (29, ?, LSUMZ); Siguatepeque, 8 July $\left(20^{\circ},{ }^{\circ}, \mathrm{CM}\right)$; $4 \mathrm{mi}$. SE La Esperanza, 24 Jan., 31 Óct. (29, tmm. 0 , o skel., LSUMZ); MuIn, 30 Dec. ( $\delta$, AMNH); Soluteca, 3-9 Apr11 (3o, 3\%, AMNH); E1 Pedernal, 12 Jan. (\%, AMNH); E1 Guayabal; 22 Dec. ( $\$$, AMNH); La Florida, 2526 Dec. (ó, 4\%, AMMH; $q$, MCZ); Muye, 27 Feb. (?, AMNH); Cerro Santa Maria, 28-30' Dec. (o, AMNH; 20, MLZ); Alto Gualmaca, 10 June (?, AMNH); Montaña Vásquez, 14 June, 19 Nov. (2\%, MCZ; $\%$, USNM); Cantoral, $6 \mathrm{Feb} .-18$ May, $13 \mathrm{Dec}$. (7ه" 2?, AMNH; o, USNM); Cerro Cantora1, 26 July-6 Aug . , 12-13 Dec. (2o, 2\%, MCZ); Alto Cantoral, 4 Jan.-16 Feb.

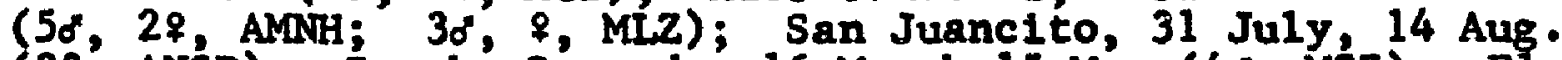
(3?', ANSP); Ranchó Quemado, 16 March-15 May (40, MCZ); EI Derrumbo, 15 July-9 Aug. (5d, 47, AMNH); El Hatillo, 3 Aug. (8', CM); Uyuca, 24-27 Sep. (2\%, UF).

228). PUBLISHED RECORDS:--Vol cán de Puce (Hellmayr, 1927:

This flycatcher is a common resident of pine-oak associations and of cloud forests in the interior highlands 
of Honduras, ranging from 2,000 feet to at least 7,500 feet elevation.

Hellmayr (1927: 228) examined a male in the Brunswick Museum taken on 1 March 1889 on Volcán de Puca by Erich Wittkïgel. I have not seen this specimen.

Geographic variation in this species in northern Central America needs further study. Populations from southern Mexico to Nicaragua are decidedly darker and richer colored, as compared with $\underline{M}$. $\mathrm{g}$. phaeocercus (Sclater) in central Mexico. There is a cline in size, the smaller individuals being found in the Honduran and Nicaraguan popu1ations. The few specimens I have seen from Nicaragua all show a slight tendency towards the Costa Rican race, $\underline{M}$. $\mathrm{R}$. aurantiventris (Lawrence), in an increased amount of yellowish on the abdomen; Honduran birds vary greatly in this respect but are generally less yellow on the under parts. Honduran specimens average in size somewhere between the Nicaraguan birds and those from Mexico and Guatemala. I tentatively restrict $\underline{M}$. $\mathrm{P}$. nicaraguae Miller and Griscom to Nicaragua, distinguishing it by the increased yellowish on the under parts and smaller size. I regard populations from Chiapas to Honduras as representing the richly colored, slightly larger race, $\underline{M}$. p. guercinus Dickey and van Rossem [1927a: 2; Mt. Cacaguat1que, Department San Miguel, E1 Salvador], although this race may prove to be 
Indistinguishable from nicaraguae when an adequate series of the latter is available.

\section{Terenotriccus erythrurus. (Cabanis)}

\section{Ruddy-tailed Flycatcher}

SPECIMENS. - -T. e. Eulvigularis (7): Lanceti11a, 26 Aug. (?, ANSE); La Ceiba, 28 July (d, CM); San Pedro Sula,

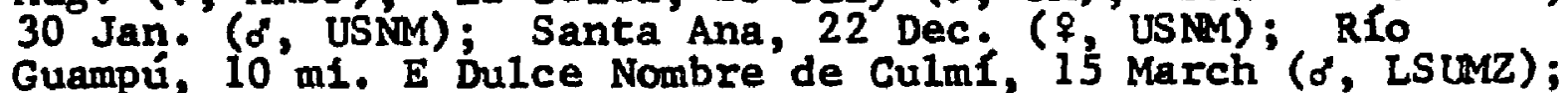
Arena 1, 18-20 Jan. (ó, \%, UCLA). way, $1891: 47$ ) $\frac{\text { PUBLISHEP }}{\text { Lancetilla }}$ (Stone, 1932: 322).

Uncommon to rare in Honduras, the Ruddy-tailed Flycatcher is an inhabitant of lowland rain forests of the Caribbean slope. It is found in the lower levels of dense forest and occasionally in heavy second growth. In Honduras it has not been recorded above 1,500 feet elevation. Honduran specimens are typical of the widespread northern race, I. e. Eulvigularis (Sa1vin and Godman).

\section{Mylobius barbatus (Gmelin) \\ Sulphur-rumped Flycatcher}

SPECIMENS.--M. b. 8ulphureipygius > gureatus (46): Lancetilia, 6 Feb., 22 March, 4 Sep. (o', ANSP; $\sigma^{\circ}, 2$, MCZ); Yaruca, 16 Feb. ( ${ }^{\circ}$, MCZ); Los Planes, 16 July ( ${ }^{\prime}, \mathrm{CM}$ ); Catacombas, 12 March-9 April (108, 6\%, ?, AMNH; ${ }^{\circ}$, $?$, BMNH; 7. MLZ); Cofradía, 4-8 March (?, AMMH; o", MLZ); RÍo de Las Pledras, 22 Dec. ( $\sigma^{\circ}$, USNM); Santa Ana, 18 Jan. ( USNM); Las Peñitas, 8 Feb. (o', AMNH); Cerro Nieve, 13 April ( 8 , AMNH); Cerro Santa Bárbara, east slope, 22-28 Nov. (o", \&, LSLUZZ); $4 \mathrm{mi}$. SW E1 Jara 1, 26 Oct. (imm. $?$, LSUMZ); Finca Fé, 15 Sep. (d, LSUMZ); Lake Yojoa, 16 June27 Aug. (60" 38, CM); Cantoral, 2 April ( ${ }^{\circ}$, AMNH); "Honduras ( $?$, AMNH). $M$. b. aureatus ( 7$)$ : Arenal, 14-28 Jan. (58, \&, UCLA); Segovia River, 13 June ( 
PUBLISHED RECORDS.--Segovia River (RIdgway, 1888c: 589). Yaruca (Bangs, 1903: 148). Santa Ang, Río de Las Piedras (RIdgway, 1903: 491). Near Lancet111a [as aureatus] (Peters, 1929b: 449). Lancetilla (Stone, 1932: 322).

The Sulphur-rumped Flycatcher is a fairly common resident of the Caribbean lowlands of Honduras, ranging up to 4,500 feet elevation. It occurs in dense rain forest, open forest, and second growth, usually at lower levels of the forest.

I agree with Zimmer (1939: 9-10) and Howell (1957: 96) that sulphureipygius is conspecific with $\underline{M}$. barbatus.

There is a rather broad zone of intergradation between the northern race, $M$. b. sulphureipygius (Sclater) and the

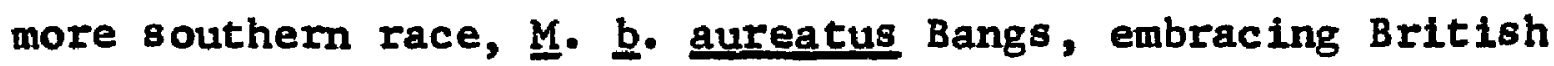
Honduras, eastem Guatemala, and most of Honduras north of the olancho rain forest. The race aureatus differs from sulphurelpygius in the paler sides of the breast and the more extensive and brighter yellow abdominal region. Specimens from southeastern Honduras compare favorably in all respects with Nicaraguan and Costa Rican examples of aureatus. The other Honduran specimens are very close to sulphurelpygius, being considerably darker on the breast than aureatus. Although Todd (1922: 96) considered these Honduran individuals as closer to aureatus, the larger series now available differs from sulphurelpygius only in being slightly brighter yellow on the abdomen. The best 
procedure is to consider these populations as intermediate but closer to sulphureipygtus.

\section{Onychorhynchus mexicanus (Sclater)}

Northern Royal Flycatcher

SPECIMENS.--(47): San Alejo, 31 March (o, LSUMZ); Lancetilla, 4 Sep. (?, ANSP); La Celba, 8 Aug. ( $q$, 8 skel., CM); Los Planes, 11 June (58, ₹, CM); Catacombas, 30 March-6 April ( $\delta^{\circ}, 29$, AMNH); Cof radla, 7-12 March (3\%, AMNH; $\delta$, BMNH; 'q, MLZ); Las Peñitas, 1-12 Feb. (d, $q$, AMNH; 8 , BMNH; 2o, 28, MLZ); Subirana, 10 March ( $\left.\sigma^{\prime}, \mathrm{MCZ}\right)$; Finca Fé, 7 Sep., 5 Nov. -2 Dec. ( $6,2 \%$, skel., LSuMZ); Lake Yojoa, 15 June $\left(\sigma^{\circ},+, C M\right)$; Ei Boquerón, 5 Sep.-10 oct. (7\%, 8\%, AMNH).

PUBLISHED RECORDS.--Choloma (Moore, 1859: 56). Lancet11la [as Iraterculus] (Stone, 1932: 323; Skutch, 1954a: 9). Near Tela (Skutch, 1945a: 20; 1960: 518).

This aberrant flycatcher is a fairly common resident in lowland rain forests on the Caribbean slope of Honduras, occurring below an elevation of 3,000 feet. It inhabits denser areas of forest, usually at low levels, but also may be found in heavy second growth or open forest; it is most common along forest streams. Breeding records for Honduras have been published by Skutch (1945a: 20; 1960: 518), who found nests in trees overhanging a stream. Vida Roth found such a nest near San Pedro Sula in the spring of 1963.

This species may be conspecific with the South American Q. coronatus (Müller), but until comparative fleld studies are made, I am maintaining them as separate species.

The only constant geographic varlation that I can see in a large series of Middle American birds is a cline in size, decreasing from north to south. If two races are 
recognized on the basis of size, ㅇ. m. mexicanus (Sclater) in the north and $\underline{Q}$. $m$. fraterculus Bangs in the south, then al1 Honduran specimens must be regarded as intermediates. Wings of Honduran skins measure as follows: $8,76.6-90.4$ $(86.0)$; $\$, 77.5-86.1(81.0)$. Extremes of both sexes occur in the series from E1 Boquerón. I prefer to maintain the species as monotypic.

\section{Platyrinchus mystaceus Vieillot} White-throated Spadebill

SPEC IMENS.--P. m. cancrominus (32): Lancetilla, 6-20

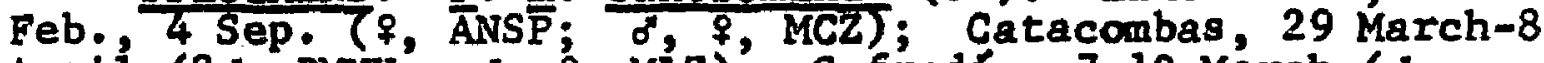

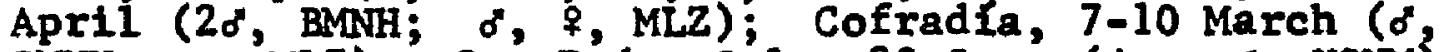
BMaNH; 0 , MLZ); San Pedro Sula, 28 Sep. (Juv. d, USNM); Río Blanco, Cortés, 16 Nov. ( $\sigma^{\circ}, q$, USNM); Santa Ana, 20 Nov. -2 Dec. ( $\sigma^{\prime},{ }^{\circ}$, USNM); La Bomba, 2 Dec. (juv. o, USNM); Río Guampí, $10^{\prime}$ mi. E Dulce Nombre de Culmi, 15 March ( $\sigma^{\circ}$, LSUMZ); Cerro Nieve, 21 Apri1-5 May ( ${ }^{\circ}$, \%, AMNH); San José de Santa Bárbara, 8 April ( ${ }^{\circ}$, AMNH); Ei Jara 1, 4 oct. ( $\%$, AMNH); $2 \mathrm{mi}$. SE'E1 Jaral, 2 March ( 9, LSLMZ); Lake Yojoa, 15-16 June, 18 July (2\%, $\$, C M)$; San Marcos de Guaimaca, 34 July (o", 2\%, ?, AMNH); Cantoral, 3 April ( 9 , AMNH); E1 Boquerón, 13 óct. ( $\delta^{\circ}$, AMNH); Arena 1, 19 Jan. ( ${ }^{\circ}, ?$, UCLA).

PUBLISHED RECORDS.--RÍo Blanco, San Pedro Sula, La Bomba, Santa Ana (R1dgway, 1907: 383). Lancetilla (Stone, 1932: 323).

The White-throated Spadebill is a fairly common inhabitant of lowland rain forest on the Caribbean slope of Honduras and occurs locally in low montane rain forest up to an elevation of 4,000 feet; it probably is present also in monsoon forest in the Pacific lowlands. It is usually encountered at low levels within dense forest, but it occasionally enters heavy second growth. 
Honduran specimens are representative of the distinct and widespread Middle American subspecies, $\underline{\text {. m. }}$ - cancrominus Sclater and Salvin. The supposed paler race from Nicaragua, ‥ m. dilutus (Miller and Griscom), is not valid (Hellmayr, 1927: 269).

\section{Platyrinchus soronatus Sclater}

Golden-crowned Spadebill

SPECTMENS - -P. c. superciliaris (4): San Alejo, 31 March-3 AprII ( ${ }^{\prime},{ }^{\prime}$, LSUMZ); Lancetilla, 29 March ( 7, MCZ); Río Guampí, $10 \mathrm{mi}$. E Dulce Nombre de Culmi, 13 March (ó, LSLMZ).

PUBLISHED RECORD.--Lancetilla (Peters, 1929b: 445).

Reaching its northern limit of distribution in the rain forests of northern Honduras east of the Sula Valley, the Golden-crowned Spadebill is an uncommon bird in Honduras, occurring in dense rain forest below 1,500 feet elevation. It is generally found at low levels within the forest and is most common in the vicinity of streams.

Peters (1929b: 445) obtained the first Honduran specimen at Lancetilla in 1928; he saw no others there. From 1952 through 1955, Mark Trafton, Jr., recorded it annually in May and June at Lancetilla. In May 1952 he found a nest on a tree branch overhanging the river at Lancetilla. Paul slud also noted the species there in June 1952.

Richard R. Graber collected a male in a mist net along the Río Guampí on 13 March 1963 and saw another one there on 23 March. From 31 March to 3 April 1963, I observed the 
species three times at San Alejo, obtaining a male on 31 Merch and a female on 3 April.

The Honduran specimens are referable to the northern race, ․․ c. Buperctliaris Lawrence.

Tolmomyias sulphurescens (Spix)

Yellow-olive Flycatcher

SPECIMENS.-T. S. cinerelceps (89): San Ale jo, 6 Aug. (7. LSUMZ); La Céiba, 30 March, 3-29 May, 2-5 Aug. (40, 2 , CM); Trujillo, 31 March-9 Apri1, 26 Sep. (20, CM; ?, USNM); Catacombas, 24 March-6 Apr11 (o', 38, AMNH; 28, MLZ); Cofradia, 5-12 March ( $6,2 \%$, AMNH; 20, 5\%, MLZ); San Pedro (?, BMNH); Las Peñitas, $30 \mathrm{Jan}$. (?, MLZ); Amapa, $18 \mathrm{sep}$. (alc, LsuMz); Subirana, 20 March (o', MCZ); Coyoles, 13 June-il July (20, 69, CM); San Es teban, 26 June ( $0^{\circ}$, CM); 5.5 mi. S San Esteban, 22 Jan. (\%, ISUMZ); Rio Guampú, $10 \mathrm{mi}$. E Dulce Nombre de Culmi, 19 March (d, LSUMZ); Cerro Higuito, Santa Bárbara, 2 May ( $\$$, AMaNH); Cerro Santa Bárbara, east slope, 28 Nov. (o skel., LSUMZ); 1 mi. W E1 Jaral, 15 Sep. (1mm. skel., LSUMZ); $4 \mathrm{ml}$. SW El Jaral, 26 Oct. (2 imm. skel., LSUMZ); $5 \mathrm{mi}$. SW El Jaral, 28 Oct. (o' skel., LSUMZ); Finca Fé, 20 July-20 Jan. (5 $\delta^{\prime}, 2 \%$, $\delta^{\prime}$, $1 \mathrm{~mm}$. \&, 20" skel., क? skel. imm. o skel., imm. skel., 5 alc., LSLMZ); Lake Yojoa, 16 June-28 Juiy (20, 49, CM; $\$$, UF); E1 Caliche, 29 June (28, \&, AMNH); Monte Redondo, 10 Dec. ( 9 , AMNH); Cantarranas, 10 Aug. ( $\%$, ANSP); E1 Derrumbo, 20 July ( $\sigma^{\circ}, \mathrm{MLZ}$ ); Tegucigalpa, 25 May ( $\sigma^{\prime}$, MLZ); vicinity Tegucigalpa, 12 May (' skel., MLZ); Yeguare River Valley, 12 June, 18 Aug. (20, UF); Río Choluteca, Dept. El Paralso, 19 May ( $d$, UF); Rlo Guayambre, 20 Feb. ( $\$$, UF); E1 Boquerón, 3 Sep., 31 oct. (28, AMNH); San Lorenzo, 1 oct. ( $q$, MCZ); 2 mi. S E1 Corpus, 7 Oct. (imm. 2, LSUMZ).

PUBLISHED RECORDS.--San Pedro region (Sclater and Salvin, 1870b: 837). Trujtllo (Ridgway, 1888c: 580). San Pedro (Salvin and Godman, 1888: 10; Sciater, 1888: 170). Lancetilla (Peters, 1929b: 445). Cantarranas (Stone, 1932: 323). Near Tela (Skutch, 1960: 499).

This flycatcher is a common inhabitant of lowland rain forests on the Caribbean slope of Honduras and an uncommon resident in vega forests of the interior and in monsoon forests on the Pacific slope. Its center of abundance is 
at medium elevations in open forest, being the dominant species of flycatcher in these situations between 2,000 and 3,500 feet elevation; it even ranges into the lower reaches of cloud forest up to 5,000 feet, where the latter is continuous with rain forest.

Honduran populations are representative of the widespread Middle American race, I. g. cinereiceps (Sclater).

\section{Rhynchocyclus brevirostris (Cabanis)}

\section{Eye-ringed Flatbill}

SPECTMENS.--R. b. brevirostris (35): Catacombas, 1-2 April (2ठ, MLZ); Sañ Pedro Sula, 21 March ( $\sigma^{\prime}$, LSUMZ); Las Peñitas, 2-17 Feb. ( $q$, BMNH; 28,9 , MIZ); Portillo Grande, 20 Feb. ( $0^{\circ}$, CNHM); San Esteban, $26^{\circ}$ June $\left(0^{\circ}, C M\right)$; Río Guampú, $10 \mathrm{mi}$. E Dulce Nombre de Culmí, 16 March ( ${ }^{\circ}$, LS UMZ); Merendớn Copán, 15 June ( $\$$, ANSP); Mt. Puca, 7 Feb. ( $q$, MCZ); San José de Santa Bárbara, 1 April ( $\sigma^{\circ}$, AMNH); Cerro Santa Bárbara, east 8 lope, 19 Feb., 21 April, 7 Nov. -9 Dec. (50", skel., LSUMZ); 4 mi. SW El Jaral, 26 Oct. ( $\sigma^{\circ}$, ISUMZ); $5 \mathrm{mi}$. SW E1 Jaral, 4 Nov. (o', LSUMZ); 2 mi. SE E1 Jara 1, 3 March ( ${ }^{*}$, LSUMZ); Lake Yojoa, 15 June, 15-18 July, 25 Aug. ( $0^{\circ}, 49$, CM); Siguatepeque, 8 July ( 8, CM); San Marcos de Guaimaca, 30 June ( 9 , MLZ); Cantora1, 6-21 April (o, ANSP; $\sigma^{\circ}$, MLZ); Cerro Cantora1, 21 Feb. ( $q$, MCZ); Tegucigaipa, 14 April ( 7, BMNH); El Paraíso, 20 April (q, BMNH); Arena 1, 22 Jan. (o", UCLA).

Although this species is generally regarded as a rare inhabitant of lowland rain forests in Central Amertca and has not been reported previously from Honduras, it is a fairly common to locally common resident of cloud forest and low montane rain forest from 2,000 to 5,500 feet elevation, ranging uncommonly to sea level in lowland rain forest. Around Lake Yojoa and on Cerro Santa Bárbara it is common in the heavy forest, being found primarily at medium and low 
heights within the forest proper.

The Honduran specimens are referable to the Middle American race, B. b. brevirostris (Cabanis).

\section{Todirostrum cinereum (Linnaeus)}

Common Tody Flycatcher

SPECTMENS.--T. c. finitimum (45): Lancetilla, 18 Jan.,

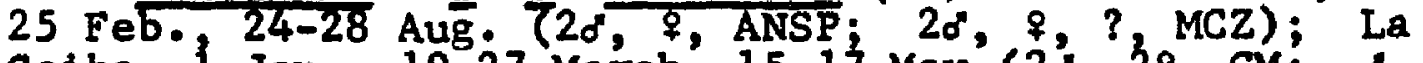
Celba, 1 Jan., 19-27 March, 15-17 May (26, 29, CM; of, MCZ; 9, USNM); Yaruca, 26 Feb. (o', MCZ); Trujillo, 31 March (d, CM); San Pedro Sula, 20 July (? BMNH; $\$$, USNM); La Lima, 4 Nov. (skel., LSUMZ); Amapa, 29 Nov. ( 8 skel., ISUMZ); Coyoles, 14-30 June ( $\left.d^{\prime,}, 9, C M\right)$; San Esteban, 22 June (2\%, CM); San José de Santa Bárbara, 30 April ( $\%$, AMNH); 1 mí. W EI Jaral, 15 Sep. (20", ₹, LSUMZ); Finca Fé, 22-23 July, 24 Nov. (2 $\sigma^{\prime}, \%$, LSLMZ); Lake Yojoa, 18 June ( $\left.\%, C M\right)$; Es cuela Agrícola Panamericana, 9 May ( $\%$, UF); Yeguare River Valley, 16-28 May, 31 Aug. ( $28^{\circ}, 28$, UF); Segovia River, 1215 June ( ${ }^{\circ}, 28$, USMM); San Lorenzo, 26 Sep. ( $\left.\sigma^{\circ}, \mathrm{MCZ}\right)$; 2 mi. NW Cedeño, $11 \mathrm{Feb}$. (7, LSUMZ); $5 \mathrm{mi}$. SE Namas 1güe, 8 Oct. ( $\sigma^{*}$, LSUMZ) ; "Honduras" (?, AMNH; 2 alc., USNM).

PUBLISHED RECORDS.--San Pedro region (Sclater and Salvin, I870b: 837) : Segovia River (RIdgway, 1888c: 589). San Pedro (Salvin and Godman, 1888: 12). La Gelba, Yaruca (Bangs, 1903: 147). Lancetilla, Lancetilla Valley (Peters, 1929b: 445-446). Lancetilla, Puerto Casti11a (Stone, 1932: 323). La Ceiba (Deignan, 1936: 192).

Ranging up to 3,500 feet in Honduras, the Comnon Tody Flycatcher is a common species in the Cartbbean lowlands and an uncommon resident in the interior and in the Pacific lowlands. It occurs in semi-open situations, usually in low shrubby growth or at lower levels in scattered trees. In the interior it generally is found along the edges of vega forests along rivers.

Honduran specimens are typical of the Middle American race, I. c. finitimum Bangs . 


\section{Todirostrum sylvia (Desmarest)}

\section{Slate-headed Tody Flycatcher}

SPEC MMENS.--T. S. Schistaceiceps (28): Lancetilla, 5 Sep. ( $\delta$, ANSP); Los Planes, 10 June ( $d, C M)$; Cofradía, 1011 March (", AMNH; ?, MLZ); San Pedro Sula, 13-31 July (36", USNM); Amapa, 19-28 April, $18 \mathrm{Sep} \cdot\left(20^{\circ}\right.$, F, LSUMZ); Coyoles, 21 June (o, CM); Rio Pataste, $12 \mathrm{mi}$. S Dulce Nombre de Culm1́, 27 Jan. ( $?$ ?, LSUMZ); San José de Santa Bárbara, 5 May (d, AMNH); Santa Bárbara, 11 May $(\sigma, q$, AMNH); Finca Fé, 27 Aug. (imm. skel., LSUMZ); Lake Yojoa, 14 June, 23 July $\left(0^{\circ}, \circ, C M\right)$; E1 Caliche, 26 June $\left(0^{\circ}, f\right.$, AMNH); Monte Redondo, 1 Dec. ( $\left.\sigma^{\circ}, \mathrm{MCZ}\right)$; El Hatillo, 30 April-6 May $\left(30^{\circ}, 38,3, \mathrm{MCZ}\right)$.

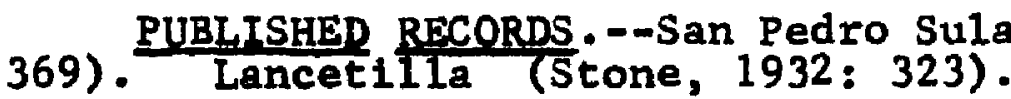

This tody flycatcher is an uncommon resident of rain forests on the Caribbean slope of Honduras, occurring primarily at low levels in open forest or in second growth. Altitudina1ly it ranges up to 3,500 feet. On the Pacific drainage it has been found locally in vega forests in the Teguclgalpa region.

Ridgway (1907: 369) mentioned reports of the species from La Ceiba and Yaruca, presumably based on a record of Bangs (1903), but the latter did not list I. sylvia. Bangs (1903: 147) did, however, collect I. cinereum at these 10calities and apparently Ridgway confused these reports.

All Middle American populations belong to the race $T$. 8. Schistaceiceps Sclater.

\section{Oncostoma cinereigulare (Sclater)}

Northern Bentbill

SPECIMENS.--(58): San Alejo, 19 March, 5 April (d, ?, 
LSUMZ); Lancetilla, 25 Aug. -6 Sep. (20, ?, ANSP); La Ceiba, 1 May, 1-7 June (36, CM); Los Planes, 9-10 June (36, CM); Trujilio, 31 March, 19-22 Sep. (o", CM; on, ${ }^{\circ}$, USM); Catacombas, 2-25 March (d, ?, AMNH); Cofradía, 9-15 March (50", ₹, AMNH; o, ${ }^{\circ}$, MLZ); San Pedro Sula, 13 July, 30 Dec . ( $\sigma^{\circ}, \%$ USNM); Rlo Blanco, Cortés, 2-19 Dec. ( $\sigma^{\circ}$, f, USNM); Las Peñitas, 3-5 Feb. (20", AMNH; $\sigma^{\circ}$, MLZ); Progreso, 31 Jan. (?, MCZ); Amapa, 24 June, 29 Nov. ( $\$$, $\$$ skel., LS UMZ; $\checkmark$, UF); Coyoles, 15-18 June ( $q, ?, \mathrm{CM})$; Merendón Copán, 12 June (o", AMNH); Cerro Higuito, Santa Bárbara, 26 April ( $\sigma^{\circ}$, AMNH); San José de Santa Bárbara, $1-6$ May (2\%, AMNH); 2 mi. SE El Jara 1, 24 Feb. ( $\sigma$, LSLMŹ); Finca Fé, 3 Sep.-13 Jan. ( $\sigma^{\circ}, q, ?$, imm. o", skel., Imm. o" ske1., 3 alc., LSUMZ); Lake Yojoa, $19-25$ June (?, CM; $\&$, UF); EI Derrumbo, 3-9 Aug. ( 0 , AMNH); Yeguare River Valiey, 22 May ( 8 , UF ; E1 Boquerón, 20 Sep. (d, AMNH); Arenal, 27 Jan. (d", UCLA); "Honduras" (?, BMNH).

PUBIISHED RECORDS.--"Honduras" (Sclater, 1888: 77). San Pedro Sula, Trujilio, Rio Blanco (Ridgway, 1907: 359). Near Progreso (Peters, 1929b: 446). Lancetilia (Stone, 1932 : 323).

Oncostoma cinerelgulare is a fairly common to common resident of lowland rain forests in Honduras, ranging up to 3,500 feet elevation. It inhabits the lower levels of dense forest, of open forest, and of second growth. On the Pacific slope and in the interior of Honduras it is decided1y uncommon, occurring in the vega forests along the rivers and in the monsoon forests of the lowlands.

C. H. Townsend obtained the species at Truj1110, but it was omitted by Ridgway (1888c) in the latter's account of Townsend's material.

Populations from the Pacific slope of Middle America have been described as 0 . c. pacifica Brodkorb [1939: 7; Finca Esperanza, Chiapas] on the basis of a longer and wider b111 and a greener pileum. An examination of specimens from this region does not show the differences mentioned 
above. I therefore retain the species as monotypic, since I follow Dickey and van Rossem (1938: 390-391) in regarding o. ollvaceum (Lawrence) of Panama as a distinct species.

\section{Elaenia flavogaster (Thunberg)}

Yellow-bellied Elaenia

SPEC MMENS.--E. f. Subpagana (31): La Ceiba, 17-20 Jan., 30 April-7 June ( $5 \%, \mathrm{CM}$; $8, \mathrm{MCZ}$ ); Trujillo, 30 March, 21 Sep. (o", CM; of, USNM); San Pedro Sula, 21-26 July, 31 Dec. (20, $\%$, USMM); Río Pataste, $12 \mathrm{mi}$. S Dulce Nombre de Culmi, 23 Jan. ( $\%$, LSUMZ); E1 Conejo, 20 May ( $\%$, MLZ); Monte EI Conejo, 15 May ( $\$$, MLZ); 1 mi. SW EI Jaral, 27 April ( $d$, LSUMZ); 1 mi. W E1 Jaral, 16 Sep. ( $\$$, LSLMZ); Agua Azui, 10 Aug. ( $($, UF); Lake Yojoa, 25 June-17 Aug. ( 0 , $39, \mathrm{CM}$; \&, UP); Monte Redondo, 30 Nov. ( $7, \mathrm{MCZ}$ ); Tegucigalpa, 6 April ( $q$, AMNH); Bromadero [= Dromodero Mts.], 26 July ( $q$, UF); Puerto Lempira, 6 Feb., 8-11 April (d, 2\%, ISUMZ); San Francis co, Choluteca, 12 Feb. ( $\sigma^{\prime}$, LSUMZ); "Honduras" (alc., USNM).

RUBLISHED RECORDS.--San Pedro region (Sclater and Salvin, 1870b: 837). Trujillo (RIdgway, 1888c: 580). San Pedro (Salvin and Godman, 1888: 35). La Celba (Bangs, 1903: 147). San Pedro Sula (RIdgway, 1907: 431). San Pedro Sula and Trujillo [as saturata] (Brodkorb, 1943c: 3).

The Yellow-bellied Elaenia is an uncommon to fairly common resident in semi-open or open situations, generally In the vicinity of broadleaf forests or in areas of scrubby growth. It is fairly common around human habitation on the Caribbean slope and is a conspicuous species in the scrubby areas in the Mosquitia. On the Pacific slope and in the interior, it occurs in arid situations up to an elevation of at least 5,500 feet.

Honduran specimens are all typical of the Middle American race, E. E. subpagana Sclater and Salvin. I cannot see any constant differences in coloration between Caribbean 
slope and Pacific slope populations, though the former are often considered a separate subspecies, E. f. Saturata Brodkorb [1943c: 1; Palenque, Chiapas]. Honduran individuals from the Pacific slope are not different from those of the Caribbean slope. If saturata is recognized, then subpagana does not extend south of El Salvador.

\section{Elaenia frantzif Lawrence}

\section{Mountain Elaenia}

SPECTMENS.--E. E. ultima (65): Las Peñitas, 15 Feb. ( ${ }^{\prime}$, MCZ); E1 Chorro, 15 June-9 July (o, AMNH; $60^{\prime}, 2 \%$, MLZ); Ei silión, $10^{\circ}$ July (20, 2\%, MLZ); Montaña E1 Sillón, 22 June-2 July ( $3 \sigma^{\prime}, q, ?$, MLz); Montaña La Cruz, 25 June-7 July (3o, MLZ); Pian del Rancho, 22 June ( $\sigma^{*}$, MLZ); Las Ventanas, 27 July ( ${ }^{\prime}$, MLZ); Mt. Puca, 14 Jan. ( $d$, MCZ); 4 mi. NW La Esperanza, 23 Jan. ( $\sigma^{\circ}$, LSUMz); 4 mi. SE La Esperanza, 22-24 Jan. ( ${ }^{\prime}$, \%, LSIMZ); La Florida, 11 Dec. ( 7 , AMNH); Cerro Santa Marla, 29 Dec. (d, MCZ); Las Delicias, 15 Nov. (", AMNH); Cantora1, 6-22 Feb., 3-15 April (2\%, AMNH; $30^{\circ}, 3 \%$, USNM); Alto Cantoral, 23 Jan. $-9 \mathrm{Feb}$. (20, MLZ; 37, MCZ); Archaga, 11 June ( ${ }^{\circ}$, AMNH); La Flor Archaga, $13 \mathrm{Jan}$. ( 6 , AMNH); San Juancito, 4 July-12 Aug. ( $\sigma^{\prime}, q, ?$, ANSP; $\left.\delta, C M\right)$; San Juancito Mts., 29 Jan., $19-29$ June $\left(2 \delta^{\circ}, q\right.$, UF); Rancho Quemado, 12-20 March, 2-17 May ( $\$$, AMANH; $\alpha, 5$, MCZ); E1 Derrumbo, $17 \mathrm{July} \mathrm{(q,} \mathrm{MCZ);} \mathrm{E1}$ Hatillo, 8 May ( $?, \mathrm{MCZ}$ ); vicinity Tegucigalpa, 29 March ( $\sigma^{\circ}$ ske1., MLZ); Monserrat, $31 \operatorname{March}(q, ?$, UF).

PUBLISHED RECORD.--San Juancito (Stone, 1932: 323).

In Honduras this elaenia is a fairly common species in cloud forest regions of the interior highlands, ranging from 3,500 to at least 7,500 feet; it is most frequently encountered above 4,500 feet. It inhabits primarily forest edge and second growth.

Zimmer (1941a: 15-16) discussed reasons for retaining E. Erantzii as a species distinct from E. obscura (d'Orbigny 
and Lafresnaye) of South America, with which I am in complete agreement.

The northernmost population of the spectes in Guatemala has been described as a distinct race, E. $\underline{\text { f. ultima [Elaenia }}$ obscura ultima Griscom, 1935b: 550; San Pedro Martyr, Guatemala], on the basis of coloration, browner above and more olive below in the breast region. Honduran specimens are close to Guatemalan Individuals in these characteristics and differ from nominate E. E. frantzit Lawrence from Costa Rica, although they are not as extreme as Guatemalan birds, as pointed out by Griscom (1935b: 550-551). The entire Honduran series is relatively uniform and compares favorably with specimens from E1 Salvador and Guatemala. Dickey and van Rossem (1938: 392-394) were in error In assigning Salvadorean populations to the nominate race.

\section{Myiopagis viridicata (Vielllot)}

\section{Greenish Elaenia}

SPECIMENS. --M. v. placens (23): La Ceiba, 12 Jan. ( $\delta$,

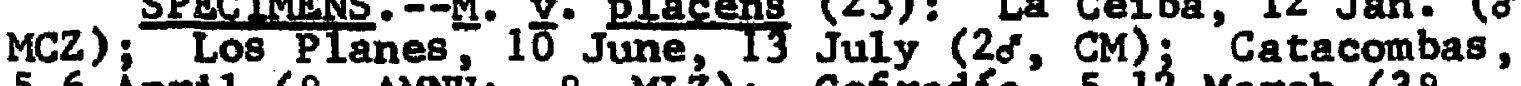
5-6 April ( $\%$, AMNH; $;$, MLZ); Cof radia, 5-12 March (3\%, AMNH; $\left.20^{\circ}, 29, \mathrm{MLZ}\right)$; Las Peñitas, $8 \mathrm{Feb}$. (?, MLZ); Subtrana, 20 March ( $\sigma^{\circ}$, MCZ); Finca Fé, 14 Jan., 20 Feb., 5-25 Nov.' ( $\delta, q$, imm. $\delta$, $q$ ske1., LSUMZ); Lake Yojoa, 16 'June-16 Aug. ( $\left.20^{\circ},{ }^{\circ}, 1 \mathrm{~mm} .0^{\circ}, \mathrm{CM}\right) ;$ Jamastrán Valley, 17 Aug. ( $q$, UF). M. y. pacificus (4): E1 Hatil10, 2 May ( $q$, ANSP); Midence's woods, 18 Aug. (imm., AMNH); $15 \mathrm{mi}$. NE'Cedeño, 9 Oct. (\%, LSLMZ); 2 mi. S EI Corpus, 10 Feb. (d, LSUMZ). PUBLISHED RECORD.--La Celba (Bangs, 1903: 147). The Greenish Elaenia is a fairly common resident in the lowlands of the Caribbean slope and an uncommon resident on 
the Pacific slope. In Honduras it has not been recorded above 3,000 feet elevation. It is a species of forest edge or second growth, occurring in arid scrub and in open situations in monsoon forest on the Pacific slope.

The recognition of the genus Myiopagis as distinct from Elaenla has been discussed at length by Zimmer (194la: 20). Populations on the Caribbean slope of Honduras are typical of the race $\underline{M} \cdot \underline{y}$. placens (Sclater). No Honduran material shows any approach to the more southern race, $\underline{M} \cdot \underline{v}$. accola Bangs, which ranges north to Nicaragua. Specimens from the Pacific slope of Honduras are decidedly paler yellow below than placens and average duller green on the back. I assign these birds to the race $\underline{M} \cdot \underline{y}$. pacificus [Elaenia viridicata pacifica Brodkorb, 1943a: 3; Finca Esperanza, Chiapas, altitude 150 meters], extending the range of that race south of E1 Salvador.

\section{Camptostoma imberbe Sclater}

Northern Beardless Flycatcher

SPECTMFNS.--C. I. imberbe (26): La Celba, 29 May ( ${ }^{\prime}$, CM); Truj1110, 8 April (7, CM); Chamelecón, 23 Feb. ( ${ }^{\prime}$, USMM) i San Marcos de Gua imace, 4-5 July (20, AMNH); Cantoral, 15 June ( $\delta$, AMNH); Monte Redondo, 14 Sep., 2-15 Dec. (o, ANSP; $\delta "$ AMNH; 3o, \&, MCZ); La Flor Archaga, 11-15 June $(2 \%, ?$, AMNH); San Antonio road, $5 \mathrm{mi}$. NE Escuela Agrícola Panamericana, 10 June (?, UF); Yeguare River Valley, 14 April, 11 May ( $\sigma^{\circ}, q^{\circ}$, UF); Rio Choluteca, Dept. E1 Paralso, 11 Aug. ( $q$, UF); Puerto Lempira, 9-11 Apri1 (20, LsUMZ); Piedra de Jesús, 3 March (d", AMNH); San Lorenzo, 26 Sep. ( $d$, MLZ); "Honduras" (2?, ANSP; ?, BMNH). PUBLISHED RECORD.--"Honduras" (Sclater, 1888: 127). 
Camptostoma imberbe is an uncommon to fairly common inhabitant of open situations with scrubby growth in either arid or humid regions of Honduras. It occurs in the interior valleys, in the Pacific lowlands, and in areas along the north coast, being fairly common locally in scrubby situations in the Mosquitia. It has not been recorded above 5,000 feet elevation in the republic.

Honduran specimens are referable to the nominate race, C. 1. imberbe Sclater.

Tyranniscus vilissimus (Sclater and Salvin) Paltry Tyrannulet SPECTMENS.--T. v. parvus (4): Lancetilla, 14 Jan. (d", \&, MCZ); La Ceiba, 27 July-2 Aug. (o', \&, CM). 1888: $\frac{\text { PUBLISHED }}{33 \text { ). TECORDS. --San Pedro (Salvin and Godman, }}$ Ta River above Lancetilla (Peters, 1929b: 447).

In Honduras this tyrannulet is an uncommon resident of 1owland rain forests on the Caribbean slope. The species inhabits open woodland and second growth, generally keeping high in trees. In the republic it has been recorded only from sea level to 1,000 feet.

George M. Whitely collected a specimen at San Pedro (Salvin and Godman, 1888: 33), but I did not find the skin in the British Museum in 1961. Peters (1929b: 447) obtalned a pair in 1928 near Lancetilla. Arthur C. Twomey and Roland $W$. Hawkins collected a female on $27 \mathrm{July}$ and $a$ male on 2 August 1950 at La Celba. 
As Peters (1929b: 447) has pointed out, Honduran specimens are representative of the smaller, southern race, $\underline{T}$. $\mathbf{v}$. parvus Lawrence. The wings ( $8,44.7,48.0$; $9,40.8,44.7$ ) are decidediy smaller than in examples of the nominate race, I. v. vilissimus (Sclater and Salvin), from Guatemala.

\section{Ornithion semiflavim (Sclater and Salvin)}

Yellow-bellied Tyrannulet

SPECIMENS.--(5): Lancetilla, 6 Feb. ( 9, MCZ); La Ceiba, 2 Aug. ( $\%$, CM); Lake Yojoa, 14 June (Juv. ${ }^{\circ,}$ CM); Arena 1, 23-28 Jan. (o", $\$$, UCLA).

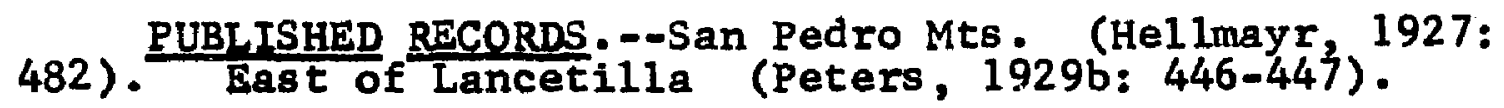

Ranging up to an elevation of 2,500 feet, the Yellowbellied Tyrannulet is a rare to uncommon resident of lowland rain forest on the Caribbean slope of Honduras. Although primarily a bird of heavy forest, it does occur occasionally in second growth. It is most frequently observed high in the forest canopy.

Hellmayr (1927: 482) listed a male specimen, presumably in the Brunswick Museum, that was taken by Erich Wittkügel in the San Pedro Mountains on 5 February 1892, but I have not seen this individual. Peters (1929b: 446-447) obtained a female near Lancetilla in 1928. Arthur C. Twomey and Roland W. Hawkins collected a male at La Celba In 1950 and a juvenal male at Lake Yojoa in 1951. T. R. Howell secured a female on 23 January and a male on 28 January 1953 at 
Arena1. I did not encounter the species in Honduras in 1962-1964.

I follow Zimmer (1941b: 3) in merging Microtriccus and ornithion, the latter name being the oldest.

I agree with Peters (1929b: 446-447) that Q. brunneicapillum (Lawrence) is probably a separate species. Pending further studies, I am therefore regarding 0. semiflavum as monotypic.

Leptopogon amaurocephalus Tschudi

Sepia-capped Flycatcher

SPECIMENS.--L. a. pileatus (38): Lancet111a, 2 Sep. (?, ANSP); La CeIba, 1 June (J, CM); Catacombas, 27 March2 April ( $\delta,{ }^{\circ}, M C Z$ ); Cofradia, 9 March (o, MCZ); Las Peñitas, 6-8 Feb. ( $\$$, AMNH; 2, MCZ); Amapa, 18 Jan. ( $0^{\circ}$, ISUMZ); Rio Pataste, $12 \mathrm{mi}$. S Dulce Nombre de Culmi, 27 Jan. ( $\$$, LSLMZ); San José de Santa Bárbara, 12 Apri1, 1 May ( ${ }^{*}, ?$ ANSP); Cerro Santa Bárbara, east slope, 27 March (fo, LSUMZ); 2 mi. SE El Jaral, 22 Feb. ( 9 , ISUMZ); Finca Fé, 9 Aug -11 Dec. (3o", 7\%, 2?, 1mm. $\&$, o skel., skel., imm. o skel., Imm. skel., alc., LSUMZ); Lake Yojoa, 27 July-23 Aug. (3o", + , Imm. of, CM); "Honduras" (?, BMNH).

PUBLISHED RECORDS.--"Honduras ?" (Sc1ater, 1862: 213). "Honduras" (Sclater, 1888: 116-117). Lancetilia (Stone, 1932: 324 ).

Although in Central America this flycatcher is generally regarded as a rare species, it is fairly common to localIy common in the lowland rain forests on the Caribbean slope of Honduras. It is most abundant at medium elevations between 1,500 and 3,000 feet but ranges at least as high as 4,500 feet into the low montane rain forest on Cerro Santa Bárbara. It tnhabits both dense forest and open forest, usually at mediun heights below the tree canopy. 
Honduran specimens are typical of the northern race, $\underline{L}$. a. pileatus Cabanis. I cannot see any constant geographic variation from Mexico to Panama and regard $\underline{\text { L. }}$. faustus Bangs as a synonym of pileatus.

Pipromorpha oleaginea (Lichtenstein)

Ochre-bellied Flycatcher

SPECIMENS.--P. ㅇ. assimilis (130): Julián [= Tulián] (?, ANSP); San AIejo, 30 March ( $\%$, LSUMZ); Lancetilla, 2023 March, 1 Sep. ( $\%$ ? ?, ANSP; 20, MCZ); La Ceiba, 28 July5 Aug. (o", $\$, C M)$; Trujillo, 31 March $(\$, C M)$; Catacombas, 18 March-9 April (27o, 39, 2?, AMNH; 36, 29, MLZ); Cofradía, 1-12 March (4d", 4q, ?, AMNH; $d^{\prime \prime}$, \%, ?, ML,Z); Las Peñitas, 30 Jan. -9 Feb.' (40, $7 \%$ ?, AMNH; $\%$, BMNH; $\delta, ?$, MLZ); Progreso, 30 Jan. ( $0^{\circ}$, MCZ); Subirana, 15 March ( ${ }^{\circ}$, MCZ); Port1110 Grande, 2-5 May (20, MCZ); San Esteban, 1 July ( $\left.0^{\circ}, C M\right)$; La Libertad, 10-28 June ( $0^{\circ}, \$$, AMNH); Santa Bárbara, 16-20 May (3d", AMNH); Finca Fé, 7 Aug.-23 Nov. (20, ?, imm. of, imm., imm. of skel., imm.'skel. 3 alc., ISUMZ); 2 mi. SE E1'Jaral, 20 April (d, LSUMZ); Lake Yojoa, 15 June-5 Aug. ( $\left.60^{\circ}, \mathrm{CM}\right) ; 2 \mathrm{mi}$. N Pito Solo, 25 oct. (imm. \& ske1., LSUMZ); San Marcos de Guaimaca, 23 June-5 July $\left(20^{\circ}, 49, ?\right.$, AMNH; $0^{\circ}$, MLZ); Alto Gua imaca, 9 June ( $0^{\circ}$, AMNH); Cantoral, 5 Feb., 11 April-17 May, 15-24 July, 16

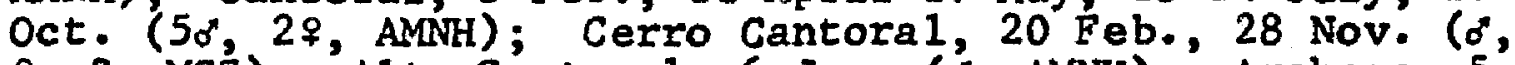
\&, ?, MCZ); Alto Cantoral, 6 Jan. ( ${ }^{\circ}$, AMNH); Archaga, 5 Aug. (o', AMNH); E1 Derrumbo, 14 July-9 Aug - (50", $\$$, AMNH); E1 Boquerón, 25 Sep. (o", AMNH); "Honduras" (?, USNM).

PUBLISHED RECORDS.--San Pedro region (Sclater and Salvin, 1870b: 837). San Pedro (Salvin and Godman, 1888: 23): Progreso, Lancet11la (Peters, 1929b: 446) Lancetilia (Stone, 1932: 324). Near Tela (Skutch, 1945a: 20; 1960: 566).

The Ochre-bellied Flycatcher is a common inhabitant of lowland rain forests on the Caribbean slope of Honduras and an uncommon to fairly common resident in broadleaf cloud forests, vega forests, and monsoon forests in the interior and on the Pacific slope, occurring up to 6,000 feet. It 
frequents low to medium levels within either dense or open forest.

I cannot detect any constant geographic variation in populations from Mexico to Costa Rica and consider these to

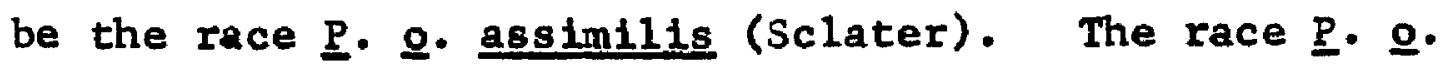
dyscola (Bangs), formerly recorded north to Nicaragua, is now restricted to populations in Panama. The type of $\underline{P}$. $\underline{o}$. obscura Dickey and van Rossem [1925: 133; San Salvador, Salvador] is an example of assimilis.

Family HIRUNDINIDAE

Progne subis (Linnaeus)

Purple Martin

SPECIMENS.--P. s. Subis (4): $5 \mathrm{mi}$. E Puerto Cortés, 9 Sep. (1mm. d, LSUMZ); LaCeiba, 3 May $(\delta, f ; C M) ; 2 \mathrm{mi}$. NW Namas igüe, 8 oct. ( $\sigma^{\prime}$, LSUMZ).

Although previously unrecorded from Honduras, the Purple Martin is a fairly common migrant along both coasts of the republic and in the Caribbean 1slands.

Arthur C. Twomey and Roland W. Hawkins collected the first Honduran specimens, a pair taken at La Ceiba in 1948. My own records of Purple Martins in Honduras are as follows: on 19 August and on 9 September 1962, flocks exceeding 25 individuals each along the beach at Tela and near Puerto Cortés, respectively; from 8 to 12 October 1962, several males in the Choluteca-Nemasigüe region along the Pacific coast; on 23 October 1962, one male at omoa, on the 
Caribbean coast; on 29 January 1963, a flock of 15 migrating In a generally northerly direction near Taulabé, not far from Lake Yojoa (elevation of observation point, 1,500 feet); from 6 to 9 April 1963, small groups of from three to 10 individuals around Little Hog Island, in the Cayos Cochinos; from 6 to 8 May 1963, several large flocks exceeding 100 individuals each over Utila Island, in the Bay Is lands, headed in a northerly direction over the Caribbean Sea; on 9 and 13 April 1964, single males at Puerto Lempira, in the Mosquitia.

I tentatively refer all Honduran specimens to the eastern race, $\underline{P}$. . subis (Linnaeus). The western subspectes, $\underline{P}$. $\underline{\text { s. hesperia }}$ Brewster, undoubtedly also migrates through Honduras; this race is identiflable only from female specimens. I doubt that it is ever worth recognizing taxonomically.

\section{Progne chalybea (Gmelin)}

\section{Gray-breasted Martin}

SPECTMENS.--p. c. chalybea (31): Martinez Creek, 27 Feb. $\left(\sigma,{ }^{7}, \mathrm{MCZ}\right) ; \mathrm{Tela} 26$ March (\%, MCZ); La Celba, 24 April-3 May $\left(20^{\circ}, 2 \%, C M\right)$; Los Planes, 13 July ( $\left.0^{\circ}, C M\right)$; San Pedro (1mm. BMNH); Chamelecón, 21 Feb. (o", $q$, USNM); Subirana, 28 Jan. (20, \&, MCZ); Portillo Grande, 6 June (?, CNFM); Coyoles, 29 June-12 July $\left(20^{\circ}, 2 \%, C M\right)$; I mi. SW E1 Jara1, 26 April (o', LSUMZ); Guaimaca, 6 June (?, MLZ); Alto Gualmaca, 9 June ( $\delta$, MLZ); Comayagüela, 16 June ( $\sigma^{\prime}$, ?, AMNH); Escuela Agrícola Panamericana, 22 Feb., 18 April, 28 June, 22 July $\left(20^{\circ}, \$\right.$, Imm., UF); Yeguare River Valley, 26 May ( $\left.\sigma^{\prime \prime}, \mathrm{MCZ}\right)$; San Lorenzo, 26 Sep. ( $\left.\sigma^{\circ}, \mathrm{MCZ}\right)$; "Hondures" (juv., BMNH). 
PUBLISHED RECORDS.--Comayagua (Taylor, 1860: 110-111). San pedro region (Sclater and Salvin, 1870b: 836). San Pedro (Salvin and Godman, 1883: 225). "Honduras," San Pedro (Sharpe, 1885: 180, 633). Martinez Creek, $34 \mathrm{~km}$. W Tela; Tela region (Peters, 1929b: 456-457). Tegucigalpa [= Comayagüela] (Zimmer, 1955a: 5).

Ranging up to an elevation of 4,500 feet, the Graybreasted Martin is a comon summer resident throughout the lowlands of both coasts and in the intertor. It is migratory in the northern part of its range, including in Honduras; there are no records for the republic between 19 October and 21 January. It is common in most open or semiopen situations and is especially common around human habitation, including the larger towns. It is a frequent nester in high buildings such as cathedrals.

Honduran specimens are typical of the widespread nominate race, $\underline{P}$.. . chalybea (Gmelin).

\section{Petrochelidon pyrrhonota (Viel1lot)}

\section{Clife Swallow}

SPECIMENS.--P. p. pyrrhonota (7): Swan Islands, 21 March (o, MCZ); Trujil o, 21 Sep. (?, USNM); $1 \mathrm{mi}$. SW E1 Jaral, 26 April ( $\sigma^{\prime}$, LSUMZ); Comayagüela, 18 Sep. ( $9, M C Z$ ); Puerto Salamar, 26 Sep. ( $\sigma^{*}, 29$, LSUMZ).

$$
\text { PUBLISHED RECORDS.--Trujillo (Ridgway, 1888c: 579). }
$$
Swan $\frac{\text { PUBLISHED }}{\text { Islands }}$ (PECOnter, 1956: 106).

The Cliff Swallow is an uncommon to common migrant along both coasts of Honduras and in the intertor, occurring up to an elevation of 3,000 feet; there is also one record for the Swan Islands. 
C. H. Townsend (Ridgway, 1888c: 579) collected the first Honduran specimen at Trujillo in 1887. Neal Wilson (Paynter, 1956: 106) obtained a male in the Swan Islands in 1927. C. F. Underwood secured a female at Comayagüela in 1932. From 26 September to 14 October 1962, I daily observed more than two hundred Cliff Swallows passing along the coast of the Bay of Fonseca, flying west to east; the three Puerto Salamar specimens were taken during this migration. I saw one near Lake Yojoa on 14 April 1963 and noted about 10 Individuals there from 26 to 29 April; one spectmen was taken on 26 April. I observed one individual on 3 May and two on 4 May 1963 on Ut1la Island, in the Bay Islands, along with a number of other migrating swallows. Presumably all the northern races of this species migrate through Central America; Dickey and van Rossem (1938: 405-406) reported four races from E1 Salvador. The seven Honduran specimens, however, are referable to the eastern North American subspecies, P. p. pyrrhonota (Vieillot).

\section{Hirundo rustica Linnaeus}

\section{Barn Swallow}

SPECIMENS. - -H. E. erythrogester (27): Swan Islands, 19

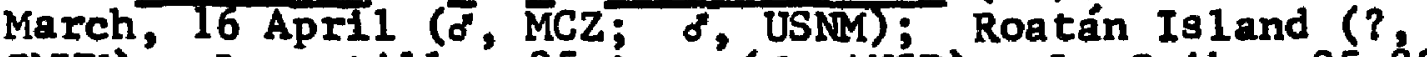
BMNH); Lancet1l1a, 25 Aug. (o, ANSP); La Celba, 25-29 Apri1 ( $\sigma^{\circ}$, CM; 20, USN); Trujillo, 21 Sep. (juv., USNM); $1 \mathrm{ml}$. W E1 Jaral, 15 Sep. (Imm. o, LSUMZ); $1 \mathrm{mt}$. SW E1 Jara 1, 26 April ( ${ }^{\circ}$, LSUMZ); Lake Yojoa, 23-25 Aug. (20, CM); La Flor Archaga, 15 oct. ( ${ }^{*}$, AMNH); Comayagüela, 16 Sep.-31 Oct. ( $\sigma^{*}, \&$, AMNH; 2 ${ }^{\circ}$, MCZ); Escuela Agricola Panamericana, 19 oct.' (?, UF); San Lorenzo, 26 Sep. -6 oct. $\left(30^{\prime}, 2 \%, 2\right\}$, MLZ; $\left.\delta, \$, M C Z\right)$. 
PUBLISHED RECORDS.---Swan Is lands, Trujillo (Ridgway, $1888 \mathrm{c}: 576,579$ ) Roatán Island (Salvin, 1888: 256). Swan Is lands (Fisher and Wetmore, 1931: 14-15; Paynter, 1956: 106) Lancetilla (Stone, 1932: 325). La Ceiba (Deignan, 1936: 192); Yeguare River Valley (Carr and Dickinson, 1951: 272).

In Honduras the Barn Swallow is a common migrant and uncommon winter visitant in the lowlands of both coasts, in the islands off the north coast, and in the interior, usually along rivers and around lakes. It has not been recorded above 2,500 feet elevation in the republic. Extreme dates of arrival and departure for Honduras are 16 August and 13 May.

Honduran specimens are referable to the North American

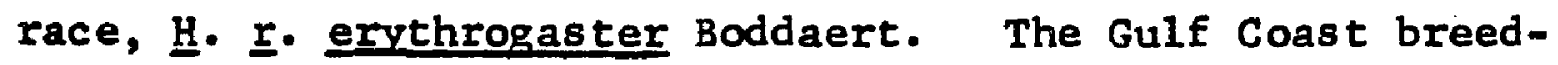
ing population of the southeastern United States has been described as H. I. insularis Burleigh [1942: 179; Ship Island, lying sixteen miles offshore from Gulfport (= Gulfport, Mississippi)] on the basis of the very pale under parts. The race insularis is generally regarded as a synonym of exythrogaster, although it may eventually prove to be a valid race. Two adult males of this species taken at Lake Yojoa on 23 and 25 August 1951 by Arthur C. Twoney and Roland $W$. Hawkins match breeding insularis and should be referred to that race if it is accepted.

\section{Stelgidopteryx ruficollis (Vieillot)}

Rough-winged Swallow

SPEC MENS - - S. ․․ Serripennis (11): Lancetilla, 14 Jan. -30 March $\left(40^{\circ}, 2 \overline{9}, \overline{M C Z}\right)$; Trujillo, 6 April (o, CM); 
Subirana, 26 Jan.-20 Feb. (3\%, MCZ); 1 mi. SW El Jaral, 26 April ( $\%$, LSUMZ). S. … fulvipennis (22): Lancetilla, 8 Feb. ( $\sigma, M C Z)$; San Esteban, 28 June ( $\sigma, q, C M)$; Agua Azul, 25 oct. ( $\sigma^{\prime}$, LSUMZ); La Cruz Grande, $16^{\circ}$ March ( ${ }^{\circ}, \%$, AMNH); Guaimaca, 6 June (2?, MCZ); Alto Guaimaca, 7-13'June (3 juv. o, AMNH; 20, MCZ); Jamas trán Valley, 12 Aug; ( $\left.\sigma^{*}, U F\right)$; E1 Boquerón, 27 Aưg., 13-14 Oct. (3\%, 2\%, 2?, AMNH); Arenal, 15 Jan. ( $\%$, UCLA).

PUBLTSHED RECORDS.--"Honduras" (Taylor, 1860: 110111). Lancetilia [as serripennis] (Peters, 1929b: 457). Lancetilla las fulvipennis] (Brodkorb, 1942b: 216-217). [Big] Swan Island (Bond, 1959: 9).

Ranging up to 4,000 feet elevation, the Rough-winged Swallow is a fairly common to common resident in the lowlands of both coasts of Honduras and in the interior, generally along watercourses. Breeding populations from North America migrate through, and winter in, Honduras, and the species is therefore least abundant from May to July. The Swan Islands records, undoubtedly based on migrants from North America, consist of a series of observations by Charles H. Blake from 11 to 23 November 1958 (Bond, 1959: 9).

The North American breeding race, $\underline{S}$. $\underline{\text {. Serripennis }}$ (Audubon), is a common migrant and winter visitant in Honduras; it differs from the resident race, $\underline{s}$. $\underline{\text {. fulvipennis }}$ (Sclater), in always lacking buff on the throat, in having the crissum entirely white, and in averaging slightly paler above. The spectmen from Lancetilla taken on 8 February 1928 has been discussed at length by Peters (1929b: 457) and by Brodkorb (1942b: 216-217); its large size (wing reported as 121 though measured by me as 119.9) indicates an approach 
to the subspecies $\underline{S}$. $\underline{\text {. }}$ stuarti Brodkorb [1942b: 217; Finca Panzamalá, Alta Verapaz, Guatemala, altitude 1230 meters], but it is not nearly as dark as that race. None of the Honduran specimens exhibits any strong approach to the race

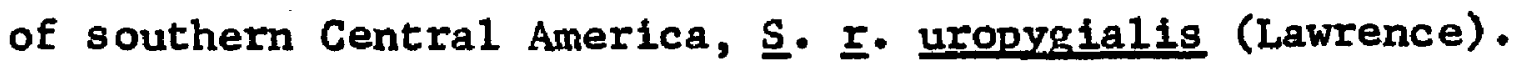

\section{Notiochelidon pileata (Gould)}

\section{Black-capped Swallow}

\section{₹, LSUMZ).}

SPECIMEN.--(1): $10 \mathrm{mi}$. NE La Esperanza, $22 \mathrm{Jan}$. (imm.

This species of swallow is confined to the highlands of northern Centra1 America. It occurs in Chiapas, Guatemala, and E1 Salvador and ranges into the mountains of western Honduras in the nonbreeding season. On 22 January 1963 I collected a single specimen from a pair seen flying over the road approximately $10 \mathrm{miles}$ northeast of La Esperanza; the elevation at this spot was 6,200 feet. Another small group of four individuals was observed the same day about six miles northeast of $\mathrm{La}$ Esperanza at an elevation of 6,400 feet. No others were seen despite several journeys over the same Mazaguara-La Esperanza road on subsequent dates. The species has not been previously recorded from Honduras .

\section{Riparia riparia (Linnaeus)}

Bank Swallow

SPECIMENS. - - R. I. Ilparia (8): Swan Is lands, 26 March ( 9 , MCZ); La Celba, 25 April ( $\delta^{\circ}$, USNM); 1 mi. SW El Jaral, 26 Apri1 ( $\%$, LSUMZ); Comayagüela, 16-22 Sep. (30", MCZ); 
San Lorenzo, 6 oct. ( $\left.\sigma^{\circ}, M C Z\right)$; 4 mi. NE Choluteca, 12 oct. (o, LSUMZ).

PUBLISHED RECORDS.--La Ceiba (Deignan, 1936: 192). Swan Islands (Paynter, 1956: 106).

In Honduras the Bank Swallow is an uncommon to fairly common migrant along both coasts, in the islands off the north coast, and in the interior. It has not been recorded above 3,500 feet elevation in the republic.

Stone (1932) 1isted the species from Honduras on the basis of a record by Salvin and Godman (1883: 240), but the latter did not report this species from Honduras.

Neal Wilson (Paynter, 1956: 106) collected a female in the Swan Is lands in 1927, the first definite Honduran record. In $1932 \mathrm{C}$. F. Underwood obtained single males at Comayagüela on 16, 20, and 22 September and another male at San Lorenzo on 6 October. Deignan (1936: 192) secured a male at La Ceiba in 1933.

My personal records for Bank Swallows in Honduras are as follows: from 24 August to 19 september 1962, one or two on numerous occasions at Lake Yojoa among hundreds of swallows of other specles; between 26 September and 15 october 1962, frequent observations of up to 50 individuals daily in the large flights of swallows migrating eastward along the Bay of Fonseca (specimen secured near Choluteca on 12 0ctober); on 17 March 1963, two at Tela; on 6 and 9 April 1963, five and two individuals, respectively, on Little Hog Is land, in the Cayos Cochinos; 'from 14 through 29 April 
1963, a flock of 10 to 20 individuals in the Lake Yojoa area (specimen obtained near El Jaral on 26 April); from 4 through 10 May 1963, a few daily among the Barn Swallows (Hirundo rustica) on Utila Is land, in the Bay Islands; and from 9 to 14 Apri1 1964, a few near Puerto Lempira, in the Mosquitia.

Honduran specimens are typical of the widespread race, R. I. riparia (Linnaeus).

Iridoprocne bicolor (Vieillot)

Tree Swallow

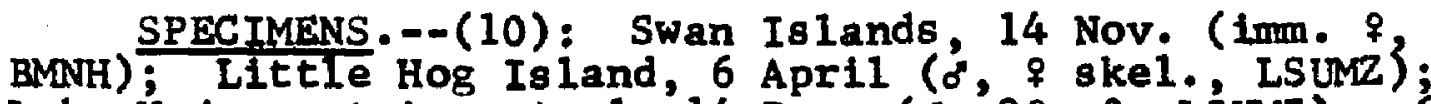
Lake Yojoa, at Agua Azul, 14 Dec. (o", 29, ?, LSUMZ); $6 \mathrm{mI}$. SE Siguatepeque, 16 Feb. ( $q$, LSUMZ); 3 mi. SE Villa de San Antonio, 29 Jan. ( 6 , LSLMZ); Puerto Lempira, 6 Feb. ( $q$, LSUMZ).

PUBLISHED RECORDS.--Toloa (Peters, 1929b: 456). Swan Is lands (Delacour, 1938: 544; Wetmore, 1958: 467-468). Tegucigalpa (Cooke, 1938b: 187).

The Tree Swallow is an uncommon to common winter visitant to the Caribbean slope of Honduras and to the lolands off the north coast. It also occurs uncommonly in the interior to an elevation of at least 5,000 feet.

Peters (1929b: 456) reported the species from Honduras on the basis of a sight record of considerable numbers at the Toloa swamp on 10 and 11 March 1928. Delacour (1938: 544) observed the species in the Swan Islands on 20 October 1927, and an Immature female was taken there on 14 November of the same year (Wetmore, 1958: 467-468). Cooke (1938b: 
187) reported that a Tree Swallow banded by Oliver L. Austin at Eastham, Cape Cod, Massachusetts, on 28 June 1933 was subsequently recovered at Tegucigalpa on 18 December 1936. I noted the species in Honduras on a number of occasions. From 12 December 1962 through 27 April 1963, the species was common throughout the Caribbean coastal region from Omoa to the Mosquitia and inland as far as Lake Yojoa, Siguatepeque, and the Comayagua Valley. On 12 December an estimated 1,000 individuals were present on Lake Yojoa, where they remained in numbers exceeding 300 birds until mid-February; few were still there on 27 April. All the specimens, except for the Swan Islands individual, were secured by J. Alan Feduccia and me during 1962-1963.' In 1964 I noted 2 large flock at Lake Yojoa on 1 and 4 April. James L. Peters, in Mayr and Greenway (1960: 81), considers Iridoprocne to be a synonym of Tachycineta, but I prefer to follow the American Ornithologists' Union (1957: 357-358) in regarding the two genera as distinct.

\section{Iridoprocne albilinea (Lawrence) \\ Mangrove Swallow}

SPEC MENS - - I. a a albilinea (47): Ia Ceiba, 18-25 Jan. ( $\sigma^{\prime}, 2$ 2\%, MCZ); Coyoles, 30 June $\left(\delta^{\prime}, 28, C M\right)$; San Esteban, 28 June $(29, C M)$; Lake Yojoa, 25 June (d, UF); E1 Boquerón, 17 Aug., 20 Sep., 13-14 Óct. (50, 28, 4?, AMNH); Nacunta River, $3 \mathrm{mi}$. S Puerto Lempira, 6 Feb. (9, LSUMZ); San Lorenzo, 26 Sep. -6 Oct. (70, 9\%, 2?, MLZ; 6o, \&, MCZ); $4 \mathrm{mt}$. SW San Lorenzo, 5 Oct. ( $\sigma^{\circ}$, LSUMz).

236). $\frac{\text { PUBLISHED RECORDS.--Amapala (Salvin and }}{\text { La Celba, Yaruca (Bangs, 1903: 152). }}$ 
Th1s resident swallow is common along both coasts of Honduras and in the interior along streams and at Lake Yojoa; it has not been recorded in Honduras above 2,500 feet.

The record from Amapala (Salvin and Godman, 1883: 236) is Iisted as a report of Osbert Salvin, presumably an observation, since there are no Honduran specimens of this species in the British Museum.

Honduran individuals are referable to the widespread nominate race, I. a. albilinea (Lawrence).

\section{Tachycineta thalassina (Swainson)}

\section{Violet-green Swallow}

SPECTMENS - - I. t. lep1da (2): $8 \mathrm{mi}$. SE Zambrano, 19 Nov. (f, LSURE); Yegua Te River Valley, 8 Dec. (q, UF). PUBLISHED RECORD.--Yeguare River Valley (Carr and Dickinson, 1951: 272).

The Violet-green Swallow is a fairly common winter visitant to the interior highlands of Honduras, of ten occurring in large flocks. It ranges from 1,000 to at least 5,500 feet in Honduras but is most common in the interior valleys from 2,500 to 3,500 feet elevation.

Stone (1932: 325) recorded the bird from Honduras on the basis of a supposed report by Salvin and Godman (1883: 234), but the latter did not list the species from Honduras. In 1945 Marjorie H. Carr obtained the first Honduran specimen, a female from the Yeguare River Valley. Richard 
R. Graber observed one individual in the town of San José de Rio Tinto on 10 January 1962 and another near Catacamas on 8 March 1963.

During the winter of 1962-1963 I noted the species on several occasions in the Tegucigalpa region and in the Comayagua Valley. On 19 November 1962 I saw a flock of at least 500 individuals near Teguclgalpa and secured one specimen from another flock of at least 100 near Zambrano.

The two Honduran specimens are representative of the smaller, northern race, I. t.. lepida Mearns, both in color and in size.

Family CORVIDAE

\section{Corvus corax Linnaeus}

Common Raven

SPECTMENS.--C. c. Sinuatus (5): $3 \mathrm{mi}$. NW La Esperanza, 23 Jan. ( 9 , LSUMZ); Cerro Cantoral, 6 Sep. ( 9, MCZ); E1 Zamorano, 3 March ( $q$, UF); Yeguare River Valley, 5 March ( 7 , UF); $10 \mathrm{~km}$. N Sabana Grande, 14 Aug. ( $d, C M)$.

PUBLISHED RECORD.--Between "Opotelma" [= Opoteca] and Sigua tepeque las C. cacalot1 ?] (Taylor, 1860: 112).

Corvus corax is an uncommon resident in open situations throughout the interior highlands of Honduras. It is most frequently encountered above 2,500 feet elevation but on occasion ranges to sea level in the Pacific lowlands.

Taylor (1860: 112) observed this spectes at about 5,000 feet elevation between Opoteca and Siguatepeque. C. F. Underwood obtalned a fenale at Cerro Cantoral in 1934. 
Marjorie H. Carr collected single females in the Yeguare River Valley on 5 and 7 March 1946, the latter at El Zamorano. Arthur C. Twomey and Roland W. Hawkins secured a male near Sabana Grande in 1951.

I observed the species frequently in various parts of the interior highlands from Ocotepeque to the Tegucigalpa region. On 12 october $1962 \mathrm{~J}$. Alan Feduccia, Rose S. Monroe, and I saw a pair of Common Ravens in the Choluteca Valley just northeast of Choluteca, at an elevation of about 100 feet. On 23 January 1963 I collected one of a sma11 group near La Esperanza.

The subspecies that occurs in Honduras is the widespread race $\mathcal{C}$. c. sinuatus Wagler. I cannot see any differences in the Nicaraguan population, described as $\mathrm{C}$. $\mathrm{c}$. rlchardsoni Miller and Griscom [1925c: 5; San Rafael del Norte (4100 ft.), Nicaragua], and regard it as a synonym of sinuatus.

\section{Calocitta formosa (Swains on)}

\section{Magpie Jay}

SPECTMENS.--C. E. pompata (36): $2 \mathrm{mi}$. E Copán, 5 Dec. ( 8 LSUMZ); Comayagua, 7 July, 22 Aug. (?, AMNH; 20, 49, CM); 5 mi. S Comayagua, 19 Nov. ( 39 , ISUMZ); Cerro Cantoral, 5 March (\%, UMMZ); Monte Redondo, 21-30 Nov. ( $\$$, AMNH; o, MCZ); Cantarranas, 19 July-6 Aug. (20, 2\%, ANSP); E1 Derrumbo, 24 July ( $\sigma^{\circ}$, BMNH); Conayagüela, 9 Nov. ( $\sigma^{\circ}$, MCZ); 2 m1. E Santa Clara, 8 June (o,, 9, MCZ); Escuela Agrícola Panamericana, 20 oct. ( $0^{\circ}$, UF); Yeguare Rtver Valley, 15 Jan. ( 9, UF); $10 \mathrm{~km}$. N Sabana Grande, 14 Aug. (2 $\left.{ }^{\circ}, \mathrm{CM}\right)$; Isla Zacate Grande, 5 Oct. (20, Lsurz); $6 \mathrm{mi}$. NE Choluteca, 3 Oct. ( 7 , LSLMZ); Honduras-Nicaragua boundary [near Pacific coast] (4?, MCZ); "Honduras" (?, AMNH; 2?, BMMH). 
PUBLISHED RECORDS. --Comayagua (Sclater, 1858b: 358). Tigre Island, Pacific coast to mountains north of plain of Comayagua (Taylor, 1860: 113). "Honduras" (Sharpe, 1877: 89). Cantarranas (Stone, 1932: 326).

In Honduras the Magpie Jay is a common resident in the arid Pacific lowlands, in parts of the arid interior highlands, and in the arid Comayagua Valley on the Caribbean slope; in addition, a population, presumably derived from that of the Motagua Valley of Guatemala, occurs in the vicinity of Copán. It has not been recorded in the repubIic above 3,000 feet elevation. The species is found in more open situations of monsoon forest and in arid scrub, usually where there are at least a few scattered tall trees. Honduran specimens are referable to the race $\underline{C}$. $\underline{f}$. pompata Bangs, which ranges from Oaxaca to Costa Rica. The supposed race $G$. $\underline{\text { f. }}$ impudens van Rossem [1941: 172; PIne Peaks, Volcan de Conchagua, El Salvador] was based on color characters that are primarily individual in nature.

\section{Psilorhinus morio (Wagler)}

\section{Brown Jay}

SPECTMENS.--P. m. CYanogenys (50): San A1ejo, 6 Aug. (f, LSUMZ); Lancetilia, 9-13 Feb., 27 March, 29 Aug • (f? ANSP; $\left.20^{\circ}, ?, M C Z\right)$; La Ceiba, 18 April-3 June $\left(120^{\circ}, 2{ }^{\circ}\right.$ CM; o, USNM); Los Planes, 10 June (juv. o, CM); Balfate, 17 Oet. ( $d ?$, CNHM); Trujil10, 30 March-6 April ( $d, 39$, CM; i, USNM); Chamelecón, $16-20 \mathrm{Feb}$. (2。, USNM); Coyoles, 21 June-11 July ( $\left.30^{\circ}, 3 \%, C M\right)$; Finca Fé, 4 Sep., 20 Oct. (?, 1mm. okel., LSUMZ); San Marcos de Guaimaca, 20-29 June (2o, 2\%, MLZ); Alto Gualmaca, 12 June ( ${ }^{\circ}, \&$ AMMH); EI Boquerón, 3 Oct. (o, AMrit); Segovia River, 17 June-16 July $(f, 3 ?$, USNM); "Honduras" (2?, BMNH). 
RUBLISHED RECORDS --Onoa (Moore, 1859: 57). Taulabé, Taulabe to At lantic coast (Taylor, 1860: 113). San Pedro region (Sclater and Salvin, 1870b: 837). "Honduras" (Sharpe, 1877: 140; Skutch, 1960: 231, 255). San Pedro (Salvin and Godman, 1887: 506). Trufillo, Segovia River (Ridgway, 1888c: 583, 588). Tela region, Progreso, $52 \mathrm{~km}$. W Tela $[=$ Urraco] (Peterg, 1929b: 478). Lancetilia (Stone, 1932: 327). La Ceiba (Deignan, 1936: 192). Chamelecón, El Boquerón, Alto Guaimaca, Balfate (Selander, 1959: 417).

Ranging to an elevation of 3,500 feet, the Brown Jay is a common species in lowland rain forests and semi-open situations on the Caribbean slope of Honduras. It is most common in open forest and in forest edge. It more or less replaces Calocitta formosa, a species of arid habitats in the interior valleys and on the Pacific slope, but it occurs sympatrically with the latter at Copán and probably also in the Comayagua Valley. There is no evidence of any hybridization of the two species in Honduras.

Although Selander (1959: 385-417) has presented evidence that the White-tipped Brown Jay ( . mexicanus Rüppe11) and the Plain-tipped Brown Jay (P. morio, sensu stricto) are color phases of one species rather than two separate species, the evidence is not conclusive and the question of specific status is still open. If, in the final analysis, the two are shown to be full species, the Honduran popula-

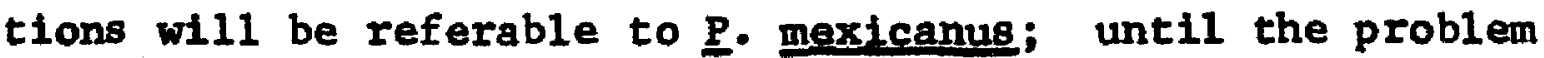
is resolved, I am following Selander in considering all Brown Jays to represent a 8 ingle species.

Honduran specimens are all typical of the widespread race, $\underline{P}$. m. cyanogenys Sharpe. 
Cyanocorax yncas (Boddaert).

Green Jay

SPECTMENS.--C. $\mathrm{Y}$. centralis (40): Julián [= Tulián] (2?, ANSP); San Álejo, 18 ApriI, 5 Aug. ( ${ }^{\circ}, 2 q$, ISUMZ); Santa Ana, 7 Nov. ( $\sigma^{*}$, USNM); Las Peñitas, 25 Jan.-28 Feb. (20, 28, AMNH; 28, BMNH; $30^{\circ}, ~ \&, 27$, MLZ; ${ }^{\circ}, 8$, MCZ); Chamelecón, 10 Nov. (d", USNM); Coyoles, 14 June-28 July (40, 5\%, CM); Cerro Nieve, 20 April ( $\%$, AMNH); Cerro Higuito, Santa Bárbara, 24 April (o', AMNH); San José de Santa Bárbara, 6 May ( $\$$, AMNH); Santa Bárbara, 2-18 May (26", AMNH); Lake Yojoa, 28 July (20", 9, CM); "Honduras" (?, AMNH; ?, USNM).

PUBLISHED RECORDS.--Omoa (Moore, 1859: 57). "Honduras" (Taylor, 1860: 113). San Pedro region (Sclater and Salvin, 1870b: 837). San Pedro (Salvin and Godman, 1887: 502). "Honduras" [= Santa Ana and Chamelecón] (Ridgway, 1900: 29). Santa Ana, Chamelecón (Ridgway, 1904: 310). Santa Bárbara, Las Peñitas, Cerro Nieve, Cerro Higuito, San José [de Santa Bárbara] (Zimmer, 1953c: 12).

The Green Jay is an uncommon to locally common species In the Caribbean lowlands of northwestern and north-central Honduras. Although the species is most common in open forest or in semi-open situations in humid areas near sea level, it ranges in lesser numbers into the interior on the Caribbean slope up to an elevation of at least 5,000 feet, entering a wide variety of habitats including pine-oak associations and open areas of cloud forest. The species reaches its southern limit of distribution in Central America in north-central Honduras, extending east along the north coast as far as the Tela regton and south into the interior as far as Lake Yojoa and the Aguán Valley; it reappears in South America but does not occur in Central America south of Honduras. 
Moore (1859: 57) stated that the Green Jay was uncommon in the Omoa region, arriving in October and remaining only a short period. While there is a great deal of local movement of flocks of these birds, the species is certainly resident in Honduras.

Honduran specimens are referable to the race $C \cdot Y$. centralis [Xanthoura luxuosa centralis van Rossem, 1934c: 397; Secanquim, Alta Vera Paz, Guatemala].

Cissilopha melanocyanea (Hartlaub)

Bushy-crested Jay

SPECIMENS.--(109): Subirana, 1 Feb. (d", \&, MCZ); Portillo Grande, 26 March, 13 Oct. ( ${ }^{\circ}, \mathrm{CNHM} ; \sigma^{\circ}$ MCZ); San Esteban, 30 June ( $\left.50^{\circ}, 49, \mathrm{CM}\right)$; Montaña E1 Chorro, 5 June ( ${ }^{\circ}$, MLZ); Montafia Los Cedros, 2 June ( $\sigma^{\circ}$, MLZ); Plan del Rancho, 26 May-1 June (3o, MLz); Monte Verde, 21 July ( $\sigma^{\prime}$, MIZ); Mt. Puca, 9 Jan. ( $\delta$, MCZ); Cerro Santa Bárbara, east slope, 1 Dec. (?, LSUMZ); Cerro Santa Bárbara, southeast slope, 24 July ( $q$, LSURZ); $4 \mathrm{ml}$. SW E1 Jara1, 21 Oct. (29, LSUMZ); Lake Yojoa, 18 July $\left({ }^{\circ}, \mathrm{CM}\right) ; 17 \mathrm{mi}$. NW Valle Bonito, 2 Nov. ( $q$ LSUMZ); 2 mi. N San José de Comayagua, 17 Jan. ( 9 , LSUMZ); Siguatepeque, 9 July ( $?$, AMNH; $q, C M$ ); $4 \mathrm{mi}$. SE La Esperanza, 24 Jan., 31 Oct. ( $0^{\circ}, 9$, 9 s kel. LSUMZ); $6 \mathrm{mi}$. SE La Esperanza, 30 oct. ( $\sigma^{\prime}$ skel., LSUMZ); MuIn, 3 Jan. ( 0 , AMNH); Cerro Santa Maria, 30 Dec. ( $\$$ MLZ); Zambrano, 10 Nov. ( $\delta$, CNEM); Cerro Cantoral, 22 Jan., 15 Feb. (20, MCZ); Cerro Vásquez [= Cerro Cantoral], 22 Jan. ( ${ }^{*}$, MCZ); A1 to Cantoral, 6 Jan.-9 Feb. (2d, 69 , AMNH; $30^{\circ} \%, ?$, MLZ); Monte Redondo, 26 Nov, -15 Dec: ( 8 , CM; 68, 7\%, ?, MCZ); San Juancito, 25 Jume-15 Aug. (2\%, 2 juv. of, juv. $q ?$, ANSP; $2 \sigma^{\prime}, q$, CM); Cerro Picacho, 3 oct.

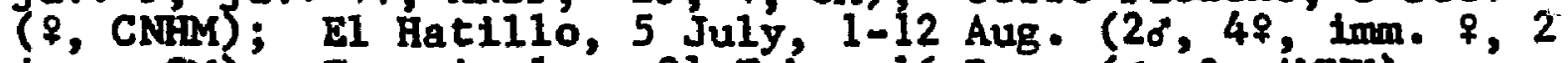
juv., CM); Tegucigalpa, 21 Feb., 16 Dec. ( $0^{\circ}, 8$, AMNH); Comayagúela, 3-13 July, 30 Sep. -12 Dec. ( 7 , ANSP; $q$, BMNH; 7\%", 49, MCZ); Yeguare River Valley, 20 Nov. ( $q$, UF); [Dept. Francisco] Morazán, 21 May (\$, MCZ); Monserrat, 28 May (", UF); El Paraíso, 20 April ( $\sigma^{\circ}$, BMNH); $13 \mathrm{ml}$. SW San Marcos de Colón, 13 Oct.' (7, LSUMz); "Honduras" (4?, AMMA).

359) $\frac{\text { PUBLISHED }}{\text { Between }}$ REORDS.--Near Siguatepeque (Sclater, 1858 112). "Honduras" [as Cyanolyca Beecheyi] (HeIne and 
Reichenow, 1890: 117). "Honduras" [as chavez1] (Miller and Griscom, 1925c: 8). San Juancito (Stone, 1932: 326-327).

This jay is a common resident of pine-oak associations and cloud forests in the interior highlands of Honduras, occasionally inhabiting areas of pure pine. It ranges from 2,000 to at least 7,000 feet in elevation, infrequently wandering lower in the nonbreeding season. Although Griscom (1932b: 405) considered the species to be characteristic of pine forests, in Honduras it apparently ts more common in areas of broadleaf trees.

Heine and Reichenow (1890: 117) 1isted a male specimen from Honduras under the name Cranolyca Beecheyi but were referring to Cissilopha melanocyanea.

The southern populations of this species in Honduras and Nicaragua have been described as $\mathrm{c}$. m. chavezi Miller and Griscom on the basis of the extensive black coloration on the usually purplish abdomen. A study of a large series of skins from Honduras and Nicaragua indicates that the amount of black below is largely dependent upon individual variation within these populations. There is a tendency towards a greater number of black-bellied birds towards the south, with a rather uniform purplish-bellied population in Guatemala and western EI Salvador. In the La Esperanza and Lake Yojoa regions of Honduras, black-bellied birds and intermediates occur in purp11sh-bellied groups; in the Tegucigalpa region both purplish-bellied and black-bellied birds are present in about equal numbers, with many 
intermediates as well. The individual from near San Marcos de Colón, almost in Nicaragua, is as purplish below as Guatemalan specimens. I cannot see any advantage in recognizing chavezi and consider the species to be monotypic.

\section{Cyanolyca cucullata (Ridgway)}

\section{Azure-hooded Jay}

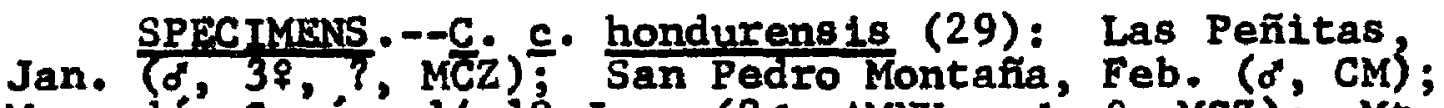
Merendón Copán, 14-18 June (20, AMNH; o", $\%$, MCZ); Mt. Puca, 6 Jan. -7 Feb. (20, AMNH; 38, 5\%, 2?, MCZ); Volcán de Puca, 6 March ( 8 , AMNH); Cerro Santa Bárbara, east slope, 21 April, 28 Nov. (2\%, LSUMZ); $5 \mathrm{mi}$. SW E1 Jara1, 4 Nov. (o", \%, LSUMZ); MuIn, 30 Dec. (o", \%, MCZ).

PUBLISHED RECORDS.--Volcán de Puca, Santa Ana Mountains, La Sapote (Helimayr, 1934: 47). Cerro Puca, Merendón [Copán], Muín, Las Pefiltas (Pitelka, 195la: 97-98).

The Azure-hooded Jay is a locally fairly common inhabitant of cloud fores ts of Honduras and ranges from 3,000 to 7,000 feet in elevation. In Honduras the species does not occur east of the Sula and Comayagua valleys, but it reappears in the mountains of Costa Rica. It is confined to dense cloud forest, usually keeping to medium or fairly low levels within the forest.

Sclater and Salvin (1859: 21) recorded the species as occurring in Honduras, but I do not know on what basis. Hellmayr (1934: 47) examined birds taken by Erich Wittkügel in Honduras, one from the Santa Ana Mountains [= San Pedro Montaña] and another from La Sapote [= E1 Zapote, Cortés]; these specimens were in the Brunswick or Frankfurt museums. 
The reasons for retaining $\underline{C}$. cucullata as a species distinct from C. pulchra (Lawrence) of South America have been discussed by Pitelka (1951a: 97). The use of $\mathrm{C}$. mitrata Ridgway in lieu of the older $\mathrm{C}$. cucullata by Pitelka (1951a: 97-98) was an error and was subsequently corrected by $\operatorname{him}$ (1951b: 300).

The Honduran populations have been described as $\mathrm{C}$. $\mathrm{c}$. hondurens is [Cyanolyca mitrata hondurensis Pitelka, 195la: 97; Las Peinitas (4 mi. W San Pedro Sula), Honduras]. The race is rather poorly differentiated but may be distinguished by the bluer (less purplish) occipital patch, when compared with the adjacent race $\underline{c}$. $\underline{c}$. guatemalae [Cyanolyca mitrata guatemalae Pitelka, 1951a: 97; near San José, 28 mi. ESE Comitán, 4900 feet, Chiapas, Mexico]. The characters of less white on the anterior margin of the occipital patch and less purplish under parts do not hold true in the large series that I have examined.

\section{Cyanolyca pumilo (Strickland)}

\section{Black-throated Jay}

SPECIMENS.--(97): Portillo Grande, 7 Jan. ( 9 , CNHM); Merendón Copán, 29 June ( $0^{\circ}$, CNHM); E1 Chorro, 9 July (40", $39,2 ?$, MLZ); Montaña E1 Chorro, 21 June-3 July (68, 39, ?, ML2); Montaña E1 Silión, 22 June (20, ?, MLZ); Monte Verde, $20-23$ July ( $\%, ?$, MLZ); Cerro Puca, $17 \mathrm{Jan}$. ( $\sigma^{*}$ ske1,: MLZ); Mt. Puca, 2 Jan.-11 Feb. (88, 69, 2?, AMNH; ", 48, 5?, MCZ); Volcán de Puca, 6 March ( 8 , AMNH); Muĺn, 3-10 Jan. (5d, \$ AMNH; d, MCZ); Cantoral, 3-20 Feb., 1-2 Apri1, 13 May, It JulY ( 9 , ANSP; 30, 5\%, AMNH; of, $2 q^{\prime}$, MLZ; MCZ) ; "Laguara" [= La Laguna Cantoral], 18' July (₹ AMNH); San Juancito, 3 Aug. ( $\left.0^{\circ}, 2 \%, C M\right)$; Rancho Quemado, 15 March 
(6", MCZ); El Derrumbo, $17 \mathrm{July-9}$ Aug. (30, 5, MCZ); Uyuca, 20 Nov. ( $\sigma^{\prime}$, UF); Alto Cantoral, 6 Jan., 4 Feb. (o", AMNH; ?, MCZ). 49).

PUBLISHED RECORP.--Volcán de Puca (Hellmayr, 1934:

In Honduras the Black-throated Jay is a locally common inhabitant of pine-oak associations and eloud fores ts at high elevations in the interior. It is not known to range below 6,500 feet in the republic.

Hellmayr (1934: 49) examined a specimen in the Brunswick Museun that was taken on Volcán de Puca by Erich Wittkügel on 25 February 1889. I have not seen this individual.

I cannot detect constant geographic variation in either size or color anywhere in the range of the species, from Chiapas to Honduras. The intensity of black on the throat and extent of this black posteriorly is highly variable on an individual basis throughout the range. The race from $E 1$ Salvador, c. P. nigrogularis van Rossem, is now generally regarded as a synonym of the nominate form and the spectes considered to be monotypic.

\section{Aphelocoma unicolor (Du Bus)}

\section{Unicolored Jay}

SPECIMENS. - -A. u. griscom1 (64): Montaña E1 Chorro, 23 June, 9 July $\left(20^{\circ}, 39\right.$, ?, ML); Montaña El Sillón, 22 June, 10 July (o, 2q, ? MLz); Montaña La Cruz, 26 June ( $q$, MLz); Monte Verde, 19-24 July ( $\sigma^{\circ}, \%, 2$, MLZ); Las Ventanas, 2427 July (20,?, MLZ); Mt. PuCa, 7 Jan -8 Feb. (4o, 48, AMNH; 40, 5\%,?, MCZ); Cerro Santa Bárbara, east slope, 10 Nov. (2\%, LSLMZ); Cerro Santa Maria, 30 Dec. ( $\$$, MCZ); Cantora1, 25 Jan.-10 Feb., 28-30 May (40, 49, AMMH; \&, MLZ; o, USAM); Alto Cantora 1, 5 Jan. -9 Feb., 10 Sep. ( $\$$, CNHM; $\left.40^{\circ}, 3 \%, \mathrm{MCZ}\right)$; San Juancito, 29 June (?, UF); Rancho 
Quemado, 15 March, 15 May (d, 2\%, MCZ); E1 Derrumbo, 23 July-9 Aug. $\left(\sigma^{\prime}, 29, \mathrm{MCZ}\right)$.

PUBLISHED RECORDS.--Volcán de Puca (Hellmayr, 1934: 59). Alto Cantoral, Rancho Quemado (Mayr and Greenway, 1962: 216).

Apheloccma unicolor is another species of jay that is confined to cloud forests and pine-oak associations at high elevations. In Honduras it does not occur below 5,000 feet, so far as is known. Though locally fairly common, it is generally outnumbered by Cyanolyca pumilo.

Hellmayr (1934: 59) examined a specimen, presumably in either the Brunswick Museum or the Frankfurt Museum, that was taken on Volcán de Puca by Erich Wittkügel on 4 March 1889.

Honduran birds represent the slightly differentiated race $\underline{A}$. ‥ griscomi van Rossem. Although the difference in color is not great, the populations in Honduras and E1 Salvador being darker purplish than examples of the Guatemalan race, A. L. coelestis Ridgway, griscomi seems to be valid on the basis of this character.

Cyanocitta stelleri (Gmelin)

\section{Steller's Jay}

SPECIMENS.--C. S. Buavis (70): Portillo Grande, 8

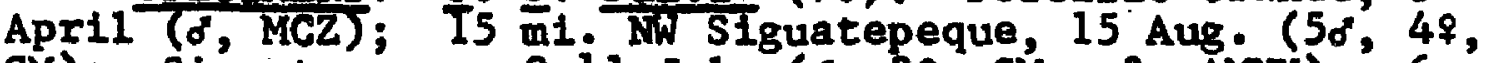
CM); Siguatepeque, 9-11 July ( $\alpha, 38, C M ; ?$, AMNH); $6 \mathrm{ml}$. SE Siguatepeque, 16 Feb. ( $\$$ LSUMZ); Gülse, 16 July ( $\%$ LSUMZ); $8 \mathrm{mi}$. W Zambrano, 17 oct. (o, LSUMZ); Cantoral, 26 Jan. ( $\delta$, AMNH); Cerro Cantoral, 28 Feb.-9 April, 29 June 26 Nov ' ( ${ }^{\circ}$, ANSP; $2 \sigma^{\circ}, 39$, MCZ); Alto Cantoral, 6 Jan., 4-8 Feb., 13 June $\left(20^{\circ},{ }^{\circ}\right.$, AMNH; $\left.30^{\circ},{ }^{\circ}, \mathrm{MLZ}\right)$; Monte Redondo, 4 March, 1-15 Dec. ( 8 , ANSP; 58, $29^{\circ}$, MCZ); La Flor Archaga, 30 May-19 July ( $9, ?$, AMNH; of, CNHM; of, MCZ); San 
Juancito, 12-14 Aug. (d, $\$$, Juv. $\%$, ANSP); Rancho Quemado, 19 March, 2-5 ApriI ( $8, \mathrm{CM}^{\circ}$ 2 $\delta^{\prime}$, MCZ); EI Derrumbo, 3-9 Aug. ( 9, BMNH); $E 1$ Hatillo, 7-18 May, 20 Aug. (2d, $\%, C M$; $20^{\circ}, 49, \mathrm{MCZ}$ ); Cerro Higuito, D.C., 9 May (8", AMNH); Cues ta

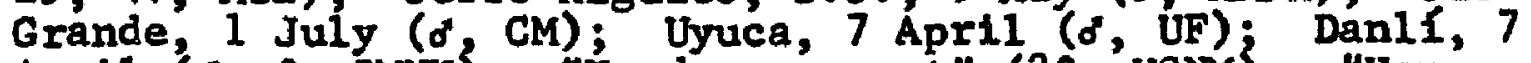
Apri1 ( 0 , $\%$, BMNH); "Honduras coast" (2?, USNM); "Honduras" (3?, AMNH).

PUBIISHED RECORDS.--Near Siguatepeque (Sclater, 1858b: 359). Between Siguatepeque and Taulabe (Taylor, 1860: 112; Salvin and Godman, 1887: 491). "Honduras" (Milier and Griscom, 1925c: 7-8). San Juancito (Stone, 1932: 326). Alto Cantoral (Moore, 1954: 237).

The Steller's Jay is a fairly common resident in highland pine regions in the interior of Honduras, ranging from 3,000 feet to at least 6,500 feet elevation.

I refer all Honduran specimens to G. s. suavis Miller and Griscom, a slightly differentiated race distinguished by the generally reduced white area of the chin and the greater contrast in color between the crest and the back. The race

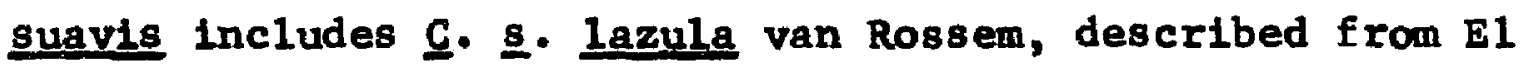
Salvador as being darker than suavis, since there is no significant variation in color from El Salvador to Nicaragua. No Honduran specimens show any approach to $\underline{\mathrm{C}}$. $\mathrm{s}$. ridgwayi Miller and Griscom, a race in Chiapas and western Guatemala that possesses an increased white chin area and lacks any contrast between crest and back.

\section{Family CERTHIIDAE}

\section{Certhia familiarls Linnaeus}

\section{Brom Creeper}

SPECIMENS.--C. E. extima (51): Port1110 Grande, 21 
July (o, MCZ); Monte Verde, $22 \mathrm{July}$ (?, MIZ); $15 \mathrm{mi}$. NW Siguatepeque, $15 \mathrm{Aug}$. ( $\sigma, C M) ; 4 \mathrm{mi}$. NW Siguatepeque, 16 Feb. ( 8 , LSUM); Siguatepeque, $9 \mathrm{July}(\delta, \%, C M)$; Soluteca, 4-9 ApriI ( $30^{\circ}$, ANMH); La Cruz Grande, 13 March (?, AMNH); La Honda, 12 March (o, MCZ); 1 mi. NW Zambrano, 19 Nov. (f, LSUMZ); Montaña Vasquez, 13 Jan. (d, ANSP); Cantora 1, 6-11 Dec. (20, \%, AMNH); Cerro Cantoral, 29 March, 4-29 May, 23 July-7 Aug •, 16 Dec. (118, 39, MCZ; d, USNM); La Flor Árchaga, 3-19 Jan., 29 May, 18 June (?, ANSṕ; d" AMNH; $\$$ MCZ; \& USMM); E1 Hatillo, 22 April-8 May, 29-30 June, 6-20 Aug - (5o, \%, CM; $\$$, CNHM; o, 2\%, MCZ); E1 Picacho, 28 Sep. ( $\sigma$, AMNH); $18 \mathrm{mi}$. NW Tégucigalpa, 17 Oct. ( $\delta$, ISUMZ); La Montafita, $12 \mathrm{Feb}$. ( $\sigma^{\prime}$ UF); Yeguare River Valley, 15 Sep. (?, UR); Yuscarán, 17 April (d', BMNH); "Honduras," 4 March ( 8 , CNHM). $1955 a: \frac{261}{76}$.

PUBLISHED RECORD.--"Honduras" [in range] (Eisenmann,

Despite the virtual lack of previously published records, the Brown Creeper is a fairly common resident in highland pine in the interior of Honduras, occurring from 2,000 feet to at least 6,500 feet elevation.

Eisenmann (1955a: 76) included Honduras in the range of the species on the basis of the serles in the American Museum of Natural History.

The southermost population of the species, in Nicaragua, has been described as G. E. extima Miller and Griscom. Specimens from Honduras and Nicaragua are decidedly smaller than those from Guatemala northward, but I cannot see any significant difference in coloration from southern Mexico to Nicaragua. The Guatemalan populations, named $\underline{\text {. }}$ E. pernigra Griscom [1935b: 552; Volcan de Fuego, Guatemala], are not distinct from C. E. alticola Miller of southern Mexico. C. E. nublgens Wetmore [1940: 51; Desconsuelo, elevation 10,200 feet, Depto. Totonicapán, 
Guatemala] is a strict synonym of pernigra. Wings of Honduran specimens measure as follows: of, 57.4-64.4 (60.6); \&, 55.7-60.1 (57.8).

\section{Family CINCLIDAE}

\section{Cinclus mexicanus Swains on}

\section{American Dipper} (

SPECIMEN.--C. m. anthonyi (1): San Juancito, 8 Aug.

The American Dipper is a rare species in Central America, previous $1 y$ unreported from Honduras. It inhabits swift-flowing mountain streams in heavily forested regions. In Honduras it is known by a single specimen taken by Arthur C. Twomey and Roland W. Hawkins at San Juancito in 1951. The bird was secured from a stream on the edge of cloud forest at an elevation of 6,000 feet.

The single Honduran specimen compares favorably with the Guatemalan race, c. m. anthonyi Griscom, and shows no approach to the Costa Rican race, ‥ m. ardesiacus Salvin. The wing of the Honduran specimen measures 84.5 .

Family TROGLODYTIDAE

Cistothorus platensis (Latham)

Short-billed Marsh Wren

SPEC IMENS. - -C. R. elegans (11): Siguatepeque, 8-10 July (65, CM); Puerto Lempira, 7 Feb., $12-14$ Aprii $\left(20^{\circ}, 39\right.$, LSUM(Z). 
Although previously unrecorded from Honduras, the Short-billed Marsh Wren is known from two localities in the republic and is common at both. In 1951 Arthur C. Twomey and Roland W. Hawkins discovered a breeding colony at Siguatepeque in the wet grasslands adjoining pine forests. They obtained six male specimens, three on $8 \mathrm{July}$, one on $9 \mathrm{July}$, and two on $10 \mathrm{July,} \mathrm{all} \mathrm{in} \mathrm{breeding} \mathrm{condition.} \mathrm{Mark} \mathrm{Traf-}$ ton, Jr., and Paul Slud also observed this colony in June 1952; Trafton recorded the spectes there subsequently in the months of March, September, and October, and it is certainly resident at Siguatepeque. The elevation at this locality is approximately 4,000 feet.

On 7 February 1961 I collected a female in a wet, longgrass savanna at sea level in the Mosquitia at Puerto Lempira. The following day I observed one additional bird there. In April 1964 an extensive colony was found by Richard R. Graber and Jean W. Graber in this same area; two males and female were obtained on 12 April and another female on 14 April. It is probably widespread in marsh and savanna throughout the Mosquitia.

The Honduran series is representative of the race currently known as C. D. elegans Sclater and Salvin, which is recorded from Veracruz to the pine ridges of British Honduras. However, Russell (1964: 135) has shown that British Honduran material averaged darker than examples from southern Mexico; comparative topotypical specimens of 
elegans from Guatemala were not available so the use of the latter name for Honduran specimens is tentative. In any case, the Honduran series matches well the one from Bxitish Honduras and will no doubt be assigned to the same race.

\section{Campylorhynchus zonatus (Lesson)}

Band-backed Wren

SPECTMENS.--C. 2. vulcanius (51): Portillo Grande, 1530 May ( $\sigma^{\circ}, 7, d^{\prime}$, MCZ); Plan del Rancho, 27 May ( $\sigma^{\circ}$, MLZ); Belén Gualcho, 18 July ( $q, 2$ ?, MLZ); Siguatepeque, 9 July ( $\sigma, C M)$; Soluteca, 6-8 Apri1 (2o, 3\%, AMNH); Cerro Santa Marla, 29 Dec. (o", MLz); Montaña Vásquez, 19 Nov. ( $q$, USNM); Cantoral, Feb, 8-12 March, 28 Nov. (20, $\$$, MLz; o , USNM) i Cerro Cantoral 12-19 Dec. ( $\$$, ${ }^{2}$, MCZ); Cerro Vásquez [= Cerro Cantora1], 22 Jan. ( 9, MCZ); La Flor Archaga, 30 May, 3 Dec. ( $d$, AMNH; $\$, M C Z$ ); San Juancito, 12-15 Aug : (30", ? ANSP); Rancho Quemado, 13-15 March, 14 May (?, MIZ; 30, MCZ); E1 Hat1110, 8-30 May (6o; 3\%, 2?, MCZ); Tigre Hatillo, 9 July (20, AMNH); Encantado, 24 Nov. ( $\$$, UF); Yeguare River Vailey, 21 May ( $q$, UF); Danli, 7 April ( $q$, BMNH); Arenal, 16 Feb. (o', UCLA); San Francisco, Choluteca, 14 Oct. ( $\$$, 9 , LSUMZ).

PUBLISHED RECORDS.--"Honduras" (Berlepsch, 1888: 449450; Hellmayr, 1934: 138). San Juancito (Stone, 1932: 327). Cantorá 1, Montafia Vásquez, San Juancito (Brodkorb, 1947: 243) Plan del "Río" [= Rancho], Belén "Guacho" [= Gualcho], Soluteca, Cantoral, Cerro Santa Maria, Montaña Vásquez, La Flor Archaga, E1 Hatillo, Tigre Hatillo, Rancho Quemado (Selander, 1964: 241).

The distribution of this wren is rather strange, at least in northern Central America. As Skutch (1960: 200) has pointed out, it occurs in this region from sea level to more than 10,000 feet in habitats ranging from openings in lowland rain forest to cloud forest, pine, and arid scrub. In Honduras it has been recorded from 1,200 feet (in rain forest at Arenal) to at least 7,000 feet elevation; it occurs in almost any type of forest edge or second growth, 
but it is sporadically distributed and decidedly uncommon below 3,500 feet. It is fairly common locally in areas of pine-oak, especlally where there is rather heavy undergrowth; it is frequent also along the edges of cloud forests, especially where there is heavy guamil due to cutting. The specimen from Honduras reported by Berlepsch (1888: 449-450) and apparently in his collection was taken by G. M. Whitely. I have not seen this individual.

Honduran specimens are all typical of the race $\mathrm{C}$. $z$. vilcanius [Heleodytes zonatus vulcanius Brodkorb, 1940a: 547; Aguacaliente, Volcán de Tacaná, Chlapas, altitude 2000 meters], which is distinguished from the race $\underline{c}$. $\underline{z}$. xestrictus (Ne1son) by more deeply rufous flanks and abdomen and by reduction or absence of spots on the flanks and abdomen. The race restrictus occurs from southern Mexico to eastern Guatemala and British Honduras, but none of the Honduran specimens shows any approach to it. Size, which is considerably more variable than indicated in the original description, is not a good character to use in defining vulcanius. Wings of the Honduran series measure as follows: $d, 78.4-89.2(83.7) ; 9,74.0-85.0(80.2)$.

\section{Campylorhynchus rufinucha (Lesson) \\ Rufous-naped Wren}

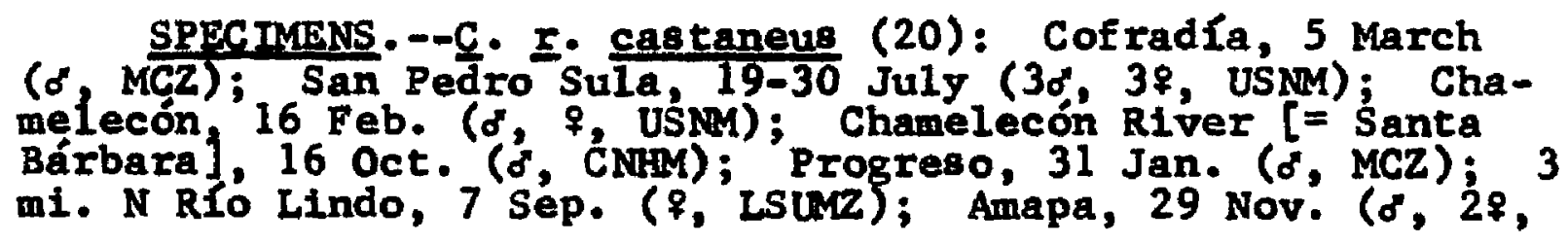


\& ske1., LSUMZ); "Spanish Honduras" (?, USNM); "Honduras" (?, AMNH; ?, BMNH; ?, USNM) . C. r. capistratus (35): Montaña Vásquez, 14 June ( $\$$, MCZ); Monte Redondo, 22-23 Nov. (o, $\$$, MCZ); La Flor Árchaga, 23 May (?, MCZ); Cantarranas, 20 July, 4 Aug. (o, $\%$,?, Juv. o, ANSP); E1 Hatillo, 20 Aug. ( $q, ?, \mathrm{CM})$; Tegucigalpa, 13 June-25 July, 17 Oct. ( $6 \delta^{\prime}, ?$, AMNH); Comayagüela, 13 June-3 July, 1-10 Oct. ( $\$$, AMNH; 2 ${ }^{\circ}$ \%, MCZ); Escuela Agrícola Panamericana, 16 Nov. ( $q$, UF); [Dept. Francisco] Morazán, 31 May ( ${ }^{\circ}$, MCZ); Dani1, 8 April ( $\$$, BMNH); $10 \mathrm{~km}$. N Sabana Grande, 14 Aug. (20, 2\%, CM); Piedra de Jesús, 7 March ( $0^{\circ}$, AMNH); San Lorenzo, 28 Sep. ( $\sigma^{\circ}, \mathrm{MCZ}$ ); Puerto Salamar, $10 \mathrm{Feb}$., 1 Oct. (2\%, LSUMZ); Honduras-Nicaragua boundary [near Pacific coast] ( $3 ?, \mathrm{MCZ})$.

PUBLISHED RECORDS.--"Honduras" (Sclater and Salvin, 1859: 8; Sclater, 1862: 17-18). Pacific slope of Honduras (Tayior, 1860: 317). San Pedro region (Sclater and Salvin, 1870b: 836). San Pedro (Salvin and Godman, 1880: 64). "Spanish Honduras" [as C. castaneus] (Ridgway, 1888b: 507). Progreso, Chamelecón, and San Pedro Sula [as castaneus]; Honduras-Nicaragua boundary "180 miles from the Paciflc coast" (= near Pacific coast) [as capistratus] (Peters 1929b: 457-458). Cantarranas [as castaneus] (Stone, 1932: 327). Chamelecón [as castaneus] (Hellmayr, 1934: 144145). San Pedro Sula, Chamelecón, and Santa Bárbara [as capistratus] (Selander, 1964: 234).

The Rufous-naped Wren is a fairly common to locally common species in the arld lowlands of the Pacific coast and the interior on the Pacific slope, occurring below 4,000 feet elevation. In addition, the species is common in open situations under rather humid conditions in the Sula Valley and the lower portions of the Quimistán Valley, not ranging above 500 feet on the Caribbean slope. It 18 most plentiful in open or semi-open situations where there is heavy underbrush or thickets.

The taxonony of the races of this wren in northern Central America has been confused in recent years. Most current authors either fail to recognize c. r. castaneus 
[Campylorhynchus castaneus Ridgway, 1888b: 507; "Spanish Honduras"] or consider it to be a poor race (Hellmayr, 1934: 144-145; Mayr and Greenway, 1960: 383). The problem arose when Hellmayr considered $\mathrm{C}$. $\underline{\underline{r}}$. xerophilus (Griscom), of the arid Motagua Valley in Guatemala, and $\underline{c}$. $\underline{\text {. nicaraguae }}$ (Miller and Griscom), of central Nicaragua, to be synonyms of castaneus, thus giving the latter a range on the Caribbean drainage from eastern Guatemala to Nicaragua. On the Pacific coast of Central America from at least El Salvador to Costa Rica there occurs a well-marked race, $\underline{\text {. }}$. capistratus (Lesson). An examination of specimens from all these regions shows that neither xerophilus nor any Nicaraguan bird has any close relationship with castaneus, which is a well-marked subspecies confined to the Quimistán and Sula valleys on the Caribbean slope of Honduras. Peters (1929b: 457-458) recognized this fact but his work has been overlooked. The race castaneus is characterized by the uniform dark brown back, as compared with the more rufous, streaked back of caplstratus. The type of nicaraguae is a variant of capistratus and the name nicaraguae should be regarded as a synonym of caplotratus, not of castaneus. The form xerophilus is close to the race $\underline{C}$. $\underline{\text {. }}$ nigricaudatus (Nelson), of the Pacific slope of Guatemala, and should be regarded elther as a synonym of the latter or as a slightly differentiated subspecies; in any case, its closest affinities are not with castaneus. One further 
point must be clarified. The type of castaneus, a specimen labeled "Spanish Honduras," was taken by Ilges and Sauter. I do not know where they obtained this individual, as I am aware of no other specimens of any species that they obtained in Honduras; however, as the type is a normal specimen of castaneus, it most likely came from the San Pedro Sula region. Since the race capistratus also occurs in Honduras, the type locality of castaneus must be restricted. I hereby designate "San Pedro Sula, Honduras," as the restricted type locality.

Thryothorus modes tus Cabanis

Plain Wren

SPECIMENS.- $-\mathrm{T}$. m. modestus (90): Catacombas, 28 March ( $\sigma^{\prime}$ BMNH); San Pedró sula, 28 July (o, USNM); Las Peñitas, 7-24 Feb. (4o", MLZ; $\sigma^{\circ}$, MCZ); Coyoles, 23 Apri1 ( $\sigma^{\circ}$, LSLMZ); Merendón Copán, 15 June ( $\sigma^{\circ}$, CNHM); La Libertad, 20 June ( $0^{\circ}$, AMaNH); Montaña El Chorro, 21 June ( $\sigma^{\prime}$, MLZ); Plan del Rancho, 27 May-30 June (50, 39, ?, Muz); Santa Bárbara, 1317 May ( $\sigma$, AMNH; $\delta$, CNHM); Finca Fé, 22 July, 24-30 Nov. (3o, LSUMZ); 1 mi. W El Jaral, $15 \mathrm{sep.} \mathrm{(} 0^{*}$, LSUMZ); Lake Yojos, 14 June-23 Aug. (50, 29, CM); Siguatepeque, 8-10 July (20, CM); E1 Caliche, 10-20 July (o, ?, ?, ANNH); Cantora1, 12 July ( $\sigma^{\prime}$, AMNH); Cerro Cantoral, 28 March-8 April ( $2 \sigma^{\circ}$ MCZ); Monte Redondo, 14 Dec. ( $d^{\prime}$, ANSP); La Flor Archaga, 19 March, 26 May (o,??, MCZ); Cantarranas, 5 Aug. ( $0^{\circ}$, ANSP); San Juancito, 15-23 July (40, 2\%, ANSP); San Juancito Mts ., 19 June ( $\$$, UF); E1 Tigre [ $=$ La Tigra, 19 June (\%, UF); Rancho Quemado, 15 March, 5 April (20, 2?, MCZ; of, USNM); E1 Derrumbo, 19 July ( $\&$, MLZ); E1 Hatillo, 19 Apri1-12 May (20, ₹, 4?, MCZ; \&, USNM); Cerro Higuito, D.C., 19 April (d, AMNH); Tegucigalpa, 18 June, 17 Oct. (?, AMNH; 9, CNHM); vicinity Tegucigalpa, 30 March (o' skel., MLZ); Comayagüela, 8 0ct.- -9 Nov. (o, 2\%, MCZ); Escuela Agricola Panamericana, 31 May ( $q$, UF); Yeguare River Va1ley, 28 Apri1, 7 Sep. (28, 9, UF); Jamastrán Valley, 17 Aug. (o, UF); 2 mi. S Cauquira, 13 April (o, LSUMZ); Nacunta River, $10 \mathrm{mi}$. SW Puerto Lempira, $5 \mathrm{Feb}$. (o", LSUMZ); Sabana Grande, 27 Feb. ( 8 , AMNH); Pledra de Jesuis, 8-11 March, 8 Nov. (o, 2?, AMNH); 2 mi. S El Corpus, 10 Feb. 
( ? ske1., LSUMZ); Finca E1 Rub1, 29 Sep. (o"?, LSUMZ); San Francisco, Choluteca, 11-14 0ct. ( $q$, skel., LSUMZ); "Honduras" (?, BMNH).

PUBLISHED RECORDS.--San Pedro region (Sclater and Salvin, 1870b: 836). San Pedro (Salvin and Godman, 1880: 84). San Pedro Sula (Ridgway, 1904: 641). San Juancito, Cantarranas, Rosario (Stone, 1932: 329).

Ranging from sea level to at least 6,000 feet, the Plain Wren is a fairly common to common species that is widespread in arid brushy and scrubby open situations throughout much of the interior of Honduras. It is most frequent on the Pacific slope and in the interior highlands. On the Caribbean drainage the species descends into the arid sections of the valleys, having been recorded from the Quimistán, Sula, Comayagua, Aguán, and Olancho valleys. It is also found at sea level in the Mosquitia, frequenting the heavy brush and undergrowth along the streams that pass through the pine savanna and occurring occasionally in mangrove swamps.

I follow Russel1 (1964: 136) In regarding $T$. ‥ pullus Ridgway as a synonym of the nominate race, $T$. m. modestus Cabanis. In a comparison of a series of costa Rican birds and more than 100 individuals from British Honduras and Honduras, I could detect no geographic variation, except perhaps a tendency towards more brownish coloration on the flanks of northern birds. The differences are too slight to warrant taxonomic recognition. 
Thryothorus rufalbus Lafresnaye

Rufous-and-white Wren

SPEC MENS. - T. $\mathbf{r}$. rufalbus $>$ castanonotus (33): La Ceiba, 12 May ( $\left.0^{\circ}, \mathrm{CM}\right)$; Los Planes, 13 July (o, CM); Cofradia, 6-11 March (?, BMNH; of, 9, MCZ); Coyoles, 14-17 June, 11 July $\left(2 \sigma^{\circ}, 29, \mathrm{CM}\right)$; San José de Santa Bárbara, 3 Maý (

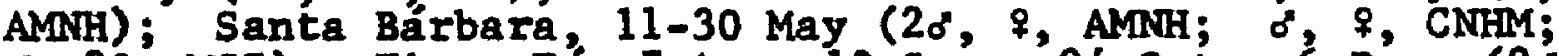
\%, 29, MCZ); Finca Fé, 7 Aug. -13 Sep. 24 Oct., 6 Dec. (20, 28,2 imm. of, imm. skel., 2 alc., Lstar); Lake Yojoa, 17-28 July $\left(20^{\circ}, C M\right)$; Cantoral; 6 March ( $\sigma^{\circ}$, AMNH); San Francisco, Choluteca, 14 Oct. (d skel., LSUMZ); $13 \mathrm{mi}$. SW San Marcos de Colón, 3 Oct. (imm., LSUMZ); "Honduras" (?, AMNH). T. r. castanonotus (19): Rfo Pataste, $12 \mathrm{mi}$. $\mathrm{S}$ Dulce Noubre de Culmi, 28 Jan. ( 9 , LSUMz); E1 Boquerón, 31 Aug.-21 Oct. $(108,49,4$, AMNH)

PUBLISHED RECORDS.--"Honduras ?" (Ridgway, 1904: 633). Wes tem Honduras" [In range] (Mayr and Greenway, 1960: 411).

The distribution of this wren in Honduras is unique. It is a species of wooded areas, occurring in the interior highlands and on the Pactific slope from 3,000 to 4,500 feet elevation and extending to sea level on the Caribbean slope in areas of open rain forest and second growth, especially where the undergrowth is dense. It is fairly common on the Caribbean slope at medium elevations (1,500 to 3,000 feet) but is decidedly uncommon elsewhere in Honduras.

Stone (1932: 329) reported it from Honduras on the basis of a supposed mention in Salvin and Godman (1880: 8283 ), but the latter did not record it from Honduras. The taxonony of the races in northern Central America Is poorly understood, and additional study will be required to determine subspecies Iimits. The arrangement that I am using is tentative. 
There is a great deal of variation with regard to age, season, and foxing, as well as noncorrelated individual variation. Young birds tend to be darker gray on the throat and chest, sometimes with faint gray streakings, and usually are much browner on the flanks, when compared with adults. Freshly molted fall adults generally are grayer on the chest than worn individuals. The width of the dark tail bars, a character often used in describing subspecies, is subject to much individual variation; for example, the Individuals from Honduras with the narrowest and with the broadest tall bars were taken at the same locality, Finca Fé. In the series that I examined, the most rellable character for subspecific determination seems to be the back coloration, with castanonotus being a brighter rufous, not nearly so dark as rufalbus, regardless of amount of foxing. On this basis I consider the Honduran populations, except for the olancho birds, to be nearest rufalbus although somewhat intermediate. The series from the olancho rain forest matches a Costa Rican series of castanonotus in all details and is assigned by me to that race.

\section{Thryothorus pleurostictus Sclater}

\section{Banded Wren}

SPECTMENS.--T. P. Lateralis (72): Cantoral, 15 Dec. (?, MLZ); Monte Redondo, 29-30 Nov. (?, MCZ; d, USMM); La Flor Archaga, 13-15 June, 8 Sep. (?, AMNH; o, Miz; 30, 3\%, ?, MCZ); Yeguare RIver Valley, 13 June ( $\delta$, UF); $10 \mathrm{~km}$. N Sabana Grande, 14 Aug. ( $d$, CM); Sabana Grande, 15 Feb. ( $q$,

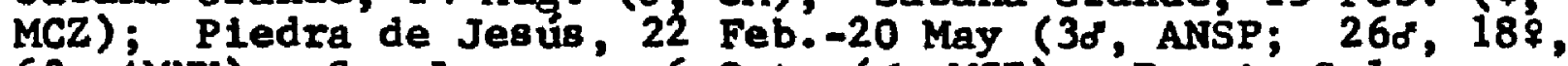
6?, AMNH); San Lorenzo, 6 oct. ( $\sigma^{\circ}$, MCZ); Puerto Salamar, 
27 Sep. (o, LSUMZ); 2 mi. S E1 Corpus, 7 Oct. (o', LSUMZ); "Honduras" (?, BMNH).

PUBLISHED RECORD.--"Honduras" (Sharpe, 1881: 214).

Despite the scarcity of previous Honduran records, the

Banded Wren is a fairly common to locally common resident in the arid scrub of the Pacific lowlands of Honduras, extending into the interior on the Pacific drainage to an elevation of 3,500 feet. It prefers heavy scrubby growth but will sometimes enter the edges of monsoon forest in situations with sufficient undergrowth.

The taxonomy of this species is in need of revision. On the basis of the specimens examined, I am assigning all Honduran material to T. p. Lateralis Dickey and van Rossem [1927a: 3; Lake Olomega, Department San Miguel, El Salvador], primarily on the basis of smaller average size (wing: 0 , 58.0-64.4, mean 60.7; $\$, 56.1-64.0$, mean 59.6) and darker brown coloration above. The southern race, $\mathbf{I}$. $\mathbf{p}$. Iavis (Ridgway), which extends from Nicaragua to Costa Rica, is also small in size but is much brighter rufous above. In western E1 Salvador, the race I. $\mathrm{P} \cdot$ oblitus [Pheugopedius pleurostictus oblitus van Rossem, 1934c: 399; Barra de Santiago, Dept. of Ahuachapan, E1 Salvador] occurs, differing from lateralis only in larger size.

Thryothorus maculipectus Laf resnaye Spot-breasted Wren SPEC IMENS.--T. m. umbrinue (160): Julián [= Tullán] (?, AMMNH); San Alejo, 15 March, 5 Aug. (20, LsuMz); 
Lancetilla, 16 Jan. -4 March, 19 Aug - -8 Sep. (40, \&, 2?, ANSP; $\delta$, CM; imm. skel., LSUMZ; $40^{\circ}, 2 \%$, MCZ); La Ceiba,

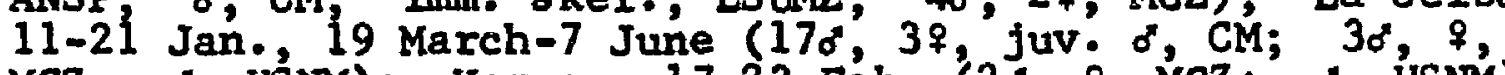
MCZ; o, UŚNM); Yaruca, 17-23 Feb. (2o, \&, MCZ; $\delta$, USNM); Balfate, 7 Nov. ( 8 , CNMM); Truj1110, 30 March-9 Apri1, 1926 Sep. (30, CM; $\delta, 2 \%$, ?, USNM); Catacombas, 21 March-5 Apri1 ( $\sigma^{\circ}, 2 \%$, AMNH; $\sigma^{\circ}, q$, BMNH; $30^{\circ}, q, ?$, MLZ); Cofradla,

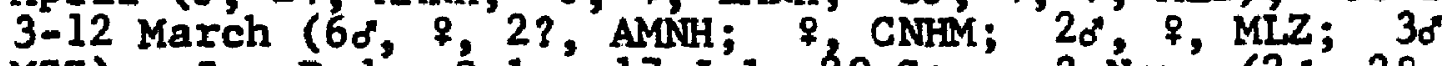
MCZ); San Pedro Sula, 17 July-29 Sep., 2 Nov. $\left(2 \delta^{\circ}, 2 \%\right.$ USNM); Santa Ana, 15 oct. ( $q$, USNM); Las Pefiitas, 4-11 Feb; $\left(80^{\circ}, 29, ?\right.$, AMNH; 29 , BMNH; $20^{\circ}, 29$, MLZ; $0^{\circ}, 29$, MCZ); La Lima, 1 Dec. (" skel., Lsumz); Chamelecón River, 22 Nov. (?, CNFM); Amapa, 26 June, 29 Nov, ( $\sigma^{\circ}, \&$, LSLAZ; $\circ$, UF); Coyoles, 15 June-12 July $\left(3 \sigma^{\circ}, \%, C M\right)$; Merendón Copán, 12-15 June (2\%, AMNH; o, MCZ); La Libertad, 11-29 June ( $\delta$, AMNH; $\sigma^{\circ}$, CNEM; $2 \sigma^{\prime}, q$, MCZ) ?, MCZ); San José de Santa Bárbara, 11-15 April ( $0^{\circ}, q$, AMMH); Finca Fé, 12 Aug. -6 Sep., 5 Nov.-2 Dec. (40", $q, 2$ imm. o, imm., \& skel., imm. skel., alc., LSUMZ); $2 \mathrm{mi}$. SE E1 Jaral, 2 March ( $\$$, ISUMZ); Lake Yojoa, 15-26 July (26, \$, CM); Cantoral, 1-26 March ( 8, ?, AMNH); E1 Boquerón, 21 Aug.-15 0ct. ( $50^{\circ}$, $\%$ ?, AMNH); Árena1, 25 Jan. ( $\$$, UCLA); Segovia River, 13 Aug.' (2 $\sigma^{\circ}$, USNM); "Honduras" (?, ANSP; 3?, BMNH).

PUBLISHED RECORDS.--San Pedro region (Sclater and Sa1vin, 1870b: 836). San Pedro (Salvin and Godman, 1880: 92). "Honduras" (Sharpe, 1881: 237). Trujillo, Segovia River (RIdgway, 1888c: 579, 585). La Ceiba, Yaruca (Bangs, 1903: 152). San Pedro Sula, Santa Ana (Ridgway, 1914: 536). Lancetilla Tela region (Peters, 1929b: 458). Lancetilla and La Ceiba las petersi] (Griscom, 1930c: 7). Lancetilia (Stone, 1932: 327-328). Chamelecón River las peter81] (Hellmayr, 1934: 204). La Ceiba (Deignan, 1936: 192-193). Lancetilia Valley (Skutch, 1940: 293). Near Tela (skutch, 1945a: 22).

The Spot-breasted Wren is a common resident in the Caribbean lowlands of Honduras and ranges up to an elevation of 4,500 feet. It frequents rain forest, open forest, and second growth, usually where the undergrowth is dense. Howell (1957: 98) gave reasons, with which I entirely agree, for maintaining I. maculipectus as a species separate from the more southern I. Iut1lus Vieillot. 
I assign Honduran specimens to the race $\underline{T}$. $m$. umbrinus Ridgway, which ranges from southern Mexico to Nicaragua. The two races described by Griscom, I. m. varians [pheugopedius maculipectus varians Griscom, 1930c: 7; San José Guatemala] and I. m. petersi [Pheugopedius maculipectus petersi Griscon, 1930c: 7; Lancetilla, eastern Honduras], are invalid, according to Hellmayr (1934: 203-204) and Howel1 (1957: 98). In a large series of Central American birds I was not able to detect any constant geographic variation and concur that only the single subspecies umbrinus can be recognized from this area. Honduran individuals show no approach to the pale, gray race, $\underline{\underline{I}}$. $\underline{\text {. canobrunneus }}$ Ridgway, which ranges south to central British Honduras.

\section{Troglodytes musculus Naumann}

Southern House Wren

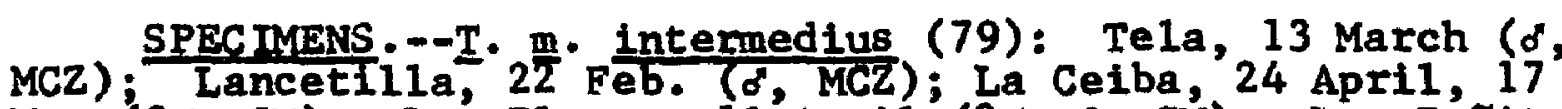
May $\left(30^{\circ}, \mathrm{CM}\right)$; Los Planes, $10^{\circ}$ April $\left(20^{\circ}, \$, C M\right)$; Las Peñit as, 17 Jan. 3 Feb. (d", MLZ; 9, MCZ); Subirana, 7-21 Jan. (20, ${ }^{\circ}$, MCZ); Portillo Grande, 30 May (o, MCZ); Coyoles, $15-16$ June $\left(40^{\circ}, C M\right)$; San Esteban, 1 Juiy $\left(20^{\circ}, q, C M\right)$; Monte $\mathrm{z} 1$ "Cercado" $[=$ Candado], 30 May (o", MLź); Finca Fé, $23 \mathrm{July,} 20$ Sep., 25 Nov. (38, LSUMZ); Lake Yojoa, 18 June, 16-17 Aug. (20, $\$$, CM); Muye, 20 Feb. (o', AMNH); Cerro Santa Maria, 30 Dec. ( $\$$, MLZ); Cerro Cantora 1, 29 May, 1316 Dec. (d", AMNH; 20, MCZ); La Flor Archaga, 29 March, 27 May-9 June, 18 July, 12 Aug ( 7 , ANSP; $q$ CNHM; 40, 2 ; ?, MCZ); San Juancito, 18-23 July (20", ANSP); Rancho Quemado, 19 March-5 April ( 9 , CNHM; 6o, $\$$ MCZ); E1 Derrumbo, 3-9 Aug. (o, BMNH); E1 Hatillo, 19-22 Apri1, 30 June-5 July, 17

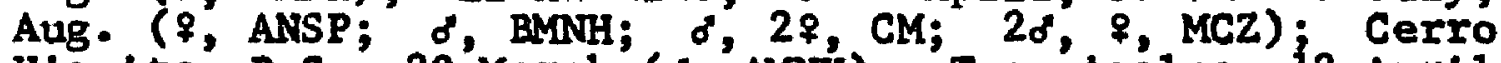
Higuito, D.C., 20 March (d, AMNH); Tegucigalpa, 12 April, 26 May, 4 July ( $d, ?$, AMNH; $d$, BMNH); Comayaguela, 29 March, 25 May-10 June (o ANSP; \&, AMNH; ${ }^{\circ}, \&$, MCZ); Uyuca, 7 Apri1, 28 July (20, 9, UF); Jamastrán' valley, 17 
Aug . (20, 9, UF); Dan11, 7 April ( $\sigma^{\circ}$, BMNH); Arenal, 26 Jan. ( $\sigma^{\circ}$, UCLA); Segovia River, 16-22 July (20, USMM). 585) PUBLISHED RECORDS --Segovia River (Ridgway, 1888c: 585). Lancetilla, Tela (Peters, 1929b: 458). San Juancito, Tela, Lancetilla (Stone, 1932: 328-329). This wren is fairly common to common in a wide variety of habitats throughout Honduras. It is at home in forest edge, open forest, semi-open situations, and second growth from sea level to at least 7,000 feet in Honduras. It tolerates either humid or arid conditions but is decidediy more plentiful in humid regions. In cloud forest, especially in areas partially cut over by man, this species and $I$. Iufocillatus occur sympatrically. On Cerro Santa Bárbara at an elevation of 6,000 feet, I discovered I. musculus males singing within a few feet of a nest-building I. rufociliatus. No evidence of any hybridization between the two species has been found; the differences in morphology and song are constant.

Species limits in the genus Iroglodytes, especially in northern Middle America, are not clearly understood. The Northern House Wren, $I$. aedon Vielllot, is very close to $I$. musculus, the two being lumped into a single species by some current authors (notably by Wetmore, Paynter, and Russel1). These two forms probably do constitute a single species since they exhibit no noticeable differences in behavior, ecology, or general song patterns. The problem is complicated, however, by the intergradation of I. brunneicolils Sclater of Mexico with aedon but not with musculus. Until 
the situation is more thoroughly studied, the best procedure is to maintain the groups as distinct species.

Honduran specimens represent the race $\underline{T}$. 뜨. intermedius Cabanis. The highland populations have been separated as I. m. oreopolus Chapman and Griscom, on the basis of supposed darker coloration, but there do not seem to be any constant differences between lowland and highland forms. The race intermedius, therefore, ranges from southern Mexico to Costa Rica.

\section{Troglodytes rufocillatus Sharpe}

\section{Rufous-browed Wren}

SPECIMENS.--T. I. Iufoclliatus $\times$ rehni (44): Montaña E1 Chorro, 20 June-9 July (2\%, 9, ML $) ;$ Montaña El Sillón, 1-16 July (?, ?, MLZ); Montaña La Cruz, 25 June-7 July (20, 7f, 2?, MLZ); Plan del Rancho, 12 June ( 9, MLZ); Belén Gualcho, 14-18 July (3o', 39, 2?, MLZ); Monte Verde, 19-26 July (78, 39, 9?, MLz). T. r. Tehni (85): Mt. Puca, 8 Jan.-1 Feb. ( $\left.0^{\circ}, 29, M C Z\right)$; Cerro Santa Bárbara, east slope, 25 April ( $\sigma^{\prime}$, LSUMZ); Gua imaca Mts., 5-10 June (2o, $\%$, AMNH); Alto Guaimaca, 5 June ( $\%$, MĆz); Cantoral, 25 Jan. 15 March, 17 Apri1, 1 May, 20 Sep., 1 Nov. (o, ?, ANSP; 10\%", 10\%, AMNH; $\delta$, CNMM; 30, 4\%, MLZ; 0 , ₹, MCZ; $8, ?$, USNM); Alto Cantoral, 10 Feb., 1 March, 13 April ( $q$, CNHM; of, $q$, MCZ); La Laguna Archaga, 7 Aug. (d", AMNH); San Juancito,

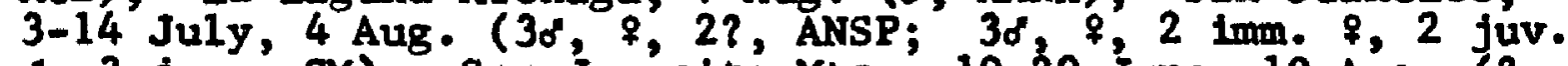
o, 3 juv., CM); San Juancito Mts., 19-29 June, 10 Aug. (?,

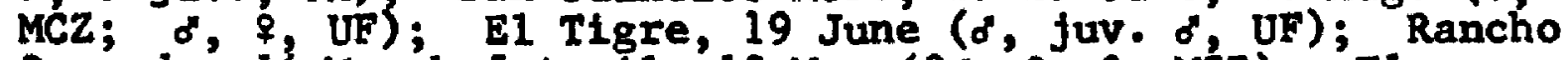
Quemado, 14 March-5 Apri1, 19 May (30, \&,?, MCZ); El Derrumbo, 13 July-9 Aug - ( $\sigma^{\circ}$, BMNA; 20, 4\%, MCZ); Mt. Uyuca, 6 Apri1, 26 May, 20 Nov. (\$, MCZ; \&, q, ?, UF); Uyuca, 22 Sep. (o", MCZ).

PUBLISHED RECORDS.--San Juancito (Stone, 1932: 328). Alto Cantoral (Brodkorb, 1943d: 1-3).

Confined to elevations above 6,000 feet, this wren is a common resident of cloud forest in Honduras. In areas of 
cut-over forest it occus sympatrically with I. musculus (see preceding account).

Although I. rufociliatus is sometimes considered conspecific with the South American I. solstitialis Sclater, I prefer to maintain the two forms as distinct species pending a revision of the entire genus. As I have mentioned in the discussion of $\underline{I}$. musculus, the species limits in the group are not well known at the present time.

The Honduran race, I. $\underline{\text { r. rehnt }}$ Stone [1932: 328; San Juancito, Honduras], is distinguished from the nominate race, I. r. rufociliatus Sharpe, by the darker coloration above and the decidedly brighter reddish coloration below and on the superciliaries. Specimens from the Department of Ocotepeque in western Honduras are intermediate between rehni and Guatemalan examples of the nominate race. Material from Los Esesmiles, E1 Salvador, is also intermediate, although Dickey and van Rossem (1938: 421-423) thought that specimens from this locality were typical of rufociliatus. No Honduran specimens show any approach to the duller, darker race, I. I. nannoldes Dickey and van Rossem, which is 1solated on Volcán de Santa Ana, El Salvador.

\section{Henicorhina leucosticta (Cabanis)}

White-breasted Wood Wren

SPECTMENS- - - H. 1. pros theleuca (123): Lancetilla, 17 Jan.-29 March, 17 Aug. -4 Sep $\left(5,9, ?\right.$, ANSP; ${ }^{2}$ LSUR:; 30", 27 MCZ); La Ceiba, 15 May-6 June, 29 July-2 Aug. (68, 38, CM); Yaruca, 23-24 Feb. ( $\delta, f$, MCZ); Trujil1o, 8 April 
9, CM); Catacombas, 29 March-17 April (60, \&, AMNH; 20",

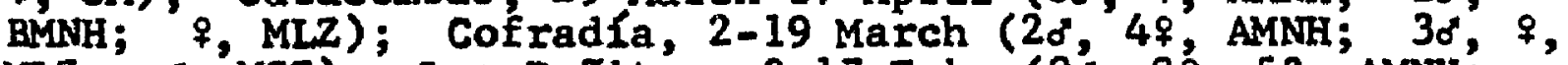
MLZ; of MCZ); Las Peñitas, 3-17 Feb. (98, 8\%, 5?, AMNH; 50", ₹, 3?, MZZ; \&, MCZ); Portillo Grande, 11 March, 14 May, 1 Sep. (20, $0^{\circ}$, MCZ); $5 \mathrm{ml}$. S San Esteban, 12 Jan. ( ${ }^{\circ}$, LSUMZ); La Leona, 25 June ( 6 , 9, AMNH); La Libertad, 10 June-1 July (20, AMNH; $\sigma^{\circ}$, $\$$, CNFM); Merendón Copán, 12-28

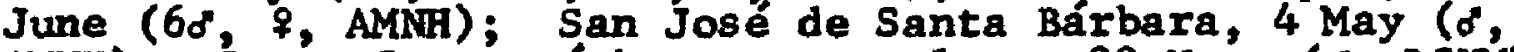
AMNH); Cerro Santa Bárbara, east slope, 22 Nov. (ó, LSUMZ); Finca Fé, 7 Aug.-13 Sep. ( $\%$ o skel., 2 alc., LSUMZ); $4 \mathrm{mi}$. SW EI Jaral, 21-22 Oct. (d, imm. + , LSUMZ); 5 mi. SW E1 Jaral, 4 Nov. ( 9 skel., Isumz); 2 mi. SE El Jaral, 3 March ( ${ }^{\prime}$ LSUMZ); Lake Yojoa, 14-19 June, 16-31 July (7\%, 49, CM); San Marcos de Guaimaca, $1-12$ July (4\%, AMNH); Alto Guaimaca, 12 June (?, AMNH); Arena 1, 16-28 Jan. (38, ?, ?, UCLA); Segovia River, 13 Aug. (?, USNM).

585). $\frac{\text { PUBLISHED }}{\text { Yaruca }} \frac{\text { RECORDS }}{\text { (Bangs, - -Segovia River (Ridgway, 1888c: }}$ Valiey (Peters, 1929b: 458-459). Lancetilla (Stone, 1932: 329).

The White-breasted Wood Wren is a common resident of lowland rain forests of Honduras, extending into low montane rain forest to an elevation of at least 4,500 feet. At higher elevations in cloud forest, it is replaced by $\underline{H}$. leucophrys. The wood wrens inhabit forest or second growth, usually occurring on or very near the ground.

The immature of $\underline{H}$. leucosticta is gray on the breast and resembles the adult of $\underline{H}$. leucophrys, as has been mentioned by Howe11 (1957: 98).

The race $\mathrm{H}$. 1 - tropaea Bangs and Peters is generally recognized for populations from Honduras to Panama, while $\underline{H}$. 1. prostheleuca (Sclater) is restricted to southeastern Mexico, Guatemala, and British Honduras. The former is supposed to differ from prostheleuca in having a more reddish brown central crown stripe, and in being more whitish 
on the breast. While it is true that more southern populations tend to average slightly more rufescent above and slightly more whitish below, the differences are very small and are clinal over a large area. I can see no constant differences in the crown stripes of a series of Mexican and Costa Rican individuals. I therefore consider the race tropaea as a synonym of prostheleuca.

\section{Henicorhina leucophrys (Tschudi)}

Gray-breas ted Wood Wren

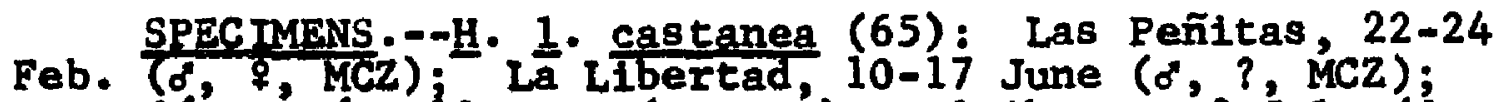
Merendón Cópán, 18 June ( $\left.\sigma^{\circ}, M C 2\right)$; E1 Chorro,' 9 July (q MLZ); Montaña El Chorro, 20 June-9 July (40", q, ?, ML); Montaña La Cruz, 25 June-1 July ( $\sigma^{\circ},{ }^{2}$ MLZ); Monte Verde, 19-21 July (2?, MLZ); Las Ventanas, 24-27 July (29, MLZ); Mt. Puca, 20 Jan. -10 Feb. ( $0^{\circ}$, AMNH; 70, 29, ?, MCZ); Muye, 20 Feb. ( $\delta$, AMNH); Cantora 1, 25 Jan. -1 March, 11-20 April (30, ${ }^{\circ}, ?$, ANSP; $50^{\circ}, 39$ AMNH; 20, MLZ; ${ }^{\circ},{ }^{\circ}$, USNM); Cerro Cantoral, 6 Aug., 13 Dec. $\left(2 \sigma^{\circ}, q, 2 ?\right.$, MCZ); Alto Cantoral, 20-23 Feb. ( 6 , \&, CNHM); E1 Derrumbo, 14 July-9 Aug. (\$, ANSP; o, \&, BMNH; 70, \&, MCZ). 61). PUBLISHED RECORD.--Cerro Cantora1 (Griscom, 1932c:

This wood wren replaces H. leucosticta in the cloud forests in the interior of Honduras above 4,000 feet; it is a fairly comon species. In areas where cloud forest is continuous with rain forest, the two specles occur sympatrically. The habits of $\underline{H}$. leucophrys are similar to those of H. leucosticta.

The Honduran populations have been described as $\underline{\mathrm{H}} \cdot \underline{1}$. composita Griscom [1932c: 61; Cerro Cantoral (6500 feet), District of Achaga (= Archaga), Honduras]. This supposed 
race was said to differ from the Guatemalan subspecies, 1. castanea Ridgway, only in the slightly paler chestnut flanks. There is no constant difference of any kind between Honduran and eastern and central Guatemalan populations, as evidenced by the large Honduran series now available for comparison, and I consider composita to be a synonym of castanea. The race occupying a range from Chlapas to El Salvador through western Guatemala, ㅂ. 1 . capitalis Nelson, a paler chestnut form with sooty pileum, has been reported from Los Esesmiles, El Salvador, but the Ocotepeque specimens (some taken only a few miles from Los Esesmiles) are castanea; I have not examined any material from El Salvador.

\section{Uropsila leucogastra (Gould)}

White-bellied Wren

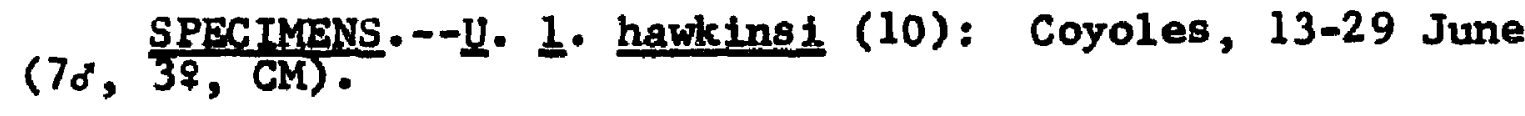

PUBLISHED RECORD.--Coyoles (Monroe, 1963a: 5-6).

The discovery of a local population of this species in the rain forests near Coyoles by Arthur $C$. Twomey and Roland W. Hawkins was indeed surprising. The closest known population to the Coyoles region is in British Honduras, approximately 150 miles to the northwest. The number of specimens obtained indicates that the species must be fairly common in the Coyoles area. Two males and a female were taken on each of three days: 16 June 1948, 13 June 1950, 
and 19 June 1950. A single male was secured on 29 June 1950. Nothing further is known concerning the species in Honduras .

The Honduran race, U. 1. hawkinsi Monroe [1963a: 5; Coyoles, Department of Yoro, Honduras], differs from $\underline{\underline{U}} . \underline{1}$. brachrura (Lawrence) of British Honduras, eastern Guatemala, and Yucatán in being a much darker and grayer brown above, often with a contrasting crown and back. Although the series from Coyoles is rather worn, these differences are evident when Honduran spectmens are compared with worn or fresh individuals of brachyure.

\section{Salpinctes obsoletus (Say)}

Rock Wren

SPECTMENS.--S. ㅇ. guttatus (14): La Flor Archaga, 8 Dec. ( ${ }^{\circ}$ MCZ); Rancho Quemado, 2 April ( ${ }^{\circ}$, MCZ); Comayagüela, 16 Nov. ( ${ }^{\prime}$, MCZ); Las Mesas, 13-15 March ( ${ }^{\prime \prime},{ }^{\circ}$, imm., UF); Yeguare River Valley, 4 April, 17 Nov. (2\%, UF); Yus carán, 16-17 Apri1 (20,3\%, BMNH); $18 \mathrm{mi}$. SW San Marcos de Colón, 14 Oct. (?, LSUMZ).

PUBLISHED RECORDS.--"Central Honduras" [as neglectus]; "south-central Honduras" [as guttatus] (Mayr and Greenway, 1960: 388).

The Rock Wren is an uncommon resident throughout the arid steppe in the interior highlands of Honduras and ranges from 2,500 to 5,000 feet. It is most frequent in areas of rocky outcroppings or lava flows, often in regions with very 1ittle vegetation of any kind.

The taxonomy of this species is still greatly confused. The Central American forms are spotted or barred below and 
are very different morphologically from the pale-breasted northern populations. In Honduras the variation in any given area is considerable, with individuals of either a spotted or a heavily barred type being present. Such a situations was responsible for the unlikely range as set up by Paynter in Mayr and Greenway (1960: 388). Paynter apparently based these ranges on the three specimens in the Museum of Comparative Zoology, a barred individual from Comayagüela and two spotted ones from La Flor Archaga and Rancho Quemado; all three localities are in the same general area within a few miles of one another. I do not know whether the barred and spotted types are the result of individual variation, of color phases, or of there being two sibling species. Until the situation is carefully studied, I am tentatively assigning all Honduran birds to the southem race, S. o. guttatus Salvin and Godman, and restricting s. o. neglectus Nelson to Chiapas and Guatemala.

\section{Microcerculus marginatus (Sclater)}

Nightingale Wren

SPECIMENS.--M. m. philomela (11): Catacombas, 2 April (o*, MCZ); Las Peñitas, 7-25 Feb. (o, ANSP; o, ₹, MCZ); 5 mi. S San Esteban, 13 Jan. ( $\%$, LSUMZ); Merendón Copán, 12 June ( $\%$, MCZ); Ait to Nieve, 9 May, ( $\%$, AMNH); Santa Bárbara, 21 May (2o, MCZ); Cerro Santa Bárbara, east slope, 9 Dec. ( $\sigma^{\prime}$, LSURZ); Arenal, 26 Jan. ( ${ }^{*}$, UCLA). $1955 \mathrm{a}$ : 79$)$.

PUBLTSHED RECORD. - "Honduras" [in range] (Eisenmann,

Ranging from sea level to at least 6,000 feet in Honduras, the Nightingale Wren is an uncommon to fairly common 
resident in rain forest and in cloud forest that is continuous with rain forest. The species is terrestrial, solltary, and very difficult to observe. The distinctive song is frequently heard, however; in Honduras, this song consists of a serles of clear notes, each succeeding note given in a pitch different from the preceding, sometimes, higher, sometimes lower. The over-all effect is one of someone trying to whistle a tune but unable to stay on key. Although the species is primarily a tropical lowland inhabitant, its center of abundance in Honduras is at medium elevations in low montane rain forest from 3,000 to 5,000 feet. The species has not been recorded on the Pacific drainage in the republic.

I tentatively follow Griscom (1932a: 360-364) in unitIng the Middle American group (philomela) with the South American M. marginatus (Sclater). However, a thorough revision of the group is necessary to determine the species Iimits in this genus with certainty.

Honduran specimens are referable to the northern race, M. m. phtlomela (Salvin).

Cyphorhinus phaeocephalus Sclater Song Wren Aug. SPECIMFN $(\%$, USNM).
585). PUBLISHED RECORD.--Segovia RIver (RIdgway, 1888c: 
The Song Wren reaches its northern 1 imit of distribution in the rain forests of olancho. It is another species that is seldom seen but frequently heard. In Honduras it Is known from a single female taken by $\mathrm{C}$. H. Townsend along the Rio Segovia in 1887 (Ridgway, 1888c: 585). The species is a terrestrial inhabitant of the interior of dense forest or heavy second growth. In northern Nicaragua it is very common (Howel1, 1957: 99) and it very likely is common and widespread in the adjacent olancho rain forests also.

I am dubious about the advisability of lumping the morphologically distinct $\underline{C}$. aradus (Hermann) of South America and $\mathrm{C}$. phaeocephalus. Until compartsons of behavior and song are made, retention of the two groups as distinct spectes seems to be the best procedure.

The single Honduran specimen is not different from examples of C. R. richardsont Salvin from Nicaragua.

Family MIMIDAE

Melanot is hypoleucus Hartlaub

Blue-and-white Mockingbird

SPECIMEANS.--(39): Merendón Copán, 26 June (o', MCZ); E1 Chorro, 5-I7 June, 9 July (30, \%, ?, MLZ); Montaña E1 Chorro, 5-21 June (20, ?, MLZ); Plan del Rancho, 27 May-30 June (6o, \&, ?, MLZ); Monte Verde, 20-25 July (3?, MLZ); Cantora 1, 2 March, 26 June, 14 July ( $\sigma^{\circ,}$ Imm., AMNH; ${ }^{\circ}$, CNIM); Cerro Cantoral, 27 Feb., 22-29 March, 12-14 July (50, $q$, MCZ); San Juancito, 16-17 July ( 7 juv. of Juv., ANSP); Rancho Quemado, 15 March-5 Apr11, 19 May (3d, AMNH; 49, MCZ). 
PUBLISHED RECORD.--San Juancito (Stone, 1932: 329).

Occurring above an elevation of 4,000 feet in Honduras, the Blue-and-white Mockingbird 18 an uncomon resident in open and semi-open situations in the interior highlands. It inhabits heavy brush or undergrowth, usually in areas where trees are sparse or absent. Areas where patches of cloud forest have been cleared away by man and have subsequently grown up in guamil form excellent habitat. The species reaches its southern limit of distribution in the Tegucigalpa region of central Honduras.

I agree entirely with Davis and Miller (in Mayr and Greenway, 1960: 442) that $M$. hypoleucus is a species distinct from M. caenulescens (Swainson) of Mexico. The occurrence of partially albinistic individuals in populations of $\underline{M}$. caerulescens has no bearing on relationships between the two species.

\section{Melanoptila glabrirostris Sclater}

Black Catbird

SPECTMEN.--(1): Omoa (?, BMAH).

PUBLTSHED RECORD.--Omoa (Sclater, 1857: 275-276; Moore, 1859: 55; Sclater, 1862: 7).

The Black Catbird is a rare and local species ranging from Yucatán south through British Honduras to the Onoa region of extreme northwestern Honduras. The type specimen was taken at Omoa in 1855 or 1856 by Joseph Leyland and was deposited in the collection of P. L. Sclater. The latter 
described the species as Melanoptila glabrirostris Sclater [1857: 275; "In rep. Honduras, prope urbem Omoa" (= Omoa, Honduras)]. Sclater stated that he had seen three individuals of the species, the type and two others taken in "Honduras " by Delattre (one each in the Derby Museum and the British Museum). The Omoa specimen was, however, the holotype, as later Indicated by Sclater (1862: 7). A critical point is that the Omoa specimen was in fact the type since, as far as is known, all of DeLattre's matertal labeled "Honduras" was actually procured in British Honduras.

According to Sclater (1857: 275-276), Leyland regarded the species as rare at Onoa, since the latter observed only one individual in addition to the specimen taken. I collected at Omoa twice during 1962-1963 but falled to find the species during these brief visits.

Paynter (1955: 224-225) has proposed uniting Melanoptila with pumetella. While there can be little doubt that Melanopt11a is a mimid and probably closest to Drmetella in its relationships, the differences in plumage and structure indicate that the relationships are not very close. On the basis of present knowledge, I can see nothing to be gained by lumping the two genera, and I prefer to maintain them as separate pending detailed study of both.

\section{Dimetella carolinengis (Linnaeus)}

\section{Common Catbird}

SPECTMFNS.--(49): Big Swan Island, 5 Jan. ( ${ }^{*}$, CNHM); 


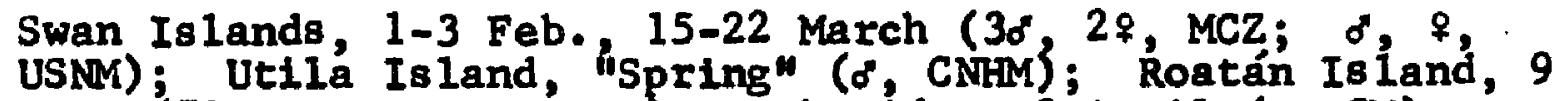
Jan. (7?, BMNH; 7, CNHM); Oak Ridge, 8 April (o, CM); Guanaja Island, 22 March ( $7, \mathrm{CM}$ ); Lancetilla, 18 Jan. (?, MCZ); La Ceiba, 2-22 Jan. ( $($, 2\%, MCZ); Yaruca, 10-16 Féb. (2o, \%, MCZ; of, USNM); Catacombas, 29 March-5 April (ó,

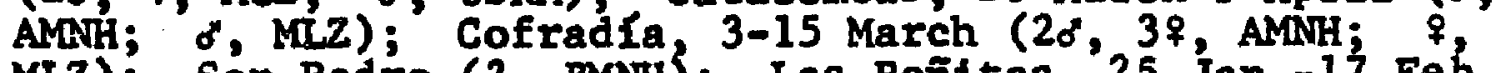
MIZ); San Pedro (?, BMNH); Las Peñitas, 25 Jan.-17 Feb. (6, \%, AMNH; o, Miz); Progreso, 30 Jan. ( $\sigma^{\circ}, \mathrm{MCZ}$ ); Finca Fé, 12 Jan., 30 Nov. (o, q, Lsumz; 2 mi. N Pito Sólo, 27 Oct. (\%, Lsinz); Monte Redondo, 24 Nov. ( $\sigma^{*}$, MCZ).

PUBTISHED RECORDS.--San Pedro region (Sclater and Salvin, 1870b: 836). San Pedro (Salvin and Godman, 1879: 26). Swan Islands (RIdgway, 1888c: 575; Lowe, 1909: 335336; Fisher and Wetmore, 1931: 15; Paynter, 1956: 106). Roatán Island (Salvin, 1888: 243-244). La Celba, Yaruca (Bang8, 1903: 152) : Tela region, Lancetilla, Progreso (Peters, 1929b: 459). Bay Is lands (Delacour, 1938: 545).

In Honduras prmetella carolinensis is a common migrant and winter visitant, occurring in the islands off the north coast and on the Caribbean slope below 3,500 feet. There is a single record from Monte Redondo in the Interior high1ands. Extreme arrival and departure dates for Honduras are 23 October and 5 May; the October date 18 not representative since the species begins its migration early enough to arrive in Honduras during late August or September.

Sclater (1859b: 336) recorded the species as wintering south to "Honduras" but this statement was based on a spec1men taken in British Honduras. Salvin and Godman (1879: 26-27) ment1oned its occurrence at Omoa but gave no bas is for this report. Lowe (1909: 335-336; 1911: 40) thought that the spectes was resident in the Swan Islands, primarily on the basis of reports by the local inhabitants, but the 
species is strictly a migrant and winter visitant there as elsewhere in Honduras.

While southeastern and western breeding populations in North America average slightly paler than central populations, differences are so silight that they may be detected only in carefully prepared and washed skins. Nothing seems to be gained by recognizing these populations taxonomically, and I therefore regard the species as monotypic, the names D. c. Iuficrissa Aldrich [1946: 132; Colville Lake, Sprague, Washington] and D. C. mertdianus Burleigh [1959a: 29; Athens, Clarke County, Georgia] being synonyms of D. carolinens is (Linnaeus). One of the males from Yaruca, taken on 12 February 1902, was Identified by Burleigh (1959a: 29-32) as meridianus. Most of the specimens that I examined seem to be nearest the darker, central populations.

\section{Mimus giluns (Vielllot)}

\section{Tropical Mockingbird}

SPECTMENS. - M. g. graglils (6): $5 \mathrm{mi}$. N Villa de San Antonio, 17 Oct. $7 \%$, LsứL) ; Monte Redondo, 11 Dec. (os MCZ); San Lorenzo, 6 oct. ( $\$$, MCZ); Puerto Salamar, 28-30

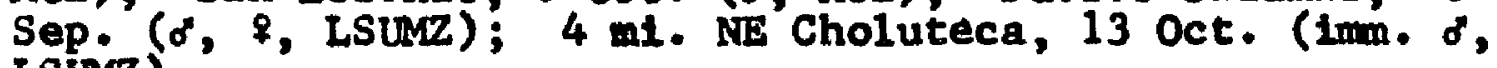
LSUMZ).

PUBLISHED RECORDS.--"Honduras ?" (Cabanis, 1851: 83). Pla in of Comayagua (Taylor, 1860: 110).

The Tropical Mockingbird is an uncommon to rare resident of the arid Pacific lowlands, of the arid interior valleys (on the Caribbean drainage only in the Comayagua and 
Otoro valleys), and of open situations in the arid interior below an elevation of 6,000 feet. The species is decidedly rare anywhere in Honduras except in the Pacific lowlands. C. F. Underwood collected single males in Honduras at Monte Redondo in 1931 and at San Lorenzo in 1932. J. Alan Feduccia and $I$ obtained the remaining four specimens in the fall of 1962. On 29 October 1962 I noted a pair in the Otoro Valley near Mazaguara; on several occasions I saw single individuals at elevations from 2,500 to 4,500 feet in the Tegucigalpa region.

A specimen that was collected by David Dyson in "Honduras" (Sclater, 1859b: 343; 1862: 9) must have been taken in British Honduras (as are many of Dyson's skins labeled "Honduras") since this spectes does not occur in the region of Honduras that Dyson visited.

The relationships between $M$. gilvus and $M$. polyglottos (Linnaeus) are not clearly unders tood at the present time. Until field studies of the two forms are made in the area of geographic overlap in Oaxaca, it seems best to retain them as distinct species, although I suspect they will eventually prove to be conspecific.

The type locality of M. g. gracilis [Mimus gracilis Cabanis, 1851: 83; "in Central-Amerika (Honduras ?)"] has caused some taxonomic confusion. The type locality must be regarded as highly doubtful, since before 1851, the year in which the race gractile was described, there was no 
ormithologist or collector anywhere in Honduras in the range now occupied by the species. Although I have not seen the type, which was deposited in the Zoological Museum in Berlin, I suspect that it may prove to represent an example of the British Honduran race, M. g. leucophaeus Ridgway; however, van Rossem (1934c: 400-401) examined this specimen and thought that it was an example of the race that ranges through the interior and along the Pacific coast of Middle America from Oaxaca to Honduras. Until the type can be examined once more, if it is still extant, retention of the present taxonony, with gracilis representing the interior Middle American race, seems advisable.

\section{Family TURDIDAE}

Turdus rufitorques Hartlaub

Rufous-collared Robin

SPECTMEN.--(1): Güise, $17 \mathrm{July} \mathrm{( \sigma ,} \mathrm{LSUMZ).}$

This species is an endemic of the Middle American highlands from Chiapas to western Honduras and El Salvador. It inhabits pine-oak associations or areas of cypress (Cupressus) in Guatemala, where it is very comon locally. In Honduras it is known only from the single male collected by J. Alan Feduccla at Güise in 1963. The specimen was secured In a stand of pine, but there are extensive areas of oak and pine-oak nearby; the elevation at this locality is 
5,600 feet. No others were seen.

The species has not been previously recorded in Honduras .

\section{Turdug assimil1s Cabanis}

$$
\text { White-throated Robin }
$$

SPECIMENS. - I. A. parcolor > leucauchen (28): Lancet111a, 26 Aug. ( 9, ANSP); Catacombas, 25 March-6 Apr11 (?, AMAH; $\sigma$, MIZ; 28, 2q, MCZ); Las Peflitas, 6-27 Feb. ( $7 \delta^{\circ}$, 48,27 AMNH; 60' MLZ; 2\%, MCZ). $T \cdot$ a. 1eucauchen (28):

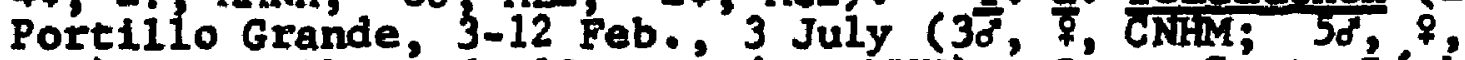
MCZ); La Libertad, 10 June ( ${ }^{\circ}$, AMNH); Cerro Santa Bárbara, east slope, 1 Dec. ( $\delta$, LS LMZ); $5 \mathrm{ml}$. SW E1 Jaral, 4 Nov. (o, LSUMZ): Lake Yojoa, 16-18 June, 15-25 July (5。, 7\%, 2

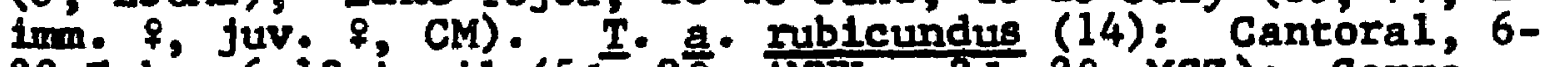
$28 \mathrm{Feb}$, 6-13 April (5d, 2\%, AMANF; 38, 2\%, MCZ); Cerro Cantoral, 17 Dec. ( 0 , MCZ); San Francisco, Choluteca, 14 Oct. (f, LSUMZ). I. a. - rubicundus $x$ leucauchen (17): San Marcos de Guatmaca, 19 June-1 July (50, 28,?, AMNH; 20, $q$, MLZ; $30^{\circ}, 39, \mathrm{MCZ}$ ). T. a. atrotinctus (5): $5 \mathrm{ml}$.' s San

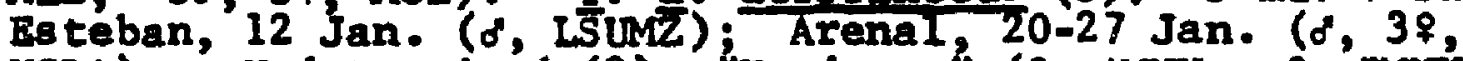
UCLA). Undetermined (2): "honduras" (?, AMNH; ?, BMNH).

PUBLTSHED RECORDS.--San Pedro region (Sclater and Salvin, 1870b: 836, 838). San Pedro (Salvin and Godman, 1879: 15). Lancetilia (Stone, 1932: 330). Portillo Grande (Blake, 1950: 410).

Ranging up to at least 6,000 feet, this robin is a locally common inhabttant of broadleaf forests in Honduras. It is found primarily within the forest but does enter second growth and semi-open situations on occasion. It has been recorded from rain forest, cloud forest, and monsoon forest.

A few recent authors have advocated lumping I. assimil18 and the South American I. albicollis Vieillot. In view of the morphological differences it seems best to retain the two as distinct until more evidence is avallable. In 
several cases two good species in the genus are closer morphologically than are I. assimilis and I. albicollis.

Geographic variation in Honduras is exceptionally great in this spectes and is not well understood at present. In general, lowland forms tend to be blackish with no trace of brownish in the plumage; the bill, feet, legs, and eye-ring are bright yellow. Montane forms are very brownish and have orange eye-rings, black bills, and dull yellowish feet and legs. This variation might suggest that two species are involved, but apparently intermediate populations exist. The British Honduran race, I. a. parcolor Austin, is a smal1, dark race, without any indication of a brownish wash on the slate plumage either above or below; the bill, legs, feet, and eye-ring are bright yellow. Specimens from Lancetilla are very similar to this race, differing only in slightly larger average size and in a trace of brownish in the plumage; Individuals from the San Pedro Sula region 11kewise are near percolor but show some approach to the characters of $I$. $\mathrm{g}$. Leucauchen Sclater. The remainder of the Interlor of Honduras on the Caribbean slope as far east as the Department of Yoro is occupied by the race leucauchen, which ranges from eastern Chiapas through eastern Mexico to north-central honduras (but south of parcolor). I. a. Leucauchen is distinguished from parcolor by 1 ts larger size and by the faint but definite wash of brownish, both above and below; the bill, feet, and legs are usually 
greenish-yellow or brownish and the eye-ring is orangeyellow. On the Pacific drainage of Honduras is found the brownest of all the Central American subspecies, I. a. rublcundus (Dearborn). Th1s latter race is considerably browner above and below than is any other race occurring in Honduras and possesses a black bill, orange eye-ring, and dull yellowish feet and legs. In the Department of Olancho, at medium elevations on the Carlbbean drainage, the race I. a. atrotinctus Miller and Griscom occurs. It ranges south into Nicaragua and is the darkest of the Honduran subspecies. It is closest to parcolor and differs from that race only in the slightly larger size and the darker, almost black, upper parts. The population near San Marcos de Guaimaca, in northern Francisco Morazán, seems to be intermediate between leucauchen and rubicundus.

\section{Turdus grayi Bonaparte}

\section{Clay-colored Robin}

\section{SPEC MMENS. - -T. g. grayi (110): Medina (?, ANSP);} Tela, 28 March $\left(\sigma^{\circ}\right.$, MCZ); tancet1lia, 20-23 Jan., 23 Feb., 28 Aug. ( $\sigma^{\circ}$, ANSP; 3o, MCZ); La Ceiba, 2-11 Jan., 25 March29 May (6o', 10\%, CM; '6o', $29, \mathrm{MCZ}_{\mathrm{j}} 20^{\circ}$, \%, USN); Yaruca, 19-24 Feb. (20, MCZ); Trujillo, 31 March-9 April (2\%, CM); Catacombas, 1 Apri1 (?, ML) ; San Pedro Sula, 28 July (?, BMNH; O USNM); Sub1rana, 19 Dec. (o, MCZ); Port11lo Grande, 11 Feb., 2 April (q, CNEM; d" MCZ); Coyoles, 29 Jume ( $\$, C M) ;$ El Chorro, 23 June ( $\%$, MLZ); E1 Sillón, 22 June ( 9, MLZ); Monte E1 Conejo, 14 May ( $q$, MLZ); Montaña La Cruz, 26 June (f, Mz); Plan del Rancho, 27 May, 22 June-3 July (3o, 2\%, Miz); Finca Fé, 30 Nov.-7 Dec. (28, LSUMZ); Lake YoJoa, 18 June, 21 July (20, CM); Siguatepeque, 9-11 July ( $\left.{ }^{7}, 7, \mathrm{CM}\right) ;$ Soluteca, 5 April ( 7 AMMH); La Florida, 8 Dec. ( $ه$, AMNH); $5 \mathrm{mi}$. N" Sabanetas, 30 Oct. (f, LStMZ); San Marcos de Gualmaca, 19 June ( $\%$ MLZ); Cantoral, 10 Feb. ( $\$$, AMNH); Cerro Cantoral, 12 March (?, 
MCZ); Monte Redondo, 20-27 Oct., 2 Dec. (20, 9, MCZ); EI Derrumbo, 16 July (d, USNM); El Hatillo, 5 July (juv. ${ }^{q}$, juv., CM); Teguclgalpa, 24 May-23 June, 18 oct. ( $\sigma^{\circ}, 2 \%$, AMNH; ?, USNM); vicinity Tegucigalpa, 14 May (o' skel.: MIZ); Comayaguiela, 19 Apri1, 11 July, 11 Oct.-18 Nov. ( 0 , MLZ; 140, 49, 2?, MCZ); Cuesta Grande, 1 July ( $\left.\sigma^{\circ}, C M\right)$; Yeguare River Valley, 20 Jan. $-9 \mathrm{Feb}$. (28, UF); Arena1, 1521 Jan. (28, UCIA); Segovia River, 15 June, 8 Aug. (28, 28, USMM); 10 lon. N Sabana Grande, 14 Aug. ( $q$, CM); Pledra de Jesuis, 1 April (o, AMNH); 2 mi. S E1 Corpus, 7 Oct. (imm.; LSUMZ); San Francisco, Choluteca, 11 oct. (क skel., LSUMZ).

PUBLISHED RECORDS.--San Pedro regton (Sclater and Salvin, 1870b: 836). San Pedro (Salvin and Godman, 1879: 18; Helimayr, 1902: 50-51). Segovia RIver (RIdgway, 1888c: 584). Near San Pedro (Seebohm and Sharpe, 1898: 261-265). La Celba, Yaruca (Bangs, 1903: 152). Lancetilla, Tela (Peters, 1929b: 459-460): Lancetilia (Stone, 1932: 330). La Ceiba (Deignan, 1936: 193). Near Tela (Skutch, 1945a: 23). Tela, Lancetilla Valley (Skutch, 1960: 70).

The Clay-colored Robin is one of the most widespread species of birds in Hondurss and a consplcuous part of the lowland avifauna. It inhabits almost any type of broadleaf forest situation from rain forest to cloud forest and from densely forested reglons to semi-open situations and second growth. It also occurs in arid climates in monsoon forest and in vega forest along the rivers. It ranges altitudinally in Honduras from sea level to at least 6,500 feet, but it is common only in humid situations below 3,500 feet; it was fairly common, however, in patches of cloud forest in the La Esperanza region at about 6,000 feet in October 1962. Hellmayr (1902: 50-51) 11sted male and one unsexed adult from San Pedro (taken by G. M. Whitely) that were deposited in the Berlepsch Collection; I have not seen these specimens. 
Breeding data for Honduras are given by Skutch (1945a: 23; 1960: 70).

The lumping of this species with the very different $\underline{T}$. pudipenis Lafresnaye of South America, as was done by Paynter (1955: 227-228), seems to be unwarranted, See also my comments under I. assimil118.

I tentatively assign all Honduran specimens to $\mathrm{T} \cdot \mathrm{g}$. gray1 Bonaparte, a race ranging from Mexico to Nicaragua. I cannot distinguish the race $I \cdot g \cdot$ umbrinus Griscom, from the Pacific coast of Guatemala, as individuals of this dark type appear at random in the Honduran collections; it may eventually prove to be valid with the Honduran birds being vagrant individuals, since none have been taken at the height of the breeding season. Size does not seem to vary geographically, although once again mixing of the races may obscure the true situation. On the basis of specimens examined I cannot recognize I. g. megas Miller and Griscom for Nicaraguan populations. The Honduran specimens from the Olancho rain forest (Arenal, Segovia River) are very slightly grayer and show an approach in this respect to the Costa Rican race, I. g. casius (Bonaparte).

\section{Turdus plebejus Cabanis}

Mountain Robin

SPECTYENS.--T. p. differens (85): Porti110 Grande, 18 Feb. (7, CNHM); E1 Chorro 17 June-9 July ( $30^{\circ}, 69, ?$, ML); Montaña E1 Chorro, 5 June-18 July (9\%, $q, ?, \mathrm{Miz}) ;$ Sillón, 22 June-10 July (40,3? MLZ); Montaña Ei silión, 22 June-31 July (40, 3\%, ?, MLZ); Montafia La Cruz, 25 
June-7 July ( $\sigma^{\prime}, 39, ?$, MLZ); Monte El Candado, 30 May (o", MLZ); Plan del Rancho, 16-30 June ( $\delta^{\circ}, q$, MLZ); Monte

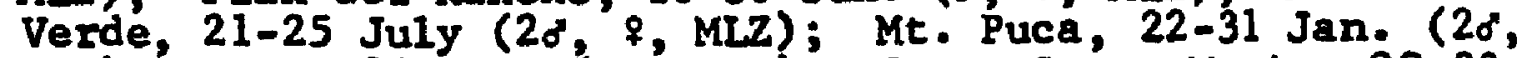
MCZ); Muye, 25 Feb. (d, AMNH); Cerro Santa Maria, 29-30 Dec. (?, MLZ; 29, MCZ); Cantora1, 25-29 Feb., 1-4 April (o, 3\%, AMnt; o, ₹, MCZ); Cerro Cantoral, 22 Feb., 26 Nov. ( $\left.{ }^{\circ},{ }^{\circ}, \mathrm{MCZ}\right)$; A1to Cantoral, 7 Feb. ( $\left.{ }^{\circ}, M C Z\right)$; San Juancito,

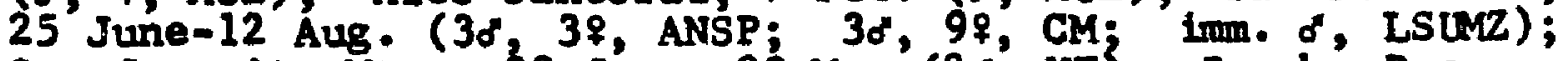
San Juancito Mts +, 29 Jan., 20 May (20, UF); Rancho Quemado, 19 March ( $q, M C Z)$.

PUBLISHED RECORD.--San Juancito (Stone, 1932: 330). Th1s robin inhabits cloud forests in the interior of Honduras above 4,500 feet; it is a locally common species, being most frequent at elevations from 5,500 to 7,000 feet. It is primarily a resident of the interior of the forest but ranges into semi-open situations on occasion.

I can see no reason for lumping I. plebejus with the distinct South American species I. Imnobilis Sclater. The differences are of a much greater magnitude than those present between members of many other known pairs of good species in this genus.

Honduran specimens are representative of the northern race, I. $p \cdot$ differens (Nelson). The supposed Nicaraguan subspecies, I. R. rafaelensis Miller and Griscom, is not valid (Hellmayr, 1934: 391).

\section{Turdus infuscatus (Lafresnaye)}

\section{Black Robin}

SPECTMFNS.--(47): Monte Los Cedros, 4 June ( 9, MLZ); El Chorro, 2 June-9 July (9o, 49 , MLZ); Montafia E1 Chorro, 20 June-1 July (28, 29, ML2); El Silión, 22 June, $10 \mathrm{July}$ (40, ₹, MLZ); Montaña E1 silión, "31" June-3 July (30, \&, 
MLZ); Montaña La Cruz, 25 June-7 July (2\%, 3\%, MLZ); Plan del Rancho, 30 June (?, MLZ); Monte Verde, 21 July (20, MLZ); Mt. 'Puca, 25 Jan. (o, MCZ); Cantoral, 10 Feb. ( $\sigma^{\circ}$, MC2); Alto Cantoral, 2-11 Feb., 11 Apri1 ( $30^{\circ}, \%$, MCZ); San Juancito, $13 \mathrm{July}$ ( $\sigma$, ANSP); Ei Derrumbo, 25 July ( $\%, M C Z)$; Mt. Uyuca, 4-11 Jume ( $\left.\alpha^{\circ}, 29^{\circ}, \mathrm{MCZ}\right)$; Monserrat, 28 May ( $\sigma^{\circ}$, MCZ).

PUBLTSHED RECORD.--San Juanc1to (Stone, 1932: 330 ).

A resident of cloud forest, the Black Robin reaches its southern limit of distribution in Honduras and 18 unknown there below 6,000 feet. Although it occurs comonly in the Department of Ocotepeque in extreme western Honduras, it is uncommon elsewhere in the republic.

I falled to encounter the species in 1962-1964, although J. Alan Feduccia observed it on $17 \mathrm{July} 1963$ in cloud forest at 6,300 feet about $14 \mathrm{miles}$ northeast of La Esperanza. In the cloud forests of this region, the species is found sympatrically with I. grayi and $T$. plebefus at approximately 6,000 feet.

\section{Mlmoctchla plumbea (Limnaeus)}

Red-legged Thrush

SPFC MMFNS.-M. p. rubrtpes (10): Swan Is lands, 4 Feb.4 Apri1, 25 May ( $\delta, \operatorname{MCZ} ; 7 \%, 2$, USM $)$.

PUBLTSHED RECORD,-Swan Islands (RIdgway, 1888c: 575; 1905: 213; Lowe, 1909: 335; Paynter, 1956: 108).

The mystery surrounding the occurrence of this species In the Swan Islands has never been satisfactorlly solved. In $1887 \mathrm{C}$. H. Towns and (RIdgway, 1888c: 575) obtained the series 118 ted above; the species must have been very common there at the time of Townsend's visit. It has not been 
recorded in the Swan Islands 8 ince that time, despite careful search by a number of visiting ornithologists. The reason for its disappearance is not known, but Paynter (1956: 106, 108) suggested that the disturbance of the forest there may have been the cause. Although the presence of this thrush in the Swan Islands in the first place was probably due to wind-blown vagrants from the northeast (Cuba or the Isle of Pines), it almost certainly bred on the 18 land for a period of time; that the great number of individuals present during Townsend's visit could have resulted solely from nonbreeding vagrants is unlikely.

I follow Hellmayr (1934: 448) and Bond (1950a: 118) in considering the form rubripes to be conspecific with $\underline{M}$. plumber.

The Swan Islands population was described as M. $\mathrm{L}$. eremita [Mimocichla rubripes eremita Ridgway, 1905: "113" (= 213); Swan Island, Caribbean Sea], based on average larger size, on shorter toes, and on the usually more extensive white of the chin and malar region. Comparison of the series from the Swan Islands with examples of M. . rubripes (Teminck) from Cuba does not show any of these differences; I therefore regard eremita as a synonym of mubripes.

Myadestes obscurus Lafresnaye Brown-backed Solitaire

SPRCTMENS.--K. o. oberholsert (34): Monte Los Cedros, 4 June (o, MLL); Montait B1 Chorro, 5-22 June (2d, MLZ); Montaña Ei Silión, 3 July (d, MLZ); Plan del Rancho, 3-8 
July ( $0^{\circ}$, tmm. $₹$, MLZ); Las Ventanas, 24 July ( $\$$, MLZ); Lake Yojoa, 21 July (o, CM); $4 \mathrm{ml}$. SE La Esperanza, 22 Jan. (7, LSLMZ); MuÍn, 14 Jan. (o, AMaNH); Soluteca, 5-8 April (o, ₹, AMNH); El Guayabal, 13 Dec. 9-29 Jan. (20, AMNH; o. MCZ); La Honda, 11 Jan. ( $\sigma$, MCZ); La Florida, 11 Dec.25 Jan.' (50, 89, ?', AMNH; 36", \%, MCZ). 1955a: 81).

PUBL, SHEP RECORD.--"Honduras" [in range] (Eisenmann,

Reaching its southernmost limit of distribution in Honduras, the Brown-backed Solitaire is a fairly common resident in the highlands of the western part of the republic, ranging as far east as the Comayagua Valley. This spectes Inhabits both cloud forest and pine-oak associations but is more common in the latter, being replaced under more humld conditions by $M$. untcolor. The Brown-backed Solitaire occurs from 2,000 to at least 6,500 feet.

The inclusion of Honduras in the range of the spectes by Eisenmann (1955a: 81) was based on the large series in the American Museum of Natural History.

I tentatively include all Honduran specimens in the smaller, southern race, M. Q. oberholseri Dickey and van Rossem, although the size differences stated by Dickey and van Rossem (1925: 133-134) and by Griscom (1932b: 303) are by no means as distinctive as those authors indicated. Wings of Honduran specimens measure: o, 97.5-105.9 (100.9); ?, 96.1-101.0 (98.6). Although southern populations average consistently smaller than northern ones, at least one Honduran male (wing, 105.9) 18 larger than any specimen examined from the more northern populations. 
Myadestes unicolor Sclater

Slate-colored Solitaire

SPECTMENS. - M. u. untcolor $\times$ pallens (24): E1 Chorro,

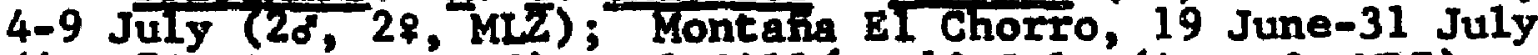
(40, 79, imm. o, MLZ); E1 S111ón, $10 \mathrm{July} \mathrm{(tmm.} \mathrm{\% ,} \mathrm{MLZ);}$ Montaña E1 S111ón, 2 July ( $\sigma^{8}, 8$, imm. of, MUz); Montafia La Cruz, 25 June ( 8, MLZ); Monte verde, 20-23 July (2o, Iman. d, MLZ). M. u.. pallens (126): San Pedro Sula, Feb., 29 March ( $d, C M$; $q$, CNIFI); San Pedro Montaha, 31 Jan. ( $\%$, CM); Santa Ana, 24 Oct. ( $\delta$, USNM); Las Peñ̉tas, 4-25 Feb. (150" 38, ?, MCZ); Portillo Grande, 18 Jan.-11 Feb., 15 April-1 June (20, 7, CNMM; 78, \%, MCZ); San Esteban, 1 July ( 8, CM); 5 mi. S San Esteban, 18 Jan. ( $q$, LSUMZ); Mt. Puca, 6 Jan.-8 Feb. (5o", 9, MCZ); Cerro Santa Bárbara, east 8 lope, 28 Nov. -7 Dec. (2\%, inm. 8 , LSuMz); Cerro Santa Bárbara, southeast slope, $25^{\prime} \mathrm{July}$ ( $\sigma^{\prime \prime}$, LSUMz); Lake Yojoa, 2021 July (20, CM); San Marcos de Gualmaca, 30 June (juv. o", AMNH); Alto Gualmaca, 11-13 June ( 0 , juv. AMNH); Cerro Santa Marla, 30 Dec. ( $?$, MLZ); Cantoral, 22 Jan.-29 Feb. (11ه, 6\%, AMNH; 20, MLz; $d, q$, USNM); Cerro Cantoral, 24 Feb. ( $q$, lamz); Alto Cantora 1,21 Jan. -11 Feb. (110, 5\%, ?, AMAH; $\delta, 2$ ?, MLZ); Archaga, 5 Aug; (juv. $f$, AMNH); La Cueva Archaga, 5 Aug. (Juv. 9, AMNH); San Juancito, 2 Feb.,

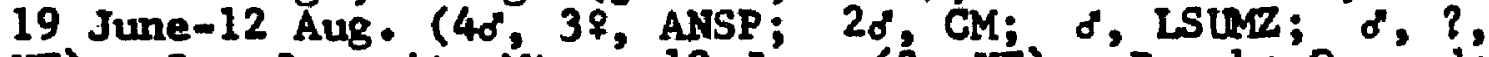
UF); San Juanctto Mts.; 19 June (?, UF); Rancho Quemado, 20 March, 20 May (2\%, MĆ); BI Derrumbo; 9 July-9 Aug. (20, 7, AMONH; of, Imm. o, MLZ; 40", 29, $1 \mathrm{~mm}$. \%, MCZ); Teguc1galpa, April (o, BMNH); Monserrat, 31 March (f, UF); Monserrat Mt., 31 March ( $\$$, UF).

PUBLISHED RECORDS.--Santa Ana (RIdgway, 1907: 170). Mountains west of San Pedro [as yeraepacis] (Hellmayr, 1934: 444). San Juancito [as paltens] (Stone, 1932: 331).

A common resident of cloud forests of Honduras, this solitaire occurs most abundantly from 3,000 to 7,000 feet. It ranges down into the upper reaches of rain forest to an elevation of 1,500 feet but is decidedly uncommon below 3,000 feet. The song is one of the common sounds associated with the cloud forest and is most pleasing to the ear, perhaps rivaling in beauty that of any other song bird. 
Three races are usually recognized in this species, M. u.. unicolor Sclater in southern Mexico, … u. veraepacis Griscom in Guatemala and northern Honduras, and ㅆ. u. pallens Mtller and Griscom in Nicaragua. These races have been separated on the basis of vartation in the gray coloration and in size. A series of specimens from localities throughout the range of the species displays no constant geographic variation in relation to body color, as far as I can detect. But size definitely decreases from north to south. The populations of Honduras (except the extreme western portion) and Nicaragua are consistently smaller (wing: o, 91.7-101.1, mean 96.6; 9, 92.8-98.5, mean 95.1) than populations from Guatemala northward. The series of Honduran specimens from the Department of Ocotepeque is intermediate (wing: o, 93.9-104.1, mean 98.6; $7,91.1$ 101.1, mean 96.4) between the Guatemalan populations and those from Nicaragua and the renainder of Honduras. On the basis of variation in 8 ize, I am able to recognize two races, M. u. unicolor (including yeraepacts) and pallens.

\section{Hylocichla mustelina (Gmelin)}

Wood Thrush

SPECTMENS.-- (25): La Celba, 5-22 Jan. (d, 29, MCZ); Yaruca, 12-22 Feb. ( $2 \sigma^{\circ}, 9$, MCZ; $\delta$, USN); Las Pefittas, 4-

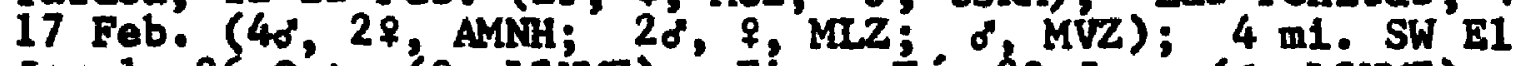
Jaral, 26 Oct. (f, Lsiug); Finca Fé, 20 Jan. (8, LSUMz); E1 Boquerón, 13 oct. (20, AMMH); Arenal, 15-16 Jan. (28, UCLA); "Honduras" (2?, BMAT). 
PUBLTSHED RECORDS.--Omoa (Moore, 1859: 55). "Honduras "Seebohm, 1881: 197). La Ceiba Yaruca (Bangs, 1903: 152). Tela-Yoro road (Peters, 1929b: 460). Bonacca [= Guanaja] Island (Bond, 1936: 354).

The Wood Thrush is a fairly comon winter visitant to the Caribbean lowlands of Honduras, ranging up to 2,500 feet elevation. It occurs in rain forest and in second growth. It very 1ikely migrates uncommonly through the Pacific lowlands though not yet found on this slope. There is one record from Guanaja Island, in the Bay Islands; it probably Is at least a regular transient in the islands off the north coast. For Honduras extreme dates of arrival and departure are 13 October and 3 April.

\section{Catharus ustulatus (Nuttall)}

\section{Swains on's Thrush}

SPFCTMENS. --C. ụ. ustulatus (22): Las Peñitas, 5-15 Feb. (d,?, Kizz); PôrtilloGrande, $5 \mathrm{Feb}$ ( $(q, \mathrm{MCZ})$; $5 \mathrm{mi}$. S San Esteban, 15 Jan. (7, IS UMZ); Muín, 14 Jan. (8, AMNH); La Flortda, 26 Dec. (2 $\sigma^{\circ}$ AMNH); Monte Redondo, 29 Nov. -14 Dec. ( 8, AMNH; 2o, $\$, 2 ?$, MCZ); La Flor Archaga, 18 Jan. (9. AMNH); Comayagüela, 9 Oct. -10 Nov. (9, AMNH; 20, 39 , MCZ); San Franc18co, Choluteca, 11 Oct. (d, ima; of isUMZ). C. uㅡ: swainsoni (22): Swan Islands, 19 April, 22 Oct. (d, MCZ; J USNM); San Alejo, 3 April ( 9 , ISUMZ); La Celba, 24 April-3 May ( $\alpha^{\prime}, 7$, CM); Catacombas, 2-8 April (o", ?, MLZ); Portillo Grande, lo Feb. (o', CNLM); Cerro Santa Bárbara, east 8 lope, 28 Nov. (o'skel., ISUKZ); 2 mi. SE E1 Jaral, 20 April ( $\sigma^{\circ}$ LSUMZ); Finca Fé, 20 Feb. ( ${ }^{\circ}$, LSUMZ); Soluteca, 5-6 April (5 , AMMH); Cantoral, 10 April ( $\sigma^{\prime}$, AMNH); Cerro Cantoral, 8 April ( $\sigma^{\prime,}$ MCZ); Comayagüela, 11 12 Oct. (30, MCZ); Arena 1 , 15 Jan. ( $\%$, UCLA).

PUBLISHEP RECORDS.--Swan Islands [as swainsoni] (Fisher and Wetmore, 1931: 16; Paynter, 1956: 106).

This thrush is a fairly common migrant and winter visitant in Honduras, occurring in migration also in the 
Swan Islands and the Bay Islands. It may be found in any type of broadleaf forest, including pine-oak associations, but is most frequent in open rain or cloud forest. Altitudinally it ranges up to at least 6,500 feet.

The removal of this and the following two species from the genus Hylocichla and their inclusion in Catharus is based on the studies of Dilger (1956a, 1956b).

The race of eastern North America, C. $\underline{u} \cdot \underline{\text { swainsoni }}$ (Tschudi), is the most common form in the Caribbean lowlands, and it has been found in the interior to an elevation of about 5,000 feet. In the interlor highlands, swainsont is replaced for the most part by the western race, $\underline{c}$. $\underline{u}$. ustulatus (Nutta11), the latter distinguished by its more rufescent coloration above. This race has not been taken below 2,000 feet In Honduras. I agree with Miller, Friedmann, Griscom, and Moore (1957: 190-191) that the races C. u. almae (Oberholser), C. u. clerescens [Hylocichla ustulata clarescens Burleigh and Peters, 1948: 118; Glenwood, Newfoundland], and C. u. Incanus [Hylocichla ustulata incana Godfrey, 1951: 173; Lapie River, Canol Road mile 132, Yukon Territory] are too weakly differentiated to recognize taxonomically and consider them to be symonyms of $G$. $\underline{u}$. swainsoni. 


\section{Catharus minimus (Lafresnaye)}

Gray-cheeked Thrush

SPECTMENS.--C. m. minimus (6): Swan Islands, 19 April ( 9 MCZ); Roatán Is Iand (2?, BMNH); La Celba, 5 May ( $\$$, CM); E1 Picacho, 23-24 oct.' (28, AMNH).

PUBLISHED RECORPS.--Roatán Island (Salvin, 1888: 243). Swan Islands (Paynter, 1956: 106).

The Gray-cheeked Thrush is a rare migrant in Honduras. George F. Gaumer (Salvin, 1888: 243) secured two specimens on Roatán Island, probably in September of 1886 or 1887. George Nelson (Paynter, 1956: 106) obtained a female in the Swan Islands in 1913. C. F. Underwood collected two males at E1 Picacho in 1935, at an elevation of approximately 5,000 feet. Arthur C. Twomey and Roland W. Hawkins obtained another female at La Celba in 1948. Nothing further is known concerning the species in Honduras.

The Honduran spectmens are referable to the nominate race, C. m. mintmus (Lafresnaye).

\section{Catharus fuscescens (Stephens)}

Veery

\section{Island (Salvin, 1888: 243). \\ PUBLISHFD RECORDS.--Roatán Island, Bonacca [= Guanaja]}

The records 1 isted above are based on specimens taken in the Bay Islands by George F. Gaumer, the Guanaja individuals presumably in September 1887 (Salvin, 1888: 243). These specimens were deposited in the British Museum but I have not examined them. The spectes is probably a regular, 
though rare, migrant through the islands off the north coast of Honduras. There are no other Honduran reports.

The records 118 ted above are generally assigned to the

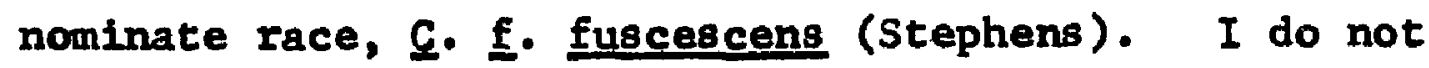
recognize the recently named race, C. E. subpallidus [Hylocichla fuscescens 8ubpallida Burleigh, 1959b: 33; Moscow, Latah County, Idaho].

Catharus dryas (Gould)

Spotted Nightingale Thrush

SPEC IMENS--C. d: dryas (11): Port11lo Grande, 9 May (o", MCZ) Mt. Puca, 1-4 Feb; (20, MCZ); Cantoral, 15-20 Feb., 8-19 April (4o, \&, MCZ); Alto Cantora1, 4 Feb., 25 June, Oct. (30", MCZ). 461).

PUBLISHED RECORD.--Volcán de Puca (Hellmayr, 1934:

This rarest of the nightingale thrushes in Honduras is confined to cloud forest and does not range below 5,500 feet elevation. It is decidedly uncoumon to rare in the republic.

He11mayr (1934: 461) examined a specimen taken by Erich Wittkügel on Volcain de Puca and apparently deposited in the Brunswick Museum. There are no other resords for Honduras except the specimens listed above.

In Iife the under parts of this species are bright orange or orange-yellow. This plgment fades rapidly in preserved specimens and, if exposed to light for any length of time, disappears completely, leaving the under parts white. 
Honduran material is representative of the nominate race, c. d. dryas (Gould).

\section{Catharus mexicanus (Bonaparte)}

Black-headed Nightingale Thrush

SPECTMENS. - -C. m. cantator $\times$ fumosus (41): Catacombas, 10 March, 5 Apri1 (o", ?, MCZ); Las Peñitas, 2-27 Feb. (108", $69,2 ?, M C Z)$; San Esteban, 25 June ( $\left.\sigma^{\circ}, C M\right) ; 5 \mathrm{mi}$. S San Esteban, 15 Jan. ( $0^{\prime}$, LSUMZ); Merendon Copán, 12-19 June (3o", AMNH); Mt. Puca, 14 Jan., 8-10 Feb. (6o, MCZ); Alto Nieve, 4 May ( ${ }^{\circ}$, AMNH); San José de Santa Bárbara, 8 April ( $\delta$, ANSP; đ", MCZ); Cerro Santa Bárbara, east slope, 21 April ( $0^{\circ}$, LSIMZ); Lake Yojoa, $25 \mathrm{July}\left(2 \sigma^{\circ}, C M\right)$; San Marcos de Guatmaca, 21-30 June (d, \%, ?, MLZ; $\delta, ~ M C Z)$.

PUBLISHFD RECORD.--San Pedro Mountains [as cantator] (Hellmayr, 1934: 463).

Occurring in Honduras from 2,500 to about 6,000 feet, the Black-headed Nightingale Thrush is a fairly common resident of cloud forests.

Hellmayr (1934: 463) examined a specimen taken by Erich Wittkügel in the San Pedro Mountains and presumably deposited in the Brunswick Museum.

Geographic variation in Central America in this species is clinal in most characters. Examples from Chiapas, currently assigned to the race $C$. $m$. cantstor Griscom, and from Costa Rica, representing the race C. m. fumosus RIdgway, are distinct. Southern populations are silghtly smaller, browner above, and much grayer (1ess olive) on the breast and flanks; In addition, the white area of the abdomen is more reduced by the greater extent of dark coloration on the flanks. Honduran birds must be regarded as intermediate, 
as they average slightly browner than Chiapan examples but not nearly as brown as fresh Costa Rican material. In coloration of the breast and extent of white on the abdomen, they are decidedly nearer the Costa Rican form. Over-all, they are best regarded as intermediates.

\section{Catharus frantzii Cabanis}

Ruddy-capped Nightingale Thrush

SPECTMENS.-C. f. alticola (70): E1 Chorro, 9 July (o', MLZ); Montaña El Chorro, 22 Jume-3 July (28, $38^{2}, ?$, ML2); E1 Sillón, 10 July (2 $\left.\delta^{\circ}, \mathrm{MLZ}\right)$; Montaña La Cruz, 3 July ( $\sigma^{\circ}$, MLZ); Monte Verde, 19-25 July (50, ${ }^{\circ}, ?$, MLZ); Mt. Puca, 25 Jan.-11 Feb. (20, MCZ); Muye, $28 \mathrm{Feb}^{\circ}$ ( ( $\sigma^{\circ}$, AMNH); Cantoral, 6-29 Feb., 1-16 April, 5 Dec. (50, 69, AMNH; \&, MLZ; ₹. MCZ; $\$$, USNM); Cerro Cantora1, 4 March, 6-7 Aug. (20", ?: MCZ); Monte Redondo, 11 Dec. ( $\sigma^{\prime}$, USNM); San Juancito, 2 Féb., 25 June-4 Aug. ( $30^{\circ}, 28, ?$, Juv., ANSP; 50" 48, Juv: $\circ$, CM; J, LSLuZ); San Juancito Mta., 29 Jan, 29 June (20", 7. UF); Rancho Quemado, $15-19$ March, 20 Mey (40, 8 , MCZ); El Derrumbo, 16 July-9 Aug. ( $\left.30^{\circ}, 28, \mathrm{MCZ}\right)$; Portillo de LOS Arados, 14 July (o', UF).

PUBLISHED RRCORP.--San Juancito [as juancitonis] (stone, 1931: 2-3; 1932: 331).

This nightingale thrush is a fairly common to common resident of cloud fores ts in Honduras. It has not been recorded below an elevation of 6,000 feet in the republic.

Although this species is sometimes regarded as a race of the Russet Nightingale Thrush, G. occidentalis Sclater, Griscom (1937b: 198) and Phillips (1962a: 362-364) gave evidence for the specific status of $\mathrm{C}$. frantzil; and, more recently, the two species have been found breeding sympatrically in Oaxaca (Rowley and Orr, 1964: 308-314). In 
addition to slight morphological distinctions, the two spectes differ in song, ethology, and egg color.

I cannot detect any geographic variation in the populations of this species from Chiapas to Honduras, when due regard is allowed for post-mortem change. I regard the

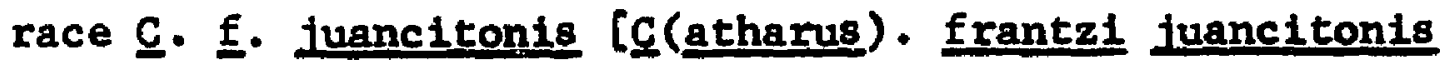
Stone, 1931: 2; San Juancito, Honduras, $6500 \mathrm{ft.]}$ as a

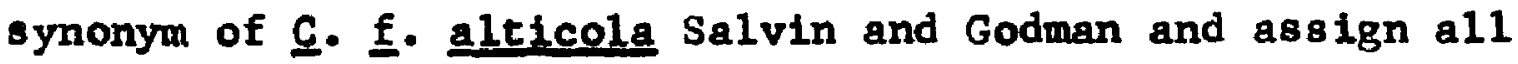
Honduran specimens to the latter.

\section{Catharus aurantilirostris (Hartlaub)}

Orange-billed Nightingale Thrush

SPECTMENS.--C. a. melpomene (31): E1 Chorro, 9 July (১, MLZ); Montaña EI Chorro, 22 June (20, MLZ); E1 Silión, 10 July ( 8, MLZ); Plan del Rancho, 1 June-8 July (8\%, \&, ML2); $4 \mathrm{mi}$. SE La Esperanza, 22 Jan. (f, LSUMZ); Gülse, 16 July (o", LSUMZ); Soluteca, 6 April (?, AMNH); Muye, 21 Feb. (7, AMNH); Cantora1, 25 Jan. (d, USNM); La Flor Archaga, 30 May ( $\left.\sigma^{\circ}, \mathrm{MCZ}\right)$; San Juancito, 10-17 July, 8 Aug. ( $\sigma^{\circ}$ juv, ANSP; $q$, CM) ; E1 Hat1110, 19 Apri1-8 MaY ( ${ }^{\circ}, \xi$, MCZ); Tegucigalpa, 14-22 April (20, AMNH; 9 , BMNH); Mt. Uyuca, $26 \mathrm{May}$ ( $\$$ UF); Yeguare River Valiey, 17 March, 16 May $\left(20^{\circ}\right.$, UF); $13 \mathrm{mi}$. SW San Marcos de Colón, 3 Oct. (ím., LSLMZ).

\section{PUBLISHED RECORPS.--San Juancito [as worth1] (Stone,} 1931: 2 ; Stone, 1932: 330-331). Rancho Quemado (Zimmer, 1944a: 407-408)?

The Orange-billed Nightingale Thrush is an uncommon resident in the interior highlands of Honduras, ranging from 2,000 to at least 6,000 feet. A species of the forest undergrowth, it occurs in pine-oak associations and in open cloud forest. 
Although there have been no less than five races described in this species for populations from Oaxaca to costa Rica, I can see no constant geographic variation in this region except for a north-south clinal trend toward a greater extent of gray (and thus greater restriction of white) on the posterior under parts. The differences in this character are slight and are subject to some individual variation. I therefore consider these populations to represent a single race, $\underline{G}$. a. melponene (Cabanis), and regard $\underline{C}$. a. costarlcensis Hellmayr, C. a. bangs 1 Dickey and van Rossem, C. aalbidior Miller and Griscom, and C. a. worthi [Catharus me1pomene worth1 Stone, 1931: 2; San Juancito, Honduras, 5100 feet] as synonyms of melpomene.

\section{Sia1ia sialis (Linnaeus)}

Eastern Bluebird

SPECIMIFS. --S. s. mertidionalis (65): Catacombas, 28 March (28, BVINH); sübirana, 9 Dec. -28 Jan. (5d, 9, MCZ); Portillo Grande, 24 July ( $q$, 8 ?, MCZ); Montafia E1 Chorro, 30 May-17 June (?, Juv. o", Juv., Maz); Plan del Rancho, 2 June ( , MLZ); Mt. Puca, 12-13 Jan. (8, AMaNH; 2, MCZ); Sigua tepeque, 9 July ( $\sigma, f$, CY); $10 \mathrm{mi}$. S Comayagua, 20 June $\left(\delta^{\circ}, \mathrm{CM}\right) ; 2 \mathrm{ml}$. W Mazaguara, 31 Oct. ( ${ }^{\circ}$, LSLMz); La Esperanza, 23 Jan. (7, LSUMZ); Montafia Vásquez, 19 Nov. ( AMNH); Cantoral, 9 March, 4 Aug - ( $\delta$, Juv. $\delta$, AMnt); Cerro Cantoral, 22-29 March, 9-26 Dec. (28, 39, MCZ); Alto Cantoral, 6 Jan. (7, MLZ); La Laguna Archaga, 20 Jan. (30", MLZ); La Flor Archaga, 13 June (d', MCZ); Monte Redondo, 21 Oct., 13 Nov, -8 Dec. ( 9 , AMNH; $2{ }^{\circ}, 29, ?, M C Z$ ); San Juancito, 17-23 July (20, Juv., ANSP); Rancho Quemado, 13 March-5 April (50, MCZ; ${ }^{\circ}$; , USNM); E1 Derrumbo, 24 July (Juv. \&, MCZ); E1 Picacho, 11 July, 1 oct. ( 9 , Juv. of, AMNH); E1 Hatilio, 3 May, 29 June, 1-11 Aug. (?, AMNH; $\delta, 8$ 1m. $\delta$, CM); Tigre Hatillo, 9 July (Juv., AMNH); Uyuca, 10 Nov. ( $(?$, UF); Yeguare River Valley, 14 Oct. ( $\$$, UF); Lavanderos, 31 March ( $\sigma^{*}$ UF); rosd to Güinope, 4 Aug. (?, UF); Morecelf, 26 March ( $q$, UF); San Francisco, Choluteca, 12 
Feb. (o, 7, LSUMZ). S. 8. 8ubsp. nov. (7): San Esteban, 25-28 Jume (4o, 2\%, CM); Segovia River, 25 July (Juv. $d$, USNM).

PUBLISHED RECORDS.--Between Opoteca and SIguatepeque (Taylor, 1860: 15,110 ) : Segovia River (Ridgway, 1888c: 584). "Siguatepeque" [= between Opoteca and Siguatepeque] (R1dgway, $1907: 147)$. San Juancito, San Juancito Mountains (Stone, 1932: 331).

The Eastern Bluebird is a falrly common resident in Honduras in pine and pine-oak associations. The species ranges from 2,000 to 6,000 feet in most of the interior of the republic but occurs as $10 \%$ as 1,000 feet in the San Esteban region and at 8 ea level in the pine savanna of the Mosquitia.

A11 the specimens from the interior highlands above 2,000 feet I assign to the race S. B. merldionalis Dickey and van Rossem [1930b: 69; Los Esesmiles, Chalatenango, E1 Salvador . - altitude 8000 feet] on the bas is of $81 z e$. Wings of Honduran specimens assigned to meridionalis (except those from Montafia E1 Chorro and Plan del Rancho in the Department of Ocotepeque) measure as follows: $\delta, 95.5-102.5$ $(100.1) ; 9,91.9-99.7(97.5)$. The four Ocotepeque spec1mens are 8 ilghtly larger and show some approach to the Guatemalan subspecies, S. 8. guatemalae Ridgway; the two females measure 105.4 and 94.8 , the juvenal male measures 103.3, and the unsexed fuvenal measures 100.5 . T. R. Howell (personal communication) has obtained a large series of the species from the lowland pine savanna of the Nicaraguan Mosquitia; from the Honduran Mosquitia only the 
single juvenal male from the Rio Segovia is known. The Nicaraguan series measures decidediy smaller than even merldionalis (wing: o, mean 96.0; $\%$, mean 93.8) and represents an undescribed race (Howell is presently in the process of describing it as new). He also informed me that the series from San Esteban, which I have not examined, consists of bluebirds that also measure small in size and will have to be assigned to the new race.

\section{Family SYLVIIDAE}

\section{Polioptila caerulea (Linnaeus)}

Blue-gray Gnatcatcher

SPEC IMENS. --P. c. caerulea (5): Portillo Grande, 3 Oct. (f, MCZ); Finca Fe, 16 Jan. ( $\%$, LSUM); $16 \mathrm{mi}$. NW Valle Bonito, 2 Nov. (o, Lsu(z); Cerro Cantoral, 9 Dec. (?, MCZ); San Francisco, Choluteca, 12 Feb. (q, LS Laz). PUBL.ISHED RECORD.--Roatán Island (Salvin, 1888: 245).

Although there has been a Honduran record in the 1iterature for more than 75 years, Polloptila caerulea is regarded as wintering south only as far as Guatemala by most current authors. The specles is an uncommon but regular winter visitant in much of Honduras, ranging up to an elevation of 5,500 feet; it has not been recorded on the Pacific slope below 3,000 feet. It may be found in most any type of open forest or second growth, including pine, pine-oak, cloud forest, and rain forest. 
George F. Gaumer (Salvin, 1888: 245) collected the species on Roatán Island, in the Bay Islands, presumably in September of 1886 or 1887 , but I was unable to locate the specimen in the British Museum in 1961. This record was reported as "Polioptila caesiogaster ?"--a name now considered to be a synonym of $\underline{P}$. caerulea. C. F. Underwood obtained an individual at Cerro Cantoral in 1931. Raymond Stadelman secured a male at Portillo Grande in 1934. V. C. Dunlap reported the species from La Lima from 1950 to 1952; all his observations were in the months of November, December, and January. Mark Trafton, Jr., noted it at La Lima, Los Dragos, and Lancetilla annually from 1951 through 1960; his observations were made from 28 September into January. On 8 January 1954 he collected an adult male for identification purposes, but the specimen was not preserved; the wing of this individual measured 46 .

From 2 November 1962 to 5 April 1963, I observed the species on several occasions at San Pedro Sula, at Copán, near Lake Yojoa, near Valle Bonito, and in the Department of Choluteca at San Francisco; three specimens were taken during this period.

A11 Honduran specimens examined are representative of the subspecies of the eastern United States, $\underline{\text {. }}$ c. caenulea (Linnaeus). 
Polloptila albiloris Sclater and Salvin

White-lored Gnatcatcher

SPEC MENS.--p. a. albiloris (55): Coyoles, 23 Apri1,

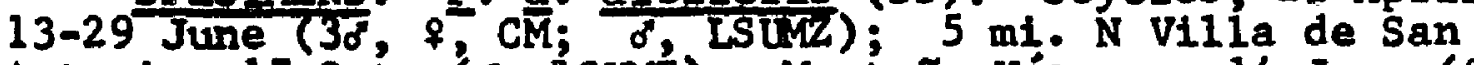

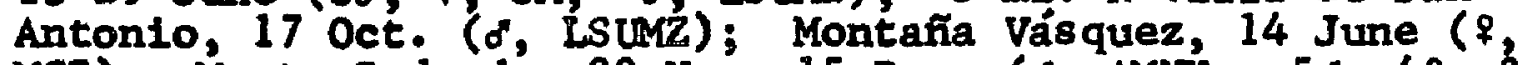
MCZ); Monte Redondo, 22 Nov. -15 Dec. ( $0^{\circ}$, AMNH; 50, 4\%, ?, MCZ); La Fior Archaga, 20 Jan.-15 Feb., 27 May-15 June ( $28^{\circ}$, 29, AMNH; 30, \%, MCZ; $0^{\circ}$, USMM); Cantarranas, 7 Aug. (2。, 2\%, ANSP); Ei Hatil10, 2-26 May (20, $\$$, MCZ); Comayagüela, 3 Feb., 10-11 June, 25 Oct., 4 Nov. (2o, 9 , AMNH; $20^{\circ}$, MCZ; $\checkmark$, USNM); Río Hondo, 18 Aug. ( $\$, C M) ; 2$ mi. NW La Ceiba, Francisco Morazán, 26 May ( 9 ? UF); Yeguare River Valley, 27 Jan., 12 June, 8 Sep. ( $8,28, ?$ UF); E1 Paralso, 20 Apri1 ( ${ }^{\prime}$, manif); San Lorenzo, 24-29 Sep. (38, MCZ); Puerto Salamar, 31 Jan., 26 Sep. (28", LSUMz); $2 \mathrm{mi}$. NW Cedeño, 11 Feb. ( $\sigma^{\prime}$, LSUMZ); $8 \mathrm{ml}$. SE Namas igüe, 8 oct. (ske1., LSUMZ); San Francisco, Choluteca, 11 Oct. (imm. $\delta$, LStMZ).

\section{PUBLISHED RECORDS.--Cantarranas [as R. bl1ineata]} (Stone, 1932: 331). Monte Redondo, Comsyaguela, La Flor Archaga, San Lorenzo, E1 Hat 1110 Montaña vas quez, Cerro Cantoral (Brodkorb, 1944b: 314-315).

This gnatcatcher is a fairly comon to common resident In arid scrub and open monsoon forest on the Pacific slope of Honduras and ranges into the interior in arid situations to an elevation of 6,000 feet. It is also found in the arid interior valleys (Comayagua and Aguán, probably also Otoro) on the Caribbean slope.

I follow Brodkorb (1944b: 311-316) and Zimmer (1942b: 1-3) in retaining albiloris as a species distinct from $\underline{P}$. plumbea. There is no evidence of any interbreeding in Honduras in areas where the habitats are adjacent, such as around Coyoles in the Aguán Valley.

Brodkorb (1944b: 311-316) recognized the Pacific lowlands race in Central America as distinct on the supposition 
that the wing plus tail measurement of the intertor birds was greater; he used the name P. A- bairdi Ridgway for the Pacific populations. I cannot see any significant measurable differences in any of the Central American material and therefore recognize only $\underline{\underline{P}}$. a. albilorts Sclater and Salvin in the region from Guatemala to Costa Rica.

\section{Polloptila plumbea (Gmelin)}

Tropical Gnatcatcher

SPECIMENS. - -P. D. superciliaris (8): Catacombas, 30 March ( $\delta, M C Z)$; Amapa, $18 \mathrm{Sep}$ (1man. ISUMZ); Coyoles, 14 June $(\delta, C M)$; San Esteban, 28 June $(28, C M) ;$ E1 Boquerón, 26 Aug. (?, AMNH); Arena 1, 17 Jan. (d, UCLA); Segovia River, 16 July ( $\%$, USM).

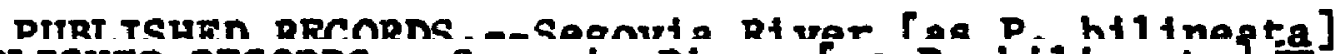
(RPUBLISHED RECORDS.--Segovia River [as $\underline{P}$. bilineata] $\frac{a}{6}$ ). way, 1888c: 585). E1 Boquerón (2imer, 1942b: 6). The Tropical Gnatcatcher is the humld lowland representative of the genus in Honduras, occurring in open rain forest, second growth, and cultivated lands on the Caribbean slope below 2,500 feet. It is uncommon in Honduras.

The species $1 \mathrm{~s}$ in need of revision. I tentatively assign Honduran specimens to the Middle American race, P. p. supercillarts Lawrence.

\section{Ramphocgenus melanurus Vieillot}

Long-billed Gnatwren

SPECTMENS.--R. m. mufiventris (32): San Alejo, 15-30 March, 6 Aug $\left(20^{\circ}, 2 \bar{q}\right.$, LSUḾ); Lancetilla, 25 March, 19 Aug., 3 Sep. ( $\$$, ANSP; $1 \mathrm{~mm}$. o ske1., LSUMZ; 7, MCZ); La Celba, 22 May, 2 Aug. (2\$, CM); Los Planes, 10 June, 14 July (20", CM); Trujilio, 31 March, 22-23 Sep. (d", CM; of, ?, USNM); Catacombas, 29 March-8 April (o, MiZ; o, MCZ); Cofradia, 10 March ( 8 , MLZ); Amapa, 26 Jan. ( $q$, Lsiuz); 
San José de Santa Bárbara, 24 April-5 May (", AMNH; o" \&, CNHM); Santa Bárbara, 13-29 May (2, 49, AMMr); Lake \%, ?, AMNH).

PUBLISHED RECORDS.--Trufillo (Ridgway, 1888c: 581). Near Lancetilla (Peters, 1929b: 460). Lancetilla (S tone, 1932: 332). Catacombas (Van Tyme and Trautman, 1941: 11).

occurring in Honduras up to an elevation of 3,000 feet, the Long-billed Gnatwren is a fairly common resident in rain forest and second growth on the Caribbean slope. The spectes is primarily a bird of the lower levels of dense forest.

I agree with Z1mmer (1931: 1-4) and Howell (1957: 99100) that the Middle American rufiventris group of races is conspecific with the South American B. melanurus.

Honduran specimens are typical of the widespread Middle American race, ㅅ․ m. rufiventris (Bonaparte). None shows any approach to the paler Yucatán race, ‥ 뜨. ardeleo [Ramphocaenus ruflventris ardeleo Van Tyne and Trautman, 1941: 9; Yucatán, Ch1chen Itzá].

\section{Family MOTACILLIDAE}

[Anthus spinoletta (Linnaeus)]
Water Pipit
PUBLISHED RECORD.--[Big] Swan Island (Bond, 1959: 9).
This species breeds in North America and in the Old World, wintering south at least to Guatemala and E1 Salvador. There is one Honduran record, an observation of three 
individuals on Big Swan Island on 5 and 6 November 1958 by Charles H. Blake (Bond, 1959: 9).

The Swan Islands birds probably represented the eastern North American race, A. S. zubescens (Tunsta11), which has been recorded from Guatemala. The Rocky Mountain race, $\underline{A}$. s. alticola [Anthus rubescens alticola Todd, 1935: 64; Estes Park, Colorado] has been reported from E1 Salvador. Both races may be expected on the mainland of Honduras.

\section{Family BOMBYCILLIDAE}

\section{Bombycilla cedrorm Vieillot}

$$
\text { Cedar Waxwing }
$$

SPECIMENS.--(29): Catacombas, 29 March-1 Apri1 (2d, ${ }^{\circ}$, MLZ; 7, MCZ); Subirana, 13 March (6o, 7, MCZ); Monte E1 Conejo, 10-21 May (5\%, ?, MLz); $4 \mathrm{mi}$. SB La Esperanza, 24 Jan. (?, LSUMZ); Tegucigalpa, 29-30 March (38, 49, AMONH); vicinity Tegucigalpa, 20 March (o skel., skel.; MLZ); Es cuela Agrícola Panamericana, $20 \mathrm{Feb}$. (d, UF); Yeguare River Valley, 17 Feb. ( 8 , UF).

$$
\text { PUBLISHED RECORDS.--Siguatepeque (Taylor, 1860: 111). }
$$
Between La Celba and Fuerto Castilla (Bond, 1937: 102).

The Cedar Waxwing is a fairly common winter visitant in Honduras, ranging from sea level to at least 6,000 feet. It is most frequent in pine or pine-oak associations at the higher elevations but has been recorded on several occasions In the Caribbean lowlands. Extreme dates of arrival and departure in Honduras are 24 January and 21 May. The recently named races, B. c. larifuga Burleigh [1963: 178; Headquarters, Clearwater County, Idaho] and B. 
c. aquilonia Burleigh [1963: 179; Searston, Newfound1and], are based on color differences so slight as to be of no practical taxonomic use. I therefore regard the species as monotypic.

\section{Family CYCLARHIDAE}

\section{Cyclarhis gujanensis (Gmelin)}

Rufous-browed Peppershrike

SPECTMENS. - -C. g. flaviventris $\times$ nlcaraguae (44): Port1110 Grande, 26 March ( $\sigma^{\circ}$, MCZ); San Esteban, 26 June ( ${ }^{\circ}$, $\$, C M)$; La Libertad, 12 June ( $\$$, CNHM); Monte E1 Conejo, 12 May (f, MLZ); Plan del Rancho, 12-21 June (q, ?, MLZ); Santa Barbara, 15-18 May ( ${ }^{2}$ AMNH; o, CNHM); Finca Fé 14 Jan., 1 March, 20-25 Nov. (38, ?, LSUMZ); Lake Yojoa, 17 Aug. ( $d, \&, C M)$; El Caliche, 20 July ( $\&$, AMNH); Alto Cantora 1, 7-8 Feb. (29, MLZ); La Flor Archaga, 24 May, 23 June (d, ?, MCZ); Rancho Quemado, 15-20 March (3d", MCZ); E1 Derrumbo, 16 July-9 Aug. ( ${ }^{\circ}, \%$, AMNH; $\sigma^{\circ}, \%$, USNM); E1 Hat111o, 28 April-12 May (3\%, \&, MCZ); Comayagüela, 10 Nov. ( $\sigma$, MCZ); Madre Vieja, 8 Feb. ( 8 , UF); Yeguare River Valley, 11 May-4 June ( $\delta^{\circ}$, MCZ; 2 $\delta^{\prime}$, UF); San Lorenzo, 26 Sep.-

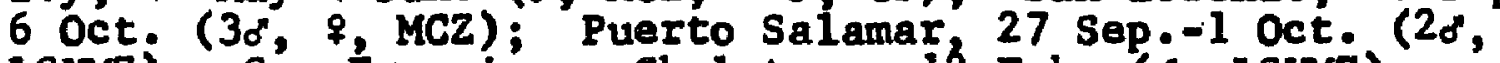
LSUMZ); San Francisco, Choluteca, 12 Feb. (d, LSUMZ); "Honduras" (?, BMNH).

PUBLISHED RECORDS.-- "Honduras" [as Cyclorhis flavipectus] (Gadow, 1883: 320). "Honduras" [as Itaviventr18] (Miller and Griscom, 1925b: 6); Volcán de Puca las tlaviventris] (Hellmayr, 1935: 194).

This species is a fairly common inhabitant of second growth, open monsoon forest, and arid scrub in the interior and on the Pacific slope of Honduras. It ranges from sea level to about 5,500 feet. The species also occurs locally under more humid conditions on the Caribbean side, especislly in the vicinity of Lake Yojoa, but has not been recorded below 2,000 feet on this slope. In the vicinity of the 
lake it is encountered in second growth and more open portions of rain forest.

Hellmayr (1935: 194) reported a specimen taken by Erlch Wittkïgel on Volcain de Puca; this individual is presumably in the Brunswick Museum.

Subspecific determination of Honduran material has proved to be difficult and the variation displayed somewhat puzzling. The northern race, $\mathrm{g}$. g. flaviventris Lafresnaye, distinguished by the deeper yellow under parts and lack of white on the abdomen, is reported to occur south to eastern Guatemala and Honduras. The specimen from Volcán de Puca, according to Hellmayr (1935: 194), was typical of the northern form. In the large series of Honduran material available, there are several spectmens (from Finca Fé, the Tegucigalpa region, and San Lorenzo) that closely approach flaviventris in deepness of yellow color and in lack of white on the abdomen. The majority of the specimens, however, display sone white on the abdomen and are 8 cmewhat paler yellow than most examples of flaviventris from Mexico. These specimens range from intermediate to nearly typical of the race $\mathrm{C}$. $\mathrm{g}$. nicaraquae Miller and Griscon, which ranges from western Guatemala and E1 Salvador to Nicaragua. Honduran birds from the Pacific slope should be typical of the latter subspecies, but the San Lorenzo specimen mentioned above is much closer to flaviventris. To confuse the issue further, the two specimens from Plan del Rancho, in the 
Department of Ocotepeque, are very greenish-yellow below and approach the Costa Rican race, $\underline{C}$. g. Subflavescens Cabanis. For the present I am regarding the Honduran populations as intermediate between flaviventris and nicaraguae.

\section{Family VIREOLANIIDAE}

Smaragdolanius pulchellus (Sclater and Salvin)

Emerald Shrikevireo

SPECIMENS. --S. p. pulchellus (6): San Alejo, 3 April (o", LSUMZ); Catacombas, 7 April ( Santa Bárbara, 16 Apri1 ( $\$$, MCZ); Cerro Santa Bárbara, eas t slope, 27 March ( 8 Lsumz); 2 mi. N Pito Solo, 27 Oct. (d", LSUMZ); Arena1, 24 Jan. (d, UCLA).

Contrary to the relative scarcity of records and specimens and the lack of prevtous reports, the Emerald Shrikevireo is a fairly comon inhabitant of rain forest on the Caribbean slope of Honduras, extending up into cloud forest in the Lake Yojoa region to at least 6,000 feet. It occurs in the high forest canopy and is much more frequently heard than seen.

C. F. Underwood obtained the first two Honduran specimens at Catacombas In 1933 and at San José de Santa Bárbara in 1935. T. R. Howell collected a male at Arenal in 1953. From October 1962 to April 1963, I recorded the species frequently in the Lake Yojoa region (especially on Cerro Santa Bárbara), near San Pedro Sula, and at San Alejo; the remaining three specimens were taken during this period. 
A11 Honduran material is representative of the bluecrowned, northern race, S. D. pulchellus (Sclater and Salvin), heretofore recorded south only as far as Guatemala. None of the Honduran specimens, not even the male from Arenal, only a few miles from the Nicaraguan border, exhibits any real approach to the race $\underline{S}$. $\mathrm{p}$. verticalis (Ridgway), which ranges from Nicaragua to Costa Rica. The latter race has the blue restricted to the nape and forehead.

Family VIREONIDAE

\section{Vireo griseus (Boddaert)}

White-eyed Vireo

SPECIMENS. - - V. g. noveboracens is (7): San Alejo, 16 March ( $\delta$, LSUNZ); Tela, 7-14 March (2d, \$, MCZ); La Ceiba, 31 March ( 7, CM); Finca Fé, 2 Dec. (Imm. o", LSUMZ); "Honduras" (?, USNM).

PUBLTSHED RECORDS.--"Honduras" (Sclater, 1862: 42 ; Baird, 1864: 354-356). Swan Is lands (Lowe, 1909: 336 ). Tela (Peters, 1929b: 460-461).

The White-eyed Vireo is an uncommon migrant and winter visitant along the north coast of Honduras and in the islands in the Caribbean Sea. It has been recorded on the mainland only on the Caribbean slope below 2,500 feet.

The specimen fron "Honduras" that was formerly in the collection of P. L. Sclater is now in the United States National Museum. Lowe (1909: 336) reported a bird that he shot in the Swan Islands sometime in January or February 
1908; his description of the bird stating that the "throat and upper breast of this specimen are of a deep buff . . ." seems to fit the species found on Cozumel Island, V. bairdi Ridgway, better than $\underline{V}$. griseus. This record should be viewed with some doubt although the White-eyed vireo is undoubtedly transient through the Swan Islands. Peters (1929b: 460-461) collected three specimens at Tela during March 1928, a pair on 7 March and another male on 14 March.

I obtained an immature male at Finca Fé in 1962 and observed another at Amapa on 26 January 1963. At San Alejo I noted single individuals on 14 and 16 March 1963, collecting one specimen on the latter date.

I tentatively assign the Honduran specimens to the northern race, $\underline{V} \cdot g$. noyeboracens is (Gmelin), a weakly characterized form based on brighter green upper parts and brighter yellow flanks. The duller, southern race, $\underline{V} \cdot g$. griseus (Boddaert), has been reported from Honduras by Miller, Friedmann, Griscom, and Moore (1957: 221), who ilsted Honduras in the range of both subspecies, but there are no specimens of griseus from the republic. For a discussion of the subspecific characters of these races, see Burleigh and Lowery (1945: 528-530).

\section{Vireo pallens Salvin}

\section{Mangrove vireo}

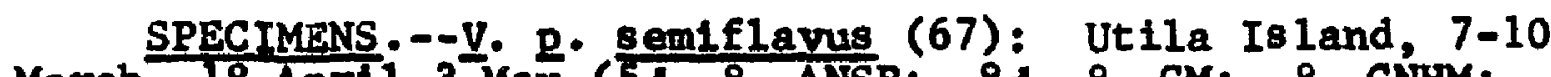

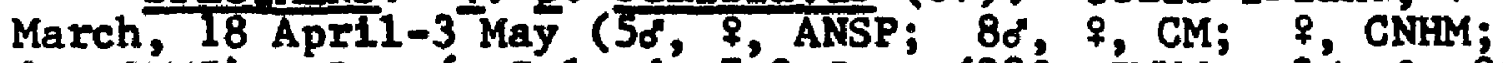

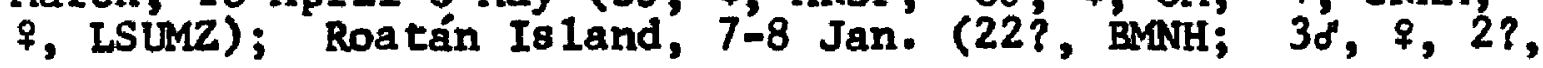


CNHM); French Harbor, 3-6 April (40, ${ }^{\circ}$ CM); Oak Ridge, 8

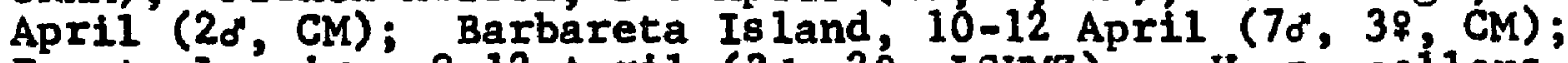
Puerto Lempira, 8-12 April (36,2q, LSUMZ). V. R. pailens (3): San Lorenzo, 29 Sep. ( $\sigma^{\circ}$, MLZ); Puerto Sālamar, 30 Sep. -2 oct. (imm. ó, iman. skel., Lsukz).

PUBLISHED RECORDS.--Roatán Is land (Salvin, 1888: 255; Hellmayx, 1935: 118). Utila Is land (Bond, 1936: 362; 1954: 8):

Vireo pallens is a common resident in mangroves in the Bay Islands (excluding Guanaja Is land), along the coast of the Mosquitia around the Laguna Caratasca, and along the Bay of Fonseca on the Pacific coast. In the region around the Laguna Caratasca, the species ranges away from mangroves, occurring in swampy thickets within one or two miles of the coast.

This species is apparently not closely related to $\underline{\mathrm{V}}$. griseus and should not be considered as conspecific with that fo:m. The call of $\underline{y}$. pallens is unique for a vireo and in no way resembles that of $\underline{V}$. griseus; there are differences, of course, in ecology and probably also in other ethological features.

Three forms of the Mangrove Vireo, $y$. pallens, $\underline{v}$. ochraceus, and $\underline{y}$. semiflavus, were all named by Salvin at the same time. The first author to consider them all conspectfic was van Rossem (1934c: 418), who was therefore the first reviser. Since he selected pallens as the specific name, it should remain as such.

Specimens from the Bay Is lands and the Mosquitia are referable to the very yellow race, $\underline{v}$. $\mathrm{g}$. semiflavus Salvin. 
In series, the populations from the Bay Islands average very slightly less yellowish below than those from British Honduras and Yucatán. Among the Bay Islands populations, that from Utila averages the grayest below. These differences are slight and subject to much individual variation; they are not sufficient to warrant taxonomic recognition. The Pacific slope specimens are typical of the pale, nominate race, $\underline{\text {. }}$. pallens Salvin.

\section{Vireo belli1 Audubon}

\section{Bell's Vireo}

MCZ). SPECIMEN.--‥ b. belli1 (1): San Lorenzo, 28 Sep. (

The Bell's Vireo is a migrant and winter visitant in northern Central America, ranging as far south as Nicaragua. It is primarily a spectes of arid scrub and is to be expected in winter in the Pacific lowlands of Honduras. There is but a single record for the country, a female collected by C. F. Underwood at San Lorenzo in 1932.

The Honduran specimen is representative of the nominate race, $\underline{v}$. $\underline{b}$. bel111 Audubon.

\section{Vireo flayifrons Vieillot}

\section{Yellow-throated Vireo}

SPECTMENS.--(22): Swan Islands, 14 March (q, MCZ); Little Hog Is Land, 10 April ( $\sigma^{\circ}$, ISUMz); Cerro Santa Bárbara, east slope, 28 Nov. ( $d$, LSUMZ); Finca Fé, 23 Nov. -14 Jan. (20, ₹, ISUMZ); Cerro Cantora1, 20 Feb. ( $\$$, MCZ); Monte Redondo, 21 Nov. -10 Dec. ( ${ }^{\prime},{ }^{\circ}$, AMNH; $5 \delta^{\prime}, 29$, MCZ); Tegucigalpa, 10 oct. ( $\%$, AMNH); Comayagüela, 29 Oct.-16 Nov. (?, AMNH; \%, MCZ); B1 Boquerón, 2 Oct. ( $\%$, AMNH); 
Puerto Salamar, 13 Feb. ( $\%$, LSUMZ); San Francisco, Choluteca, 11 Oct. (o", Lsunz).

PUBLISHED RECORD.--Swan Islands (Paynter, 1956: 106).

The Yellow-throated Vireo breeds in eastern North America and is a fairly common migrant and winter visitant in Honduras. It is most frequently encountered in the Caribbean lowlands and in the islands off the north coast but occurs also in the Pacific lowlands and in the interior highlands below 6,000 feet. The species inhabits almost any type of broadleaf forest or semi-open situation with large trees. In the islands in the Caribbean Sea it is known as a transient only. Extreme dates of arrival and departure for Honduras are 2 October and 27 April.

\section{Vireo solitarius (Wilson)}

Solitary Vireo

SPEC TMENS. - -V. 8. 8olitartus (44): Subirana, 29 Dec. (o, MCZ); Portilio Grande, 16 March-15 Apr11 (39, MCZ); Plan del Rancho, 8 July ( $\%$, MLZ); Mt. Puca, 7 Jan.-1 Feb. (3\%, AMNH); Cerro Santa Bárbara, east slope, 9 Dec. (2\%, ISLUZ); $5 \mathrm{mi}$. SW El Jaral, 28 Oct. ( 9 ISIMZ); $2 \mathrm{mi}$. SE E1 Jaral, 3 March ( $\delta$, LSUMZ); Finca Fé, 27 Nov. ( $\%$, LSUMZ); mi. SE La Esperanza, 23 Jan., 31 Oct. ( $\sigma^{*}, 2 \%$, $\delta$ skel. , Lstumz); Soluteca, 3-8 Apri1 ( $\sigma^{\circ} \%, ?$, AMNH); Cerro Grande, 6 March (?, AMMH); Cantoral, 29 Feb., 13 Dec. ( $\sigma^{\circ}, 28$, AMNH); Cerro Cantoral, 13 Dec. (d, MCZ); Alto Cantoral, 12 Jan. -9 Feb. (50, \%, MLZ); Monte Rédondo, 23 Nov, -10 Dec: ( $0^{\circ}, 49, ?, \mathrm{MCZ}$; $0^{\circ}$ USMM); La Flor Archaga, 3-17 Jan. (?, ?'AMNH); Rancho Quemado, 19 March, 8 DeC. (?, AMNH; ?, MCZ); Cerro Higuito, D.C., 10 Nov. ( $\$$, AMNH); Yeguare River Valley, 6 Nov. (o, UF). V. g. nottus (12): San Es teban, 1 July ( $\%, C M)$ Cerro Cantoral, 29 June ( $8, M C Z$ ); Monte Redondo, 29 Nov. (\%, USNM); La Flor Archaga, 8 June ( $\sigma_{3}$ ANSP); Rancho Quemado, 16 Aug ( $\sigma^{\circ}, \mathrm{MCZ}$ ); EI Derrumbo, 3-9 Aug - (29, MCZ); Comayagüela, 10 June ( $\left.{ }^{\prime}, \mathrm{MCZ}\right)$; Yeguare River Valley, 16 Aug. ( $\sigma^{\circ}$ UF); San Francisco, Choluteca, 12 Feb., 11 Oet. (39, LsUn). 
PUBLISHED RECORD.--La Flor Archaga [as montamus ?] (Bond, 1950b: 395 ).

A fairly common resident in Honduras, the Solitary Vireo inhabits pine-oak associations and open cloud forest from 3,500 to 7,000 feet. In winter individuals from the eastern North American breeding populations occur in Honduras, primarily in the same habitat as the local nesters, but the species has been recorded occasionally in the Cartbbean lowlands during migration. It is undoubtedly also a migrant in the 1slands off the north coast, but there are no records at present.

The larger, nominate race, $\underline{v}$. s. solitarlus (Wilson), which breeds in North America, is a migrant and winter vis1tant in Honduras; extreme dates of arrival and departure for this race in Honduras are 28 October and 15 April, although a single individual, presumably a summer straggler, has been recorded on 8 July. Breeding birds are tentative1y referred to $\underline{V}$. . notlus Van Tyne, heretofore restricted to British Honduras; I cannot recognize the Guatemalan form, $\underline{V}$. S. montanus van Rossem, as there is much overlap of Guatemalan and Honduran birds when compared with British Honduran individuals. Wings of Honduran notius measure as follows: $d, 66.0-66.8(66.3)$; $\$, 63.3-68.3(65.7)$. Wings of migrant solitarius taken in Honduras measure: d, 72.1$78.6(75.8) ; \quad \&, 70.9-77.0(74.0)$. 


\section{Vireo ollvaceus (Linnaeus)}

Red-eyed Vireo

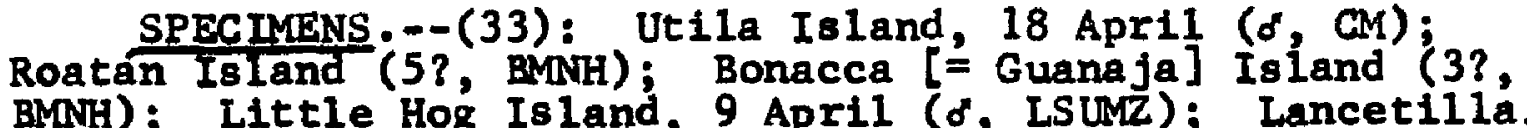
25 Marck, Litle Hog Is land, 9 April (d") LSUMZ); Lancetilla, (o, 29, CM); Truji110, 6 Apri1, 21-26 Sep. (o, CM; o, $\$$ USMM); Finca Fé, 13 Aug.-14 Sep. (o", imm., 2 alc., LSiMz); Comayagüela, 12-21 0ct. (30", MCZ); E1 Boquerón, 31 Aug - 30 Sep. (30, 2?, AMNH); San Francisco, Choluteca, 11-14 Det. ( $\sigma^{\prime}$ skel., Imm. \& skel., LSURZ).

PUBLTSHED RECORDS.--San Pedro region (Sclater and Salvin, 1870b: 836). San Pedro (Salvin and Godman, 1881: 1883. Trujillo (Ridgway, 1888c: 579). Roatán Is land, Bonacca [= Guanaja] Island (Salvin, 1888: 253). East of Lancetilia (Peters, 1929b: 460). Lancetilla (Stone, 1932: 332).

The Red-eyed Vireo is a common migrant through Honduras, occurring for the most part in the Caribbean lowlands and in the 1slands off the north coast; it has been recorded in the intertor on both slopes up to 3,500 feet, but there are no records for the Pactfic lowlands below 2,500 feet. Extreme dates of arrival and departure in Honduras are 25 March and 29 May for spring and 13 August and 22 October for fall.

The name $V$. virescens vielllot is sometimes used for this species on the grounds that Linnaeus' name Motacilla olivacea applied to both the Red-eyed Vireo and the Blackwhiskered Vireo, $\underline{v}$. altiloquus (Vielllot). While there can be no doubt that Linnaeus based the name on two spectes, the name olivacea is not Invalidated for this reason. Baird (1864: 335) restricted this name to the Red-eyed Vireo; thus the name applies to that species, not to $\underline{v}$. altiloquus, 
and 18 perfectly valid.

This species and the following are sometimes considered conspecific and may well prove to be. For the present, pending life history study, I am maintaining $\underline{v}$. flavovirtdis as a full species.

The northwestern breeding population of the Red-eyed Vireo has been recently described as $\underline{v}$. o. caniviridis Burleigh [1960a: 214; Moscow, Latah County, Idaho], based on paler and grayer upper parts and more olive pileum. These differences are extremely slight in the breeding plumage and of no value with migrant and wintering Individuals. Recognition of these differences taxonomically seems undesirable, and I therefore regard the species as monotypic.

\section{Vireo flavoviridis (Cassin)}

$$
\text { Yellow-green Vireo }
$$

SPECTMENS.--V. f. Elayovirldis (19): Amapa, 28 Apri1

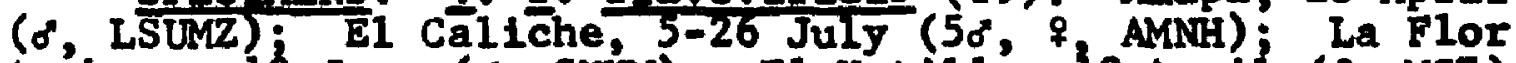
Archaga, 12 June ( ${ }^{\circ}$, CNIM); E1 Hatilio, 19 April ( 9, MCZ); Tegucigalpa, 25 May ( $ه$, AMNH); Yeguare River Valley, 14 June ( $\delta^{\prime}, q^{\prime}$ UF); Río Choluteca, at Danlí bridge, Dept. E1 Paralso; 19 May (20, \%, UF); El Boquerón, 4 Sep. ( $0^{\circ}$, AMNH); Puerto Salamar, 27 Sep.-2 Oct. (28, Imm., LSURZ).

Despite the absence of previous records for Honduras, this species is an uncommon to locally fairly comon migrant and summer resident. During the breeding season, it is found in the interior at medium elevations from 2,000 to 4,000 feet, usually in open broadleaf forest, second growth, or scrubby growth with scattered trees. In migration it may be encountered down to sea level on both coasts, in 
either open forest or scrub. Extreme dates of arrival and departure in Honduras are 19 April and 13 October.

For the retention of this form as a full spectes, see the discussion under $\underline{V}$. ollvaceus.

Al1 Honduran specimens are referable to the nominate race, ‥ f. flavoviridis (Cassin). The two Mexican races, $\underline{V}$. $\underline{\underline{f}}$. forreri Madarasz and $\underline{V}$. $\underline{\underline{f}}$. hypoleucus [Vireo olivaceus hypoleucus van Rossem and Hachisuka, 1937: 159; San Francisco Cafion on the extreme eastern boundary of Sonora at Lat. $27^{\circ} \mathrm{N}$. ], both of which have been recorded in E1 Salvador on migration to wintering grounds in South America, presumably pass through Honduras, but there are no records at present for these subspecies.

\section{Vireo magioter (Lawrence) \\ Yucatan Vireo}

SPECIMENS. - - V. m. mag1ster (49): Utila Island, 15 Feb. ( 6 , LSUMZ); Roatan Is land, 8-9 Jan., 8 Sep. (10? BMNH; 40, ?, CNEM; $0^{\circ}, ?$, USNM); Barbareta Is land, 11-12 April (40", 38, Imm. $0^{\circ}, \mathrm{CM}$ ); Guana ja (Bonacca) Island, 29 Feb., 22 March-14 Apr 11, Sep. ( ${ }^{\circ}$, ANSP; 5 ?, BMNH; 8 ${ }^{\circ}, 4$ \%, CM; ?, CNTM); Little Hog Island, 6-7 April (39, LSUḾ); Big Hog Is land, 8 April (d, LSLAZ).

PUBLISHED RRCORDS.--Roatán Island (RIdgway, 1888c: 578-579). Roatán Island, Bonacca [= Guanaja] Is land (Salvin, 1888: 254; Hellmayr, 1935: 145). Bonacca [= Guana ja ] Island (Bond, 1936: 363). Bonacea [II Guanaja] Is land, Barbarat [= Barbareta] Is land, Hélène [z Santa Elena Is land] (Delacour, 1938: 545).

This vireo is a conmon resident in the Bay Islands and the Cayos Cochinos, occurring on Utila, Roatán, Barbareta, Santa Elena, and Guanaja in the former group and on both 
Little Hog and Big Hog Ls lands in the latter. Although Bond (1936: 363) reported that $\underline{v}$. magister was absent from Utila Island, I found it to be common there in May 1963. Honduran spectmens are typical of the nominate race, v. m. magister (Lawrence).

\section{Vireo philadelphicus (Cassin)}

Philadelphia Vireo

SPECTMENS-- - (23): Truji110, 6 April (20, CM); Subirana, 11 Jan., 12 March ( $\delta, 2 \%, M C Z)$; $13 \mathrm{mi}$. NW Graclas, 28 Feb. ( $q ?$, LSUMz); Finca Fé, 20 oct. -8 Dec. (30', Imm., LSURZ); $4 \mathrm{mi}$. SE La Esperanza, 31 Oct. ( $\sigma$ skel., LSUMZ); La Laguna Archaga, 3 Jan. ( $\$$ AMNH); Monte Redondo, 25 Nov.-10 Dec. ( $\sigma^{\circ}$, AMNH; 6 $6,28, M C Z$ ); San Juancito, 2 Feb. (o, LSUMZ); E1 Hatillo, 8 May ( 8, MCZ).

Despite the absence of published records for Honduras, the Philadelphia Vireo is a fairly common migrant and winter visitant, occurring primarily in broadleaf forests in the interior from 2,000 to 6,500 feet elevation. In migration it has been recorded in the Caribbean lowlands and on Utila Island, in the Bay Islands. Extreme dates of arrival and departure for Honduras are 20 October and 8 May.

\section{Vireo glivus (Viet1lot)}

Warbling Vireo

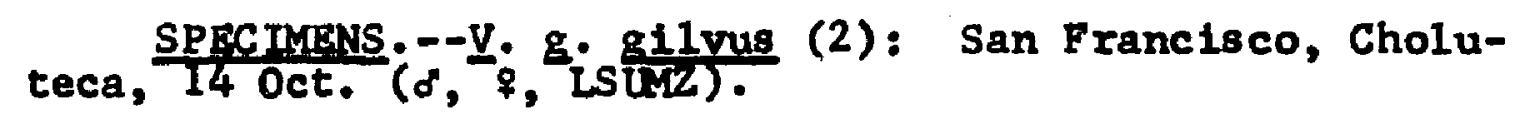

The Warbling Vireo is a regular winter visitant as far south as Guatemala and has been recorded in E1 Salvador, once in Nicaragua (T. R. Howell, personal communication), and once in Costa Rica (sight record, Slud, 1964: 312). 
The only Honduran record is the pair that I collected at San Francisco in 1962. These two individuals were the only ones noted and were found in scrubby growth at an elevation of 3,300 feet. The species is probably regular, though rare, in winter on the Pacific slope of Honduras. The two specimens are typical of the eastern race, $\underline{y}$. g. gilvus (Vieillot). Although the culmen (d, 10.6; $\&$, 9.9) and wing $(\delta, 71.6 ; \%, 69.9)$ measurements are in the region of overlap between glluss and the western race, V. G. swainsonif Baird, the greater depth of bill and coloration of the upper parts match the eastern race, and the two specimens are therefore assigned to that form.

\section{Vireo leucophrys (Lafresnaye)}

\section{Brown-capped Vireo}

SPEC MYENS.- -V. 1. Btrenuus (11): Las Ventanas, 24-27

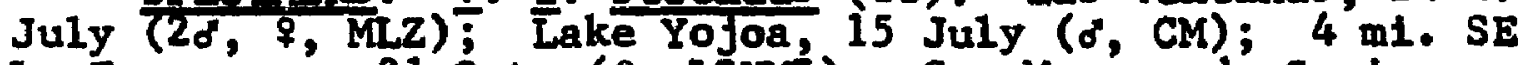
La Esperanza, 31 Oct. (q, LSUMZ); San Marcos de Guaimaca, $2-4 \mathrm{July}\left(\sigma^{\circ}, \%, \mathrm{MCZ}\right)$; Cantoral, $24 \mathrm{Feb}$. ( $\%, \mathrm{MCZ}$ ); A1to Cantora1, 3 Feb., 13 April ( $\$$, CNFM; 6 , MCZ); San Juancito, 2 Feb. (o", LSUMZ).

In Honduras this vireo is an uncommon resident of cloud forests and pine-oak associations in the interior. It ranges down to about 2,500 feet but is decidedly rare below 4,000 feet.

C. F. Underwood obtained the Alto Cantoral and San Marcos de Guaimaca specimens in 1934 and the Cantoral and Las Ventanas material in 1936. Arthur C. Tromey and Roland W. Hawkins secured a male at Lake Yojoa in 1951. J. Alan 
Feduccia and I collected single individuals near La Esperanza In 1962 and at San Juancito in 1963; I noted only one additional bird while in Honduras, a singing individual on Cerro Santa Bárbara on 21 Apri1 1963.

This species is sometimes considered conspecific with V. gllvus and may well prove to be. Although the song patterns are similar, there are differences in the quality of the song in addition to others that are morphological or ethological. Until a thorough study can be made of this group, I am tentatively maintaining $y$. Leucophrys as a distinct species.

Al1 Honduran material is representative of the Chiapan and Guatemalan race, ‥ 1. strenuus Nelson. There is no approach in any of the specimens to the much yellower, Costa Rican subspecies, V. 1. chiriquensis (Bangs).

\section{Hylophtlus ochracelceps Sclater}

Tawny-crowned Greenlet

SPEGTYFAS. - - H. o. pallidipectus (26): San Alejo, 15 March ( 8 tSUiz); Lancetilla, 6-10 Feb. ( $9, ?, \mathrm{MCZ}$ ); Los Planes, 9-10 June (2o, CM); Truji11o, 31 March (\$, CM); Catacombas, 28 March-9 April (40, MLZ; o, ?, ?, MCZ); Cofradia, 4 March (o, ML); Rio de Las Pledras; 12 Nov. ( USNM); Cerro Santa Bárbara, east s lope, $19 \mathrm{Feb}$. ( $\sigma^{\prime}, \&$,

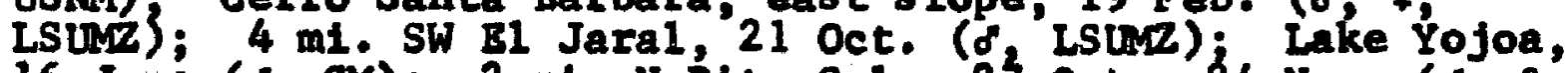
16 June (o, CM); 2 mi. N Pito Solo, 23 oct., 24 Nov. (d, ?, \& ske1., LSuMz); Cantoral, 9 Marth, 13 April (7, ?, AMMH); Segovia River, 19 June, 13 Aug. (d', \%, USM).

PUBLTSHED RFCORDS,--Segovia River (RIdgway, 1888c: 585; Cherrie, 1892: 529). Río de Las Piedras las ochracelceps], Segovia River las pallidipectus] (Ridgway, 1904: 219). East of Lancetilia [as palifdpectus] (Peters, 1929b: 461-462). 
The Tawny-crowned Greenlet is a fairly common resident in the lower levels of rain forest on the Caribbean slope of Honduras, ranging up to an elevation of 4,500 feet.

Honduran specimens are referable to the southern race, H. o. pallidipectus (Ridgway). I do not agree with Hellmayr (1935: 177-178) and Howell (1957: 100) that pallidipectus is a synonym of the nominate race, $\underline{H}$. O. ochracelceps Sclater. A series from Mexico is decidedly more ochraceous on the chest and darker on the abdomen when compared with birds from Honduras and Costa Rica. Specimens from British Honduras are intermediate, perhaps closer to ochracelceps, but Honduran individuals are all typical of pallidipectus.

\section{Hylophilue decurtatus (Bonaparte) \\ Gray-headed Greenlet}

SPECTMENS.--H. d. decurtatus (58): San Alejo, 7 Aug. (3, LSTuZ); Lancetilla, 23 Jan., 25 Aug - -8 Sep. (3o', ANSP; 9 MCZ); La Celba, 20 May-1 June (2\%, \&, CM); Los Planes, if June, 16 July (20, CM); Truj1110, 31 'March-8 Apri1, 2023 Sep. (78, 9, CM; of, \&, ?, USMM); Catacombas, 24 March21 April ( ${ }^{\prime}$ AMNH; 2o, Miz); Cofradla, 4-14 March (?, AMNH; 40, 39, MLZ); Amapa, 24 June, 18 Sep. (d' skel.', alc., LSURZ); \&, UF); Coyoles, 14-29 June (2\%, GM); La Libertad, 22 June ( $d, \mathrm{MZ}^{2}$; Cerro Santa Bárbara, east 8 lope, 19 Feb., 28 Nov. (o", $\%$, LSUMZ); $4 \mathrm{ml}$. SW E1 Jaral, 21 Oct. ( $\delta$, Lsimz); Finca Fé, 16-19 Jan., 13 Aug -14 Sep. (o", 29, o skel., 3 alc., LSUL) ; Lake Yojos, 20-27 July (38, $\%$, GM); E1 Caliche, 21-22 July, 4 Sep, (2o, 2?, AMNA); Janas trán valley, 17 Aug: $\left(\sigma^{\circ}{ }^{\circ}\right.$ UF). H. d. pallidus (1): Finca El Rubi, 29 Sep. (o'?, Lsứz).

PUBLTSHED RECORDS.--San Pedro region (Sclater and Salvin, 1870b: 836). San Pedro (Salvin and Godman, 1883: 2063. Truj1110 (RIdgway, 1888c: 579). Upper Lancetilla Valley [as pus 111us] (Peters, 1929b: 461). Lancet11la (stone, -1932: 332). 
Occurring on both slopes of Honduras up to an elevation of 4,000 feet, the Gray-headed Greenlet is a comon resident in rsin forest, monsoon forest, and second growth. Within the forest it is usually found in the high canopy or at medium levels. It is one of the most frequently encountered species in lowland rain forest.

Populations on the Caribbean slope of Honduras are referable to the widespread race $H$. d. decurtatus (Bonaparte). If the race H. d. pusillue Lawrence is recognized, it must be confined to Costa Rica and Panama as Nicaraguan birds are typlcal of decurtatus (Howell, 1957: 100). The Paciflc lowlands race, H. O. pallidus (Dickey and van Rossem), which inhabits monsoon forest, is distinct. Compared with decurtatus, it is much yellower on the flanks, whiter on the throat, paler gray on the pileum, and brighter green on the back. The single specimen is the first evidence of the occurrence of pallidus in Honduras, the subspecies being previously known only from Pacific sl Salvador and Nicaragua.

\section{Family COEREBIDAE}

\section{Diglogsa baritula Waglex}

\section{Cinnamon-bellied Flowerpiercer}

SPECTYENS - - -D. b. montang $x$ parya (14): Montaña E1 Chorro, July ( 8, Miz) MIZ). D. b. parva (40): Las Peflitas, 20 Feb. (o, MCZ); 6 m1. NE La Esperanza, 29 Oct. (o, Lsug); Muye, 25 Feb. (d, AMNH); San Marcos de Gualmaca, 5 July (d, MIZ); Cantoral; 
24 Jan.-26 Feb., 17-19 April, 13 July (3o, ${ }^{\circ}, 3$ 1mm. $\sigma^{\prime \prime}$

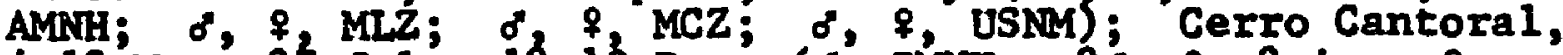

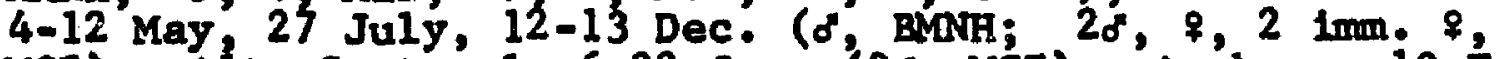
MCZ); Alto Cantora1, 6-22 Jan. (3\%, MCZ); Archaga, 10 Feb. ( ${ }^{\circ}$, , AMNH); San Juancito, 13 July, 13 Aug. (20, ANSP); San Juancito Mte , 22 May (o, UF); Rancho Quemado, 12 March-10 Apri1, 20 May (5o, 2 1mm. $\delta^{\circ}, 2$ imm. \&, MCZ).

PUBL.ISHYED RECORPS.--San Juancito (Stone, 1932: 332). Rancho Quemado (Griscom, 1932c: 61). Cantora1, Archaga, Muye (zimmer, 1942c: 3).

This aberrant honeycreeper is resident in scrub, forest edge, and open cloud forest in the interior of Honduras from 5,500 to 8,000 feet. It is decidedly common and one of the conspicuous species of scrub country at high elevations.

A11 Honduran specimens, except those from the Department of Ocotepeque, are typical of the race D. b. parve Griscon [1932c: 61; Rancho Quemado (6700 ft.), District of Achaga (= Archaga), Honduras] in darker and duller coloration and smaller size. Their wings measure as follows: $\delta$, 49.4-58.1 (54.8); $\$, 50.4-54.3(52.2)$. The specimens from Ocotepeque average silghtly larger and are intermediate in this respect between parya and the Guatemalan race, $\mathrm{D}$. b. montana Dearborn, although nearer the former in coloration. Wings of these individuals measure as follows: o, 54.5-58.5 $(57.2) ; \quad \%, 53.0-55.8(54.8)$.

\section{Chlorophanes spiza (Linnaeus)}

Green Honeycreeper

SPECIYENS:-C. ․ guatemsiens 18 (17): San Alejo, 15 March-3 April ( $\%, 2 \%$ Lstivi ); Lancet1lla, 17 Jan., 20 March $\left(0^{\circ}, 29, \mathrm{MCZ}\right) ;$ La Celba, 3-21 Jan. (30, 4\%, MCZ); San Pedro (o,, BMNH); $2 \mathrm{mi}$. SE El Jaral, 20 April ( $q$, LSUMz); Finca Fé, 2 Dec. (o', LSUMZ); Lake Yojoq, 12 June ( 9, CM). G. S. 
arguta (3): Río Guampí, $10 \mathrm{mi}$. E Dulce Nombre de Culmí, 20 March (d, LS uvZ); Arenal, 13 Jan. (o, UCLA); Segovia River, 19 July ( $\$$, USNM).

PUBITSHED RECORDS.--San Pedro region (Sclater and Salvin, 1870b: 836). San Pedro (Salvin and Godman, 1883: 247; Sclater, 1886: 30 ). Segovia RIver (RIdgway, 1888c: 585). La Ceiba (Bangs, 1903: 153). East of Lancet11la (Peters, 1929b: 469).

Chlorophanes spiza is an uncommon resident in the Caribbean lowlands of Honduras, ranging up to 3,500 feet elevation. It occurs in open rain forest, forest edge, and second growth, usually at fairly high levels above the ground.

Honduran specimens from rain forest areas north of the Olancho are typical of the larger, northern race, $\underline{C}$. $\underline{\text {. }}$ guatemalensis Sclater. Measurements of Honduran birds, not Including those from 0lancho, are as follows: wing, of, $75.5-78.2(76.3), \%, 70.6-76.6$ (74.4); exposed culmen, $\delta$, 17.0-18.1 (17.7), $9,17.2-17.9(17.4)$. The three birds from the olancho rain forest are much smaller and compare favorably with examples of $\mathrm{C}$. $\underline{B}$. argute Bangs and Barbour from Nicaragua and Costa Rica (wing, $\delta, 68.5,69.2,7,66.4$; exposed culmen, $\delta, 15.8,15.1, \%, 15.2)$.

\section{Cyanerpes cyaneus (Linnaeus)}

Red-legged Honeycreeper

SPECMMENS. -C. c. carnelpes (88): Medina (o, $\%$, ANSP); Tela, 24-26 March (3\%, M(CZ); Lancetilla, 25-27 Aug ' (d, \&,

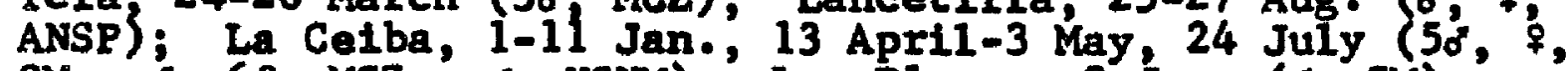
CM; 8,69, MCZ; $\%$, USNM); Los Planes, 9 June ( ${ }^{\circ}, \mathrm{CM}$ ); Trujilio, 6-8 April, 19 Sep. -1 Oct. (68, f, CM; 8 , CNRM; 140, 39, USNM); Cataccmbas, 23-28 March (20, MLZ); Cofradia, 5-12 March (2d, 2q, MLZ); Santa Ana, 2 Dec.-3 Jan. (q, 
2 juv. ${ }^{*}$, USNM); La Lima, 19 Nov. (o ske1., LSLMZ); Coyole6, $17 \mathrm{July}$ ( $\delta, C M$ ); La Libertad, $20 \mathrm{Jume}$ ( $\delta$, AMNH); San José de Santa Bárbara, 6 April-6 May (30, 2\%, AMNH); Santa Bárbara, 12 April ( ${ }^{\circ}$, ANSP); Finca Fé, 21 July-14 Sep., 524 Nov. (30, 3\%, q skel., q alc., LSUNZ); $2 \mathrm{ml}$. SE Bl Jaral, 3 March (\%, LStay); Agua Azul, 7-12 Aug - (2o, \%?, UF); Lake Yojoa, 15 June-18 July $\left(30^{\circ}, 3 \%, \mathrm{CM} ; \delta^{\circ}\right.$, UF); 5 mi. SE Namasigũe, 8 Oct. ( 8 , LSLMZ); "Honduras" (3d, ANSP).

PUBLISHED RECORDS.--San Pedro region (Sclater and Salvin, 1870b: 836). San Pedro (Salvin and Godman, 1883: 249). Trujillo (Ridgway, 1888c: 579). La Celba (Bangs, 1903: 153; Delgnan, 1936: 193). Tela (Peters, 1929b: 469). Lancetilla (stone, 1932: 333). Lancetilla Vailey (Skutch, 1954c: 399).

The Red-legged Honeycreeper is a common resident in the lowlands of both cossts of Honduras, occurring below 2,500 feet. It inhabits rain forest, monsoon forest, forest edge, second growth, and semi-open situations with large trees, generally frequenting the high tree canopy. It is also found in trees in the towns and villages.

Honduran specimens represent the Middle American race, C. c. carnetpes (Sclater).

\section{Cyanerpes lucidus (Sclater and Salvin)}

\section{Shining Honeycreeper}

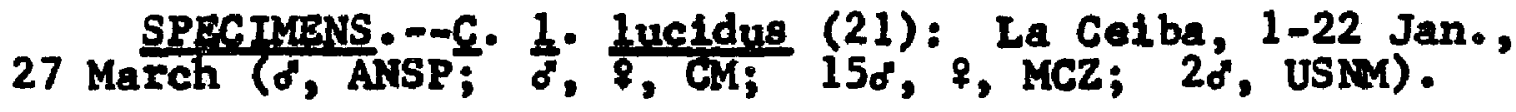

PUBT,ISHED RECORDS.--Onoa (Moore, 1859: 53). La Ceiba (Bangs, 1903: 153).

The distribution and occurrence of this species in Honduras is rather puzzling. From Costa Rica southward it is a comon bird, but north of Nicaragua it is very local, occurring in the tops of large trees in open rain forest, forest edge, or seml-open situations. In Honduras it is 
known from two localities only. Joseph Leyland (Moore, 1859: 53) reported it as common in the Onoa region in 1855 and 1856. W. W. Brown (Bangs, 1903: 153) obtained a large series at La Ceiba in January 1902 and was responsible for al1 the 1isted specimens except the pair in the Carnegie Museum. Arthur C. Twomey secured this latter pair at La Ceiba in March 1947. There are no other records for Honduras, although the spectes must occur elsewhere on the Caribbean slope below 1,500 feet.

This honeycreeper is sometimes considered conspecific with the South American C. caeruleus (LInnaeus), but both species occur sympatrically in Colombia.

Honduran specimens are typleal of the smaller, northern race, G. 1. 1ucidus (Sclater and Salvin), which extends as far south as northern Nicaragua (Zimmer, 1942c: 13; Howell, 1957: 101). None shows any approach to the southern race, C. 1. 1sthmicus Bangs.

\section{Coerebe flaveola (Linnaeus)}

Bananaquit

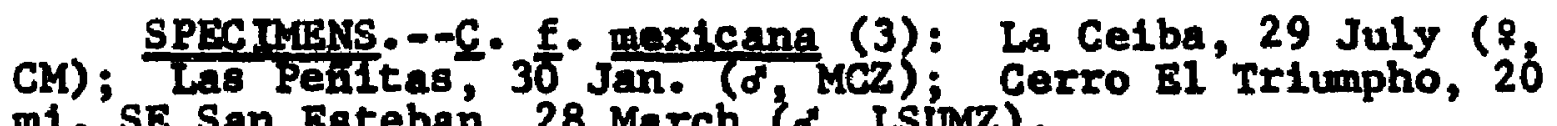
mi. SE San Esteban, 28 March ( $\sigma^{\circ}$, LSing).

The Bananaquit is an uncommon to rare species in Honduras, inhabiting open rain forest or forest edge, usually at high levels in the tree canopy. It is known from the republic only by the three spectmens listed above. C. F. Underwood collected a male at Las Pefitas in 1933, Arthur C. 
Twomey and Roland $W$. Hawkins obtained a female at La Celba In 1950, and Richard R. Graber secured a male on Cerro E1 Triumpho in 1963.

The three Honduran specimens are representative of the widespread Middle American race, ‥ f. mexicana (Sclater).

\author{
Family PARULIDAE
}

\title{
Miniotilta yaria (Linnaeus)
}

\section{Black-and-white Warbler}

SPEC MMENS.--(46): Swan Is land, 1 Feb., 28 March ( ${ }^{\prime}, q$, USNM); Roatan Island, 8 Sep. (5?, BNAN; ${ }^{7}$ USNM); Oak Ridge, 8 April ( $9, C M)$; Barbareta Island, 18 April ( $\left.{ }^{\circ}, C M\right)$; Guanaja Island, 24 March (d, 8, Cri); Little Hog Island, 8 April ( $0^{\circ}$ LSUMz); La Celba, 8-12 Jan. (20, MCZ); Trujillo, 6 April (o, CM); Catacoabas, 31 March-8 Apri1 ( $\$$, AMNH; $q$, ML2); Cofradía, 5-9 March ( 8, \%, AMAH; ?, MIZ); Las Pefitas, 31 Jan. -15 Feb. ( $\%$, ?, AMar ); $3 \mathrm{mi}$. E La Lima, 9 Dec. ( $q$ skel., LSUR ); Finca Fé, 16 Jan., 27 Aug - - 1 Sep., 23 Nov. (29, imm. of $q$ alc., LSunz); Lake Yojoa, 17-23 Aug. $\left(2 \sigma^{\circ}, \mathrm{CM}\right)$; Monte Redondo, \& Sep., 29 Nov. -6 Dec. (o', AMNH; 20, MCZ); Cantarranas, 7-24 Aug. ( 8,3 , ANSP); Rancho Que-

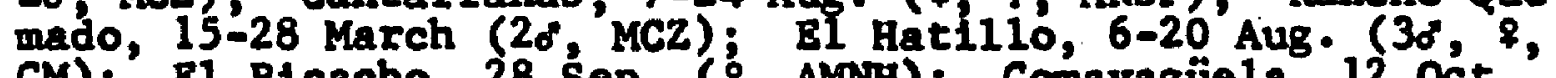
CM); E1 P1cacho, 28 Sep. ( 9 , AMH); Comayaguela, 12 oct. ( $\delta$, MCZ); Yeguare River Valley, 8 Sep. (o, UF); $10 \mathrm{~km}$. N Sabana Grande, 14 Aug. ( 9, CM); San Lorenzo, 29 Sep. (?, MCZ).

way, $1888 \mathrm{c}: 575,578$ ) 5 - Roatán Is land (Salvin, 1888: 246). La Celba (Bangs, 1903: 153). Swan Islands (Lowe, 1909: 336; F1sher and Wetmore, 1931: 19) Tela reglom (Peters, 1929b: 462). Cantarranas, Lancetilia (Stone, 1932: 333).

This warbler is a comon migrant and winter visitant in Honduras, ranging from sea level to at least 7,000 feet. It is equally at home in rain forest or in pine-oak associations, occurring in almost any type of wooded situation throughout the country. It has been recorded also in the 
Swan Islands, Bay Islands, and Cayos Cochinos, primarily during migration; on the Pacific slope it is decidedly uncommon. For Honduras extreme dates of arrival and departure are 6 August and 27 Apr 11.

\section{Protonotarla citrea (Boddaert)}

Prothonotary Warbler

SPECIMENS. --(7): Roatán Island ( 6 , BMNH); Little Hog Is land, 6-8 April (2q, LSUAZ); Big Hog Island, 8 April (2q, LSUMZ); Truj1110, 20-30 Sep. (2?, USMM).

PUBLISHED RECORDS.--Roatán Island (Salvin, 1888; 246). Truj1I10 (RIdgway, 1888c: 579).

The Prothonotary Warbler is a rare migrant and winter visitant in the Caribbean lowlands and in the 18 lands off the north coast of Honduras. George F. Gaumer (Salvin, 1888: 246) collected a male on Roatán Island. C. H. Townsand (Ridgway, 1888c: 579) obtained two individuals at Truj1110 in September 1887. Mark Trafton, Jr., observed single birds at Lancetilla, and at La LIma, both in January 1953. On 17 March 1963 at La Lima, Kenneth S. Hamilton banded a male caught in a mist net. In 1963 I saw two individuals on Little Hog Is land on 6 April, two more there on 8 April, and three on Big Hog Island on 8 April, obtainIng the four specimens listed above on these dates. There are no other records for Honduras. The species is probably a regular, but rare, migrant and winter visitant on the Caribbean slope. 


\section{Ltmnothlypis swainsonti (Audubon)}

Swatns on's Warbler

SPECIMEN. --(1): Swan Is lands, 1 March ( $q, M C Z)$. PUBLISHED RECORD,--Swan Islands (Peters, 1913: 378).

In Honduras the Swainson's Warbler is a very rare migrant and winter visitant. There are only two records for the country, a specimen taken by George Nelson in the Swan Islands in 1912 (Peters, 1913: 378) and an observation of a single Individual at Lake Yojoa by Mark Trafton, Jr., in January 1956. The latter bird was seen in the sedges along the lake shore.

I am unable to distinguish the race $\mathrm{L}$. a + alta Meanley and Bond [1950: 192; Walhalla, S. C. (= South Carolina)] and regard the species as monotypic.

\section{Heimitheros vermivorus (Gmelin)}

Worm-eating Warbler

SPECIMIRNS:--(16): Swan Islands, 11 March (o, MCZ); Bonacca [= Guanaja] Is land (2?, BMHH); Lancetilis, 15 Jan. ( $\%$, MCZ); Catacombas, 31 March ( 9 MLZ); Santa Ana, 1 Dec. (\%, USNM); Las Peñitas, 17 Peb. (?, MLZ); Amapa, 29 Nov. (o, Isuz); Río Pataste, 12 mi. S Dulce Nombre de Culmí, 29 Jan. (f, LSLMZ); $5 \mathrm{ml}$. SW El Jara 1, 26 Oct. (Imm. of, LSUMz); 2 mi. SE E1 Jaral, 22 Feb. (?, LSUrz); Finca Fé, 17 Sep., 25 Nov, -21 Jan. (3\%, ?, imen. \&, Isurz).

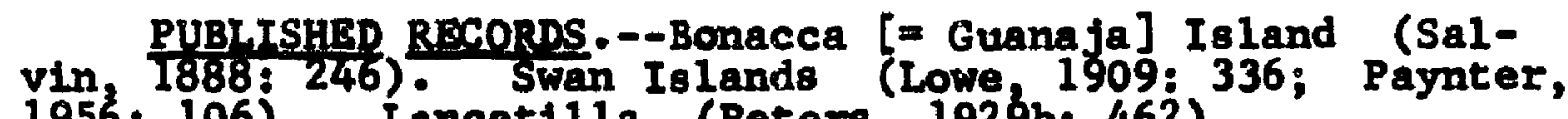
1956: 106). Lancet111a (Peters, 1929b: 462).

The Worm-eating Warbler is an uncommon migrant and winter visitant in the Caribbean lowlands of Honduras, occurring below 2,500 feet. It is found in rain forest and 
In second growth. It also migrates through the Swan

Islands and the Bay Islands. Extreme dates of arrival and departure in Honduras are 31 August and 18 April.

\section{Vemivora chrysoptera (Linnaeus)}

Golden-winged Warbler

SPRCIMENS.--(10): Lancetilla, 19 March (8?, MCZ); Catacombas, 5 April (o, MLZ); Mt. Puca, 31 Jan. (o, MCZ); Cerro Santá Bárbara, east slope, 22 Nov. (o, LSUMa); Finca Fé, 1 March, 4 Sep., 24 Nov., 11 Dec. (d", 2\%, $1 \mathrm{~mm}$. LSURZ); BI Picacho, 28 Sep. ( 9 , AMNH); San Francisco, Choluteca, 14 Oct. (d, LSLMZ).

PUBLISHED RECORD.--Lancet111a (Peters, 1929b: 462).

This specles is an uncommon migrant and winter visitant in Honduras, occurring in broadleaf forest, second growth, and pine-oak assoclations from sea level to at least 6,000 feet. It is most frequent on the Caribbean slope but occurs regularly in the interlor highlands; it has not been recorded on the Paciflc slope below 3,000 feet. For Honduras, extreme dates of arrival and departure are 4 September and 18 April.

\section{Vemivora pinus (LInnaeus)}

Blue-winged Warbler

SPECTMENS.--(12): Mantecristo, 24 March ( $q$ LSUMZ); 8 mi. S Potrerilios, 21 Feb. ( $\$$, LSUMZ); Amapa, 26 Jan., 18 Sep. ( $0^{\circ}, 9$ LSUMZ); $4 \mathrm{mi}$. SW E1 Jaral, 21 Oct. (d, LSLiz); $5 \mathrm{mi}$. SW El Jaral, 28 oct.-11 Nov. (2o", LsumZ); Finca Fé, 2 Dec.-20 Jan. (40, Lsuaz); Nacunta River, $3 \mathrm{mi}$. S Puerto Lempira, 6 Feb. ( 8 , LSUMZ).

Despite a lack of published records, this warbler is a fairly common migrant and winter visitant on the Caribbean 
slope of Hoaduras, ranging up to an elevation of 3,500 feet. It is found in second growth, in scrub, along forest edge, and occasionally in open rain forest.

At Lancetilla on 10 December 1952, Mark Trafton, Jr., and $v$. C. Dunlap saw an individual, the first ever recorded - in Honduras. From September 1962 to March 1963, Richard R. Graber, J. Alan Feduccia, Rose S. Monroe and I noted the species on 26 occasions; all Honduran specimens were secured during this period. On 31 March 1964 I saw one male near La Lima. Kenneth S. Hamilton observed one individual at La Lima on 13 September 1964. Extreme dates of arrival and departure in Honduras are 13 September and 31 March.

\section{Vermivora peregring (Wilson)}

Tennessee Warbler

SPEGMYENS:--(36): Utila Is land, 18 April (o, CM) Roatán Island (2?, BMNH); Bonacca [? Guanaja] Island (?, BMNH); Catacombas, 23-31 March (d, 2?, AMNH); Cofradia, 912 March (2q, ?, AMNH); Las Pefiltas, 3-6 Feb. (o, ?, AMNH); Finca Fé, 1 March, 22 Óct., 24 Nov. (\$, 1mm., \& skel., LSLaYZ); $3 \mathrm{mi}$. N E1 Mogote, 17 Jan. (alc., Lślaz); Cántora1, 4-12 May (27, AMNH); Cerro Cantorai, 6-12 March ( 6 , 59,?, MCZ); Rancho Quemado, 20 March, 14 May (?, AMNH; ?, MCZ); E1 Picacho, 29 Sep. ( $\$$, AMNH); Cerro Higuito, D.C., 10 Dec. ( $($, AMNH) Comayaguiela, 11 oct. 9 Nov. (30, MCZ); San Lorenzo, 28-29 Sep. ( $\left.2 \delta^{\circ}, M_{1} z_{;} d, M C z\right)$; ; San Francisco, Choluteca, 14 oct. (1mm. o", LSUMZ).

PUBLTSHED RECORDS.--San Pedro region (Sclater and Salvin, I870b: 836). San Pedro (Salvin and Godman, 1880: 117). Roatán Island, Bonacca [= Guanaja] Island' (Salvin, 1888: 247).

The Tennessee Warbler is a common migrant and winter visitant in Honduras, ranging up to an elevation of 6,500 feet. It is found in open broadleaf forest, second growth, 
pine-oak associations, and even arid scrub, but is most common in the open forests of the Interior above 2,000 feet. In migration it occurs in the Bay Islands and undoubtedly also in the Swan Islands and Cayos Cochinos. Extreme dates of arrival and departure in Honduras are 28 September and 14 May.

\section{Vemiyora superciliosa (Hartlaub)}

Crescent-ches ted Warbler

SPECTMENS. - -V. 8. superctliosa (6): Montaña E1 Chorro, 20 June $(i, ?, \mathrm{~mL})$; Monte verde, 20-25 July (d, \&, ?, MLZ); Las Ventanas, 24 July (o, MLZ). V. 8. parva (32): Mt. Puca, 18 Jan.-1 Feb. ( $0^{\circ}, 2$ ?', MCZ); Cérró Santa Bárbara, east slope, 28 Nov. ( $d^{\circ}$, LSUMZ); Lake Yojoa, 18-20 July (20", CM); 4 mi. SE La Esperanza, 24 Jan., 31 Oct. (20, ${ }^{\circ}$, LSUMz); Soluteca, 9 April (o', 8 , AMNH); Cantoral, 2 May, 3 June, 25 July ( ${ }^{\circ}, q$, AMAH; 9 , MCZ); Cerro Cantorel, 28 June, 24-29 July (2d, \&, MCZ); Alto Cantoral, 2-12 Feb. (6o, \&, MCZ); La Flor Archaga, 17 July (o, MCZ); San Juanc1to, 2 Feb. ( 9, Lsumz); E1 Derrumbo, 16 July-9 Aug. (2。', 3\%, MCZ); "Honduras" [= probably Cantoral region], 24 Apri1 $(q, \mathrm{MCZ})$ ?

PUBLISHED RECORDS.--Las Ventanas, Monte Verde, Montafia E1 Chorro (Moore, 1941: 38).

occurring from 3,000 to 7,500 feet, the Crescent-chested Warbler is a fairly common resident in cloud fores ts and pine-oak associations in the interlor highlands of Honduras. Specimens from the republic, except those from the Department of Ocotepeque, are representative of the smaller, southern race, $\underline{V}$. s. parya Miller and Griscom, heretofore recorded only from Nicaragua. Wings of the Honduran specimens not including those from ocotepeque measure as follows: o, 52.3-60.0 (57.1); $7,45.1-59.0(53.9)$. The $81 x$ birds 
from Ocotepeque are decidedly larger and are assigned to the Guatemalan race, v. s. superciliosa (Hartlaub). Their wings measure as follows: o, 61.2, 64.4; \$, 54.5, 60.9; questionable sex (probably male and female, respectively), $64.5,54.5$.

\section{Parula americana (Linnaeus)}

Parula Warbler

SPRGIMENS.--(20): Swan Is lands, 2-28 Feb. ( $9, \mathrm{MCZ}$; $\left.2{ }^{\circ}, 2,2\right\}$, USTY); Roatán Island (5?, BMNH); French Harbor, 6 April (o, CM); Bonacca [= Guanaja] Is land (6?, BMNH); Little Hog Island, 7 April. ( $\sigma^{\circ}$, LSUMZ); B1g Hog Island, 8 Apri1 ( $d$, Lsuez).

PURLTSHAD RECORDS-- - Swan Is lands (RIdgway, 1888c: 575; Paynter, 1956: 106) Roatán Is land, Bonacca [= Guanaja] Island (Salvin, 1888: 247).

The Parula Warbler is an uncommon migrant and winter visitant in the islands off the north coast of Honduras. It probably reaches the mainland on occasion, but there are no records at present.

C. H. Townsend (RIdgway, 1888c: 575) obtained five specimens in the Swan Islands in February 1887, and George Nelson (Paynter, 1956: 106) secured another there on 28 February 1912. George F. Gaumer (Salvin, 1888: 247) collected the series from Guanaja and Roatán 18lands; Arthur C. Twomey obtained one at French Harbor on Roatán Island in 1947. I observed one on Little Hog Island on 7 April and two on Big Hog Island on 8 April 1963; the two specimens listed above were collected on these dates. 
I do not recognize any of the several named races in this species.

Parula pitiaymi (Vielllot)

Olive-backed Warblex

SPECIMENS.--P. p. inornata $\times$ spec1osa (44): Portillo Grande, J Jan. ( $\sigma^{\prime}$, CNHM); San Esteban, 22 June ( $0^{\circ}, C M$ ); San José de Santa Bárbara, 5 May (ó, MCZ); $5 \mathrm{mt}$. SW E1 Jaral, 26-28 oct. (q, \& skel., Lstuz); Finca Fé, 22 April, 4 Sep. ( ${ }^{\circ}$, Imm., LSLAZ); Lake Yojoa, 18 June-23 Aug. (5o, CM); 2 mi. N Pito Solo, 25 Oct. (q, LSuMZ); San Marcos de Guaimaca, 2-4 July (40", 29, AMHH; $\sigma^{\circ}, 48$, ?, MIZ; $30^{\circ}, 28$, MCZ); Guaimaca, 6 June (?, MCZ); Alto Guaimaca, 5-12 June (20, 2?, AMaNH; o, MLZ; $\sigma^{\circ}$, MCZ); Monte Redondo, 4 July (d, AMNH); Rfo Vallecillo, $26^{2} \mathrm{July}$ (\&, UF); E1 Boquerón, 3 Aug ., 20 Sep. (2o, ANSP; $\delta$, AMNH); San Francisco, Choluteca, 12 Feb., 11 oct. (2\%, Istak)? $1955 \mathrm{a}: 89)$.

PUBLISHED RECORD.--"Honduras" [in range] (Eisenmann,

Although this warbler is regarded as exceedingly rare in Guatemala (Griscom, 1932b: 327) and has been recorded only a few times in Nicaragua, the species is an uncommon to fairly common resident in the interior of Honduras. Ranging from 2,000 to 6,000 feet, it inhabits open broadleaf forest (mostly cloud forest and pine-oak associations), second growth, and occasionally scrub.

Eisenmann (1955a: 89) Included Honduras in the range of the species on the basis of the specimens in the American Museum of Natural History.

This species may eventually prove to be conspecific

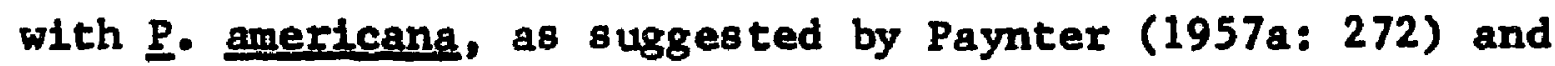
Pht1lips (1962a: 365). 
Taken as a series, Honduran material is intermediate between the northern P. $\mathrm{P}$. Inomata Baird and the southern P. P. speclosa (Ridgway). Most Honduran specimens approach Inornata more closely in intensity of the orange-ochraceous wash on the breast in the males; a few Individuals, however, are much more highly colored, both above and below, than typical inornata. Over-al1, I feel that the best procedure is to consider the Honduran populations intermediate, probably closer to inornata.

\section{Peucedramus taentatus (Du Bus)}

\section{Olive Warbler}

SPECIMENS.--P. E. micrus (50): Port1110 Grande, 3 July ( $\&, M C Z$ ); San Esteban, 24 June (juv . ${ }^{\circ}, C M$ ); Monte Verde, 22 July ( ${ }^{\prime}$, q, MLZ); Siguatepeque, 31 July ( $\left.{ }^{\prime}, C M\right)$; $4 \mathrm{ml}$. SE La Esperanza, 23 Jan. ( ${ }^{\prime}$, LSUMz); Cantora1, 2 March, 12 May ( 8, AMNH; o, USNM); Cerro Cantoral, 18 June-14 July,

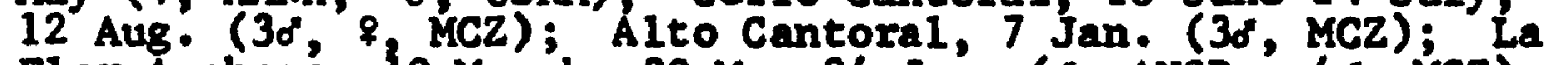
Flor Archagá, 10 March, 30 May-24 June ( $0^{\circ}$, ANSP; 40, MCZ); San Juancito, 25 June (7, CM); Rancho Quemado, 19 March, 5 April ( $\sigma$, AMNH; 9, MCZ); E1 Derrumbo 15 July, 3-9 Aug. (\%. ANSP; 20, 28, MCZ); E1 Hat1110, 22 Apr11, 29-30 June, 31 'July-17 Aug. (5d, 3\%', imm. \&, 1mm: \&, CM; \&, USN); Bi Picacho, 28-29 Sep. (20,\%, AMnH); Cerro Higuito, D.C., 22 Apr11, 19 June-15 July (5o, \&, AMNH); $18 \mathrm{ml}$. NW Teguci: galpa, 17 oct. (d, LSLiz); Port1llo de Los Arados, 5 July (?, UF). 1955a: 89).

PUBLISHED RECORD.--"Honduras" [in range] (Eisenmann,

Ranging from 3,000 to 7,000 feet, the Olive Warbler is a fairly common resident in $p$ ine and in pine-oak associations in the interior of Honduras.

For a discussion of the taxonomic position of the genus Peucedramus, see George (1962: 1-41). 
Honduran specimens are representative of the southern race, $\mathrm{P}$. ․․ micrus Miller and Griscom, which differs from the nominate race, $\underline{P}$. $t$ - taeniatus (Du Bus), in average smaller size and more golden tawny crown.

\section{Dendrolca petechia (Linnaeus)}

\section{Yellow Warbler}

SPECIMENS.--D. D. mubloinosa (8): Little Hog Is land, 9 Apri1 (o, LStiz); Julian [= Tulián] (?, ANSP); La Celba, 17 May ( $\$, C M) ;$ Cofradla, 9 March ( $d$, MLZ); Las Peñitas, 29 Jan. ( $\delta$, MLZ); Monte Redondo, 30 Jan. ( $\$$, MCZ); Archaga, 3 Oct. ( $\$$ AMMH); San Lorenzo, 28 Sep. (o', MLZ). D. D. morcomi (13): Cofradla, 5 March ( 9, Miz); Las Peñitas, 29 Jan. (? MIZ); Monte Redondo, 29 Nov.-1 Dec. (2?, MCZ); Comayagúela, 1 Nov. ( $q, ?$, MCŹ); San Lorenzo, $27-29$ Sep. (7, AMMH; ?, MIZ; \&, MCZ); Puerto Salamar, 12 Feb., 1 oct. (imm. o, Imm., LSUK); $5 \mathrm{mi}$. NE Cholutecs, 13 Oct. (8, LSUMZ); Honduras-Nicaragua boundary [near Pacific coast] ( $?, \mathrm{MCZ}$ ). D. R. destiva (35): vtila Is land, 18-19 April (5o, \&, CM); French Harbor, 3-5 Apr11 ( $0^{\circ}, 39, \mathrm{CM}$ ); Oak Ridge, 8 April (o, CM); Barbareta Ialand, 10 April ( ${ }^{\circ}$,

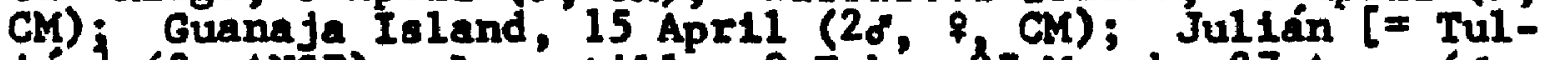
lán] (?, ANSP); Lancetilla, 9 Feb: 27 March, 27 Aug. ( 8 , ANSP; of, \&, MCZ); La Celba, 3-23 Jan. (20, MCZ); Truj1110, 30 March, 20-23 Sep. ( 8, CM; o, \$2 USNC); Finca Fé, 3-12 Sep. (7, Imm. of, LSUMZ); Archaga, 23 Sep. (8, AMLNH); Comayaguela, 30 March ( ${ }^{\prime}$, MCZ); Puerto Lemplra, 6 ' Feb., 12 Apri1 (o, Imm, LSUMZ); San Lorenzo, 27-29 Sep. (o, $\%$, AMNH; 6 , MLZ); Puerto Salamar, 1 Oct. (8, LSuyz); Honduras-Nicaragua boundary [near Pacific const] (?, MCZ). D. P. amnicole (4): La Celba, 20 Jan. (o, MCZ); Trujtillo, 26 Sep. (7, USRM); Subirana, 19 Dec. (o, MCZ); E1 Boquerón, 28 Sep. (d, AMNH). Indetermined (20): Uttla Is land, 28 Nov. (1mm. Bkel., ISUaz); Roatan Is land (15?, BMNH); Yeguare River Valley, 2-7 Feb, 22 Sep. ( ${ }^{\prime}, q, ?$, UF); Rlo Choluteca, Dept. EI Paraíso, 11 Aug. ( $q$, UF).

PUBLTSHED RECORDS.--San Pedro region (Sclater and Salvin, 1870b: 836). San Pedro (Salvin and Godman, 1881: 1243. Truj1110 (Ridgway, 1888c: 579). Roatán Island (Salvin, 1888: 247; Hellmayr, 1935: 365). La Celba (Bangs, 1903: 153). Lancet11la (Peters, 1929b: 462; Stone, 1932: 333). 
The Yellow Warbler is a common migrant and winter visitant in Honduras, occurring up to an elevation of 6,000 feet. It inhabits scrub, second growth, forest edge, semiopen situations, and mangroves, being espectally comon in the vicinity of water; it is also frequent around human habitation. In migration and infrequently in winter, it occurs in the islands off the north coast. It is perhaps the most common migrant warbler in the lowlands of Honduras but is decidedly uncommon above 2,500 feet. For Honduras extreme dates of arrival and departure are 11 August and 10 May.

The current tendency among taxonomists has been to consider the three allopatric groups of forms in this complex as a single spectes, D. petechia. I doubt that the resident mangrove-inhabiting group (erithachorides) is really conspecific with petechia. However, the group of races once considered as $\mathrm{p}$. aestive (Gmelin), which Includes all the migrant races that occur in Honduras, is not distinguishable either morphologically or ethologically from petechia and will be regarded herein as conspecific with the latter.

Presumably all the North American races of the species north of Mexico reach Honduras in migration. Identification of females and immatures in migration and in winter is at best an educated guess. The assignment of specimens to the various races, with the exception of the adult males, 
must be regarded as tentative. The Newfoundland race, D. R. amnicola Batchelder, and the eastern race, D. p. aestiva (Gmelin), occur primarily on the Caribbean slope and in the 1slands of $f$ the north coast, while the western races, D. $p$. rubiglnosa (Pallas) and D. p. morcomi Coale, occur mainly on the Pacific slope and in the interior. A specimen from San Lorenzo taken on 27 September 1932 was previously identified by Ludlow Griscom as D. D. sonorana Brewster, but I feel that it is nearer morcomi; at present there is no record for sonorana in Honduras although it probably winters on the Pacific coast. The race $\mathrm{D}$. $\mathrm{p}$. brewster $\mathrm{Grinnell}$ is considered by most authors to be a symonym of morcomi.

\section{Dendroica ertthachortdes Baird \\ Mangrove Warbler}

SPECIMENS.--D. e. bryanti (6): Bonacca [= Guanaja] Is land (6?, BMNH) D. e. Xanthotera (47): San Lorenzo, 26

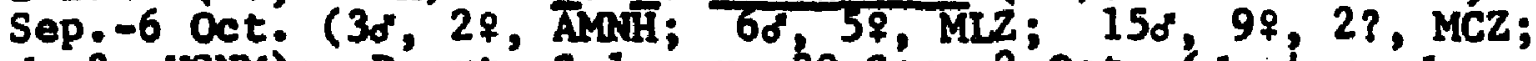
$d, ?$, USNM); Puerto Salamar, 30 Sep. -2 Oct. ( ${ }^{\circ}$, lmm. $\delta$, imm. 9?, Lsimz).

1888 : 248).

This warbler is a common resident in mangroves along the Pacific coast of Honduras. In addition, George F. Gaumer (Salvin, 1888: 248) reported it from Guanaja Island In the Bay Islands and collected the $81 x$ specimens 118 ted above, but Bond (1936: 363-364) falled to find it there and considered Gaumer's record to be in error as to locality. On the other hand, Bond falled to find vireo magister on 
Utila Island, where it was common in 1963. There is a possibility that these species may have been overlooked or that their populations are subject to change in a relatively short time. Since the habitat on Guanaja is ideal for the species, I see no reas on for not accepting Gauner's record at face value.

The Mangrove Warbler was 118 ted from "Honduras" by Baird, Brewer, and Ridgway (1874b: 218), apparently on the basis of a spectmen in the British Museum taken on MHalfMoon Cay, Honduras" and 118ted by Sharpe (1885: 645). Half-Moon Cay, of course, is now part of British Honduras.

For retention of this warbler as a full species, see the discussion under $\mathrm{p}$. petechia.

Specimens from Guanaja Island are typical of the Caribbean race, $\mathrm{D}$. e. bryanti Ridgway. Pacific coast populatlons represent the slightly smaller, darker-backed, D. e. xanthotera Todd.

\section{Dendrotca magnolia (Wilson)}

\section{Magnolla Warbler}

SPACIMENS.--(63): Utila Island, 18-19 April (2d, CM); Roa tán Island (6?, BMNH); Oak Ridge, 8 April (d, CM); Guanaja Island, 24 March, 13 April (28, CM); Lancetilla; 2 Feb., 27 March (20, MCZ); La Celba, 6-9 Jan. ( $8,8 ?$, MCZ); Yaruca, 26 Feb. (d?, MCZ); Truj1110, 6-9 April, 27 Sep. (20, CM; ?, USNM); Catacombas, 31 March (o, AMNH; ? MLZ); Cofradía 7-11 March (20,39, 3?, ANLH; \%, MLZ); Las Peffitas, 3-15 Feb. ( ${ }^{\circ}, ?$, AMNH; 28, ?, MLZ); Chamelecón, $24 \mathrm{Feb}$. (?, USNM); 4 mi. N Río Lindo, 29 Nov. (1mm. of, LSULZ); Subirana, 17 March (d, MCZ); Cerro Higuito, Santa Bárbara, 25 April ( $\%$ AMNH); San José de Santa Bárbara, 1730 April (2d, 2\%, AMNH); Finca Fé, 19 Jan., 20 oet., 2 Dec. (Imm. o, d'? ske1., alc., LsuMz); Montafia Vásquez, 5 Feb. 
(?, MCZ); Cantoral, 9-13 April ( $d, \&$, AMNH); Cerro Cantoral, 29 March (?, MCZ); Alto Cantoral, 1 March (o, AMNH); Archaga, 3 March ( $\$$, AMNH); E1 P1cacho, 1 Oct. (2\%, AMNH); Cerro Higuito, D.C.; 28 April (d, AMNH); Tegucigalpa, 9-10 April ( $30^{\circ}, 7$, AMNH); Yeguare River Valley, 7 Feb., 7 Nov. ( $\$, ?$, UF); E1 Boquerón, 21 Oct. ( 8 , AMNH); "Honduras" (?, AMNH).

PUBLTSHED RECORDS.--Trujil lo (RIdgway, 1888c: 579). Roatan Island (Salvin, 1888: 249). La Celba, Yaruca (Bangs, 1903: 153). Lancetilla (Peters, 1929b: 463).

The Magnolia Warbler is a common migrant and winter visitant in Honduras, ranging up to an elevation of at least 5,000 feet. It is most common in the Caribbean lowlands and in the islands off the north cosst, but it is of regular occurrence in the interior and on the Pacific slope. The species inhabits open broadleaf forest, forest edge, second growth, and occasionally scrub. In Honduras extreme dates of arrival and departure are 27 September and 7 May.

\section{Dendrolca tigrina (Gmelin)}

\section{Cape May Warbler}

SPECTMINS.--(3): Swan Islands, 22 March (d, MCZ); Roatán Island (?, BMNH); Guanaja Is land, 24 March ( $\left.\sigma^{*}, C M\right)$. PUBLISHED RRCORDS.--Roatán Is land (Salvin, 1888: 251). Swan Islands (Paynter, 1956: 106).

This warbler has been recorded in Honduras only as a rare migrant in the 18 lands off the north coast. It is known from three records, a specimen collected in 1886 or 1887 on Roatán Island by George F. Gaumer (Salvin, 1888: 251), a male taken in the Swan Is lands in 1912 by George Nelson (Paynter, 1956: 106), and a male obtained on Guana ja Is land in 1948 by Arthur C. Twoney and Roland W. Hawkins. 


\section{Dendrotca caerulescens (Gmelin)}

Black-throated Blue Warbler

SPEC IMENS.--D. c. caerulescens (2): Swan Islands, 9-29 Feb. (\%, MCZ; o", USTM).

PUBLTSHED RECORDS.- -Swan Is lands (RAdgway, 1888c: 575; Fisher and Wetmore, 1931: 20; Paynter, 1956: 106).

Otherwise unreported from Honduras, the Black-throated Blue Warbler is a rare migrant and winter visitant in the Swan Is lands. C. H. Townsend (Ridgway, 1888c: 575) secured a male on 9 February 1887. George Nels on (Paynter, 1956: 106) collected a female on 29 February 1912. A. R. Fisher (Fisher and Wetmore, 1931: 20) observed several there on 19 Apr\$1 1929.

I have examined both Honduran specimens and consider then to represent the widespread, nominate race, D. c. caerulescens (Gmelin). The American Ornithologists' Unton (1957: 491) considered the Townsend specimen to be referable to the race $D$. c. calrnst Coues, but I cannot detect any differences in this specimen when compared with examples of the nominate race. The subspecies cairnst is based on darker coloration above and 18 not a very good race; perhaps the spectes should be regarded as monotypic.

\section{Dendroica coronata (LInnaeus)}

Myrtle Warbler

SPECIMENS.--(62): Swan Is lands, 2-9 Feb., 14-22 March (39, MCZ; F, ;, 2 ?, USNM); Utila Island, 25 Jan., "Spring" ( ${ }^{\prime \prime}, ?$, CNEM); Roatán Island (19?, BMNH; o, 7, CNHM); Little Hog Island, 9 April ( 8 , LSUMz); Lancetilla, 13 March ( 5, MCZ); La Celba, 21-23 Jan. (3o, MCZ); Cofradla, 6-10 
March (47, AMNH); San Pedro (2?, BMNH); Las Peñttas, 25 Jan.-2 Feb. (6 6 , 2\%, ?, AMNH); Subirana, 7 Dec. -10 Jan. (40, ?, MCZ); 1 mi. SW E1 Jara1, 27 Apri1 (?, LSUMZ); Finca Fé, 14 Jan. (imm. \%, LSUMZ); Pito Solo, 15 Dec. (?, LSUMZ); $4 \mathrm{mi}$. SE La Esperanza, 23-24 Jan. ( $9, ?$, ISUMZ); Cerro Vásquez [= Cerro Cantoral], 6 March ( 9, AMNH); La F1or Archaga, 9 March ( 9 , AMNH).

PUBLISHED RECORDS.--San Pedro region (Sclater and Salvin, 1870b: 836). San Pedro (Salvin and Godman, 1881: 127; Sharpe, 1885: 649). Swan Islands (Ridgway, 1888c: 575; Lowe, 1909: 337; Paynter, 1956: 106). Roatán Is land (Salvin, 1888: 248-249; Hellmayr, 1935: 390) La Ceiba (Bang8, 1903: 153). Lancet11la (Peters, 1929b: 463).

The Myrtle Warbler 18 a common migrant and winter visitant in Honduras, occurring primarily in the Caribbean lowlands, In the islands off the north cosst, and in the interior up to 6,500 feet elevation; it is decidedly uncommon in the Pacific lowlands below 3,000 feet. It is found in almost any scrub or open forest situation. For Honduras extreme dates of arrival and departure are 2 November and 7 May.

While there is a definite cline in North American breeding populations from west to east (larger to smaller size), the overlap in measurements is 80 great that only about 15 per cent of the specimens can be assigned to race. I therefore prefer to regard the species as monotypic, with D. c. hoover1 McGregor being a synonym of the nominate form. Honduran specimens on the whole average smaller and are probably mostly from the eastern part of the breeding range. 


\section{Dendroica audubont (Towns end)}

Audubon's Warbler

SPECTMENS.--D. a memorabilis (4): $4 \mathrm{mi}$. SE La Esperanza, 22-24 Jan. $(\%, 2 \%$, LSLMZ); $6 \mathrm{ml}$. SE La Esperanza, 30 Oct. (o, LSUMZ).

Although not previously ascribed to Honduras in the 1iterature, the Audubon's Warbler is an uncomon to rare winter visitant, occurring mainly in pine-oak associations from 4,500 to 6,500 feet elevation. It has also been reported in the Caribbean lowlands.

Mark Trafton, Jr., observed the species at Lancetilla in February 1953 and February 1955, and at Lake Yojoa in December 1954 and December 1955. On 30 October 1962 I saw a flock of about 12 near La Esperanza, from which the first Honduran specimen was secured. From 22 to 24 January 1963 the species was fairly common in this same pine-oak region near La Esperanza, and three more were obtained, a female on 22 January and a pair on 24 January. There are no other records for Honduras.

This form may eventually prove to be conspecific with D. coronata, but until intergradation is shown to be the usual situation, I am maintaining the two as distinct species.

Honduran specimens material from western North America in coloration; and, because of their large size, I refer them to the Rocky Mountain race, D. a. memorabilis Oberholser. Wings of the Honduran specimens measure as 
follows: $\delta, 81.1,85.2 ; 9,75.2,75.5$. The races ㅁ. ‥ audubont (Townsend) and $\underline{D}$. ‥ nigrifrons Brewster have been recorded in winter as far south as Guatemala.

\section{Dendroica townsendi (Townsend)}

Townsend's Warbler

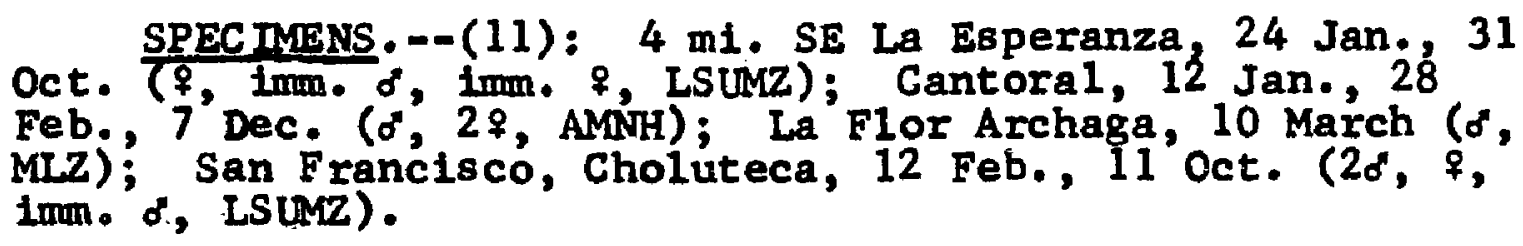
1955a: 90 ).

Ranging from 3,000 to 7,000 feet in the interior of Honduras, this warbler is an uncommon to fairly common migrant and winter visitant in pine-oak associations, pine, and cloud forest. For Honduras extreme dates of arrival and departure are 11 October and 10 March.

Eisenmann (1955a: 90) Included Honduras in the range of the species on the basis of specimens in the American Museum of Natural History.

\section{Dendroica virens (Gnelin)}

\section{Black-throated Green Warbler}

SPECTMENS.--(68): Guana ja Island, 22 March, 15 April (20, ${ }^{\circ}$, CM) ; Catacombas, 26 March ( $\%$, AMNH); Cofradía, 9 March (o, Miz); Las Peñitas, 2-25 Feb. (10o', 4q, 2?, AMiNH; 30, \&, MLZ); Subirana, 11-27 DeC. (20, MCZ); Portilio Grande, 30 Jan., 16-30 March ( $\sigma^{\prime}$, CNHM; 2o, $\delta^{\prime}$, \&?, MCZ); Mt. Puca, 6 Feb. ( $d$, AMNH); Cerro Santa Bărbara, east slope, 1-7 Dec. (d, q?, LSÚmZ); Finca Fé, $20 \mathrm{Feb}$, $20 \mathrm{sep}$. (imm.; alc., LSuMz); $7 \mathrm{ml}$. N Valle Bonito, 2 Nov. (s", LSUMZ); $4 \mathrm{mi}$. NW S1guatepeque, $16 \mathrm{Feb}$. (o'? Lsumz); $4 \mathrm{ml}$. SE La Esperanza, 24 Jan. (imm. o, LSUMz); Montaña Vásquez, 2 Jan. (8', MCZ); Cantoral, 2 March, 9 Dec. (2\%, AMNH); 
Cerro Cantoral, 26 Nov., 13 Dec. (20, MCZ); Alto Cantoral, 4 Feb. ( $d^{\circ,}$ AMNH); Monte Redondo, 23 March, 23 Nov. -12 Dec.

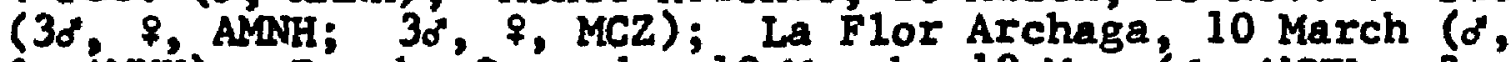
q. AMNH); Rancho Quemado, 19 March, 19 May (o', AMNH; ?, MCZ); EI Hatillo, 22 April (2\%, MCZ); EI Picacho, 29 Sep. (o", AMNH); Cerro Higuito, D.C., 5 Oct. ( 9 , AlNH); Tegucigalpa, 4 Oct. ( $\sigma^{\circ}$, AMNH); Yeguare River Valley, 20-27 Jan., 18 Nov. ( $\%, 2 ?$, UF); Dan1 1,7 April ( $\sigma^{\circ}$, BMNH); San Francisco, Choluteca, 14 oct. (o" skel., Lsumz).

PUBLTSHED RECORD.--Utila Is land (Bond, 1936: 354).

The Black-throated Green Warbler is a common migrant and winter visitant in Honduras. In migration it is most plentiful in the Caribbean lowlands and in the islands off the north coast, while in winter it is usually found in pine, pine-oak associations, and cloud forest from 2,500 to 8,000 feet. Extrene dates of arrival and departure in Honduras are 20 September and 19 May.

I consider the supposed Atlantic coastal race, D. $y$. Laynei Bangs, to be invalid since even breeding specimens cannot be allocated with any certainty. I therefore regard the species as monotypic.

\section{Dendroica chrysoparia Sclater and Salvin}

Golden-cheeked Warbler

SPECTMENS.--(7): $4 \mathrm{ml}$. SE La Esperanza, 22-24 Jan. (20, \%, IStivz); Cantoral, 10 Feb., 28 Nov. -9 Dec. (d, \&, AMNH; d, YPM); Cerro Cantora 1, 7 Dec. ( 9, MCZ). $1955 a: 90)$.

PUBLISHED RECORP.--"Honduras" [in range] (Eisenmann,

This rare to uncomon winter visitant is confined in Honduras to pine-oak associations in the interior from 5,000 to 6,500 feet. The species, which breeds in Texas, has 
been recorded once as far south as northern Nicaragua. At Cerro Cantoral, C. F. Underwood collected a female in 1931; at Cantoral, he obtained single males on 10 February 1935 and 28 November 1936 and a female on 9 December 1936. Near La Esperanza in 1963, I secured single males on 22 and 23 January and a female on 24 January; I also observed two additional males during this three day period. These records are the only data for Honduras.

Eisenmann (1955a: 90) Included Honduras in the winter range of the spectes on the basis of the two specimens in the American Museum of Natural H1story.

\section{Dendroica occidentalis (Townsend)}

Hermit Warbler

SPECTMENS.--(19): Port1110 Grande, 14 March ( ${ }^{*}, \mathrm{MCZ}$ ); $4 \mathrm{mi}$. SE La Esperanza, 24 Jan. (imm., LSLMz); Montana Vásquez, 22 Nov. ( $\$$, AMaNH); Cerro Cantoral, 7-9 Dec. ( ${ }^{\prime}, q$, 2?, MCZ); Alto Cantoral, 7 Jan. (d, MLZ); Monte Redondo, 5 Sep., 9 Dec. ( 8, AMNH; \&, MCZ); La Flor Archaga, 11 March (o, AMNH; of, MiZ); E1 Picacho, 28-29 Sep. (o, \&, AMNH); $18 \mathrm{mi}$. NW Tegucigalpa, 17 Oct. (d, Lsum); Cerro Higuito, D.C., 7-14 Oct. (o, 2\%, AMNH); La Montafilta, 12 Feb. (?, UF). 1955a: 90).

PUBL,ISHED RECORD..-"Honduras" [in range] (E1semmann,

Dendroica occidentalis is a fairly common migrant and winter visitant in pine, pine-oak associations, and cloud forest in the interior of Honduras, ranging from 4,500 to 7,500 feet elevation. It is most frequently encountered in pine. In Honduras extreme dates of arrival and departure are 28 September and 14 March. 
Eisermann (1955a: 90) based the inclusion of Honduras in the winter range of this species on the series in the American Museum of Natural History.

\section{Dendrolca cerulea (Wils on)}

Cerulean Warbler

SPECTMENS.--(10): Little Hog Island, 10 April ( ${ }^{\circ}$, LSUMZ); Puerto Cabalios [= Puerto Cortés] (2?, ANSP); Finca Fé, 1-13 Sep. ( $\delta, ?, 1 \mathrm{~mm} .$, imm. alc., LSUMZ); Lake Yojoa, 23 Aug. (d, CM); Yeguare River Valley, 16 Aug., 7 Sep. ( $q$, imen., UF).

PUBLISHED RECORD.--San Pedro region (Sclater and Salvin, 1870b: 836). San Pedro [= Puerto Cortés] (Salvin and Godman, 1881: 130-131).

This warbler is an uncommon to rare migrant in Honduras, occurring primarily in the Caribbean lowlands below 2,500 feet. There are two specimens from the Yeguare River Valley on the Pacific drainage at about 2,600 feet elevation. The species frequents open rain forest, forest edge, and second growth. In the spring, there is but a single record for Honduras, a male that I collected on Little Hog Is land, in the Cayos Cochinos, in 1963. During September and October 1962, the spectes was uncommon but regular at Finca Fé, near Lake Yojoa. For Honduras in the fall, extreme dates of arrival and departure are 16 August and 12 october.

\section{Dendrolca fusca (Müller)}

Blackburnian Warbler

SPEC TMENS:--(26): Utila Island, 18 April (20, CM); Roatán Island (2?, BMNH); Bonacca [= Guanaja] Island (?, 
BMNH); Finca Fé, 1-20 Sep. ( $0,9, ?, 4$ alc., LSUMZ); Lake Yojoa, 23 Aug. ( $\%$, CM); Archaga, 24-27 Sep. ( $8, \%$, AMNH); E1 Picacho, 28 Sep.-1 óct. ( $\delta, 2 \%, A M N H) ;$ Cerro Higuito, D.C., 19 April (o, AMNH); Tegucigalpa, 10 Oct. (o, AMNH); Yeguare River Valley, 10 March, 6 Sep. (2?, UF); E1 Boquerón, 8 Sep. (?, AMNH); San Lorenzo, 26-30 Sep. (d, ?, MCZ); Honduras-Nicaragua boundary [near Pacific coast] (?, MCZ).

PUBLISHED RECORDS--Roatán Island, Bonacca [= Guanaja] Island (SaIVIn, 1888: 249-250). Swan Islands (Fisher and Wetmore, 1931: 20).

The Blackburnian Warbler is an uncommon to comon migrant through Honduras, occurring in the lowlands of both coasts and in the interior up to 3,500 feet; it is also a regular transient in the 18 lands off the north coast. In the intertor and on the Pacific slope it is decidedly uncommon, while in the Caribbean lowlands and in the 1slands off the north coast it is common in the fall migration and fairly common to uncomon in spring. The species is found in open rain forest, forest edge, and second growth. For Honduras extreme dates of arrival and departure are 10 March and 6 May for spring and 23 August and 21 October for fall.

\section{Dendroica dominice (Linnaeus)}

\section{Yellow-throated Warbler}

SPECIMENS.--D. d. albtlora (27): Roatain Island (3?, BMNH); Bonacca [= Guanaja] Is land (3?, BMNH); Lancetilia, 18 Jan. (?, MCZ); Truj111o, 26 Sep. (f, USKY); Lako Yojoa, 13 Aug. (o, CM); $15 \mathrm{ml}$. NW S1guatepeque, 15 Aug. $\left(\sigma^{*}, C M\right)$; $2 \mathrm{mi}$. NN Zambrano, 24 Aug. (Imm. o, LSUiz); Cantoral, 2 March, 9 Dec. (2\%, AMNH); Cerro Cantora1, 7 Aug., 7 Dec. (20, MCZ); Monte Redondo, 9 Dec. ( $\sigma^{\circ}$, MCZ); EI Derrumbo, 3-

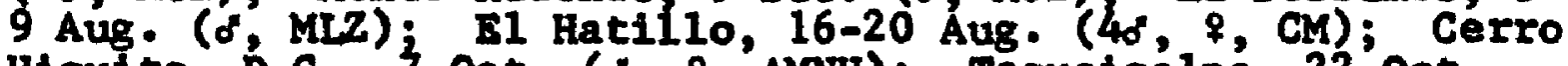
Higuito, b.C., 7 Oct. (o, $\%$, AMNH); Tegucigálpa, 22 Oct. (\%, AMNH); Río Hondo, 18 Aug. ( $\%, C M)$; road to Giinope, 4 Aug. (, UF). D. d. dominlea (1): Swan Is lands, 29 Feb. $(\%, \mathrm{MCZ})$. 


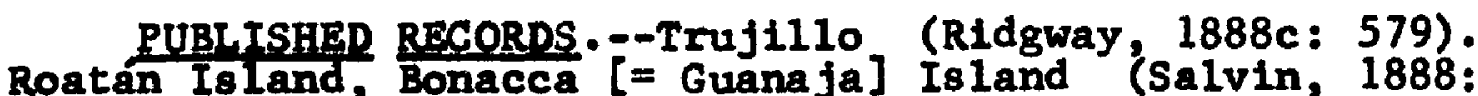
150). Swan Islands (Lowe, 1909: 337; Paynter, 1956: 106). Near Lancetilla (Peters, 1929b: 463).

The distribution of this wintering spectes of warbler In Honduras does not conform to the general rule that species that breed in the eastern United States winter in hardwood forests of the Caribbean lowlands and those that breed in the western United States winter in the interior highlands. A fairly common migrant and winter visitant in Honduras, the Yellow-throated Warbler inhabits, for the most part, pine between 2,000 and 6,000 feet elevation. During migration it is fairly comon in the Caribbean lowlands and in the islands off the north coast, especially in the fall. In August the north coast is often deluged with individuals of this species. A few individuals also winter in the Swan Islands, but these birds are from breeding populations of the southeastern United States that winter primarily in the West Indies. Extreme dates of arrival and departure in Honduras are 4 August and 11 April.

The single specimen from the Swan Islands, taken in 1912 by George Nelson, is a typical example of the largerbilled, yellow-lored race, D. d. dominica (Linnaeus). I assign all other Honduran specimens to the smaller-billed, white-lored race, D. d. albilora RIdgway, although several of the birds from Roatán and Guanaja lslands have traces of yellow on the lores and should perhaps be regarded as intermediates . 
Dendroica graclae Baird

Grace's Warbler

SPECIMENS.--D. g. remota (109): Subirana, 21 Jan., 10 March, 21 Dec. ( $\sigma^{\circ}, 3 \%$, MCZ); Portillo Grande, 20 Aug., 3 Nov. (7, CNHM; of,?, MCZ); San Esteban, 24 June (60; 49, imm. o, Juv. $\delta$, CM); Plan del Rancho, 9 July (?, MLZ); Lake Yojoa, 12 June ( $\left.d^{\circ}, C M\right)$; Siguatepeque, 31 July ( $\left.\$, C M\right)$; $5 \mathrm{ml}$. NW Siguatepeque, 22 Jan. ( $\sigma^{\prime}$, LSUMZ); $4 \mathrm{mi}$. NW Siguatepeque, $16 \mathrm{Feb}$. ( $\delta$, LS Laz); $3 \mathrm{mi}$. W Zambrano, 17 0ct. (of, LSIMZ); Cantoral, 2 March, 30 June, 12 July (20, $\$$, AMNH); Cerro Cantoral, 23 July-8 Aug. ( $40^{\circ}, 8, \mathrm{MCZ} ;$; USNM); Alto Cantoral, $7 \mathrm{July}$ ( $\sigma^{\circ}, \mathrm{MCZ}$ ); Monte Redondo, $8 \mathrm{sep.}\left(\alpha^{\circ}, \mathrm{MCZ}\right.$ ); La Flor Árchaga, 12 Jan., 9 March, 27 May-17 July (of, AMNH; 98, 4\%, 4?, MCZ; d, USNM); San Juancito, 18-22 July, 12 Aug. ( $3 \alpha^{\prime}, ?$, ANSP); E1 Derrumbo, 3-9 Aug. ( $40^{\circ}$, $q$, AMNH); E1 Hatillo, 19 Apri1, 10 May, 29-30 June, 11-20 Aug. (90", 28, CM; 2\%, ?, MCZ); TIgre Hat1110, 30 June-15 July (8d', 29, AMNA); E1 P1cacho, 12 July, 28 Sep.-1 Oct. (7o, 3\%, AMMH); Cerro Higuito, D.C., 30 June, 7 Oct. ( $30^{\circ}$, AMNH); Tegue Igalpa, 11 Apri1, 7 Oct. ( $\%$, AMAH; d, BMNH); Uyuca, 15 Sep. ( 3 , UF); San Antonio road, $5 \mathrm{mi}$. E Escuela Agrícola Panamericana, 10 June (juv. \&, UF); road to San Antonio, 12 June ( $\delta$, UF); Yeguare River Valley, 12 June ( $q$, UF); road to Güinope, 4 Aup. (q, UF); Honduras " 5 April (d, MCZ). D. g. decora (13): Puerto Lempira, 8-14 Apri1 (78, 38, juv. o., Juv. \$, ISUMz); Segovia River, 17 July (?, USNM).

PU5) PUBLISHED RECORDS.--Segovia River (RIdgway, 1888c:

585). San Juneito [as decora] (Stone, 1932: 333). Tegucigalpa [as decora] (Gr1scon, 1935b: 548). Cerro Cantoral, San Esteban, and "Honduras" [as remota] (Webster, 1961: 564-565).

The Grace's Warbler is a falrly common to common resident in pine throughout Honduras, ranging primarily from 2,000 to 6,500 feet elevation, but descending in pine in the San Esteban region to 1,000 feet and reappearing at sea level in the pine savanna of the Mosquitia in eastern Honduras.

Sclater and Salvin (1873a: 9) included Honduras in the range of the species, but I do not know on what basis since 
I can find no definite record prior to that of Ridgway (1888c: 585).

The distribution of the races of this warbler follows the pattern exhibited by other species that inhabit pine in both the interior highlands and the Mosquitia. Webster (1961: 564-565) treated all Honduran and Nicaraguan specimens as belonging to the race D. g. remota Griscom [1935b: 548; Volcan Viejo, Chinandega, Nicaragua], which inhabits the interior highlands of Central America from southern Mexico to Nicaragua. Webster restricted the range of $\mathrm{D}$. $\mathrm{g}$. decora Ridgway to the pine ridges of British Honduras. A large series now avallable from the lowland pine savanna of the Mosquitia of eastern Honduras and northeastern Nicaragua 1s representative of the race decora, which differs from remota in the more orange-yellow, rather than yellow, throat and in slightly smaller size. Wings of males of decora from the Honduran Mosquitia measure 54.4-60.0 (56.2) as opposed to 57.9-62.0 (58.8) for Honduran examples of remota.

\section{Dendroica pensylvanica (Iinnaeus)}

Ches tnut-sided Warbler

SPECIMENS.--(29): Roatán Island (15?, BMNH); Bonacca [= Guanaja] Isiand (?, BMNH); BIg Hog Is land, 8 April (o', ISUMZ); La Ceiba, 29 Apri1 ( ${ }^{\circ}$, CM); Truj1110, 26 Sep. (?, USNM); Catacombas, 8 Apri1 ( 9 , AMNH); Cofradia, 9-11 March (29, MLZ); Amapa, 15 Jan. (d, ISLuZ); $5 \mathrm{ml}$. SW E1 Jara 1, 28 Oct. (alc., Lsumz); Finca Fé, 20-27 Oct., 2-11 Dec. (40", LSURZ); Ei Picacho, 1 Oct. ( $\$$, AMNH).

PUBLISHED RECORDS.--San Pedro region (Sclater and Sa1vin, 1870b: 836). San Pedro (Salvin and Godman, 1881: 132). Trujillo (RIdgway, 1888c: 579). Roatán Island, 
Bonacca [= Guanaja] Island (Salvin, 1888: 249). Roatán Is land (Hellmayr, 1935: 402).

Although the wintering of this species north of Nicaragua has not been generally recognized, it is a fairly common migrant and winter visitant in both Guatemala and Honduras. It is primarily a species of the Caribbean lowlands, occurring rarely in the interior to an elevation of 4,000 feet. In the 1slands off the north coast it is a transient only. The species prefers broadleaf forest but occurs in second growth and forest edge as well. Extreme dates of arrival and departure in Honduras are 10 September and 3 May.

\section{Dendrotca cestenea (Wilson)}

Bay-breas ted Warbler

SPECTMENS.--(5): Utila Is land, 3 May ( $\sigma^{\prime}, 7$, LSUMZ); Roatan Island (2?, BMNH); 2 mi. N Pito Solo, 27 Oct. (imm. i, LStMZ).

PUBLTSHED RECORD.--Roatán Island (Salvin, 1888: 249).

The Bay-breasted Warbler is an uncommon to rare migrant through the Caribbean lowlands of Honduras and in the Bay Islands. George F. Gaumer (Salvin, 1888: 249) collected two specimens on Roatán Island in 1886 or 1887 . On 27 October 1962 I obtained one female from a group of three individuals seen along the edge of Lake Yojoa near Pito Solo. Fram 3 through 10 May 1963, I observed the species on Utila Island, in the Bay Islands (maximum recorded, 10 on 
3 May); the two Utila Island specimens were secured on 3 May .

\section{Dendroica discolor (Vieillot)}

Prairie Warbler

SPECIMENS.--D. d. discolor (3): Swan Islands, 10 Feb. ( , USNM); Bonacca $[=$ Guanaja $]$ Island (2?, BMNH).

PUBT.ISHED RECORDS.--At sea near Swan Islands (Salvin and Godman, 1881: 142). Swan Islands (RIdgway, 1888c:

576). Bonacca [= Guanaja] Island (Salvin, 1888: 250).

Dendroica discolor is a rare migrant and winter visit-

ant in the islands off the north coast of Hoinduras. Salvin and F. D. Gaumer (Salvin and Godman, 1881: 142) reported the capture at sea of a young Prairie Warbler not far from the Swan Is lands in September 1861. C. H. Townsend (Ridgway, 1888c: 576) obtatned a female in the Swan Islands in 1887. In September 1886 or 1887, George F. Gaumer (Salvin, 1888: 250) collected two Individuals on Guanaja Island. There are no other Honduran records.

The Honduran specimens represent the nominate race, $D$. d. discolor (Vielllot).

\section{Dendroica yitellina Cory}

Vitelline Warbler

SPECIMENS.--D. y. nelsoni (58): Big Swan Island, 5 Jan. (40, CNIII); Swan Islands, 2 Feb. -20 April, 10-12 July

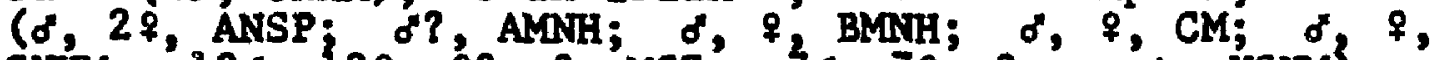
CNHM; 138, 13\%, क?, ?, MCZ; 4\%, 7\%, ?, nest, USNM).

PUBLISHED RECORDS.--Swan I81ands (Ridgway, 1888c: 576; Lowe, 1909: 337-338; Bangs, 1919: 494; Fisher and Wetmore, 1931: 20; Hellmayr, 1935: 410; Delacour, 1938: 544; 
Paynter, 1956: 106, 108). Little Swan Island (Bond, 1950: 144).

This warbler, the only resident passerine spectes in the Swan Islands at the present time, is common on both Big Swan and Little Swan is lands.

The Swan Islands population represents an endemic race, D. I. nelsoni Bangs [1919: 494; Swan Island (Caribbean sea) 1 .

\section{Dendrolca palmarum (Gmelin)}

Palm Warbler

SPECTMENS.--(15): Swan Is lands, 3-28 Feb., 21 March ( $\%$, 9, MCL; 7 3?, USNM); Roatán Is land (?, BMNH); Little Hog Island, 7-10 April (2\%, d'?, LSLMZ); Big Hog Island, 8 April (\%, \%?, LSUMZ); Puerto Lempira, 9-14 Apri1 (3\%, LSUMZ).

PUBLTSHED RBCORDS.--Swan Is lands (Ridgway, 1888c: 575; Lowe, 1909: 338 Paynter, 1956: 106). Roatán Is land (Salvin, 1888: 251).

The Palm Warbler is a fairly common winter visitant to the islands off the north coast and to the pine savanna of the Mosquitia in extreme eastern Honduras. The discovery of the species in the Mosquitia of northeastern Nicaragua by Thomas R. Howell (personal communication) was a distinct surpisise; he reported it as fairly common there in winter and obtained several specimens. In Apr11 1964 I found it to be fairly common around Puerto Lempira: I obtained specimens on 9, 11, and 14 April and noted several other individuals during this period. 
The spectes has been recorded from the Swan Islands, from Roatin Island in the Bay Islands, and from the Cayos Cochinos. Extreme dates of arrival and departure in Honduras are 3 February and 14 April.

I assign all Honduran material to the western race, D. p. palmarum (Gmelin), although one unsexed specimen from the Swan Is lands, taken by C. H. Townsend on 3 February 1887 , is rather yellow below and may be referable to either palmarum or the eastern race, D. p. hypochrysea Ridgway.

\section{Seturus aurocap1llus (Linnaeus)}

\section{Ovenbird}

SPRCTMENS.--S. ․ㅗ: gurocapil1us (25): Swan Is lands, 24-

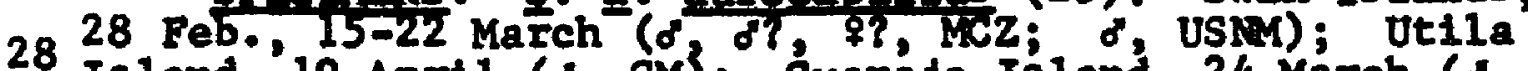
Is Is land, 19 Apri1 ( $\delta^{\prime}, \mathrm{CM}$ ); Guana ja Is land, 24 March ( $\delta^{\circ} \mathrm{CM}$ );

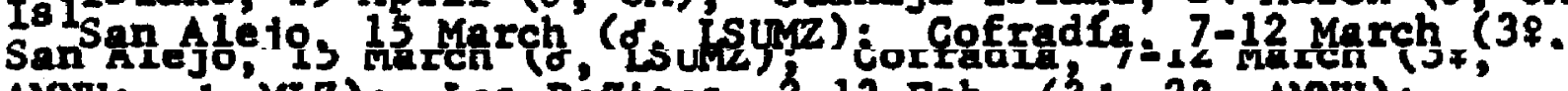
AMNH; o, MZ); Las Péfltas, 2-13 Feb. (3o, 2?, ANNH); Finca Fé, 22 Oct., 27 Nov.-11 Dec. (30, Istuz); Muye, 25 Feb. ( 9 , AMNH); Cantoral, 8 April (?, AMNH); Monte Redondo, 20 llov ( $\%$, MCZ); Comayaguela, 30 Oct. ( ${ }_{2}$, MCZ); E1 Boquerón, 19 Oet. ( $\%$, AMMH); Puerto Salamar, 2 oct. ( $($, LSUL). S. a. cinereus (2); Oak Ridge, 8 April (d, CM); E1 Hatil10, 19 April (?, MCZ). Indetemined (10): Rostán Island (7?, BMHE); Bonacca $[=$ Guanajal Island (3?, BMHA).

PUBL.TSHIR RECORDS.--Omoa (Moore, 1859: 55). San Pedro region (Sclacer and Salvin, 1870b: 836). San Pedro (Salvin and Godman, 1881: 144). Swan Islands (RIdgway, 1888c: 576; Paynter, 1956: 106). Roatán Island, Bonacca [= Guanaja] Island (Salvin, 1888: 251). Rear Tela (Peters, 1929b: 463). Monte Redondo [as clnervus] (Amer1can Ornithologists ' Union, 1957: 506).

In Honduras the Ovenbird is a fairly common migrant and winter visitant, occurring in the interior up to an elevation of 5,000 feet and on both coasts. It is found also in the islands off the north coast. It is a bird of forest 
undergrowth, generally in broadleaf forest or second growth. For Honduras extreme dates of arrival and departure are 2 October and 5 May.

The Newfoundland race, S. a. furvior Batchelder, is exceedingly poor and probably not worthy of taxonomic recognition; it is perhaps slightly darker-backed with more extensive black crown stripes, but there are no other differences in a serles of breeding birds that I examined. I have considered furytor as a synonym of $\underline{S}$. An- aurocaptllus (LInnaeus); one spectmen, however, collected at Cofradia on 7 March 1933 by C. F. Underwood, has been marked "furvior" on the label and would probably be referable to this race it It is recognized. The Rocky Mountain race, S. a. cinereus Miller [1942: 185; 4 miles west of Fort Howe Ranger StatIon, 4000 feet, Powder River County, Montana], seems to be recognizable on the basis of 1 ts much grayer dorsal coloration. The two specimens 118 ted above as cinerens match breeding examples of this race; another specimen, taken at Monte Redondo and Identified as "cinereus" on the label, 18 typical of the greener-backed nominate race. s. a. cantyirens Burleigh and Duva11 [1952: 39; Margret, Fannin County, Georgia] is not recognizable and is generally considered to be a symonym of aurocap111us.

\section{Selurus noveboracens18 (Vieillot)}

Northem Waterthrush SPECTMENS.--S. n. notab1118 (17): Swan Is 1ands, 21 
Feb., 27 March, 28 Sep. (?, MCZ; of, ?, USNM); French Harbor, 4 April (d, CM); Guanaja Island, 24 March (d, \&, CM); Tela, 21 Feb. (?, MCZ); La Celba, 6 Jan., 27 April (8, CM; o, MCZ); Yaruca, 11 Feb. (?, MCZ); $3 \mathrm{mi}$. E La Itma, 18 Nov. (\%, LSUMZ); Amapa, 18 Sep. (imm. \%, LSUMZ); Lake Yojoa, 23 Aug. ( $9, \mathrm{CM}$ ); Comayagüela, $12-20$ oct. ( ${ }^{\circ}$, AMNH; J, MCZ); San Lorenzo, 27 Sep. (o", AMNH; \&, MCZ). s. n. noveboracens 18 (1): $5 \mathrm{mi}$. NE Choluteca, 13 oct. ( $\sigma$, LSUMz). Thdetermined (8): Roatán Is land (4?, BMANH); Bonacca [= Guanaja] Is land (?, BMNH); $3 \mathrm{ml}$. B'Ia Lima, 18 Nov. (? skel., ISUR); Yeguare River Valley, 16 May, 8 Sep. (28, UR).

PURLISHFP RECORDS.--San Pedro region (Sclater and Salvin, 1870b: 836). San Pedro (Salvin and Godman, 1881: 146). Swan Is lands (R1dgway, 1888c: 576). Roatán Is land, Bonacce [= Guana Ja Is land (Salvin, 1888: 252). La Celba and Yaruca [as notabil1a] (Bangs, 1903: 153). 5 km.W Tela [as notabilis] (Peters, 1929b: 464). Roatán Is land [as notabilis] (Hellmayr, 1935: 419). Swan Is lands [as notabi118] (Paynter, 1956: 106 ).

The Northern Waterthrush is a fairly common to common migrant and winter visitant in Honduras, occurring on both slopes, in the 1slands off the north coast, and in the interior up to 3,000 feet elevation. It is found in forest undergrowth, second growth, or scrub, usually in the vicinity of water. Extreme dates of arrival and departure in Honduras are 23 August and $16 \mathrm{May}$.

Although Eaton (1957: 229-239) claimed that the species Is monotypic, three races seem to be recognizable on the basis of yellowness of under parts and darkness or grayness of upper parts. The nominate race, S. $\underline{n}$. noyeboracensis (Vielliot), is the yellowest below; in Honduras it is known from a single specimen that I collected near Choluteca in 1962. Th1s race, however, is probably regular in the republic. The northwestern breeding population, named s. 
Limnaeus McCabe and Miller, is the darkest race above and 18 less yellow below than the preceding subspecies; there are no specimens at present fron Honduras but it undoubtedly occurs in migration. Most of the Honduran specimens are referable to the gray-backed, whltish-bellied race, $\underline{\text { s. }}$. notabilis Ridgway. I cannot distinguish the Newfoundland race, S. n.. ullistnosus Burleigh and Peters [1948: 120; Topsa1l, Avalon peninsula, Newfoundland], and I therefore consider it to be a synonym of the nominate race.

\section{Seturus motacilla (Vieillot)}

Louls Iana Waterthrush

SPECTMENS --(19): Swan Is lands, 14 July (8, MCZ); Roatin Island (?, BMNH); Bonacca [- Guanaja] Isiand (3?, BMNH); Lancetilla, 5 Feb., 24 Aug - -4 Sep. (2d, ANSP; d", MCZ); La Celba, 28 July ( ${ }^{\circ}$, CM); Yaruca, 12 Feb. ( ${ }^{\circ}$, MCZ); Cofradia, 8-10 March (?, AMNH; \&, MLZ); Finca Fé, 2-6 Dec. (o", ?, LStakz); Alto Cantoral, 9 Feb. (?, AMNH); La Flor Archaga, 14 Dec. ( $\sigma^{\circ}$, AMNH); Archaga, $10^{\circ}$ Aug. ( 8, AMNH); Boquerón, 3 Sep. (?, AMMH); Arenal, 26 Jan. ( $\$$, UCLA).

PUBI,ISHED RECORDS.--Roatán Island, Bonacca [= Guanaja] Is land (Salvin 1888: 251). Yaruca (Bangs 1903: 152). Tela River near Lancetilla (Peters, 1929b: 463-464). Lancetilla (Stone, 1932: 334). Swan Islands (Bond, 1950a: 147-148; Paynter, 1956: 106).

This waterthrush is an uncomon migrant and winter visitant in Honduras, occurring on the Caribbean slope, in the islands off the north coast, and in the interior up to 5,000 feet elevation; it has not been recorded on the Pacific drainage below 3,000 feet. In habits it is similar to S. noveboracensis. For Honduras extreme dates of arrival and departure are $14 \mathrm{July}$ and $23 \mathrm{March}$. 
Oporornis formosus (W11s on)

Kentucky Warbler

SPECIMFNS.--(17): Bonacca [= Guanaja] Island (?, BMNH); Lancetilla, 1-3 sep. ( $d,{ }^{\circ}$, ANSP); Truj1110, 30 March ( $d, C M)$; Cofradia; 9 March (d, MLZ); Finca Fé, 1 March, 28 Aug., 23-30 Nov. (20, imm. of, o'? skel., ISUMZ); Cantora1, 15 April ( 8 , AMMH); Monte Redondo, 7-8 Sep. ("), AMNH; O, MCZ); Yeguare River Valley, 18 Aug., 7-8 Sep. (20,?, UF); E1 Boquerón, 2-21 Oct. (20, AMNH).

PUBLISHED RECORDS.--Bonacca [= Guanaja] Is1and (Sa1vin, 1888: 252). Near Lancet111a (Peters, 1929b: 463). Lancetilia (Stone, 1932: 334).

The Kentucky Warbler is a migrant and winter visitant in Honduras, ranging up to an elevation of 6,000 feet. Inhabiting primarily broadleaf forest and second growth, it is uncomon in the Caribbean lowlands, in the 1slands off the north coast, and in the interior, but is decidedly rare on the Pacific slope below 3,000 feet. Extreme dates of arrival and departure in Honduras are 9 August and 19 April.

[Oporomis agilis (Wilson)]

Connecticut Warbler

Records of this species during migration between the southern United States and the wintering grounds in South America are very scarce indeed. The migration route is presumed to be through the West Indies but records are few even there. In recent years there have been $8 \mathrm{ight}$ records for Cozumel Island and for the cays off the coast of British Honduras, always in spring. V. C. Dunlap observed the species twice in March 1959 on 1slands off the north cosst of Honduras. On 17 March he saw one on Utila Is1and, in 
the Bay Islands, and he noted another on 27 March on Hunting Cay, in the Cayos Zapotillas at the southern end of the Iine of cays off the coast of British Honduras. There are no other records for Honduras.

Oporomis philadelphia (W11son)

Mourning Warbler

SPECTMENS.--(10): E1 Picacho, 2 May ( 9, AMNH); Tegucigalpa, 1 -13 May ( $d, 2 \%$, AMNH); Yeguare River Valley, 24 April, 19 May (o, $\$$ UF); E1 Paralso, 20 April (o, $q$, BMNH); San Lorenzo, 24 Sep. (1mm. o, MCZ); 4 mi. NE Choluteca, 3 Oct. (imm. ó, LsiMz).

The Mourning Warbler is an uncomon migrant in Honduras, occurring primarily in the intertor highlands from 2,500 to 6,000 feet. It is exceedingly difficult to distinguish from the more common $\mathrm{g}$. tolmiel in the fall and winter, and all Honduran occurrence data for fall are based on specimens. On 2 and 3 May 1963 I observed an adult male on Utila Island, in the Bay Islands; this bird is the only one yet recorded for the Caribbean lowlands or 181ands off the north coast, although the species is probably a regular transient there. It occupies the same general habitat as o. tolmiei, being a skulker in dense thickets and undergrowth. Bxtreme dates of occurrence in Honduras are 30 April and 9 May for spring and 24 September and 3 October for fall.

The species has not been previously reported from Honduras in the 1iterature. 
Oporornis tolmiei (Townsend)

MacGilitvray's Warbler

SPECTMENS.--(17): Cerro Santa Bárbara, east slope, 1 Dec. ( ${ }^{\prime}$, LSUTK); Finca Fé, 14 Jan. (\%, LSURZ); Cantoral, 27 Jan. 20 April (20, AMAH); E1 Hatilio, 19 April, 4 May (29, MCZ); Cerro Higuito, D.C., 22 April ( 9 , AMDH); Tegucigalpa, 4 April, 3 Oct. ( $d, q, 1$ mo. $\delta$, AMNH); vicinity Teguclgalpa, 12 May (d ske1., MLZ); Comayagüela, 7 Nov. (?, MCZ); Yeguare River Valley, $1-11$ May $\left(\sigma^{\prime}, q\right.$, UF); Piedra de Jesús, 12 March ( $\sigma^{\circ}$, AMNH); San Lorenzo, $27^{\circ}$ Sep. ( $\sigma^{\prime}$, MCZ); 4 mi. NE Choluteca, 3 oct. ( 8 skel., Lsimz).

Although, surprisingly, published records for this species in Honduras are lacking, it is an uncormon to fairly common migrant and winter visitant in the interior highlands and in the Pacific lowlands. This warbler inhabits dense thickets, scrub, and undergrowth in either arld or humid situations. Altitudinally, it ranges up to at least 7,000 feet but has not been recorded in the Caribbean lowlands below 2,000 feet. Extreme dates of arrival and departure In Honduras are 26 September and 11 May.

While there is a clinal tendency in breeding populations from duller, grayer, and less yellow birds in easternmost areas to brighter and yellower birds along the Pacific coast of North America, there is so much overlap of characters and such a wide range of intermediates that taxonomic subdivision seems undesirable. In addition, migrant and winter birds are virtually impossible to allocate subspecifically. Phillips (1947: 296-300) divided the species into four races: $Q$. t. montlcole Phillips [1947: 297; Hart Prairie, San Francisco Mt., Arizona], ․․ t. austinsmithi 
Ph111ips [1947: 298; Bnigrant Gulch, 6500 feet alt., 3 miles southeast of Chico, Montana], $Q$. t. . Intermedia Phil1ips [1947: 299; Okanagan, British Columbla], and ‥ t. tolmiel (Townsend). I cannot distinguish these forms and regard the species as monotypic. One specimen from the Yeguare River Valley, taken on 1 May 1946 by Marjorie $H$. Carr, has been Identified as "monticola," according to the label.

\section{Geothlypls trichas (Linnaeus)}

Common Yellowthroat

SPECTYFNS.-G. t. occidenta1 1s (4): Cofradla, 4 March (o, MLL); Las Pehitas, 10 Feb. (J?, MLz); Soluteca, 3 April (d'? AMNA) Tegucigalpa, 4 April (d, AMMH) $G . t$. brachtdactyius (24): Swan Is lands, 12 Feb. (o?, USNM); Guanaja Is Land, 22 March ( $d^{\prime}, C M$ ); La Celba, 22 Jan, 2-7 May (2o, f, CM; of MCZ); Trujil1o, 6-8 April (d, q, CM); Cofradfa, 9 March (?, MLz) ; Santa Bárbara, 12 May ('? AMNH); Finca Fé, 30 Nov. (Ima., ISUMZ); Agua Azul, 24 Nov.

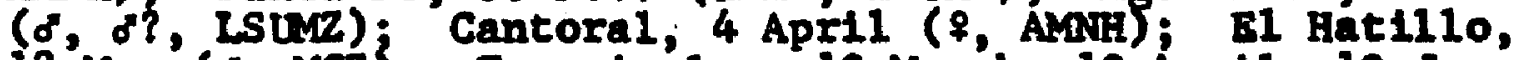
$12 \mathrm{May}$ (\$, MCZ); Tegucigalpa, 10 March, 10 April, $10 \mathrm{Jume,}$ 9 Dec. (38, of?, AMNH); Comayagüela, 19 Apri1, 6 Nov. (d", AMNH; Imm. of, MCZ); Escuela Agrícola Panamericana, 13 March ( $\%$, UF); Yeguare RIver Valley, 20 Jan. (f?, UF); Yuscaran 17 Apri1 ( 8, BMNH). Undetermined (4): Roatán Is land (4?, BMirH).

PUBLISHIRD RECORDS.--San Pedro region (Sclater and Sa1vin, 1870b: 836). San Pedro (Salvin and Godman, 1881: 150). Swan Is lands (RIdgway, 1888c: 576). Roatán Is land (Salvin, 1888: 252). Swan Islands [as brechidactyla] (RIdgway, 1902: 665; Lowe, 1909: 338-339; H18her and Wetmore, 1931: 21). La Celba (Bang8, 1903: 152). "Honduras " [= near Tela and Lancet111a]' (Peters, 1929b: 464).

Geothlypis trichas is a common migrant and winter visitant in Honduras, occurring on the mainland up to an elevation of 5,000 feet and in the islands off the north coast. It is an inhabitant of marshes, heavy scrub, and 
grassy areas, usually near water. Extreme dates of arrival and departure in Honduras are 23 October and $10 \mathrm{June}$.

The western race, G. $t$. occldentalis Brewster, winters regularly as far south as Guatemala. There are four Honduran specimens, all males, that I assign to this race on the basis of their larger size and white, rather than gray, post-ocular areas. These four specimens measure as follows (measurements 118 ted in sequence that appears under "SPECIMiN" 1isted above): wing, 57.5, 58.2, 54.6, 56.4; tall, worn on all four; exposed culmen, 11.5, 10.5, 10.8, 10.4. I refer all other specimens to the northeastern race, $G$. $t$. brachidactylus (Swatnson). Measurements of these specimens are as follows: wing, of, 52.1-58.9 (56.1), $\$, 50.8-59.0$ (54.2); tail, $\delta, 45.0-52.3$ (47.6), 8, 40.2-47.3 (43.9); exposed culmen, of, 10.3-11.7 (10.8), $8,9.8-11.5$ (10.5). One male specimen from Guanaja Island, taken on 22 March 1948 by Arthur C. Twomey and Roland W. Hawkins, is small (wing, 52.I; tail, 45.0; exposed culmen, 10.4) and may represent the southeastern breeding race, G. t. trichas (Linnseus), which ranges south to Costa Rica in winter. However, until a specimen that is definitely referable to this subspecies is obtained in Honduras, I consider the above individual to be an example of brachldactylus, the measurements being within the extremes of that race. Possibly some of the females assigned to brachldactrlus are representative of occidentalis, as they are in the range of 
size overlap. One specimen taken at Cofradla on 9 March 1933 by C. F. Underwood, presumably a female although the bird is unsexed, has been identified (according to the label) as G. t. . typhicola Burleigh. This race, which breeds along the coast of the southeastern United States and winters south to Mextco, probably does not occur in Honduras; measurements of this specimen are representative of brechidactylus (wing, 52.8; tail, 46.9; exposed culmen, 10.3).

Geothlypis seniflava Sclater

Olive-crowned Yellowthroat (juv., USTM). - G. \&. bairdi (1): Segovia River, 3 July 585).

PUBLISHRD RECORD,--Segovia River (Ridgway, 1888c:

This yellowthroat reaches its northern 1 imit of distribution in the rain forests of 0lancho. There is but a ingle record for Honduras, a juvenal collected by $C$. H. Townsend along the Rio Segovia in 1887 (Ridgway, 1888c: 585). The species 18 probably widespread and fairly comon in parts of Olancho.

The single juvenal specimen is not identifiable subspecifically; I tentatively assign it to the northern race, G. 8. bairdi Nutting. 


\section{Geothlyp18 pollocephala Baird}

\section{Gray-crowned Yellowthroat}

SPECIMENS.--G. D. caninucha (72): Montecris to, 23 Maxch (d, LSLuz); La Cêba, 30 April-29 May, 29 July (3d", 28, CM); Los Planes, 9 June ( $8,9, C M$ ); Truj1110, 30 March-8 April (3d, GM); Catacombas, 28 March (?, MLZ); Cofradia 5-11 March (o, 39, 3?, MCZ); San Pedro Sula, 1627 July (20, USMM); Las Pehitas, 25 Jan., 13 Feb. (?, MIZ; 2\%, \&, MCZ); $1 \mathrm{mi}$. N PImienta Nueva, 13 Sep. (imm. \&, LSUMZ); Subirana, 10 Dec. ( $\sigma^{\circ}, \mathrm{MCZ}$ ); Coyoles, 16 June, 9 July $\left(20^{\circ}, 48, C M\right)$; Monte EI Conejo, 21 May ( $\sigma^{\circ}$, MLZ); P1an del Rancho, 9 July ( $\sigma^{\prime}, q$, MLZ); Cerro Higulto, Santa Bárbara, 19 April ( $\%$, AMint); Cerro Santa Bárbara, southeast s lope, 26 July (d, LSUMz); Lake Yojoa, 19 June (d, CM); Monte Redondo, 27 Nov. (?, MCZ); La Flor Archaga, 8 June (o", MCZ); Cantarranas, 20 July-8 Aug. (d", $q, ?, 2$ Juv $;$, ANSP); E1 Derrumbo, 3-9 Aug. ( $0^{\circ}$ AMNH); E1 Hatil10, 20 Aug. ( $\left.{ }^{*}, C M\right)$; Cerro Higuito, D.C., I May ( ${ }^{\prime}$, AMNH); Tegucigalpa, 30 March, 12 May-1 June (50, \&, AMNH; of, USNM); Comayaguiela, 10-15 June, 18 Nov. ( ${ }^{\circ}, \%$, MCZ; $\%$, USIM); Escuela Agrlcola Panamertcana, 28 June ( 9 UF); Yeguare River Valley, 25 May-18 June, 2-27 Oct. ( $20^{\circ}, 2 \%, ?$, UF); Puerto Lempira, 6 Feb., 9 April ( ${ }^{\circ}, 29$, IStuz); $10 \mathrm{~km}$. N Sabana Grande, 14 Aug. ( $0^{\prime \prime}$, CM); 2 mi. SE Namasigüe, 8 Oct. (o", LSUR ); San Francisco, Choluteca, 12 Feb. (o", isurz); Honduras-Nicaragua boundary [near Pacific coast] (?, MCZ).

PUBLISHEP RECORP.--Cantarranas (Stone, 1932: 334).

The Gray-crowned Yellowthroat is a falrly common to common resident throughout suitable habitat in Honduras, ranging up to an elevation of 5,500 feet. Occurring in areas of deep grass or dense undergrowth in open situations, it is found under either humid or arid conditions and is frequent along fence rows and in cultivated fields.

For the inclusion of the genus Chamaethlypis in Geothlypis, see Eisenmann (1962a: 265-267).

Honduran specimens represent the race $G \cdot \mathrm{P}$. caninucha Baird. 


\section{Icteria virens (Linnaeus)}

Yellow-breasted chat

SPECIMENS.--I. y. virens (22): La Ceiba, 8-24 Jan., 1 Apri1 (2\%, CM; 3\%, 2 ; , MCZ); Yaruca, 25 Feb. (o", MCZ); San Pedro (?, BMNH); Las Peñitas, 30 Jan., 17 Feb. (2\%, ?, MIZ); Is Lima, 19 Nov. (o' skel., LSUMZ); Urraco, 11 March ( 9, MCZ); Chamelecón, 18 Dec. (o , AMNH); San José de Santa Bárbara, 25 Apri1 ( ${ }^{\circ}$, AMNH); Finca Fé, 24 Nov. ( $\sigma^{\circ}$, LSLMZ); Monte Redondo, 14 Dec. ( $\delta$, MCZ); Tegucigalpa, 16 oct., 10 Dec. ( $\sigma^{\circ}, \%$, AMNH); E1 Boquerón, 19 Oct. ( $\sigma^{\circ}$, AMNH); 2 mi. S E1 Corpus, 7 oct. ( 9 , Lsuiz).

PUBLISHED RECORDS.--San Pedro region (Sclater and Salvin, I8706: 836). San Pedro (Salvin and Godman, 1881: 158; Sharpe, 1885: 376). La Ceiba, Yaruca (Bangs, 1903: 152). $52 \mathrm{~km}$. W Tela [= Urraco] (Peters, 1929b: 464).

The Yellow-breasted Chat is an uncommon to fairly common migrant and winter visitant in Honduras, occurring below 4,500 feet elevation. Dense second growth, heavy scrub, and undergrowth in open forest are its preferred habitats. Extreme dates of arrival and departure in Honduras are 18 September and 25 April.

This species may eventually prove to be a member of the Thraupidae; it certainly does not: exhibit most characteristics of the Parulidae (E1senmann, 1962a: 265-267).

All Honduran specimens examined compare favorably with the eastern race, I. y. virens (Linnaeus). None exhibits the grayness above that is characteristic of the western race, I. V. auricollis (Deppe), which is known to winter Bouth to Guatemala. In addition, all Honduran specimens have the wing longer than the tail. 


\section{Wilsonia citrina (Boddaert)}

Hooded Warbler

SPEC TMENS.--(37): Swan Is lands, 25 March (o", MCZ); Roatan Island (2?, BMNH); Guanaja (Bonacca) Is land, 24-26 March (?, BMNH; of, $f$, CM); Lancetilla, 15 Jan. ( $f$, MCZ); La Celba, 18 Jan. ( $\left.{ }^{\circ}, \mathrm{MCZ}\right)$; Yaruca, 7-22 Feb. ( $30^{\circ}$, \&, MCZ); Truj1110, 9 April, 26 Sep. ( $\%$ CM; of, USNM); Catacombas, 19 March-6 April (o" AMNH; 29, ?, MLZ); Cofradla, 14 March (20, AMNH); Las Peñitas, 3-22 Feb. ( 8 , AMNH; 20, MLZ); 3 mi. E La Lima, 9 Dec. (o skel., LSLMZ); Amapa, 18 Sep. (Imm. o, LSLaZ); Portillo Grande, 26 March ( ${ }^{\circ}$, MCZ); Mt. Puca, 2 Feb. ( ${ }^{\circ}$, AMNH); Cerro Santa Bárbara, east 8 lope, 7 Dec. (1mm. o", LSUAZ); $2 \mathrm{mt}$. SE $E 1$ Jaral, 22 Feb. ( $\delta$, LStuz); Finca Fé, 25-27 Nov. (20', Lsumz); Cantoral, 16 Apr11-27 May (30', AMNH); E1 Boquerón, 19-30 Sep. (30", AMNH).

PUBR.TSHED RECORDS,--Comayagua (Sclater, 1858b: 358; Taylor, 1860: 1T0). Truj1110 (Ridgway, 1888c: 579). Roatán Is land, Bonacca [= Guana ja] Island (Salvin, 1888: 253). La Ceiba, Yaruca (Bangs, 1903: 152). Lancetilia Valley (Peters, 1929b: 464). Swan Islands (Paynter, 1956: 106).

Ranging up to an elevation of 4,500 feet, the Hooded Warbler is a fairly common migrant and winter visitant in the Caribbean Iowlands of Honduras and in the 1slands off the north coast; it is decidedly uncommon on the Pacific drainage. The spectes inhabits open or dense rain forest, usually at low levels within the forest, and occurs comonly in second growth and scrub. For Honduras extreme dates of arrival and departure are 18 September and 27 May.

\section{Wilsonia pusille (Wilson)}

\section{Wils on's Warbler}

SPECIMENS - -W. p. pileolata (12): Cerro Cantoral, 1317 Dec. (2\%, o?, FCZ); Alto Cantoral, 4 Jan. (o', AMNH); Monte Redondo, 14-16 Dec. (28, MCZ); La Flor Archaga, 17 Nov. (d, AMant); Rancho Quemedo, 15 March ( 8 ?, MCZ); E1 Hatillo, 22 April (\%, MCZ); Tegucigalpa, 22 Feb. (o, AMNH); 
Uyuca, 24 Sep ( ( , UF); San Francisco, Choluteca, 11 Oct. (o", LSUMZ). W. p. chryeeola (3): Monte Redondo, 6-10 Dec. (2d, MCZ); E1 Picacho, 15 oct. (d?, AMNH). W. E. pusilla (11): Catacombas, 6 April (?, MCZ); Cofradia, 3 March (J, MCZ); Port1110 Grande, 14 March ( ${ }^{\circ},{ }^{\circ}$ MCZ); Finca Fé, 20 Oct.-21 Jan. (38, \&, imm. of, ISUMz); $2 \mathrm{mi}$. N Pito Solo, 25 oct. ( $\$$, IsUMZ); Yeguare River valley, 20 Jan. (d?, UF). Undetenmined (6): $2 \mathrm{mi}$. SE EI Jaral, 3 March (o aic., \&? alc., LSUMí); Finca Fé, 8 Dec. (o' skel., Lsumz); Yuscarán, 19 April (f, BMNH); San Francisco, Choluteca, 11 oct. (2o" skel., Lsumz).

Despite the absence of previous records, this species is perhaps the most common forest-inhabiting winter visitant in Honduras. It occurs in broadleaf forest, second growth, and scrub throughout the country up to at least 7,500 feet; It is least common in the lowlands below 2,000 feet. Extreme dates of arrival and departure in Honduras are 24 September and 23 April.

The duller-colored eastern race, W. R. pusilla (W11son), occurs primarily on the Caribbean drainage below 3,000 feet (one specimen from the Pacific drainage at 2,600 feet). The northwestern race, W. P. plleolatg (Pallas), which is brighter colored than the preceding with a definite goldenyellow cast on the under parts, is found exclusively in the Pacific lowlands and in the interior above 2,500 feet and 18 very common in these areas. Wing measurements of specimens of pileolata from Honduras are as follows: $d, 54.8-58.9$ (57.2); $9,55.4-58.6(56.5)$. Three specimens from Honduras are representative of the smaller, even brighter colored, Pacific coast race, W. p. chryseola RIdgway; their wings measure $51.7,52.7$, and 52.9 . 


\section{W11sonta canadens 18 (Linnaeus)}

Canada Warbler

SPFCTMENS.--(11): Hunting Cay, 26 April ( ${ }^{\circ}$, LSUMZ); Cerro Nieve, I3 April (o, \&, AMNH); E1 Picacho, 28 sep: ( $0^{\circ}$, AMNH); Tegueigalpa, 11 Dec: (?, AMNH); E1 Boquerón, 21 Sep. (f, AMLH); San Lorenzo, 28 Sep.-6 Oct. (d, AMNH; $d$, 7, MCZ); 2 mi. S E1 Corpus, 7 oct. (Im. o, LSlMz); Finca EI Rubi, 29 Sep. (Imm., Lsuiz).

PUBLTSHED RECORD.--HuntIng Cay (Russel1, 1964: 160). Ranging up to 4,500 feet, the Canada Warbler is an uncommon migrant and rare winter visitant in Honduras, inhabiting open forest, second growth, and scrub. It is decidedly rare on the Caribbean slope but much more frequent on the Pacific drainage, especially in the fall. Extreme dates of arrival and departure in Honduras are 21 September and 18 April.

Eisenmann (1955a: 92) mentioned that the Canada Warbler winters rarely In Honduras; this statement was based on the Tegucigalpa specimen taken by $C$. F. Underwood on 11 December 1934.

\section{Cardellina rubrifrons (Giraud) \\ Red-faced Warbler}

Oct. (3F, Im., LSUYZ); Güise, 30 Oct. (\%, ? 23-24 Jan., 31

The Red-faced Warbler has been previously recorded in the literature only as far south as Guatemala. It is apparently an uncommon, but regular, winter visitant in the interior highlands of western Honduras, occurring in pineoak associations. Three individuals were observed on 30 
October 1962 near Güise, Department of Intibucá, by J. Alan Feduccia, Wllliam W. Plowden, Jr., Rose S. Monroe, and me, and three more near La Esperanza on the following day; two specimens were taken each day. At the same locality near La Esperanza, I saw single birds on 22, 23, and 24 January 1963 and secured single females on the latter two days. The spectes is apparently regular in this region in winter. The elevation in the area is 5,600 to 5,900 feet. Mark Trafton, Jr., observed one individual near Lake Yojoa on 11 July 1955. This observation was the first for Hondures; the date in July is odd. There is a possibility that the species breeds in Honduras, but there 1 s no direct evidence at the present time. The individual reported by Trafton was in pine-oak at about 3,200 feet elevation. Geographic variation needs to be studied in this 8pecies. Although the supposed Guatemalan race, G. I. bella Griscom, described as being more crimson on the head and grayer below than the nominate form, has been conoldered by most authors to be based on individual variation in migrant birds, the 8 ix specimens from honduras show extrene variation in the red coloration. One individual is orangered, four are typically red (matching breeding birds from northwestern Mexico), and one is crimson. Until the problem of vartation is cleared up, I am maintaining the species as monotypic. 
Setophaga ruticilla (Linnaeus)

American Redstart

SPECIMENS.--(56): Swan Is lands, 7-29 Feb., 9 Oct. (28, MCZ; $\delta, \%$, USNM); Roatán Is land (8?, BMNH); Guanaja Island, 26 'March ( $(\circ, C M)$; Little Hog Is land, 9 April (d, LSUaz); La Celba, 11-13 Jan. (3d, MCZ); Trujillo, 8 April ( ${ }^{\circ}, \mathrm{CM}$ ); San Pedro Sula, 22 Jan., 8-10 Dec (20, $\$$, USIM); Las Pefitas, $17 \mathrm{Feb}$. ( $0^{\circ}, \mathrm{MLZ}$ ); Fínca Fé, 21 Jan., 9 Aug.

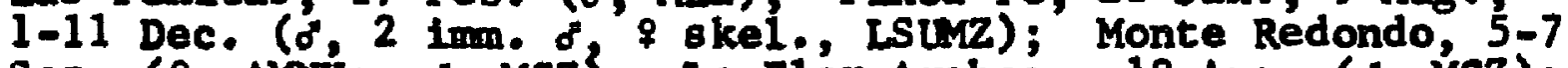
Sep. (8, AMMH; of, MCZ); La Flor Archaga, 18 Aug. (o, MCZ); Rio Hondo, 18 Aug. ( $\%, C M$ ); Teguelgalpa, 19-30 Oet. ( 8 , \&, AMNH); Escuela Agricola Panamericana 11 May, 22 Aug: (q, Imm. of? UF); Yeguare River Valley, 18 Aug - $8 \mathrm{Sep} .\left({ }^{\circ}, \delta^{\prime}\right.$, UF); El Boquerón, 10 Aug - -26 Sep. (140", 49, AMaNH); San Lorenzo, 25 Sep. ( $($, MCZ); "Honduras" (juv. o, USNM).

PUBLTSHEP RECORDS.--Swan Islands (Ridgway, 1888c: 576; Lowe, 1909: 253; Floher and Wetmore, 1931: 21; Paynter, 1956: 106). Roatán Island (Salvin, 1888: 253; Hellmayr, 1935: 458): La Celba (Bangs, 1903: 152). Lancetilla (Peters, 1929b: 464).

The American Redstart is an uncommon to common winter visitant and migrant in Honduras, occurring in broadleaf forest, second growth, and sometimes scrub up to 5,500 feet elevation. It 18 decidediy uncomon on the Pacific slope and in the interior above 2,500 feet, but it is fairly common to coumon in the islands off the north coast and in the Caribbean 10wlands. Bxtreme dates of arrival and departure in Honduras are 9 August and 11 May.

While there is a defintte cline in the breeding range from larger birds in the north to smaller birds in the south, the cline is smooth with a broad area of intermediates, and only about 15 per cent of the entire population may be identified with any certainty. I cannot see any significant geographic variation in color in adulta of 
either sex. I therefore regard S. I. tricolora (Müller) as Invalid and the species as monotypic.

\section{Myloborus pictus (Swainson)}

Painted Redstart

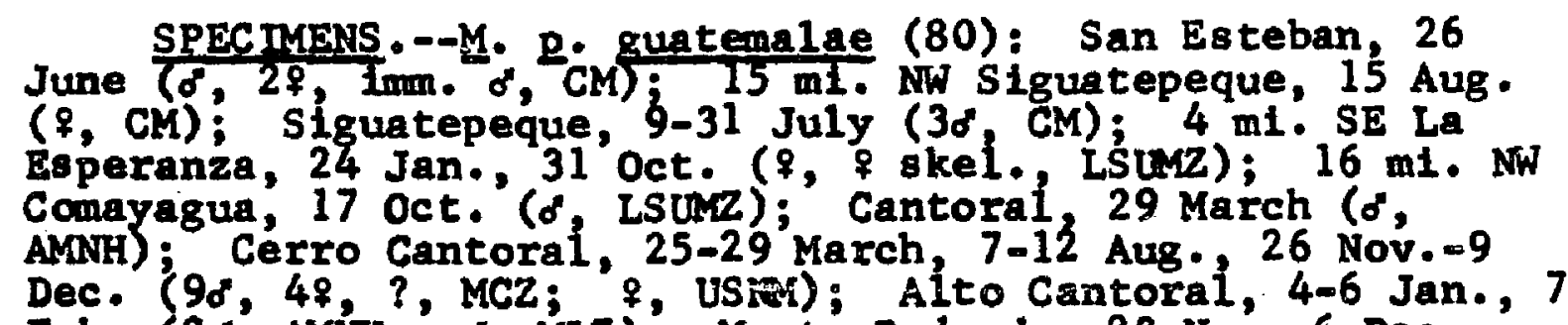
Feb. (2o, AMNH; of, MLZ); Monte Redondo, 23 Nov.-6 Dec. (49, MCZ); La Flor Archaga, 25 March, 3-18 June (o", AMNH; 40, $28, \mathrm{MCZ}$; o, USNM); San Juanc1to; 23-27 July, 14 Aug. (3o, 2?, ?, ANSP); Rancho Quemado, 2 April, 15 May ( $\sigma^{\circ}$, MC2); E1 Hat1110, 19 Apri1 4 May, 30 June, 3-17 Aug ' (28, \&, Im. o, Juv. ${ }^{2}$ CM; ${ }^{\circ}$; 2 , MCZ); Tigre Hatillo, 30 June-1 July (20, 28 , AMNH); E1 PIcacho, 28-29 Sep., 21 oct.

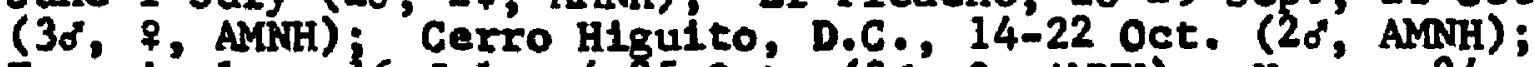
Tegucigalpa, 16 July, 4-25 oct. ( $30^{\circ}$ ? ?, AMNH); UYuca, 24 Apri1, 28 July (2?, UF); La Montafiltas, 12 Feb. (20, UF); Yuscarain, 17 Apri1' (o', BMNA); Dan1f, 6 Apri1 (\%, BMon); San Francisco, Choluteca, 12 Feb. ( $0^{\circ}$, LSUMZ); "Honduras" (?, AMNH; ;, MIZ).

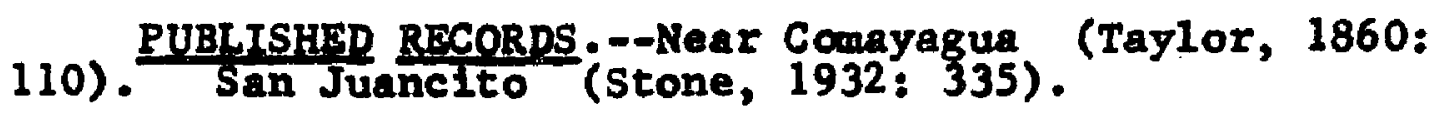

The Painted Redstart is a fairly common resident in pine and pine-oak assoclations in Honduras. It ranges primarily from 3,500 to 7,500 feet but occurs in pine in the San Esteban region down to 1,500 feet.

Parkes (1961: 374-379) has shown that this species belongs in the genus Mytoborus, not in Setophege. The genus Exythrosoma Swainson, which antedates Myloborus and has plctus 28 its type, is a nomen oblitum and should not be used to replace the well-known Myloborus. 
Honduran specimens represent the southern race, M. $\mathrm{D}$. guatemalae (Sharpe).

\section{Myloborus miniatus (Swainson)}

Slate-throated Redstart

SPEGIMBNS.--M. m. connectens (81): Las Peñitas, 15-27 Feb. (12б, 5\%, MCZ); Portillo Grande, 5-6 April, 13-17 May (40, \&, MCZ); Cerro E1 Triumpho, $20 \mathrm{mi}$. SE San Esteban, 28 March ( $\sigma^{\circ}$, LSUMZ); Merendón Copán, 12 June ( ${ }^{\circ}$, AMNH); Monte Los Cedros, 4 June ( $f^{\prime, ~} 7$, MLZ); Montaña E1 Chorro, 22 June

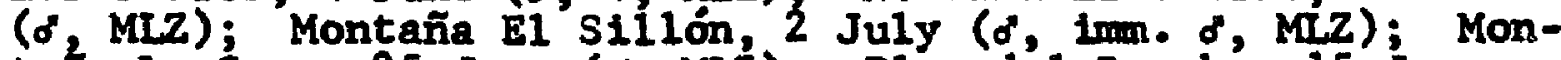
taña La Cruz, 25 June (o, MLZ); P1an del Rancho, 15 June (d, MIZ); Mt. Puca, 11 Feb. ( $q$, MCZ); Cerro Santa Bárbara, east slope, 1 Dec. ( $\$$, LSUR ); $5 \mathrm{ml}$. SW El Jaral, 26 Oct. (1mm. of, LSUMZ); 6 mi. SW El Jaral, 26 Oct. (o, LSUM); Lake Yojoa, 18 July ( $9, C M) ; 10 \mathrm{ml}$. NW LA Esperanza, 23 Jan. ( $\delta$, LŚluz); $4 \mathrm{ml}$. SB La Bsperanza, 31 Oct. ( $\sigma^{\prime}, q$, LSUMZ); San Marcos de Guaimaca, 30 June ( $\$$, AMNH); Cerro Santa Maria, 30 Dec. (d, ?, AMNH; $?$, MIZ); Cantora 1, 13 Dec. (8, AMNH); Cerro Cantoral, 5 Jan., 27 Feb., 12 March, 14-25 July, 28 Nov.-19 DeC. (3o', 49, 4?; MCZ; 2 ; USM); Monte Redondo, 2 Jan. (?, MCZ); San Juanctto, 2 Feb., 19 June-12 Aug. (30, \$, 2? ANSP; $20^{\circ}, 28$, CM; ?, LSIMZ; ?' UF); ?, Rancho Quemado, 9 March-5 April, 15 May (d, ANMH; $5 \delta^{\prime \prime}$ AMNH):

PUBLISHED RECORDS.--San Juancito (Stone, 1932: 335). Volcan de Puca (Fellmayr, 1935: 461). "Honduras" (van Ros8 em, 1936b: 117-118).

Occurring from 3,000 to 8,000 feet, this redstart is a common resident of cloud forest and pine-oak associations in the intertor of Honduras.

Hellmayr (1935: 461) examined two specimens, presumably in the Brunswick Museum, that were taken by Erich Wittkügel on Volcán de Puca.

Honduran populations are typical of the orange-bellied race, M. m. connectens Dickey and van Rossem. None of the Honduran specimens shows any approach to the red-bellied 
race of eastern Guatemala, M. m. intemedius (Hartlaub), or to the yellow-bellied Costa Rican race, $\underline{M}$. $m$. comptus Wetmore [1944: 74; 900 meters elevation on Cerro Santa María, a spur of Volcán Rincón de la Vieja, above the Hacienda Santa María, Costa Rica]. Honduran birds average slightly smaller (wing: $\delta, 57.2-67.4$, mean 62.4; $\%, 58.5-66.4$, mean 61.3) than the race in E1 Salvador and western Guatenala, M. ㄸ. hellmayr1 van Rossen [1936b: 117; Volcan de Santa Ana, Depto. Sonsonate, El Salvador, altitude 6000 feet], although the size differences are not as clear-cut as indicated in the original description of helimayri.

\section{Euthlypis lachrymosa (Bonaparte)}

\section{Fan-tailed Warbler}

SPEC TMENS.--(38): Cantoral, 22 March, 2 May (8, ANSP; $\sigma$ AMiiti); Cerro Cantoral, 25-29 March (3d,?, MCZ; ${ }^{\circ}$, US̉N); Le Laguna Archaga; 13 July ( 9 , AMLH); Monte Redondo, 18 Nov. (o, AMNH); La Flor Archaga, 22 Jan,, 29 March, 12 May ( $\$$, AMMH; $d, q$, MCZ); El Derrumbo, 18 July (d, AMNH); Ei Hat1110, 8 March, 19 April-7 May $\left(6 \sigma^{\circ}, 49, ?\right.$ MCZ); Cerro Higuito, D.C.,' 2 May (o, f, AMMH); Tegucigalpa, 14 April ( $\delta$, BMNG); Monserrat Mt., 31 March (?, UF); Sabana Grande, 27 Feb. ( 9 , ANSP); Pledra de Jesús, 19 Feb., 3 March, 4-11 April (?, ANSP; o", 39, AMNH); 2 mi. S EI Corpus, 10 Feb. ( $q$, o?, LSLRZ); San Franc1sco, Choluteca, 11 Oct. ( $q$, LSUMZ); MHondurasì ( $q$, AMNE).

Confined in Honduras to the Pacific drainage, the Fantailed Warbler occurs in monsoon forest, cloud forest, second growth, and scrub. Desplte the absence of previous records, it is uncommon to fairly common in Honduras and ranges from 1,000 to 6,000 feet. It is most frequent in the lower levels of vegetation within monsoon forests. 
The southern race, E. 1. schistacea Dickey and van Rossem, is not valid and the species is monotypic (van Rossem, 1934c: 474).

\section{Basileuterus culicivorus (Deppe)}

Golden-crowned Warbler

SPECIMENS:-B. C. Culicivorus (92): Lancetilla, 17 Jan., 6 Feb., 9 Sep. (d, ANSP; 27, MCZ); La Ceiba, 8 Aug . (, , CM); Truj1110, 7 April ( $8,9, C M$ ); Catacombas 20

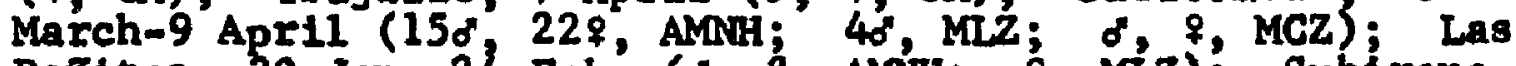
Peflitas, 30 Jan. -24 Feb: (d, ? AMMH; q, Miz); Subirana, 12 March ( 8, MC2); La Leona, 25 June ( ${ }^{*}$, AMarH); La Libertad, 11 June-1 Juí (20, ${ }^{\circ}$, AMNH); Merendón Copán, 12-19 June (30, 2\%, AMNH); San José de Santa Bárbara, 6 April, 5 May ( $0^{\circ}, 8$, AMNH); Cerro Santa Bárbara, east 8 lope, 27 Jan. , 7 Dec. (2ợ, LSUMz); 2 m1. SE El Jaral 3 March (o', LSUMZ); Finca Fe, 8 Aug. -22 Oct., 21 Nov. ( ${ }^{\prime}, 2 q, \delta^{\prime}$ skel., alc., LSUMZ); Lake Yojoa, 15 June-25 Aug. (12\%, \&, CM); Cantoral, 5 April (\%, USIM); E1 Derrumbo, 17 July (?, MCZ); E1 Boquerón, 16 Sep. ( $q$, AMNH); Arenal, 14-20 Jan. (38, UCLA); "Honduras" ( $\%$, AMNH).

PUBLISHED RECORDS.--East of Lancetilla (Peters, 1929b mayr, 1935: 504).

Occurring up to an elevation of 4,500 feet, this warbler is a common resident in rain forest and the lower reaches of cloud forest on the Caribbean slope of Honduras. The species also is found in heavy second growth but in general prefers the lower levels within rain forest. It is most common at the medium elevations from 1,500 to 3,500 feet and is decidedly uncomon below 1,500 feet.

Hellmayr (1935: 504) reported that he saw a specimen from San Pedro, but I do not know where this individual is located; it is probably a Wittkügel specimen in the Frankfurt Museum or the Brunswick Museum. 
Honduran material is typical of the widespread race, B. c. cullaivorus (Deppe).

\section{Bas1leuterus bel1i (Giraud)}

Golden-browed Warbler

SPECTMENS.--B. b. scitulus (35): Montafia El Chorro, 22 June-9 July (4\%, 6?, MLZ); Montafia La Cruz, 25 June-7 July (40" 69, 3?, MLZ); Monte Verde, 19-25 July (38, $29,6 ?$, ML2); Monte E1 Portillo, 28 May (?, ML). B. b. subobscurrus (39): Cerro Santa Bárbara, east slope 25 April (?, ISUMZ); Muye, 21 Feb. (d, AMNH); Cantoral, 16 Jan.-1 March, 6-20 April, 20 Sep. (4o, 3\%, ANSP; 6o, 6\%, AMNH; $q$, MLZ; 'f, $q, ?$, MCZ); Cerro Cantoral, $23-25$ Jan. ( $\delta, q$, USNM); Alto Cantoral, 5 Jan. -3 Feb. (o, AMNH; 30, ?, MCZ); E1 Derrumbo, 17 July-9 Aug. (40, 39, MCZ).

PUBLISHED RECORDS.--Cantoral (Wetmore, 1940: 52-53). "Honduras [" Montaia El Chorro, Montafia La Cruz, Monte Verde, and Monte EI Portillo] (Moore, 1946: 101).

The Golden-browed Warbler is a falrly common to comon resident at high elevations in cloud forest; it has not been recorded below 6,000 feet in Honduras. The lower levels of vegetation within the forest are preferred by this 8 pecies.

The Guatemalan race, B. b. scitulus Nelson, extends into the Department of Ocotepeque in extreme western Honduras. The remainder of the habitat in Honduras is occupied by the race B. b. Bubobecurus Wetmore [1940: 52; Cantoral, Honduras], a slightly differentiated form that is darker and grayer above when compared with seltulus. Although the differences are slight, they seem to be constant in the Honduran series that I examined. 
Basileuterus rufifrons (Swatns on)

Rufous-capped Warbler

SPECTMENS.--B. I. delattril (60): Portillo Grande, 13 May ( $\delta$, AMLith); Lâ Leona, 25 June ( $\%$, AMaNH); La Libertad, 16 June ( $\sigma^{\circ}$ AMNH); Monte E1 Conejo, 20 May ( $q$, MLZ); Santa Bárbara, $12-16$ Maý ( $8, \$$, AMNH); $5 \mathrm{mi}$. SW EI Jaral, 28 Oct. (alc., Isuaz); Finca Fé, 21 July, 31 Aug.-10 Sep., 6-8 Dec.

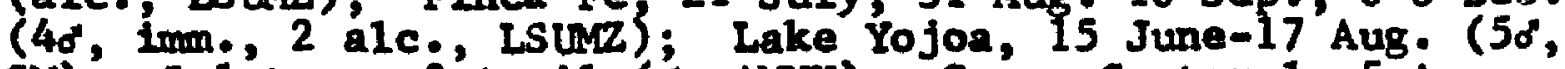
CM); Soluteca, 3 April (d, AMNH); Cerro Cantora1, 5 Aug. (?, MCZ); Altó Cantoral, 25 Jan.-3 Feb. ( ( ${ }^{\circ}$, AMaN); Monte Redondo, 22 Nov. -14 Dec. (2d, $2 q, \mathrm{MCZ})$; Archaga, 6 June ( $\sigma$, AMNH); La Fior Archaga, 15-13 June, 8 Sep. (3q,?, MCZ); Río Hondo, 18 Aug. ( 8, CM); Cantarranas, 20 July-10' Aug. (3\%, 2\%, 2?, ANSP); San Juancito, 23 July ( $\sigma^{\circ}$, ANSP); EI Derrumbo, 3-9 Aug. (o, AMNH); E1 Hat111o, 19 Apr11-2 May (40", ?, ?, MCZ); Tegucigalpa, $25 \mathrm{May}-11$ June (o, \&, AMMA; 30' MLZ); Comayagüela, 10-11 Oct. (20, MCZ); Yéguare RIvar Valley, 4-13 June ( $\sigma^{\circ}, q$, UF); road to Yuscarán, 1 June ( $q$, UF); Sabana Grande, $15 \mathrm{Feb}$. (\%, AMNH); $2 \mathrm{ml}$. S El Corpus, 10 Feb. (?, LSUMZ).

PUBILISHED RECORDS.--Cantarranas and San Juancito [as anivint (Stone, 1932: 334).

In Honduras the Rufous-capped Warbler is a common res 1dent of broadleaf forests. On the Pacific slope it occurs In monsoon forest from about 500 feet to at least 3,500 feet elevation, and on the Caribbean slope it inhabits deciduous forest and occasionally open rain forest from 1,000 to 5,500 feet. It is usually found in lower levels within the forest but may sometimes be seen in the tree canopy, and on occasion it enters second growth.

The relationships of populations of this species in northern Central America have been thoroughly confused in recent years. The stated range of $\underline{B}$. rufifrons balvint usually includes southern Mexico, Guatemala, and Honduras, while that of delattril extends north as far as Guatemala, 
E1 Salvador, and Hondurss. Thus the apparent sympatry of the two forms indicated their specific status. As I will show in the following account, the two forms are allopatric and intergrade over a wide area of eastern Guatemala, El Salvador, and Honduras.

Todd (1929a: 87-89) not only recognized the form delattrit as specifically distinct from mufifrons, but he also placed rufifrons (including salvint) in Idlotes, a genus based primarily on the width and shape of the rectrices and on the wing/tail ratio. Supposedly, in Idiotes the tail exceeds the wing in length while in Basileuterus the reverse was true. As Dickey and van Rossem (1938: 510512) have pointed out, populations of delattri1 in E1 Salvador vary from one condition to the other. I have found a 8 intlar situation in Honduran populations of delattrif, with about 80 per cent of the specimens having the wing longer than the tail, the remainder being the reverse. The form delattril also differs from salyint in having a wite area between the chestnut cheeks and yellow throat, in having a deeper chestnut crown, and in being deeper yellow below; these characters hold true but are bridged by intergradation In El Salvador, central Guatemala, and western Honduras. The character of an unstreaked crown in delattril 18 not constant, and I can see no constant differences in width of the rectrices (other than an avarage greater width in more southern populations), supposediy an important generic 
character of Idiotes. There are no apparent differences in song pattern, ethology, or morphology, other than the intergrading features mentioned heretofore; thus delattril and salvint are conspecific as well as congeneric. The whitebellied Mexican groups, B. rufifrong sensu stricto, supposedly intergrade with the gellow-bellied salvini in southern Mexico and eastern Guatemala; the few specimens from these regions that I have examined do exhibit this Intermediacy and I therefore consider the whole complex to represent a single spectes, B. rufifrons.

I assign all Honduran material to the race B. ㄷ. delattril Bonaparte, although specimens from central and western Honduras approach the Guatemalan B. . salvini (Cherrie) In the varying wing/tail ratios and in the presence of traces of white below the chestnut auriculars in a few individuals. I have examined all specimens from Honduras previously reported as salvint and have found them referable to delattril.

\section{Bhaeothlypis fulvicauda (Sp1x)}

Buff-rumped Warbler

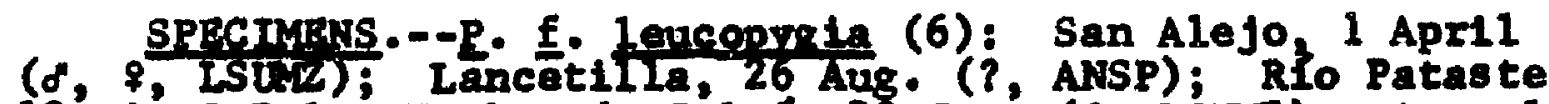
$12 \mathrm{mi}$. S Dulce Nombre de Culmf, 28 Jan. ( 9, Isug); Arenal, 25 Jan. (8, UCLA); Segovia River, 13 Aug. (f, USRM).

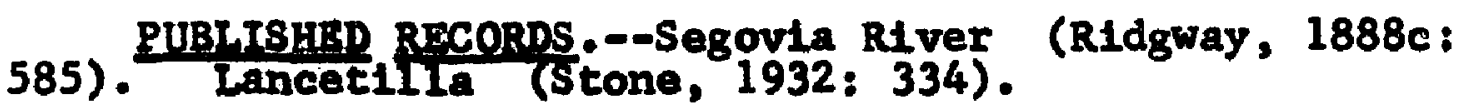
The Buff-rumped Warbler is another example of a rain forest inhabitant that reaches its northern iimit of 
distribution in the coastal forests of northern Honduras fust east of the Sula valley. It is uncommon to fairly common along streams in the rain forests around San Alejo, at Lancet1lla, and in the Olancho. In Honduras the species is not known above 1,500 feet elevation.

I follow Todd (1929a: 10-19) and slud (1960: 110;

1964: 335-336) in placing th1s species in a genus separate from Basileuterus. The habits and calls of the Buff-rumped Warbler are quite different from those of true Basileuterus, being similar to those exhibited by the waterthrushes (Seinrus). I a1so agree with Miller (1952b: 17) that fulvicauds is specifically diatinct from B. rivularls (W1ed).

Honduran specimens represent the northern race, $\underline{\underline{P}} . \underline{\underline{f}}$. lencoprgie (Sclater and Salvin).

\section{Family ICTERIDAE}

\section{Zarbrnchus waglert (Gray and Mitche11)}

Chestnut-headed Oropendola

27 SPECTYENS. --Z. Wy Whilert (19): La CeIba, 1-20 May, 27-29 July ( $\delta$, 4\%, CK); San Pedro Montafia, 31 March-2 April

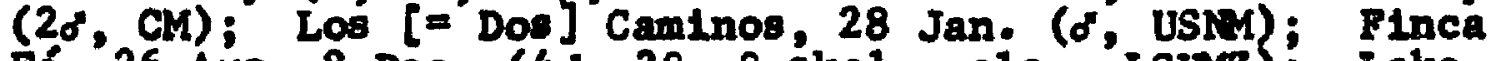
Fé, 26 Aus - -8 Dec. (4o, 3\%, q ske1., alc., Lsurz); Lake Yojoa, 18 July $(2 \%, \mathrm{CM})$. Z. W. ridgwayi (3): Arena1, 23 Jan. ( $d, 29$, UCLA):

PUBLISHFD RECORDS---Cholom (Moore, 1859: 57). San Pedro region (Sclater and Salvin, 1870b: 836). San Pedro (Salvin and Godman, 1886: 436). San Pedro, La Pita, Chamelecón (Hellmayr, 1937: 3). 
This oropendola is an uncommon resident in the Caribbean lowlands of Honduras, ranging up to an elevation of 2,500 feet. It occurs in regions of rain forest, especial1y in forest edge and semi-open situations. In the nonbreeding season, mixed flocks of this species and the more abundant Gymostinops montezuma are frequently seen.

I have not seen the specimens from Choloma, taken by Joseph Leyland, or from San Pedro, obtained by G. M. White1y, all of which are supposedly in the British Museum.

He1lmayr (1937: 3) examined specimens taken In Honduras by Erlch Wittkügel, apparently deposited in the Brunswick Museum; these specimens included 8 ingle individuals from San Pedro and La PIta (Department of Cortés) and two from Chamelecón.

Spectmens from Honduras, except from the Olancho rain forest of the southeastern section, are typical of the northern race, . w. waglert (Gray and Mitchell). The three birds from Arenal, in the Olencho rain forest, compare favorably with the paler, southern subspectes, Z. Itdowryi van Ros8em.

\section{Gymnostinops monterima (Lesson)}

\section{Montezuma Oropendola}

SPFG TMENS.--(59): Lancet11la, 19-21 Jan., 23-24 Aug. (2o, ANSP; 4\%, MCZ); La Celbe, 1-12 Jan., 3 March-1 June (58, 69, CM; \&, 28, MCZ; 7, USNM); Truji110, 31 March-6 April (20, CM); San Pedro Súla (?, CNHM); Chamelecón, 18

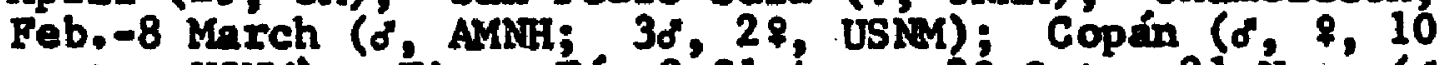
nests, USMM); Finca Fé, 8-31 Aug., 20 oct,, 21 Nov. ( ${ }^{*}, 9$, o skel., q skel., ISURz); Lake Yojoa, 14 June (d, CM); 
Taulabé (?, AMNH); Jamastrán Valley, 19 Feb. (d, UF); Segovia River, 17-20 June (o, 2\%, ?, USMM); Honduras N1caragua boundary "180 miles from Paclfic coast" (3?, MCZ); "Honduras" (2\& ske1., egg, USNM).

PUBRTSHED RECORDS.--Tanlavi [= Taulabé] (Sc1ater, 1858b: 358). Omoa (Moore, 1859: 57). Taulabé, Taulabé to Atlantic coast (Taylor, 1860: 111). San Pedro region (Sclater and Salvin, 1870b: 836). San Pedro (Salvin and Godman, 1886: 438). Segovia River (Ridgway, 1888c: 588). La Celba (Bange, 1903: 154; Deignan, 1936: 193) Tela region, Lancetilla, Lancetilla Valley (Peters, 1929b: 474). Lancetilla (Stone, 1932: 337). San Pedro Sula (Hellmayr, 1937: 7). Lancetilla Valley, Lancetilla (Skutch, 1954a: 291-301).

The Montezuma Oropendola is a fairly coumon to common resident on the Caribbean slope of Honduras, occurring below 3,500 feet. It is a highly gregarious spectes, forming huge flocks in the nonbreeding season and nesting in colonies in the summer. It inhabits open rain forest, forest edge, or semi-open situations, preferring the latter for nesting purposes. Scattered trees in open situations are often filled with the characteristic hanging nests of this oropendola. Breeding colonies are frequently parasitized by Glant Cowbirds (Scaphtdura oryztyora), which are usually seen in any active colony. During the nonbreeding season, mixed flocks of the Montezuma Oropendola and Zarhynchus wagleri are comonly noted.

Cacicus uropyial1s (Lafresnaye)

Scarlet-rumped Caçique (\%, UCLA)

PUBLISHED RECORD.--"Extreme southeas tern Honduras" [in range] (SIud, 1964: 337 ). 
The single specimen taken by Thomas $R$. Howell at Arenal in 1953 is the only Honduran record and was the basis for Slud's (1964: 337) inclusion of Honduras in the range of the species. It is another of the many rain forest inhabitants that reach their northern 1imit of distribution in the forests of 0lancho. It occupies much the same habitat as Amblycercus holoserlceus.

The Honduran specimen is referable to the noxthern race, C. u. microrhynchus (Sclater and Salvin).

\section{Amblycercus holosertceus (Deppe)}

\section{Yellow-billed Caçique}

SPECTMENS.-A. h. holosericeus (46): Julián [= Tulián] (?, ANSP); San AIejo, 16 March, 8 Aug. (20, ISUMZ); Lancet1lla, 8 Feb., 23 March, 24 Aug -6 Sep. (38, \&, ANSP; $\sigma^{\circ}$, MCZ); La Celba, 16 April-22 May, 3 Aug - ( ${ }^{\circ}, 28, \mathrm{CM}^{\circ}$ 2 28, USNM); Los Planes, 9-11 June (3\%, CM); Catacombas, 28 March-3 April (7, AMNH; o, MLZ); Cofradla, 4-7 March (2。, ML2); Las Pefitas, 2-7 Feb, (28, BMH; \&, MIZ); Amapa, 29 Nov. ( $\delta$, LStak); Coyoles, 17-28 June (2\%, CM); Finca Fé, 12 Aug. -10 Sep. (2\%, \& skel., LSUMz); Lake Yojoa, 16-28 July (2o, CM); Cerro Cantoral, 22-28 March, 2 Dec. (28, ${ }^{\circ}$, MCZ); Cantarranas, 5 Aug; ( ${ }^{\circ}$ AMaNH); Rancho Quemado, 20 March ( $\sigma^{\prime}$ MCZ); Bi Hatilio, 29 April ( $\%$, MCZ); Yeguare River Valley, 29 May (o', UF); Río de La Orilla, 29 May (?, MCZ); Jamss trán Valley, 17 Aug. ( $q$ UF); Arená1, 23 Jan. (?, UCLA); Segovia River, 11 Aug. (o, USLN); $2 \mathrm{mI}$. S El Corpus, 7 oct. (d, LSUE); Monduras (2?, LACM).

PUBL.TSHED RECORDS.-Omoa (Moore, 1859: 57). San Pedro region (Sclater and Salvin, 1870b: 836). San Pedro (Salvin and Godman, 1887: 447). Segovia River (RIdgway, 1888c: 588) Lancetilla, Lancetilla Valley (Peters 1929b: 474-476). Lancetilia Cantarranas (Stone, 1932:

335). La Ceiba (Delgnan, 1936: 193).

Ranging up to 5,000 feet, this caçique is a fairly common resident of undergrowth in broadleaf forests on both slopes of Honduras. It is found in dense brush and heavy 
second growth but prefers undergrowth within the forest itself. On the Pacific drainage it inhabits monsoon forest and vega forest along the rivers and is somewhat less common than on the Caribbean slope.

Honduran specimens represent the widespread, nominate race, A. h. hologericeus (Deppe).

\section{Scaphidura oryzivora (Gmelin)}

\section{Giant Cowbird}

SPECIMENS.--(11): Tela, 5-8 March ( $\left.{ }^{\circ}, 28, \mathrm{MCZ}\right)$; Montecristo, 23 March ( $\delta$, Lsîn); La Celba, 31 March, 3 May-6 June (2d, 3i, CM); San Pedro Sula, 9 April (d, CM); Las Pefitas, 15 Feb. (8', MCZ).

PUBIISHED RECORDS.--Choloma (Moore, 1859: 57). Omoa [as Csssidx crissirostris?] (Moore, 1859: 57). Tela, west of Tela, Lancetilla Valley (Peters, 1929b: 476). Lancetilla (Skutch, 1954a: 301).

The Giant Cowbird is an uncommon resident confined to the Caribbean 1owlands, occurring up to 2,500 feet elevation in Honduras. It frequents open situations such as fields, pastures, and scrubby areas, and is most often observed in and around colonies of Gymnostinops monteruma, which it parasitizes. I have also noted the species in company with Cassidix mexicanus along the Rio Jaitique near Taulabé.

I agree with Parkes (1954b: 229) that Scaphtdure is valid and has priority over Psomocolax.

Honduran specimens are typical of the Middie American race, S. o. Impacifa (Peters). 
Tangayius aeneus (Wagler)

Bronzed Cowbird

SPECTMEAS.--T. a. aeneus (25): San Alejo, 16 March (o', LSUMZ); Ia Ceiba, 26 April, 15 May ( $d, \&, C M)$, San Pedro Sula; 3 Aug. ( 9 , USMM); 7 mi. S Potrerilios, 26 Nov. ( gke1., LSUMz); San Esteban, 25 June (4\%, 2\%, CM); P1an del Rancho, 2-30 June ( $0^{\circ}, ?$, ML2); Monte Redondo, $14 \mathrm{Dec}$. ( $\sigma^{*}$, MCZ); Cantarranas, 5 Aug. (juv. o, ANSP); Ei Hatillo, 2-23 May (d, 3\%, MCZ); Comayagüela, 26 March, 5 Nov. ( $\delta^{\prime}, f$, MCZ); Escuela Aǵrícola Panamertcana, 22 Nov. (o', UF); Yeguare RIver Valley, 25 May, 14 June ( $q, \mathrm{MCZ}$; \&, UF); "honduras" ( $\delta$, ANDH)?

PUBLTSHEP RECORD.--Cantarranas (Stone, 1932: 336).

Ranging up to 3,500 feet, this cowbird is a falrly comnon resident in open situations throughout Hondures. It frequents open fields, pastures, and scrubby country, usual1y in flocks. Large roosts of these birds are often noted; one such roost is located near Tegucigalpa, and each evening long lines of this species may be seen over the town itself. The trees around the Presidential Palace are frequently loaded down with cowbirds.

The young male collected at Cantarranas by John $T$. Emlen, Jr., was being fed by a Thryothorus modestus. The Bronzed Cowbird no doubt parasitizes a wide range of small passerines in Honduras.

Honduran populations are referable to the widespread, nominate race, I. ‥ geneus (Wagler).

\section{Cessidix mexicanus (Gmelin)}

Great-talled Grackle

SPEGTMENS.--G. m. mextcanug (73): Utila Island, 9 March, "Spring" ( $\bar{\delta}, \bar{A} N S \bar{p} ; \delta, \bar{q}$ CNHM); Roatán Island, 8-10 
Jan. (10?, BMNH; 2d, q, 3?, CNHM); French Harbor, 4-7 April (2o, f, CM); Barbareta Is land, 12 April ( $\left.{ }^{\circ}, q, C M\right)$; Guanaja Island, 24-26 March ( $\left.8,{ }^{\circ}, \mathrm{CM}\right)$; Iittle Hog Island, 9-10 April (d, q, LSUMz); Tela, 29 Feb. -8 March (3o", 39, MCZ); Lancetilla, 16 Jan. ( $\sigma$, MCZ); Los Planes, 11 June (o, CM); Cofradia, 9 March ( $\$$, BMNH); Las Pefittas, 2-15 Feb. (2d, BMAH); Subirana, 2 April ( $\left.d^{\prime}, M C Z\right) ;$ San Esteban, 30 June ( $\left.0^{\circ}, 8, C M\right)$; Finca Fé, 20 Jan., 24 Nov. -7 Dec. (20", , LSURz); Cantarranas, 2 Aug. (juv. $\delta$, ANSP); San Juancito, 10-17 July, 12 Aug. (28, juv. o, juv. \&, ANSP); Tegucigalpa, 3 Féb., 7 July, 23 Oct., 16 Nov. (Juv. o, ANSP; o, AMGH; of ske1., MLZ; f, MCZ); Comayagüela, 20 Feb., 20 June, 21 oct. -16 Nov. ( 9 , AMNH; $50^{\circ}, 39$, MCZ); Escuela' Agrícola Panamericana, $4 \mathrm{July}, 28 \mathrm{Dec}$ ( $2 d$, UF); Yeguare River Valley, 15 Jan., 14-18 June ( $38^{\circ}, 2 \%$, UF); "Honduras" (2\%, imm. of, BMONH).

PUBT ISHED RECORDS.--Canagagua (Sclater, 1858b: 358; Taylor, 1860: 112). Onoa (Moore, 1859: 58). San Pedro region (Sclater and Salvin, 1870b: 837). "Honduras" (Sclater, 1886: 396). San Pedro (Salvin and Godman, 1887: 483). Roatán Island (Salvin, 1888: 265). Lancetilla, Tela (Peters, 1929b: 478). Teguctgalpa, Cantarranas, San Juancito, Rosario (Stone, 1932: 337). Bonacca [= Guana Ja] Island, Uttla Is land (Bond, 1936: 364). Rostán-Island, Chamelecón (Hellmayr, 1937: 91).

In Honduras the Great-tailed Grackle is a comnon and widespread resident, occurring throughout the country up to an elevation of 6,500 feet. It 18 most common in the Caribbean lowlands and in the Bay Is lands and Cayos Cochinos off the north coast. It is found in almost any type of open country, elther humid or arid, but 18 more frequently seen in the humid lowlands.

Hellmayr (1937: 91) examined an individual from Chamelecón, presumably taken by Erich Wittkügel and deposited In the Brunswick Museum or the Frankfurt Museum.

I assign Honduran birds to the widespread, noninate race, $\mathrm{C}$. $\mathrm{m}$. mexicanus (Gmelin). Geographic variation has not been carefully studied in the specles, as pointed out by 
Griscon (1932b: 400), who mentioned various aspects of this variation. Salvin (1888: 265) remarked on the darker females and smaller males from Roatán Is land, when compared with the mainland birds. Examination of the series from the Bay Islands and Cayos Cochinos indicates that the Insular birds differ from those of the adjacent mainland of Honduras in having stralghter, less decurved maxillae and more massive feet (with longer tarsi and toes) in both sexes and in being sightly darker in the females. All these characteristics, however, may be matched in individuals from various regions of the mainland of Middle America. I feel that no taxonomic name should be given these insular birds prior to a complete examination and revision of the entire species.

\section{Dives dives (Deppe)}

\section{Melodious Blackbird}

SPFCTYFNS. --p. d. dtres (55): Lancet111a, 2-5 Feb., 2 March ( $3 \delta^{7}$ \%, MCZ); La Celba, 28 March-27 May, 24 July (58, $3 \%$, CM; 2\%, USNM); Truj1110, 30 March (\%, CM); Guaruma, 23 Jan. (o, USNM); Chamelecón, 8 March (o, USNM); Coyoles, 15 Jume, 9-11 July (20, \%, CY); Monte $\mathrm{El}$ Conejo, $20 \mathrm{Mny}$ ( MLZ); Finca Fé, 9 Dec: (d, Lsurz); Bl Callche, 26 June, 18 JulY ( $\delta^{\circ}, 8$, AMaNH); Monte Redondo, 2 Nov. -15 Dec. $\left(5 \delta^{\circ}, 28\right.$, MCZ); La F1or Archaga, 29 May (o" MCZ); Cantarranas; 19 July, 2-9 Aug ( $20^{\circ}$, \$, Juv., ANSP); E1 Hat1110, 19 April,

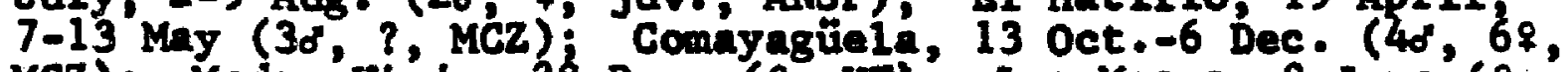
MCZ); Madre' Viéja, 28 Dec. ( $q$ UF); Las Mesas, 8 June' ( $q$;

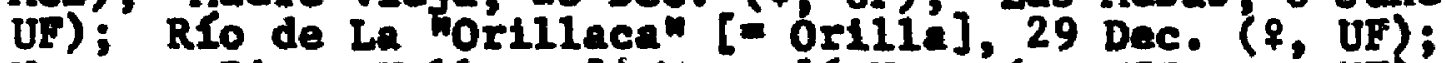
Yeguare River Valley, 24 May, 16 Nov.' (o,, MCZ; of, UF).

PUBL,TSHED RECORPS.--Guaruma (RIdgway, 1891: 470); Lancetilla Valley, Lancetilla (Peters, 1929b: 477-478). Cantarranas (Stone, 1932: 336). La Cetbe (Delgnan, 1936: 193). 
Occurring below 5,000 feet in Honduras, this blackbird is a fairiy common to common resident in a wide variety of open or semi-open situations. It prefers scrub, semi-open siturions, or forest edge, and occasionally enters second growth forests. It may be found in either humid or arid habitats but is most common in the former; it also is frequent around towns and villages.

Honduran specimens are referable to the widespread, nominate race, $D$. d. dives (Deppe).

Icterus spurlus (Linnaeus)

Orchard Oriole

SPECTyENS.--(69): Swan Islands, 17 April (o, MCZ); Utila Island, 19 April ( $\%, C M)$; Roatán Island (4?, BMNH); Little Hog Island, 7 April (8, LSUMZ); San Alejo, 1 April

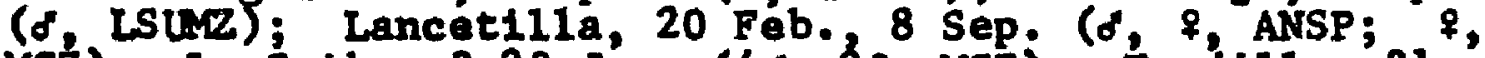
MCZ); La Celba 3-23 Jan. (40, 28 MCZ); Trujillo, 31 March-8 April (20", \&, GM); Cofradla, 2-6 March (2d, \&, AMNT; of, MLZ); San Pedro (20, BMNH); Las Peñitas, 1-9 Feb. (10\%, 49, 2?, AMNH; 20, $\$$, MIZ); La Lima, $26^{\circ} \mathrm{Feb}$. ( ${ }^{\circ}$, Lsucz); Progreso, 30 Jan. (d, MCZ); Subirana, 8 Dec. (?, MCZ); Merendón Copán, 12 Juné ( $\sigma^{\prime}$, AMar); Finca Fé, 24 Nóv. ( $\sigma^{\circ}$, LSuMZ); Archaga, 20 sep. ( $\sigma^{\circ}$, AMNH); Teguclgalpa, 4 Oct. (o', AMnH); Comayagüela, 20 Jan., 13 Oct.-15 Nov: (6o", MCZ); Hscuela Agrícola Panamericana, 13 March (q, UF); Yeguare River Valley, $26 \mathrm{July}$, 15 Aug. (8, \%, UF); San Lorenzo, 24-27 Sep. (38, AMNH; 28, MIZ; ?, MCZ); Honduras-Nicaragua boundary [near Pacific cosst] (?, MCZ); "Honduras" (o,, AMNH).

PUBL ISHED RECORPS.--San Pedro region (Sclater and Salvin, I870b: 837). San Pedro (Sclater, 1886: 368). Roatán Island (Salvin and Godman, 1887: 465; Salvin, 1888: 263-264). La Celba (Bangs, 1903: 154). Progreso, Lancetilla, Toloa Canal (Peters, 1929b: 476). Lancet1lia, Cantarranas (Stone, 1932: 336). Swan Islands (Paynter, 1956: 107).

The Orchard Oriole 18 a comon to abundant migrant and winter visitant in the lowlands of both coasts of Honduras 
and in the interior, ranging up to 3,500 feet elevation. It Inhabits open country, generally with much scrub or scattered trees present, and may occur in either humid or arid situations, though usually more common in the former. It is espectally frequent in cultivated or cut-over areas in the humld Caribbean lowlands. The islands off the north coast are also occupied by numbers of this oriole during migration and winter. Extreme dates of arrival and departure in Honduras are $26 \mathrm{July}$ and 19 April, but there is one summer record, that of a male collected at Merendon Copán on 12 June 1935 by C. F. Underwood.

I cannot distinguish the recently described race, I. $B$. phil11pgi Dickerman and Warner [1962: 311; 1 mile west of Acambaro, Guanafuato, Mexico]. This subspecies was based on average smaller aize (in which there is overlap to a very large extent) and silght color differences in the immatures.

\section{Icterus pros themelas (Strickland)}

\section{Black-cowled Oriole}

SPECTYENS. - - I. p. pros themelas (113): Juliain [= Tul1-

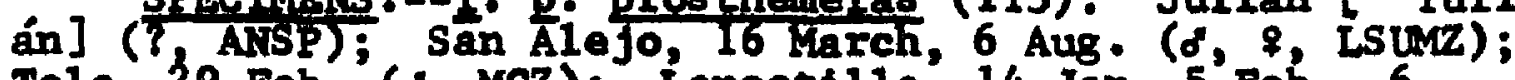
Tela, 29 Feb. (d, MCZ); Lancetilla, 14 Jan. -5 Feb., 6 March, 23-30 Aug; (3d, ANSP; 4o, 3i, MCZ); La Ceiba, 1-26 Jan. 26 March-29 May, 2 Aug. (11\%, 58, CM; 13\%, 78, MCZ; $2 \sigma^{\circ}, 2 \%$, USNM); Yaruca, 10-27 Feb. (30; 3\%, MCZ); Los Planes, 11 June ( $9, C M$; Trujillo, 30 March-8 April (2\&, 28, CM; 20, USMM) Cataccombas, 23 March-23 Apri1 ( $0^{\circ}, 2 \%$, AMNH; 80, MLZ); Cofradí, 11 Mareh ( $\%$, AMMH; ${ }^{\circ}$, MLZ); San Pedro Sula, 9 July, 5 Aug (?, Imm., BMNH; 28, USM); Las Pefiltas, 21 Jan, -15 Feb, (20, 3q, ANan; o, \&, MLZ); La IIma (o, IStMz); Coyoles, if June ( $\%, \%, \mathrm{CM}$ ); Finca Fe, 31

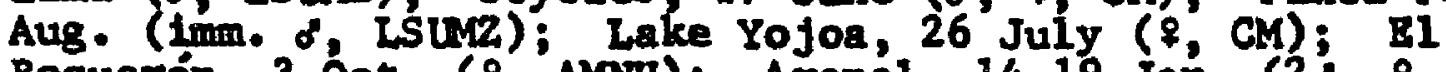
Boquerón, 3 oct. ( $\%$, AMnA) Arenal, 14-19 Jan. (2o, $\%$, UCLA); Segovia River, 12-23 June, 5-13 Aug. (40,2 2 , ?, 
USNM); Puerto Lempira, 8 April ( $\sigma^{*}$, LSUMZ); Nacunta River, 3 ml. S Puerto Lempira, 6 Feb. ( 9 , LSUMZ); "Honduras" (2?, ANSP; ?, AMNR; ?, BMNH).

PUBLTSHED RECORDS--Ccmayagua (Moore, 1859: 58). San Pedro region (Sclater and Salvin, 1870b: 837). San Pedro, "Honduras" (Sclater, 1886: 373). Truj1110, Segovia River (Ridgway, 1888c: 580, 588). La Celba, Yaruca (Bangs, 1903: 153). Lancetilla, Tela (Peters, 1929b: 477). Lancet11la (Stone, 1932: 335; Skutch, 1954a: 266-268).

A falriy common to common resident in the Caribbean lowlands of Honduras, this oriole occurs up to an elevation of 2,500 feet. It inhabits semi-open situations, forest edge, open rain forest, second growth, and cultivated lands, especially in the vicinity of water.

Honduran specimens are referable to the widespread, nominate race, I. Q. prosthemelas (Strickland).

\section{Icterus wagleri Sclater}

Black-vented ortole

SPECIMENS. --I. W. waglert (40): Subirana, 30 Jan., 10 DalDac. (25, KC'L); Konte Los Cedros, 2 June ( $8, \$$, ML2); Plan dedel Rancho, $12-30$ June (5d, 28, Miz); La Cruz Grande, 13-16 March ( $d, q$, AMaNh); Monte Redondo' $8 \mathrm{Feb}, 3 \mathrm{May}, 18$ Nov.18 Dec. $\left(\sigma^{\circ}, 2 q\right.$, ALNH; 4o, 2q, MCZ); La Fior Archaga, 2-3 May (\%, \& AMNH); San Juanc1to, 16-27 July (2\%, ANSP); E1 Hat1110, 20-28 April (2d, MCZ); Cerro Higutto, D.C., 4 May (7, AMAH); Tegucigalpa, 21 Apri1, $4 \mathrm{Julg}$ (28, AMNH); vicinity Tegucigalpa, $30 \mathrm{May}$ (d skel., Miz); Comayagüela, 5-6 Nov. ( 8 , AMNH; 2o, MCZ); Escuela Agrícola Panamertcana, 25 Aug. (?, UF); Yeguare RIver Valley, 12 Feb., 29 May (28, UF); Piedra de Jesús, 20 March (?, AMMA); hHonduras" ( $?$, AMNH).

PUBLISHED RECORD.--San Juancito (Stone, 1932: 335).

Icterus wagleri is closely related to I. prosthenelas and replaces it in the interior highlands of Honduras from 2,500 to 6,500 feet elevation. The Black-vented oriole 
prefers scrubby areas, second growth, edges of pine-oak associations, and ravine undergrowth. It is a fairly common species in Honduras.

Honduran specimens are representative of the nominate race, I. W. waglexi Sclater.

Icterus mesomelas (Wagler)

Yellow-tailed Oriole

SPECTMANS. - - I. m. mescmeles (27): San Alejo, 8 Aug. (o, ${ }^{\circ}$ LSUKZ); Laguña Toloa, 30 Aug: (o, ANSP); $52 \mathrm{~km}$. W Tela [= Laguna Toloa], 10 March ( ${ }^{\prime}, \&$, MCZ); Lancetilla, 8 Feb. ( $\&, f, M C Z)$; La Celba, 22 May $(o, q, C M)$; Cofradfa, 14-29 March (o', AMNH; ?, Miz); San Pedro Sula, 5 April, 9 July, 4 Aug - ( ${ }^{*}$ CM; $\&$; USN); Santa Ana, 8 Nov. ( $\sigma^{\circ}$, USNMY) Las Pefiltas, 1-10 Feb. (f, AMNH; 40", MLZ); Amapa, 24 June (o", UF); San José de Santa Bárbara, 23 April ( ${ }^{\circ}$, AMNH); Santa Bărbara, 16-17 May (2\%, AMNH); 4 mi. S E1 Jaral, 12 Sep. ( $\delta$, LSUMZ); "Honduras" (2?, BMNH).

PUBLTSHED RECORDS.--Omoa (Moore, 1859: 58). San Pedro region (Sclater and Salvin, 1870b: 837). San Pedro (Sclater, 1886: 379). Lancetilla, $52 \mathrm{~km}$. W Tela [= Laguna Toloa] (Peters, 1929b: 477). Laguna Toloa, Lancetilla (stone, 1932: 336).

The Yellow-tailed Oriole is an uncommon resident on the Caribbean slope of Honduras, ranging up to 2,500 feet elevation. It inhabits scrubby or brushy areas, especially in swamps or marshy lands, but is rarely found distant from water.

I refer all Honduran specimens to the smaller, northern race, I. m. mesomelas (Wagler). None shows any approach to the southern race, I. m. salyinil Cassin, which ranges north to Nicaragua; however, there are no Honduran specimens from the Olancho region where this latter race may occur. Wings 
of the Honduran specimens measure as follows: $\delta, 91.4-97.1$ $(94.4) ; \quad$; 83.3-87.1 (85.4).

Ictenus chrysater (Less on)

Yellow-backed Oriole

SPECTYENS:--I. C. chrysater (71): Roatán Is land (?, BMarH); Cotradia, 2-14 Karch (o, AMNH; of 8, MCZ); Las Pefittas, 25 Jan.-20 Feb. (20, AMONH; 30, 28,?, MLZ; o, q, MCZ) i Portillo Grande, 26 March, 8 May ( 8,9, MCZ); Coyoles, 16 June-11 July (2\%, 49, CM); San Esteban, 24 June ( CM); 3 mi. E Santa Rita, 4 Dec. ( ${ }^{\circ}$, LSUMZ); La Libertad, 22 June ( $\delta$, AMNH); Merendón Copán, 12-15 Jưne ( $\delta^{\circ} \%$, AMNH); Montaña $\mathrm{E1}$ Chorro, 19 June (28, ML2); Montafía La Cruz, 25

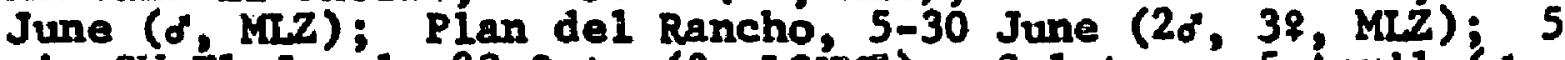
m1. SW E1 Jaral, 28 oct. (? LSUMZ); Soluteca, 5 April (d", 8, AMNH); La Cruz Grande, 12-16 March (3\% AMNH); E1 Horno, 13 Dec. (28, AMNH)' Guaimaca, 24-23 Jan. (20, 8 , AMarh); Cantoral, 3 May, 1 July (2\%, AMNH); Cerro Cantora1, 29 March, 26 July (d, $2 \%$, MCZ); Monte Redondo, 24 Nov, - 15 Dec. (?, AMNH; \&, 2\%, MCZ); La Flor Archaga, 30 MaY-7 June

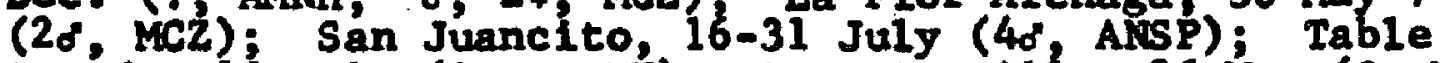
Grande, 13 July (iman., UF); Agua Amartila, 26 May ( 9, MCZ); Segovia River, 16 Aug. ( $q, 2$ Juv., USMM); Puerto Lempira, 7 Feb., 11 April (30, LSUMZ); Monduras" ( ${ }^{\circ}, 3$, AMNH).

PUBLISHEP RRCORDS.--Onoa (Moore, 1859: 58) Roatán Island (Salvin and Godman, 1887: 469; Salvin, 1888: 264). Segovla River (RIdgway, 1888c: 588). San Juancito (stone, 1932: 336). "Honduras" (Hellmayr, 1937: 130).

This oriole is a fairly comon to locally common resident in pine-oak associations in the interior of Honduras from 1,500 to 6,000 feet. It prefers open pine-oak forest or brushy areas in the vicinity of pine. There are populations also in the pine savanna of the Mosquitia of eastern Honduras at sea level and in the pine belt on Roatán Island, in the Bay Islands. In the Mosquitia the species is more common than anywhere else in the republic. 
Honduran specimens represent the widespread, nominate race, I. c. chrysater (Lesson).

Icterus pectoralis (Wagler)

Spot-breasted Oriole

SPEC IMENS.--I. P. pectora1is (78): La Celba, 13 May ( $\circ$, CM); $1 \mathrm{mI}$. N Pimienta Nueva, 9 sep. ( $\sigma$ skel., LSLM); Coyoles, 23 April, 16 June, 11 July (ot, 2 \% CM; ; Lsuaz); San Esteban, 24 June $\left(30^{\circ}, \$, C M\right)$; Copan $(2 ?, M C Z) ;$ Plan del Rancho, 12 June ( $\sigma^{\prime}, \%$, ML); Lake Yojoa, near Pito Solo, 2 Jan. ( 9 , ISUMZ); $2 \mathrm{mi}$. N Villa de San Antonio, 24 Aug. ( ${ }^{\prime}$, Lsierz); E1 Caliche, 28 June-31 July ( ${ }^{\circ}$, ANSP; 2q, AMNH); Cantoral, $10 \mathrm{Feb}$. ( $\delta$, AMMN); Monte Redondo, 12 Sep. 17 Oct., 24 Nov.-10 Jan. (29, ANSP; o, AMNH; o, CM; $50^{\circ} 48,1 \operatorname{man} ., \mathrm{MCZ}$ ); La F1or Archaga, 1 May-15 June (q) ANSP; 2o, AMNH; $\delta$ ' CM); Cantarranas; 29 July-3 Aug. (3d, 7, ANSP); E1 Hatillo, 19-22 April ( $9, \mathrm{CM}$; yaguiela, 11 oct. -17 Nov ( $\$$, ANSP; $6 \delta^{\circ}, 10 \%, \mathrm{MCZ}$ ); Escuela Afrícola Panamericana, 19 March ( $\sigma$, UF); Capa Rosa, 31 May, 18 Nov. ( 8,7, UF); Yeguare RIVer Valley, 31 May-3'June, 18 Nov; ( $\sigma$ MCZ; 29, UF); Danlf-Tegucigalpa road, $25 \mathrm{July}$ ( MCZ); Choluteca River, Dept. El Paralso, 23 Jan. (\&, UF); Pledra de Jesús, 18-20 March ( $\%$, ANSP; o, AMNH); San Lorenzo, 26 Sep. -3 Oct. (o, MLZ; 29, MCZ); Honduras Nicaragua boundary [near Pacific coast] (?, MCZ); "Honduras " (3?, AMNH).

PUBL,ISHED RBCORDS.--Copán (Griscom, 1930e: 18). Cantarranas (stone, 1932: 336).

Ranging up to 5,000 feet, the Spot-breasted Ortole is a resident in the arid lowlands of the Pacific slope and the interior of Honduras. It is one of the three spectes of orioles, the other two being I- gularis and I. pustulatus, that are primarily inhabitants of the arid Paclfic slope but occur also in the arid valieys on the Caribbean drainage and scmetimes under more humid conditions along the Caribbean coast. I. pectoralis is a fairly common to common resident In the Otoro, Comayagua, Aguán, and Sula valleys as well as 
on the Pacific slope, and it also occurs sparsely in the humid Caribbean lowlands as far east as La Ceiba. It is found in open or semi-open situations, generally where there is much scrubby growth. On the Pacific coast it enters open monsoon forest and vega forest along the rivers and is frequently recorded in towns and villages.

I tentatively refer all Honduran material to the larger, northern race, I. R. pectoralis (Wagler). In an extensive series from all parts of Central America, size variation ranges clinally from larger northern birds to smaller examples from Costa Rica. All color characters seem to be bridged by Individual variation; these characters include intensity of orange, amount of black streaking dorsally, and amount of black pectoral spotting. The $\mathrm{Pa}-$ cific lowlands from Guatemala to Nicaragua are supposed to be occupied by a race smaller than pectoralis, I. D. anthonyi Griscom, but specimens from the Pacific coast of Honduras average larger than birds from the rest of the country; If anthonyi is regarded as valid, its range will probably exclude Honduras. The range in size varlation in the Honduran specimens is extreme, but this variation does not seem to be correlated geographica1ly. Wing measurements of Honduran material are as follows: of, 101.5-116.5 (107.9); $9,97.9-111.2(102.4)$. 
Icterus gularis (Wagler)

\section{Black-throated ortole}

SPECTMENS.-I. g. troglodytes (27): Cofradia, 12 March (7, MCZ); Las Pefiltas, 29 Jan. -13 Feb. (d, 2\%, MCZ); Coyoles, 16 June, 11-18 July (o, 2\%, CM); San Esteban, 24 June (28, CM); Copán (?, MCZ); $5 \mathrm{mi}$. S Comayagua, 19 Nov. (Imm. o, Lsumz; $5 \mathrm{mi}$. N V111a de San Antonio, 17 oct. (o", \%, LSUMz); E1 Caliche, 3-16 July (o, 29, AMNH); E1 Boquerón, 20 sep: (o, AMNH); road to south coast, Dept. Valle, 5 Feb. ( $\%$ UF); San Lorenzo, 26 Sep,-6 oct. (4o, 2\%, MCZ); Puerto Salamar, 2 Oct. (o, LSur); 2 mi. NW Cedéfio, 11 Feb. (o', Lsurz): $13 \mathrm{ml}$. W Choluteca, 1 oct. (o, LSuz). I. g. gigas (57): Monte E1 Conejo, 15-20 May (2o, 28, Miz); Plan del Rancho, $12-30$ June (2\%, 2\%, MrZ); La Laguna Archaga, 20 Jan. ( $d$, USNM); Monte Redondo, 22 Sep., 18 Oct.-16 Jan. (d, 2\%, Imm. d, AMNH; 98, 6\%, imm. 4, MCZ; $\%$, USMY); Archaga,

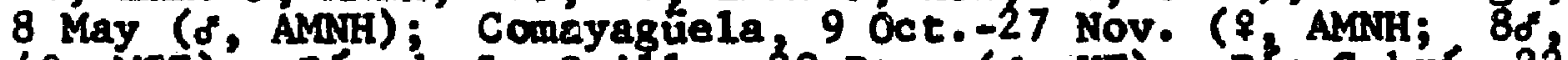
49. MCZ); Rlo de La Orilla, 29 Dec. ( ${ }^{*}$ UF); Rlo Cobri, 22 Jan. ( $d, 9, U F)$; $4 \mathrm{mi}$. W Ojo de Agua, 8 June ( 8, MCZ); Choluteca River, Dept. El Parafso, 23 Jan. ( $\sigma, U F) ;$ Piedra de Jesús, 18 Feb.-19 March, 17 May (28, ANSP; 28, 39, 1 m. o, AMNH):

PUBT,SHED RECORDS--Comayagua (Sclater, 1858b: 358). Pacific slope of Honduras; Atlantle side of Honduras (Tay1or, 1860: 111-112). HHonduras" (Hellmayr, 1937: $148)$.

The Black-throated Oriole is a common resident in arid regions of Honduras, occurring up to 6,000 feet. It is most common in the Pacific lowlands and in the arid interior valleys but ranges throughout most of the interlor highlands, Inhabiting scrub, semt-desert, monsoon forest edge, and second growth. In addition, it is found locally under slightly more humid conditions in the Sula Valley, especial1y around the town of San Pedro Sula. On the Caribbean drainage it has been recorded in the Otoro, Comayagua, Sula, Aguán, Agalta, and Olancho valleys and around Copán. 
Much study is yet needed to determine geographic variation in this species. Variation in color and in size is remarkable and has been responsible for the naming of many races in northern Central America. In the large series that I examined, most of the variation did not seem to be correlated geographically. Extremes with bright orange or pale yellow plumage (adults of either sex), as well as intermediates of all shades, may appear in any population; while it is true that a greater percentage of one type or the other is usually found at any one locality, delimiting races on this basis is not possible. There is a definite geographic trend in size, but it seems to be related more to altitude than to latitude, at least in Honduras. Populations in the interlor highlands above 1,500 feet on the Pacific drainage are consistently larger (wing: o, 122.1138.0 , mean $130.1 ; f, 115.3-127.6$, mean 122.3) than those found in the Pacific lowlands below 1,500 feet and in the valleys on the Carlbbean slope (wing: o, 113.9-127.0, mean $121.0 ; f, 112.9-124.0$, mean 118.5). I have tentatively assigned the larger interior birds to the subspecies I. g. gigas Griscom, of which I. g. Kerophilus Griscon is a symonym (Hellmayr, 1937: 148, acting as first reviser), and the lowland populations to the smaller, Pacific coast race, I. g. troglodytes Griscon. Dickey and van Rossem (1938: 524527) considered the size variation to occur randomly in El Salvador and referred all specimens from that country to the 
nominate race, I. g. gularis (Wagler). Since there is a geographic correlation in size in Honduras on the basis of the present material, I am retaining glgas and troglodytes.

\section{Icterus galbula (IInnaeus)}

Baltimore Oriole

SPECTYENS.--I. g. galbula (37): La Ceiba, 2-24 Jan. (5o, 2\%, MCZ; $0^{\circ}$, USTM); Trufillo, 20 sep.-1 Oct. $\left(2 \sigma^{\circ}, \%\right.$, USNM); Cofradia, 2-25 March (40, MLZ); San Pedro (20", BMAH); La Lima, 26 Feb. ( $\sigma^{\circ}$, Lsuiz); Subirana, 31 Jan. ( $\sigma^{*}$, MGZ); 5 mi. SW' El Jaral, 26 Oct. (alc., LSLaZ); Finca Fé, 14 Sep., 22 Oct., 30 Nov. -2 Dec. (2s, 28, Lsurz); 2 mi. N Pito Solo, 13 oct. ( $q$ skel., LSugz); E1 Hatil1o, 19 April (7, MCZ); Comayagüela, 11 oct.-11 Dec. (30, 78, ?, MCZ).

PUBLISHED RECORDS.--San Pedro region (Sclater and Salvin, I870b: 836) . San Pedro (Sclater, 1886: 365) . Truj1110 (RIdgway, 1888c: 580). La Celba (Bangs, 1903: 154). Tela region (Peters, 1929b: 476). Utila Island (Bond, 1936: 364). Choloma (Selnes, 1958: 14).

Ranging up to 4,500 feet, the Baltimore Oriole is a fairly common to common migrant and winter visitant in the Caribbean lowlands of Honduras; it occurs sparingly in the Pacific lowlands and in the interior on the Pacific drainage, and it has been recorded in migration from the Bay Is lands and the Cayos Cochinos. It frequents broadleaf forest, second growth, forest edge, semi-open situations, and occasionally scrub. Extreme dates of arrival and departure in Honduras are 4 September and 4 May.

Stone (1932: 336) mentioned an Onoa record, but this report was based on a specimen shot by Joseph Leyland on one of the cays off British Honduras (Moore, 1859: 57). Ridgway (1888c: 580) erroneously 11sted 1 September as the date 
of one of C. H. Townsend's three specimens taken at Trujillo In 1887; these three individuals were collected on 20 and 22 September and 1 October, according to the labels. Sibley and Short (1964: 130-150) have presented evidence that the Baltimore Orlole and the Bullock's Oriole, I. bullockit, are conspecific, and I follow them here.

All Honduran specimens are referable to the eastern race, I. g. galbula (Linnaeus). The western subspecles, I. g. bullockif (Swainson), winters in the highlands of Central America south to Costa Rica. On 30 October 1962 near Sabanetas, Department of La Paz, at an elevation of 5,500 feet, I tentatively identified a female bullockit in the field; the bird was shot but could not be retrieved.

\section{Icterus pustulatus (Wagler)}

\section{streak-backed oriole}

SPFCTMENS.--I. p. Aclatert (68): $3 \mathrm{ml}$. E Copán, 5 Dec. ( $q$, LSULi ; 5 mi. N villa de San Antonio, 17 oct. ( $\sigma_{3} \%$, ISIMZ); Cantoral, 15 May ( 8 , USNM); Monte Redondo, 27 Oct. -15 Dec. ( $\%$, imm. $\%$, AMNH; $\left.7 f^{\prime}, 12 \%, 2\right\}$, MCZ); Archaga, 26-27 Sep. (9, imen, o, AMNH); La Blor Archaga, 3 May-15 June (2。, AMMH; $\delta$, MCZ); Bi Hatillo, 2-16 May (o, 28 , MC2); Tegucigalpa, 11 oct. (d, AMnH); Comayagüela, 13 July, 13 oct., 2-10 Nov. (d, Imm. $q$, AMNH; 38, 3\%, MCZ); Yeguare River Valley, 18 Nov. ( $\delta, 1$ imm. 9 , UF); Río Cobri, 22 Jan. ( $q$ UF); bridge over Rlo Choluteca, Dept. El Paraiso, 25 Juiy ( $\delta$, UF); Sabana Grande, 5 March ( $\%$, ANSP); Piedra de Jesús, $17^{\prime} \mathrm{Feb}$-20 March, $17 \mathrm{May}$ (28, ANSP; 50, 2\%, Imm. \%, AMNH); 4 mi. S Goascorán, 1 oct. ( 9 , Isunz); San Lorenzo, 25 Sep. -6 Oct. (o, 39, MCZ); Puerto Salamar, $11 \mathrm{Feb}$. (o", LSURZ); $7 \mathrm{ml}$. W Choluteca, 1 oct. (o, Isurz); 3 mi. E Choluteca, $10 \mathrm{Feb}$. ( 8, ISLMZ); "Honduras coast" (?, USNM).

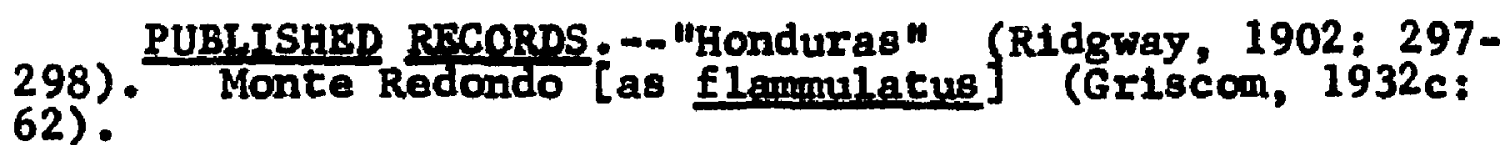


As is the case with I. pectoralis and I. gularis, the Streak-backed Oriole is a common resident on the arid $\mathrm{Pa}$ cific slope and locally in arid interlor valleys on the Caribbean slope. It generally prefers arid scrub or semiopen situations and ranges up to at least 6,000 feet. On the Caribbean slope it has been recorded as common in the Comayagua valley and uncommon in the Sula valley and around Copán.

The group of races ranging from Oaxaca south through Central America is sometimes regarded as a separate species, I. Bclater Cassin. In Oaxaca, however, the sclateri and pustulatus groups are allopatric, not sympatric; they are obvious geographic representatives of one another and are now considered to be conspecific by most authors.

Many races of $I$. pustulatus have been described from northern Central America on the basis of 8 ize and of intensity of orange or yellow in the plumage. However, variation in color in populations south of Oaxaca seens to be entirely individual in nature. Size in Honduran populations varies considerably (wing: o, 103.1-117.9, mean 110.7 ; $\$, 101.9-115.5$, mean 105.7), but this variation cannot be correlated either geographically or altitudinally. Spectmens from the Paciftc lowlands should be the race I. D. sclateri Cassin, while interior birds should be elther the Guatemalan form, I. R. alticola Miller and Griscom, or I. ․ Elammulatus [Icterus sclater1 flammulatus Griscom, 1932c: 
62; Monte Redondo, Honduras], both of which are supposed to be larger than sclateri. The Pacific lowlands birds from Honduras, however, are not small, and size variation in this species is probably nongeographic. I. R. flammulatus, supposedly with a greater amount of black streaking on the back, is invalid, since it is based on a character that is greatly dependent upon wear and, furthermore, one that is generally individual in its variation. In view of the foregoing considerations, I prefer to maintain the Central American populations as a single race, I. p. sclateri, until a thorough revision of the species can be undertaken.

\section{Agelaius phoentceus (Linnaeus)}

\section{Red-winged Blackbird}

SPECIMENS. --A. R. brevirostris (14): $4 \mathrm{mi}$. N Río Lindo 29 Nov. ( $\alpha^{\prime},{ }^{\circ}$ LSTIK); Coyoles, is June-8 July (2o, \$, CM); El Jaral; 12 Jan. ( $\$$, LSUMZ); 1 mi. W E1 Jaral, 21 Aug. (imm. of LSUAZ); Agua Azul, 30 July-5 Aug. (20', UF); Lake Yojoa, 13-25 July $(28,3 \%, \mathrm{CM})$.

PUBLTSFED RECORDS.--Laguna Toloa (Stone, 1932: 335). Coyoles, Lake Yojoa, Agua Azul, 1 mi. W [E1] Jaral, $4 \mathrm{mi}$. N Rio Lindo (Monroe, 1963a: 7).

The Red-winged Blackbird is a locally common resident in marshes on the Caribbean slope of Honduras, occurring below 2,500 feet. It is known to breed at Laguna Toloa (Stone, 1932: 335) and at Lake Yojoa; specimens have been taken also at Coyoles and near Amapa (north of Rio Lindo), and the spectes undoubtedly breeds also at these localities. It occurs on the Pacific coast of E1 Salvador and Nicaragua but has not been recorded on the Pacific slope of Honduras. 
The Honduran and Nicaraguan populations on the Caribbean slope have been described as A. p. brevirostris Monroe [1963a: 6; 4 miles north of Río Lindo, Department of Cortés, Honduras]; this race differs from A. Q. richmondi Nelson, a subspecies ranging south to British Honduras, in Its shorter bill and in the females in a more yellowish, less distinctly streaked breast. Measurements of the culmen (chord from nostril) of Honduran specimens are as follows: $0,15.6-16.3(16.0) ; \uparrow, 13.5-14.3(13.8)$. Culmen measurements of a series of richmondi from Tabasco and British Honduras are as follows: $\delta, 16.8-18.8$ (17.7); $q$, 14.1-15.0 (14.6). A much larger race, A. Q. grinnel11 Howell, occurs on the Pacific slope of Central America but has not yet been recorded in Honduras.

\section{Sturnella magna (Linnaeus)}

Eastern Meadowlark

SPECTMENS.--S. m. alticola (33): Subirana, 9-17 Dec. (3d,, , MCZ); Sañ Esteban, 22 June (6d, 3\%, CM); $15 \mathrm{mi}$. NW Siguatepeque, 15 Aug. (2\%, CM); Siguatepeque, 8 July ( $\sigma^{\circ}, \%$, GM); 3 mi. E Siguatepeque, 24 Aug. (d, Lsurz); Cerro Cantoral, 15 Feb. ( $\delta$, MCZ); Monte Redondo, 21-27 Nov. (2o, \&, MCZ); Comayagüela, 10 oct., 8-16 Nov. (d, ?, ?, MCZ); Es cuela Agrícola Panamericana, 31 May (o, MCZ); Las Mesas, 8 June ( $7, ?$, UF); Yeguare River Valley, 25 Jan., 4-6 March (2o, $\&$, UF); Danil, 6-7 April ( $\sigma^{\circ} q^{\circ}$, BMNH): s. m. inexpectata (11): Segovia River, $17-19$ July (2d, o, USNM); Puerto Lempira, 6 Feb., 11-14 April (50, 39, Lstuz).

PUBLISHED RECORDS.--"Honduras" (Sclater, 1858b: 358). Near Siguatepeque (Taylor, 1860: 317). "Comayagua" [= near Siguatepeque] (Salvin and Godman, 1887: 457). Segovia River [as inexspectata] (Ridgway, 1888c: 587-588). 
The Eastern Meadowlark is a fairly conmon to common resident in grasslands in the interior highlands of Honduras, occurring primarily in the vicinity of pine from 1,500 feet to 6,500 feet elevation but ranging down to about 1,000 feet in the San Esteban region. It is also a common and conspicuous species in the sea level pine savanna of the Mosquitia in eastern Honduras.

Interior populations of this species in Honduras represent the larger race, S. m. alticola Nelson. Wing measurements of these birds are as follows: ot, 100.2-111.4 $(106.1) ; 9,94.9-95.9(95.4)$. The tsolated population in the Mosquitla is decidedly smaller (wing: $d, 95.5-98.7$, mean 97.4; $\%, 85.7-89.4$, mean 87.8) and, as is the case in many other species of similar distribution, is identical (or very nearly 80 ) with the population inhabiting the pine ridges of British Honduras. I assign these Mosquitia individuals to the race $\underline{S}$. $\underline{\text { m. inexpectata [Sturnella magna }}$ Inexspectata (1apsus, = inexpectata) RIdgway, 1888c: 587; Honduras (Segovia River)].

\section{Dolichonyx oryzivorus (Linnaeus)}

Bobolink

SPECIMENS:--(2): Swan Islands, 2 Oct. ( $\sigma^{*}$, MCZ); Utila Island, 4 May ( 8 , LSUMZ).

PUBLISHED RECORD.--Swan Islands (Paynter, 1956: 107).

In Honduras the Bobolink is a rare migrant through the islands off the north coast. There are only two records, a 
male taken by George Wilson in the Swan Islands in 1926 (Paynter, 1956: 107), and another male that I obtained on Utila Island, in the Bay Islands, in 1963. Eisemann (1955a: 97) 1isted the species from Honduras but he informed me (personal communication) that his records do not show any specific Honduran report.

Family THRAUPIDAE

Chlorophonia occipitalis (Du Bus)

Blue-crowned Chlorophonia

SPECIMENS.--C. 으. occipitalis (30): La Celba, 9 Jan. (2d, MCZ) ; San Pedro sula, 29 March (d, 8, CNHM); Las Pefiltas, 30 Jan.-15 Feb. (38, 47, MCZ); Port1llo Grande, 29 Jan. -26 "Feb. (40", $\%$, CNHM; $30^{\circ}, 39$, MCZ); Cerro E1 Triumpho, 20 mi. SE San Esteban, 2 April (7, isurz); Montaha El Chorro, 20 June ( $q$, MLZ); Cerro Santa Bárbara, east slope, 21 April, 1 Dec. ( $8, \%$, LSUMZ); Lake Yojoa, 25 July, 25 Aug. $\left(20^{\circ}, 2 \%, \mathrm{CM}\right)$.

PUBLISHED RECORDS.--La Ce1ba (Bangs, 1903: 155). San Pedro Sula (Hellmayr, 1936: 13).

A species of the high tree canopy, this tanager is an uncommon to fairly common inhabitant of cloud forests, occurring in Honduras from 3,000 to 6,500 feet elevation. In winter some individuals descend into lowland rain forest nearly to sea level.

Honduran specimens are typical of the well-marked, nominate race, G. o. occipltalis (Du Bus). 
Tanagra elegantissima (Bonaparte)

Blue-hooded Euphonia

SPECIMENS.--T. e. yincens (22): Monte E1 Conejo, 15 May ( $\left.\sigma^{\prime}, M Z\right)$; San Jose de Santa Bárbara, 29 April-16 May ( $\sigma^{\circ}, 2 \%$, AMNH); $4 \mathrm{mi}$. SW El Jaral, 21 Oct. ( ${ }^{\prime}, 1 \mathrm{~mm} . \sigma^{\circ}$, ISUMZ); Finca Fé, 21 Jan. ( $\%$, LSƯMz); Montaña Vásquez, 19 Nov. (o, AMNH); Cerro Cantoral, 9 Dec. ( $\$$, MCZ); Monte Redondo, 20 Nov. 8 Dec. ( ${ }^{\circ}$, AMNH; $\sigma^{\circ,} \&$, MCZ); Tegucigalpa, 6 Apri1, 20-27 June (46, AMNH); Comayagüela, 3 July (d, MCZ); Yeguare River Valley, 5 June, 15 Dec. (3\%, UF); San Francisco, Dept. Francisco Morazán, 14 June ( $\sigma^{\circ}, 7$, UF).

PUBLISHED RECORD.--"Honduras" (ZImmer, 1943a: 5).

In Honduras the Blue-hooded Euphonia is an uncommon to fairly common resident in cloud forest, pine-oak associations, rain forest (at medium elevations), and monsoon forest. It ranges during the breeding season from 1,500 feet to 7,500 feet elevation and descends in the nonbreeding season into lowland rain forest to sea level. As is the case with most members of this genus, it is a species of the high tree canopy; its distribution is closely correlated with that of its primary food, mistletoe.

Zimmer (1943a: 5) mentloned that he examined eight spectmens from Honduras, presumably those in the American Museum of Natural History.

T. elegantissima is sometimes considered conspecific with the West Indian I. musica (Gmelin). In view of the many color differences (throat, rump, under parts) and the fact that color differences of a much smaller degree usually indicate separate species in other members of the genus, the 
Middle American group is best regarded as a separate species, I. elegantissima.

Zimmer (1943a: 5) recognized the race $I$. e. vincens

(Hartert) for populations from Guatemala to Costa Rica. An examination of a large series of Middle American birds indicates that this race may be distinguished by the average darker purplish crown of both sexes, although I cannot see any constant differences in female plumage coloration otherwise. Populations in southern Mexico are intermediate between yincens and $T$. e. elegantisgima (Bonaparte) of central Mexico.

Tanagra affinis Lesson

Scrub Euphonia

SPECIMENS.--(51): San Alejo, 3 April, 6 Aug $\cdot(0,9$, LSUMZ); La Ceiba, 13 May (imm. of, CM) Cofradía, 9-12 March (20, \&, AMNH); San Pedro Sula, 28 July ( $0^{\circ}$, USNM); Las Peñitas, $13 \mathrm{Feb}$. ( $\delta$, AMNH); Amapa, 15 Jan. ( ${ }^{\circ}$, LSUMZ); Coyoles, 14-15 June (30, CM); Finca Fé, 18 July-13 Aug. ( $0^{\circ}$, o skel.; alc., LSUMZ); Lake Yojoa, 13 July (Imm. \&, CM); El Callche; 27 June ( ${ }^{\circ}$, \&, AMNH); Cantarranas, 20 July-10 Aug. ( $3 d^{\prime}$, Juv., ANSP); Comayaguela, 12 Nov. ( $\left.\$, M C Z\right) ; 1$ mi. E Escuela Agrícola Panamericana, 5 June ( $\sigma^{*}, \%$, UF); Madre Vieja, 27 Jan. ( $\sigma^{*}$, UF); Yeguare River Valley, 18 May12 June, 7 Sep., 18 Nov. (20, 49, UF); Choluteca River, Dept. El Paraíso, 19-20 May ( $\$$, $q$, UF); E1 Boguerón, 22 Aug. ( 9 , AMNH); San Lorenzo, 26 Sep. -6 Oct. ( $70^{\circ}, 29$, MCZ); 3 mi. E'Choluteca, 10 Feb. ( $\delta$, LSUMz); $5 \mathrm{mi}$. SE Namaatgüe, 8 oct. ( $\sigma^{\prime}$, LSUMZ); San Franclsco, Choluteca, 14 0st. ( $\sigma^{\circ}$, IS UMZ); Honduras-Nicaragua boundary [near Pacific coast] $(4 ?, M C Z)$.

PUBLISHED RECORDS.--Cantarranas (Stone, 1932: 337). Las Peñitas, Cofradia, El Caliche, El Boquerón (Zimmer, 1943a: 14). 
Ranging up to an elevation of 3,500 feet, the Scrub Euphonia is a fairly common resident in the arid Pacific lowlands and arid intertor of Honduras, occurring also under humid conditions around Lake Yojoa, in the Sula Valley, and in the Tela region. It inhabits open broadleaf forest, forest edge, second growth, semi-open situations, and scrub, usually occurring high in trees.

\section{[Tanagra luteicapi11a (Cabanis)]}

Yellow-crowned Euphonia

This species occurs in open rain forest and semi-open situations in the humid Caribbean lowlands north to northern Nicaragua. Howell (1957: 102) reported it as common in the Nicaraguan rain forest about 100 miles south of the Rfo Segovia. On two occasions in January 1955, Howell (personal communication) observed black-throated euphonias, tentatively identified as I. Luteicapilla, at Arenal, at an elevation of 1,200 feet.

\section{Tanagra lauta Bangs and Penard}

Yellow-throated Euphonia

SPECIMENS. - T. 1. 1auta (75): Tela, 7 March ( ${ }^{*}$, ?, MCZ); La Celba, I4 Jan., 6-7 June ( $\sigma^{\circ}, 8$, CM; d, MCZ); Trujillo, 7 April ( ${ }^{*}$, CM); Catacombas, 9-29 March ( $\delta$, AMNH; 20, MLZ); Cofradia, 10-11 March (20, MLZ); San Pedro ( $0^{\circ}$, BMNH); Las Peñitas, 8 Feb. (2\%, BMNH); Progreso, 30 Jan. ( ${ }^{\prime}$, MCZ); Coyoles, 11 July ( $\left.{ }^{\circ}, f, C M\right)$; San Esteban, 1 July (2\&, CM); La Libertad, 18 June ( Santa Bárbara, 10 April, 1-6 May (5\%, 3\%, AMNH); Santa Bárbara, 11-29 May (30, 2\%, AMNH); Cerro Santa Bárbara, east slope, 21 Apri1, 9 Dec. (2\%, LSUMZ); Finca Fé, 20 Féb. -1 March, 18 July-8 Sep., 5 Nov., 8-9 Dec. (6o", 4\%, $?$ ?, $?$ skel., Imm. o' skel., 2o' alc., ' alc., LSIMZ); Lake Yojoa, 
12 June, 15 July-17 Aug. (4d, 2f, CM); B1 Caliche, $18 \mathrm{July,}$

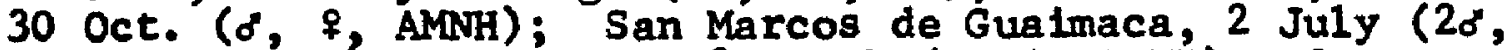
AMNH; $\sigma^{\circ}, M L Z$; Cantoral, 2 March ( $0^{\circ}, \%$, AMNH); Cantarranas, 20 July-5 Aug. (3 $\sigma^{\circ}$, ANSP); Puerto Lempira, 12 April ( $0^{\circ}$, LSIMZ); "Honduras" (7?, ANSP).

PUBLISHED RECORPS.--San Pedro region (Sclater and Salvin, I870b: 836) San Pedro (Salvin and Godman, 1883: 261; Sclater, 1886: 76). La Ceiba (Bangs, 1903: 155). Progreso, Tela (Peters, 1929b: 469). Cantarranas (Stone, 1932: 333 ).

Occurring in Honduras up to 3,500 feet elevation, this euphonia is a fairly common to common resident in open broadleaf forest, forest edge, second growth, and semi-open situations on both slopes. It is most cormon at medium elevations, being decidedly less frequent below 1,500 feet on either slope. On the Pacific drainage it is confined to monsoon forest and to vega forest along the rivers.

All Honduran specimens are referable to the nominate race, $\underline{1}$. 1. 1auta Bangs and Penard. None shows any approach to the greener-backed, larger-billed race, I. 1 . proba Bangs and Penard, which ranges north to Nicaragua.

\section{Tanagra gouldt (Sclater)}

\section{Olive-backed Euphonia}

SPECIMENS.--T. g. gould1 (44): San Alejo, 15-31 March (2o, LSULC); Lancetilla, 14 Jan. -6 Feb., 2-8 Sep. (2o, ?, ANSP; $20^{\circ}, 3 \%, 1 \mathrm{~mm}$. ${ }^{\circ}, \mathrm{MCZ}$ ); La Celiba, 2-20 Jan. (30, 39', MCZ); Santa Ána, 24 Óct., 25 Dec. -3 Jan. (d, $2 \%$, USNM); Rio Blanco, Cortés, 19 Dec. ( $\%$, USNM); Chamelecón, 2 Jan., 15 Nov. (20, $\%$, USNM); Arena1, $23-28$ Jan. $\left(2 \sigma^{\circ}, 2 \%\right.$ UCLA); Segovia River, 18 June, 8-13 Aug. (2d, \%, d?, USNM); "Honduras" (12?, ANSP).

585) $\frac{\text { PUBLISHED RECORDS.--Segovia River }}{\text { La Ceiba (Bangs 1903: 155). Lancetilia }}$ (Peters,
1929 b: 470-471; Stone, 1932: 337 ).


Ranging up to 1,500 feet, the Olive-backed Euphonia is an uncommon to fairly common resident in the Caribbean lowlands of Honduras. It inhabits the tree canopy in rain forest, forest edge, and second growth.

All Honduran specimens are referable to the northern race, I. g. gouldi (Sclater). Howell (1957: 102-103) reported the smaller, southern race, $T \cdot G \cdot$ praetermissa Peters, from Nicaragua, about 100 miles south of the Rfo Segovia. The Honduran specimens from the Olancho rain forest, however, match gouldi both in size and in coloration of the males (male praetermissa have the chestnut abdominal patch reduced in size).

\section{Tangara larvata (Du Bus)}

\section{Golden-masked Tanager}

SPECIMENS.--T. 1. Larvata (62): Medina (?, ANSP); San Alejo, 16 March, 5 Aug (27, Lstuz); Tela, 28 March (\$, MCZ); Lancetilia, 14-23 Jan., 2 March ( $\left.30^{\prime},{ }^{\circ}, \mathrm{MCZ}\right)$; La

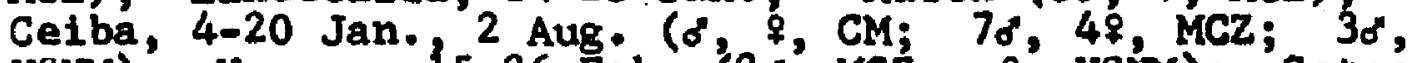
USNM) Yaruca, 15-26 Feb. (28, MCZ; \&; USMM); Catacombas, 2 April (o, BMNH); San Pedro (?, BMNH); RĹo Blanco, Cortés, 19 Dec. ( $\delta, \$$, USNM); Chamelecón River (2?, BMNH); 1 mi. SW El Jara1; 27 April ( $\delta$, \& skel., LSUMZ); 2 mi. SE E1 Jaral, 2-3 March (3o, \%, LSLúz); Agua Azul, 27 July-7 Aug. (20, ₹, UF); Lake Yojoa, 12-23 June, 13-25 Aug. (58, 39 , imm. $\delta^{\circ}, \mathrm{CM} ; 4 \delta^{\circ}, \mathrm{UF}$ ); Arenal, $17-18 \mathrm{Jan} .\left(\delta^{\circ}, \$\right.$, UCLA); Segovia River, 16-30 July (4\%, USNM).

PUBLISHED RECORDS:--Chamelecón River (Sclater, 1856a: 260-261; 1858c: 81-82). San Pedro region (Sclater and Salvin, 1870b: 836). San Pedro (Salvin and Godman, 1883: 274). "Honduras," San Pedro (Sclater, 1886: 125). Segovia River (RIdgway, 1888c: 585). Río Blanco [Cortés] (Ridgway, 1902: 49). La Celba, Yaruca (Bangs, 1903: 155). Lancetilia, Tela (Peters, 1929b: 471). Santa Ana (Hellmayr, 1936: 131). 
This fairly common resident of the Caribbean lowlands of Honduras has not been reported above 2,500 feet. Occurring mainly in the high tree canopy, it inhabits open rain forest, forest edge, second growth, and occasionally semiopen situations.

Hellmayr (1936: 131) 118ted two specimens from Santa Ana, presumably taken by Erich Wittkügel and deposited in the Brunswick Museum or the Frankfurt Museum.

In view of the striking color differences of the heads of I. Larvata and the South American I. nigrocincta (Bonaparte), I am reluctant to combine the two into a single species, as is done by many recent authors. In other members of the genus, color differences of this degree usually Indicate a specles level of differentiation.

I agree with Z1mmer (1943b: 13-14) and Howell (1957: 103) that populations in Honduras and northern Nicaragua are typical of the northern race, I. 1. 1aryeta (Du Bus). None of the Honduran specimens shows any approach to the southern subspecies, I. 1. Eranciscae (Sclater) and I. 1. centralis (Berlepsch), both of which occur in Costa Rica and differ from larvata in having a coppery golden instead of a coppery reddish crown and throat.

\section{Tangara lavinia (Cassin)}

Rufous -winged Tanager

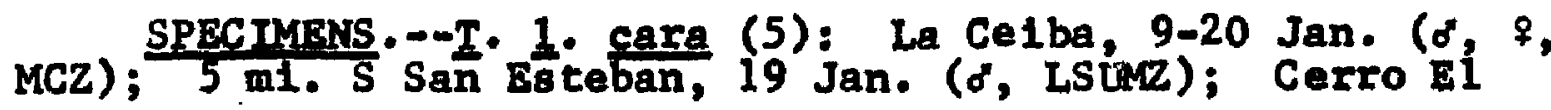


Triumpho, $20 \mathrm{mi}$. SE San Esteban, 1 April ( 9 , LSUMZ); Arenal, 18 Jan. (d, UCLA). $155-156)$.

PUBLISHED RECORD.--La Ceiba (Bangs, 1903: 155; 1905 :

occurring in Honduras up to 2,500 feet elevation, the Rufous-winged Tanager is an uncomnon to rare resident in the lowland rain forests of the Caribbean 8lope. Although primarily a species of the tree canopy, it often enters second growth and is frequent in forest edge. The species reaches its northern 1imit of distribution in the rain forests of eastern Guatemala in the Puerto Barrios region.

W. W. Brown (Bangs, 1903: 155) obtained two specimens in 1902 at La Cetba, a mele on 9 January and a female on 20 January. J. G. Montrello collected a male at Arenal in 1955. Richard R. Graber and Jean W. Graber secured male on 19 January 1962 and a female on 1 Aprtl 1963, both from the Olancho rain forest near San Esteban; and during January 1962 and March 1963, they observed the species in that region on several occasions.

The Honduran specimens represent the northern race, I. 1. cara [Calospiza layinta cara Bangs, 1905: 155; Ceiba (= La Ceiba), Honduras ].

Thraupls vireng (Linnaeus)

Blue-gray Tanager

MCZ) SPECTMENS.-T. Y. cana (56): $5 \mathrm{~km}$. W Tela, 21 Feb, ( MCZ); Tela, 13-28 Märch ( $8,2,1 \mathrm{~mm}$. o, 1ma. \%, MCZ); San Alejo, 4 Aug. (\%, LSur); La Celba, 1-25 Jan., 24 Apri1-5 May, 24 July ( $70^{\circ}, 59, \mathrm{CM} ; 55^{\circ}, 39, \mathrm{MCZ} ; 20^{\circ}, 29$, USN ); Trujillo, 6 April, 20-21 Sep. (o, CM; of, 2\%, USNM); 
Cofradía, 7 March ( $\alpha^{\prime}$, MLZ); San Pedro ( ?, BMNH); $1 \mathrm{ml}$. W E1 Jaral, 25 Aug. ( $q$ skel., LSuMZ); Finca Fé, 13 Jan., 11 Dec. (2\%, LSUMZ); Agua Azul, 25 Oct. ( ${ }^{2}$ LStak); Lake Yojoa, 18 June (o, CM); B1 Caliche, $15-16$ July (d, ?, AMNH); Cantarranas, 5-8 Aug. (d, f, ANSP); Comayagüela, 12-16 Nov. ( $8, q, \mathrm{MCZ}$ ); E1 Boquerón, 26 Sep. -6 oct. (28, AMNH); Arenal, 23-27 Jan. (o, 9, UCLA); Segovia RIver, 15 June, 2 Aug . ( $\delta, ?$, USNM); Honduras-Nicaragua boundary [near Pacific coast] (?, MCZ); "Honduras" (2?, BMNH).

PUBLISHED RECORDS.--Omoa (Moore, 1859: 59). "Honduras (Taylor, 1860: 111; Sclater, 1862: 75). San Pedro region (sclater and Salvin, 1870b: 836). San Pedro (Salvin and Godman, 1883: 277; Sclater, 1886: 157). Truj1110, Segovia River (Ridgway, 1888c: 580, 585). La Ceiba (Bangs, 1903: 155). Téla (Peters, 1929b: 471). Cantarranas, near Tela (Stone, 1932: 338). "Honduras" [ $\mathrm{E} 1$ Caliche and EI Boquerón] (Żimer, 1944b: 15). Lancetilla Valley (Skutch, 1954a: 9).

In Honduras this tanager occurs throughout the lowlands of both coasts and in the interior below 3,000 feet, inhabiting semi-open situations, forest edge, and second growth. It is common in the humid Caribbean lowlands, ranging frequently into cultivated lands and into towns and villages. In the interior and on the Pacific slope it varies from uncommon to fairly common and usually is restricted to areas in which a few large broadleaf trees are found.

Present indications are that the IInnaean name Loxia virens applies to the immature plumage of this species (Hellmayr, 1936: 205), and several recent authors have been using yirens in place of the well-established $I$. eplscopus (Miller, Frledmann, Griscom, and Moore, 1957: 300; Slud, 1964: 354). Guldenstolpe (1945: 310-311) selected yirens as the species name on the basis of line priority and thus 
became first reviser. Unless a proposal for the retention of episcopus, currently pending before the International

Commission on Zoological Nomenclature, is accepted, the name yirens must be retained. Since episcopus has had a wider usage, as well as having been applied by Linnaeus to the adult plumage, I personally favor its retention.

I agree with Blake (1958: 566) that the Middle American race I. I. diaconus (Lesson) is based upon characters that are dependent upon sex, age, or season and that diaconus 18 therefore a synonym of $I$. $\underline{y}$. cana (Swainson).

\section{Thraupis abbas (Deppe)}

Yellow-winged Tanager

SPECTMRNS,--(85): Julián [= Tultaín] (?, ANSP); Medina ( $?$ ANSP); Tela, 24-26 March ( $30^{\circ}, 29$, MCZ); Lancetilla, 1 Apri1, 29 Aug. ( $\delta^{\prime},{ }^{\circ}$ ANSP; $\delta$, UF); La CeIba, 2-23 Jan., 30 March-6 June (100, 4\%, CM; 78, 3\%, MCZ; 28,28 USNM); Yaruca, 14-15 Feb. (28, MCZ; 8 , usNe); Trujtilo, 20-23 Sep. (2o, ₹, USNM); Catacombas, 22 March, 4 April (2\%, MLZ); San Pedro (?, BMart); Las Penttas, 27 Jan.-25 Féb. ( $\sigma^{\circ}$, AMNH; $\sigma^{\circ}, 58, \mathrm{MLZ}$ ); Progreso, 30-31 Jan. (20, 9, MCZ); San Esteban, 26 June (o, \&, CM); Copán (?, MC2); La Libertad, 11-29 June (20, \$, AMNH; \$, CNMM); Merendón Copán, 12 Jume ( ${ }^{\circ}$, CNFM); Monte El Conejo, $22 \mathrm{May}$ ( ${ }^{\circ},{ }^{2}$, MIZ); Finca Fé, 13 Jan., 20 oct., 23 Nov. -2 Dec. (28, 29 , isurz); Agua Azul, 27 July-9 Aug. (2 9 UF); Lake Yojoa, 15-26 July (?, AMNH; o, f, CM); E1 Caliche, 3 Jan., 15 July ( 8,9, AMNH); Jamastrán Valley; 17 Aug. (2', ${ }^{\prime}$, UF); Segovla River, 18 June (o", ?, USNM); San Francisco, Choluteca, 14 Oct. ( $\sigma^{\circ}$, ISLUZ); "Hoonduras" (?, ANSP).

PUBLTSHED RECORDS - "Honduras" (Sclater 1856a: 235). Lake Yojoa (Sciater 1858b: 358; Taylor, 1860: 111). Omoa (Moore, 1859: 59). San Pedro region (Sclater and Salvin, 1870b: 836). San Pedro (Salvin and Godman, 1883: 279; Sclater, 1886: 162). Truj1110, Segovia River (RIdgway, 1888c: 580, 585). La Ceiba Yaruca (Bangs, 1903: 1553. Progreso, Tela (Peters, 1929b: 471). Lancet1lia (Stone, 1932: 338). La Celba (Deignan, 1936: 193). San Pedro, Chamelecón, Volcán de Puca (Hellmayr, 1936: 224). 
In Honduras the Yellow-winged Tanager is resident in the lowlands of both slopes up to 5,500 feet. It occurs in any type of open broadleaf forest, in semi-open situations with large trees, and in trees in the towns and villages. Occastonaliy found in arid scrub on the Pacific slope, it is of regular occurrence in monsoon forest and vega forest along the rivers on that drainage. Its center of abundance is In the Caribbean lowlands below 3,000 feet, where it is comon; elsewhere in Honduras it varies from uncommon to fairly common.

Hellmayr (1936: 224) examined two specimens from San Pedro and one each from Chamelecón and Volcán de Puca; presumably these specimens were obtained by Erich Wittkügel and deposited in the Brunswick Museum or the Frankfurt Museum.

\section{Bamphocelus passerinit Bonaparte}

\section{Scarlet-rumped Tanager}

SPECTYRNS. - -R. P. passertnil (115): San Alejo, 7 Aug. (d, LSLÚ); Lancetilia, 15 Jan.-1 Apri1, 24-27 Aug. (2d, 28, ANSP; $5 \sigma^{\circ}, 49$, Imm. 'o, MCZ; ${ }^{\circ}$, UF); Montecrlato, 24 March (8, LSuMz); La Ceiba, 2-24 Jan., 4 Apri1-7 June, 2

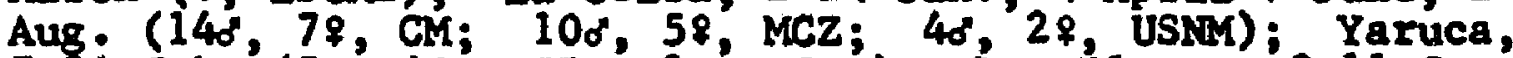
7-24 Feb: (50" 49, MCZ; 20', USNM); Los Planes, 9-11 June, 16 July ( $\left.30^{\circ}, 8, C M\right)$; San Pédro Sula, 24 July-5 Aug. (?,

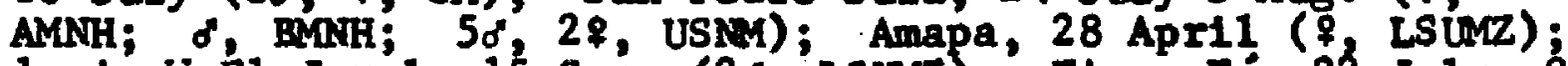
$1 \mathrm{ml}$. W El Jaral, 15 Sep. (20, Lstarz); Finca Fé, 22 July, 8 Dec. (28, LSUMz); Lake Yojoa, 18-26 June, 23-26 July, 17

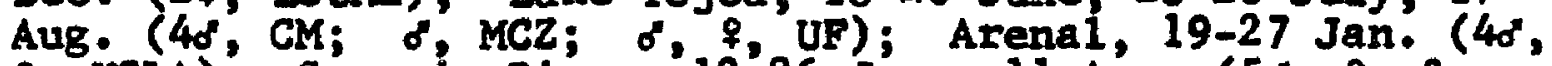
q, UCLA); Segovia River, 12-26 June, 11 Aug. (5o, \&, ? Juv., USNM); Wankybila [= Huanquibila], Patuca River ( $d$, USNM); "Honduras" (20, ANSP; $q$, Imm. $\sigma^{\circ}$, BMNH; 2 alc., USNM).

PUBLISHED RECORDS.--Omoa (Moore, 1859: 59). "Near Atlantic coast" (Taylor, 1860: 111). "Honduras" (Sclater, 1862: 79). San Pedro region (Sclater and 
Salvin, 1870b: 836). San Pedro (Salvin and Godman, 1883: 281). "Honduras," San Pedro (Sclater, 1886: 176)." Segovia River (RIdgway, 1888c: 585). La Celba, Yaruca (Bangs, 1903: 154). Lancetilla (Peters, 1929b: 472; Stone, 1932: 338). La Ceiba (Deignan, 1936: 193). Lancetilia Valley, near Tela (Skutch, 1954a: 9, 163).

The Scarlet-rumped Tanager is a fairly common to coumon inhabitant of the Caribbean lowlands of Honduras, occurring up to 2,500 feet elevation. It frequents areas of $8 \mathrm{crub}$ and is found regularly in second growth and in forest edge.

Honduran specimens are referable to the widespread, nominate race, R. p. passerinit Bonaparte.

\section{Phlogothraupis ganguinolenta (Lesson)}

\section{Crims on-collared Tanager}

SPECTMENS.--P. 8. Sanquinolenta (40): Lancetilla, 29 Aug.-2 Sep. (o, 9, AN̂SP); La Celba, 17-22 Jan, 11 April-7 June (50, CM; 39, MCZ; $q$, USNM); Yaruca, 9-24 Feb. ( $\sigma^{\circ}$, CM; 28, ₹, MCZ; of USNM); Catacombas, 25-26 March (o, $q$, MLZ); San Pedro Sula, 5 Apri1, 20 JulY (?, BMart; o CM; d. USNM); Las Peñitas, 8 Feb.' (d, MLZ); Progreso, $30 \mathrm{Jan}$. (₹, MCZ); Coyoles, 11 June ( $f, q, C M)$; La Leona, 25 June (7. AMNH); San José de Santa Bárbara 20-28 April (? AMHi); Fínca Fé, 12 Aug., 20 oct., 25 Nov.-12 Jan. (2o, 38, o skel., \& skel.' ISURZ); Lake Yojoa, 26 June, 23-28 July (d, 2q, CM; \&, UF); "Honduras" (?, ANSP; ?, BMNA) $2{ }^{P}{ }^{8}$. Jan. (o, ₹, UCLA); Segovia River, 11 Aug. (d, USNM).

PUBLISHED RECORDS.-- "Camalacan River near Truxillo" $[=$ Chamelecon $R$ iver] (Sclater, 1856a: 132). Omoa (Moore, 1859: 59). Chamelecón River (Sclater and Salvin, 1859: 16). "Honduras" (Sclater, 1862: 80). San Pedro region (Sclater and Salvin, 1870b: 836). San Pedro (Salvin and Godman, 1883: 285-286). San Pedro, "Honduras" (Sclater, 1886: 179). Segovia River (RAdgway, 1888c: 585). La Celba, Yaruca (Bangs, 1903: 154). Progreso, Tela, near Lancet1lia (Peters, 1929b: 472). Lancetilia (Stone, 1932: 338). La Celba (Delgnan, 1936: 193).

Occurring up to 3,000 feet in Honduras, the Crims oncollared Tanager is a fairly common resident in open rain 
forest, forest edge, and second growth in the humid Caribbean lowlands. Although encountered on occasion in scrub adjacent to rain forest, it is much more of a forestInhabiting tanager than is Ramphocelus passerinit.

The larger, northern race, $\underline{P}$. S. sanguinolenta (Lesson), ranges south to Honduras, occurring at suitable elevations throughout the Caribbean slope except in the Olancho rain forest. Wing measurements of specimens of this race from Honduras are as follows: o, 92.7-94.1 (93.2); , 88.6-94.2 (91.2). The four specimens from the olancho rain forest are decidedly smaller and are referred to the sma11er, southern race, $\underline{P} \cdot \underline{s} \cdot$ aprica Bangs. Wing measurements of these specimens are as follows: $\delta, 87.3,86.3 ; \$, 88.7$, 84.3. Measurements of exposed culmen also Indicate the $81 z e$ difference (sanguinolenta, 15.3-16.9; aprica, 14.115.8).

\section{Piranga rubra (Linnaeus)}

\section{Sumer Tanager}

SPECTMENS.--P. ‥ mubra (64): Utila Island, 19 April (") CM; ${ }^{\circ}$, CNHM); Roatán Is land (4?, BMNH); Little Hog Island, 9 April (o', LSURZ); $5 \mathrm{ml}$. W Tela, 21 Feb. (o, MCZ); Lancetilla, 21-24 Jan, 20-26 Feb. (3d, ?, MCZ); La Celba, 3-24 Jan., 29 March-29 April (2o, $2 q$, CM; 3o' 4q, MCZ; $q$, USNM); Yaruca, 22 Feb. ( 9, MCZ); Truf1110, 30 March-9 Apri1 ( 29, CM); Catacombas, 27 March-4 April (d, AMNH; $\&$, MLZ); Cofradía, 6-12 March (5o, MLZ); San Pedro Sula, 10 Nov: (o', BMNH; $q$ USNM); Progreso, 31 Jan. (o', MCZ); Portillo Grande, 8-27 Jan. (20, CNMM); Río Pataste, 12 mi. S Dulce Nombre de Culmf, 29 Jan. ( 7 , Lstur ); Finca Fé, 17 Feb., 20 oct., 1 Dec. (20, 2\%, Lsivz); $16 \mathrm{mi}$. NW Comayagua, 17 oct. (\%, Lśuz); Cantoral, 4-11 Apr11 (20, AMNH); Tegucigalpa, 15 Feb., 27 Sep., 14-29 Dec. (4o, AMNH); Comayaguela, 10 oct.-13 Nov. ( 9 , AMNH; 38, $39, \mathrm{MCZ})$; Yuscarán, 
16 Apri1 ( ${ }^{\circ}$, BMNH); Jamastrán Valley, 20 Feb. (20, UF'); E1 Boquerón, 1 'Oct. ( ${ }^{\prime}$, AMNH); Arenal, 23 Jan. ( $q$, UCLA); Puerto Salamar, 9 Feb. ( 9, LSUMZ).

PUBLISHED RECORDS.--Comayagua (Sclater, 1858b: 358; Taylor, 1860: 1II). San Pedro region (Sclater and Salvin, 1870b: 836). San Pedro (Salvin and Godman, 1883: 289; Sclater, 1886: 183). Roatán Island (Salvin, 1888: 258). La Ceiba, Yaruca (Bangs, 1903: 154). Lancetilla, Progreso, $5 \mathrm{~km}$. W Tela (Peters, 1929b: 472). Swan Islands (Fisher and Wetmore, 1931: 22). La Ceiba (Deignan, 1936: 193).

The Summer Tanager is a fairly common to common migrant and winter visitant in Honduras, occurring throughout the country below 4,000 feet but most abundant in the Caribbean lowlands and in the is lands off the north coast. It inhabits broadleaf forest, forest edge, second growth, and sometimes scrub. Extreme dates of arrival and departure in Honduras are 27 September and 29 April.

Before 1900, reports of "P. aestiva" from Honduras pertained to the Sumer Tanager, while "‥ rubra" was applied to the Scarlet Tanager, $\underline{P}$. Ollvacea.

All Honduran specimens represent the eastern North

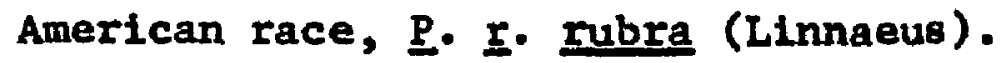

\section{Piranga flava (Vielllot)}

\section{Hepatic Tanager}

SPECIMENS.--P. E. albifactes (84): Sublrana, 8 Feb. 15 March, 9-14 Dec. (3o, 29, ?, MCZ); Port1110 Grande, 12 July ( $\left.{ }^{\circ}, M C Z\right)$; Coyoles, 28 June-11 July $\left(2 \sigma^{\circ}, 28, C M\right) ;$ San Esteban, 23 June (6o, $5 \$$, CM); Plan del Rancho, 3 July ( $\sigma_{3}$

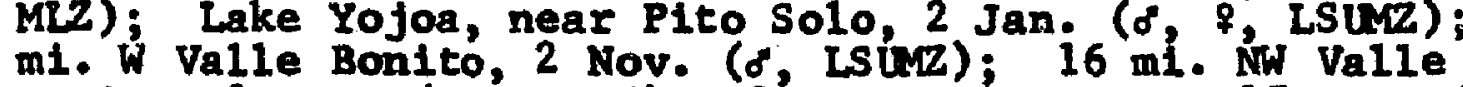
Bonito, 2 Nov. (o', LsuMz); 3 mi. N E1 Mogote, 17 Jan. (?, ISURZ); Siguatepeque, 9-31 July (2o, \& GM); El Caliche,

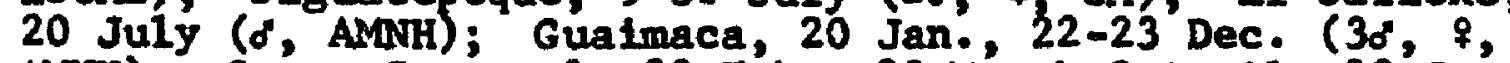
AMNH); Cerro Cantora1, 28 Feb., 23 March-8 Apri1, 29 June, 
26 Nov, -6 Dec. ( $0^{\circ}$ \%, ANSP; $50^{\circ}, 7, \mathrm{MCZ}$ ); Monte Redondo, 24 Nov. -30 Dec. ( $\sigma^{\circ}, 9$, ANSP: $20^{\circ}, 8$, AMNH; $20^{\circ},{ }^{\circ}$, MCZ); Lá Flor Archaga, $8-17^{\circ}$ June (1mm. $\%$, AMNH; 20, $\%$, MCZ); San Juanc 1to, 27 July ( $q$ ANSP); Rancho Quemado, 17 March ( $\sigma^{\circ}$, MCZ); Casa Quemado [ = Rancho Quemado], 16 Aug. (o', MCZ); E1 Hatillo, 22 April, 20 June, 1-20 Aug. (48, Juv,; CM; d, MCZ); E1 Picacho, 11 July, 23 sep.-15 Oct. (50' juv., AMAH); Cerro Higuito, D.C:, 19 April, 30 June-5 July (3d, 28, Juv., AMNH); Uyuca, $25^{\prime}$ Aug ., 6 Oct. (20, UF); San Antonio, 15-21 Nov. ( $\sigma^{\circ}, q$ UF); near San Antonio, 8 Feb., 21 Nov. ( $\sigma^{\prime}, q$ UF); Danil, 8 April ( $d^{\circ}$, BMNH). subsp. nov. (4): Puerto Lempira, 12 Apri1 (q, Lsữz); Segovia RIver, 22 July-8 Aug. ( 8,29 , USNM).

PUBLISHED RECORDS.--Segovia River [as $R \cdot$ figlina] (RIdgway, $1888 \mathrm{c}$ 585). San Juancito [as $\mathrm{E} \cdot$ hepatica] (Stone, 1932: 338).

This fairly common to comon tanager inhabits regions of pine in the interior of Honduras from 2,000 to 6,000 feet, following pine down to about 1,000 feet in the San Es teban region. There is also a population of $\underline{P}$. flava at sea level in the lowland pine savanna of the Mosquitia in eas tern Honduras and northeas tern Nicaragua.

The report of Berlepsch (1912: 1,064) from "Rio Manat1, Honduras" pertains to a locality in British Honduras.

As is the case with nearly all pine-inhabiting spectes In Honduras that occur in both the highland ocotal and the lowland pine savanna of the Mosquitia, the lowland race is distinct from that of the interior. In most cases these differences between lowland and interior highland populations are tendencies in the former toward smaller size and darker coloration. The Mosquitia populations are close to the British Honduran race, P. f. flglina (Salvin and Godman); T. R. Howell (personal communication) informed me 
that he found differences in the Mosquitia birds when compared with British Honduras material, and he is currently in the process of describing this population as a new subspecies. In any event, as is the case in other lowland pine species, the closest affinities of this population are apparently with the British Honduran birds, not with those of the interior of Honduras. I refer interior populations to the race $\underline{\underline{P}}$. $f$. albifactes $\mathrm{Zimmer,} \mathrm{which} \mathrm{differs} \mathrm{from}$ flgling in larger size, deeper red coloration in males, and whiter cheeks and chin. Honduran specimens of alblfacles measure slightly smaller than a comparable sertes of Guatemalan birds (wing: o, 91.0-100.4, mean 96.1; $7,88.2-96.0$, mean 92.7$)$ and reflect a north-south clinal trend in the interior highland populations. A series of specimens from San Esteban, where albifacies reaches its lowest altitude, at about 1,000 feet, measures decidedly smaller than other examples of albifactes and probably represents an approach to the Mosquitia birds. This situation 18 precisely the same as in Atmoph11a mufesceng. Wings of the San Esteban birds measure as follows: o, 86.9-93.7 (89.6); $\$, 84.2$ 91.5 (88.5). Wings of a series of birds from both the Honduran and Nicaraguan Mosquitia (Howell, personal communtcation) measure: $d, 85.2-90.7$ (88.5); $\$, 83.7-89.8$ $(86.6)$. 
Plranga olivacea (Gmelin)

Scarlet Tanager

SPECIMENS - $-(6)$ : Roatán Island (?, BMNH); Bonacca [= Guana]a] Is land (?, BMNH); Little Hog Island, 7 April (o, LSUMZ); $16 \mathrm{mi}$. NW Conayagua, 17 oct. (o, LSiMZ); Tegucigalpa, 22 oct. ( $\delta$, MCZ); 2 mi. NW Cedeño, 12 oct. $(q$, LSUMZ).

PUBLISHED RECORDS.--Roatán Is land, Bonacca [= Guanaja] Is land [as P. rubra] (Salvin, 1888: 258). [Big] Swan Is land (Bond, I959: 9).

The Scarlet Tanager is a rare to uncommon migrant in Honduras, occurring in the lowlands of both coasts, in the interior to at least 4,000 feet, and in the 1s1ands off the north coast; it appears to be most frequent in the 18lands and in the Caribbean lowlands. It has been observed in broadleaf forest, highland pine, and arid scrub. For Honduras extreme dates of arrival and departure for spring are 7 April and 4 May and for fall are 12 October and 23 November.

The report from Big Swan Island (Bond, 1959: 9) was based on a sight record by Charles $\mathrm{H}$. Blake on 6 November 1958.

Prior to 1900 , this species was known as $\underline{P}$. rubra, the name now applied to the Summer Tanager.

\section{Piranga leucoptera (Trudeau)}

White-winged Tanager

SPECTMENS.--P. 1. leucoptera (30): Yaruca, 19 Peb. ( ${ }^{\prime}$, MCZ); Catacombas, 22 March-9 April (3\%, ${ }^{\circ}$, MCZ); Las Pentitas, 13 Feb. (o', MCZ); Subirana, 2 Feb., 15 March ( ${ }^{\circ}$, ?, MCZ); Portillo Grande, 1 Feb., 2 April ( $q$, CNHM; $o$, MCZ); San Esteban, 26 Jume ( $\left.\sigma^{\circ}, C M\right)$; La Libertad, 20 June 
( $0^{\circ}, 7$, MCZ); San José de Santa Bárbara, 12 Apr11 ( ${ }^{\circ}$, MCZ); Cerro Santa Bárbara, east 8 lope, 21 April, 28 Nov. -9 Dec. (20, \&, LSUMZ); $5 \mathrm{mi}$. SW El Jaral, 26 Oct. (o', ₹, LSUMZ); Lake Yojoa, 22 June, 15-18 July (2o, $28, \mathrm{CM} ;$, UF); 15 mi. NW Siguatepeque, 15 Aug. ( $9, \mathrm{CM}$ ); San Marcos de Guaimaca, 30 June-5 July ( $30^{\circ}, 9$, MLZ); $13 \mathrm{mi}$. SW San Marcos de Colon, 3 oct. (o', Lsum).

PUBLISHED RECORDS.--Yaruca (Bangs, 1903: 154). San Pedro (Hellmay 1934 : 289).

Ranging from 1,000 to 5,500 feet, the White-winged

Tanager is an uncommon to fairly common resident in pine-oak associations, in cloud forest, and in the upper reaches of rain forest; it is most frequent above an elevation of 2,000 feet. This species is found primarily in the tree canopy within the forest.

Hellmayr (1934: 289) examined a male taken at San Pedro, presumably obtained by Erlch Wittkügel and deposited in the Brunswick Museum or the Frankfurt Museum.

Honduran specimens are referable to the widespread, northern race, $\underline{P}$. 1. 1eucoptera (Trudeau).

\section{Piranga ludoviciana (Wils on)}

Western Tanager

SPFCIMFNS.--(18): Santa Bárbara, 14 Feb. (o', AMNH); Monte Redondo, 14 Sep., 22 Nov. -4 Dec. (2o, 2?, AMNH; of, MCZ); Tegucigalpa, 18 Nov. ( $d$, AMNH); Comayagüela, 2-17 Nov. (o', AMNH; $20^{\circ}, 39, \mathrm{MCZ}$ ) Yeguare River Valley, $30 \mathrm{Jan}$. (q, UF); Pledra de Jesús, 19 Feb. ( 9 , AMNH); Puerto Salamar, 9 Feb. (20", LSUMZ); "Honduras" (?, AMNH). 1955a: 99).

PUBLISHED RECORD.-- "Honduras" [in range] (Eisenmann,

After breeding in western North America, this tanager migrates south through Middle America, wintering at least to 
Panama. In Honduras it is an uncommon migrant and winter visitant in the interior highlands and on the Pacific slope, occurring up to an elevation of at least 6,000 feet; it has not been reported on the Caribbean drainage below 2,500 feet but it ranges on the Pacific side to sea level. It prefers pine-oak assoctations, pine, or cloud forest but during migration frequently inhabits arid scrub. Extreme dates of arrival and departure in Honduras are 14 September and 19 February .

Eisenmann (1955a: 99) included Honduras in the range of the species on the basis of the series in the American Museum of Natural History.

\section{Piranga bidentata (Swains on)}

Flame-colored Tanager

SPECIMENS.--P. b. sanguinolenta (8): Las Peñitas, 13 Feb. ( $\delta$, MCZ); Portilio Grande, 15 July, 3 Oct. ( $\delta$, CNHM; ?. MCZ); Belén Gualcho, 14 July ( 9 MIZ); Cerro Cantoral, 20 Feb. (o , MCZ); Rancho Quemado, 15-19 March (o, $\$, M C Z)$; Uyuca, 26 Nov. (o, UF).

\section{Ross em, 19345: $\frac{\text { PUBLTSHED }}{368 \text { ) }}$}

Ranging in Honduras from 3,500 feet to 7,500 feet, the Flame-colored Tanager is an uncommon resident of cloud forests. It is known from the republic only on the basis of the eight specimens 11sted above; presumably van Rossem (1934b: 368), who mentioned examining a series from northwestern Honduras, saw the birds in the Museum of Comparative Zoology. 
The Honduran Individuals represent the Middle American race, $\underline{P}$. b. sanguinolenta (Lafresnaye).

\section{Habia rubica (Vielllot)}

Red-crowned Ant Tanager

SPECIMENS-- - H. I. rubicoldes $(80)$ : Lancetilla, 17 Jan.-29 March, 2-9 Sep. (38, 9,? ANSP; 38, 49, MCZ); La Celba, 29 July (o, CM); Yaruca, 23-27 Feb. (30, 39, MCZ); Trujilio, 31 March-7 April (20, 39, CM); Catacombas, 25

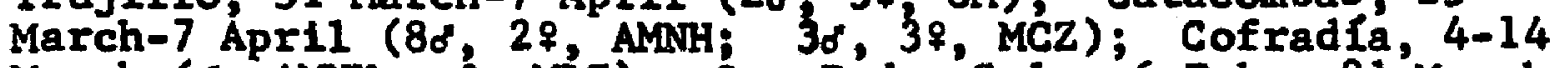
March ( 0 , AMNH; $q$, MZz); San Pedro Sula, 6 Feb., 21 March, 26 July ( $\sigma^{\circ}$, LSUMZ; 7, MCZ; o, USNM); Las Pefittas, 30 Jan. -17 Feb. (50", 3\%, AMNH; 28, MZZ); La Libertad, 22-30 June $\left(20^{\circ}, M C Z\right)$; Merendón Copán, 15 June $\left({ }^{\circ}\right.$, MCZ); E1 Jaral, 8 oct. ( $\sigma, M C Z$ ); $2 \mathrm{mi}$. SE E1 Jaral, 22 Feb. ( LSUMZ); Lake Yojoa, $13-21$ July (4q, 2 juv. o, CM); 2 mi. N Pito Solo, 13 Oct. (f skel., ISUMZ); El Caliche, 29 June ( 8, MCZ); San Marcos de Guaimaca, ig June-3 July (40, 3\%, imm., AMNH; 2?, MLZ); El Boquerón, 24 Sep. (o', MCZ); "Honduras" ( 0 , ANSP).

PUBLISHED RECORDS.--Road from Omoa to Choloma (Moore, 1859: 58). San Pedro region (Sclater and Salvin, 1870b: 836). San Pedro (Salvin and Godman, 1883: 300). Yaruca [as rubicoldes] (Bangs, 1903: 154). Yaruca [as confinis] (Bangs, 1903: 156). Palmar (Berlepsch, 1912: 1,069). Lancetilla [as rubicoldes] (Peters, 1929b: 472-474; Stone, 1932: 339). Palmar, San Pedro (Héllmayr, 1936: 306). "Honduras" [= Catacombas, Cofradla, Las Pentitas, and San Marcos de Guaimaca] (Phelps and Phelps, Jr., 1957: 127).

of the two species of ant tanagers that occur in Honduras, the present one is somewhat the 1 ess numerous. The Red-crowned Ant Tanager is a fairly common to locally common resident in rain forest, second growth, and dense areas of undergrowth along forest edge throughout the Caribbean lowlands; it ranges up to 4,000 feet. It is slightly more frequent in the forest interior than $\mathrm{H}$. gutturalis, although both specles may be found together in either forest or 
second growth. $\underline{H}$. rubtca $\propto c c u r s$ at low levels within the forest, rarely ranging into the tree canopy.

Hellmayr (1936: 306) examined one specimen from Palmar and two others from San Pedro, which were presumably taken by Erich Wittkügel and deposited in the Frankfurt Museun.

As has been pointed out by Hellmayr (1936: 306), nongeographic variation in this species has caused taxonomic confusion. Characteristics on which most of the many "races" ascribed to northern Central America are based may be found in many series throughout the range, if sufficient material is available. The amount of seasonal variation and age variation in both sexes is surprising. The large series now available from Honduras cannot be separated from series from southeastern Mexico and British Honduras. I assign all Honduran specimens to the race $\underline{H}$. $\underline{\text { r. Fubicoldes }}$ (Lafresnaye) and consider H. I. confinis [Phoenicothraupis rubica confinis Bangs, 1905: 156; Yaruca, Honduras ] a synonym of rubicoldes.

\section{Habia gutturalis (Sclater)}

\section{Red-throated Ant Tanager}

SPECIMANS.--H. g. 8alvini (110): Lancetilla, 21 Jan.-1 April (5d, 28, MCZ; o, UF); La Ceiba, 9-16 Jan., 3 May (9,

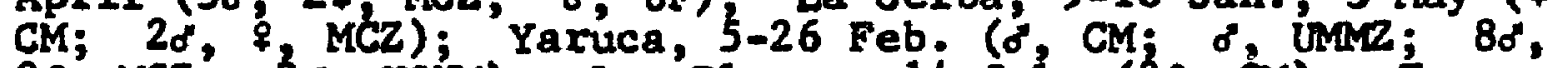
$2 \%$, MCZ; 2o, USiM); Los Planes, 14 July (28, CM); Trujillo, 30 March-9 April ( $\delta, 49$, CM); Catacombas, 25 March-5

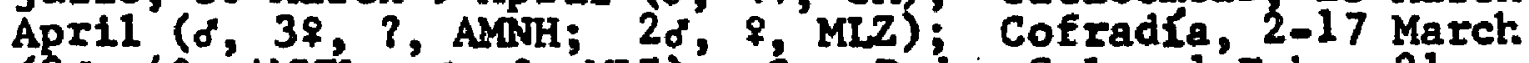
(28, 49, AMNH; ' $\$$, \&, MLZ); San Pedro Sula, 1 Peb., 21 March ( 8 , MCZ; $q$, LSUMZ); Las Pefiltas, 1-15 Feb. (6o, 78,

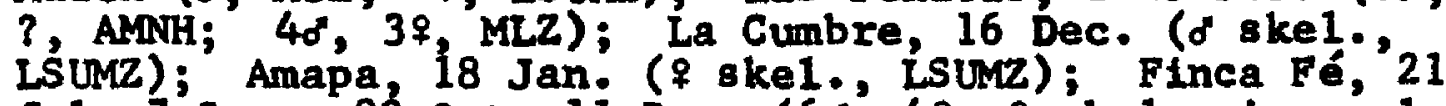
July-7 Sep., 22 oct.-11 Dec. (6o, 49, 9 ske1., Imm. alc., 
alc., LSUMZ); Lake Yojoa, 21-26 June, 17-28 July (30, 27, CM; '20, UF); 2 mi. N Pito Solo, 24 Nov. ( 9, LSUMZ); 3 mi. N E1 Mogote, 17 Jan. ( $0^{\circ}$, LSUMZ); Arenal, 14-24 Jan. (36, 2\%, UCLA); Segovia River, 19-28 June, $22-25$ July ( $40^{\circ}$ USMM); $1 \mathrm{mi}$. SE Cauquira; 13 April (2o, ${ }^{\circ}$, LSLMZ); $2 \mathrm{mi}$. S E1 Corpus, 7 oct. (o, LSUNZ); "Honduras" (?, ANSP).

PUBLTSHED RECORDS.--Segovia River (Ridgway, 1888c: 585). La Celba, Yaruca (Bangs, 1903: 154). Chamelecón, Rlo de Las Pledras, San Pedro Montaña (Berlepsch, 1912: 1,070-1,071). Lancetilla [as discolor] (Peters, 1929b: 474). "Western Honduras" [as discolor] (He11mayr, 1936: 312).

This ant tanager is a common resident in the lowlands of both coasts of Honduras, ranging up to 4,000 feet. It occurs in rain forest, forest edge, second growth, monsoon forest, and sometimes in mangroves, being most common where there is rather heavy undergrowth. It usually forages closer to the ground than H. rubtca.

Berlepsch (1912: 1,070-1,071) mentioned the localities of Chamelecón, Rio de Las Pledras, and San Pedro Montafia; al1 three are collecting localities of Erich Wittkügel, and the report 18 probably based on that collector's spectmens in the Frankfurt Museum.

There is sone doubt that the Middle American fuscicauda group of races is actually conspecific with the South American H. guttural18; Slud (1964: 360) treated fuscicauda as a separate species. I have not examined South American material and w11 continue to follow the current general usage, regarding fusclcaude as conspecific with gutturalis.

As 18 the case with ‥ rublea, this specles exhibits considerable variation, much of which is nongeographic. A 
definite tendency toward darker coloration in a north to south direction is noticeable, with the Costa Rican H. g. fuscicauda (Cabanis) being very distinct. In a large series of specimens from localities from southeastern Mexico to Nicaragua, however, I cannot find any constant geographic variation on which to separate the Nicaraguan race, $\mathrm{H}$. $\mathrm{g}$. discolor (Ridgway), from the northern subspectes, $\underline{H} . g$. salvini (Berlepsch), although Nicaraguan material shows a slight approach towards fuscicauda. The 1ighter, palerthroated Yucatán and British Honduran race, H. g. rooens 18 Griscom, appears to be valid. Populations on the Pacific 8 lope of Guatemala and El Salvador have been described as $\mathrm{H}$. g. wetmorei Dickey and van Rossem on the basis of darker coloration, but the single male from the Pacific slope of Honduras is lighter than the average of Cartbbean birds; if wetmorei is valid, it does not range into Honduras. All Honduran materlal, therefore, is assigned by me to $\mathrm{H} \cdot \mathrm{g}$. salyini.

\section{Lanto aurantius Lafresnaye}

\section{Black-throated Shrike Tanager}

SPECTMENS.--(21): Lancetilla, 4-9 Sep. (d, ₹, ANSP); Yaruca, 22 Feb. ( $8, \mathrm{MCZ}$ ); Catacombas, 24 March-7 April ( ${ }^{\prime \prime}$, ₹, AMNH; ${ }^{\circ}$, BMNH; 70, 2q, MLZ); San Pedro Sula, 21 March (q, LSUMZ); Las Peñitas, 13-17 Feb. (f, BMNH; of, 29, MLZ); "Honduras" ( 8 ", BMNH).

PUBLISHED RECORDS.--"Honduras" (Sclater, 1856a: 119; Sclater and Salvin, 1859: 15; Sclater, 1886: 203). Yaruca (Bangs, 1903: 154). San Pedro Montaña (Berlepsch, 1912: 1,072 ). Lancetilia (Stone, 1932: 338). San Pedro (Hellmayr, 1936: 319). 
Lanio aurantius is an uncomon resident in the Caribbean lowlands of Honduras, ranging up to 1,500 feet. The species reaches its southern limit of distribution in Honduras, occurring as far east as the La Ceiba region; it is replaced in the olancho rain forest by $\mathrm{E}$. leucothorax. The Black-throated Shrike Tanager is confined to heavy rain forest and may be found at lower levels within the forest as well as in the tree canopy.

Although this species and L. leucothorax are currently considered to be conspecific, the abruptness of change from one to the other in central Honduras suggests that they are specifically distinct. The strong morphological differences between the two forms are evident in both sexes. The two species are known to approach each other in range to about 60 miles, although the habitat is more or less continuous through this region and the gap may be the result of lack of material. The fact that a geographically disjunct race, L. leucothorax reversus Bangs and Griscom, of northwestern Costa Rica, is similar to $\mathrm{L}$. aurantius in the female sex does not indicate conspecificity. The critical consideration is that the adjacent forms remain distinct in the region of geographical proximity. Until intergradation between the two forms is shown to occur, I am retaining them both as full species.

Berlepsch (1912: 1,072) reported the species from San Pedro Montaña, and Hellmayr (1936: 319) examined five 
specimens from San Pedro; these reports are presumably based on specimens taken by Erich Wittkügel and deposited in the Frankfurt and Brunswick museums.

\section{Lanio leucothorax Salvin}

White-throated Shrike Tanager

SPECIMENS.--L. 1. leucothorax (6): $5 \mathrm{ml}$. S San Es teban, 15 Jan. ( $\sigma^{\circ}$, LSUMZ); Arenal, 19-28 Jan. (28, 39, UCLA). This shrike tanager reaches its northern 1 imit of distribution in the rain forests of olancho and has not been previously recorded from Honduras. Its habits and habitat preferences are much the same as in L. aurantius. In Honduras the species is rather uncommon, especially along the northern edge of the Olancho rain forest.

Thomas R. Howell and J. G. Montrello obtained five specimens at Arenal, single males being taken on 27 January 1953 and 22 January 1955 and single females on 20 and 28 January 1953 and 19 January 1954. On 12 January 1962 Richard R. Graber and Jean W. Graber caught one in a mist net near San Esteban; on 15 January they obtained another In a net, this latter specimen being preserved.

For retention of this species as distinct from $Z$. aurantius, see the discussion under the latter.

Specimens from Honduras are typical of the northern race, ‥ 1. Leucothorax Salvin, and show no morphological approach in any character to $\mathrm{L}$. aurantius. 
Tachyphonus luctuosus Lafresnaye and d'Orbtgny White-shouldered Tanager

SPECTMENS.--T. 1. axillaris (6): La Celba, 27 July ( $\sigma^{\circ}$, ₹, CM); Los Planes, 16 July (\%, CM); Río Guampú, $10 \mathrm{mi}$. E Dulce Nombre de Culmí, 18 March (o', LSUMZ); Arenal, $20 \mathrm{Jan}$. ( ${ }^{\circ}$, UCLA); Segovia River, 18 June ( $\$$, USNM). 586).

PUBLISHED RECORD.--Segovia River (RIdgway, 1888c:

The White-shouldered Tanager is another species that reaches its northern limit in the rain forests along the north coast of Honduras. It has not been recorded west of the La Ceiba region. The spectes inhabits regions of lowland rain forest, especially more open areas, forest edge, or second growth; it frequently roams around in large bands, generally at high levels in the tree canopy. In Honduras it has not been reported above an elevation of 1,500 feet and is uncommon to fairly common in abundance.

C. H. Townsend (Ridgway, 1888c: 586) collected a female along the Río Segovia in 1887. Arthur C. Twomey and Roland W. Hawkins obtained the individuals from La Ceiba and Los Planes in 1950. T. R. Howell secured a male at Arenal in 1953. Richard R. Graber and Jean $W$. Graber collected a specimen near the Río Guampú in March 1963 and observed the species on several other occasions in that region during that month.

I refer Honduran specimens to the northern race, I. 1 . axillaris (Lawrence). The tendency towards an average 
greater amount of yellow on the throats of Honduran females does not warrant taxonomic recognition.

Eucometis penicillata (Spix)

Gray-headed Tanager

SPECIMENS. - -E. . . pallida $\times$ spodocephala $(9):$ La Ceiba, $19-23$ Jan. (2\%, 29, MCZ); $3 \mathrm{mi}$. E La Lima, 9 Dec. ( 9 , LSUMZ); Amapa, 19-28 April (20, LSUMZ); Río Guampú, 10 mi. E Dulce Nombre de Culmí, 15 March (d, LSUMZ); Arenal, 22 Jan. (o', UCLA).

PUBLISHED RECORDS.--San Pedro region (Sclater and Salvin, 1870b: 836). San Pedro (Salvin and Godman, 1883: 307). La Ceiba [as spodocephala] (Bangs, 1903: 154).

Ranging up to 1,500 feet, the Gray-headed Tanager is an uncommon resident in scrubby areas or regions of heavy undergrowth in rain forest on the Caribbean slope of Honduras.

There is a clinal variation in this species from the paler Yucatán race, E. p. pallida Berlepsch, to the darker, southern race, E. D. spodocephala (Bonaparte), in Nicaragua and Costa Rica. All Honduran specimens are intermediate between these races, with the northern birds being perhaps slightly closer to pallida and the olancho specimens nearer to spodocephala.

\section{Chlorospingus ophthalmicus (Du Bus)}

Common Bush Tanager

SPECIMENS.--C. ㅇ. honduratius (173): Catacombas, 1-3 April (30, MCZ); Las Pefitas, 30 Jan. $-24 \mathrm{Feb} .\left(60^{\circ}, 28, ?\right.$, MCZ ); Port11lo Grande, 8 Jan., 1-11 Feb., 5 Apri1-28 May, 8 Nov. (20, ?, CNEM; 70, MCZ); $5 \mathrm{mi}$. S San Esteban, $15 \mathrm{Jan}$. ( $0^{*}$, LSUMZ); Montaña Ei Chorro, 22 June-5 July (6o, ?, ? MLZ); E1 Silión, 10 July ( $\$$, MLZ); Montaña E1 Silión, 2-10 
July (28, MLZ); Monte El Conejo, 21 May (?, MLZ); Montaña La Cruz, 25 June-7 July (4o, $\%$, MLZ); Belén Gualcho, 18 July (2o, ?, MLZ); Monte Verde, 20-22 July (4q, ?, MLZ); Monte E1 Portillo, 28 May (40, MLZ); Mt. Puca, 8 Jan. -4 Feb. (7॰, 2\%,?, MCZ); Cerro Puca, 21 Jan. (skel., MLZ); Cerro Nieve, $10-20$ April ( ${ }^{\circ}, \&$, AMNH); San José de Santa Bárbara, 7 April (o", CNHM); Santa Bárbara, 4-27 May ( $q$, AMNH; $q$, CNHM); Cerro Santa Bárbara, east slope, $27 \mathrm{Jan}$, 28 Nov. -9 Dec. (36, 9 skel., LSUMZ); $5 \mathrm{mi}$. SW E1 Jara1, 26 Oct. -4 Nov. ( $30^{\circ}, q^{\circ}, 2^{\circ}$ skel:, LSUMZ); 2 mi. SE El Jaral, 3 March ( $\sigma^{\circ}$, LSUMZ); Lake Yojoa, 16 June, 15-20 July (20, 1mm. \& CM); Siguatepeque, 8 July ( $\delta, C M)$; Soluteca, 4-8 April (2o, $\%$ AMNH); 5 mi. N Sabanetas, 31 'Oct. (Imm. \& LSUMZ); Muye, 17-21 Féb. (28, $29, ?$, AMNH); Cantoral, 2-22 Feb., 15 March (?, AMNH; 2\%, MLZ); Cerro Cantoral, 21 Feb. -4 March,

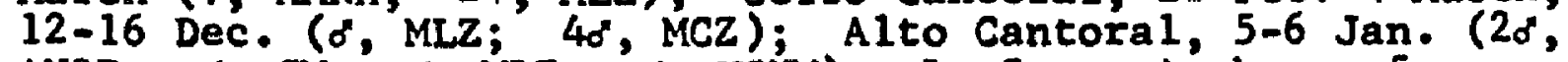
ANSP; $\&$, CM; $\delta^{\circ}$, MLZ; ${ }^{\circ}$, USMM); La Cueva Archaga, 5 April, 6 June (20, AMNH); San Juancito, 2 Feb., 25 June-9

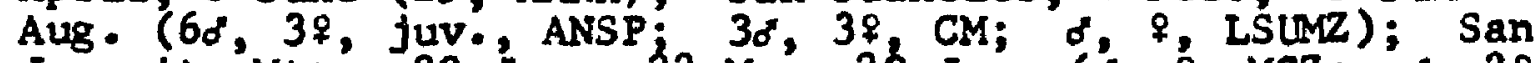

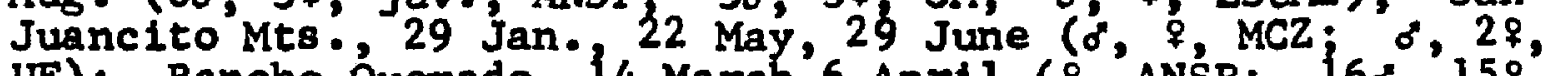
UF); Rancho Quemado, 14 March-6 April ( $\$$, ANSP; 160' 15\%, 3?, MCZ); E1 Derrumbo, 15-18 July ( $q$, ANSP; $\%$, USNM); ME. Uyuca, 26 May-11 June, 20 Nov. ( $f, M C Z$; o, 29 , UF); Monserrat, 10 March ( $q, ?$, UF).

PUBLISHED RECORDS.--Volcán de Puca (Berlepsch, 1912: $1,088,1,142 ;$ Underdown, 1932: 645-646). San Juanc1to (as 8chlstaceiceps] (Stone, 1932: 339). Cerro Cantoral (Z1mer, 1947: 5). San Juancito (Russe11, 1964: 174).

Among the species that inhabit cloud forest in Honduras, Chlorospingus ophthalmicus is umquestionably the most common. It is a member of virtually every bird group that is encountered in cloud forest, and at times when birds are scarce, it alone may be present. The large series of Honduran skins is an indication of its abundance. In elevation, the species ranges from 3,000 to 8,000 feet, descending into lowland rain forest to 1,000 feet in the nonbreeding season. It is restricted to the forest interior, occurring at low levels as well as in the tree canopy. 
There is one female specimen in the Berlepsch Collection (Berlepsch, 1912: 1,088) taken by Erich Wittkügel on Volcan de Puca on 3 March 1889; this specimen is the type of $\mathrm{C}$. honduratius and was in the Berlepsch Collection when it passed to the Frankfurt Museum. Underdown (1932: 645646) examined another Wittkügel specimen taken at the same locality on 26 March 1889; this latter individual was in the Brunswick Museum. Hellmayr (1936: 401) presumably examined both these Wittkügel birds.

A11 Honduran specimens are representative of the distinct race, C. o. honduratius [Chlorospingus honduratius Berlepsch, 1912: 1,088; Volcan de Puca, Honduras ], distinguished by its clearer gray plleum, brighter green back, and deeper yellow pectoral band. None of the Honduran specimens shows any approach to the more southern, brown-headed race, C. ‥ regionalis Bangs. Specimens from western Honduras show a slight approach to the Guatemalan subspecies, C. ‥ postocularis Cabanis, but on the whole all are much nearer honduratius. The populations in El Salvador, named C. 2. schistaceiceps Dickey and van Rossem, do not differ from honduratius.

Family FRINGILLIDAB

Saltator atrtceps (Lesson) Black-headed Saltator SPECIMENS.--S. ‥ - atriceps (65): La Ceiba, 24 Apri1-7 
June (2\%, 3\%, CM); Yaruca, 11 Feb. ( ${ }^{\circ}$, MCZ); Catacombas, 1 April $\left(\sigma^{\circ}, \mathrm{MLZ}\right)$; Cofradía, 16 March ( $q$, MLZ); San Pedro Sula, 4 Aug. (Imm.d, USMM); Las Peñitas, 26 Jan.-13 Feb. (d, AMMH; 2q, MLZ); Progreso, 30 Jan. ( $\delta, 2 \%$, MCZ); Coyoles, 15-29 June ( $\left.3 \sigma^{\circ} 2 \%, C M\right)$; San Esteban, 25 June ( $q$, CM); Monte 81 Conejo, 21 May (d", MLZ); $2 \mathrm{mi}$. SE El Jaral, 3 March ( ${ }^{\circ}$, LSUMZ); Lake Yojoa, 23 June, 16-25 July (20", CM; 2, UF); Cerro Cantoral, 20-29 March (20, \$, MCZ); Monte Redondo, 8-13 oct., 5-8 Nov. (36, 39, MCZ); Cantarranss, 7 Aug . 7 Sep. (2\%, ANSP); San Juancito, 16-18 July (2o", 7, ANSP); Tegucigalpa, 20 DeC. ( $\sigma^{\prime}$, AMNH); Comayaguiela, 19 oct. -18 Nov. (11o, 6\%, MCZ); Capa Rosa, 28 Aug. ( 9, UF); Yeguare River Valley, 12 Feb., 14 June ( ${ }^{\circ}, \%$, UF); Choluteca River, Dept. El Paralso, 13 Feb., 19 May (d" MCZ; 9, UF); Segovia River, 13 June ( ${ }^{\circ}$, USMM); $5 \mathrm{mi}$. NE Nama8 igüe, 29 Sep. ( $q$, LSUMZ).

PUBLISHED RECORDS.--Comayagua (Sclater, 1858b: 358). Onoa (Moore, 1859: 58). Near Comayagua (Taylor, 1860: 111). San Pedro region (Sclater and Salvin, 1870b: 836). San Pedro (Salvin and Godman, 1884: 326) Segovia River (Ridgway, 1888c: 586). Yaruca (Bangs 1903: 155). Southeast of Progreso (Peters, 1929b: 467). San Juancito, Cantarranas (Stone, 1932: 341 ).

Ranging up to 6,000 feet, this saltator is a fairly common resident in a variety of open and semi-open situations in Honduras. It occurs in both arid and humid regions of scrub, along forest edge, in second growth where undergrowth is heavy, in semi-open situations with scattered trees, in areas of cultivation, and around the larger towns and villages. It is commonest in the humid situations, while s. coerulescens generally prefers more arid habitats. Honduran specimens are referable to the widespread, nominate race, $\underline{S}$. a. atriceps (Lesson). None shows any approach to the paler-bellied subspecies, s. a. raptor (Cabot), which occurs in Yucatán and British Honduras. 


\section{Saltator maximus (Müller)}

\section{Buff-throated Saltator}

SPECIMENS.--S. m. magnoides (62): Laguna Toloa, 30

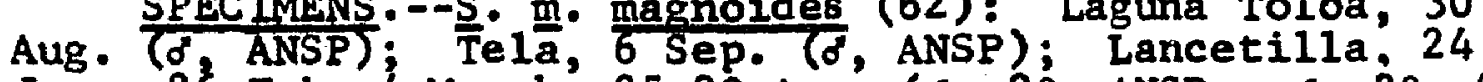
Jan., 26 Feb, -4 March, 25-30 Aug; ( $0^{\circ}, 29$, ANSP; of 3q, ?, " ske1., MCZ); La Ceiba, 3 May-7 June (9o, 39, CM);

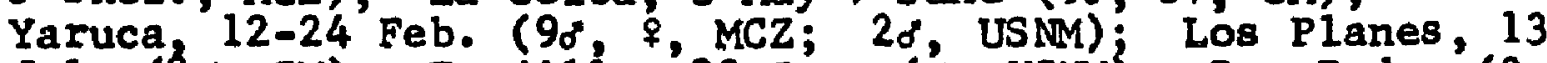
July $\left(2 \sigma^{\prime}, C M\right)$; Trujilio, 22 sep. ( $\sigma^{\prime}$, USM ); San Pedro (?, BMNH); Subirana, 8 Feb. ( $\$$, MCZ); Coyoles, 29 June (?, CM); San José de Santa Bárbara, 7 Apri1, 6 May (20", AMNH); Santa Bárbara, 19 May ( $q$, AMNH); Finca Fé, 1 March, 3-8 Sep., 21 Nov.-12 Dec. ( $40^{\circ}, q, 2 \$$ skel., alc., LSUMZ); Lake Yojoa, 13-27 July ( $\left.{ }^{\circ}, 29, \mathrm{CM}\right)$; Alto Cantoral, 10 Feb. (o' ske1., MLZ); Arena1, 13-25 Jan. ( 8,39 , UCLA); Segovia River, 24 June, 11 Aug. (20, USM).

PUBLISHED RECORDS.--San Pedro region (Sclater and Sa1vin, 1870b: 836) San Pedro (Salvin and Godman, 1884: 327; Sclater, 1886: 285). Trujillo, Segovia River (Ridgway, 1888c: 580, 586). Yaruca (Bangs, 1903: 156). Lancetilla Valley, Tela region (Peters, 1929b: 467-468). Lancetilla, Tela Laguna Toloa (Stone, 1932: 341). Near Tela (Skutch, 1951b: 8). Lancetilla Valley (Skutch, 1954a: 76).

Of the three species of saltators occurring in Honduras, the Buff-throated Saltator is the most abundant. Ranging up to 3,500 feet, this species is a conmon resident in the Caribbean lowlands. It is much more characteristic of forest than is either of the other two Honduran members

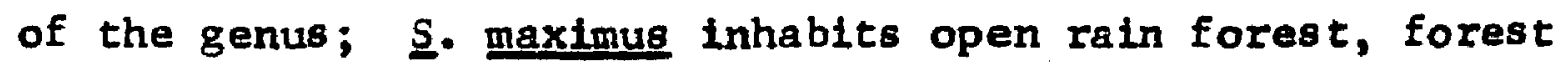
edge, second growth, and occastonally semi-open situations or cultivated lands.

Al1 Honduran specimens are typical of the Middle

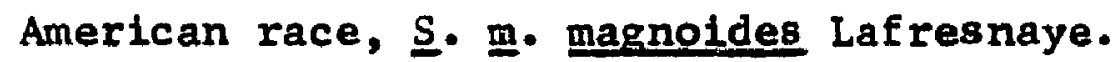


Saltator coerulescens vieillot

Grayish Saltator

SPECTMENS.--S. c. grandis (50): La Ceiba, 21-24 Jan., 16 April-17 May (80, $5 \%$, CM; $0^{\circ}$, MCZ; of, USNM); San Pedro (?, BMNH); Amapa; 28 April (o, LSUMZ); Coyoles, 15 June-12 July (30, 9 , CM); San Es teban, 25 June ( 7, CM); San José de Santa Bấrbara, 28 April (o", AMNH); 4 mi. S E1 Jaral, 12 Sep. ( $₫$, LSUMZ); Finca Fé, 9 Dec. ( $\%$ LSUMZ); E1 Caliche, 27 June, 16 July (29, AMNH); Monte Redondo, 24 Nov., 10 Dec. (28, MCZ); Tegucigalpa, 23 July, 11 Nov. ( imm., AMNH); Comayagüela, $13-19$ July, 10 Oct. -17 Nov. ( $\%$, MLZ; $5 d^{\prime}, 7,2$ ?, MCZ); 1 mi. E Escuela Agrícola Panamericana, 6 June ( $f$, UF); Yeguare River Valley, 15 Jan., 2 Feb.: 24 May, 29 Dec. ( $\sigma^{\circ}, 29$, imm. UF); Jamastrán Valiey, 17 Aug. (?, UF); Segoviá River, i2 Aug. ( 9 , USNM); "Honduras II (?, BMNH). S. c. hesperis (1): 15 mi. NE Cedeño, 9 Oct. ( $\%$, LSUMZ).

PUBLISHED RECORDS.--Omoa (Moore, 1859: 58). San Pedro region (Sclater and Salvin, 1830b: 836). San Pedro (Salvin and Godman, 1884: 328). San Pedro, "Honduras" (Sclater, 1886: 289). Segovia River (RIdgway, 1888c: 586). La Ceiba (Bangs, 1903: 156; Deignan, 1936: 193). Near Tela (Skutch, 1945a: 24; 195la: 8).

Occurring up to 3,500 feet, the Grayish Saltator is a fairly common resident in scrub in the lowlands of both coasts and in the interior. It may be found in either arid or humid scrub, in second growth, along forest edge, and around towns and villages. It often inhabits regions that are too arid for either of the other two Honduran species of the genus.

Honduran populations on the Caribbean slope and in the interior are referable to the widespread race, $\underline{s} \cdot \underline{c}$. grandis (Deppe); this subspecies does not occur on the Pacific drainage below 1,500 feet. In the Pacific lowlands is

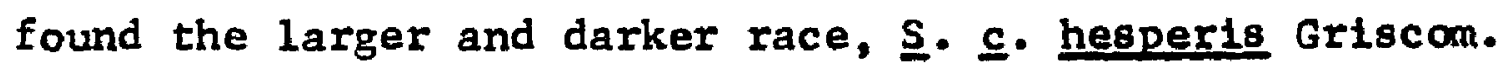
Wing measurements of Honduran examples assigned to grandis 
are as follows: $d, 95.8-105.0(101.1) ; q, 97.0-101.8$

(99.1). The single female of hesperis has a wing measurement of 109.2. The subspecies hesperis has not been reported previously from Honduras, although it is known to range from Chiapas to Nicaragua in the Pacific lowlands.

\section{Caryothraustes poliogaster (Du Bus)}

Black-faced Grosbeak

SPECIMENS.- -C. p. poliogaster (12): Medina (?, ANSP); La Ceiba, 7 Aug. $\left(20^{\circ}\right.$, CM); Catacombas, 26-29 March (20, 9, MLZ); Santa Ana, 19 Nov.; 6 Dec. ( $20^{\circ}, \&$, USNM); Las Peñitas, 24 Feb. ( $\$$, MCZ); "Honduras" [= San Pedro Sula region] (2?, USNM). C. p. Scapularis (6): Arenal, $19=28$ Jan. (20, 9 , UCLA); Segovia River, 17-18 June (2\%,?, USNM).

PUBLISHED RECORDS.--San Pedro region (Sclater and Sa1vin, 1870b: 836). San Pedro (Salvin and Godman, 1884: 333). Segovia River [as scapularls] (Ridgway, 1888c: 586). Santa Ana [as poliogaster] (Ridgway, 1901: 656). Palmar [as poliogaster] thellmayr, 1938: 50).

Ranging up to 1,500 feet, this species is an uncommon resident in the humid Caribbean lowlands of Honduras. Occurring primarily in the tree canopy, it inhablts rain forest, forest edge, and occasionally second growth.

Hellmayr (1938: 50) examined at least one specimen from Palmar, presumably taken by Erich Wittkügel and deposited in the Frankfurt Museum.

The larger, northern race, C. p. pollogaster (Du Bus), reaches its southern 1 imit in Honduras and has been recorded east to the la Celba region; this subspecies always has the scapular region olive-green. Wing measurements of Honduran examples of póltogaster are as follows: $\delta, 87.2-93.2$ 
(90.9); $7,86.0-89.0(87.5)$. The smaller, southern race, C. p. scapularis (Ridgway), ranges north to the olancho rain forest; this subspecies usually has the scapular region gray. Wings of Honduran spectmens of this form measure as follows: $o, 82.0,89.1 ; 9,82.8,83.9,85.6$.

\section{Pheucticus ludovicianus (Linnaeus)}

\section{Rose-breasted $G$ ros beak}

SPECIMENS.--(43): Utila Island, 24 April (o, $\&, C M)$; Roatán Island (3?, BMNH); La Ceiba, 13 Jan., 27 April (?; CM; ${ }^{\circ}$, MCZ); Catacombas, 26 March-6 Apri1 (2\%, AMNH; 28, $\$$ MLZ); Cofradía, 10 March (o", MLZ); "Honduras" $[=$ Cofradia], 6 March ( 9, MLZ); Chamelecón, 16 Feb., 8 March (20, USNM); Mt. Puca, 11-13 Jan., 6-11 Feb. (40, AMNH); Cerro Santa Bárbara, east slope, 22 Nov.-7 Dec. ( $\$, q$ skel., LSUMZ); $5 \mathrm{mi}$. SW El Jarai, 26 oct. ( $\delta^{\circ}$, LSUMŹ); Finca Fé, 7 Dec. ( $\sigma^{\prime}$, LSUMZ); Cantoral, 1 April ( $\sigma^{\prime}$, AMNH); Monte Redon-

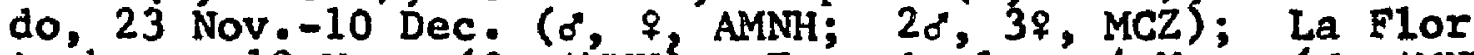
Archaga, 18 Nov. ( $q$, AMNH); Tegucigalpa, 4 Nov; ( $\sigma$, AMNH); Comayaguiela, 29 Oct. -18 Nov. ( $\sigma^{\circ}$, AMNH; 5d, MCZ); Yeguare River Valley, 15-20 Jan. (c", $\$$, UF); "Honduras" (?, ANSP).

PUBLISHED RECORDS.--Omoa (Moore, 1859: 58). San Pedro region (Sclater and Salvin, 1870b: 836). San Pedro (Salvin and Godman, 1884: 337). Roatán Is land (Salvin, 1888: 260). La Celba (Bangs, 1903: 156). Chalmeca near Nueva "Arcadra" [= Arcadia] (Ćooke, 1950b: 148). [Big] Swan Island (Bond, 1959: 9).

The Rose-breasted Grosbeak is a fairly common migrant and winter visitant in the Caribbean lowlands, in the islands off the north coast, and in the interior of Honduras. It occurs up to an elevation of at least 6,500 feet but is decidedly uncommon in migration in the Pacific lowlands below 2,500 feet. It is found in open broadleaf forest of almost any type, in pine-oak associations, in second growth, and even in arid scrub. Extreme dates of 
arrival and departure in Honduras are 21 October and 10 May. Cooke (1950b: 148) reported that an individual banded at Pomeroy, Iowa, on $19 \mathrm{July} 1936$ by M. L. Jones was caught at Chalmeca, Honduras, on 15 March 1939.

\section{Guiraca caerulea (Linnaeus)}

Blue Grosbeak

SPECIMENS.--G. $c$. caerulea (20): Lancetilla, 23 March ( 9 , MCZ); La Ceiba, $15-16$ Jan., 26 April ( $\$$ CM; 6 , ${ }^{\circ}$, MC2); Yaruca, 18 Feb. ( $\sigma^{*}, \mathrm{MCZ}$ ); Truj1110, 30 March-7 April (30", CM); Catacombas, 4 April (7, MLZ); Cofradía, 5 March ( ${ }^{\circ}$, MLZ); Tegucigalpa, 18 Nov. ( ${ }^{\circ}$ ?, AMNH); Comayagüela, 10 Oct. -16 Nov. ( $1 \mathrm{~mm}$. $\%$, AMNH; 40, $29, \mathrm{MCZ}$ ); Yeguare River Valley, 11 Feb., 10 March ( $d^{\prime \prime}, q$, UF). G. c. interfusa (2): La Flor Archaga, 24 May ( $\sigma^{\circ}$, AMNH); Tegucigalpa, 8 March ( $\sigma^{\circ}$, AMNH). G. c. lazula (29): E1 Caliche, 24 May, 15 July (d", \&, Imm. o, AMNH); Monte Redondo, 18 Oct. 24 Nov. (2\%, MCZ); La Flor Archaga, 18 April, 1 May, 11 June ( ${ }^{\circ},{ }^{\circ}$, juv. 7, AMNH; $26^{\circ}, 7, \mathrm{MCZ}$; Cantarranas, 9 Aug - ( $0^{\prime}$, ANSP); Cerro Higuito, D.C., Ig April ( ${ }^{\circ}$, AMNH); Tegucigalpa, 25 May, 30 oct., 30 Nov. ( ${ }^{*}, \$$, AMNH; $₹$, USNM); Comayagüela, 10 oct. -16 Nov. (40, $2 \%$, MCZ); Capa Rosa, 31 May ( ${ }^{\circ}$, MCZ; \&, UF); Yeguare River Valley, 14-27 Feb., 11 May ( $\sigma^{\prime}, q, \sigma^{\prime \prime}$, UF); Pledra de Jesús, 12 April (o", AMNH); $10 \mathrm{mi}$. W Choluteca, 1 oct. ( 8 , LSUMZ).

PUBLISHED RECORDS. --La Ceiba and Yaruca [as caerulea] (Bangs, 1903: 156). Lancetilla (Peters, 1929b: 465). Cantarranas [as caerulea] (Stone, 1932: 339). Río Goascorán [as lazula] (Dickey and van Rossem, 1938: 587). [Big] Swan Island (Bond, 1959: 9).

The Blue Grosbeak is an uncommon to fairly common resident in Honduras, breeding from 3,000 to 6,000 feet in scrub in the interior highlands. During migration and winter the species occurs in the lowlands of both coasts and in the is lands off the north coast; it is considerably more common in the nonbreeding seas on than in summer. 
The record from Big Swan Island (Bond, 1959: 9) is based on sight records by Charles H. Blake from 11 through 27 November 1958.

The resident race in Honduras is $\mathrm{G}$. $\mathrm{c}$. Iazula (Lesson), distinguished from the migrant North American races by its more massive b111 (bi11 depth: $0,12.2-14.5$, mean 13.4; $\%$, 12.7-14.1, mean 13.4). None of the males assigned to lazula shows any approach to the darker $G$. $c$. eurhyncha Coues, a resident subspecies in western Guatemala. Most of the North American migrants are referable to the eastern race, G. c. caerulea (Linnaeus); this race has been taken in Honduras in the Caribbean lowlands and in the interior but not on the Pacific drainage below 2,500 feet. Extreme dates of arrival and departure for caerulea in Honduras are 1 Detober and 26 April. Bill depth measurements of Honduran examples assigned to caerulea are as follows: 6 , 10.8-12.2 (11.6); $+10.2-12.6(11.7)$. Two male specimens taken by C. F. Underwood at Tegucigalpa and La Flor Archaga in 1936 are typical of the western North American race, $\mathrm{G}$. c. interfusa Dwight and Griscom, a paler subspecies with contrasting wing bars. These two specimens extend the known wintering range of interfusa south of Guatemala.

\section{Cyanocompsa cyanotdes (Lafresnaye)}

Blue-black Gros beak

SPECIMENS - - -G. c. concreta (37): San Alejo, 19 March-2 April, 6-7 Aug. (20", $q, 9 ?$, Imm., $q$ skel., ISUMZ); La Ceiba, 7 June ( $\%, C M)$; Los Planes, 9-10 June (2\%,CM); 
Catacombas, 4-8 Apri1 (20, MLZ); Cofradia, 9-14 March (d", AMNH; $₹$, BMNH; $\delta$, MLZ); Santa Ana, 20 Oct., 2 Dec. (2\%, USNM); Las Pen̂́itas, 5-15 Feb. ( $q$ AMNH; of, BMNH; of, ${ }^{\circ}$ $M L Z)$; San Esteban, 1 July ( $\left.0^{\circ}, \mathrm{CM}\right)$; 2 mi. SE E1 Jarai, 22 Feb. ( $\$$ LSUMZ); Finca Fé, 4-6 Sep. (20, LSUMZ); Lake Yojoa, 12 June-17 Aug. $\left(60^{\circ}, 9, \mathrm{CM}\right) ; 2 \mathrm{mi}$. N Pito Solo, 27 Oct. (imm. of, LSUMZ); Arenal, 18-25 Jan. (o", 3\%, UCLA); Segovia River, 12 June ( $\delta$, USNM).

PUBLISHED RECORDS.--San Pedro region (Sclater and Salvin, 1870b: 836). San Pedro (Salvin and Godman, 1885: 3463. Segovia River (Ridgway, 1888c: 586). Santa Ana [as cyanescens] (Ridgway, 1901: 598). Lancetilia Valley (skutch, 1954a: 53).

Occurring below 2,500 feet, the Blue-black Grosbeak is an uncommon to fairly common resident on the Caribbean slope of Honduras in rain forest, forest edge, and second growth. It is generally found at low levels within the forest. Hellmayr (1938: 95) remarked that the populations from southern Honduras to western Panama, described as $G$. c. caerulescens Todd, are intermediate between the northern race, G. c. concreta (Du Bus), and the nominate subspecies, G. c. cyanoides (Lafresnaye), which ranges from central Panama south into South America. The race caerulescens is based on the male sex only, which is generally more bluish (less blackish) in coloration, and appears to be valid for populations in Costa Rica and southern Nicaragua. All Honduran specimens, however, are indistinguishable from Mexican material and are referable to concreta.

\section{Cyanocompsa parellina (Bonaparte)}

\section{Blue Bunting}

SPECIMENS.--C. p. parellina (47): Cofradía, 10 March (o", MCZ); Coyoles, 16-19 June ( $\left.0^{\circ}, \%, C M\right)$; San Ésteban, 1 
July ( ${ }^{\circ}$, CM); Cerro Cantoral, 28 March-8 April (30, MCZ); Alto Cantoral, 17 Jan. ( $\$$, MLZ); La Flor Archaga, 3 May-27

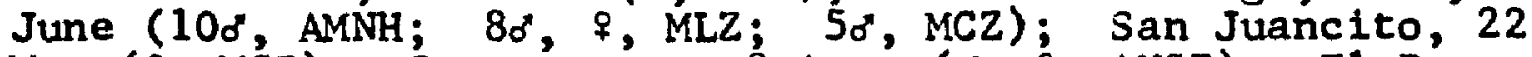
May ( $\$, M C Z)$; Cantarranas, 8 Aug: ( $\sigma^{\circ}, q$, ANSP); E1 Derrumbo, 18 July ( $\$$, MLZ; $\$$, MCZ); E1 Hatilio, 18 April-9 May ( $\%$, MLZ; 38, MCZ); Tegucigalpa, 26 May ( ${ }^{\circ}$, AMNH); Escuela Agrícola Panamertcana, 1 May (o, UF); Catacamas, 24-27 Aug., $20 \mathrm{Sep}$. (20, $q, \mathrm{MLZ})$; E1 Boquerón, 21 Oct. ( $\$$, AMNH).

PUBLISHED RECORDS.--Cantarranas (Stone, 1932: 339). San Pedro (Hel Imayr, 1938: 94).

Although Griscon (1932b: 349) considered this species to be exceedingly rare south of Mexico, it is a fairly common resident locally in Honduras, occurring in forest undergrowth in the interior from 1,000 to 6,000 feet elevation. It prefers arid types of forest, being found in monsoon forest, arid scrub, and pine-oak associations, usually where there is a dense understory. In Honduras it has not been taken below 1,000 feet on the Caribbean drainage or below 2,500 feet on the Pacific slope.

Hellmayr (1938: 94) examined a male specimen from San Pedro, presumably taken by Erich Wittkügel and deposited in the Frankfurt Museum or the Brunswick Museum.

I agree with Smithe and Paynter (1963: 307) that the southern race, $C$. p. dearborni Miller and Griscom, is unrecognizable. I therefore assign Honduran specimens to the nominate subspecies, . R. parellina (Bonaparte).

Passerina cyanea (Linnaeus)

Indigo Bunting

SPECIMENS.--(73): Utila Island, 18 April (o, CM; $\&$, CNHM); Roatán Is land (10?, BMNH;?', CNHM); Oak Ridge, 8 April ( $\$, C M)$; Barbareta Island, 10 April ( $\$, C M)$; 
Lancetilla, 20 Feb. ( $\left.0^{\prime}, \mathrm{MCZ}\right)$; La Celba, 24-27 April ( $0^{\circ}, 29$, CM); Yaruca, 23 Feb. ( $9, \mathrm{MCZ}$ ); Trujilio, 31 March (o, CM); Catacombas, 9-30 March (20, 3\%, AMNH; 20, MLZ); Cof radía, 4-16 March (40, \%, ?, AMNH; 50, 67, MLZ); San Pedro (? BMNH); Las Pentitas, 1-24 Feb. (o, AMNH; 2o, 29, ?, MLZ); Chamelecón, $23 \mathrm{Feb}$. (20', USNM); Subirana, 10-15 March (20", MCZ); Río Pataste, $12 \mathrm{ml}$. S Dulce Nombre de Culmr, 27 Jan. ( $\$$, LSUMZ); San José de Santa Bárbara, 11 April ( Finca Fé, 25 Nov. ( $\sigma^{\circ}$, LSUMZ); Cantoral, 15 March ( $\sigma^{\circ}$ AMNH);

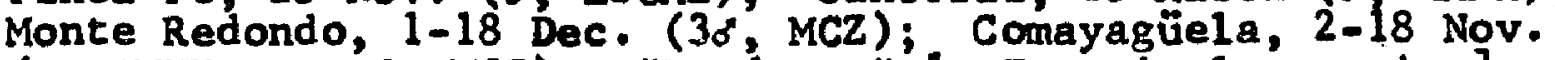

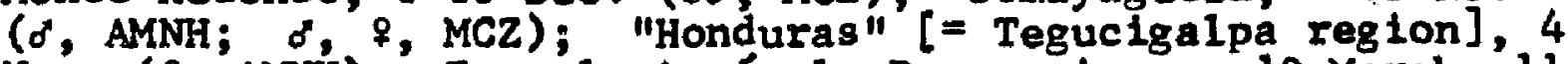
Nov. ( 7 , AMNH); Escuela Agrícola Panamericana, 10 March, 11 Nov. ( $\sigma^{\circ}$, UF); Yeguare RIver Valley, 14-17 Feb. (2o, UF); Pledra de Jesús, 2 April ( $\delta$, AMNH); "Honduras" (?, AMNH).

PUBLISHED RECORDS.--San Pedro region (Sclater and Salvin, 1870b: 836). San Pedro (Salvin and Godman, 1886: 364). Roatán Island (Salvin 1888: 261; Hellmayr, 1938: 107): Yaruca (Bangs, 1903: 156). Lancet1lla (Peters, $1929 \mathrm{~b}: 468$ ). [B1g] Swan Island (Bond, 1959: 9).

The Indigo Bunting is a common migrant and winter visitant in the lowlands of Honduras and in the interior, ranging up to 4,500 feet elevation. In migration it is also common in the 18 lands off the north coast. The species prefers open situations with scrub, weedy growth, or grassy fields but occurs also in second growth and forest edge. In the interior above 3,000 feet and on the Pacific drainage it is decidedly less abundant than in the Cartbbean lowlands. For Honduras extreme dates of arrival and departure are 12 October and 10 May.

\section{Passerina ciris (Linnaeus)}

Painted Bunting

SPECIMENS.--P. c. ciris (13): Lancetilla, 20 March ( $\sigma^{\circ}$ MCZ); Trujillo, 31 March ( $\delta$, CM); Cofradí, 5 March ( $\delta$, ? MLZ); San Pedro Sula, 23 Jan. (d", USNM); Las Peñitas, 1-13 Feb. (58, 8, MLZ); Monte Redondo, 8-14 Dec. (9, AMNH; 8 , MCZ). E. C. palildior (9): La Ceiba, 2-19 Jan. (5o, MCZ); Truj1110, 3I March (f, CM); La Lima, 1 Dec. (ó, LSUMZ); 
Finca Fé, 30 Nov. ( ${ }^{\circ}$, LSUMZ); Cantoral, 5 March (o', AMNH). Undetermined (10): Roatán Island (58, 2\%, 2 imm. of, BMNH); San Pedro (?, BMNH). PUBLISHED RECORDS. --Comayagua (Sclater, 1858b: 358).
Omoa (Moore, $1859: 58$ ). Near Comayagua (Taylor, 1860:
111). San Pedro region (Sclater and Salvin, 1870b: 836). San Pedro (Salvin and Godman, 1886: 365). Roatán Island (Salvin, 1888: 262; Sharpe, 1888: 615). La Ceiba (Bangs, 1903: 156). Lancetilla (Peters, 1929b: 469). La Ceiba [as pallidior] (Griscom, 1932b: 365).

In Honduras this bunting is a fairly common migrant and winter visitant, though considerably less abundant than $\underline{P}$. cyanea. It is found throughout Honduras below an elevation of 4,500 feet but is decidedly unconmon on the Pacific drainage and above 2,500 feet in the interior. During migration it occurs in the islands off the north coast. It prefers scrub, forest edge, second growth, or open situations with brush or scattered trees. Extreme dates of arrival and departure in Honduras are 5 October and 28 Apri1.

Both North American races winter in Honduras. On the basis of existing data, the slightly smaller, deeper red race, $\underline{P}$. . . ciris (Linnaeus), and the larger, paler $\underline{P}$. . pallidior Mearns occur in about equal numbers without tendencies toward different ranges.

\section{Tiaris olivacea (Linnaeus)}

\section{Yellow-faced Grassquit}

SPECIMENS. - - T. O. pus111a (77): La Ceiba, 17 May (20, ${ }^{2}$ CM); Los Planes, 9-10 June, 16 July (30, CM); Subirana, 17 Dec. -7 Jan. (20, $\%, M C Z)$; Coyoles, 16 June ( $\$, C M)$; San Esteban, 1 July ( $\left.\sigma^{\circ}, \mathrm{CM}\right)$; Río Pataste, $12 \mathrm{ml}$. S Dulce Nombre de Culmi, 29 Jan. ( $\%$, LSUMZ); Monte E1 Conejo, 21 May ( ${ }^{\circ}$, 
MLZ); Finca Fé, $20 \mathrm{Feb}, 23 \mathrm{July}\left(2 \sigma^{\circ},{ }^{\circ}\right.$, ISUMZ); Lake Yojoa, 14 June-16 Aug. ( $75, C M$; \&, UF); $4 \mathrm{mi}$. NW Siguatepeque, 16 Feb. ( $\sigma$, LSUMZ); Sigua tepeque, $31 \mathrm{July}\left(\sigma^{\circ}, \mathrm{CM}\right)$; Cerro Santa Maria, 29 Dec. (o', AMNH); Cantoral, 8 April (d", AMNH); Cerro Cantoral, 22 March, 12-13 Jec. (40", MCZ); Cantarranas, 4 Aug. (c", ?, ANSP); San Juancito, 10-22 July, 18 Nov. (20, 3\%, ANSP; of, LSUMZ); Rancho Quemado, 8 March19 April ( $\%$, AMNH; 28, 3\%, MCZ); E1 Hat1110, 25 April-12 May, 6 July, 5-17 Aug : (50", 29, CM; 40, 29 , ?, MCZ); Tegucigalpa, 10-26 May (5o, 49, AMNH); Comayagüela, 4 Oct. -4 Nov. ( $3 d^{\circ}, 7, M C Z$ ); Capa Rosa, 10 March ( $d^{\prime}$, UF); Escuela Agrícola Panamericana, 12 June ( $\sigma^{\circ}$, UF); Arenal, 23 Jan. ( $d^{\prime}$, UCLA); San Francisco, Choluteca, 12 Feb. ( 9 , LSLMZ).

1932: $\frac{\text { PUBLTSHED RECORDS. - -San Juancito, Cantarranas (Stone, }}{340)}$ Cantarranas [as Sporophila Sp.] (Stone, 1932: 340).

Occurring up to 6,500 feet, this species is a fairly common to common resident in grassy or brushy open areas in Honduras; it is decidediy uncommon and local, however, in humid areas below 2,000 feet. It is most frequent at medium elevations, in cut-over fields that have been allowed to grow up in guamil.

Honduran specimens are typical of the widespread, Middle American race, T. ㅇ. pugilla Swainson.

Spiza americana (Gmelin)

Dickcissel

SPEC IMENS.--(46): Swan Islands, 25 March, 14-19 April (30", USNM); Roatán Is land (23?, BMNH; 5?, CNHM); Guana ja Is land, 13 April ( $\delta, C M)$; Littie Hog Is land, 7 April ( 8 , LSIMZ); Trujillo, 6-9 April (d, $?$, CM); E1 Hatillo, 29 April ( 7, MCZ); Tegucigalpa, 24 April ( $8,{ }^{\circ}$, AMNH); Comayagüela, 22 April, 17 Nov. (2o", MCZ); Escuela Agrícola Panamericana, 6 Feb., 18 Dec. ( ${ }^{\circ}$, UF); Yeguare River Valley, 13 Nov. (juv., UF); San Lorenzo, $24 \mathrm{Sep} .\left(0^{\circ}, \mathrm{MCZ}\right)$; Puerto Salamar, 13 Feb. (2 9 , LSUMZ).

PUBLISHED RECORDS.--San Pedro region (Sclater and Salvin, 1870b: 836). Roatán Island, San Pedro (Salvin and Godman, 1886: 416). Swan Islands (Ridgway, 1888c: 576; 
Fisher and Wetmore, 1931: 23). Roatán Island (Salvin, 1888: 263; Sharpe, 1888: 773; Hellmayr, 1938: 129). Lancetilla (Peters, 1929b: 468).

The Dickcissel is a common migrant and uncommon winter visitant in the lowlands of Honduras, occurring primarily below 500 feet but ranging at least uncommonly up to 3,000 feet. The species also migrates in numbers through the islands off the north coast. It inhabits open country, generally with scrub or scattered trees. Extreme dates of arrival and departure in Honduras are 18 September and 10 May.

Dickcissels sometimes appear during migration in huge flocks exceeding 1,000 individuals. The species must have been quite common on Roatán Is land when George F. Gaumer secured the series listed above. Mark Trafton, Jr., and V. C. Dunlap witnessed a large flock roosting overnight at La Lima on 24 April 1952, and Trafton reported flocks exceeding 1,000 individuals on 23 and 24 April 1955 at the same locality. From 27 September to 8 October 1962, large flocks passed along the Pacific coast at Puerto Salamar, migrating west to east; on several days I observed more than 1,500 individual birds.

\section{Sporophila torqueola (Bonaparte)}

\section{White-collared Seedeater}

SPECIMENS.--s.t. morelleti (81): Julián [= Tulián]

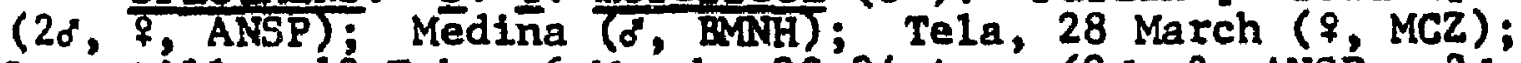
Lancetilla, 18 Feb., 6 March, 23-24 Aug. (20, ?, ANsp; 38", \$, MCZ); La Ceiba, 2-14 Jan., 27 March, 24 April-29 May

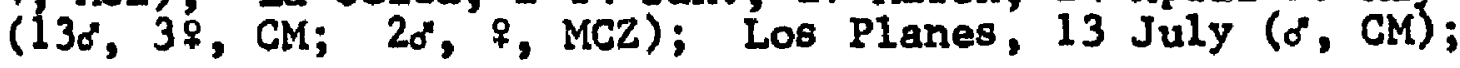




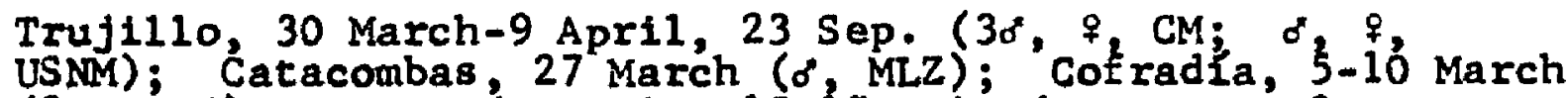
(2\%, MLZ); San Pedro Sula, $15-17$ July ( $\delta$, BMNH; $2 \sigma^{\circ}$; USNM); Las Pefiltas, $17 \mathrm{Feb}$. ( $\sigma$, MLZ); Chamelecón, 17-23 Feb. ( $\sigma^{\circ}, q ?$, USNM); Coyoles, 16 June, 12 July $\left(6 \sigma^{\prime}, \%, C M\right)$; San José de Santa Bárbara, 25 Apri1-1 May (20, AMNH); Finca Fé, $22 \mathrm{Feb}-2$ March, 22 July, $2 \mathrm{Dec}$. (40, \%, LSUMZ); Lake

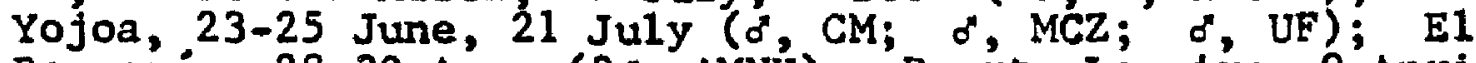
Boquerón, 28-30 Aug . (30", AMNH); Puerto Lempira, 9 April (20, LSUMZ); San Lorenzo, $14-29$ Sep. ( $\sigma$, $\%$, AMNH; $2 \%$, MLZ; o, $\$, M C Z$ ); $4 \mathrm{mi}$. NE Cedeño, 4 oct. (imm. \&, LSUMZ); "Honduras " ( $\$$, AMNH; $\sigma, q, B M N H ;$ alc., USNM).

PUBLISHED RECORDS.-- "Honduras" (Sclater, 1856c: 302; 1862: 105 ). San Pedro region (Sclater and Salvin, 1870b: 836). San Pedro, Medina (Salvin and Godman, 1885: 353). Trujillo (Ridgway, 1888c; 580). "Honduras," Medina, San Pedro (Sharpe, 1888: 124). San Pedro Sula (RIdgway, 1901: 576; Hellmayr, 1938: 188). La Ceiba (Bangs, 1903: 156). Lancetilla, Tela (Peters, 1929b: 466). Lancetilla (Stone, 1932: 340; Skutch, 1954a: 9, 34-36). Near Tela (Skutch, 1945a: 24; 1951b: 8). Julián [= Tulián] (de Schauensee, 1952: 173).

On the Caribbean slope of Honduras, this seedeater is one of the most common and conspicuous species of birds in open situations. It also occurs in the Pacific lowlands but is decidedly uncommon there and is outnumbered by $\underline{S}$. minuta. Altitudinally it has not been recorded above 2,500 feet. The White-collared Seedeater prefers open situations with scattered scrub or scattered trees and frequently occurs in and around towns and villages.

Hellmayr (1938: 188) examined seven specimens from San Pedro Sula, presumably taken by Erich Wittkügel and deposited in the Brunswick Musem or the Frankfurt Museum.

I assign all Honduran specimens to the widespread, Middle American race, $\underline{S}$ - $\underline{t}$. morellet1 (Bonaparte). Males from the Pacific slope of Guatemala, E1 Salvador, and 
Honduras vary from white-throated to black-throated types; these latter individuals were described as $\underline{s}$. $\underline{t}$. mutanda Griscom. As Hellmayr (1938: 188) pointed out, this "race" appears to be based on a mutation among the Pacific slope populations (it also crops up in the Motagua Valley of Guatemala), since normal birds occur in about equal numbers with the black-throated individuals in the same populations; de Schauensee (1952: 173-174) agreed with this conclusion and both authors considered mutanda to be unrecognizable as a subspecies.

\section{Sporophila aurita (Bonaparte)}

Variable Seedeater

SPECIMENS.--S. a. corvina (46): San Alejo, 16 March (d, LSUMZ); Lancetilia, $14 \mathrm{Jan} ., 12 \mathrm{Feb} .-6$ March, 23 Aug -1 Sep. (50", ??, ANSP; $40^{\circ}, 49, \mathrm{MCZ}$ ); La Celba, 2-14 Jan., 17 Feb.-31 March, 30 April-7 June (6o, 47, CM; $\left.30^{\circ}, \mathrm{MCZ}\right)$;

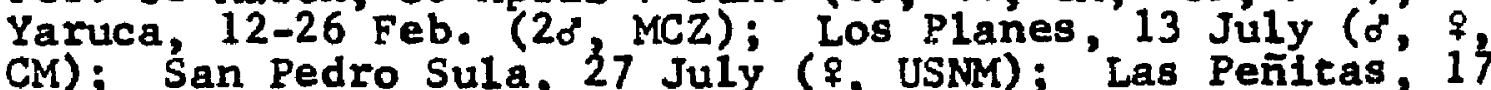
CM); San Pedro Sula, 27 July ( $\$$, USNM); Las Peñitas 21 Jan. ( $6^{\circ}$, UCLA); Segovia River, 12 June, 12-13 Aug. (50, ?, USNM); "Honduras" ( $\sigma$, Juv. $\delta$, BMNH; 2 alc., USNM).

PUBLISHED RECORDS.--"Honduras" (Sclater, 1859c: 379; 1862: 105; Sharpe, 1888: 137). San Pedro region (Sclater and Salvin, 1870́b: 836). San Pedro (Salvin and Godman, 1886: 356). Segovia River (RIdgway, 1888c: 586). La Ceiba, Yaruca (Bangs, 1903: 156). Lancetilla (Peters, 1929b: 466; Stone, 1932: 340). San Pedro Sula (Hellmayr, 1938: 190). Near Tela (Skutch, 1951b: 8). Lancetilla Valley (Skutch, 1954a: 9, 30).

Ranging up to 2,000 feet, this seedeater is an uncommon to fairly common resident in the Caribbean lowlands of Honduras and occurs in open rain forest, forest edge, second growth, and scrub. It is much more characteristic of 
forested regions than the other two Honduran species of Sporophila.

Hellmayr (1938: 190) examined two specimens from San Pedro Sula, presumably taken by Erich Wittkügel and deposited in the Brunswick Museum or the Frankfurt Mus eum.

A few authors consider this species to be conspecific with the South American S. americana (Gmelin), but since there is no evidence of intergradation of the two forms in South America and in view of the fact that many pairs of species in the genus differ but little morphologically, retention of the two forms as full species for the present seems to be the best procedure.

Honduran specimens are referable to the Middle American race, S. a. corvina (Sclater). Although Sclater (1859c: 379) had a specimen from Honduras in his collection at the time of his description of corvina, the type is one from Playa Vicente, Oaxaca, Mexico.

\section{Sporophila minuta (Linnaeus)}

Ruddy-breas ted Seedeater

SPECIMENS.--S. m- parva (15): San Lorenzo, 25-29 Sep. (30, 3\%, MLZ; $\left.30^{\circ}, \%, M C Z\right) ; ~ 15 \mathrm{mi}$. NE Cedeño, 4 Oct. ( ${ }^{\circ}$, LSUMZ); $3 \mathrm{mi}$. NE'Cedefio, 11 Feb. (20, 9 , $9 ?$ ?, LSUMZ).

Despite the absence of previous published reports, the Ruddy-breasted Seedeater is a fairly common resident in the arid Pacific lowlands of Honduras; it has not been found in Honduras above 1,500 feet elevation. It occurs in open situations, usually with scrubby growth or long grass 
present. During the nonbreeding season, it often flocks with S. torqueola. It is decidedly more common than the latter in the Pacific lowlands.

Honduran specimens are representative of the northern race, S. … parva (Lawrence).

\section{Amaurospiza concolor Cabanis \\ Blue Seedeater}

(d, CM); Arana $1,-{ }_{26}$ S.: concolor (2): Lake Yojoa, 14 Aug.

Known in Honduras only as a rare resident of the Caribbean lowlands, the Blue Seedeater reaches 1 ts known northern limit of distribution in the Lake Yojoa region. It inhabits open rain forest, forest edge, or second growth.

There are only two Honduran records. A male was taken by Arthur C. Twomey and Roland W. Hawkins at Lake Yojoa in 1950, and another male was secured by Thomas $R$. Howell at Arenal in 1953. The elevations of the two localities are 2,100 and 1,200 feet, respectively.

After examination of a recently obtained series of A. relicta (Griscom) from southern Mexico, I feel that the latter is not conspecific with $A$. concolor. In addition to a number of morphological differences in both sexes, $A$. relicta 18 an inhabitant of mountainous regions and occupies a habitat much different from that of $A$. concolor. The Honduran specimens of A. concolor, the northerrmost known 
for the species, show no approach towards A. relicta in any character.

Hellmayr (1938: 237) stated that the supposed Nicaraguan race, A. $\subseteq$. grandior Griscon, is not recognizable. The two Honduran specimens are therefore referable to the

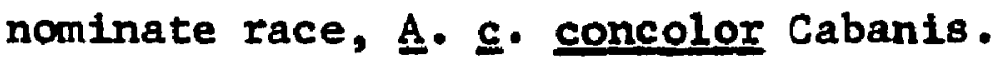

\section{Oryzoborus funereus Sclater}

Thick-billed Seed Finch

SPECTMENS.--(21): $4 \mathrm{mi}$. E Omoa, 11 March (8 skel., LSUMZ) $3 \mathrm{mI}$. E Onoa, 23 oct. (d, LSUMZ); Lancetilla, 17 Jan., 18 Feb.-6 March, 28 Aug. ( $\sigma^{\circ}$, ANSP; 5o, 38, MCZ); La Ceiba, 10 Jan. 15 May ( ${ }^{\circ}$ CM; ${ }^{\circ}$, MCZ); Los Plánes, 13-14 July $(0, \&, C M)$; Las Peñitas, 2 Feb. ( $\delta$, MLZ); 1 mi. W El Jara 1, 24 Feb. (o*, LSUMZ); Lake Yojoa, 25 July ( $q$, CM); Puerto Lempira, 9-12 Apri1 (d, ?, LSUMZ); "Honduras" (q, BMNH).

PUBLISHED RECORDS.--"Honduras" (Sharpe, 1888: 81). La Celba (Bangs 1903: 156). Lancet11la (Peters, $1929 \mathrm{~b}$ : 465; Stone, 1932: 340).

This finch is an uncommon resident in the Caribbean lowlands of Honduras, occurring up to 2,500 feet elevation. It inhabits open sttuations, usually being found in scrub, in grassy areas, and sometimes along forest edge.

\section{Volatinia Jacarina (Linnaeus)}

Blue-black Grassquit

SPECTMENS. - - V. 1. Splendens (94): Lancetilla, 2-26 Feb., 4 Sep. (20, ANSP; 40, 28 ?, MCZ); La Ce1ba, 24

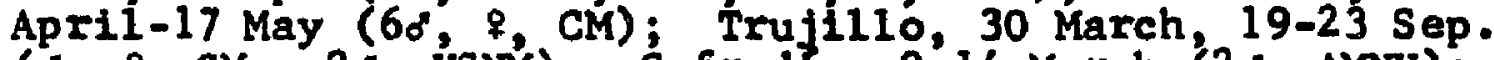
( $\sigma^{\prime}, 8, C M ; 2 \sigma^{\circ}$, USNM); Cofradla, 9-14 March (20, AMaH); San Pedro Sula, 10-31 July ( $30^{\circ}, \$$, USMM); Las Peñitas, 30 Jan. -2 Feb. (40, AMNH); Chamelecón, 16-23 Feb. (20, USNM); Subirana, 20 March (o, MCZ); Coyoles, 15-16 June, $12 \mathrm{July}$ (6o, 2\%, CM); San Esteban, 1 July $\left(\sigma^{\circ}, C M\right)$; Río Pataste, 12 mi. S Dulce Nombre de Culmí, 27 Jan. (o", LSUMZ); Plan del 
Rancho, 30 May-30 June (7d, 3\%, MLZ); Finca Fé, 22 July, 1 Sep. , 7-25 Nov. (20, $\$$ Imm. $\sigma^{\circ}$, ISUMz); Agua Azul, 10 Aug. (o, UF); Lake Yojoa, 28 July, 25 Aug. (20, CM); E1 Caliche, 27 July (o, AMNH); San Marcos de Guatmaca, 5 July (?, AMNH) ; Cerro Cantoral, 4-29 March (o", ₹, MCZ); Monte Redondo, 8 Dec. ( 9, ANNH); La Flor Archaga, 21 May, 11-15

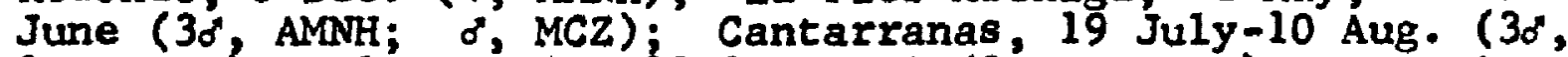
2\%, ANSP); E1 Hatillo, 28-30 April (20, $\%$, MCZ); Tegucigalpa, 26 March, 26 May (2\%, AMNH); Comayagüela, 8-11 Oct., 3 Nov. (5o, MCZ); Madre Vieja, 19 May ( $\sigma^{\circ}, \mathrm{MCZ}$ ); Escuela Agrícola Panamericana, 27 Feb. 15 March ( $2 q, U F) ; S a n$ Francisco, Francisco Morazán, 14 June ( $\%$, UF); Yeguare River Valiey, $18-25 \mathrm{May}, 1-21 \mathrm{Sep}$ ( $d, 3 q$, UF $; 15 \mathrm{~m}$. NE Cedeño, 4 oct. (Imm. ó, LSUMZ); $4 \mathrm{mi}$. NE' Cedeño, 4 Oct. (d, LSLMZ).

PUBLISHED RECORDS.--San Pedro region (Sclater and Salvin, 1870b: 836). San Pedro (Salvin and Godman, 1886: 3583. Trujillo (Ridgway, 1888c: 580). Lancetilla (Peters, 1929b: 466). Cantarranas, Lancetilla (Stone, 1932: 340$)$.

Ranging up to 3,500 feet, this species is perhaps the most common small passerine of open situations in the lowlands of Honduras. It occurs in grassy fields, in scrubby areas, in second growth, and in and around towns and villages.

Honduran specimens are typlcal of the widespread Middle American race, $\underline{V}$. j. splendens (Vieillot). For use of the name splendens in lieu of $\underline{v}$. 1 . atronitens Todd, see Hellmayr (1938: 254).

\section{Spinus notatus (Du Bus)}

Black-headed Siskin

SPECTMENS.--S. n. oleaceus (55): Santa Ana, 23 Dec. (30, 2q, ?, USNM); Las Peñitas, 14 Feb. ( $0^{\circ}$, MCZ); Subirana, 11 Jan. ( $q, M C Z)$; Yorito; 3 June ( $\delta, M C Z) ;$ San Esteban, 28 June (40, $2 \%, C M$ ); Santa Bárbara, $3-18$ May $\left(\sigma^{\circ}, 2 \%\right.$, AMNH); Lake Yojoa, 12 June $\left(\sigma^{\circ}, C M\right) ; 2$ mi. N P1to Solo, 13 Oct. ( $\sigma^{\prime}$ skel., LSUMZ); $15 \mathrm{ml}$. NW Siguatepeque, 15 Aug. ( $\sigma^{\prime}$, $\mathrm{CM})$; Siguatepeque, $31 \mathrm{July}(d, \mathrm{CM}) ; 6 \mathrm{mi}$. SE'Siguatepeque, 
16 Feb. (o, LSUMZ); $17 \mathrm{mi}$. NW Comayagua, 17 oct. ( ${ }^{\circ}$, ISUMZ); Güise, $17^{\circ} \mathrm{July}$ (d, LSUMZ); $3 \mathrm{mi}$. W Zambrano, 17 oct. (imm. \%, LSUMZ); Cantora1, 6 Dec. (imm. o', AMNH); Cerro Cantora 1, 6-7 Dec. (20, MCZ); La Flor Archaga, 30 May, 17 July ( $\delta$, AMNH; $\$$, MCZ); Rancho Quemado, 5 April (\$, BMNH; "USNM); E1 Hatilio, 29 June-6 Ju1y, 1-12 Aug.

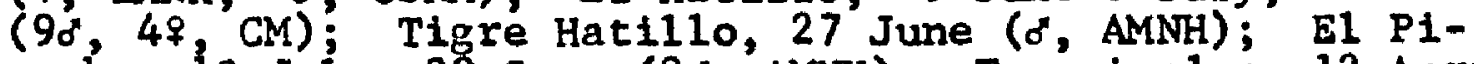
cacho, 10 July, 29 Sep. (20, AMNK); Tegucigalpa, 12 April ( $\sigma^{\circ}, 2 \%$, BMNH); Uyuca, 28 July ( $q$ UF); Portillo de Los Arados, 5 July ( 8, UF); Danli, 7 April ( 9, BMNH).

PUBLISHED RECORDS.--Santa Ana (Ridgway, 1891: 470). Cerro Cantoral (Griscom, 1932c: 61). E1 Hatillo, San Esteban, Siguatepeque (Russe11, 1964: 181).

The Black-headed Siskin is a fairly common to common resident of pine and pine-oak associations in the interior of Honduras, occurring mostly above 2,000 feet elevation but descending to about 1,500 feet in the San Esteban region. It has not been recorded in the lowland pine savanna of the Honduran Mosquitia but probably occurs there, since T. R. Howel1 (personal communication) has obtained it in the Nicaraguan Mosquitia.

The southernmost populations of the species in Honduras and northern Nicaragua have been described as $\underline{S}$. $n$. oleaceus Griscom [1932c: 61; Cerro Cantoral (6500 ft.), District of Achaga (= Archaga), Honduras] on the basis of smaller size and generally darker coloration, especially below. The large series now avallable from Honduras indicates that this race is rather weakly differentiated, differing in the darker coloration (which is based mainly on a greater percentage of the southern birds being darker, less yellowish below, though individuals from Mexico sometimes match certain ones from Honduras) and in average smaller size. Wing 
measurements of Honduran specimens are as follows: ${ }^{\prime}, 60.7-$ 66.6 , one specimen $68.3(64.0) ; \%, 60.6-62.9$, one specimen $65.8(62.5)$.

\section{Spinus psaltria (Say)}

\section{Lesser Goldfinch}

SPECIMENS. - -S. p. columbianus (66): Montaña El Chorro, 3 July $\left(8^{\circ},{ }^{\circ}\right.$, MLZ); Plan del Rancho, 8 July ( $\sigma^{\circ}$, MLZ); Soluteca, 6 April (o", AMNH); Cantora 1, 1 April' ( $q$, AMNH); Cerro Cantoral, 2-5 Ápril, 26 Nov. -7 Dec. ( $0^{\prime}$, BMNH; 40", 29 , MCZ); Monte Redondo, 29 Oct., 14-15 Dec. (29, ?, MCZ); La Flor Archaga, 17 Jan., 9 June-14 July ( 6 , ANSP; 'o', AMNH; $\sigma^{\circ,} \mathrm{MCZ}$; $\delta^{\circ}$, USNM); Cantarranas, 8 Aug - (20", ANSP); Rancho Quemado, 2-5 April ( $\%$, BMNH; 120, 2\%, ?, MCZ); EI Hatillo, $4 \mathrm{May}, 17$ Aug. (d, CM; o", MCZ); Cerro Higuito, D.C., 10-23 Jume, 14 oct. (40", AMNH); Tegucigalpa, 4-27 June (50, 49, AMNH ; Comayaguiela, 10 July, 29 Oct., 16 Nov. ( 9 , MLz; o", \$, MCZ); Madre Vieja, 1 Sep; ( $d^{*}$ UF); Escuela Agrícola

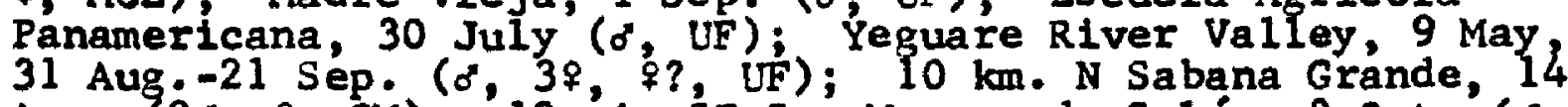
Aug. $\left(20^{\circ}, f, C M\right) ; 12 \mathrm{ml}$. SE San Marcos de Colón, 3 Oct.' ( $\sigma^{\circ}$, LSUMZ).

PUBLISHED RECORD.--Cantarranas (Stone, 1932: 340).

This goldfinch is an uncommon to fairly common resident in pine-oak associations in the interior of Honduras, breedIng from 3,500 feet to at least 6,000 feet. In the nonbreeding season it occurs in almost any open or semi-open situation with scrubby growth or scattered trees and of ten descends to sea level. According to Dickey and van Rossem (1938: 594-595), it breeds in the winter in E1 Salvador; apparently the same is true in Honduras since all records from the lowlands have been obtained during the sumer months. 
Honduran specimens are referable to the widespread race, S. p. columbianus (Lafresnaye). I agree with Hellmayr (1938: 301) that $\underline{\text { S. }}$. croceus Jouy is not distinguishable from columbianus.

\section{Loxia curvirostra Linnaeus}

Red Crossbill

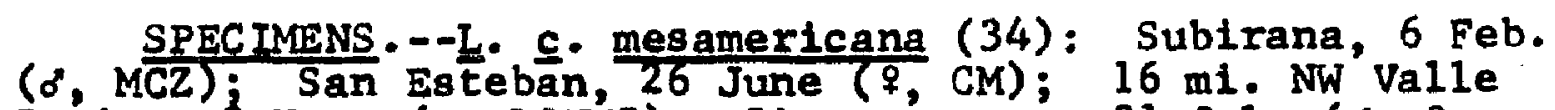
Bonito, 2 Nov. ( $\sigma$, LSUMz); Sigua tépeque, 31 Juiy ( $\delta, \%$, imm. $\%, C M) ; 17 \mathrm{mi}$. NW Comayagua, 17 Oct. ( 9 , LSUMZ); 4 mi. SE La Esperanza, 24 Jan. (9, LSUMZ); Cerro Cantoral, 79 Dec. ( $20^{\circ}, \mathrm{MCZ}$ ); Monte Redondo, 23 Nov. ( $\left.{ }^{\circ}, \mathrm{MCZ}\right)$; La Flor Archaga, 10 March ( $q, \mathrm{MCZ}$ ); Rancho Quemado, 5 April, 16

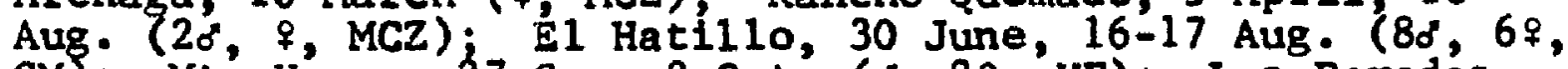
CM); Mt: Uyuca, 27 Sep.-8 OCt. (o", 29, UF); Los Paredes, 12 Jan. ( $\sigma$, UCLÁ); "Honduras" ( $\$, M C Z)$.

PUBLISHED RECORDS.--Rancho Quemado; "DLstrict of Archaga" "= Cerro Cantoral, La Flor Archaga, and Monte Redondo] (Griscom, 1937a: 136).

The Red Crossbill is a boreal species that reaches its southern limit of distribution in the interior highlands of northern Nicaragua. It is fairly common in highland pine areas of Honduras; altitudinally its primary range is fxom 3,500 to 6,500 feet, but it occurs down to 1,500 feet in the vicinity of San Esteban and Los Paredes. It is not known to occur in the lowland pine savanna of the Honduran Mosquitia but undoubtedly will be found there as it is present in the Nicaraguan Mosquitia (T. R. Howell, personal communication).

The southern population of the species has been described as L. c. mesamericana Griscom [1937a: 136; Rancho 
Quemado, south central Honduras] on the basis of smaller size and darker coloration, when compared with the race $L$. c. strlcklandi Ridgway of Mexico and Guatemala. The Honduran series exhibits the characters ascribed to mesamericana and Individuals show no approach to stricklandi.

\section{Sicalis luteola (Sparrman)}

Yellow Grass Finch

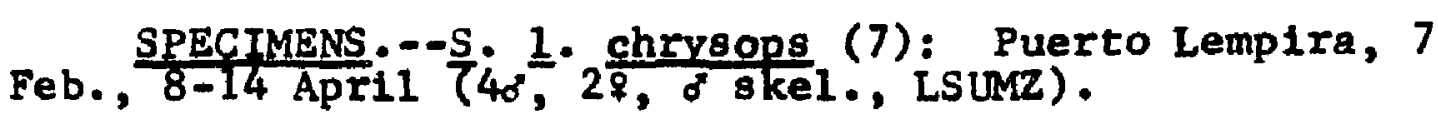

In the lowland pine savanna of the Mosquitia in eastern Honduras, this species is one of the dominant resident birds, although it has not been previously reported from the republic. It is common in open areas of the savanna, generally avoiding stands of pine. During the nonbreeding seas on it often occurs in large flocks. It frequently feeds along the beaches of the Laguna Caratasca, preaumably on seeds washed up on the shore. The species, like several other savanna inhabitants, does not occur elsewhere in Honduras.

I secured the first Honduran specimen from a pair seen at Puerto Lempira on 7 February 1963. The remainder of the series 11sted above was taken during April 1964.

The Honduran specimens are not distinguishable from a series from eastern Mexico. I therefore assign them to the northern race, S. 1. chrysops Sclater. 
Spodiornts rusticus (Tschudi)

Slaty Finch

SPECIMENS.--S. r. barrilesensis (2): E1 Chorro, 9 July (o, ML̃ ); Montaña EI Chorro, 12 JuIy $\left(\sigma^{\circ}\right.$, MLZ). Medina, 1957: $67 \%$.

This species is exceedingly rare and local north of Costa Rica. It is known from Honduras only by the two males taken by C. F. Underwood in July 1936 (Moore and Medina, 1957: 67). There are no other records from Middle America between Mexico and Costa Rica.

The southern race, $\underline{S}$. $\underline{r}$. barrilesens is Davids on, seems to be distinguishable on the basis of smaller size, at least; in addition, the few specimens that I have seen

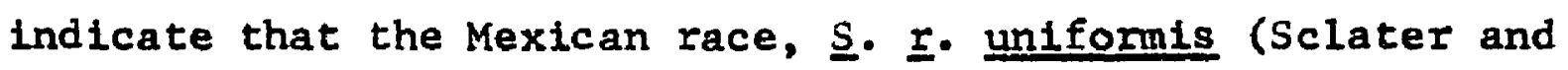
Salvin), has a light-colored lower mandible while barrilesensis possesses a dark-colored bill. Measurements of the two Honduran males are as follows: wing, 69.0, 72.5; tail, 43.7, 45.5; exposed culmen, 10.9, 11.8 .

\section{Atlapetes gutturalis (Lafresnaye)}

Yellow-throated Brush Finch

SPECIMENS.--A. g. fuscipygius (80): Portillo Grande, 8 Feb., 30 May (o, $\frac{q}{9}, M_{C 2}$; Merendon Copán, 26 June ( AMNH); Montaña EI' Chorro, "31" June ( $\sigma^{\prime \prime}, M L Z$ ); El Sillón, 10 July ( $0^{\circ}, M L Z$ ); Monte El Candado, 30 May (? MLZ); Beíén Gualcho, 18 July (2\%, ?, MLZ); Las Ventanas, 24-27 July ( $d^{\prime}$, 9. ?, MLZ); Cerro Santa Bárbara, southeast 81ope, 26 July ( $\sigma^{\prime}, \$$, LSUMZ); Lake Yojoa, 21 July $(q, C M)$; 10 mi. S Coma yagua; 20 June ( $\$$, Juv. $\%, C M$ ); Cantora1, 8-27 Feb., 26 July (38, 2\%, AMNH; $\delta^{\prime \prime}, \mathrm{MCZ}$ ); Cerro Cantoral, 1-23 March, 13 Dec. ( $30^{\circ}, 3 \%, ?$, MCZ); Aito Cantoral, 6 Jan., 6 Feb. (28, 7, MLZ); La Cueva Archaga, $12 \mathrm{Sep.}\left({ }^{\circ}\right.$, AMNH); La Flor 
Archaga, 12 Aug: ( 8, MCZ); San Juancito, 11-18 July, 3-10 Aug. (40, $₹, 2$ juv. $\sigma^{\prime}$, juv., ANSP; $20^{\prime \prime}$, , CM; ?, UF); Rancho Quemado, 1 March-5 Apri1 (o", AMNH; 6o, 9\%, MCZ); El Derrumbo, 19-23 July (juv. $\delta$, MLz; $\delta, ~ f, M C Z)$; E1 Hatillo, 5 July, $11-20$ Aug. ( $30^{\circ}$, imm. $q$, juv. $q, C M$ ); Cerro Higuito, D.C., 7 July (imm. o, AMNH); Tegucigalpa, $30 \mathrm{Sep}$. (imm. o", AMNH); Cuesta Grande, 1 July $(\sigma, \&, C M)$; Uyuca, 12 Feb. (?, UF); Mt. Uyuca, 2 Aug. (imm., UF); Valie Encantado, 24 Nov. -3 Dec. ( $9, ?$, UF); E1 Paraíso, 20 April (q, BMNH).

PUBLISHED RECORDS.--San Juancito (Stone, 1932: 341). Volcán de Puca, El Paraíso (Hellmayr, 1938: 389).

In the interior of Honduras this species is a falrly common to common resident, ranging from 4,000 to 7,500 feet elevation. It is a species of scrubby growth, frequenting also forest edge, second growth, undergrowth in pine-oak associations, and occasionally even open cloud forest.

Hellmayr (1938: 389) examined a female specimen from Volcán de Puca, presumably collected by Erich Wittkügel and deposited in the Brunswick Museum or the Frankfurt Museum.

Honduran specimens, including those from the Department of Ocotepeque, are typical of the race A. g. fuscipygius Dwight and Griscom in the more restricted yellow throat patch and whiter breasts; in addition, the backs of Honduran birds average browner than those from Guatemala. None of the Honduran specimens shows any approach to the Guatemalan race, A. g. griseipectus Dwight and Griscom.

\section{Atlapetes brunneinucha (Laf resnaye)}

\section{Ches tnut-capped Brush Finch}

SPECTMENS.--A. b. allent (101): Las Peñitas, 30 Jan.17 Feb. $\left(30^{\circ}, 2 \%, ?\right.$ AMNH; 40, 39, MLZ); Portillo Grande, 22 May, 6 Oct. ( $\delta$, CNEM; $\&$, MCZ); $5.5 \mathrm{mi}$. S San Esteban, 23 Jan. ( $\sigma^{\circ}$, LSUMZ); La Libertad, 27 June ( $\sigma^{\circ}$, CNHM); E1

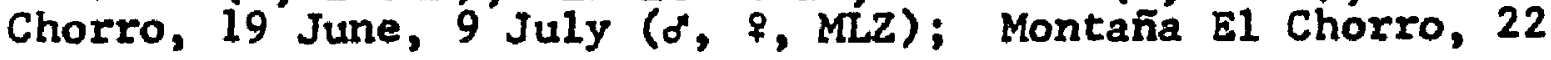


June, 3 July ( $d, q$, MLZ); Montaña El Sillón, 22 June-3 July (49, ?, MLZ); Montaña La Cruz, 25-26 June ( $\$$, ?, MLZ); Monte Él Candado, 30 May ( $\sigma^{\circ}$, MLZ); Monte Verde, 20-25 July (30, ?, MIZ); Mt. Puca, $25^{\circ}$ Jan. -5 Feb. (20, ${ }^{\circ}, \mathrm{MCZ}^{\circ}$; Cerro Santa Bárbara, east slope, 28 Nov. (\%, LSUMZ); Cerro Santa Bárbara, southeast slope, 25 July (o, LSUMZ); $5 \mathrm{ml}$. SW El Jara1, 4 Nov. ( $\sigma^{\circ}, 7$, LSUMZ); Soluteca, 7 April ( $\sigma^{\circ}$, AMNH); Muye, 20-26 Feb. (20, 2\%, AMNH); Cantoral, 6-20 Feb., 12 May, 16 July-10 Aug. ( $8, \%$, juv. of, juv. $\%$, AMNH; $\$$, CNEM; o, MLZ); Cerro Cantoral, 4 March, 26 Nov. -13 Dec. $\left(5 \delta^{\circ}, 9\right.$, MCZ); La Cueva Archaga, 2 Feb., 5 Aug. ( $8,2 \%$, AMNH); San Juancito, 2 Feb., 19 June-14 Aug. (40", $3 \%, 4$ juv. d", juv. $\$$, ANSP; $80^{\circ}, 3 \%$, Juv. 8, CM; $0^{\circ}$, ISUMZ; $0^{\circ}$, juv., UF); Rancho Quemado, 13 March-5 April (40, 3?, MCZ); Tegucigalpa, 27 Feb., 10-14 Aug. (20, Juv. 9, AMNH); Mt. Uyuca, 26 May, 20 Nov. (o, MCZ; \&, UF); Portillo de Los Arados, 14 July (o", Juv., UF).

PUBLISHED RECORDS.--San Juancito (Stone, 1932: 341). San Pedro, Volcan de Puca (Hellmayr, 1938: 414). Cantora 1, La Cueva Archaga, La Libertad Muye, Portilio Grande, San Juancito, "San Pedro (Copán)" [" San Pedro Sula], and Soluteca [as alleni] (Parkes, 1954a: 134).

Ranging from 4,000 to 8,000 feet, the Ches tnut-capped Brush Finch is a common resident of cloud forest in Honduras. It is generally a species of the forest floor or undergrowth, occurring on or near the ground.

Hellmayr (1938: 414) examined two specimens from San Pedro and two others from Volcán de Puca, all collected by Erich Wittkügel and presumably deposited in the Frankfurt Museum or the Brunswick Mus eum.

All Honduran material is referable to the race $\underline{A}$. $\underline{b}$. alleni [Atlapetes brunne1-nucha allent Parkes, 1954a: 134; San Juancito, Honduras], which is distinguished from the Guatemalan race, A. b. macrourus (Atlapetes brunnel-nucha macrourus Parkes, 1954a: 133; Volcán Tajumulco (9200 feet), San Marcos, Guatemala], by the lack of yellow borders to the 
chestnut crown patch. A few scattered specimens from various parts of Honduras exhibit faint traces of this yellow margin, but none shows any close approach to macrourus.

\section{Arremon aurantilrostris Lafresnaye}

$$
\text { Orange-billed sparrow }
$$

SPECIMENS:--A. a - rufidoralis (9): San Alejo, 29 March-3 ApriI (2o, o ske1, LSUMZ); Yaruca, 18-20 Feb. (2d, MCZ); Arenal, 21 Jan. ( $d^{\circ}, 8$, UCLA); Segovia River, 19 June ( 8, USNM).

586). $\frac{\text { PUBLISHED }}{\text { Yaruca }} \frac{\text { RECORDS }}{\text { (Bangs }}--$ Segovia River (RIdgway, 1888c:

Occurring below 2,000 feet, the orange-billed Sparrow

is an uncommon resident of the humtd Caribbean lowlands of Honduras. A bird of the undergrowth, it inhabits rain forest, forest edge, and guamil.

I refer Honduran specimens to the race A. a. rufidorsalis Cassin, which ranges from Honduras to Panama. A1though I cannot see any constant differences in the darkness of the upper parts, the wider and longer supraorbital white stripe (extending anteriorly nearly to the bill and lacking a gray wash posteriorly) seems to be a valid character, when examples of rufidorsalis are compared with the nominate race, A. A- aurantilrostris Laf resnaye. None of the Honduran specimens approaches A. a. saturatus Cherrie, a larger and darker race ranging from Mextco to British Honduras. 


\section{Arremonops chloronotus (Salvin)}

\section{Green-backed Sparrow}

SPECIMENS.--A. c. chloronotus (24): San Pedro Sula, 9 July-3 Aug. (58, के, USNM); Amapa, 18-26 Jan., 28 Apri1, 18 Sep. (40" ske1., LSUMZ); San José de Santa Bấrbara, 5 May (6", AMNH); El Jara1, 5 Oct. ( 9 , AMNH); 2 mi. SE EI Jara1, 24 Feb. ( ${ }^{\prime}$ ?, LSUMZ); Finca Fe, 6-8 Aug., 1-4 Sep., 2 Dec. $\left(20^{\circ}, 28, ?\right.$, Juv. of, skel., 2 alc., LS UMZ); Lake Yojoa, 17 July (o, CM). A. c. twomeyi (8): Coyoles, 23 April, 14-26

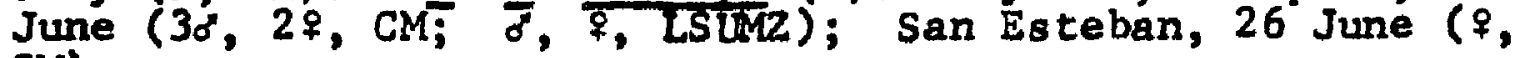
CM).

PUBLISHED RECORDS.--San Pedro Sula (RIdgway, 1901: 452). San Pedro Sula, Amapa, Lake Yojoa, San José de Santa Bárbara, Finca Fé, and near Ei Jaral [as chloronota]; Coyoles and San Esteban [as twomeyt] (Monroe, 1963c: 8).

The Green-backed Sparrow is a fairly common resident in the Caribbean lowlands of north-central Honduras, reaching its southern limit of distribution in Honduras. The species ranges as far east as the sula valley and as far inland as the Lake Yojoa region, with isolated populations in the Aguán and Agalta valleys. It inhabits brushy and scrubby areas, generally in the vicinity of rain forest; it may be encountered in undergrowth in open rain forest, forest edge, or second growth, always on or near the ground. The populations in the Aguán and Agalta valleys occur under more arid conditions in undergrowth of the vega forests along the Rfo Aguán and Rio Sico, respectively. Altitudinally, the species does not occur above an elevation of 2,500 feet.

The relationships among Middle American populations assigned to various species in this genus, and especially to the species now known as A. conirostris and A. chloronotus, 
were discussed at length in an earlier paper (Monroe, 1963c: 1-12). Since that paper was completed, further field work in Honduras has indicated that $A$. chloronotus is indeed a very distinct species.

I should like to point out that my return to the use of the masculine gender for Arremonops in lieu of the feminine, which had been established as the correct gender according to its original usage (Monroe, 1963c: 2), is based entirely on a proposal recently accepted by the International Commission of Zoological Nomenclature (October 1963 meeting) to consider all names ending in -ops as masculine, regardless of derivation.

Specimens from Honduras west of the Sula Valley are typical of the nominate race, A. c. chloronotus (Salvin), except in the Lake Yojoa region where some specimens show an approach to A. c. twomeyi [Arremonops chloronota twomey1 Monroe, 1963c: 8; Coyoles, Honduras] in the slightly paler crown stripes and buffier wash on the breast. The race twomeyi, confined to the Aguain and Agalta valleys, is slightly smaller (see measurements in Monroe, 1963c: 10), has the light crown stripes paler (grayish white rather than gray), has a light buff (not gray) wash on the breast, and possesses brighter green upper parts. The possibility of this race being a link to the superciliosus group of $A$. rufiyirgatus (Lawrence) has been discussed in another publication (Monroe, 1963c: 5). 


\section{Arremonops conirostris (Bonaparte)}

Black-striped Sparrow

SPECIMENS.--A. c. richmondi (52): San Alejo, 4-8 Aug. ( ${ }^{*}, ?$, LSUMZ); Lancetilla, I April, 17-19 Aug. ( $\%$, 1mm., LSUMZ; $q$, UF); Montecristo, 24 March (o, LSUMZ); La Ceiba, 11-24 Jan., 27 March-7 June (13d", 4\%, CM; of, 29 , MCZ; \&, USNM); Los Planes, 13 July ( $\left.\sigma^{\prime}, C M\right)$; Trujillo, 1 oct. ( 8 , USMM); $6 \mathrm{mi}$. NE Progreso, 29 March (o, ISUMZ); Río Pataste, $12 \mathrm{mi}$. S Dulce Nombre de Culmi, 27 Jan. ( $q$, LSUMZ); Jamastrán Valley, $20 \mathrm{Feb} .17$ Aug. ( $9, ?$, UF); E1 Boquerón, 21 Aug. -7 oct. ( $30^{\circ}, 3 \%, 2$ ? AMNH); Patuca River, 11 March ( $\delta^{\circ}$, USNM); Segovia River, 12 June, 2 Aug. (20,?, USNM); Puerto Lempira, 6 Feb., 9-10 April (30, $\$, ?, \sigma^{\circ}$ skel., \& ske1., LSUMZ):

PUBLISHED RECORDS.--Trujillo, Segovia River (Ridgway, $1888 \mathrm{c}: 580,587)$ La Celba [as centratus] (Bangs, 1903 : 156-157). La Ceiba [as richmondi] (Deignan, 1936: 193). $6 \mathrm{mi}$. NE Progreso, San Alejo, Montecristo, Lancetilla, [Los] Planes, La Celba, Trujillo, Patuca River, near Dulce Nombre de Culmi, El Boquerón. Jamastrán Valley, puerto Lempira, and Segovia River [as richmond1] (Monroe, 1963c: 10).

This species more or less replaces A. chloronotus east of the Sula Valley. It is fairly common to common from Progreso and San Alejo east through much of the Caribbean lowlands below 1,500 feet elevation. The species inhabits scrubby areas, dense undergrowth, forest edge, and second growth, usually staying near the ground.

Reasons for considering this species and $A$. chloronotus as distinct have been previously discussed (Monroe, 1963c: 1-12). In addition to morphological differences in adults (larger size, wing of males $>73$, females $>67$, as opposed to $<72$ in males and $<67$ in females for chloronotus; different bill color patterns; relatively heavier and longer legs and feet), there are distinct differences in vocalizations and in the immature plumages, including the post-juvenal molt. 
Honduran specimens are representative of the northern race, A. C. Fichmondi Ridgway. Reasons for suppressing A. c. centratus Bangs [1903: 156; Ceiba, north coast of Honduras] have been stated in an earlier paper (Monroe, 1963c: 5-6). Blake (1958: 574) further mentioned that richmondi is only slightly differentiated from the South American A. c. striatlceps (Lafresnaye) and may not be worthy of recognition; I have not studied striaticeps and cannot comment on this problem.

Melozone biarcuatum (Prévost and Des Murs)

Prévost's Ground Sparrow

SPECIMENS.--(25): Catacombas, 7 April ( $9, \mathrm{MCZ}$ ); La Leona, 25 June ( 0 , 9 , AMNH) ; La Libertad, 27 June ( $0^{\circ}$, AMNH); Montaña El Chorro, 22 June-3 July (20, $\$$, MLZ); Plan del Rancho, 20 May-12 June $\left(30^{\circ}, 3{ }^{\circ}, \mathrm{ML}\right)$; Belén Gualcho, 18 July (o', MLZ); Mt. Puca, 5 Jan. (d, MCZ); Santa Bárbara, 18 May ( $\$$, AMNH); Cerro Santa Barbara, southeast slope, 26 July ( $\$$, LSUMz); $1 \mathrm{mi}$. W El Jaral, 15 Sep. ( $\sigma^{\circ}$, Imm., LSUMZ); Finca Fé, 20 Feb., 25 Nov. -20 Jan. (36, $29, q$ skel., LSUMZ). $1955 \mathrm{a}:(105)$.

PUBLISHED RECORD.--"Honduras" [ In range] (Eisenmann, This sparrow is an uncomon to locally fairly common resident in the interior highlands of Honduras east to the Sula and Comayagua valleys. Occurring at elevations from 2,000 to 6,000 feet, it frequents scrubby areas, regions of dense undergrowth, cut-over areas, and cultivated corn fields. The species ranges from Chiapas to Honduras, reaching its limit of distribution as indicated above. 
Eisenmann (1955a: 105) included Honduras in the range of the species on the basis of the four specimens in the American Museum of Natural History.

As has been pointed out by Miller, Friedmann, Griscom, and Moore (1957: 360), the striking differences between this species and $\underline{M}$. kieneri (Bonaparte) of Mexico, evident even in the juvenal plumages, seem to indicate that the two are separate species. In addition, these authors showed that even if the two forms are considered as conspecific, the specific name would be biarcuatum, not kieneri.

I cannot distinguish the supposed Chiapan race, ‥ b. hartwegi Brodkorb; I therefore regard the species as monotypic.

Passerculus sandwichensis (Gmelin)

Savannah Sparrow

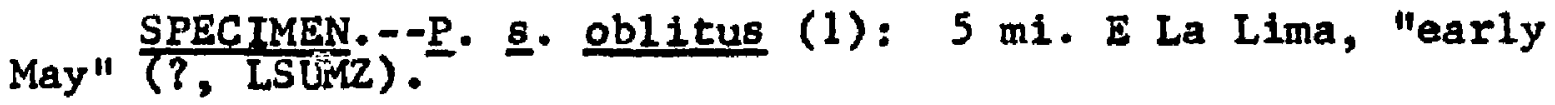
[Big] SWan Island (Bond, 1959: 9). (Lowe, 1909: 339). known only as a winter visitant, the Savannah Sparrow must be regarded as rare in Honduras. Charles H. Blake secured one specimen (subsequently $108 t$ ) and banded two other Individuals on Big Swan Island between 10 and 26 November 1958 (Bond, 1959: 9); Lowe (1909: 339) had previously included the species from the Swan Is lands on the basis of reports by the local residents, although Lowe himself never observed it there. Kenneth S. Hamilton secured a specimen 
in early May 1963 near La Lima; this individual was extremely fat and could not be sexed when skinned. There are no other records for Honduras .

The single extant Honduran specimen is referable to the

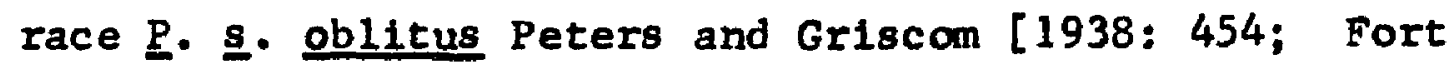
Church111, Manitoba], a race breeding in central Canada and wintering for the most part along the Gulf coast of the United States.

\section{Ammodramus savannarum (Gmelin)}

\section{Grasshopper Sparrow}

SPECIMENS. -A. 8. bimaculatus (6): Cantoral, 1 April (q, AMNH); Cerro Cantoral, 7 Dec. (o, MCZ); Monte Redondo, 25 Nov. -14 Dec ( $\sigma^{\prime}$, AMNH; $\delta, \%, M C Z$ ); Escuela Agricola Panamericana, 19 March ( $\%$, UF). A. 8. cracens (15): Puerto Lempira, $7 \mathrm{Feb} ., 8-14$ April (9\%, 5\%, LSUMz); Nacunta River, $10 \mathrm{ml}$. SW Puerto Lempira, $5 \mathrm{Feb}$. ( $q$, LSUMZ).

PUBLISHED RECORD.--[Big] Swan Is land (Bond, 1959: 9).

In the lowland pine savanna of the Mosquitia of eastern Honduras, this sparrow is a very common resident, being perhaps the dominant species of bird in the open savanna grasslands. It prefers areas recently burned over or with very short grass and generally avolds those with long grass. In the interior highlands of Honduras, the species has been recorded from November to April at elevations above 2,500 feet in open grassy situations; it is presumed to be resident there, since breeding populations, which represent the subspecies bimaculatus, extend from southern Mexico to Costa Rica, but this race is known from Honduras only by the 8 ix 
specimens listed above. There is a single record of the species for the Swan Islands, one individual having been banded on 23 November 1958 by Charles H. Blake (Bond, 1959: 9).

The specimens from Cantora1, Cerro Cantoral, and Monte Redondo were obtained by C. F. Underwood in November and December 1931 and in April 1932. The other interior specimen was taken by Marjorie H. Carr on 19 March 1946. Richard R. Graber, Jean W. Graber, and I secured the extensive series from the Puerto Lempira region in February 1963 and in April 1964.

The lowland pine savanna population in the Mosquitia is typical of the very dark, buffy-breasted subepectes, $\underline{A} \cdot \underline{\text {. }}$ cracens (Bangs and Peck); this race has not been heretofore reported south of Guatemala and British Honduras in the 1iterature, although Thomas $R$. Howell (personal communication) has obtained a series from the Nicaraguan Mosquitia. The interior birds represent the much paler, 1 ess buffy race, A. ‥ bimaculatus Swainson. The single record from the Swan Islands presumably pertains to the eastern North American race, A. B. pratens is (Vtelllot), which winters south to British Honduras and Guatemala, although subspecific determination of the banded bird was not made. 


\section{Chondestes grammacus (Say)}

Lark Sparrow

Oct. $\frac{\text { SPECIMEN }}{(\delta, \text { LSUMZ })-C . ~ g . ~ g r a m m a c u s ~}(1): 2 \mathrm{mi}$. E La Lima, 25

In 1964 Kenneth S. Hamilton obtained a male of this species in a pasture two miles east of La Lima, Department of Cortés. The specimen constitutes the first Honduran record and the first report of the species south of Guatemala and El Salvador. This individual was extremely fat.

The single specimen is typical of the eastern North American race, C. g. grammacus (Say), in the dariker ches tnut head markings. The records from Guatemala and E1 Salvador pertain to the western race, $\underline{C}$. $g$. strigatus Swainson.

\section{Aimophila ruficauda (Bonaparte)}

\section{Stripe-headed Sparrow}

SPECIMENS. - -A. r. ruficauda (44): Monte Redondo, 8 May, 29 Sep., 4 Nov. -19 Dec. (o', \%, ANSP; 20, \%, ?, MCZ; o, USNM); Archaga, 29 May (q, CM); La Flor Archaga, 14-15 June ( $q$, ANSP; $d, C M)$; El Hatilio, 19 April ( $q, M C Z$ ); Tegucigalpa, 2 oct. ( $\$$, ANSP); Comsyagüela, 15 June, 5 July, 9-11 Oct., 3-18 Nov. (28, \&; ANSP; 7o, MCZ; \&, USNM); Escuela Agrícola Panamericana, 4 Nov. (juv., UF); Yeguare River Valley, 11 May, 6 Nov. ( $0^{\circ}, 7$, UF); $4 \mathrm{mi}$. B Tegucigalpa-Danli road, Dept. Francisco Morazán, 2 July ( $\delta$, UF); Dromodero Mts., near Danl 1,26 July ( $q$, UF); $10 \mathrm{~km}$. N

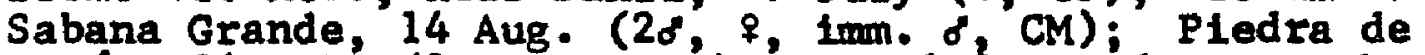
Jesuis, $24 \mathrm{Feb}$. (2o, $q$ AMNH); $\mathrm{Km}$. 108, road to south coast, Dept. Valle, 5 Feb. (2 $\sigma^{\prime}, 3 \%$, UF); San Lorenzo, $25 \mathrm{Sep}$. ( $\sigma^{\circ}$, MCZ); Puerto Salamar, 9-13 Feb. (d, \&, LSUMZ); $13 \mathrm{mi}$. W Choluteca, 1 Oct. ( $q$, LSUMZ). $1955 a \equiv(106)$.

PUBLTSHED RECQRD.--"Honduras" [In range] (Eis enmann,

In Honduras the Stripe-headed Sparrow is confined entirely to arid regions on the Pacific slope below 4,500 
feet. It is an inhabitant of arid scrub and is fairly common to common, being most frequent in the lowlands near the Pacific coast. Although the species reappears in the arid Motagua Valley of Guatemala, it does not occur in any of the dry interior valleys on the Caribbean slope of Honduras.

Eisenmann (1955a: 106) included Honduras in the range of the specles on the basis of the specimens from Pledra de Jesis. In view of its relative abundance, it is surprising that there are no other published records for the republic. Honduran specimens are all typical of the nominate race, A. ․ ruficauda (Bonaparte). None shows any approach to the grayer Motagua Valley subspecies, A. $\underline{\mathbf{r}}$. connectens Griscom.

\section{Aimophila rufescens (Swainson)}

\section{Rusty Sparrow}

SPEC IMENS.--A. ‥ Iufescens (107): Catacombas, 21-29

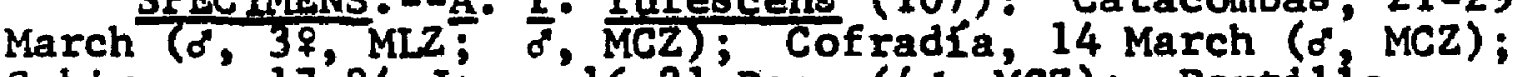
Subirana 17-24 Jan., 16-21 Dec. (40, MCZ); Portilio Grande, Io May ( $\left.\sigma^{\prime}, \mathrm{MCZ}\right)$; Coyoles, 18 July $(d, C M)$; San Esteban, 26-28 June (60, 39, CM); La Libertad, 18 June ( $0^{\circ}$ AMNH); E1 Chorro, 22 June ( 7, Miz); Montafia E1 Chorro, 22 June ( $\left.\sigma^{\circ}, \mathrm{MLZ}\right)$; Monte E1 Conejo, 21 May ( $\sigma^{*}$ MLZ); Plan del Rancho, 26-28 May, 24 June-9 July (30, ${ }^{2}, 2 ?$, MLz) i Agua Azul, 7 Aug. (1mm., UF); Lake Yojoa, 12-22 June, 19 July, 16 Aug. (20, $₹$, juv. o, CM; Imm. of, UF); Siguatepeque, 9 July ( $8 \mathrm{CM}$ ); Cerro Grande, 12 Oct. ( $\delta$, AMNH); Cerro Santa Maria, 30 Dec. ( $\%$, ANSP; $\%$, AMNH); Cantoral, 8 March, 1216 Dec. (o", AMNH; $q$ CM; o, $q$, USNM); Cerro Cantoral, 4 March-8 Apri1, 12-21 Dec. ( $0^{\circ}$, ANSP; $\delta^{\circ}$ CM; $60^{\circ}, 29,2 ?$, MCZ); San Juancito, 10 July-15 Aug. $\left(\sigma^{*}, 3 q, 2\right.$ juv $d d^{\prime}$, juv. ₹. Juv., ANSP; o, CM); Rancho Quemado, 12 March-12 Apri1 (7\%, 59, MCZ); El Hatillo, 19 April, 29 June-5 July, 1-20 Aug. $\left(20^{\circ}, 49, \mathrm{CM} ; 40^{\circ}, 9, \mathrm{MCZ}\right) ; \mathrm{B1}$ Plcacho, 1 Oct. ( 7 , AMNH); $18 \mathrm{mi}$. NW Tegucigalpa, 17 Oct. ( $q$, IsLMZ); 
Tegucigalpa, 15-22 Feb., 29-30 0ct. (o, 29, AMNH; 1mm. o", CM); Comayagüela, 9-12 Oct. (2?, MCZ); Mt. Uyuca, 26 May, 3 July, 2 Aug. ( 0 , \&, ?, UF); Yeguare River Valley, 27 Jan. (o, UF); Yuscarán, 16 April ( $\%$, BMNH); Portillo de Los Arados, 5 July (juv., UF); Jamas trán Valley, 11 Aug. (8, UF); Piedra de Jesús, 2 April ( $\delta$, AMNH); San Francisco, Choluteca, 11 oct. ( $\sigma^{\prime}$, imm. $q$, Lsumz). A. r. discolor (8): Segovia River, 19-22 July, 8 Aug. (40, $2 f^{\circ}$, imm. $\delta^{\prime}$, USNM); Puerto Lempira, 14 April ( 9 , LSUMZ).

PUBIISHED RECORDS.--Segovia River [as discolor] (Ridgway, I888c: 587 ): San Juancito [as rufescens] (Stone, 1932: 342). Cantoral and Cerro Cantoral [as rufescens] (Brodkorb, 1940a: 549).

In Honduras the Rusty Sparrow occurs wherever there are extensive stands of pine, both in the interior highlands and in the lowland Mosquitia of eastern Honduras. It is generally found in and around scrubby growth in the vicinity of pine and is fairly common to common in the republic. Alt1tudinally it is not known above 6,000 feet in Honduras.

The distribution of the races of this sparrow conforms to the general pattern exhibited by those species that inhabit pinelands both in the interior and in the Mosquitia. The lowland populations of such species tend towards smaller size and darker coloration and are identical with (or very similar to) populations in the lowland pine "ridges" of British Honduras. In the case of Aimophila rufescens, the Mosquitia birds are virtually identical with those of British Honduras, differing only in the average slightly darker rufous upper parts. As Bangs and Peck (1908: 46) and Hellmayr (1938: 526) have correctly indicated (although Hellmayr was puzzled by the discontinuity of range), the race A. ‥ discolor Ridgway [1888c: 587; Segovia River, 
Honduras] occupies both the lowland pine of Guatemala and British Honduras and the pine savanna of the Mosquitia in eastern Honduras and northeastern Nicaragua. A fresh series from Nicaragua (Thomas R. Howe11, personal communication) and a single fresh female from Honduras compare favorably with a recently taken series from British Honduras. I tentatively restrict the race $\mathbf{A} \cdot \underline{\mathbf{r}} \cdot$ pyrgitoides (Lafresnaye) to eastern Mexico; the differences between this race and discolor are alight and perhaps all populations from southeastern Mexico to the Mosquitia should be united in the single subspecies pyrgitoides. Wings of Honduran examples assigned by me to discolor measure as follows: $8,65.8-68.0(66.8) ; q, 63.0-65.9(63.7)$. The interior highland populations in Honduras are referable to the larger, slightly paler subspectes, A. I. rufescens (Swainson). Wings of specimens of nominate rufescens measure: $\sigma^{t}, 68.4-78.1(73.2) ; \%, 64.9-75.0(70.0)$. T. R. Howell informed me that the series from San Esteban, which I have not examined, is almost exactly intermediate in size between nominate rufescens and discolor but matches the former in coloration; this situation is paralleled in other spectes, such as Piranga flave.

\section{Aimophila petenica (Salvin)}

Petén Sparrow 
In Honduras Almophila petentca is known only from the lowland pine savanna of the Mosquitia, where it is an uncommon to fairly common resident. It is found almost exclusively in open situations with deep grass or scattered scrubby growth. Richard R. Graber, Jean W. Graber, and I secured the three specimens and $s$ aw several other individuals during early April 1964. There are no other Honduran records.

I am not at all convinced that $A$. petenica and $\underline{A}$. botterif (Sclater) are conspecific, as they are considered to be by Webster (1959: 136-146). In a genus where morphological differences between some species are slight and where ethological factors are apparently the critical isolating mechanisms, retention of the petenica and botterii groups of forms as full spectes seems to be the best procedure, pending complete fleld studies. In morphology, A. petentca is more different from $A$. botteril than is $A$. cassinil (Woodhouse), which has always been considered specifically distinct from $A$. bottertl.

As might be expected, the Honduran specimens from the Mosquitia are not separable from a series from the Nicaraguan Mosquitia. Thomas R. Howell (personal commintcation) has informed me that the Mosquitia population constitutes a distinct and unnamed race, which he is in the process of describing. In the interior highlands of Middle America, the species is resident as far south as Costa Rica, 
but there are no records for the interior of Honduras. In Guatemala the subspecies A. R. vantynei Aimophila botterii vantynei Webster, 1959: 143; Guatemala City, Guatemala] occurs, while in Nicaragua and Costa Rica the subspecies is A. p. vulcanica Miller and Griscom.

\section{Spizella passerina (Bechstein)}

\section{Chipping Sparrow}

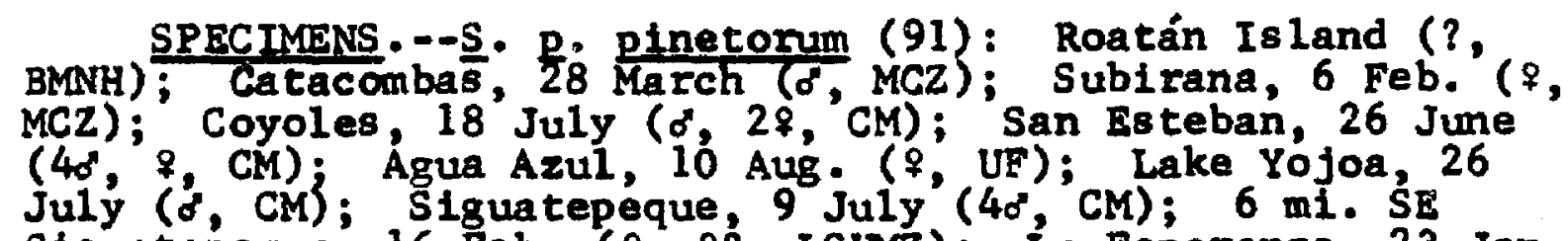
Siguatepeque, 16 Feb. ( $\%$, $\% ?$, ISUMZ); La Esperanza, 23 Jan. (o, LSUMZ); Soluteca, 9-10 April ( $0^{\circ}$, \&, AMNH); La Cruz Grande, 15 March ( ${ }^{*}, q$, AMMH); San Marcos de Guaimaca, 5 July ( $\delta$, MLZ); $3 \mathrm{mi}$. W Zambrano, 17 Oct. ( $\%$, Lsuz); Montafia Vásquez, 14 June ( $0, M C Z$ ); Cantoral, 2-15 March, 8 April (20, 9, AMNH); Cerro Cantora1, 8 Apr11, 7 Aug., 1-9 Dec. (68, 48, ?, MCZ; 8 , USNM); La Flor Archaga, 25 May-17 July (8, AMNH; '6o', 38, MCZ; $\$$ ' USNM); El Gomalota1, 3 Dec. ( $\sigma^{\circ}$, AMNH); San Juanctto $18-27$ July $\left(2 \sigma^{*} \%\right.$, Juv. $\sigma^{*}$, ANSP); E1 Hatil10, 4-8 May, 29 June-17 Aug. (40, ₹, CM; on, 48, MCZ); Tigre Hatt110, 26 June-9 July (40, 38, ANNH); Ei Picacho, 3-11 July, 21 Oct. (20, \&, AMNH); Tegucigalpa, $11-$ 12 April, 20 June ( $\sigma^{\circ}$, AMNH; $30^{\prime}$, BMNH); Yeguare River Valley, 26 March ( $d$, UF); road to Gülnope, 4 Aug. (4?, UF); Dan11, 7 April (o, BMNH); Los Paredes, 12 Jan. ( $\$$, UCLA); Segovia Rtver, 22 July (?, USMM); Pledra de Jesus, 1 April (\%, AMNH).

PUBLISHED RECORDS.--Roa tán Is land (Salvin, 1888: 262; Sharpe, 1888: 664). Segovia River (RIdgway, 1888c: 587). San Juanct to (Stone, 1932: 342).

The Chipping Sparrow is a fairly common to common resident in pine throughout the interior of Honduras, in the lowland pine savanna of the Mosquitia in eastern Honduras, and in the pine belt on Roatain Is land, in the Bay Islands. 
Altitudinally it has not been recorded in Honduras above 6,000 feet.

I refer all Honduran specimens to the race $\underline{S} \cdot \underline{Q}$. pinetorum Salvin. While there is some variation between lowland and interior highland populations of this species, the differences are very slight and at best detectable only in series. The highland birds often have the chestnut cap extending farther posteriorly than is usual in the lowland ones. The black nuchal markings are more restricted and the dorsal coloration averages richer, but the degree of difference does not seem to warrant taxonomic recognition. I therefore consider S. R. clcada D1ckey and van Rossem to be a synonym of pinetorum.

\section{Zonotrichia capensis (Müller)}

Rufous-collared Sparrow

SPECIMENS.--Z. c. Septentrionalis (27): Montaña Los Cedros, June ( $q$, MIZ) El Chorro, 23-24 June ( ${ }^{\circ}, q, M L Z$ ); Montafia E1 Chorro; 27-"31" June (20, MLZ); Plan del Rancho, 15 June-2 July (2o, 39, MLZ); San Juanc1to, 11-12 July, 813 Aug - (20, $\%$ ANSP; $\%$, CM); Rancho Quemado, 19 March ( $0^{\circ}$, MCZ); El Hatillo, 19 April, 5-6 July, 6-20 Aug - (80, 29 , $\mathrm{CM}$; o, MCZ); Uyuca, 2 Aug. (?, UF).

\section{$1932: \frac{\text { PUBLIS }}{342)}$ \\ PUBLISHED RECORD.--San Juancito [as peruviana] (Stone,}

This sparrow is a falrly common resident locally in the interior highlands of Honduras, occurring at elevations of 5,000 to 7,500 feet. It inhabits open scrubby situations, second growth, and forest edge, of ten being numerous in and around towns and villages. 
Honduran specimens are not distinguishable from examples of $\underline{Z}$. c. septentrionalis Griscom from Guatemala and Chiapas and are assigned by me to that race. None shows any approach to the Costa Rican subspecies, $\underline{z}$. $\underline{\text { c. costa- }}$ ricensis Allen.

Melospiza lincolnit (Audubon)

\section{Lincoln's Sparrow}

SPECIMENS. --M. 1. I1ncolnii (2): Cerro Santa Bárbara, east slope, 25 April (?, LSTMZ); Monte Redondo, 23 Nov. ( ${ }^{\prime}$, MCZ). M. 1. grac1l is (1): Rancho Quemado, 12 March (f, AMNH).

The Lincoln's Sparrow is a rare to uncommon migrant and winter visitant in the interior highlands of Honduras, occurring in scrubby growth and cut-over areas of cloud forest above 4,500 feet.

C. F. Underwood obtained the first two Honduran specimens at Monte Redondo in 1931 and at Rancho Quemado in 1932. I obtained the other specimen on Cerro Santa Bárbara on 12 March 1963; on that occssion I noted the specles at several different locations on the mountain between 4,500 and 6,000 feet. There are no other Honduran records.

Paynter (1964: 277-281) advocated merging Melospiza in Zonotrichia, but I prefer to maintain these genera as separate.

The male specimen from Monte Redondo and the one of undetermined sex (probably male) from Cerro Santa Bárbara are referable to the nominate race, M. 1. 1incolnii (Audubon); 
wings of these individuals measure 63.0 and 63.7 , respectively. The other Honduran specimen, a female, is identified as $M$. 1. gracilis (Kittlitz) on the label; its wing measurement (58.5) and the paler brown coloration above indicate tiat the identification is probably correct. The third subspecies, M. 1. alticola (Miller and McCabe), winters as far south as El Salvador and probably also occurs in Honduras. 
HYPOTHETICAL LIST

Eudocimus ruber (Linnaeus)

Scarlet Ibis

In the "Beautiful Bird Exhibit" at the Chicago Natural History Museum is a mounted specimen of the Scarlet Ibis, supposedly taken in Honduras; it was first reported in the 1iterature by Hellmayr and Conover (1948a: 263-264). The bird in question bears the information "Honduras, 1896" on the label but no further data. Enmet R. Blake (personal communication) informed me that the specimen was acquired by the museum as a part of the Bishop Collection (with Bishop no. 23,965$)$. A check with the Bishop catalogue revealed that the specimen came to him from the collection of either Ward or Amstrong.

Although the bird has been accepted by most authors as a genuine Honduran record, I feel that the origin of the specimen is doubtful. First of all, it is the only Central American record for the species; secondly, there are no other Honduran specimens of any species from the collections of Bishop, Ward, or Armstrong; and thirdly, the year "1896" was one in which, so far as I am aware, there was no ornithologist nor collector in Honduras. Another factor for consideration is that a number of skins labeled "Honduras" 
have since proven to have originated in British Honduras, especially ones collected during the 1800 's.

I think the proper procedure is to regard the record as doubtful and to remove it from Honduran and Central American 1 is ts.

\section{Agriocharis ocellata (Cuvier)}

Ocellated Turkey

The Ocellated Turkey, Agriocharls ocellata [Meleagris ocellata Cuvier, 1820: 1; "Honduras"], is a species currently restricted to portions of Yucatán, Petén, and British Honduras. In the original description Cuvier mentioned only "Honduras" as its range, but the type in the Paris Museum is labeled "Gulf of Honduras." Taylor (1860: 311312) attributed it to the "forests of Honduras," but he mentioned specifically its occurrence at Belize, now in British Honduras. Gray (1870: 262) also 118 ted it as from "Honduras" but Sclater and Salvin (1873a: 137) corrected the range to read "British Honduras"; all subsequent authors have excluded Honduras from the range of the species. Little doubt remains that the type came from British Honduras and the type locality should read "Gulf of Honduras [= British Honduras ]."

On the chance that it might have occurred in recent times in the rain fores ts of northwestern Honduras, I made numerous inquiries among local residents in the Omoa region. 
Apparently the species has not existed in Honduras in modern times.

Hoploxypterus cayanus (Latham)

Pied Plover

Moore (1859: 63) 1isted this South American species as having been taken in 1855-1856 on the Aloor [= Uluia] River, Honduras, by Joseph Leyland. Sharpe (1896: 136) stated that no specimen from Honduras could be located in the Derby Museum, where Leyland's material was deposited. Forbes and Robins on (1899: 63) also searched for Honduran specimens in the Derby Museum but to no avail. I concur with most recent authors that the record must be the result of an error and that the species should be conitted from Honduran and Central American 1ists.

Thalasseus sandvicensis (Latham)

Sandwich Tern

The inclusion of Honduras in the range of this species is based on Ridgway (1919: 477-478), who cited Salvin (1866: 198) as his source of information. Salvin stated that it is "a very common spectes on both coasts," but he was referring to Guatemala, not Honduras. At the present time there is no valid Honduran record although the species occurs regularly in migration in Central America. 


\section{Thalasseus elegans (Gambel)}

\section{Elegant Tern}

The Elegant Tern, which breeds in western Mexico and winters off the west coast of South America, is a rare migrant along the Pacific coast of Central America. It is generally included in Honduran lists on the basis of a specimen taken by Captain J. M. Dow on the "Bay of Fonseca" (Salvin, 1866: 198-199). Saunders and Salvin (1896: 84) stated that the specimen was taken on 18 December 1862 at La Unión, El Salvador, on the western shore of the Bay of Fonseca.

In the absence of an actual Honduran record, the best procedure is to exclude the spectes from Honduran 118 ts.

\section{Anous minutus Bole \\ White-capped Noddy}

This species formerly bred in large numbers on the cays off the cosst of British Honduras, but these colonies are no longer extant (Russel1, 1964: 69). Individuals probably wandered into Honduran waters from that colony. Baird, Brewer, and Ridgway (1884: 324 ) recorded the spectes as breeding "along the coast of Honduras," but this reference pertains to the British Honduran colony.

\section{Columba squamosa Bonnaterte}

$$
\text { Scaly-naped Pigeon }
$$

Lowe (1909: 333) recorded this species (as "Columba 
corens 1s") from the Swan Islands on the basis of reports and descriptions obtained from the local residents. Bond (1950a: 57-58) 1isted it as "of doubtful occurrence... on the Swan Is lands."

The species certainly does not occur in the Swan Islands at the present time, as none of the many visiting ornithologists has ever recorded it. No definite evidence of its occurrence there exists and I therefore relegate the species to the hypothetical list.

\section{Otus cooperi (Ridgway)}

Pacific Screech Ow1

This species ranges through the Arid Upper Tropical Zone of the Pacific slope of Central America from southwes tern Mexico to Costa Rica. Although it certainly must occur in Honduras, there are no definite records of the species at present. Taylor (1860: 226) recorded a small owl on Tigre Island as "tolerably abundant . . ." but did not observe it elsewhere; he listed it as "Scops ___ ?" Sclater (1858b: 357) recorded "Scops trichops 1s ?" as having been collected by Taylor in Honduras, presumably on the basis of the Tigre Island reference; I was unable, however, to find this specimen in the Britioh Museum. Ridgway (1914: 718) tentatively transferred the Tigre record to Otus guatemplae but expressed doubt concerning its allocation to this species. ․ guatemalae is the only other member of the genus besides $\underline{0}$. cooperi that might be expected on Tigre 
Is land. However, geographically, ‥ cooperi is the species that most probably occurs on Tigre and, if this specimen is ever rediscovered, it will probably represent this species. In the absence of a definite Honduran record for the species, I am placing $\underline{0}$. cooperi on the hypothetical list.

\section{Chrysolampis mosquitus (Linnaeus)}

$$
\text { Ruby-and-topaz Hummingbird }
$$

Moore (1859: 54) 11sted as "Chrysolampis moschitus ?" a specimen secured by Joseph Leyland at Omoa; this individual is presumably in the Derby Museum in Liverpool, England. Neither Ridgway (1911) nor Cory (1918) made any mention of this specimen, and I can find no other reference to it. The spectes is South American and its occurrence in northern Central America is highly unlikely. Until the specimen is found and definitely identified, the Moore record must be regarded as a probable error.

\section{Amazilia microrhyncha (E111ot)}

\section{Sma11-billed Azurecrown}

This species was described on the basis of a single specimen as A. microrhyncha [Cyanomyia microrhyncha E111ot, 1876: 315; Honduras ?]. The unique type cannot be traced to its origin with any degree of certainty, as admitted by Elliot in the original description; he reported that the specimen "was said to have cone from Honduras; but for the accuracy of this habitat I cannot vouch." 
The specimen itself appears, at first glance, to be an example of A. cyanocephala, except for the noticeably small, slender bill. The exposed culmen measures 13.5 as opposed to 18.2 for the smallest cyanocephala that I have measured. In all other characters the type of microrhymcha falls within the limits of variation exhibited by syanocephala; but, as Eugene Eisemann (personal communication) pointed out, many characters are not typical of most examples of cyanocephala. The tail is bronzy with no greenish tinge and the feathers of the sides and under tail-coverts, in addition to lacking whitish edgings, are more rufous than is usually the case in cyanocephala.

After careful examination of the type, however, I feel that this individual is most 1ikely an aberrant example of A. cyanocephala. Regardless of what disposition is made of the specimen taxonomically, its place of origin is certainly in doubt. I therefore do not believe that A. microrhyncha should be included in the Honduran avifauna.

\section{Cissilopha rucatanica (Dubois)}

\section{Yucacán Jay}

Sharpe (1877: 134) 1isted two Yucatán Jays, a male collected by Joseph Leyland and a female by David Dyson, in the British Museum as having been taken in "Honduras." Salvin and Godman (1887: 498) reported these two specimens from their exact localities, both of which are in British Honduras. Despite the correction given by Salvin and Godman, 
Stone (1932: 326) continued to list the species from Honduras. There are no records for the republic and the occurrence of the species there is unlikely.

\section{Vireo altiloguus (Vielllot)}

Black-whiskered Vireo

Elsenmann (1955a: 86) listed this species as having been recorded from "Caribbean Honduras," but I can find no record of the species from the republic. Eisermann (personal communication) informed me that he was not sure about this record and it may have been included erroneously. In any event, the species is here relegated to the hypothetical 1 ist pending a definite record for Honduras. It may well occur during migration along the north coast or in the Caribbean islands.

\section{Icterus cucullatus Swainson}

\section{Hooded Oriole}

There is a specimen of Icterus cucullatus in the American Museum of Natural History labeled "Honduras." This individual, formerly in the collection of George N. Lawrence, is without data except for the collector's initials "D.L.F." It is an example of the British Honduran race, I. c. masoni Griscom, and almost certainly is another of those "Honduran" birds that actually came from British Honduras. The species may occur in the Onoa region of northwestern Honduras, but there are no records at the present time. 


\section{Tanagra minuta (Cabants) \\ White-vented Euphonia}

This euphonia inhabits rain forest on the Caribbean slope from Guatemala south to South America and undoubtedly occurs in Honduras. At the present time, however, there are no records for the country. Eisenmann (1955a: 97) Included Honduras in the range of the species, but he has informed me (personal communication) that his notes show no definite record for the republic. Unt11 a definite record is obtained, the occurrence of the species in Honduras must be considered hypothetical.

\section{Tanagra mesochrysa (Salvadori)}

Bronze-green Euphonia

A specimen of Tanagra mesochrysa (sex undetermined) in the Academy of Natural Sciences at Philadelphia is labeled "Honduras / Wood." This specimen is undoubtedly mislabeled since the species is restricted to South America.

\section{Richmondena cardinalis (Linnaeus)}

Common Cardinal

There is a specimen of this species in the American Museun of Natural History that was taken on 4 February 1890 by D. P. Ingraham; the locality on the label reads "Honduras." This specimen is representative of the British Honduran race, $\underline{R} \cdot \underline{c}$. flammigera (Peters) and most probably was secured in British Honduras, not Honduras. As far as I 
am aware, Ingraham never collected anywhere in Honduras. The species apparently does not range south of northeastern British Honduras. 
MIGRATION IN HONDURAS

Surprisingly little is known concerning migratory movements of tropical birds. Only those species that vacate an area entirely during one season have been studied at all. Migrations of only a few resident species, usually montane forms that descend to lower levels in the nonbreeding season, have been reported from the tropical regions of this hemisphere. Anyone who has spent a year in tropical rain forest will realize the remarkable turnover of individuals of resident species in a given area during the annual cycle. No analysis of this phenomenon has ever been made; it may be due to local movements, to dispersal of birds of the year, or to actual seasonal migrations.

In the following account of bird migration in Honduras, I have included only those forms that are known to be migratory into, out of, or through the republic, i.e., species or breeding subspecific populations of resident species that are present in Honduras in one season and totally absent in others. In all following 11sts, the trinomial is used only in cases where different subspecies of the same species

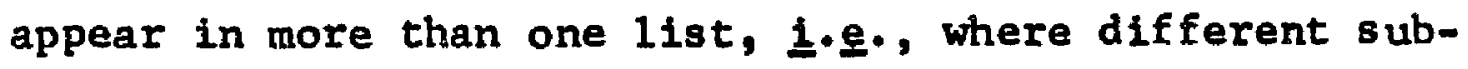
species of the same species are considered to be of different migrational status in the republic. 
Eight forms breed in Honduras and winter farther south, being entirely absent in Honduras during the winter season; Chordelles acutipennis probably should be added to this category although there are no definite breeding records at present. These eight forms are:

Elanoides forficatus yetapa

Ictinia plumbea

Chordeiles minor neotropicalis

Legatus leucophatus

Myiodymastes luteiventris

Myiodynastes maculatus

Progne shalybea

Vireo flavoviridis

The remainder of the forms discussed in this chapter are not known to breed in Honduras but are present during the nonbreeding season or are resident breeding species with extralimital breeding populations that appear in Honduras after breeding elsewhere.

At least one South American species (Cypseloides cryptus) migrates north to Honduras during the nonbreeding season (northern summer). Two others (Phaetusa simplex and Pygochelidon cyanoleuca) display a similar migrational pattern and have been recorded as far north as Honduras but never in the republic itself. Jabiru mycteria apparently breeds south of Honduras and is present in the country only during the fall and winter months. 
The remaining 170 species of migratory birds all breed to the north of Honduras and are either transients in the republic (wintering to the south) or are visitants in Honduras in the winter months. At least 34 species have populations that are regarded only as transient through the republic, there being no winter records of them; those species marked with an asterisk $(*)$ have been recorded casually in winter in areas north of Honduras. These 34 transients are:

Elanoides forficatus forficatus

Ictinia misis ippiensis

*Buteo swainsoni

Bartramia longicauda

Erolia melanotos

* MLcopalama himantopus

Tryngites subruficoli1s

Steganopus tricolor

*Larus pipixcan

Chlidonias niger

Coccyzus erythropthalmus

Coccyzus americanus

*Chordeiles acutipennis texensis micromeris

*Chordelles minor chapmani

Chordeiles gundlachi1

Caprimulgus maculicaudus 
Chaetura pelagica

Tyrannus dominicensis

Nuttallornis borealis

Contopus virens

Empidonax virescens

*Progne subis

Petrochelidon pyrrhonota

Riparia riparia

*Catharus minimus

Gatharus Euscescens

Vireo olivaceus

*Dendroica tigrina

Dendrotica cerulea

*Dendroica fusca

Dendroica castanea

*Oporornis phtladelphta

Dolichonyx oryztvorus

Plranga olivacea

One interesting fact as that of the above 34 specles, only a single one (Buteo swainsont) is primarily far western in its distribution in North America. Many are widespread, especially those that breed in arctic regions, but the majority are breeders in eastern North America. Four species (Chordelles gundlachil, Catharus Euscescens, Dendroice tigrina, and polichonyx oryzivorus) have been 
recorded from Honduras only in the Swan Islands or Bay Islands in the Caribbean Sea.

of the remaining migrant species, all of which are here classified as winter visitants to Honduras (although some may be more common during the spring and fall migrational periods), two (Anthus spinoletta and Dendroica discolor) have been reported from Honduras only from the Caribbean 18 lands. Six (Heteroscelus incanus, Larus pipixcan, Tyrannus yociferans, Myiarchus cinerascens, Vireo beliii, and Vireo gilvis) have been recorded only from the Pacific slope or from islands along the Pactfic coast, and three others (Zenaida asiatica, Muscivora forficata, and Tyrannus verticalis) winter primarily in this region but occur rarely on the Caribbean slope. The remaining species fall into several other categories that show migrational tendencies worthy of special note.

A few forms winter mostly in the interior highlands of Honduras, ranging into the lowlands of either coast only rarely and then usually during the spring or fall migrational periods. These forms are:

Sphyrapicus varius nuchalis

Empldonax hammondi1

Tachyclneta thalassing

Catharus ustulatus ustulatus

Dendroica auduboni

Dendroica chrysoparia 
Dendroica occidentalis

Dendroica dominica

Oporomis tolmiel

Wilsonia pusilla pileolata chryseola

Piranga ludovictana

Guiraca caerulea interfusa

Melospiza lincolnii

An examination of the above $118 \mathrm{~s}$ reveals that only one form (Dendroica dominica) is primarily eastern in its distribution on the breeding grounds in North America. Dendroica dominica is unique in that it is very common in the Caribbean lowlands during the migrational periods but seems to be restricted to the interior highlands in the winter months.

Seven additional forms winter in the Caribbean lowlands and in the intertor highlands in about equal numbers. These seven forms are:

Caprimulgus vociferus voctferus

Pollopt1la caerulea

Vireo solitarlus solitarius

uniotilta varia

Vemivora peregrina

Dendroica coronata

Dendroica virens 
A number of forms are relatively widespread in their winter distribution in Honduras, occurring regularly on both slopes and in some cases also in the interior highlands. These 62 forms are:

Botaurus lentiginosus

Anas acuta

Anas platyrhynchos

Anas discors

Spatula clypeata

Mareca americana

Aythya valisineria

Aythya affinis

Cathartes aura meridionalis

Elanus leucurus

Accipiter cooperi1

Accipiter striatus

Buteo lamaicensis calurus

Buteo platypterus

Circus cyaneus

Pandion hallaetus

Falco peregrinus

Falco columbarius

Falco sparverius sparverius

Porzana carolina

Squatarola squatarola

Charadrius semipalmatus 
Numenius phaeopus

Numenius americanus

Totanus flavipes

Totanus melanoleucus

Tringa solitaria

Actitis macularia

Catoptrophorus semipalmatus

Arenaria interpres

Limnodromus griseus

Capella gallinago

Calidris canutus

Crocethia alba

Eremetes pusillus

Ereunetes mauri

Erolia minutilia

Himantopus mexicanus

Lobipes lobatus

Gelochelidon nilotica

Sterna albifrons

Zenaidura macroura

Caprimulgus carolinens is

Archilochus colubris

Megaceryle alcyon

Sphyrapicus yartus varius

Tyrannus tyrannus

Empidonax brewsteri 
Empidonax mintmus

Hirundo rustica

Stelgidopteryx ruficollis serripennis

Iridoprocne bicolor

Bombycilla cedrorum

Dendroica petechia

Seiurus aurocapillus

Seiurus noveboracens is

Geothlypis trichas

Icteria virens

Wilsonia canadens is

Setophaga Euticilla

Icterus spurius

Spiza americana

The last group of wintering species includes those that are confined to the Caribbean lowlands or have seldom been recorded elsewhere in Honduras. These 46 forms are:

Bubulcus ibis

Plegadis chini

Chen hyperborea

Anas carolinens is

Anas cyanoptera

Aythya collaris

Oxyura jamaicens is

Haematopus palliatus

Charadrius alexandrinus 
Charadrius wilsonia

Limosa fedoa

Recurvirostra americana

Larus argentatus

Hydroprogne caspia

Sterna hirundo

Sterna forsteri

Rynchops nigra

Chaetura vauxi vauxi

Myiarchus crinitus

Empidonax flaviventris

Dumetella carolinens is

Hylocichla mustelina

Vireo griseus

Vireo flavifrons

Protonotaria citrea

Limnothlypis swainsonit

Helmitheros vermivorus

Vermivora chrysoptera

Vermivora pinus

Parula americana

Dendroica magnolia

Dendrolca pensylvanica

Dendroica palmarum

Seiurus motacilla

Oporornis formosus 
Wilsonia citrina

Wilsonia pusilla pusilla

Icterus galbula

Plranga rubra

Pheucticus ludovicianus

Guiraca caerulea caerulea

Passerina cyanea

Easserina ciris

Passerculus sandwichensis

Chondestes grammacus

Dis regarding the water bird entries for the moment, as many are based on one or two records only, an examination of the land bird entries in the above list reveals that all but three (Chaetura vauxi vauxi, Passerculus sandwichensis, and Chondestes grammacus) are basically eastern in their North American breeding distribution. The inclusion of Chaetura vauxi vauxi is based on a single winter straggler south of the normal wintering range in Guatemala and perhaps should not be considered here at all. Passerculus sandwichensis and Chondestes grammacus are widespread in North America, but Honduran specimens of both specles are from eastern populations.

Thus the general trend is for birds that breed in the western portions of North America to winter in the interior highlands of northern Central America; in fact, very few of these species extend south as far as northern South America. 
Birds that are breeders in eastern North Amertca tend either to migrate south of Honduras in winter or to remain through this seas on in the Caribbean lowlands; many of these species normally range well into South America.

One further manifestation of migration in Honduras should be mentioned at this time. Nocturnal studies during the full moon period from 2 through 9 May 1963 were conducted on Utila Island by my wife and me. Results were surprisingly good, despite the relatively late date in the migrational period. Every night a watch was conducted for birds crossing the lunar disc (by means of a $40 \times$ telescope), and every night yielded a relatively large magnitude of migration. Expanded observational data indicated that migration varied from a minimum of 4,000 birds per mile of migrational front per hour (on 2 May) to a maximum of 13,000 birds per mile of front per hour (on 6 May). These data show that trans-marine migration departing from northern Honduras is a regular phenomenon. All movements noted were north to northwest in general direction of migration. Thus the birds involved probably made landfall the following day on the Yucatán Peninsula or in British Honduras. No Lunar observations for all are available, but the records of m1gratory birds appearing in the Swan Islands and Bay Islands is indicative of trans-marine movements on a lage scale in the fall as well as in the spring. 
ANALYSIS OF THE AVIFAUNA

In the following analysis of the Honduran avifauna, I have treated the birds by habitat and have discussed their relattonships and probable origins at a group level. Many species exhibit a wide tolerance for environmental conditions and occupy more than one of the major habitats. I feel that the best procedure is to treat these widespread species separately at the outset and to save the detalled analysis for those that may be considered to be characteristic of a particular habitat.

Perhaps the two most nearly ubiquitous birds in Honduras are the two common vultures, cathartes aura and Coragyps atratus. They occur throughout the mainland at all elevations and in all habitats, at least to the extent of ranging over them dally. Neither could be considered as typical of any particular habitat although perhaps both are more abundant in the lowland regions.

There are 56 species in Honduras that I consider to be characteristic of the lowlands, 1.e., the Tropical zone, but which exhibit a wide tolerance for humidity. In most cases, these are species that inhabit open situations, forest edge, or the like and are not typical of heavily forested regions, although many may be found in more open 
portions of rain and deciduous forest. In every case these 56 species occur in the lowlands of both coasts and are too widespread to place satisfactorily in a single habitat. Among them are some of the commonest birds in Honduras and those that are most frequently seen about towns and villages. The 56 species in this category are as follows: Sarcoramphus papa

Buteo magnirostris

Buteo brachyurus

Buteo nitidus

Buteogallus anthracinus

Hypomorphnus urubitinga

Herpetotheres cachinnans

Falco albigularis

Columbigallina talpacoti

Ara macao

Playa cayana

Crotophaga sulcirostris

Tapera naevia

Tyto alba

Nyctibius griseus

Nyctidromus albicollis

Streptoprocne zonaris

Chaetura vauxi Eichmondi

Anthracothorax prevost11

Chlorostilbon canlvet 11 
Eumomota superciliosa

Momotus momota

Pteroglossus torquatus

Piculus rubiginosus

Dryocopus lineatus

Phloeoceastes guatemalens is

Xiphorhynchus flavigaster

Lepidocolaptes souleyeti1

Thamnophtlus doliatus

Tyrannus melancholicus

Mylodynastes luteiventris

Megarymchus pitangua

Myiozetetes similis

Pitangus sulphuratus

Mylarchus tuberculifer

Contopus cinereus

Tolmonytas sulphurescens

Elaenia flavogaster

Progne chalybea

Campy lorhymchus zonatus

Thryothorus rufalbus

Troglodytes musculus

Turdus grayi

Cyclarhis gujanensis

Vireo flavoviridis

Hylophtlus decurtatus 
Geothlypis pollocephala

Tangavius aeneus

Cassidix mexicanus

Dives dives

Thraupis virens

Thraup is abbas

Saltator atriceps

Tiaris olivacea

Sporophila torqueola

Volatinia jacarina

In addition to the above, there are six other species which are of similar distribution but which are restricted to the vicinity of watercourses. These six are:

Megaceryle torquata

Chloroceryle amazona

Chloroceryle americana

Sayornis nigricans

Stelgidopteryx ruficollis

Iridoprocne albilinea

By far the most varied segment of the Honduran avifauna inhabits the tropical lowland rain forests of the Caribbean slope. Two hundred and two specles are characteristic of this habitat, either in the forest itself or at least along forest edge and in semi-open situations of forested regions. A few species, which are generally representative of the Humid Lower Tropical Zone elsewhere in their range, exhibit 
a wide tolerance for temperature and inhabit both lowland rain forest and montane rain or cloud forest from sea level to elevations in excess of 5,500 feet. These nine species are:

Micrastur ruficollis

Odontophorus guttatus

Lophostrix cristata

Trogon collaris

Formicarius analis

Rhynchocyclus brevirostris

Microcerculus philomela

Turdus assimilis

Smaragdolanius pulchellus

Another group of rain forest species exhibit altitudinal distribution that includes both lowland rain and low montane rain forest. In Honduras these species are re8 tricted to forest below 5,500 feet, but all occur at least as high as 3,000 feet. The 68 species in this category are:

Tinamus major

Crypturellus soui

Elanotides forficatus

Harpagus bidentatus

Ictinia plumbea

Leucopternis albicollis

Spizaetus ornatus 
Geranospiza caerulescens

Micrastur semitorquatus

Daptrius americanus

Crax rubra

Penelope purpurascens

Ortalis vetula

Columba nigrirostris

Leptotila plumbeiceps

Leptotila cassinii

Geotrygon montana

Pionopsitta haematotis

Pionus senilis

Amazona autumna1 is

Amazona farinosa

Ciccaba virgata

Phaethornis superciliosus

Phaethornis 1onguemareus

Thalurania furcata

Hylocharis eliciae

Amazilia candida

Amazilia tzacat 1

Hellothryx barrot1

Trogon violaceus

Electron carinatum

Ramphastos sulfuratus

Celeus castaneus 
Veniliornis fumigatus

Dendrocincla anabatina

Dendrocincla homochroa

Sittasomus griseicapillus

Glyphorhynchus spirurus

Dendrocolaptes certhia

Automolus ochrolaemus

Xenops minutus

Sclerurus guatemalens is

Dys ithamnus mentalis

Myrmotherula schisticolor

Cercomacra tyrannina

Pipra mentalis

Cotinga amabilis

Attila spadiceus

Legatus leucophaius

Mylodynastes maculatus

Myiobius barbatus

Platyrinchus mystaceus

Todirostrum sylvia

Oncostoma cinereigulare

Myiopagis viridicata

Leptopogon amaurocephalus

Pipromorpha oleaginea

Psilorhinus morto

Thryothorus maculipectus 
Henicorhina leucosticta

Hylophilus ochraceiceps

Chlorophanes spliza

Basileuterus culicivorus

Amblycercus holosericeus

Tanagra lauta

Habia rubica

Habia gutturalis

Saltator maximus

Along the north coast of Honduras east of Trujillo, the lowland rain forest becomes greatly constricted by the mountains just inland. The resultant narrowing of the rain forest is at least a partial barrier to continuous northward distribution of some species that are found in olancho. No less than 23 species are known to range north into olancho but have not been recorded north of this region; in addition, there are more than 20 others that are known from northern Nicaragua and are most likely to occur in Olancho as well. The 23 species reaching a northern limit of distribution in olancho are:

Leucopternis semiplumbea

Ortalis garrula

Ara ambigua

Microchera albocoronata

Monasa moxphoeus

Ramphastos swainsonil 
Dendrocincla fuliginosa

Deconychura long lcauda

Cymbilaimus 1ineatus

Dysithamnus striaticeps

Myrmotherula fulviventris

Mymotherula axillaris

Phaenostictus mcleannant

Grallaria fulviventris

Coraptpo leucorrhoa

Procnias tricarunculata

Colonia colonus

Myiozetetes granadens is

Cyphorhinus phaeocephalus

Geothlypis semiflava

Caclcus uropyglalis

Tanagra lutelcapilla

Lanio leucothorax

Farther to the west along the north coast, the rain forest is broken by the Sula Valley, which apparently acts as another barrier to distribution of forest inhabitants. The 13 species reaching a known northern limit of distribution fust east of the sula valley are:

Odontophorus erythrops

Rhymchortyx cinctus

Klais guimeti

Trogon rufus 
Electron platyrhynchum

Selenidera spectabilis

Piculus simplex

Synallaxis brachyura

Carpodectes nitidus

Platyrinchus coronatus

Phaeothlypis fulvicauda

Tachyphonus 1uctuosus

Arremonops conirostris

All the species just listed are residents of the forest itself except Synallaxis brachyura and Arremonops conirostris, which usually frequent brushy areas outside the forest. In addition to the 13 listed above, there are four species that reach a northern limit of distribution in northwestern Honduras or eastern Guatemala not more than 50 miles west of this valley. These four species are:

Morphnus guianens is

Gymnopithys leucaspis

Tangara layinia

Amaurospiza concolor

A few rain forest inhabitants exhibit distributions worthy of special note at this point. The single Honduran endemic, Amazilia luciae, has been taken from the region west of Lake Yojoa to Olancho and seems to be unaffected by any of the partial barriers in this habitat; furthemore, there seems to be nothing to preclude its occurrence in 
suitable habitat in either Guatemala or Nicaragua. Campylopterus curvipennis, a relict species occurring from Mexico to British Honduras, has an isolated population in the forests of 0lancho. Lanio aurantius reaches its southern 1imit of distribution in the La Celba region but perhaps should not be considered in the analys is since it and its replacement from Olancho southward, L. Leucothorax, may prove to be conspecific. Uropsila leucogastra, another relict of the forests from Mexico to British Honduras, has an isolated population in the rain forest of the Aguan Valley. Melanoptila glabrirostris, representing a monotypic genus virtually restricted to the Yucatan-British Honduras region, barely reaches Honduras in the Omoa region. Synallaxis erythrothorax ranges south to the Tela region, where it occurs sympatrically with its replacement from that point southward, $\underline{S}$. brachyura. Arremonops chloronotus is found south to central Honduras, ranging east to the Sula Valley with isolated populations in the Aguain and Agalta valleys .

The remainder of the species inhabiting the humid Caribbean lowlands of Honduras are restricted to that region in the republic but are widespread in over-all distribution, occurring throughout muck of the tropics both north and south of Honduras. A few of these species are primarily residents of open or scrubby situations rather than the forest itself. These six species are: 
Columba cayennensis

Aratinga astec

Scaphidura oryzivora

Ramphocelus passerinit

Eucometis penicillata

Oryzoborus funereus

The following 66 species are lowland rain forest species, widespread in distribution but restricted in Honduras to elevations on the Caribbean slope below 3,000 feet:

Crypturellus boucardi

Agamia agami

Leptodon cayanens is

Chondrohierax uncinatus

Accipiter bicolor

Harpla harpyia

Spizastur melanoleucus

Spizaetus tyrannus

Falco delrolencus

Eurypyga helias

Columba spectosa

Claravis pretiosa

Pulsatrix perspicillata

Glaucidium minutissimum

Ciccaba nigrolineata

Nyctibius grandis

Panypt 1la cayennens is 
Threnetes ruckeri

Phaeochroa cuvierii

Flortsuga mellivora

Colibri delphinae

Paphosia helenae

Heliomaster longirostris

Trogon massena

Chloroceryle aenea

Hylomanes momotula

Galbula ruficauda

Notharchus macrorhynchos

Malacoptila panamens is

Picumnus olivaceus

Centurus pucherani

Xiphorhynchus guttatus

Taraba major

Thamnophilus punctatus

Thamnistes anabatinus

Microrhopias guixens is

Gymnocichla nudiceps

Piprites griseiceps

Manacus cande1

Schiffornis turdinus

Lantocera rufescens

Rhytipterna holerythra

Lipaugus unirufus 
Pachyramphus cinnamomeus

Pachyramphus polychopterus

Tityra inquisitor

Terenotriccus erythrurus

Onychorhynchus mexicanus

Tyranniscus vilissimus

Ornithion semiflavm

Polioptila plumbea

Ramphocaenus melanurus

Cyanerpes cyaneus

Cyanerpes lucidus

Coereba flaveola

Zarhynchus wagleri

Gymnostinops montezuma

Icterus prosthemelas

Icterus mesomelas

Tanagra gouldi

Tangara Larvata

Phlogothraupis sanguinolenta

Caryothraustes poliogaster

Cyanocompsa cyanoides

Sporophila aurita

Arremon aurantilrostris

As has been pointed out previously by Griscom (1932b: 40-54), the affinities of the avifaunal element of the tropical lowland rain forest are overwhelmingly Neotropical, 
the degree of geographic variation and the relative decrease in numbers of species in a south-north direction indicating a recent arrival of these species in northern Central America. Of the 260 spectes that occur in the humid tropical lowlands of Honduras, 242 (93 per cent) range as far south as Panama and 220 ( 84 per cent) extend into South America; these percentages are on the conservative side since at least seven of the 40 species not reaching South America are sometimes regarded as conspecific with closely related South American forms. In most cases, there is little or no geographic variation in the rain forest species from Olancho south to southern Costa Rica or Panama.

Several of the 40 species not reaching South America, 8 one of which were discussed on pages 890 and 891 , have restricted ranges in northern Central America and are apparently relicts of a relatively ancient tropical avifauna probably of pre-glacial origin. A few others, such as Odontophorus guttatus and Procnias tricarunculata, may be species of Subtropical (cloud forest) origin that have only recently occupied rain forest habltat from higher elevations. Thus we can summarize the humid lowland rain forest avifauna of Honduras as consisting primarily of Neotropical forms of relatively recent arrival from the south with an addition of a few Subtropical spectes (also of recent arrival, at least in the habitat itself) and with an ancient element of a few pre-glacial tropical forms. 
In the interior highlands of Honduras occur four species of wide-ranging swifts (Cypseloides rutilus, C. niger, Aeronautes saxatalis, and Panyptila sanctihieronymi). Since they are primarily cliff nesters, it is best not to consider them in the analysis of any of the upland habitats.

A few species are restricted to the interior highlands but exhibit a wide tolerance for humidity, occurring in about equal numbers in both cloud forest and pine-oak associations. These 10 species are:

Dendrortyx leucophrys

Aratinga holochlora

Glaucidium gnoma

Caprimulgus vociferus

Dendrocopos villosus

Xiphocolaptes promeropirhynchus

Elaenia Erantzii

Cissilopha melanocyanea

Parula pitiayum

Atlapetes gutturalis

A rather distinct element of the Subtropical (cloud forest) avifauna inhabits forest edge or scrubby areas rather than the forest itself; some are the dominant species in the guamiles of the cloud forest habitat. These 11 species are:

Cyrtonyz ocellatus Geococcyx yelox 
Doricha enicura

Tilmatura duponti1

Atthis ellioti

Melanotis hypoleucus

Diglossa baritula

Icterus wagleri

Guiraca caerulea

Melozone blarcuatum

Zonotrlchia capens is

I consider 47 species to be confined to cloud forest and montane rain forest in Honduras, at least in the breeding season. None is resident below 3,000 feet elevation although several species in this category may wander in the nonbreeding season into rain forest or pine-oak associations. These 47 spectes are:

Penelopina nigra

Dactylortyx thoracicus

Clarayis mondetoura

Geotrygon albifacies

Bolborhynchus 1ineola

Qtus guatemalae

Strix fulvescens

Campylopterus hemileucurus

Colibri thalassinus

Abeillia abelile1

Eupherusa eximia 
Lampornis amethystinus

Lampornis viridipallens

Lampornis sybillae

Lamprolaima rham1

Pharomachrus mocinno

Aspatha gularis

Aulacorhynchus prasinus

Dendrocolaptes picumnus

Xiphorhynchus erythropygius

Lepidocolaptes affinis

Anabacerthia variegaticeps

Automolus rubiginosus

Sclerurus mexicanus

Grallaria guatimalens is

Empidonax flavescens

Cyanolyca cucullata

Cyanolyca punilo

Aphelocoma unicolor

Cinclus mexicanus (along streams)

Troglodytes rufociliatus

Hentcorhina leucophrys

Turdus plebejus

Turdus infuscatus

Myadestes unicolor

Catharus dryas

Catharus mexicanus 
Catharus frantzil

Vireo leucophrys

Myioborus miniatus

Basileuterus belli

Chlorophonia occipitalis

Tanagra elegantissima

Piranga leucoptera

Piranga bidentata

Chlorospingus ophthalmicus

Atlapetes brunnelnucha

With respect to relationship and origin, the species of the cloud forests are entirely different from those of the lowland rain forests. There have been 77 species recorded from cloud forest areas in Honduras (including nine that occur also in ratn forest, as previous ly mentioned). of the 68 species that are closely associated with cloud forest (including the 11 that occupy niches outside the forest itself), 16 (Penelopina nigra, Cyrtonyx ocellatus, Geococcyx velox, Strix fulvescens, Abelilia abeillei, Doricha enicura, Atthis ellioti, Lampornis viridipallens, L. sybillae, Aspatha gularis, Bmpidonax flavescens, Cissilopha melanocyanea, Cyanolyca pumilo, Troglodytes rufociliatus, Melanotis hypoleucus, and Melozone biarcuatum) are endemic to the highlands of northern Middle America from southern Mexico to northern Nicaragua. This high degree of endemism indicates a relatively ancient origin of this portion of the 
avifauna, a point further emphasized by the fact that three of these species (Penelopina nigra, Abeillia abeillei, and Aspatha gularis) also constitute monotypic genera; in addition, the genus Doricha is represented elsewhere only by a relict species in Yucatán.

More than half the species of the cloud forest belong to genera that are primarily Neotropical in their distribution; the remainder have Boreal affinities but are generally very distinct at the specific level. Of the cloud forest species that are currently widespread in South America as well as in Central America, many are primarily inhabitants of the Tropical Zone (rain forest) in the more southerly populations, as both Griscom (1932b: 60) and Chapman (1926: 88-89) have previously pointed out. It is interesting to note that there are two very distinct and wide breaks in the distribution of cloud forests at the present time between Honduras and the Andes of South America; these are across the lowlands of southeastern Nicaragua and across a relatively arid region of northwestern Colombia. Thus there has not been a recent connection permitting the northward expansion of spectes in this habitat, in direct contrast to what has occurred in the lowland rain forest.

The distribution of cloud forest in Honduras may be seen by referring to Figure 3. At the present time, this habitat is highly dissected into disjunct patches, yet the 
avifauna, at the species level and to a reasonably high degree at the subspecific level, is relatively uniform throughout all these isolated forests. Since a number of species are restricted to the forest interior itself yet occur undifferentiated in all segments of the habitat, one is led to the conclusion that the forests were more or less continuous until very recent times. Griscom has previously mentloned that during the late Pleistocene, temperatures were considerably cooler in this part of Central America (perhaps as much as $7^{\circ} \mathrm{C}$. ) and undoubtedly cloud forest was considerably more extensive, probably reaching sea level in places; the avifauna certainly supports this contention. Such geographic variation as does occur in cloud forest species within Honduras is most interesting. One would expect the Honduras Depression, which is not only the lowest point along the Continental Divide in northern Central America but also of an origin prior to the Pleistocene, to form the only major barrier to cloud forest distribution and, therefore, to be a major break ractally in cloud forest species. While it is true that two species (Cyanolyca cucullata and Melozone biarcuatum) appear to terminate their ranges just west of the Depression and that the Depression Is the dividing line between morphologically different populations of Abeillia abeillei and between the two species of the Lampornis viridipaliens complex (L. viridipallens and $L$. sybillae), there seems to be another significant break 
between cloud forests in the Department of Ocotepeque and adjacent ones in Lempira and Intibucá. Four species (Lampornis amethystinus, Lamprolaima rhami, Myadestes unicolor, and Basileuterus beli1) vary geographically between these localities. Why these differences should occur here is a mystery since there is no more of a geographical break than between most other adjacent patches of cloud forest and, Indeed, a good deal less of a one than in most reglons. In addition, seven species (Otus trichopsis, Atthis ellioti, Cyanolyca cucullata, Aphelocoma unicolor, Chlorospingus ophthalmicus, Atlapetes gutturalis, and A. brunneinucha) are represented in Guatemala and in Honduras by different described subspecies, but I feel that the apparent dis junction of these races may be due in large part to inadequate work in the eastern Guatemalan highlands along the Honduran border rather than to any geographic barrier there.

The element of the cloud forest avifauna that is northern in its origin, although not as rich as the Neotropical one, appears to have been derlved from two sources. The endemic element (such species as Strix fulvescens, Ciss11opha melanocyanea, and (yanolyca pumilo) is certainly relatively ancient and probably evolved at the spectes level in this region; perhaps the ancestors of these species became isolated at the time of the last water barrier across the Isthmus of Tehuantepec in southern Mexico. The other northern element (such species as Glaucldium gnoma, 
Caprimulgus vociferus, and Dendrocopos villosus) is more recent in its arrival in the region and consists mostly of widespread species that occupy other habitats elsewhere in the range.

In general, therefore, the Honduran cloud forest avifauna comprises in large part species of Neotropical origin, exhibiting relationships with South American groups but with a high degree of endemicity at both the specific and the generic levels. In cases where the species occurs in South America as well as in Honduras, it often inhabits areas of rain forest rather than cloud forest in the former region, or else is widespread in both habitats everywhere. The derivation of the northern element of the cloud forest avifauna was discussed in the preceding paragraph.

The avifauna of the deciduous (monsoon) forests of Honduras is not as distinctive as that of the two preceding major habitats; that is to say, there are very few species that are characteristic of deciduous forest alone. The major portion of this avifauna consists of birds of two categories: species generally of widespread occurrence in the lowlands of both coasts and of wide tolerance for humidity (1..e., forest inhabitants in the list on pages 882-884), and species derived from the avifauna of the arid Pacific lowlands (1…., those species marked with an asterisk in the 1ist on pages 904-906). In addition, there are five species that I consider to be characteristic of deciduous 
forest, at least in Honduras :

Dromococcyx phasianellus

Otus choliba

Amazilia cyanura

Chiroxiphia linearts

Basileuterus rufifrons

Two other species (Euthlypis 1achrymosa and Cyanocompsa pareliina) are frequent inhabitants of monsoon forest but occur also at higher elevations in pine-oak associations or cloud forest edge.

There are two distinct elements of the arid lowland avifauna (birds occupying arid scrub and thorn forest habitats): a rather diverse but less dominant group of species of widespread distribution throughout the lowlands in either humid or arid situations (1..e.., those listed on pages 882-884); and another group, the dominant one, that is characteristic primarily of arid lowland habitats, some species of which occur also in deciduous forest (the latter species marked with an asterlsk in the following 1ist). The 39 species of the dominant group are:

*Crypturellus cinnamomeus

Polyborus plancus

Colinus cristatus

Burhinus bistriatus

Columba flavirostria

Zenaida asiatica 
Scardafella inca

Columbigallina passerina

*Leptotila verreauxi

Aratinga strenua

Aratinga canicularis

Brotogeris jugularis

* Amazona albifrons

Amazona ochrocephala

Morococcyx erythropygus

Chordeiles acutipennis

Amazilia rutila

*Heliomaster constant 11

* Trogon melanocephalus

* Trogon elegans

*Centurus aurifrons

*Centurus hoffmannif

*Platypsarts aglaiae

Myiarchus nutting1

*Mylarchus tyrannulus

Camptostoma imberbe

*Calocitta formosa

Campylorhynchus rufinucha

*Thryothorus modestus

Thryothorus pleurostictus

Mimus gilvus

Pollopt1la albiloris 
Icterus pectoralis

* Icterus gularis

Icterus pustulatus

Saltator coerulescens

Sporophila minuta

Aimophila ruficauda

In the above 1 ist, seven species (Aratinga strenua, Brotogeris jugularis, Centurus hoffmannii, Myiarchus nutting1, Thryothorus pleurostictus, Sporophila minuta, and Aimophila ruficauda) are confined to this habitat and to the Pacific slope. The remainder of the species range in arid scrub to elevations of 3,000 feet or more and occur in suitable situations on the Caribbean slope. Six of the species (Columbigallina passerina, Amazona ochrocephala, Glaucidium brasilianum, Amazilia rutila, Camptostoma imberbe, and Thryothorus modestus) also reappear in the Mosquitia, occurring in pine or in the scrubby areas along the streams of the region.

The group of spectes typical of the arid lowland habitats seems to be of relatively ancient origin. Most species exhibit a relict distribution, $1 . e$. , they occur in scattered areas from the southwestern United States or western Mexico south Into South America, despite a number of significant breaks in the arid habitat. Almost half the species reappear in South America despite an intervening expanse of humid habitats in southern Central America. 
About one-third of the species range northward to the southwestern United States. The genera involved are usually of widespread distribution, occupying a variety of habitats elsewhere. There are representatives of Boreal as well as Neotropical genera in the arid lowland habitats.

In contrast to the situation that exists with relation to the Motagua Valley in Guatemala, the arid interior valleys on the Caribbean slope of Honduras have relatively low connections with the arid Pacific lowlands $(<3,000$ feet). Therefore, a much lower degree of endemism is exhibited by the birds of these valleys. Only three of the arid lowland species (Colinus cristatus, Amazona ochrocephala, and Campylorhynchus rufinucha) exhibit distinct races from one slope to the other, as compared to eight Iisted by Griscom (1932b: 50) for the Motagua Valley of Guatemala. Primarily on the basis of the herpetofauna, Carr (1950: 578-579) considered the arid interior valleys of Guatemala, Honduras, and Nicaragua to contain a characteristic and homogeneous (although discontinuous) fauna, and that of the Pacific lowlands to be derived in part from this interior fauna. The birds do not support Carr's conclusions but rather clearly show that the interior valley inhabitants are derived from the widespread arid Pacific species. An additional consideration in support of this contention is that all species of the arid interior valleys occur also in the Pacific lowlands, while at least seven are 
restricted to the latter. Furthermore, there is a much greater degree of difference between the avifaunas of the Motagua Valley and the Comayagua Valley, at both the specific and the subspecific levels, than there is between those of the Comayagua Valley and the Pacific lowlands of Honduras. Apparently, the arid tnterior avifauna of Honduras has been derived primarily from that of the Pacific lowlands and the relatively low gaps in the Continental Divide (especially the Honduras Depression) tend to prevent isolation of these faunas.

The arid Aguán, Agalta, and Olancho valleys, although isolated to a much greater degree than the otoro, Quimistán, Sula, and Comayagua valleys, do not support any endemic forms in the arid scrub-thorn forest habitat. This situation is due in large part to the fact that all inhabitants of these valleys in this habitat are species that have considerable altitudinal range (often to 6,000 feet) and therefore are not subject to isolation.

In the interior highlands of Honduras, there are a few species that are typical of open, dry regions, either steppe country or remnants of savannas. Corvus corax and SalDinctes obsoletus are perhaps the only two species that could be considered as characteristic of steppe country. Speotyto cunicularia is an inhabitant of open regions of short grass. The colony of Cistothorus platensis in an area of long grass near Siguatepeque is the only one known 
from the intertor of Honduras. Stumella magna is widespread throughout the ocotal regions, occurring in pine stands where there is only a grass understory.

In addition to the 10 species 11 sted on page 896 , which are characteristic of either cloud forest or pine-oak, there are 39 species that I regard as typical of pine-oak associations in Honduras. Of this group, 17 are primarlly pine inhabitants and may therefore be found also in regions of pure ocotal; these species are indicated in the following 1ist by an asterisk (*). The 39 species are:

Acciplter chionogaster

* Buteo jamaicensis

Buteo albonotatus

Ealco sparverius

Columba fasclata

*otus trichopsis

Bubo virgtnianus

*Chordeiles minor

Caprimulgus ridgwayi

Hylocharis leucotis

*Amazilia cyanocephala

Amazilia beryl1ina

Eugenes fulgens

Trogon mexicanus

Colaptes auratus

Melanerpes formicivorus 
*Dendrocopos scalaris

Pachyramphus major

Contopus sordidulus

Contopus pertinax

Empidonax fulvifrons

Mitrephanes phaeocercus

*Cyanocitta stelleri

*Certhia familiaris

Turdus rufitorgues

Myadestes obscurus

Catharus aurantiirostris

*Sialia sialis

*Vireo solitarius

Vermivora superciliosa

*Peucedramus taeniatus

*Dendroica graciae

*Myioborus pictus

*Piranga flava

*Spinus notatus

Spinus psaltria

*Loxia curvirostra

*Aimophila rufescens

*Spizella passerina

The avifaunal element inhabiting pine-oak associations (and especially the segment that is characteristic of highland pine alone) is, for the most part, Boreal in origin. 
of the 17 species occurring in ocotal, only three (Amazilia cyanocephala, Spinus notatus, and Aimophila rufescens) fail to extend northward into the pine regions of the southwestern United States; two of these species (A. cyanocephala and A. rufescens) occupy habitats other than pine in northern Mexico. Most of the pine-inhabiting species seem to be of relatively recent origin; that is to say, the Central American populations generally differ from those of central Mexico in small degree only, and the species is usually variable as a cline over the Middle American region. Only two species of the 39 listed above (Accipiter chionogaster and Turdus rufitorques) are endemic to the highland region from southern Mexico to northern Nicaragua, in contrast to the high degree of endemism in the cloud forest avifauna of the same region. The few species (such as Trogon mexicanus and Pachyramphus major) that are of Neotropical origin were most likely derived from forms inhabiting the cloud forest habitat.

There can be little doubt that the lowland pine savanna of the Mosquitia is the oddest of the Honduran habitats and perhaps the most interesting from an avifaunal 8 tandpoint. Much work has been done recently concerning the origins of these pine savannas in regions where one would expect rain forest, as I have previously mentioned (pages 54-56). I do not intend to delve further into the arguments concerning these origins except to present the evidence as indicated by 
the avifauna. I intend to show only that the birds exhibit a high degree of endemism when compared with the avifauna of the highland pine regions, thus indicating a relatively long isolation from the latter. In addition, the Mosquitia shows close affinity with the "pine ridge" region of British Honduras, the avifauna of which has been discussed at length by Russell (1964: 188-190); this close affinity indicates a more recent connection with the latter region despite a present separation of more than 300 miles.

In the vega forests and scrubby areas along the streams in the Mosquitia is found an avifauna derived mainly from rain forest inhabitants but with a few arid scrub species (six listed on page 906) also occurring; of these, only Amazona ochrocephala is really associated with pine and this species will be the only one of this group here considered. The remainder of the Mosquitia birds may be divided into those that are associated with the pines and those that are grassland inhabitants. In the category of pine inhabitants are the following 13 species:

Falco sparvertus

Amazilia cyanocephala

Ptculus rubiginosus

Melanerpes formicivorus

Pyrocephalus rubinus

Sialia sialis

Dendroica graciae 
Icterus chrysater

Piranga flava

Spinus notatus

Loxia curvirostra

Almophila rufescens

Spizella passerina

The nine species that are typical of the grassland niches of the pine savanna are:

Buteo albicaudatus

Colinus nigrogularis

Columbigallina passerina

Muscivora tyrannus

Cistothorus platensis

Sturnella magna

Sicalis Iuteola

Ammodramus savannarum

Aimophila petenica

If we examine the pine inhabitants, we find that only

two fall to occur also in the highland pine. Amazona ochrocephala is also an inhabitant of arld lowland regions in Honduras; the pine savanna populations, present in the Mosquitia and in the pine areas on Roatán and Guanaja is lands, constitute an endemic race distinct from the Pacific birds. Pyrocephalus rubinus reappears in the pinelands of British Honduras but not in between nor in the interior highlands of Honduras; the Mosquitia birds are an 
endemic (but only slightly differentiated) race, closely related to that in British Honduras.

of the remaining 12 pineland spectes, five (piculus rubiginosus, Icterus chrysater, Spinus notatus, Loxia curvirostra, and Spizella passerina) do not exh1bit different races in the Mosquitia and in the interior highland pine region. It appears that Loxia curvirostra and probably also Spinus notatus are recent invaders of the lowland pine, having arrived as wanderers across regions of rain forest. Although only a single race of piculus rubiginosus is currently recognized in Honduras, the species exhibits considerable geographic variation in parts of its Honduran range; the two available Mosquitia specimens are different from all others and the Mosquitia population may indeed represent a distinct subspecies. Spizella passerina also shows slight geographic variation between populations in the Mosquitia and those in the interior but of such a slight degree that subspecific separation is not warranted. Icterus chrysater is widespread in Honduras and does not vary geographically, as far as I can ascertain.

The remalning seven species all show distinct racial variation between the Mosquitia and the highland pine. In the case of the forms treated under the name Amazilia cyanocephala, the Mosquitia bird differs to such a degree that it could be considered a full species, depending on one's taxonimic concept. Only one of the seven spectes (Falco 
sparverius) is not represented in the pine savanna of British Honduras. Sialia stalis, Piranga flava, and Aimophila rufescens all have endemic races in the Mosquitia, but all these races are most similar to the British Honduran populations and appear to be more closely related to them than to the highland ones. Dendrolca graciae and Melanerpes formicivorus are excellent examples of the situation that exists here, for both species show no variation between British Honduran and Mosquitis populations though they have a distinct race in the intertor highlands. Only the single species Amazilia cyanocephala does not fit this picture: the British Honduran and interior Honduran populations are the same while a distinct, green-crowned form is endemic to the Mosquitia.

The savanna inhabitants also support the idea of a recent connection between the lowland pine savannas of British Honduras and the Mosquitia. Of the nine residents of the grasslands, four (Buteo albicaudatus, Columbigallina passertna, Muscivora tyrannus, and Cistothorus platens is) are widespread, occurring at least locally in the interior as well as in the Mosquitia; none shows any racial variation between the lowland and highland pine areas, Columbigallina passerina being widespread also in the arid lowland regions. Sturnella magna shows exactly the same sort of variation as does Melanerpes formicivorus or Dendroica graciae, with one subspecies in British Honduras and the 
Mosquitia and a distinct one widespread in the northern Central American interior. Ammodramus savannarum is not known to breed in the interior highlands of Honduras although it very likely does; the Mosquitia populations are the same as those of British Honduras and distinct from the interior race that breeds from southern Mexico south to Costa Rica. Colinus nigrogularis and Aimophila petenica have endemic races in the Mosquitia that are closely similar to populations in British Honduras, both species not occurring in between. Sicalis luteola is not known from British Honduras but reappears in southern Mexico and Guatemala; the Mosquitia population is not distinct racially from the more northern birds.

Thus the avifaunas seem to show a more recent connection between British Honduran and Mosquitia lowland pine regions than between the Mosquitia and the not far distant highland pine area. That the Mosquitia could have been populated with all the species it now possesses via invasions over intervening regions (either water or land) that lack the habitat seems out of the question. Very few species are lacking in either region when one compares the British Honduran and Mosquitia lowland pine areas. Furthermore, several species (such as Colinus nigrogularis and Aimophila petenica) are highly sedentary and almost certainly arrived in the Mosquitia at a time of continuous distribution of the habitat. 
On the other hand, a recent connection with the highland pine is unlikely, since the degree of differentiation in almost every case is greater between low and high regions than between the two disjunct areas of lowland pine in the two countries. One can only conclude that the lowland pine regions were much more widespread whereas the interior pine has probably increased in area or at least not decreased to the extent of the former.

I should like to mention one further point concerning this region. The theory that all or at least most pine regtons in warm and humid climates (and perhaps elsewhere as wel1) were created as a result of man's activities has been gaining popularity of late. If such an origin 18 postulated for the Mosquitia, then it must have occurred very early in man's history. The high degree of endemism exhibited by the avifauna indicates a relatively long presence of the current avifauna in this habitat.

The following 16 species are characteristic of marsh habitats in Honduras:

Tigrisoma lineatum

Heterocnus mexicanus

Ixobrychus exilis

Cathartes burrovianus

Rostrhamus sociabilis

Busarellus nigricoliis

Aramus guarauna 
Aramides cajanea

Latera11us exilis

Laterallus melanophaius

Latera11us ruber

Gallinula chloropus

Porphyrula martinica

Fulica americana

Jacana spinosa

Agelaius phoeniceus

of the species 1isted, two (Tigrisoma lineatum and

Laterallus melanophaius) reach their northern limit in the marshes of extreme eastern Honduras, and one other (Laterallus exilis) ranges north into British Honduras. Laterallus ruber ranges south only as far as Nicaragua.

There are 14 species that breed primarily or exclusively in swamps of almost any kind (including mangroves); all are colonial except those marked with an asterisk (*) in the following 1ist. These 14 spectes are:

Phalacrocorax olivaceus

Anhinga anhinga

*Butorides virescens

Florida caerulea

Casmerodius albus

Egretta thula

Hydranassa tricolor

Nycticorax nycticorax 
Nyctanassa violacea

Cochlearlus cochlearius

Mycteria americana

Eudocimus albus

Ajata ajaja

*Cairina moschata

A few open-water species breed along the edges of lakes and lagoons in Honduras. These five species are:

Podiceps dominicus

Podilymbus podiceps

Dendrocygna bicolor

Dendrocygna autumnalis

Heliornis fulica (presumably)

The mangrove habitat is somewhat difficult at analyse although there is one element of the avifauna that is confined entirely to it. The five species in this latter category are:

Buteogallus subtilis

Aramides axillario

Coccyzus minor

Vireo pallens

Dendroica erithachorides

Buteogallus subtilis is confined to mangroves on the Pacific coast; the others occur on both cossts. Coccyzus minor is not restricted to mangroves elsewhere in its range. A few other species regularly utilize the mangrove habitat 
but are widespread in nonswampy habitats. These four species are:

Buteogallus anthractnus

Chloroceryle aenea

Mylarchus tuberculifer

Habia gutturalis

Additional species occur in mangroves but apparently are not resident therein and will not be considered here.

The only regular breeder on beaches, excluding oceanic forms that are resident in island situations, is Charadrius collaris, which also nests along the larger streams. Breeding colonies of oceanic birds have been reported from the Swan Islands (Sula sula, S. leucogaster, Fregata magnificens) and from the Bay of Fonseca (Pelecanus occidentalis, Sula nebouxi1, s. leucogaster, Fregata magnificens).

There are 30 resident specles of birds in the Bay Islands. Of these, six also breed in the Cayos Cochinos; these six are indicated in the following list by an asterisk (*). The 30 species are:

Eudocimus albus

Cathartes aura

Buteo magnirostris

Buteo nitidus

Buteogallus anthracinus

Falco albigularis

Ortalis vetula 


\author{
Aramides axillaris \\ *Columba leucocephala \\ Columbigallina passerina \\ *Leptotila jamaicens 18 \\ Amazona xantholora \\ Amazona autumnalis \\ Amszona ochrocephala \\ Coccyzus minor \\ Crotophaga ani \\ Tyto alba \\ Nyctiblus griseus
}

*Anthracothorax prevostii

*Chlorostilbon canivetil

Ghloroceryle aenea

Centurus aurifrons

Centurus pygmaeus

Myiarchus tyrannulus

Vireo pallens

*Vireo mag18ter

Dendroica erithachorides

*Cassidix mexicanus

Icterus chrysater

Splzella passerina

A relatively high degree of endemism exists in the avifauna of the Bay Islands. Four species (Buteo magnirostris, Buteggallus anthracinus, Ortalis vetula, and Mylarchus 
tyrannulus) have distinct endemic races that were probably derived from coastal populations of the species on the main1and. The 18land populations of Anthracothorax prevostii and Cassidix mexicanus exhibit some geographic variation in comparison with mainland populations but not enough for satisfactory definition of subspecies. Each of the three main islands has its own endemic race of woodpecker of the genus Centurus, each race being derived from a different source. The subspecies of $\underline{C}$. aurifrons presently confined to Utila Is land is closely related to the santacruzi group on the mainland and was no doubt derived from it. The race of $\mathrm{C}$. aurifrons on Roatán Island, however, belongs to the dubius group found in the Yucatán Peninsula and British Honduras and must have developed from that stock after overwater invasion. The endemic race of $\underline{\underline{c}}$. pygmaeus on Guanaja Is land is most closely similar to the population on Cozumel Is land and was most probably also derived by overwater invasion; the spectes 18 restricted elsewhere to Cozumel and the Yucatán Peninsula, where it occurs sympatrically with $\underline{C}$. aurifrons.

In addition to Centurus pygmaeus, five other species (Columba leucocephala, Leptotila Jamaicensis, Amazona xantholora, Crotophaga ant, and Vireo magister) were derived from the West Indies, Cozumel Island, or the Yucatain Peninsula and do not occur on the Honduran mainland. It 18 interesting to note that three of these (see list on pages 
920-921) occur also only nine miles from the Honduran mainland in the Cayos Cochinos (which has only six resident bird species). Leptotila lamaicens is is extremely peculiar in its distribution, occurring only on Barbareta Island in the Bay Islands and on Little Hog Island in the Cayos Cochinos, two of the smallest islands in the entire region. 
SUMMARY AND CONCLUSIONS

This study has presented separate accounts for each of the 670 species of birds of unquestionable occurrence in Honduras and for 16 additional species of "hypothetical" occurrence. These accounts have incorporated the following information: a 1ist of extant Honduran specimens, with Indication of sex, age, date and locality of collection, and present repository; a summary of published Honduran records of the species; a statement of the status of the bird in the republic, including extreme dates of occurrence of migratory forms; comments on ecological preferences; a discussion of geographic variation and nomenclatural problems; and miscellaneous matter such as new data concerning habits and behavior.

Chapters have been devoted to general physlography, geology, soil, climate, habitats, and migrational movements of Honduran species. The occurrence of avian spectes in the republic has been analysed by habitat. A history of ornithological research in Honduras, a gazeteer of al1 10calities pertinent to this study, and a bibliography of Honduran ornithology have also been presented.

An analysis of the avifauna shows 56 species that exhibit a wide tolerance for either arid or humid conditions 
to be characteristic of the tropical lowlands; another six have a similar distribution throughout the lowlands but are confined to the vicinity of streams. In the tropical lowland rain forests are found 202 species, nine of which have a high tolerance for temperature and range altitudinally into cloud forest about 5,500 feet elevation; of the remaining 193 species, 68 range at least as high as 3,000 feet, occurring in low montane rain forest. At least 23 rain forest species reach their northern limit of distribution in the olancho rain forest and 13 more do not range beyond the Sula Valley. An overwhelming proportion of the residents of the rain forest are Neotropical in their affinities and apparently of relatively recent arrival in Honduras from the south.

In the interior highlands are 10 species that occur with equal regularity in either cloud forest or in more arid pine-oak associations; 11 others are attached to scrubby habitats associated with cloud forest. Forty-seven species are regarded as confined to cloud forest. The cloud forest avifauna exhibits a relatively high degree of endemism and is thought to be more ancient in its arrival in Honduras, many species having probably evolved in this general region. Some are Boreal in their affinities, others are Neotropical, the latter of ten exhibiting relationships with species that Inhabit lowland rain forest in other parts of their ranges. The present distribution of cloud forest in Honduras is in 
small, disjunct patches of habitat, but the virtual lack of endemism in individual patches indicates the relatively recent disjunction of these areas. The breaks that do occur racially in this avifauna are between Ocotepeque and Lempira, and at the Honduras Depression. Why there should be differences between the populations in Ocotepeque and those in Lempira is a mystery, although a break at the Honduras Depression is to be expected.

The species that occur in deciduous forest in Honduras consist of two elements: species that are Neotropical in origin but exhibit a tolerance for aridity, and those that are basically part of the arid Paciflc lowland avifauna. Only five species are regarded as typical of deciduous forest and of no other habitat.

Thirty-nine species are typical of the arid scrub habitat; seven of these are confined entirely to the Pacific lowlands, and the remainder occur both in the Pacific lowlands and in the arid interior valleys on the Caribbean slope. The arid lowland avifauna is apparently relatively ancient, the species exhlbiting mostly relict distributions in disjunct areas of the arid habitat from Mexico to South America. Evidence from subspecific relationships and current distribution of species indicates that the interior arid fauna is derived from that of the Pacific lowlands and has no affinity with the avifauna present in the arid Motagua Valley of Guatemala, which apparently was derived 
independently from the Pacific region through western Guatemala.

In addition to the $10 \mathrm{species}$ mentioned that occur in both cloud forest and pine-oak associations, there are 39 others regarded as typical of pine-oak alone, 19 of which are primarily inhabitants of the pine. Most of these species are Boreal in origin and seem to be of relatively recent arrival in Honduras. The high degree of endemism shown by the cloud forest inhabitants in northern Central America as a whole is not reflected in the avifauna of the pine-oak associations, most of these forms being wideranging and varying only slightly over the northern Middle American region.

The lowland pine savanna of the Mosquitia in eastern Honduras and northeastern Nicaragua is the oddest habitat of a11. The existence of the habitat in a region of high rainfall and high temperature has not been satisfactorily explained, although man, fire, soil conditions, and grazing of large herbivores have all been mentioned as possible contributing factors. In any event, there are 14 spectas of birds that inhabit pines in this region, 12 of which reappear in the interior highland pine. Of the seven of these that show any racial variation within Honduras, four exhibit close relationships with the populations in the pine ridge area of British Honduras while differing from the nearer Honduran highland populations to a much greater 
degree. Of the nine species present in the grassland habttat in the Mosquitia, four are not found elsewhere in Honduras and three of these reappear in British Honduras; one additional grassland species also exhibits relationships with British Honduran populations while differing from the interior Honduran ones. Thus it appears that from the avifaunal standpoint the Mosquitia has had a more recent connection with the British Honduran pine ridge area than with the interior pine of the highlands, the birds exhibiting much closer affinities to the British Honduran populations. The high amount of endemism found in the lowland pine regions taken as a whole (British Honduras in addition to the Mosquitia) indicates a relatively ancient origin of this part of the avifauna.

Sixteen species are typical of marsh habitats, 14 of swamp, five of lake or lagoon edge, and five of mangroves. Most of these species are very widespread in their respective habitats.

Thirty spectes of birds are resident in the Bay Islands. There is a relatively high degree of endemism here, and almost half the species exhibit affinities with the avifauna of the Yucatán Peninsula, British Honduras, Cozumel Is land, or the West Indies, rather than for the adjacent Honduran mainland. The Cayos Cochinos have only six resident birds, but three of these are not found on the Honduran mainland, which is only nine miles away. 
At least 178 of the 670 species occurring in Honduras are known to be migratory. Eight species have populations that breed in Honduras and winter to the south of the republic. However, the vast majority of the migrants are transient through the country or are winter visitants, including at least one that migrates north from South America during the Southern Hemisphere winter. 


\section{GAZETEER OF LOCALITIES}

Maps of Honduras, especially those available to most North American workers, are notoriously poor and inadequate with reference to both place names and names of geographic features. Most maps have been printed on such a small scale that only about one-sixth of the localities included in the present gazeteer may be found thereon. Only in recent years have there been adequate aerial surveys of remote parts of the republic, permitting production of an accurate map of geographic features. Border disputes with neighboring countries have caused added confusion.

I have attempted in this gazeteer to list all localities mentioned in the ornithological literature as well as all localities visited by ornithologists or included by them on specimen labels. Consequently, it should be possible to pinpoint a place name with a minimum of difficulty. I feel that such a gazeteer is essential to a distributional work, not only because many localities are difficult or impossible to locate on available maps, but also because of misuse of locality names by the naturalists themselves. I have endeavored to trace place names of doubtful $s$ tatus and have succeeded in locating all but a very few of the ones mentioned herein. In many instances ornithologists have 
employed names of local haciendas or fincas that have long since disappeared and are now impossible to trace. In Instances where an exact locality could not be determined but the worker could be placed in a general area, available information pertaining to the approximate location is given.

I have used as a standard base map the Mapa General de La Republica de Honduras (1954), prepared by Dr. Jesús Aguilar Paz and accepted by the government of Honduras as its official map; it is on the scale of 1:500,000. Approximately 90 per cent of the place names listed in the gazeteer may be found on this map; spelling of place names follows this map where possible. In addition, the Municlpio series of maps of Honduras, 260 sheets drawn to various scales under the supervision of the Direccion General de Censos y Estadistica Nacional (1950-1952), and the American Geographical Society map no. ND-16 (in the $1: 1,000,000$ series) were used as supplementary maps. Locality names not appearing on any of these maps (less than five per cent of those included in the gazeteer) have been traced by other means and locations are given as precisely as existing knowledge permits.

In the gazeteer the primary entries of the 18 departments of Honduras, plus the Distrito Central, are given in straight capital letters. Names that are errors in spel1ing as well as errors resulting from incorrect use of a place name are italicized. Names are presented in their 
Spanish form except in cases where there are no Spanish names (e.g., Little hog Island), in cases of alternate names in the English form (e.g., Bird Island for Isla Pájaro), and in cases of large or well-known geographic features (e.g., Caribbean Sea, Bay of Honduras, Bay of Fonseca, Lake Yojoa, Bay Islands).

In indexing, the plan employed in the index to the American Geographical Society maps is followed. This procedure consists of Indexing Spanish names beginning with bahia (bay), cabo (cape), cayos (cays), cerro (mountain), cordillera (mountain range), golfo (gulf), isla (island), lago (lake), laguna (lagoon), montaña (forested mountain), monte (mountain), rfo (river), sierra (mountain range), valle (valley), and yolcain (volcano) with reference to the second part of the name to avoid double entries (e.g., "Río Segovia" is listed only under "Segovia, Río). Spanish place names beginning with an article (타, 르, 10s, las) are likewise indexed solely on the basis of the second part of the name (e.g., "La Celba" may be found under "Celba, La"). It should be pointed out that omission of the article, which is frequent, usually results in an incorrect place name (e.g., "Ceiba" is an incorrect use of "La Ceiba"). In addition, the preposition "de" is often omitted in place names and in such cases, in the present gazeteer, the situstion is indicated by enclosing the "de" in parentheses [e.g., San Juan (de) Las Flores]. 
A11 alternate spellings, alternate names, and misspellings or errors appear in parentheses immediately after the accepted name. Only those names that would not appear adjacent to the accepted name in the index are cross-Indexed; the accepted name is preceded in these entries by the word "see." All entries for localities and geographic features that are situated entirely within one department will show the departmental name in square brackets immediately following the accepted name (or 1 ist of alternate names, if present). In this gazeteer the following departments are abbreviated: Atlántida (At1.), Choluteca (Chol.), Comayagua (Com.), El Paraíso (El P.), Francisco Morazán (F.M.), Gracias a Dios (G.D.), Intibucá (Int.), Islas de La Bahia (I.B.), Ocotepeque (Ocot.), and Santa Bárbara (S.B.). The Distrito Central is abbreviated "D.C." A11 other departmental names are spelled out.

A brief phrase describing the location of the place name with reference to a large town or well-known landmark is given. If there is doubt as to the exact location or if there has been some confusion in the orntthological 1iterature concerning 1t, discussion of the problem is also presented here.

If the locality is one that may be pinpointed to a specific spot (such as a town, village, small 18land, or mountain peak) and is not a large physiographic feature (such as a river or mountain range spanning many miles), the 
latitude north and longitude west are given in square brackets. The elevation above sea level (if known) is also given, to the nearest 50 feet; it is enclosed within the same square brackets, Immediately following the longitude. If a locality is one that appears as a numbered point on the map (Figure 4), that number appears last, enclosed in parentheses. Physiographic features are shown in Figure 5.

\section{List of Localities}

Achaga: see Archaga.

Agalta, Sterra (de).--A high, mostly forested mountain range In northeastern Olancho and eastern Colon, bounded on the north by the Rio Sico and on the south by the Rio Guayape and the Río Tinto.

Agalta, Valle de [Olancho].--A semi-arld valley along the Río Sico in the vicinity of San Esteban.

Agua Amarilla [F.M.].--A locality on the slopes of Cerro Uyuca about 3 miles northwest of E1 Zamorano $\left[14^{\circ} 02^{\prime}\right.$, $87^{\circ} 05^{3}$ ].

Agua Azul [Cortés].--A village on the eastern shore of Lake Yojoa about 6 miles southeast of E1 Jaral; references of G. C. Taylor pertain to the village, but all subsequent workers have applied the name to the present location of the "Motel Agua Azu1." situated on the eastern lake shore about $3 \mathrm{miles}$ northwest of the village $\left[14^{\circ} 51^{\prime}, 88^{\circ} 00^{\prime} ; 2,100 \mathrm{ft}.\right]$ (69).

Agua Colorado [Yoro].--A village about 5 miles northwest of Yorito $\left[15^{\circ} 06^{\prime}, 87^{\circ} 15^{\prime}\right]$.

Aguán, Río (Río Román).--A large river draining the Valle del Aguán, with headwaters in south-central Yoro and mouth on the Caribbean Sea at Santa Rosa de Aguán.

Aguán, Valle del.--An arid valley along the Rlo Aguain in Yoro and Colón.

Aloor Rlver: see Rlo Ulúa. 
Figure 4. Map showing Honduran departments and selected collecting localities. Numerical sequence of localities is listed in Table $v$, pages 937-938. 


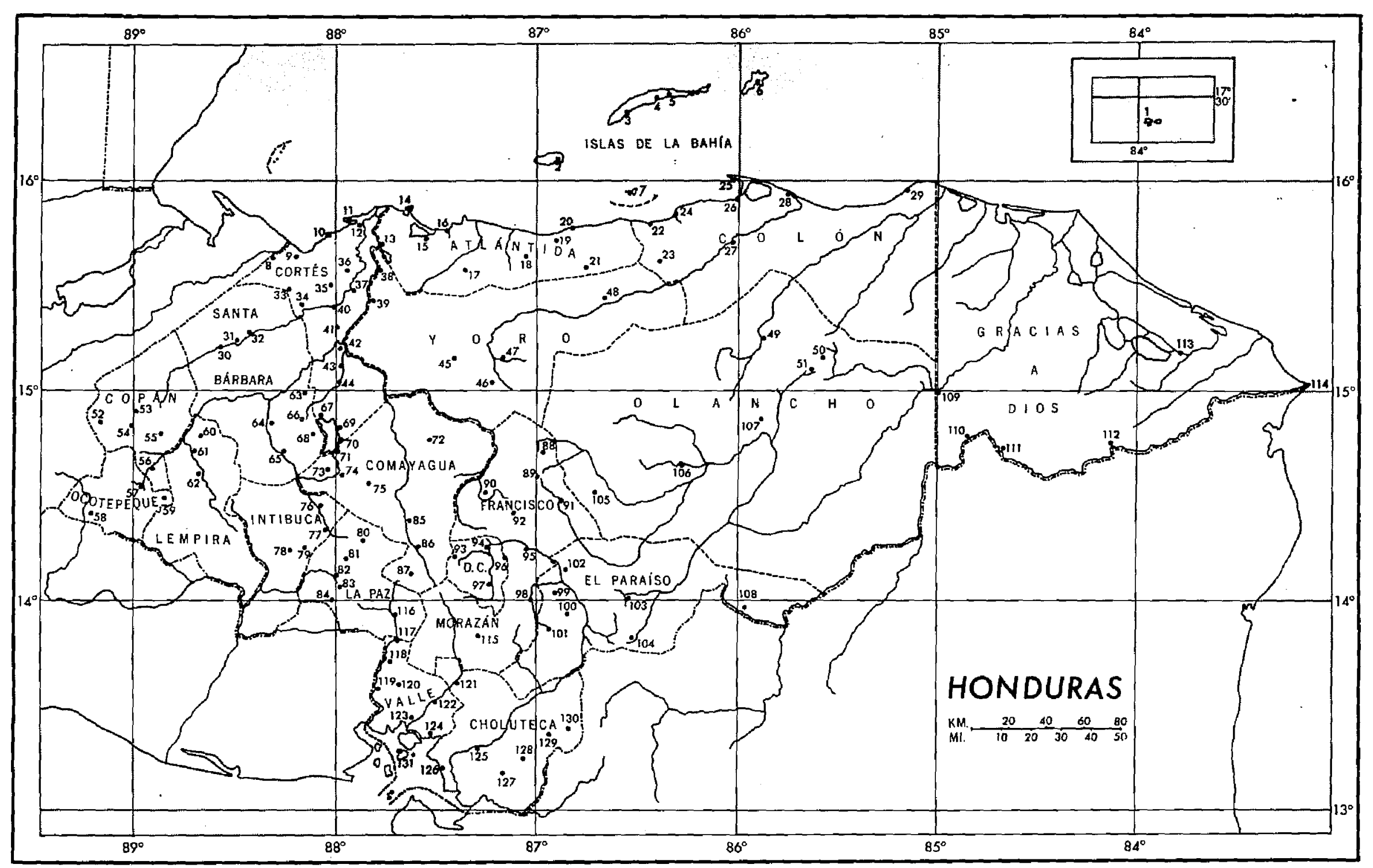

$\stackrel{0}{\sigma}$ 
TABLE V. Key to numbered localities appearing in Figure 4, page 936.

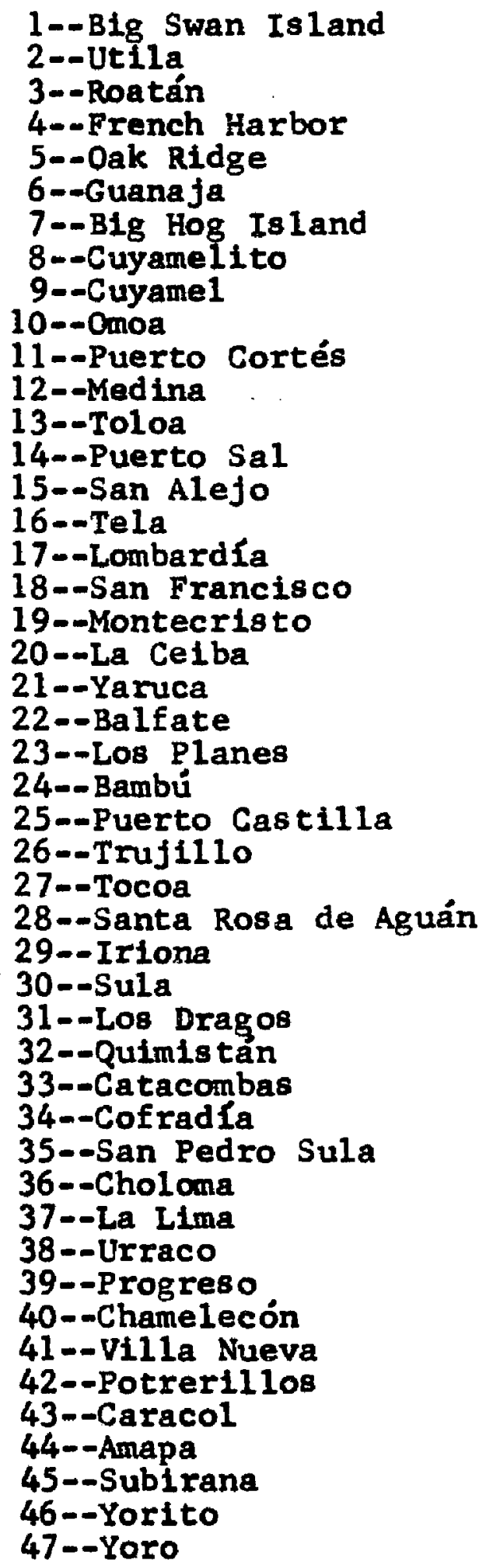

48--Coyoles

49--San Esteban

50--Dulce Nombre de Culmí

51--Cerro E1 Triumpho

52--Copán

53--La Leona

54--La Libertad

55--Santa Rosa de Copán

56--Cucuyagua

57--Lucerna

58--Nueva Ocotepeque

59--Belén Gualcho

60--Lepaera

61--Las Flores

62--Gracias

63--San José Oriente

64--Santa Bárbara

65--Ceguaca

66--Cerro Santa Bárbara

67--El. Jaral

68--E1 Mochito

69--Agua Azu1

70--EI Cacao

$71--P 1 t o$ Solo

72--Valle Bonito

73--San José de Comayagua

74--Taulabé

75--Siguatepeque

76--Jesús de Otoro

77--Mazaguara

78--La Esperanza

79--Gülse

80--Soluteca

81--San José de La Paz

82--Marcala

83--La Florida

84--Sabanetas

85--Comayagua

86--Villa de San Antonio

87--Lamani

88--Orica

89--San Marcos de Guaimaca

90--Cerro Santa Maria

91--Guaimaca

92--Talanga

93--Zambrano

94--Archaga 
TABLE V--Continued

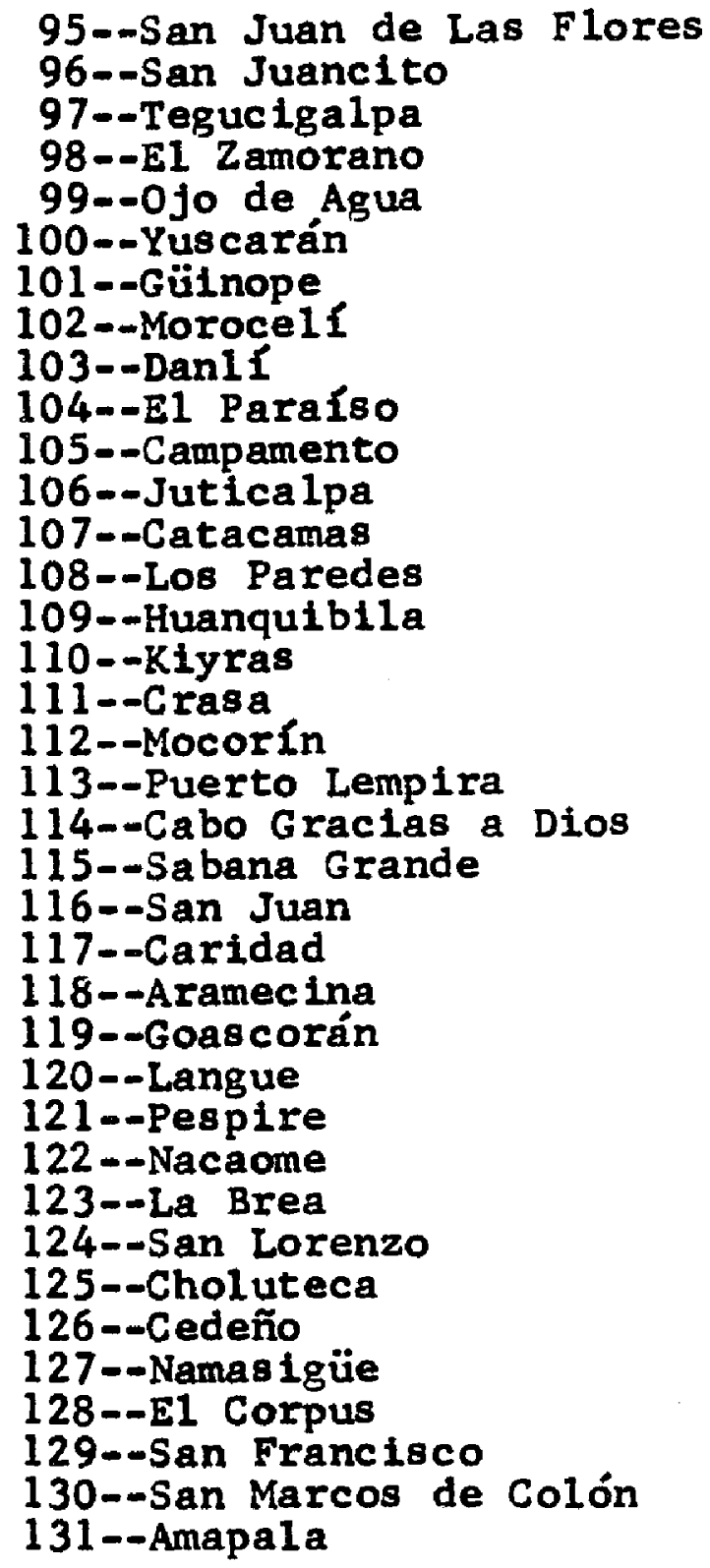


Figure 5. Map of physiographic features of Honduras. Abbreviations on map are as follows: Cord.--Cordillera; I.--Isla; Lag---Laguna; M.--Montaña; R.--Río; S.--Sierra; V.--Valle. 


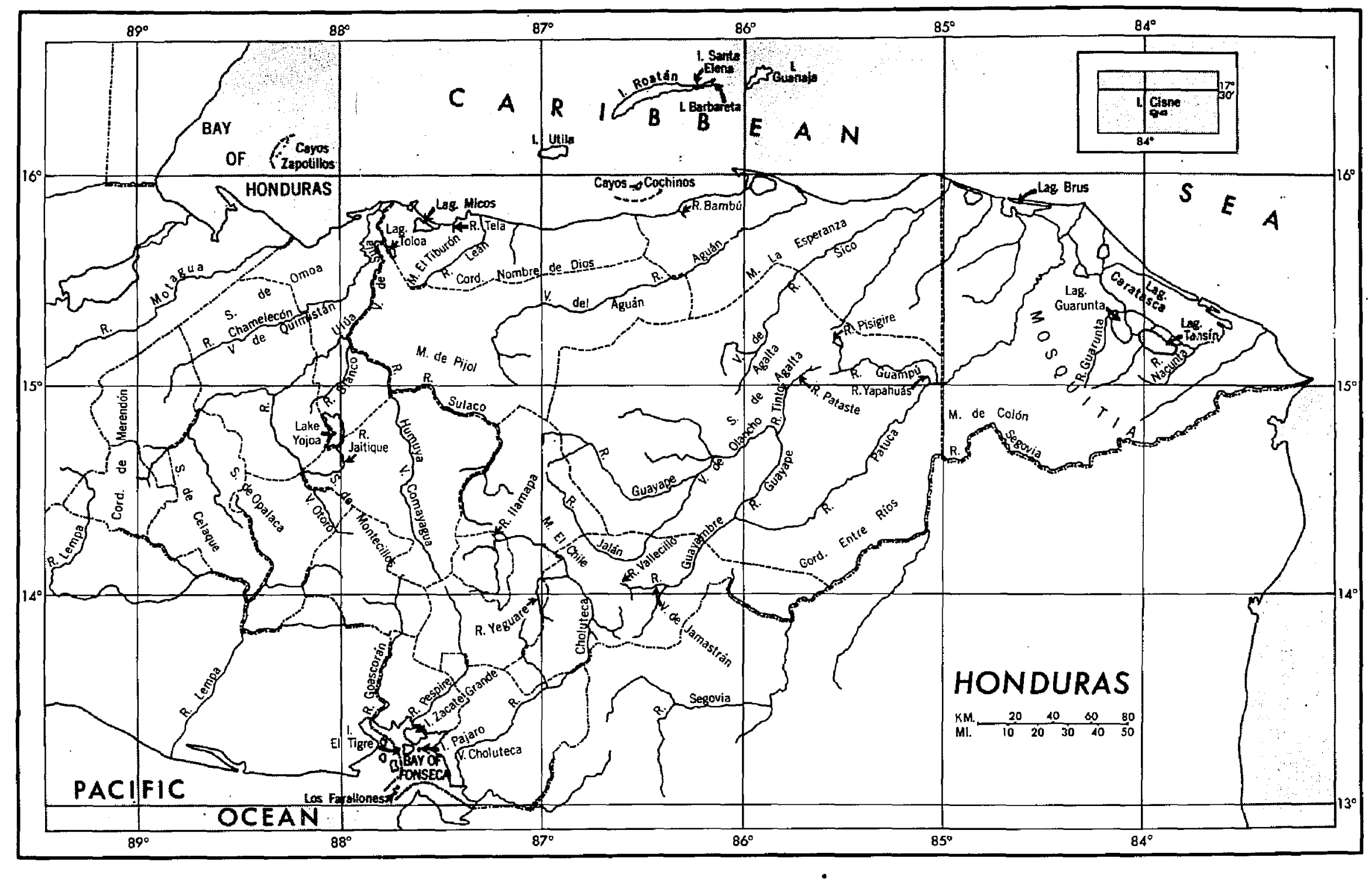


Al to Cantoral (Alto Contoral) [D.C.].--The highest part of Cerro Cantoral; Underwood specimens with this locality designation mostly from cloud forest at $6,000 \mathrm{ft}$.

Alto Guaimaca (A1 to Guaymaca) [F.M.].--Part of Montafia de Guaimaca; Underwood specimens mostly from 3,000 ft.

Alto Nieve [S.B.].--The highest part of Cerro Nieve; Underwood specimens from 4,000 to $5,500 \mathrm{ft}$.

Amapa [Cortés].--An area of lowland, gallery-type rain forest near the Río Blanco, located about 10 miles south of Potrerillos $\left[15^{\circ} 03^{\prime}, 87^{\circ} 59^{\prime} ; 350 \mathrm{ft}.\right]$ (44).

Amapala [Va1le]..-A seaport on the northwest shore of Isla de E1 Tigre, on the Bay of Fonseca $\left[13^{\circ} 17^{\prime}, 87^{\circ} 39^{\prime}\right]$ (131).

Aramecina (Aremecina) [Valle] -- A town on the trail from Langue to Caridad $\left[13^{\circ} 42^{\prime}, 87^{\circ} 41^{\prime} ; 350 \mathrm{ft}.\right]$ (118).

Archaga (Achaga, Archajo) [D.C.].--A village about $15 \mathrm{miles}$ north of Tegucigalpa and just north of the Río Choluteca; also used as a district name for the northern third of the Distrito Central; Underwood specimens mostly from 2,000 to $3,000 \mathrm{ft}$. $\left[14^{\circ} 17^{\prime}, 87^{\circ} 13^{\prime} ; 2,950\right.$ ft.] (94).

Aremecina: see Aramecina.

Arenal [El $\mathrm{P}.] .--A$ lumber camp located about 9 miles eastnortheast of Los Paredes, situated along the south-

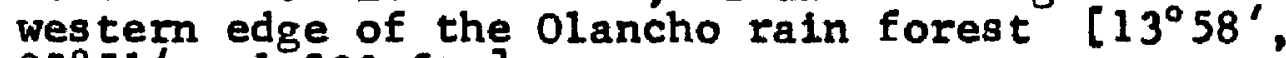
$\left.85^{\circ} 51^{\prime} ; 1,200 \mathrm{ft}.\right]$.

ATLÁNTIDA.--A department on the north coast bounded on the west by Cortés, on the east by Colón, and on the south by Yoro.

Bahia, Islas (de) La: see Bay Islands.

BAHIA, ISLAS DE LA.--A department including the Bay Islands and Cayos Cochinos off the north coast of Honduras.

Baja Mar [Cortés].--A village on the Caribbean coast 5 miles east of Puerto Cortés $\left[15^{\circ} 50^{\prime}, 87^{\circ} 52^{\prime}\right]$.

Balfate [Colón].--A village on the north coast about 8 miles west of the mouth of the R10 Bambi and 27 miles east of La Ceiba $\left[15^{\circ} 48^{\prime}, 86^{\circ} 25^{\prime}\right]$ (22).

Bamboo River: see Río Bambú. 
Bambú [Colón].--A village on the north coast about 8 miles east of Balfate $\left[15^{\circ} 51^{\prime}, 86^{\circ} 17^{\prime}\right]$ (24).

Bambí, Río (Bamboo River) [Colón].--A small stream a few miles in length, with its mouth on the north coast at Bambú.

Barbareta, Is la (Barbarat, Barburat Island, Barburata Is land) [I.B.].-A small is land, $4 \mathrm{miles}$ by 2 miles in size, situated off the eastern tip of Roatán Island, in the Bay Islands.

Bay Islands (Islas de La Bahia) [I.B.].--A group of three main is lands (Utila, Roatán, and Guanaja) and a number of smaller is lands, located in the Caribbean Sea of $f$ the north coast of Honduras.

Belén Gualcho (Belén Guacho) [Ocot.].--A town in the eastern tip of Ocotepeque about 20 miles eas $t$ of Nueva Ocotepeque; Goodwin (1942: 108) erroneous ly gave "about 12 miles north of [Nueva] Ocotepeque" as the location; Underwood specimens from 4,900 to $5,500 \mathrm{ft}$. [14'29', $88^{\circ} 47^{\prime} ; 4,900$ ft.] (59).

Bermejo, Río (Río Permejo) [Cortés].--A locality on the northwestern outskirts of San Pedro Sula $\left[15^{\circ} 28^{\prime}\right.$, $\left.88^{\circ} 02^{\prime} ; 250 \mathrm{ft}.\right]$.

Big Hog Is land [I.B.].--The larger of the two forested islands of the Cayos Cochinos, size about 2 miles in diameter $\left[15^{\circ} 58^{\prime}, 86^{\circ} 31^{\prime}\right]$ (7).

Big Swan Island.--The larger of the two Swan Islands, size about 1 mile by 2 miles $\left[17^{\circ} 25^{\prime}, 83^{\circ} 56^{\prime}\right]$ (1).

Bird Island: see Isla Pájaro.

Blanco, Río (Río Blanca) [Cortés].--A locality on the northern outskirts of San Pedro Sula; the "Rlo Blanco" of Erich Wittkügel $\left[15^{\circ} 28^{\circ}, 88^{\circ} 01^{\prime} ; 250 \mathrm{ft}\right.$. $]$.

Blanco, Rfo.--A river with its headwaters on Cerro Santa Bárbara, emptying into the Río Ulua near Potrerillos; the "Rio Blanco" of Monroe and Feduccla.

Boca de Río Romín [Colón].--Mouth of the Río Aguain, located in the vicinity of Santa Rosa de Aguán.

Bomba, La [Cortés].--A locality on the outskirts of San Pedro Sula, exact location not known. 
Bonaca Island, Bonacca Is land, Bonacco Island, Bonaco Island: see Isla de Guanaja.

Bonas Village [F.M.].--A village in the general vicinity of Cedros, exact location unknown.

Bonito, Valle [Com.] - -A yillage 25 miles northeast of Siguatepeque $\left[14^{\circ} 47^{\prime}, 87^{\circ} 32^{\prime} ; 4,300 \mathrm{ft}.\right]$ (72).

Bobby Cay [I.B.].--A tiny is let, about 50 yards in diameter, situated about $1 / 2$ mile east of Little Hog Is land, in the Cayos Cochinos $\left[15^{\circ} 57^{\prime}, 86^{\circ} 33^{\prime}\right]$.

Boquerón, E1 [Olancho].--A village about 6 miles southwest of Catacamas; Goodwin (1942: 108) erroneous ly placed the locality on the outskirts of Catacamas; Underwood specimens mostly from 2,000 to $2,500 \mathrm{ft}$. on the adjoining wooded slopes $\left[14^{\circ} 50^{\prime}, 86^{\circ} 01^{\prime} ; 1,000 \mathrm{ft}.\right]$.

Brea, La [Valle].--A town on the Bay of Fonseca about 6 miles southwest of Nacaome $\left[13^{\circ} 27^{\prime}, 87^{\circ} 35^{\prime}\right]$ (123).

Bromadero, Bromadero Mts.: see Dromodero Mts.

Brus, Laguna [G.D.].--A large lagoon on the north coast just west of the mouth of the Rlo Patuca.

Cabrí, Río: see Río Cobrí.

Cacao, El [Cortés].--A village on the eastern shore of Lake Yojor about 5 miles north of Pito Solo $\left[14^{\circ} 46^{\prime}\right.$, $\left.87^{\circ} 58^{\prime} ; 2,050 \mathrm{ft}.\right]$ (70).

Caliche, E1 (E1 Caliche Cedros, El Caliche Comayagua, El Caliche La Paz, El Caliche Orica) [F.M.].--A Locality on the western outskirts of the town of orica; Under-

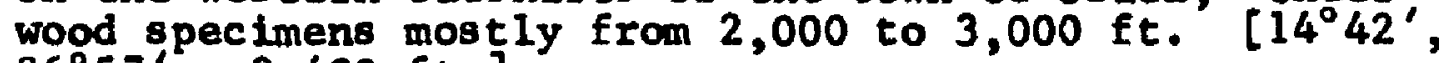
$\left.86^{\circ} 57^{\prime} ; 2,400 \mathrm{ft}.\right]$.

Camalacain, Rfo: see Río Chamelecón.

Caminos, Los: see Dos Caminos.

Camp Tomasa [At1.].--A temporary station of the United Frult Company, located near the Toloa Canal.

Campamento [Olancho].--A town 9 miles east of Guaimaca $\left[14^{\circ} 33^{3}, 86^{\circ} 42^{\prime} ; 2,200 \mathrm{ft}.\right]$ (105).

Campín [Cortés].--An area of flood-fallow lakes about 4 miles southeast of La Lima $\left[15^{\circ} 21^{\prime}, 87^{\circ} 52^{\prime} ; 250 \mathrm{ft}.\right]$. 
Candado, Monte E1 (Monte El Cernado) [Ocot.].--A locality in the vicinity of Nueva Ocotepeque, exact location not known.

Cantarranas: see San Juan de Las Flores.

Cantora1 (Contoral) [D.C.].--A locality about 5 miles northwest of Archaga; Goodwin (1942: 108) erroneous1y gave the location as "12 or 15 miles northeast of Archaga"; Underwood pecimens mostly from 5,000 to 6,000 ft. $\left[14^{\circ} 20^{\prime}, 87^{8} 24^{\prime}\right]$.

Cantora1, Cerro (Cerro Quemado, Montaña Cantora1) [D.C.]..The mountain at Cantoral; Underwood specimens mostly from $5,500 \mathrm{ft}$.

Caracol [Cortés].--A village 3 miles north of Amapa [1506, $\left.87^{\circ} 58^{\prime} ; 300^{\mathrm{ft} .}\right]$ (43).

Caratasca, Laguna [G.D.].--The largest Inland body of water in Honduras, located in the Mosquitia in extreme eastern part of the republic.

Caridad [Valle] - $-A$ town about 5 miles northeast of Aramecina $\left[14^{\circ} 48^{\prime}, 87^{\circ} 38^{\prime} ; 500 \mathrm{ft}\right.$. $]$ (117).

Carmen, Laguna E1 [Cortés] - -A small lake 9 miles northeast of San Pedro Sula $\left[15^{\circ} 30^{\circ}, 87^{\circ} 53^{\prime}\right]$.

Casa Quemada, Casa Quemado: see Rancho Quemado.

Catacamas [Olancho] - -A large town about $23 \mathrm{miles}$ northeast of Juticalpa $\left[14^{\circ} 53^{\prime}, 85^{\circ} 55^{\prime} ; 1,350 \mathrm{ft.}\right]$ (107).

Catacombas (Cotacombas) [Cortés].--A farm about 15 miles nor thwest of Cofradia; Underwood specimens from 3,000 to $4,500 \mathrm{ft}$. $\left[15^{\circ} 29^{\prime}, 88^{\circ} 14^{\prime}\right]$ (33).

Cauquira [G.D.].--A village on the Laguna Caratasca $10 \mathrm{miles}$ northeast of Puerto Lempira $\left[15^{8} 18^{\prime}, 83^{\circ} 37^{\prime}\right]$.

Cedefio [Chol.].--A village on the Bay of Fonseca $13 \mathrm{miles}$ south of $\operatorname{San} L$ Lorenzo $\left[13^{\circ} 13^{\prime}, 87^{\circ} 26^{\prime}\right]$ (126).

Cedros [F.M.].--A town about 10 miles west of San Marcos de Guaimaca $\left[14^{\circ} 35^{\prime}, 87^{\circ} 07^{\prime} ; 3,000 \mathrm{ft}\right.$.

Cedros, Los (Monte LOS Cedros) [Ocot.].--A locality in the general vicinity of Nueva Ocotepeque, exact location not known, but undoubtedly one of the mountains along the El Salvador border. 
Ceguaca [S.B.].--A town about 7 miles south of Santa Bárbara $\left[14^{\circ} 46^{\circ}, 88^{\circ} 13^{\prime} ; 1,950 \mathrm{ft}.\right]$ (65).

Ceiba, La [Atl.]..-A large town on the north coast, capital of Atiántida; references to "Celba" and "La Celba" of all authors except Carr and Dickins on pertain to this locality; all references to "La Ceiba" in the present work, unless specifically indicated otherwise, also pertain to this locality $\left[15^{\circ} 47^{\prime}, 86^{\circ} 50^{\prime}\right]$ (20).

Celba, La (La Cleba) [F.M.].--A locality 2 miles northwest of El Zamorano; used only by Carr and Dickinson $\left[14^{\circ} 01^{\prime}, 87^{\circ} 03^{*}\right]$.

Celaque, Slerra (de).--A high mountain range, containing the highest elevations in Honduras, located in extreme southern Copán, eastern Ocotepeque, and central Lempira.

Cercado, Monte El: see Monte El Candado.

Cernado, Monte E1: see Monte E1 Candado.

Chalmeca [Copán] - -A village 3 miles northeast of Nueva Arcadia $\left[15^{\circ} 04^{\prime}, 88^{\circ} 43^{\prime}\right]$.

Chaloma: see Choloma.

Chamelecón (Chamalicán, Chamelicón, Chimalicón) [Cortés].-A town on the Rio Chamelecón 5 miles south of San Pedro Sula $\left[15^{\circ} 24^{\prime}, 88^{\circ} 01^{\prime} ; 250 \mathrm{ft}.\right]$ (40).

Chamelecón, Río (Río Camalacán, Río Chamalicán, Río Chamelicán, Rio Chamelicon).-A large river with its headwaters In Copán and its mouth on the north coast about 7 miles east of Puerto Cortés; erroneously 118 ted by Sclater (1856a) as "near Truxillo."

Chasnigua (Chasniguas) [Cortés].--A locality on the southeastern outskirts of La Lima $\left[15^{\circ} 23^{\prime}, 87^{\circ} 56^{\prime} ; 250\right.$ ft.].

Chile, Montafia (de) E1 (Cerro de E1 Chile, Chile Mts., Chili Mts., Mt. Chile, Mt. Chili).--A high mountain range (maximum elevation, 7,400 ft.) in east-central Francisco Morazán and northwestern El Paraiso between the Río Choluteca and the Río Jalán: Carr and Dickinson specimens from the vicinity of Moroceli.

Chimalicón: see Chamelecón. 
Choloma (Chaloma, Chiloma, Chilomo) [Cortés] -A town about 10 miles northeast of san Pedro sula [15 $34^{\prime}, 87^{\circ} 56^{\prime}$; $150 \mathrm{ft}] \quad.(36)$.

Cholona, Río (Río Chilomo) [Cortés].--A small stream running through the town of Choloma, emptying into the Rio Chamelecón east of Choloma.

Choluteca [Chol.].--A large town, capital of the Department of Choluteca, on the lower reaches of the Rio Choluteca $\left[13^{\circ} 18^{3}, 87^{\circ} 12^{\prime} ; 150 \mathrm{ft}.\right]$ (125).

CHOLUTECA.--The southernmost department of Honduras, bordering the Bay of Fonseca and Nicaragua.

Choluteca, Río (Rlo Grande).--A large river with headwaters in the Distrito Central and mouth on the Bay of Fonseca near the Nicaraguan border; called "Rlo Grande" where it passes through Tegucigalpa and San Juan de Las Flores; specimens of Carr and Dickinson from the bridge on the Tegucigalpa-Danli road at an elevation of $1,900 \mathrm{ft}$.

Choluteca, Valle (de) [Chol.].--An arid valley about $100 \mathrm{ft}$. in elevation, extending from the vicinity of Choluteca to an area about $15 \mathrm{miles}$ east-northeast of Choluteca.

Chorro, El (Montaña El Chorro) [Ocot.].--A stretch of forest on the eastern edge of Nueva Ocotepegue; Underwood specimens mostly from $4,500 \mathrm{ft}$. $\left[14^{2} 24^{3}, 89^{\circ} 14^{\prime}\right]$.

Cleba, La: see La Ceiba.

Cisne, Islas de El: see Swan Islands.

Cobri, Río (Río Cabrí) [El P.].--A small stream that flows through Morocel1, emptying into the Río Choluteca near Morocelf; Carr and Dickins on specimens from 1,900 ft.

Cochinos, Cayos (Hog Islands) [I.B.].--A group of small is lands 9 miles of the north coast and about $12 \mathrm{miles}$ northwest of Balfate.

Coco, Río: see Río Segovia.

Cofradia (Confradia, Corfridia) [Cortés].--A town 9 miles east of Chamelecón $\left[15^{\circ} 24^{\prime}, 88^{\circ} 09^{\prime} ; 550 \mathrm{ft.}\right]$ (34).

COLÓN.--A small deparement on the central portion of the north coast, formerly embracing all of the Department of Gracias a Dios in addition to present day extent. 
Colón, Montañas (de).--A range of low forested hills in southeas tern Olancho and south-central Gracias a Dios, between the Río Patuca and the Río Segovia.

Comayabuela: see Comayagüela.

Comayagua [Com.].--A large town, the old capital of Honduras, situated in the Valie de Comayagua on the Rio Humuya $\left[14^{\circ} 25^{\prime}, 87^{\circ} 38^{\prime} ; 1,900 \mathrm{ft.}\right]$ (85).

COMAYAGUA.--A centrally located department from Lake Yojoa and the Río Sulaco south to La Paz and Francisco Morazán.

Comayagua Plain: see Valle de Comayagua.

Comayagua, Río: see Río Humuya.

Comayagua, Valle (de) (Comayagua Plain).--A dry valley embracing most of the central portion of Comayagua along the Rio Humuya; elevation ranges from 1,700 to 2,000 ft.

Comayagüiela (Comayabuela) [D.C.].--A large town situated on the south side of the Rlo Choluteca opposite Tegucigalpa; Underwood specimens mostly from surrounding

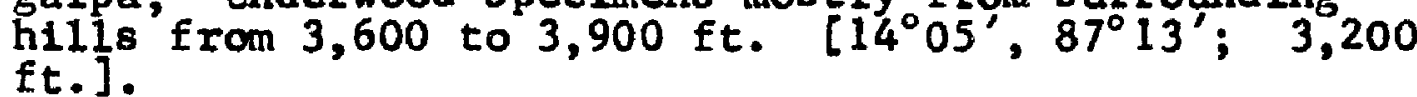

Conejo, El (Monte E1 Conejo) [Ocot.].--A locality in the general vicinity of Nueva Ocotepeque, exact location not known; Underwood specimens from $3,100 \mathrm{ft}$.

Confradia: see Cofradía.

Contoral: see Cantoral.

Copán (Ruinas de Copán) [Copán].--A town in western Honduras very near the Guatemalan border, a location of extensive Mayan ruins; Underwood specimens from between 3,000 and $3,500 \mathrm{ft} . \quad\left[14^{\circ} 50^{\prime}, 89^{\circ} 09^{\prime} ; 1,850 \mathrm{ft}.\right]$ (52).

COPÁN.--A western department bordering Guatemala, located west of Santa Bárbara and north of Ocotepeque.

Copa Rosa (Capa Rosa) [F.M.].--A part of the grounds of the Escuela Agrícola Panamertcana at El Zamorano.

Copén [Cortés].--An area of flood-fallow lakes about 5 miles north-northeas $t$ of La Lima $\left[15^{\circ} 27^{\prime}, 87^{\circ} 54^{\prime} ; 250 \mathrm{ft}.\right]$. 
Corfridía: see Cofradia.

Corocito [Colón].--A village about 13 miles southwest of Santa Rosa de Aguán $\left[15^{\circ} 47^{\prime}, 85^{\circ} 50^{\prime}\right]$.

Corpus, E1 [Chol.].--A town about 9 miles east-southeast of Choluteca, situated on the edge of monsoon forest $\left[13^{\circ} 16^{\prime}, 87^{\circ} 03^{\prime} ; 1,000 \mathrm{ft}.\right]$ (128).

Cortés: see Puerto Cortés.

CORTÉS.--A northwestern department bordering Guatemala and the Bay of Honduras, extending inland west of the Rio Ulúa and Rlo Humuya to include all of Lake Yojoa.

Cotacombas: see Catacombas .

Coxen's Hole: see Roatán.

Coyoles [Yoro].--A town in an arid portion of the valle del Aguan just north of the Río Aguán; specimens of Twomey and Hawkins from arid country around the town, from monsoon forest and marshes along the river, and from rain forest 8 ome 10 miles to the north, ali labeled

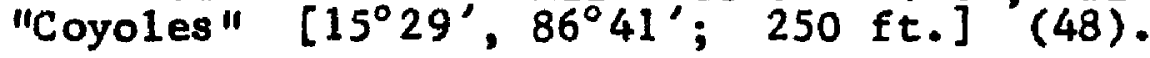

Crasa (Krasa) [G.D.].--A village situated on the Rio Segovia about 100 miles from the coast $\left[14^{\circ} 40^{\prime}, 84^{\circ} 45^{\prime}\right]$ (111).

Cruz Grande, La (La Cruz, La Cruz Grande La Paz) [La Paz].-A locality on the outskirts of San José de La Paz; Underwood specimens from $3,000 \mathrm{ft}$. [14 $\left.13^{\prime}, 87^{\circ} 55^{\prime}\right]$.

Cucuyagua [Copán].--A town $11 \mathrm{~m} 11$ es southwest of Santa Rosa de Copán $\left[14^{\circ} 39^{\prime}, 88^{\circ} 51^{\prime} ; 2,200 \mathrm{ft}.\right]$ (56).

Cues ta Grande [F.M.].--A locality 3 miles southwest of E1 Zamorano $\left[13^{\circ} 58^{\prime}, 87^{\circ} 03^{\prime}\right]$.

Cueva Archaga, La (La Cuera) [D.C.].--A locality on the outskirts of Archaga; Underwood specimens from 2,000 to $2,500 \mathrm{ft}$. $\left[14^{\circ} 17^{\xi}, 87^{\circ} 13^{\prime}\right]$.

Cueva Sabana Grande, La [F.M.].--A cave at Sabana Grande $\left[13^{\circ} 50^{\prime}, 87^{\circ} 15^{z}\right]$.

Cumbre, La (Montagnes La Cumbre) [Cortés]..-A locality in the mountains 3 miles northwest of Chamelecón $\left[15^{\circ} 25^{\prime}\right.$, $88^{\circ} 03^{\prime}$ ]. 
Cuyamel [Cortés].--A town near the north coast not far from the Guatemalan border $\left[15^{\circ} 38^{\prime}, 88^{\circ} 12^{\prime} ; 50 \mathrm{ft}.\right]$ (9).

Cuyamelito [Cortés].--A village almost on the Guatemalan border $8 \mathrm{mtles}$ west of Cuyamel $\left[15^{\circ} 38^{\prime}, 88^{\circ} 19^{\prime} ; 50\right.$ ft.] (8).

Danli [E1 P.].--A town 10 miles north of E1 Paralso $\left[14^{\circ} 00^{\circ}, 86^{\circ} 35^{\prime} ; 2,500 \mathrm{ft}.\right]$ (103).

Delicias, Las (Las Dolicias) [Com.].--A village 5 miles southwest of zambrano $\left[14^{\circ} 11^{\prime}, 87^{\circ} 27^{\prime}\right]$.

Derrumbo, E1 (E1 Derrumbe, E1 Durrumbo) [D.C.].--A village 2 miles north of Archaga; Underwood specimens taken at 8 ource of the Rio Ilamapa between 4,000 and $5,000 \mathrm{ft}$. $\left[14^{\circ} 18^{\prime}, 87^{\circ} 13^{\prime} ; 4,800 \mathrm{ft}.\right]$.

DISTRITO CENTRAL. --The central administrative district containing the capital of the country, Tegucigalpa.

Dolicias, Las: see Las Delicias.

Dos Caminos (Los Caminos) [Cortés] --A village 4 miles north of Villa Nueva $\left[15^{\circ} 19^{\prime}, 87^{\circ} 59^{\prime} ; 300 \mathrm{ft}.\right]$.

Dragos, Los [S, $\left.\mathrm{B}_{;}\right]$.-A village 4 miles southwest of Quimistân $\left[15^{\circ} 17^{\prime}, 88^{\circ} 26^{\prime} ; 600 \mathrm{ft}.\right]$ (31).

Dromodero Mts. (Bromadero, Bromadero Mts.) [E1 P.].--Mountains in the vicinity of DanII, exact location not known; Carr and Dickinson specimens from 4,500 ft.

Dulce Nombre (de) Culm1 [0lancho].--A town on the edge of the Olancho rain forest about $18 \mathrm{miles} 8$ outheast of San Es teban $\left[15^{\circ} 09^{\prime}, 85^{\circ} 37^{\prime} ; 1,400 \mathrm{ft}.\right]$ (50).

Durrumbo, E1: see E1 Derrumbo.

Encantado, Valle (Encantado, Valle Encentado) [F.M.].--A locality on the slopes of Cerro Uyuca at $4,600 \mathrm{ft}$., northwest of El Zamorano.

Entre Ríos, Cordillera.--A range of low, forested hills in southeastern Olancho and extreme eastern El Paraíso between the Río Patuca and the Rlo Segovia.

Escuela Agrícola Panamericana [F.M.].--An agricultural 8chool at $\mathrm{E} 1$ Zamorano, in the Yeguare River Valley $\left[14^{\circ} 00^{\prime}, 87^{\circ} 02^{\prime} ; 2,800 \mathrm{ft}.\right]$. 
Esperanza, La [Int.].--The departmental capital of Intibucá, 15 miles southwest of Jesús de Otoro $\left[14^{\circ} 16^{\prime}, 88^{\circ} 10^{\prime}\right.$; $5,350 \mathrm{ft.}]$ (78).

Esperanza, Montaña La.--A range of forested hills near the north coast in Colón and extreme northern olancho, between the Río Aguán and the Río Sico.

Falda (de) Santa Bárbara (Faldon de Santa Bárbara) [S.B.].-The western slopes of Cerro Santa Bärbara; Underwood specimens from $3,800 \mathrm{ft}$.

Farallones, LOB.--A group of tiny, rocky 18 lets in the mouth of the Bay of Fonseca $\left[13^{\circ} 05^{\prime}, 87^{\circ} 40^{\prime}\right]$.

Finca El Rubf [Chol.]..-A coffee finca in monsoon forest 3 miles southwest of El Corpus $\left[13^{\circ} 13^{\prime}, 87^{\circ} 04^{\prime} ; 1,900\right.$ ft.].

Finca Fé (Los Naranjos) [Cortés].--A coffee fince located about 1 mile west of El Jaral, near Lake Yojoa $\left[14^{\circ} 54^{\prime}, 88^{\circ} 04^{\prime} ; 2,300\right.$ ft. $]$.

Flor Archaga, La (La Flor, Las Flores Archaga, La Florida Archaga] [D.C.].--A small village $2 \mathrm{mtles}$ eas $\mathrm{t}$ of Archaga; Underwood specimens mostly from 4,500 to $5,000 \mathrm{ft}$., erroneous $1 \mathrm{y} 11 \mathrm{sted}$ as "2050'" on labels of specimens in the Museum of Comparative Zoology $\left[14^{\circ} 17^{\prime}, 87^{\circ} 11^{\prime}\right]$.

Flores, Las [Com.].--A small village on the ComayaguaTegucigalpa road 3 miles 8 outheast of Villa de San Antonio; this "Flores" may be the one visited by Joseph Leyland (Moore, 1859), as there is no other anywhere along the route from Comayagua to Omoa or nearby, but see discussion on pages $60-61\left[14^{\circ} 15^{\prime}, 87^{\circ} 35^{\prime}\right.$; $2,000 \mathrm{ft}$.$] .$

Flores, Las (Las lores Pucca) [Lempira].--A village 6 miles northwes $t$ of Graclas; Underwood s pecimens from adjacent hills at $3,000 \mathrm{ft} . \quad\left[14^{\circ} 40^{\prime}, 88^{\circ} 37^{\prime} ; 1,850 \mathrm{ft}.\right]$ (61).

Flores Tegucigalpa, Las [D.C.].--A locality of Underwood's in the immediate vicinity of Tegucigalpa, exact location not known; not the same as "La Flor Archaga."

Florida, La (La Flor Intibucá) [La Paz].--A village 3 miles south-southeast of Marcala; Underwood specimens marked "La Florida" and collected in December 1936 and January 1937 pertain to this locality; all others labeled "La 
Florida" pertain to La Flor Archaga $\left[14^{\circ} 04^{\prime}, 87^{\circ} 59^{\prime}\right]$ (83).

Florida Archaga, La: se La Flor Archaga.

Fonseca, Bay of (Golfo de Fonseca, Gulf of Fonseca).--A

large bay on the Pacific coast, bordered by EI Salvador on the northwest and Nicaragua on the southeast, with the Honduran coast being entirely within the confines of the bay.

Fowl key [I.B.].--A tiny sand bar about 200 yards southeast of Little Hog Is land, in the Cayos Cochinos.

FRANCISCO MORAZÁN.--The centrally located department that almost encircles the Distrito Central, bordering the latter on the north, east, and south.

French Harbor (French Harbour) [I.B.].--A seaport on the central southern coast of Isla de Roatán, in the Bay Islands $\left[16^{\circ} 23^{\prime}, 86^{\circ} 24^{\prime}\right]$ (4).

Garrobas, Laguna (de).--A small lake situated in the lower portion of the valle de Sula about 15 miles southeast of Puerto Cortés.

Goascorán [Valle].--A town located on the Río Goascorán 6 miles west of Langue $\left[13^{\circ} 36^{\prime}, 87^{\circ} 45^{\prime} ; 300 \mathrm{ft}.\right]$ (119).

Goascorán, Río.--A river forming the border between El Salvador and Honduras on the Pacific coast, with its headwaters in La Paz and mouth on the Bay of Fonseca.

Gomalotal, E1 [D.C.].--A locality in the immediate vicinity of Archaga, perhaps an alternate name for this village; exact location not known.

Gracias [Lempira].--A large town, the capital of the Department of Lempira, located 6 miles southeast of Las Flores $\left[14^{\circ} 35^{\prime}, 88^{\circ} 34^{\prime} ; 2,600 \mathrm{ft}.\right]$ (62).

GRACIAS: see LEMPIRA.

GRACIAS A DIOS.--The eas ternmost department in Honduras, embracing all of Honduras east of the 85th meridian of longitude and Including all of the Mosquitia and part of the olancho rain forest; formerly a part of Colón.

Gracias a Dios, Cabo (de) $[G, D],$.$-A , town at the mouth of$ the Río Segovia $\left[15^{\circ} 01^{\prime}, 83^{\circ} 10^{\prime}\right]$ (114). 
Grande, Cerro [La Paz].--A high mountain 3 miles north of Soluteca; Underwood specimens from $6,500 \mathrm{ft}$. [ $\left[14^{\circ} 19^{\prime}\right.$, $87^{\circ} 49^{\prime}$ ].

Grande, Rfo: see Río Choluteca.

Guaimaca (Guaymaca) [F.M.].--A town on the Catacamas road between Talanga and Campamento $\left[14^{\circ} 32^{\prime}, 86^{\circ} 51^{\prime} ; 2,500\right.$ ft.] (91).

Guaimaca, Montaña (de) (Guaimaca Mts., Guaymaca Mts.).--A mountain region a few miles northeast of Guaimaca on the Francisco Morazán-olancho border.

Guaimaca, Río, Río Guaymaca: see Río Jalán.

Guampú, Río.--A large river in Olancho with its headwaters in the Sierra de Agalta and its mouth on the Rio Patuca Just upstream from Huanquibila.

Guanaca, Río: see Río Jalán.

Guanaja [I.B.].-The only village on Is la de Guanaja, in the Bay Islands $\left[16^{\circ} 28^{\prime}, 85^{\circ} 54^{\prime}\right]$ (6).

Guanaja, Isla (de) (Bonacca Island, Bonacco Is land, Bonaco Island) [I.B.].-.The easternmost of the Bay Is lands, 9 miles by 4 miles in size and reaching $1,200 \mathrm{ft}$. in maximum elevation.

Guape, Río: see Río Guayape.

Guaruma [Cortés].--A name applied to three adjacent $s$ tations (Guaruma nos. 1, 2, and 3) of the United Fruit Company located from 1 to $3 \mathrm{miles}$ west of La Lima; Guaruma no. 3 is the one most frequently referred to as "Guaruma" $\left[15^{\circ} 23^{\prime}, 87^{\circ} 57^{\prime} ; 250 \mathrm{ft}.\right]$.

Guarunta, Laguna [G.D.].--A large lagoon in the Mosquitia, dralning into the northwestern portion of the Laguna Caratasca.

Guarunta, Rio [G.D.].--A river in the Mosquitia with its source in the Montañas de Colón and mouth on the Laguna Guarunta.

Guayabal, E1 (E1 Guayaba) [La Paz].--A village 5 miles east of San Jose de La Paz; Underwood specimens from 4,000 ft. $\left[14^{\circ} 12^{\prime}, 87^{\circ} 51^{\prime}\right]$. 
Guayambre, Rio.--A large river with its headwaters in E1 Paraiso, joining with the Rio Guayape in south-central olancho to form the Rio Patuca.

Guayape, Rio (RIo Guape).--A large river with its headwaters in northern Francisco Morazan, uniting with the Rio Guayambre to form the Rio Patuca.

Guaymaca, Guaymas: see Gua imaca.

Güinope $[E 1, P.] \cdot--A$, town 6 miles southwest of Yuscarán $\left[13^{\circ} 51^{\prime}, 86^{\circ} 55^{\prime} ; 4,200 \mathrm{ft}.\right]$ (101).

Güise [Int. $] \cdot-$ A $^{\circ}$ locality 5 miles east of La Esperanza
$\left[14^{\circ} 15^{\prime}, 88^{\circ} 07^{\prime} ; 5,600 \mathrm{ft}.\right]$ (79).

Hacienda Santa Ana: see Santa Ana.

Hatillo, E1 (Cerro Tigre, E1 Tigre, E1 Tigre Hatillo) [D.C.].-A village on the mountain overlooking Tegucigalpa, about 3 miles northeast of the city; Underwood specimens from this locality are, sometimes erroneously attributed to ocotepeque $\left[14^{\circ} 08^{\prime}, 87^{\circ} 10^{\prime} ; 4,800 \mathrm{ft}.\right]$.

Hélène: see Isla Santa Elena.

Higuito, Cerro (Cerro Higuita) [D.C.].--A locality in the immediate vicinity of Tegucigalpa, exact location not known; not the same as $\mathrm{El}$ Higuito de Santa Bárbara, sometimes called "Cerro Higuito" by Underwood; all Underwood specimens labeled "Cerro Higuito," except those taken during April 1935, pertain to the locality in the Distrito Central.

Higuito, El (Cerro Higuito, El Higuito de Santa Bárbara, Cerro Hiquito) [S.B.].--A mountain in the vicinity of Cerro Nieve and San José Oriente, exact location unknown; all Underwood specimens labeled "Cerro Higuito" and taken in April 1935 pertain to this locality.

Hog Islands: see Cayos Cochinos.

Honda, La [La Paz].--A locality in the immediate vicinity of Llano Grande, probably referring to the stream at that location.

Hondo ${ }_{\left[14^{\circ}\right.}^{\text {Rio }}\left[4^{\text {D }}, 87^{\circ} \mathrm{i}^{\circ}\right]$.

Honduras, Bay of (Bahia de Honduras, Golfo de Honduras, Gulf of Honduras).--That portion of the Caribbean Sea between the Cayos Zapotillos and the coasts of southern 
British Honduras, northeastern Guatemala, and northwestern Honduras in the Puerto Cortés region.

Honduras Depression.--A low connection (maximum elevation, $2,850 \mathrm{ft}$. at the Continental Divide) across the central part of Honduras, joining the area along the Rio Goascorain on the Pacific slope with the Valle de Comayagua on the Caribbean slope.

Honduras-Nicaragua boundary.--A number of specimens, taken around 1900, are labeled "Honduras-Nicaragua boundary 180 miles from the Pacific coast"; almost all of these specimens have been shown to have been collected in the Pacific lowlands not more than 20 miles from the Pacific coast (see pages 66-67).

Horno, E1 [La Paz].--A locality 5 miles north of Marcala; Underwood specimens taken at 4,000 ft. [14 $10^{\prime}$, $88^{\circ} 00^{\prime} \mathrm{J}$.

Huanquibila (Wankybila) [Olancho].--A village on the Río Patuca just below the mouth of the Rio Guampí. $\left[14^{\circ} 58^{\prime}, 85^{\circ} 00^{\prime} ; 400 \mathrm{ft}.\right]$ (109).

Humuya, Río (Rfo Comayagua).--A large river draining the Valle de Comayagua and emptying into the Río vía near Potrerillos.

Hunting Cay,--Largest of the Cayos Zapotillos $\left[16^{\circ} 09^{\prime}\right.$, $88^{\circ} 16^{\prime} j$.

Ilamapa (Ilama, Ilamada, Ilamafa, Llama) [D.C.].--A village 2 miles northwest of Archaga; erroneously recorded by Goodwin (1942: 110) as referring to the town of Ilama in the Department of Santa Bárbara $\left[14^{\circ} 18^{\prime}, 87^{\circ} 15^{\prime}\right]$.

Ilamapa, Río (Río Llama) [D.C.].--A small 8 tream running through the town of Ilamapa and emptying into the Rio Choluteca just east of Archaga.

Intibucá (Intebucá) [Int.].--A small viliage situated on the northeasterm outskirts of La Esperanza $\left[14^{\circ} 16^{\prime}\right.$, $88^{\circ} 10^{\prime} ; 5,200$ ft. .

INTIBUCÁ.--A department on the El Salvador border bounded on the west by Lempira and on the east by La Paz.

Iriona [Colón].- A town on the north coast 50 miles east of Trujillo [15 $\left.57^{\prime}, 85^{\circ} 11^{\prime}\right]$ (29).

Jaitigue [Com.].--A village $3 \mathrm{miles}$ west of Taulabé $\left[14^{\circ} 37^{\prime}, 88^{\circ} 01^{\prime} ; 1,950 \mathrm{ft}.\right]$. 
Jaitique, Rio.--The river draining Lake Yojoa; originating at the south end of the lake near Pito Solo and emptying into the Río Ulúa west of San José de Comayagua.

Jalán, Río (Rlo Gualmaca, Río Guanaca, Río Guaymaca).--A large river originating in the Guaimaca region of Francisco Morazain and emptying into the Rio Guayape southeast of Juticalpa.

Jamastrán, Valle (de) [ $E 1$ P.].--A valley along the Rio Guayambre just east of Danli.

Jaral, E1 (E1 Jara) [Cortés].--A village at the northernmost point of take Yojoa $\left[14^{\circ} 54^{\prime}, 88^{\circ} 03^{\prime} ; 2,100 \mathrm{ft}.\right]$ (67).

Jesús de Otoro [Int.].--A large town in the Valle de otoro about 11 miles southwest of Siguatepeque $\left[14^{\circ} 26^{\prime}\right.$, $\left.88^{\circ} 06^{\prime} ; 2,050 \mathrm{ft}.\right] \quad(76)$.

Jicaro Galán [Valle].--A village 2 miles east of Nacaome $\left[13^{\circ} 31^{\prime}, 87^{\circ} 28^{\prime} ; 50 \mathrm{ft}.\right]$.

Julián: see Tulián.

Juticalpa [0lancho] --A large town 23 miles southwest of Catacamas $\left[14^{\circ} 42^{\prime}, 86^{8} 15^{\prime} ; 1,300 \mathrm{ft}.\right]$ (106).

Kiyras [G.D.].--A village along the Río Segovia 10 miles northwest of Crasa $\left[14^{\circ} 46^{\prime}, 84^{\circ} 53^{\prime}\right]$ (110).

Krasa: see Crasa.

Laguna Cantoral, La (Laguara, La Laguna, La Laguna Archaga) [D.C.].--A smali village northeast of Archaga at the foot of Cerro Cantoral; Underwood specimens from 4,000 to $5,000 \mathrm{ft}$. $\left[14^{\circ} 21^{\prime}, 87^{\circ} 19^{\prime}\right]$.

Lamanf [Com.].--A town in the Valle de Comayagua 8 miles south of Villa de San Antonio $\left[14^{\circ} 08^{\prime}, 87^{\circ} 35^{\prime} ; 2,350\right.$ ft.] (87).

Lancetilla [Atl.].--An agricultural experimental station situated in a rain forest area 3 miles 8 outh of Tela; specimens have been taken between 100 and $1,200 \mathrm{ft}$. on the adjoining ridges $\left[15^{\circ} 42^{\prime}, 87^{\circ} 28^{\prime} ; 100^{\prime} \mathrm{ft}.\right]$.

Lancetilla, Valle de [Atl.].--The narrow valley in which the Lancetilla station is located; elevation of valley floor, $100 \mathrm{ft}$.

Langue (Langui) [Valle].--A town 6 miles east-northeast of Goascorán $\left[13^{\circ} 37^{\prime}, 87^{\circ} 39^{\prime} ; 650 \mathrm{ft}.\right]$ (120). 
Lapaera, Lapaere: see Lepaera.

Lavanderos (Lavenderas) [El P.] - -A locality about 8 miles southeast of EI Zamorano $\left[13^{\circ} 54^{\prime}, 86^{\circ} 57^{\prime}\right]$.

Leain, $R f_{0 .--A}$ river in north-central Honduras with its source in the Cordillera Nombre de Dios and mouth on the north coast 9 miles east of Tela.

Leain, Valle (de).--The valley of the Río Leán.

Lempa, Río.--A large river with its source in the mountains of eastern Guatemala and mouth on the Pacific coast of E1 Salvador, but passing through western Ocotepeque near Its source and, after traversing part of El Salvador, forming the Honduran-El Salvador boundary in southern Lempira and southwestern Intibucá.

LEMPIRA (GRACIAS).--A department on the El Salvador border flanked on the west by Ocotepeque and on the east by Intibucá.

Leona, La [Copán].--A village $5 \mathrm{miles}$ north of La Libertad; Underwood specimens from $3,000 \mathrm{ft}$. [1 $\left.4^{\circ} 52^{\prime}, 88^{\circ} 59^{\prime}\right]$ (53).

Lepaera (Lapaera, Lapaere, Sepaena) [Lemplra].--A town 6 miles north-northeast of Las Flores $\left[14^{\circ} 45^{\prime}, 88^{\circ} 36^{\prime}\right.$; $3,300 \mathrm{ft}] \quad.(60)$.

Libertad, La (La Libertad Copán) [Copán].--A village $7 \mathrm{miles}$ east of Copán $\left[14^{\circ} 49^{\prime}, 89^{\circ} 01^{\prime} ; 3,200 \mathrm{ft}.\right]$ (54).

Lima, La [Cortés]. --A large town 8 miles southeast of San Pedro Sula; Goodwin (1942: 110) erred in attributing this locality to the Tegucigalpa region at $5,000 \mathrm{ft}$. [15.24, $\left.87^{\circ} 56^{\prime} ; 300 \mathrm{ft}.\right]$ (37).

Limones: 8 ee Monte Redondo.

Lindo, Río [Cortés].--A village on the Río Blanco 3 miles southwest of Amapa $\left[15^{\circ} 00^{\prime}, 88^{\circ} 01^{\prime} ; 350 \mathrm{ft}\right.$. $]$.

Little Hog Island [I.B.].--The smaller of the two forested islands of the Cayos Cochinos, about 1 mile in diameter and situated 1 mile west of Big Hog Island [15 $57^{\prime}$, $86^{\circ} 32^{\prime}$ ].

Little Swan Island.--The smaller of the two 1slands of the Swan Islands, 1 ess than $1 \mathrm{mile}$ in diameter and located $1 \mathrm{mile}$ east of B1g Swan Is land $\left[17^{\circ} 25^{\prime}, 83^{\circ} 55^{\prime}\right]$. 
Llama: see Ilamapa.

Llano Grande [La Paz].--A locality 3 miles southwest of San José de La Paz $\left[14^{\circ} 11^{\prime}, 87^{\circ} 57^{\prime}\right]$.

Lomas, Las [E1 P.].--A locality on the Tegucigalpa-Danli road at the bridge over the Río Choluteca, $3 \mathrm{miles}$ northeast of 0 jo de Agua $\left[14^{\circ} 04^{\prime}, 86^{\circ} 52^{\circ} ; 1,900 \mathrm{ft}.\right]$.

Lombardia [At1.] - A locality 15 miles southeast of Tela $\left[15^{\circ} 34^{\prime}, 87^{\circ} 17^{\prime}\right]$ (17).

Lucerna [Ocot.] --A village 9 miles southwest of Cucuyagua $\left[14^{\circ} 33^{\prime}, 88^{\circ} 56^{\circ} ; 2,600 \mathrm{ft}.\right]$ (57).

Madre Vieja [F.M.].--Part of the Escuela Agrícola Panamericana at E1 Zamorano.

Manacal [Cortés].--A station of the United Fruit Company 1 mile south of Cofradía $\left[15^{\circ} 23^{\prime}, 88^{\circ} 09^{\prime} ; 500 \mathrm{ft}\right.$. $]$.

Marcala [La Paz] - A large town 14 miles southeast of La Esperanza $\left[14^{\circ} 07^{\prime}, 88^{\circ} 00^{\prime} ; 4,000 \mathrm{ft}.\right]$ (82).

Martinez Creek [At1.].--An area on the eas tern edge of the Laguna Toloa about 2 miles east of the village of Toloa and $20 \mathrm{miles}$ west of Tela.

Mazaguara (Masaguara) [Int.].--A village on the edge of the Valle de Otoro 9 miles south of Jesús de Otoro $\left[14^{\circ} 19^{\prime}, 88^{\circ} 06^{\prime} ; 2,900 \mathrm{ft}.\right]$ (77).

Medina [Cortés].-A, village 3 miles southeast of Puerto Cortés $\left[15^{\circ} 46^{\prime}, 87^{\circ} 54^{\prime} ; 50 \mathrm{ft}.\right]$ (12).

Merendón, Cordillera (de).--A mountain range in western Honduras bordering Guatemala in Copán and Ocotepeque.

Merendón Copán (Merendón, Mirendón) [Copán]:-A locality about 6 miles eas $t$ of La Libertad $\left[14^{\circ} 49^{\prime}, 88^{\circ} 56^{\prime}\right.$; $4,300 \mathrm{ft.}$.

Mesas, Las [F.M.].--A village on the Francisco Morazán-El Paraiso border 5 miles east of E1 Zamorano $\left[14^{\circ} 02^{\prime}\right.$, $86^{\circ} 57^{\prime} ; 3,200$ ft. ].

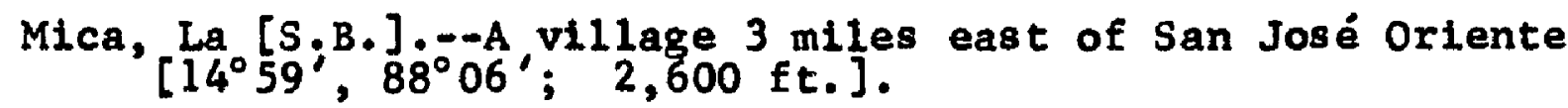

Micos, Laguna (de) [Atl.].--A coastal lagoon about 7 miles in diameter, located about 10 miles west of Tela. 
Midence's woods [F.M.].--A collecting locality of Marjorie H. Carr, located at EI Zamorano.

Mirendón: see Merendón Copán.

Mochito, E1 (Mochita) [S.B.].--A settlement about $7 \mathrm{miles}$ southwest of EI Jaral, at the southwestern base of Cerro Santa Bárbara $\left[14^{\circ} 50^{\prime}, 88^{\circ} 07^{\prime} ; 2,100 \mathrm{ft}.\right]$ (68).

Mocorin (Mocorina) [G.D.].--A village on the Río Segovia about 70 miles upstream from the mouth $\left[14^{\circ} 43^{\circ}\right.$, $\left.84^{\circ} 11^{\prime}\right]$ (112). Mogote $\left[14^{\mathrm{E}} 42^{[S}, 88^{\circ} 05^{\prime}\right]$.

Monserrat, Montaña (de) (Monserat, Monserrate, Monterat, Montserat, Montserrat, Mt. Monserat, Mt. Montserrat) [EI P.].--A mountain range Just east of Yuscarán.

Montañita, La [F.M.].--A locality in the vicinity of Cerro Uyuca, just northwesterly of $E 1$ Zamorano, exact location not known.

Montecillos, Sierra (de).--A high mountain range located between the Valle de Otoro and the valle de Comayagua.

Montecris to (Montechristo) [Atl.] --A village $8 \mathrm{miles}$ southwest of La Celba $\left[15^{\circ} 44^{\prime}, 86^{\circ} 55^{\prime}\right.$; $\left.100 \mathrm{ft}.\right]$ (19).

Monterat, Montserat, Montserrat: see Montaña de Monserrat.

MORAZÁN: see FRANCISCO MORAZÁN.

Morocel1 (Morecel1) [E1 P.].--A town about 7 miles northnor theast of ojo de Agua $\left[14^{\circ} 07^{\prime}, 86^{\circ} 52^{\prime} ; 2,250 \mathrm{ft}.\right]$ (102).

Mosquitia.--A term frequently used to indicate the largely uninhabited region of eastern Honduras, including most of Gracias a Dios and parts of eastern Colón and eastern Olancho; generally restricted now to the lowland pine savanna and marshy coastal districts of eastern Colón and Gracias a Dios.

Muín [La Paz].--A wooded area on the Intibucá-La Paz border 7 miles north of Marcala; Underwood specimens from $2,500 \mathrm{ft} . \quad\left[14^{\circ} 14^{\prime}, 88^{\circ} 01^{\prime}\right]$. 
Muye (Muya) [La Paz].--A locality 7 miles northeast of Mar-

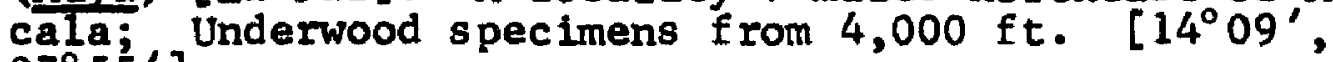
$87^{\circ} 55^{\prime}$ ].

Nacaome [Valle] - -A large town 8 miles northwest of San Lorenzo $\left[13^{\circ} 31^{\prime}, 87^{\circ} 30^{\prime} ; 100 \mathrm{ft}.\right]$ (122).

Nacaome, Río: see Río Pesptre.

Nacunta, Rfo [G.D.].--A river draining part of the Mosquitia pine savanna and emptying into the Laguna Caratasca at the latter's southermmost tip.

Namasigüe (Namasique) [Chol.].--A town 8 miles southeast of Choluteca $\left[13^{\circ} 12^{\prime}, 87^{\circ} 09^{\prime} ; 300 \mathrm{ft}.\right]$ (127).

Naranjos, Los: see Finca Fé.

Nieve, Cerro [S.B.].--A mountain 2 miles north of San José Oriente; Underwood specimens from about $4,000 \mathrm{ft}$. $\left[15^{\circ} 02^{\prime}, 88^{\circ} 09^{\prime}\right]$.

Nisperal (Nispero) [Cortés].--A Wittkügel collecting locality in the immediate vicinity of San Pedro Sula, exact location unknown.

Nombre de Dios, Cordillera.--A mountain range situated on the central portion of the Atlántida-Yoro border.

Nueva Arcadia (Nueva Arcadra) [Copán].--A village located about 21 miles northeast of La Leona $\left[15^{\circ} 02^{\prime}, 88^{\circ} 45^{\prime}\right.$; $1,900 \mathrm{ft}$.$] .$

Nueva Ocotepeque (Ocotepeque, Ocotopeque) [Ocot.].--A large town 18 miles southwest of Lucerna $\left[14^{\circ} 26^{\prime}, 89^{\circ} 11^{\prime}\right.$; $2,600 \mathrm{ft.]}$ (58).

Oak Ridge [I.B.].--A village on Isla de Roatán 4 miles eastnortheast of French Harbor $\left[16^{\circ} 24^{\prime}, 86^{\circ} 21^{\prime}\right]$ (5).

Ocotepeque, Ocotopeque: See Nueva Ocotepeque.

OCOTEPEQUE. --The westermost department of Honduras, located at the junction of the borders of $\mathrm{E} 1$ Salvador and Guatemala.

Ojo de Agua [El P.].--A village on the Tegucigalpa-Danlf road 7 miles north-northwest of Yuscarán $\left[14^{\circ} 03^{\prime}\right.$, $\left.86^{\circ} 53^{\prime}\right]$ (99). 
OLANCHO.--The largest department in Honduras, bordering Nicaragua between EI Parafso and Gracias a Dios; the term "Olancho rain forest," as used in the present work, refers to the vast, undisturbed, forested area of eastern Olancho, embracing also parts of southeastern Colón, extreme eastern El Paraíso, and western Graclas a Dios.

0lancho, Valle (de) [0lancho].--The valley along the RIo Guayape from the vicinity of Juticalpa to Catacamas.

Omoa [Cortés].--A seaport on the north coast 7 miles southwest of Puerto Cortés $\left[15^{\circ} 43^{\prime}, 88^{\circ} 02^{\prime}\right]$ (10).

Omoa, Sierra (de).--A mountain range in northern Honduras along the Guatemalan border in northern Santa Bárbara and northwestern Cortés.

Opalaca, Sierra (de).--A mountain range in northeastern Lempira and northwes tem Intibuca.

Opoteca (Opotelma), [Com:],-A town 5 miles east of Siguatepeque $\left[14^{\circ} 32^{\prime}, 87^{\circ} 44^{\prime}\right]$.

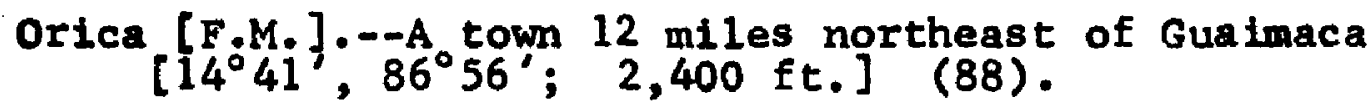

Orilla, Rio de La, Rio de La Orillaca: see Río Yeguare.

Oromilaca [Copán].--A village 6 miles west of Santa Rosa de Copán $\left[14^{\circ} 45^{\prime}, 88^{\circ} 48^{\prime} ; 3,200 \mathrm{ft}.\right]$.

Otoro, Valle (de).--An arld valley (elevation 1,900 to 2,100 ft.) located along the upper reaches of the Rlo Uluia between the Sierra de Opalaca and Sierra de Montecil108.

Pájaro, Isla (BLrd Island) [Valle].--A small is land less than $1 / 4 \mathrm{mile}$ in diameter, located in the Bay of Fonseca about 2 miles east of Isla de E1 Tigre [13 $17^{\prime}$, $87^{\circ} 37^{\prime} \mathrm{J}$.

Palmar [Cortés].--A Wittkügel collecting localityy 3 miles north-northwest of Chamelecón $\left[15^{\circ} 25^{\prime}, 88^{\circ} 04^{\prime} ; 600\right.$ ft.].

Palmas, Las, [Int.] - -A local1ty 2 miles west of Güise $\left[14^{\circ} 16^{\prime}, 88^{\circ} 09^{\prime} ; 6,400 \mathrm{ft}.\right]$.

Palomas-Toloa Canal: see Toloa Canal.

Panitas, Las: see Las Pefitas. 
Paraiso, E1, [E1 P.] - -A large town 12 miles south of Danli $\left[13^{\circ} 51^{\prime}, 86^{\circ} 34^{i} ; 2,800 \mathrm{ft}.\right]$ (104).

PARAfSO, EL.--A southwestern department bordering Nicaragua south of Olancho and northeast of Choluteca.

Paredes, LOB [E1 P.].--A v1llage on the western edge of the olancho rain forest, situated about 40 miles eastsoutheast of Danlf or about 10 miles east of Jalapa, Nicaragua $\left[13^{\circ} 56^{\prime}, 85^{\circ} 58^{\prime} ; 250 \mathrm{ft}.\right]$ (108).

Pataste, Rfo (Río Petaste) [Olancho].--A stream originating in the mountains south of Dulce Nombre de Culml and emptying into the Río Tinto northeast of Catacamas.

Patuca, Rio.--A large river draining most of the olancho rain forest, originating with the junction of the Rio Guayape and the $R$ io Guayambre in south-central olancho and emptying into the Caribbean Sea just east of the Laguna Brus.

PAZ, LA.-A department on the El Salvador border bounded by Intibucá on the west and Francisco Morazán and Comayagua on the east.

Pedernal, E1 [La Paz].--A locality 3 miles northeast of San José de La Paz; Underwood specimens from 2,500 to $3,000 \mathrm{ft}$. $\left[14^{d} 14^{\prime}, 87^{\circ} 54^{\prime}\right]$.

Pedras, Río de Las: see Río de Las Pledras.

Peña Blanca (Piña Blanca) [Cortés].--A village 2 miles north of EL Jaral [1456", $88^{\circ} 03^{\prime \prime} ; 2,100 \mathrm{ft}$.].

Peñitas, Las (Las Panitas, Las Pelnitas) [Cortés].--A farm located about 3 miles southwest of San Pedro Sula, situated in the foothills of the mountains to the west of San Pedro Sula; Underwood specimens from 500 to $4,500 \mathrm{ft}$. $\left[15^{\circ} 25^{\xi}, 88^{\circ} 04^{\prime}\right]$.

Permejo, Río: see Río Bermejo.

Pespire [Valle] --A town 8 miles northeast of Nacaome [13 $\left.34^{\prime}, 87^{\circ} 23^{\prime} ; 200 \mathrm{ft}.\right]$ (121).

Pespire, Río (Río Nacaome).--A river with its source in southern Francisco Morazín and mouth on the Bay of Fonseca Just west of San Lorenzo.

Petaste, Río: see Río Pataste. 
Picacho, E1 (Cerro de El Picacho) [D.C.].--A locality in the mountains about 4 miles northeast of Tegucigalpa $\left[14^{\circ} 07^{\prime}, 87^{\circ} 17^{\prime} ; 4,300 \mathrm{ft}.\right]$.

Piedra de Jesuis, La [F.M.] - -A locality about $3 \mathrm{miles}$ south of Sabana Grande $\left[13^{\circ} 47^{\prime}, 87^{\circ} 15^{\prime} ; 3,250 \mathrm{ft}.\right]$.

Płedras, Río de Las (Río de Las Pedras) [Cortés].--A 1ocality on the northwestern outskirts of San Pedro Sula $\left[15^{\circ} 28^{\prime}, 88^{\circ} 03^{\prime} ; 250 \mathrm{ft}.\right]$.

Pijol, Montaña (de) [Yoro].--A mounta in range in southwestern Yoro north of the Rio Sulaco.

Pimienta, La (La Pimienta Nueva) [Cortés].--A village on the Río vlúa 2 miles north of Potrerillos $\left[15^{\circ} 14^{\prime}, 87^{\circ} 58^{\prime}\right.$; $250 \mathrm{ft}$.$] .$

Piña Blanca: see Peña Blanca.

Pisigire, Río [0lancho].--A small stream northeast of Dulce Nombre de Culmí, originating in the Sierra de Agalta and emptying into the Río Guampú.

Pita, La [Cortés].--A village 5 miles east of Chamelecón, on the Río Chamelecón; this locality is the "La Pita" of Wittkügel $\left[15^{\circ} 23^{\prime}, 88^{\circ} 06^{\prime} ; 250 \mathrm{ft}\right.$. $]$.

Pita, La [F.M.].--A locality about 4 miles south of Sabana Grande; this locality is the "La Pita" of Underwood $\left[13^{\circ} 45^{3}, 87^{\circ} 16^{\prime}\right]$.

Pito Solo [Cortés].--A locality at the southern tip of Lake Yojoa, at the source of the Rio Jaltique [14 $43^{\prime}$, $88^{\circ} 00^{3} ; 2,050 \mathrm{ft.}$. (71).

Plan del Rancho (Plan del Rio) [Ocot.]--A locality 5 miles east of Nueva Dcotepeque $\left[14^{\circ} 26^{\prime}, 89^{\circ} 06^{\prime} ; 3,800 \mathrm{ft}.\right]$.

Planes, Los (Planus) [Colón].--A Standard Fruit Company station about 30 miles southwest of Trujillo $\left[15^{6} 36^{\prime}\right.$, $\left.86^{\circ} 21^{\prime} ; 200 \mathrm{ft}.\right]$ (23).

Portillo Grande (Portrillo Grande) [Yoro] - -A locality 5 miles northwest of Yorito $\left[15^{\delta} 05^{\prime}, 87^{\circ} 16^{\prime}\right]$.

Portillo (de) Los Arados (Portillo de Los Arcados) [El P. ] - A locality abour 4 miles northwest of Gülnope $\left[13^{\circ} 52^{\prime}, 86^{\circ} 59^{\prime} ; 5,000 \mathrm{ft}.\right]$. 
Portillo, Monte El (Monte E1 Portrillo) [Ocot.].--A 1ocality in the general vicinity of Belén Gualcho, exact location unknown.

Portrillo Grande: see Portillo Grande.

Potrerillos (Potrerellos) [Cortés].--A town on the Río Blanco near 1 ts function with the Rio Humuya $\left[15^{\circ} 11^{\prime}\right.$, $87^{\circ} 58^{\prime} ; 250 \mathrm{ft.j}$ (42).

Porto Caballos: see Puerto Cortés.

Progreso [Yoro].--A large town on the Río Ulia 7 miles southeast of La Lima $\left[15^{\circ} 21^{\prime}, 87^{\circ} 48^{\prime} ; 100 \mathrm{ft.}\right]$ (39).

Puca, Montaña (de) (Cerro Puca, Cerro Pucca, Mt. Pucca, Pucca, Volcán de Paca, Volcán de Peca, Volcán de Puca) [Lempira].--A high mountain about 4 miles southeast of Lepeera; Underwood specimens mostly from 6,000 to $7,000 \mathrm{ft}$.; Wittkügel specimens from unknown elevations $\left[15^{\circ} 21^{\prime}, 87^{\circ} 49^{\prime}\right]$.

Pueblo viefo [Yoro];-A village 3 miles northwest of Yorito $\left[15^{\circ} 04^{\prime}, 87^{\circ} 14^{\prime}\right]$.

Puerta, La (La Puerte, La puerto) [Cortés];--A locality 3 miles northwest of Chamelecón $\left[15^{\circ} 26^{\prime}, 87^{\circ} 59^{\prime}\right]$.

Puerto Arturo [Atl.].--A village 3 miles southwest of Tela $\left[15^{\circ} 43^{\prime}, 87^{\circ} 30^{\prime} ; 50 \mathrm{ft}.\right]$.

Puerto Caballo, Puerto Caballos, Puerto Cabello: see Puerto Cortés.

Puerto Castilla [Colón].--A seaport on the north coast, 7 miles north-northwest of Truf1110 [16 $\left.01^{\prime}, 86^{\circ} 01^{\prime}\right]$ (25).

Puerto Cortés (Cortés, Porto Caballos, Puerto Caballo, Puerto Caballos, Puarto Cabel1o, Puerto Cortez) (Cortés ].--A large seaport on the north coas t 10 miles northeas $t$ of Omoa $\left[15^{\circ} 48^{\prime}, 87^{\circ} 56^{\prime}\right]$ (11).

Puerto Lempira (Puerto Lampira) [G.D.].--A village on the southwes tern shore of the Laguna Caratasca; references in the present work to "Puerto Lempira" pertain to a camp of the Pure 011 Company, located 3 miles southeast of the village $\left[15^{\circ} 13^{\prime}, 83^{\circ} 47^{\prime}\right]$ (113).

Puerto Sal [At1.].--A village on the north coast 14 miles northwest of $\mathrm{Tela}\left[15^{\circ} 51^{\prime}, 87^{\circ} 39^{\prime}\right]$ (14). 
Puerto Salamar [Valle].--A locality on the Bay of Fonseca 3 miles east of San Lorenzo $\left[13^{\circ} 25^{\prime}, 87^{\circ} 25^{\prime}\right]$.

Quemado, Cerro: see Cerro Cantoral.

Quemado Rancho: see Rancho Quemado.

Quimistán [S.B.].--A town near the Río Chamelecón 5 miles northeast of Los Dragos $\left[15^{\circ} 20^{\prime}, 88^{\circ} 23^{\prime} ; 550 \mathrm{ft}.\right]$ (32).

Quimistán, Valle (de).--The valley along the Río Chamelecón from northeastern Copán to just west of the town of Chamelecón.

Rancho Quemado (Casa Quemada, Casa Quemado, Quemado Rancho, Ranchón, Rancho guenada) [D.C.].--A locality 7 miles northeast of Tegucigalpa; Underwood specimens from 5,000 to 6,000 ft., erroneously listed as "3,100'" on labels in the Museum of Comparative Zoology ' $\left[14^{\circ} 10^{\prime}\right.$, $\left.87^{\circ} 08^{\prime} ; 4,650 \mathrm{ft}.\right]$.

Redondo, Monte (Limones, Redondo) [D.C.].--A locality about 2 miles southwest of Archaga; Underwood specimens from 3,500 to 4,000 ft. $\left[14^{\circ} 16^{\circ}, 87^{\circ} 15^{\prime}\right]$.

Roatán (Coxen's Hole, Ruatan) [I.B.].--The largest town on Is la de Roatán, located on the south coast in the central part of the is land $\left[16^{\circ} 18^{\prime}, 86^{\circ} 35^{\prime}\right]$ (3).

Roatán, Is la (de) (Ruatan Island) [I.B.].--The largest of the Bay Islands, 30 miles long by 4 miles wide.

Román, Río: see Río Aguán.

Rosario [D.C.].--A mining camp on San Juancito [14 $13^{\prime}$, $\left.87^{\circ} 05^{\circ} ; 5,000 \mathrm{ft}.\right]$.

Ruatan: see Roatán.

Ruatan Island: see Isla de Roatán.

Ruinas de Copán: see Copán.

Sabana Grande (Sabanagrande, Savanna Grande) [F.M.].--A town about 18 miles south of Tegucigalpa; altitude erroneous ly 11sted as "1,100'" by Goodwin (1942: 111) $\left[13^{\circ} 50^{\prime}, 87^{\circ} 15^{\prime} ; 3,400 \mathrm{ft}.\right]$ (115).

Sabanetas [Lempira].--A village $9 \mathrm{miles}$ south-8outhwest of Marcala $\left[14^{\circ} 00^{\prime}, 88^{\circ} 01^{\prime} ; 5,600 \mathrm{ft}.\right]$ (84). 
Sabirana: see Subirana.

San Alejo [At1.].--An oil-palm plantation of the United Fruit Company, located 7 miles west-southwest of Tela $\left[15^{\circ} 42^{\prime}, 87^{\circ} 33^{\prime} ; 50 \mathrm{ft}.\right]$ (15).

San Antonio Oriente (San Antonio) [F.M. $]_{-}-\mathrm{A}$ village 4 miles north of E1 Zamorano $\left[14^{\circ} 02^{\prime}, 87^{\circ} 02^{\prime}\right]$.

San Esteban [Olancho].--A town on the Río Sico 20 miles northwest of Dulce Nombre de Culm $\left[15^{\circ} 17^{\prime}, 85^{\circ} 52^{\prime}\right.$; $1,200 \mathrm{ft.}$ (49).

San Francisco (San Francisco Plantation) [At1.].--A town 18 miles southwest of La Ceiba $\left[15^{\circ} 39^{\prime}, 87^{\circ} 03^{\prime} ; 50 \mathrm{ft}.\right]$ (18).

San Francisco [Chol.]-A village 8 miles southwest of San Marcos de Colón; this locality is the "San Francisco" of Monroe and Feduccia $\left[13^{\circ} 23^{\prime}, 86^{\circ} 55^{\prime} ; 3,000 \mathrm{ft}.\right]$ (129).

San Francisco [F.M.].--A locality on the Río Yeguare at EI Zamorano; this locality is the "San Francisco" of Carr and Dickinson $\left[14^{\circ} 00^{\prime}, 87^{\circ} 02^{\prime} ; 2,600 \mathrm{ft}.\right]$.

San Francisco Plantation: see San Francisco [At1.].

San Jacinto: see San Juancito.

San José (de) Conayagua [Com:].--A town 6 miles northwest of Taulabé $\left[14^{\circ} 40^{\circ}, 88^{\circ} 03^{\circ} ; 1,950 \mathrm{ft}.\right]$ (73).

San José (de) La Paz [La Paz] --A village 8 miles northeast of Marcala $\left[14^{\circ} 13^{\prime}, 87^{\circ} 56^{\prime} ; 4,100 \mathrm{ft}.\right]$ (81).

San José Orlente (San José de Santa Bảrbara) [S.B.].--A village 10 miles northeast of Santa Bárbara; Underwood spectmens usually labeled from "2, $386^{\prime \prime}$ or " $3,960^{\prime \prime \prime}$ $\left[14^{\circ} 59^{\prime}, 88^{\circ} 09^{\prime}, 2,250 \mathrm{ft}.\right]$ (63).

San José (de) Río Tinto [Olancho].--A town on the Río Tinto about 9 miles northeast of Catacamas $\left[14^{\circ} 59^{\prime}, 85^{\circ} 46^{\prime}\right.$; $1,100 \mathrm{ft}$.$] .$

San José (de) Santa Bárbara: see San José Oriente.

San Juancito (San Jacinto, San Juancito Mts., La Tigra) [D.C.].--A mountainous area of cloud forest about 10 miles northeast of Tegucigalpa; elevations on specimen labels vary, depending upon collector, from 4,700 to $7,500 \mathrm{ft.}\left[14^{\circ} 3^{\prime}, 87^{\circ} 04^{\prime}\right]$ (96). 
San Juan [La Paz].--A town 9 miles north of Caridad, on the Rio Goascorán $\left[13^{\circ} 56^{\prime}, 87^{\circ} 38^{\prime} ; 1,700\right.$ ft. $]$ (116).

San Juan (de) Las F1ores (Cantarranas) [F.M.].--A town 10 miles south-southeast of Talanga, on the Rio Choluteca $\left[14^{\circ} 15^{\prime}, 87^{\circ} 02^{\prime} ; 2,300 \mathrm{ft}.\right]$ (95).

San Juan Tegucigalpa [D.C.].--A locality in the immediate vicinity of Tegucigalpa, exact location unknown.

San Lorenzo [Valle].--A coastal town on the Bay of Fonseca 8 miles south-southeast of Nacaome $\left[13^{\circ} 25^{\prime}, 87^{\circ} 27^{\prime}\right]$ (124).

San Marcos (de) Colón (San Marcus de Colón) [Chol.].--A town on the Panamerican Highway 5 miles west of the Nicaraguan border $\left[13^{\circ} 25^{\prime}, 86^{\circ} 49^{\prime} ; 3,200 \mathrm{ft.}\right]$ (130).

San Marcos (de) Guaimaca (San Maracos, San Marcos, San Marcos de Guaymaca, San Marcos de Guaymas) [F.M.].--A locality 9 miles west-northwest of Guaimaca; this locality is the "San Marcos" of Underwood; specimens from 3,000 to 3,500 ft. $\left[14^{\circ} 35^{\prime}, 88^{\circ} 00^{\prime}\right]$ (89).

San Pedro: see San Pedro Sula.

San Pedro Montaña (San Pedro Mts., Santa Ana Mts.) [Cortés].--The mountain range just to the west of San Pedro Sula.

San Pedro region.--A general term employed herein to indicate the region in the lower Sula Valley between Puerto Cortés and San Pedro Sula.

San Pedro Sula (San Pedro) [Cortés].--A clty, second largest in Honduras and capital of Cortés, located 8 miles southwest of Choloma; elevation was erroneously 11 sted as "5,000'" by Goodwin (1942: 111) [15'28, $88^{\circ} 01$; $250 \mathrm{ft.]} \quad(35)$.

San Pedro Tutule (Tutule) [La Paz],--A village 7 miles east of San José de La Paz $\left[14^{\circ} 13^{\prime}, 87^{\circ} 50^{\prime} ; 3,900 \mathrm{ft}\right.$. $]$.

Santa Ana (Haclenda Santa Ana, Santa Anna) [Cortés] - A locality 2 miles northwest of San Pedro Sula [15'29', $88^{\circ} 03^{\prime} ; 300 \mathrm{ft} . \mathrm{J}$.

Santa Ana Mts.: see San Pedro Montafia. 
Santa Bárbara [S.B.].--A large town, capital of Santa Bárbara, 8 miles north-northwest of Ceguaca, near the Rio Ulua; Underwood specimens from the outskirts of the city at about $1,000 \mathrm{ft} . \quad\left[14^{\circ} 53^{\prime}, 88^{\circ} 14^{\prime} ; 900 \mathrm{ft}.\right]$ (64).

SANTA BÁRBARA.--A department in northwestern Honduras bordering Guatemala between Copán and Cortés.

Santa Bárbara, Cerro [S.B.].--A high mountain, second highest in Honduras, with elevation of the top at 9,300 ft., located 5 miles east of Santa Bárbara; specimens of Monroe and Feduccia from the east and southeast slopes from 3,700 to $7,500 \mathrm{ft}$.; Underwood specimens from the west slope are labeled "Falda de Santa Bárbara" $\left[14^{\circ} 53^{\prime}, 88^{\circ} 10^{\prime}\right]$ (66).

Santa Clara [D.C.] --A locality 2 miles northeast of E1 Zamorano $\left[14^{\circ} 02^{\prime}, 87^{\circ} 00^{\prime}\right]$.

Santa Elena, Is la (Hélène) [I.B.].--A small islet about 1 mile tn diameter, situated between Isla de Roatán and Is la Barbareta $\left[16^{\circ} 25^{\prime}, 86^{\circ} 13^{\prime}\right]$.

Santa Marla: see Santa Marta.

Santa Maria, Cerro [F.M.].--A mountainous area about 12 miles northwest of Talanga; erroneously attributed to the Department of $\mathrm{La} \mathrm{Paz}$ by some authors; Underwood specimens from $4,500 \mathrm{ft}$. $\left[14^{\circ} 32^{\prime}, 87^{\circ} 15^{3}\right]$ (90).

Santa Marta (Santa Maria) [Yoro] --A village 6 miles northwest of Yorito $\left[15^{\circ} 05^{\prime}, 87^{\circ} 18^{\prime}\right]$.

Santa Rita [Copán] --A town 5 miles northeast of Copán $\left[14^{\circ} 52^{\prime}, 89^{\circ} 05^{\prime}\right]$.

Santa Rosa (de) Aguán [Colón].--A town on the north coast at the mouth of the Rio Aguán, 16 miles east of Trujillo $\left[15^{\circ} 57^{\prime}, 85^{\circ} 43^{\prime}\right]$ (28).

Santa Rosa (de) Copán [Copán] - A large town 12 miles northeast of Cucuyagua $\left[14^{\circ} 48^{\circ}, 88^{\circ} 48^{\prime} ; 3,350 \mathrm{ft}.\right]$ (55).

Sapodillas Cays: see Cayos Zapotillos.

Sapote, La: see El Zapote [Cortés].

Sauce, E1 [S.B.] --A village near the western shore of Lake $88^{\circ} 05^{\prime} ; 2$ miles south-s outhwest of $\mathrm{El}$ Jaral $\left[14^{\circ} 50^{\prime}\right.$, 
Savanna Grande: see Sabana Grande.

Segovia, Río (Rfo Coco, Wanks River).--A large river forming the boundary between Honduras and Nicaragua from western E1 Paraiso to the mouth on the Car1bbean Sea at Cabo Gracias a Dios; headwaters in the mountains of western Nicaragua.

Sepaena: see Lepaera.

Sico [Colón].--A village about 9 miles south-s outheast of Iriona $\left[15^{\circ} 50^{\prime}, 85^{\circ} 10^{\prime} ; 100 \mathrm{ft}.\right]$.

Sico, Rio.--A large river originating in northern Olancho, passing through central and eastern Colón, and emptying into the Caribbean Sea on the boundary between Colón and Gracias a Dios.

Siguatepeque (Siguatepec, Siguatipique, Siguitipeque, Sihuatepeque, Siquatepec, Siquatepeque, Sisquatepeque) Com: :-A large town 16 miles northwest of Comayagua $\left[14^{\circ} 32^{\prime}, 87^{\circ} 49^{\circ} ; 3,400 \mathrm{ft.}\right]$ (75).

Sillón, El (Montaña El Sillón) [Ocot.].--A mountainous locality 5 miles east-southeast of Nueva Ocotepeque $\left[14^{\circ} 24^{\prime}, 89^{\circ} 05^{\prime}\right]$.

Sinapa [D.C.].--An Underwood locality in the general vicinity of Tegucigalpa, exact location unknown.

Siquatepec, Siquatepeque, Sisquatepeque: see Siguatepeque.

Soluteca [La Paz] - -A locality 8 miles northeast of San José de La Paz $\left[14^{\circ} 16^{\prime}, 87^{\circ} 49^{\prime} ; 4,000 \mathrm{ft}.\right](80)$.

Subirana (Sabirana) [Yoro] --A village on a plateau $10 \mathrm{miles}$ northwest of Yorito $\left[15^{\circ} 08^{\prime}, 87^{\circ} 21^{\prime}\right]$ (45).

Sula [S.B.] - A village 12 miles southwest of Quimistán $\left[15^{\circ} 15^{\prime}, 88^{\circ} 33^{\prime} ; 650 \mathrm{ft}.\right]$ (30).

Sula, Valle (de) (Valle de Ulúa).--A low valley on the Caribbean slope along the Rio Ulua from the junction of the Rio Humuya to the north coast.

Sulaco, Rfo.--A river forming the border between Comayagua and Yoro, and between Comayagua and Francisco Morazán, emptying into the Rio Humuya.

Swan Is lands (Islas de E1 Cisne).--A group of small islands in the Caribbean Sea about 100 miles north of the mouth of the Rio Patuca. 
Tabla Grande.--A locality in the Yeguare River Valley, exact location not known; Carr specimens from 3,500 ft.

Talanga (Talienga) [F.M.].--A town $9 \mathrm{miles}$ north-northwest

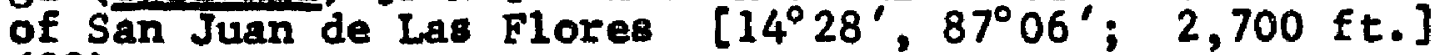
(92).

Talanga, Valle (de) [F.M.].--The valley embracing the town of Talanga.

Talanquita (E1 Talanglta. El Talangta) [F.M.].--A locality 4 Talanquita (E1 Talangita, El Talangta) [F.M.].--A locality 4 miles west-northwest of Talanga $\left[14^{\circ} 29^{\prime}, 87^{\circ} 10^{\prime}\right]$.

Tallenga: see Talanga.

Taulabé (Tanlavi, Taulebé, Taulevi) [Com.] --A town 9 miles northwest of siguatepeque $\left[14^{\circ} 38^{\prime}, 87^{\circ} 59^{\prime} ; 1,400 \mathrm{ft}.\right]$ (74).

Tegucigalpa [D.C.].--Capital and largest city of Honduras; Underwood specimens mostly from 3,200 to $3,400 \mathrm{ft}$. in hills surrounding city $\left[14^{\circ} 04^{\prime}, 87^{\circ} 13^{\prime} ; 3,050 \mathrm{ft}.\right]$ (97).

TEGUCIGALPA.--old departmental name for Francisco Morazán when the latter included also the Distrito Central.

Tela [Atl.].--A large town on the north coast just east of the Laguna Micos $\left[15^{\circ} 43^{\prime}, 87^{\circ} 29^{\prime}\right]$ (16).

Tela, Laguna: see Laguna Toloa.

Tela, Rio [At1.]. - A stream originating in the Montaña de E1 Tiburón and emptying into the Caribbean Sea at Tela.

Tibombo [Cortés].--An area of flood-fallow lakes 12 miles northeast of La Lima $\left[15^{\circ} 33^{\prime}, 87^{\circ} 49^{\prime} ; 150 \mathrm{ft}.\right]$.

Tiburón, Montafia de E1.--A short mouncain range mostly in western Atlántida, near the north cosst.

Ticamaya, Lago (de) [Cortés].--A small lake, 1 ess than 1 mile in diameter, located 6 miles southeast of Choloma $\left[15^{\circ} 31^{\prime}, 87^{\circ} 54^{\prime} ; 150 \mathrm{ft}.\right]$.

Tigra, La: see San Juancito.

Tigre, E1, Cerro Tigre, E1 Tigre Hatillo: see E1 Hatillo.

Tigre, Is la (de) El [Valle].--A volcanic 1s land, 3 miles in diameter, located in the Bay of Fonseca about $15 \mathrm{miles}$ 
southwest of San Lorenzo; elevation of summit of is land, 2,650 ft.

Tinto, Río [Olancho].--A stream originating in the Sierra de Agalta and emptying into the Rio Guayape southeast of Catacamas.

Tocoa [Colón].--A town on the Río Aguán 15 miles southsouthwest of Trujillo $\left[15^{\circ} 41^{\prime}, 86^{\circ} 03^{\prime} ; 100 \mathrm{ft}.\right]$ (27).

Toloa [At].].--A locality on the Río Ulua 20 miles west of Tela $\left[15^{\circ} 41^{\prime}, 87^{\circ} 46^{\prime} ; 50 \mathrm{ft}.\right]$ (13).

Toloa Canal (Palomas-Toloa Cana1) [At1.].--A short canal from Camp Tomasa to the Laguna Toloa.

Toloa, Laguna (Laguna Tela, Laguna Tolva).--A lagoon on the border between At Tantida and Yoro, emptying into the Río Ulúa at Toloa.

Tomasa, Camp: see Camp Tomasa.

Toncontin [D.C.].--A locality on the southern outskirts of Comayaguiela and site of the Tegucigalpa airport.

Triumpho, Cerro E1 [0lancho].--A mountain in the Sierra de Agaita, situated $8 \mathrm{miles}$ southwest of Dulce Nombre de Culmi ' $\left[15^{\circ} 06^{\prime}, 85^{\circ} 43^{\prime}\right]$ (51).

Triunfo, El [Chol.].--A town 14 miles southeast of Namasigüe $\left[13^{\circ} 06^{\prime}, 87^{\circ} 00^{\prime} ; 350 \mathrm{ft.}\right.$.

Trujillo (Truxillo) [Colón].--A large seaport on the north coast 17 miles west of Santa Rosa de Aguán $\left[15^{\circ} 55^{\prime}\right.$, $\left.85^{\circ} 59^{\prime}\right]$ (26).

Tulian (Julián) [Cortés].--A village on the north coast 6 miles northeas $t$ of Omoa $\left[15^{\circ} 45^{\prime}, 87^{\circ} 57^{\prime}\right]$.

Tutule: see San Pedro Tutule.

Ulía, Rio (Aloor River).--A large river originating in the mountains of northern $\mathrm{La}$ Paz and eastern Intibucá and emptying into the Caribbean Sea on the border between At lántida and Cortés.

Ulúa, Valle (de): see Valle de sula.

Urraco (Urraca) [Yoro] $--A$ yillage on the Río Ul ia 9 miles south of Toloa $\left[15^{\circ} 36^{\prime}, 86^{\circ} 44^{\prime} ; 100 \mathrm{ft}.\right]$ (38). 

Utila $\left[\begin{array}{c}I \cdot B ; \\ \left.86^{\circ} 56^{\prime}\right]-\frac{\text { The }}{(2)} \text {. }\end{array}\right.$

Utila, Is la (de) (Utilla Island) [I.B.].--The westernmost of the Bay Islands, located about 20 miles north of La Ceiba.

Uyuca, Cerro (Mt. Uyuca, Uyuca) [F.M.].--A high mountain about, 3 miles northwest of E1 Zamorano $\left[14^{\circ} 01^{\prime}\right.$, $87^{\circ} 05^{\prime} \mathrm{J}$.

Valladolid [Lempira].--A town 31 miles south of Gracias, near the E1 Salvador border $\left[14^{\circ} 08^{\prime}, 88^{\circ} 39^{\prime}\right]$.

VALLE.--A southern department bordering E1 Salvador and the Bay of Fonseca, west of Choluteca.

Vallectllo, Río [El P.].--A stream northwest of Danli, emptying into a tributary of the Río Guayambre.

Vásquez, Cerro: see Cerro Cantora1.

Vásquez, Montaña [D.C.].--A locality about 5 miles northwest of Archaga; sometimes erroneously attributed to the mountain range on the eastern rim of the Valle de Comayagua; Underwood specimens mostly from 6,000 ft. $\left[14^{\circ} 18^{\prime}, 87^{\circ} 18^{\prime}\right]$.

Ventanas, Las [Ocot.].--A locality in the vicinity of Belén Gualcho, exact location unknown; Goodwin (1942: 110) erroneous ly referred to the "Las Ventanas" in Cortés, near Lake Yojoa; Underwood specimens from 2,500 ft.

Verde, Monte [Ocot.].--A densely forested area within a few miles of Belén Gualcho, exact location unknown; Underwood specimens from 4,500 ft.

Villa Nueva [Cortés].--A village 6 miles northwest of Potrerillos $\left[15^{\circ} 17^{\prime}, 88^{\circ} 00^{\prime} ; 300 \mathrm{ft}.\right]$ (41).

Villa (de) San Antonio [Com.].--A village in the Valle de Comayagua 9 miles south of Comayagua $\left[14^{\circ} 16^{\prime}, 87^{\circ} 36^{\prime}\right.$; 2,000 ft.] (86).

Vojoa, Lake: see Lake Yojoa.

Wanks River: see Río Segovia.

Wankybila: see Huanquibila.

Yajoa, Lake: see Lake Yojoa. 
Yapahuás, Río (Yapuras River) [Olancho].--A small stream emptying into the Rio Patuca just upstream from the mouth of the Río Guampu.

Yaro: see Yoro.

Yaruca [At1.] --A village 13 miles south-southeast of La Ceiba $\left[15^{\circ} 36^{\prime}, 86^{\circ} 46^{\prime} ; 1,000 \mathrm{ft}.\right]$ (21).

Yeguare, Río (Río de la orilla).--A river in east-central Francisco Morazán and western El Paraíso, emptying into the Río Choluteca south of Moroceli.

Yeguare River Valley.--A locality reference of Carr and Dickinson, pertaining to the area along the Río Yeguare in the vicinity of E1 Zamorano.

Yojoa, Lake (Lake Vo joa, Lake Yahoa, Laguna de Yohoa, Lake Yohoa, Yojoa, Lago de Yojoa) [Cortes].--A large inland lake, 14 miles by 6 miles in size, located in southern Cortés on the border of Santa Bárbara and Comayagua.

Yorito [Yoro].-A town $10 \mathrm{miles}$ southwest of Yoro $\left[15^{\circ} 02^{\prime}\right.$, $\left.87^{\circ} 12 ; 2,500 \mathrm{ft}.\right]$ (46).

Yoro (Yaro) [Yoro].--A large town 10 miles northeast of Yorito $\left[15^{\circ} 09^{\prime}, 87^{\circ} 07^{\prime} ; 2,150 \mathrm{ft}.\right]$ (47).

YORO.--A large department bordered on the north by Atlantida and on the south by the Río Humuya.

Yuscarán [E1 P.] - -A town 7 miles northeast of Güinope $\left[13^{\circ} 56^{\prime}, 86^{\circ} 52^{\prime} ; 3,300 \mathrm{ft}.\right]$ (100).

Zacate Grande, Is la [Valle].--A volcanic island, $4 \mathrm{miles}$ in diameter, In the Bay of Fonseca just north of Is la de E1 Tigre; elevation of sumit of 18 land, $2,250 \mathrm{ft}$.

Zambrano (Zambrana) [D.C.].--A village 14 miles northwest of Tegucigalpa; Underwood specimens from 4,500 ft. $\left[14^{\circ} 14^{\circ}, 87^{d} 24^{\prime} ; 4,100 \mathrm{ft} \text {. }\right]^{\text {(93). }}$.

Zamorano, El [F.M.].--A town 13 miles southeast of Tegucigalpa $\left[14^{\circ} 00^{\circ}, 87^{\circ} 02^{\prime} ; 2,600 \mathrm{ft}.\right]$ (98).

Zapote, E1 (La Sapote) [Cortés].--A locality 4 miles northnortheast of E1 Jaral; this locality is the "E1 Zapote" or "La Sapote" of Carr and Dickins on [14 $57^{\prime}$, $88^{\circ} 02^{\prime} ; 2,000 \mathrm{ft}$.]. 
Zapote, E1 [F.M.].--A small farm 5 miles south of Sabana Grande; this locality is the "E.1 Zapote" of Underwood $\left[13^{\circ} 46^{3}, 87^{\circ} 16^{\prime} ; 2,500 \mathrm{ft}\right.$. $]$.

Zapot1llos, Cayos (Sapodilles Cays).--A group of several small cays at the southern end of the line of cays off the east coast of British Honduras, in the Bay of Honduras. 


\section{LITERATURE CITED}

Aldrich, John W.

1946. New subspecies of birds from western North Amer1ca. Proc. Biol. Soc. Washington, 59: 129136.

1951. A review of the races of the Trail1's Flycatcher. Wils on Bull., 58: 192-197.

Aldrich, John $W .$, and Benjamin Patterson Bole, Jr.

1937. The birds and mammals of the western slope of the Azuero Peninsula (Republic of Panama). Sci. Publ. Cleveland Mus. Nat, H1st., 7: 1-196.

Aldrich, John $W .$, and Allen J. Duvall.

1958. Distribution and migration of races of the Mourning Dove. Condor, 60: 108-128.

Allen, Paul $\mathrm{H}$.

1955. The conquest of Cerro Santa Barbara, Honduras. Ceiba, 4: 253-270.

Amadon, Dean.

1949. Notes or Harpyha 11aetus. Auk, 66: 53-56.

1954. On the correct names for the caracaras and for the Long-winged Harrier. Auk, 71: 203-204.

1964. Taxonomic notes on birds of prey. Amer. Mus. Novit., no. 2166, 24 Pp.

Amadon, Dean, and Don R. Eckelberry.

1955. Observations on Mexican birds. Condor, 57 : 65-80.

American Ornithologists ' Union.

1957. Check-118t of North American birds. 5th ed. Lord Baltimore Pres8, Baltimore, $1 x+691$ pp.

Anonymous .

1935. Lista 8 istematica de las Aves Argentinas. E1 Hornero, 6: 151-196.

Austin, Oliver, L., Jr.

1929. Birds of the Cayo D1strict, British Honduras. Bul1. Mus . Comp. Zool., 69: 363-394. 
Austin, Oliver L., Sr.

1953. The migration of the Common Tern (Sterna hirundo) in the Western Hemis phere. BirdBanding, 24: 39-55.

Batrd Spencer $F$.

1864. Review of American birds. Pt. 1. Smithsonian Institution, Washington, $450 \mathrm{pp}$.

Batrd, Spencer F., T. M. Brewer, and Robert Ridgway.

1874a. A history of North American birds. Land birds, vol. 1. Little, Brown, and Co., Boston, xxv11i +597 pp.

1874b. A history of North American birds. Land birds, vol. 2. Little, Brown, and Co., Boston, $\mathrm{vi}+590 \mathrm{pp}$.

1884. The water birds of North America. Vo1. 2. Memoirs Mus. Comp. Zoo1., 13: 1-552.

Baird, Spencer F., and Robert Ridgway.

1873. On some new forms of American birds. Bull. Essex Inst., 5: 197-201.

Bangs, Outram.

1902. Description of a new thrush from Chiriqui. Proc. Now England Zool. C1., 3: 91-92.

1903. Birds and mammals from Honduras. Bull. Mus. Comp. Zoo1., 39: 141-159.

1905. Descriptions of seven new subspecies of American birds. Proc. Biol. Soc. Washington, 18: $151-156$.

1907a. On the wood ralls, genus Aramides, occurring north of Panama. Amer. Natur., 41: 177-187.

$1907 \mathrm{~b}$. On a collection of birds from western Costa Rica. Auk, 24: 287-312.

1908. On certain Costa Rican birds. Proc. New England Zool. C1., 4: 23-35.

1919. The races of Dendrolca vitellina Cory. Bull. Mus . Comp. Zoo1., 42: 493-495.

1930. Types of birds now in the Museum of Comparative Zoology. Bul1. Mus. Comp. Z001., 70: 145-426.

Bangs, Outram, and Thomas Barbour.

1922. Birds from Darien. Bull. Mus . Comp. Zool., 65: 191-229.

Bangs, Outram, and Morton E. Peck.

1908. On some rare and new birds from British Honduras. Proc. Bio1. Soc. Washington, 21: 43-46. 
Bangs Outram, and Thomas E. Penard.

1919. Some critical notes on birds. Bull. Mus. Comp. Zool., 63: 21-40.

1921. Notes on some American birds, chiefly Neotropical. Bul1. Mus . Comp. Zool., 64: 365-397.

1922. The identity of Attila flammulatus Lafresnaye. Proc. Biol. Soc. Washington, 35: 223-224.

Bangs, Outram, and James L. Peters.

1927. Birds from the rain forest region of Vera Cruz. Bul1. Mus . Comp. Zool. 67: 469-487.

1928. A collection of birds from Oaxaca. Bull. Mus. Comp. 2001., 68: 385-404.

Bard, Samuel A. [pen name for Ephraim George Squier].

1855. Walkna; or, adventures on the Mosquito shore. Harper and Bros., New York, 366 pp.

Beard J. S.

1944. Climax vegetation in tropical America. Ecol., 25 : $135-163$.

Bengs ton, N. A.

1926. Notes on the physlography of Honduras. Geogr. Rev., 16: 403-413.

Berlepsch, Hans Graf von.

1888. Descriptions of new species and subspecies of birds from the Neotropical region. Auk, 4: 449460 .

1907. On the genus Elaenla Sundev. Ornis, 14: 372448 .

1912. Revision der Tanagriden. Verh. V. Inter. Orn.-Kong. (1910): 1001-1148.

Berlioz, J.

1938. Notes critiques sur des Trochilidés. O1seau, 8: 3-19.

Blake, Enmet R.

1950. Report on a collection of birds from Oaxaca, Mexico. Fieldiana, Zoo1., 31: 395-419.

1958. Birds of Volcán de Chiriquí, Panama. Fieldiana, Zool., 36: 499-577.

Bonaparte, Carolo Luciano.

1850. Conspectus Generum Avium. E. J. Bril1, 543 pp. 
Bond, James .

1936. Resident birds of the Bay Islands of Spanish Honduras. Proc. Acad. Nat. Sci. Philadelphia, 88: 353-364.

1937. New records for Spanish Honduras. Auk, 54: 102.

1939. Notes on birds from the West Indies and other Caribbean 1slands. Notulae Naturae, no. 13, 6 pp.

1950a. Check-1ist of birds of the West Indies. 3rd ed. Wickersham Print.ing Co., Lancaster, Pa., $x i 11+200$ pp.

1950b. Vireo solitarius in Honduras. Auk, 67: 395.

1954. Birds of Turnetfe and Northern Two Cays,
British Honduras. Notulae Naturae, no. 260, 10 pp.

1959. Fourth supplement to the check-1ist of birds of the West Indies (1956). Acad. Nat. Sci. Philadelphia, 12 pp.

Boucard, Adolphe.

1895. Genera of humming birds. Pardy and Sons, London, xiv + 412 pp.

Bourcier, J., and F. Mulsant.

1852. Description des Quelques Nouvelles Espèces D'oiseaux-Mouches. Ann. Sci. Phys. Nat. d'Agr. et d'Ind., (2), 4: 139-144.

Brodkorb, Pierce.

1938. New birds from the District of Soconusco, Chiapas. Occas. Papers Mus. Zool., Univ. Michigan, no. 369,7 pp.

1939. New subspecies of birds from the District of Soconusco, Chiapas. Occas. Papers Mus. Zool., Univ. Michigan, no. 401,7 pp.

1940a. New birds from southern Mexico. Auk, 57: 542549.

1940b. A new hawk from southern Mexico. Occas. Papers Mus. Zool., Univ. Michigan, no. 425, 4 pp.

1942a. A revisionary study of the wren Thryothorus pleurostictus. Occas. Papers Mus. Zool., Univ. Michigan, no. $459,19 \mathrm{pp}$.

$1942 \mathrm{~b}$. Notes on 3 cne races of the Rough-winged Swallow. Condor, 44: 214-217.

1942c. The chachalaca of interior Chiapas. Proc. Biol. Soc. Washington, 55: 181-182.

1943a. Geographic variation in the Band-tailed Pigeon. Condor, 45: 19-20.

1943b. Birds from the Gulf lowlands of southern Mexico. Misc. Publ. Mus . Zool., Univ. Michigan, no. 55, 88 pp. 
1943c. Two new flycatchers of the genus Elaenia. Occas. Papers Mus. Zool., Univ. Michigan, no. 478, 4 PP.

1943d. The Rufous-browed Wrens of Chiapas, Mexico. Occas. Papers Mus, Zool., Univ. Michigan, no. 480 , 3 pp.

1944a. Geographical variation in the Black Vulture. Papers Michigan Acad. Sci., Arts, and Letters, 29 (1943): 115-121.

1944b. The subspecies of the gnatcatcher Polioptila a1bilorts. Jour. Washington Acad. Sc1., 34: 311316.

1947. The Banded Wrens of northern Middle America. Condor, 49: 242-243.

1948. Taxonomic notes on the Laughing Falcon. Auk, 65: 406-410.

1950. Geographical variation in the Gray Kingbird, Tyrannus domintcensis. Auk, 67: 333-334.

Buchanan, 0. Marcus.

1964. The Mexican races of the Least Pygmy Owl. Condor, 66: 103-112.

Burleigh, Thomas D.

1942. A new Barn Swallow from the Gulf coast of the United States. Occas. Papers Mus. Zool., Louls Lana State Univ., no. 11: 179-183.

1959a. Geographic variation in the Catbird. Oriole, 24: $29-32$.

1959b. A new subspecies of Veery from the northwestern United States. Proc. Biol. Soc. Washington, 72; 33-36.

1960a. Three new subspecies of birds from western North America. Auk, 77: 210-215.

1960b. Geographic variation in the Western Wood Pewee (Contopus sordidulus). Proc. Biol. Soc. Washington, 73: 141-146.

Burleigh, Thomas D., and Allen J. Duvall.

1952. A new ovenbird from the southeastern United States. W11s on Bul1., 64: 39-42.

1963. Geographic variation in the Cedar Waxwing (Bombycillia cedrorum). Proc. Btol. Soc. Washington, 76: 177-180.

Burleigh, Thomas D., and George H. Lowery, Jr.

1945. Races of Vireo griseus in eastern united States. Amer. Mid. Natur, , 34: 526-530.

Burleigh, Thomas D., and Harold S. Peters .

1948. Geographic variation in Newfoundland birds. Proc. Biol. Soc. Washington, 61: 111-124. 
Cabanis, Jean.

1851. Mus eum Ornithologicum Heineanum. Pt. 1. R. Frantz, vili + 253 pp.

Cabanis, Jean, and Ferdinand Heine.

1859. Mus eum Ornithologicum Heineanum. Pt. 2 . R. Frantz, $11+175$ pp.

1860. Mus eum Ornithologicum Heineanum. Pt. $3 . R$. Frantz, 220 pp.

1863. Museum Ornithologicum Heineanum. Pt. 4, sect. I. R. Frantz, 229 pp.

Carr, Archle Fairly, Jr.

1950. Outline for a classification of animal habitats in Honduras. Bull. Amer. Mus. Nat. Hist., 94: 563-594.

1953. High jungles and low. Univ. Florida Press, Gainesville, xvil + 226 pp.

Carr, Marjorie H., and J. C. Dickins on, Jr.

1951. The San Geronimo Swift in Honduras. Wils on Bu:11., 63: $271-273$.

Carriker, M. A., Jr.

1910. An annotated 11st of the birds of Costa Rica including Cocos Island. Ann. Carnegle Mus., 6: 314-915.

Chapman, Frank $M$.

1923. The distribution of the motmots of the genus Momotus. Bull. Amer. Mus. Nat. Hist., 48: 27-59.

1925. The relationships and distribution of the warblers of the genus Compsothlypis. Auk, 42: 193-208.

1926. The distribution of bird-1ife in Ecuador. Bul1. Amer. Mus. Nat. Hist., 55: 1-784.

1940. The post-glacial history of Zonotrichia capen81s. Bull. Amer. Mus. Nat. Hist., 77: 381-438.

Chapman, Frank M., and Ludlow Griscom.

1924. The house wrens of the genus Iroglodytes. Bull. Amer. Mus. Nat. Hist., 50: $279-304$.

Cherrie, George $\mathrm{K}$.

1892. Notes on Costa Rican birds. Proc. U. S. Natl. Mus. (1891), 14: 517-537.

Chubb, Charles.

1919a. [Descriptions of new forms of South and Central Amertcan birds]. Bull. Brit. Orn. Cl. (1918), 39: 21-23. 
1919b. [Descriptions of new forms of South and Central American birds]. Bull. Brit. Orn. C1. (1918), 39: 41-42.

Coffey, Ban B., Jr.

1943. Post-juvenal migration of herons. BirdBanding, 14: 34-39.

1948. Southward migration of herons. Bird-Banding, 19: $1-5$.

Conover, H. B.

1932. A new race of bob-white from Costa Rica. Condor, 34: 174-175.

1933. The races of the tinamou Crypturellus cinnamomeus. Proc. Biol. Soc. Washington, 46:113II7.

1937. A new race of Dactylortyx from Honduras. Proc. B1ol. Soc. Washington, 50: 73-74.

1941. A study of the dowitchers. Auk, 58: 376-380.

Cooch, Graham.

1961. Ecological aspects of the Blue-Snow Goose complex. Auk, 78: $72-89$.

Cooke, May Thacher.

1938a. Returns of banded birds: Recoveries of banded marsh birds. Bird-Banding, 9: 80-87.

1938b. Some interesting recoveries of banded birds. Bird-Banding, 9: 184-190.

1941. Banded birds recovered in E1 Salvador. Auk, 58: $589-590$.

1950a. Returns from banded birds. Bird-Banding, 21: $11-17$.

1950b. Returns from banded birds. Bird-Banding, 21 : $145-148$.

Cooke, Wells w.

1909. The migration of flycatchers--8th and concluding paper. Bird-Lore, 11: 12-14.

1914. Distribution and migration of North American rails and their allies. Bull. U. S. Dept. Agr., $128: 1-50$.

Cory, Charles B.

1892. Catalogue of West Indian birds. Cory, Boston, $160 \mathrm{pp}$.

1918. Catalogue of birds of the Americas and the adjacent Islands -. . Pt. 2, no. 1. Field Mus. Nat. Hist., publ. 197, Zool. Ser., no. 13, 315 pp. 
1919. Catalogue of birds of the Americas and the ad jacent is lands ... Pt. 2, no. 2. Field Mus. Nat. Hist., publ. 203, Zool. Ser., no. 13, 316-607.

Cory, Charles B., and Charles E. Hellmayr.

1924. Catalogue of birds of the Americas and the adjacent is lands . . Pt. 3. Field Mus. Nat. Hist., publ. 223, Zool. Ser., no. 13, vil + 369 pp.

Cuvier, M. G.

1820. Description D'Une Nouvelle Espèce de Dindon de la Bate de Honduras. Mém. Mus. D'Hist. Nat., 6: $1-4$.

Dearborn, Ned.

1903. Catalogue of a collection of birds from Guatemala. Fleld Mus. Nat. Hist., publ. 125, Orn. Ser., 1: 69-138.

Deignan, H. G.

1936. Notes on a small collection of birds from the Republic of Honduras. Auk, 53: 186-193.

1949. The correct name for the Mexican Crested Flycatcher. Condor, 51: 270.

Delacour, Jean.

1938. Journal de Croisiere (Yacht Rosaura, octobre 1937-Janvier 1938). O18eau, (n.s.), 8: 541-557.

Delacour, Jean, and Ernst Mayr.

1945. The family Anatidae. Wilson Bull., 57: 3-55.

de Schauensee, Rodolphe M.

1952. A review of the genus Sporophila. Proc. Acad. Nat. Sct. Philadelphia, 104: 153-196.

1964. The birds of Colombia and adjacent areas of South and Central America. Livingston Publishing Co., Narberth, Pa., xvI + 427 pp.

Dickerman, Robert $W$.

1961. A new subspecies of the Pinnated Bittern. Wils on Bul1., 73: 333-335.

Dickerman, Robert W., and Dwain W. Warmer.

1961. Distribution records from Tecolutla, Veracruz, with the first record of Porzana flayiventer from Mexico. W118 on Bul1., 73: 336-340.

1962. A new Orchard Oriole from Mexico. Condor, 64: 311-314. 
Dickey, Donald.

1929. A new wood rail from El Salvador. Condor, 31: 33-34.

Dickey, Donald, and A. J. van Rossem.

1924. A new race of the Least Bittern from the Pacific coast. Southern California Acad. Scl., 23: 11 .

1925. Four new birds from Salvador. Proc. Biol. Soc. Washington, 38: 133-135.

1926a. Two new pigeons from Salvador. Proc. Biol. Soc. Washington, 39: 109-110.

1926b. A southern race of the Fan-talled Warbler. Condor, 28: 270-271.

1927a. Seven new birds from Salvador. Proc. Biol. Soc. Washington, 40: 1-8.

$1927 \mathrm{~b}$. The spotted Rock Wrens of Central America. Proc. Blol. Soc. Washington, 40: 25-28.

1928a. A new race of the White-throated Swift from Central America. Condor, 30: 193.

1928b. Further descriptions of new birds from E1 Salvador. Proc. Biol. Soc. Washington, 41: 129-132.

1928c. A new subspecies of Myloborus and a new species of Chlorospingus from E1 Salvador. Proc. Biol. Soc. Washing ton, 41: 189-190.

1928d. A new Chipping Sparrow from Central America. Condor, 30: 359 .

1929a. A new race of Troglodytes rufociliatus from E1 Salvador. Ibis, 1929: 264-266.

1929b. The races of Lampornis viridipallens (Bourcier and Mulsant). Proc. Biol. Soc. Washington, 42: 209-211.

1929c. A new Attila from E1 Salvador. Proc. Biol. Soc. Washington, 42: 217-218.

1929d. A new race of the Hairy Woodpecker from El Salvador. Proc. Biol. Soc. Washington, 42: 219-220.

1930a. Geographic variation in Aulacorhymchus prasinus (Gould). Ibis, 1930: 48-55.

1930b. A new bluebird from El Salvador. Condor, 32: $69-70$.

1930c. The identity of Ortyx leucopogon Lesson. Condor, 32: 72-73.

1938. The birds of El Salvador. Field Mus. Nat. Hist., Zool. Ser., 23: 1-609.

Dickinson, J. C., Jr.

1951. A nest of Chaetura vauxi richmondi in central Honduras. WTison Bu11., 63: 201-202. 
Dilger, William C.

1956a. Hostile behavior and reproductive isolating mechanisms in the avian genera Catharus and Hylocichla. Auk, 73: 313-353.

$1956 \mathrm{~b}$. Adaptive modifications and ecological isolating mechanisms in the thrush genera Catharus and Hylocichla. Wilson Bull., 68: 171-199.

Dunn, Emmett Reid.

1932. Reptiles and amphibians from Honduras. Proc. Acad. Nat. Sci. Philadelphia, 84: 21-32.

Durón, Jorge Fidel.

1946. Indice de la bibliografla hondureña. Calderón, Tegucigalpa, vili + $211 \mathrm{pp}$.

Dwight, Jonathan, and Ludlow Griscon.

1921. A revision of Atlapetes gutturalis with description of three new races. Amer. Mus. Novit., no. 16,4 pp.

1924. Descriptions of new birds from Costa Rica. Amer. Mus. Novit., no. 142,5 pp.

1927a. A new and remarkable flycatcher from Guatemala. Amer. Mus. Novit., no. 254, 2 pp.

$1927 \mathrm{~b}$. A revision of the geographical races of the Blue Gros beak (Guiraca caerulea). Amer. Mus. Novit., no. 257,5 pp.

Eaton, Stephen $W$.

1957. Variation in Seiurus noveboracensis. Auk, 74: 229-239.

Eisenmann, Eugene.

1955a. The species of Middle American birds. Trans. Linn. Soc. New York, 7: 1-128.

1955b. Status of the Black-polled, Bay-breasted, and Connecticut warblers in Middle America. Auk, 72: 206-207.

1958. The spelling of Notharchus macrorhynchus hyperthynchus (Sclater). Auk, 75: 101.

1959. The correct specific name of the Quetzal, Pharomachrus mocinno. Auk, 76: 108.

$1962 \mathrm{a}$. On the genus "Chamaethlyp is" and its supposed relationship to rteria. Auk, 79: 265-267.

$1962 \mathrm{~b}$. Notes on nighthawks of the genus Chordeileg in southern Middle America, with a description of a new race of Chordeiles minor breeding in Panamá. Amer. Mus. Novit., no. 1094, 21 pp. 
Eisenmann, Eugene, and F. Carlos Lehmann V.

1962: A new species of swift of the genus Cypseloides from Colombia. Amer. Mus . Novit., no. 2117, 16 pp.

Elliot, David Giraud.

1860. Description of a new species of Eupsychortyx. Ann. Lyc. Nat. Hist., New York, 7: 106-10\%.

1875. Notes on the Trochilidae. The genera Chlor-

ostilbon and Panychlore. Ibis, 1875: 149-172.

1876. Notes on the Trochilidae. The genera Cyano-

1878 myia and Heliotrypha. Ibis, 1876: 311-319.

Thaumatias. Ib $18,1878: 35-53$.

1879. A classification and symops is of the Trochilidae. Smith. Contr. to knowledge, no. 317, $\mathrm{xi1}+277 \mathrm{pp}$.

1888. The Jacanidae. Auk, 5: 288-305.

Fisher, Albert K., and Alexander Wetmore.

1931. Report on birds recorded by the Pinchot Expedition of 1929 to the Caribbean and Pacific. Proc. U. S. Nat1. Mus., 79: 1-66.

Forbes, Henry $0 .$, and Herbert $C$. Robinson.

1897. Catalogue of the parrots (Psittaci) in the Derby Mus eum. Bul1. Liverpool Mus ., 1: 5-22.

1898a. Catalogue of the cuckoos and plantain-eaters (Cuculi) in the Derby Museum. Bull. Liverpool Mus ., 1: 37-48.

1898b. Catalogue of the picarian birds (Pici): . . , in the Derby Museum. Bull. Liverpool Mus., 1: $87-118$.

1899a. Catalogue of the Coraclae . . , in the Derby Mus eum. Bul1. Liverpool Mus ., 2: 15-34.

1899b. Catalogue of the charadriomorphic birds ...., in the Derby Museum. Pt. 1. Bull. Liverpool Mus ., 2: $51-75$.

1900. Catalogue of the charadriomorphic birds ..., in the Derby Museum. Pt. 2. Bull. Liverpool Mus ., 2: 117-150.

Friedmann, Herbert.

1927. A revision of the classification of the cowbirds. Auk, 44: 495-508.

1935. A new race of the Crested Eagle-hawk, Spizaetus ornatus. Jour. Washington Acad. Sc1., 25: 450451 .

1944. A review of the forms of Colinus leucopogon (Lesson). Proc. Biol. Soc. Washington, 57: 15-16. 
1947. Geographic variation of the Black-bellied, Fulvous, and White-faced tree-ducks . Condor, 49: 189-195.

Friedmann, Herbert, Ludlow Griscom, and Robert T. Moore.

1950. Distributional check-1ist of the birds of Mexico. Pt. 1. Pacific Coast Avif., no. 29, 202 pp.

Gadow, Hans.

1883. "Catalogue of birds in the British Museum." vol. 17. London, $x i 11+385 \mathrm{pp}$.

Gavito, Sanchez.

1962. A border dispute settled. Americas, 14: 10-12.

George, William G.

1962. The classification of the Olive Warbler. Amer. Mus. Novit., no. 2103,41 pp.

Godfrey, W. Earl.

1951. A new northwestern O11ve-backed Thrush. Canadian Field-Natur., 65: 172-174.

Goodwin, Derek.

1958. Remarks on the taxonomy of some American doves. Auk, 75: 333-334.

Goodwin, George $C$.

1942. Mamma1s of Honduras. Bull. Amer. Mus. Nat. Hist., 79: 107-195.

Gosner, Kenneth $L$.

1957. Birds of Hondurss highlands. Nat. Mag., 50: 70-72.

Gould, John.

1838. [New specles of birds]. Proc. Zool. Soc. London, 1837: 79-81.

1843. [New species of the genus Ortyx]. Proc. Zool. Soc. London, 1842: 181-184.

1846. A monograph of the odontophorinae, or partridges of America. London, $23 \mathrm{pp} .+32 \mathrm{pl}$. (with text).

1875. A monograph of the Trogonidae, or family of trogons. London, $x \times$ pp. +46 pl. (wtth text).

1886. A monograph of the Trochilidae, or family of huming-birds. Supplement. Henry Sotheran and Co., London, [101] pp. 
Graber, Jean W., and Richard R. Graber.

1959. Winter observations of birds in Oaxaca, Mexico. Southwestern Natur., 14: 66-82.

Gray, George Robert.

1848a. List of the specimens of birds in the collection of the British Museum. Pt. 1: Accipitres. London, vili + $120 \mathrm{pp}$.

1848b. List of the specimens of birds in the collection of the British Museum. Pt. 2, sect. I: Fissirostres. London, $80 \mathrm{pp}$.

1859. List of the specimens of birds in the collection of the British Museum. Pt. 3, sect. II: Psittacidae, London, $110 \mathrm{pp}$.

1867. List of the specimens of birds in the collection of the British Museum. Pt. 5: Gallinae. London, $120 \mathrm{pp}$.

1868. List of the specimens of birds in the collection of the British Museum. Pt. 3, sect. III and IV: Capitonidae and Picidae. London, 137 pp.

1869. Hand-1ist of genera and species of birds, distinguishing those contained in the British Museum. Pt. 1: Accipitres, Flssirostres, Tenuirostres, and Dentirostres. London, xx + $404 \mathrm{pp}$.

1870. Hand-1ist of genera and'species of birds, distinguishing those contained in the British Museum. Pt. 2: Conirostres, Scansores, Columbae, and Gallinae. London, $\mathrm{xv}+278 \mathrm{pp}$.

1871. Hand-iist of genera and species of birds, distinguishing those contained in the British Museum. Pt. 3: Struthiones, Grallae, and Anseres. London, $x I+350 \mathrm{pp}$.

Griscom, Lud low.

1926. The ornithological results of the Mason-Spinden Expedition to Yucatan. Pt. 1. Amer. Mus. Novit., no. 235,19 pp.

1928. New birds from Mexico and Panama. Amer. Mus. Novit., no. 293,6 pp.

1929a. A collection of birds from Cana, Darien. Bul1. Mus. Comp. Zool., 69: 149-190.

1929b. Studies from the Dwight Collection of Guatemala birds. Pt. 1. Amer. Mus. Novit., no. 379, 13 pp.

1929c. A review of Eumomota supercillosa. Proc. New England 2001. C1., 11: 51-56.

1930a. New name for Caprimulgus ridgwayl minor. Auk, 47: 85 .

1930b. Studies from the Dwight Collection of Guatemala birds. Pt. 2. Amer. Mus. Novit., no. 414,8 pp. 
1930c. Critical notes on Central American birds. Proc. New England Zool. C1., 12: 1-8.

1930d. Revisions of two Central American birds. Occas. Papers Boston Soc. Nat. Hist., 5: 287-292.

1930e. Studies from the Dwight Collection of Guatemala birds. Pt. 3. Amer. Mus. Novit., no. 438, 18 pp.

1931. Notes on rare and little known Neotropical pygmy owls. Proc. New Eng land Zool. C1., 12: 3743.

1932a. The ornithology of the Caribbean coast of extreme eastern Panama. Bull. Mus. Comp. Zool., 72: $301-372$.

1932b. Distribution of bird-1ife in Guatemala. Bull. Amer. Mus. Nat. Hist., 64 : ix +439 pp.

1932c. New birds from Honduras and Mexico. Proc. New Eng land 2001. C1., 13: 55-62.

1935a. The ornithology of the Republic of Panama. Bul1. Mus . Comp. Zoo1., 78: 259-382.

1935b. Critical notes on Central American birds in the British Museum. Ibis, 1935: 541-554.

1937a. A monographic study of the Red Crossbill. Proc. Boston Soc. Nat. Hist., 41: 77-210.

1937b. A collection of birds from Omilteme, Guerrero. Auk, 54: 192-199.

Gross, Alfred 0 .

1940. The migration of Kent Island Herring Gul1s. Bird-Banding, 11: 129-155.

Gyldenstolpe, Nils.

1945. The bird fauna of Rio Jurua in western Brazil. K. svensk. Vetensk.-Akad. Hand1., 22: 310-311.

Harg1tt, Edward.

1890. "Catalogue of birds in the British Museum." vol. 18. London, $x v+597 \mathrm{pp}$.

Hartert, Emst.

1892. "Catalogue of birds in the British Museum." Vo1. 16. London, xvi $+703 \mathrm{pp}$.

1900. Trochilidae (Das Tierreich no. 9). R. Friedländer and Son, Berlin, ix +254 pp.

1913. [Description of new subspecies of birds]. Bull. Brit. Orn. $\mathrm{Cl} 1,33: 76-79$.

Havers chmidt, F.

1958. Notes on the breeding habits of Panyptila cayennens is. Auk, 75: 121-130. 
Heine, Ferdinand, and Anton Reichenow.

1890. Nomenclator Musel Heineani Ornithologica. R. Friedländer and Son, Berlin, vi $+373 \mathrm{pp}$.

Helbig, Karl M.

1959. Die Landschaften von Nordost-Honduras. Hermann Haack, Hamburg, vi $+270 \mathrm{pp}$.

Hel Imayr, Charles E.

1902. Revision einiger neotropischen Turdidae. Jour. f. Orn., (9), 50: 44-69.

1911. A contribution to the ornithology of western Coíombia. Proc. Zool. Soc. London, 1911: 10841213.

1925. Catalogue of birds of the Americas and the adjacent islands . . Pt. 4. Field Mus. Nat. Hist., publ. 234,2001 . Ser., no. 13, 1v + 390 pp.

1927. Catalogue of birds of the Americas and the adjacent 18Iands . . Pt. 5. Field Mus . Nat. Hist., publ. 242 , Zool. Ser., no. $13, v i+517$ pp.

1929. Catalogue of birds of the Americas and the adjacent is lands . . Pt. 6. Field Mus . Nat. Hist., publ. 266, zool. Ser., no. 13, v + 258 pp.

1934. Catalogue of birds of the Americas and the adjacent islands - . Pt. 7 . Fleld Mus . Nat. H1st., pub1. 330, Zool. Ser., no. 13, v1 + 531 pp.

1935. Catalogue of birds of the Americas and the adjacent is lands . - Pt. 8. Fleld Mus . Nat. Hist., publ. 347, Zool. Ser., no. 13, vi + 541 pp.

1936. Catalogue of birds of the Americas and the adjacent islands. . Pt. 9. Fleld Mus. Nat. Hist., pub1. 365, Zool. Ser., no. 13, v + 458 pp.

1937. Catalogue of birds of the Americas and the adjacent islands . . Pt. 10. Fleld Mus. Nat. Hist., publ. 381, Zool. Ser., no. 13, v + 228 pp.

1938. Catalogue of birds of the Americas and the ad jacent is lands . . Pt. 11. Field Mus. Nat. Hist., publ. 430, Zool. Ser., no. 13, vi + 662 pp.

Hellmayr, Charles E., and Boardman Conover.

1932. Notes on some Neotropical game birds. Auk, 49: $324-336$.

1942. Catalogue of birds of the Americas and the adjacent islands ... Pt. 1, no. 1. Field Mus. Nat. Hist., pub1. 514, Zoo1. Ser., no. 13, $\mathrm{v1}+636 \mathrm{pp}$.

1948a. Catalogue of birds of the Americas and the ad facent islands . $\cdot$ Pt. 1, no. 2. Field Mus. Nat. Hist., pub1. 615, Zool. Ser., no. 13, vii +434 pp. 
1948b. Catalogue of birds of the Americas and the adjacent is lands ... Pt. 1, no, 3. Field Mus. Nat. Hist., publ. 616, Zool. Ser., no. 13, $\mathrm{v} 1+383 \mathrm{pp}$.

1949. Catalogue of birds of the Americas and the adjacent is lands... Pt. 1, no. 4. Field Mus. Nat. Hist., publ. 634, Zool. Ser., no. 13, $\mathrm{vi}+358 \mathrm{pp}$.

Henderson, George.

1809. An account of the British settlement of Honduras. C. and R. Baldwin, London, 191 pP.

Holdridge, Leslie R.

1947. Determination of world plant formations from simple climatic data. Science, 105: 367-368.

1953. The vegetation of mainland Middle America. Proc. 8th Pacific Sci. Congr., 4: 149-161.

Howell, Thomas $\mathrm{R}$.

1955. A Southern Hemisphere migrant in Nicaragua. Condor, 57: 188-189.

1956. Variation in Deconychura longlcauda in Central America and Colombia. Auk, 73:517-528.

1957. Birds of a second-growth rain forest of Nicaragua. Condor, 59: 73-111.

Huber, Wharton.

1923. Two new birds from Nicaragua. Auk, 40: 300302 .

1932. Birds collected in northeastern Nicaragua in 1922. Proc. Acad. Nat. Sc1. Philadelphia, 84: 205-249.

Janes, Donald $W$.

1964. The Goss ornithological collection--a centennial. Kansas Orn. Soc. Bul1., 15: 9-12.

Johannessen, Car1 L.

1963. Savannas of interior Honduras. IberoAmericana, no. 46, $160 \mathrm{pp}$.

Johns on, R. A.

1953. Breeding notes on two Panamanian antbirds. Auk, 70: 494-496.

Johnston, Richard F.

1961. The genera of American ground doves. Auk, 78: $372-378$. 
Keenagh, Peter.

1938. Mosquito coast. Houghton Mifflin Co., Boston and New York, $x i+286 \mathrm{pp}$.

Lack, David.

1956. A review of the genera and nesting habits of swifts. Auk, 73: 1-32.

Lafresnaye, F. de.

1852. Sur quelques nouvelles espèces d'Oiseaux. Rev. et Mag. Zool., (2), 4: 460-471.

Land, Hugh $C_{\text {., }}$ and William L. Schultz.

1963. A proposed 8 ubspecies of the Great Potoo, Nyctibius grandis (Gmelin). Auk, 80: 195-196.

Land, Hugh C., and Larry L. Wolf.

1961. Additions to the Guatemalan bird 1ist. Auk, 78: $94-95$.

Lantz, D. E.

1899. A list of birds collected by Col. N. S. Goss in Mexico and Central America. Trans. Kansas Acad. Sc1. (1897-1898), 16: 218-224.

Lanyon, Wesley $\mathrm{E}$.

1960. The Middle American populations of the Crested Flycatcher Myiarchus tyrannulus. Condor, 62: $341-350$.

1961. Specific 1 imits and distribution of Ashthroated and Nutting flycatchers. Condor, 63:

$441-449$.

Lawrence, George N.

1867. Descriptions of five new species of Central American birds. Proc. Acad. Nat. Sci. Philadelphia, 19: 232-234.

Lincoln, Frederick $C$.

1933. State distribution of returns from banded ducks. Second paper--British Columbia, California, Connecticut, Georgia, Illinois, Iowa, and Kansas. Bird-Band ing, 4: 19-32.

1936. Returns of banded birds. Third Paper. BirdBanding, 7: 139-148.

Lowe, Percy R.

1909. Notes on 8 ome birds collected during a cruise in the Caribbean Sea. Ib1s, 1909: 304-347.

1911. A naturalist on desert 1slands. Charles Scribner's Sons, New York, xil +300 pp. 
Lowery, George H., Jr., and Walter W. Dalquest. 1951. Birds from the state of Veracruz, Mexico. Univ. Kansas Pub1. Mus. Nat. Hist., 3: 531-649.

Lowery, George H., Jr., and Robert J. Newman.

1949. New birds from the state of San Luis Potosi and the Tuxtla Mountains of Veracruz, Mexico. Occas. Papers Mus. Zool., Loulsiana State Univ., no. 22, $10 \mathrm{pp}$.

Mayr, Ernst.

1958. The correct gender of generic names ending in -rhynchus, -rhamphus, -gnathus. Auk, 75: 225.

Mayr, Ernst, and James C. Greenway, Jr. (editors).

1960. Check-1ist of birds of the world. Vol. 9. Cambridge, xil +506 pp.

1962. Check-ist of birds of the world. Vol. 15. Cambridge, $x+315$ pp.

Mayr, Ernst, and Raymond A. Paynter, Jr. (editors).

1964. Check-1ist of birds of the world. Vol. 10. Cambridge, ix $+502 \mathrm{pp}$.

Meanley, Brooke, and Gorman M. Bond.

1950. A new race of Swains on's Warbler from the Appalachian Mountains. Proc. Biol. Soc. Washington, 63: 191-193.

Miller, Alden $\mathrm{H}$.

1942. Differentiation of the oven-birds of the Rocky Mountain region. Condor, 44: 185-186.

1952a. Two new races of birds from the upper Magdalena valley of Colombia. Proc. Biol. Soc. Washington, 65: 13-17.

1952b. The generic name of the White-bellied Wren in Mexico. Condor, 54: 322.

Miller, Alden H., Herbert Friedmann, Ludlow Griscom, and Robert I. Moore.

1957. Distributional check-1ist of the birds of Mexico. Pt. 2. Pacific Coast Avif., no. 33, $436 \mathrm{pp}$.

Miller, Waldron de Witt.

1905. List of birds collected in southern Sinaloa Mexico, by J. H. Batty, during 1903-1904. Buil. Amer. Mus. Nat. Hist., 21: 339-369.

Miller, Waldron de Witt, and Ludlow Griscom. 192la. Notes on Ortalis vetula and its allies. Auk, $38: 44-50$. 
1921b. Descriptions of proposed new birds from Central America, with notes on other 1ittle-known forms. Amer. Mus. Novit., no. 25, 13 pp.

1925a. Descriptions of new birds from Nicaragua. Amer. Mus. Novit., no. 159,9 pp.

1925b. Notes on Central American birds, with descriptions of new forms. Amer. Mus. Novit., no. $183,14 \mathrm{pp}$.

1925c. Further notes on Central American birds, with descriptions of new forms. Amer. Mus. Novit., no. $184,16 \mathrm{pp}$.

Monroe, Burt L., Jr.

1963a. Three new subspecies of birds from Honduras. Occes. Papers Mus. Zool., Loulsiana State Univ., no. $26,7 \mathrm{pp}$.

1963b. A revision of the Lampornis viridipallens complex (Aves: Troch1lidae). Occas. Papers Mus. Zool., Loulstana State Univ., no. 27, 10 pp.

1963c. Notes on the avian genus Arremonops with description of a new subspectes from Honduras. Occas. Papers Mus. Zool., Louls iana State Univ., no. $28,12 \mathrm{pp}$.

Moore, Robert $T$.

1934. A review of the races of Geococcyx velox. Trans. San Diego Soc. Nat. Hist., 7: 456-468.

1937. Four new birds from northwestern Mexico. Proc. Biol. Soc. Washington, 50: 95-102.

1938. Rediscovery of Agyrtria luciae (Lawrence). Auk, 55: 534 .

1939. Doricha enlcura in Honduras and Chiapas, Mexico. Auk, 56: 337:

1940a. New races of Bmpidonax from Middle America. Proc. Biol. Soc. Washington, 53: 23-29.

1940b. Notes on Middle American Bmpidonaces. Auk, 57: $349-389$.

1941. New races of flycatcher, warbler and wrens from Mexico. Proc. Biol. Soc. Washington, 55: 35-42.

1946. Two new warblers from Mexico. Proc. Biol. Soc. Washington, 59: 99-102.

1947. Two new ow1s, a swift and a poorwill from Mexico. Proc. Biol. Soc. Washington, 60: 141146.

1950a. A new race of the species, Amazllia beryllina, from southern Mexico. Proc. Blol. Soc. Washington, 63: 59-60.

1950b. Northern record for Klats guimet in Central America. Auk, 67: 387 . 
1954. A new jay from Mexico. Proc. Biol. Soc. Washington, 67: 235-238.

Moore, Robert T., and Don R. Medina. 1957. A record of the slaty Finch for Honduras. Condor, 59: 67 .

Moore, Robert T., and James L. Peters.

1939. The genus Qtus of Mexico and Central America. Auk, 56: 38-56.

Moore, Thomas J.

1859. List of maminals and birds collected by Mr. Joseph Leyland in Honduras, Belize, and Guatemala. Proc. Zoo1. Soc. London, 1859: 50-65.

Mulsant, E.

1876. Catalogue des Olseaux-Mouches ou Colibris. Ann. Soc. Linn. Lyon, (n.s.), 22: 199-228.

Mulsant, E., and Edouard Verreaux.

1834. Histoire Naturelle des O1seaux-Mouches ou Colibris constituant la famille des Trochilidés. Vol. 1. Lyon, $v+343 \mathrm{pp}$.

1878. His toire Naturelle des Oiseaux-Mouches ou Colibris constituant la famille des Trochilidés. Vol. 4. Lyon, $308 \mathrm{pp}$.

Nehrkorn, A.

1889. Mittheilung über Trogoniden-Eier. Jour. f. orn., (Band 17), 37: 286 .

Nels on E. W.

1897. Preliminary descriptions of new birds from Mexico and Guatemala in the collection of the United States Department of Agriculture. Auk, 14: $42-76$.

1900. Description of a new subspecies of Meleagris gallopavo and proposed changes in the nonenclature of certain North American birds. Auk, 17: 120126.

1901. Descriptions of five new birds from Mexico. Auk, 18: 46-49.

1904. A revision of the North American mainland spectes of Mylarchus. Proc. Biol. Soc. Washington, 17: 21-50.

Nutting, Charles $C$.

1884. On a collection of birds from Nicaragua. Proc. U. S. Nat1. Mus. (1883), 6: 372-410. 
Oates, Eugene W.

1901. Catalogue of the collection of birds' eggs in the British Museum (Natural History). Vol. 1: Ratitae and Carinatae (Tinamiformes-Lariformes). London, $x \times 111+252 \mathrm{pp}$.

oberholser, Harry C.

1904a. A review of the wrens of the genus Troglodytes. Proc. U. S. Nat1. Mus ., 27: 197-210.

1904b. A monograph of the genus Dendrocincla Gray. Proc. Acad. Nat. Sci. Philadelphia, 56: 447-463.

1911. A revision of the forms of the Hairy Woodpecker (Dryobates villosus [Linnaeus]). Proc. U. S. Nat1. Mus , 40: 595-619.

1912. A revision of the subspectes of the green heron (Butorides virescens [Linnaeus]). Proc. U. S. Nat1. Mus ., 42: 529-577.

1932. Descriptions of new birds from Oregon, chiefly from the Warner Valley region. Sci. Publ. Cleveland Mus. Nat. Hist., 4: 1-12.

1959. A new Red-talled Hawk from Honduras. Proc. Biol. Soc. Washington, 72: 159.

Ogilvie-Grant, $W$. R.

1893. "Catalogue of birds in the British Museum." vo1. 22. London, xv1 + $585 \mathrm{pp}$.

1897. A hand-book of the game-birds. Vol. 2. Edward Lloyd, London, xV + $316 \mathrm{pp}$.

Olson, Everett Claire, and Paul Orman McGrew.

1941. Mammalian fauna from the Pliocene of Honduras. Bul1. Geogr. Soc. Amer., 52: 1219-1244.

Parkes, Kenneth $C$.

1954a. A revision of the Neotropical finch Atlapetes brumnel-nucha. Condor, 56: 129-138.

1954b. The generic name of the Rice Grackle. Condor, 56: 229 .

1955. Systematic notes on North American birds. 1. The herons and ibises (Clconilformes). Ann. Camegte Mus ., 33: 287-293.

1957. The Juvenal plumages of the Einch genera Atlapetes and Pip1lo. Auk, 74: 499-502.

$1958 \mathrm{a}$. Specific relationships in the genus Elanus. Condor, 60: 139-140.

1958b. Systematic notes on North American birds. 2. The waterfowl (Anatidae). Ann. Carnegie Mus., 35: 117-125.

1961. Taxonomic relationships among the American reds tarts . Wilson Bull., 73: 374-379. 
Parsons James J.

1955. The Miskito pine savanna of Nicaragua and Honduras. Ann. Assoc. Amer. Geogr., 45: 36-63.

Parzudaki, Emile.

1841. Manakin nouveau, decouvert par M. Demaussion Cande. Rev. Zool., 4: 306.

Paynter, Raymond A., Jr.

1955. The Ornithogeography of the Yucatan Peninsula. Peabody Mus . Nat. Hist. Bul1., no. 9, 347 pp.

1956. Blrds of the Swan Islands. Wilson Bul1., 68: 103-110.

1957a. Birds of Laguna Ocotal. Bull. Mus. Comp. Zool., 116: 249-285.

$1957 \mathrm{~b}$. Taxonomic notes on the New World forms of Troglodytes. Mus. Comp. Zool., Breviora, no. 71, $15 \mathrm{pp}$.

1964. Generic Iimits of Zonotrichia. Condor, 66: $277-281$.

Peters, James L.

1913. List of birds collected in the Territory of Quintana Roo, Mexico, in the winter and spring of 1912. Auk, 30: 367-380.

1925. A review of the limpkins (Aramus Vieillot). Occas. Papers Boston Soc. Nat. Hist., 5: 141-144.

$1929 \mathrm{a}$. The Identicy of Corvus mexicanus Gmelin. Proc. Biol. Soc. Washington, 42: 121-124.

1929b. An ornithological survey in the Caribbean lowlands of Honduras. Bull. Mus. Comp. Zool., 69: $397-478$.

1930a. The identity of the toucans described by Linnaeus in the 10th and 12 th editions of the Sys tema Naturae. Auk, 47: 405-408.

1930b. A review of the races of Picus ilneatus Linne. Occas. Papers Boston Soc. Nat. H1st., $5: 317-322$.

1931a. Check-1ist of birds of the world. Vol. 1. Harvard Press, Cambridge, xvi11 + 345 pp.

1931b. Additional notes on the birds of the Almirante Bay region of Panama. Bul1. Mus . Comp. Zool., 71: $291-345$.

1931c. An account of the Yellow-green Vireo (Vireosylva flavoviridis Cass in). Auk, 48: 575-587.

1934. Check-iist of birds of the worid. vol. 2 . Harvard Press, Cambridge, xvil + 401 pp.

1935. The range of Amazona oratrix. Auk, 52: 449450 .

1937. Check-11st of birds of the world. Vol. 3 . Harvard Press, Cambridge, xili + $311 \mathrm{pp}$.

1940. Check-ilst of birds of the world. Vol. 4. Harvard Press, Cambridge, xil + $291 \mathrm{pp}$. 
1945. Check-1ist of birds of the world. Vo1. 5. Harvard Press, Cambridge, $x 1+306$ pp.

1948. Check-1ist of birds of the world. Vol. 6.

Harvard Press, Cambridge, $x i+259 \mathrm{pp}$. Vol. 7.
1951. Check-1ist of birds of the world. Vol. Harvard Press, Cambridge, $x+318 \mathrm{pp}$.

Peters, James L., and Ludlow Griscon.

1929. The Central American races of Rupornis magnirostris. Proc. New England Zool. C1., 11: 43-48.

1938. Geographical variation in the Savannah Sparrow. Bul1. Mus . Comp. Zool., 80: 443-478.

Phelps, William H., and William H. Phelps, Jr.

1951. Four new Venezuelan birds. 'Proc. Biol. Soc. Washington, 64: 65-72.

1952. Nine new birds from the Perija Mountains and eleven extensions of ranges to Venezuela. Proc. Biol. Soc. Washington, 65: 89-108.

1953. Eight new birds and thirty-three extensions of ranges to Venezuela. Proc. Biol. Soc. Washington, 66: 125-144.

1955. Five new Venezuelan birds and nine extensions of ranges to Colombia. Proc. Biol. Soc. Washington, 68: 47-58.

1956. Three new birds from Cerro EL Teteo, Venezuela, and extensions of ranges to Venezuela and Colombia. Proc. Biol. Soc. Washington, 69: 127-134.

1957. Descriptions of four new Venezuelan birds, extensions of ranges to Venezuela and other notes. Proc. Bio1. Soc. Washington, 70: 119-128.

Phillips, Allan R.

1943. The races of MacGillivray's Warbler. Auk, 64: 296-300.

1948. Geographic variation in Empidonax trailiil. Auk, 65: 507-514.

1960. La acrecencia de errores acerca de la ornithologia de Mexico, con notas sobre Myiarchus. Anales Inst. de Biol., Univ. Nac. Aut. México, 30: 349-368.

1962a. Notas sistematicas sobre aves Mexicanas. I. Anales Inst. de Biol., Univ. Nac. Aut. México, 32 : 333-381.

1962b. Notas sistematicas sobre aves Mexicanas. II. Anales Inst. de Blol., Univ. Nac. Aut. México, 33: $331-372$.

1962c. Notas sobre la chupparosa Thaluranta y ciertos plumajes de otras aves Mexicanas. Anales Inst. de Biol., Univ. Nac. Aut. México (1961), 32: 383390 . 
Pitein, Frank A.

1950. Geographic variation and the spectes problem in the shore-bird genus Limnodromus. Univ. California Pub1. Z0o1., 50: 1-108.

1951a. Cent2 1 American races of Cyanolyca mitrata. ondor, 53: $97-98$.

195lb. Nomenclature of the Jooded Jay: a correction. Condor, 53: 300 .

Radley, J.

1960. The physical geography of the east coast of Nicaragua. M. A. Thesis, Dept. Geogr., Univ. California, Berkeley.

Rand, Austin L.

1960. Races of the Short-tailed Hawk, Buteo brachyurus. Auk, 77: 448-459.

Rand, Austin L., and Melvin A. Traylor.

1953. The systematic position of the genera Ramphocaenus and Mlcrobates. Auk, 70: 334-337.

1954. Manual de las aves de El Salvador. Univ. El Salvador, San Salvador, iv + 308 pp.

Record, Samuel F., and D. Mell Clayton.

1924. Timbers of tropical America. Yale Univ. Press, New Haven, xvili $+610 \mathrm{pp}$.

Redfield, A. H.

1923. The petroleum posstbilities of Honduras. Econ. Geol., 18: 474-493.

Rehndah1, Hialmar.

1919. Notes on a collection of birds from Panama, Costa Rica and Nicaragua. Ark. f. Zool., (Band 12), $8: 1-36$.

Richmond, Charles W.

1894. Notes on a collection of birds from eastern Nicaragua and the Rio Frio, Costa Rica, with a description of a supposed new trogon. Proc. U. S. Nat1. Mus. (1893), 16: 479-532.

Ridgway, Robert.

1835. Studies of the American Falconidae.--Monograph of the genus Micrastur. Proc. Acad. Nat. Sc1. Philadelphia, 27: 470-502.

1881. Catalogue of Trochilidae in the collection of the United States National Museum. Proc. U. S. Nat1. Mus. (1880), 3: 308-320.

1882. A review of the genus Centurus, Swains on. Proc. U. S. Nat1. Mus. (1881), 4: 308-320. 
1883. Description of several new races of American birds. Proc. U. S. Nat1. Mus. (1882), 5: 9-15.

1886. On Cathartes burrovianus, Cass in, and $C$. urubitinga, Pelzeln. Proc. U. S. Nat1. Mus. (1885), 8: 34-36.

1887. A manual of North American birds. J. B. Lippincott, Philadelphia, xi + 631 pp.

1888a. A review of the genus Dendrocincla Gray. Proc. U. S. Nat1. Mus. (1887), 10: 488-497.

1888b. Descriptions of 8 ane new species and subspecies of birds from Middle America. Proc. U. S. Natl. Mus . (1887), 10: 505-510.

1888c. Catalogue of a collection of birds made by Mr. Chas. H. Townsend, on 18 lands in the Caribbean and in Honduras. Proc. U. S. Nat1. Mus. (1887), 10: $572-597$.

1891. The huming birds. Report U. S. Nat1. Mus., 1890: 253-383.

1892. Notes on some birds from the interior of Honduras. Proc. U. S. Nat1. Mus. (1891), 14: 467-471.

1900. New species, etc., of American birds. Pt. 5: Corvidae. Auk, 17: 27-29.

1901. The birds of North and Middle America. - Pt. 1. U. S. Nat1. Mus. Bul1., no. $50, \mathbf{x x x}+715 \mathrm{pP}$.

1902. The birds of North and Middle America. Pt.

2. U. S. Nat1. Mus. Bull., no. 50, $\mathbf{x x}+834$ pp.

1904. The birds of North and Middle America. ${ }^{\circ}$ Pt. 3. U. S. Nat1. Mus. Bul1., no. $50, x x+801$ pp.

1905. New genera of Tyrannidae and Turdidae, and new forms of Tanagridae and Turdidae. Proc. Btol. Soc. Washington, 18: 211-213.

1906a. Descriptions of some new forms of American cuckoos, parrots, and pigeons. Proc. Biol. Soc. Washing ton, 19: 105-107.

$1906 \mathrm{~b}$. Description of some new forms of oligonyodian birds, Proc. Biol. Soc. Washington, 19: 115-120.

1907. The birds of North and Middle America. - Pt. 4. U. S. Nat1. Mus. Bul1., no. $50, \times \times 11+973$ pp.

1911. The birds of North and Middle America. . Pt. 5. U. S. Nat1. Mus. Bull., no. 50, xx111 + 859 pp.

1912. Descriptions of some new species and subspecies of birds from tropical America. Proc. Biol. Soc. Washington, 25: 87-92.

1914. The birds of North and Middle America.. Pt. 6. U. S. Nat1. Mus. Bul1., no. $50, \mathrm{xx}+882 \mathrm{pp}$.

1915. Descriptions of some new forms of American cuckoos, parrots, and pigeons. Proc. Biol. Soc. Washington, 28: 105-108. 
1916. The birds of North and Middle America. . Pt. 7. U. S. Nat1. Mus. Bul1., no. 50, xi1i +543

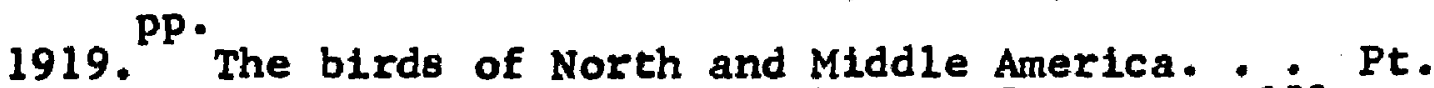
8. U. S. Nat1. Mus. Bull., no. 50 , xvi +852 pp.

Ridgway, Robert, and Herbert Friedmann.

1941. The birds of North and Middle America. 4 Pt. 9. U. S. Nat1. Mus. Bul1. no. $50,1 \mathrm{x}+254 \mathrm{PP}$.

1946. The birds of North and Middle America. P Pt. 10. U. S. Nat1. Mus. Bull., no. $50, \times 11+484$

1950. ${ }^{\text {pp }}$ The birds of North and Middle America. . Pt. 11. U. S. Nat1. Mus. Bull., no. $50, x 11 i+793$ pp.

Roberts Ralph J., and Ear1 M. Irving.

1957. Mineral deposits of Central America. U. S. Dept. Int., Geol. Surv. Bull., no. 1034, $x+205$ pp.

Rowan, William.

1932. The status of the dowitchers with a description of a new subspecles from Alberta and Manitoba. Auk, 49: 14-31.

Rowley, J. Stuart, and Robert T. Orr.

1964. The status of Frantzius' Nightingale Thrush. Auk, 81: 308-314.

Russell, Stephen $M$.

1964. A distributional study of the birds of British Honduras. Orn. Monog., no. 1, 195 pp.

Salvadori, $T$.

1891. "Catalogue of birds in the British Museum." vo1. 20. London, xvi1 + 658 pp .

1893. "Catalogue of birds in the British Museum." Vo1. 21. London, xv11 + $676 \mathrm{pp}$.

1895. "Catalogue of birds in the British Museum." Vo1. 27. London, $\mathrm{xv}+636 \mathrm{pp}$.

Salvin, Os bert. 1861a ${ }_{149}$ Quesal-shooting in Vera Paz. Ibis, 1861: 138-

1861b. A 118t of species to be added to the orntthology of Central America. Ibis, 1861: 351-357.

1866. A further contribution to the ornithology of Guatemala. Ibis, 1866: 188-206.

1871. On the Psittacidae of Central America. Ibis, 1871 : 86-100. 
1888. A 1ist of the birds of the islands of the coast of Yucatan and of the Bay of Honduras. Ibis, 1888: 241-265.

1889. A 1ist of the birds of the islands of the coast of Yucatan and of the Bay of Honduras (continued). Ib18, 1889: 359-379.

1890. A 118t of the birds of the islands of the coast of Yucatan and of the Bay of Honduras (concluded). Ibis, 1890: 84-95.

Salvin, Osbert, and Frederick Ducane Godman.

1879-1904. Biologia Centrali-Americana. Aves.

Taylor and Francis, London: vol. $1, x 11 v+512$

Pp.; vol. 2, 598 pp.; vol. 3, 1v + 510 pp.

Salvin, osbert, and Philip Lutley Sclater.

1860. Contributions to the ornithology of Guatemala. Ibis, 1860: 28-45, 272-278, 396-402.

Sapper, Karl.

1902. Beitrage zur Physischen Geographie von Honduras. Zeit. Gesell. f. Erd., Berlin, 1902: $33-56,143-164,231-241$.

1905. Ueber Gebirgsbau und Boden des süd11chen Mittelamerika. Peterm. Mitth., Erg. 32, no. 151, 82 pp.

Sass1 1938. Die vögel der österreichischen Costa-RicaExpedition (Erster Teil). Temminckia, 3:

279-322.

1939. Die vögel der Österreichischen Costa-RicaExpedition (Zweiter Tei1). Teminckia, 4: 135-222.

Saunders, George B.

1951. A new White-winged Dove from Guatemala. Proc. Biol. Soc. Washington, 64: 83-90.

Saunders, Howard, and Osbert Salvin.

1896. "Catalogue of birds in the British Museum." Vol. 25. London, $\mathrm{xI}+475 \mathrm{PP}$.

Schuchert, Charles.

1935. The historical geology of the AntilleanCaribbean region. Wiley and Sons, xxvi $+811 \mathrm{pp}$.

Sclater, Philip Lutley.

1855a. On some new or 1ittle known species of birds in the Derby Museum at Liverpool. Proc. Zool. Soc. London, 1855: 74-77. 
1855b. Characters of some apparently new spectes of Bucconidae, accompanied by a geographical table of the family. Proc. Zool. Soc. London, 1855: 193-196.

1856a. Synops is Avium Tanagrinarum.--A descriptive catalogue of the known species of tanagers. Proc. Zoo1. Soc. London, 1856: 64-94, 108-132, $230-281$.

$1856 \mathrm{~b}$. On the species of the American genus Parra. Proc. Zool. Soc. London, 1856: 282-283.

1856c. Catalogue of the birds collected by $M$. Auguste Sallé in Bouthern Mexico, with descriptlons of new species. Proc. Zool. Soc. London, 1856: 283-311.

1857. Description of eleven new species of birds from tropical America. Proc. Zool. Soc. London, 1857: $271-277$.

1858a. Notes on some birds from southern Mexico. Proc. Zool. Soc. London, 1858: 95-99.

$1858 \mathrm{~b}$. List of birds collected by Geo. Cavendish Taylor, Esq., in the Republic of Honduras. Proc. Zool. Soc. London, 1858: 356-360.

1858c. A monograph of the birds forming the tanagrine genus Calilste. John van Voorst, London, xvili + $104 \mathrm{pp}$.

1859a. A list of the tyrant-birds of Mexico, with descriptions of some new species. Ibis, 1859: 436-445.

$1859 \mathrm{~b}$. A symops is of the thrushes (Turdidae) of the New World. Proc. Zool. Soc. London, 1859: 321.347.

1859c. List of birds collected by M. A. Boucard in the State of Daxaca in south-western Mexico, with descriptions of new species. Proc. Zool. Soc. London, 1859: 369-393.

1860. Notes on a collection of birds from the vicinity of Orizaba and neighbouring parts of southern Mexico. Proc. Zool. Soc. London, 1860: 250-254.

1862. Catalogue of a collection of American birds. $\mathrm{N}$. Trübner and Co., London, $x v+338 \mathrm{pP}$.

1870. Further notes on the cuckoos of the genus Coccyzus. Proc. Zool. Soc. London, 1870: 163169.

1871a. A revision of the species of the fringiline genus Spermophila. Ib1s, 1871: 1-23.

$1871 \mathrm{~b}$. Remarks on the species of the genera Myiozetetes and Conopias, belonging to the fanily Tyrannidae. Proc. Zool. Soc. London, 1871: $751-756$.

1874. On the species of the genus Synallaxis of the family Dendrocolaptidae. Proc. Zool. Soc. London, 1874: 2-28. 
1879. Note on the American crows of the subgenus Xanthura. Ibis, 1879: 87-89.

1883. Review of the species of the family Icteridae. Ibis, 1883: 145-163, 352-374.

1886. "Catalogue of birds in the British Museun." Vol. 11. London, xvi1 + $427 \mathrm{pp}$.

1888. "Catalogue of birds in the British Museum." Vo1. 14. London, $x i x+494 \mathrm{pp}$.

1890. "Catalogue of birds in the British Museum." Vol. 15. London, xvii + $371 \mathrm{pp}$.

Sclater, Philip Lutley, and Osbert Salvin.

1859. On the ornithology of Central America. Ibis, 1859: 1-22, 117-138, 213-234.

1868a. Exotic ornithology, containing figures and descriptions of new or rare species of American birds. Bernard Quaritch, London, vi + 204 pp.

$1868 \mathrm{~b}$. Descriptions of new species of birds of the families pendrocolaptidae, Strigidae, and Columbidae. Proc. Zoo1. Soc.London, 1868: 5360.

1868c. Synopsis of the American rails (Rallidae). Proc. Zool. Soc. London, 1868: 442-470.

1869a. Notes on the species of the genus Asturina. Proc. Zoo1. Soc. London, 1869: 129-134.

1869b. On a collection of birds made by Mr. H. S. le Strange near the city of Mexico. Proc. Zool. Soc. London, 1869: 361-364.

1869c. Description of $\mathrm{six}$ new species of American birds of the families Tanagridae, Dendrocolaptidae, Formicarlidae, Ty rannidae, and Scolopacidae. Proc. Zool. Soc. London, 1869: 416-420.

1870a. Synops is of the Cracidae. Proc. Zool. Soc. London, 1870: 504-544.

$1870 \mathrm{~b}$. On birds collected by Mr. George M. Whitely on the coast of Honduras. Proc. Zool. Soc. London, 1870 : $835-839$.

1871. A revised 11st of the Neotropical Laridae. Proc. Zool. Soc. London, 1871: 564-580.

1873a. Nomenclator Aviun Neotropicalium . . London, vi1i + $163 \mathrm{pp}$.

$1873 \mathrm{~b}$. Notes on the range of several American Limicolae. Proc. Zool. Soc. London, 1873: 453-457.

1876. A revision of the Neotropical Anatidae. Proc. Zool. Soc. London, 1876: 358-412.

Sclater Philip Lutley, and G. E. Shelley.

1891 . "Catalogue of birds in the British Museum." Vol. 19. London, xi1 + 484 pp. 
Sclater, W. L.

1919. [Description of a new subspecies of Leucopternis from Central America]. Bull. Brit. Orm. CI., 39: 76.

Seebohm, Henry.

1881. "Catalogue of birds in the British Museum." Vol. 5. London, xvi $+426 \mathrm{pp}$.

1887. The geographical distribution of the family Charadrildae, or the plovers, sandplpers, snipes, and their allies. Henry Sotheran and Co., London, $x \times 1 x+524$ pP.

Seebohm, Henry, and R. Bowdler Sharpe.

1898. A monograph of the Turdidae, or the family of thrushes. Henry Sotheran and Co., London, $\mathrm{xI}+$ 311 pp.

Selander, Robert $K$.

1954. A systematic review of the Booming Nighthawks of western North America. Condor, 56: 57-82.

1959. Polymorphism in Mexican Brown Jays. Auk, 76: $385-417$.

1964. Specistion in the wrens of the genus Campylorhynchus. Untv. California Publ. Zool., 74: $1-259$.

Selander, Robert $K$, and Miguel Alvarez del Toro.

1955. A new race of Booning Nighthawk from southern Mexico. Condor, 57: 144-147.

Selander, Robert K., and Donald R. G11ler.

1963. Species 1 imits in the woodpecker genus Centurus (Aves). Bull. Amer. Mus. Nat. H18t., 124: 213274.

Selnes, Mrs . E. R.

1958. Minnesota Baltimore Orlole recovered In Honduras. Inland Bird Banding News, 30: 14.

Sharpe, R. Bowdler.

1874. "Catalogue of birds in the British Museum." Vo1. 1. London, $x 111+479 \mathrm{pp}$.

1875. "Catalogue of "birds in the Brit18h Museum." Vo1. 2. London, $x 1+325 \mathrm{pp}$.

1877. "Catalogue of birds in the Brit1sh Museum." Vol. 3. London, $x 111+343 \mathrm{pp}$.

1881. "Catalogue of birds in the British Museum." Vo1. 6. London, $x 111+420 \mathrm{pp}$.

1885. "Catalogue of birds in the Brit1sh Museum." Vol. 10. London, $x 111+682 \mathrm{pp}$.

1888. "Catalogue of birds in the British Museum." vol. 12. London, xv +871 pp. 
1894. "Catalogue of birds in the British Museum." Vol. 23. London, $x 11 i+353 \mathrm{pp}$.

1896. "Catalogue of birds in the British Museum." Vo1. 24. London, Xil + 794 Pp .

1899. A hand-1ist of the genera and species of birds. Vol. 1. London, $x \times 1+303 \mathrm{pp}$.

1900. A hand-11st of the genera and species of birds. Vol. 2. London, $\mathrm{xv}+312 \mathrm{pp}$.

1901. A hand-1ist of the genera and species of birds. Vol. 3. London, $x 11+367$ pp.

1903. A hand-1ist of the genera and species of birds. Vo1. 4. London, $x i 1+391 \mathrm{pp}$.

1909. A hand-1ist of the genera and species of birds. vol. 5. London, $\mathbf{x x}+694 \mathrm{pp}$.

Sharpe, R. Bowdler, and W. R. Ogilvie-Grant.

1892. "Catalogue of birds in the British Museum." Vol. 17. London, $x 1+522 \mathrm{pp}$.

1898. "Catalogue of birds in the British Museum." Vol. 26. London, xvil $+687 \mathrm{pp}$.

Shelford, V. E., et al.

1926. Naturalist's gulde to the Americas. Williams and Wilkins Co., 761 pp.

Sibley, Charles G., and Lester L. Short, Jr.

1964. Hybridization in the orioles of the Great Plains. Condor, 66: 130-150.

Simon, Eugène.

1897. Catalogue des Espèces Actuellement Connues de la Famille des Trochilides. L. Mulo, Par1s, 46 Pp.

Simon, Eugène, and Charles E. Hel lmayr.

1908. Notes critiques sur quelques Trochilidae. Novit. Zool., 15: 1-12.

Sinclair, Joseph H.

1924. Notes on the mapping of an area in southern Honduras. Geogr. Rev., 14: 275-281.

Skutch, Alexander F.

1.931. The life history of Rleffer's Humingbird (Amazilia tzacatl) in Panama and Honduras. Auk, 48: 481-500.

1937. Life-history of the Black-chinned Jacamar. Auk, 54: 135-146.

1940. Social and sleeping habits of Central American wrens. Auk, 57: 293-312.

1942. Life history of the Mexican Trogon. Auk, 59: $341-363$. 
1945a. Incubation and nestling periods of Central American birds. Auk, 62: 8-37.

1945b. On the habits and nest of the ant-thrush, Formicarius analis. Wilson Bull., 57: $122-128$.

$1945 \mathrm{c}$. Life history of the Blue-throated Green Motmot. Auk, 57: 489-517.

1945d. Studies of Central American redstarts. Wilson Bul1., 57: 217-242.

1946. Life history of the Costa Rican tityra. Auk, 63 : $327-362$.

1947. Life history of the Turquoise-browed Motmot. Auk, 64: 201-217.

1948a. Life history notes on puff-birds. Wilson Bull., 60: 81-97.

1948b. Life history of the citreoline Trogon. Condor, 50: 137-147.

1949a. Life history of the Yellow-thighed Manakin. Auk, 65: 1-24.

1949b. Life history of the Ruddy Quail-Dove. Condor, $51: 3-19$.

1950. Life history of the White-breasted Blue Mocking bird. Condor, 52: 220-227.

1951a. Life history of the Boat-billed Flycatcher. Auk, $68: 30-49$.

1951b. Congeneric species of birds nesting together in Central America. Condor, 53: 3-15.

1952. Life history of the Chestnut-tailed Automolus. Condor, 54: 93-100.

1953. The White-throated Magpie-jay. Wils on Bull., 65: 68-74.

1954a. Life histories of Central American birds. Vol. 1. Pacific Coast Avif., no. 31,448 pp.

1954b. Life history of the Troplcal Kingbird. Proc. Linn. Soc. New York, 61-63: 21-38.

1954c. Life history of the White-winged Becard. Auk, $71: 113-129$.

1955. The Hairy Woodpecker in Central America. Wils on Bull., 67: 25-32.

1956a. Life history of the Ruddy Ground Dove. Condor, 58: 188-205.

1956b. Roosting and nesting of the Golden-olive Woodpecker. Wils on Bull., 68: 118-128.

1956c. A nesting of the Collared Trogon. Auk, 73: 354-366.

1957. Life history of the Amazon Kingfisher. Condor, 59: 217-229.

1958a. Life history of the Violet-headed Hummingbird. Wilson Bull., 70: 5-19.

1958b. Roosting and nesting of the Aracar1 Toucans. Condor, 60: 201-219.

1959a. Life history of the Black-throated Trogon. Wils on Bull., 71: 5-18. 
1959b. Life history of the Blue Ground Dove. Condor, 61: $65-74$.

1960. Life histories of Central American birds. Vol. 2. Pacific Coast Avif., no. 34, 593 pp.

1964. Life histories of hermit humingbirds. Auk, $81: 5-25$.

Slud, Paul.

1958. Observations on the Nightingale Wren in Costa Rica. Condor, 60: 243-251.

1960. The birds of Finca "La Selva," Costa Rica: A tropical wet forest locality. Bul1. Amer. Mus. Nat. Hist., $121: 49-148$.

1964. The birds of Costa Rica. Bull. Amer. Mus . Nat. Hist., 128: 1-430.

Smith, W. John.

1959. Movements of Michigan Herring Gulls. BirdBanding, 30: 69-104.

Smithe, Frank B., and Raymond A. Paynter, Jr.

1963. Birds of Tikal, Guatemala. Buil. Mus . Comp. Zool., 128: 247-324.

Squier, Ephraim George.

1855. Notes on Central America. . - Harper and Bros., New York, 397 pp.

1858. The states of Central America. - Harper and Bros ., New York, 782 pp.

1870. Honduras; descriptive, htstorical and statistical. N. Trübner and Co., London, 278 pp.

Standley, Paul Carpenter.

1931. Flora of the Lancet11la Valley of Honduras. Field Mus. Nat. H1Bt., Bot. Ser., 10: 1-418.

Stein, Robert Carring ton.

1963. Isolating mechanisms between populations of Traili's Flycatchers. Proc. Amer. Philos. Soc., 107: 21-50.

Stone, Witmer.

1908. A review of the genus Playa Lesson. Proc. Acad. Nat. Sci. Philadelphia, 60: 492-501.

1931. Three new birds from Honduras. Proc. Acad. Nat. Sci. Philadelphia, 83: 1-3.

1932. The birds of Honduras with special reference to a collection made in 1930 by John T. Enlen, Jr., and $\mathrm{C}$. Brooke Worth. Proc. Acad. Nat. Sci. Philadelphia, 84: 291-342. 
Storer, Robert $W$.

1952. Variation in the resident Sharp-shinned Hawks of Mexico. Condor, 54: 283-289.

1955. A preliminary survey of the sparrows of the genus Aimophila. Condor, 57: 193-201.

1962. Varlation in the Red-tailed Hawks of southern Mexico and Central America. Condor, 64: 77-78.

Strangeways, Thomas .

1822. Sketch of the Mosquito shore, including the territory of Poyais. Blackwood and Caddell, Edinburgh, $355 \mathrm{pp}$.

Stresemann, Erwin.

1925. Mutationsstudien.--XXII.--Attila spadiceus (Gmelin). Jour. f. Orn., 73:274-277.

1954. Ferdinand Deppe's travels in Mexico, 1824-1829. Condor, 56: 86-92.

Stuart, I. C.

1954. A description of a subhumid corridor across northern Central America, with comments on its herpetofaunal indicators. Contr. Lab. Vert. Btol. Univ. Michigan, no. 65,26 pp.

Sundeva11, Carolus J.

1866. Conspectum Avium Picinarum. Sams on and Wallin, Stockholm, xiv + 116 pp.

Sutton, George Miksch.

1944. The kites of the genus Ictinia. Wils on Bull., $56: 3-9$.

1951. Caprimulgus ridgwayi in Michoacan, Mexico. Condor, 53: 261-262.

Swann, H. Kirke.

1919a. A synoptical 11st of the Accipitres (Diurnal Birds of Prey). Pt. 1. John Wheldon and Co., London, $38 \mathrm{pp}$.

$1919 \mathrm{~b}$. A synoptical 1ist of the Accipitres (Diurnal Birds of Prey). Pt. 2. John Wheldon and Co., London, 39-74 pp. (t new 15-16 pp.).

1920a. A synoptical ist of the Accipitres (Diurnal Birds of Prey). Pt. 3. John Wheldon and Co., London, 75-114 pp.

1920b. A synoptical list of the Accipitres (Diurnal Birds of Prey). Pt. 4. John Wheldon and Co., London, 115-164 pp.

Tashian, Richard E.

1953. The birds of southeastern Guatemala. Condor, 55: $198-210$. 
Taylor 1962 . W. The status and development of the Nicaraguan pine savanna. Caribbean Forester, 23: 21-26.

Taylor, E. Cavendish.

1858. Note on the eggs of the frigate bird and crocodile of Jamaica. Proc. Zool. Soc. London, 1858: $318-319$.

Taylor, George Cavendish.

1859. Account of a visit to a nesting-place of the frigate-bird (Fregata aquila L.). Ibis, 1859: $150-152$.

1860. On birds collected or observed in the Republic of Honduras, with a short account of a journey across that country from the Pacific to the At lantic Ocean. Ibis, 1860: 10-24, 110-122, $222-228,311-317$.

Todd, W. E. Clyde.

1910. Two new woodpeckers from Central America. Proc. Biol. Soc. Washington, 23: 153-155.

1913. A revision of the genus Chamaepelia. Ann. Carnegie Mus ., 8: 507-603.

1920a. A revision of the genus Eupsychortyx. Auk, 37: $189-220$.

1920b. Descriptions of apparently new South American birds. Proc. Biol. Soc. Washington, 33: 71-75.

1922. Studies in the Tyrannidae. Pt. 2: the restricted genus Mylobius. Proc. Blol. Soc. Washington, 35: 17-38.

1923a. A review of the genus Cyanocompsa. Auk, 40: $58-69$.

1923b. A synopsis of the genus Arremonops. Proc. B101. Soc. Washington, 36: 35-44.

1924. Descriptions of eight new Neotropical birds. Proc. Biol. Soc. Washington, 37: 121-124.

1926. A study of the Neotropical finches of the genus Spinus, Ann. Carnegie Mus ., 17: 11-82.

1929a. A revision of the wood-warbler genus Basileuterus and its allies. Proc. U. S. Natl. Mus., 74 (art. 7): $1-95$.

1929b. A review of the vireonine genus Pachysylvia. Proc. Biol. Soc. Washington, 42: 181-206.

1935. Geographic vartation in the American Titlark. Proc. Blol. Soc. Washington, 48: 63-65.

1942a. List of the tinamous in the collection of the Carnegie Mus eum. Ann. Carneg te Mus. 29: 1-29.

$1942 \mathrm{~b}$. L1st of the humingbirds in the collection of the Carnegie Museum. Ann. Carnegle Mus., 29: $271-370$. 
1943. Critical remarks on the trogons. Proc. Biol. Soc. Washington, $56: 3-16$.

1948. Critical remarks on the wood-hewers. Ann. Carnegie Mus ., 31: 5-18.

1950. The northern races of Dendrocolaptes certhia. Jour. Washington Acad. Sc1., 40: 236-238.

Todd, W. E. Clyde, and M. A. Carriker, Jr.

1922. The birds of the Santa Marta region of Colombla. Ann. Carnegie Mus., 14: 3-611.

Twomey, Arthur C.

1950. A new race of paroquet of the species Aratinga astec from the Republic of Honduras. Ann. Carnegie Mus., 31: 297-298.

1956. A new race of black hawk of the species Buteogallus anthracinus from the Republic of Honduras. Ann. Carnegle Mus., 33: 387-389.

Underdown, C. Eliot.

1932. A study of Chlorospingus ophthalmicus (Dubus) and 1ts allies. Ib18, 1932: 638-655.

van Rossem, A. J.

1927. A new race of Sclater Oriole. Condor, 29: $75-76$.

1928a. A new Central American flycatcher. Auk, 45: 359-360.

1928b. Three new jays from E1 Salvador. Auk, 45: 361-363.

1929. The genus Brachyspiza not distinct from Zonotrichia. Auk, 46: 549-550.

1930a. Some geographic variations in Playa cayana. Trans. San Diego Soc. Nat. Hist., 6: 209-210.

1930b. A northwestern race of the Mexican Goshawk. Condor, 32: 303-304.

1931a. Concerning some Polloptilae of the west cosst of Middle America. Auk, 48: 33-39.

1931b. Notes on the races of Saltator grandis (Iichtenstein). Trans. San Dlego Soc. Nat. Hist., 7: 21-24.

1932a. El Salvador races of Dactylortyx thoracicus. Trans. San Diego Soc. Nat. Hist., 7: 151-152.

1932b. A southern race of the Spotted Screech Owi. Trans. San Diego Soc. Nat. Hist., 7: 183-186.

1933. A new Solitary Vireo from Central America. Trans. San Diego Soc. Nat. Hist., 7: 285-286.

1934a. Two new races of the Black Chachalaca from Central Amertca. Trans. San Diego Soc. Nat. H18t., 7: 363-365. 
1934b. A new race of Piranga bidentata from Central America. Trans. San Diego Soc. Nat. Hist., 7: 367-368.

- 1934c. Critical notes on Middle American birds . Bul1. Mus, Comp. 2001., 77: 387-490.

1934d. A new puff-bird from El Salvador. Trans. San Diego Soc. Nat. Hist., 8: 3-4.

1936a. Description of a race of Myiarchus cinerascens from El Salvador. Trans. San Dlego Soc. Nat. Hist., 8: 115-117.

1936b. The Orange-bellied Redstart of western Central America. Condor, 38: 117-118.

1938. [Descriptions of new races of Fringillidae and Icteridae from Mexico and Guatemala]. Bull. Brit. Orn. C1., 58: 124-138.

1941. Three new races of birds from Central America. Proc. Btol. Soc. Washington, 54: 171-173.

1942a. Du Bus' types of Cyanocorax unicolor and Sylvia taeniata. Wilson Bul1., 54: 212-213.

1942b. The name of the Mexican Tiger Bittern. Auk, 59: 572 .

van Rossem, A. J., and the Marquess Hachisuka.

1937. The Yellow-green Vireo of northwestern Mexico. Proc. Biol. Soc. Washington, 50: 159-160.

Van Tyne, Josselyn.

1935. The birds of northern Petén, Guatemala. Misc. Pub1. Mus. Zool., Univ. Michigan, 27: 1-46.

Van Tyne, Josselyn, and Mtlton B. Trautman.

1941. New birds from Yucatán. Occas. Papers Mus. 2001., Univ. Michigan, no. 439, 11 pp.

Vaurie, Charles .

1964. Systematic notes on Palaearctic birds. No. 53. Charadrildae: the genera Charadrius and Pluvialis. Amer. Mus. Novit., no. 2177,22 pp.

Verdoorn, Frans.

1945. Plants and plant science in Latin America. Chronica Botanica Co., Waltham, Mass., xxxvil + $381 \mathrm{pp}$.

Von Hagen, Victor Wolfgang.

1946. Jungle in the clouds. Due11, Sloan and Pearce, New York, $x+268$ pp.

Wagner, Helmuth 0 .

1944. Notes on the life history of the Emerald Toucanet. Wilson Bul1., 56: 65-76. 
1945. Notes on the life history of the Mexican violet-eax. Wils on Bull., 57: 165-187.

Warner, Dwain W., and Byron E. Harrell.

1957. The systematics and blology of the Singing Quail pactylortyx thoracicus. W1lson Bull., 69: 123-148.

Webster, J. Dan.

1958. Systematic notes on the Olive Warbler. Auk, 75: 469-473.

1959. A revision of the Botteri Sparrow. Condor, 61: $136-146$.

1961. A revision of Grace's Warbler. Auk, 78: 554566.

1963. A revision of the Rose-throated Becard. Condor, 65: 383-399.

Webster, J. Dan, and Robert T. Orr.

1958. Variation in the Great Horned Owls of Middle America. Auk, 75: 134-142.

Wells, William Vincent.

1857. Exploration and adventures in Honduras. Harper and Bros., New York, xxiv + 588 pp.

Wernstedt, Frederick L.

1961. World Climatic Data. Latin America and the Caribbean. Edwards Bros., Inc., Ann Arbor, Mich., 87 pp.

Wetmore, Alexander.

1940. Two new geographic races of birds from Central America. Proc. B101. Soc. Washington, 53: 51-53.

1944. A collection of birds from northern Guanacaste, Costa Rica. Proc. U. S. Nat1. Mus ., 95: 25-80.

1945a. The Golden Plover in Nicaragua. Auk, 62: 313-314.

1945b. A review of the forms of the Brown Pelican. Auk, 62: 577-586.

1950. The identity of the American vilture described as Cathartes burrovianus by Cass in. Jour. Washington Acad. Sci., 40: 415-417.

1956. Additional forms of birds from Panamá and Colombia. Proc. Biol. Soc. Washington, 69: $123-126$.

1958. Extralimital records for the Eastern Kingbird, Tree Swallow, and Black-poll Warbler. Auk, 75: 467-468.

1964. A revision of the American vultures of the genus Cathartes. Smiths. Misc. Coll., 146 (no. 6): $1-18$ 
Wetmore, Alexander, and Kenneth C. Parkes.

1962. A new subspecies of Ivory-billed Woodhewer from Mexico. Proc. Biol. Soc. Washington, 75: 57-60.

Wilson, Percy.

1903. Report on exploration in Honduras. Jour. New York Bot. Garden, 4: 99-102.

Wise, Harry.

1958. Agricultural possibilities in Honduras. Celba, 7: 1-43.

Young, Thomas .

1842. Narrative of a residence on the Mosquito shore, during the years 1839,1840 and 1841. Smith, Elder and Co., London, $172 \mathrm{pp}$.

Yuncker, Truman George.

1938. A contribution to the flora of Honduras. Field Mus. Nat. Hist., Bot. Ser., 17: 287-407.

Zimmer, John $T$.

1929. A study of the Tooth-billed Red Tanager, Piranga flava. Field Mus. Nat. Hist., Zool. Ser., 17: 167-219.

1930. Birds of the Marshall Field Peruvian Expedition, 1922-1923. Field Mus. Nat. Hist., Zool. Ser., 17: $231-480$.

1931. Studies of Peruvian birds. No. 2. Amer. Mus. Novit., no. 509, 20 pp.

1932. The Central American forms of the Musician Wren, Cyphorhinus lawrencii. Amer. Mus. Novit., no. $573,4 \mathrm{pP}$.

1935. Studies of Peruvian birds. No. 17. Amer. Mus. Novit., no. 785,24 pp.

1936. Studies of Peruvian birds. No. 21. Amer. Mus. Novit., no. 862,25 pp.

1937a. Studies of Peruvian birds. No. 27. Amer. Mus . Novit., no. 962,28 pp.

$1937 \mathrm{~b}$. Studies of Peruvian birds. No. 28. Amer. Mus . Novit., no. 963,28 pp.

1938. Studies of Peruvian birds

No. 29. Amer.

1939. Studies of Peruvian birds Mus. Novit. no. $1042,13 \mathrm{pp}$.

1941a. Studies of Peruvian birds. Mus. Novit., no. $1108,23 \mathrm{pp}$.

1941b. Studies of Peruvian birds. Mus. Novit., no. 1126,25 pp.

1942a. Studies of Peruvian birds. No. 40. Amer. Mus. Novit., no. $1159,12 \mathrm{pp}$.

No. 30. Amer.

No. 36. Amer.

No. 38. Amer. 
1942b. Studies of Peruvian birds. No. 42. Amer. Mus. Novit., no. 1168,7 pp.

1942c. Studies of Peruvian birds. No. 44. Amer. Mus. Novit., no. 1203, $15 \mathrm{pp}$. No. 45. Amer.

1943a. Studies of Peruvian birds. No. 45. Amer. Mus. Novit., no. $1225,24 \mathrm{pp}$. No. 46 . Amer.

1943b. Studies of Peruvian birds. No. 46. Amer.
Mus. Novit., no. 1245, 14 pp.

1944a. Two new subs pecies of Catharus aurantilrostris. Auk, 61: 404-408.

1944b. Studies of Peruvian birds. No. 48. Amer. Mus. Novit., no. 1262,21 pp.

1945. A new swift from Central and South America. Auk, 62: 586-592.

1947. Studies of Peruvian birds. No. 52. Amer. Mus. Novit., no. 1367,26 pp.

1948a. The specific name of the Olive Warbler. Auk, 65: $126-127$.

1948b. Studies of Peruvian birds. No. 53. Amer. Mus. Novit., no. $1380,56 \mathrm{pp}$.

1949. Studies of Peruvian birds. No. 54. Amer. Mus. Novit., no. 1428,59 pp.

1950a. Studies of Peruvian birds. No. 55. Amex. Mus . Novit., no. 1449, 51 pp.

1950b. Studies of Peruvian birds. No. 57. Amer. Mus. Novit., no. 1463, 28 pp.

1950c. Studies of Peruvian birds. No. 58. Amer. Mus. Novit., no. $1474,31 \mathrm{pp}$.

1953a. Studies of Peruvian birds. No. 63. Amer. Mus. Novit., no. 1604,26 pp.

1953b. Notes on tyrant flycatchers (Tyrannidae). Amer. Mus. Novit., no. 1605, 16 pp.

1953c. Studies of Peruvian birds. No. 65. Amer. Mus. Novit., no. 1649,27 pp.

1955a. Studies of Peruvian birds. No. 66. Amer. Mus. Novit., no. $1723,35 \mathrm{pp}$.

$1955 \mathrm{~b}$. Further notes on tyrant flycatchers. Amer. Mus. Novit., no. 1749,24 pp. 


\section{BIOG RAPHY}

Burt Leavelle Monroe, Jr., was born on 25 August 1930 - In Louisville, Kentucky. He received his elementary education in Louisville and in Anchorage, Kentucky, gradusting in May 1948 from Anchorage High School. In September 1948 he entered the University of Louisville, and in June 1953 he graduated with highest honors and received a Bachelor of Science degree in Blology. At this time he was also commissioned an Ensign in the United States Navy after serving four years in the Reserve Officer Training Corps as an undergraduate. In February 1959 he finished his active duty holding the rank of Lieutenant and in September 1959 entered graduate school at Louisiana State University. He became a candidate for the degree of Doctor of Philosophy in Vertebrate Zoology in 1962. 
Candidate: Burt Leavelle Monroe, Jr.

Major Field: $\quad$ Zoology

Title of Thesis: A Distributional Survey of the Birds of Honduras

Approved:

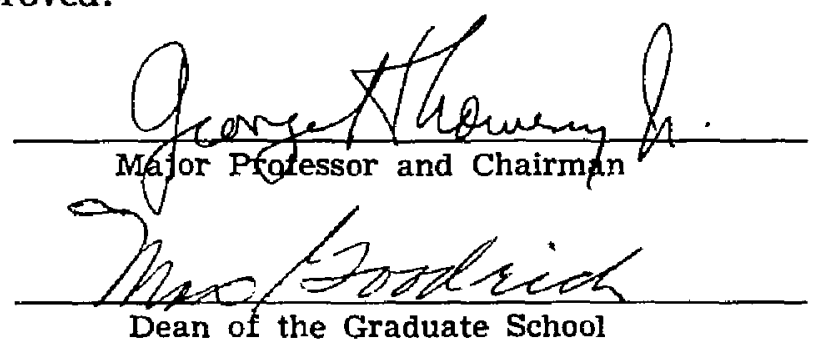

EXAMINING COMMITTEE:
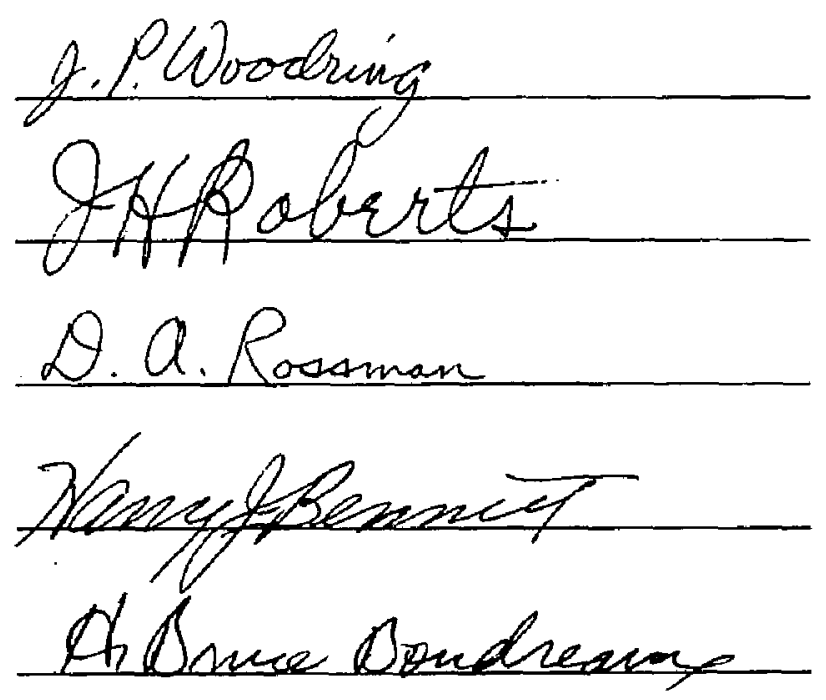

Date of Examination: 5 May 1965 